Cell 1

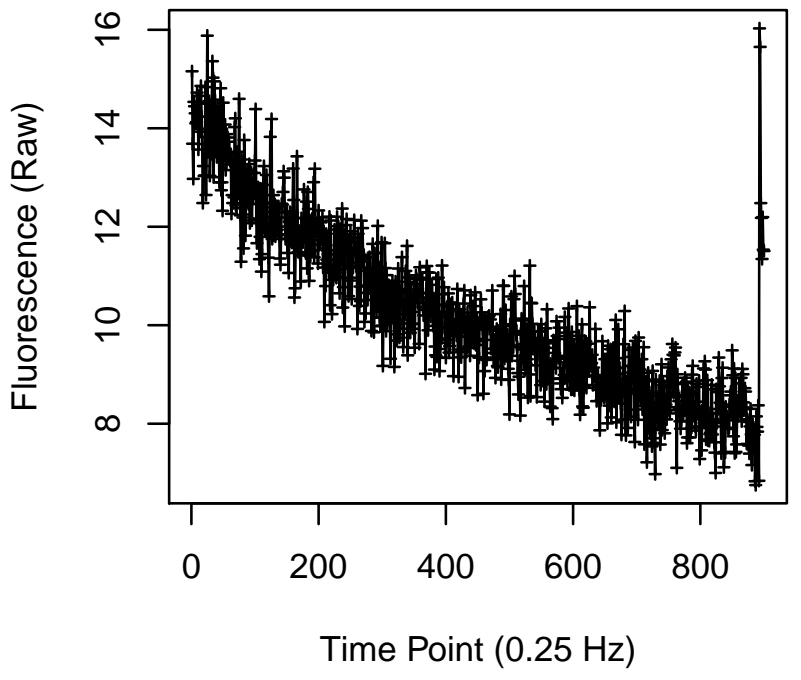

Cell 3

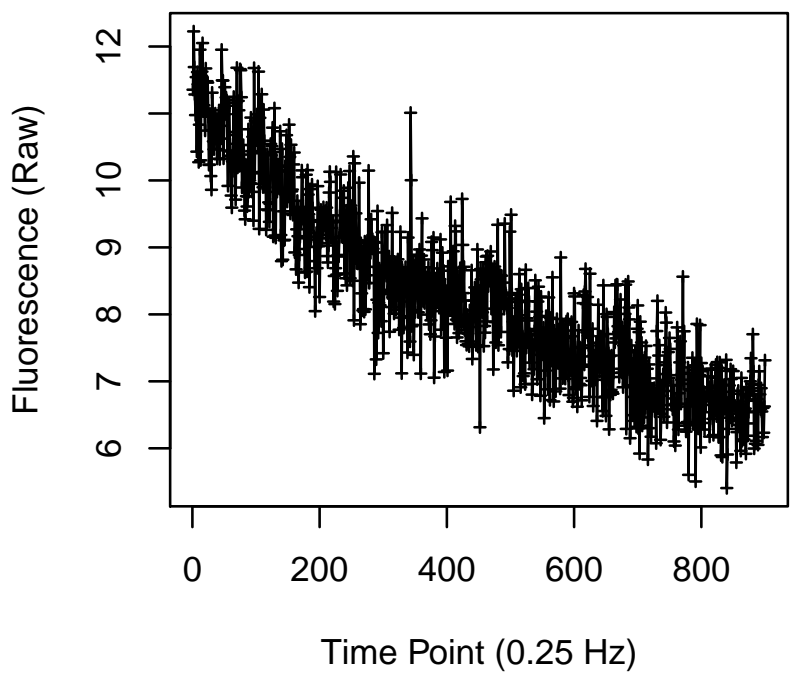

Cell 2

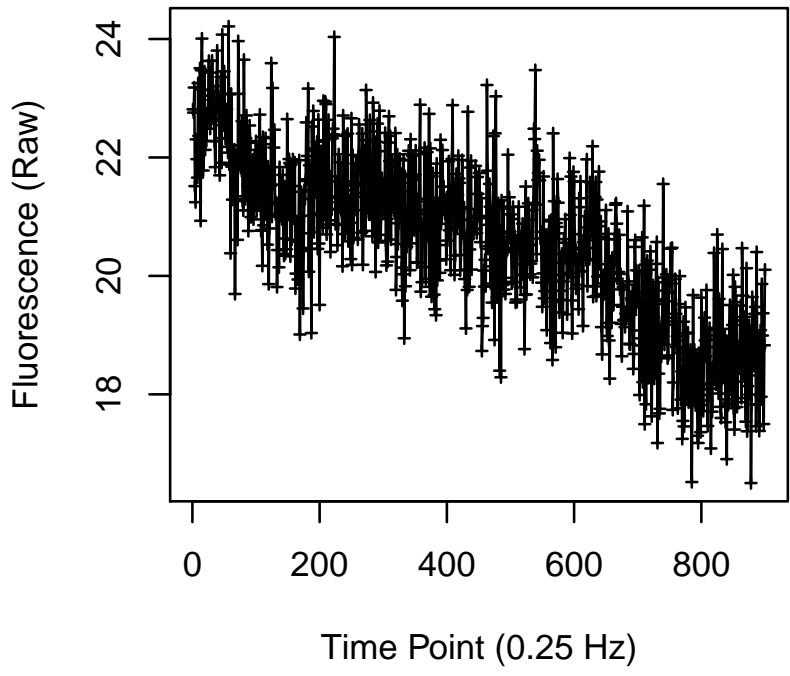

Cell 4

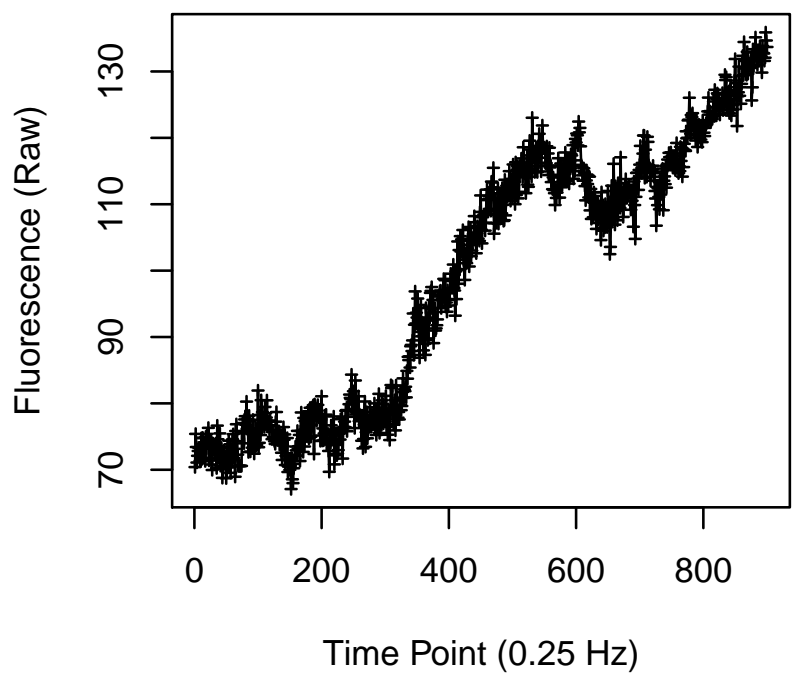


Cell 5

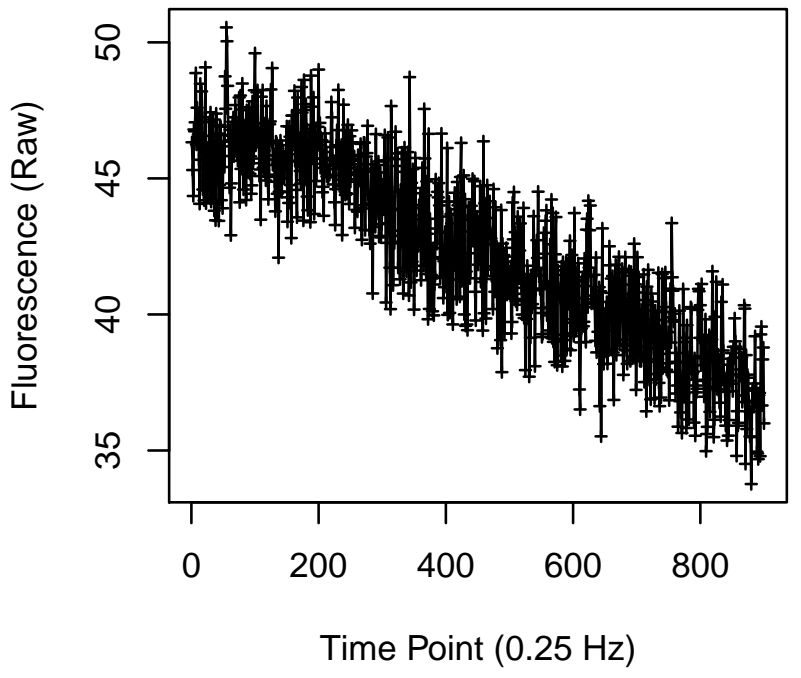

Cell 7

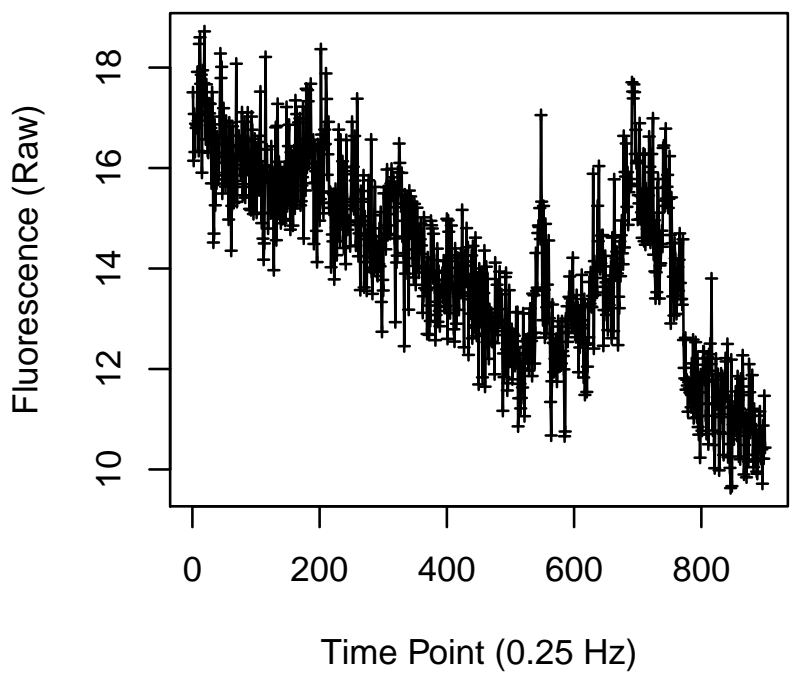

Cell 6

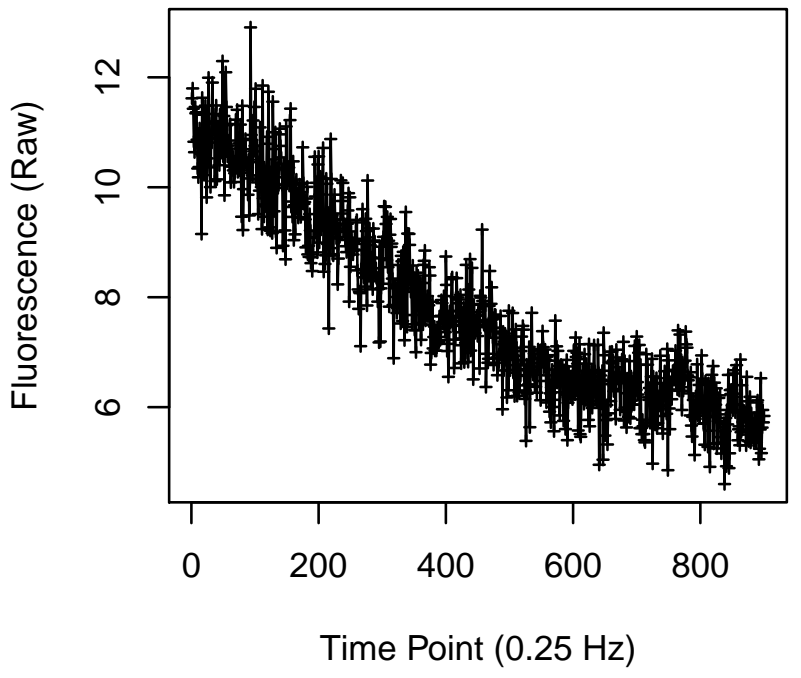

Cell 8

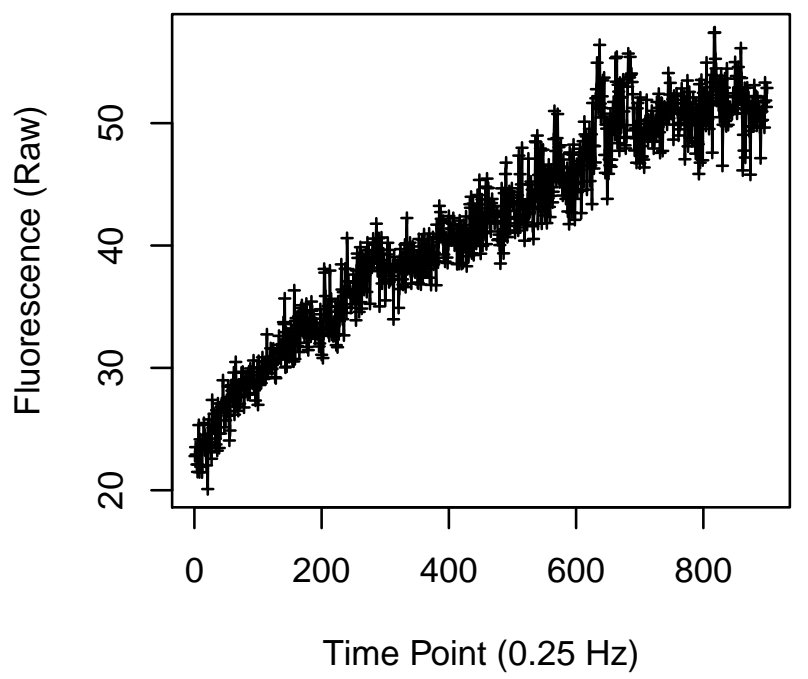


Cell 17

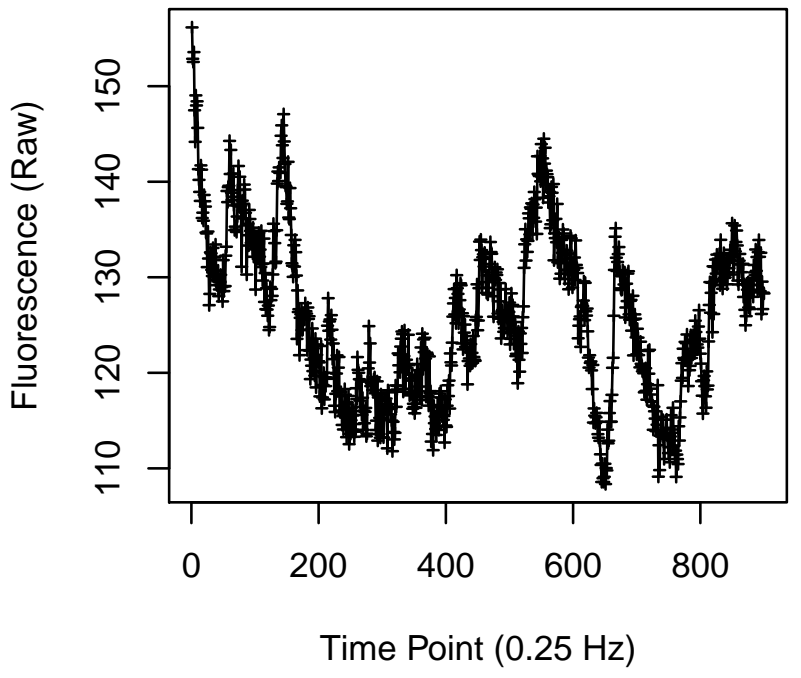

Cell 19

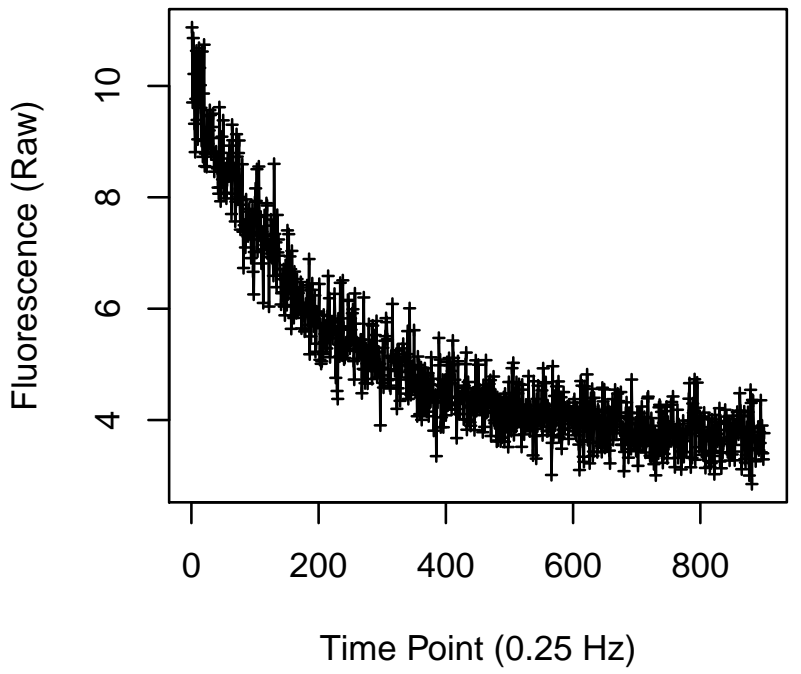

Cell 18

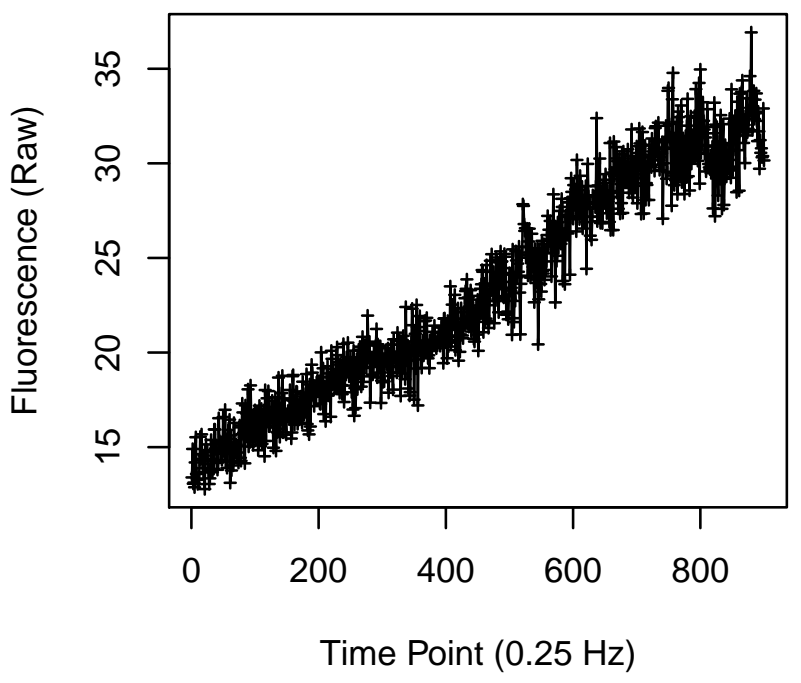

Cell 20

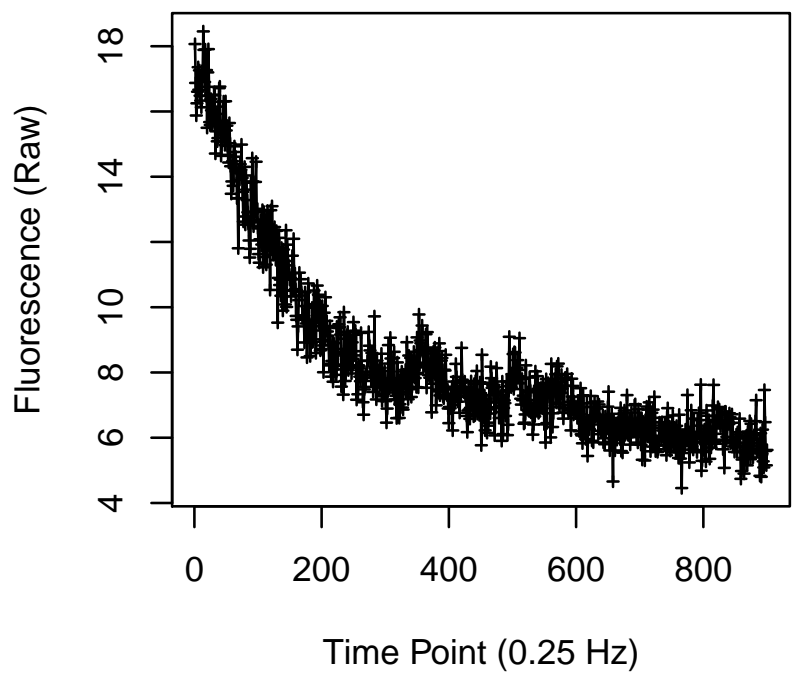


Cell 25

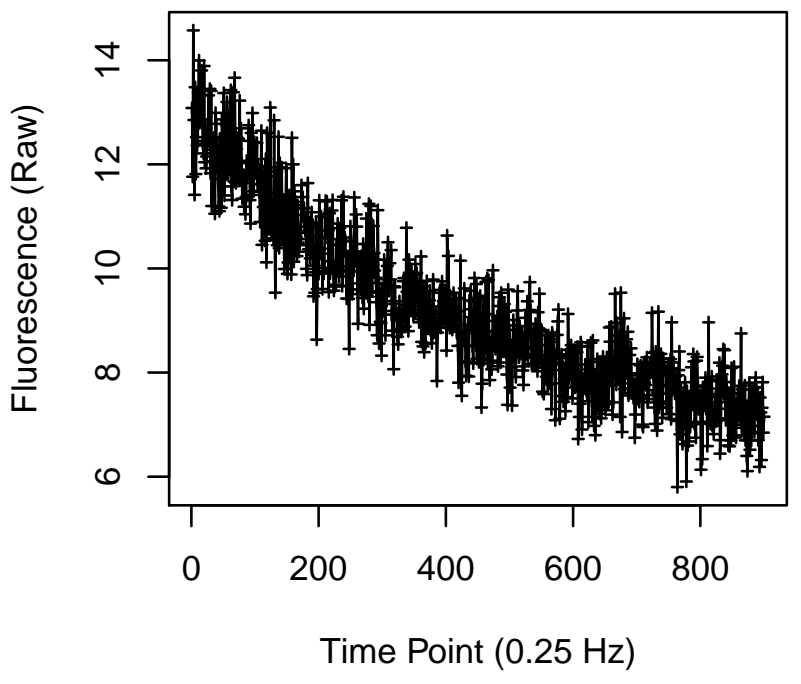

Cell 27

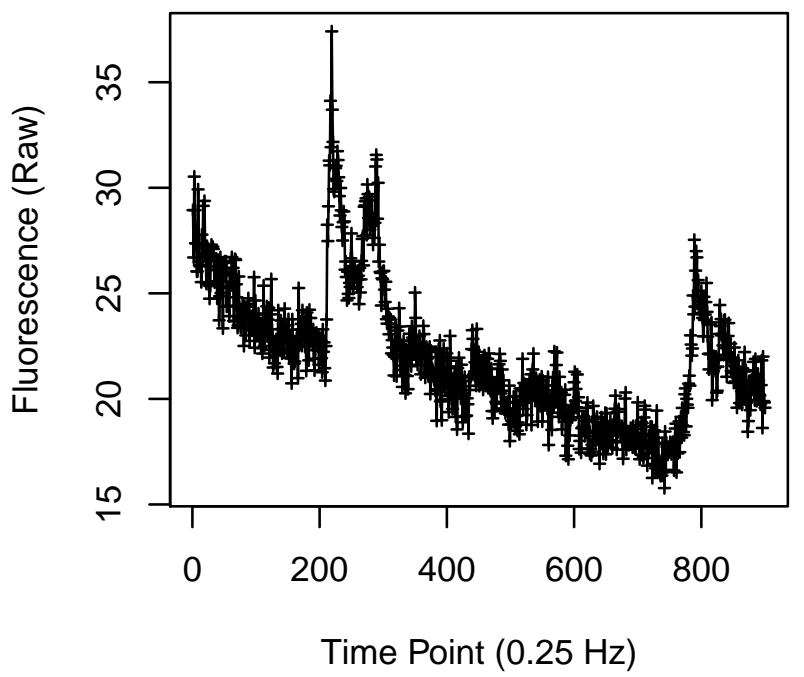

Cell 26

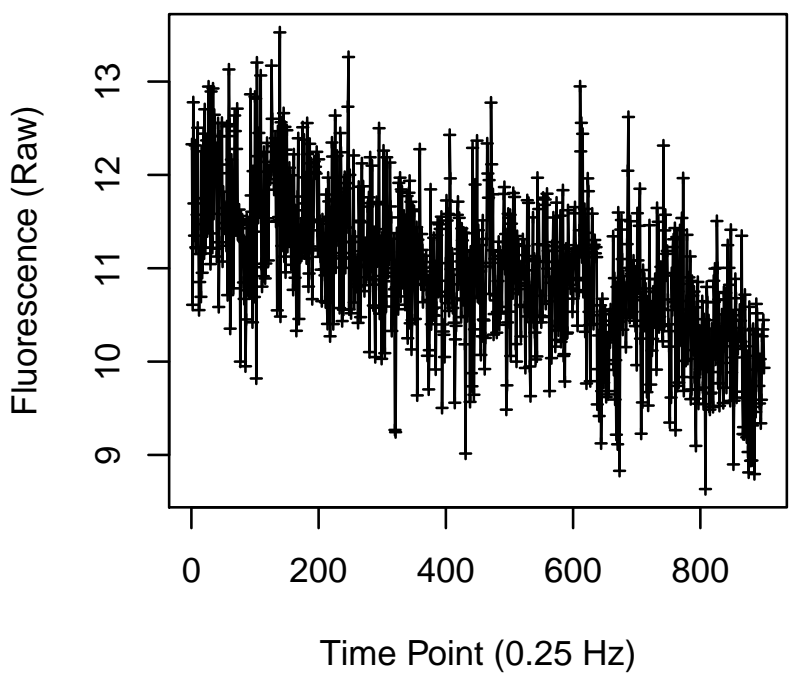

Cell 28

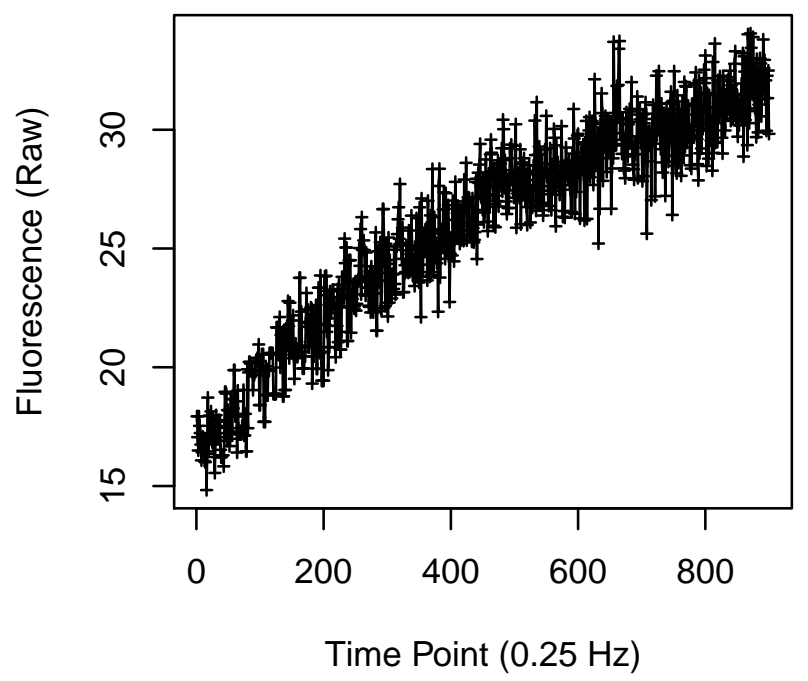


Cell 29

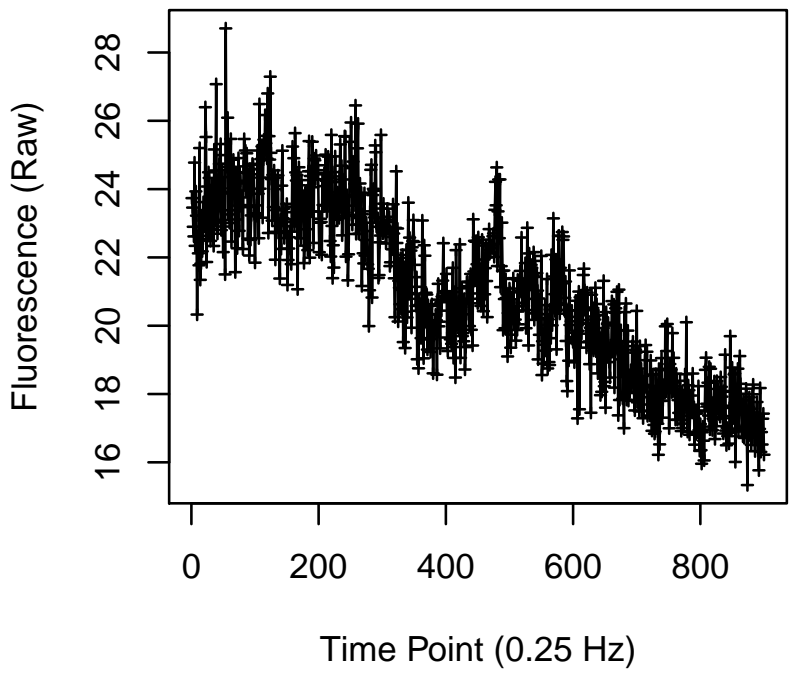

Cell 31

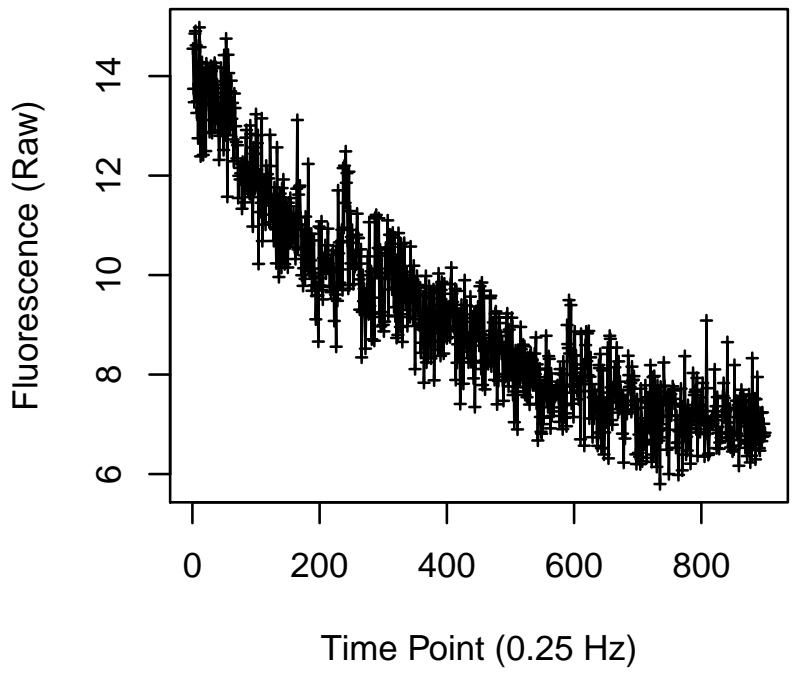

Cell 30

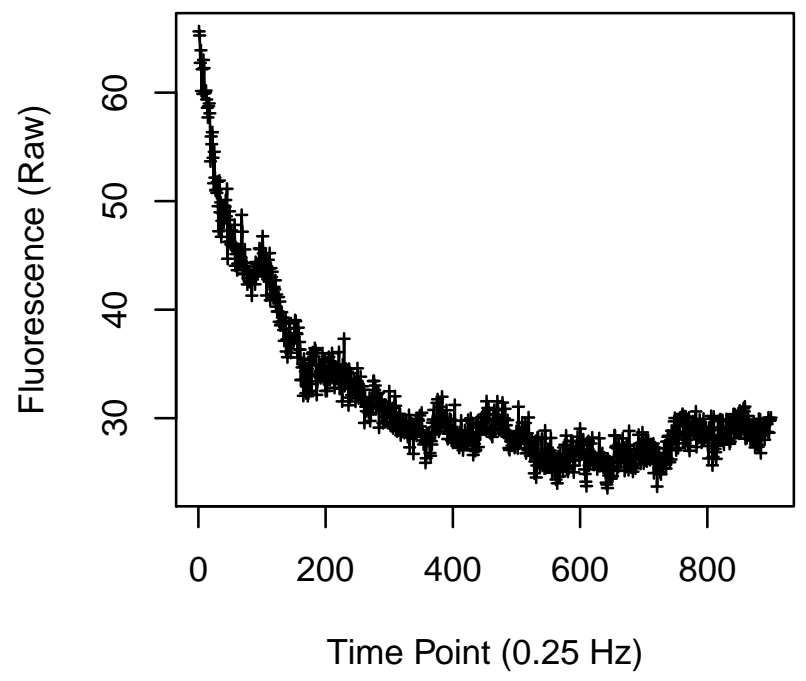

Cell 32

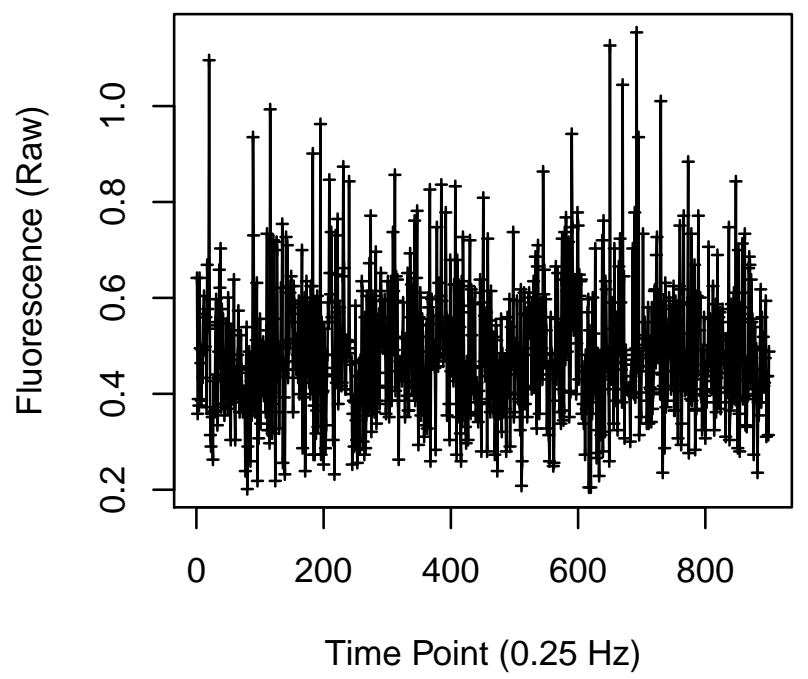


Cell 37

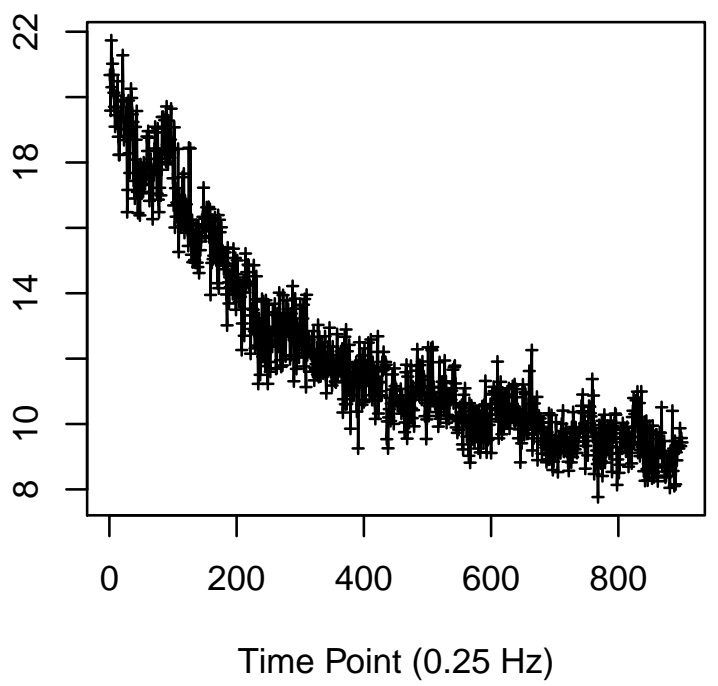

Cell 39

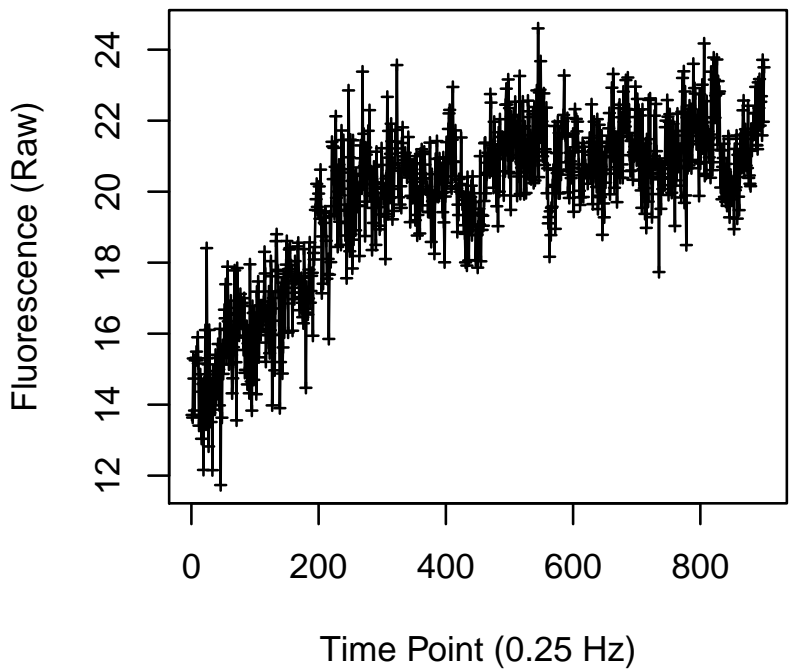

Cell 38

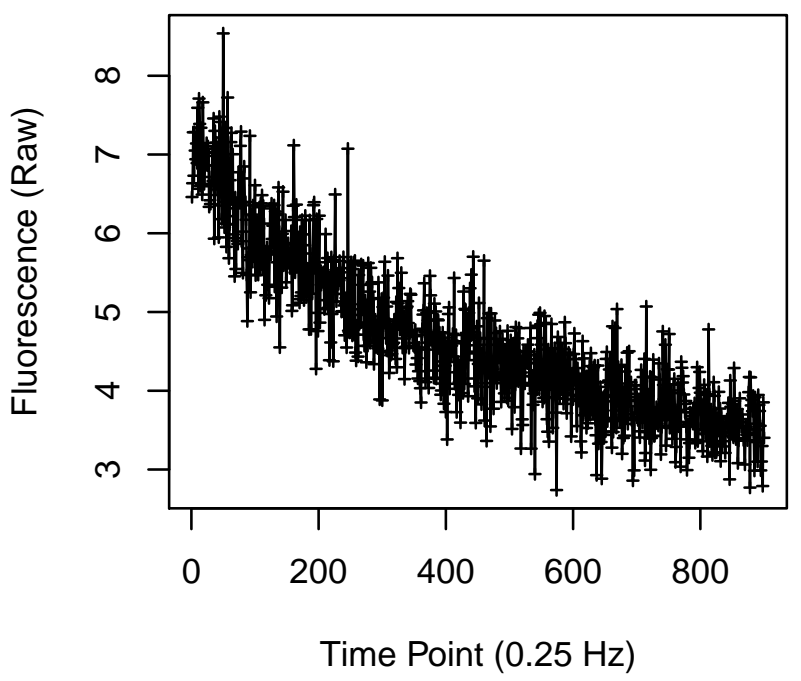

Cell 40

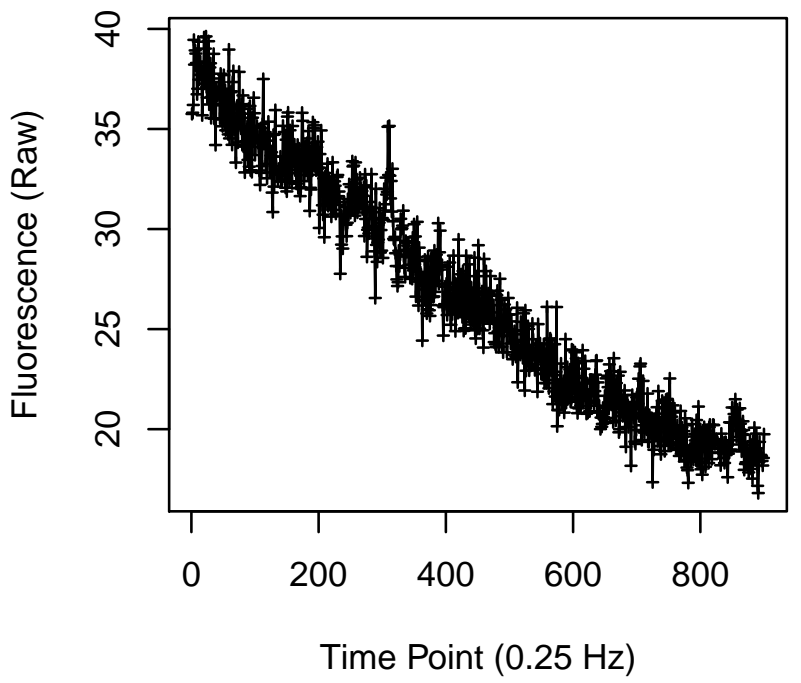


Cell 41

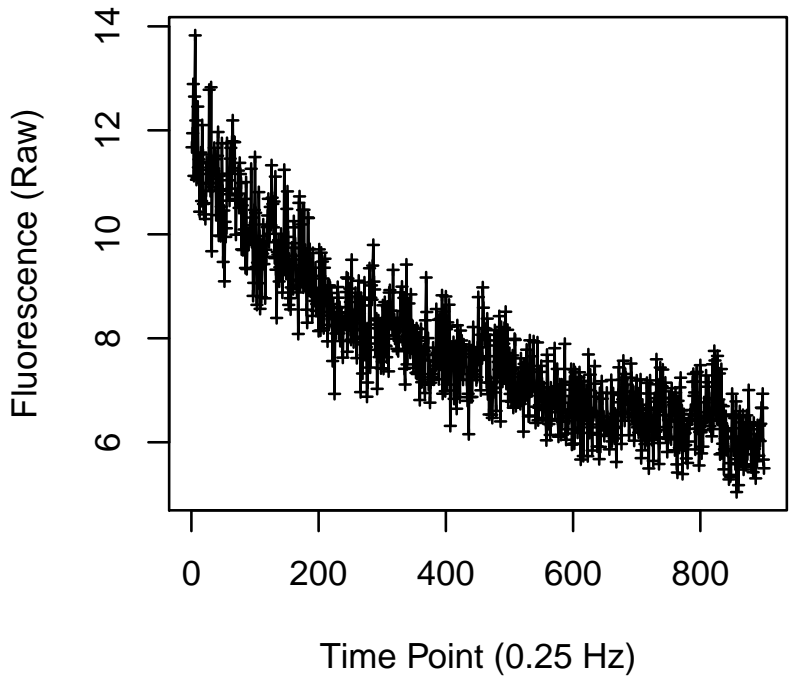

Cell 43

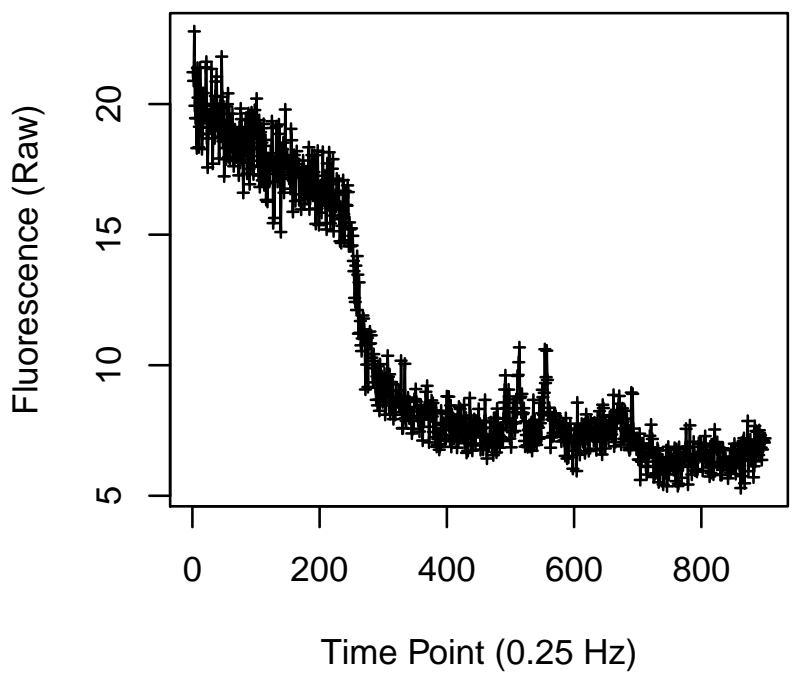

Cell 42

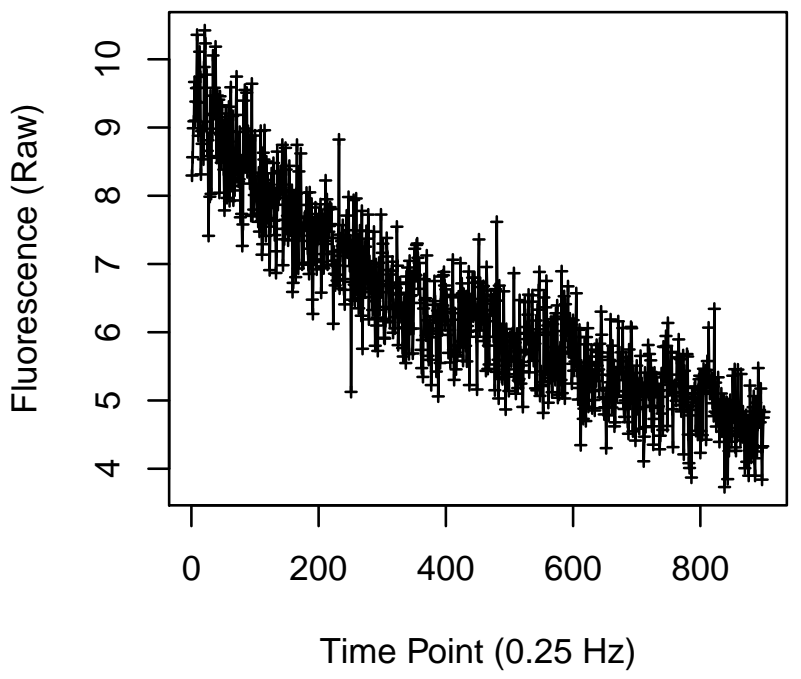

Cell 44

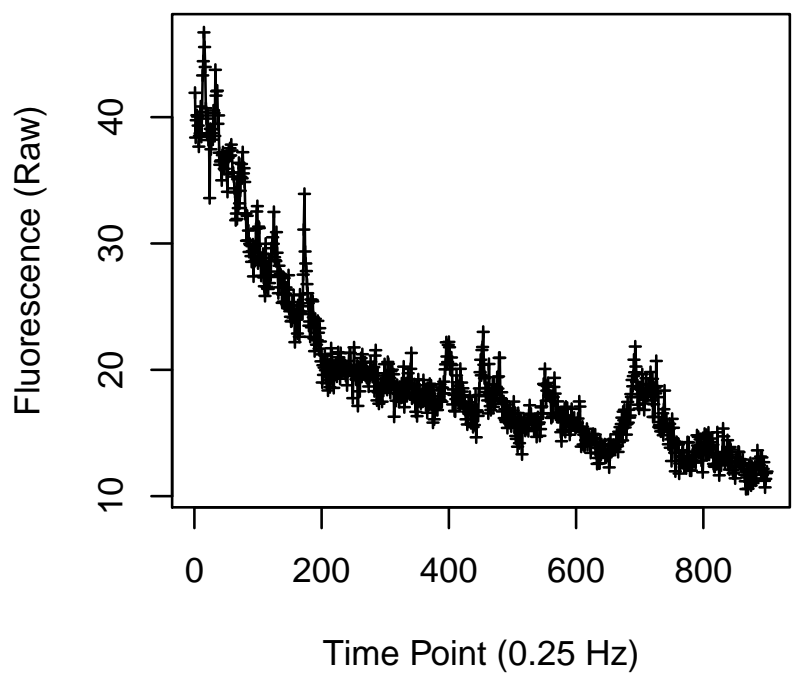


Cell 45

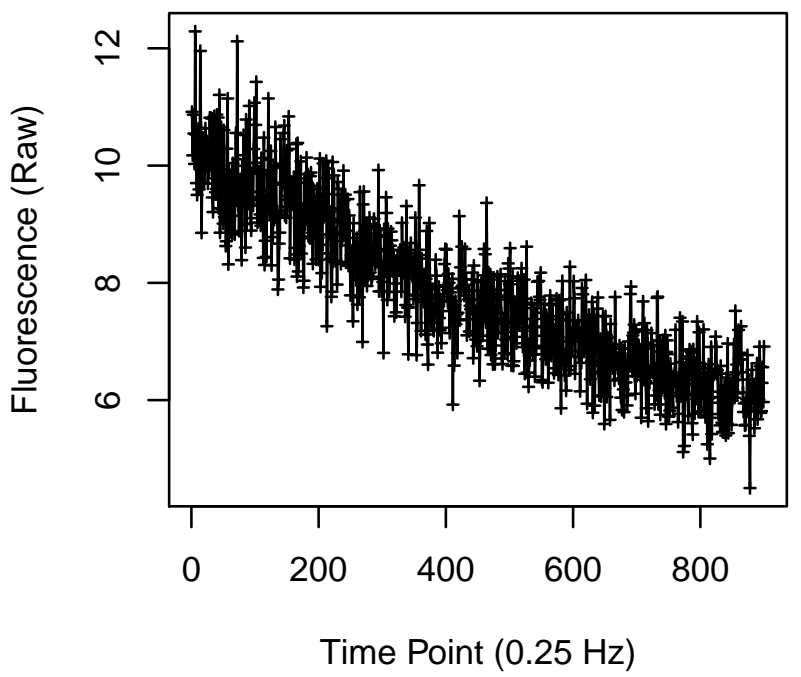

Cell 47

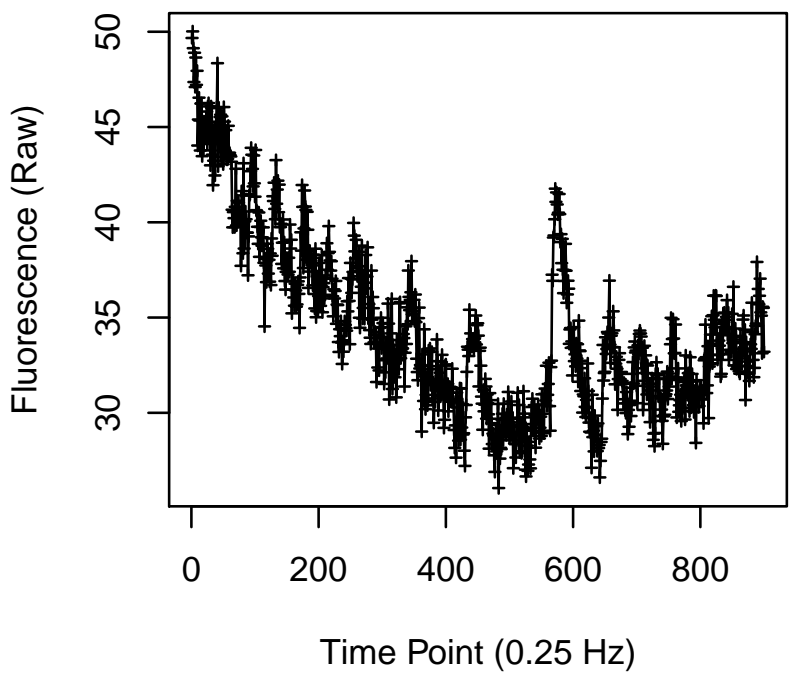

Cell 46

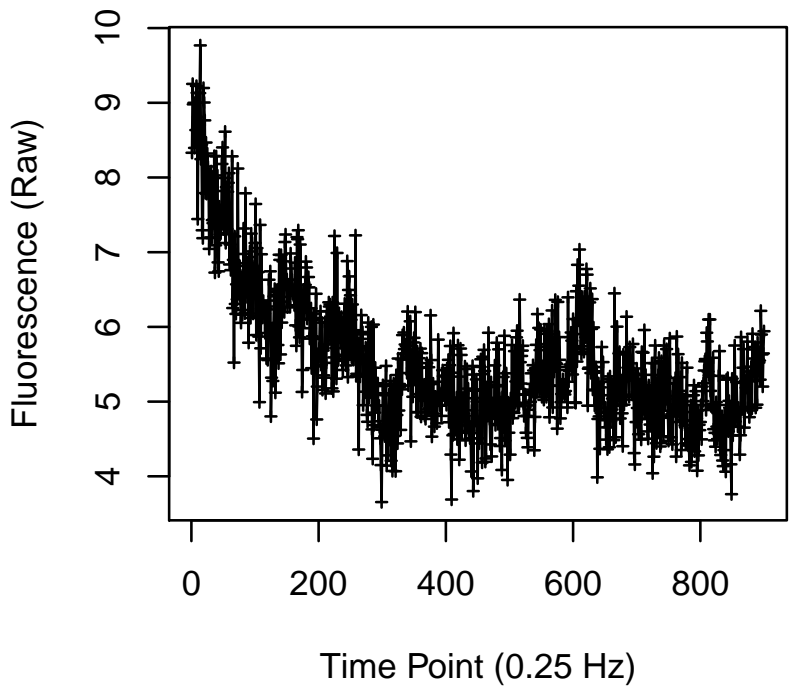

Cell 48

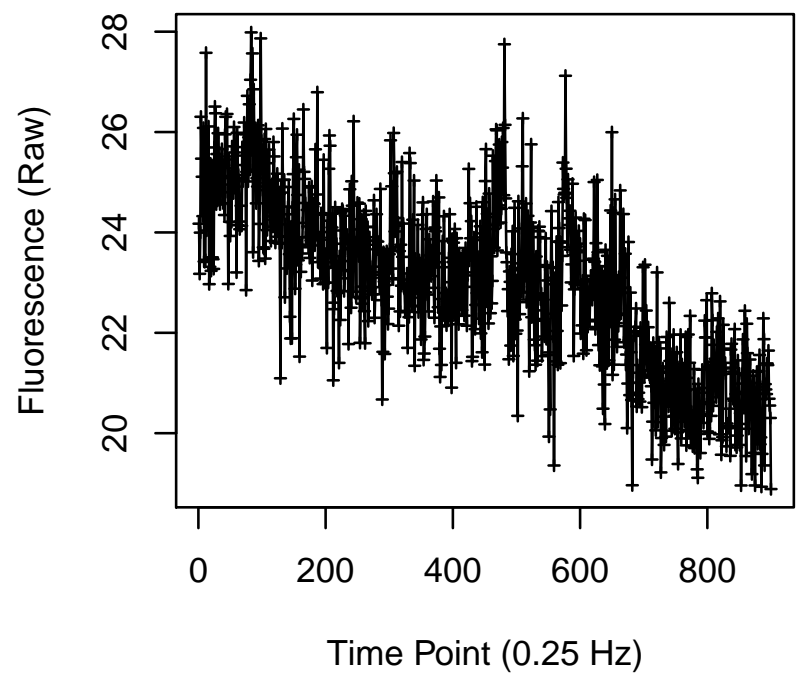


Cell 49

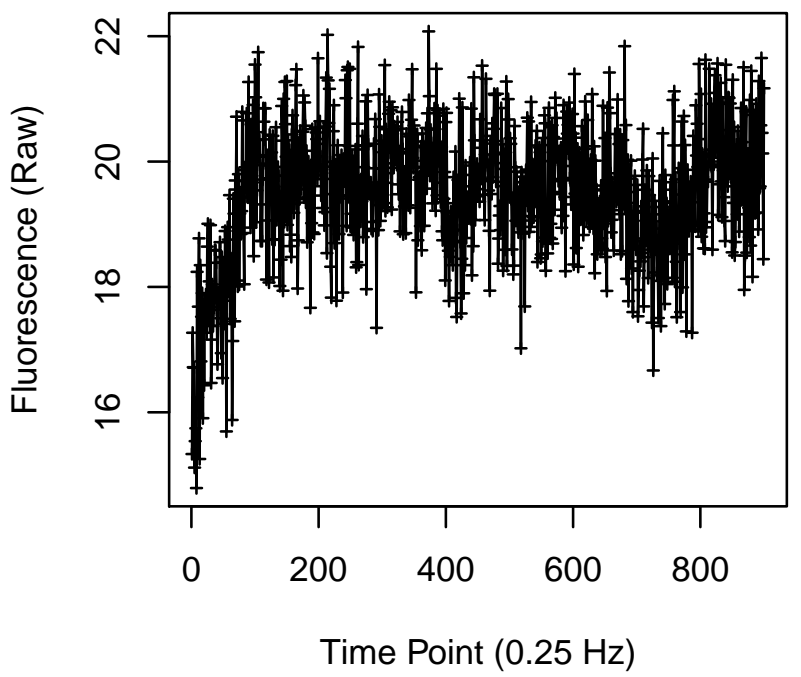

Cell 51

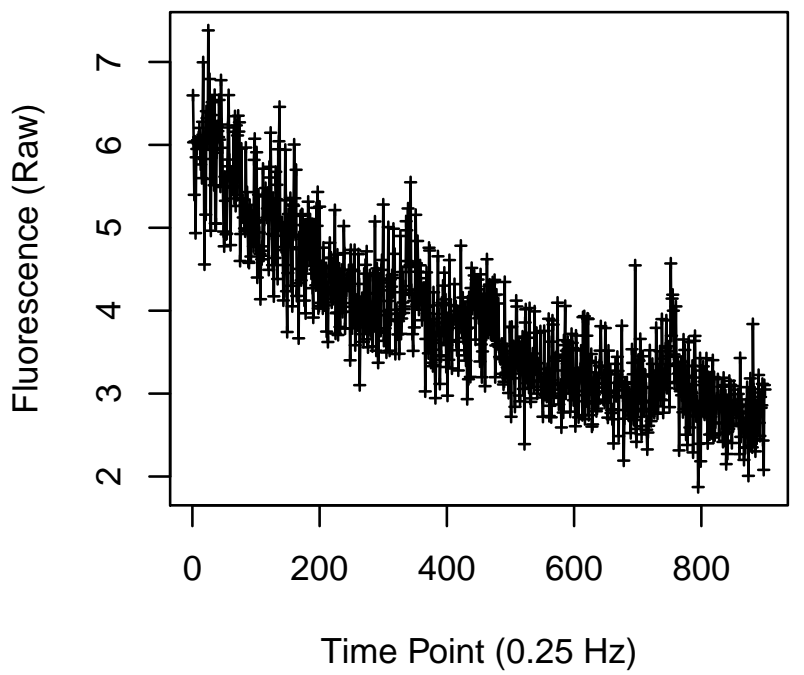

Cell 50

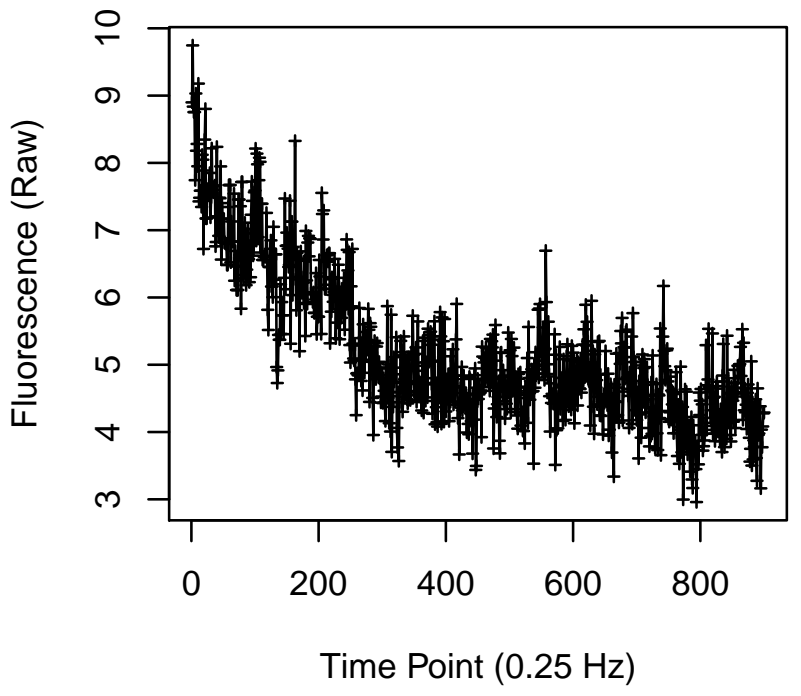

Cell 52

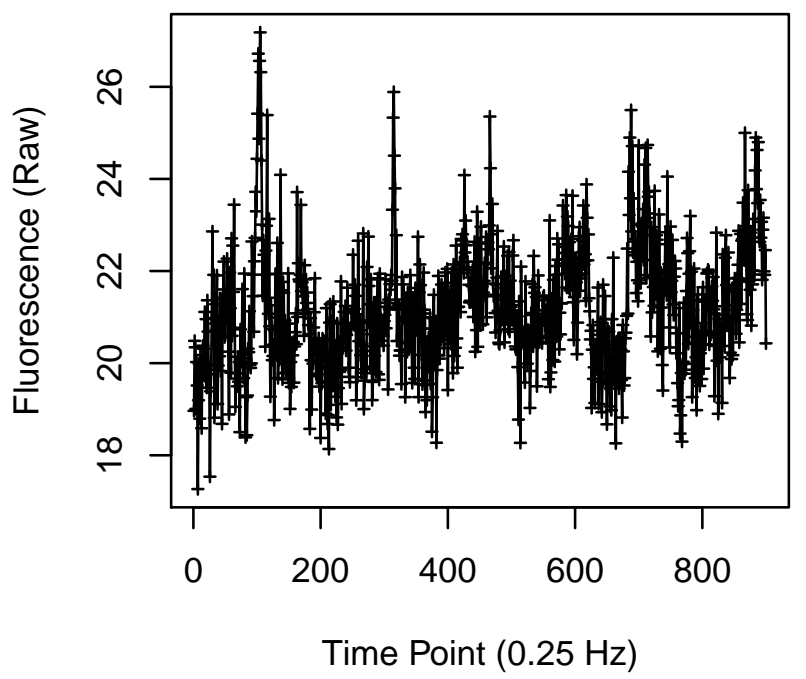


Cell 53

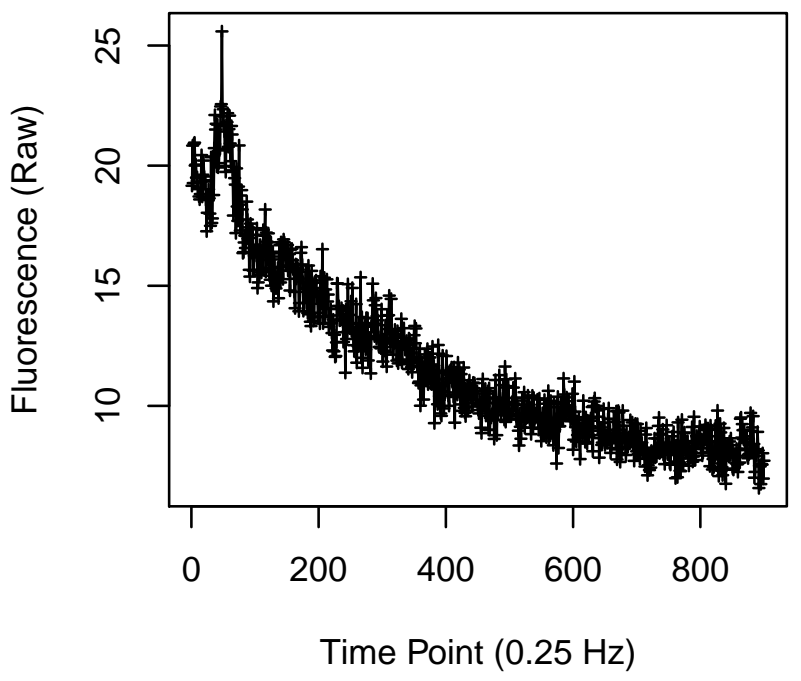

Cell 55

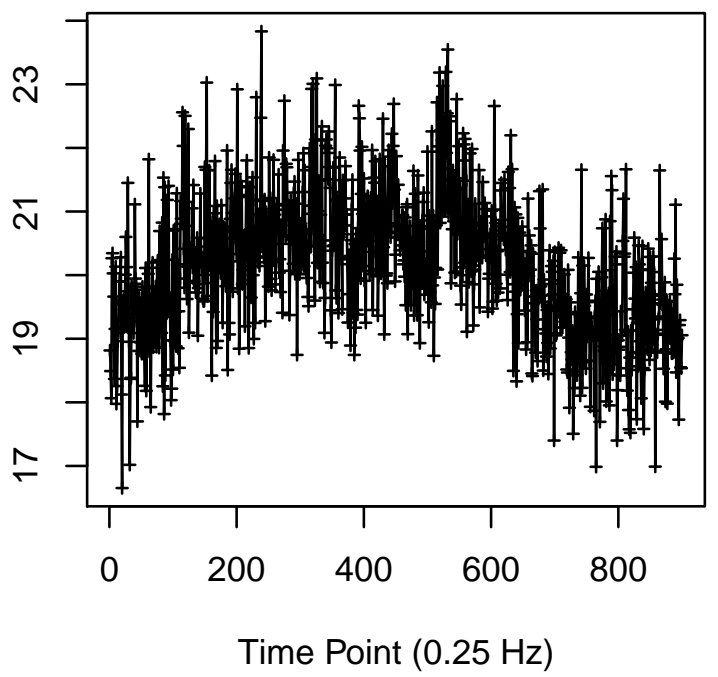

Cell 54

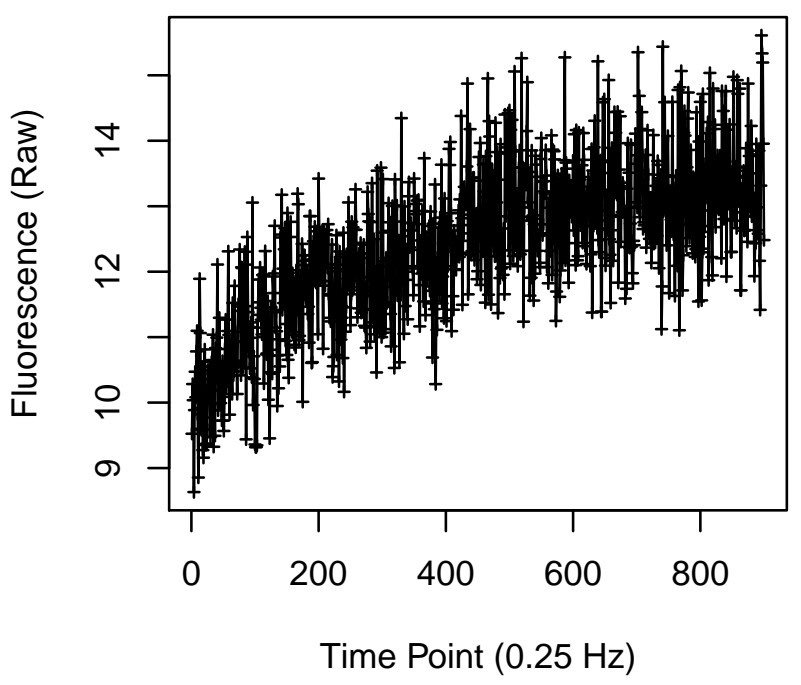

Cell 56

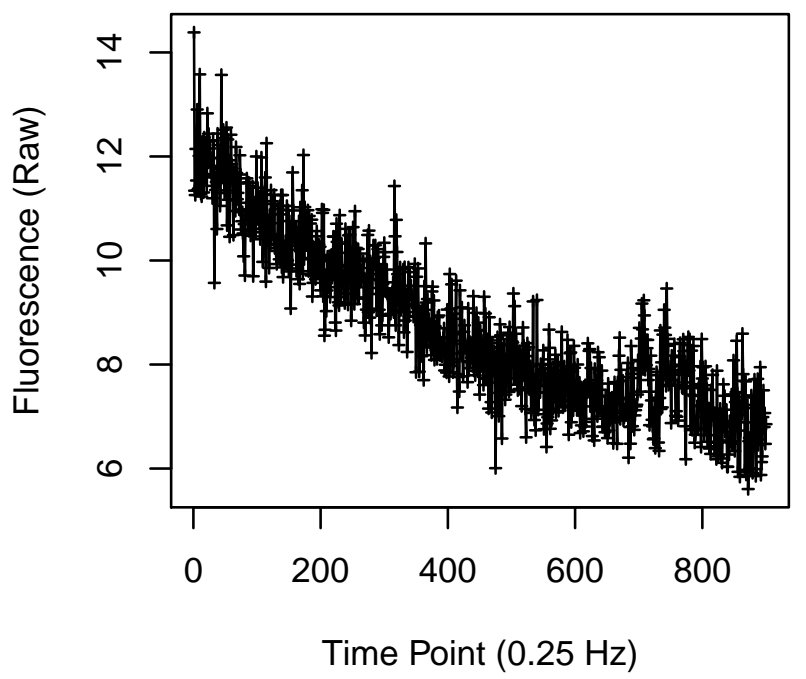


Cell 57

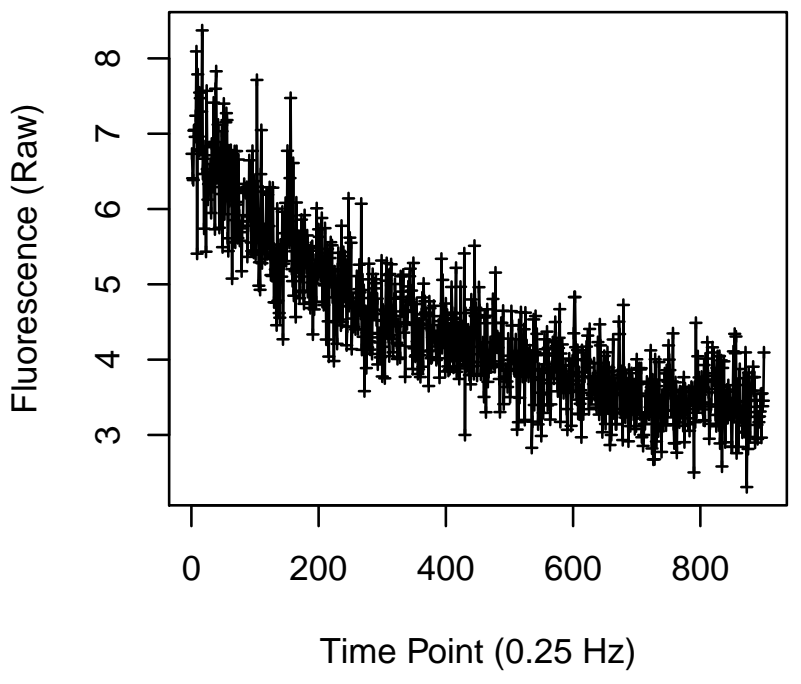

Cell 59

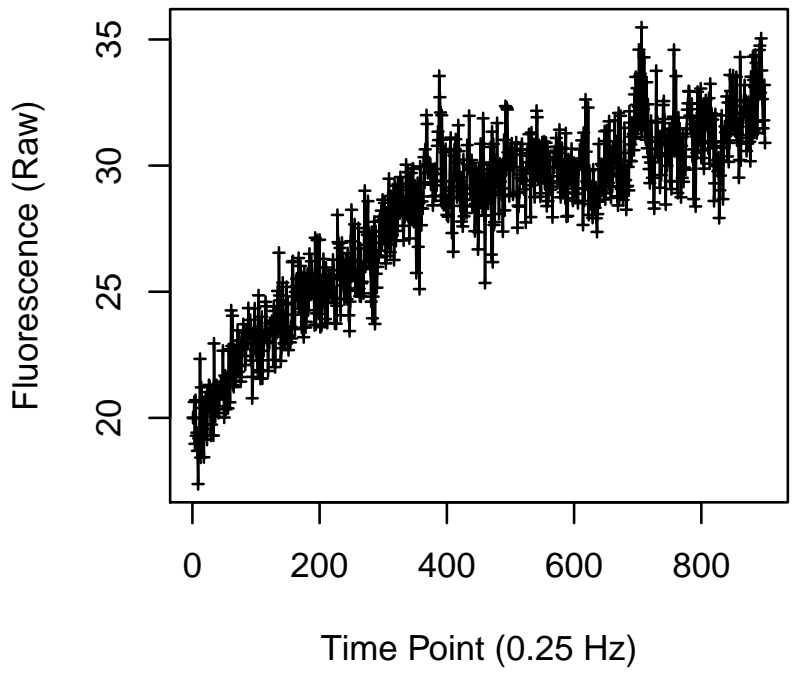

Cell 58

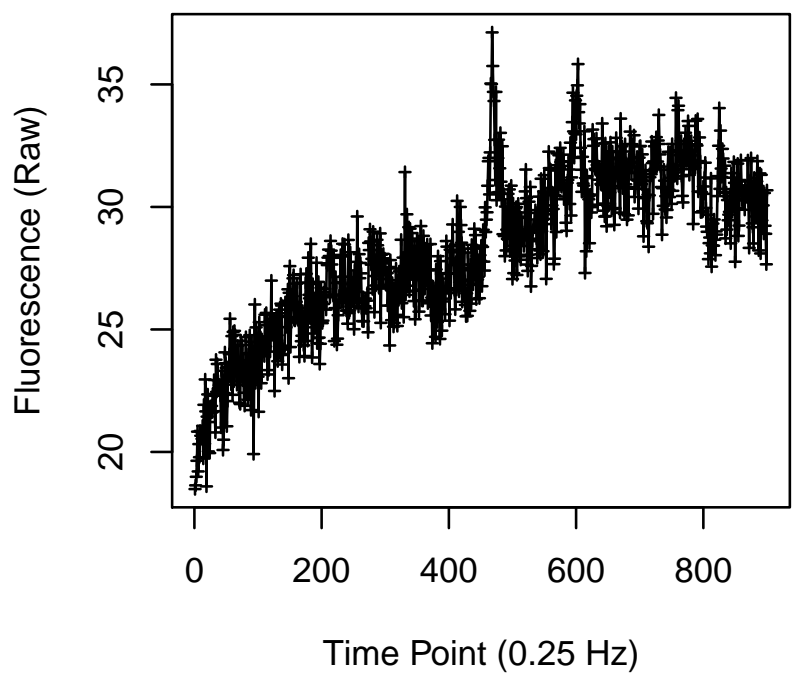

Cell 60

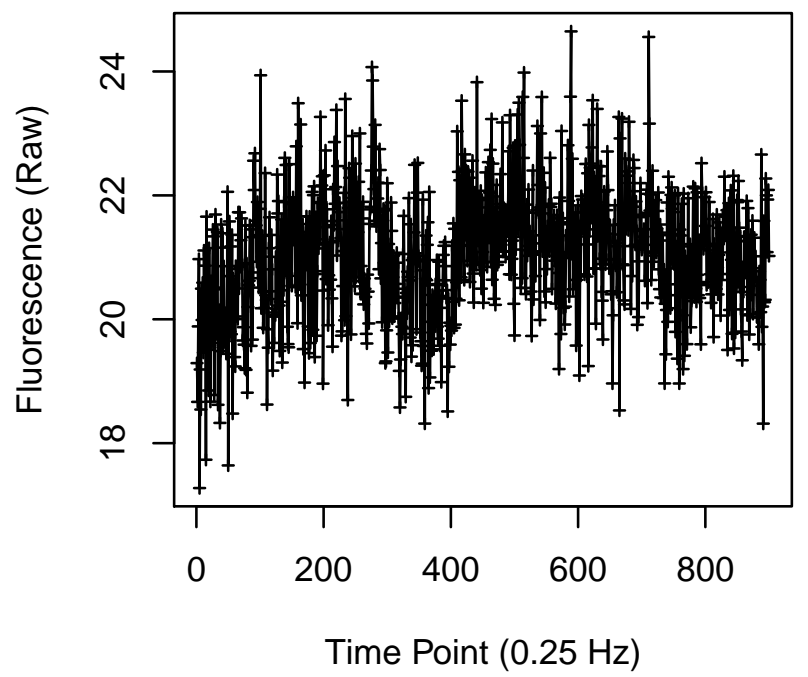


Cell 65

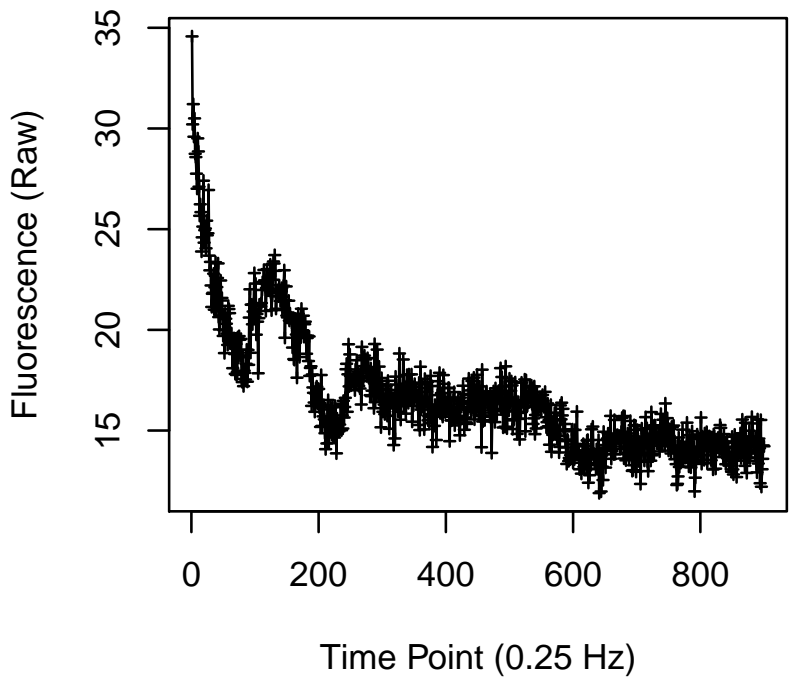

Cell 67

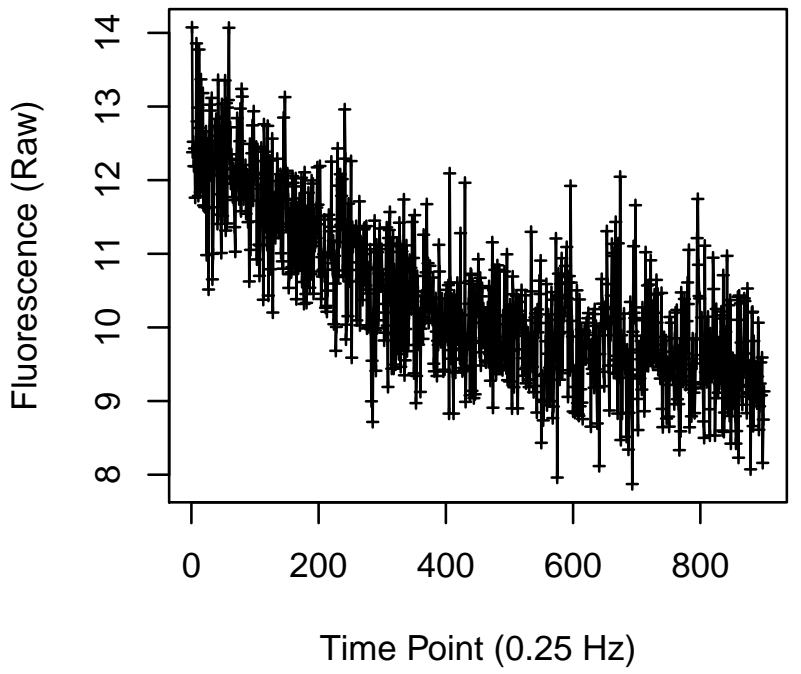

Cell 66

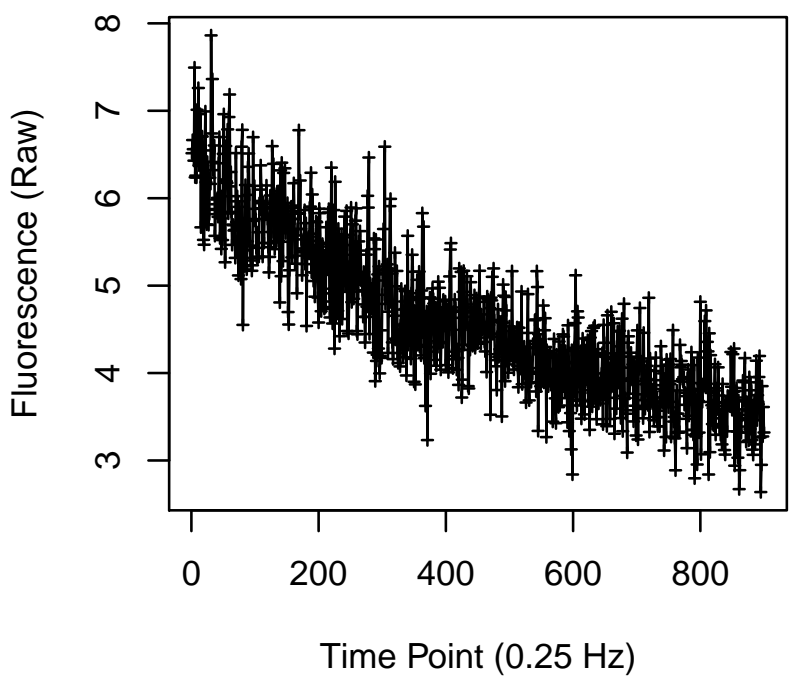

Cell 68

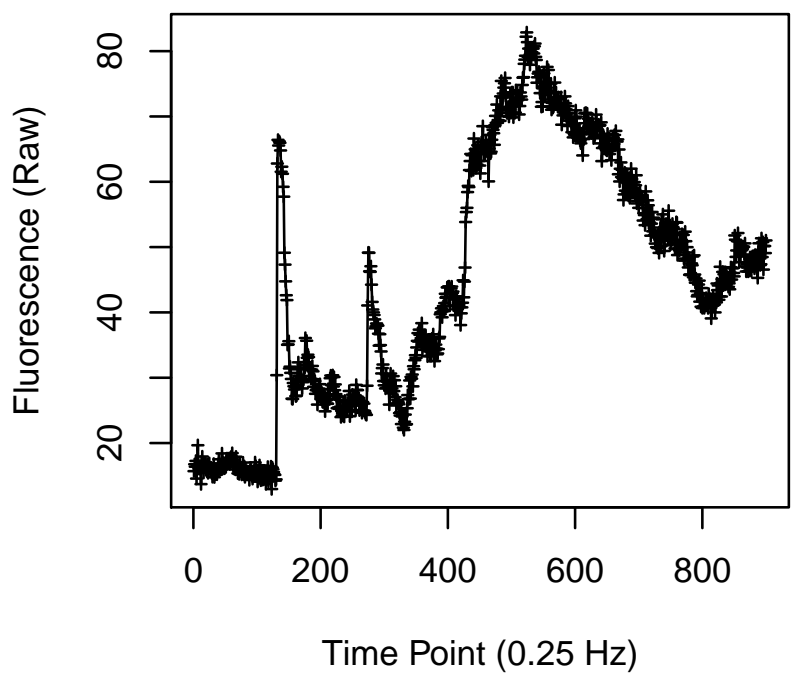




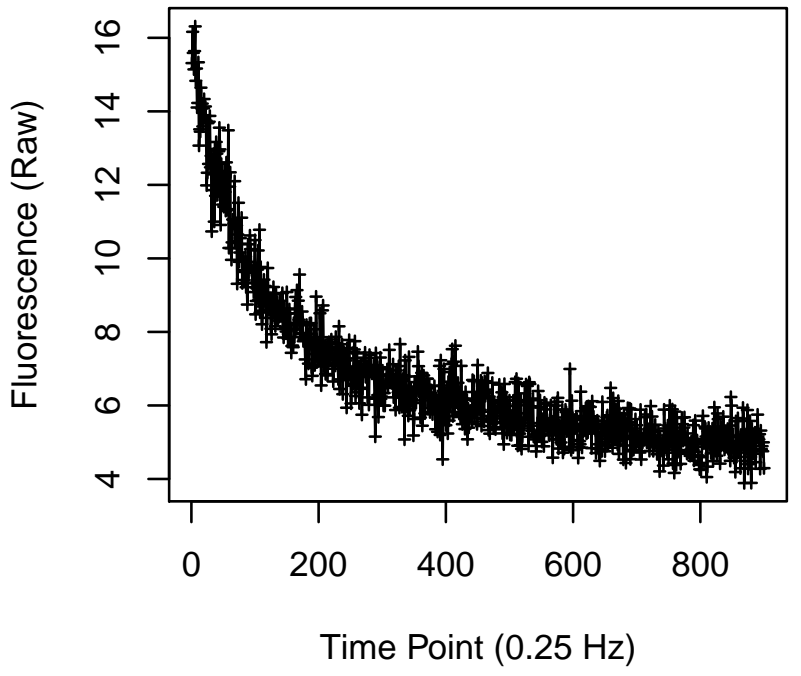

Cell 71

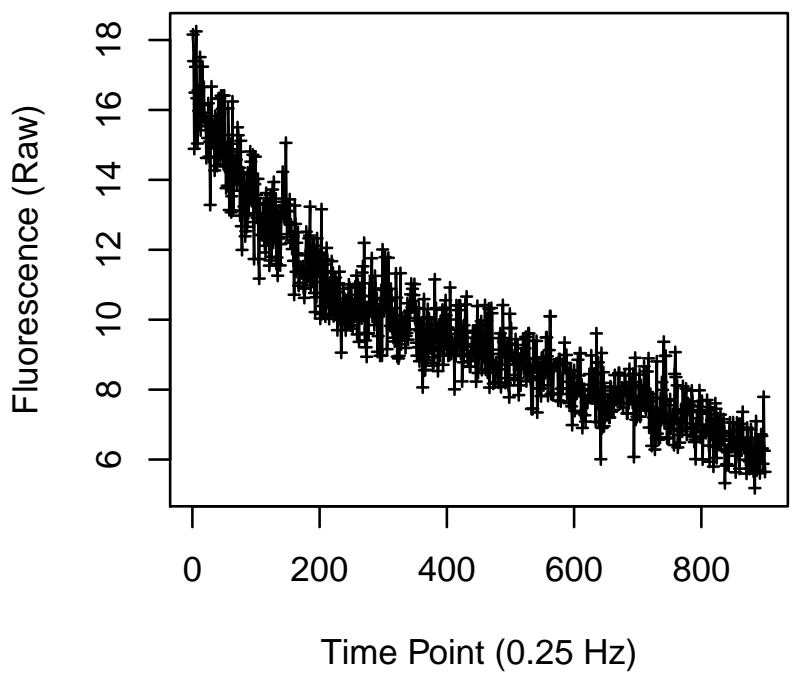

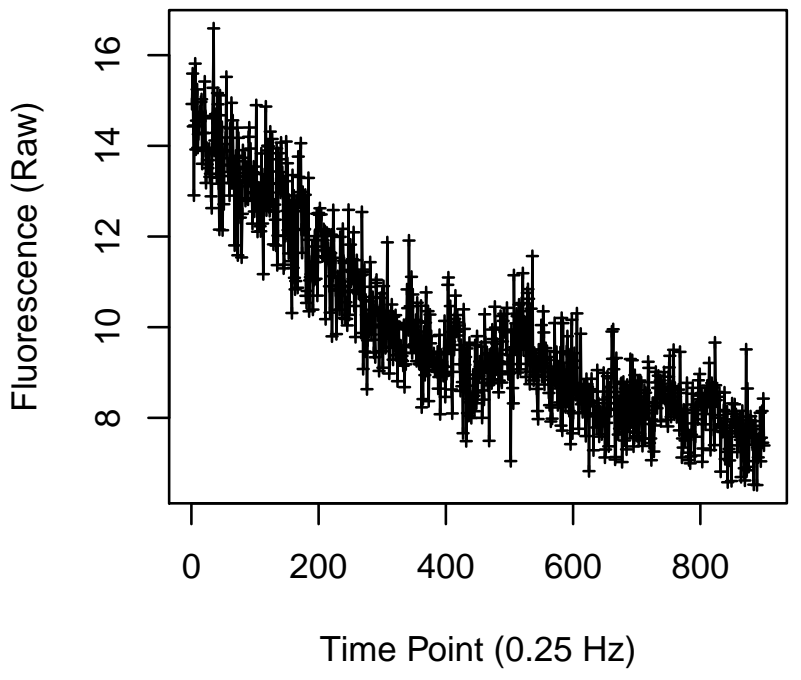

Cell 72

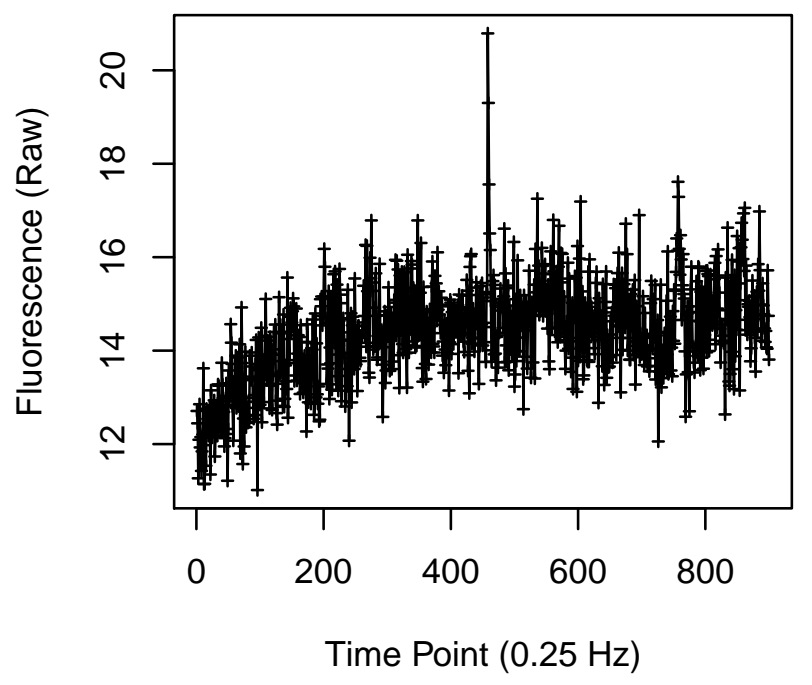


Cell 77

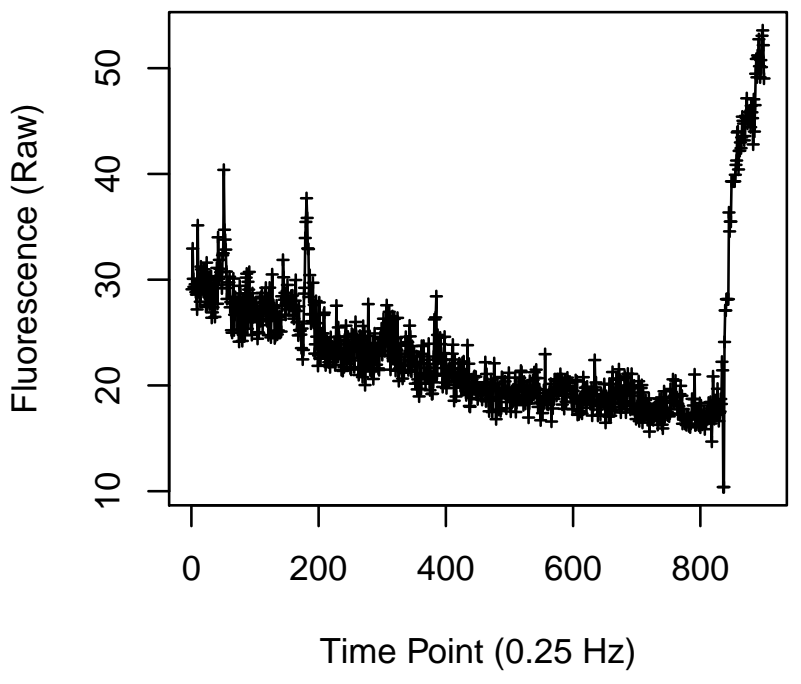

Cell 79

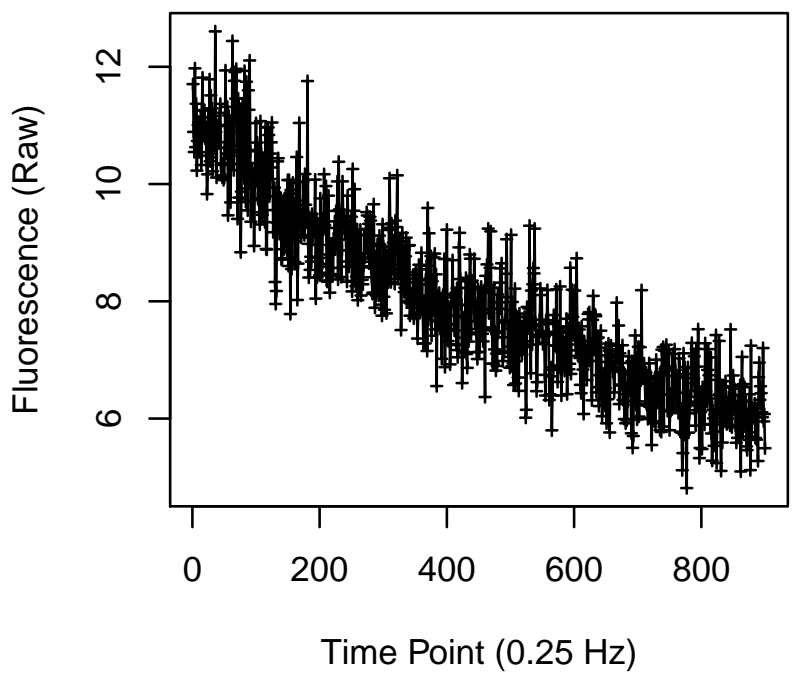

Cell 78

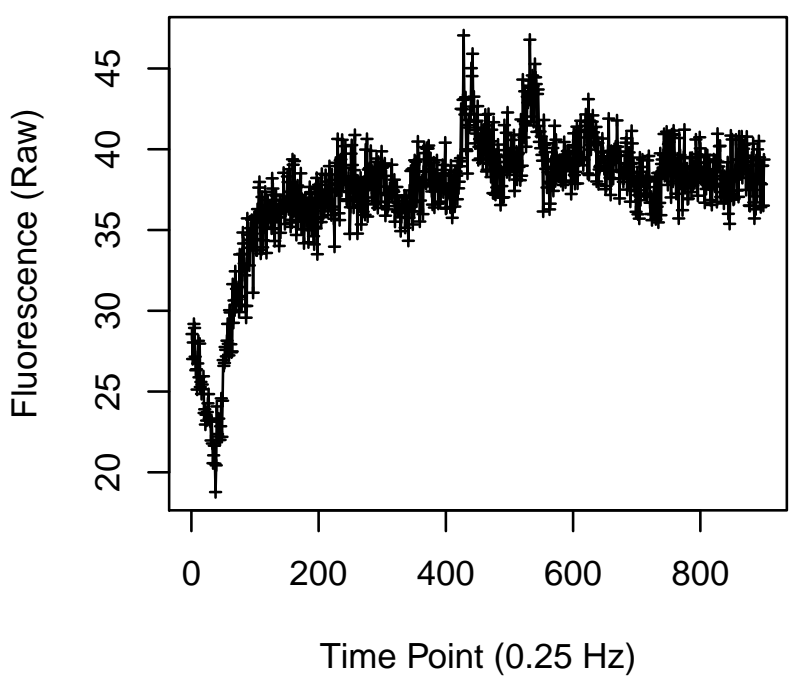

Cell 80

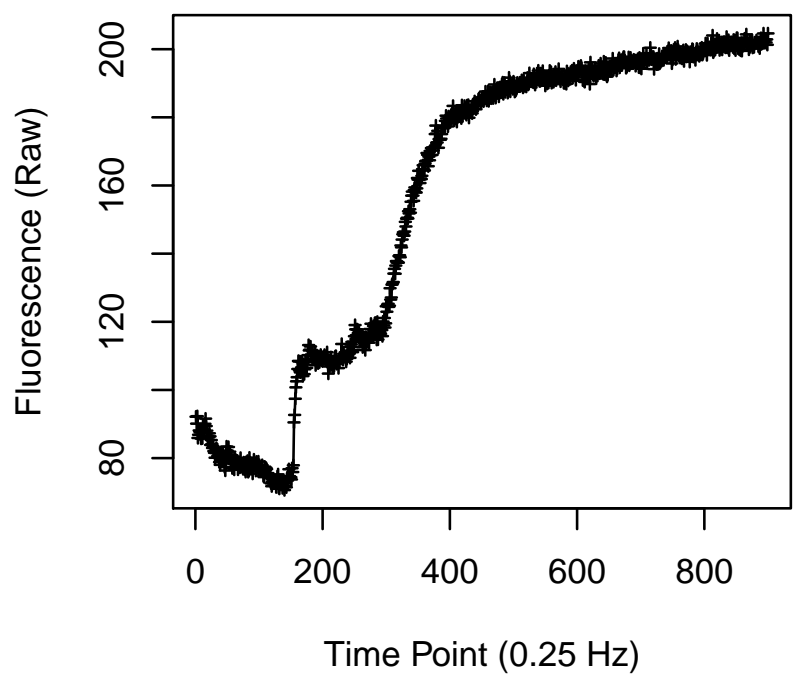


Cell 81

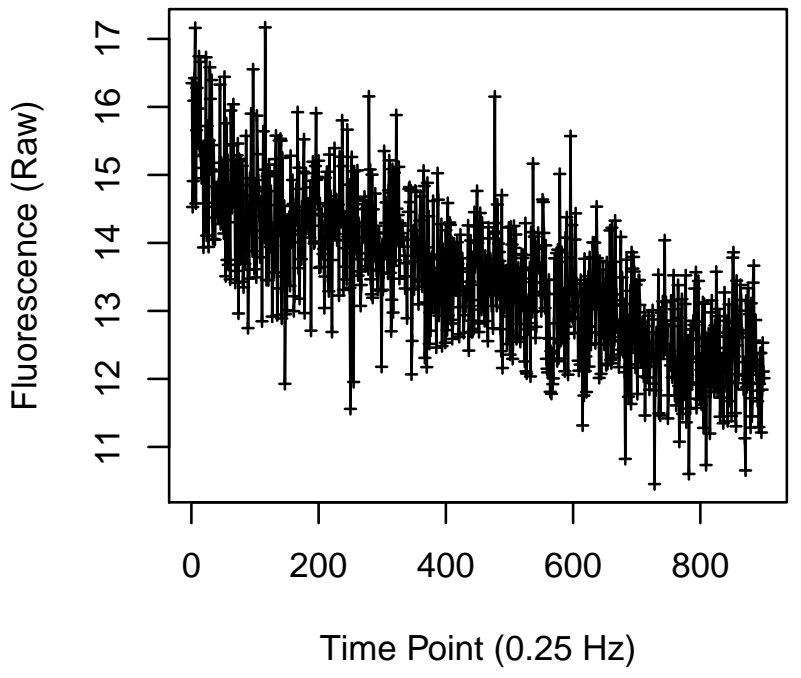

Cell 83

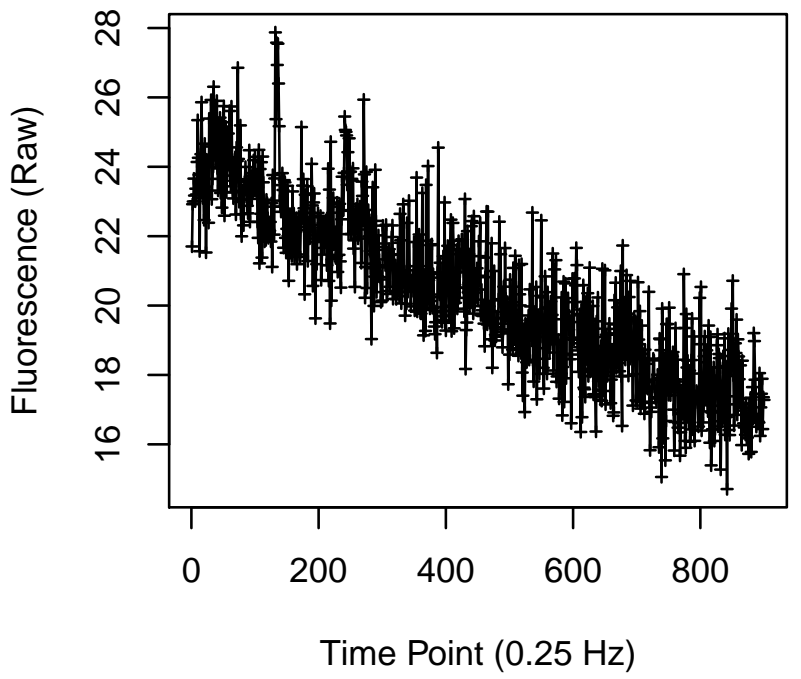

Cell 82

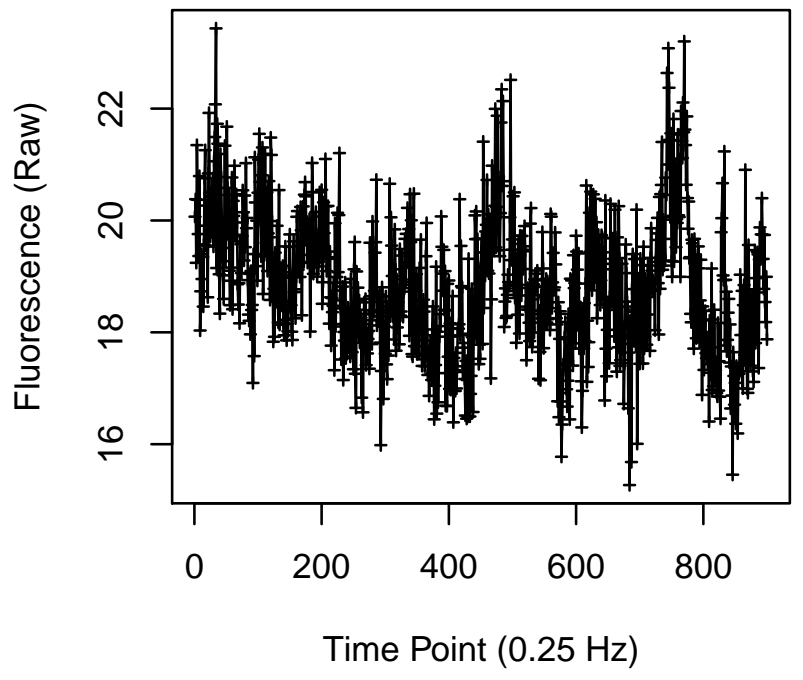

Cell 84

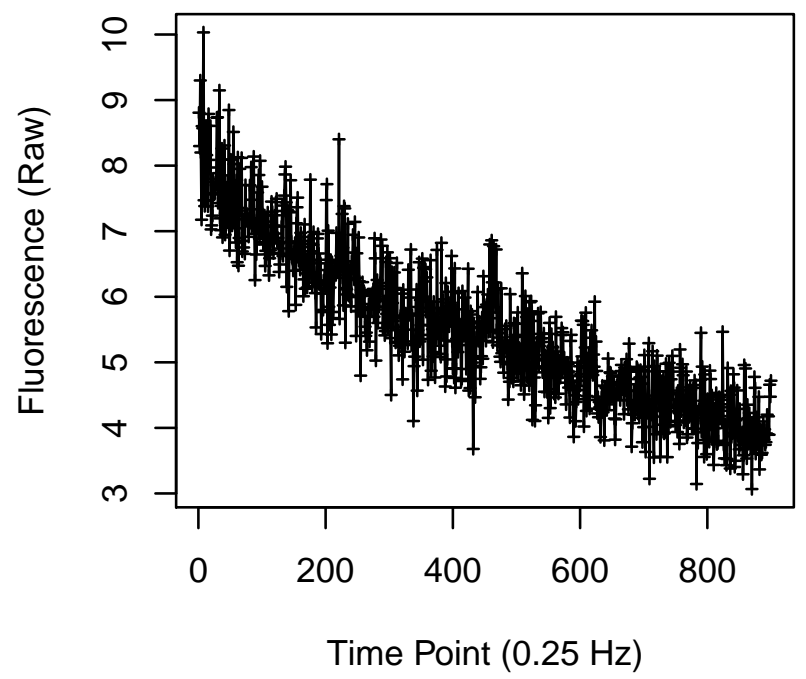




\section{Cell 85}

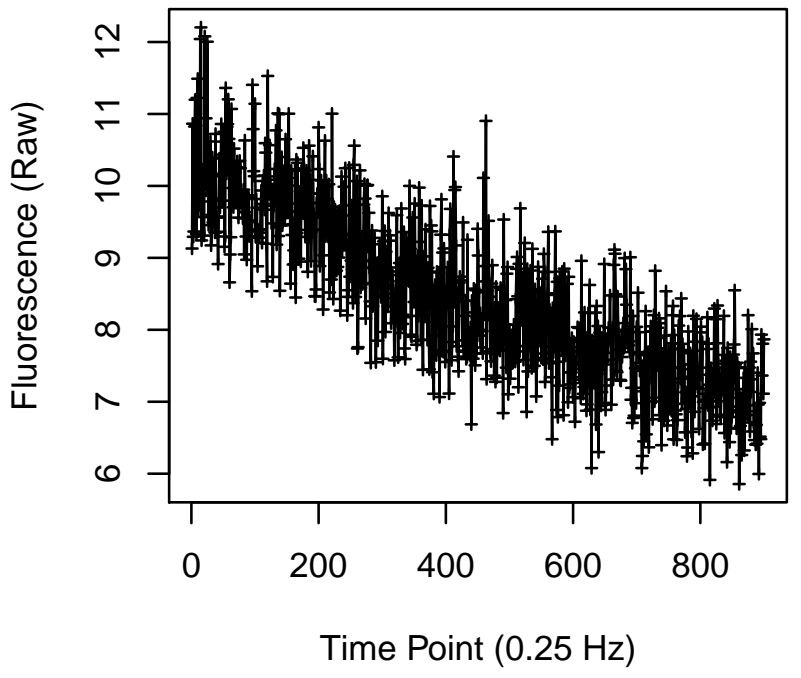

Cell 87

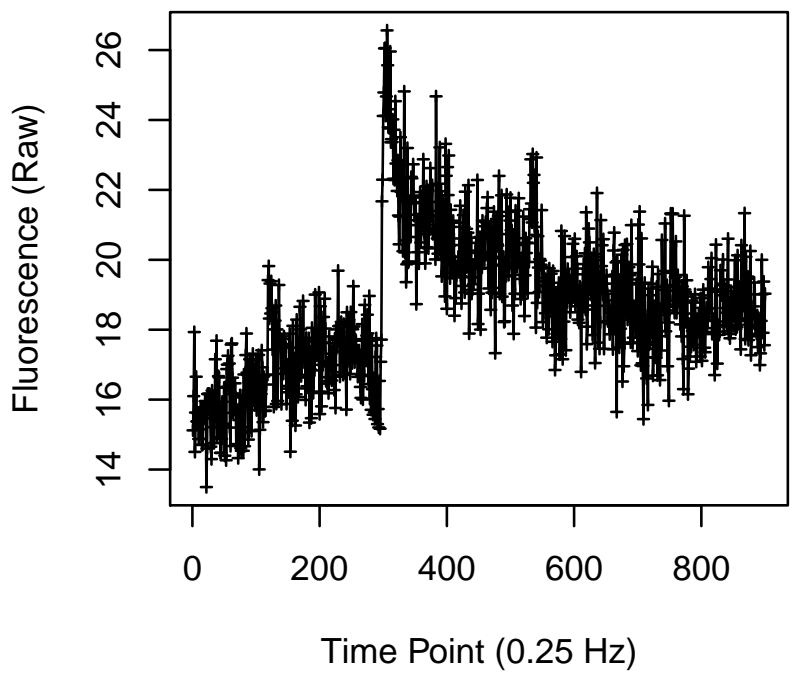

Cell 86

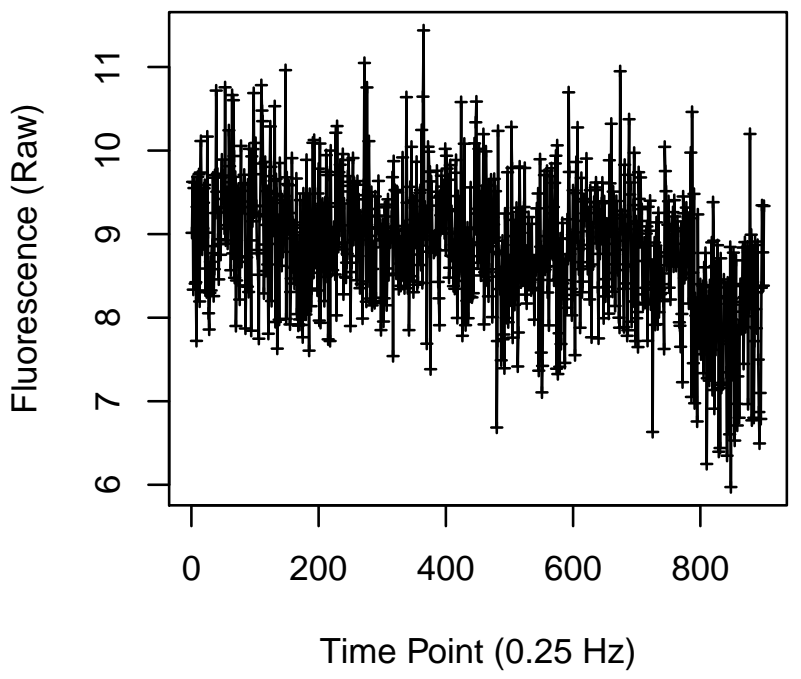

Cell 88

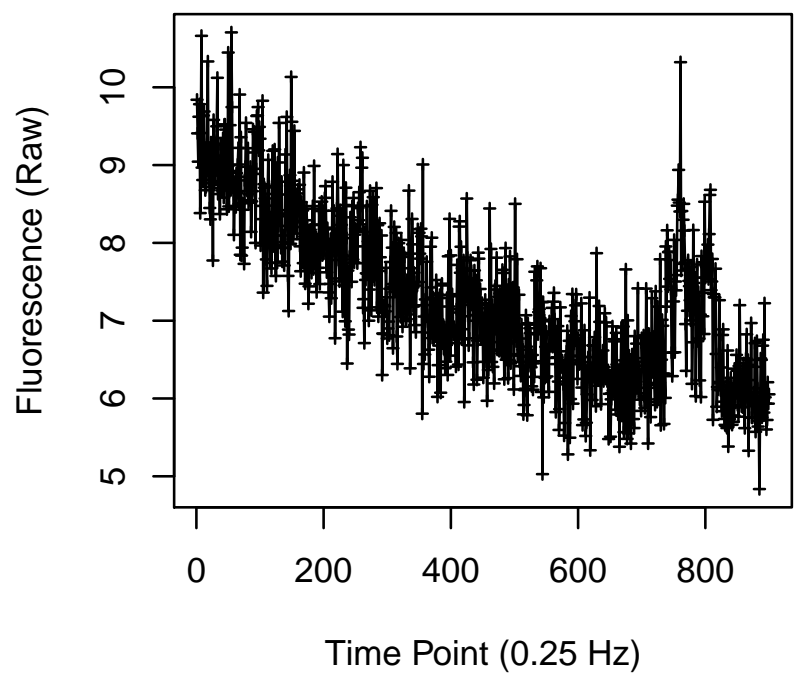


Cell 89

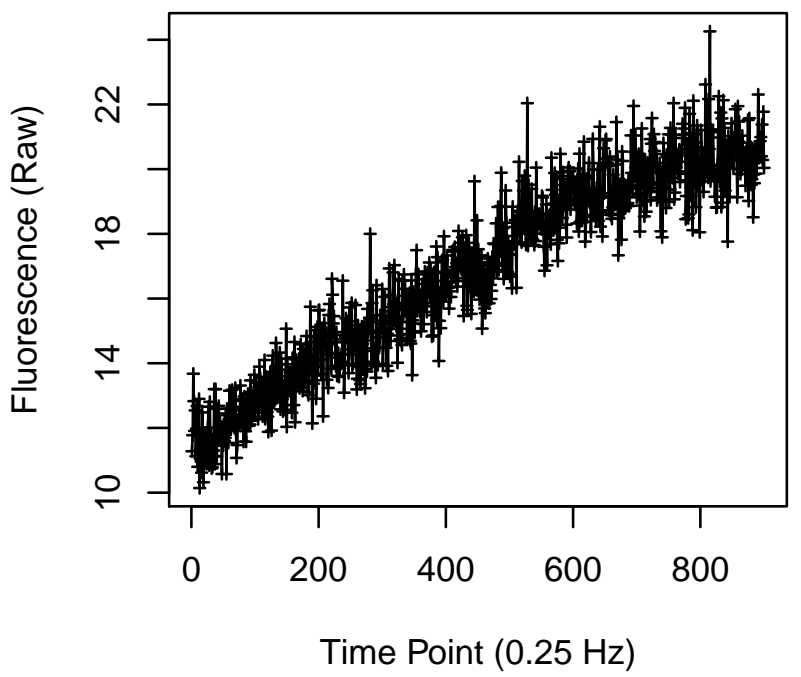

Cell 91

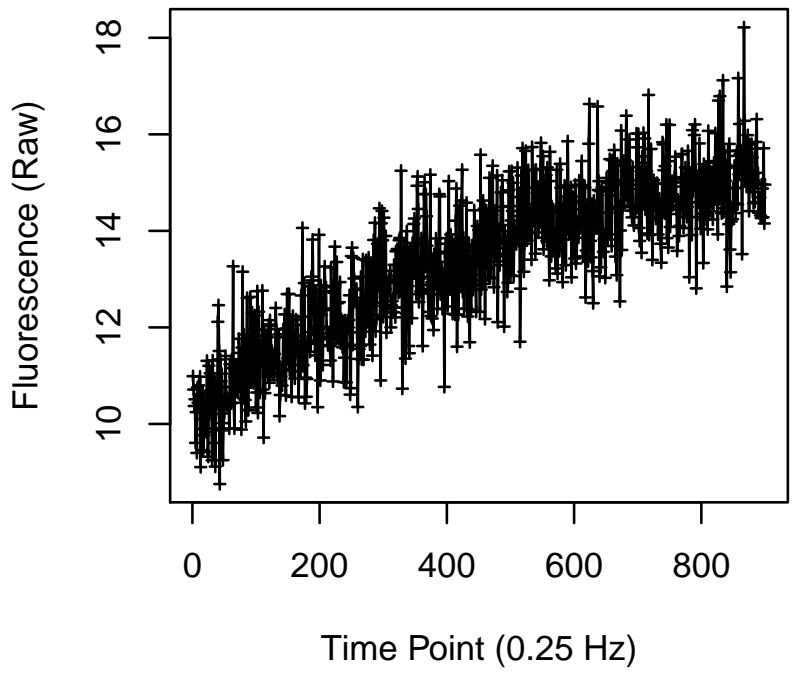

Cell 90

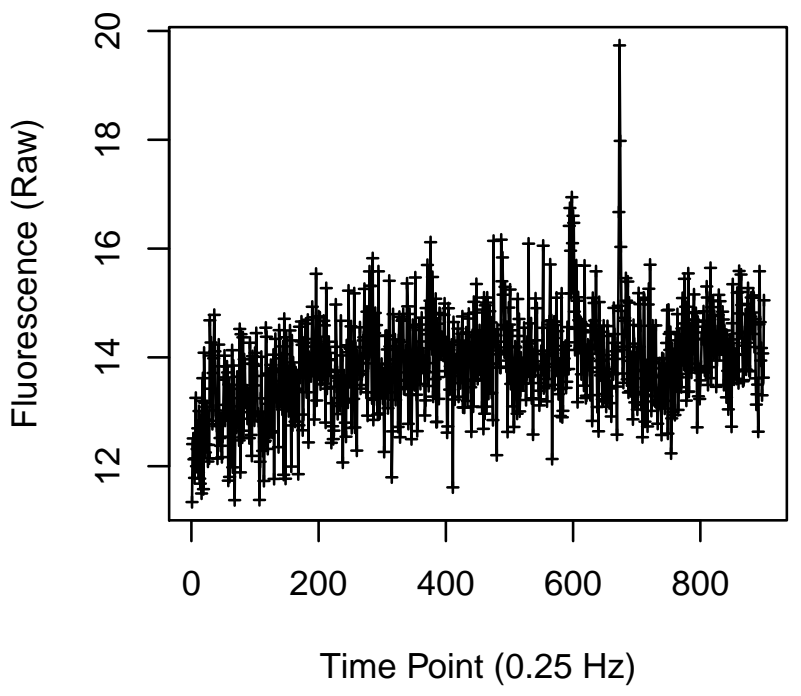

Cell 92

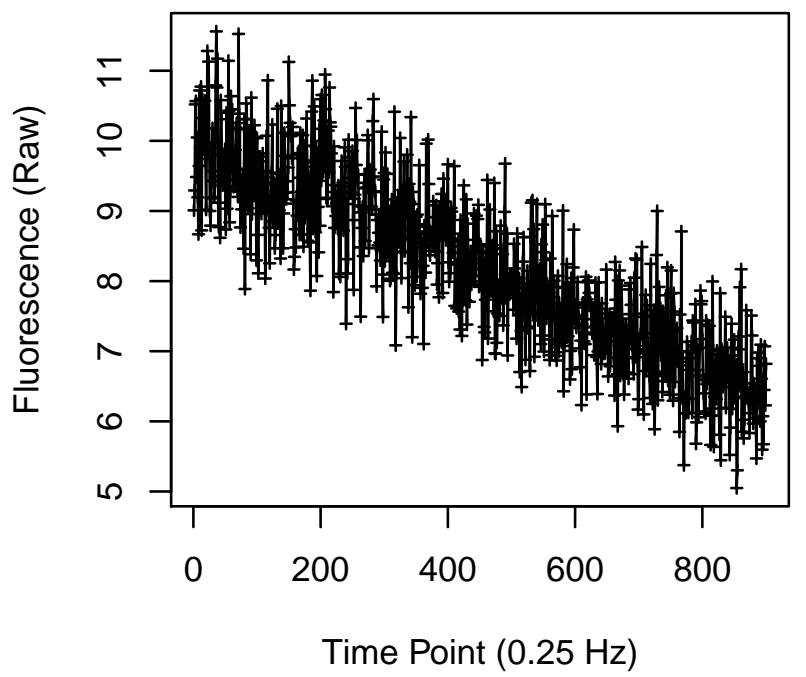




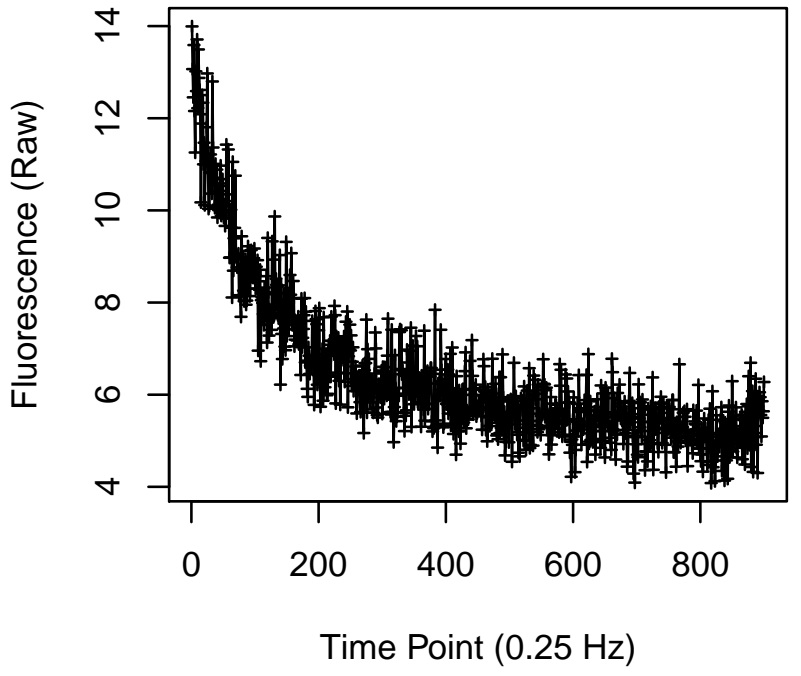

Cell 103

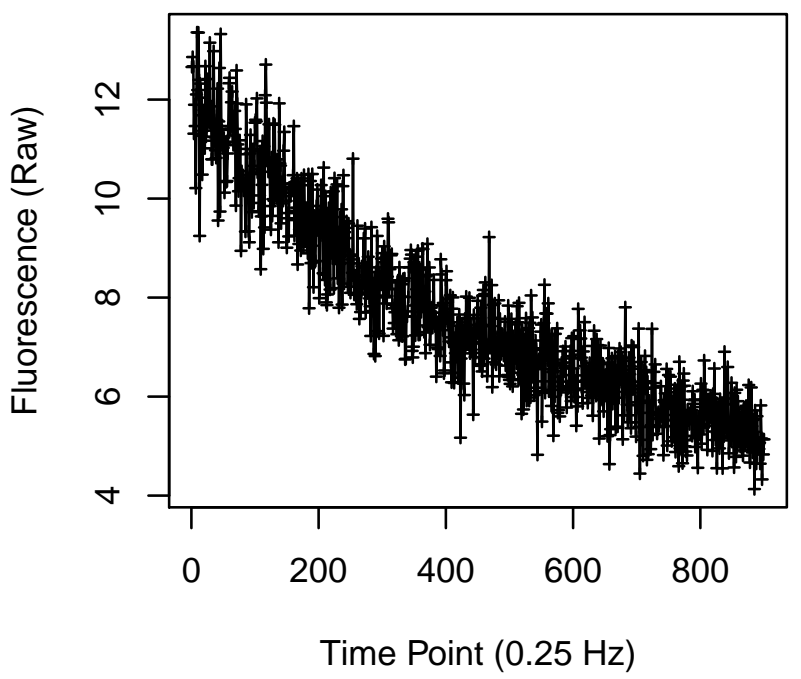

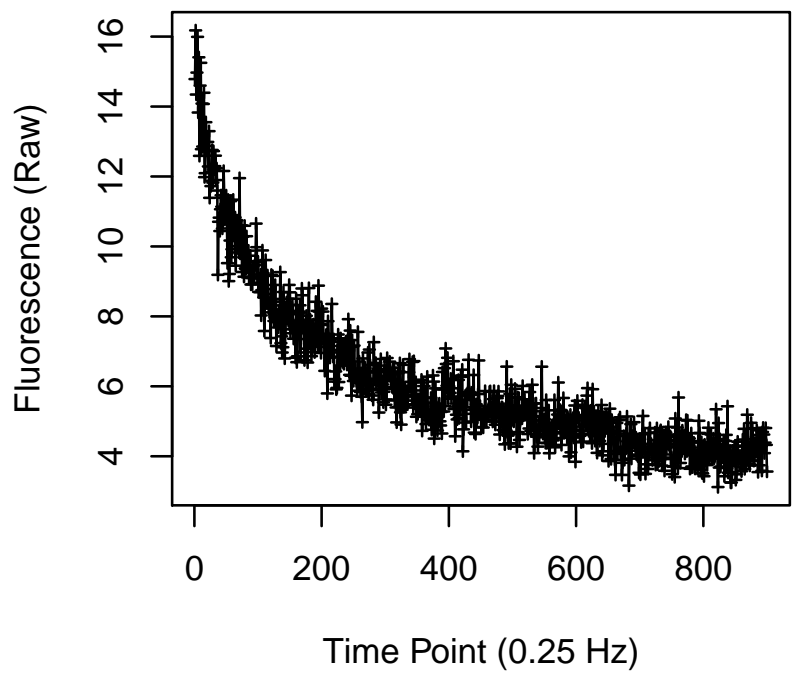

Cell 104

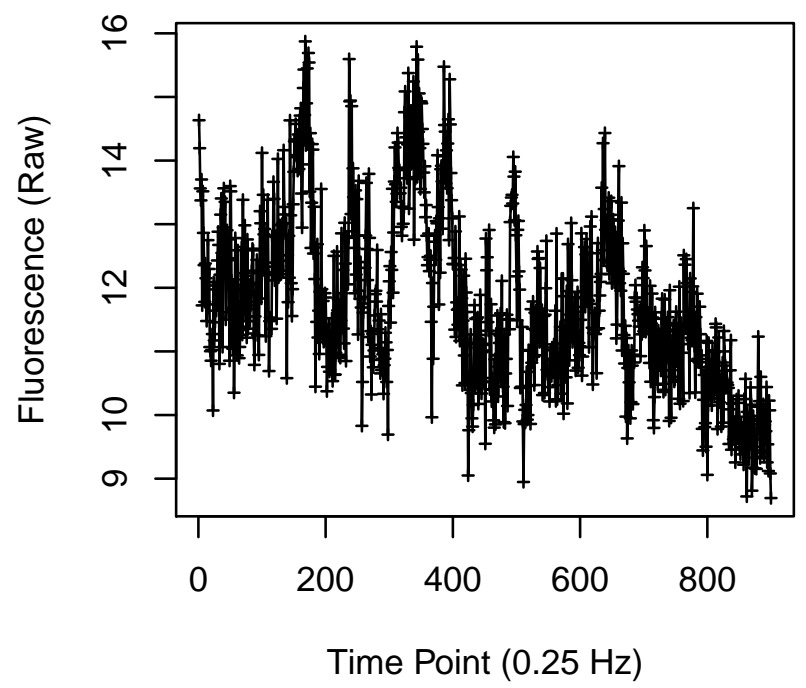




\section{Cell 105}

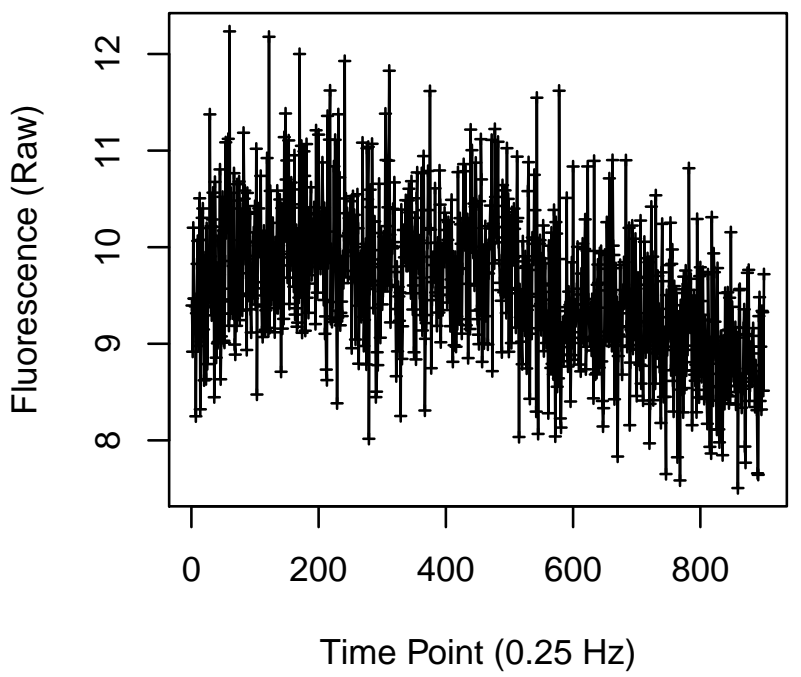

Cell 107

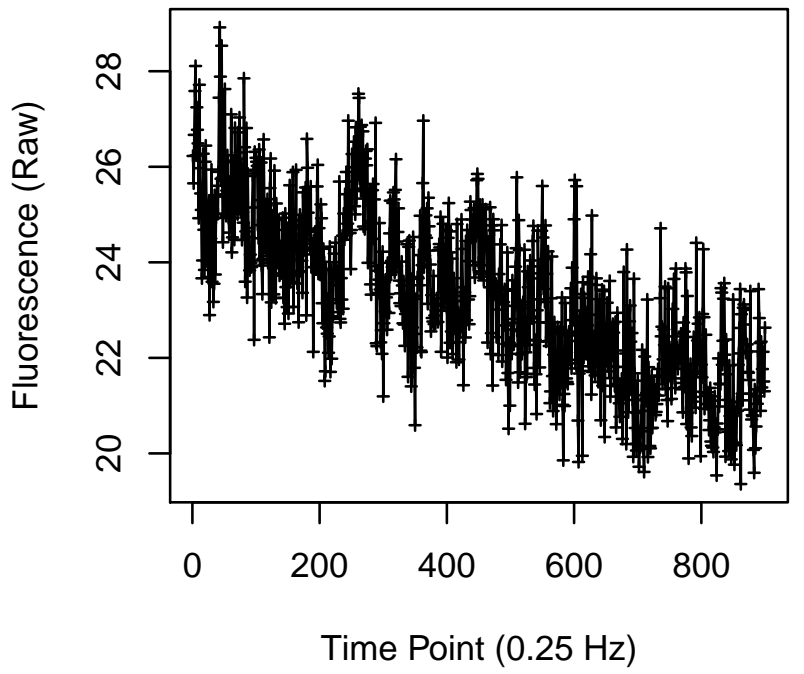

Cell 106

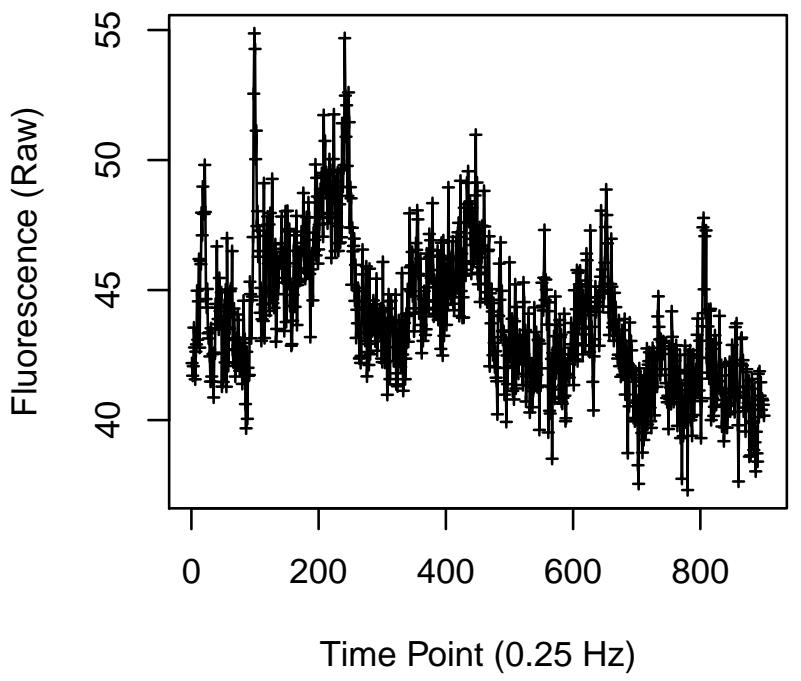

Cell 108

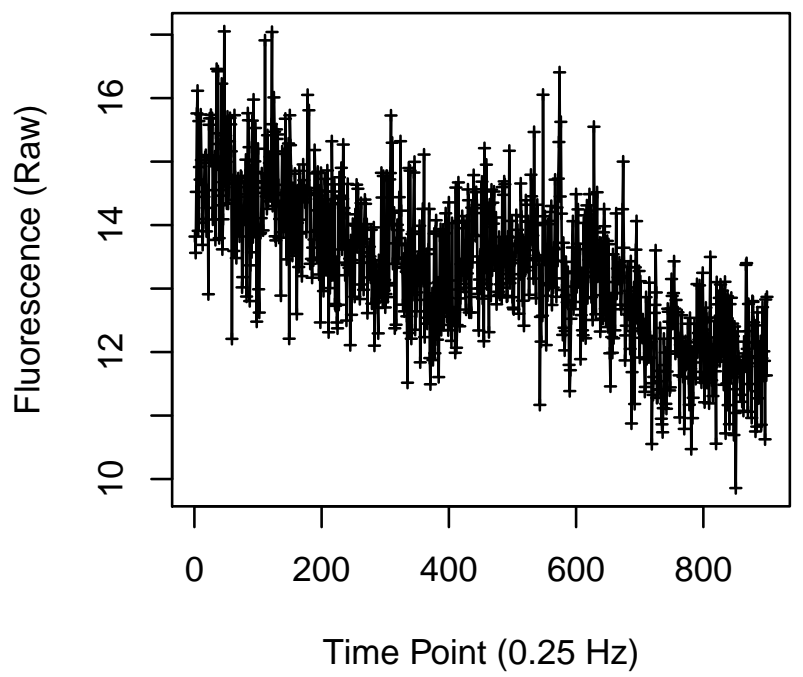


Cell 109

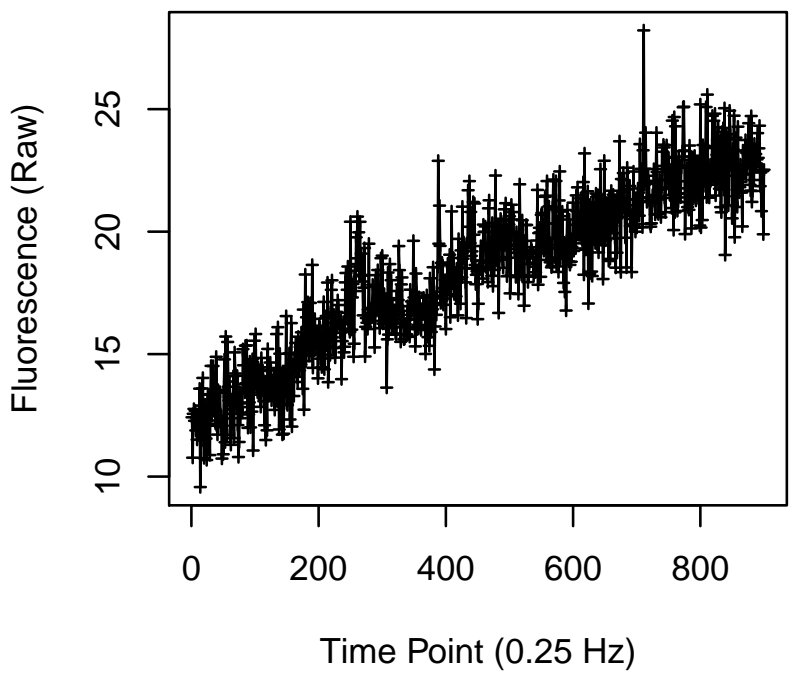

Cell 111

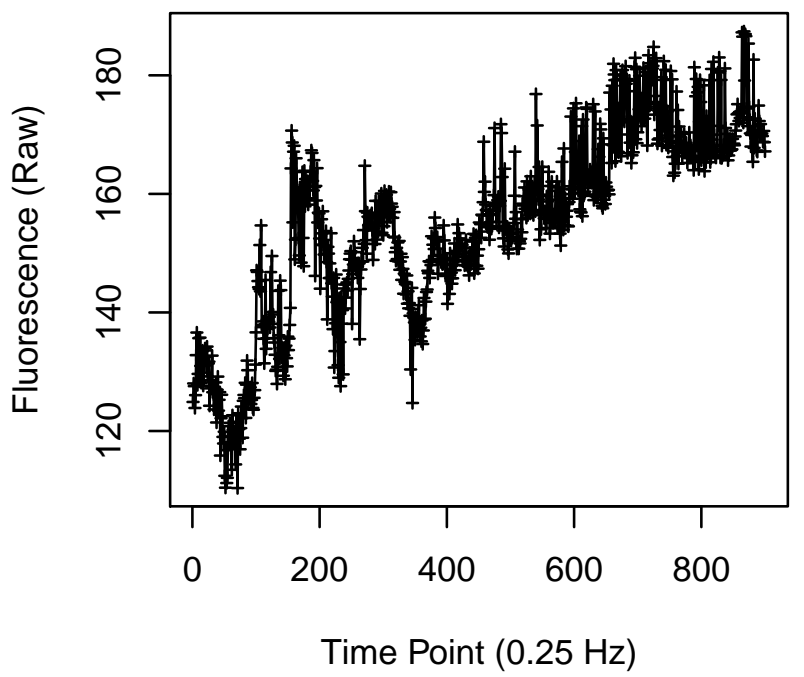

Cell 110

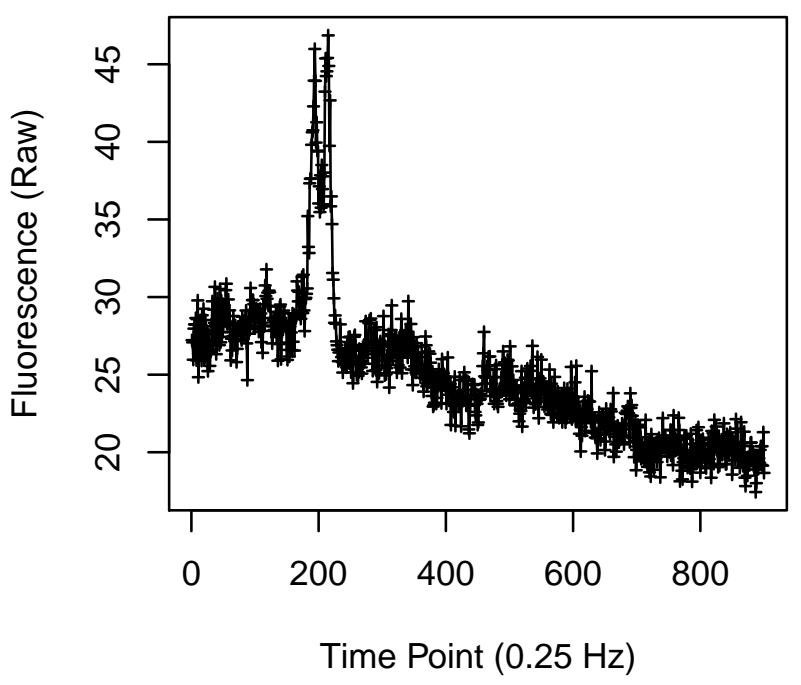

Cell 112

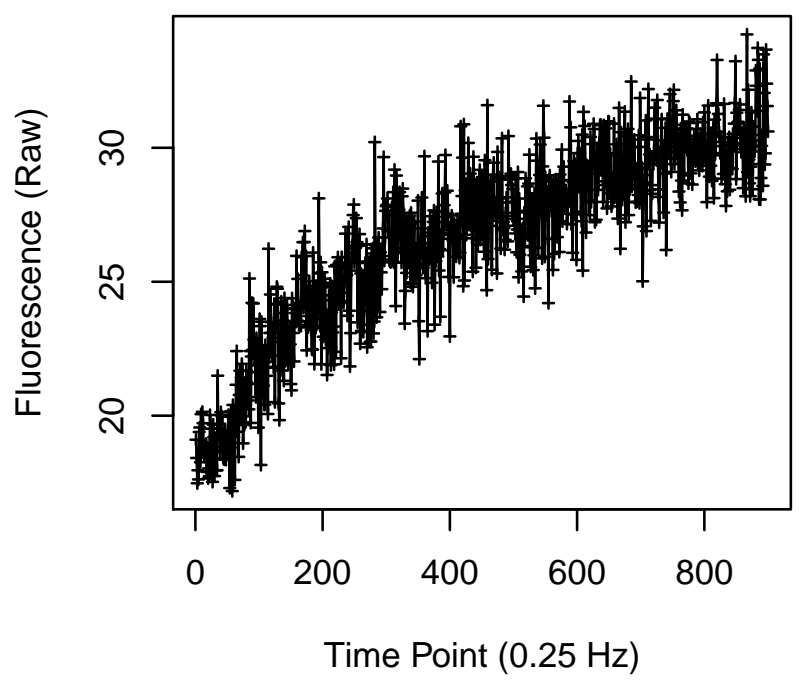




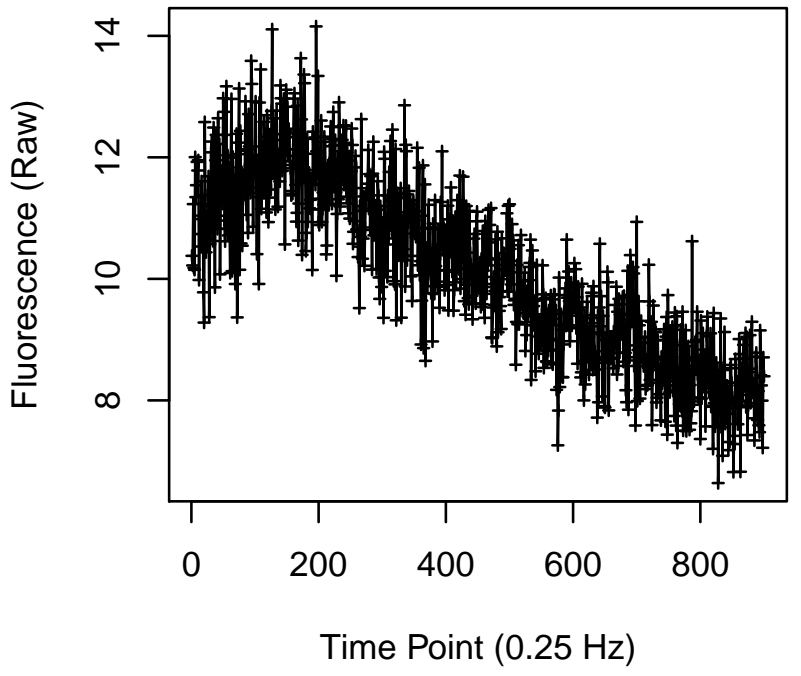

Cell 115

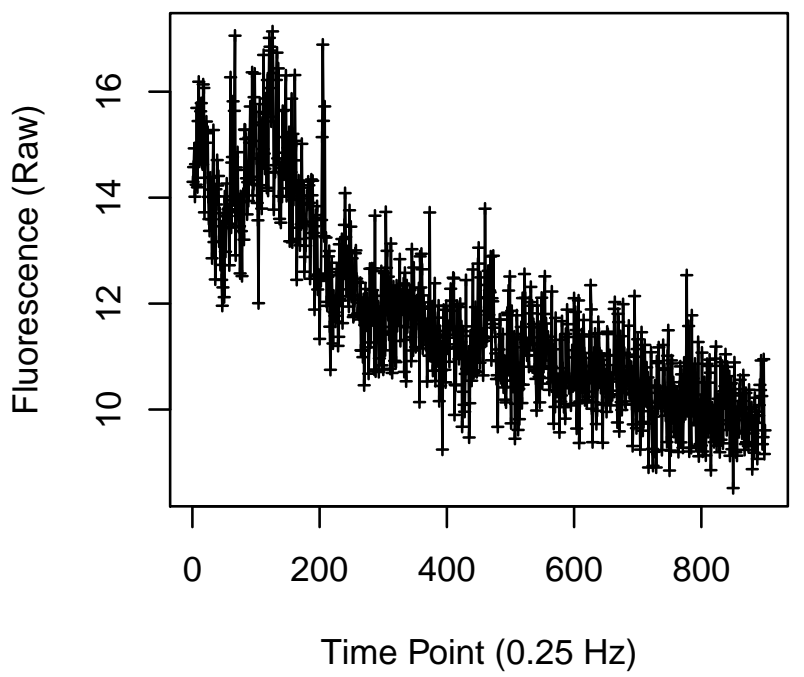

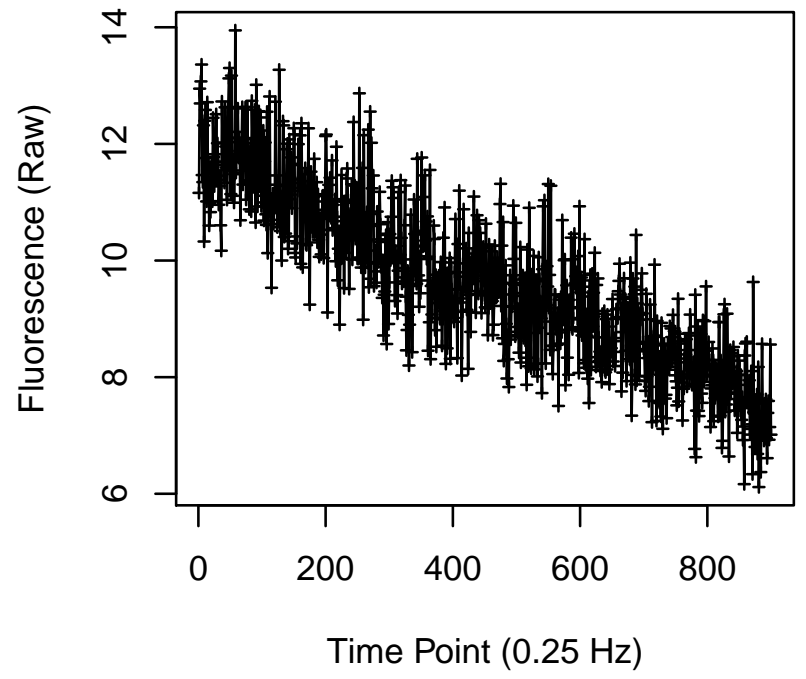

Cell 116

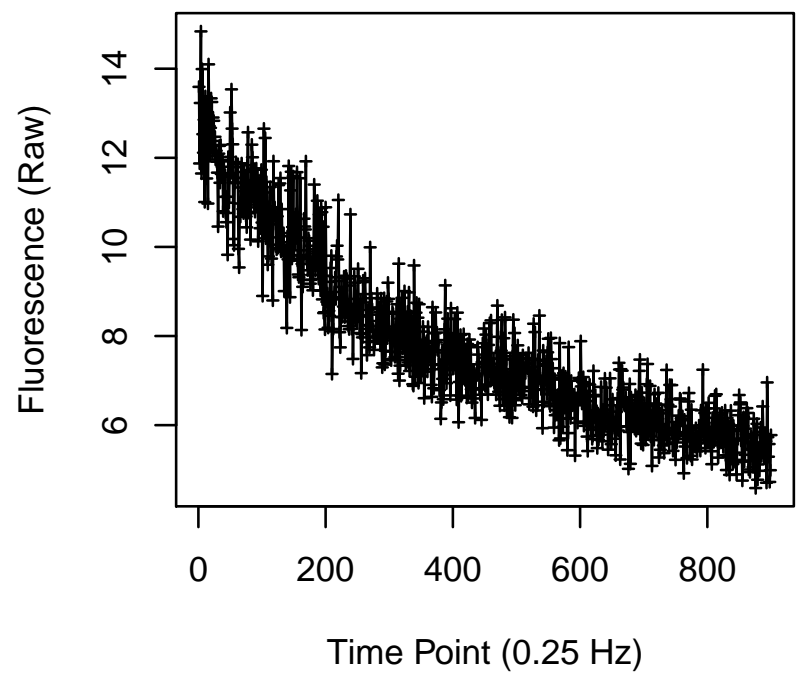


Cell 121

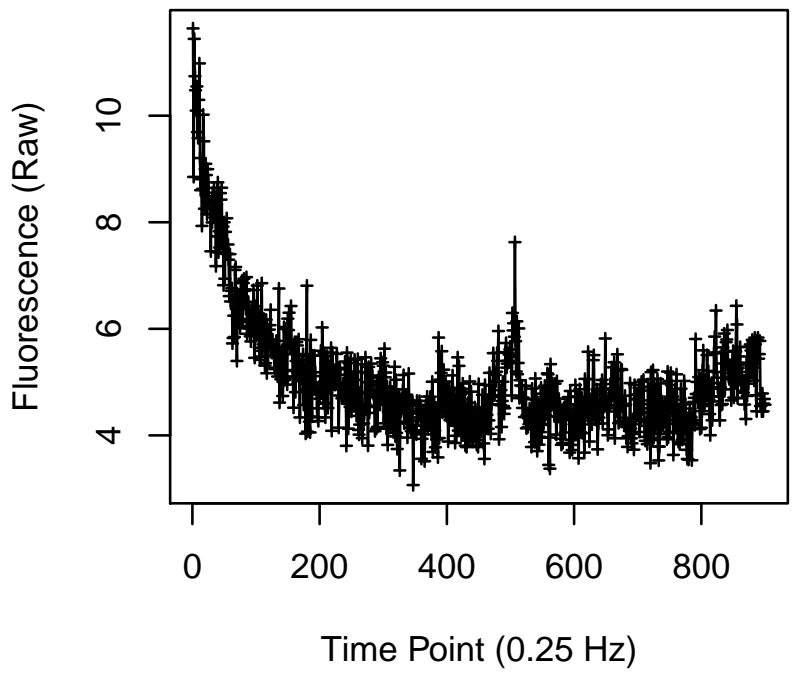

Cell 123

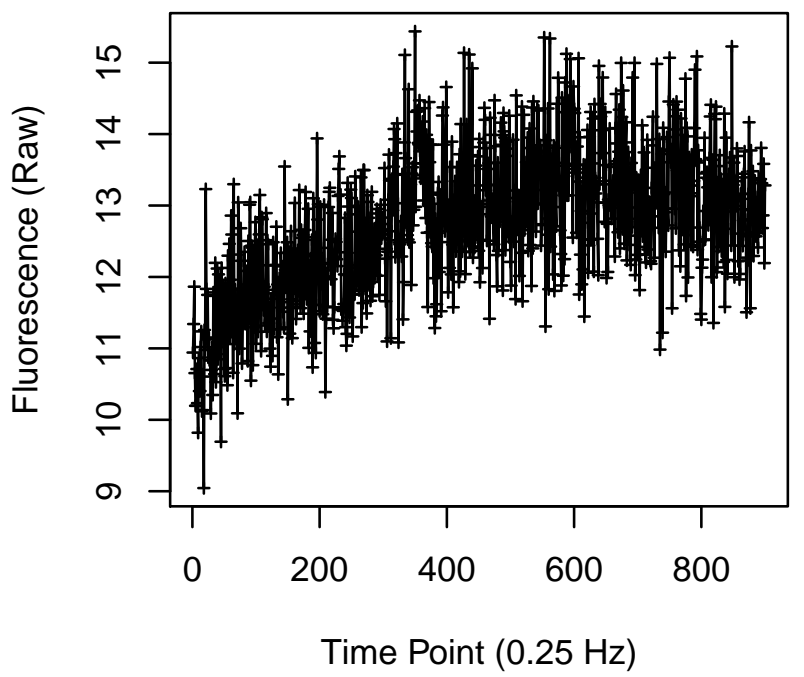

Cell 122

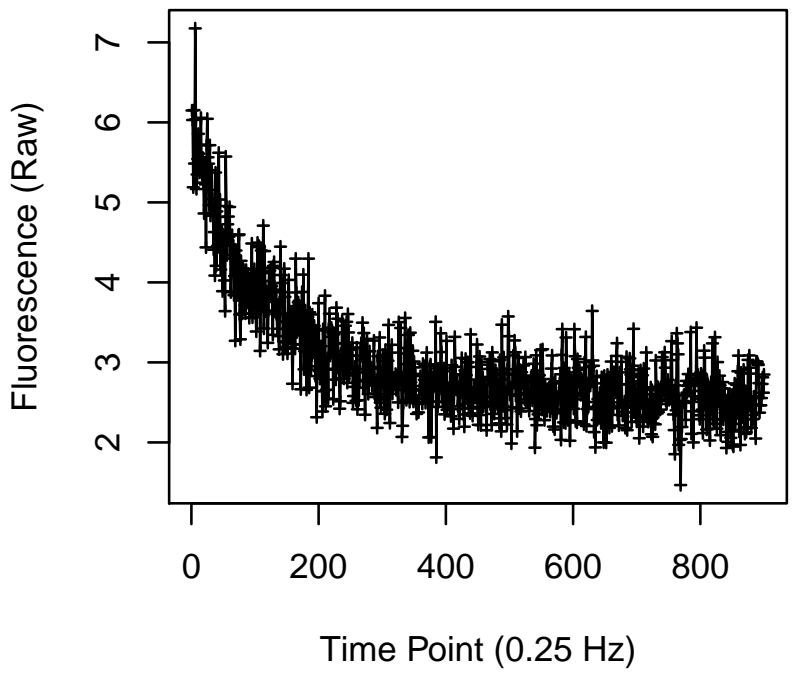

Cell 124

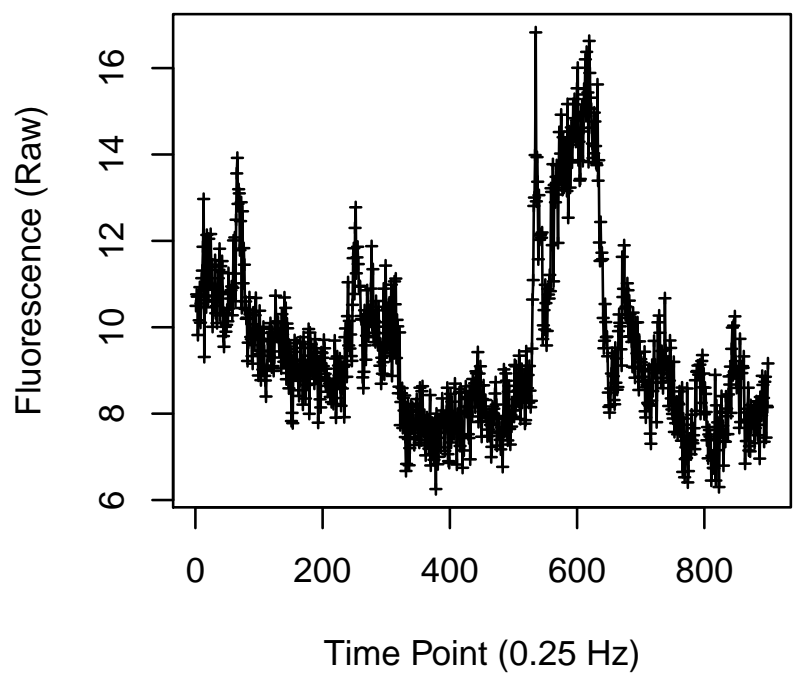




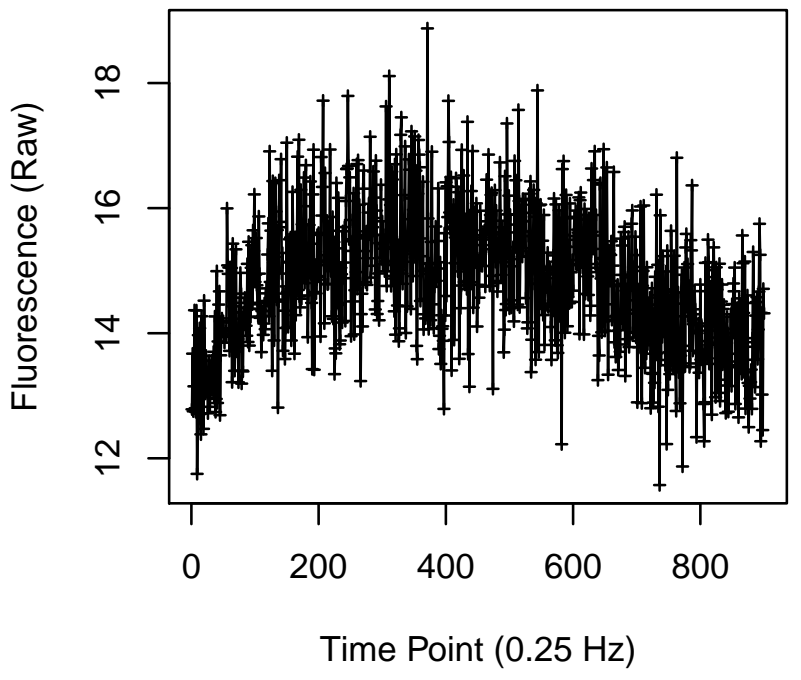

Cell 127

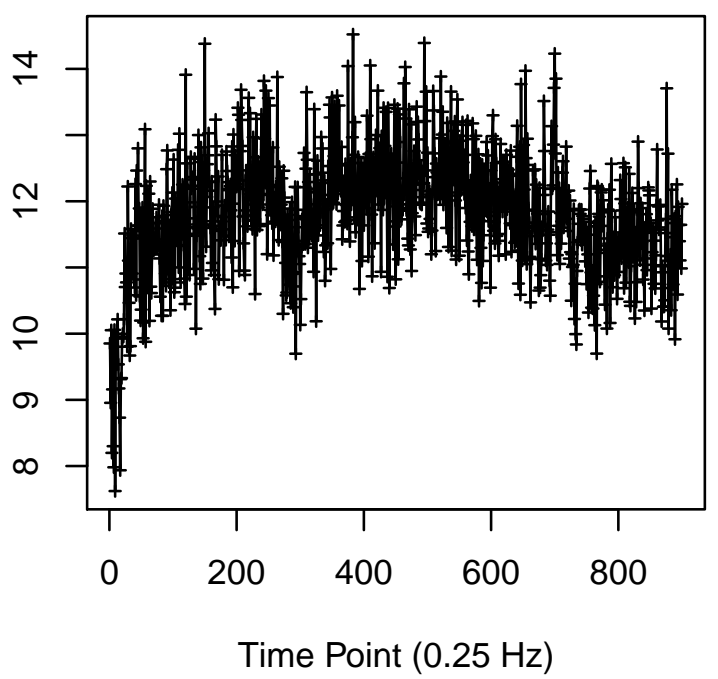

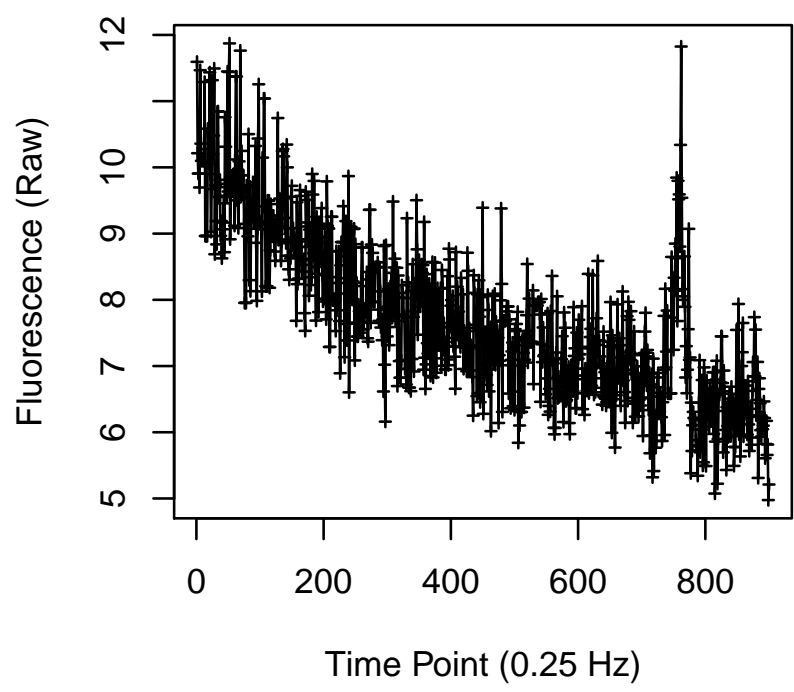

Cell 128

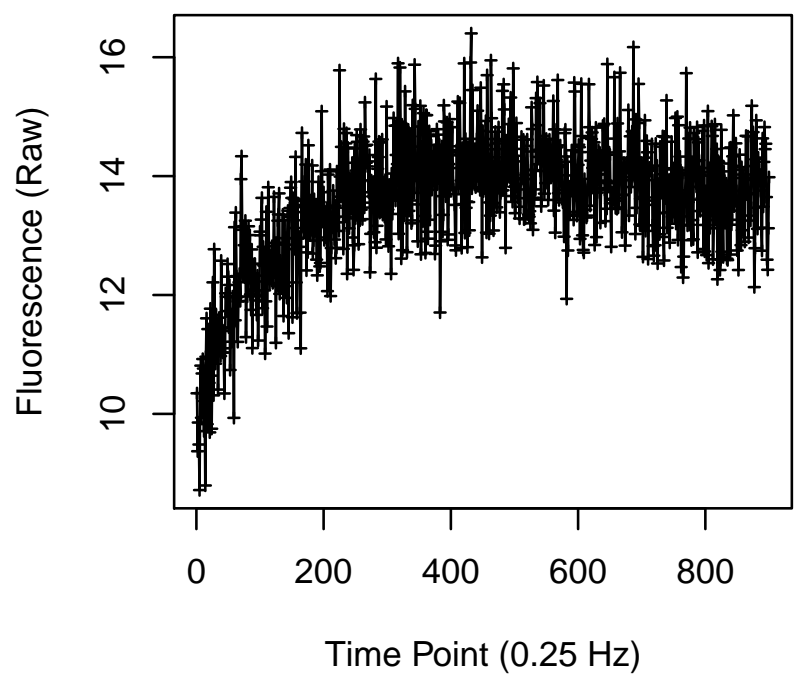


Cell 129

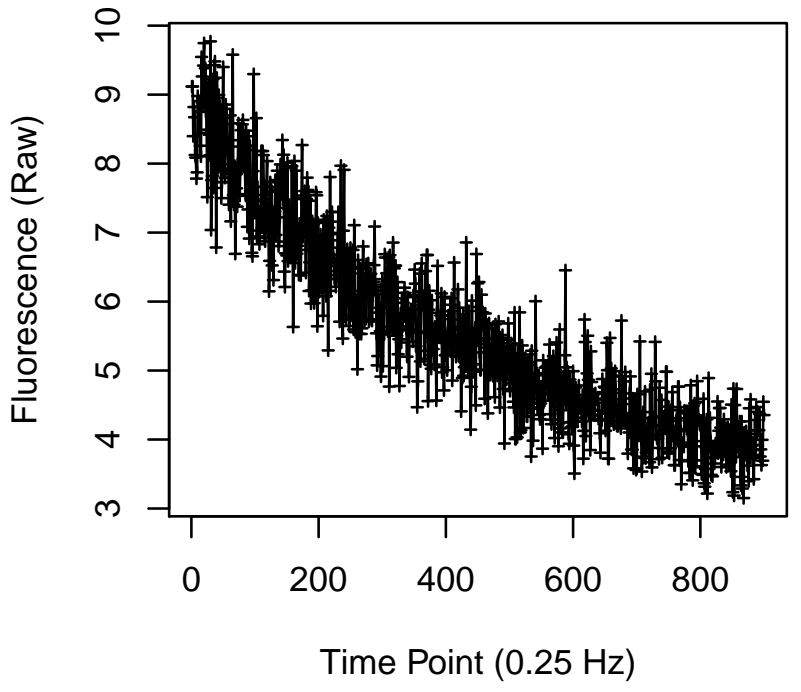

Cell 131

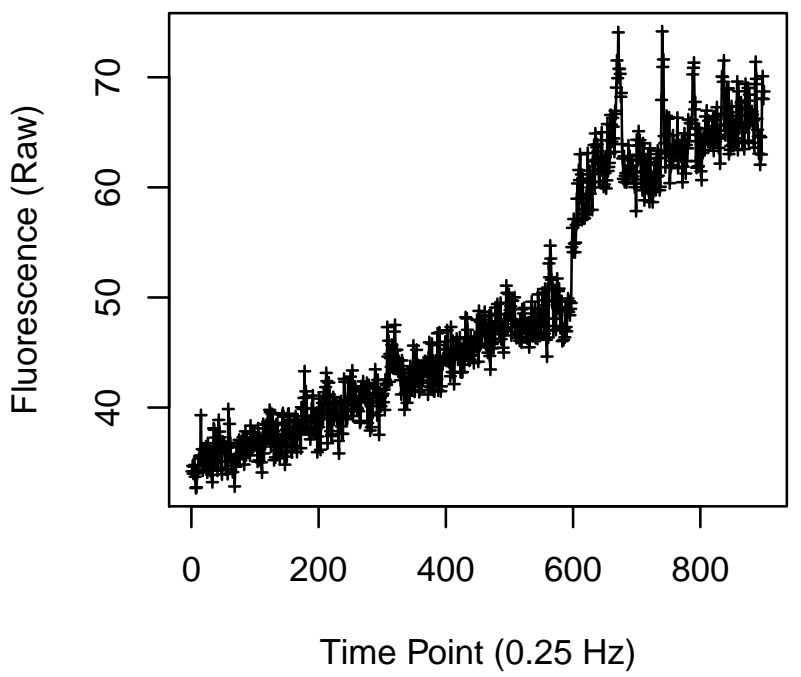

Cell 130

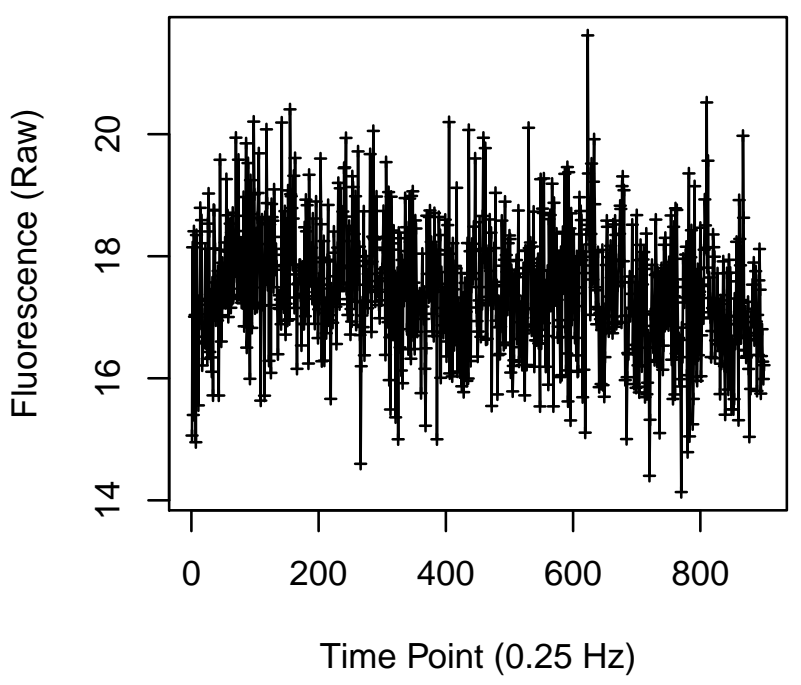

Cell 132

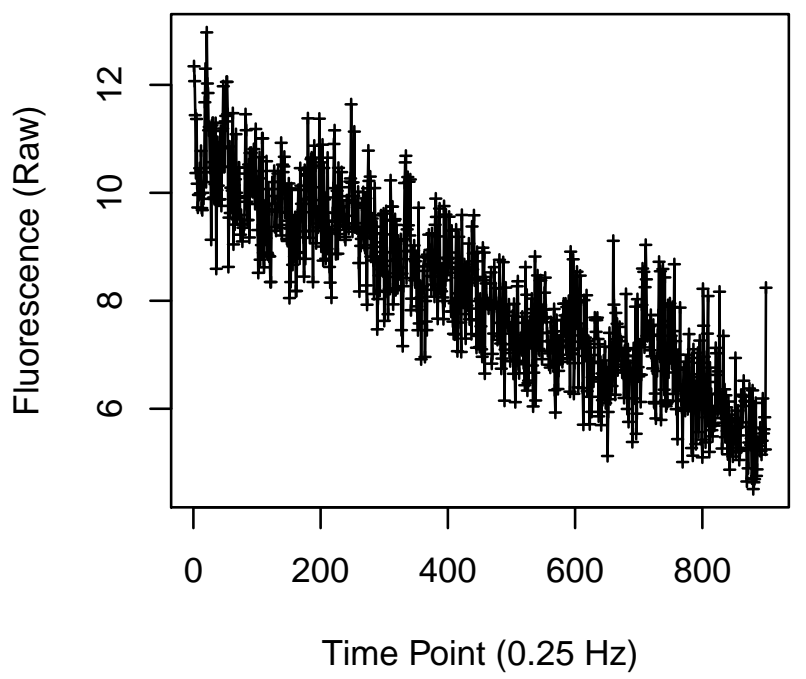


Cell 133

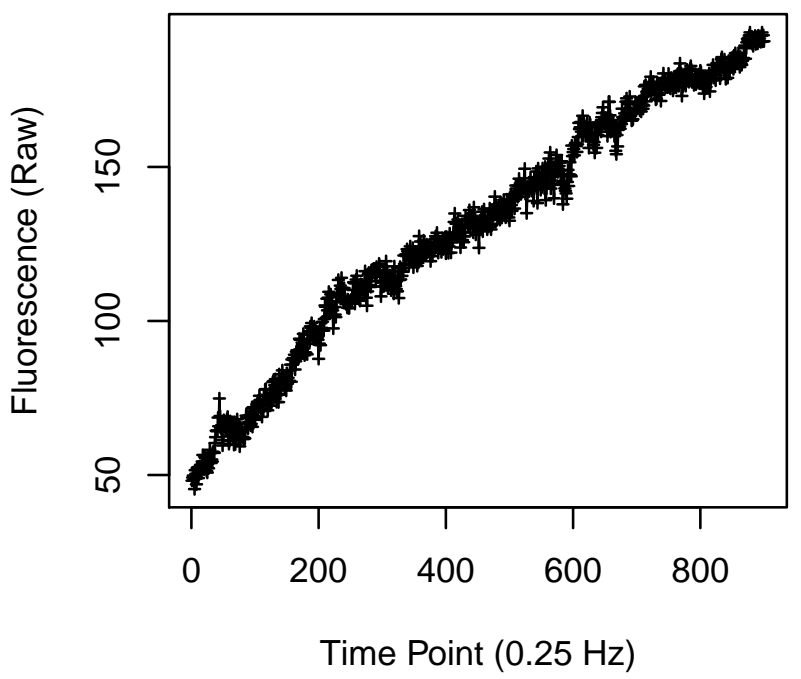

Cell 135

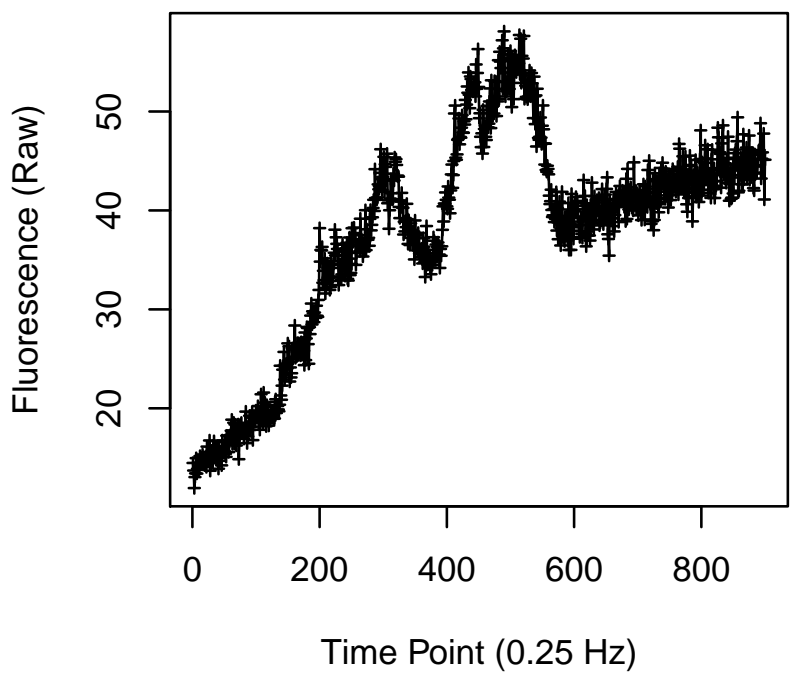

Cell 134

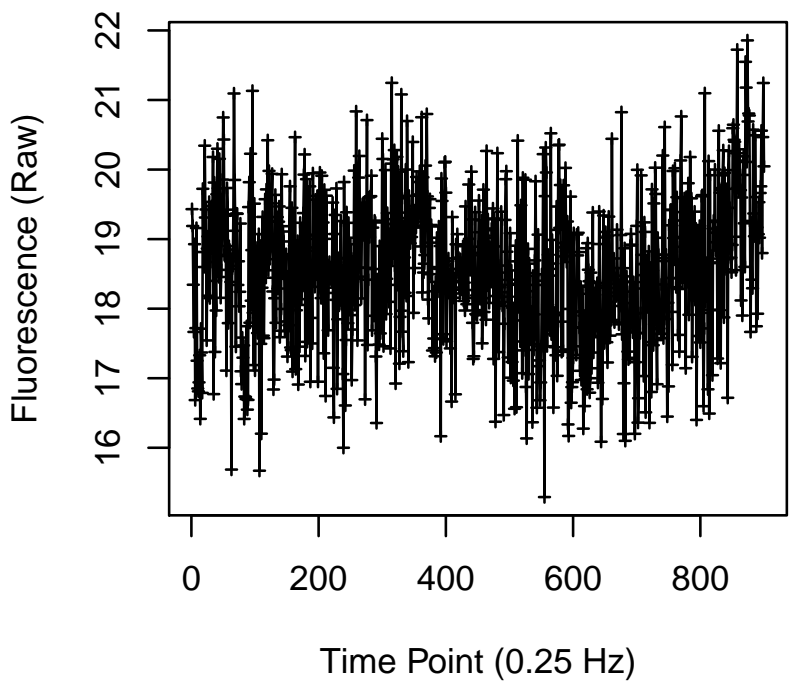

Cell 136

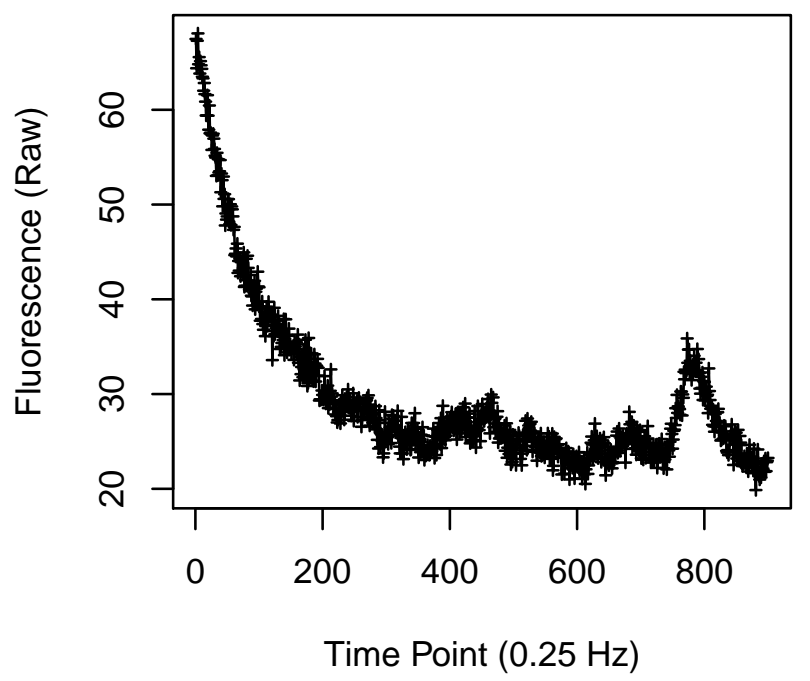


Cell 137

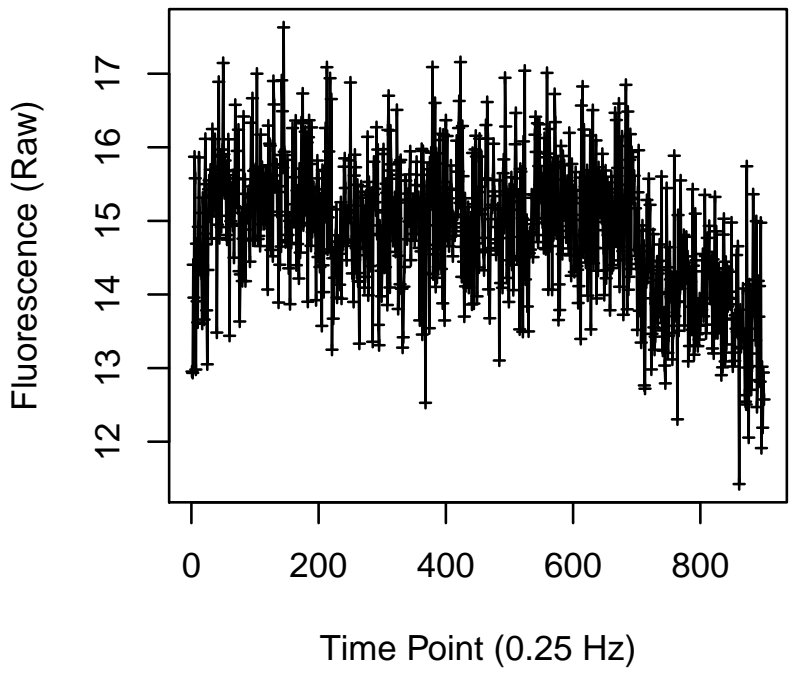

Cell 139

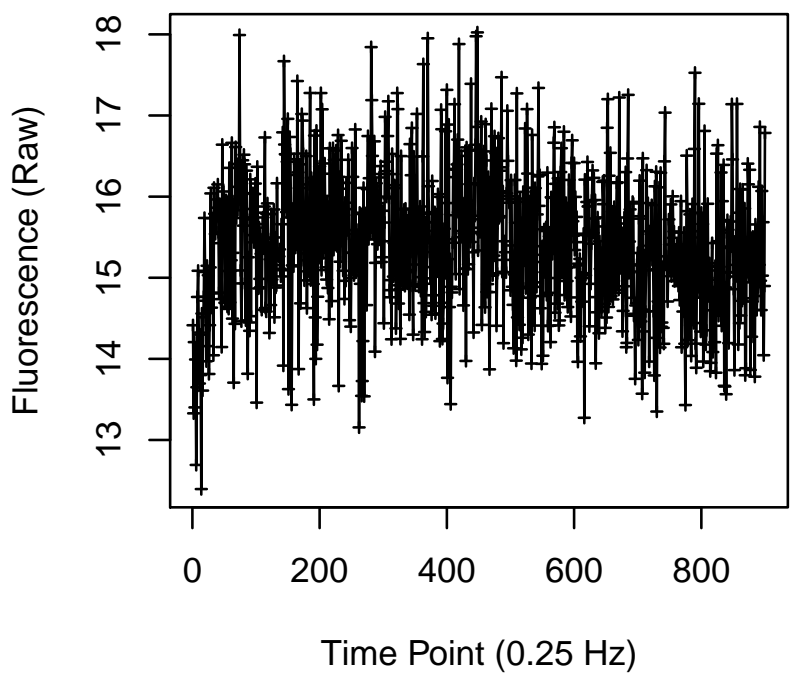

Cell 138

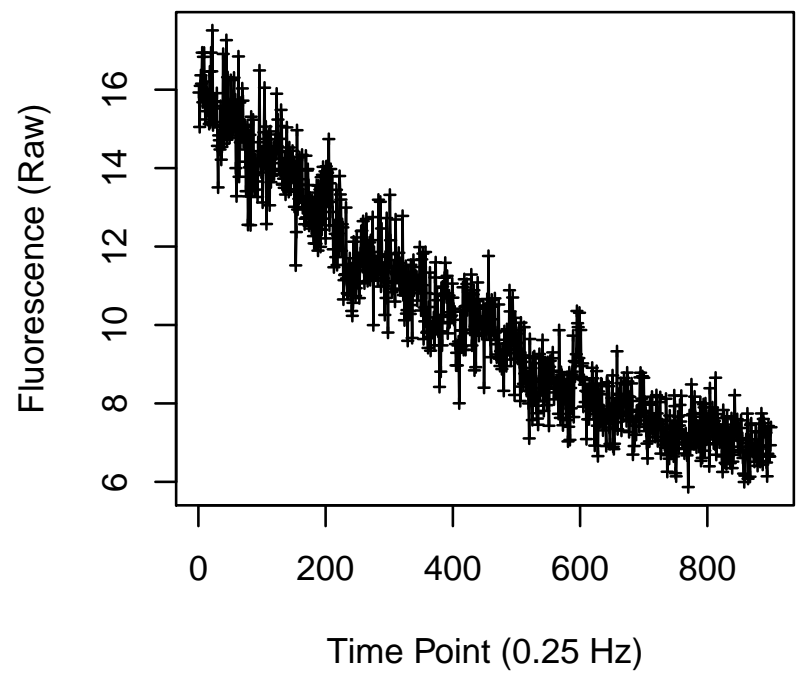

Cell 140

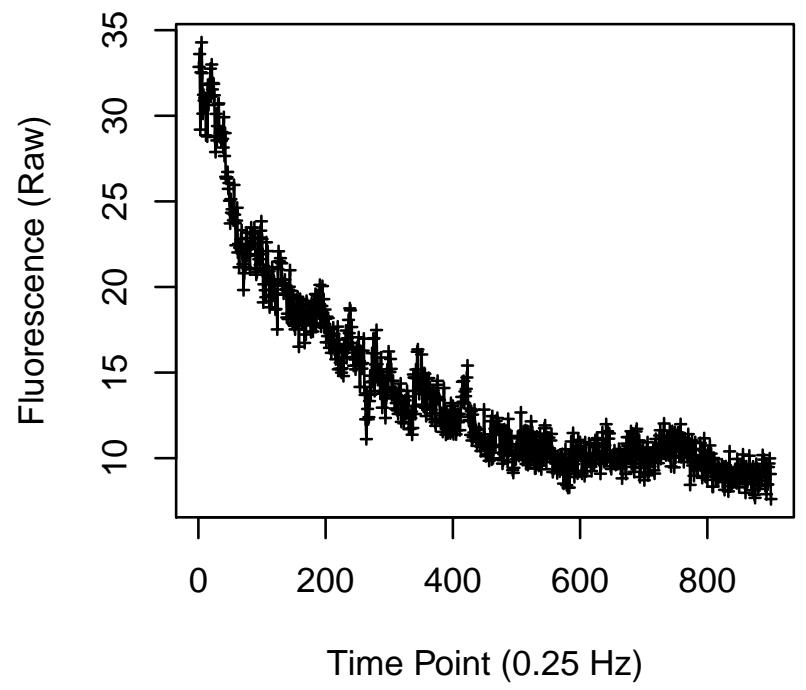




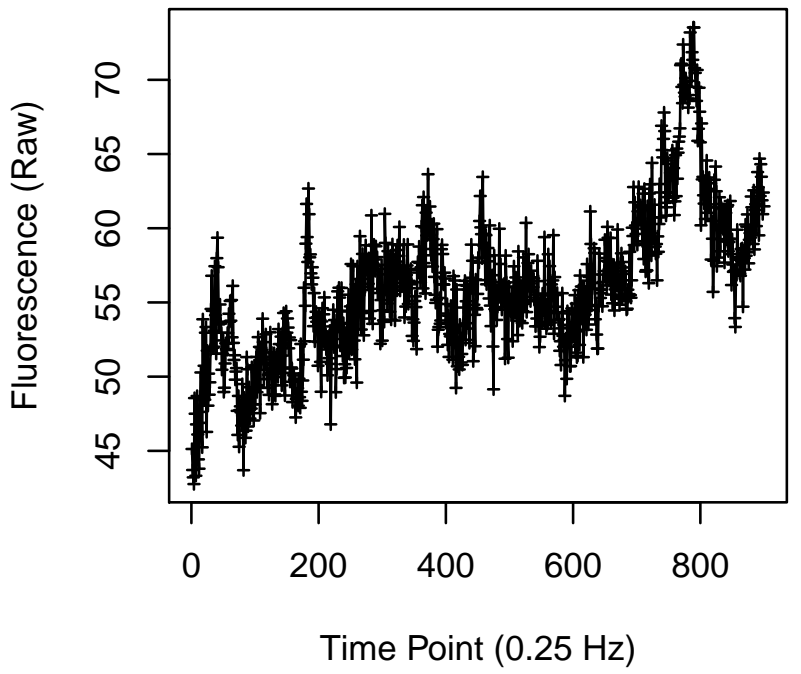

Cell 143

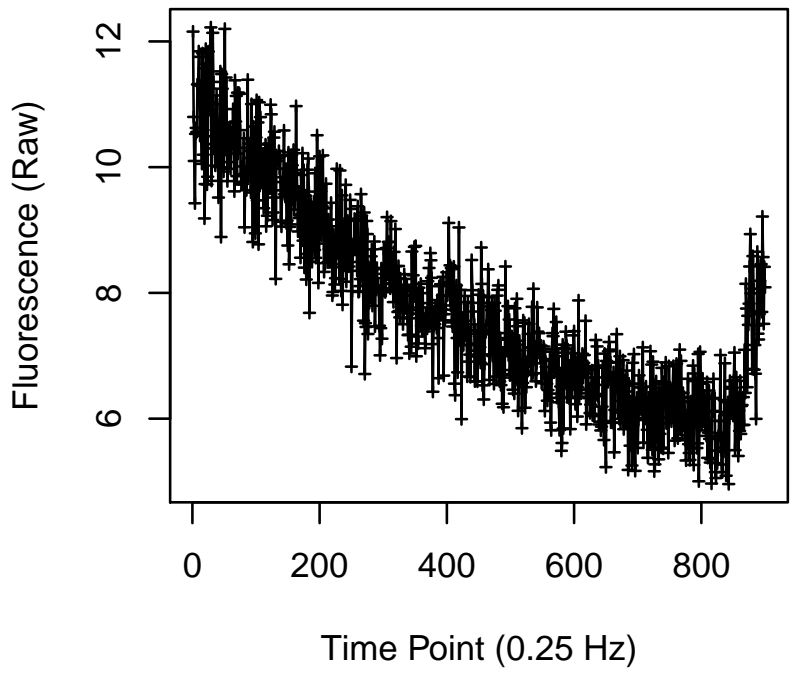

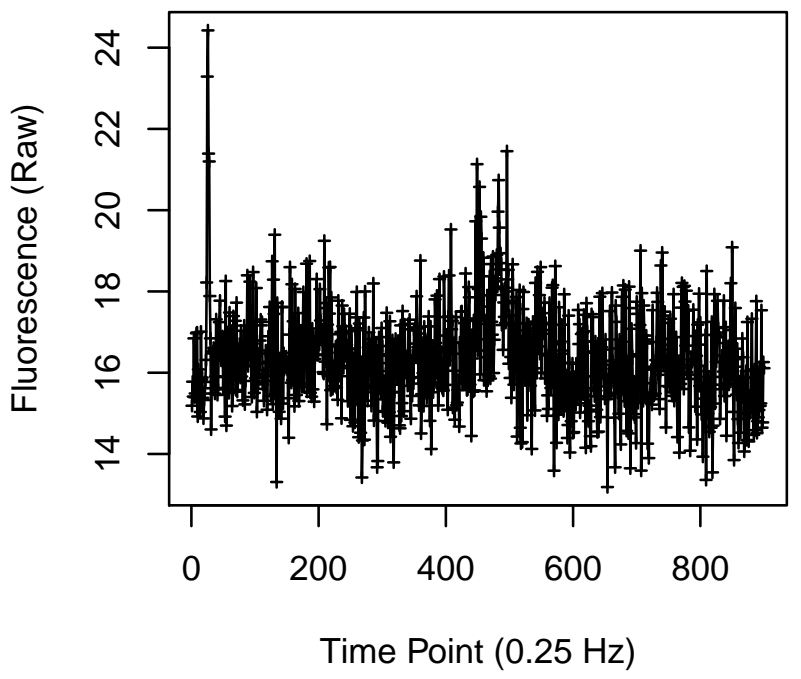

Cell 144

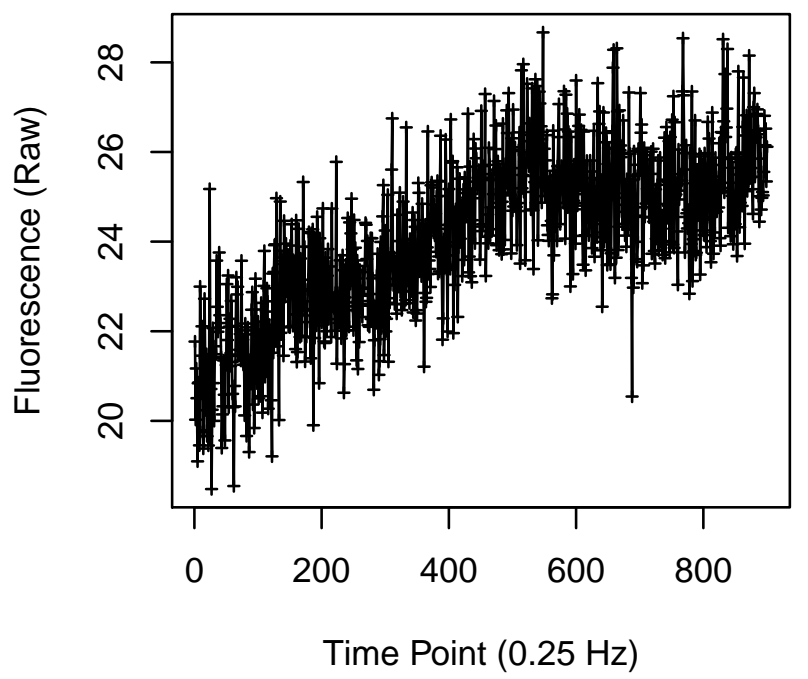




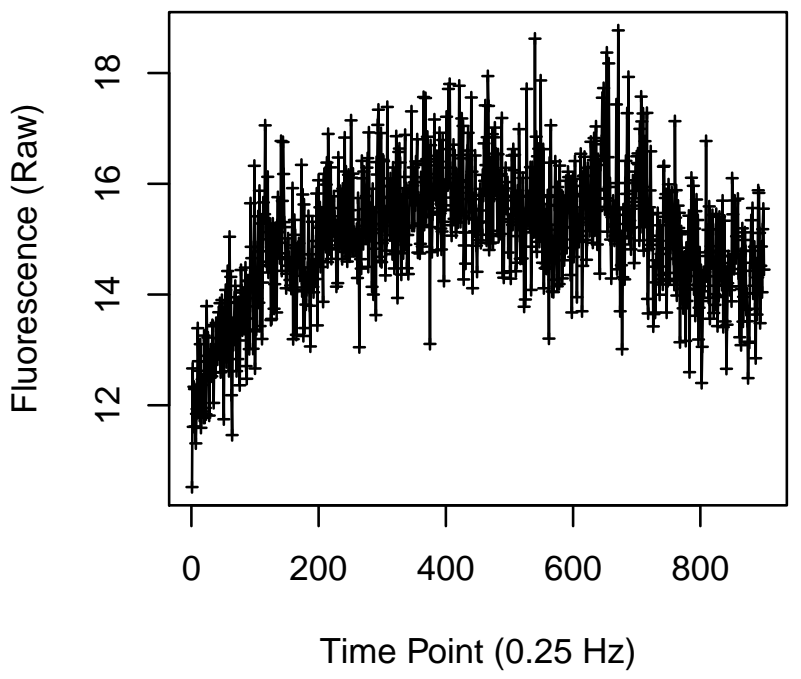

Cell 147

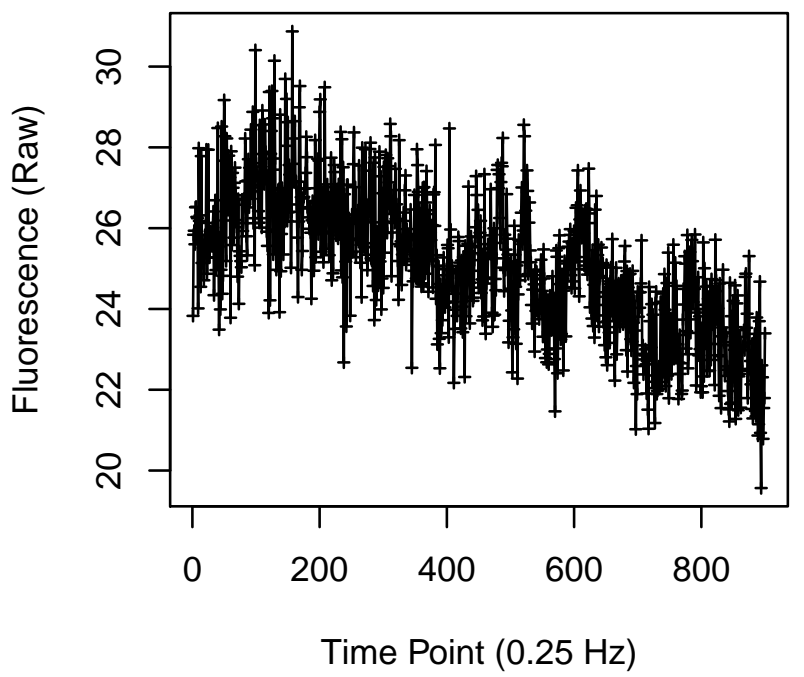

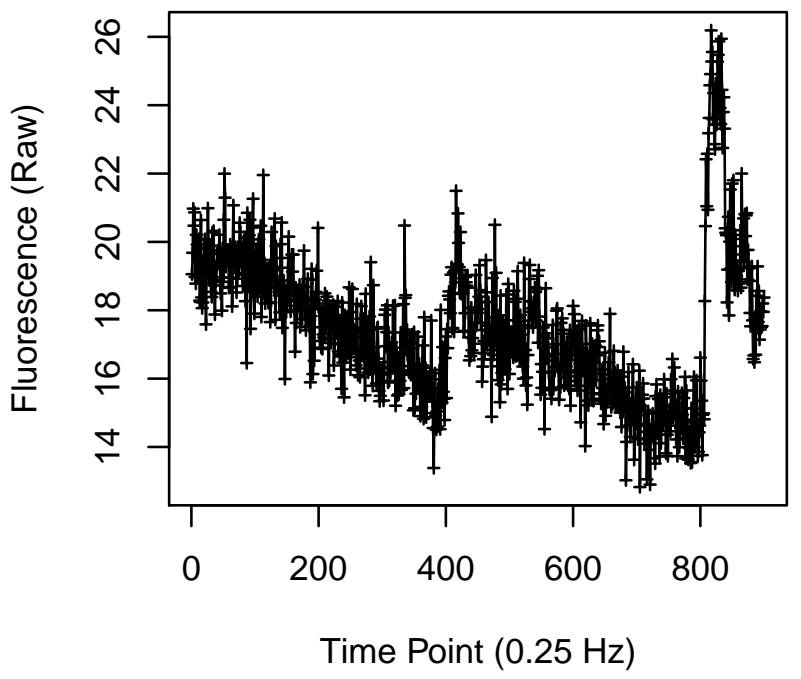

Cell 148

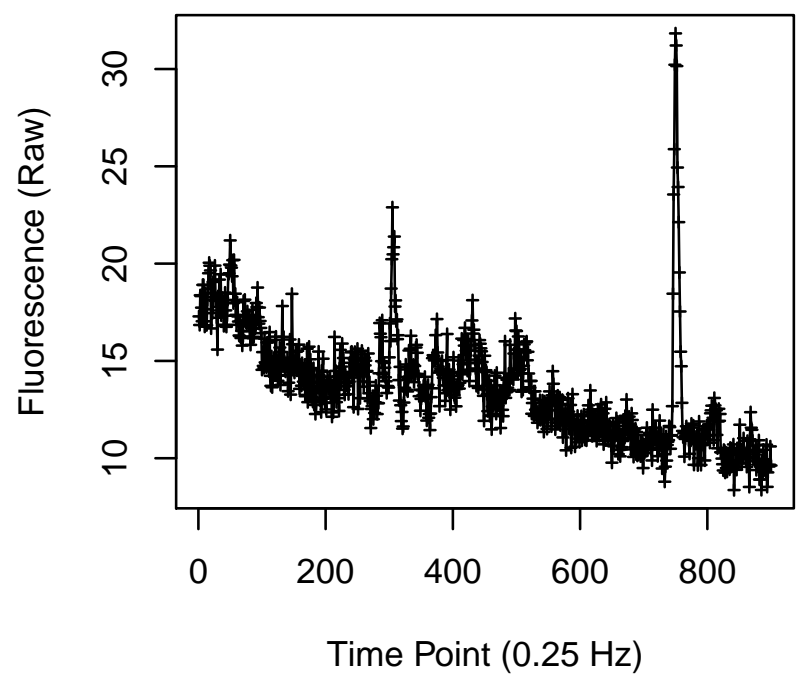


Cell 149

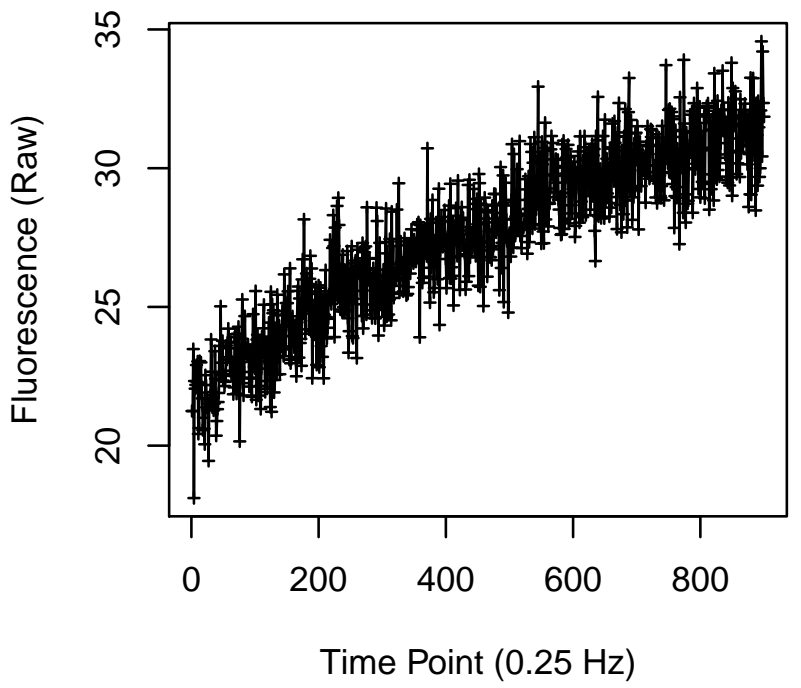

Cell 151

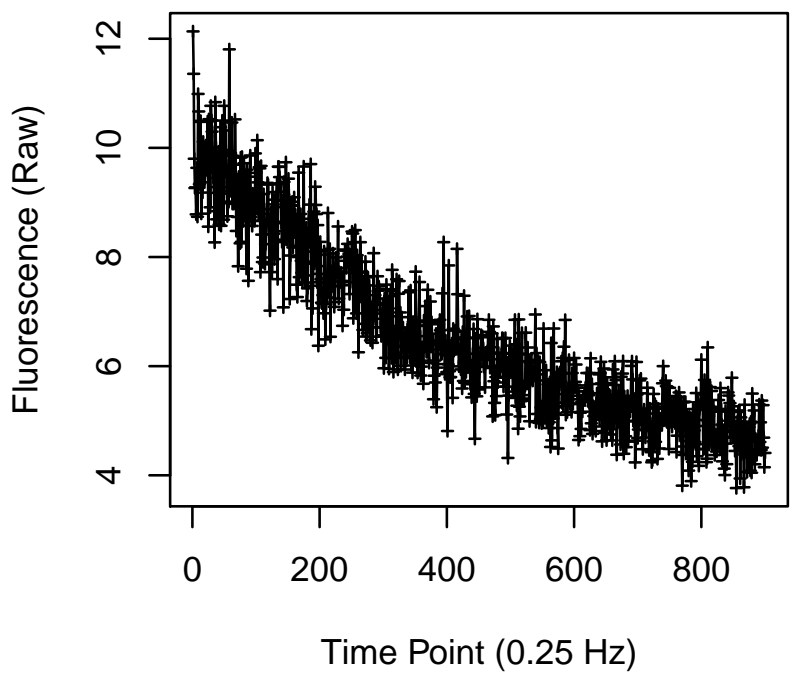

Cell 150

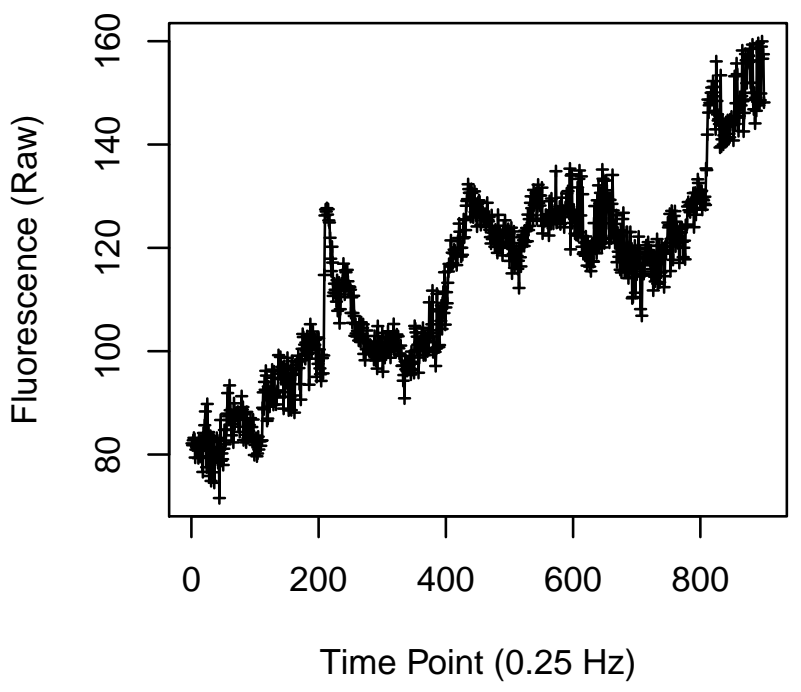

Cell 152

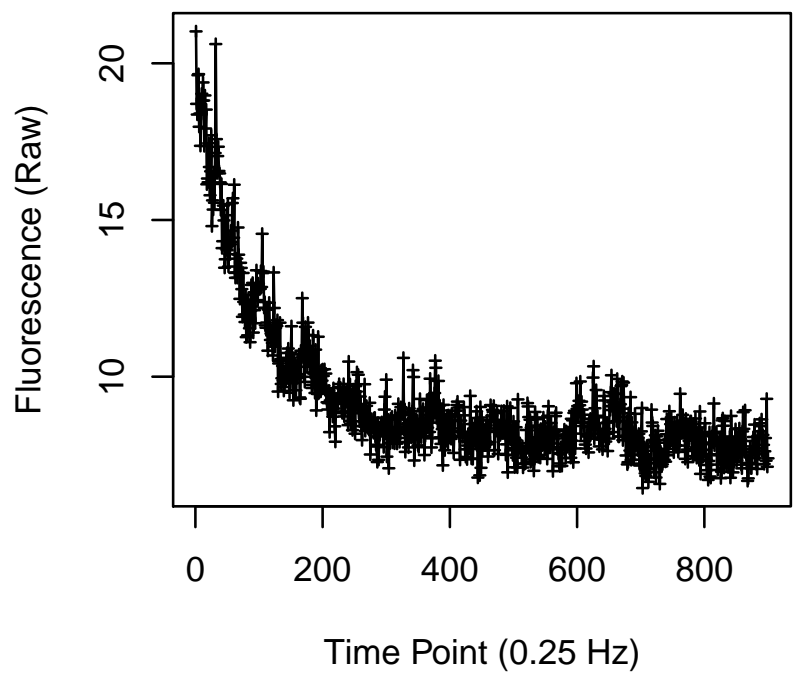




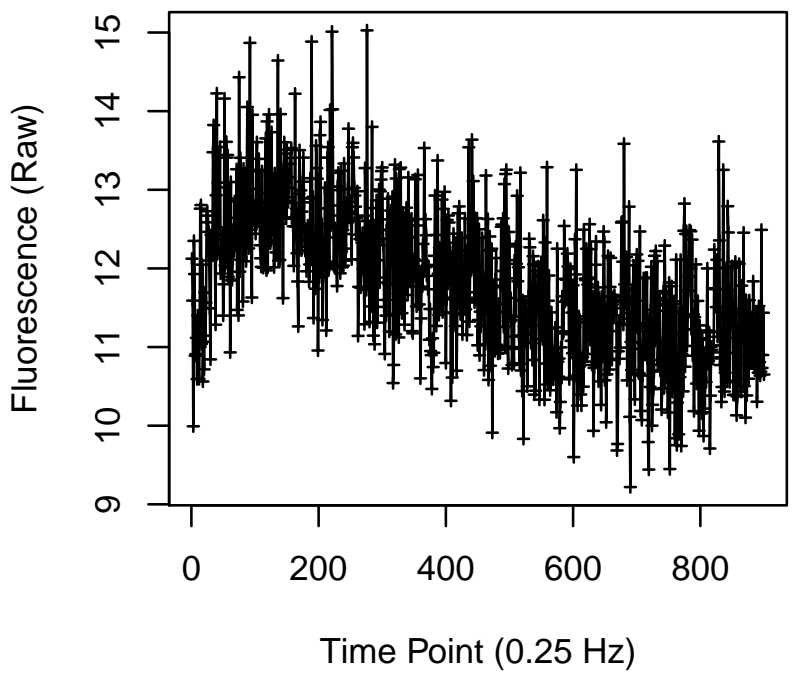

Cell 155

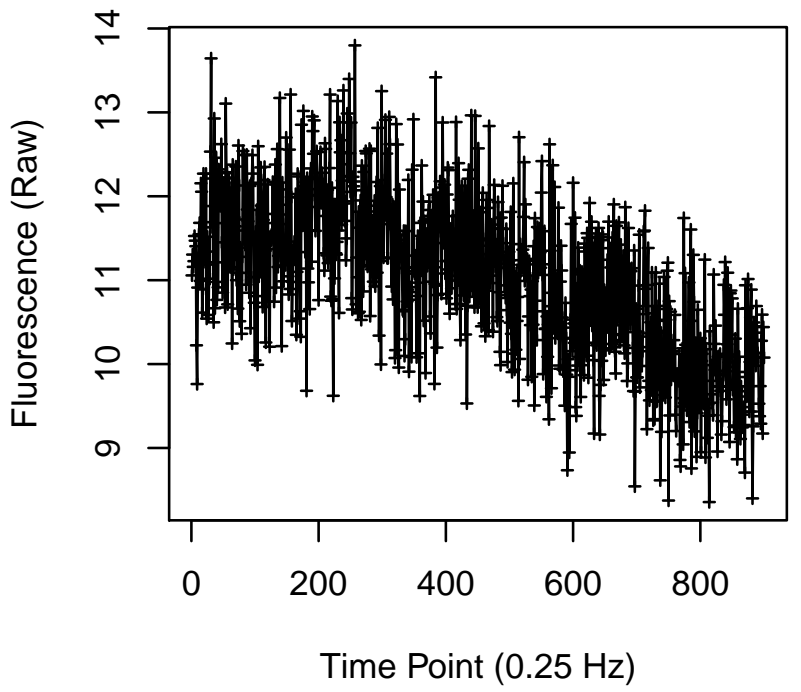

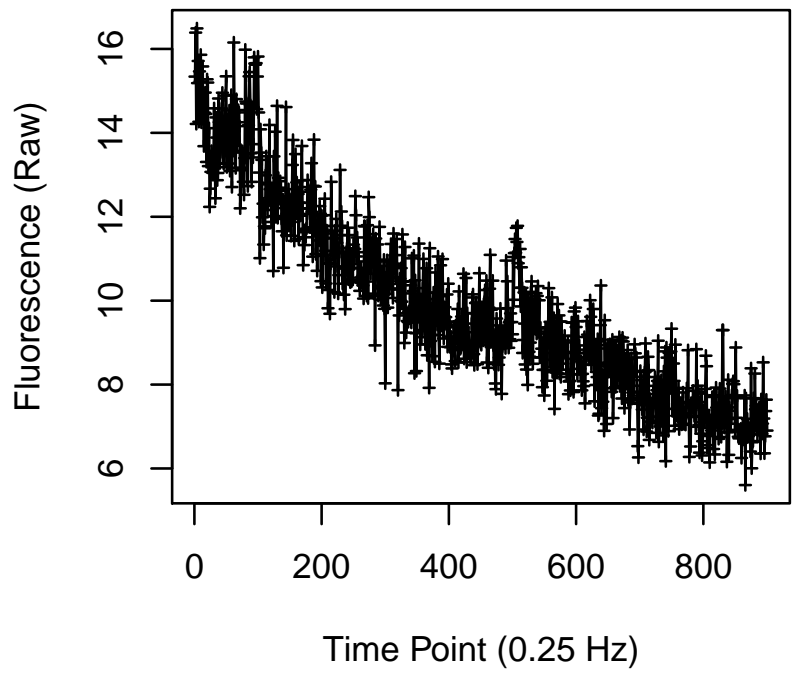

Cell 156

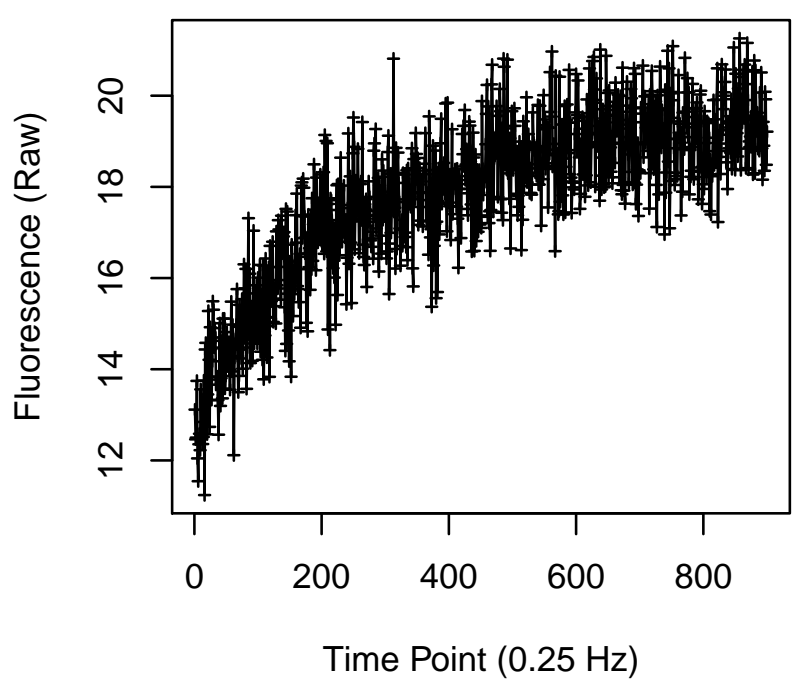


Cell 157

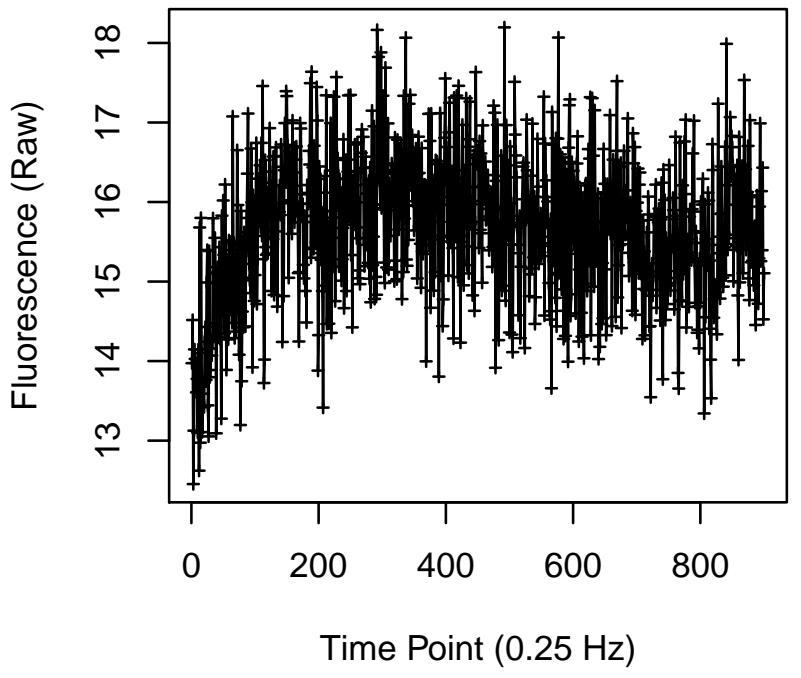

Cell 159

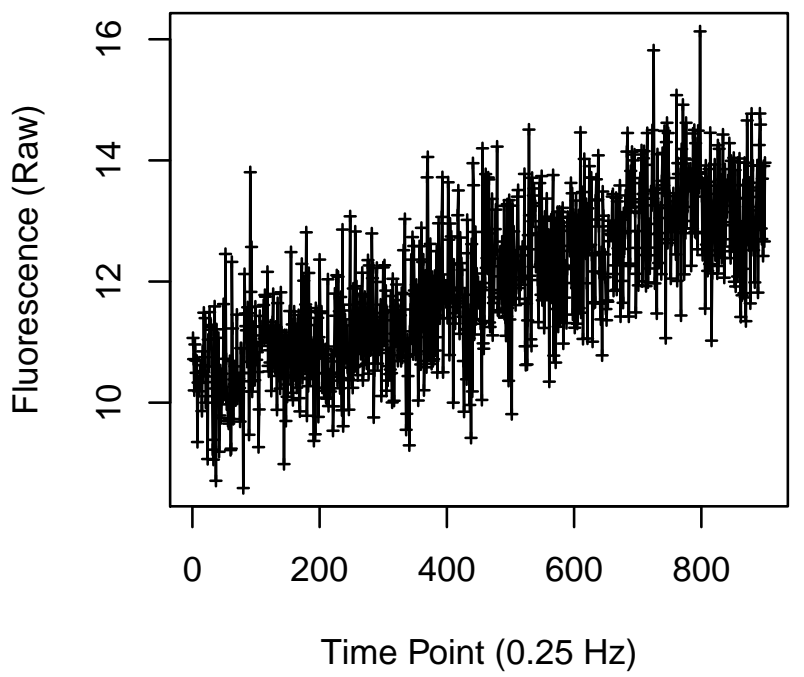

Cell 158

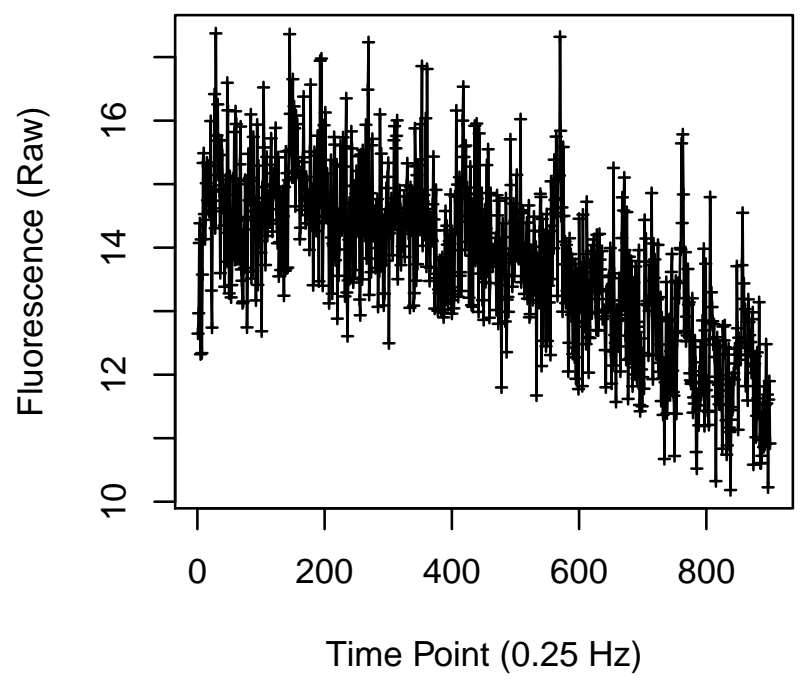

Cell 160

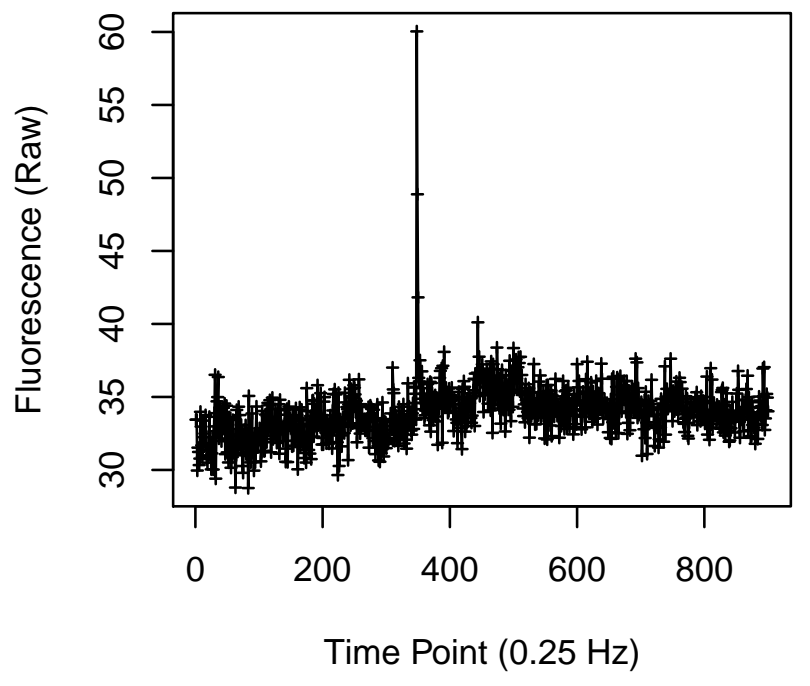


Cell 161

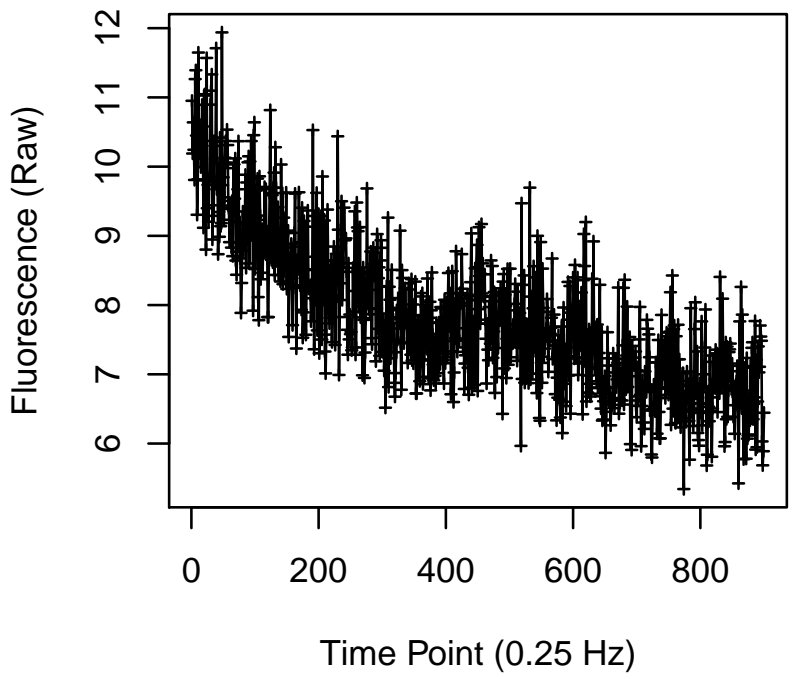

Cell 163

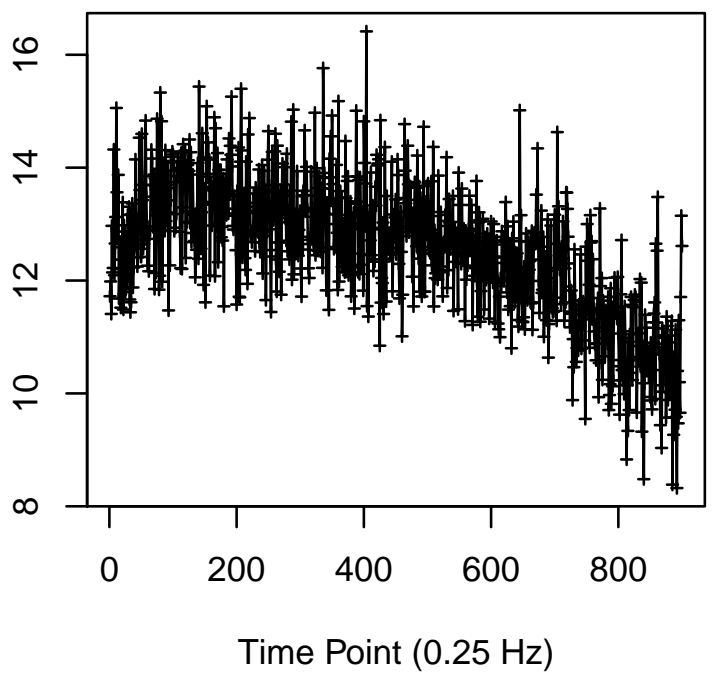

Cell 162

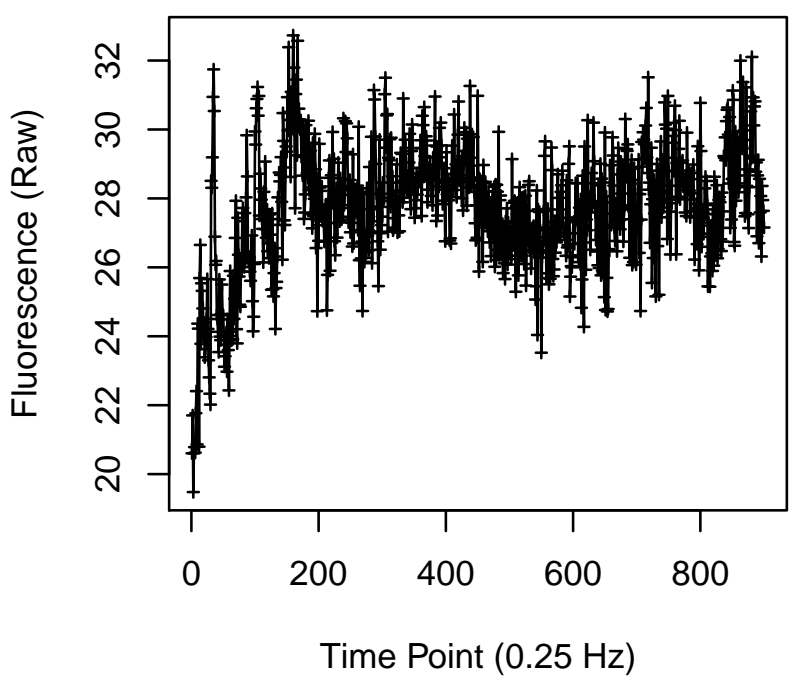

Cell 164

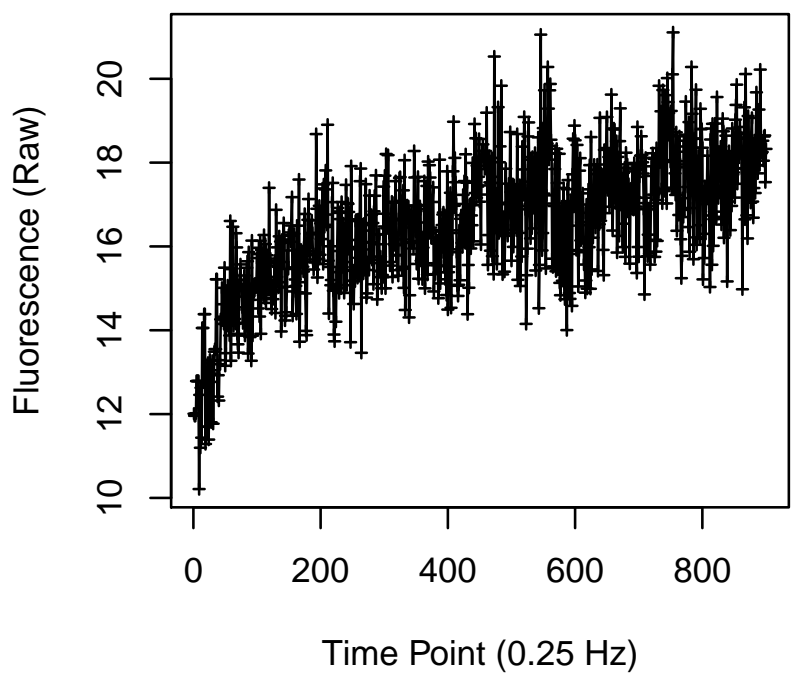


Cell 169

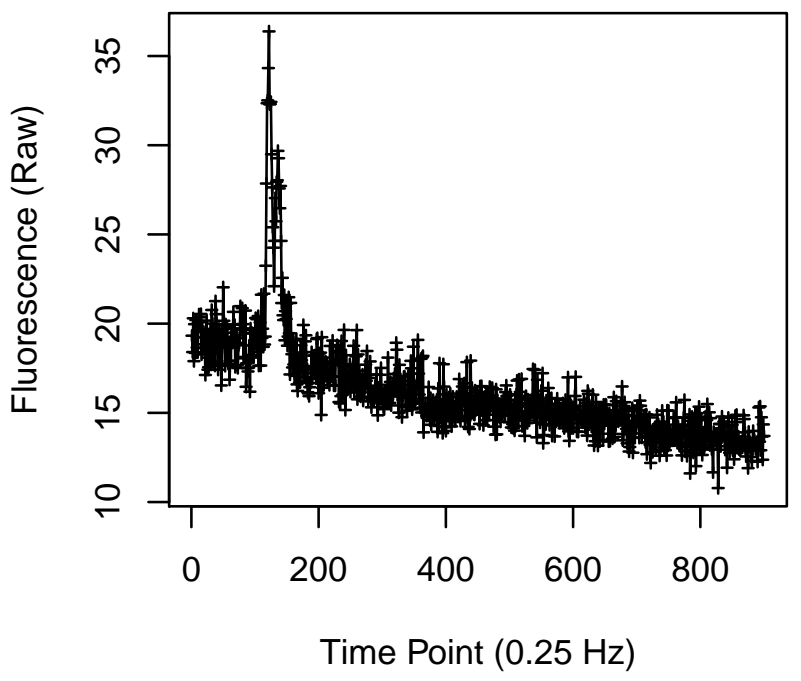

Cell 171

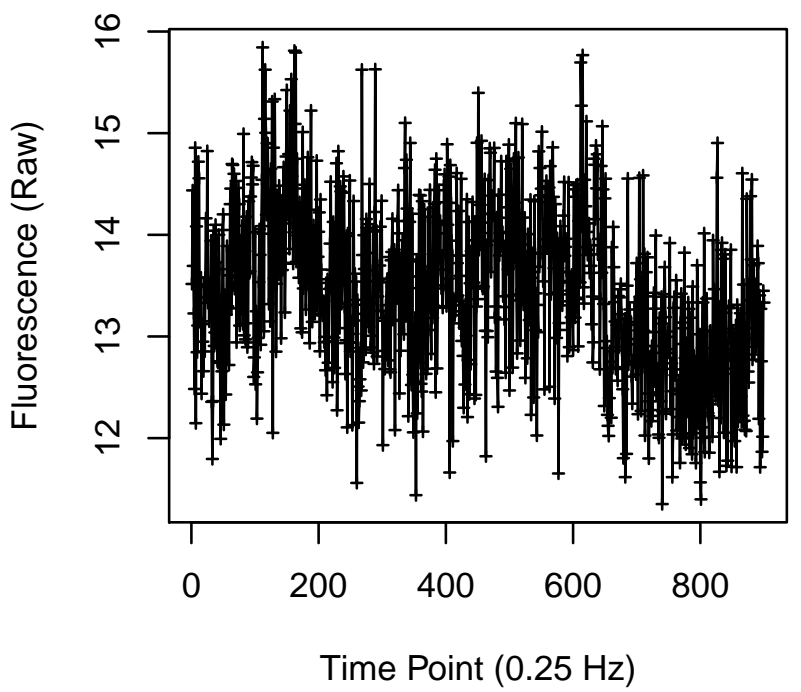

Cell 170

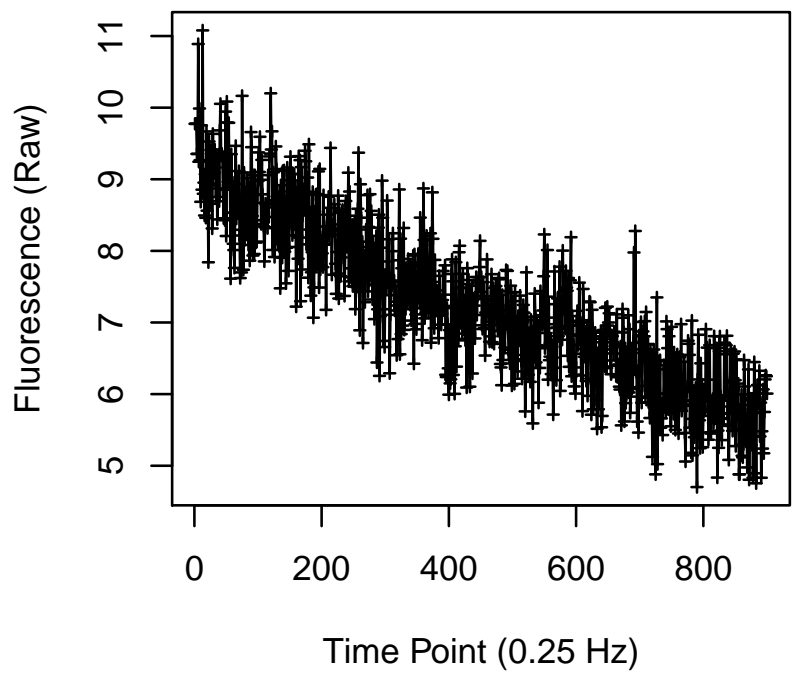

Cell 172

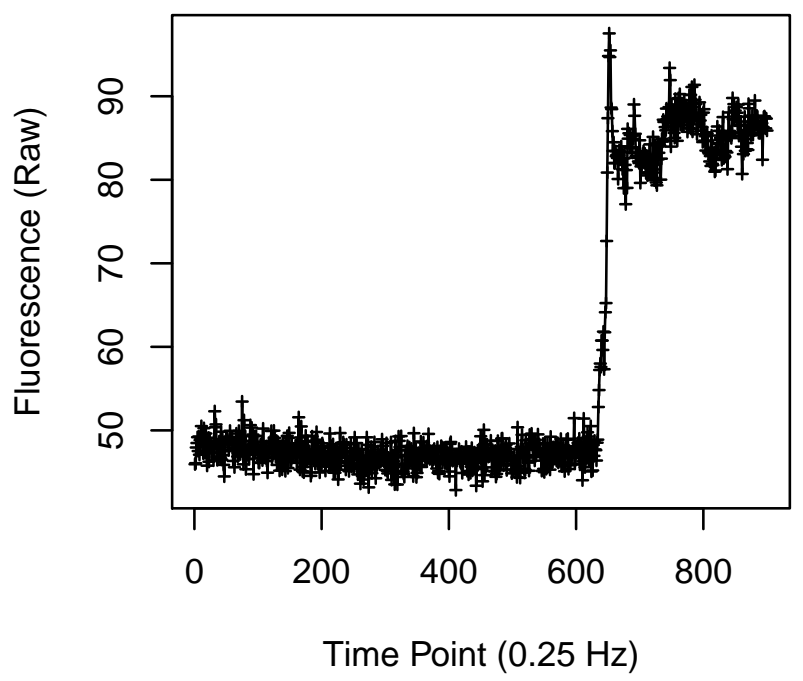




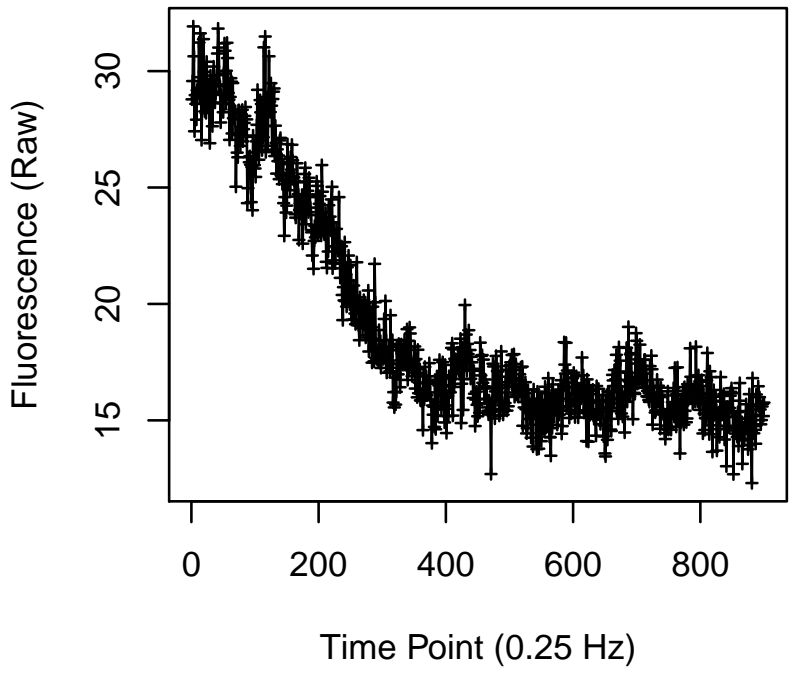

Cell 179

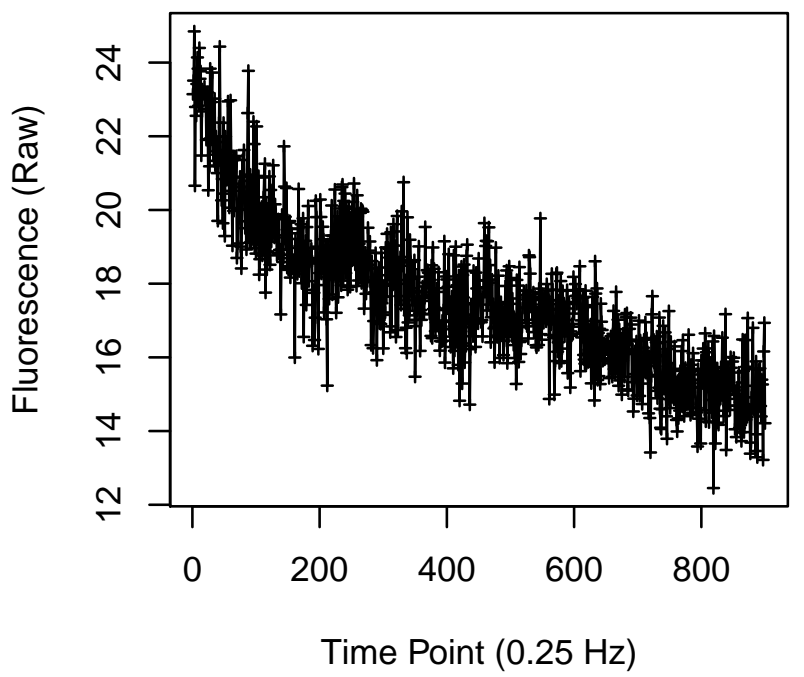

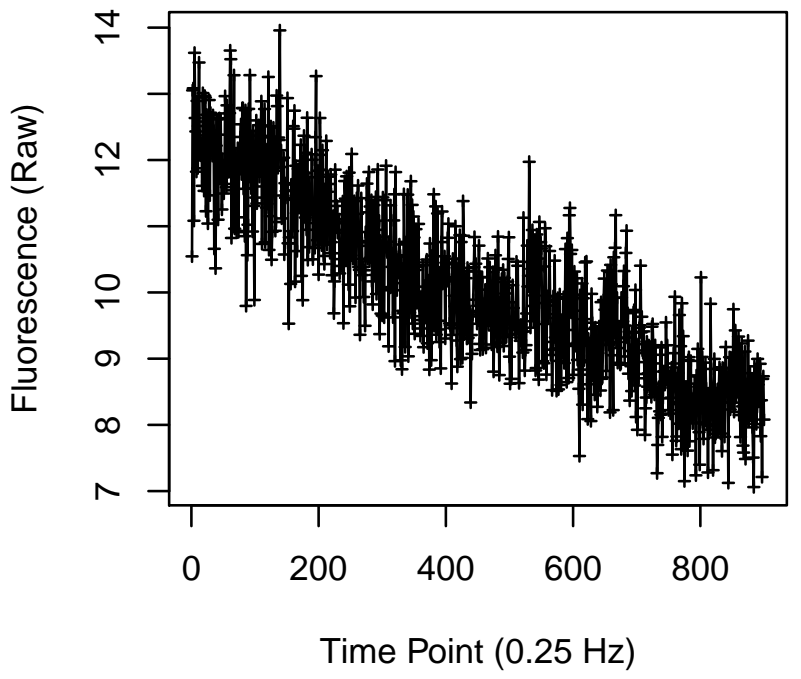

Cell 180

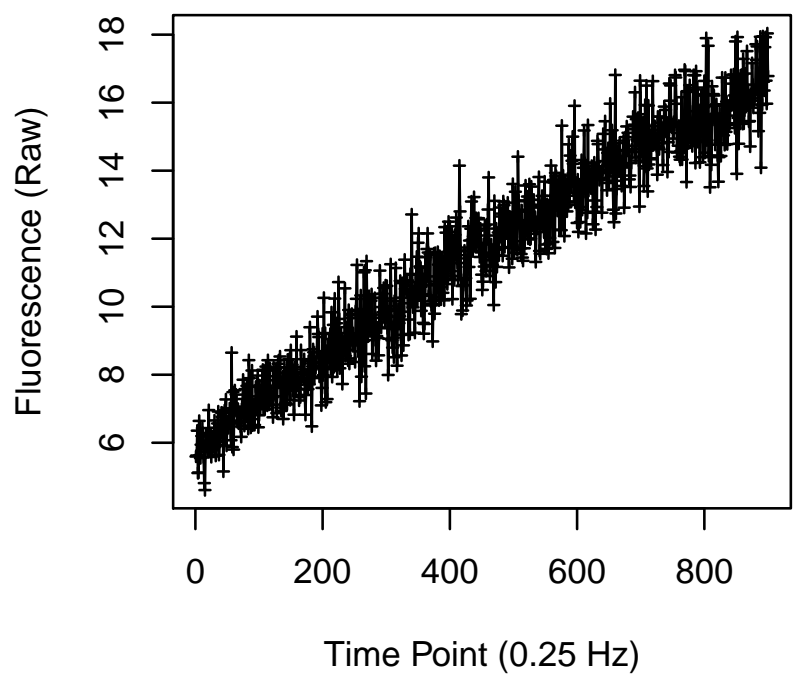


Cell 181

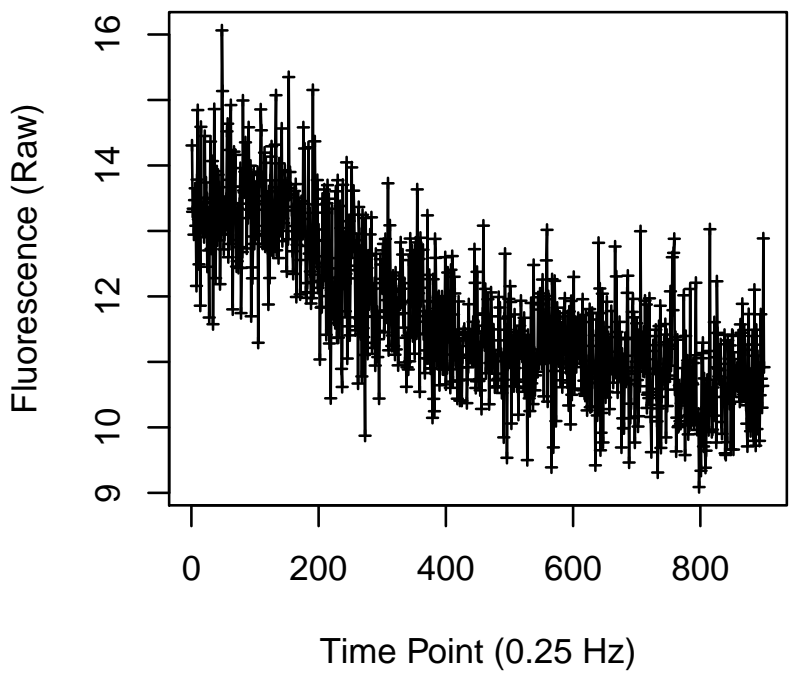

Cell 183

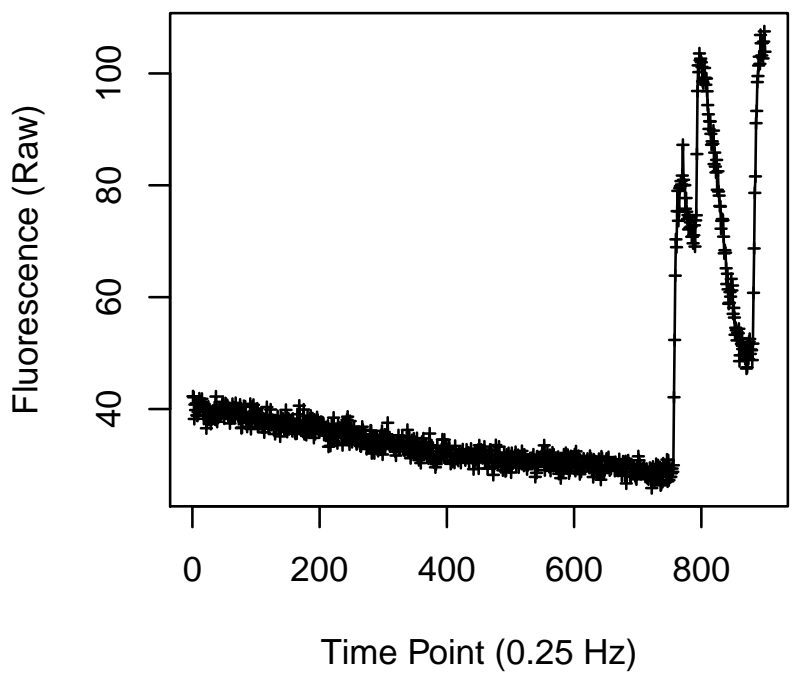

Cell 182

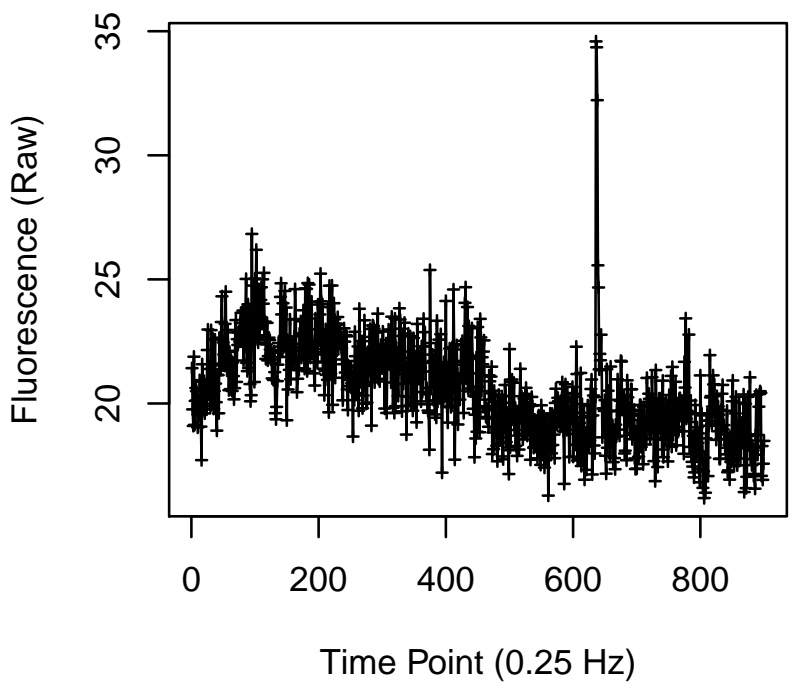

Cell 184

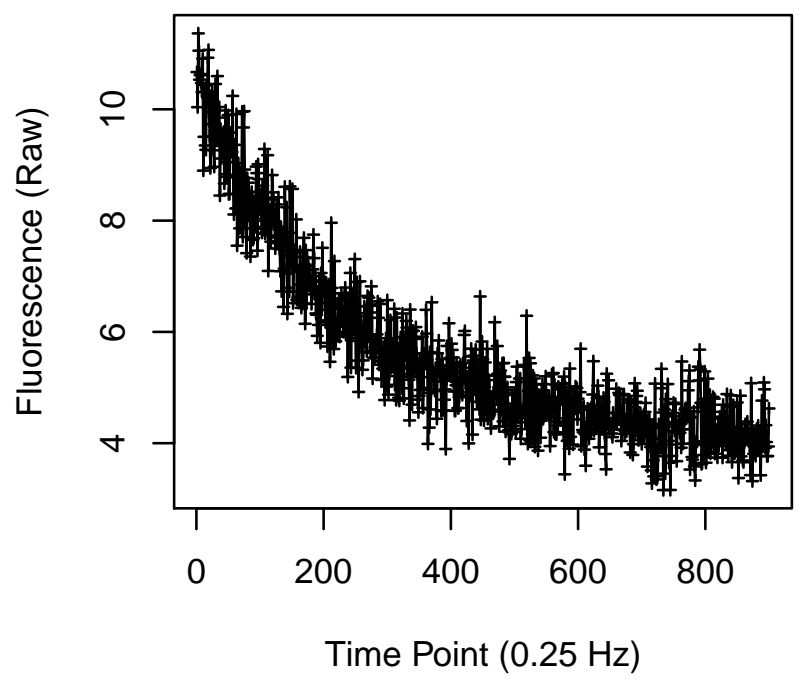


Cell 193

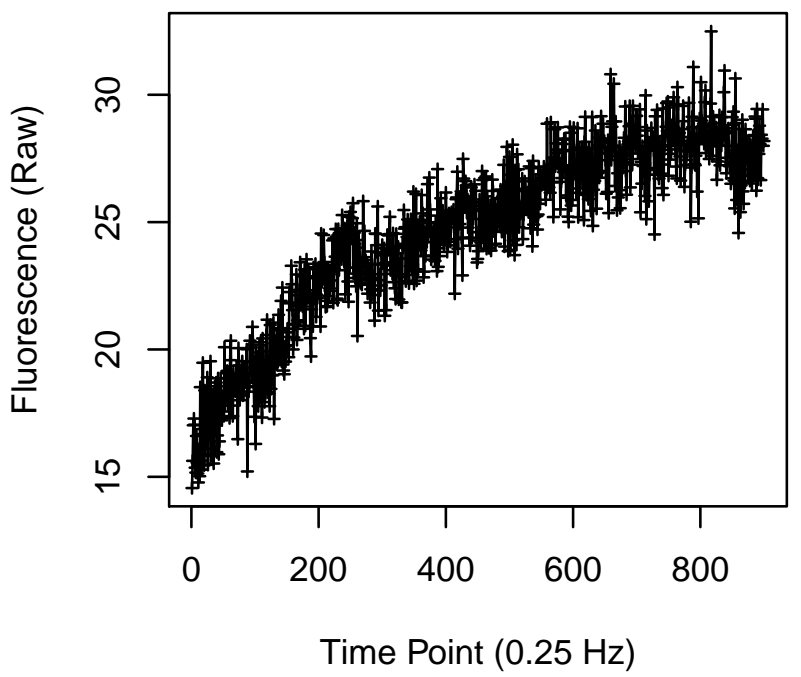

Cell 195

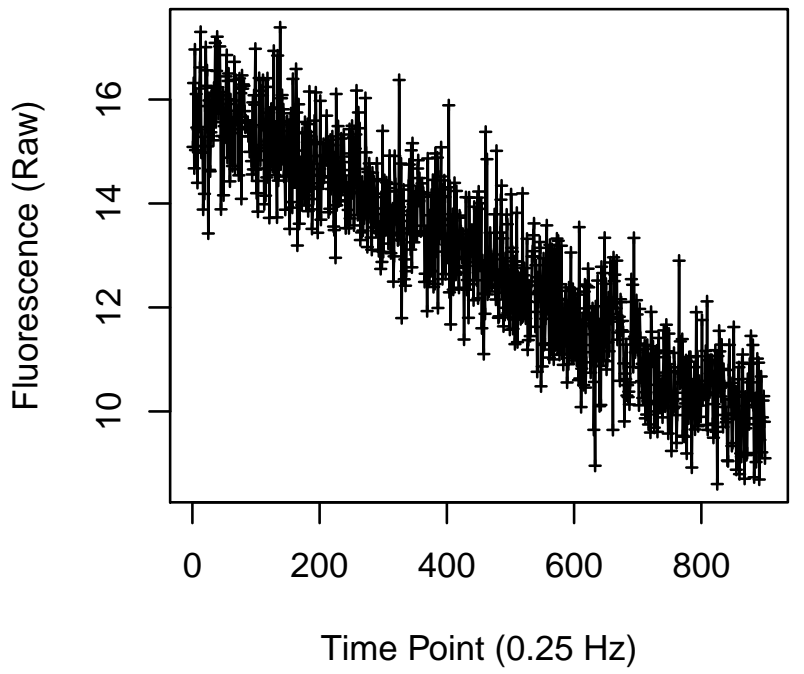

Cell 194

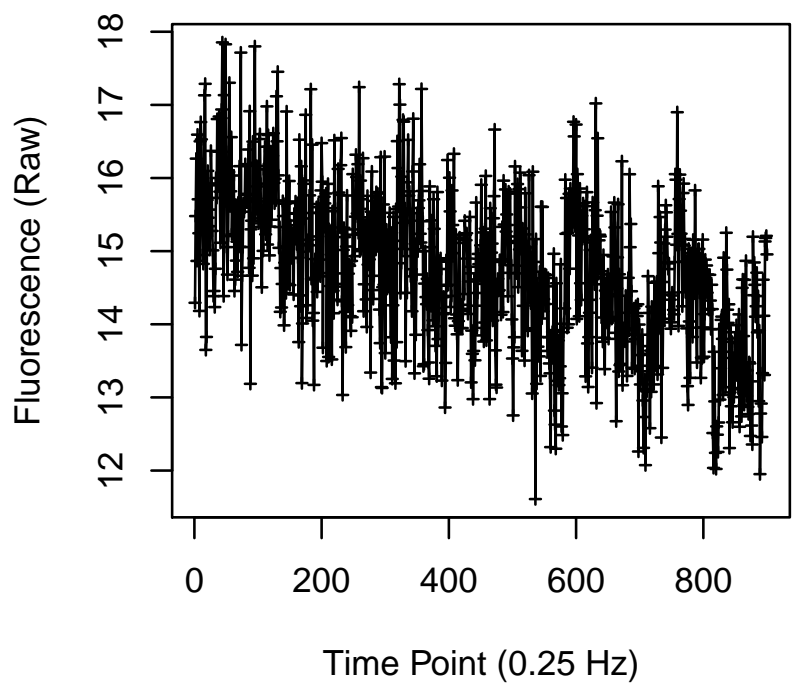

Cell 196

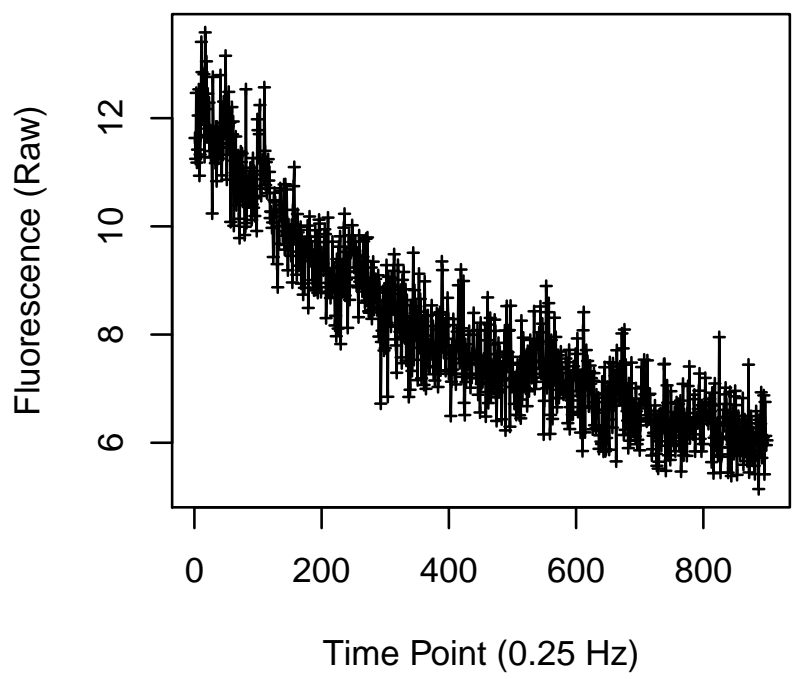


Cell 197

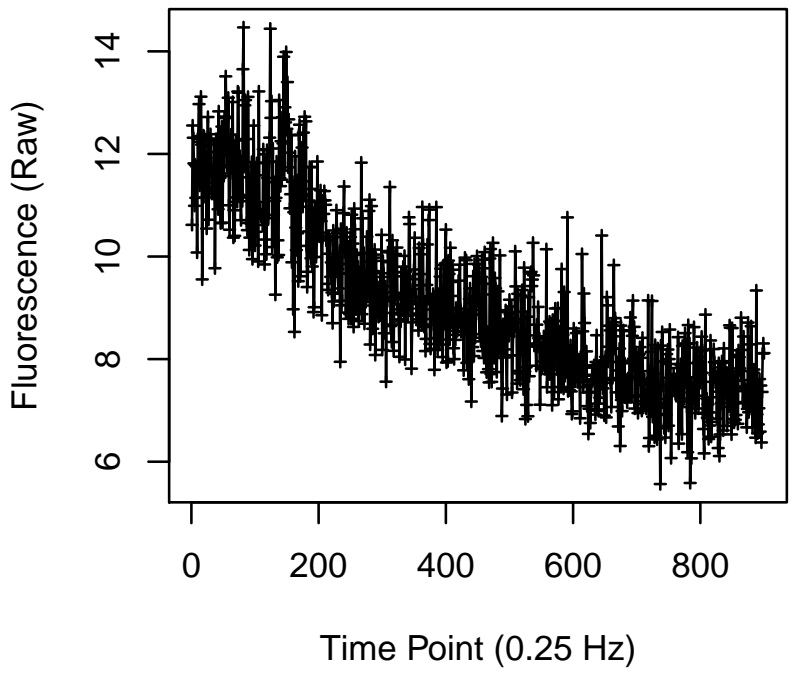

Cell 199

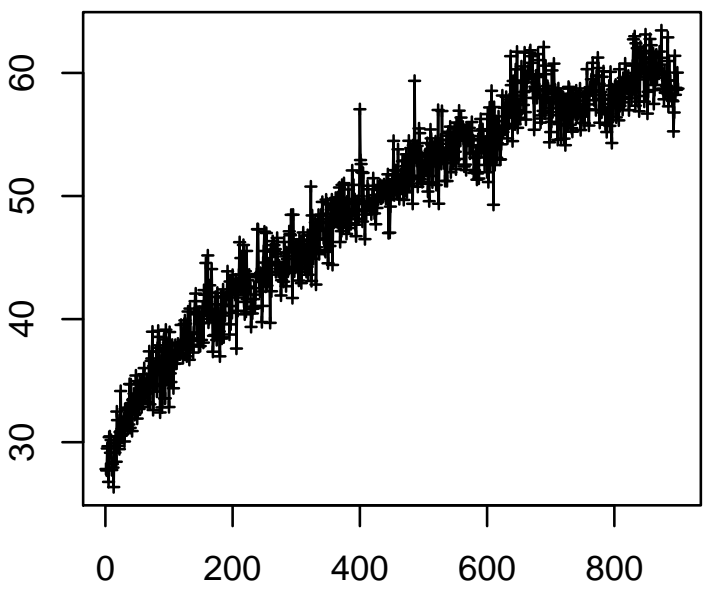

Time Point $(0.25 \mathrm{~Hz})$
Cell 198

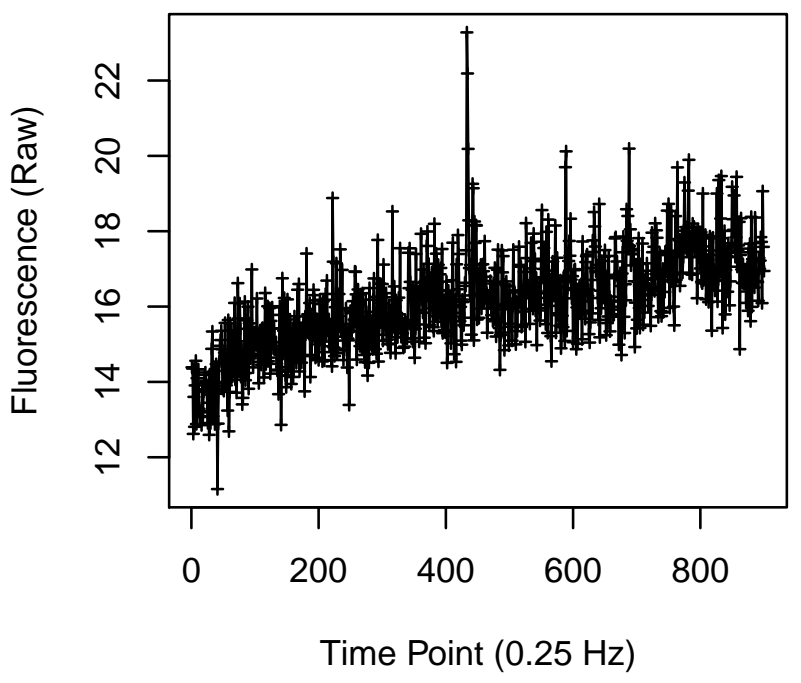

Cell 200

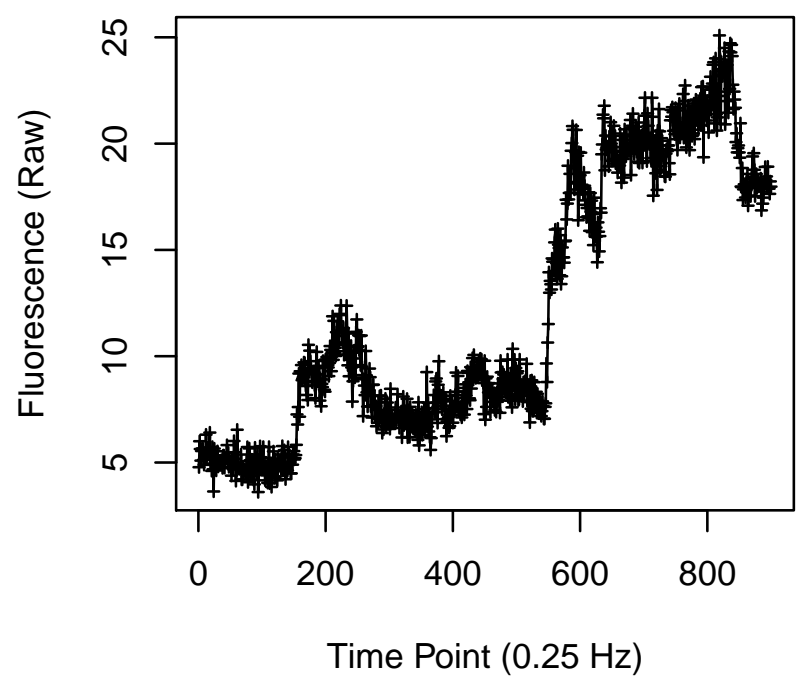


Cell 201

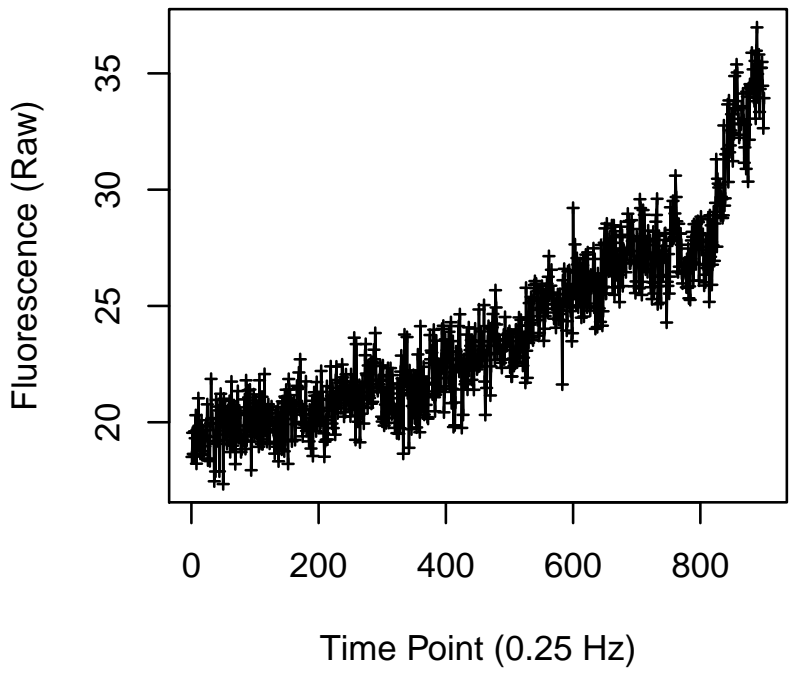

Cell 203

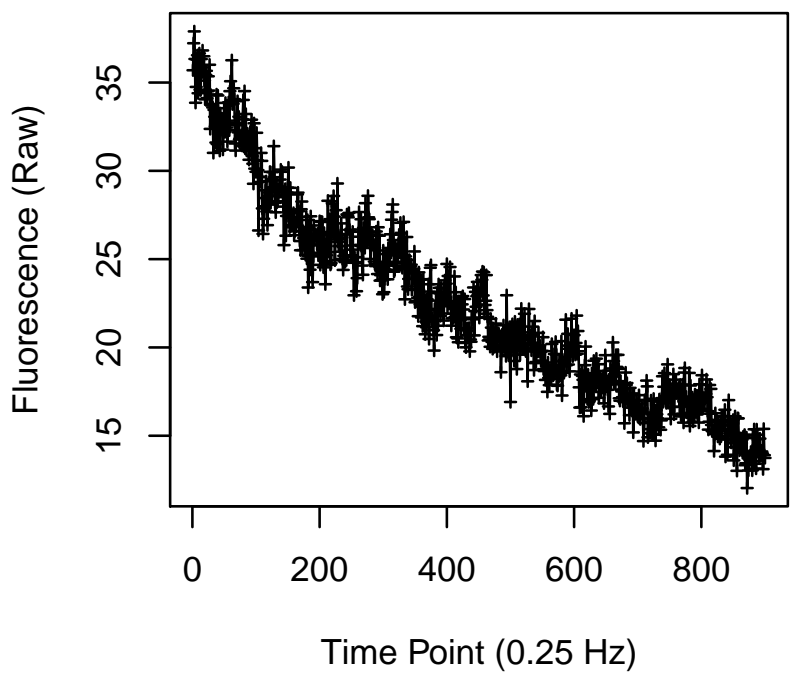

Cell 202

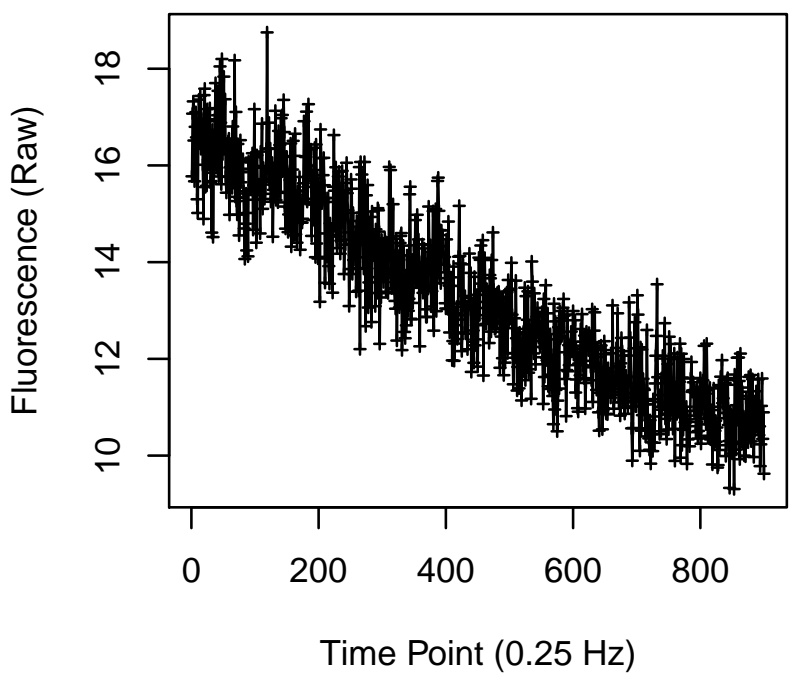

Cell 204

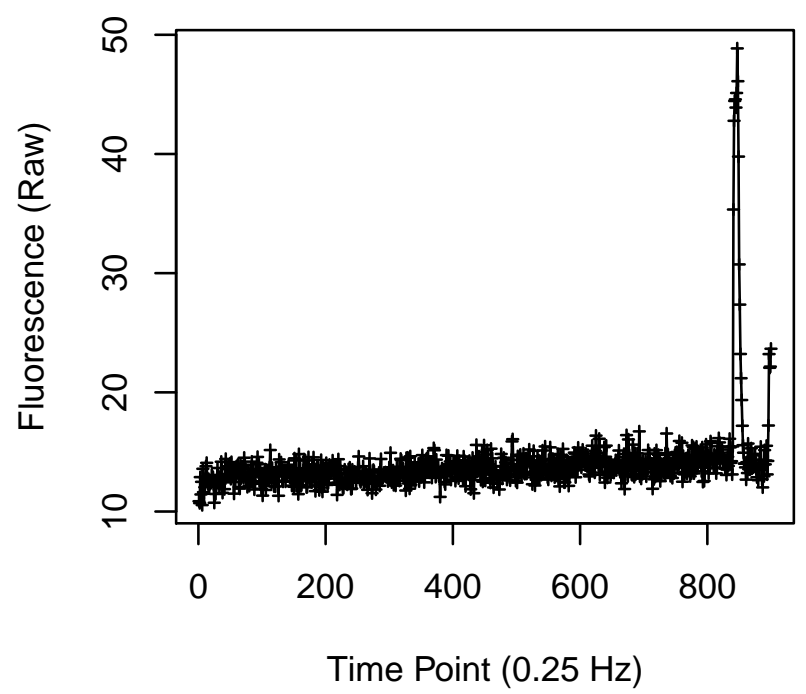




\section{Cell 205}

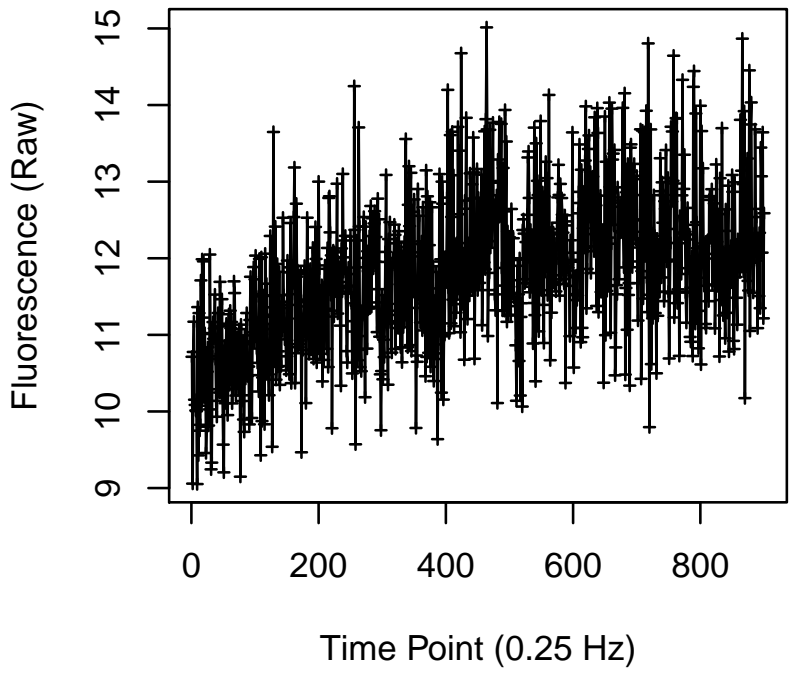

Cell 207

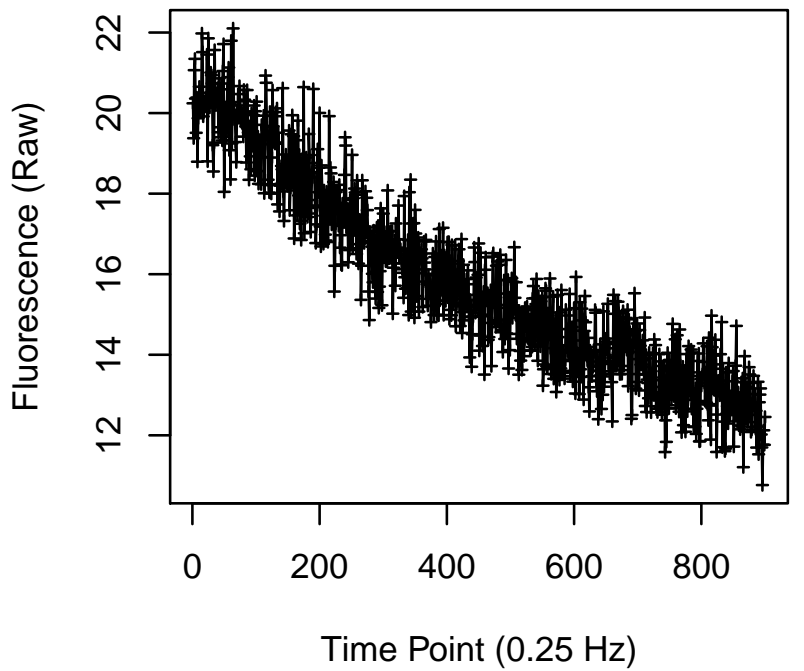

Cell 206

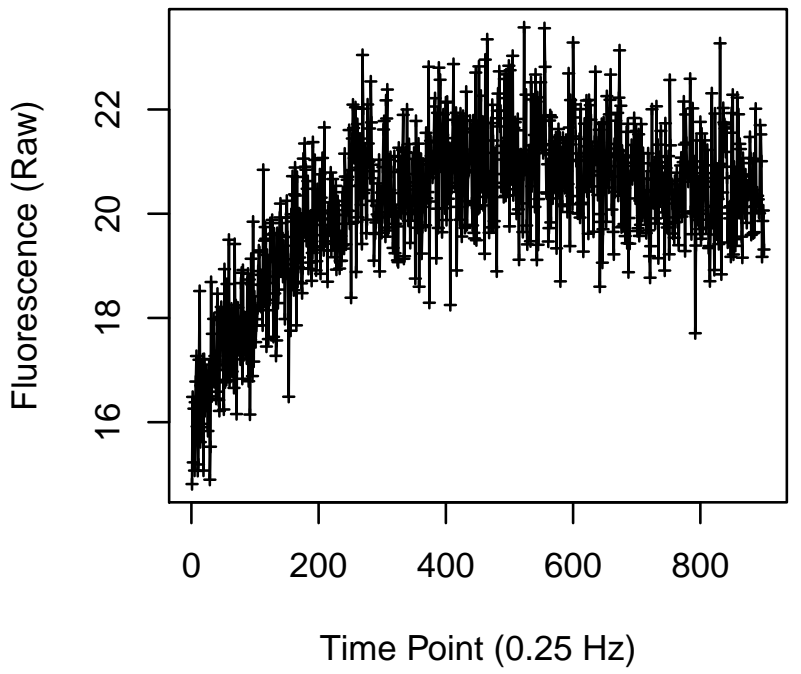

Cell 208

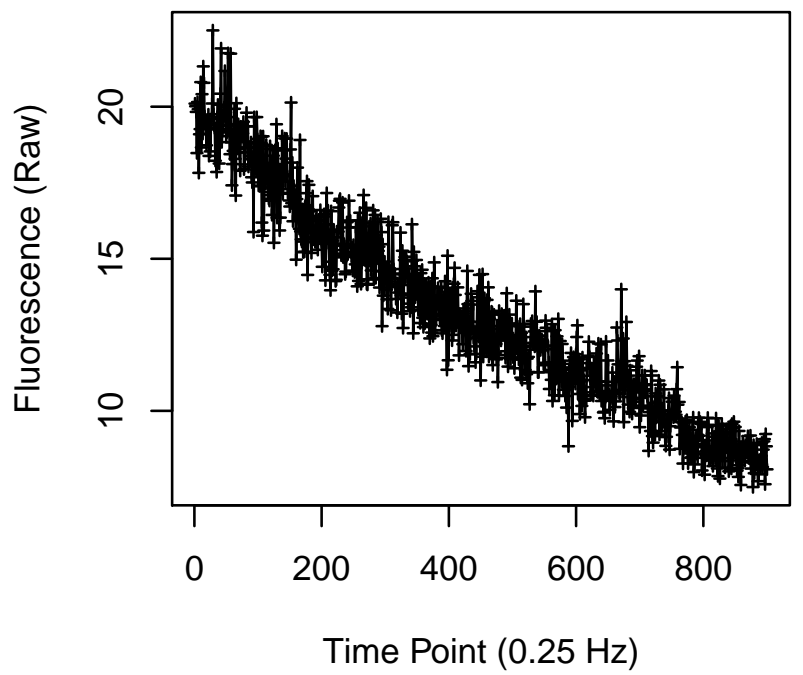


Cell 209

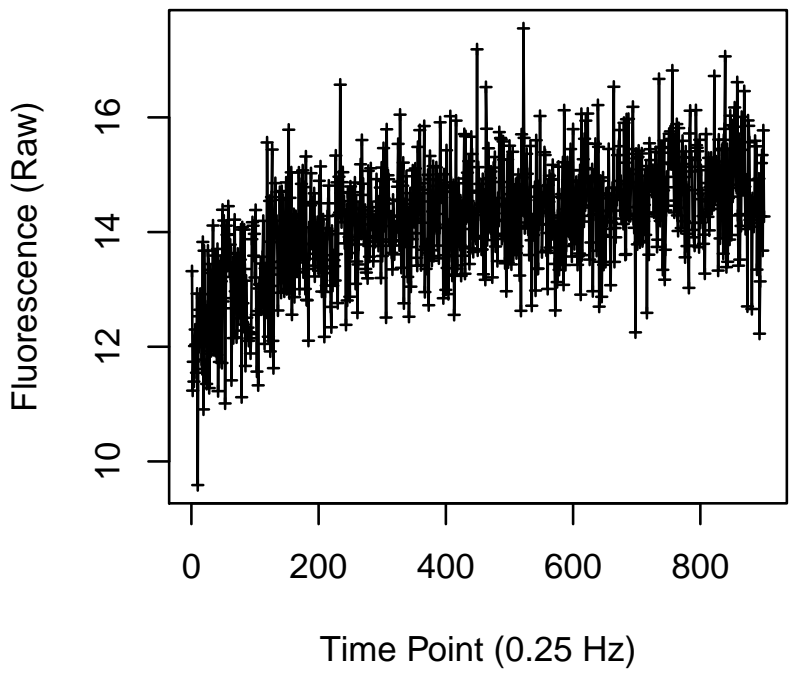

Cell 211

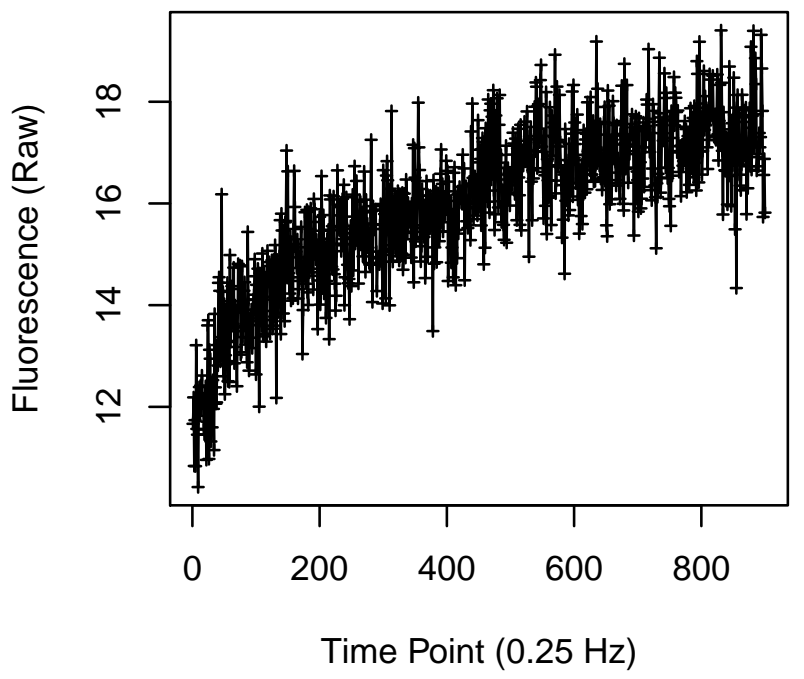

Cell 210

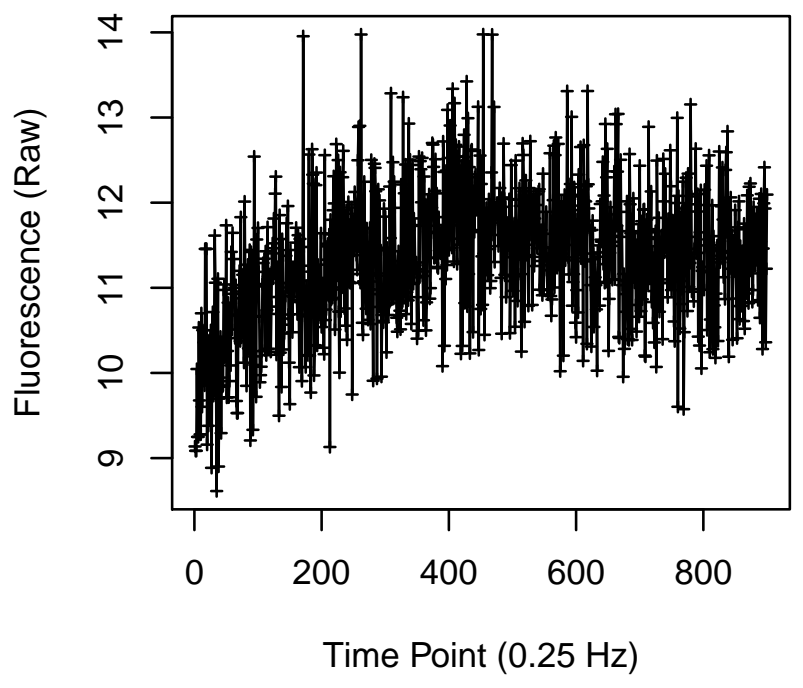

Cell 212

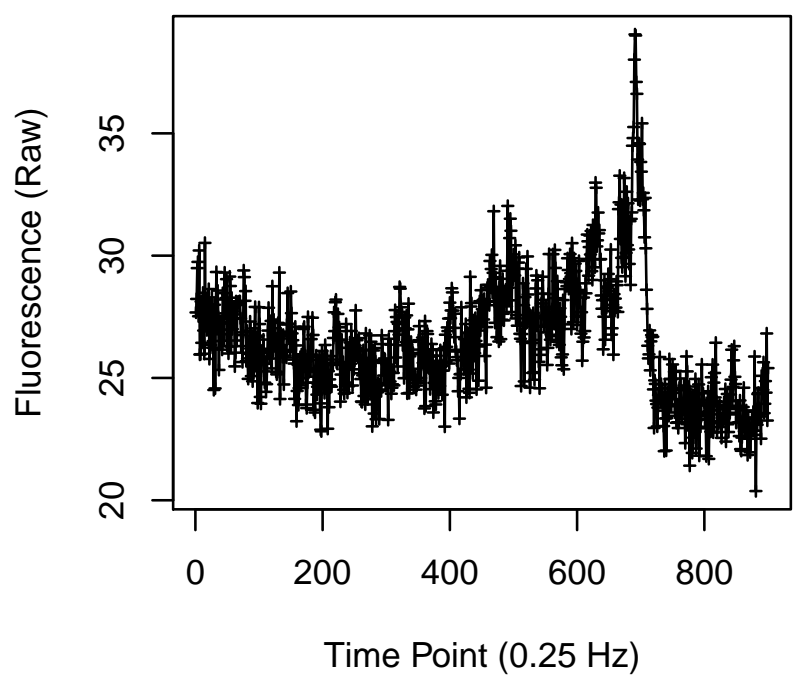


Cell 217

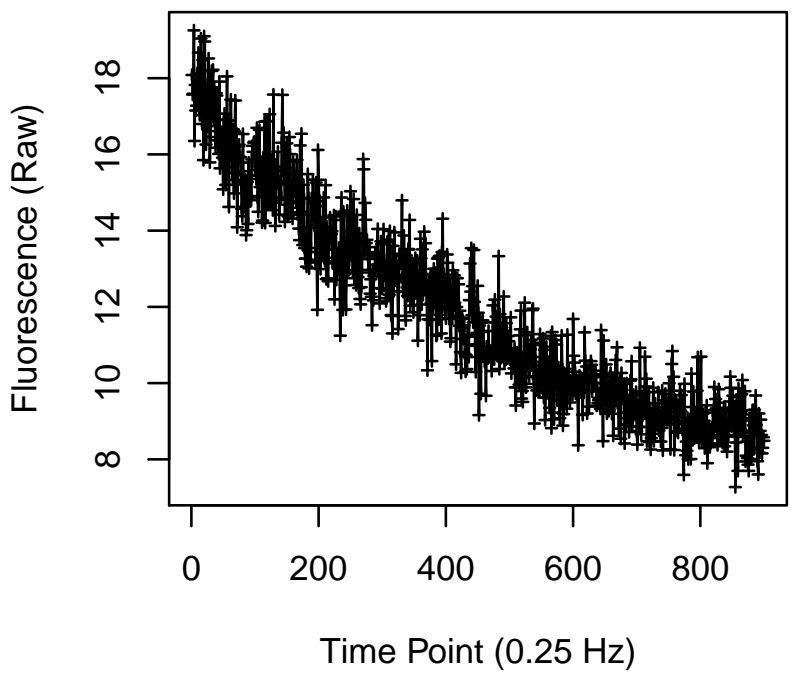

Cell 219

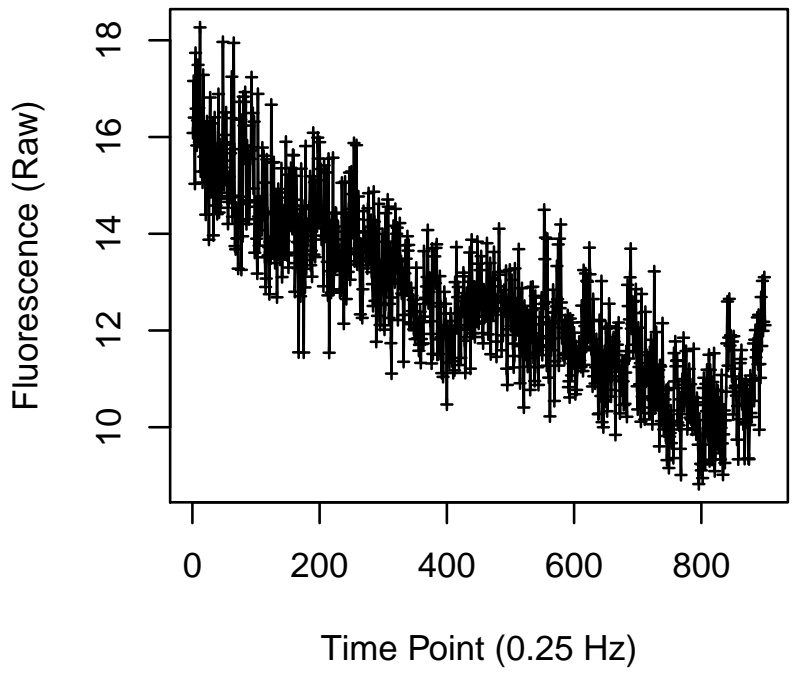

Cell 218

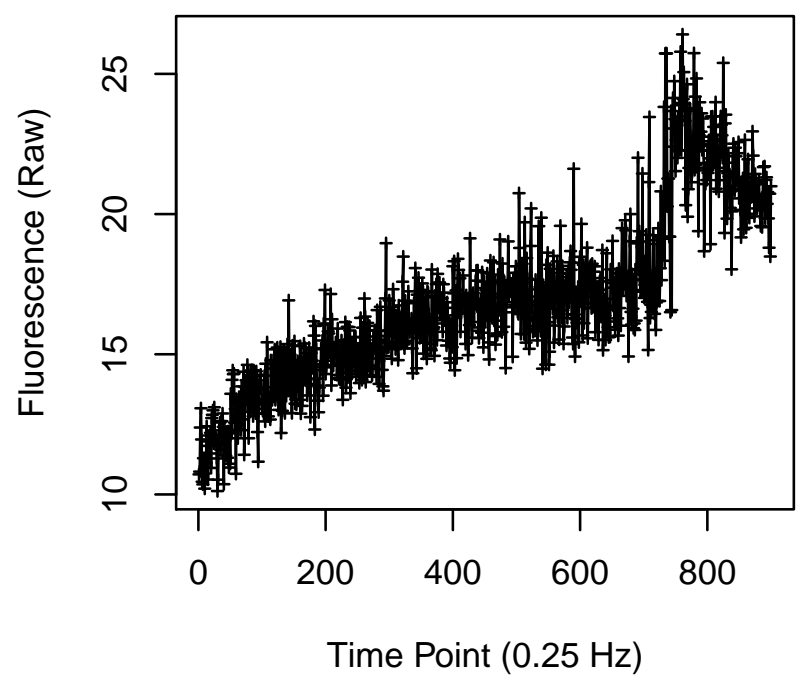

Cell 220

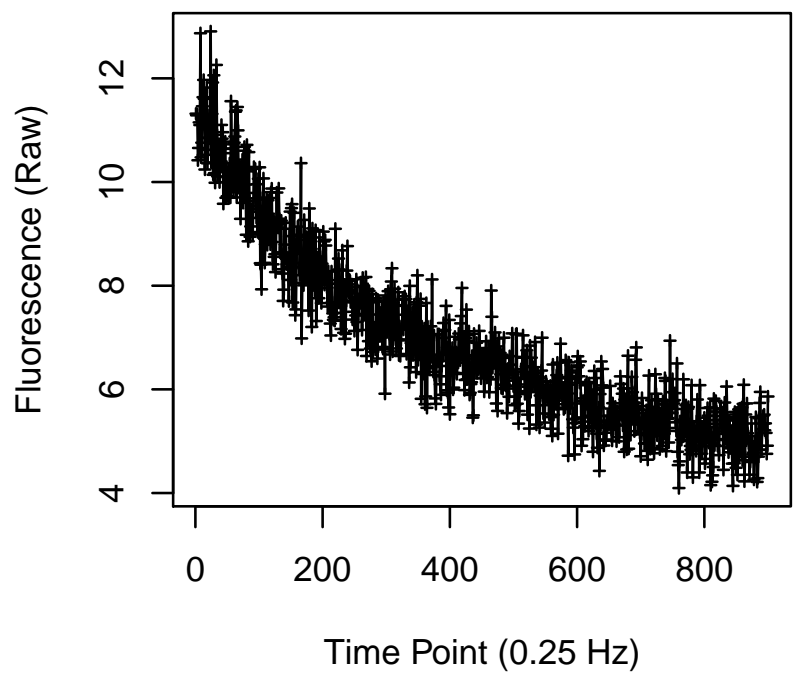


Cell 221

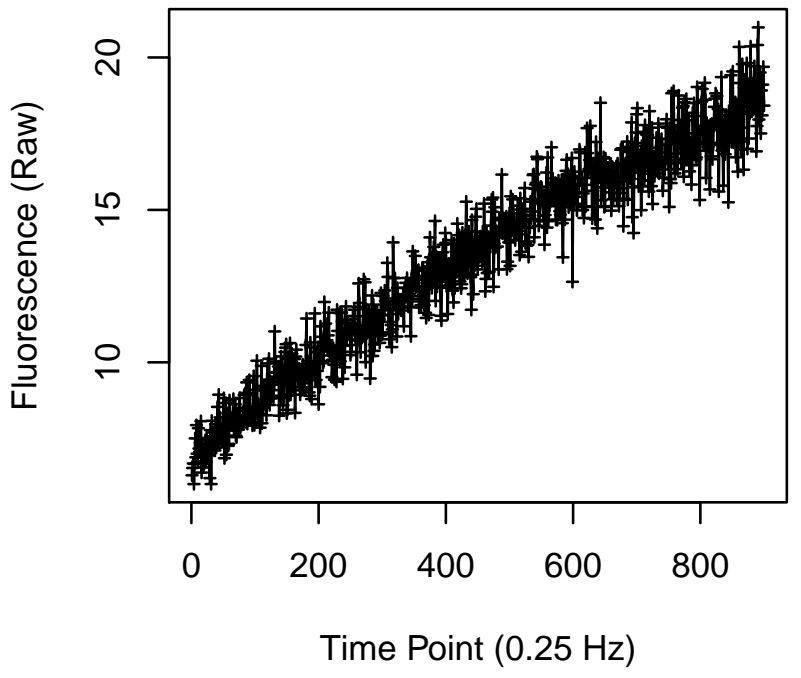

Cell 223

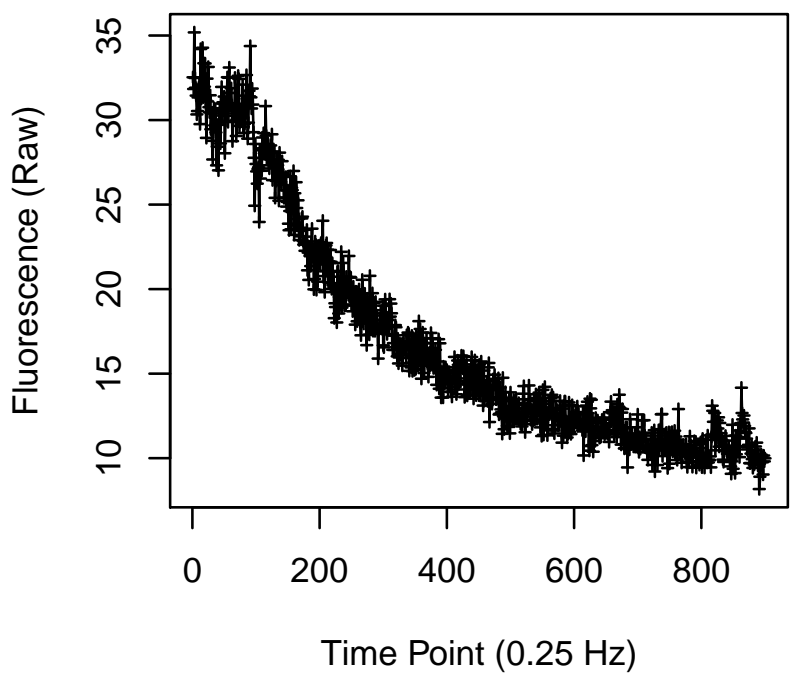

Cell 222

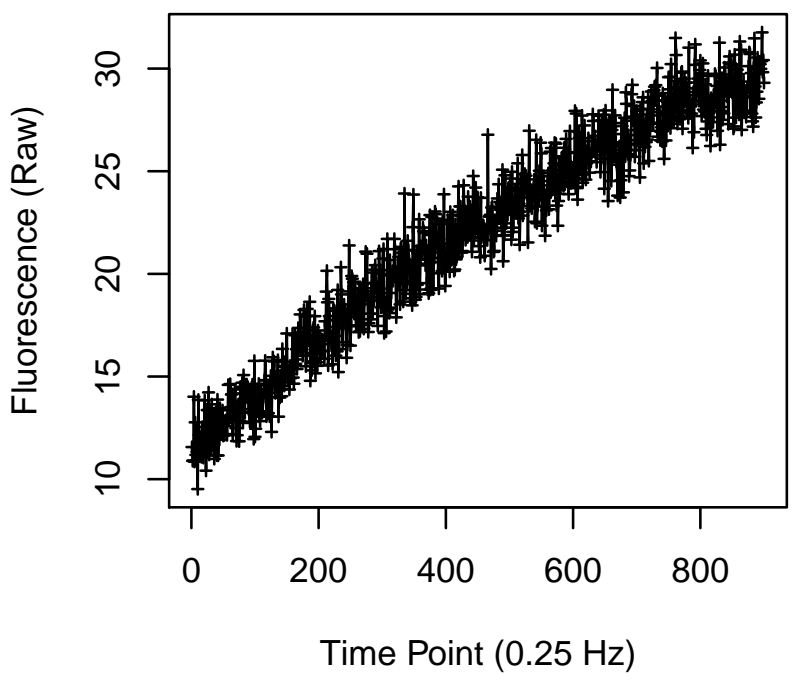

Cell 224

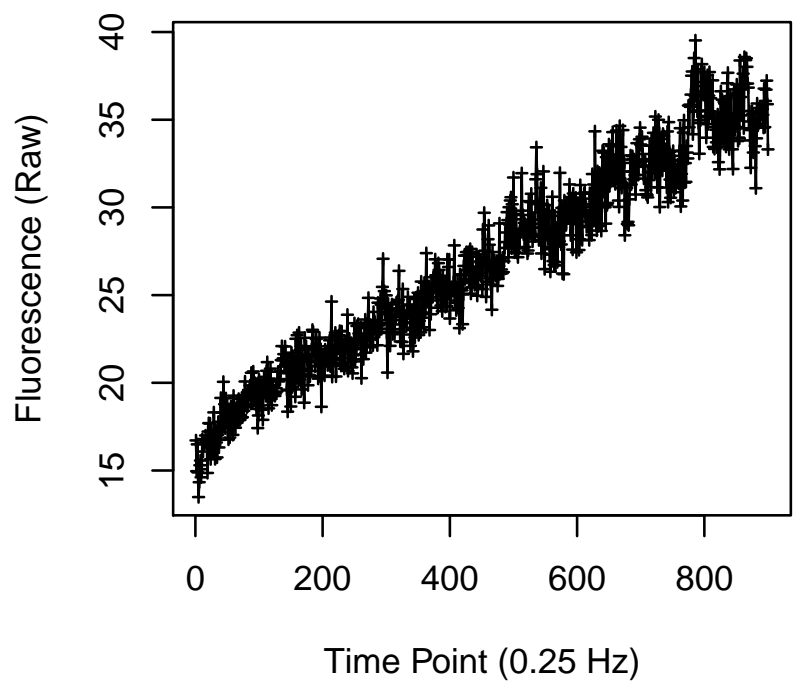


Cell 233

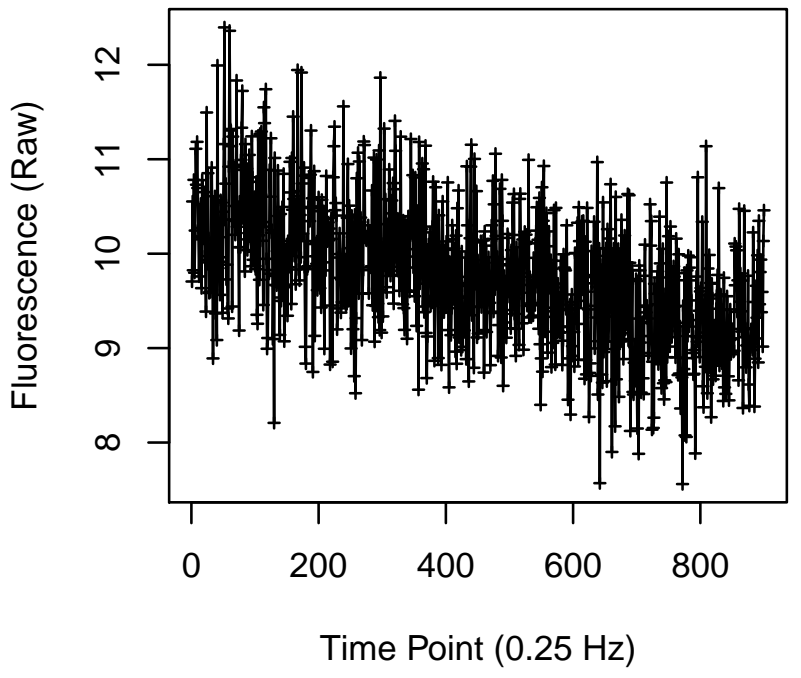

Cell 235

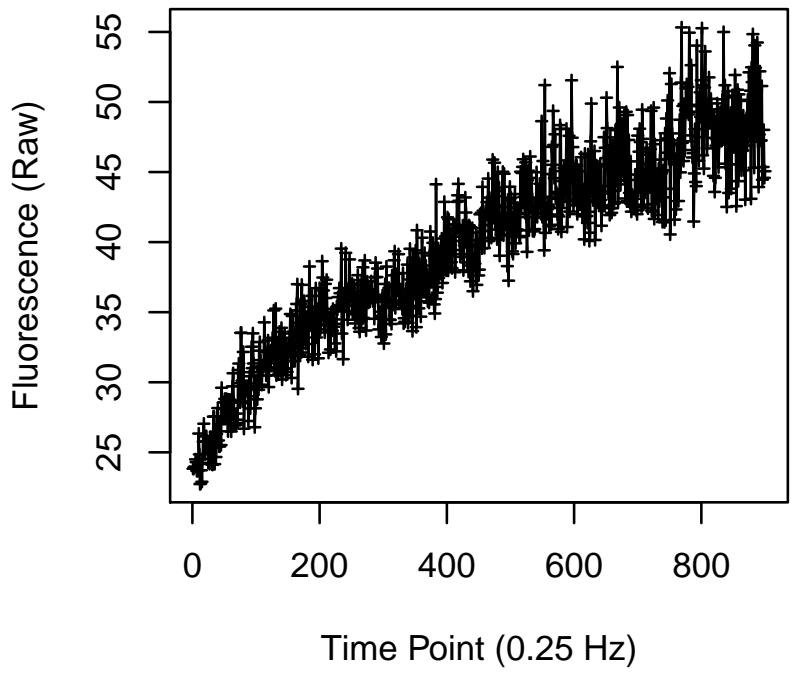

Cell 234

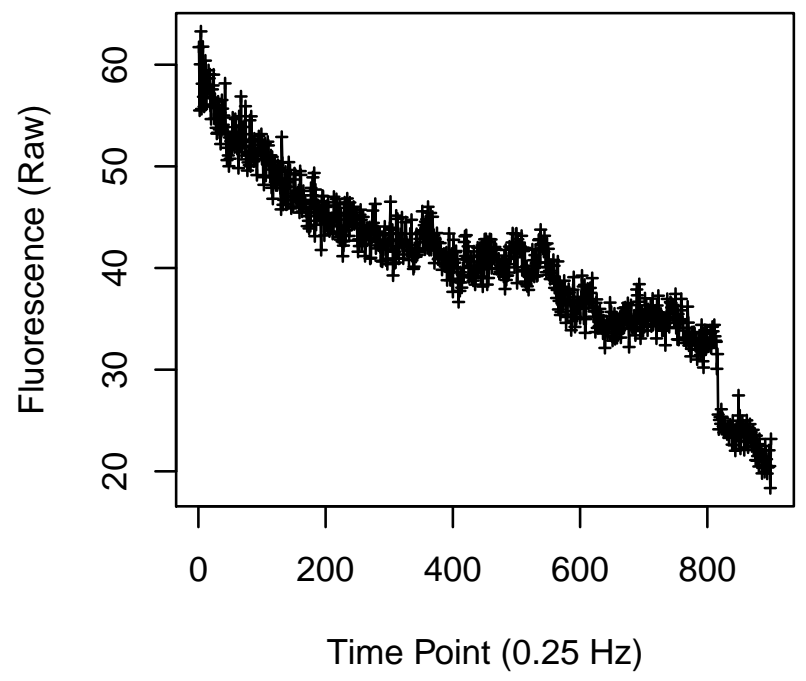

Cell 236

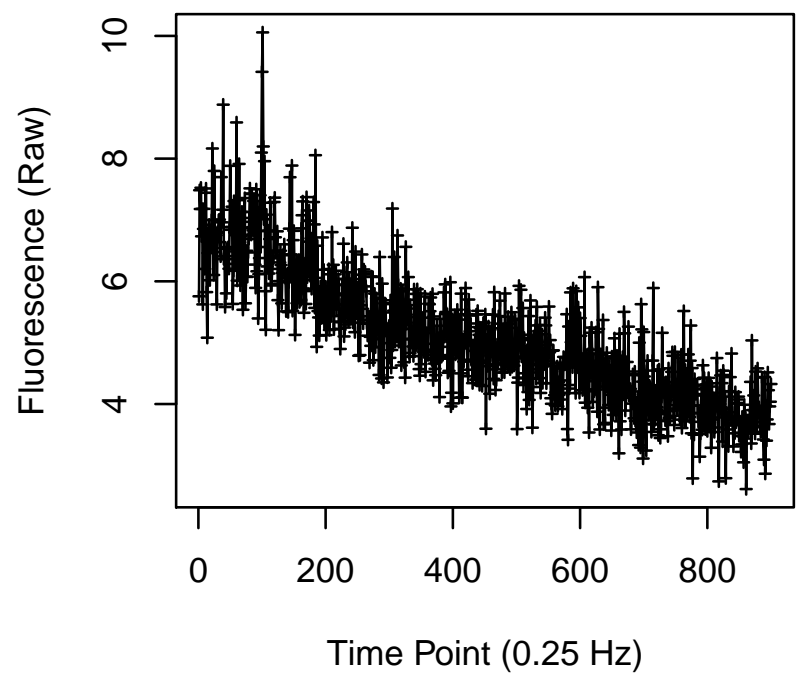


Cell 237

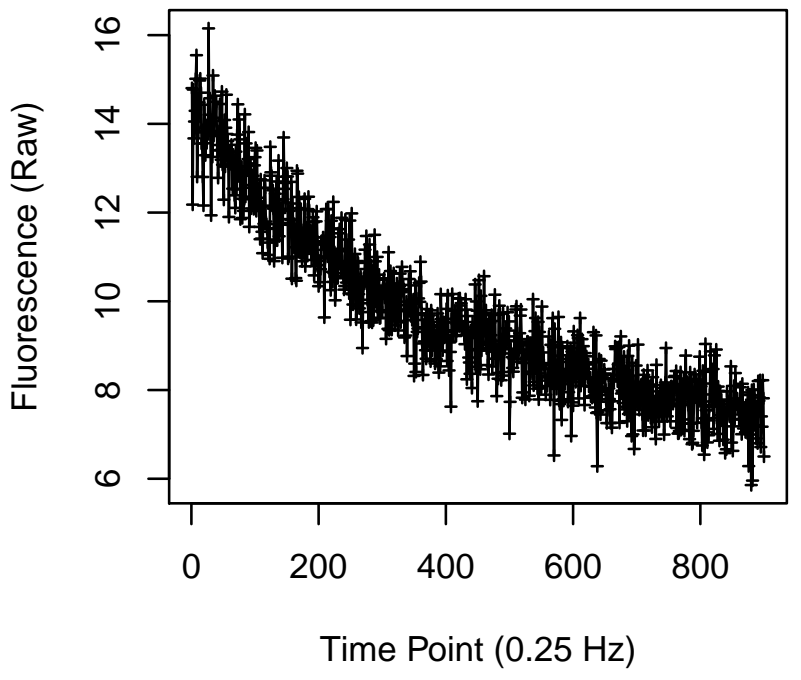

Cell 239

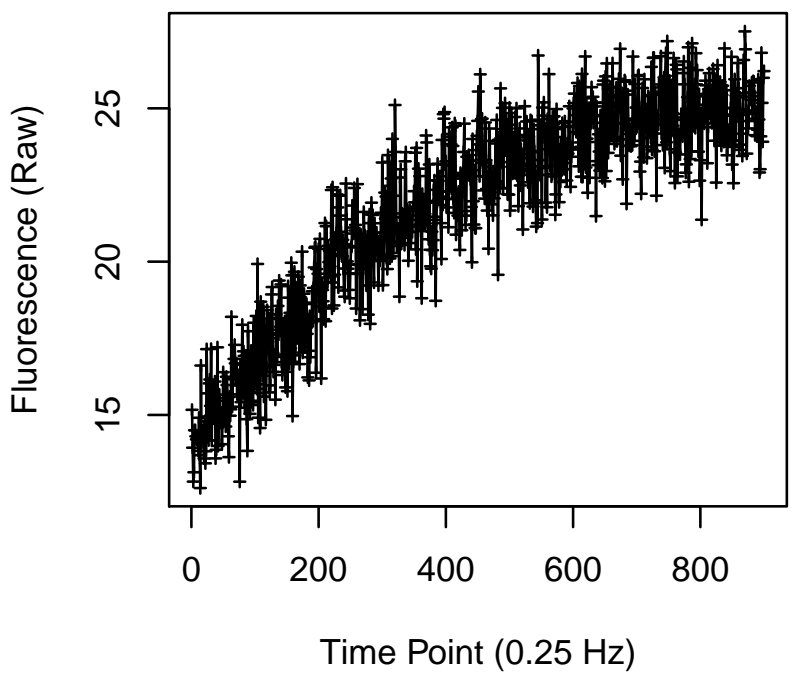

Cell 238

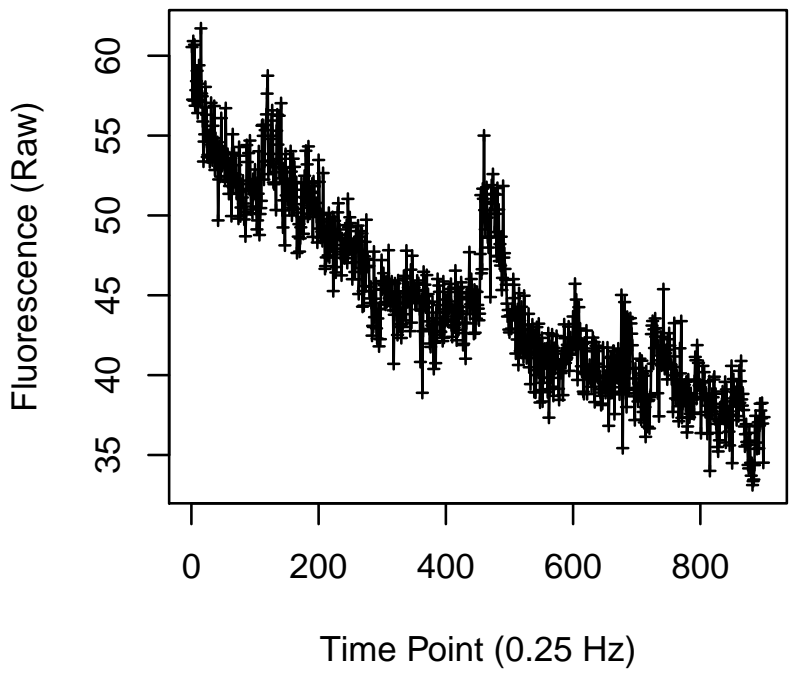

Cell 240

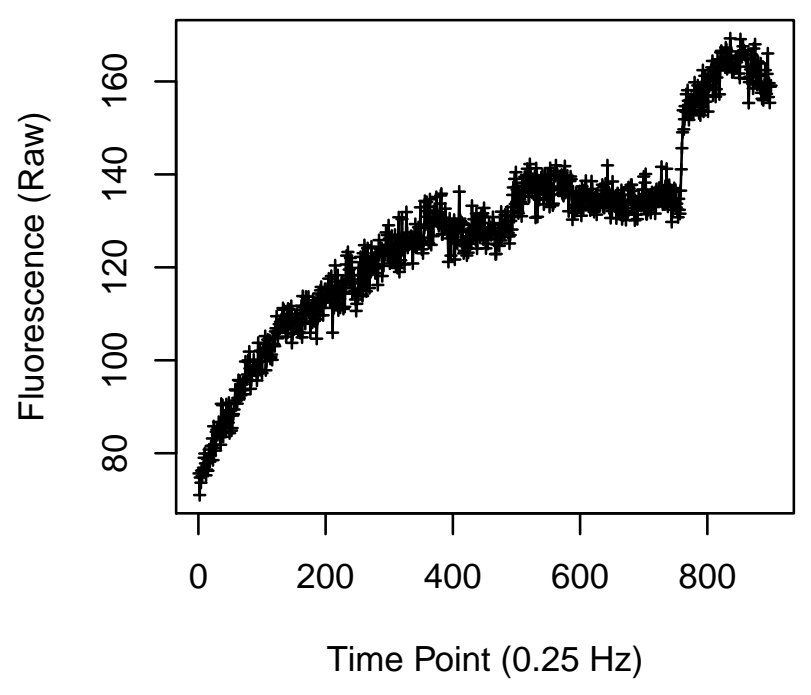


Cell 249

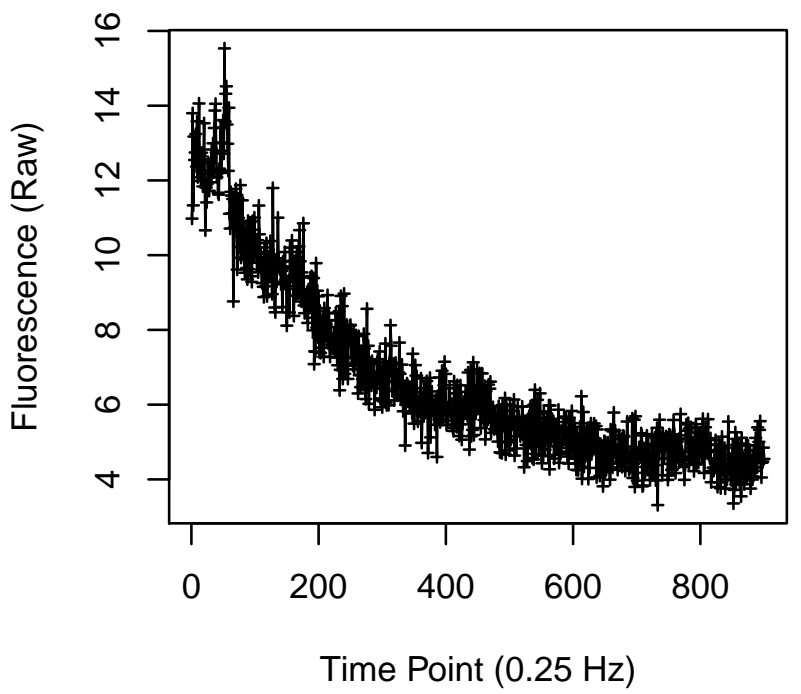

Cell 251

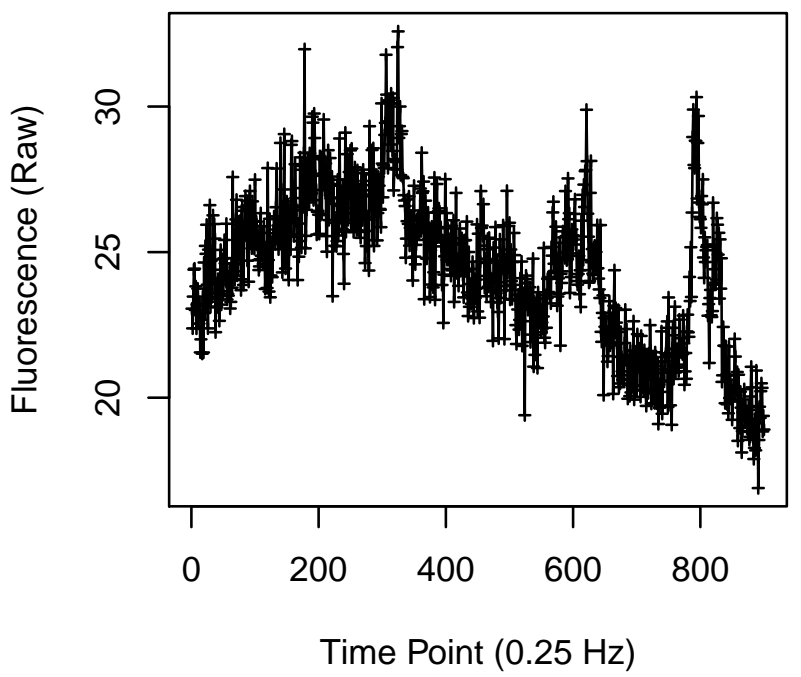

Cell 250

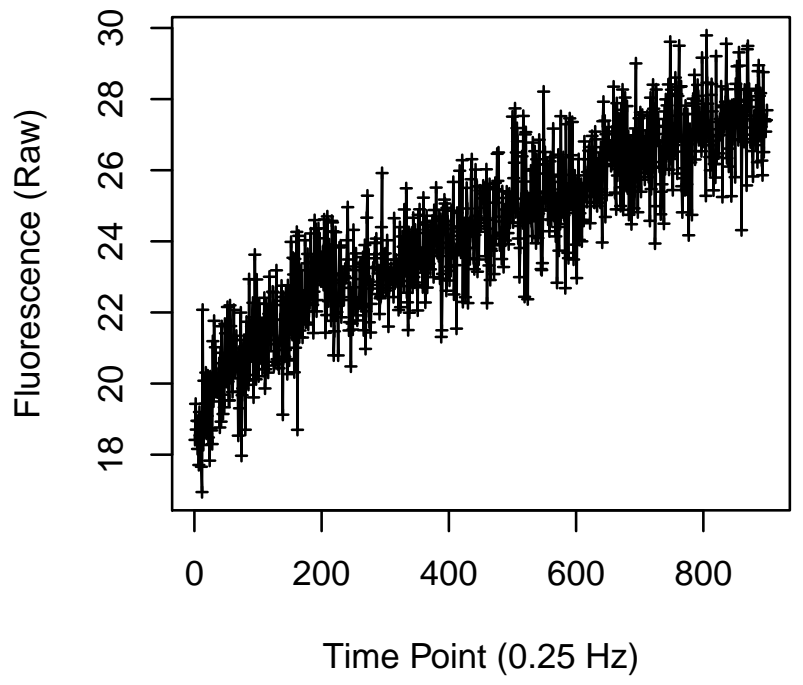

Cell 252

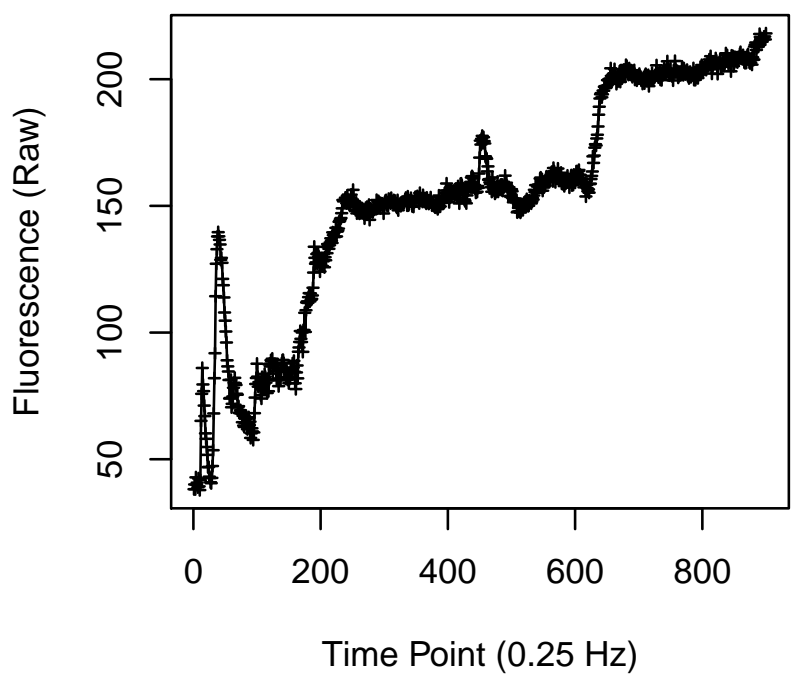


Cell 253

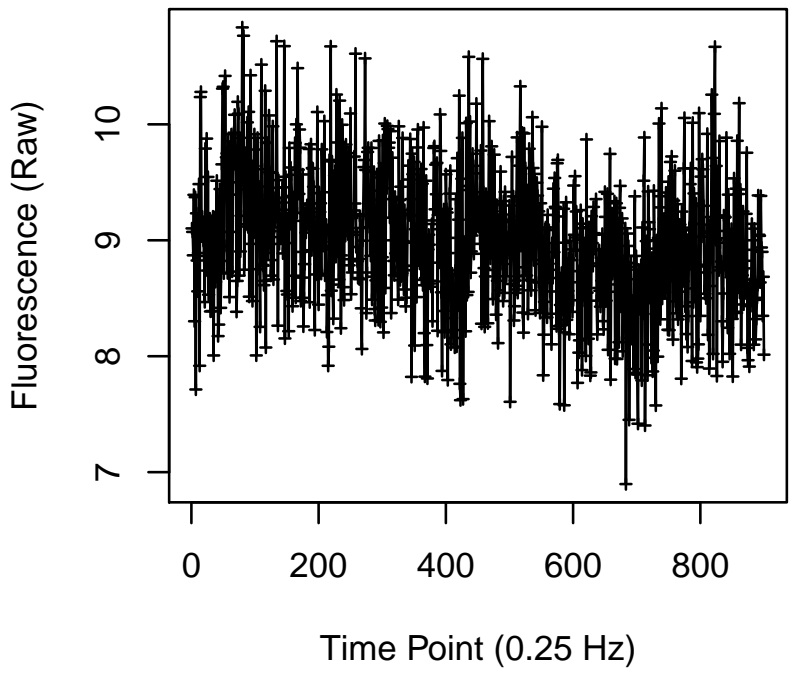

Cell 255

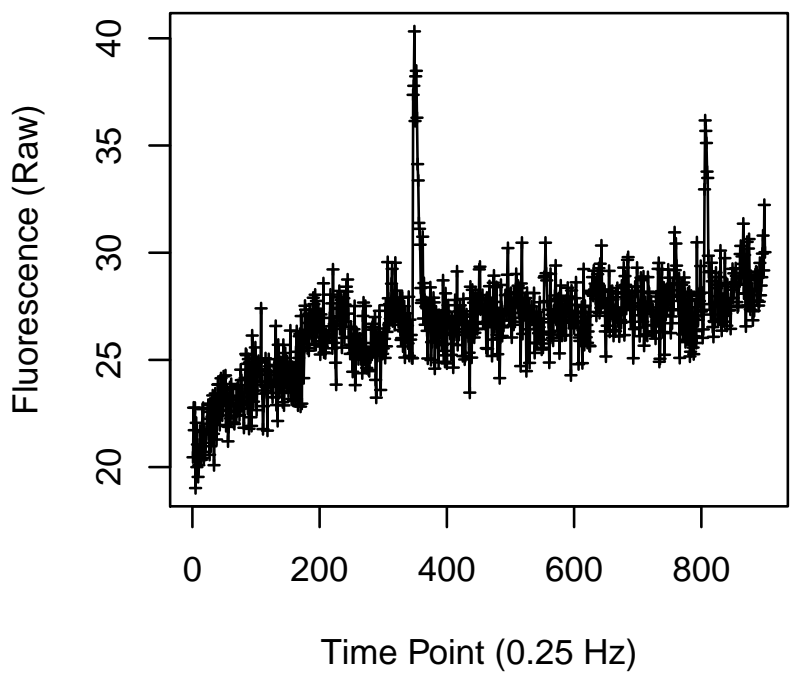

Cell 254

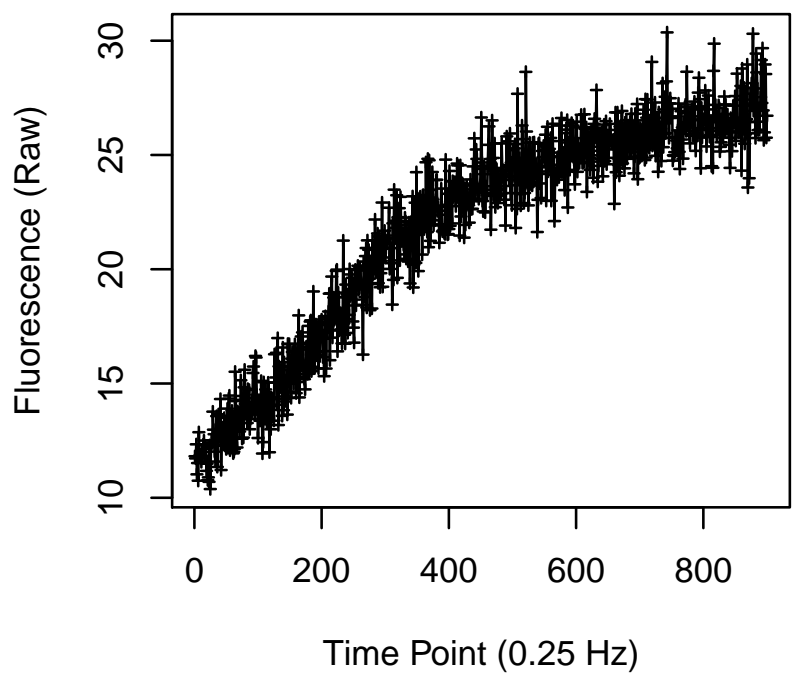

Cell 256

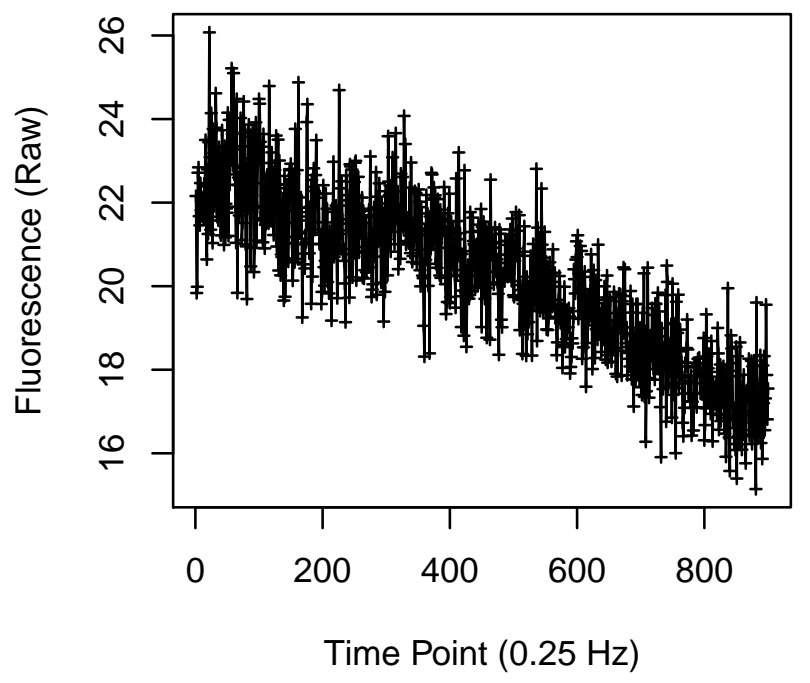


Cell 265

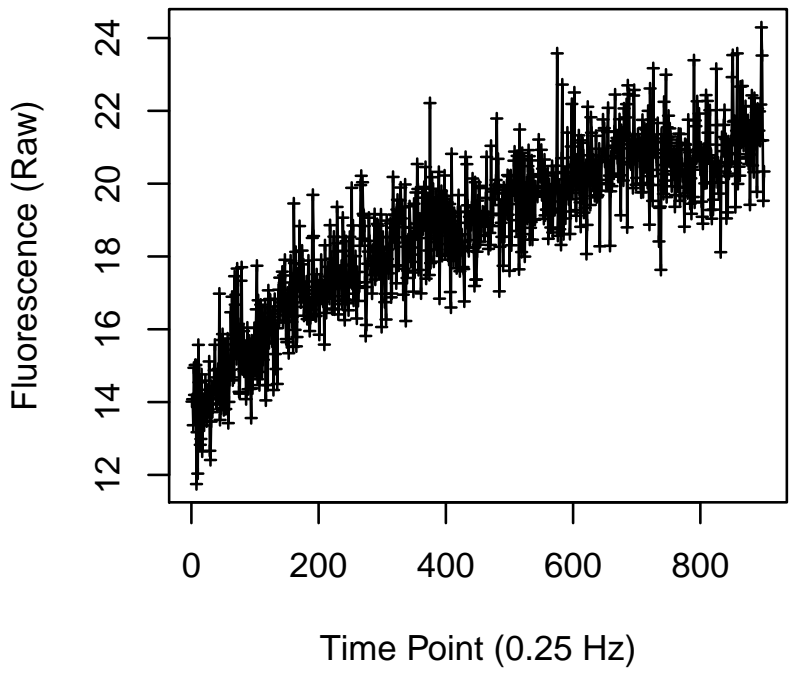

Cell 267

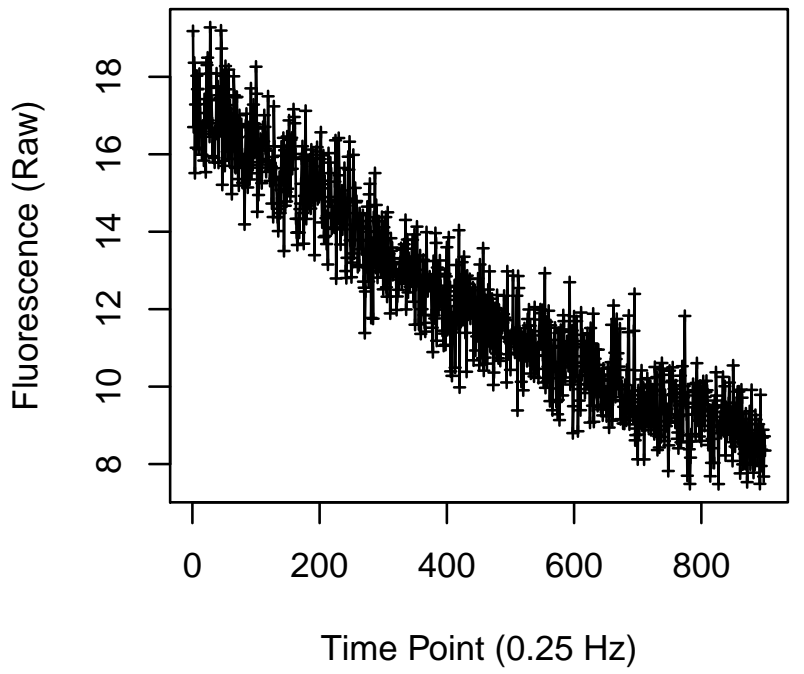

Cell 266

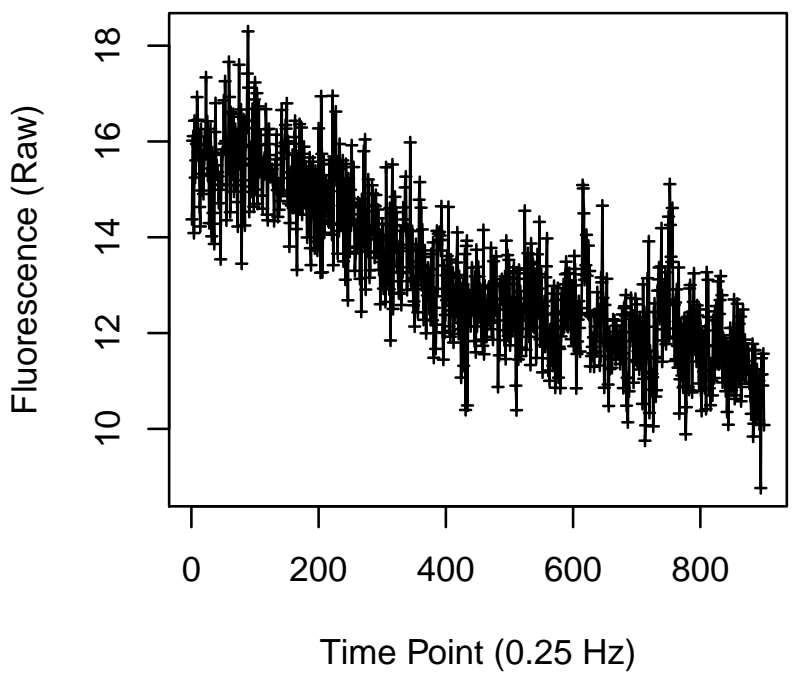

Cell 268

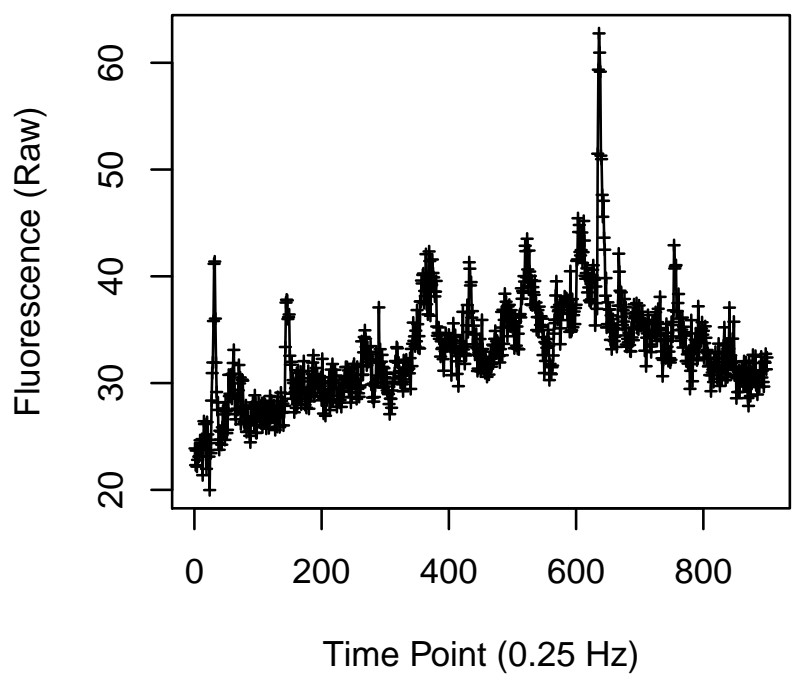


Cell 269

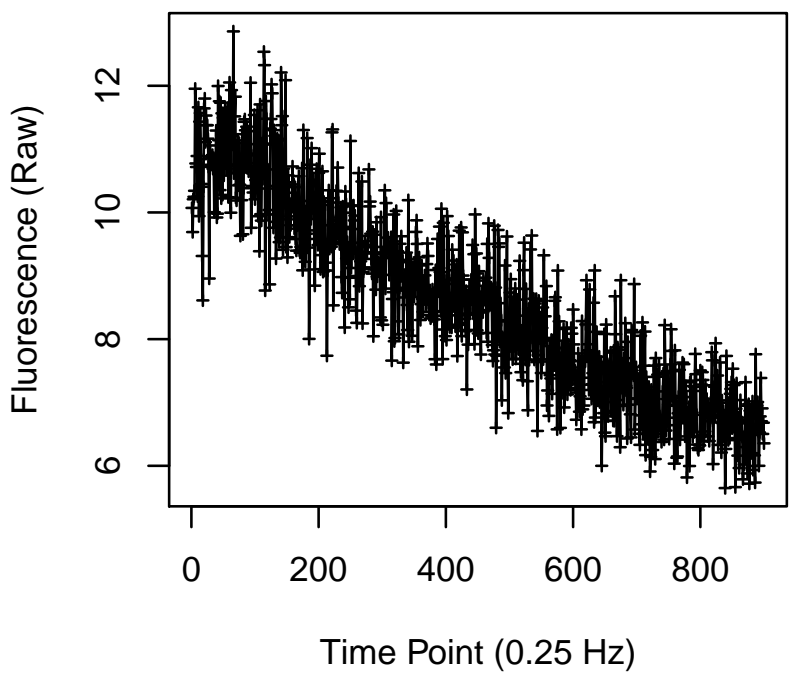

Cell 271

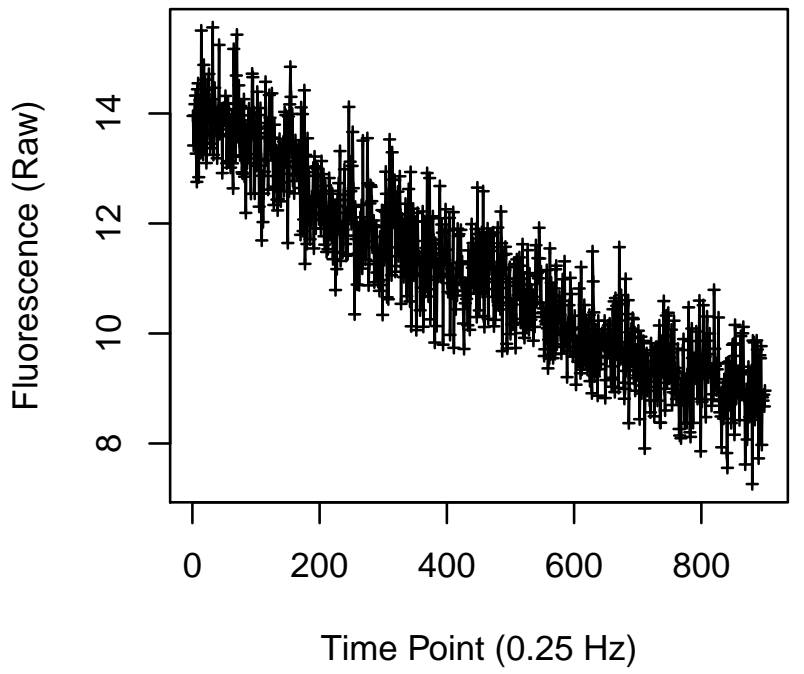

Cell 270

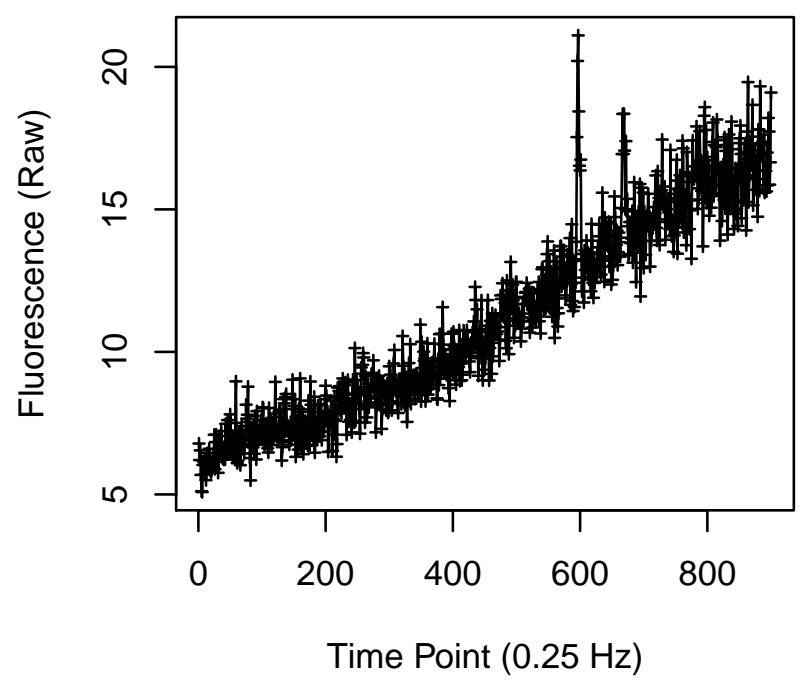

Cell 272

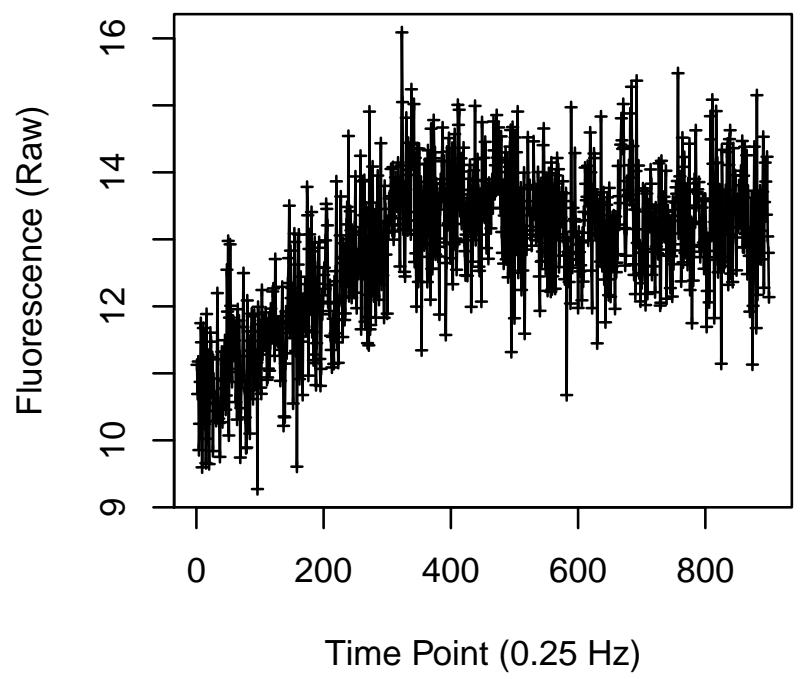


Cell 273

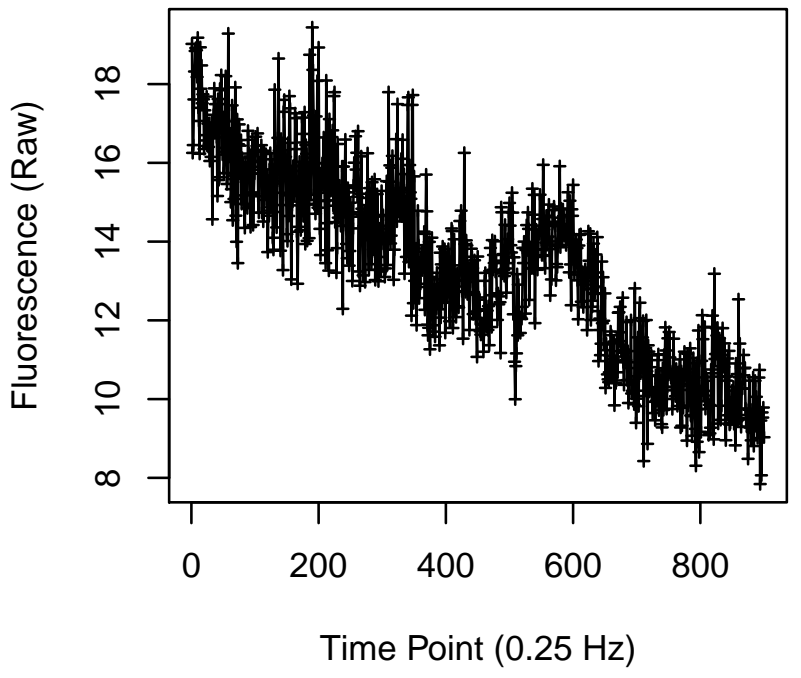

Cell 275

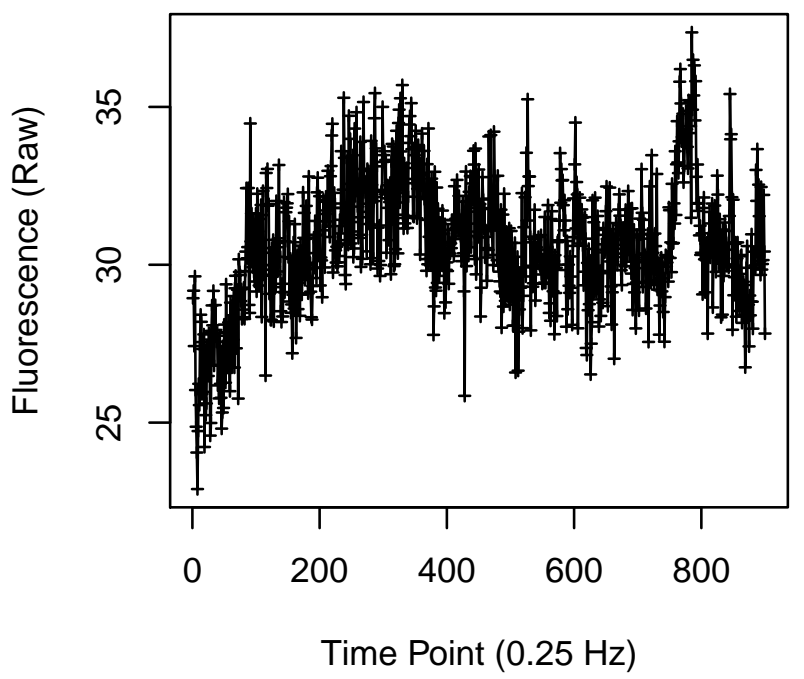

Cell 274

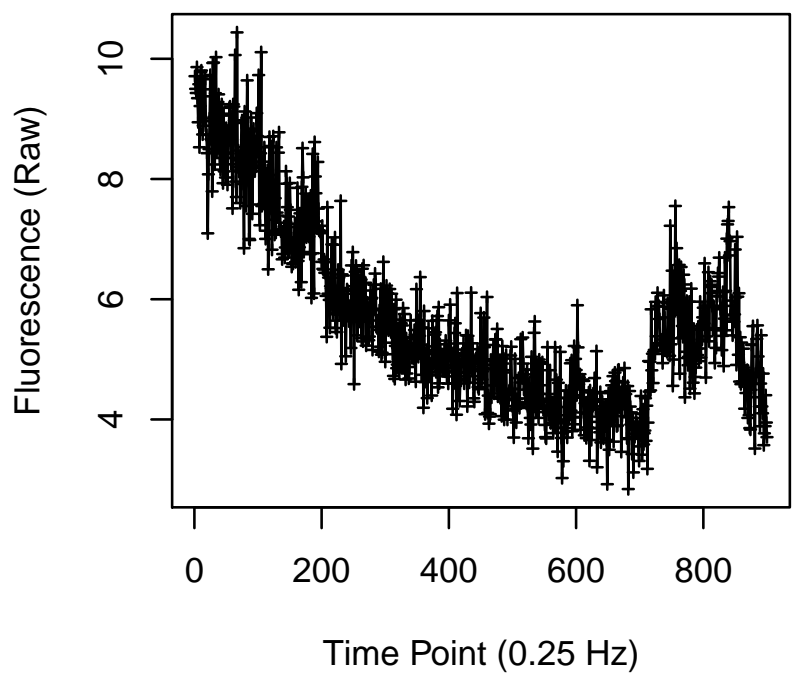

Cell 276

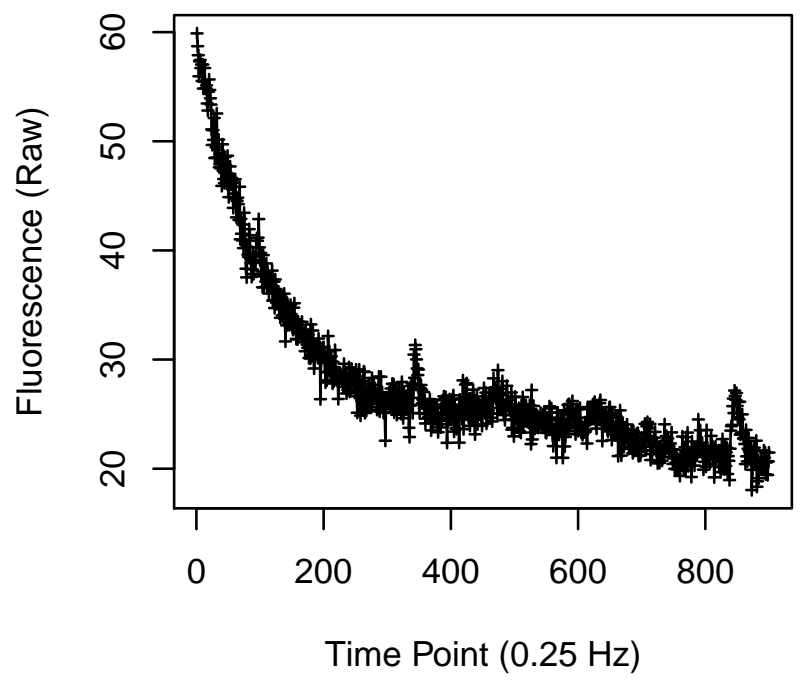


Cell 277

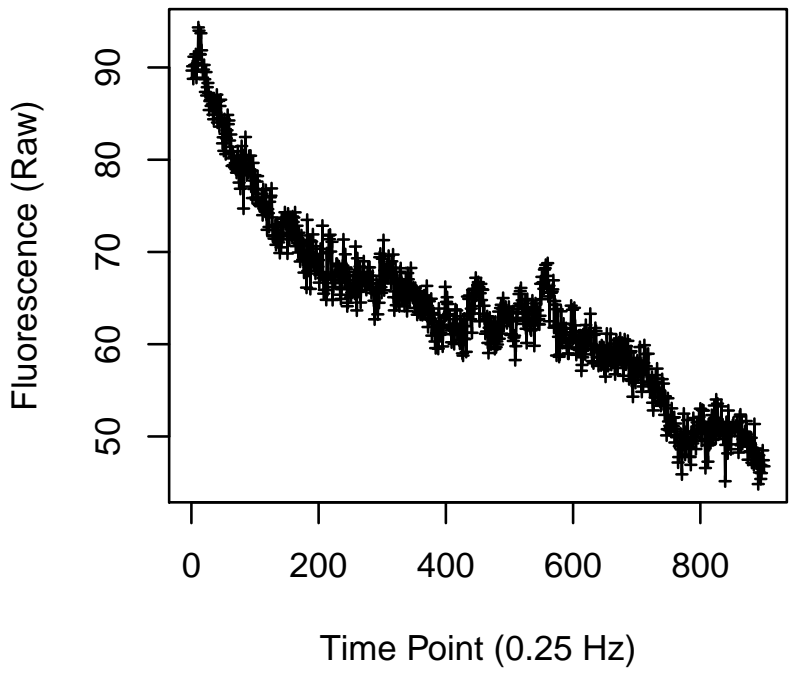

Cell 279

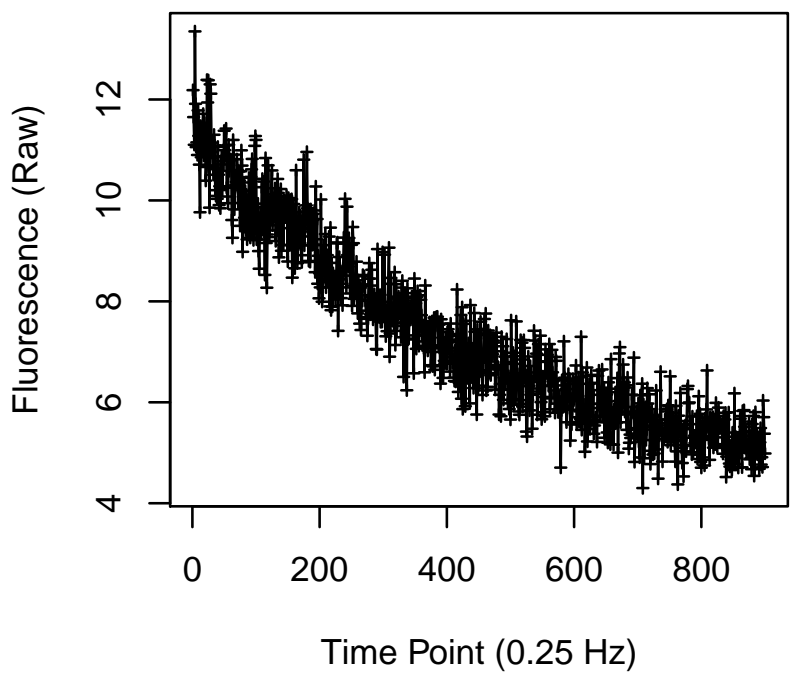

Cell 278

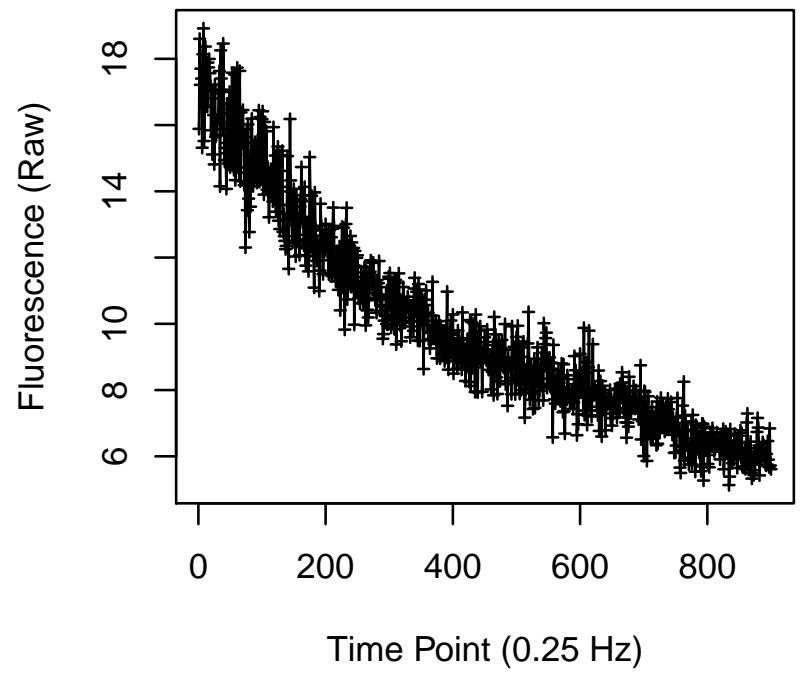

Cell 280

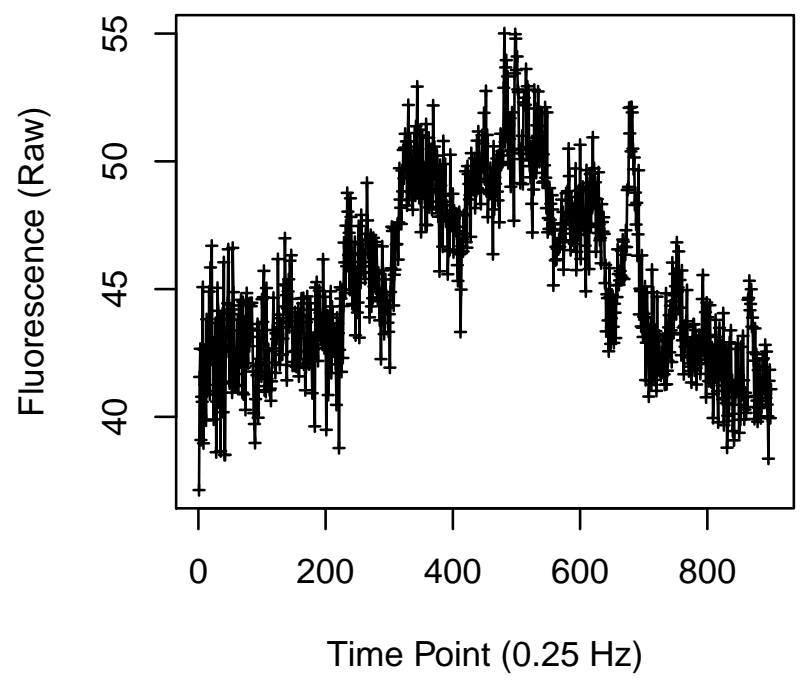




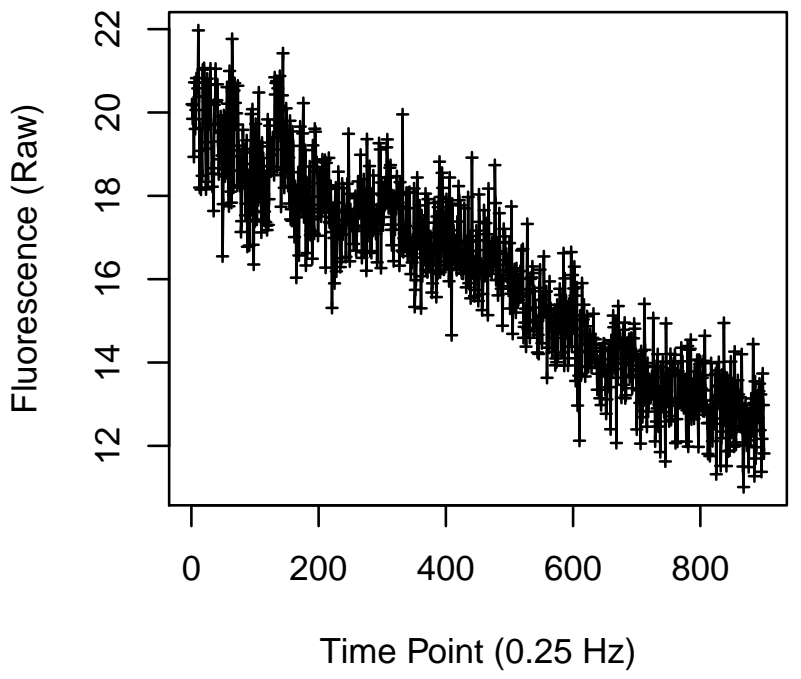

Cell 283

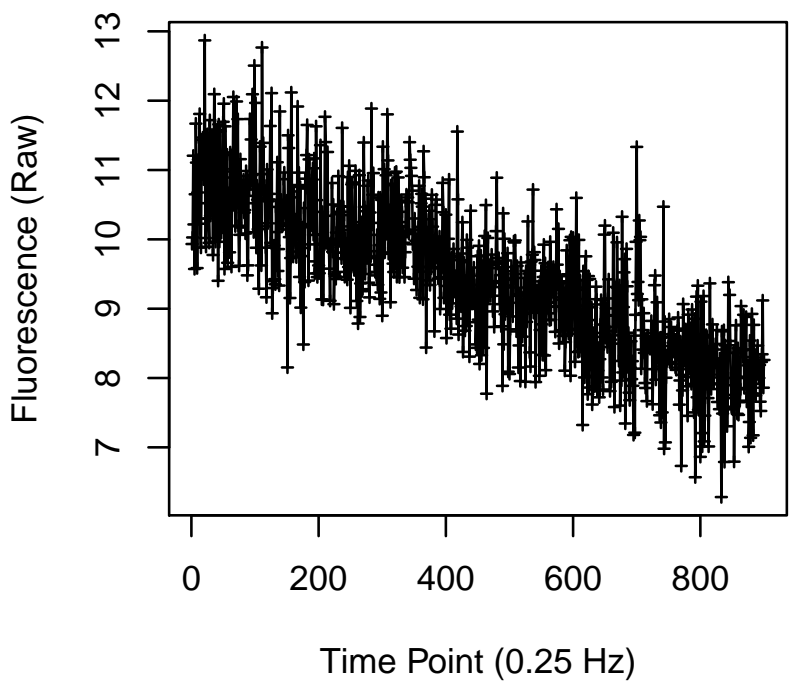

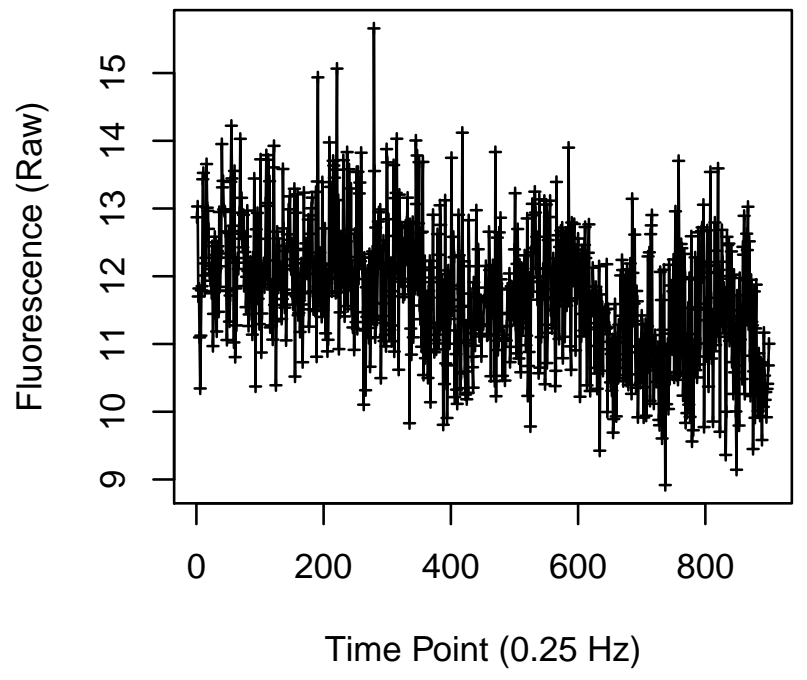

Cell 284

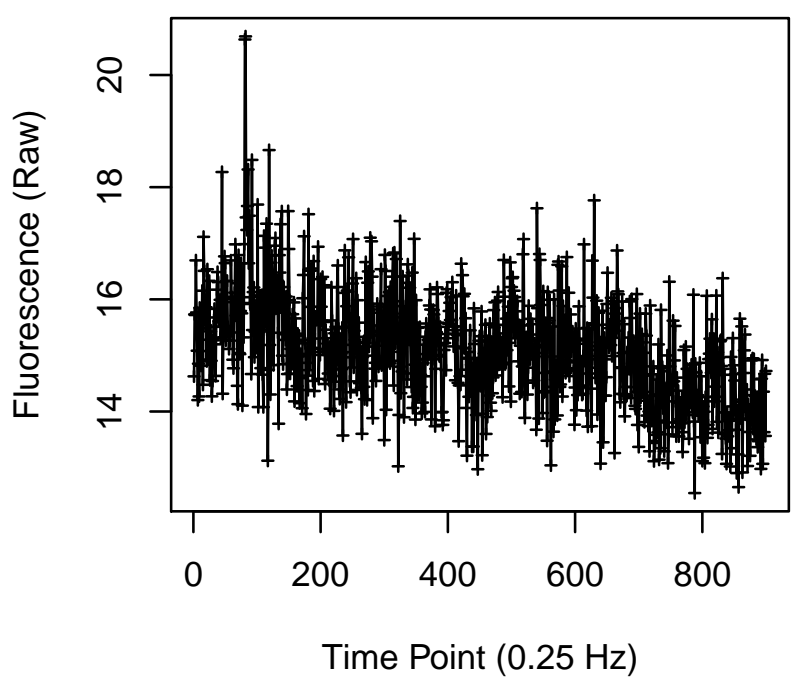


Cell 285

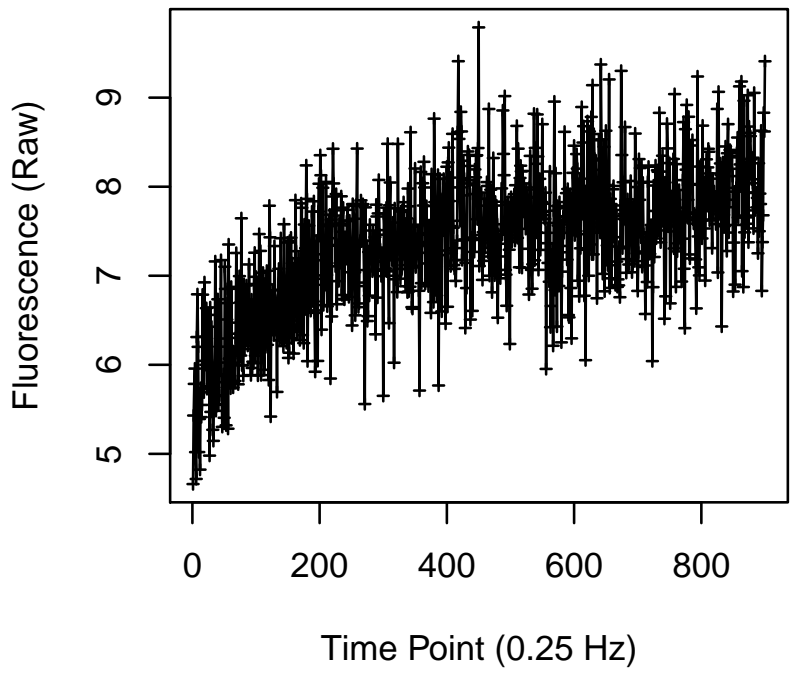

Cell 287

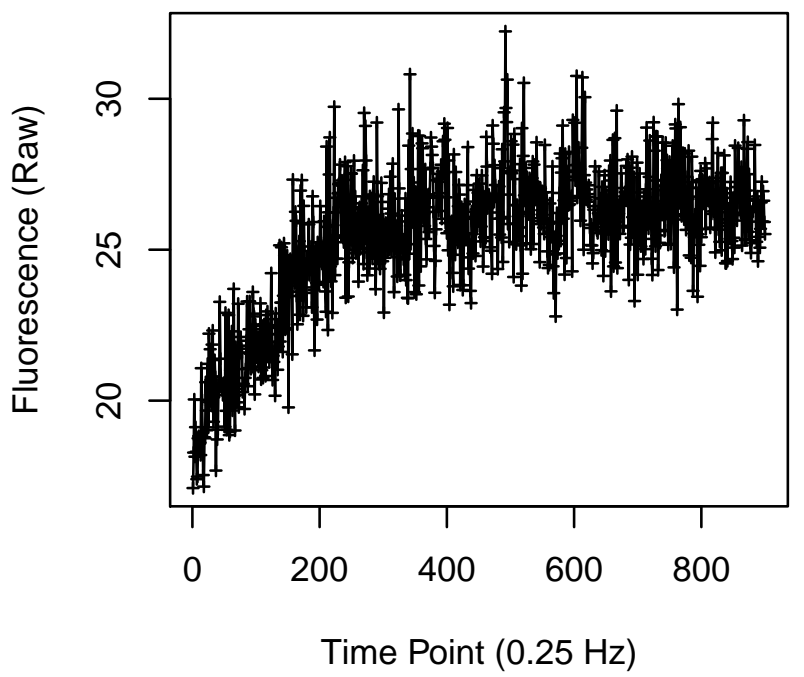

Cell 286

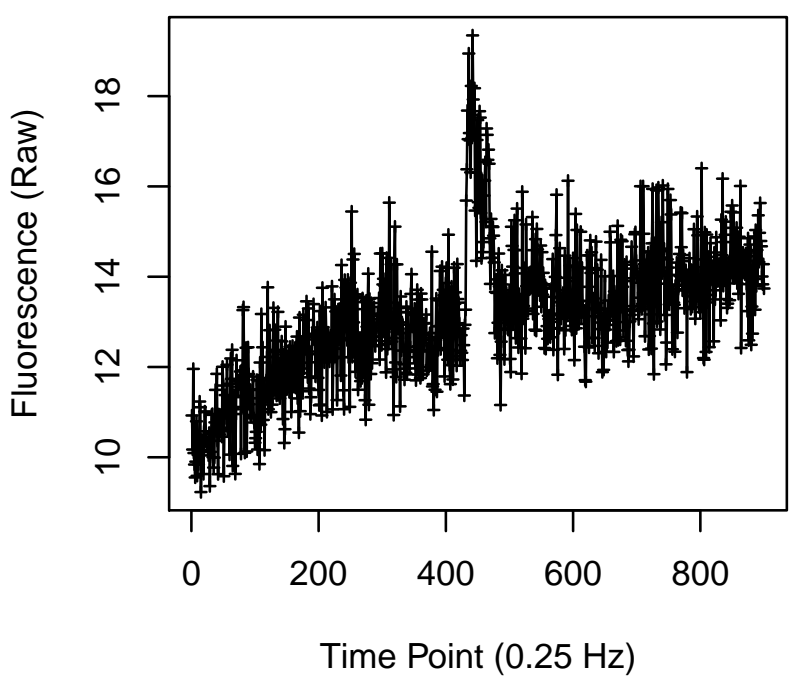

Cell 288

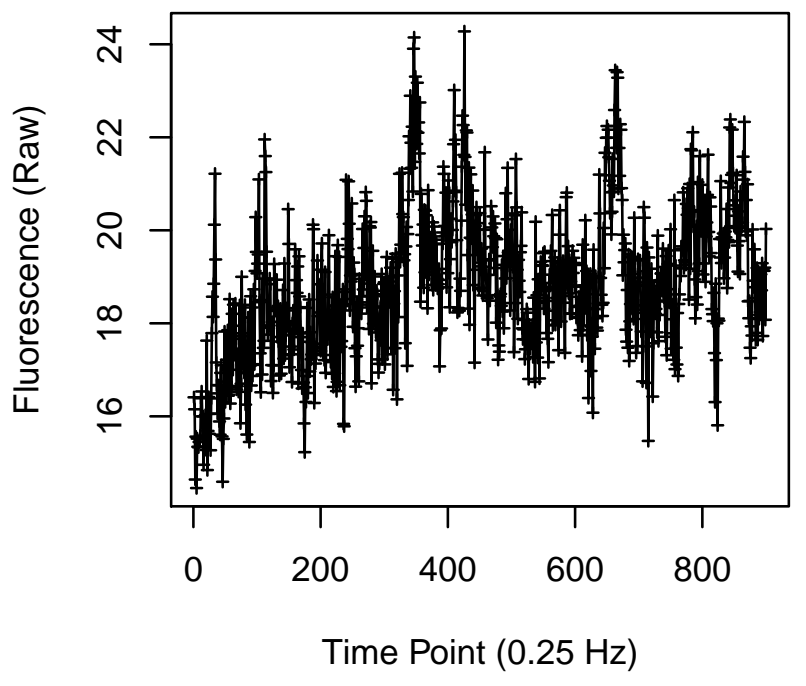


Cell 289

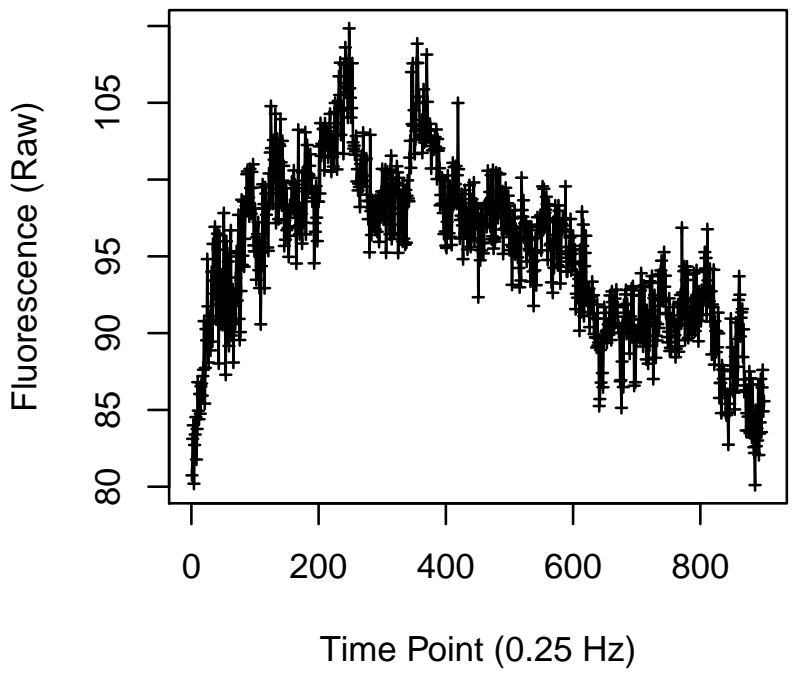

Cell 291

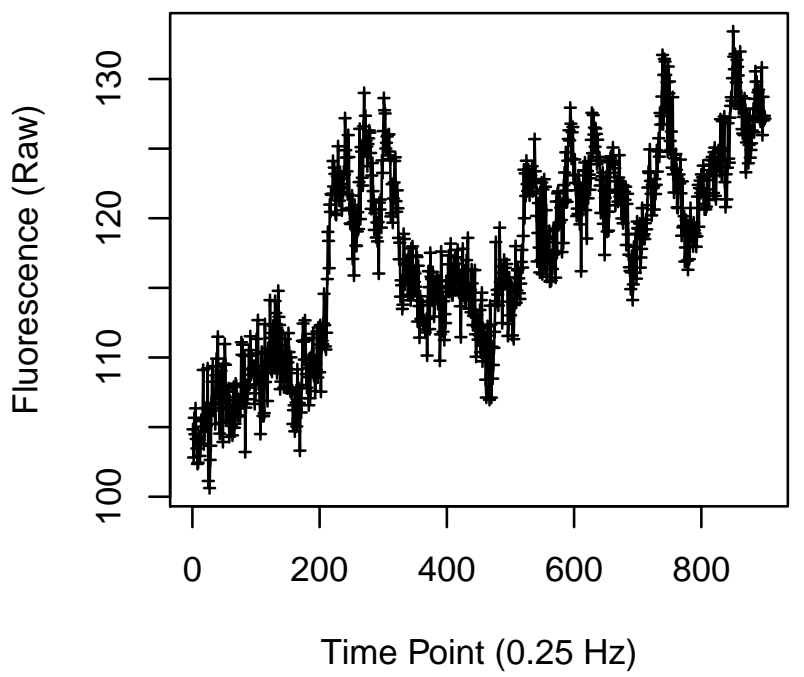

Cell 290

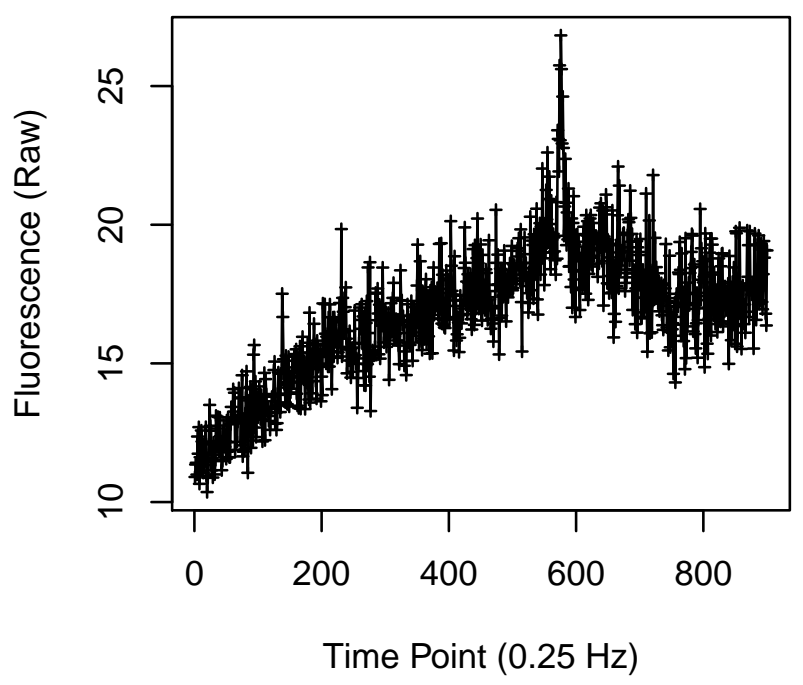

Cell 292

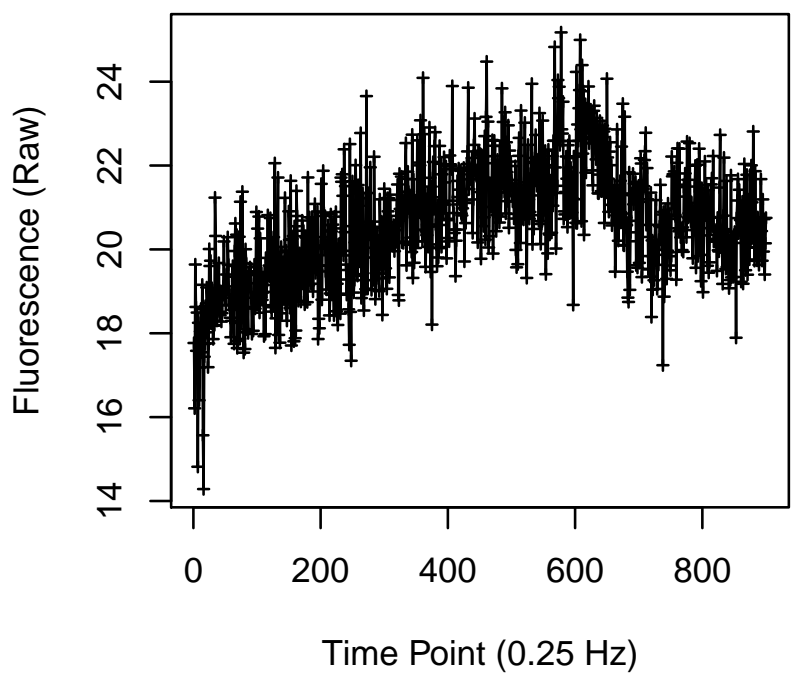


Cell 301

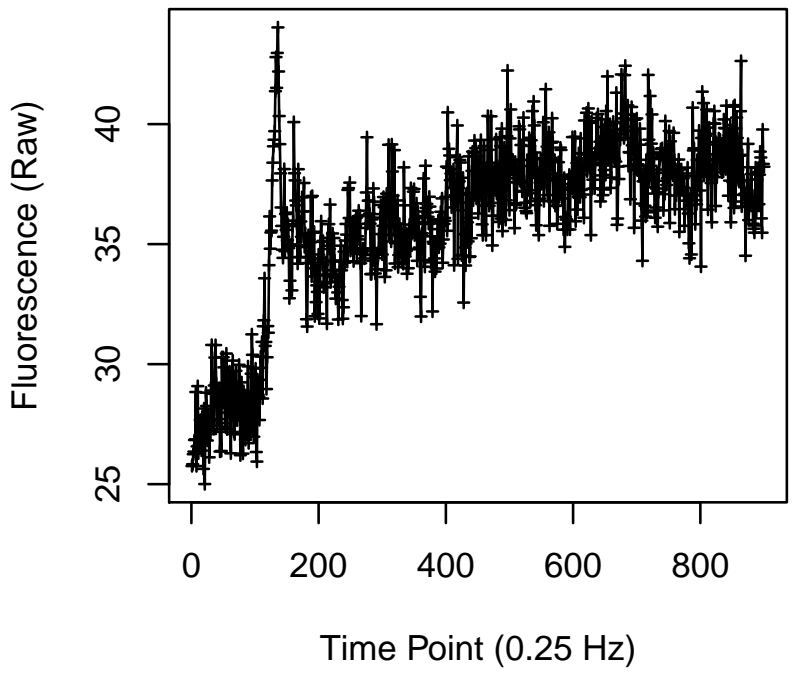

Cell 303

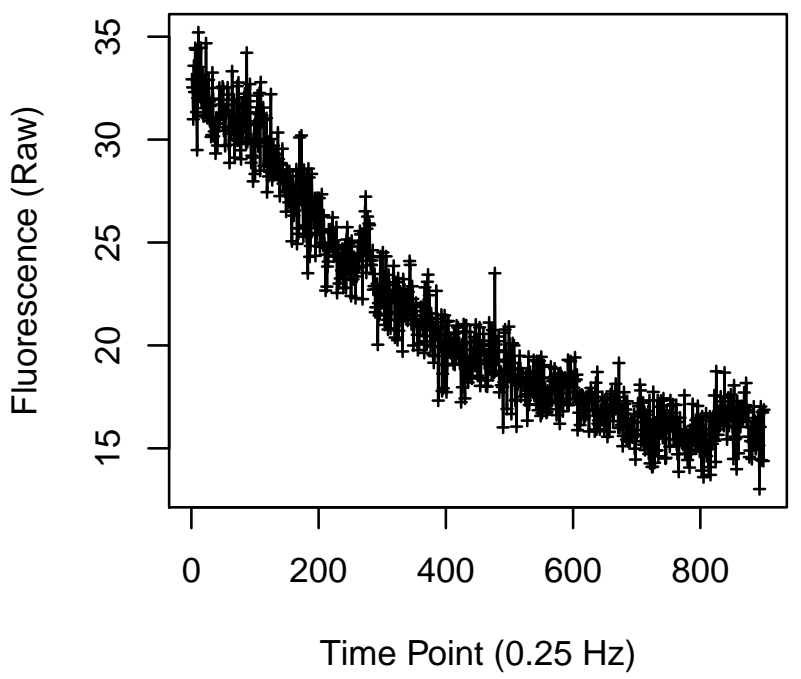

Cell 302

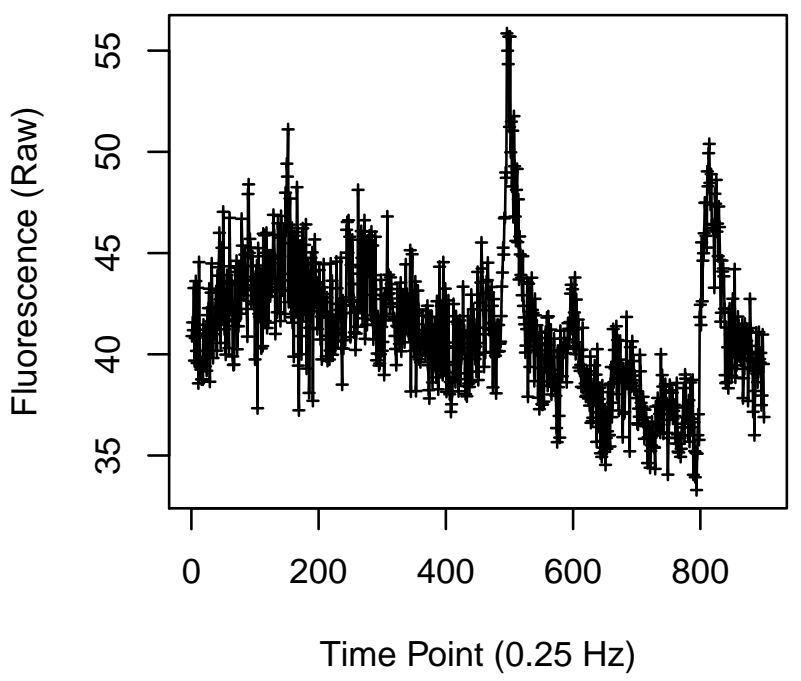

Cell 304

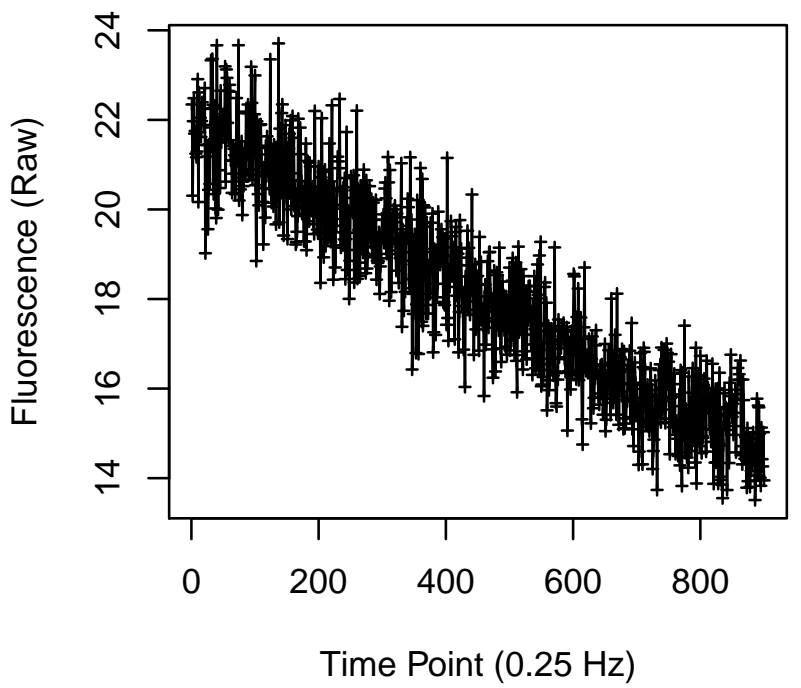


Cell 309

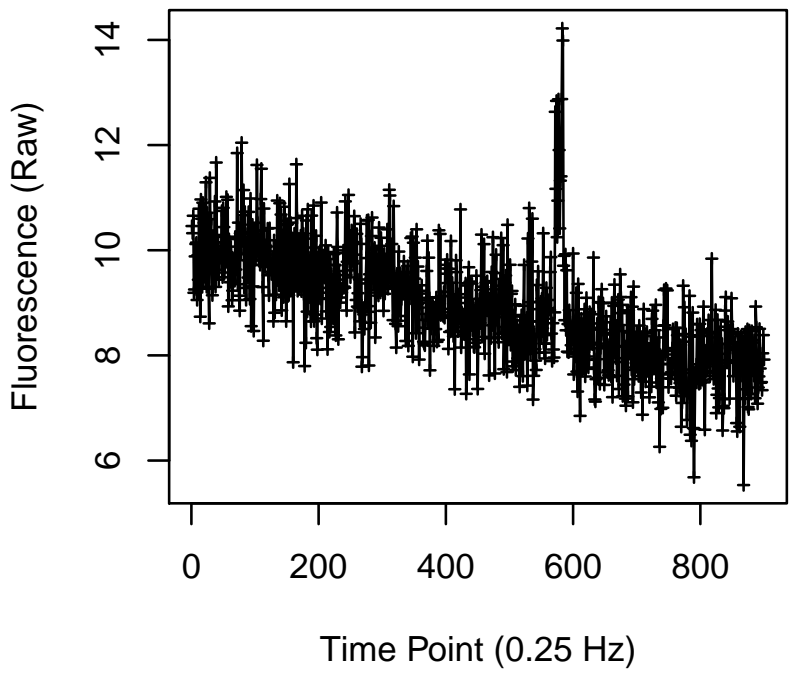

Cell 311

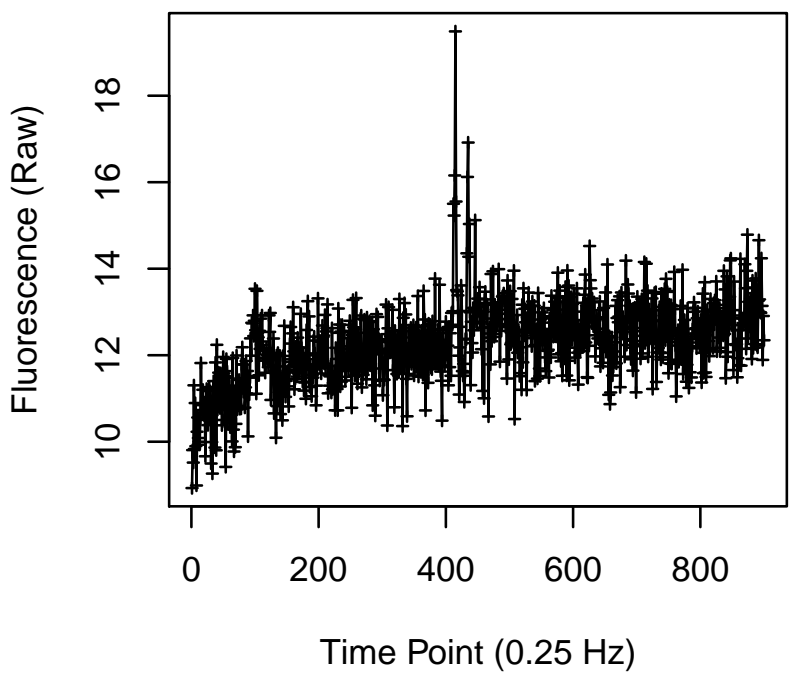

Cell 310

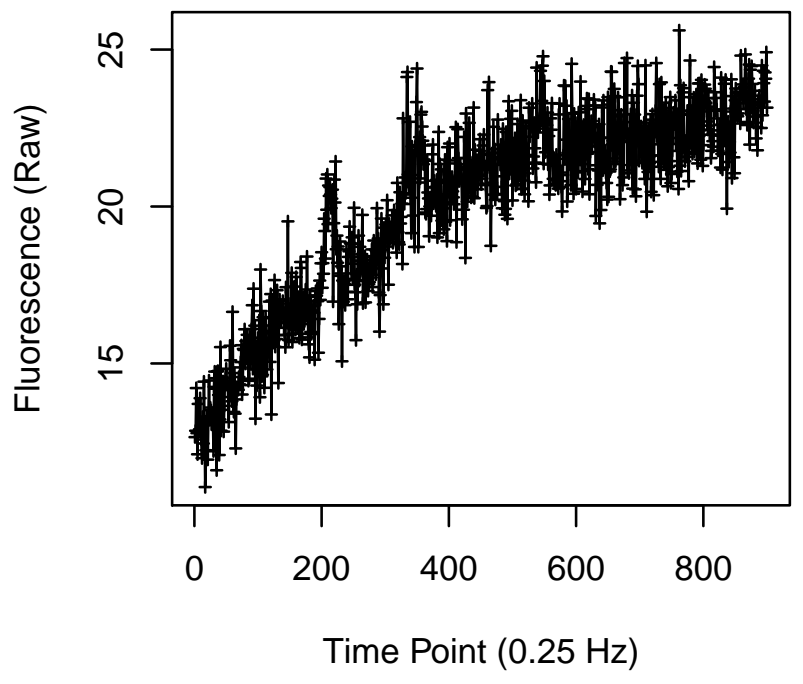

Cell 312

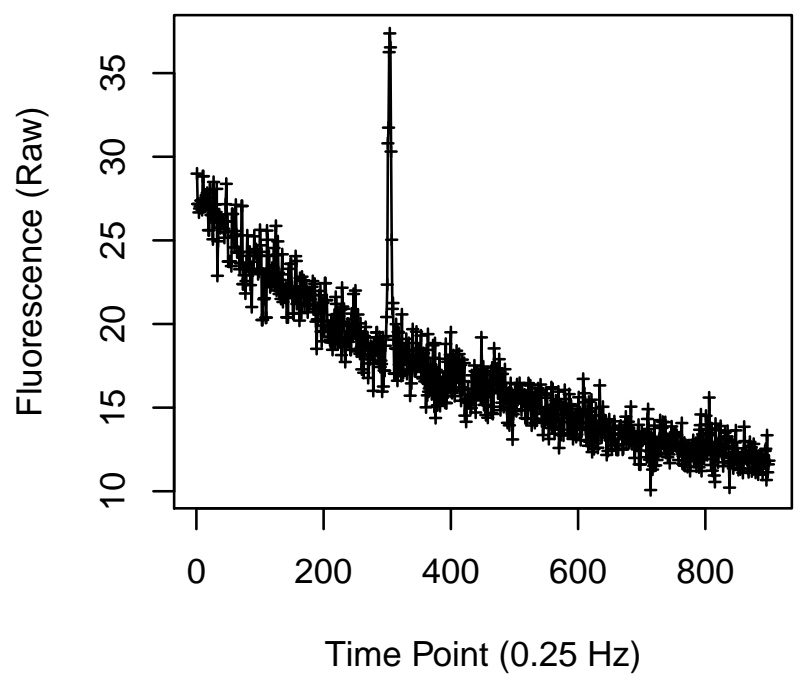


Cell 313

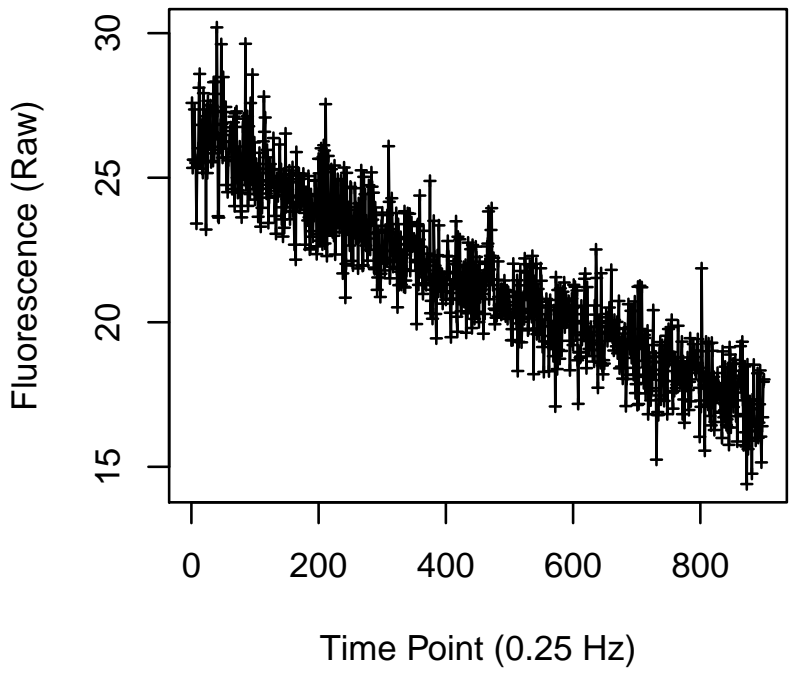

Cell 315

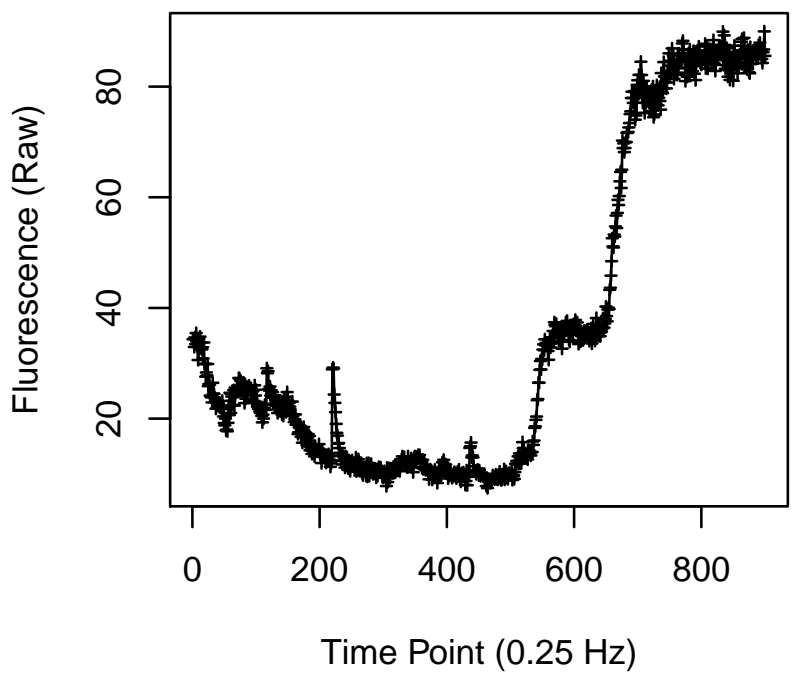

Cell 314

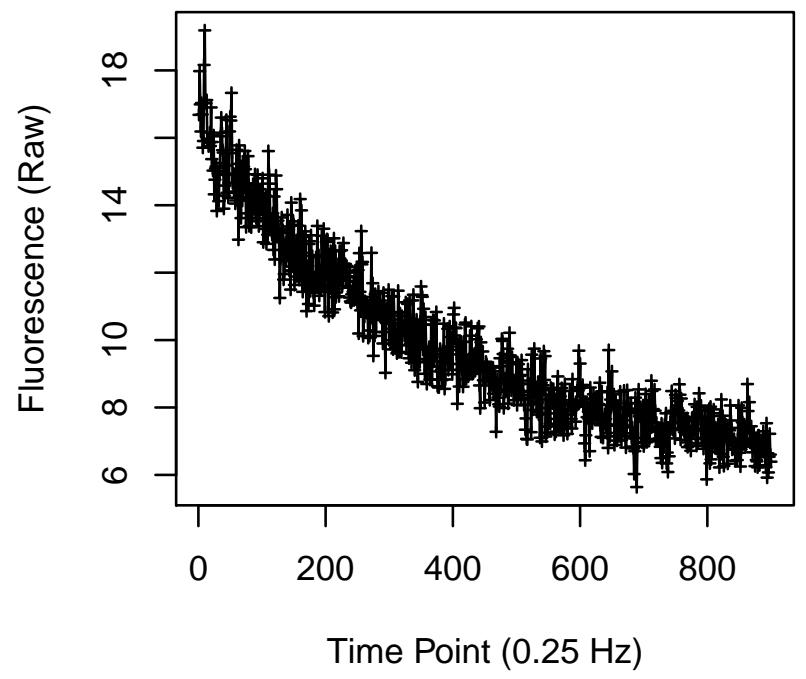

Cell 316

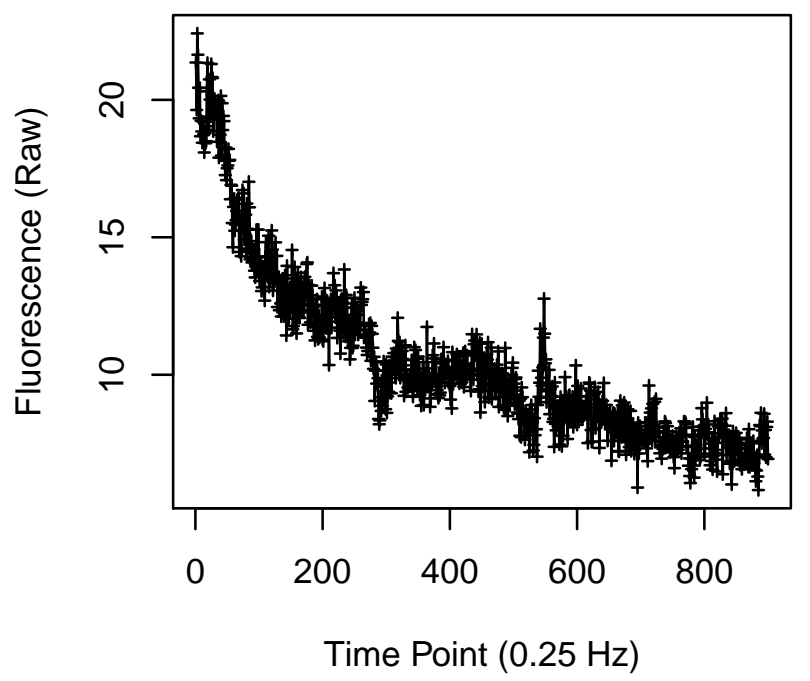


Cell 321

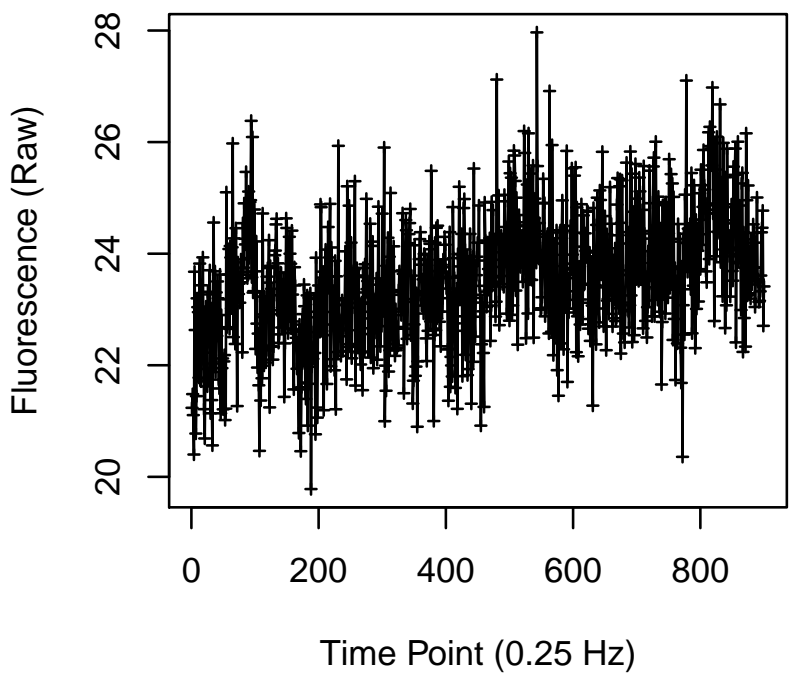

Cell 323

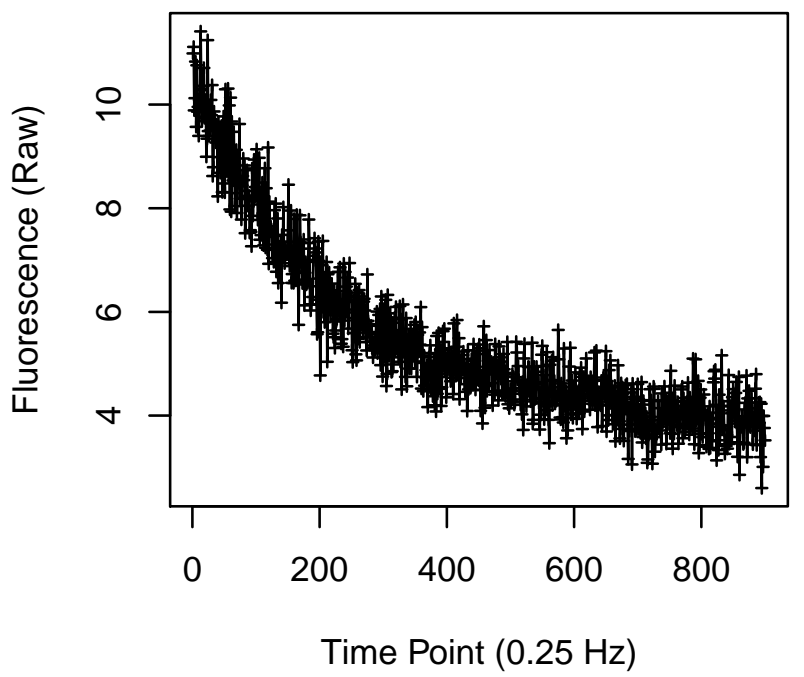

Cell 322

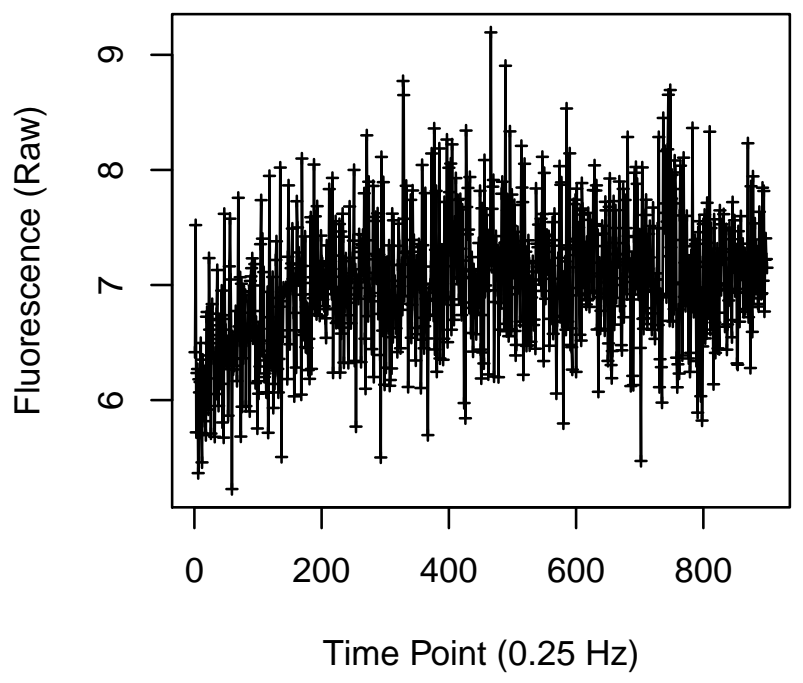

Cell 324

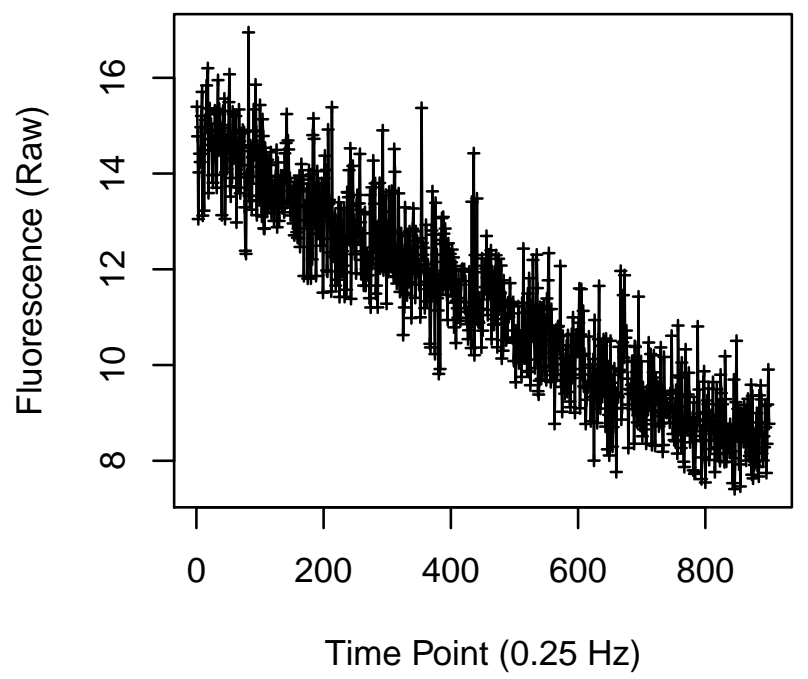


Cell 333

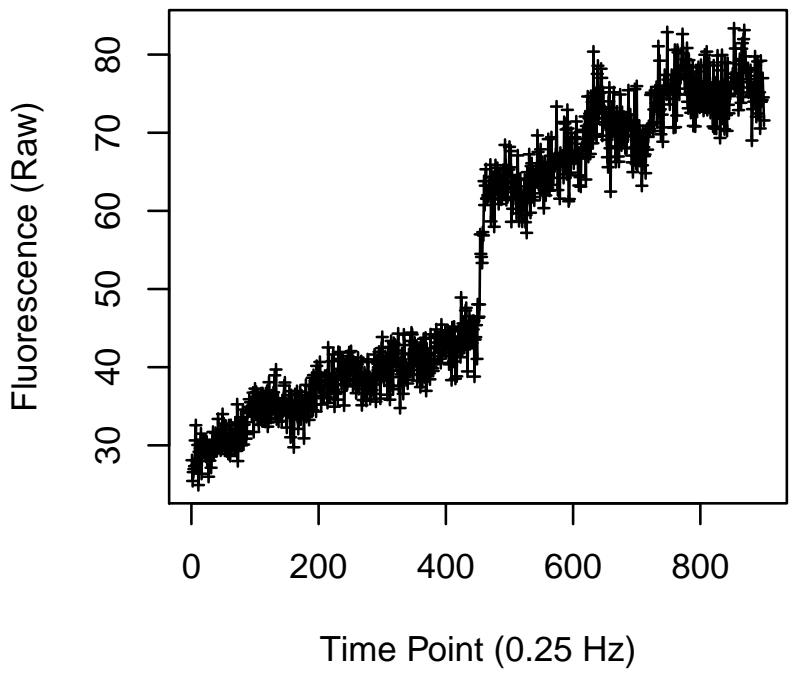

Cell 335

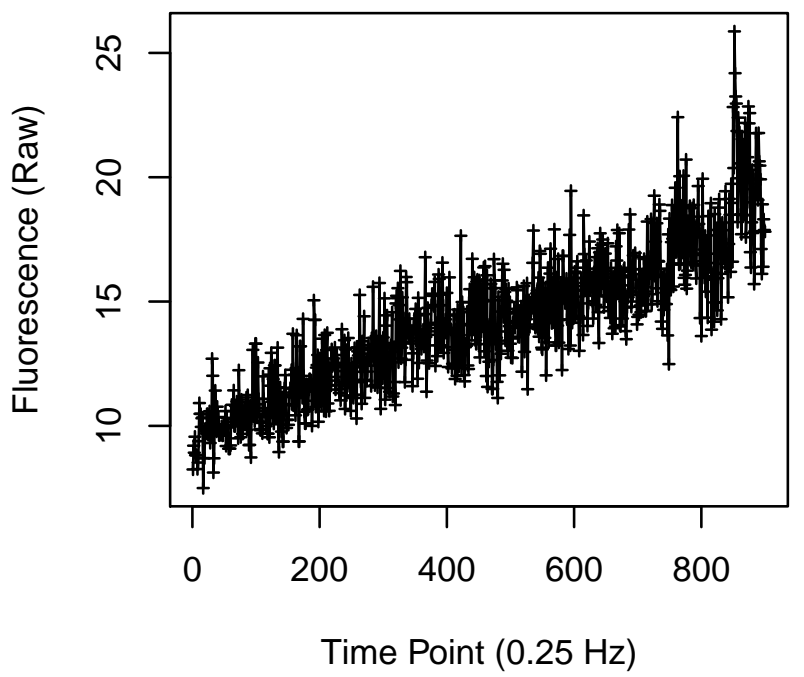

Cell 334

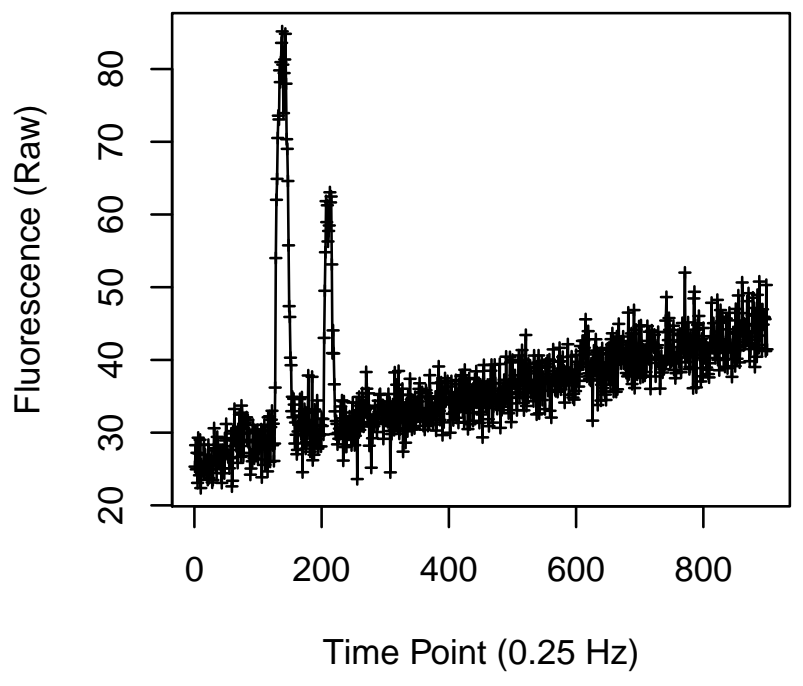

Cell 336

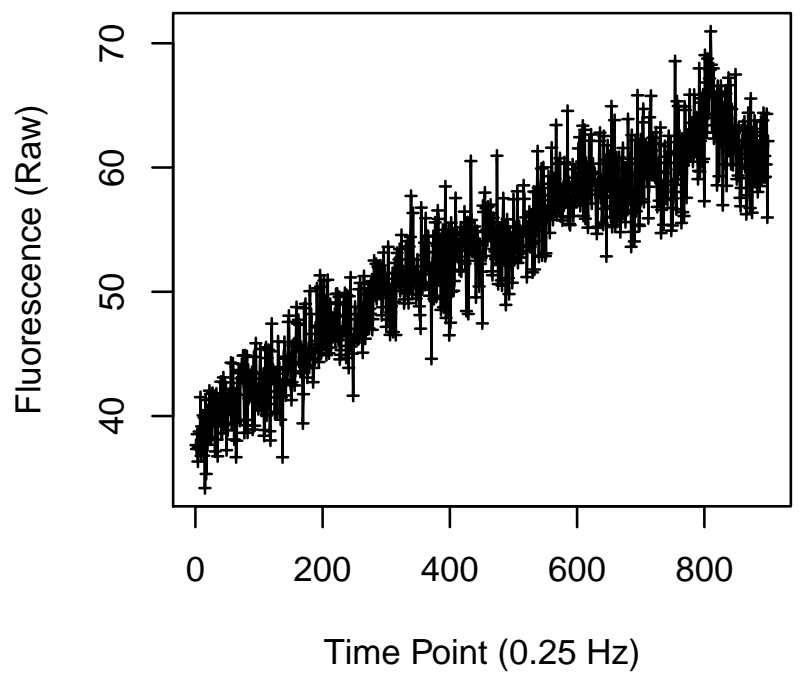


Cell 341

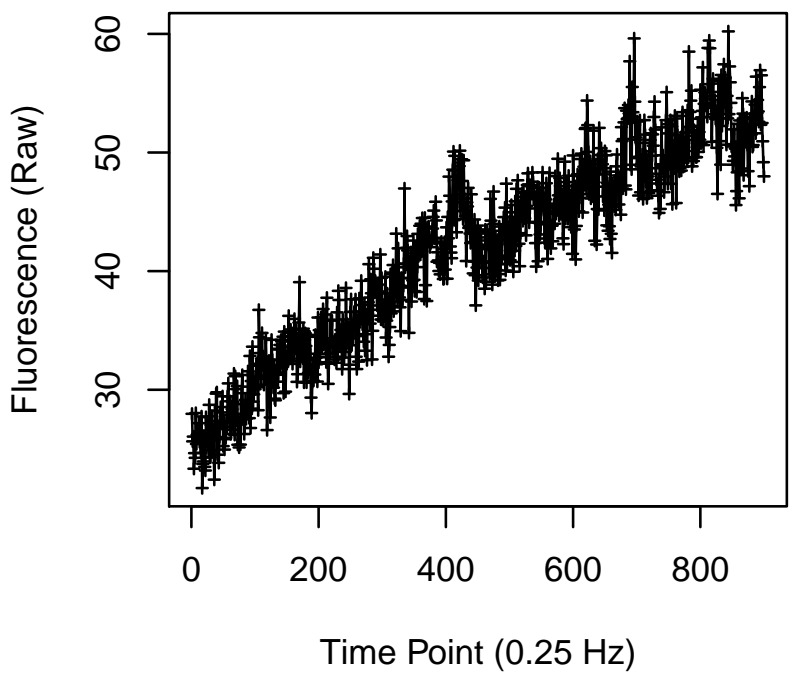

Cell 343

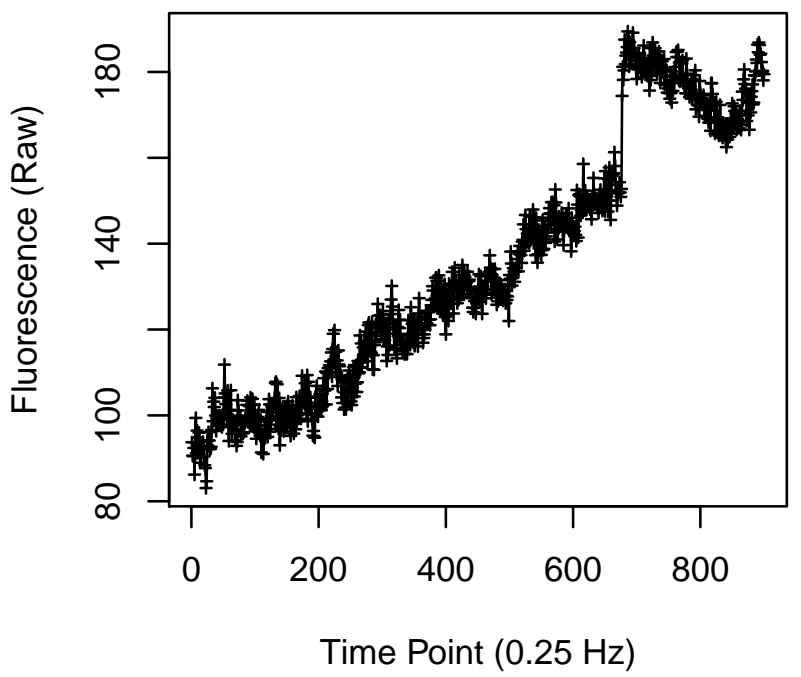

Cell 342

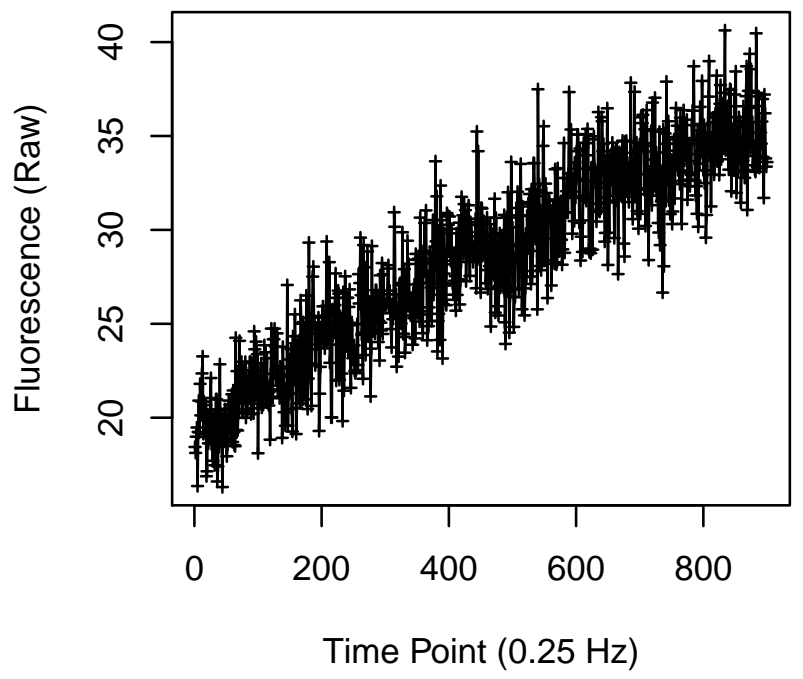

Cell 344

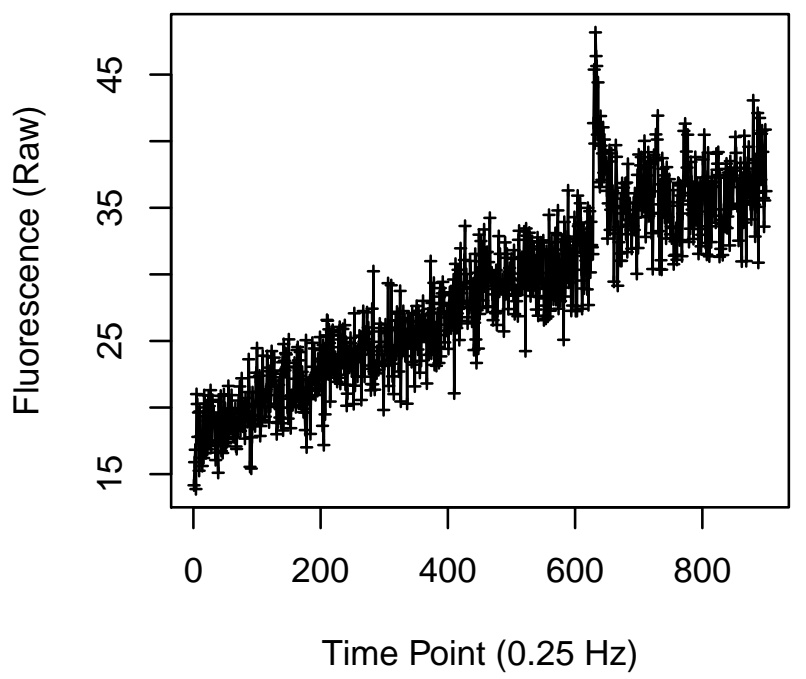




\section{Cell 345}

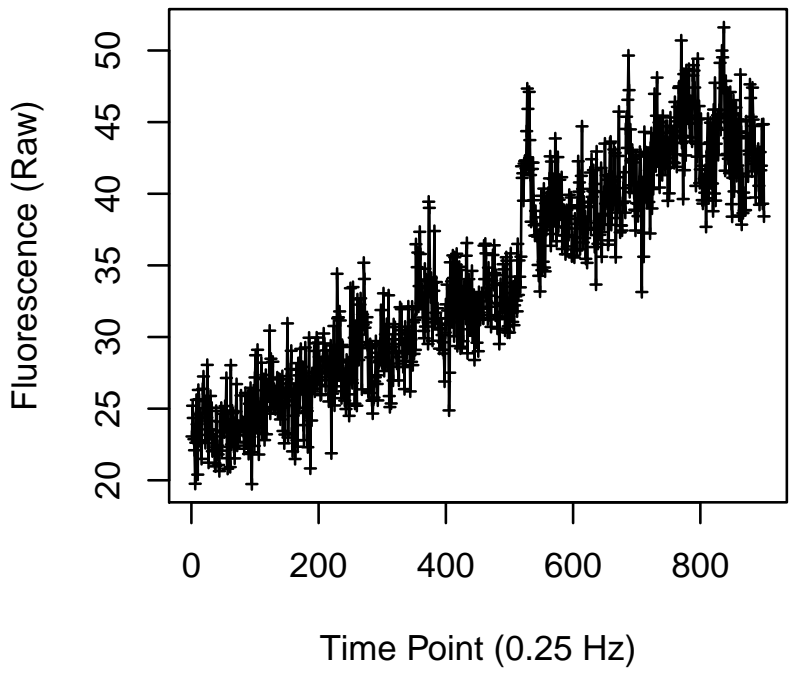

Cell 347

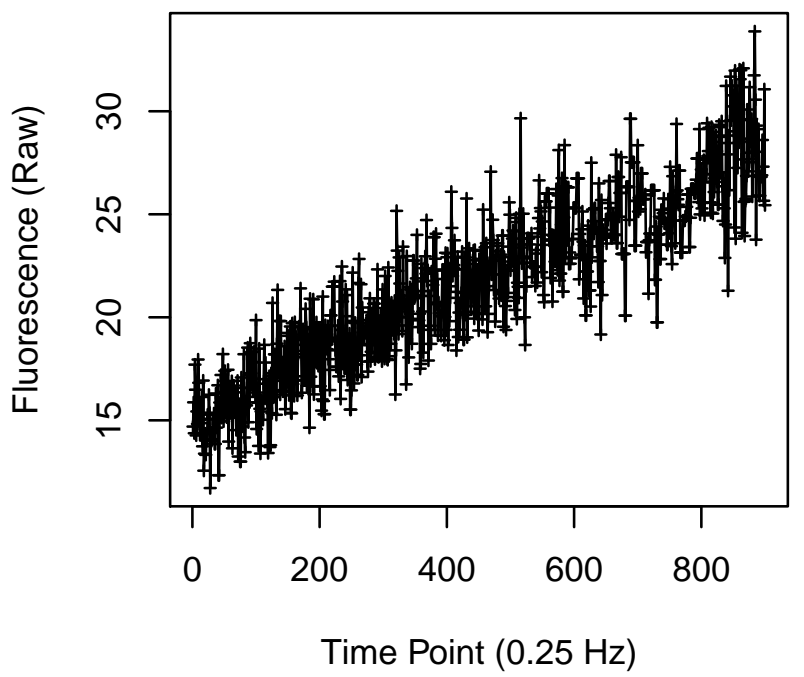

Cell 346

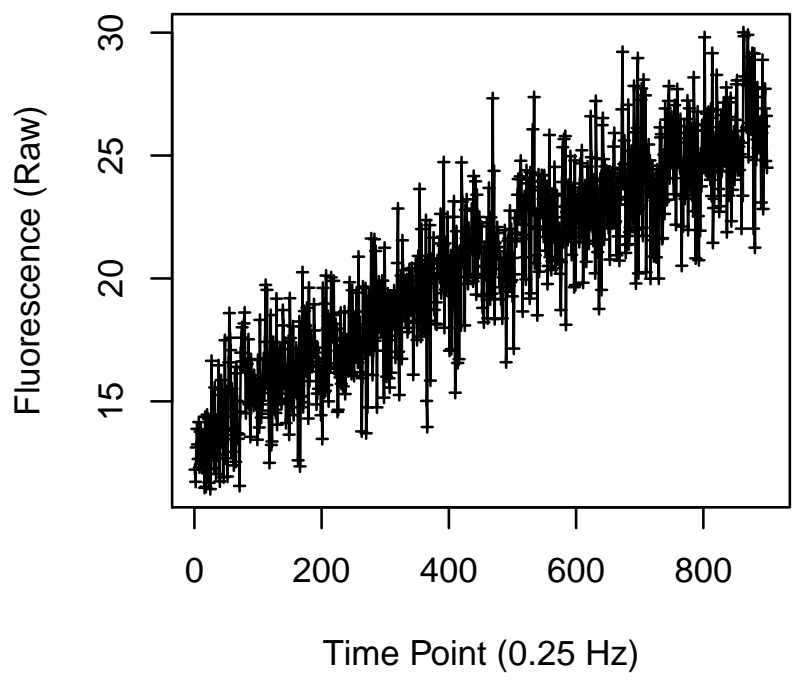

Cell 348

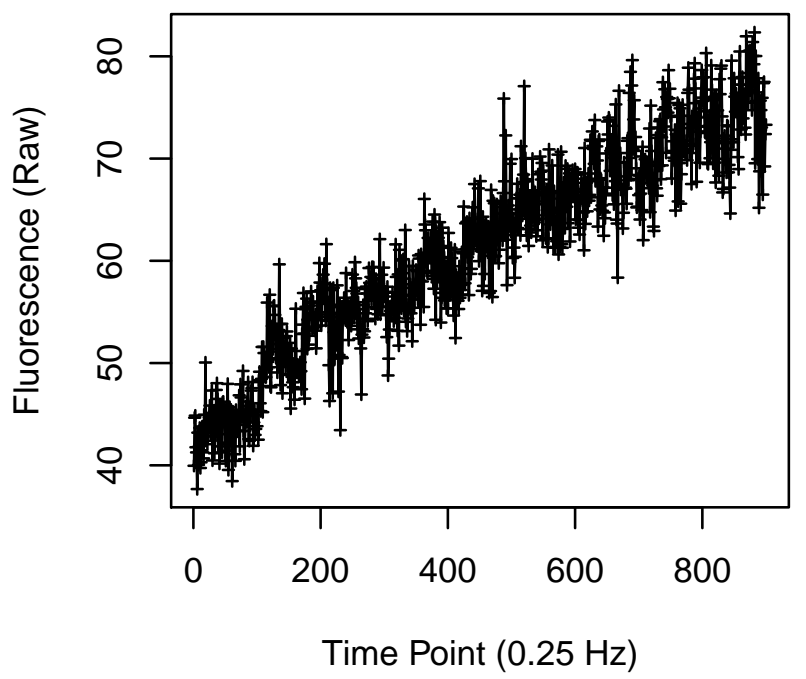




\section{Cell 353}

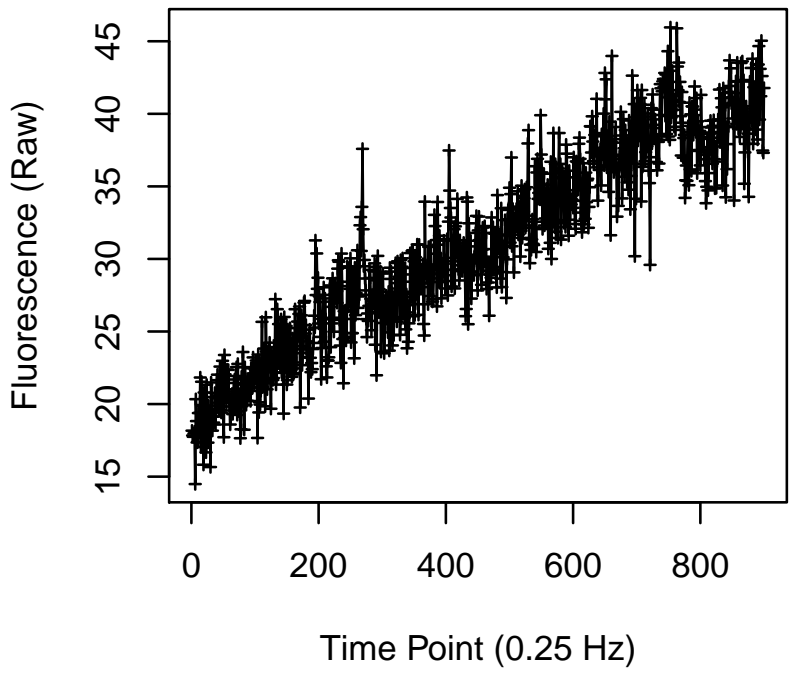

Cell 355

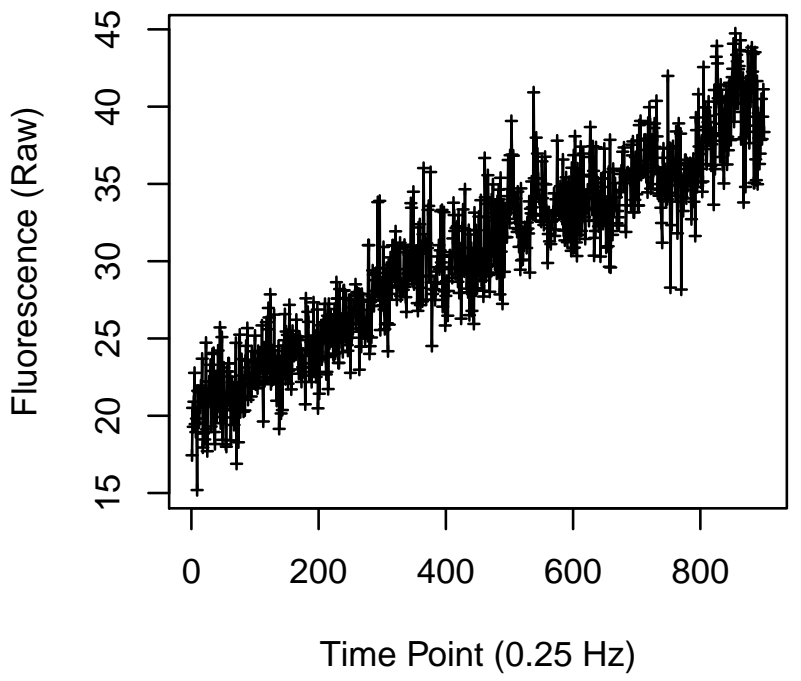

Cell 354

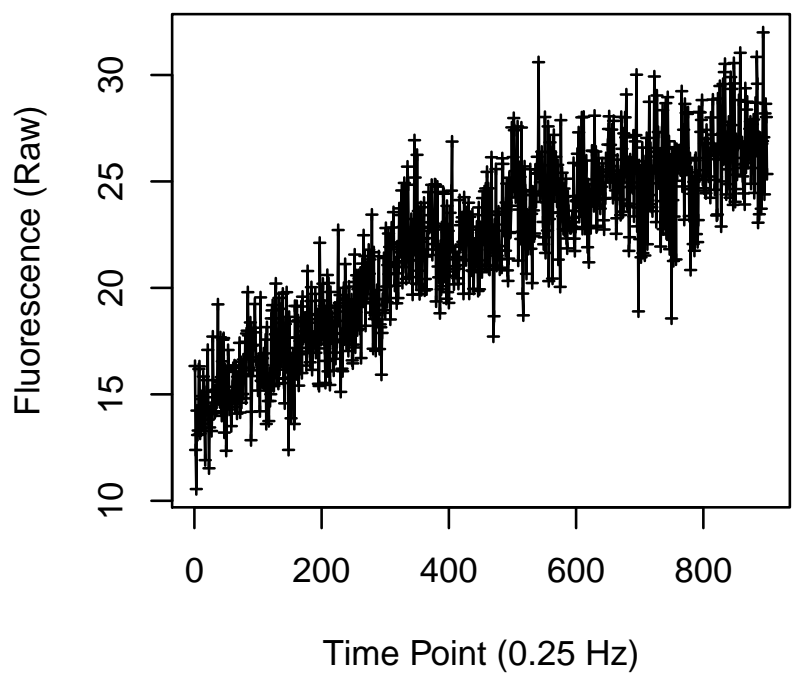

Cell 356

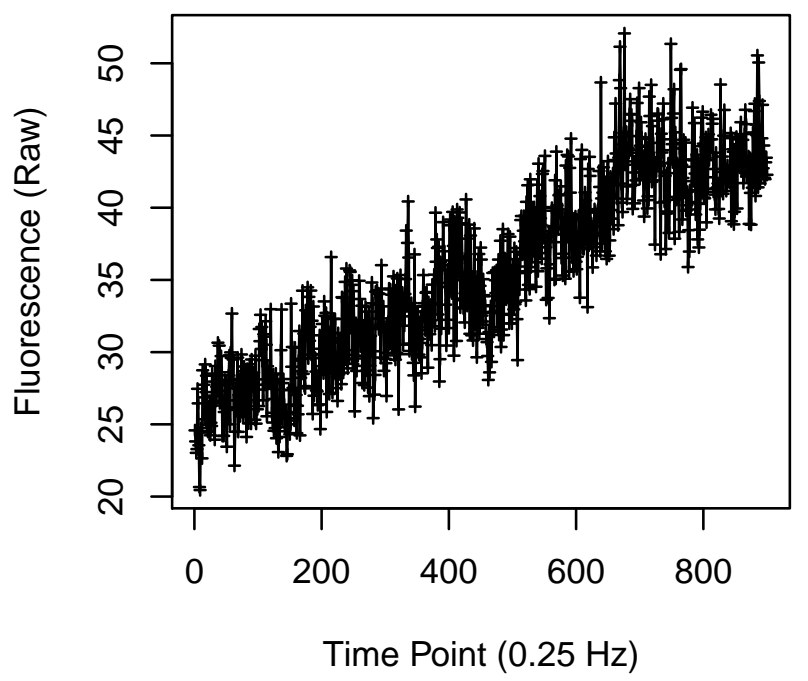


Cell 369

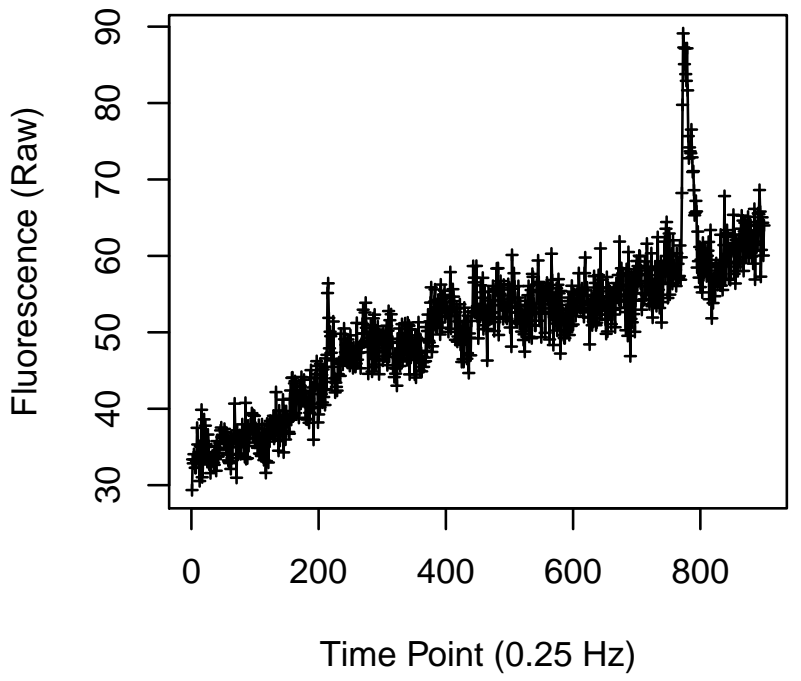

Cell 371

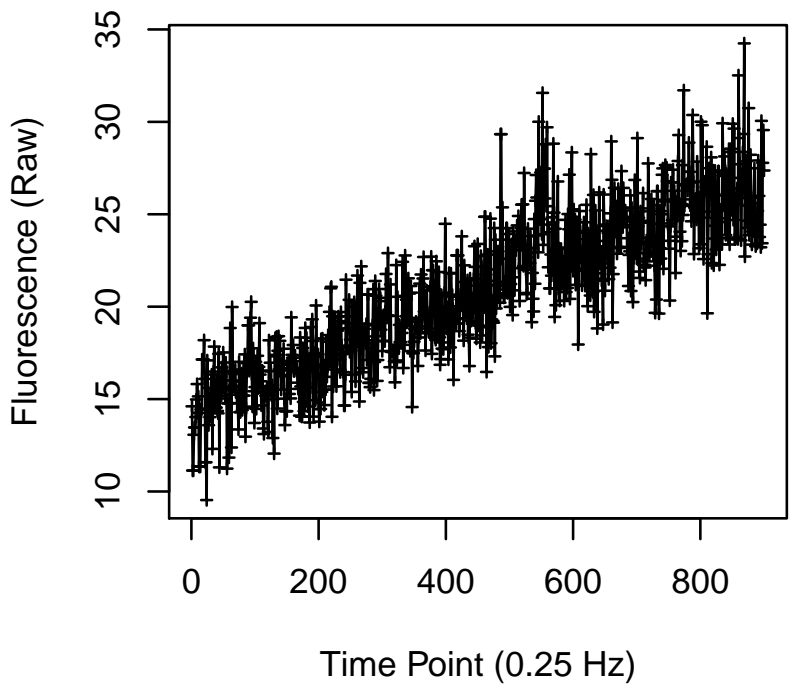

Cell 370

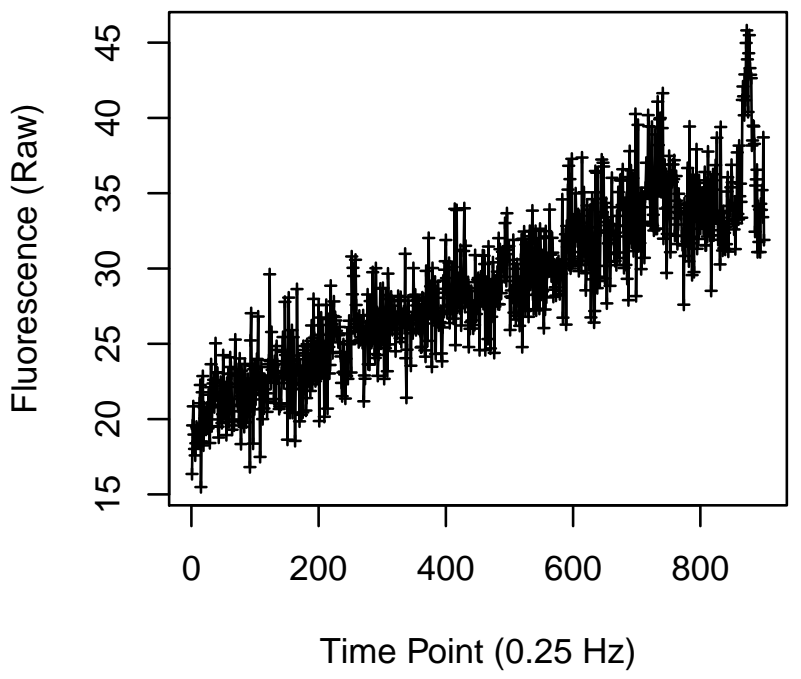

Cell 372

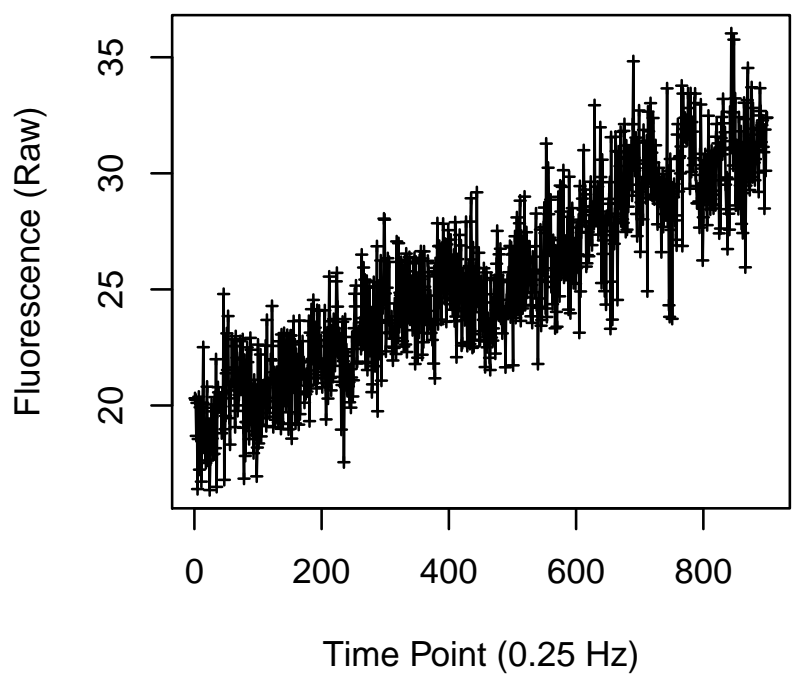




\section{Cell 373}

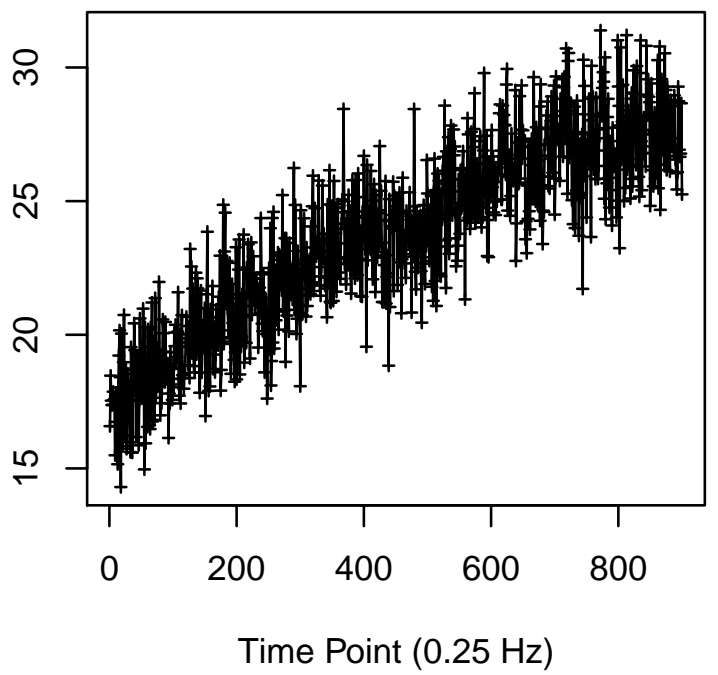

Cell 375

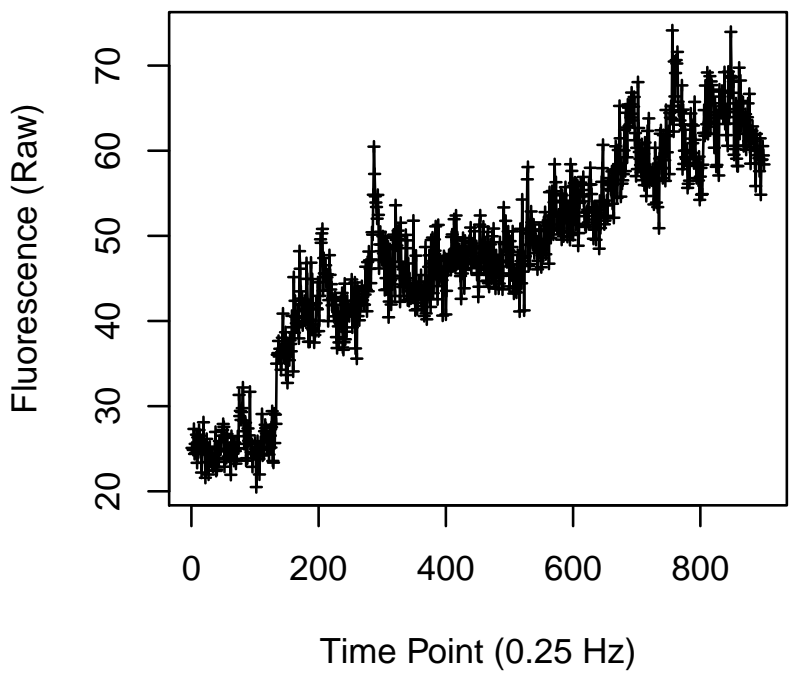

Cell 374

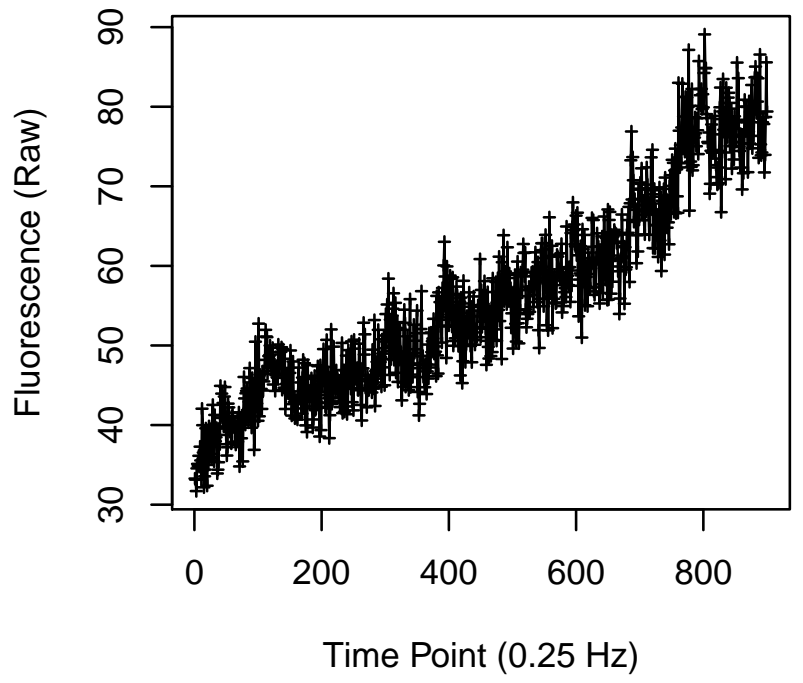

Cell 376

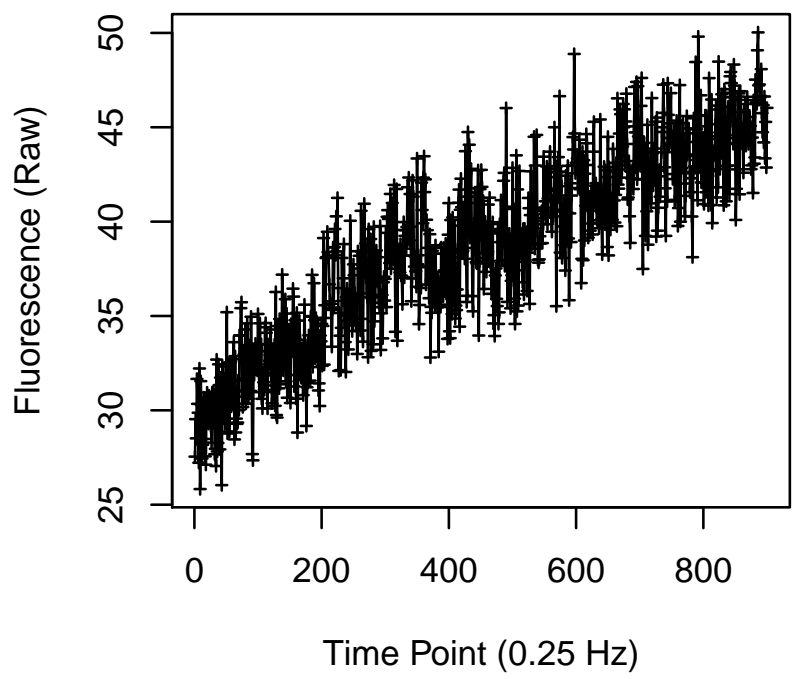


Cell 377

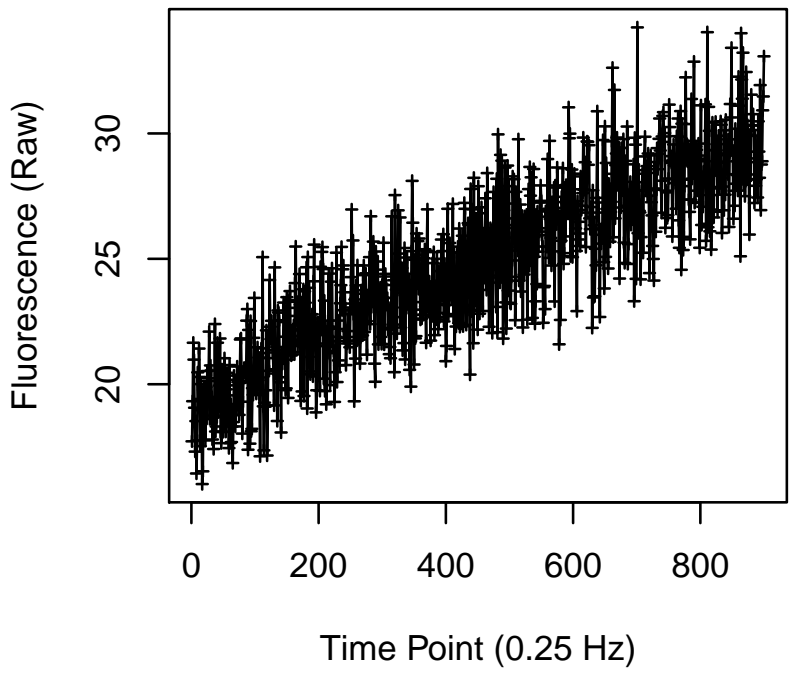

Cell 379

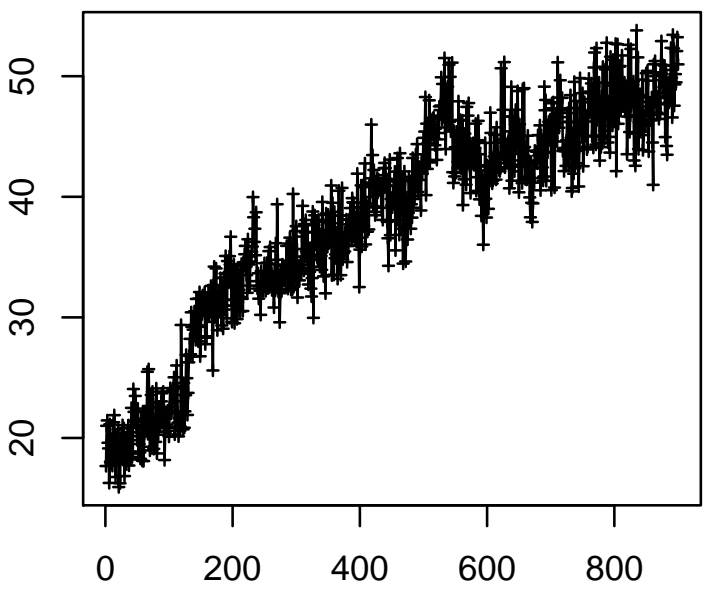

Time Point $(0.25 \mathrm{~Hz})$
Cell 378

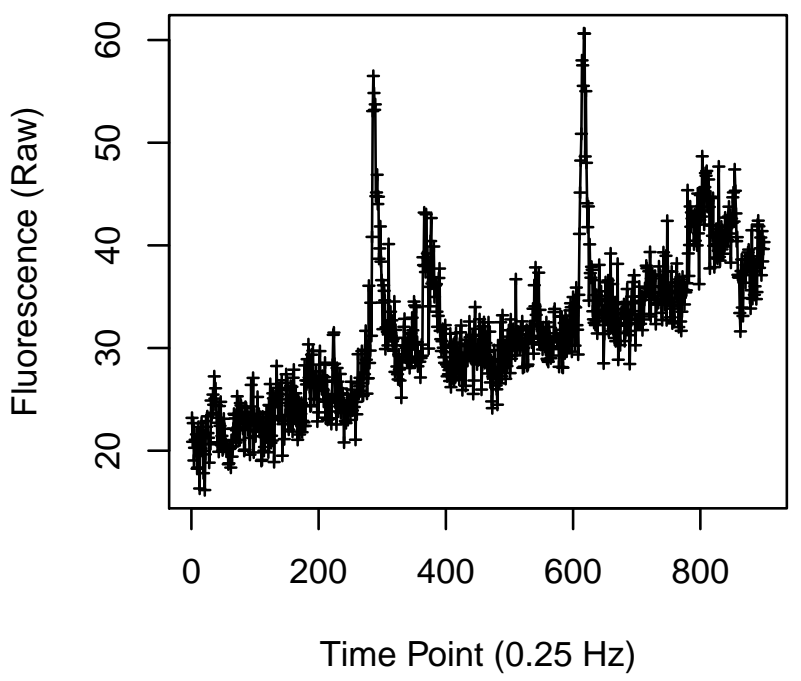

Cell 380

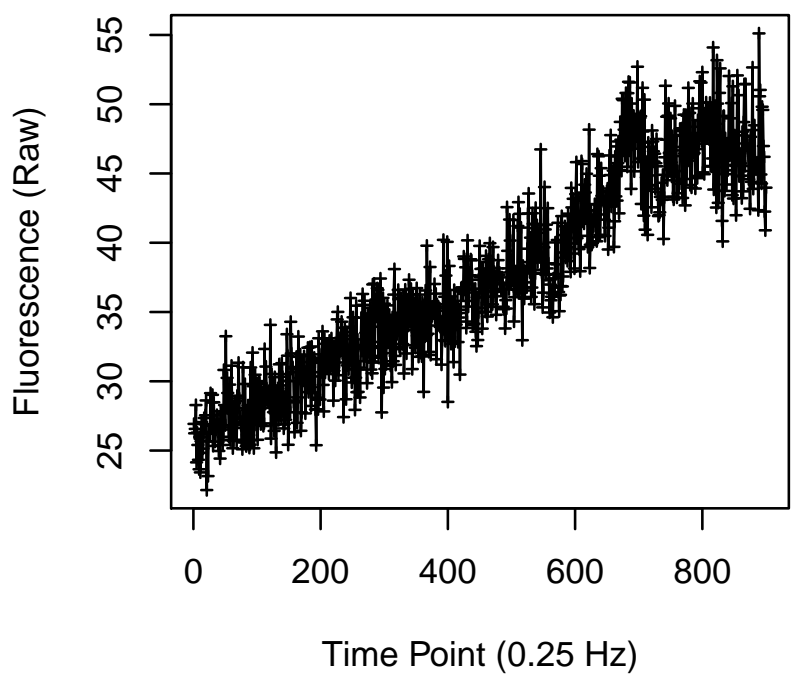


Cell 381

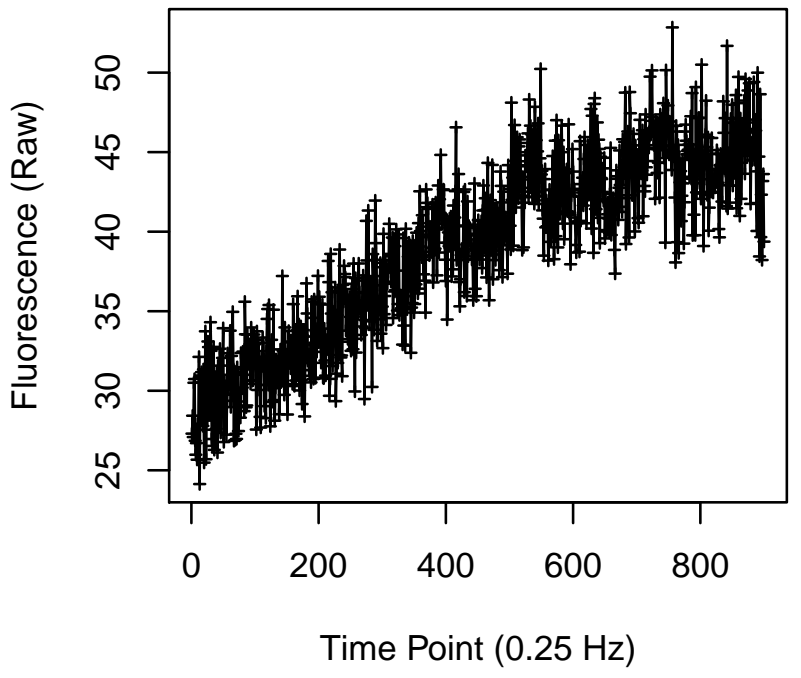

Cell 383

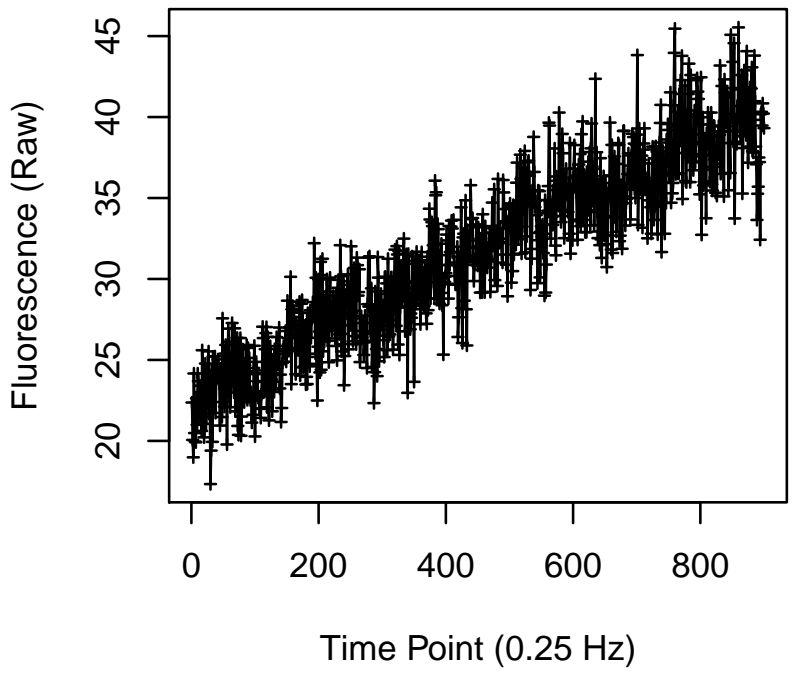

Cell 382

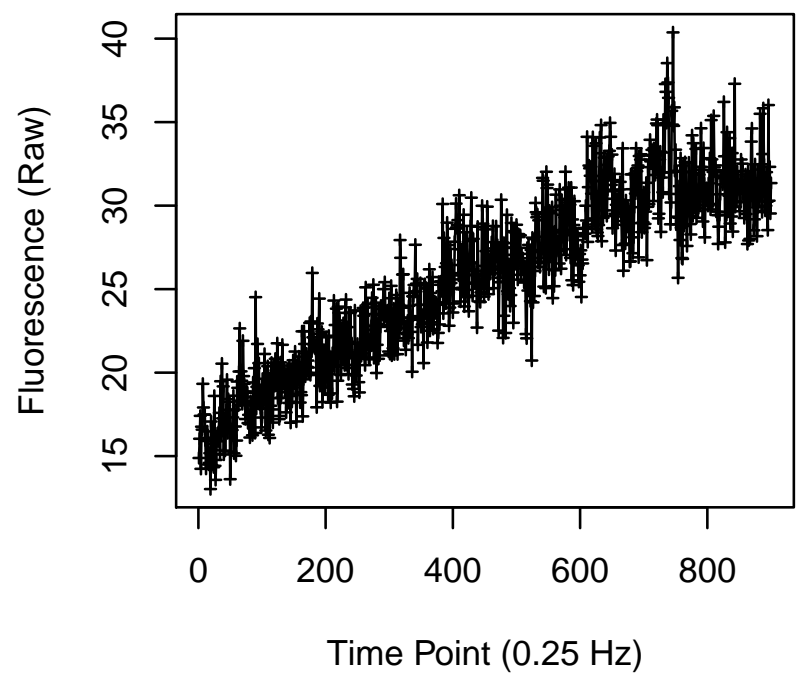

Cell 384

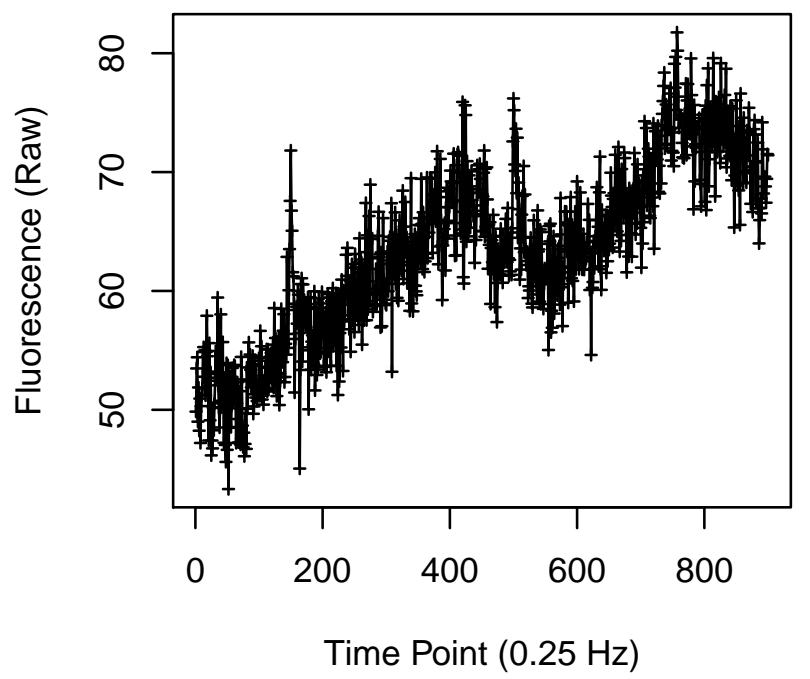




\section{Cell 389}

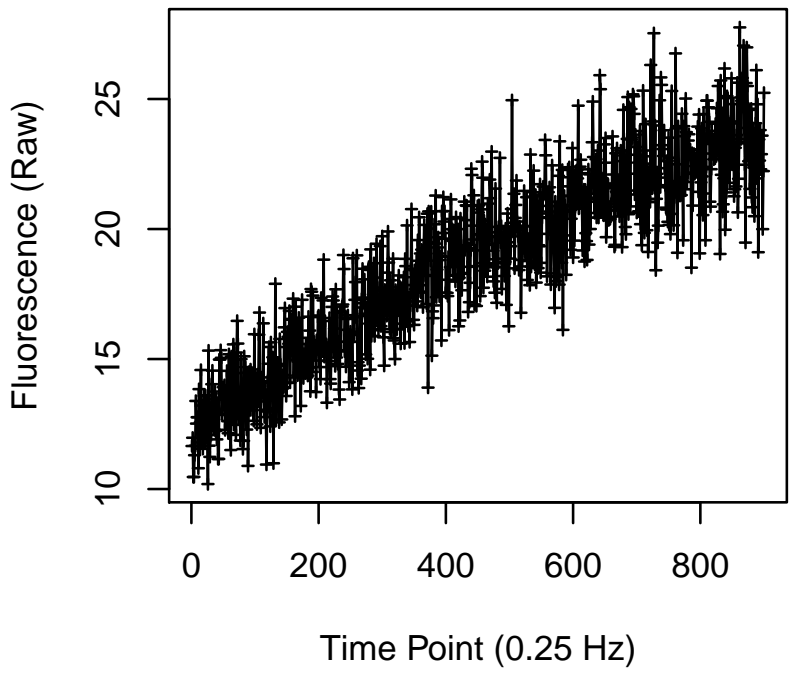

Cell 391

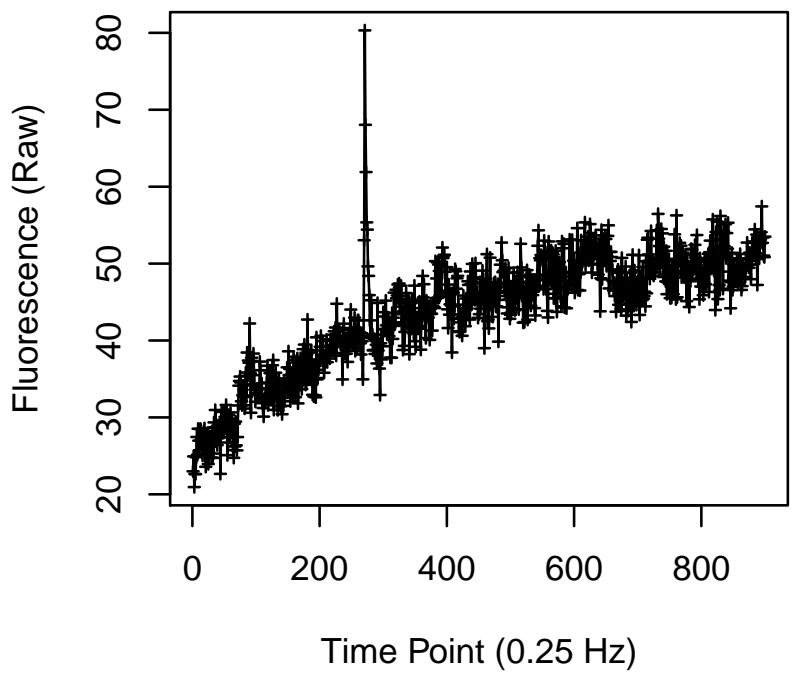

Cell 390

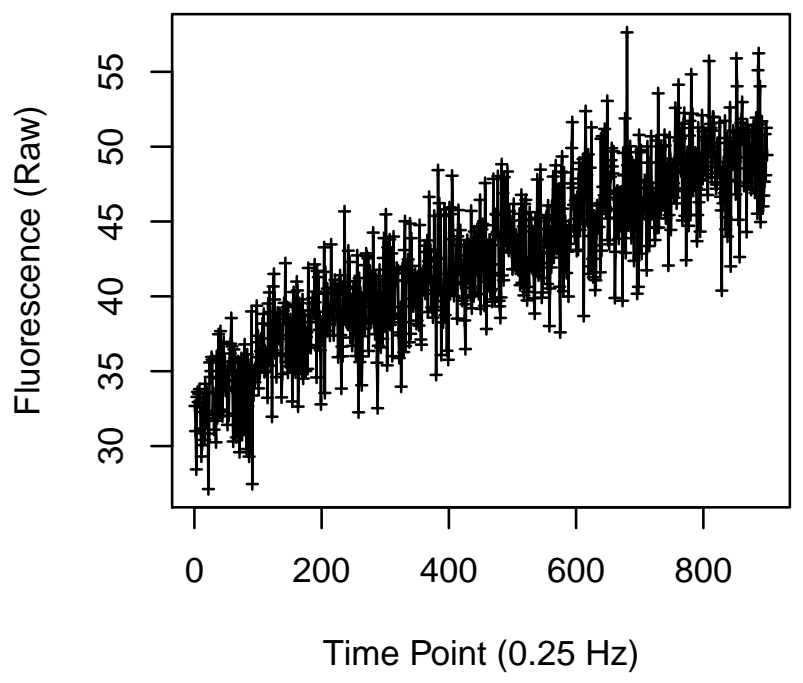

Cell 392

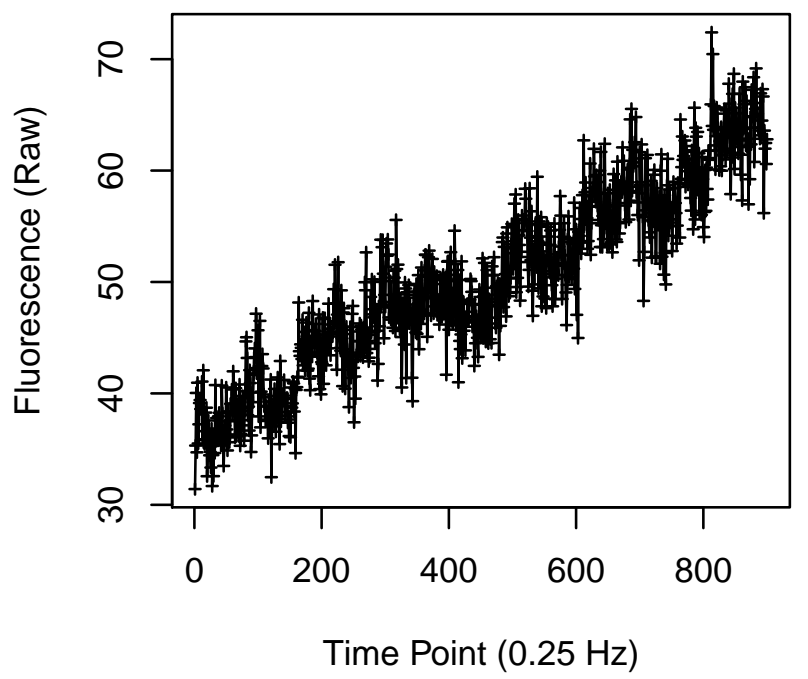


Cell 393

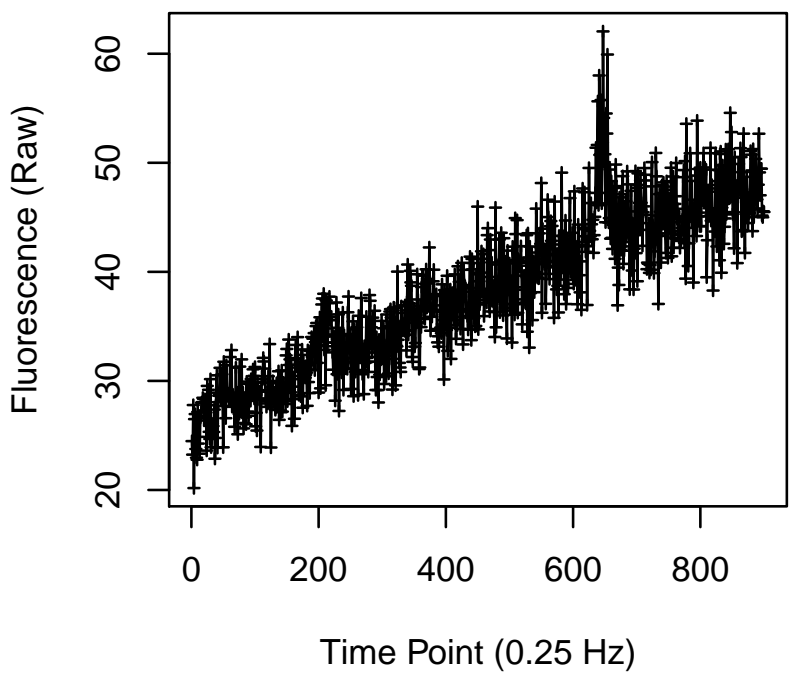

Cell 395

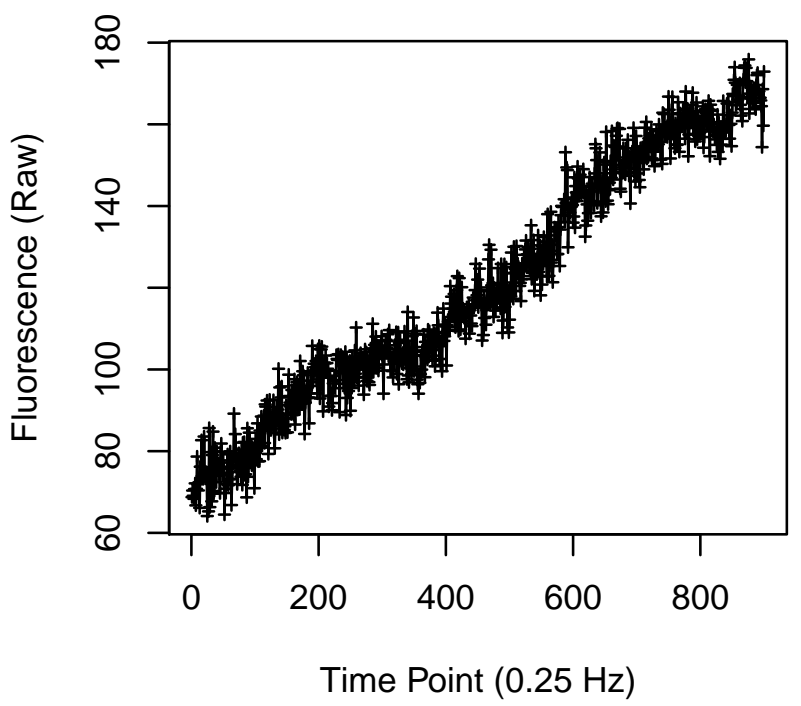

Cell 394

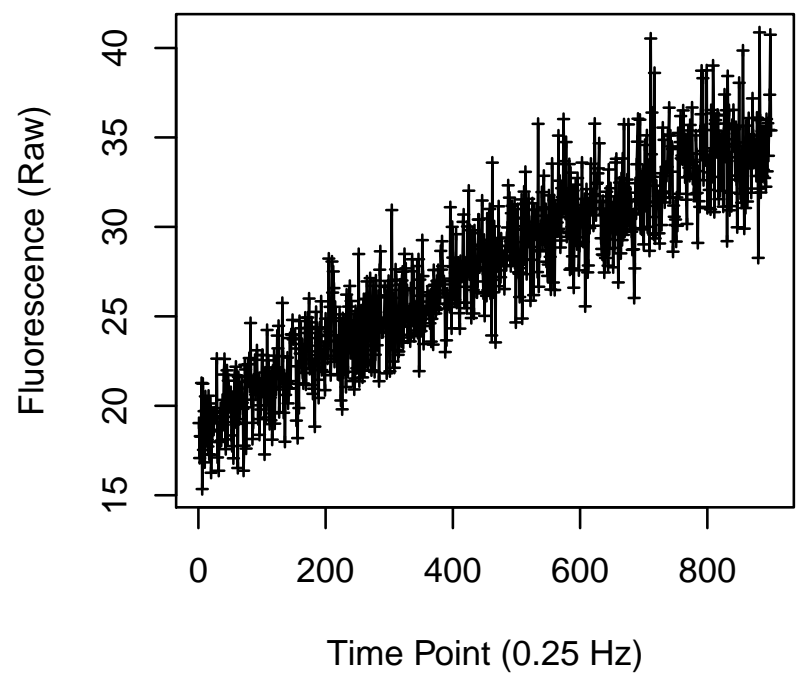

Cell 396

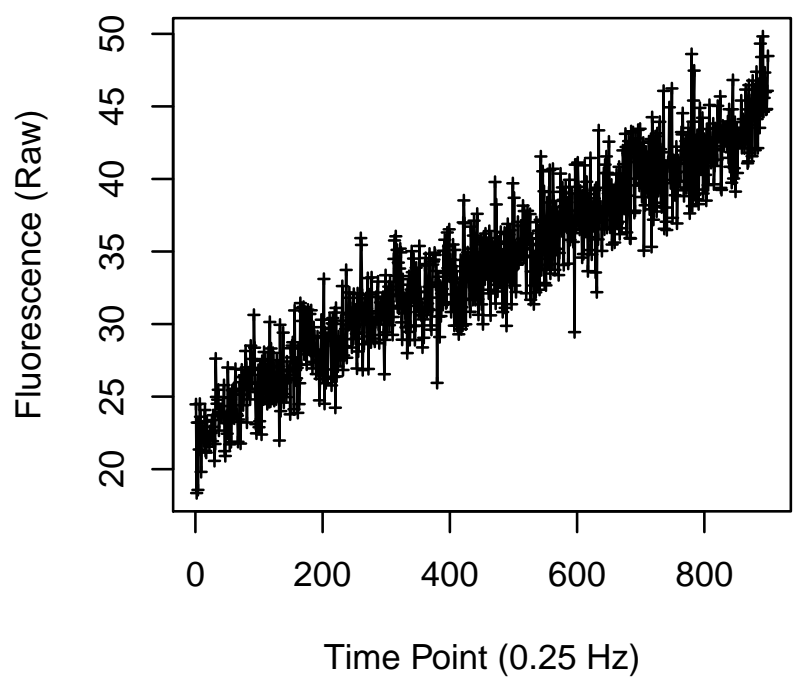


Cell 397

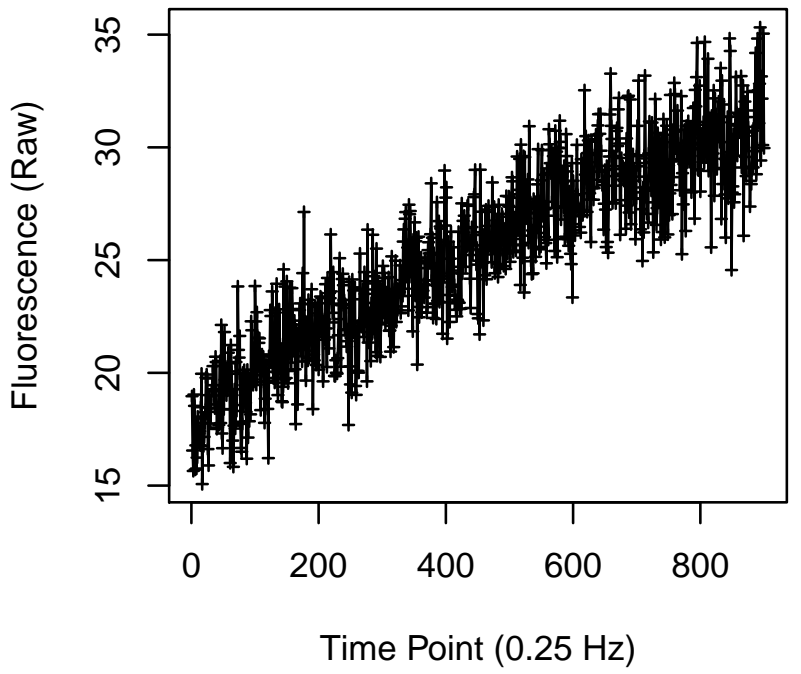

Cell 399

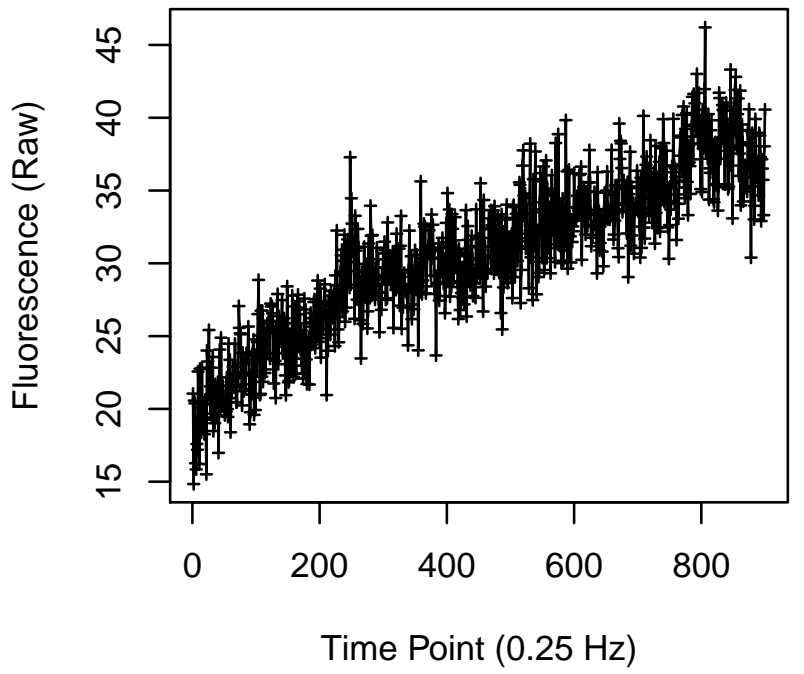

Cell 398

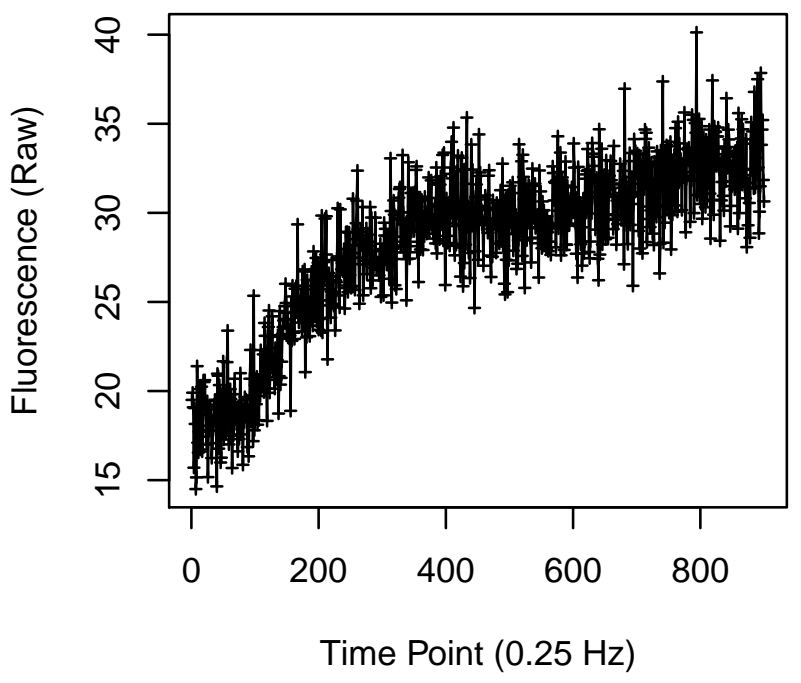

Cell 400

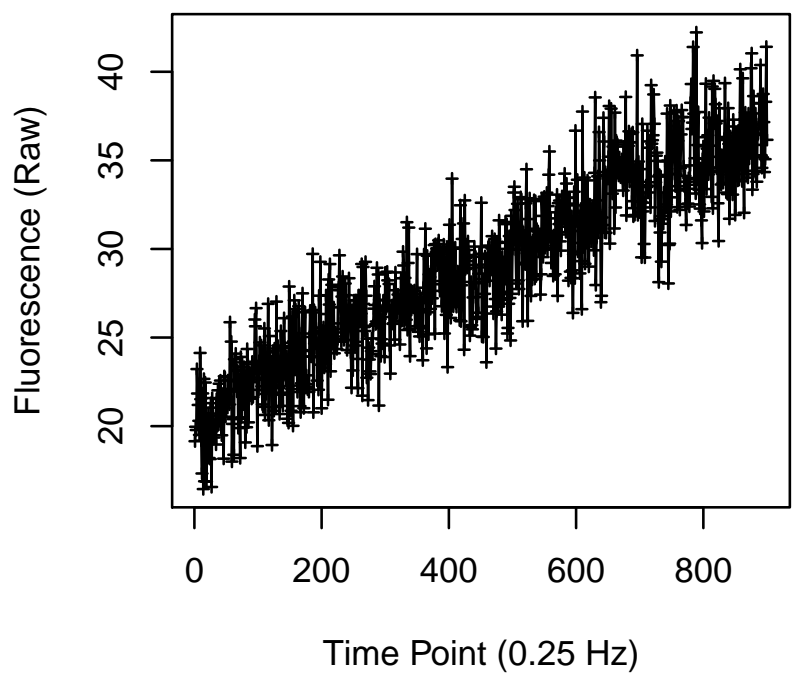


Cell 401

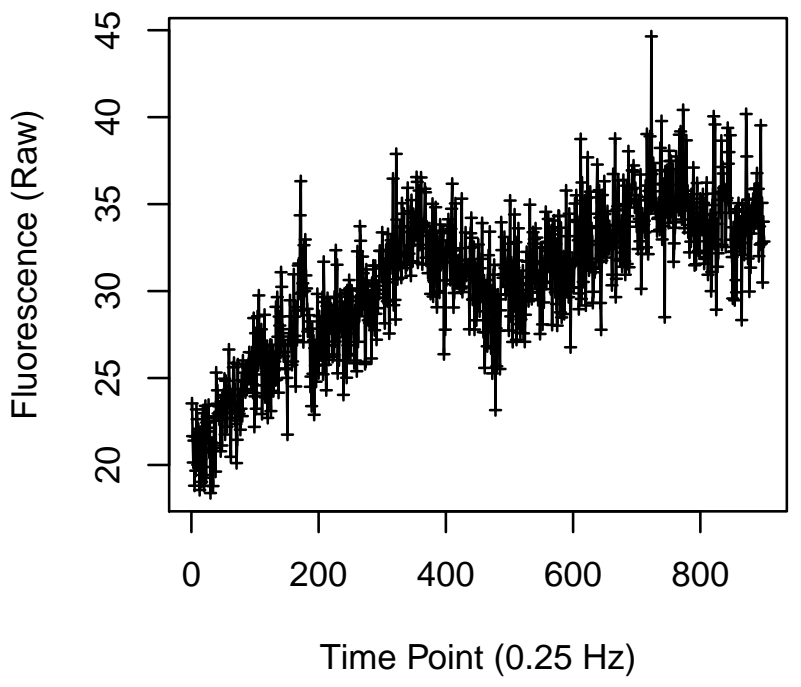

Cell 403

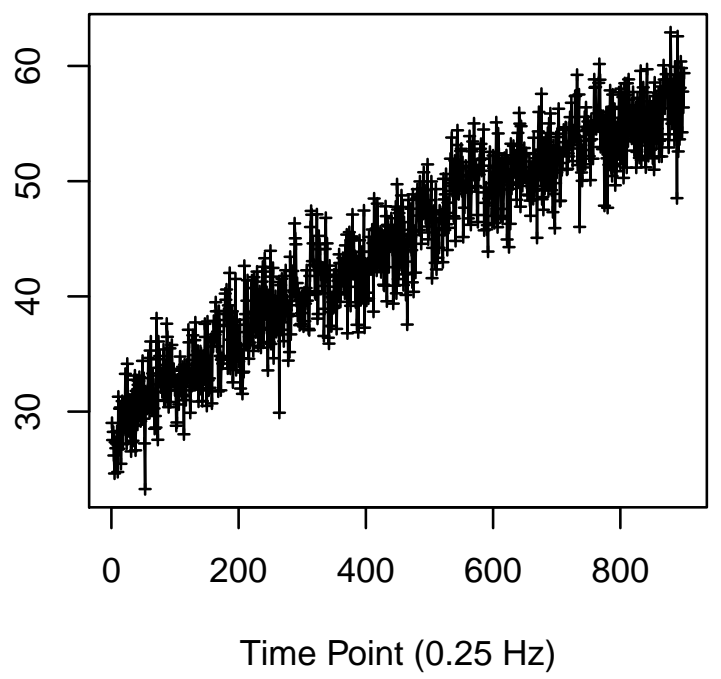

Cell 402

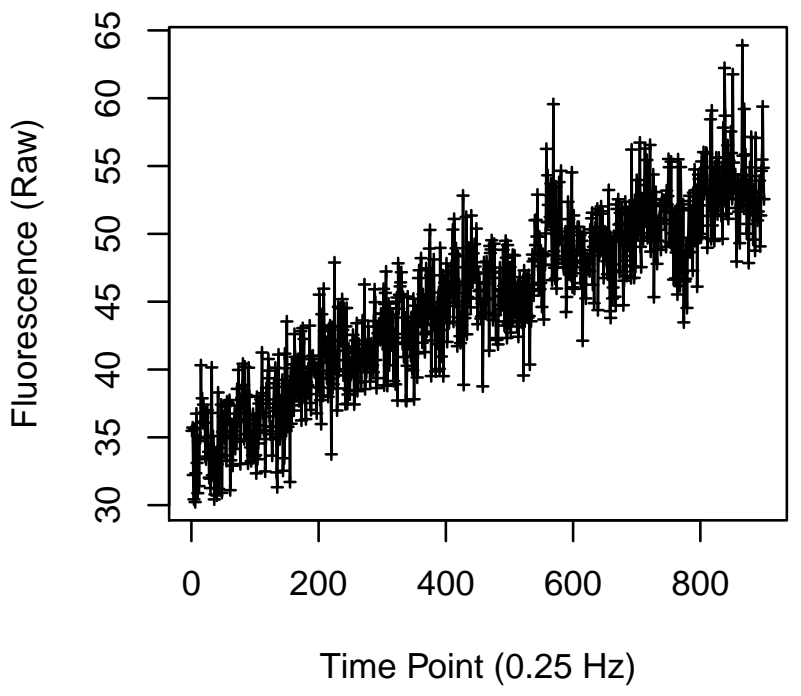

Cell 404

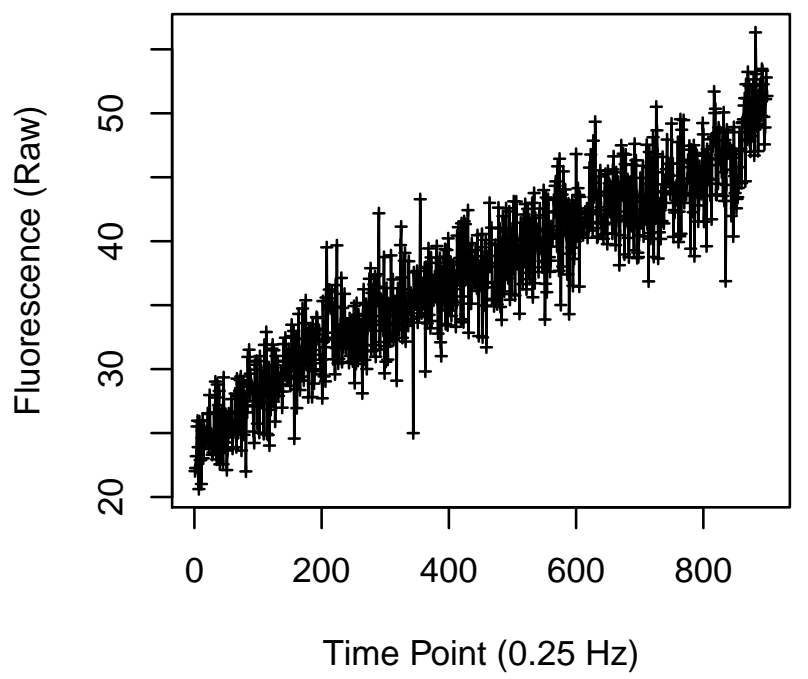


Cell 405

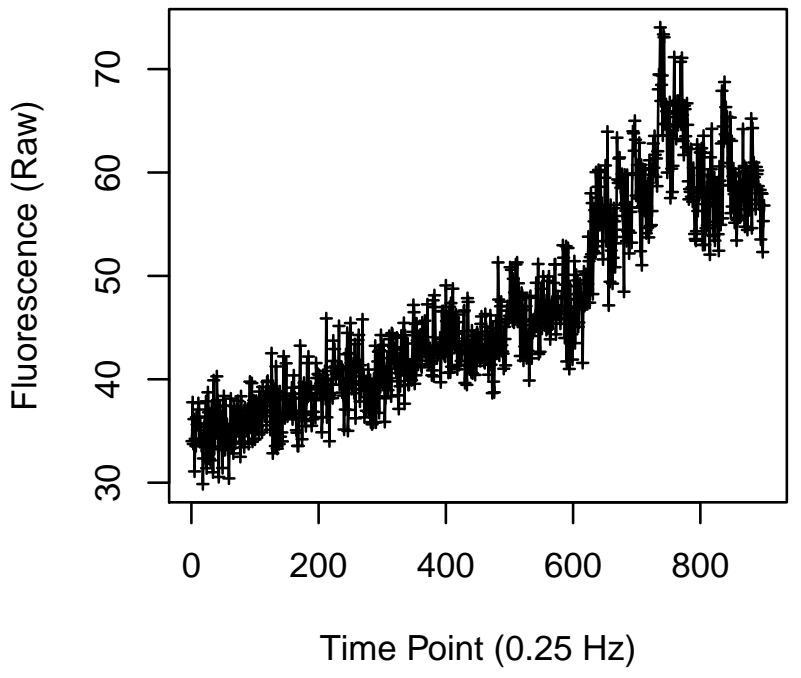

Cell 407

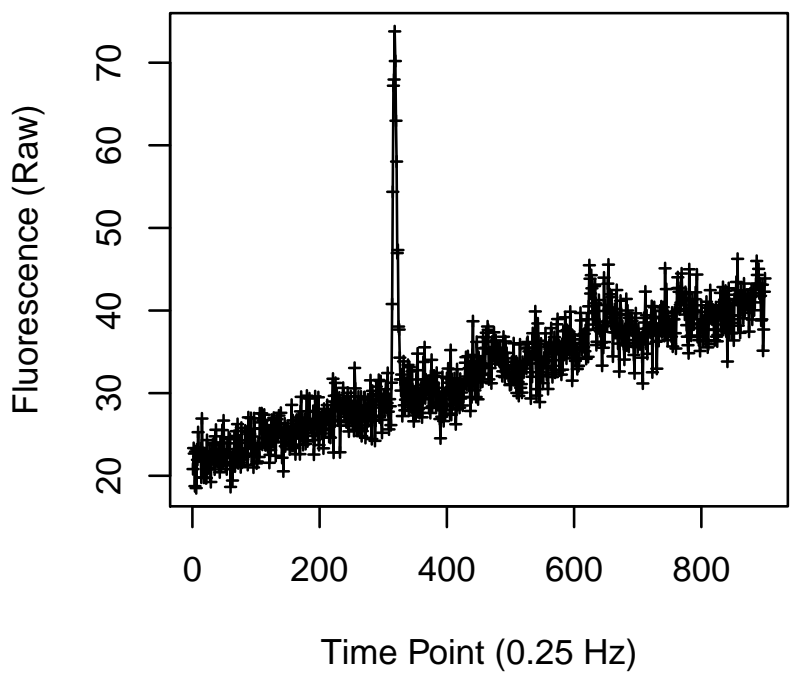

Cell 406

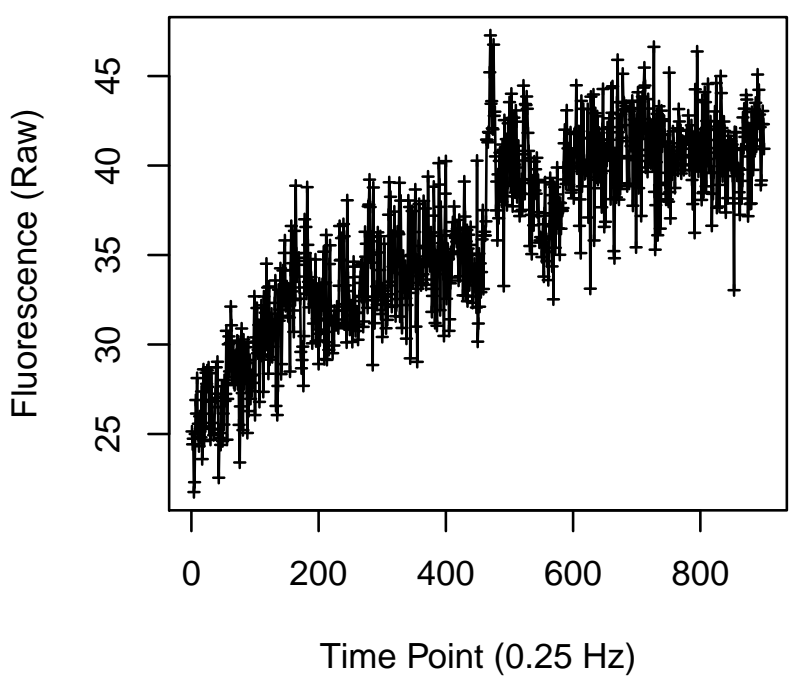

Cell 408

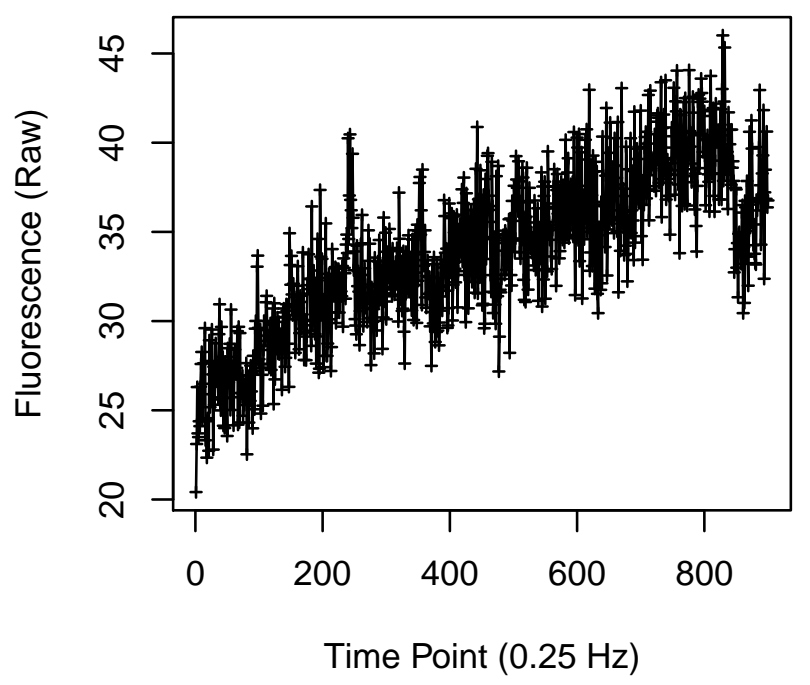


Cell 409

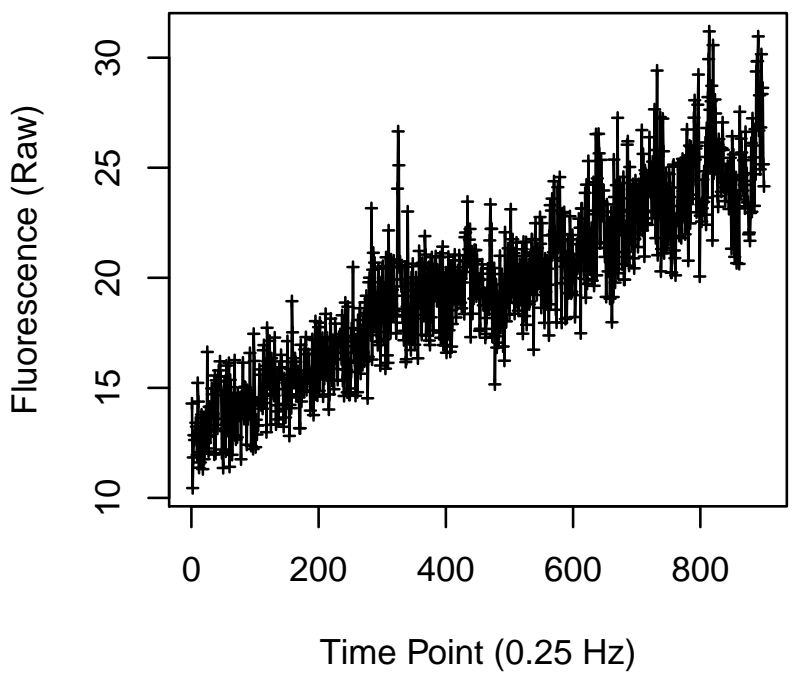

Cell 411

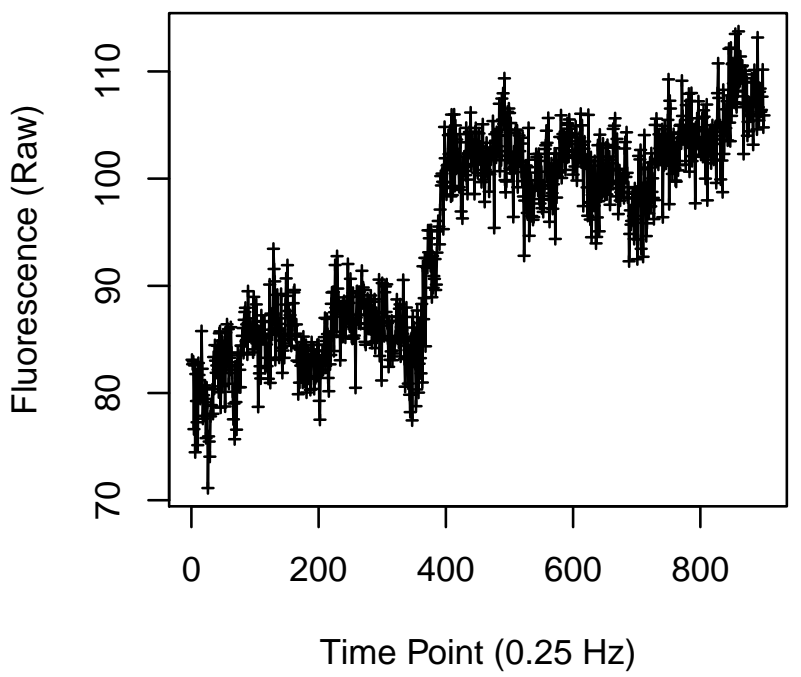

Cell 410

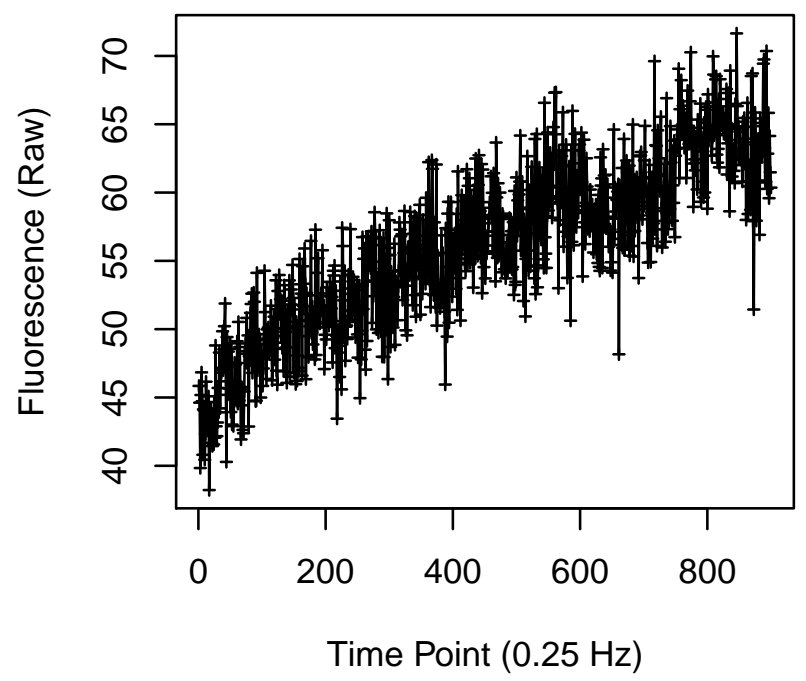

Cell 412

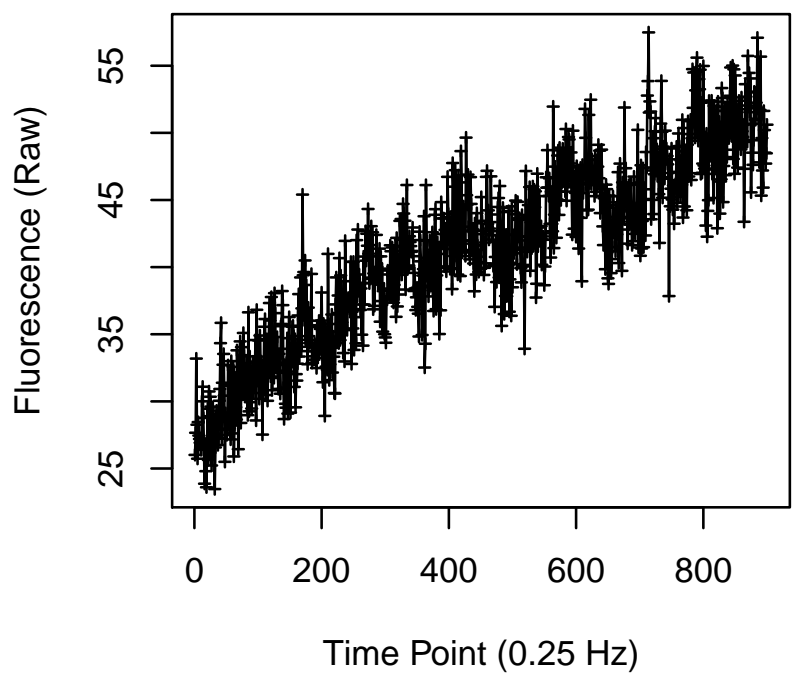




\section{Cell 413}

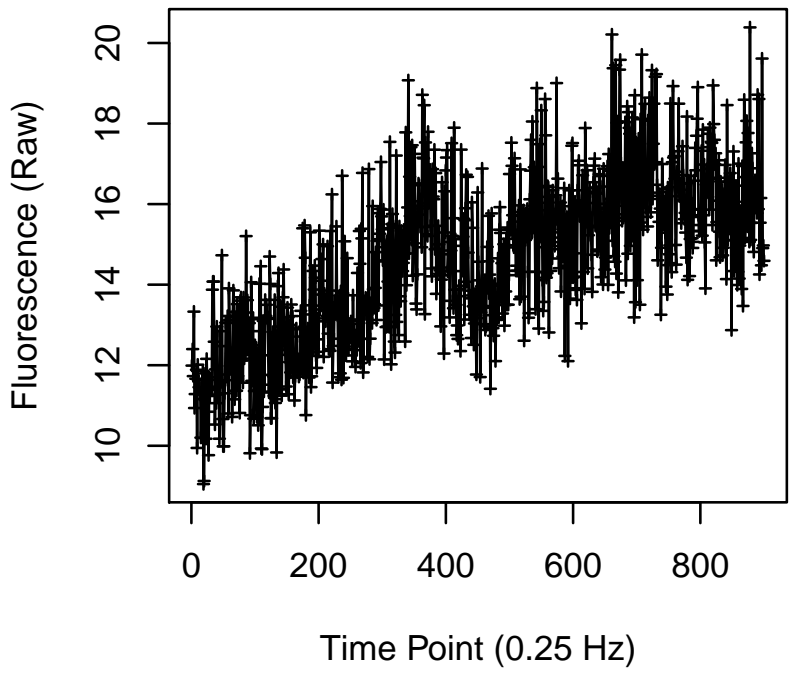

Cell 415

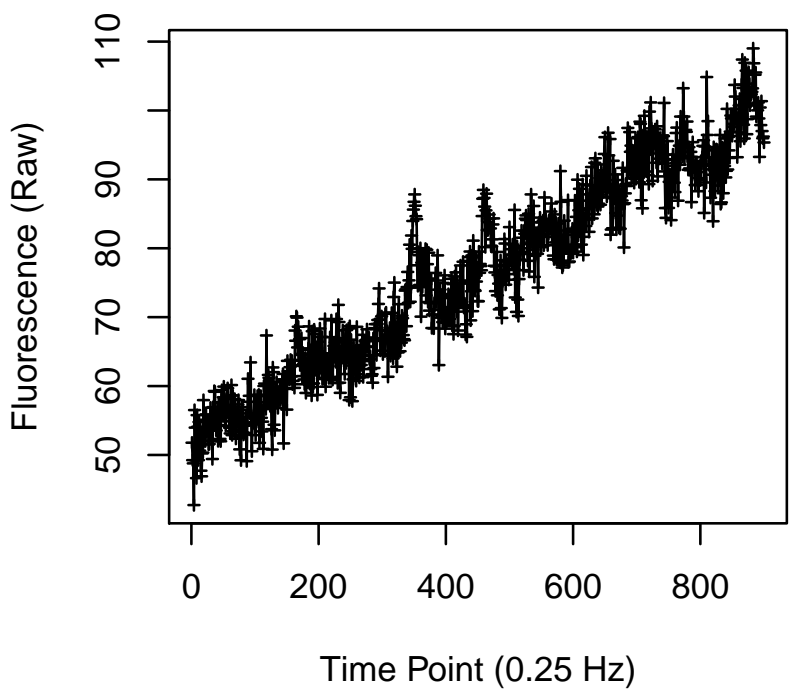

Cell 414

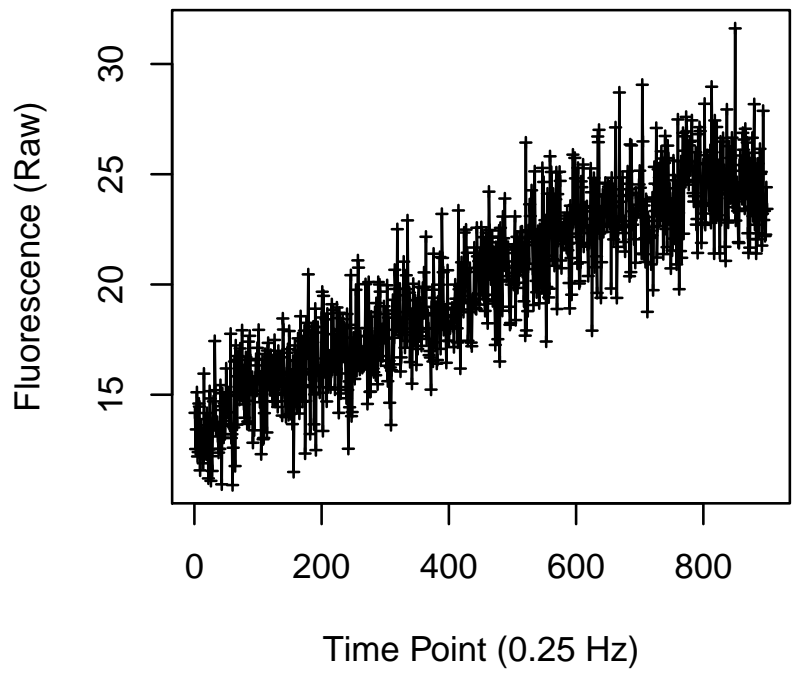

Cell 416

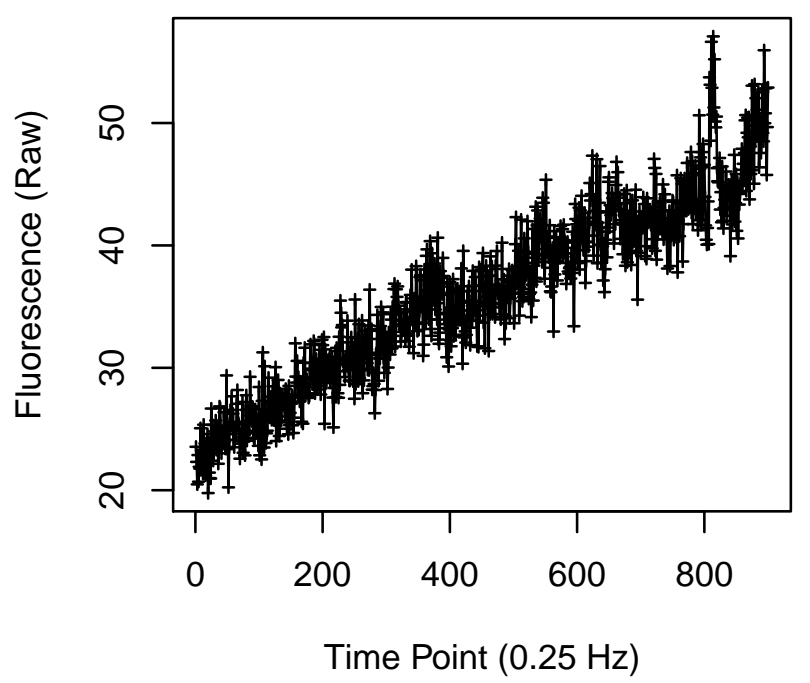


Cell 417

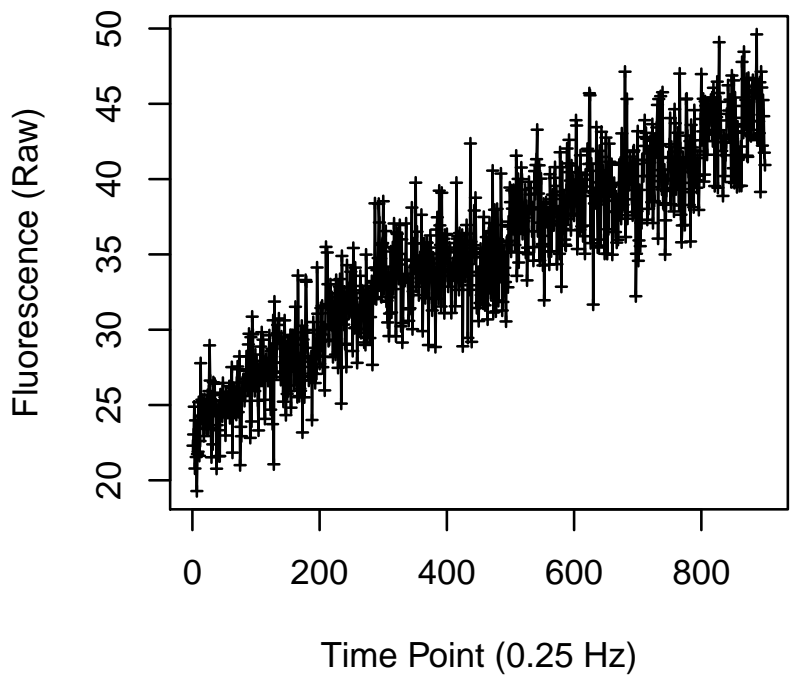

Cell 419

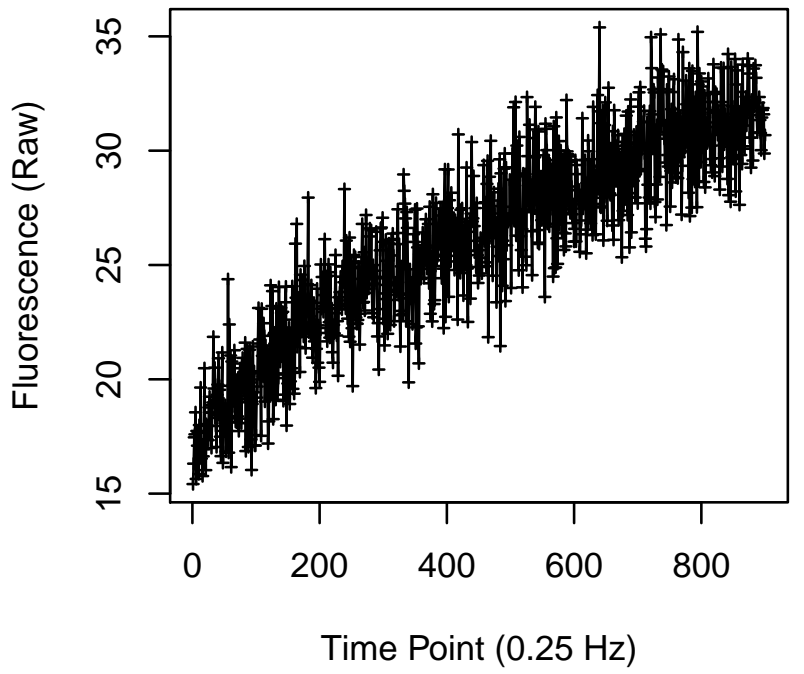

Cell 418

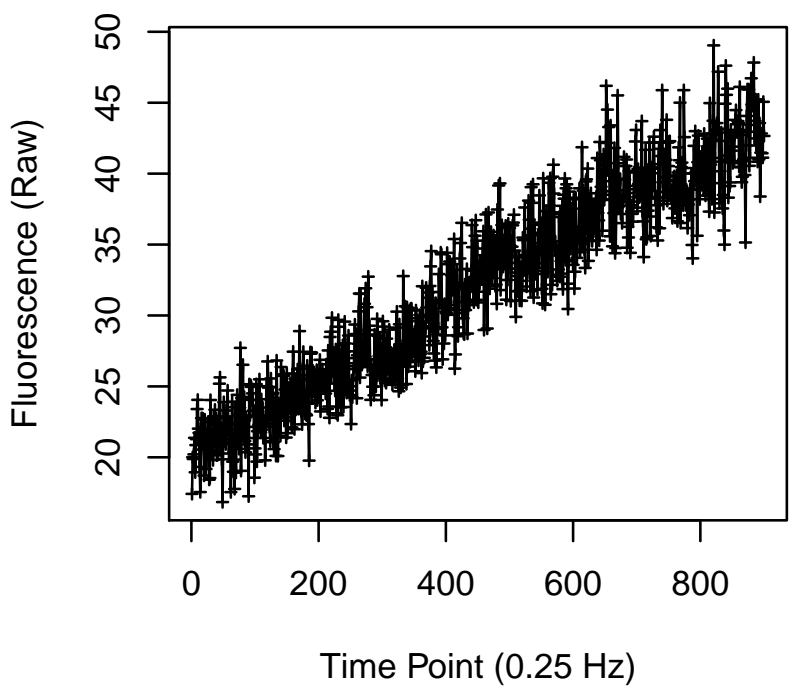

Cell 420

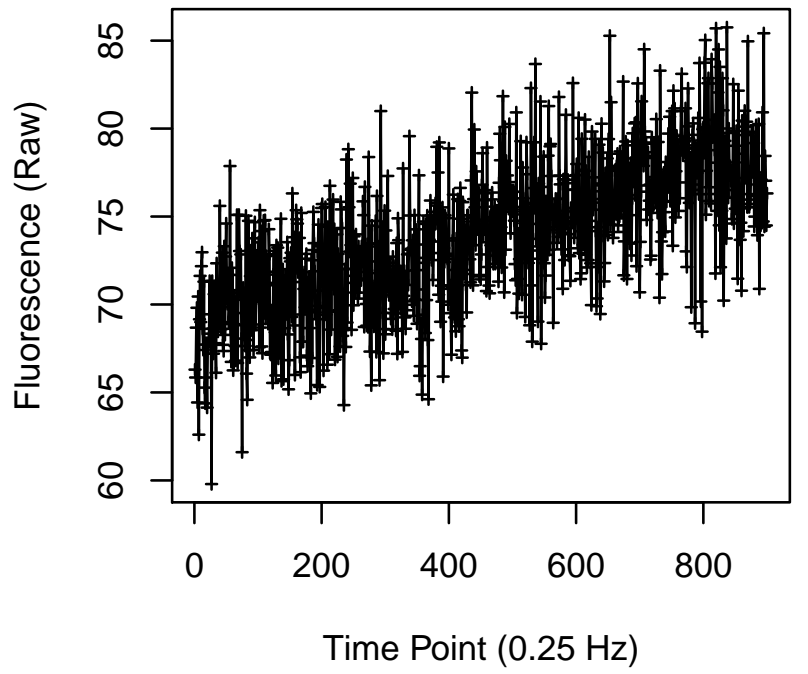


Cell 421

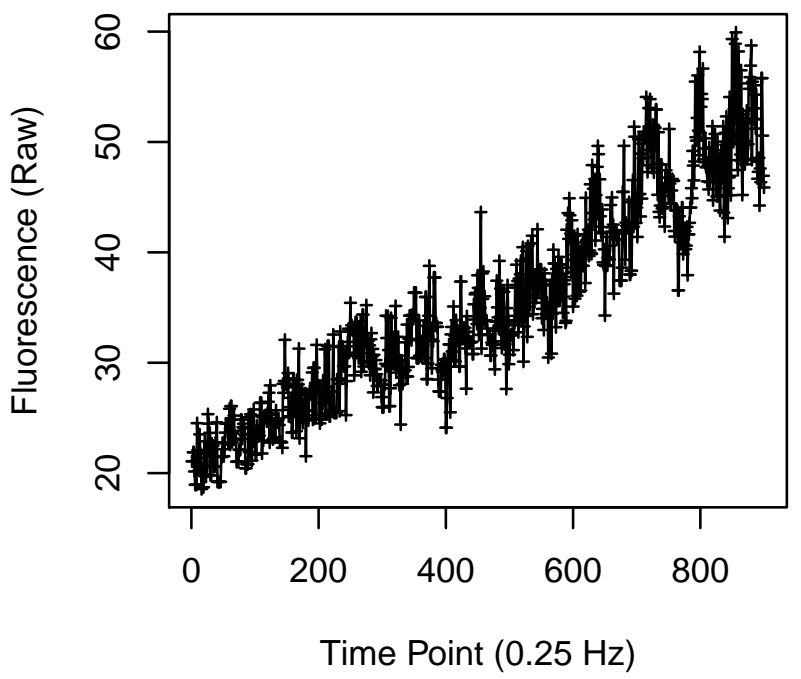

Cell 423

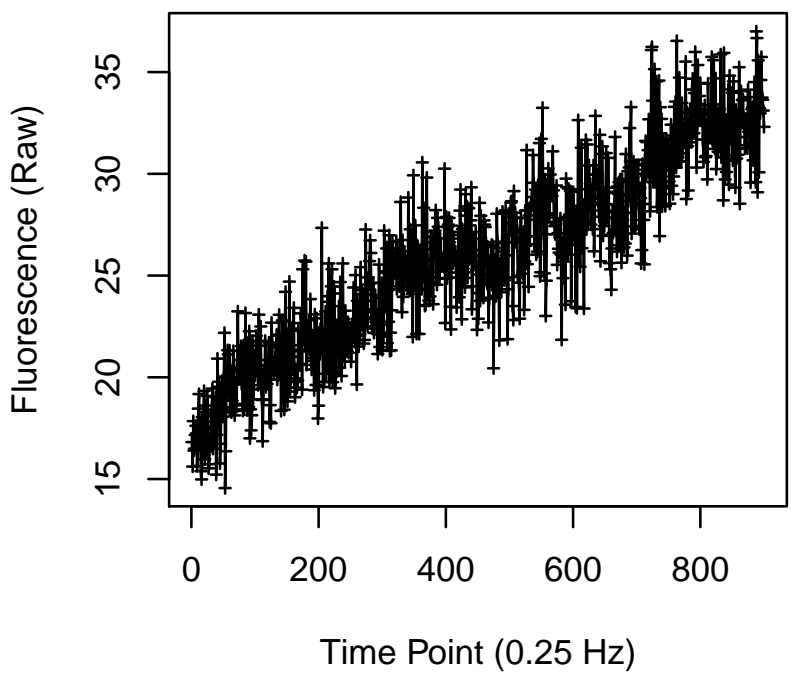

Cell 422

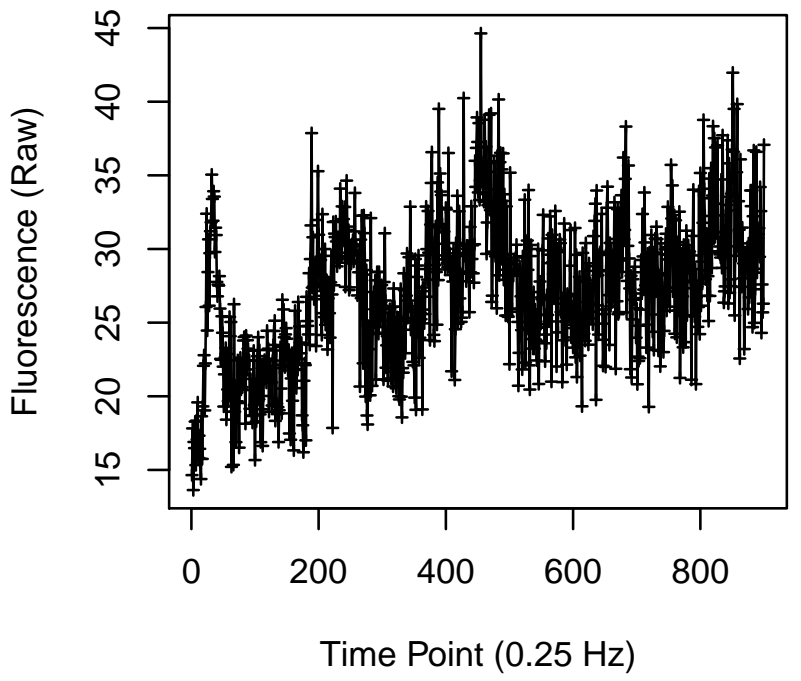

Cell 424

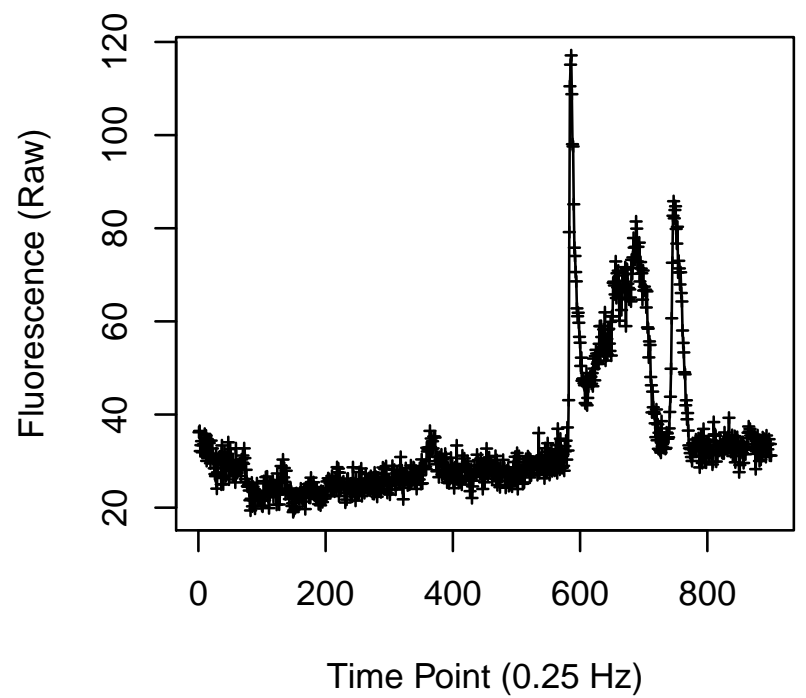


Cell 425

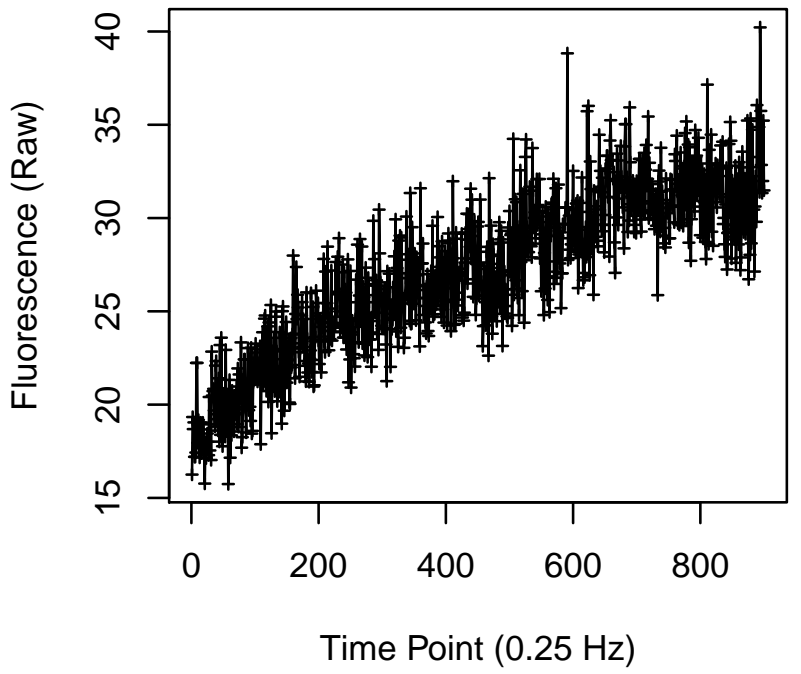

Cell 427

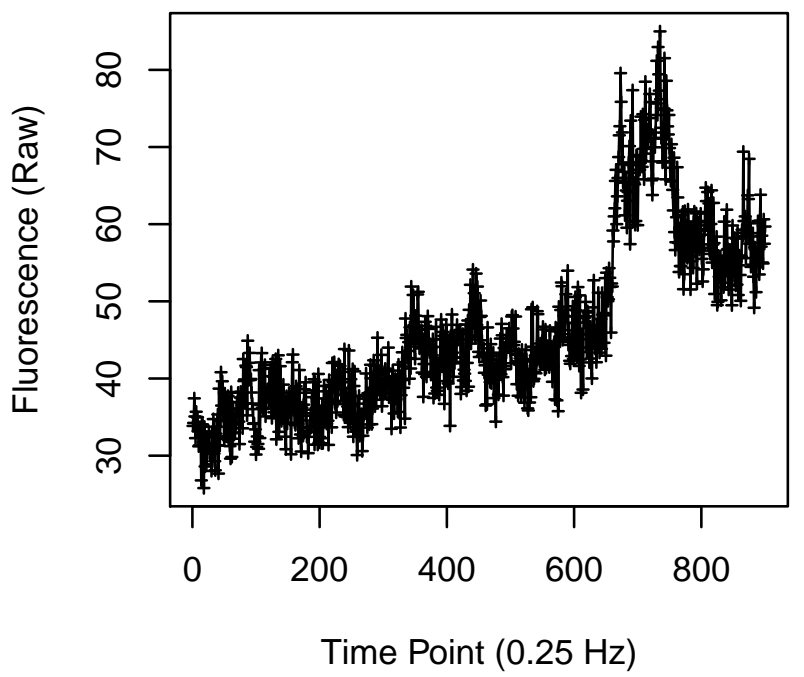

Cell 426

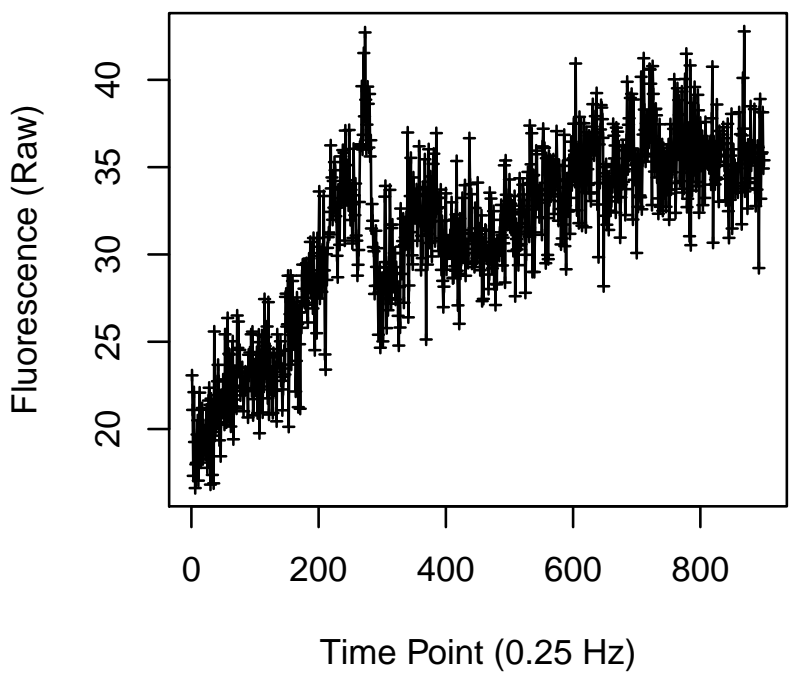

Cell 428

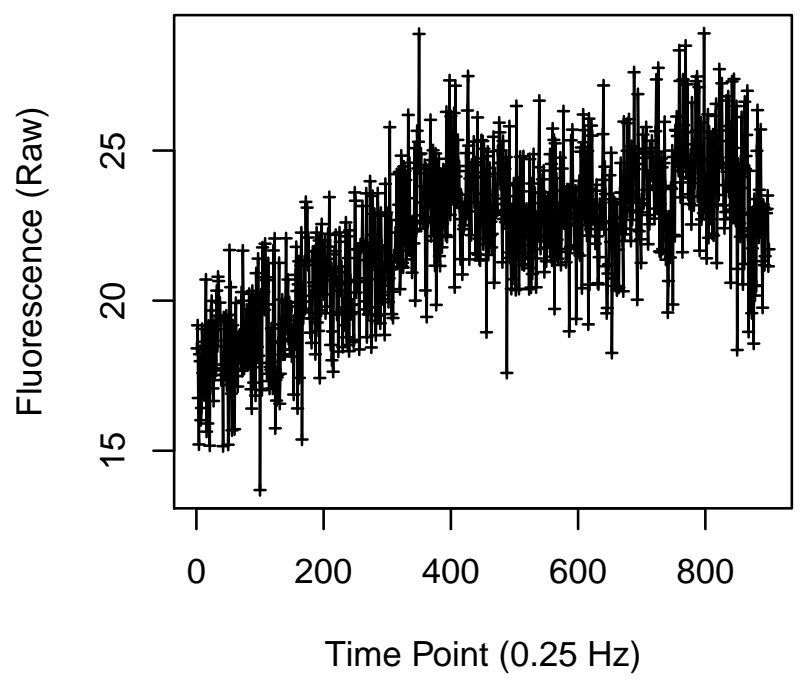


Cell 429

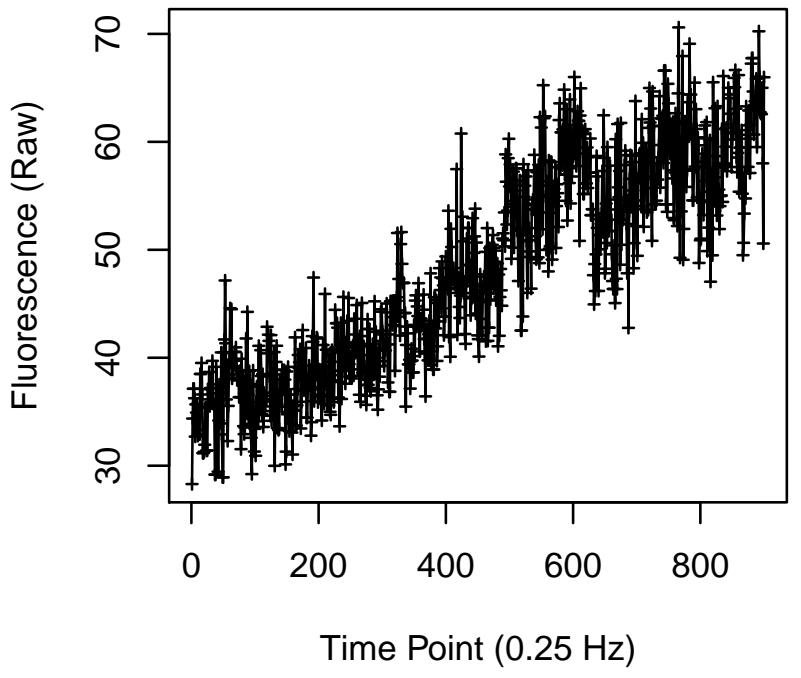

Cell 431

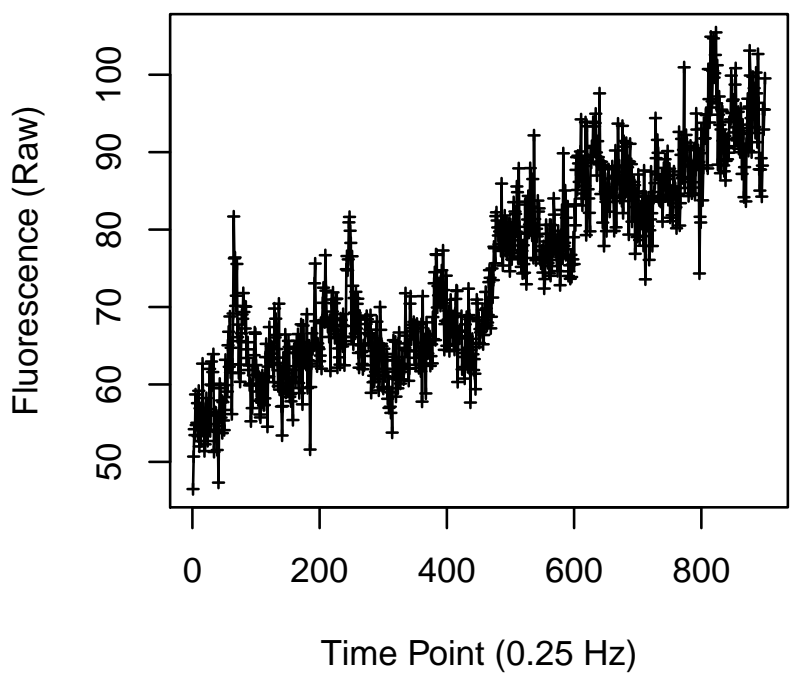

Cell 430

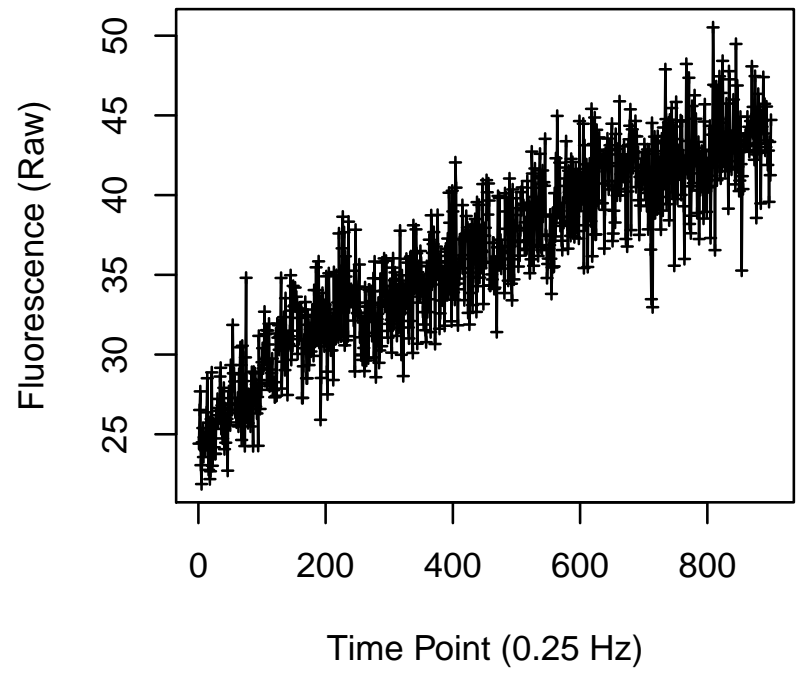

Cell 432

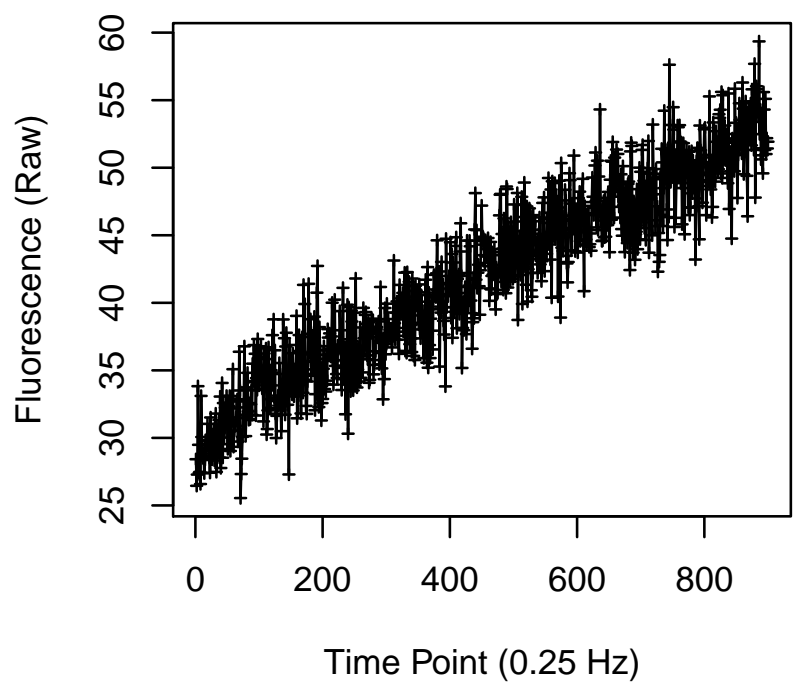




\section{Cell 433}

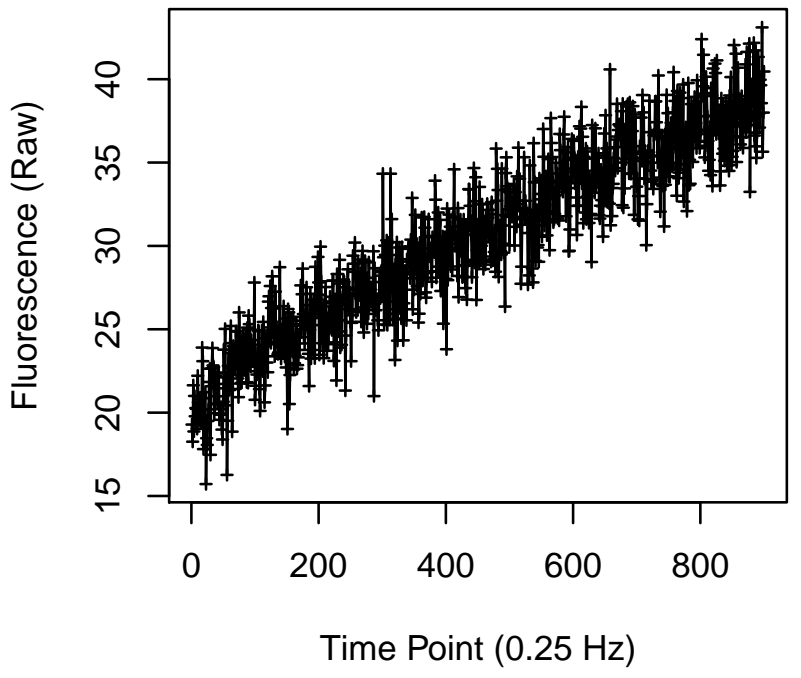

Cell 435

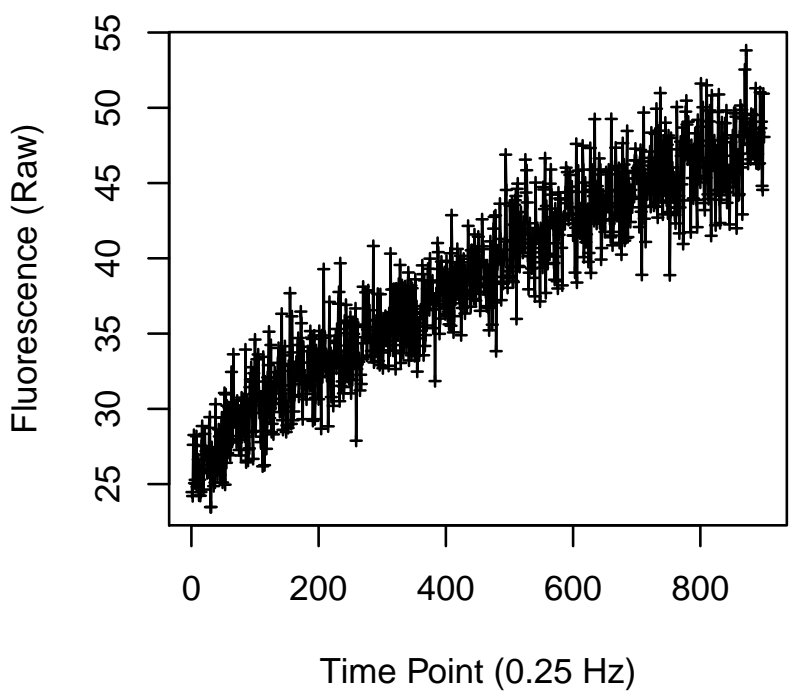

Cell 434

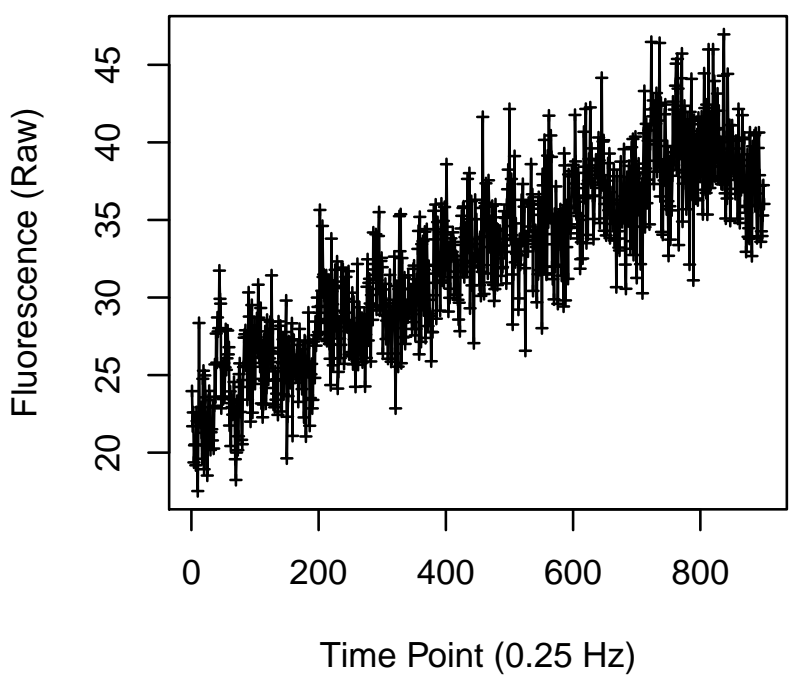

Cell 436

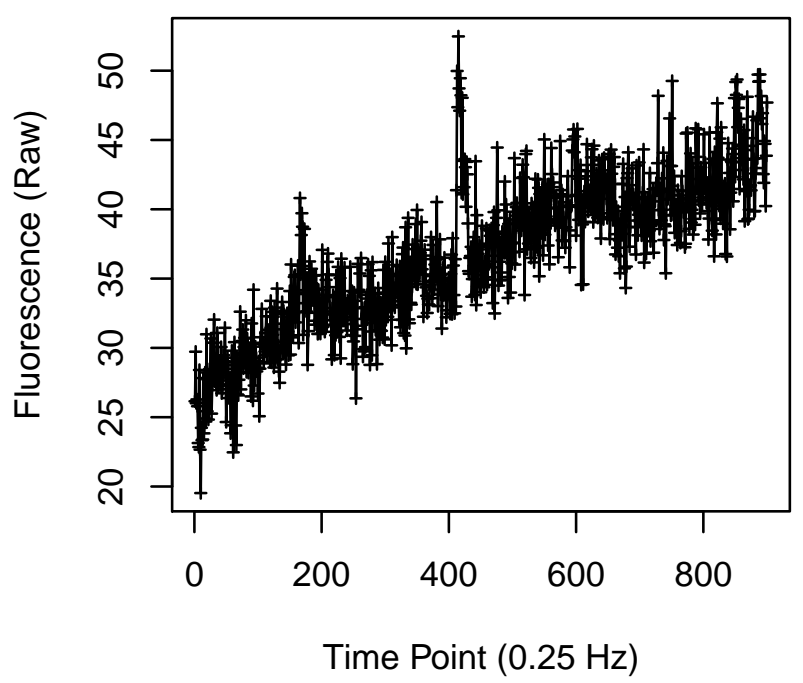


Cell 441

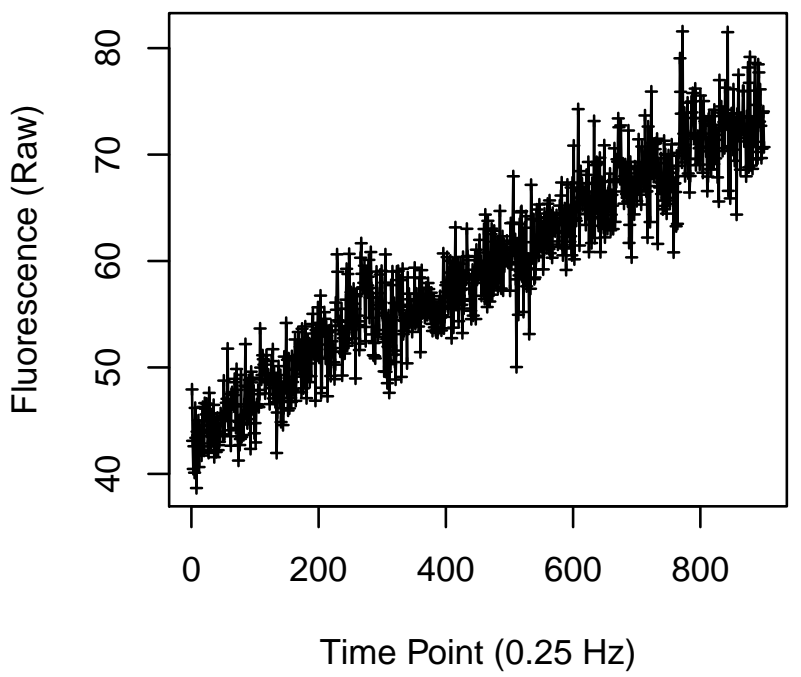

Cell 443

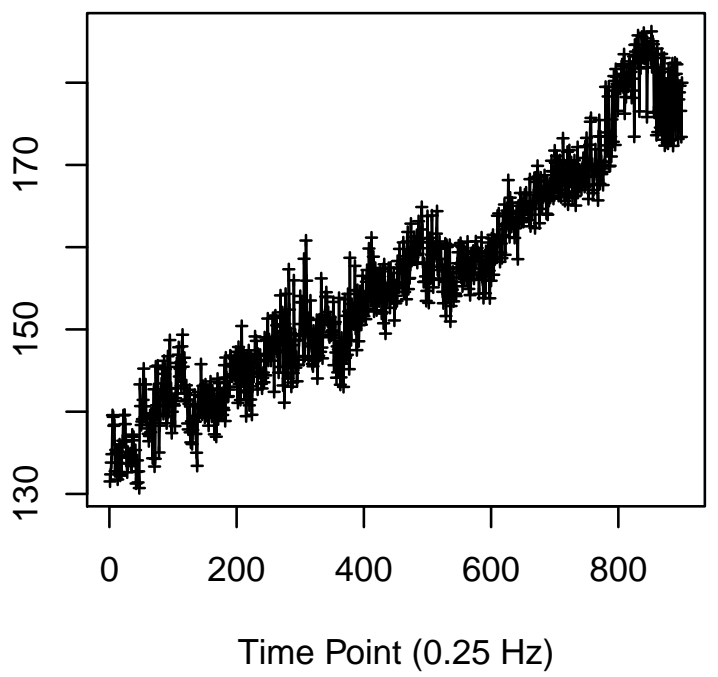

Cell 442

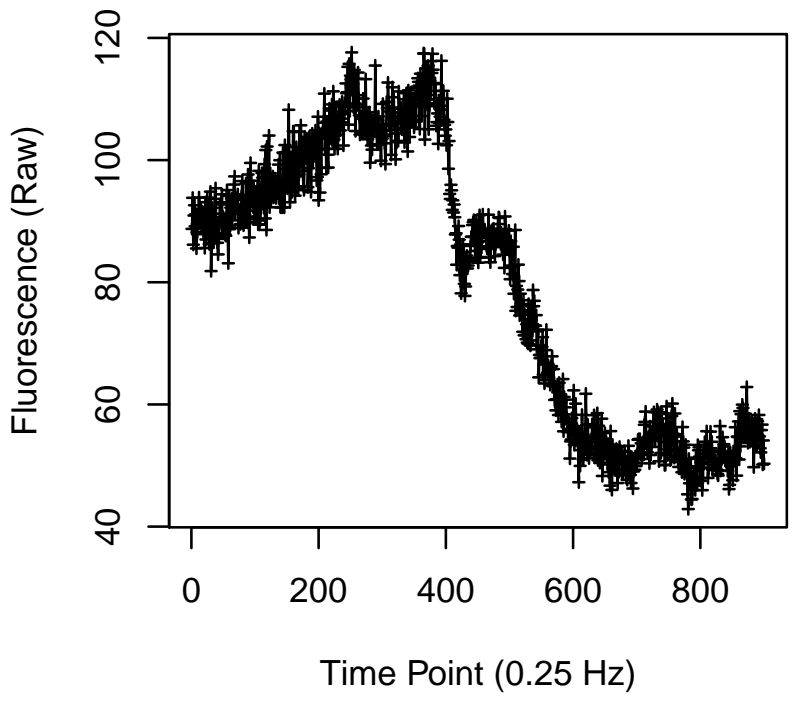

Cell 444

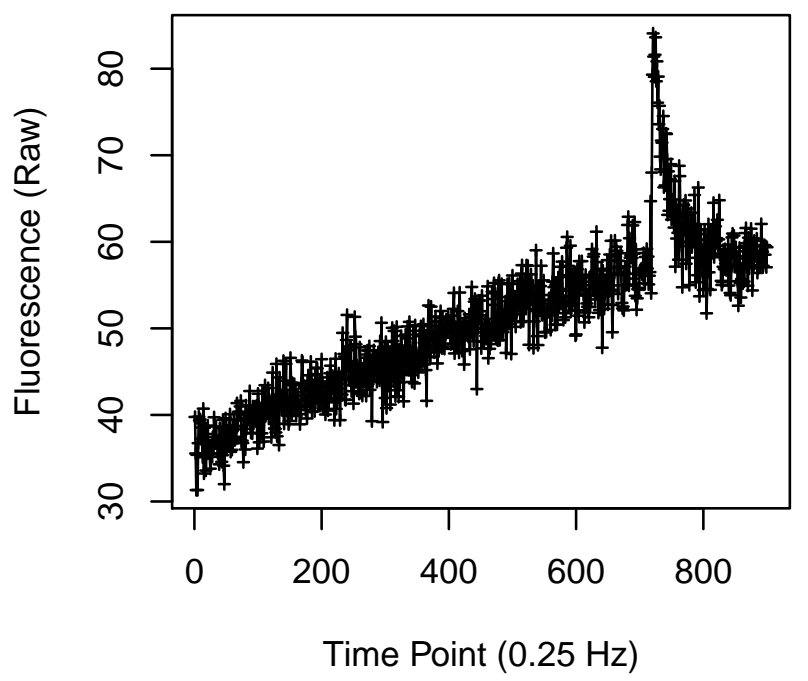


Cell 453

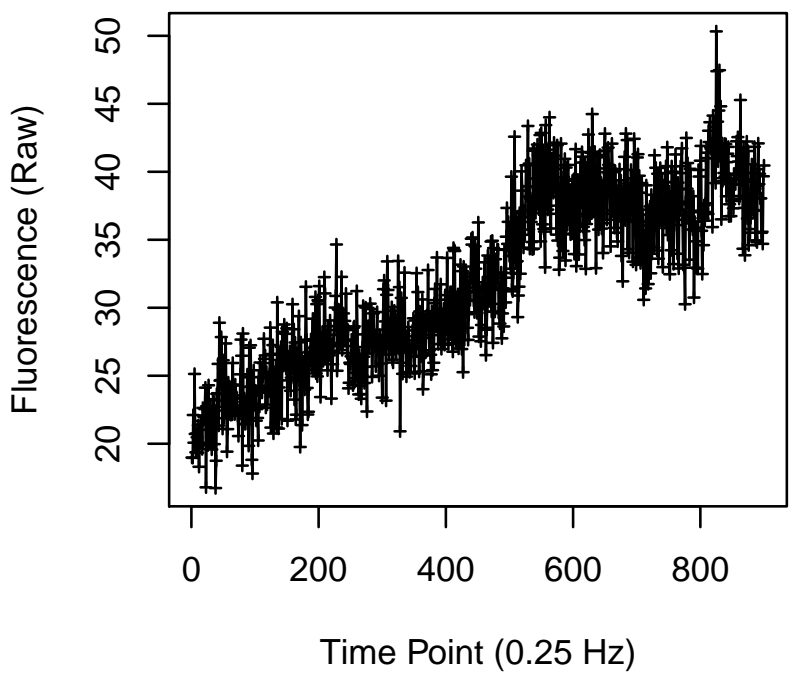

Cell 455

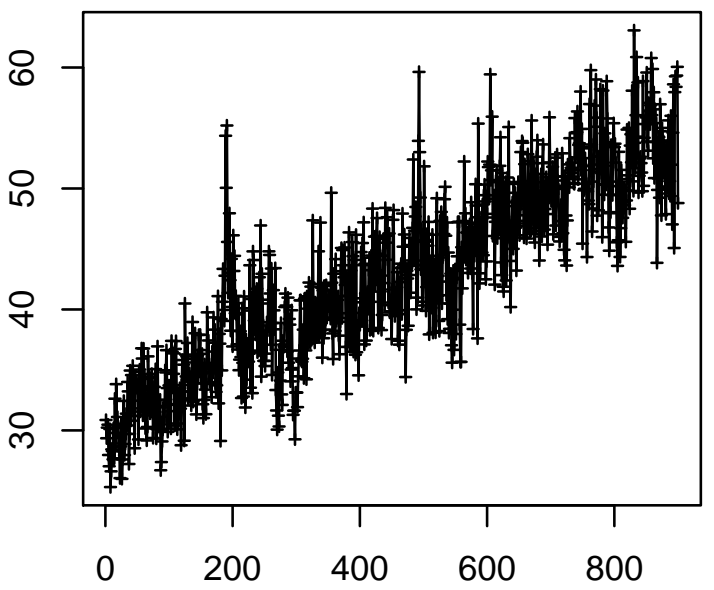

Time Point $(0.25 \mathrm{~Hz})$
Cell 454

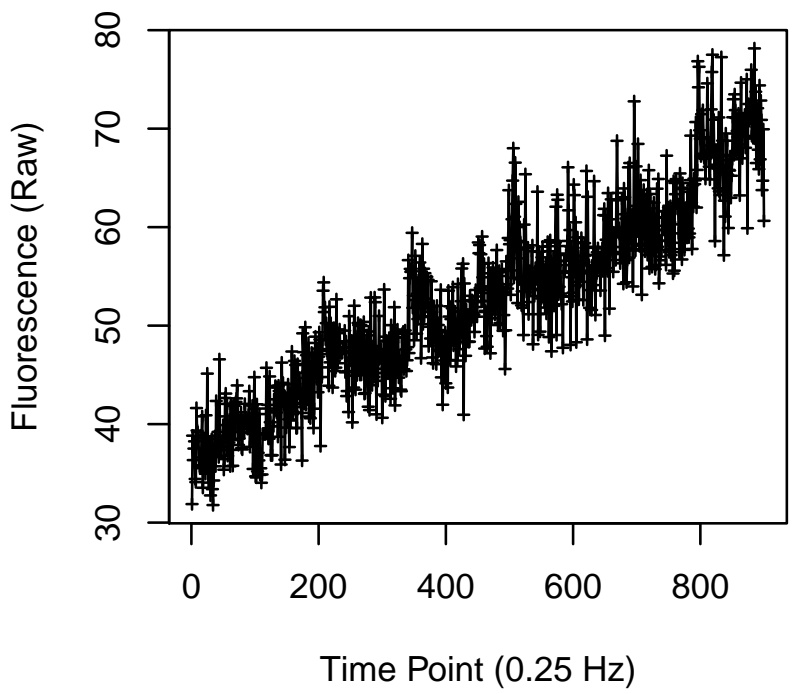

Cell 456

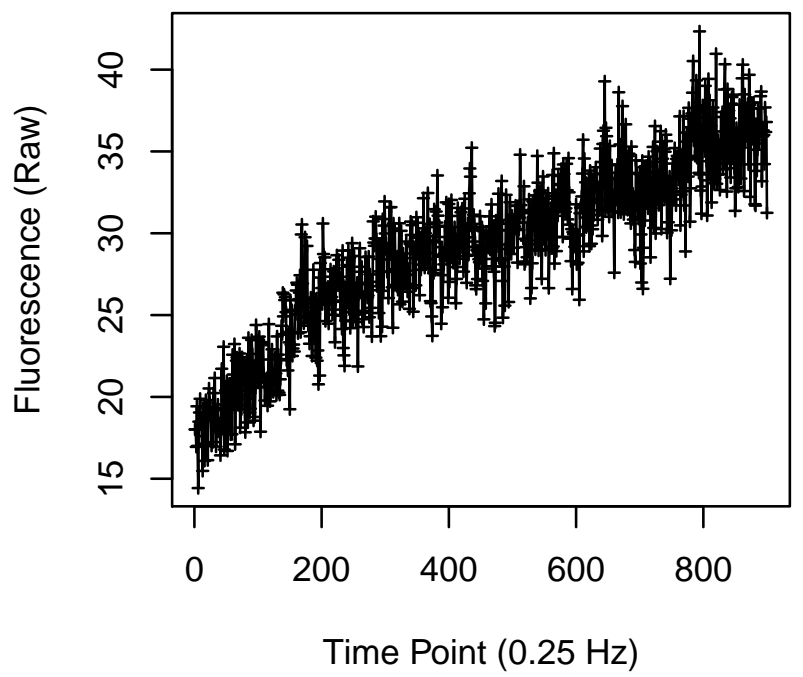


Cell 457

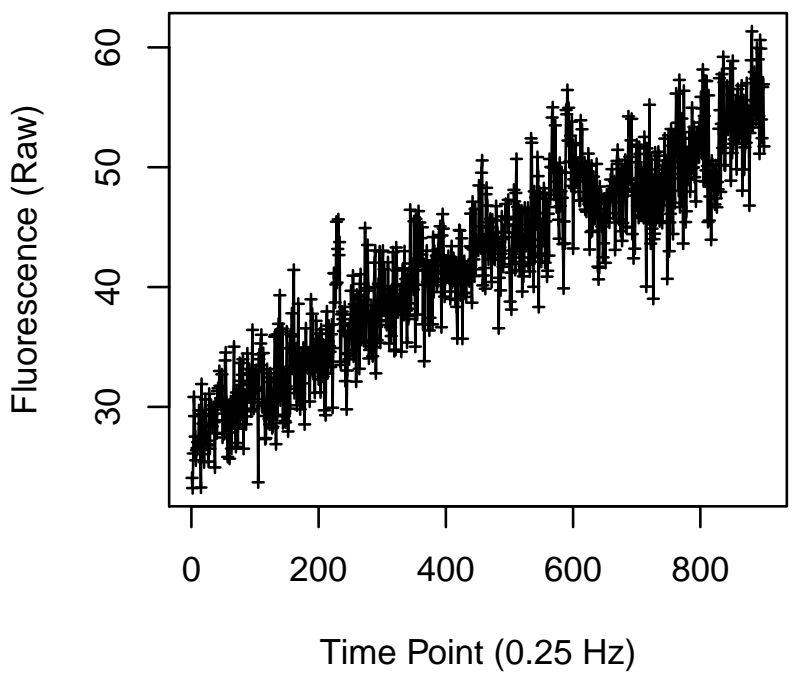

Cell 459

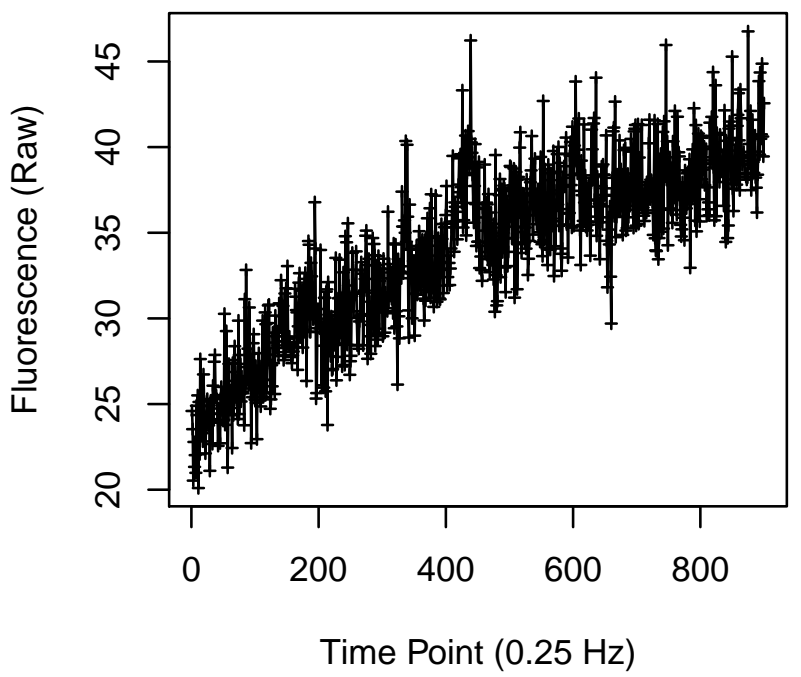

Cell 458

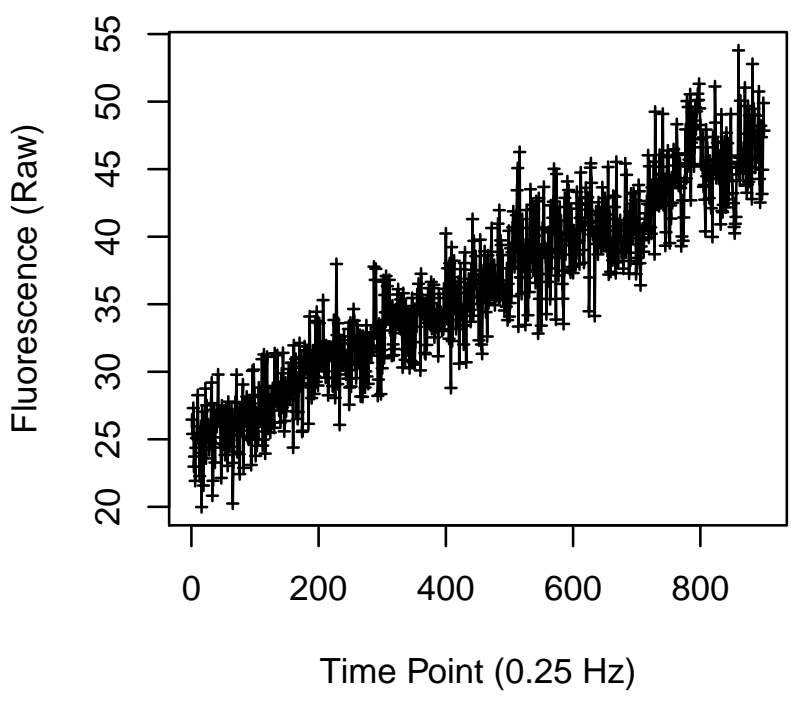

Cell 460

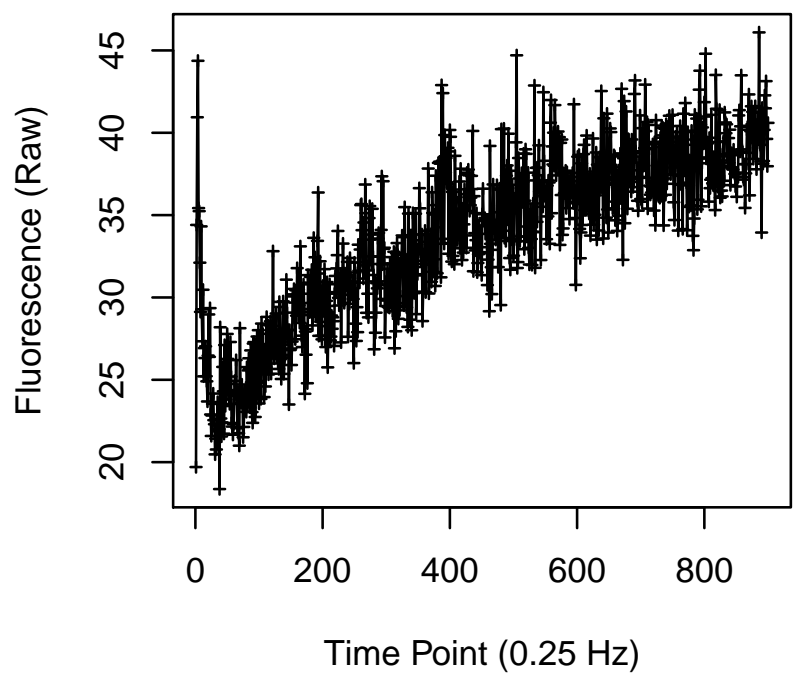




\section{Cell 465}

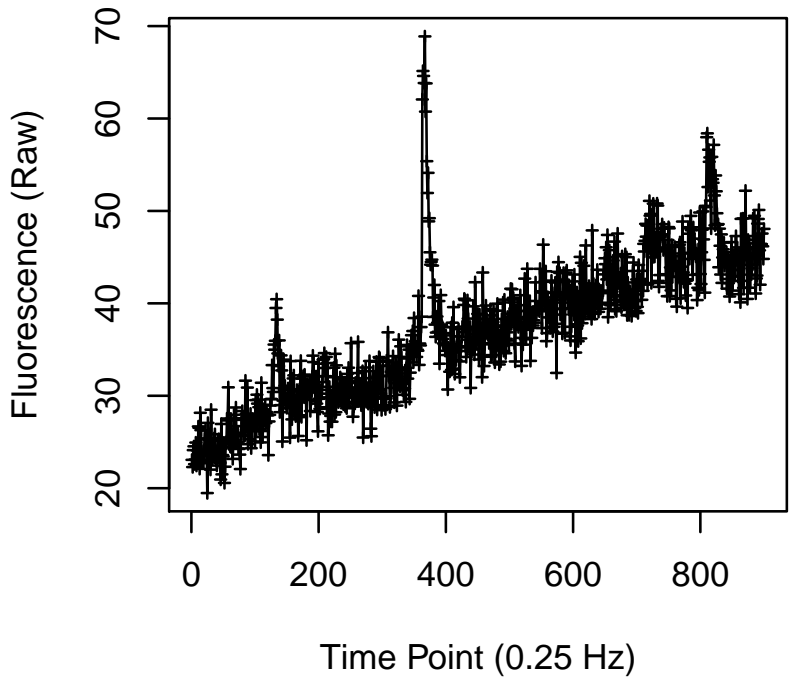

Cell 467

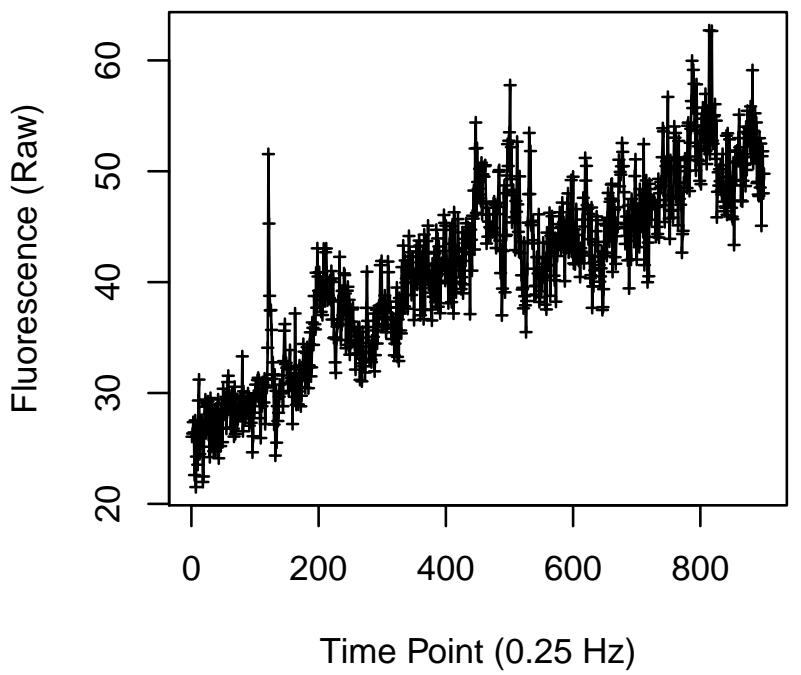

Cell 466

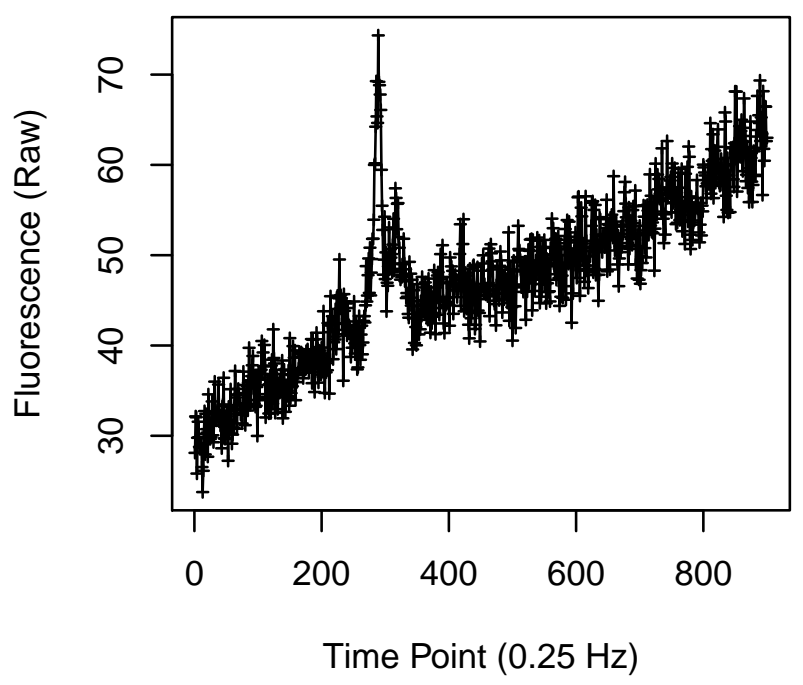

Cell 468

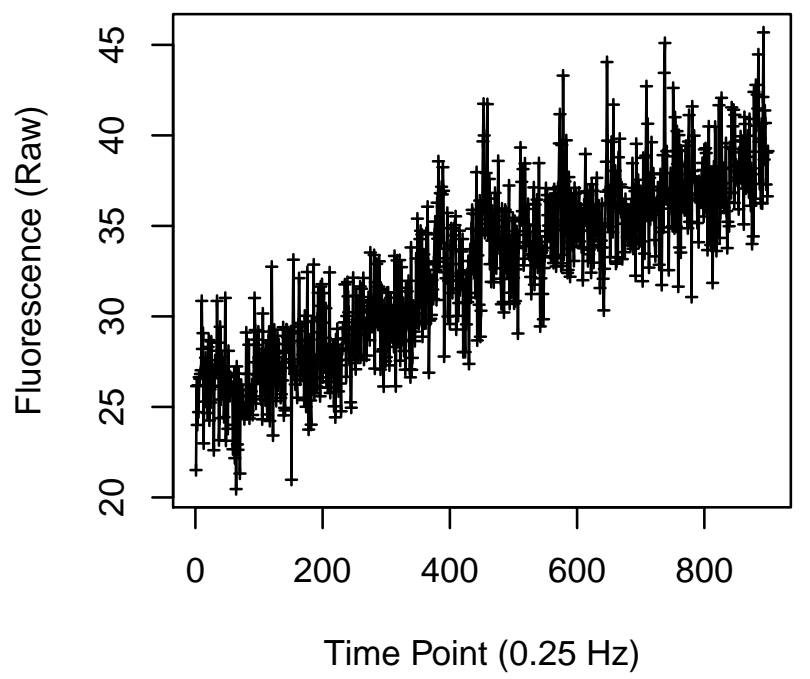




\section{Cell 469}

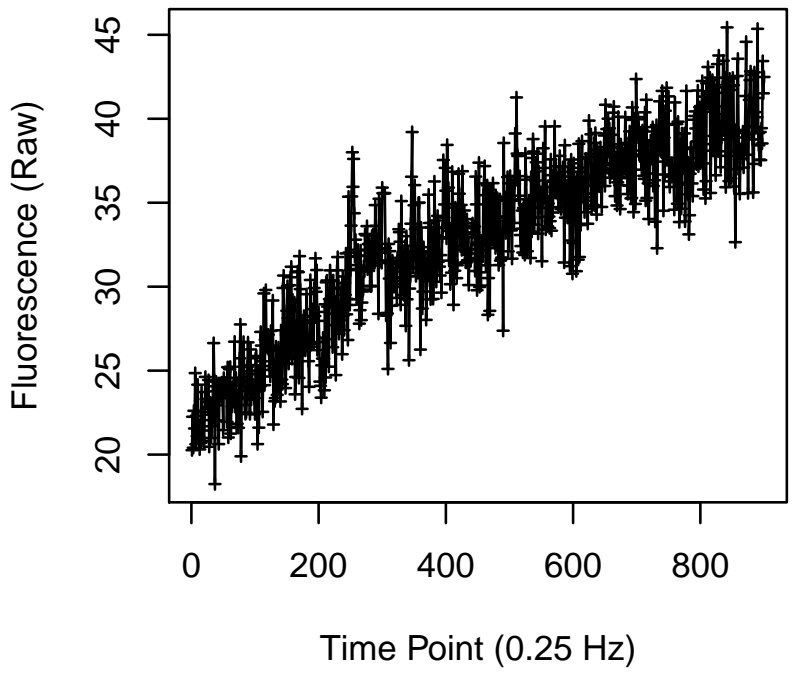

Cell 471

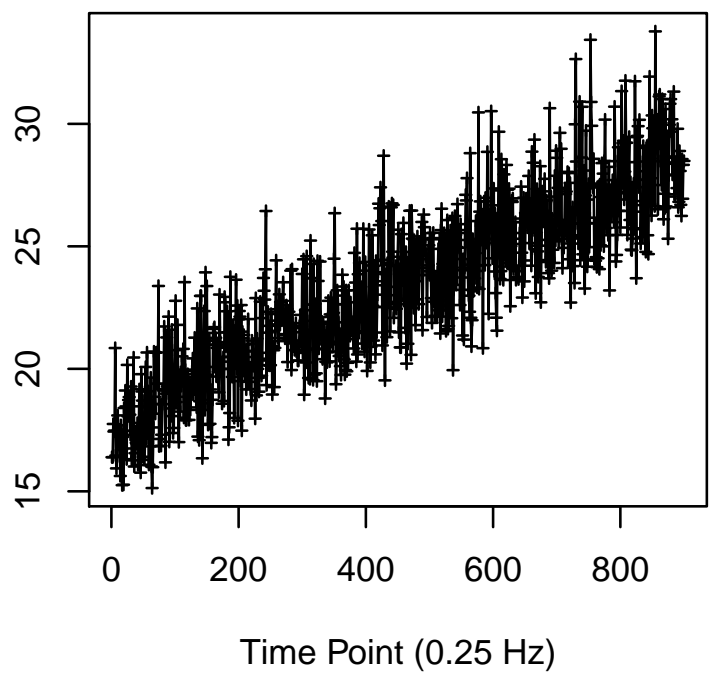

Cell 470

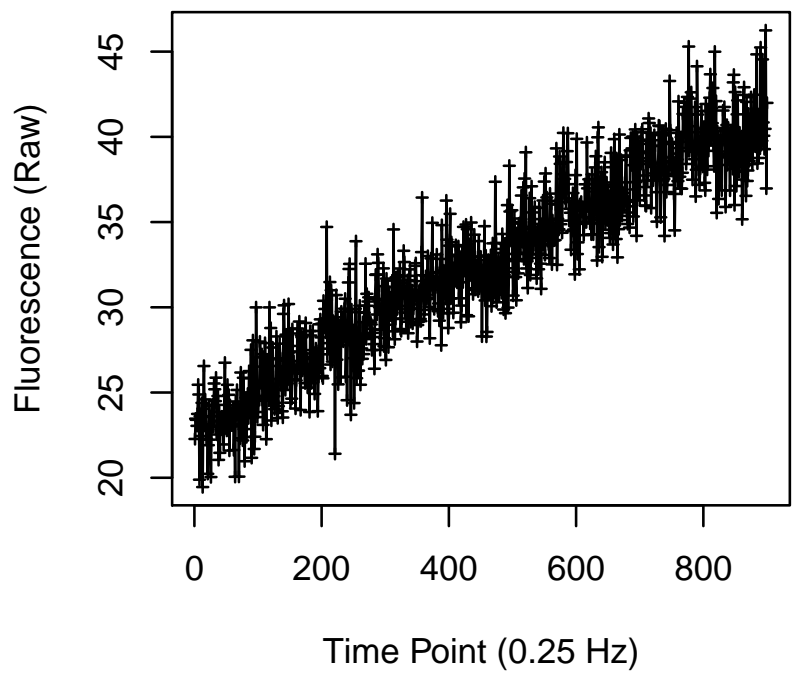

Cell 472

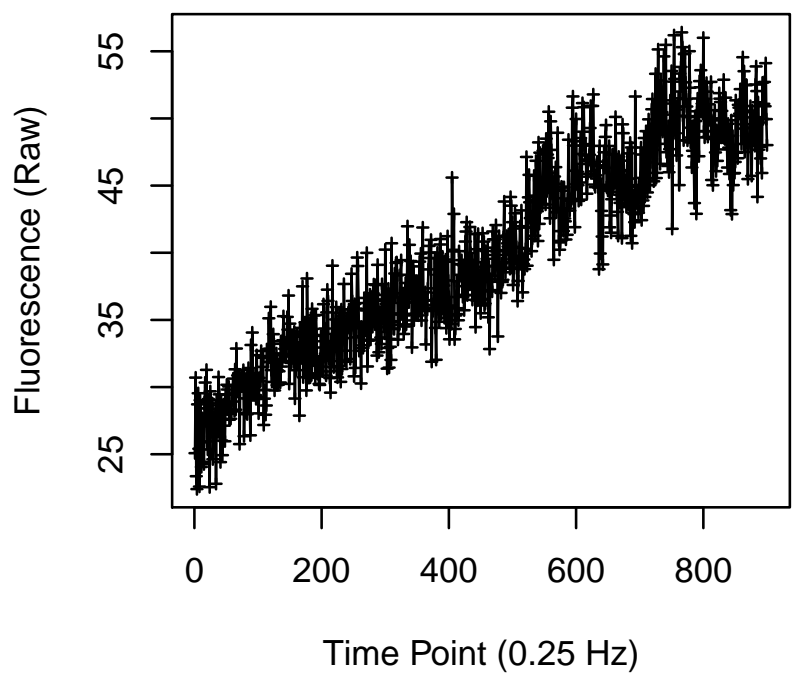




\section{Cell 485}

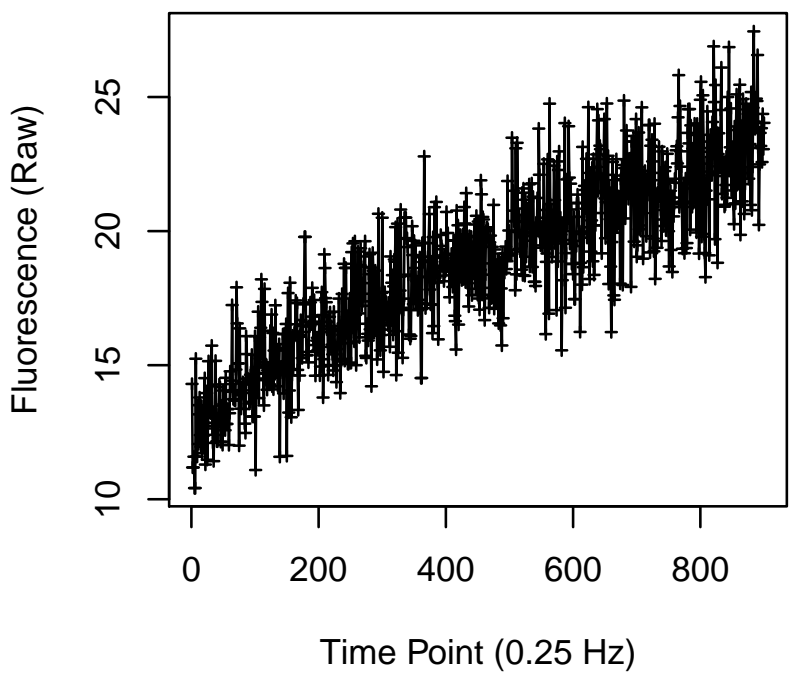

Cell 487

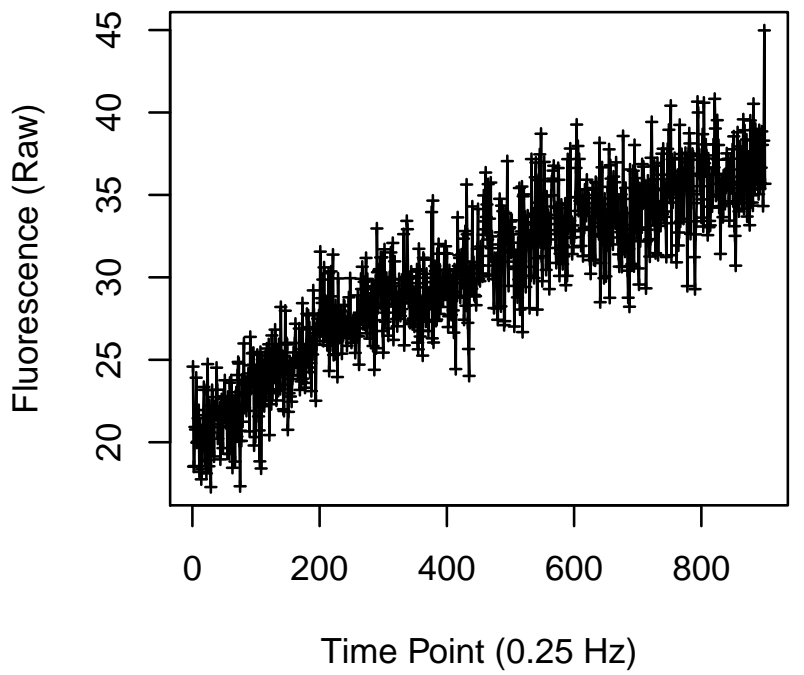

Cell 486

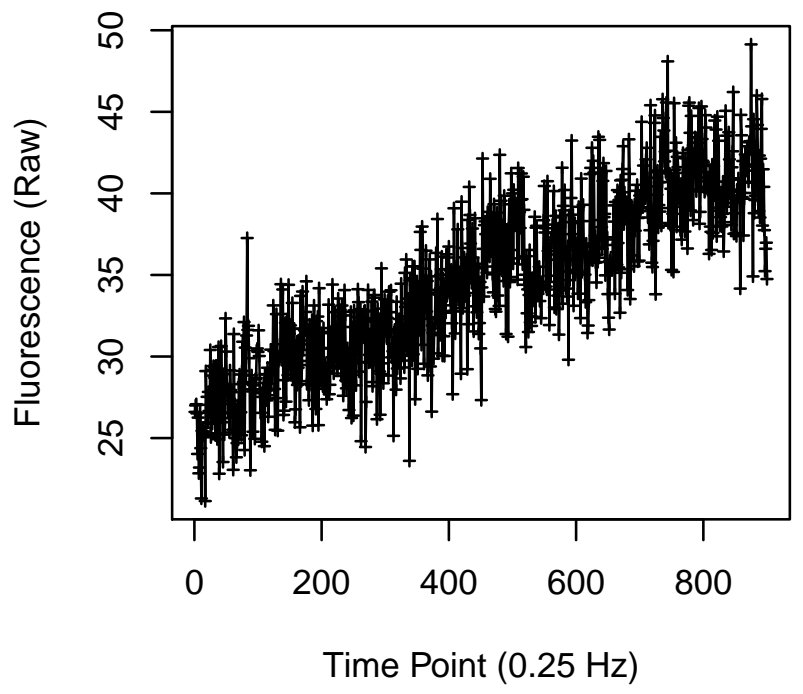

Cell 488

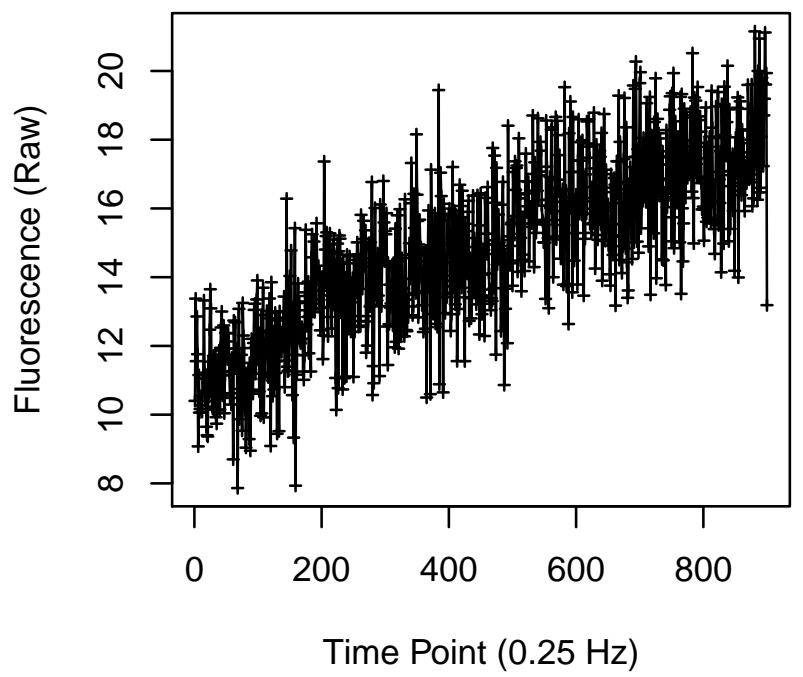


Cell 489

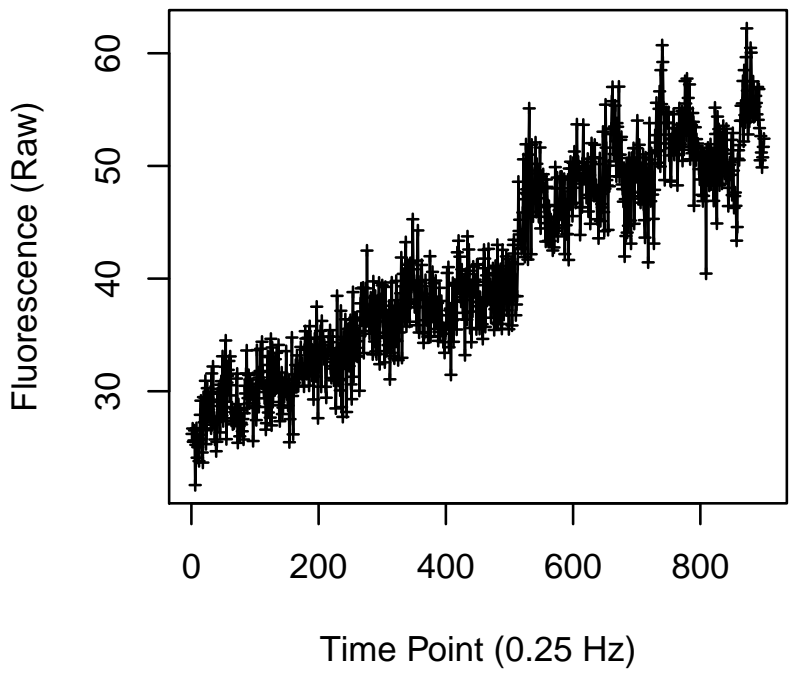

Cell 491

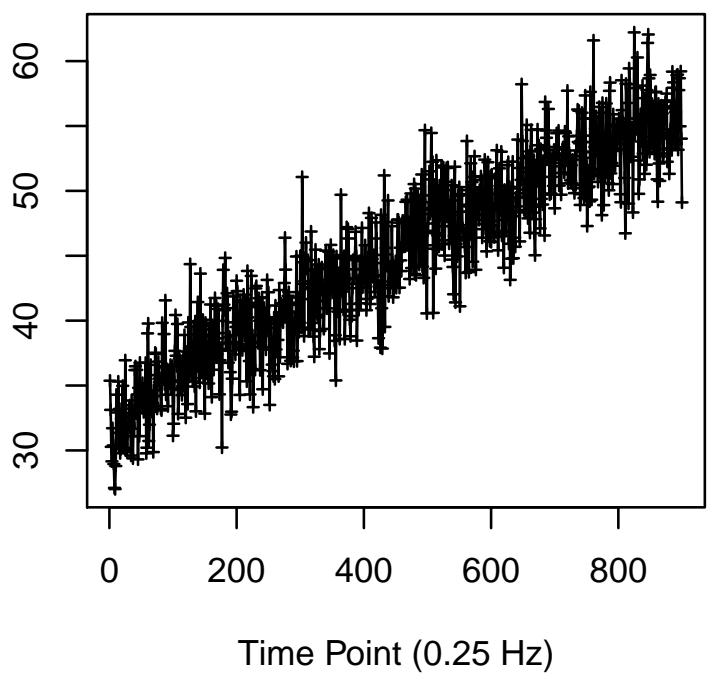

Cell 490

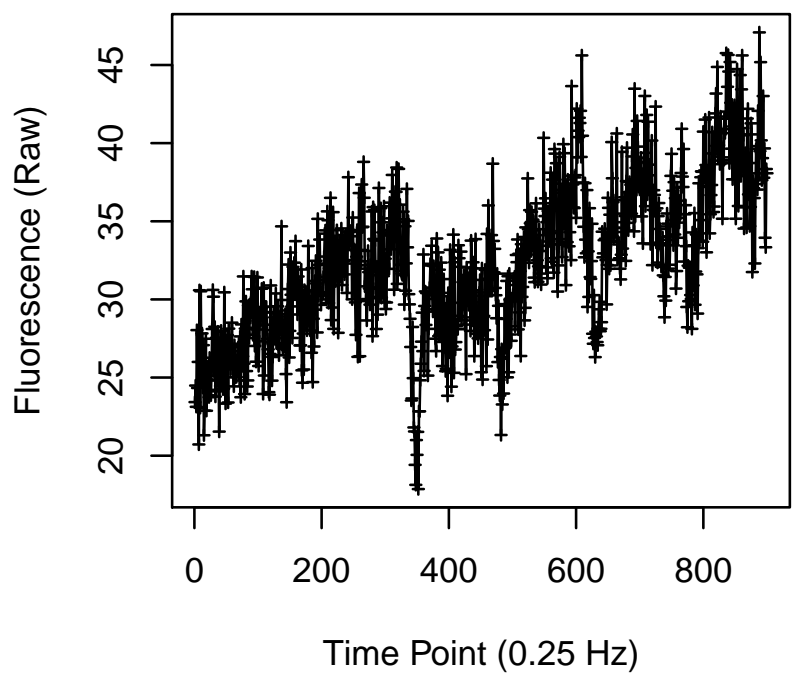

Cell 492

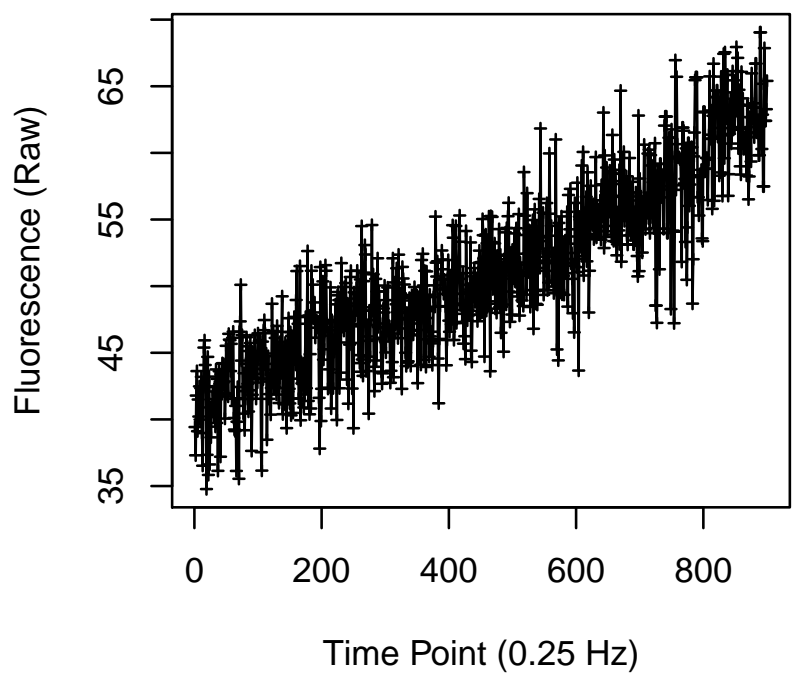




\section{Cell 493}

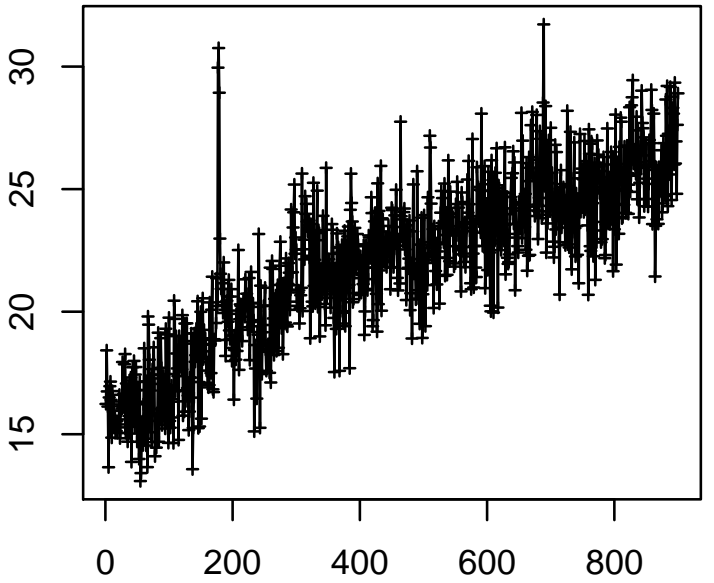

Time Point $(0.25 \mathrm{~Hz})$

Cell 495

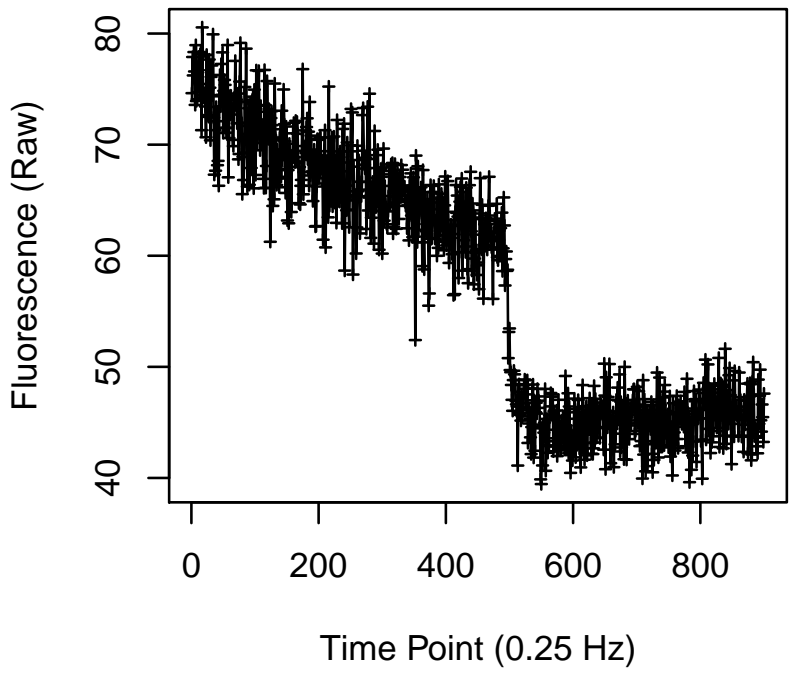

Cell 494

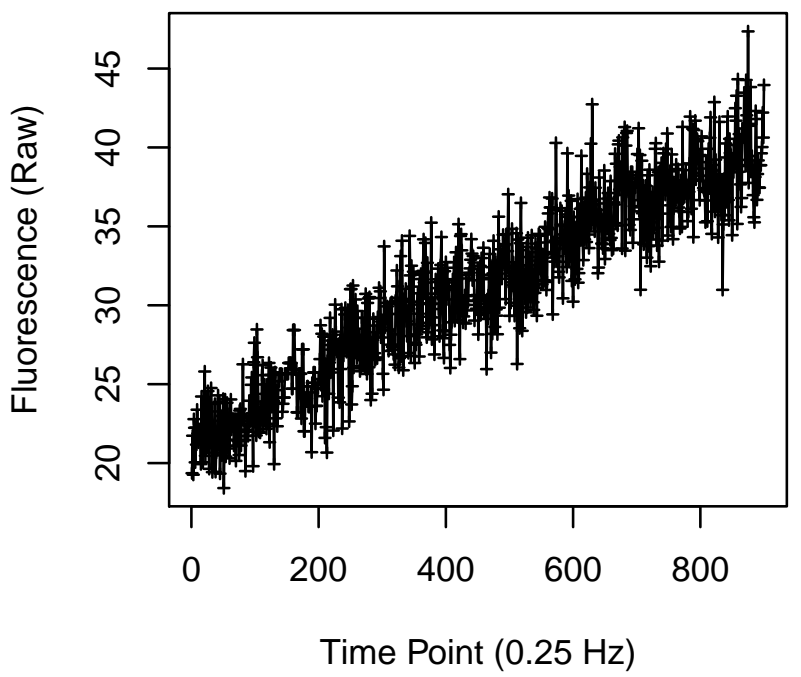

Cell 496

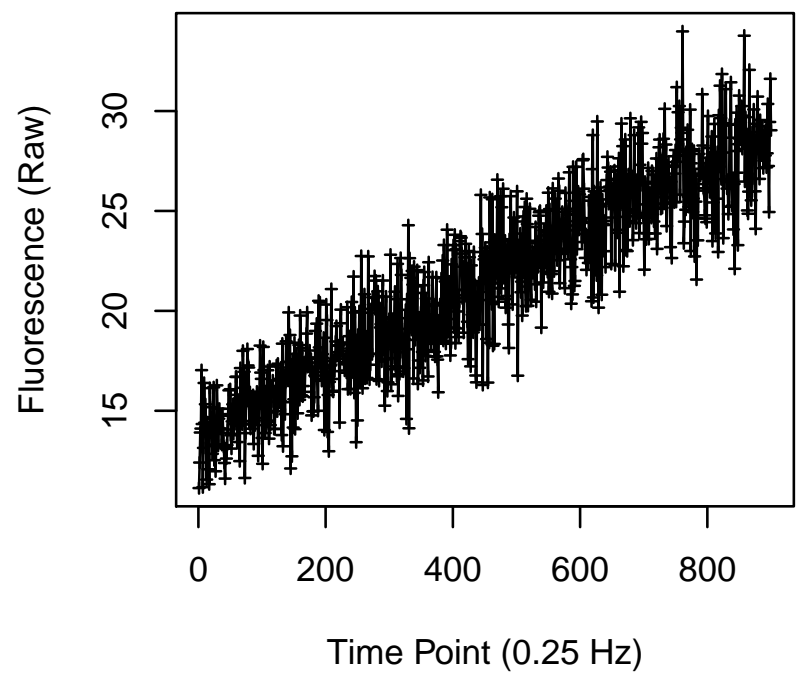


Cell 505

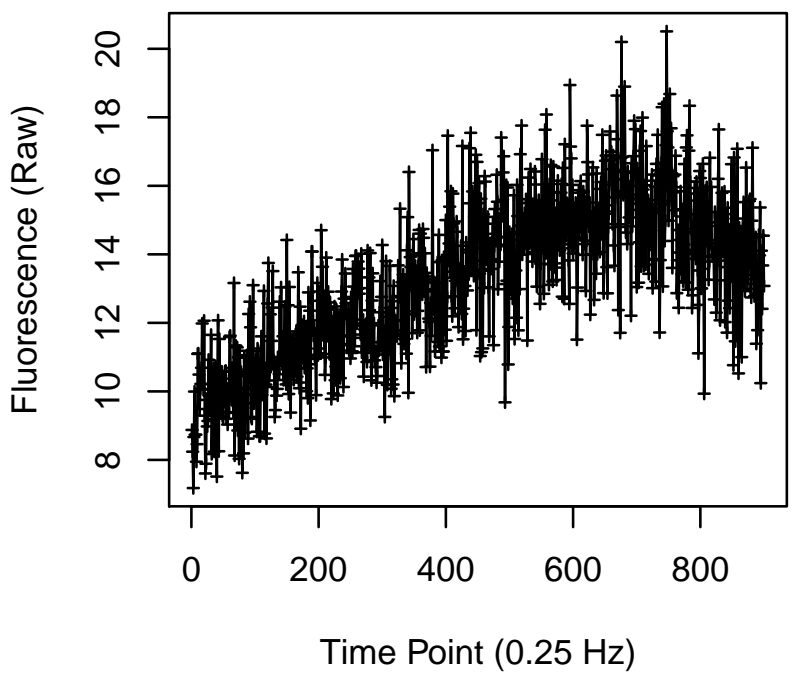

Cell 507

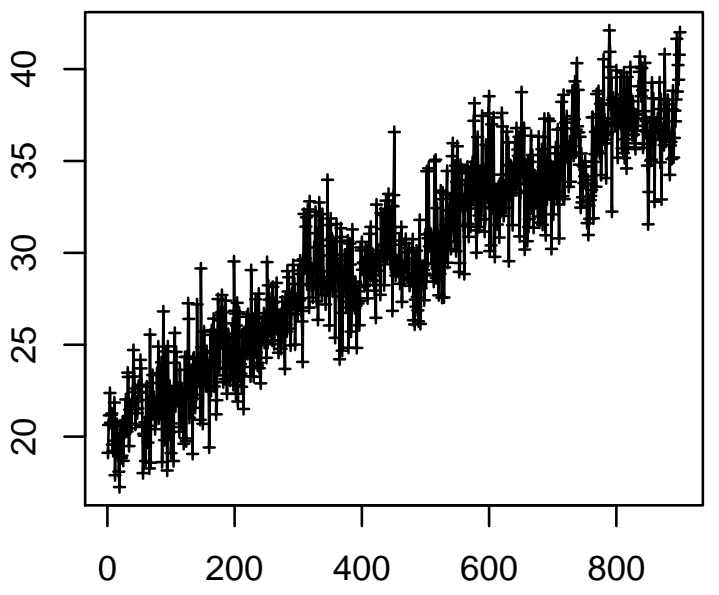

Time Point $(0.25 \mathrm{~Hz})$
Cell 506

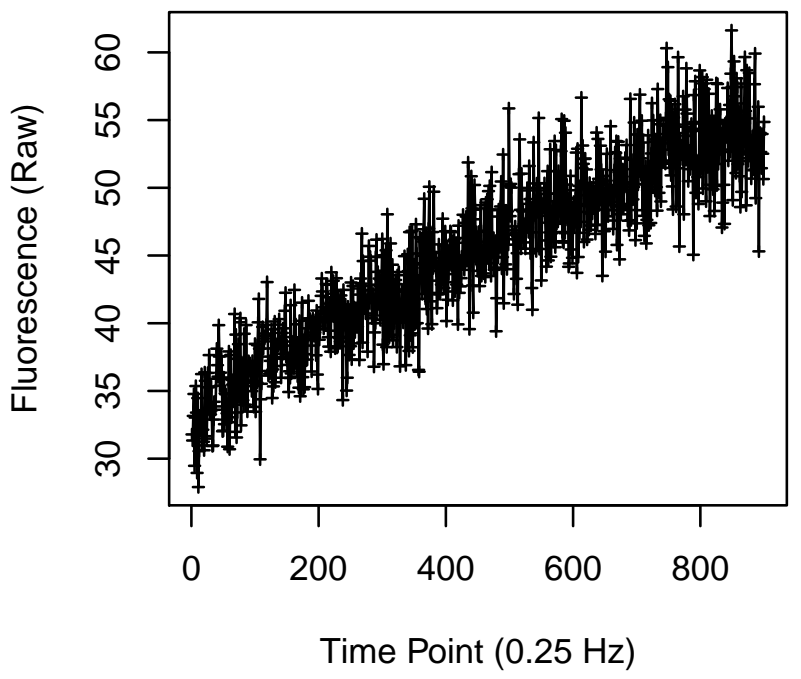

Cell 508

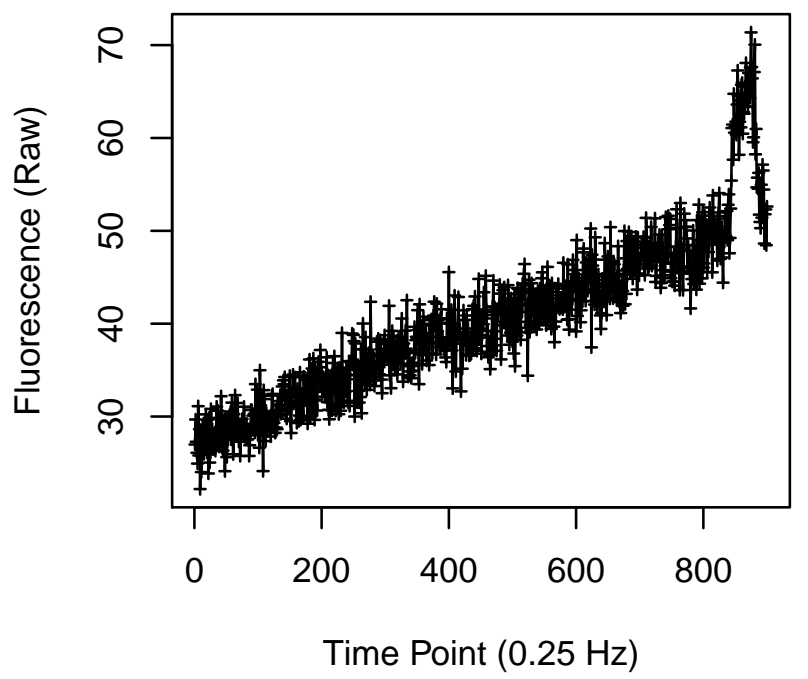




\section{Cell 513}

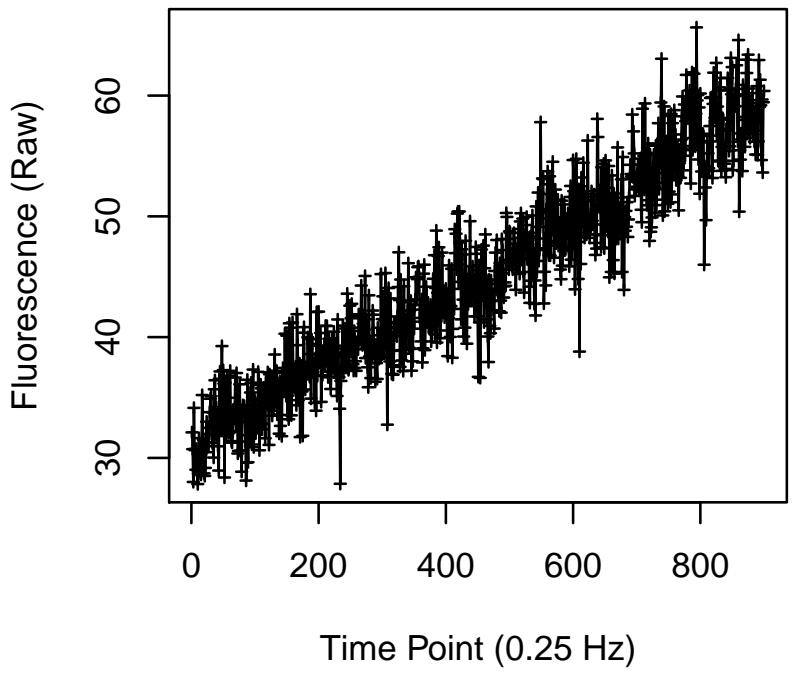

Cell 515

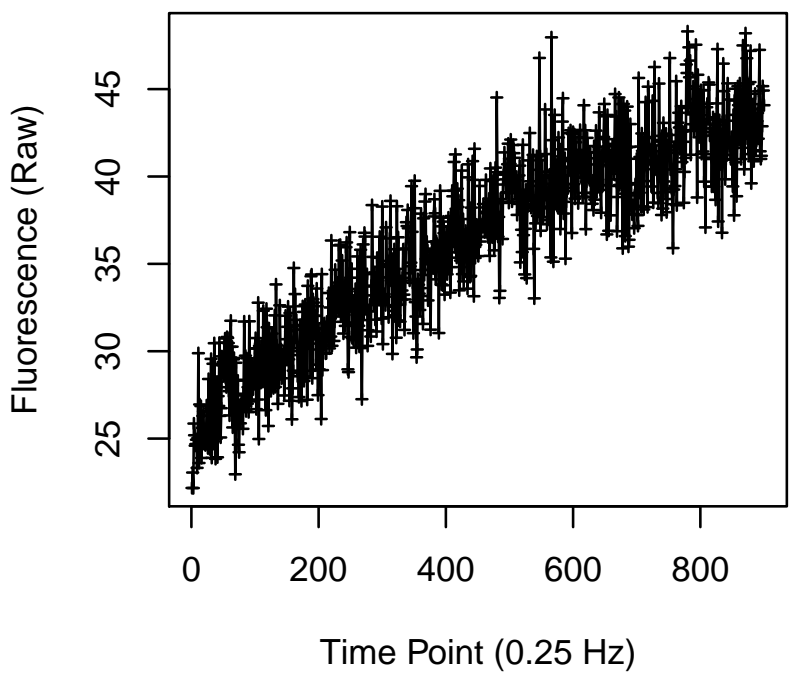

Cell 514

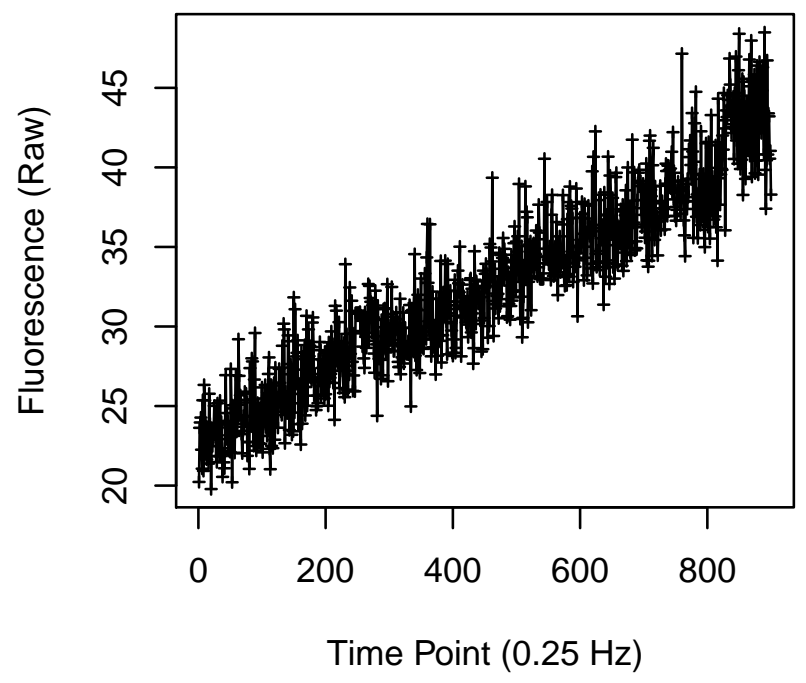

Cell 516

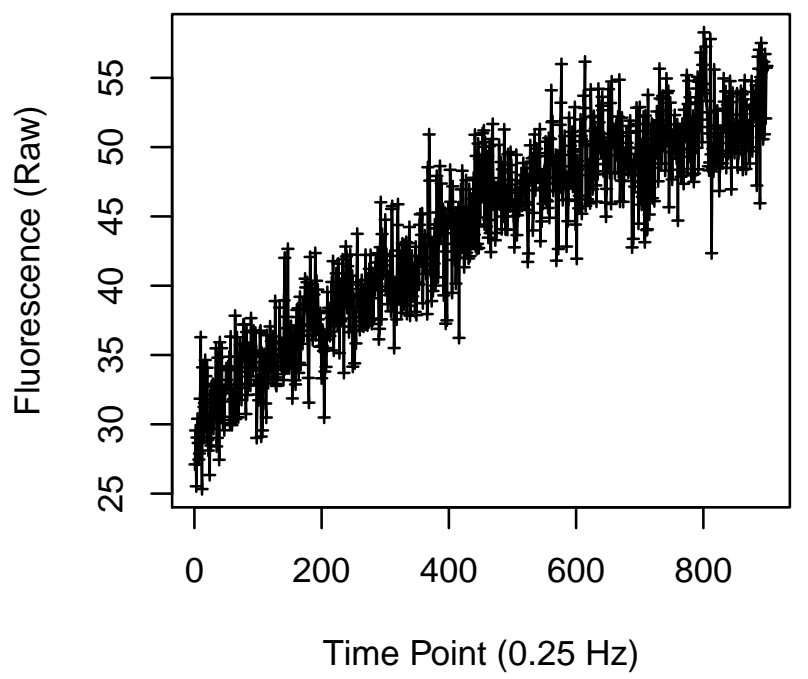


Cell 517

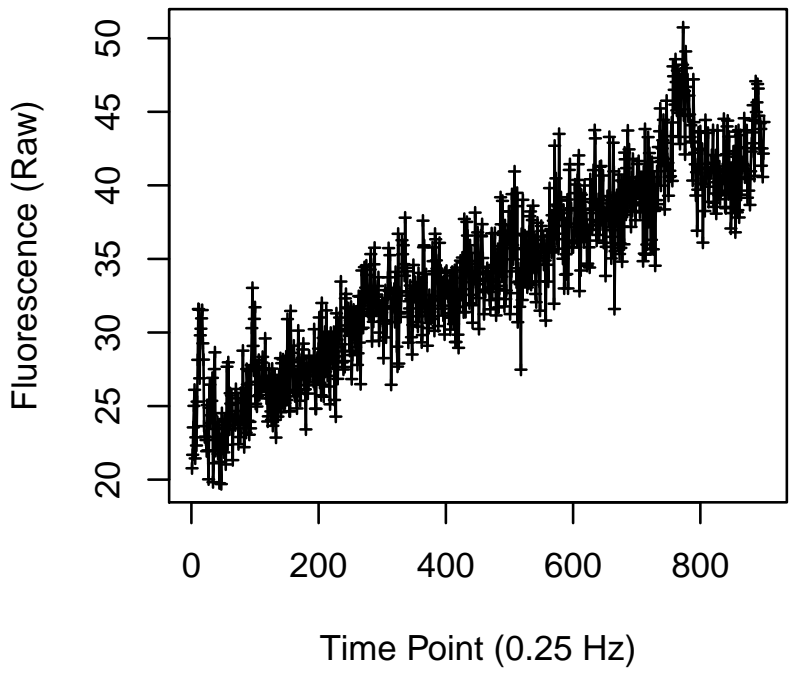

Cell 519

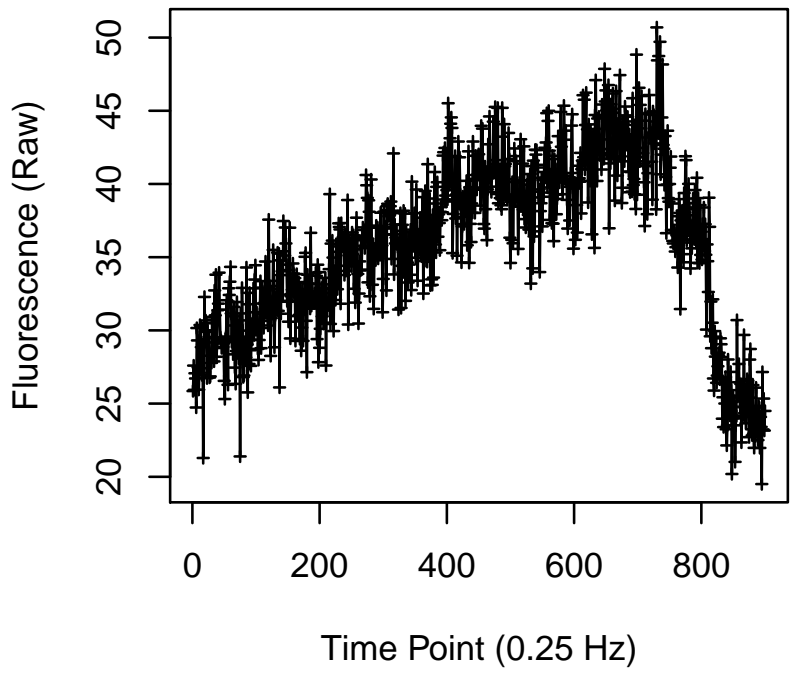

Cell 518

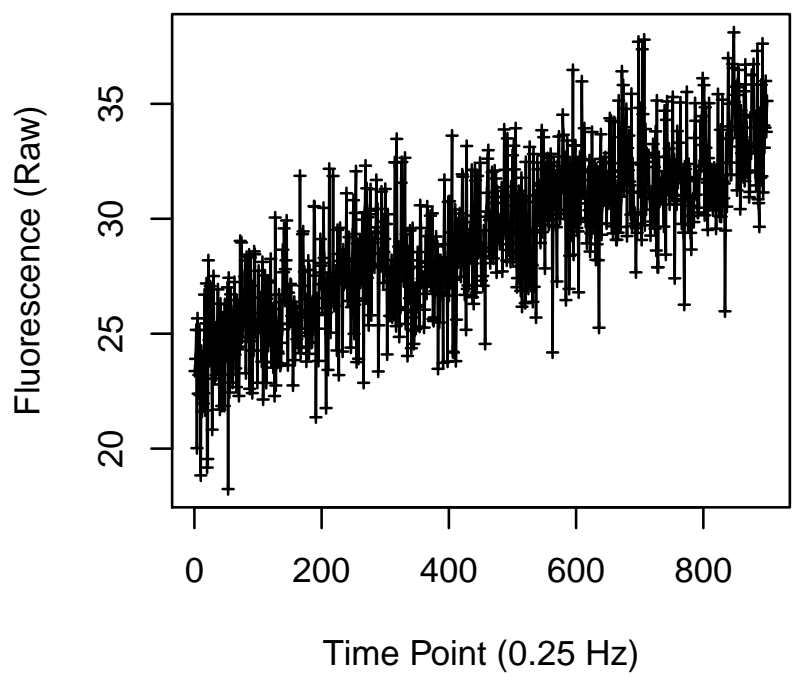

Cell 520

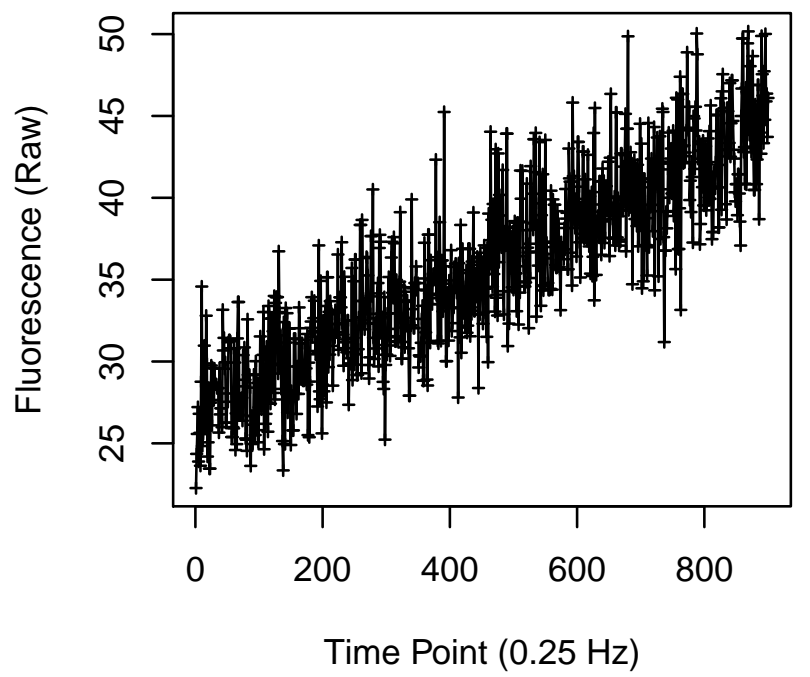


Cell 521

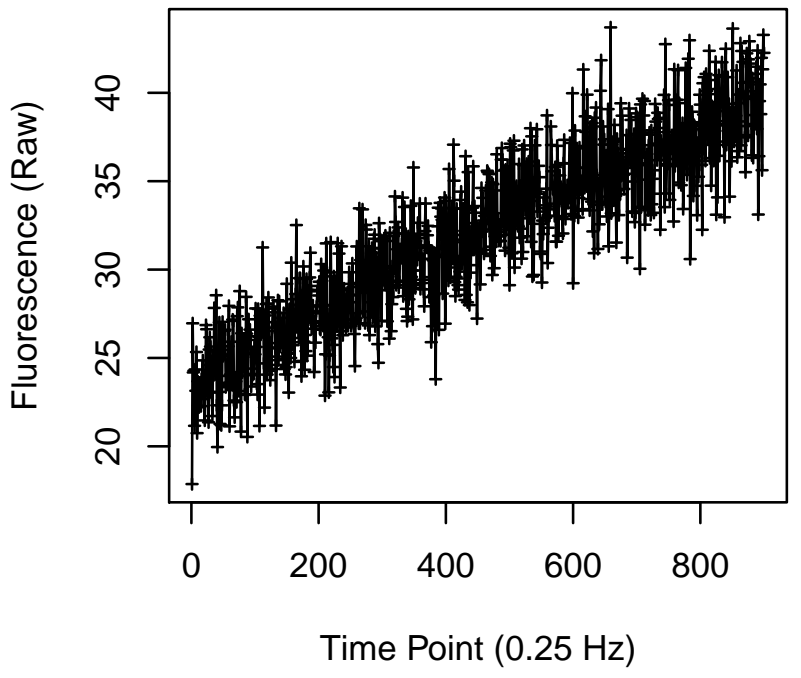

Cell 523

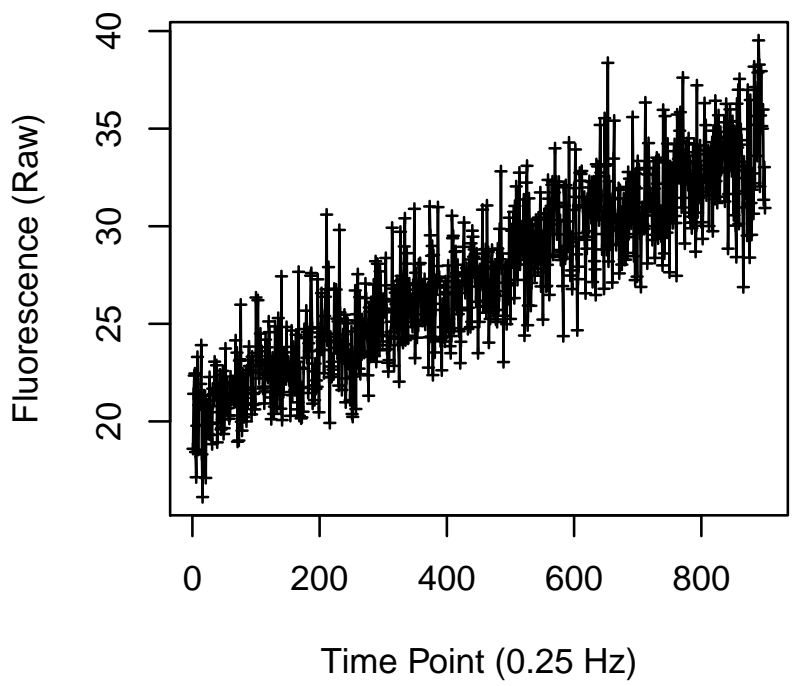

Cell 522

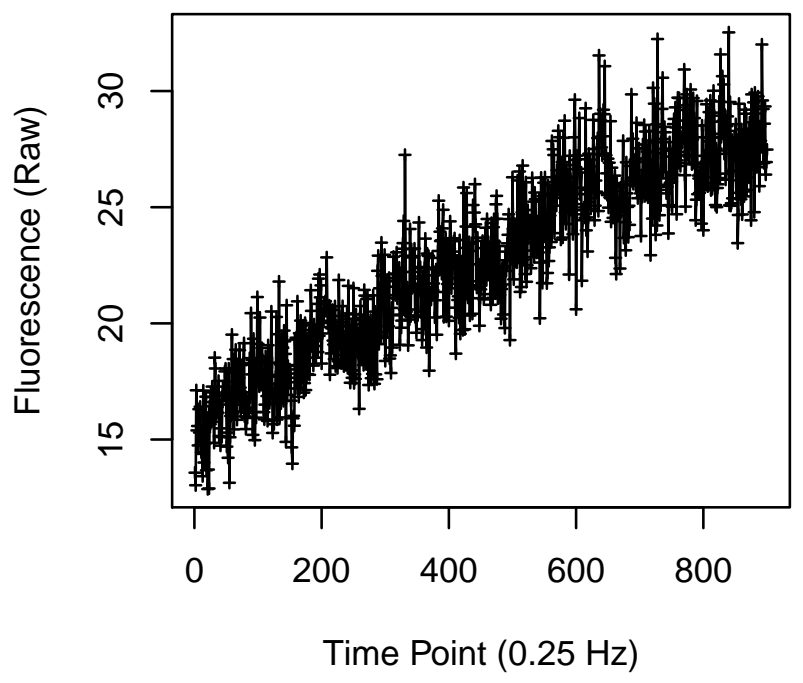

Cell 524

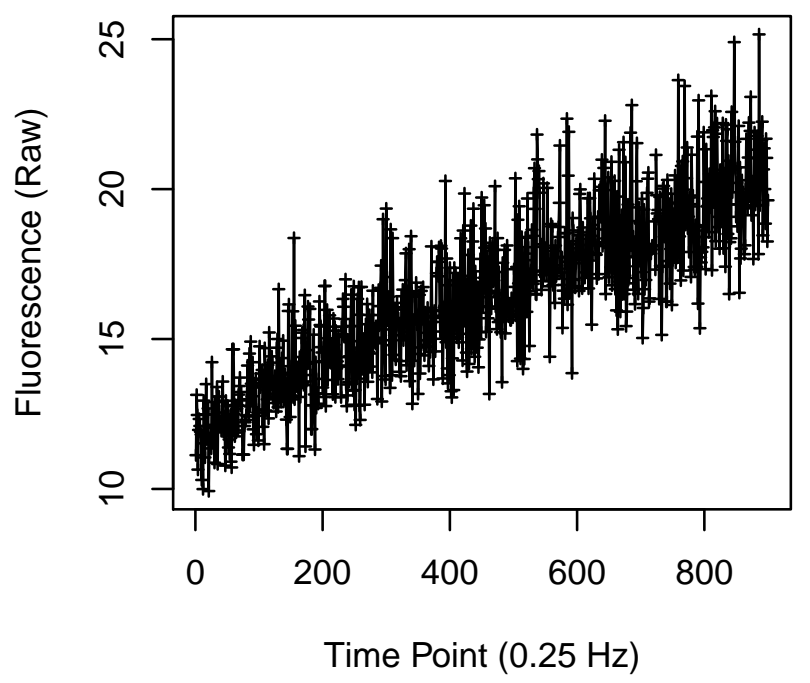


Cell 525

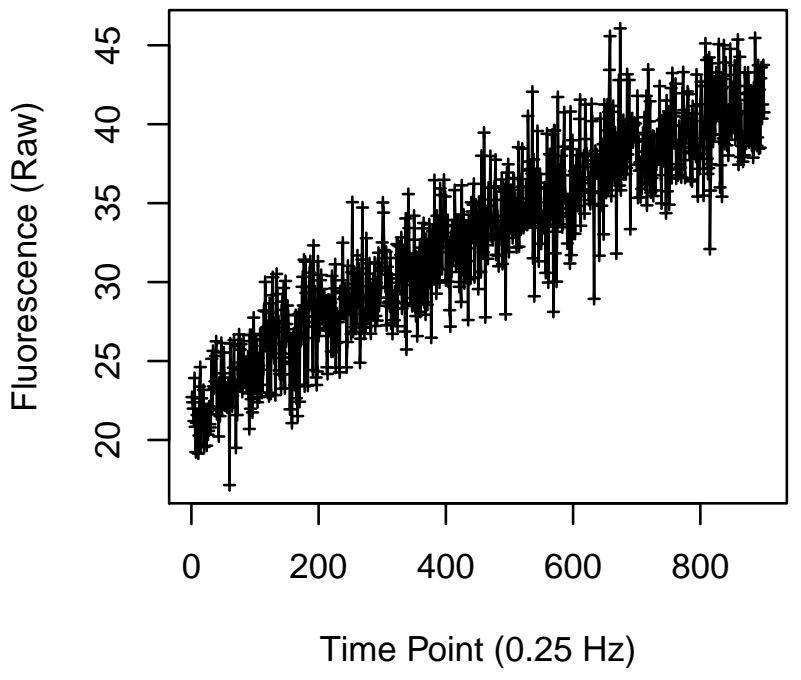

Cell 527

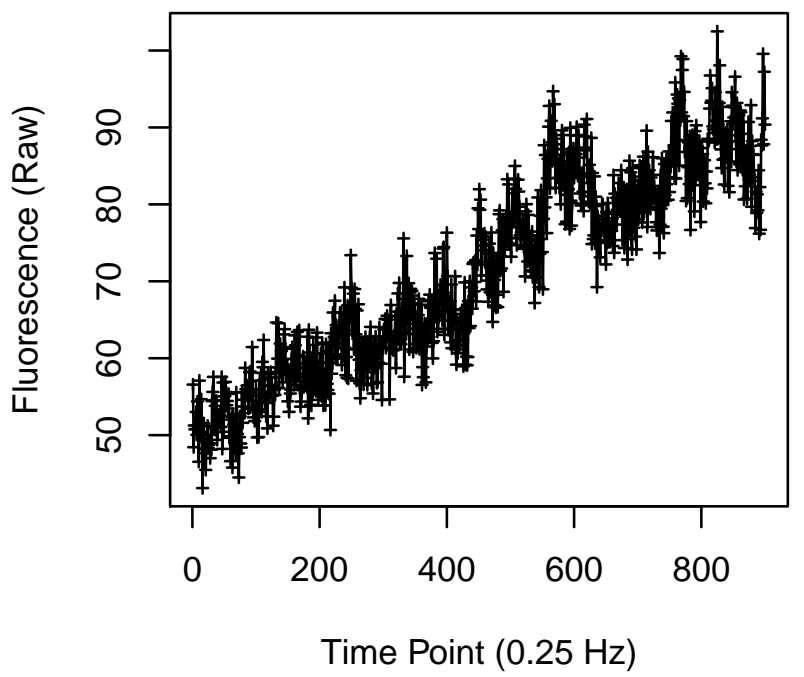

Cell 526

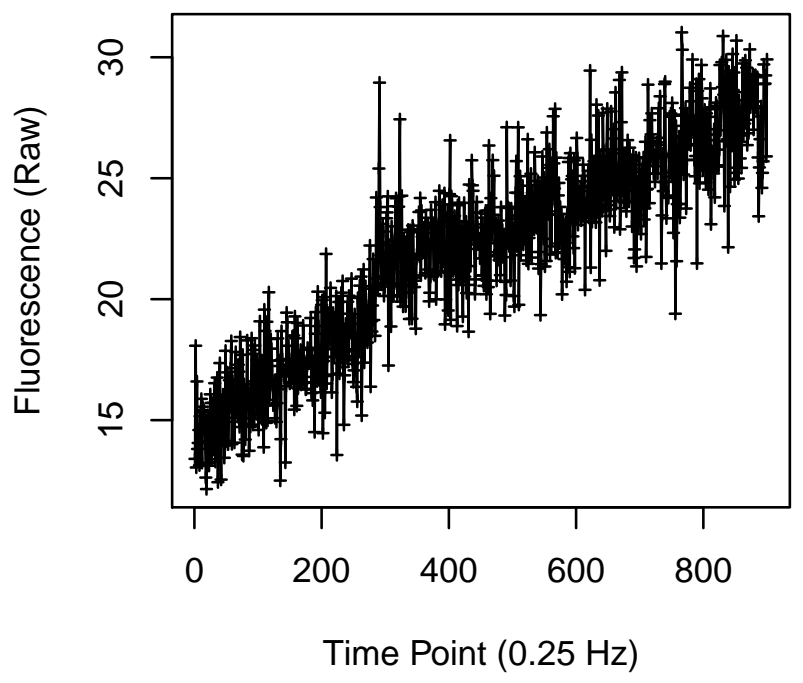

Cell 528

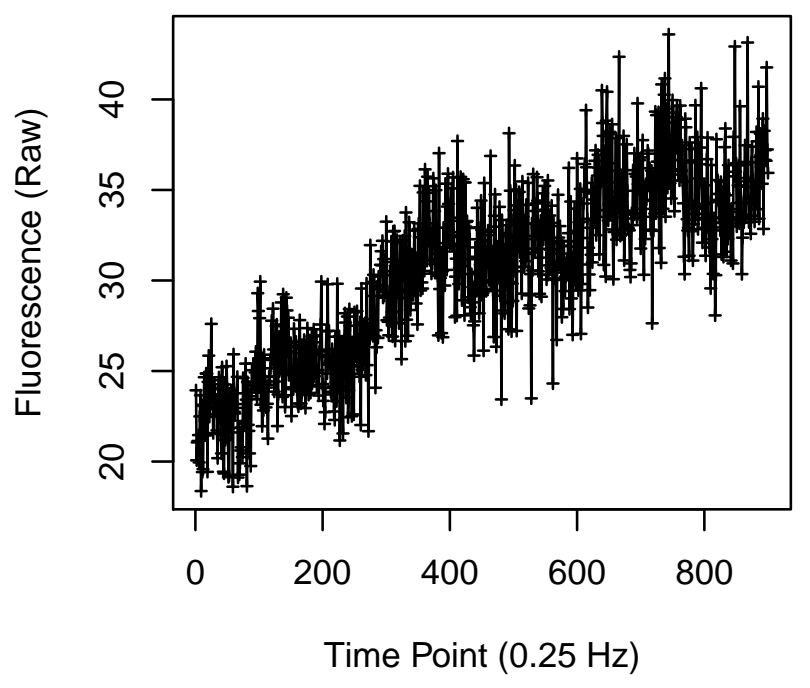


Cell 533

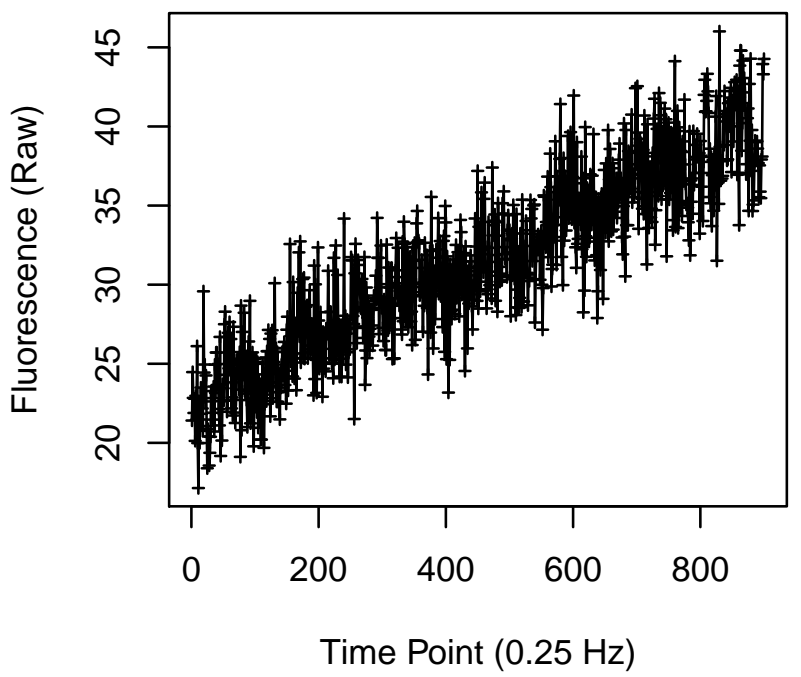

Cell 535

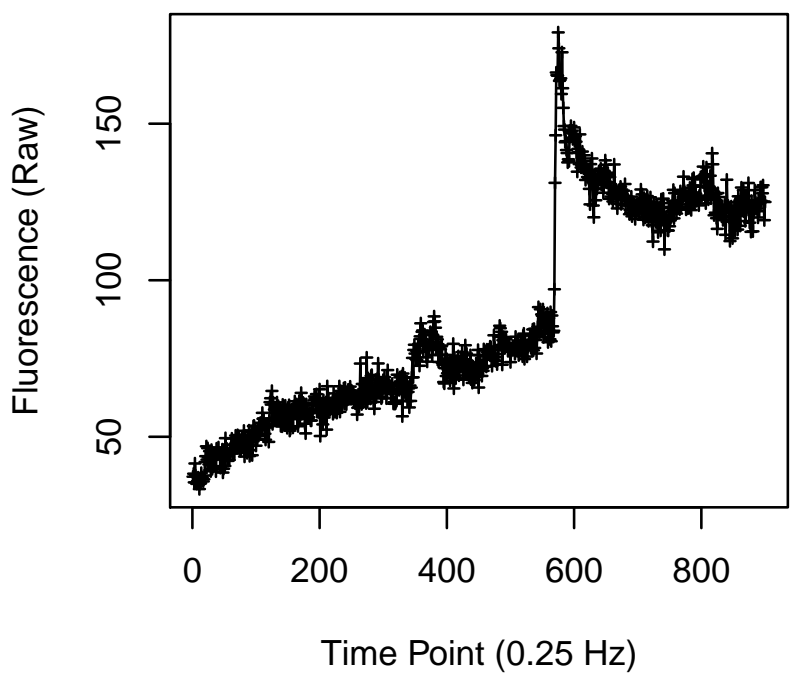

Cell 534

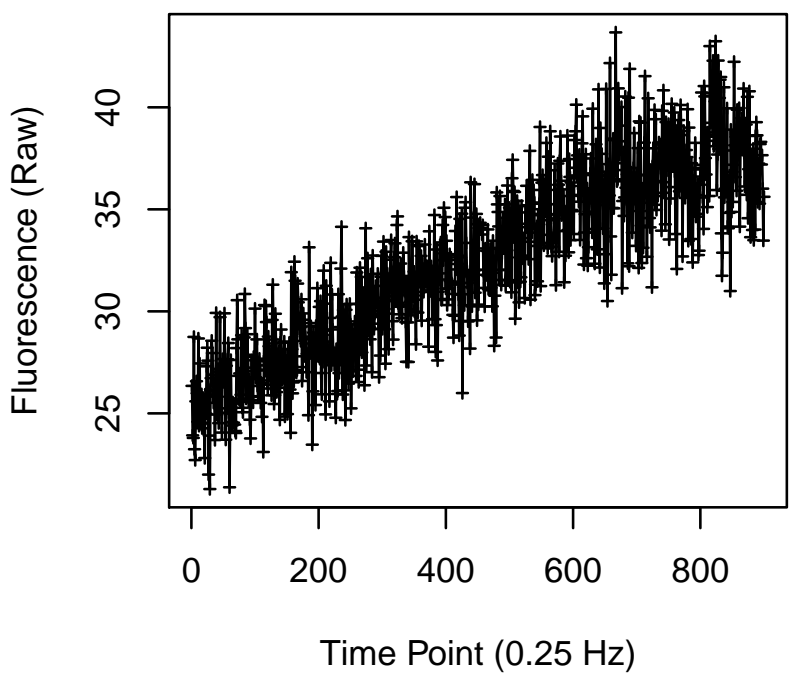

Cell 536

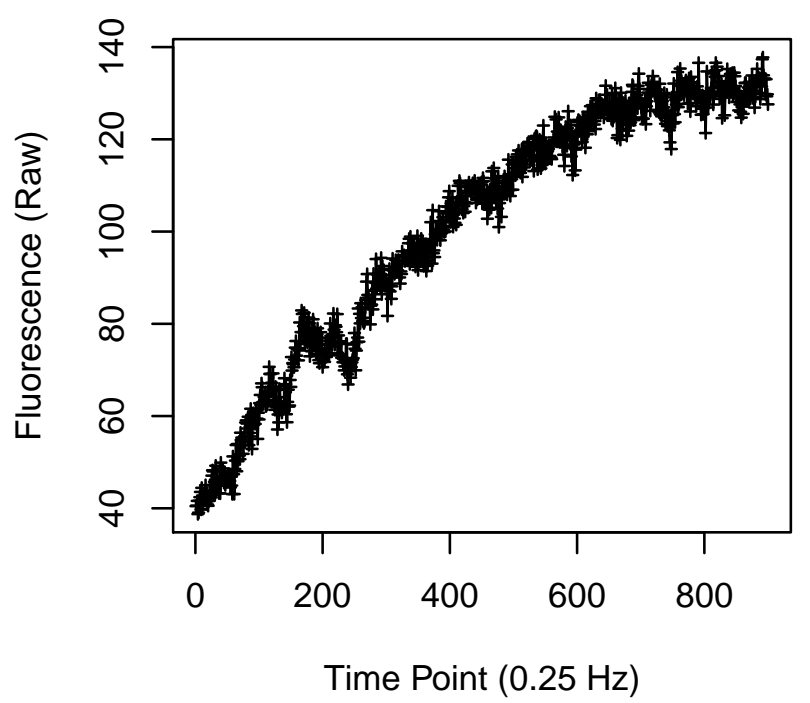


Cell 541

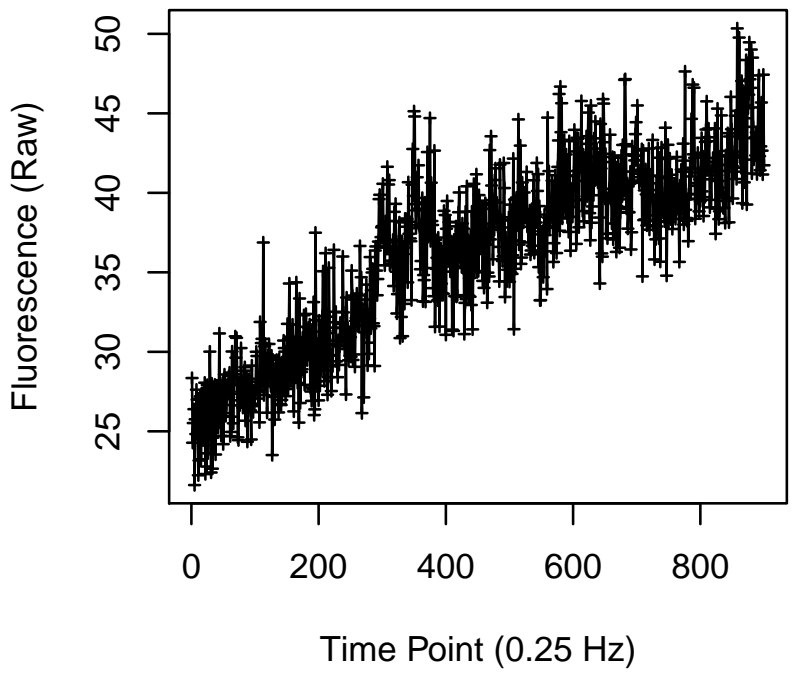

Cell 543

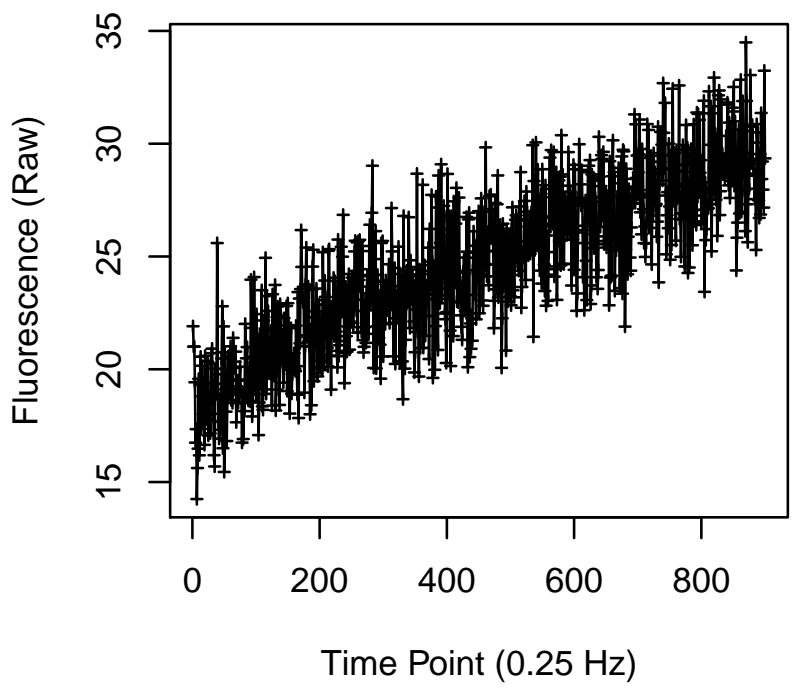

Cell 542

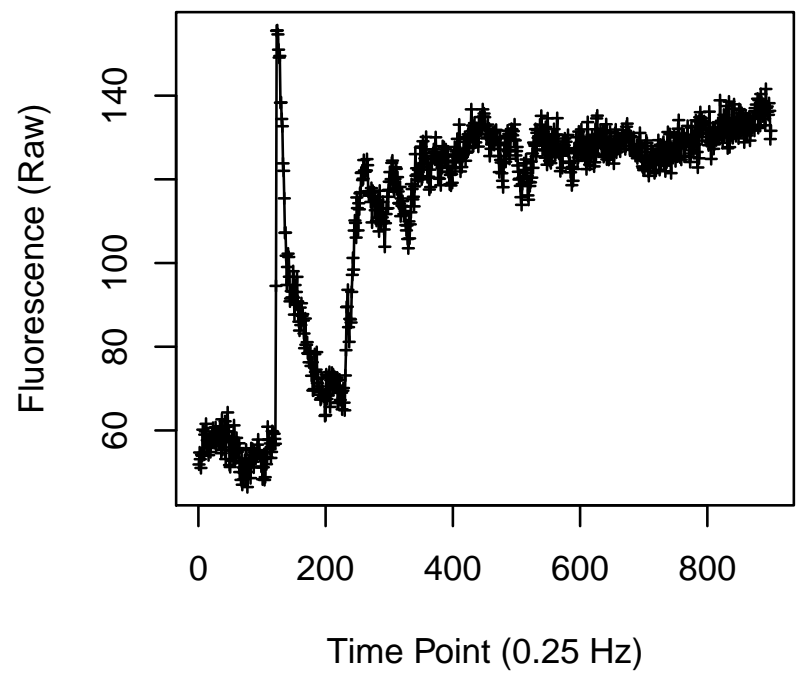

Cell 544

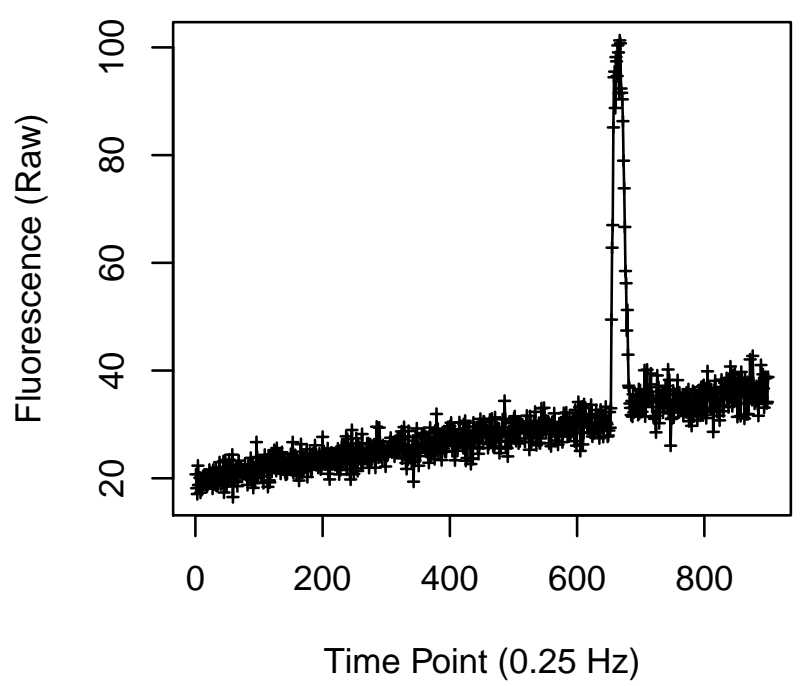




\section{Cell 545}

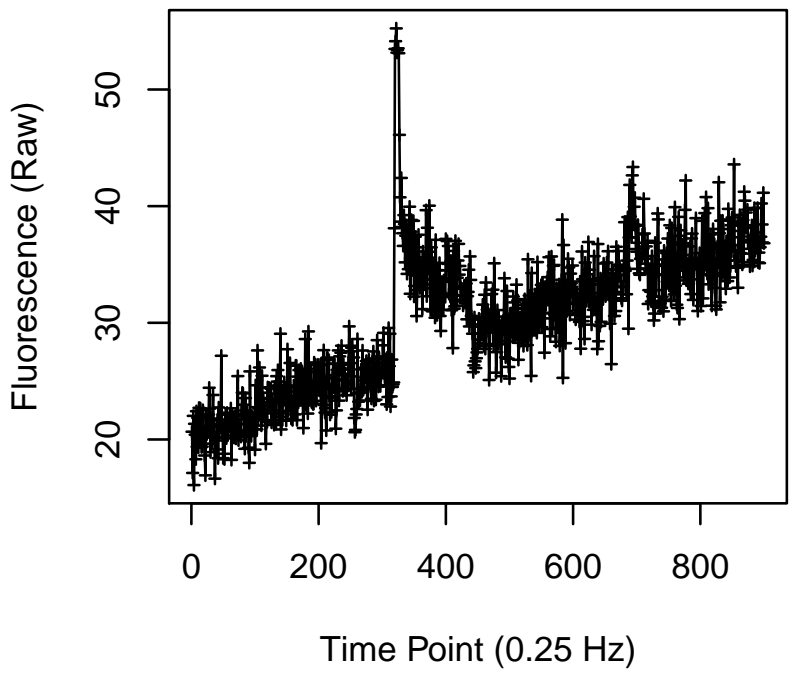

Cell 547

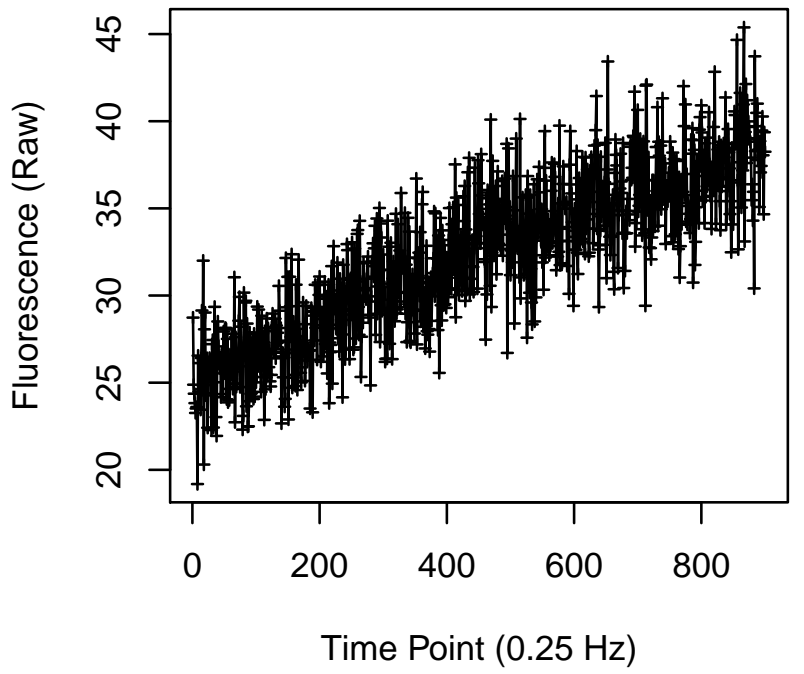

Cell 546

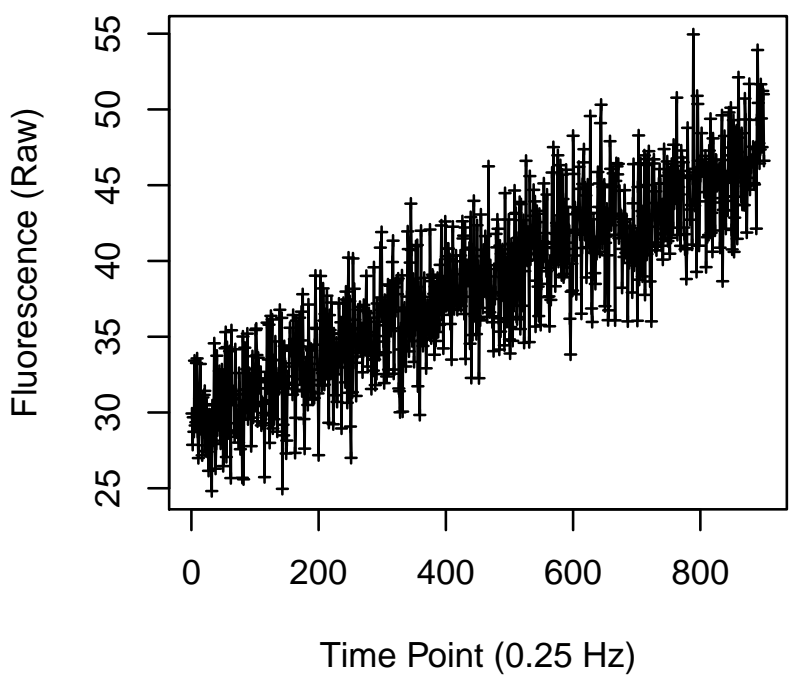

Cell 548

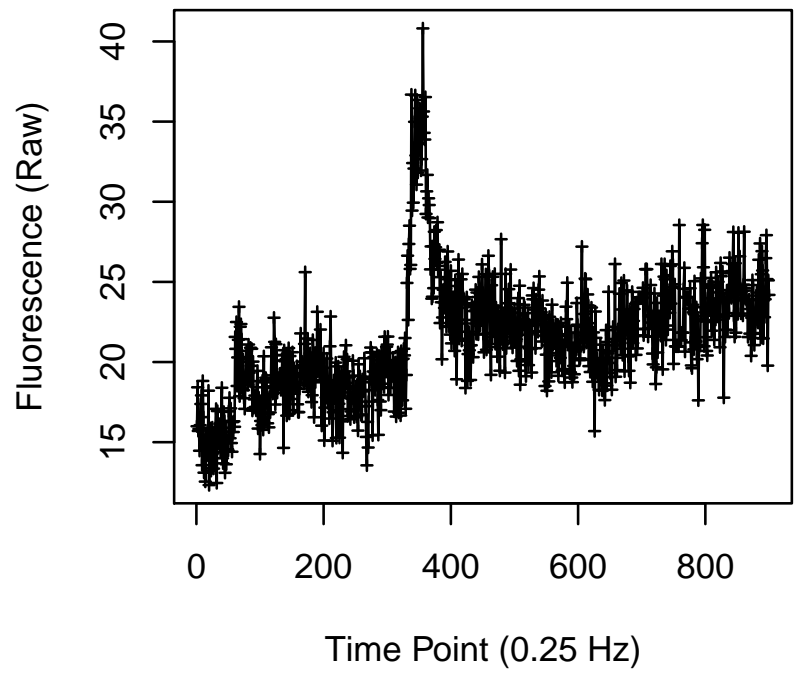


Cell 549

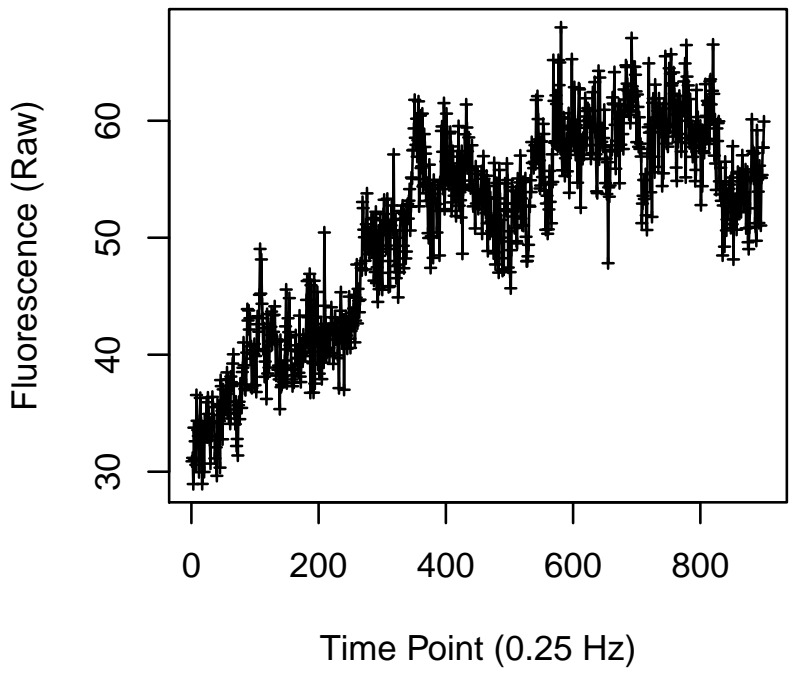

Cell 551

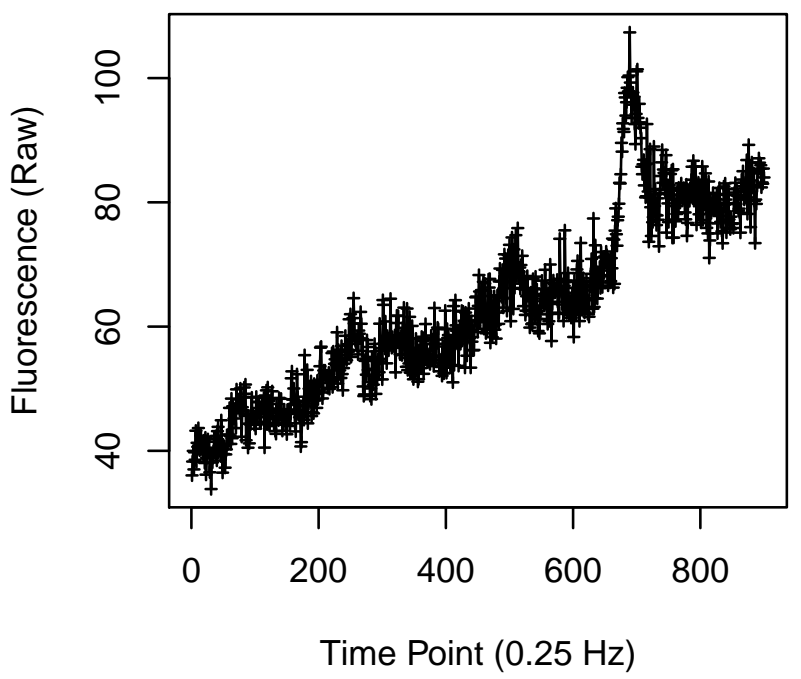

Cell 550

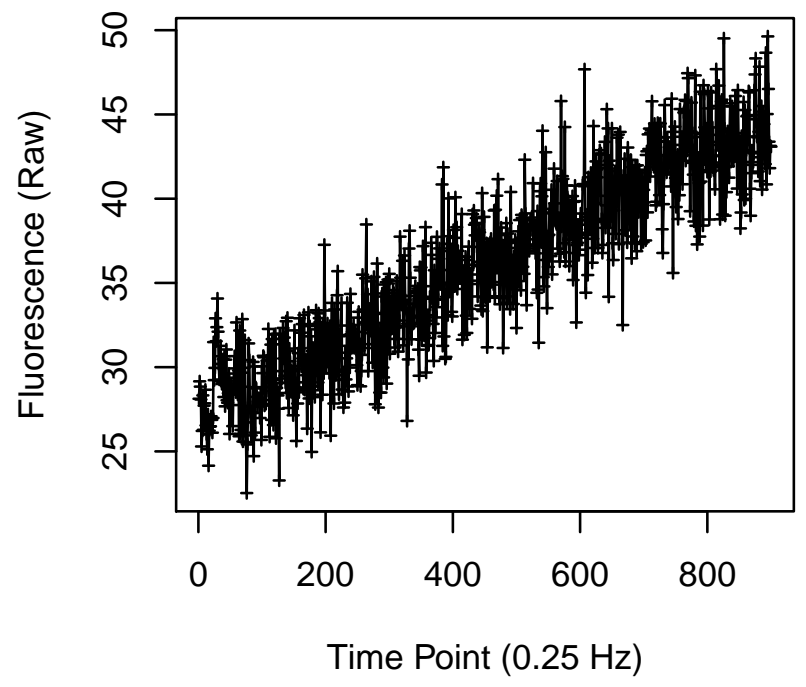

Cell 552

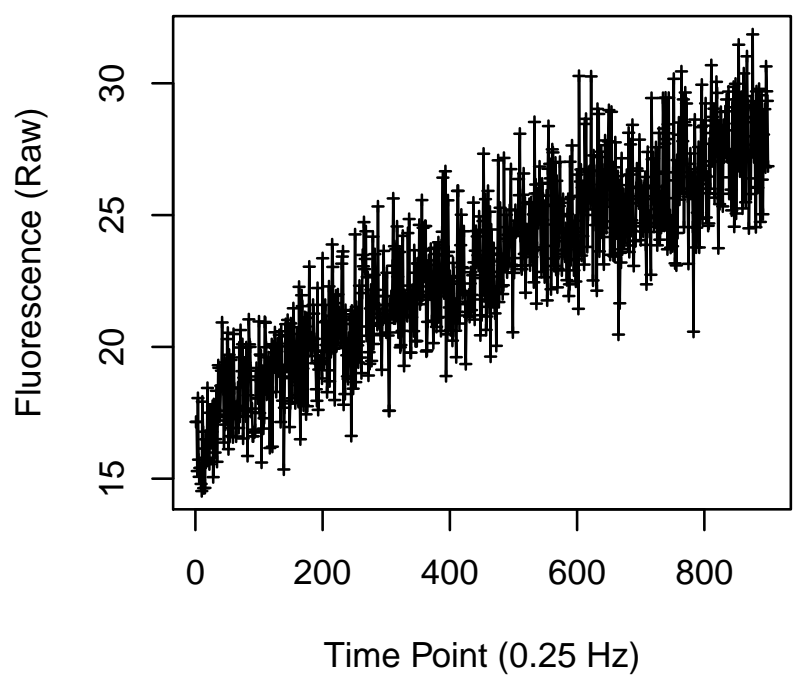


Cell 561

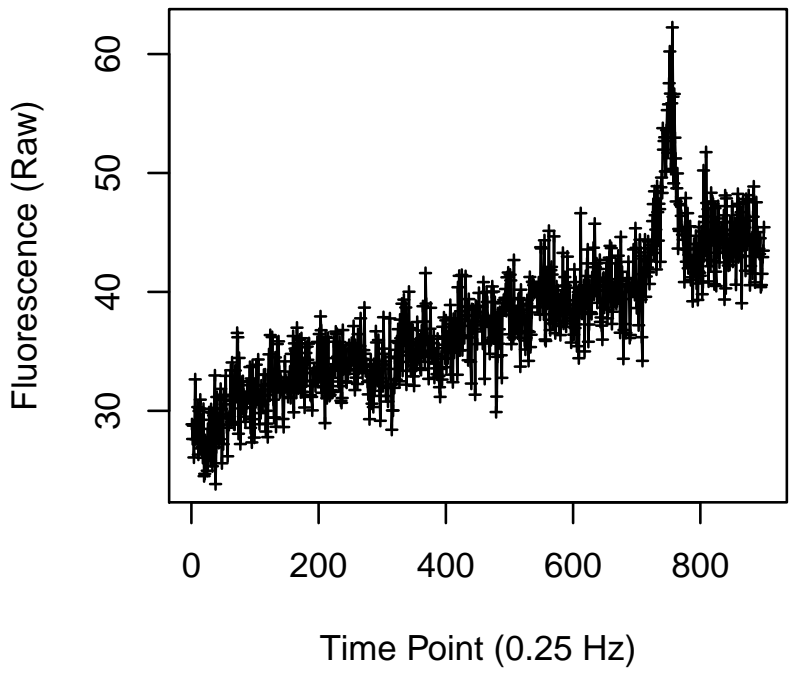

Cell 563

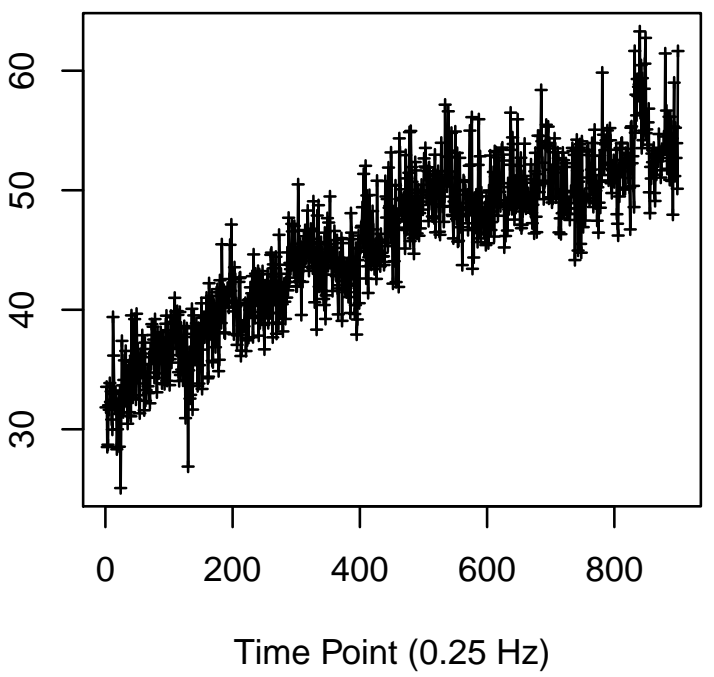

Cell 562

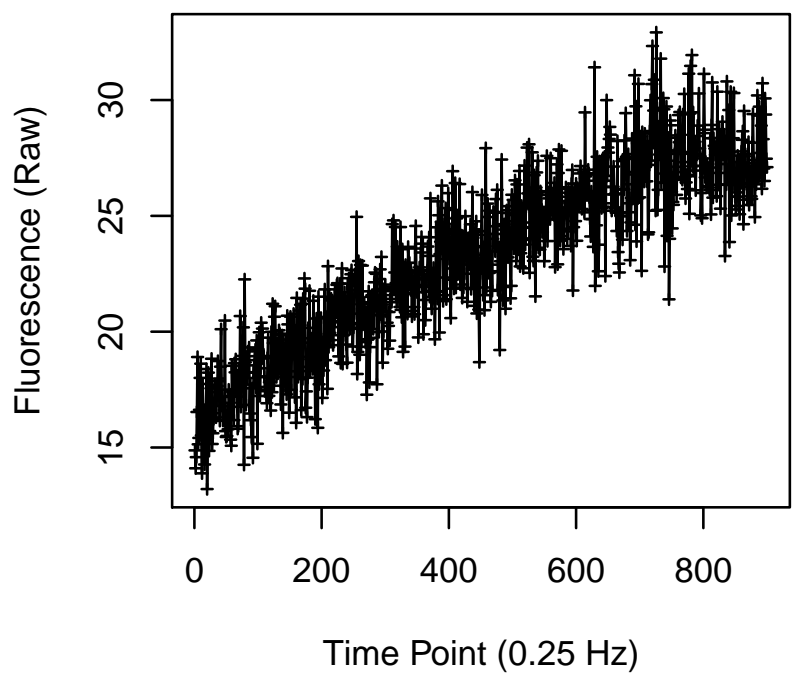

Cell 564

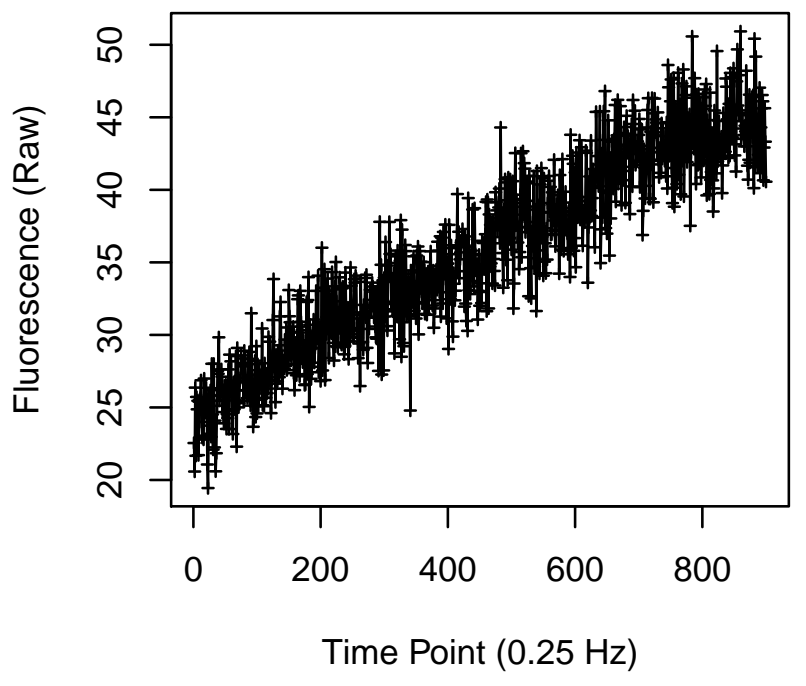




\section{Cell 565}

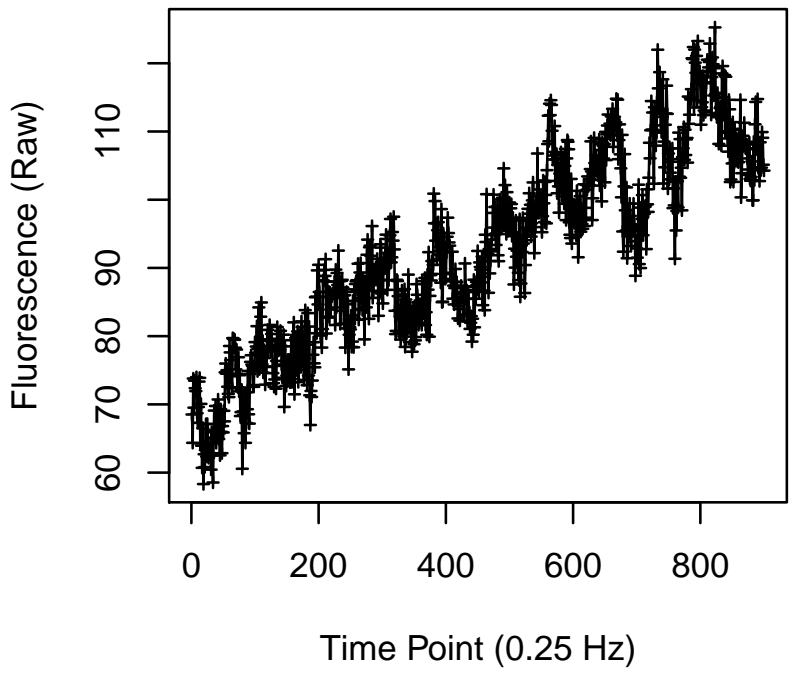

Cell 567

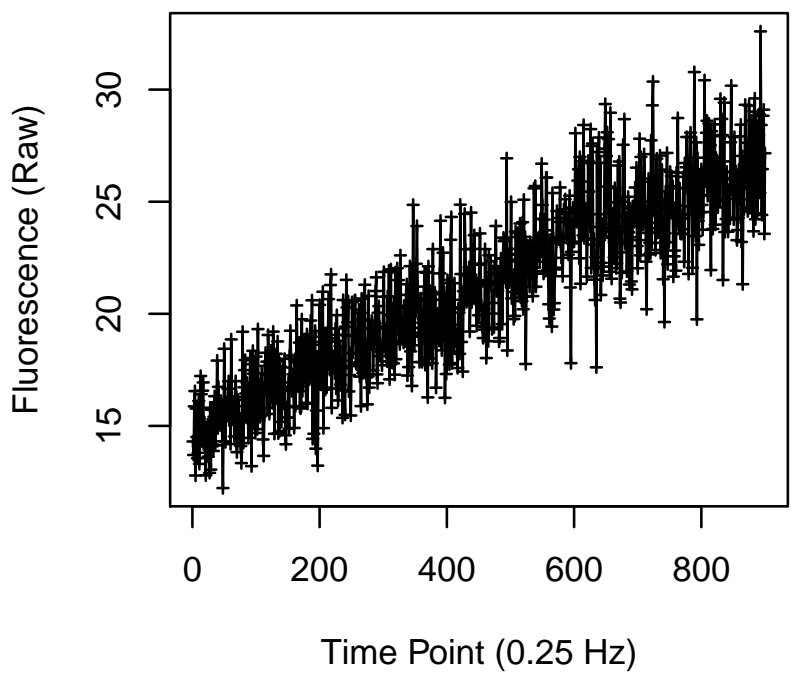

Cell 566

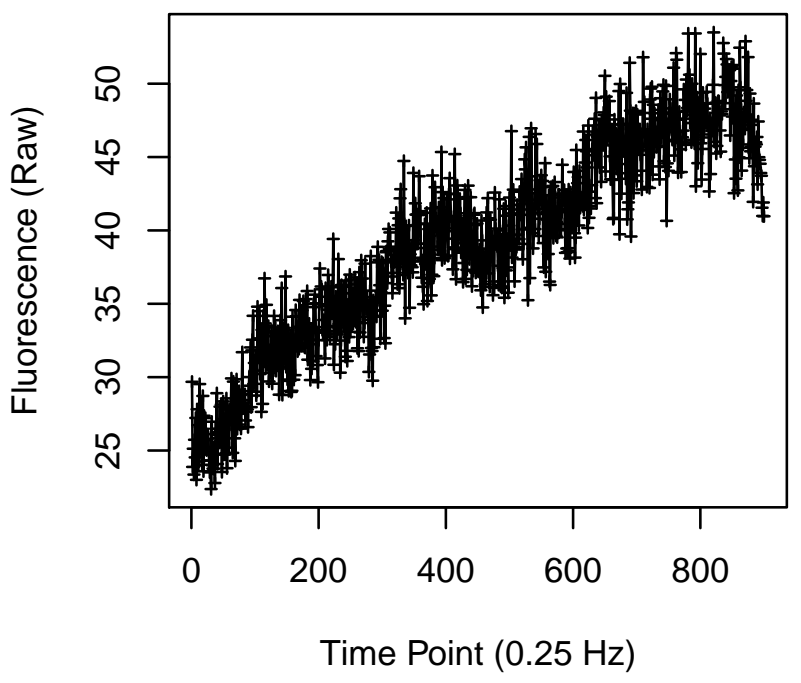

Cell 568

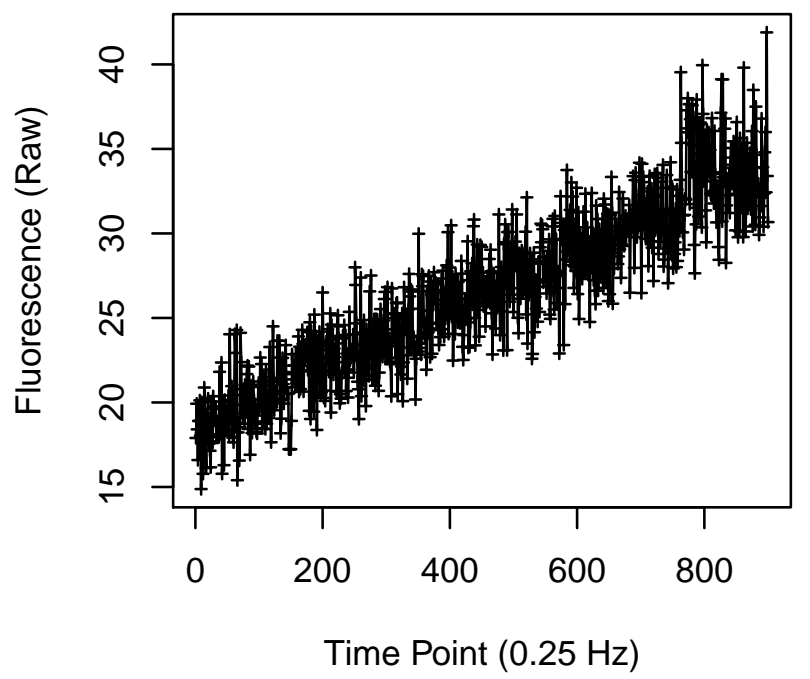




\section{Cell 569}

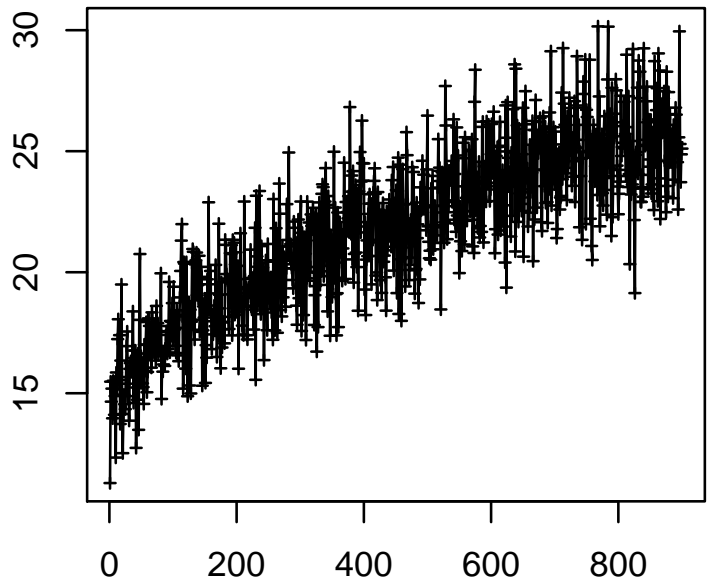

Time Point $(0.25 \mathrm{~Hz})$

Cell 571

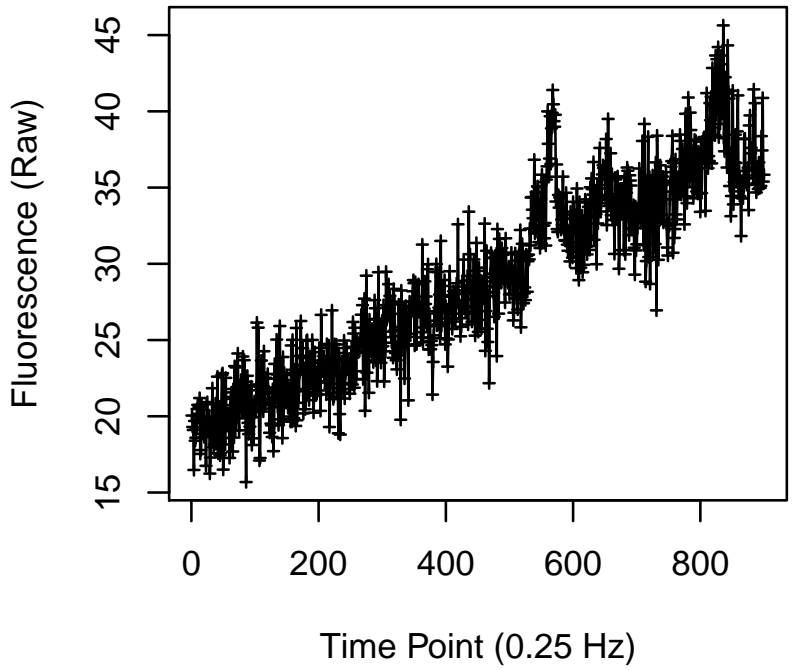

Cell 570

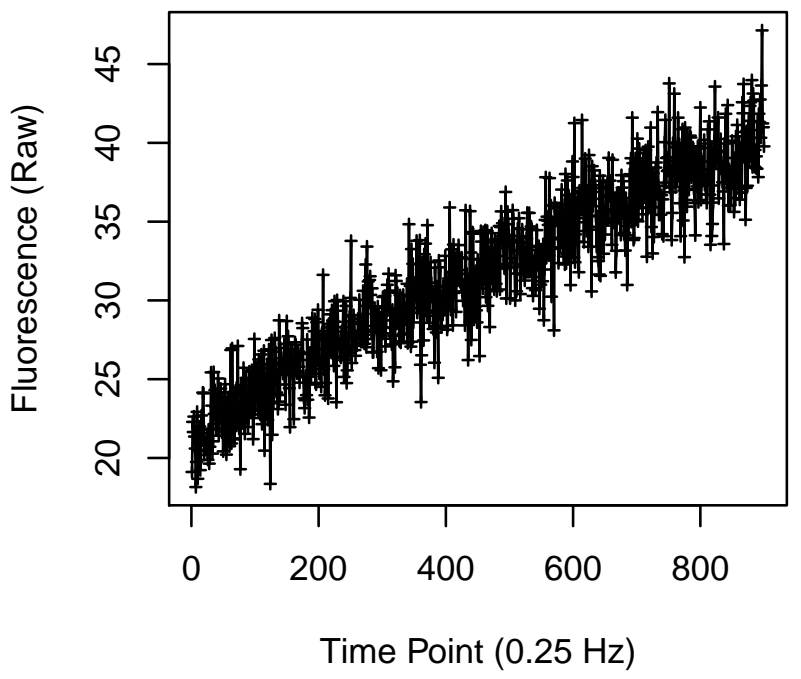

Cell 572

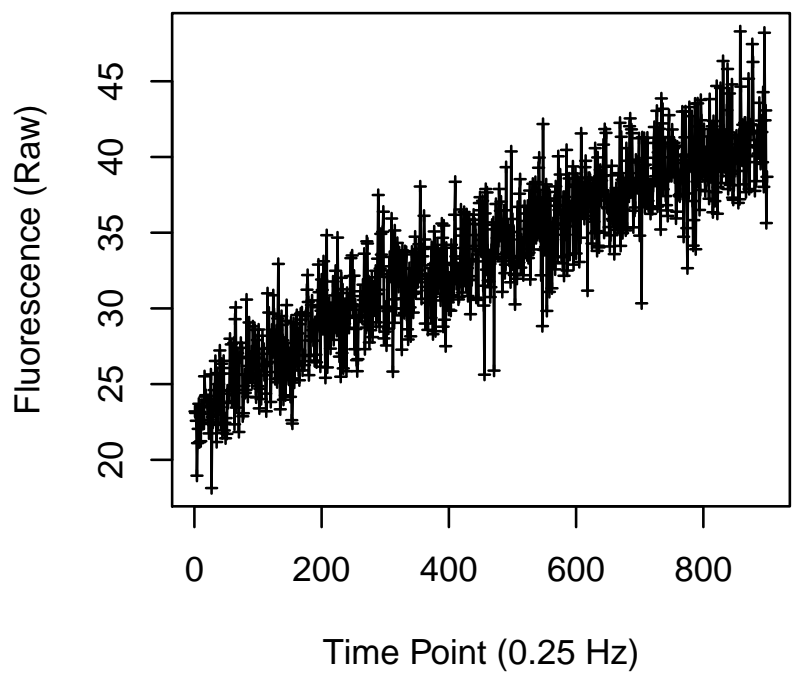


Cell 573

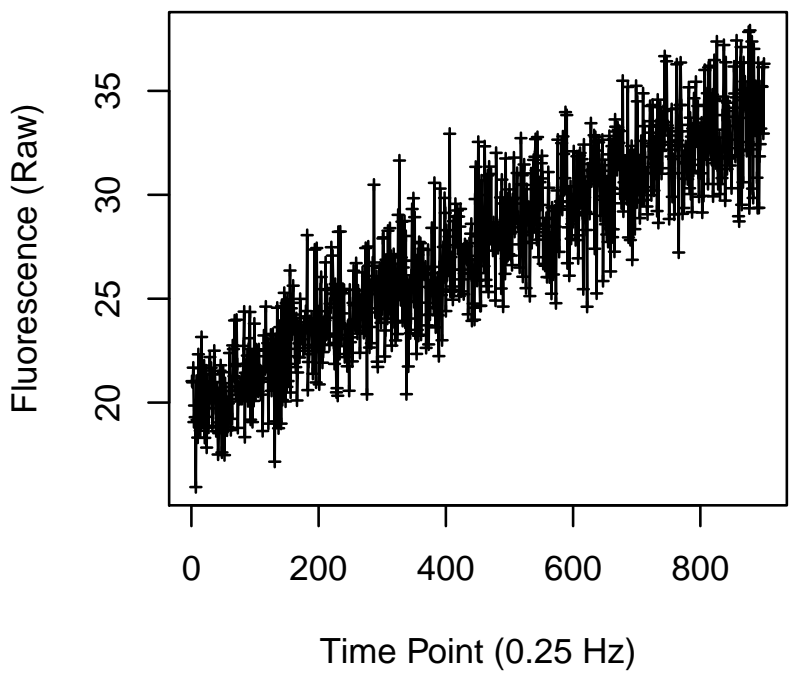

Cell 575

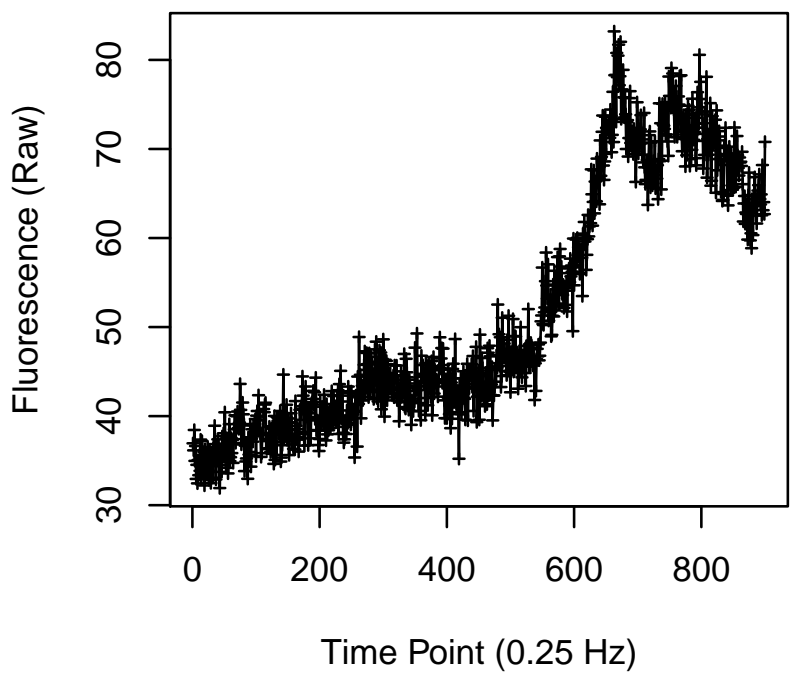

Cell 574

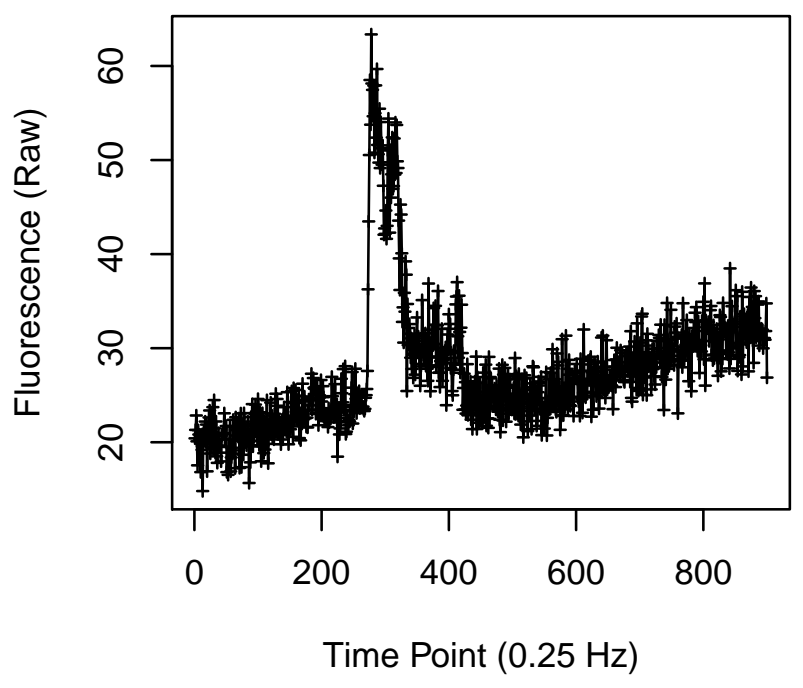

Cell 576

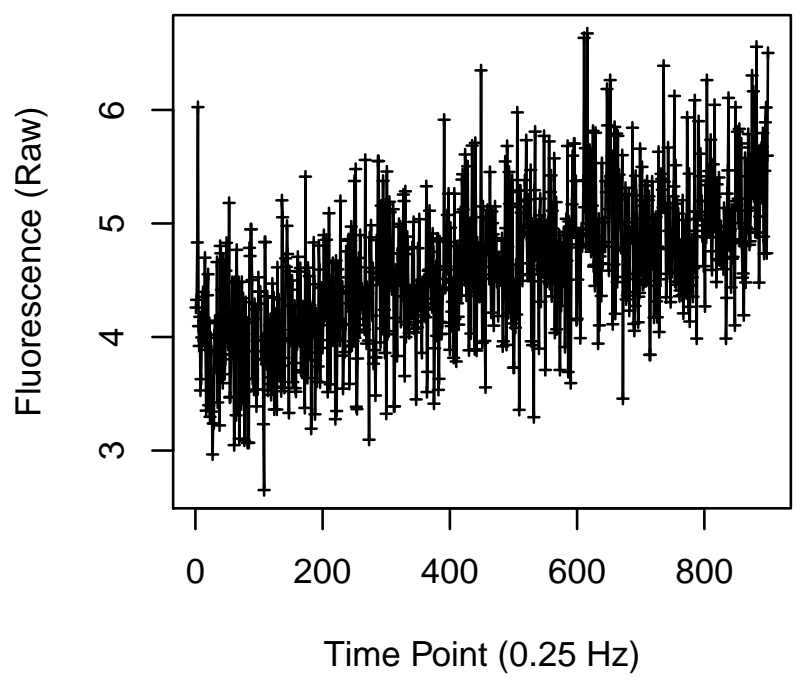




\section{Cell 577}

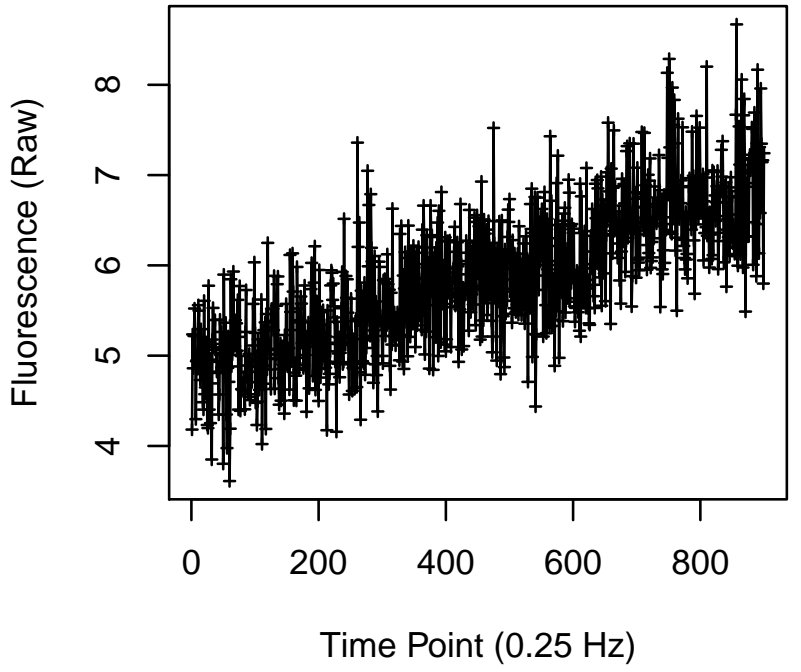

Cell 579

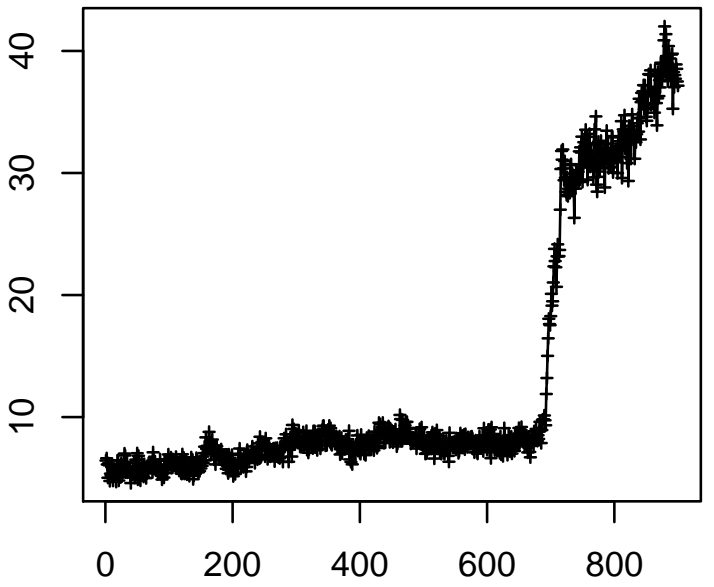

Time Point $(0.25 \mathrm{~Hz})$
Cell 578

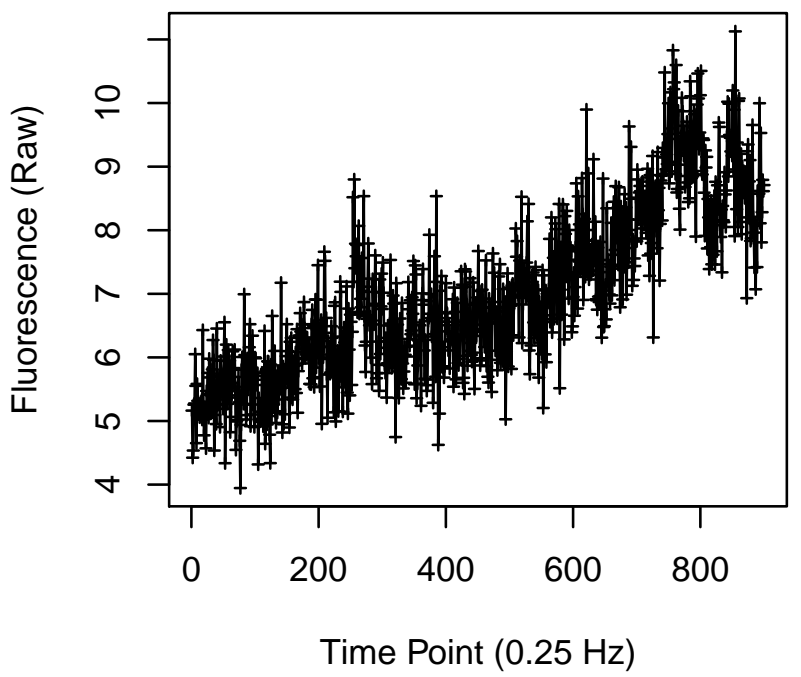

Cell 580

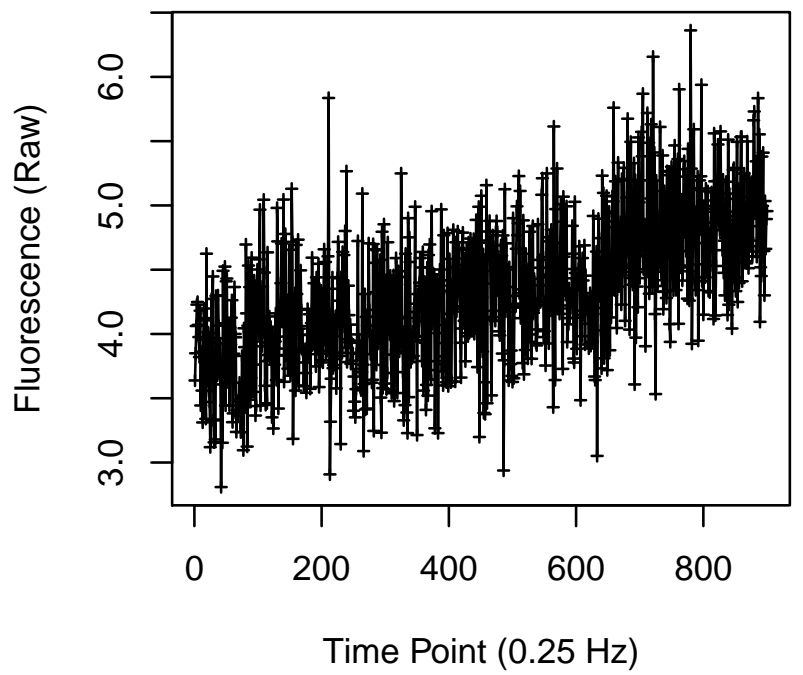


Cell 581

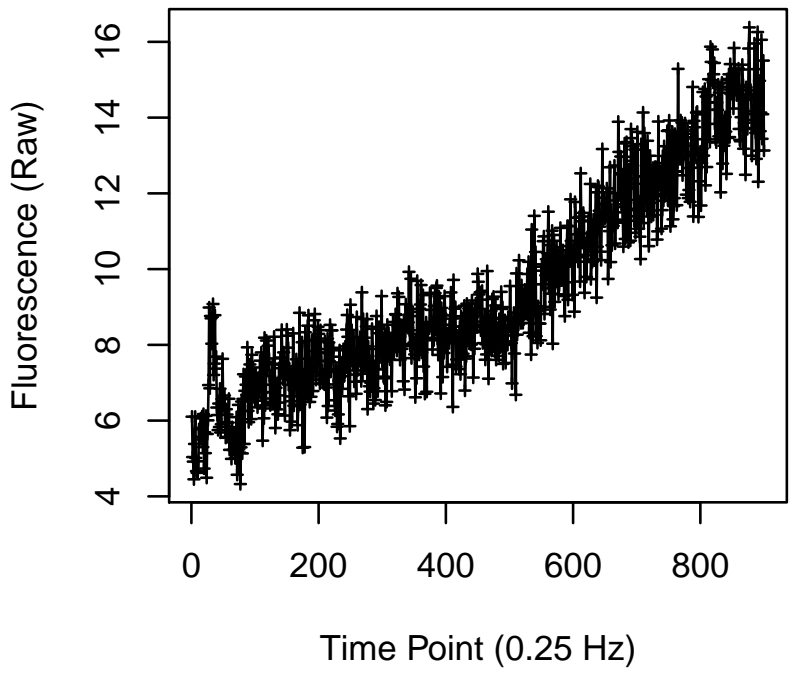

Cell 583

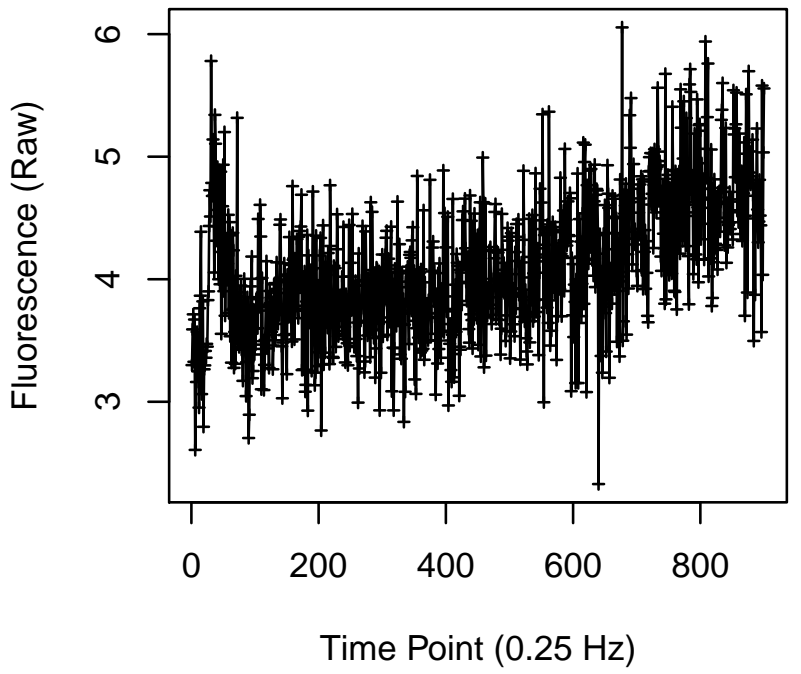

Cell 582

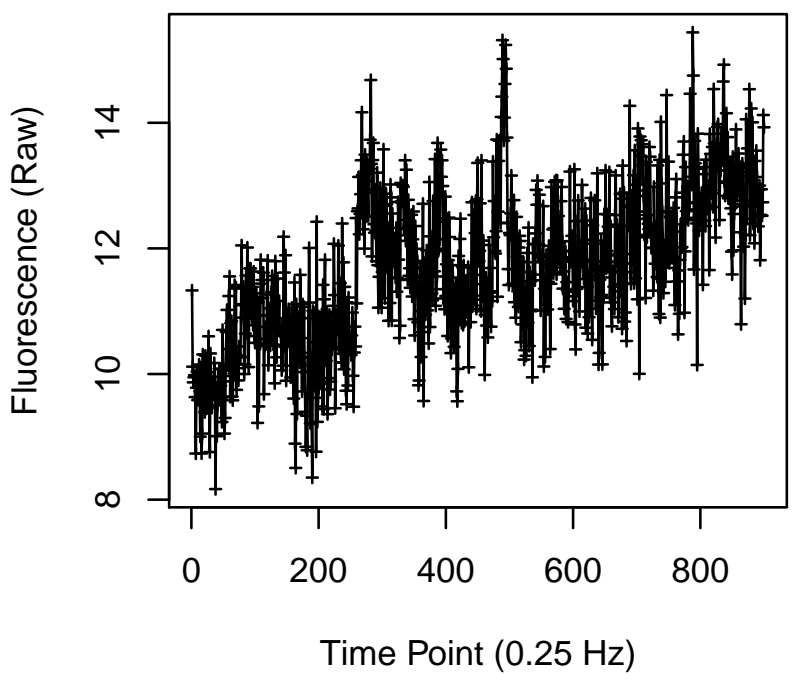

Cell 584

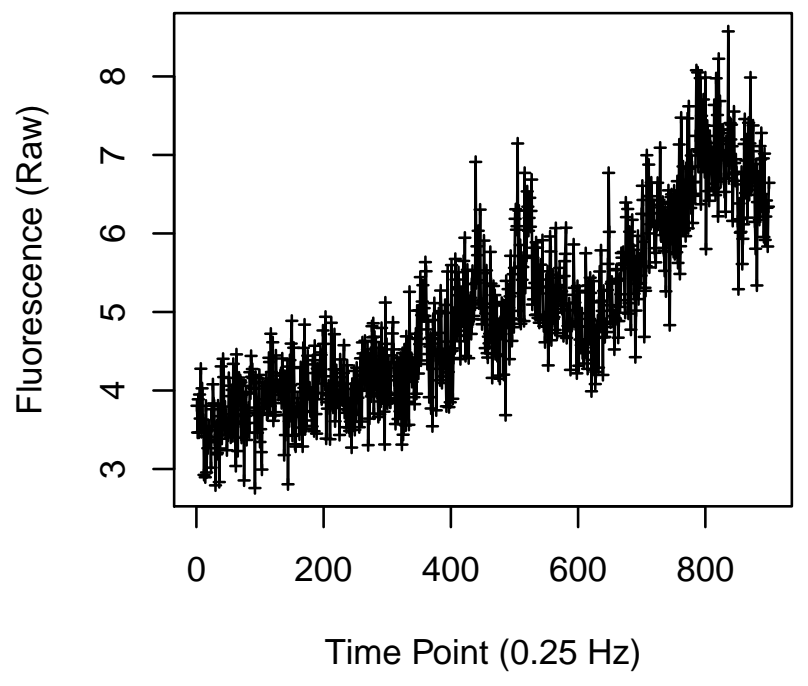


Cell 585

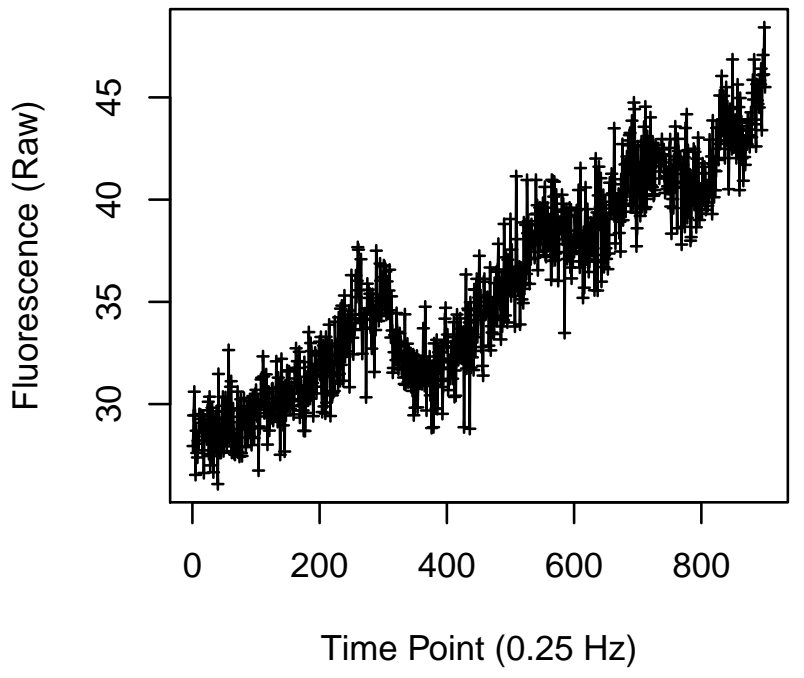

Cell 587

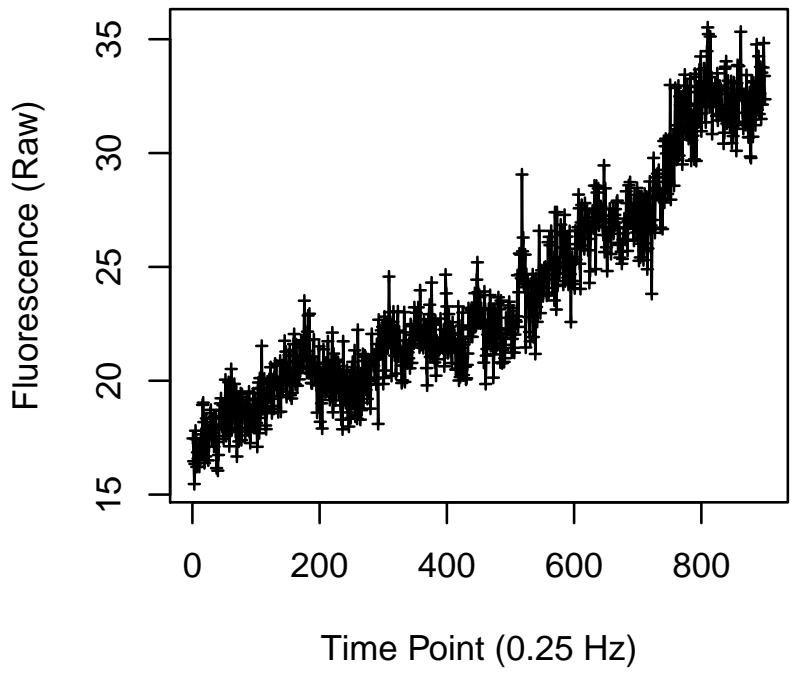

Cell 586

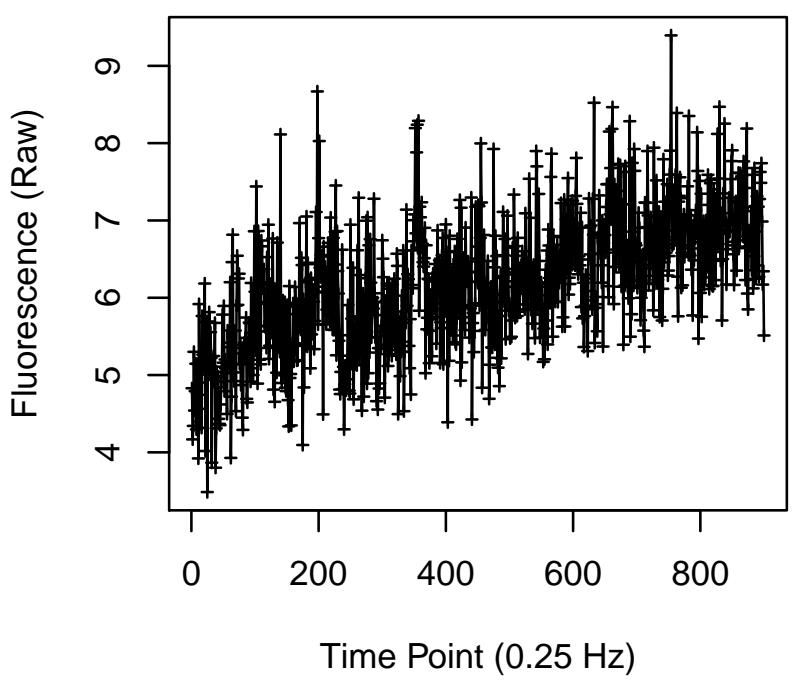

Cell 588

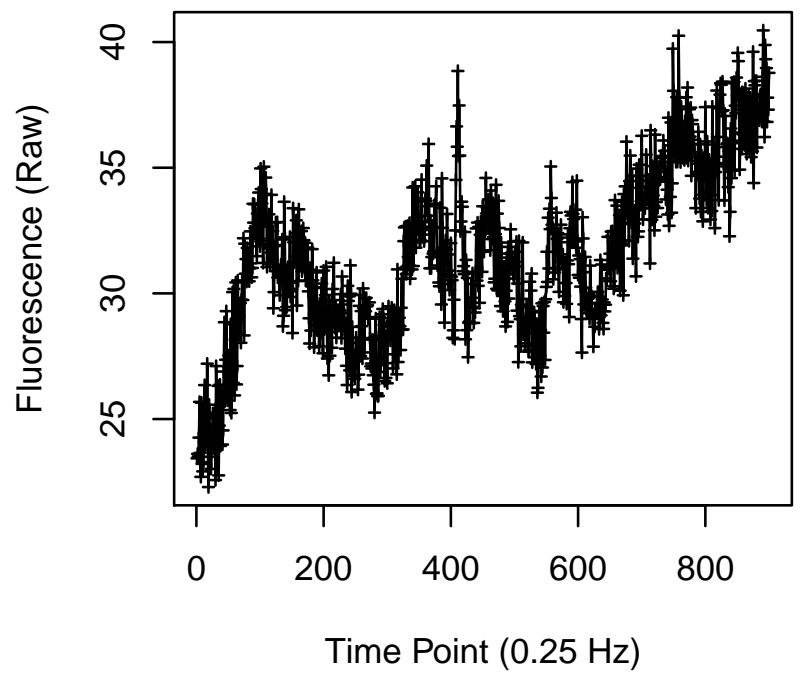


Cell 589

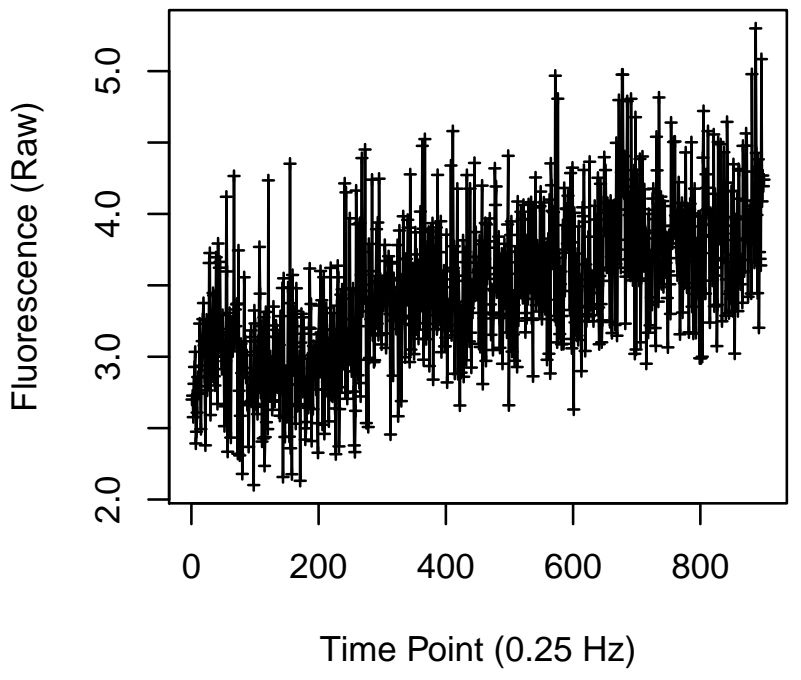

Cell 591

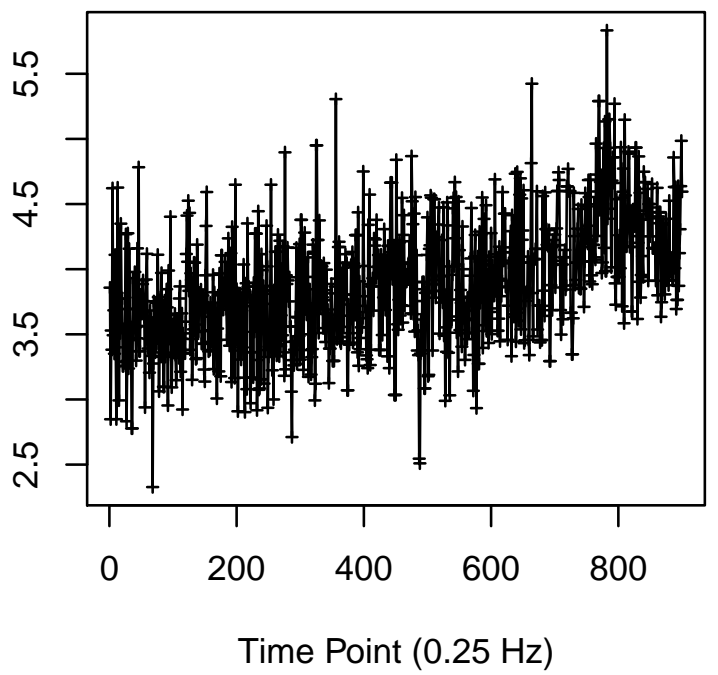

Cell 590

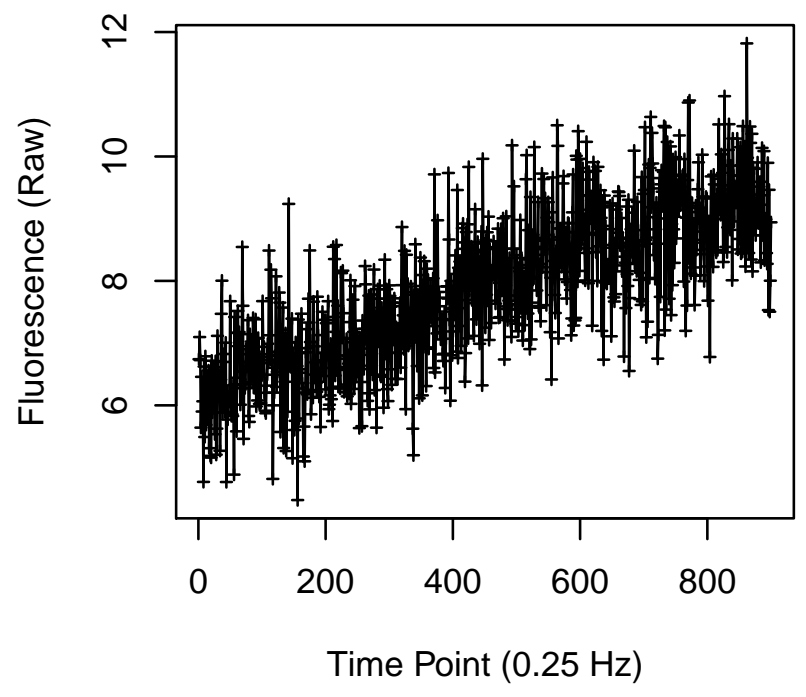

Cell 592

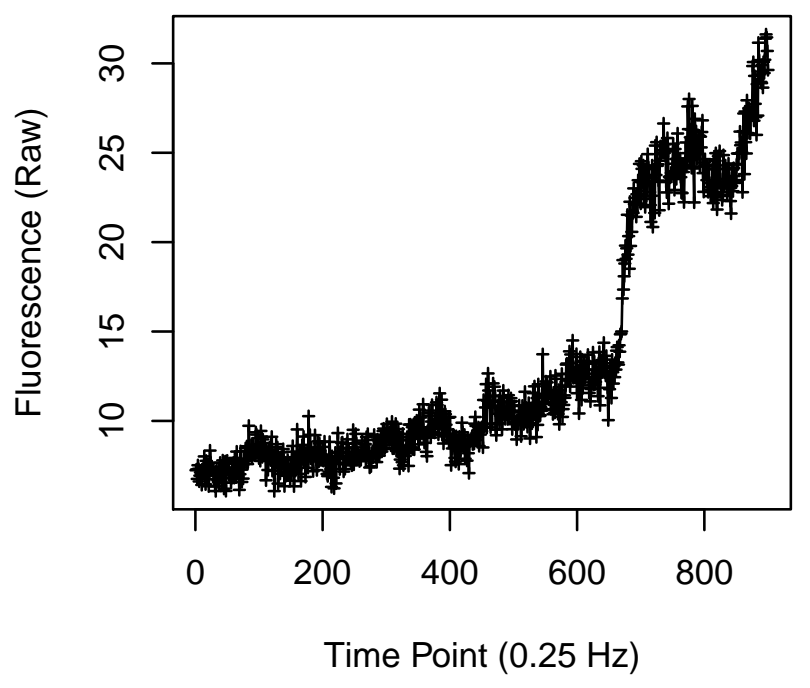


Cell 593

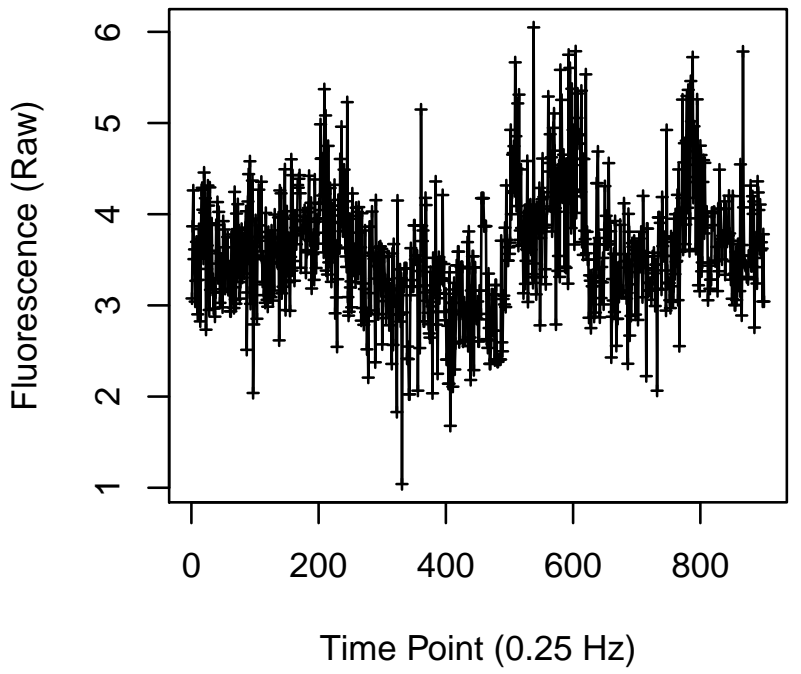

Cell 595

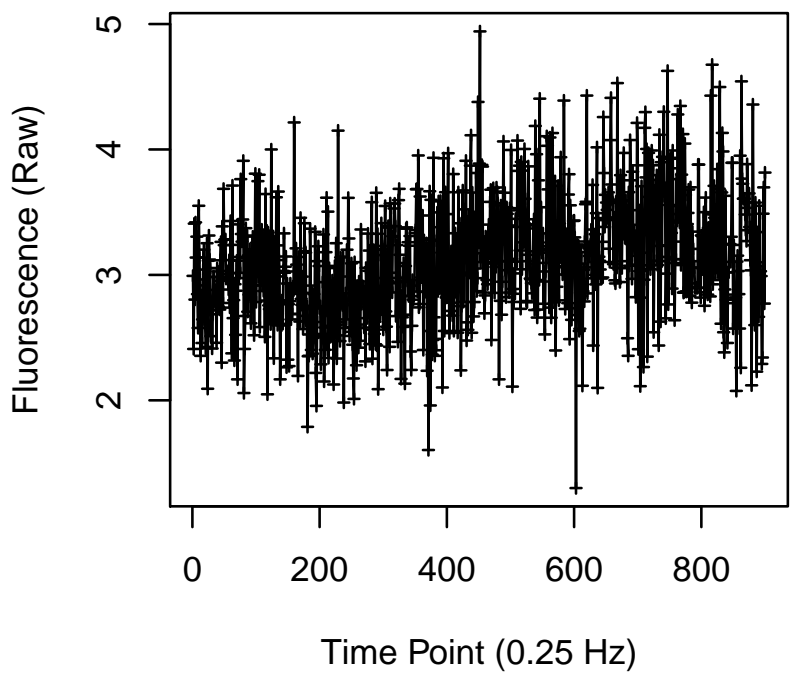

Cell 594

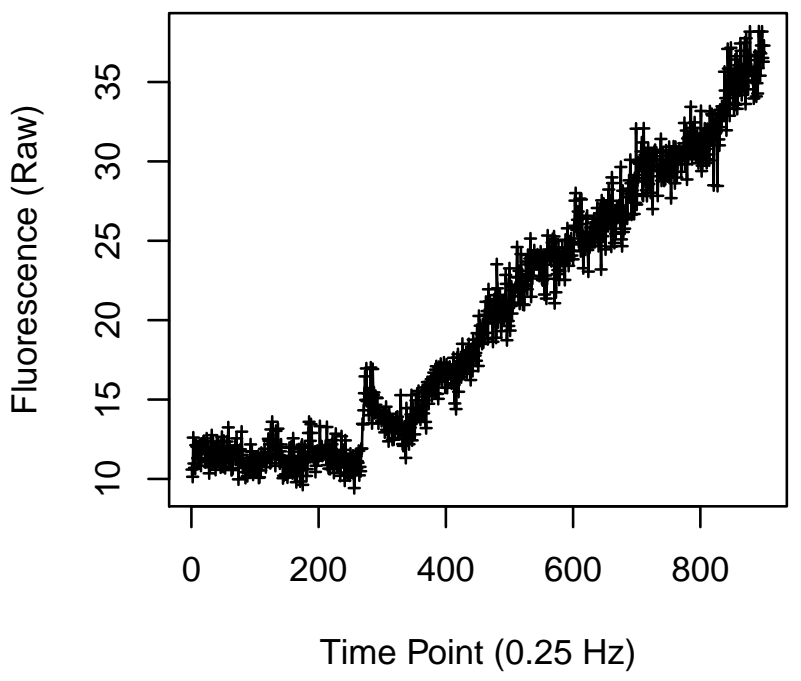

Cell 596

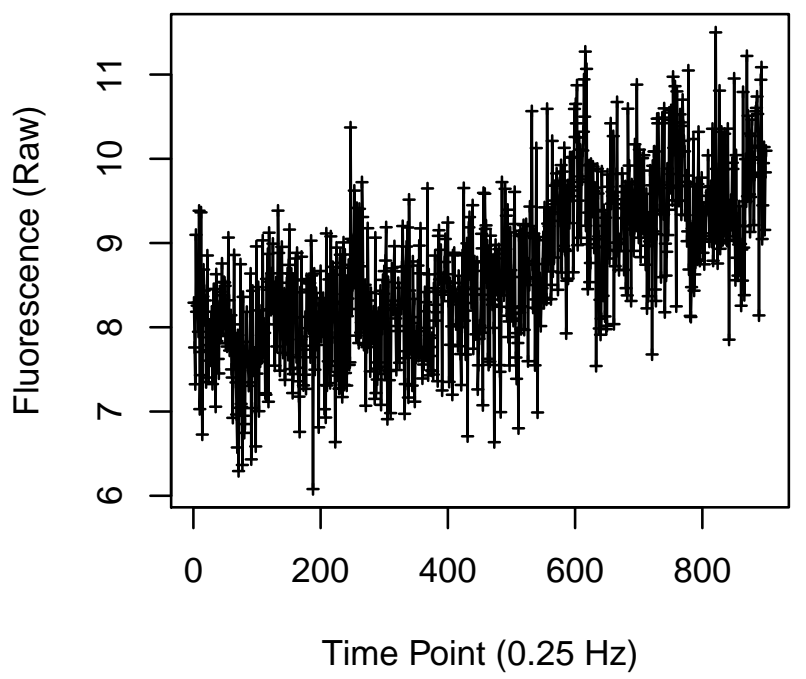




\section{Cell 597}

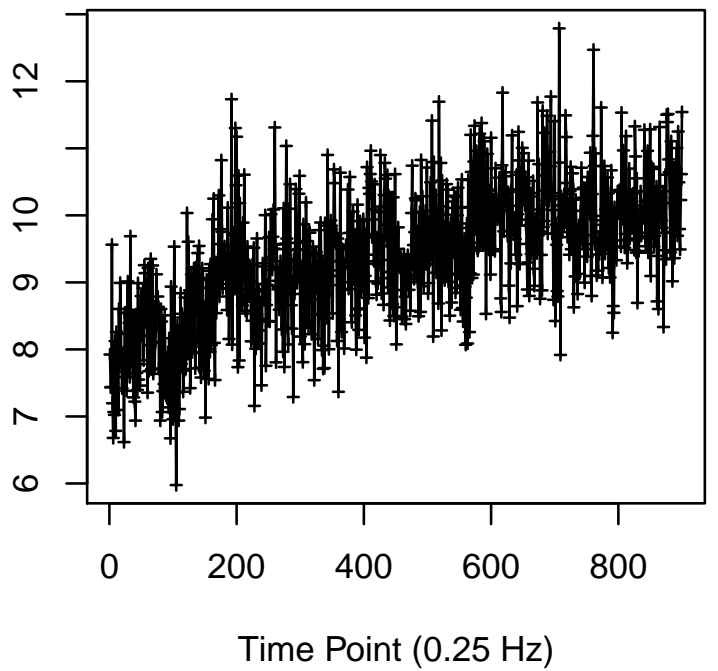

Cell 599

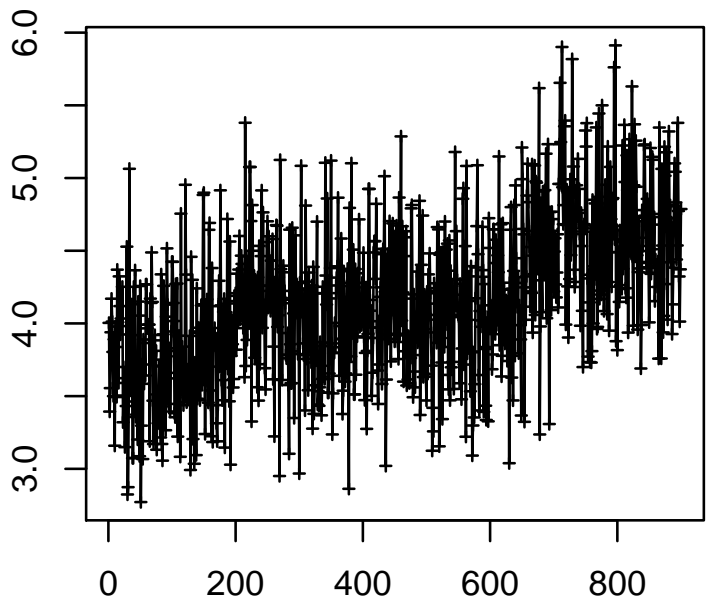

Time Point $(0.25 \mathrm{~Hz})$
Cell 598

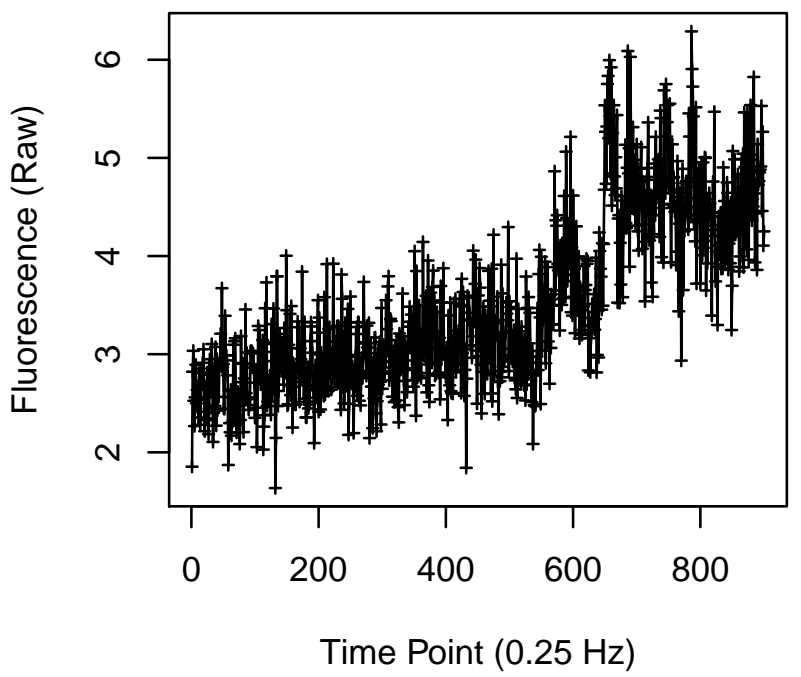

Cell 600

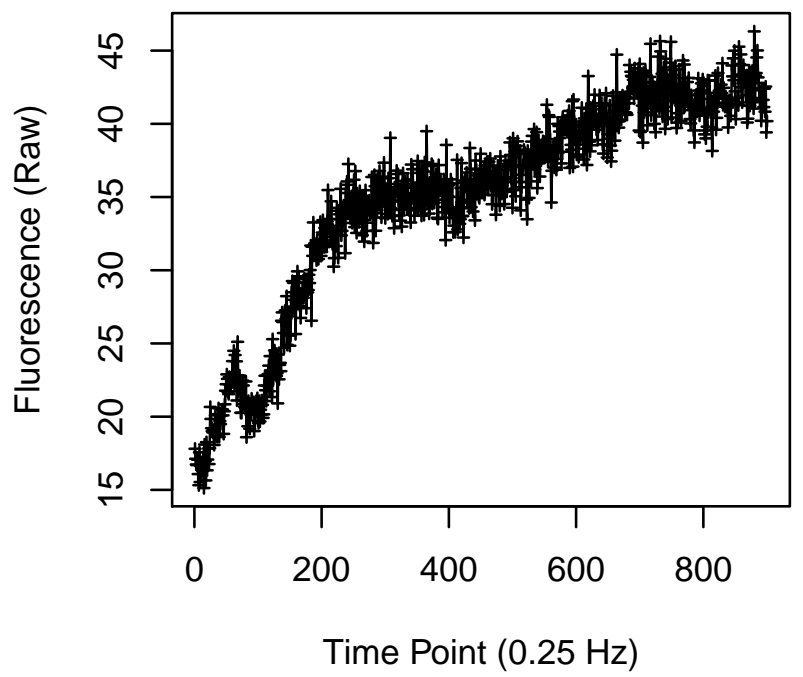


Cell 601

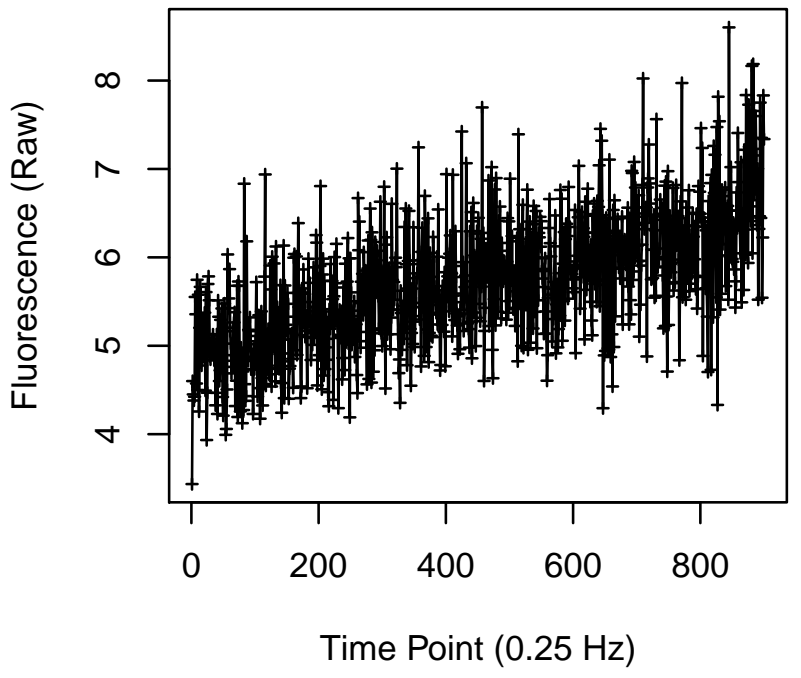

Cell 603

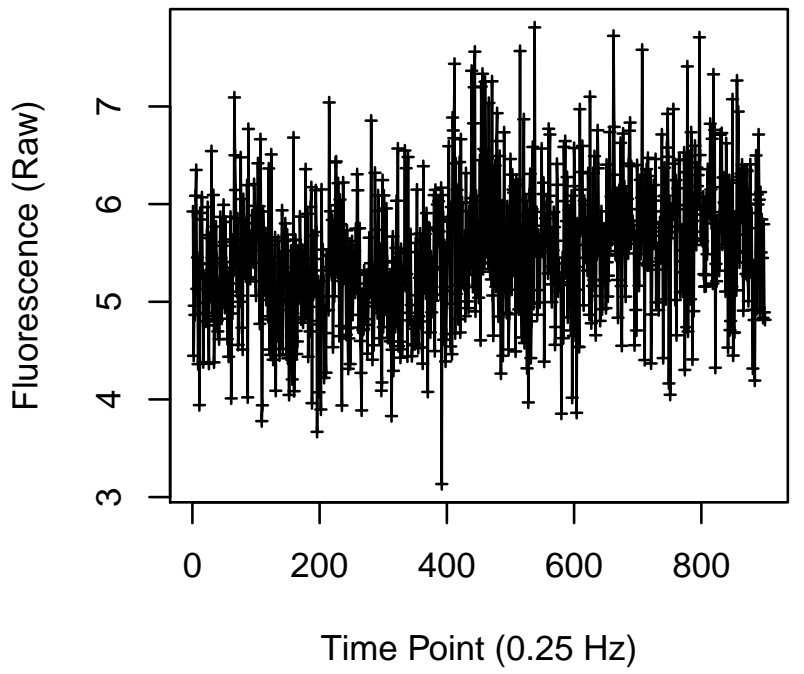

Cell 602

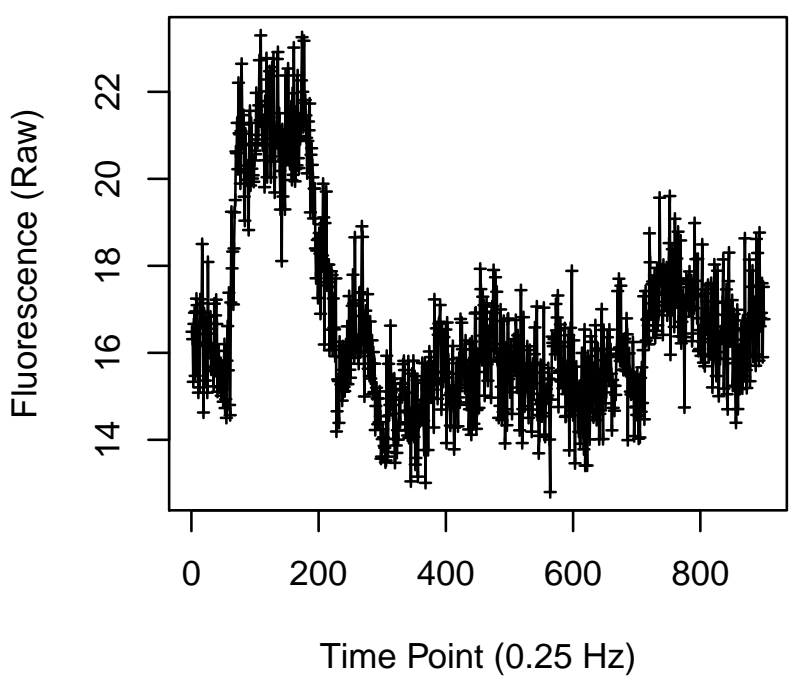

Cell 604

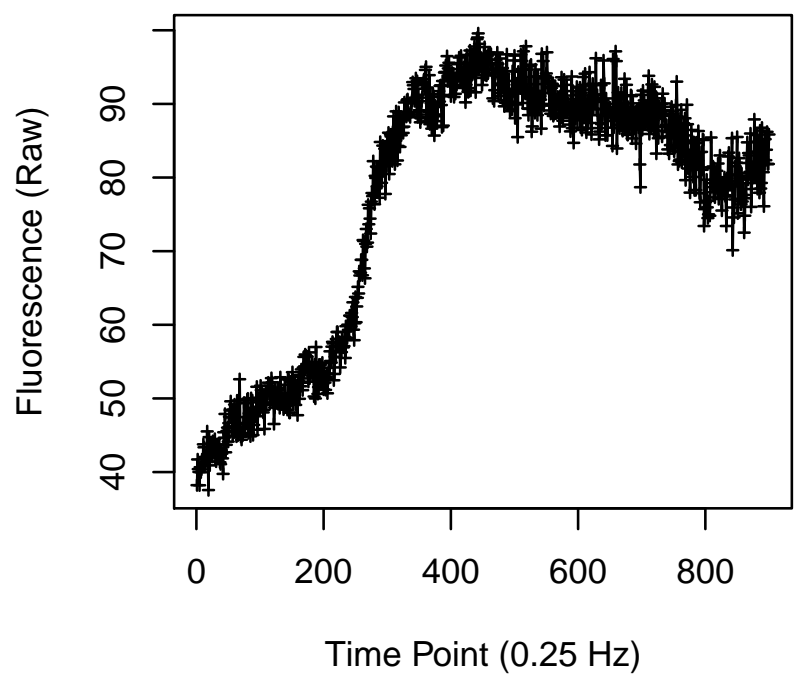




\section{Cell 605}

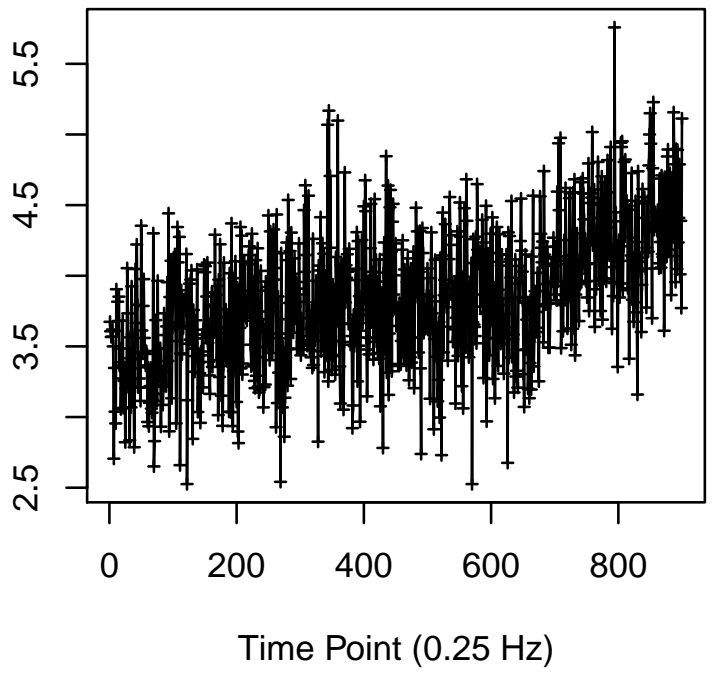

Cell 607

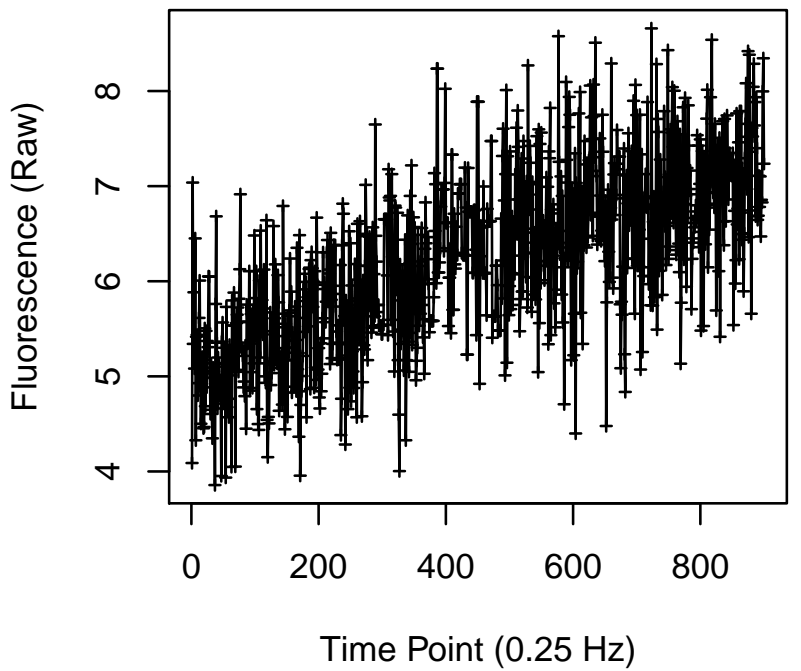

Cell 606

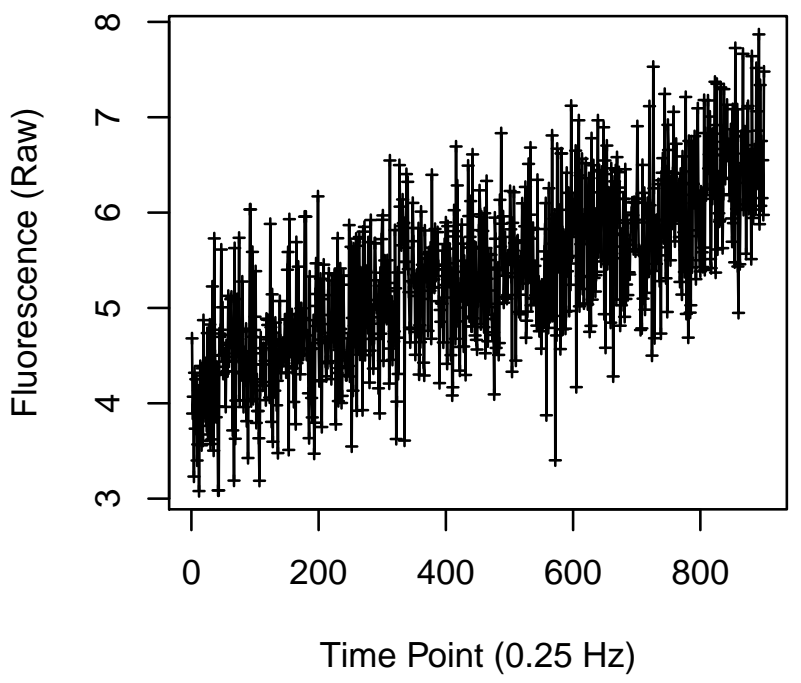

Cell 608

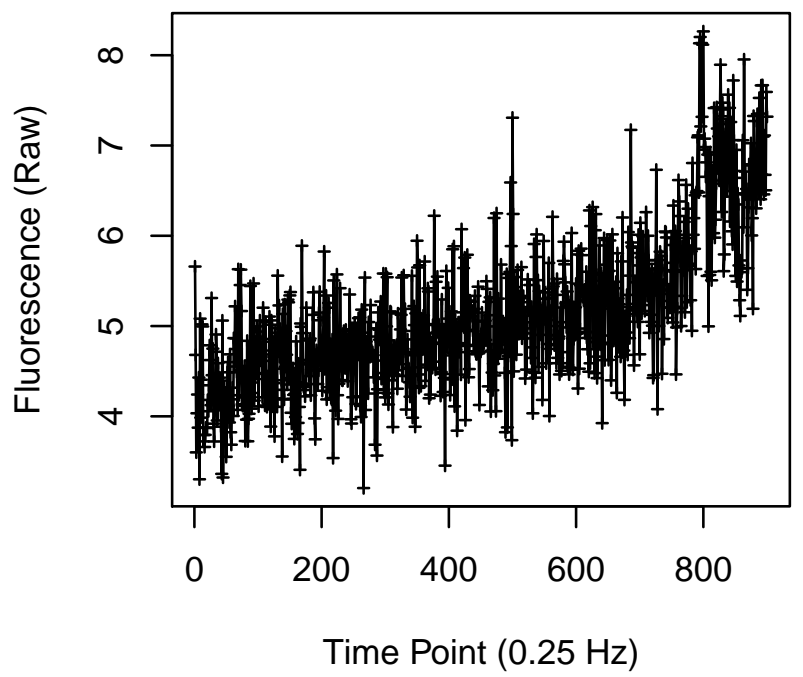


Cell 609

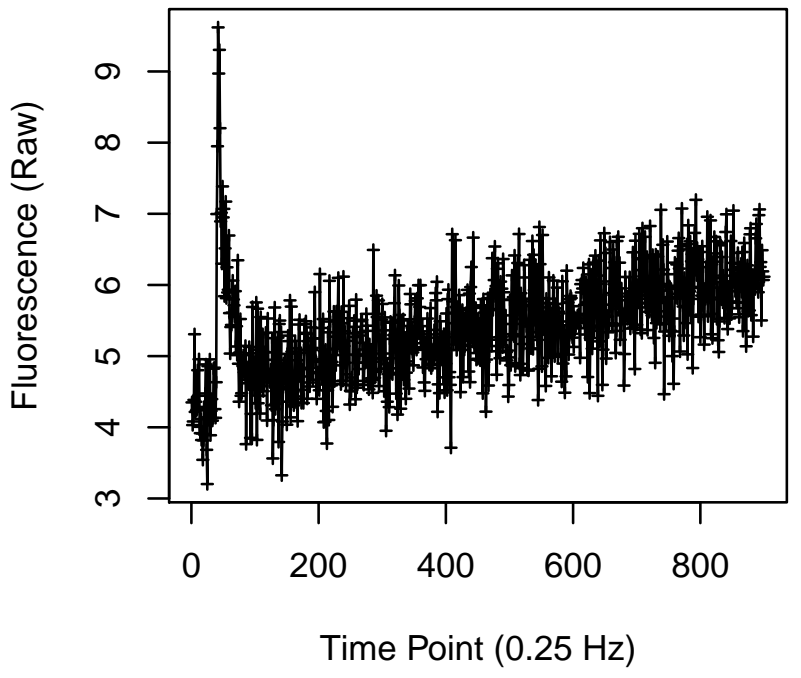

Cell 611

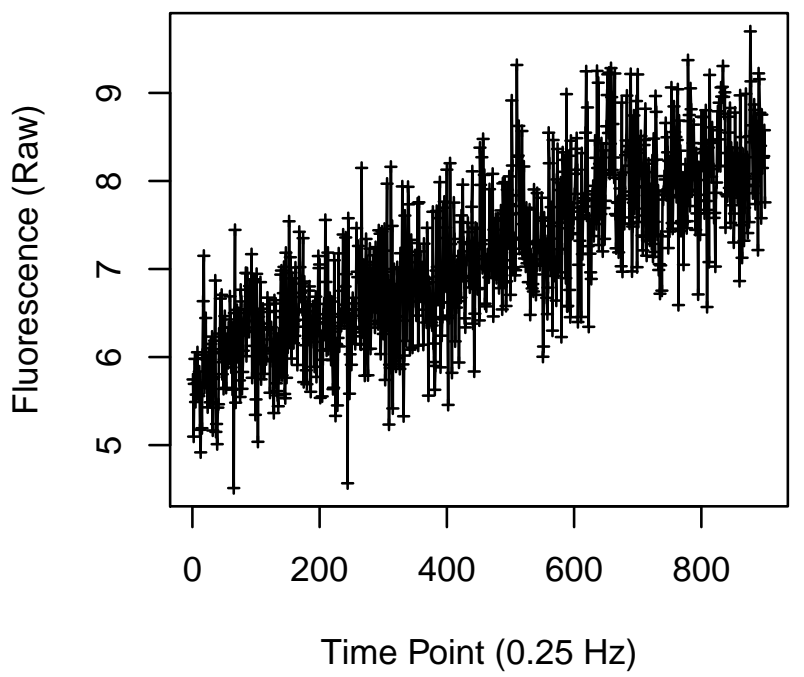

Cell 610

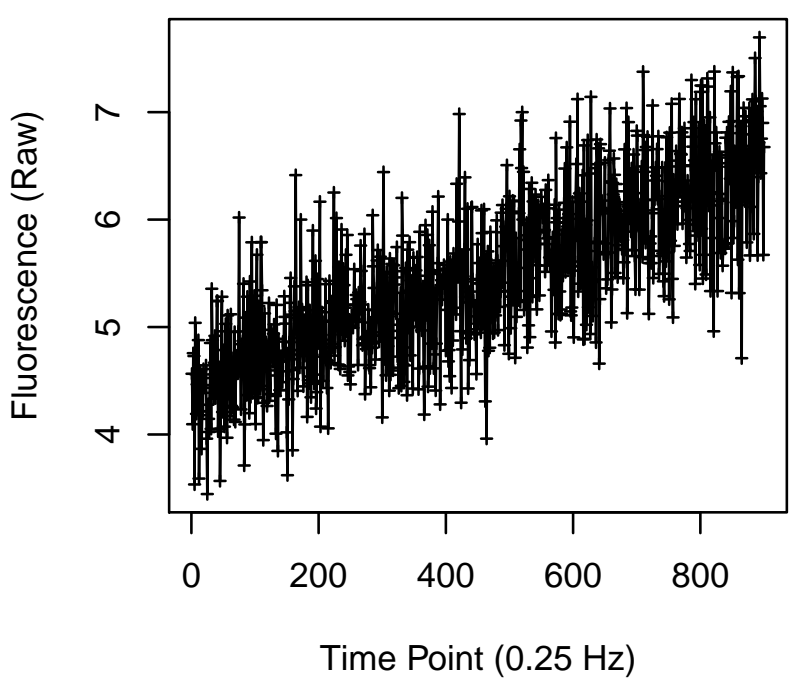

Cell 612

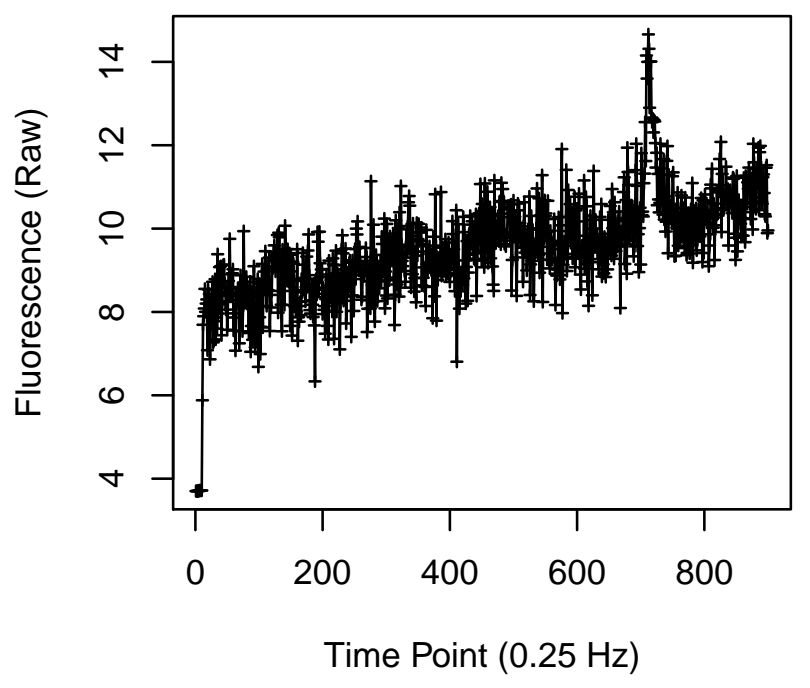




\section{Cell 613}

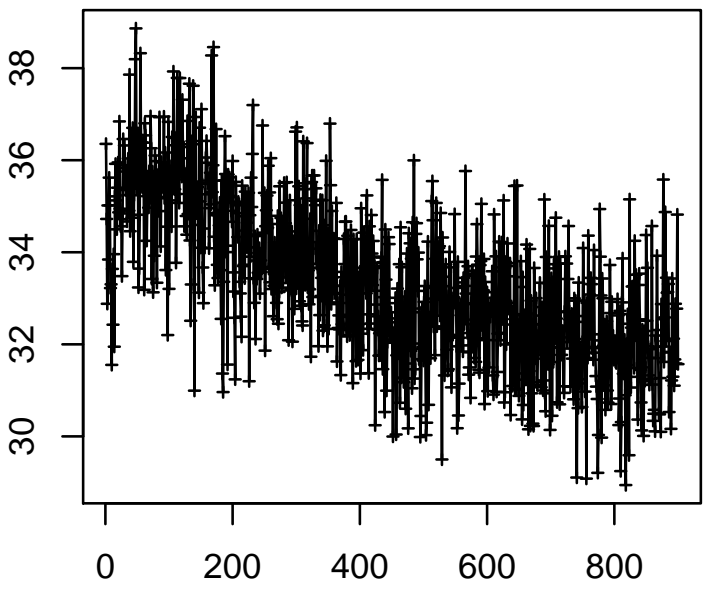

Time Point $(0.25 \mathrm{~Hz})$

Cell 615

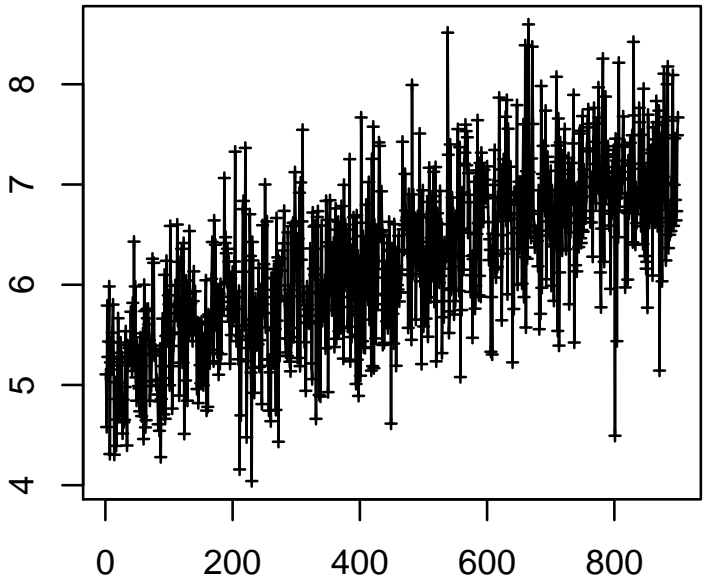

Time Point $(0.25 \mathrm{~Hz})$
Cell 614

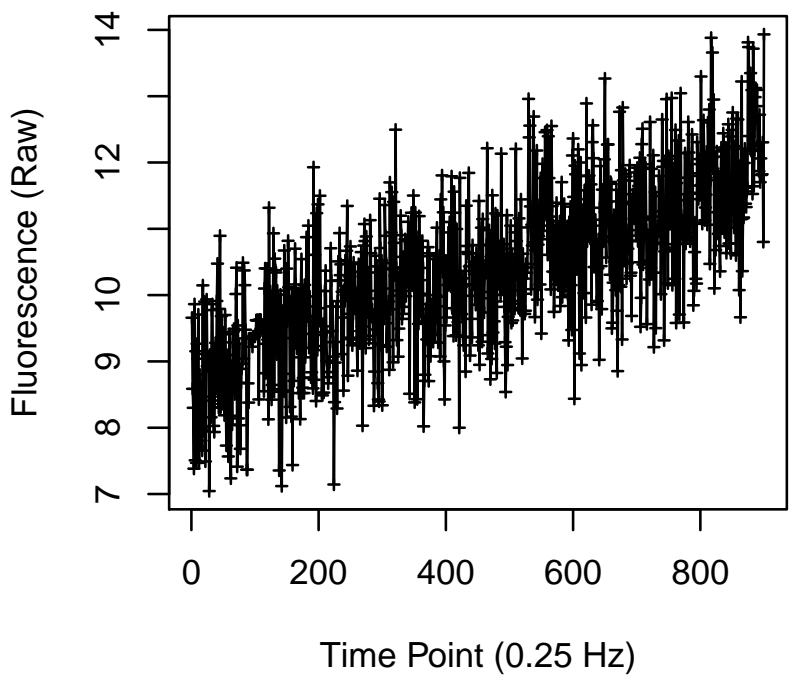

Cell 616

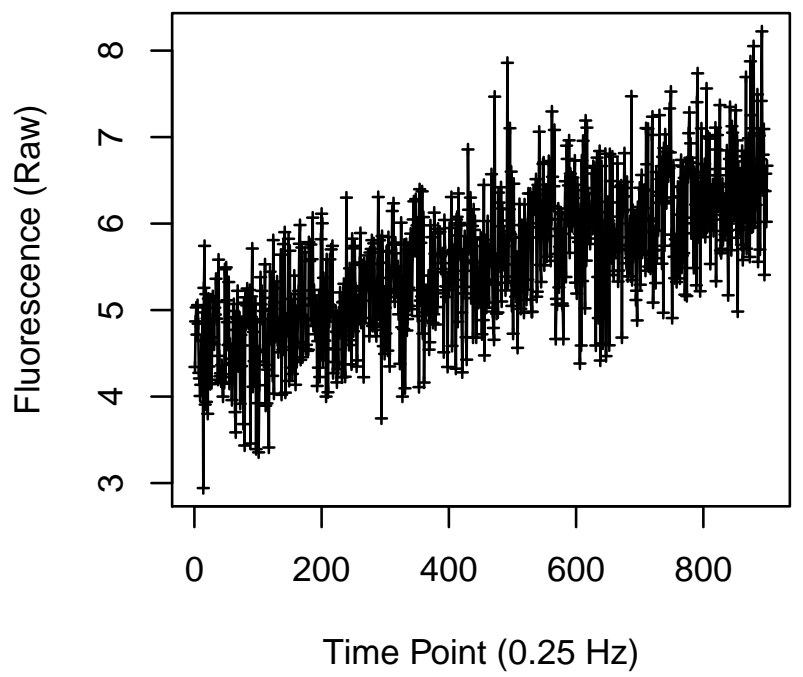


Cell 621

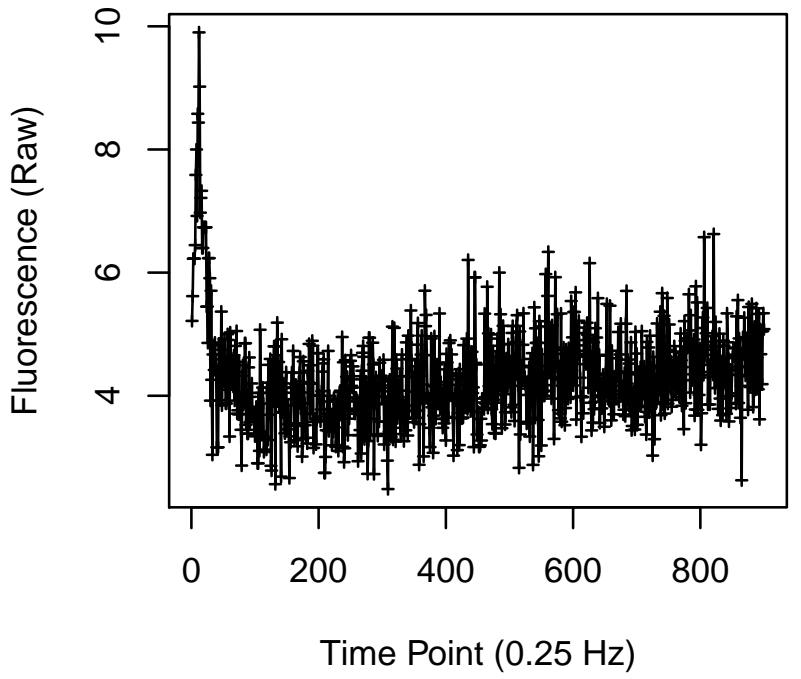

Cell 623

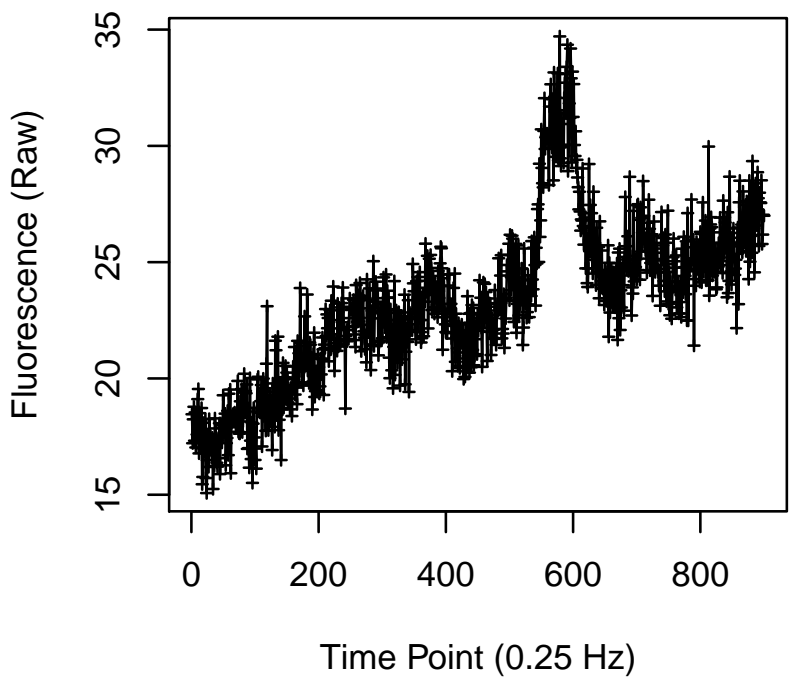

Cell 622

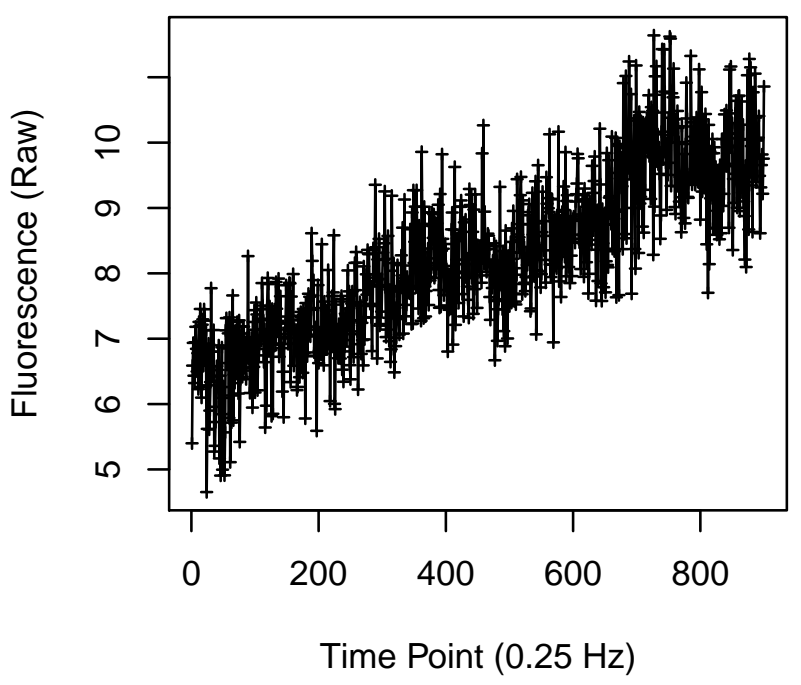

Cell 624

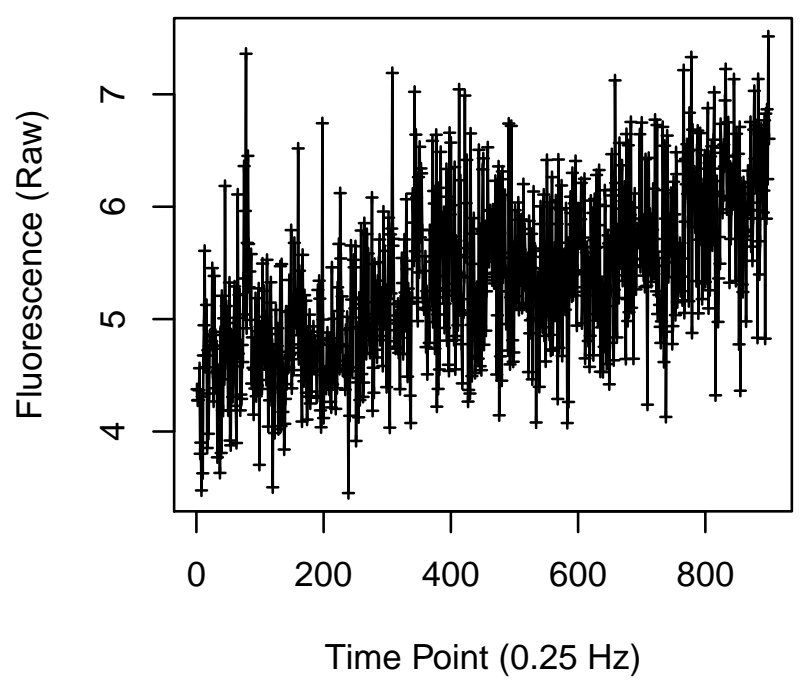


Cell 629

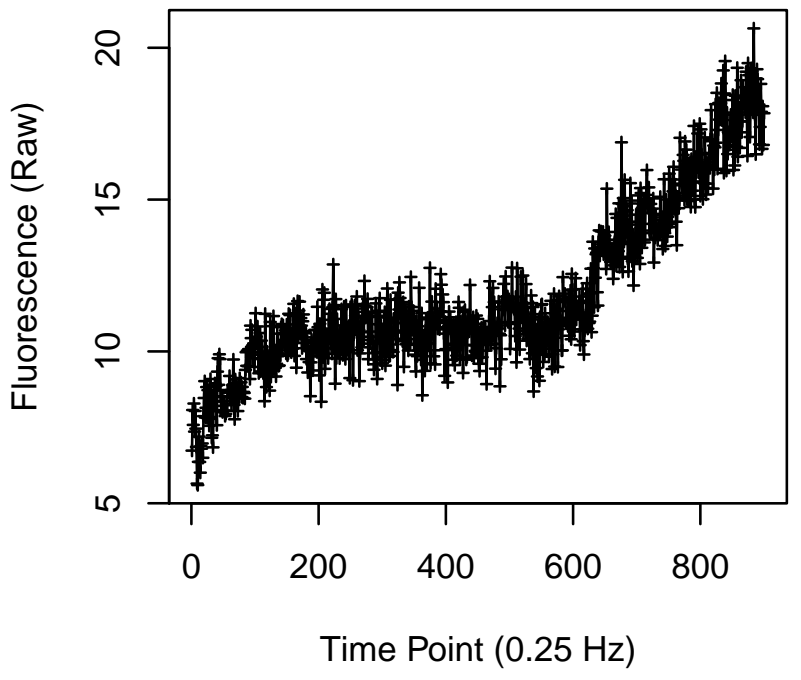

Cell 631

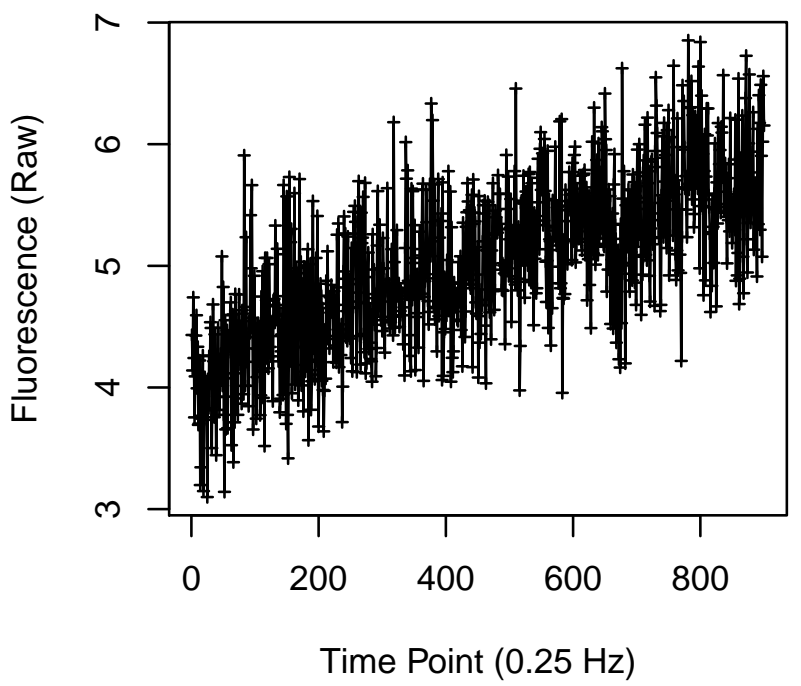

Cell 630

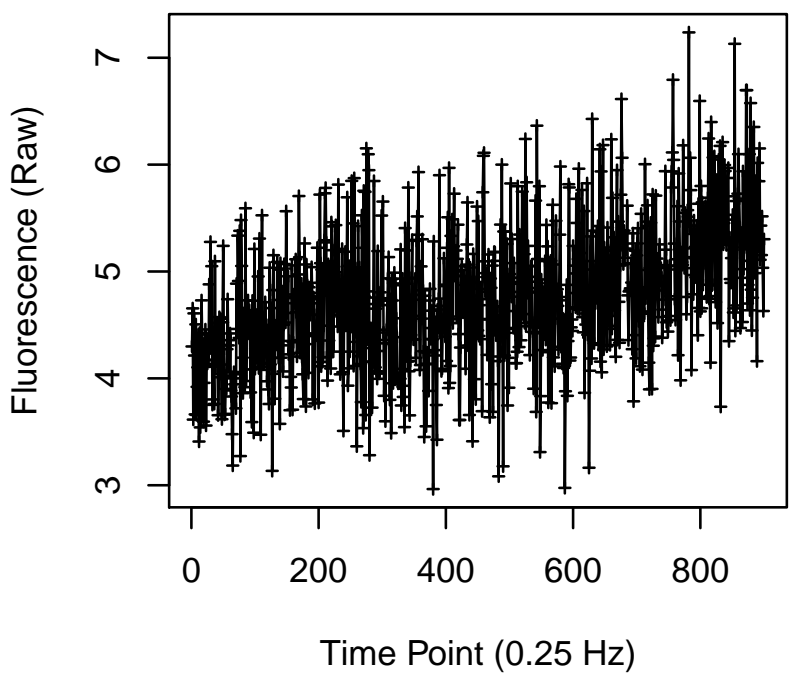

Cell 632

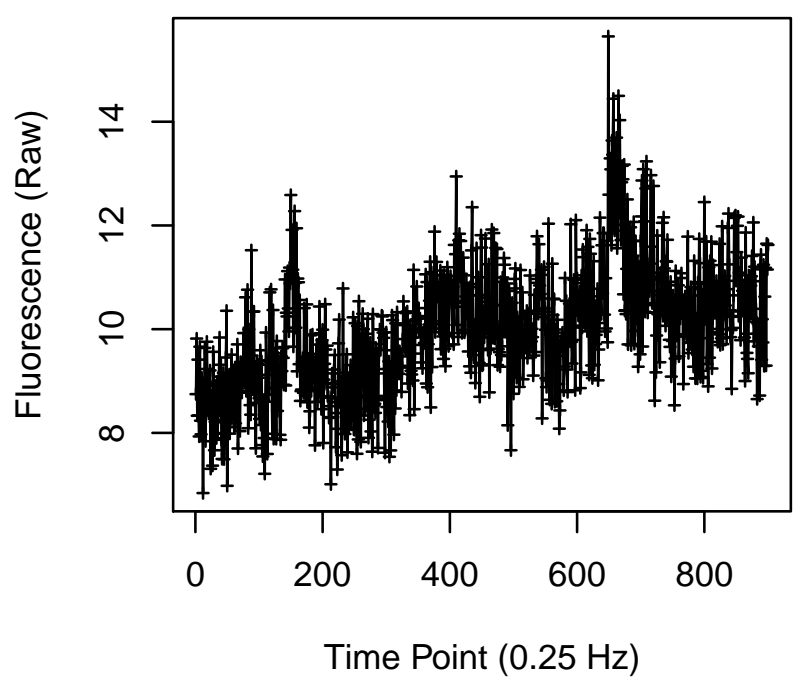


Cell 633

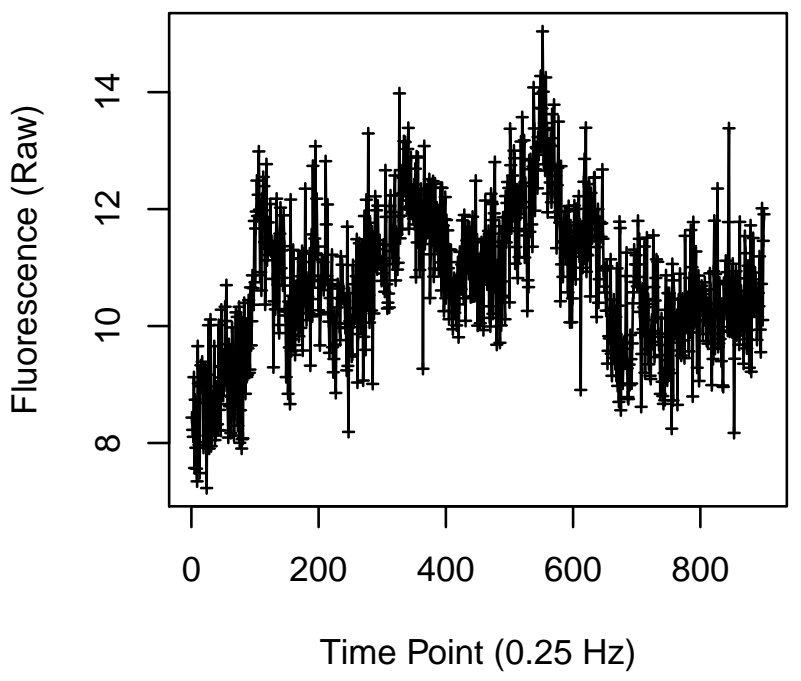

Cell 635

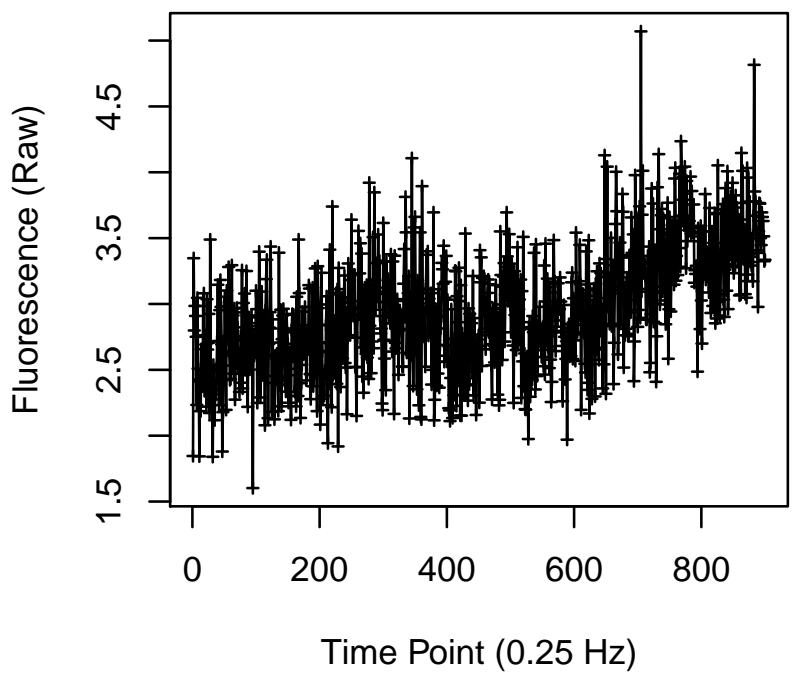

Cell 634

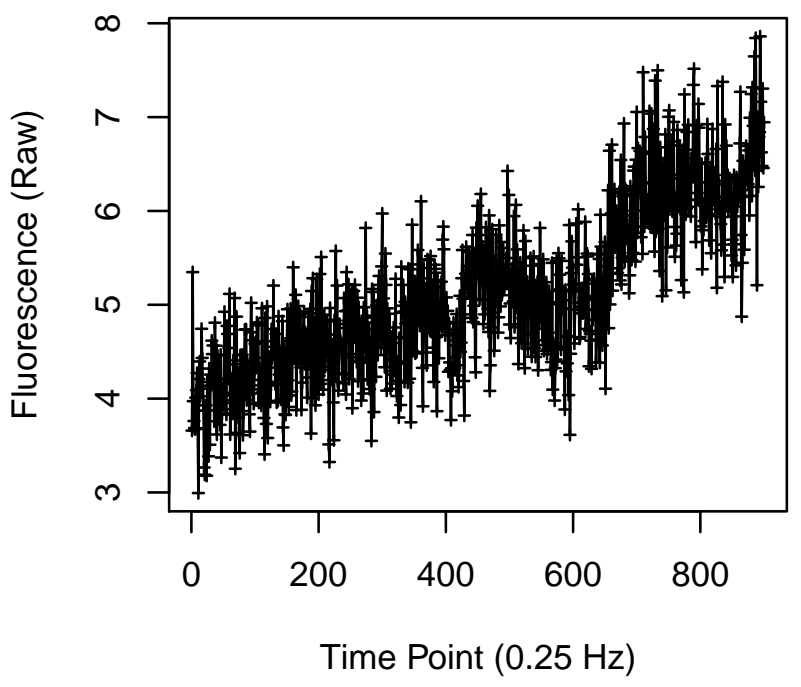

Cell 636

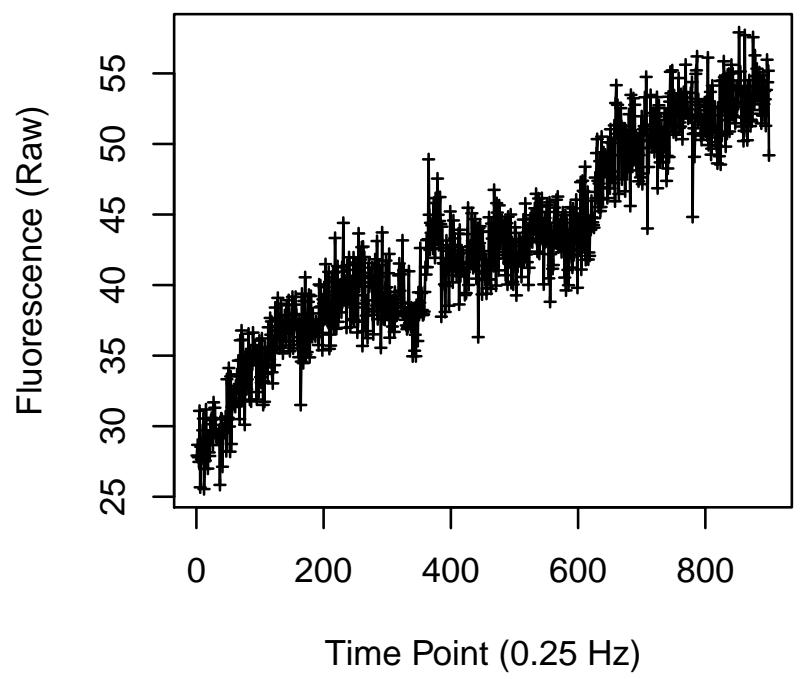


Cell 637

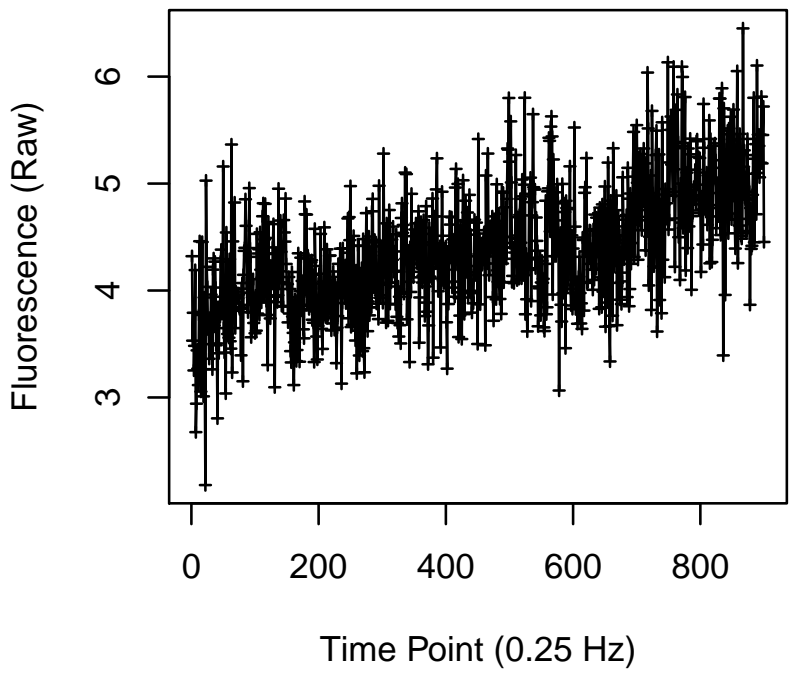

Cell 639

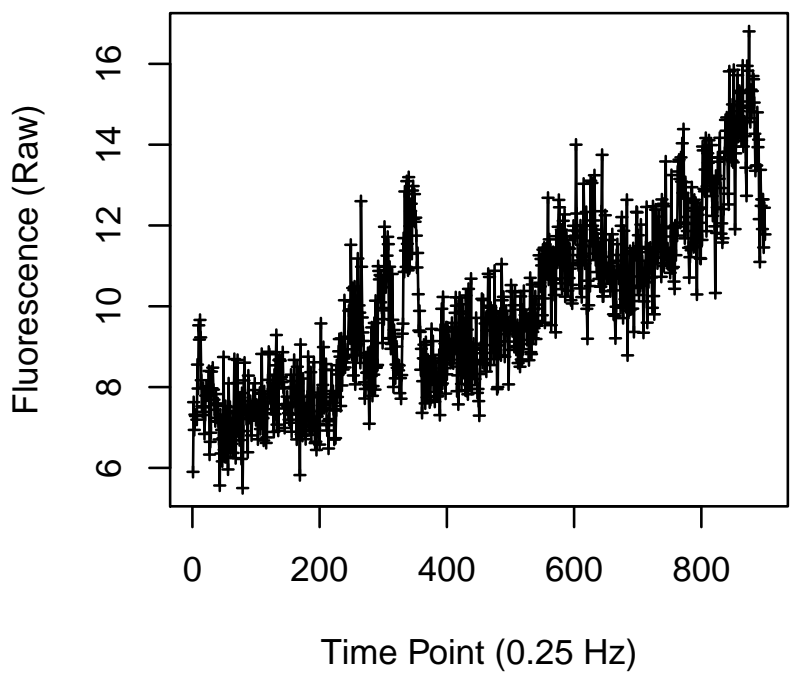

Cell 638

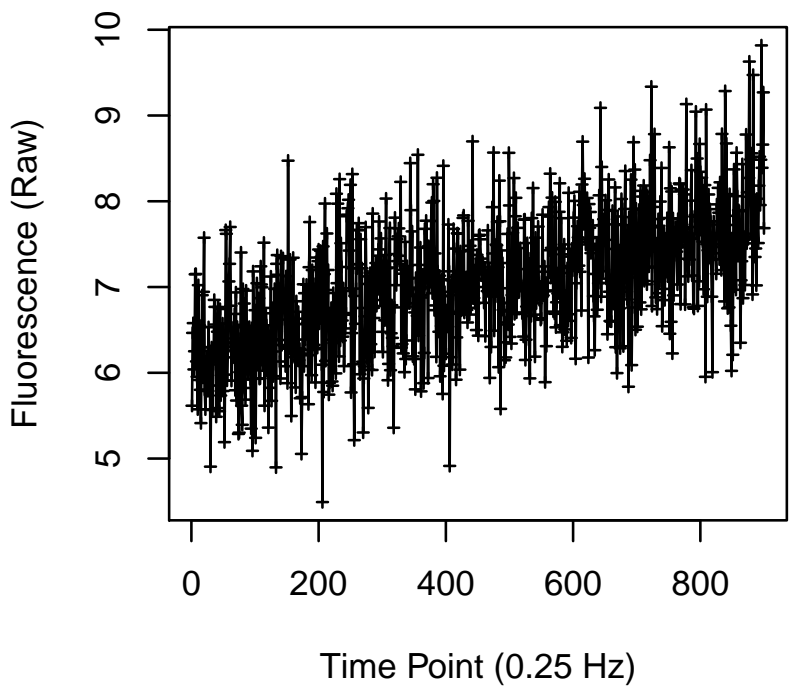

Cell 640

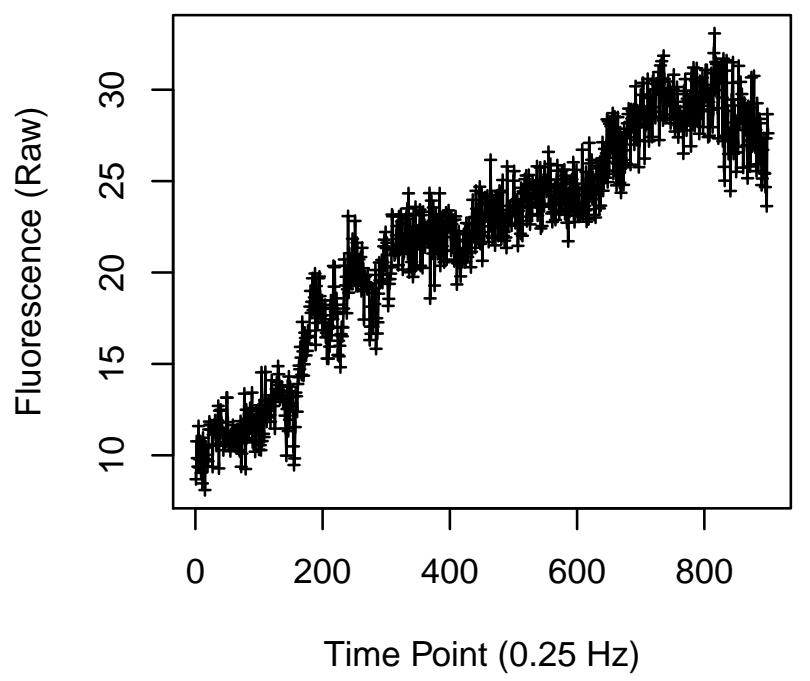


Cell 641

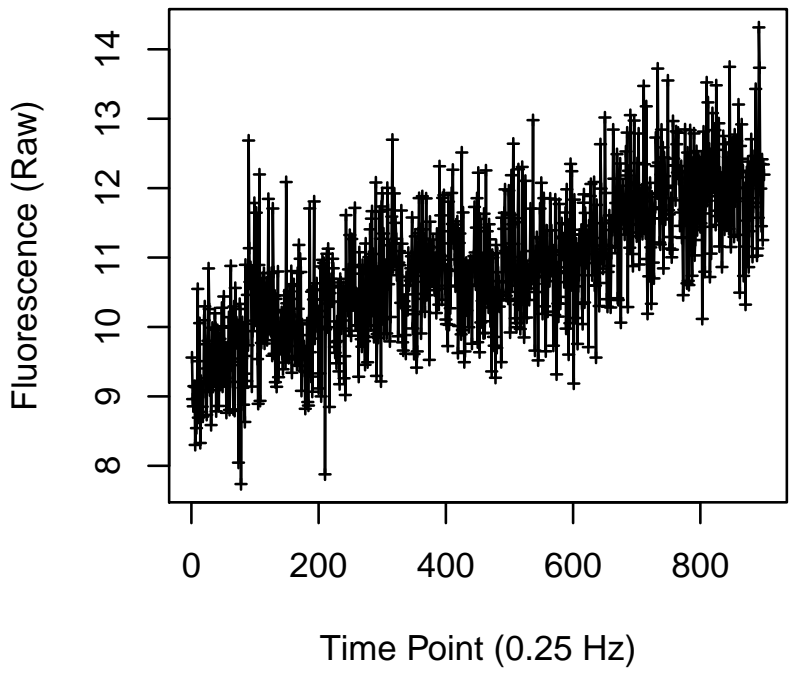

Cell 643

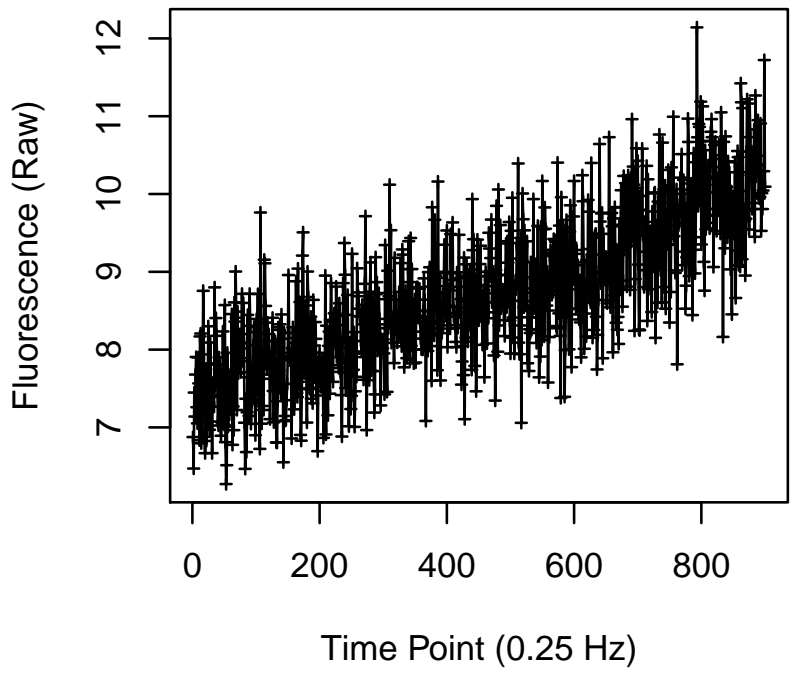

Cell 642

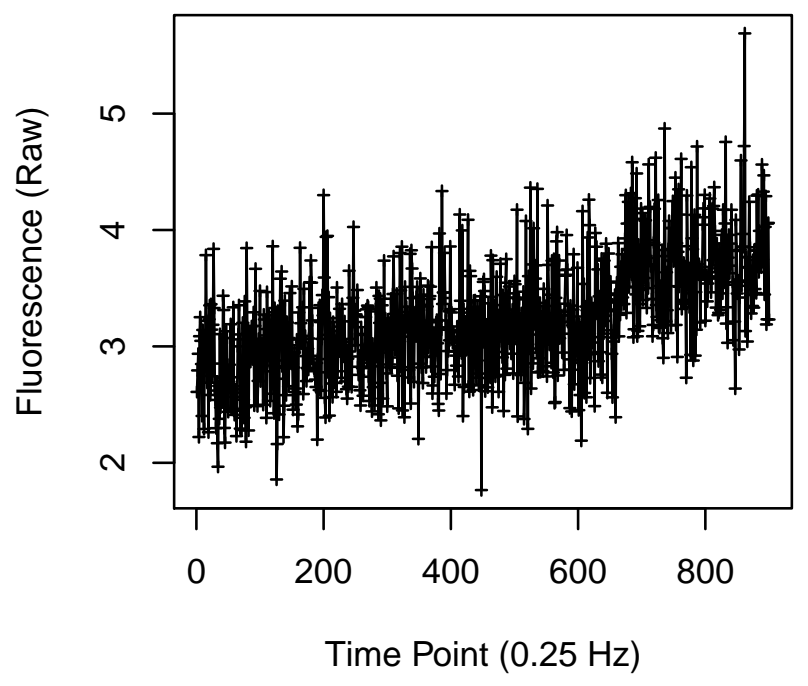

Cell 644

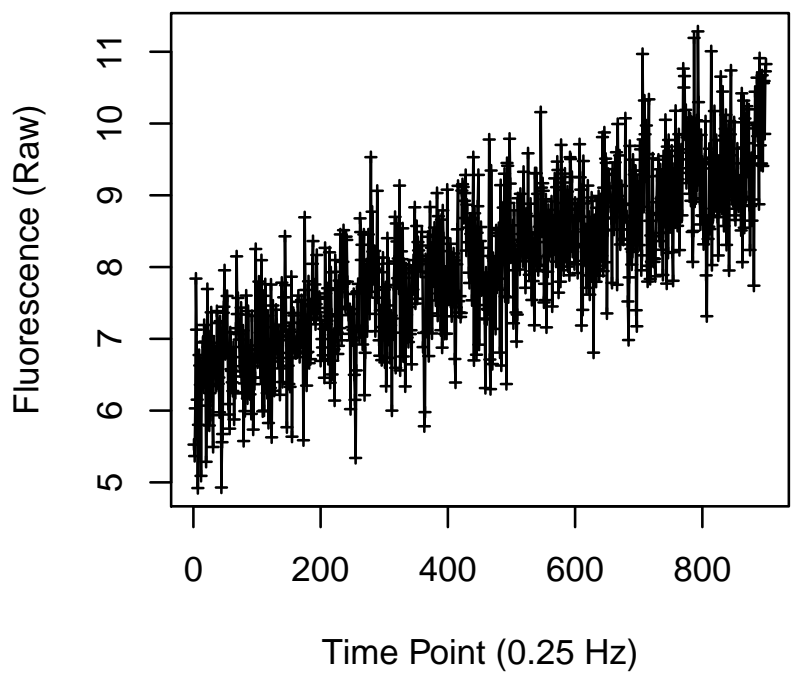




\section{Cell 645}

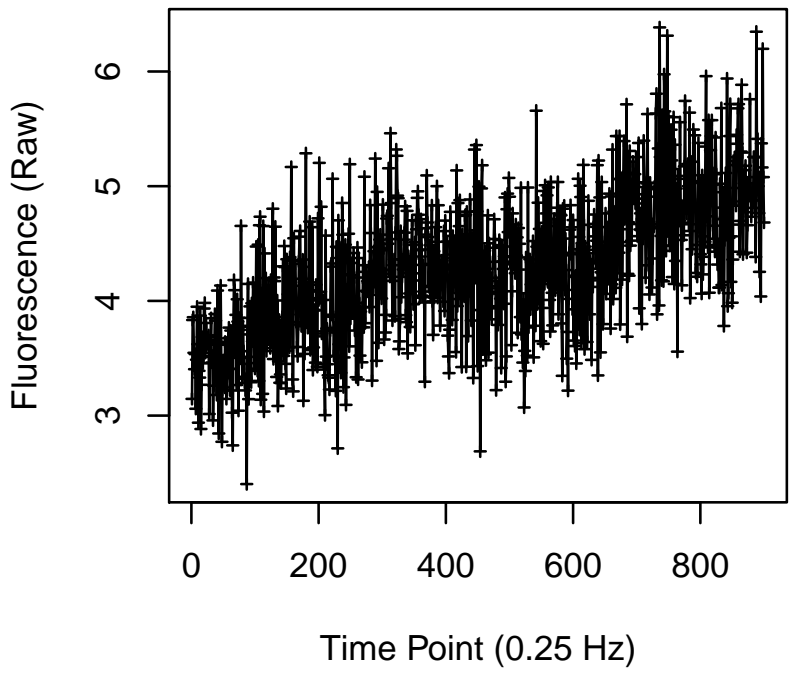

Cell 647

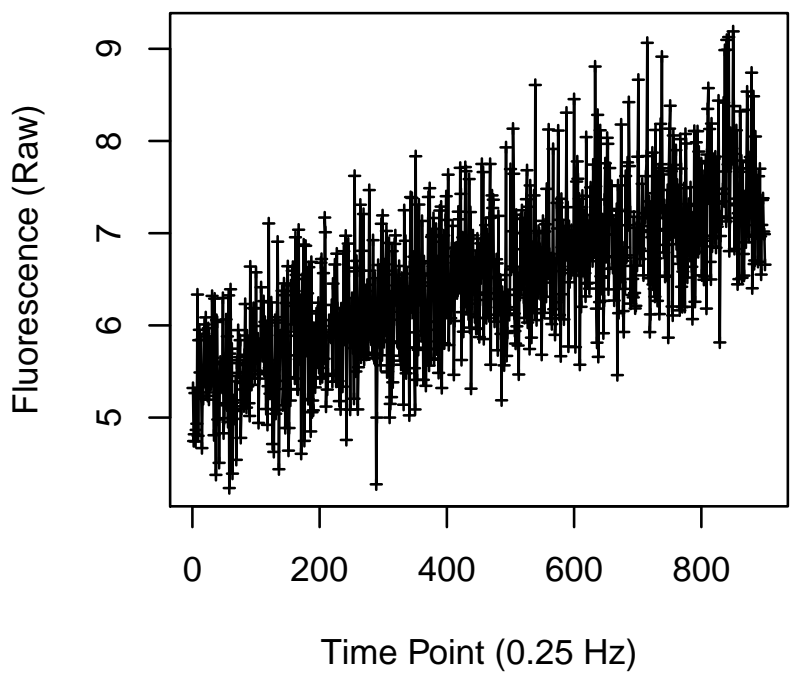

Cell 646

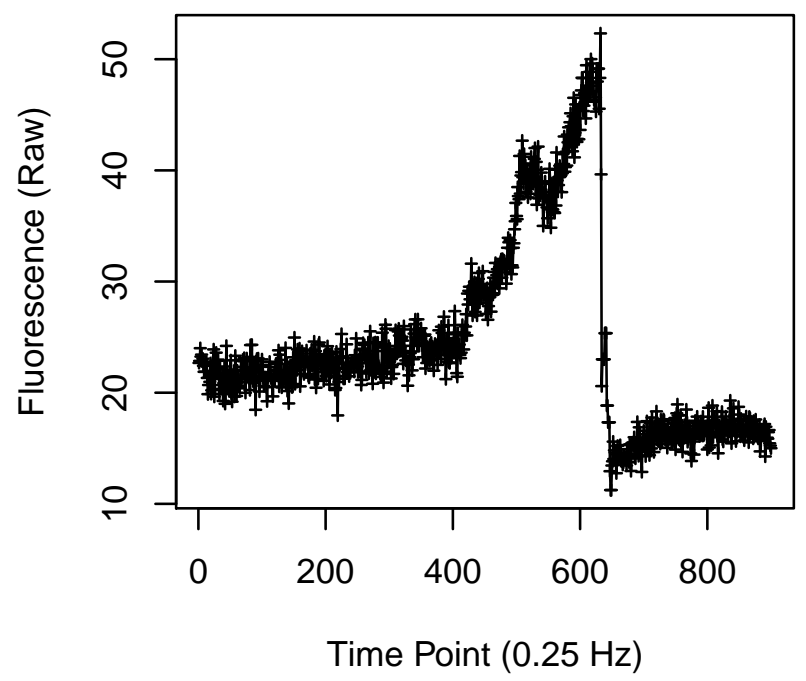

Cell 648

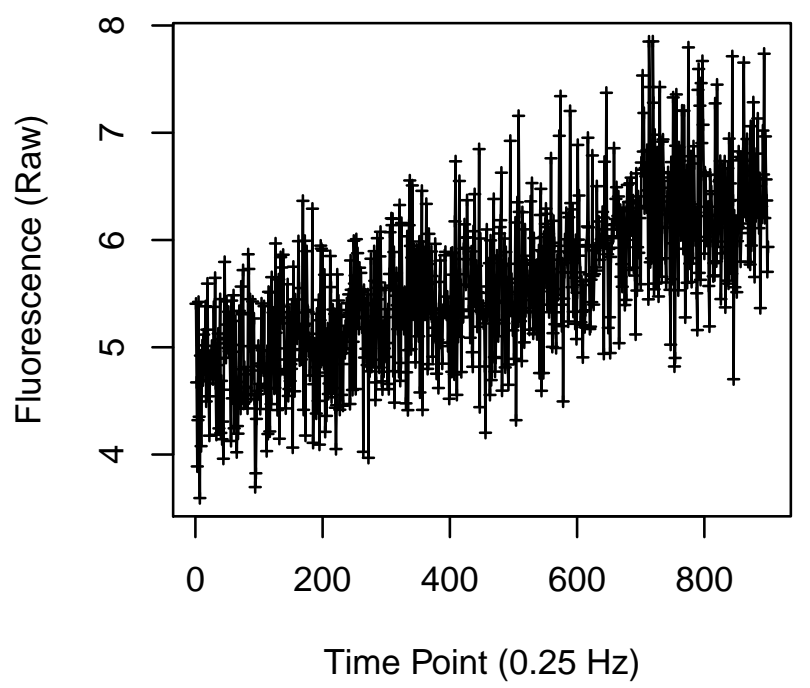




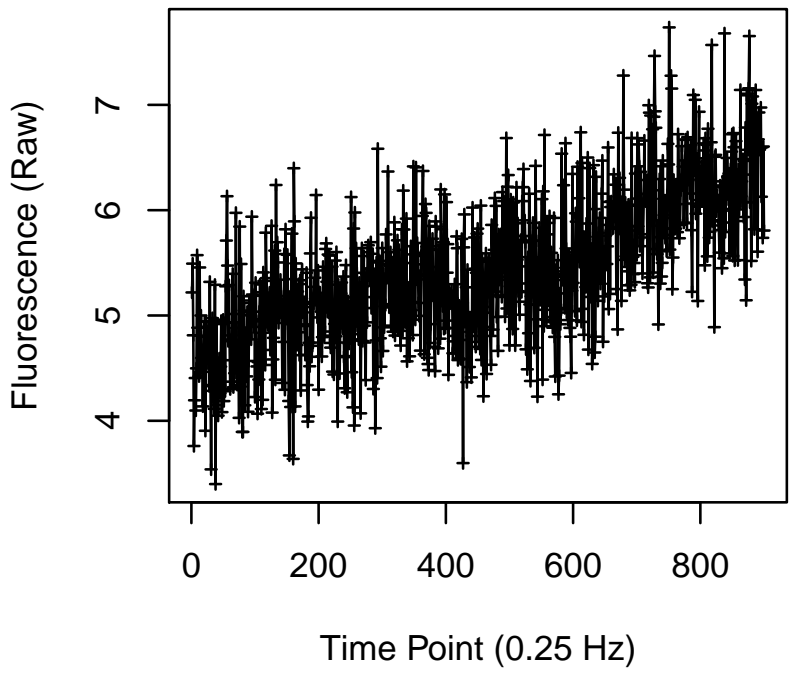

Cell 651

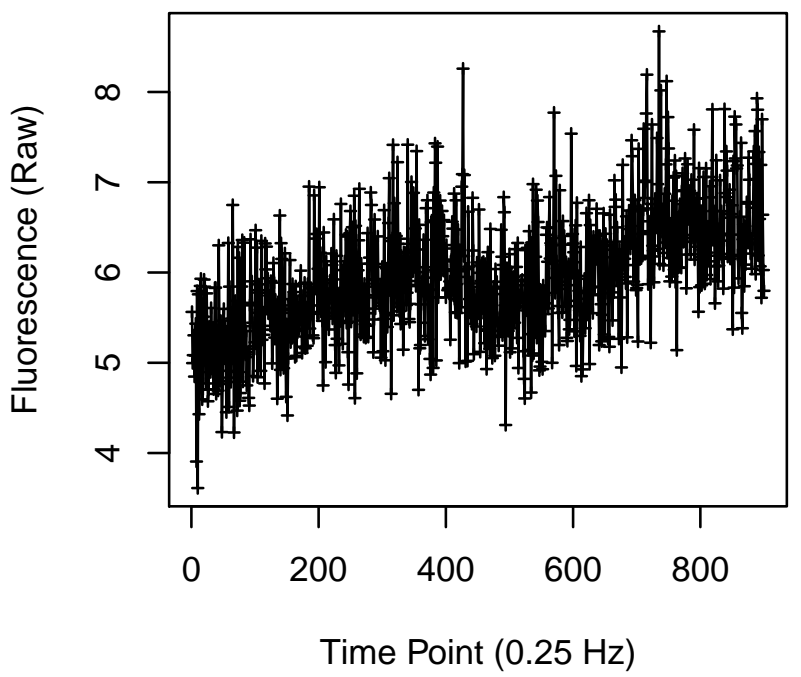

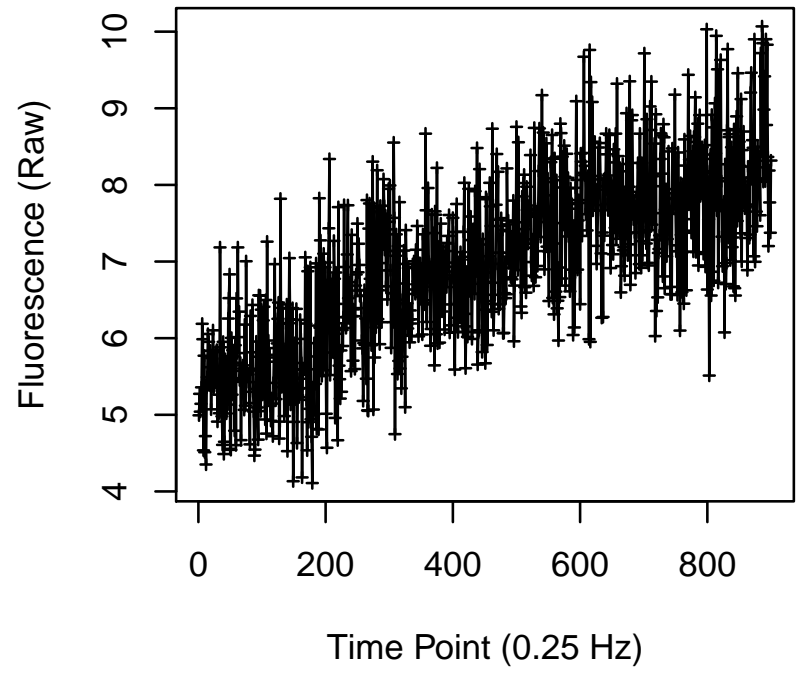

Cell 652

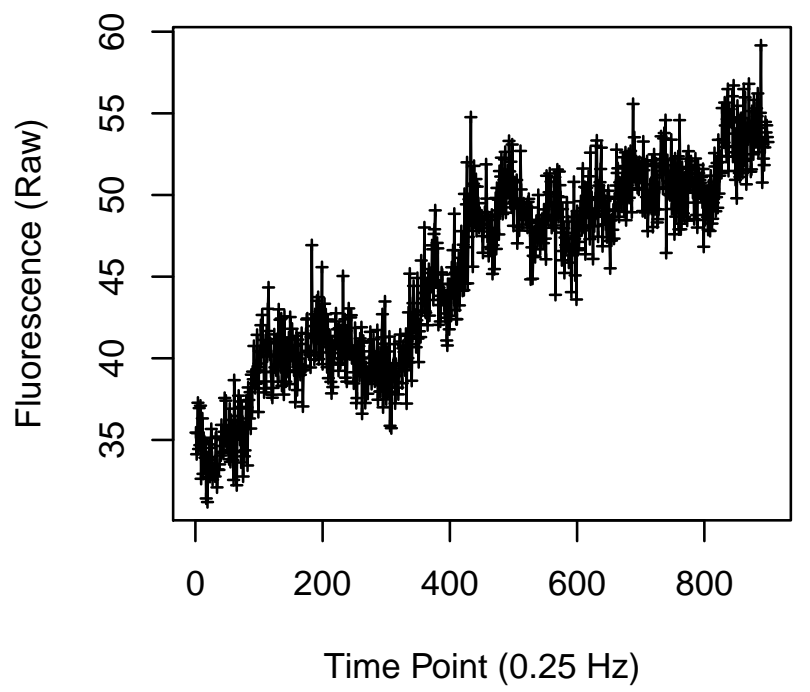


Cell 657

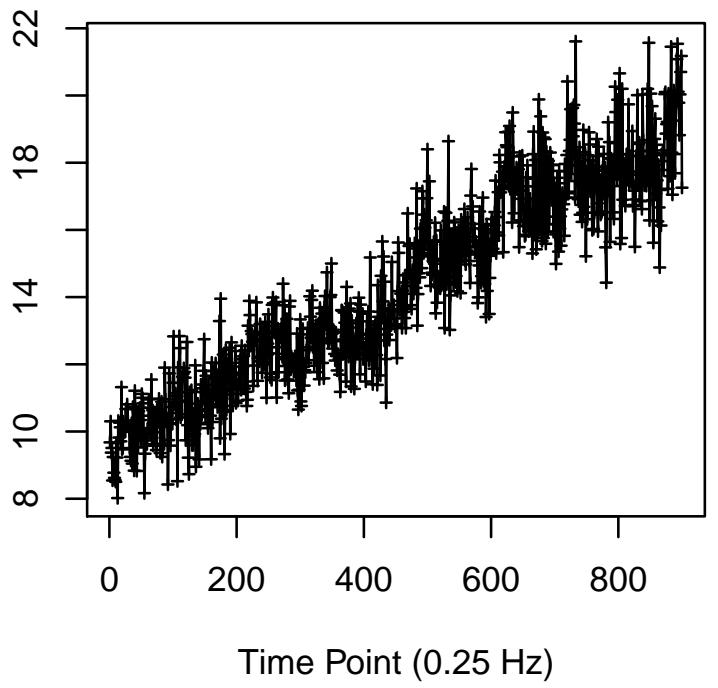

Cell 659

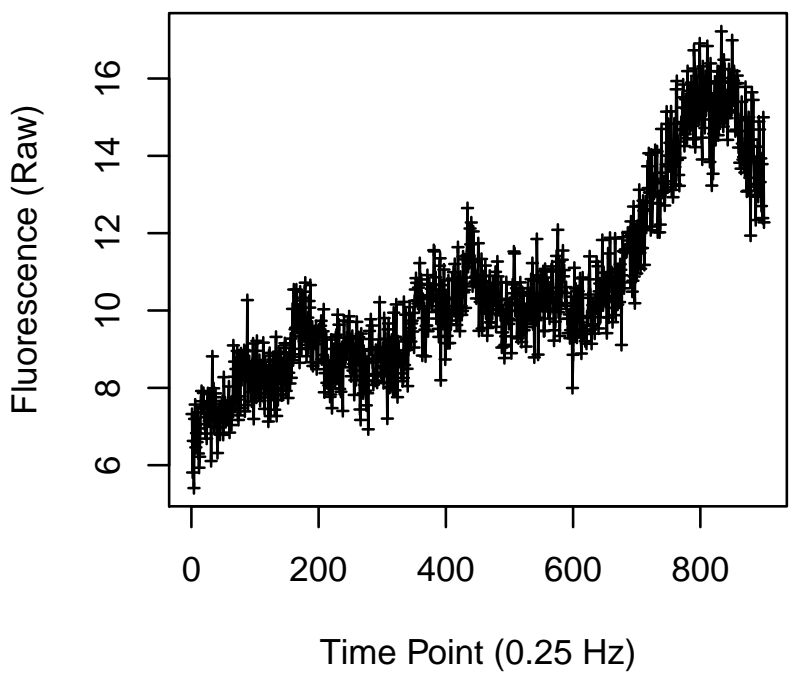

Cell 658

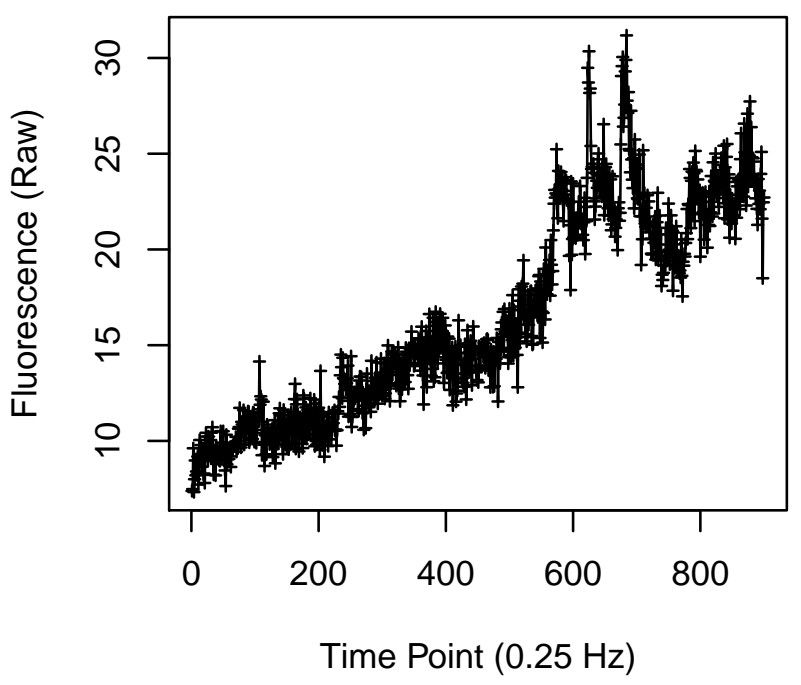

Cell 660

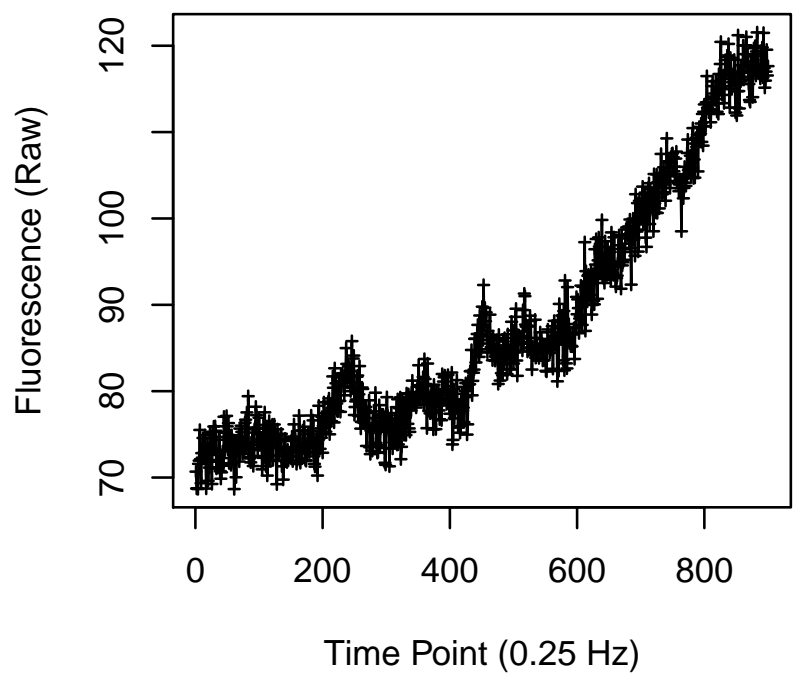


Cell 661

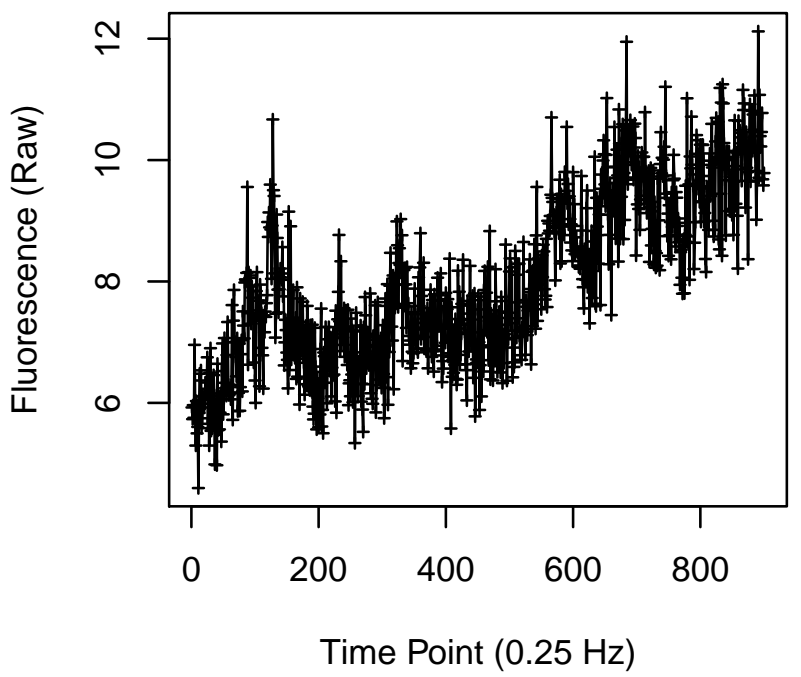

Cell 663

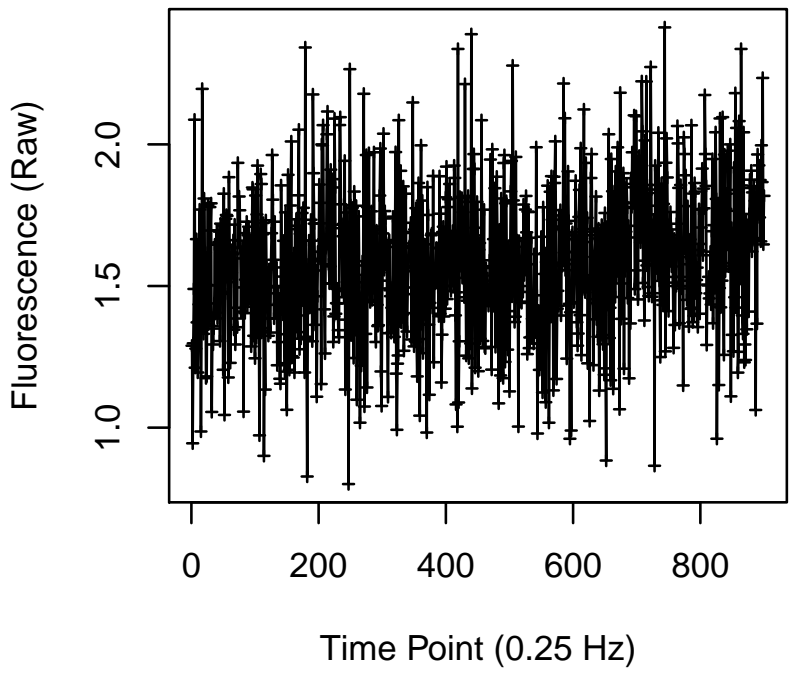

Cell 662

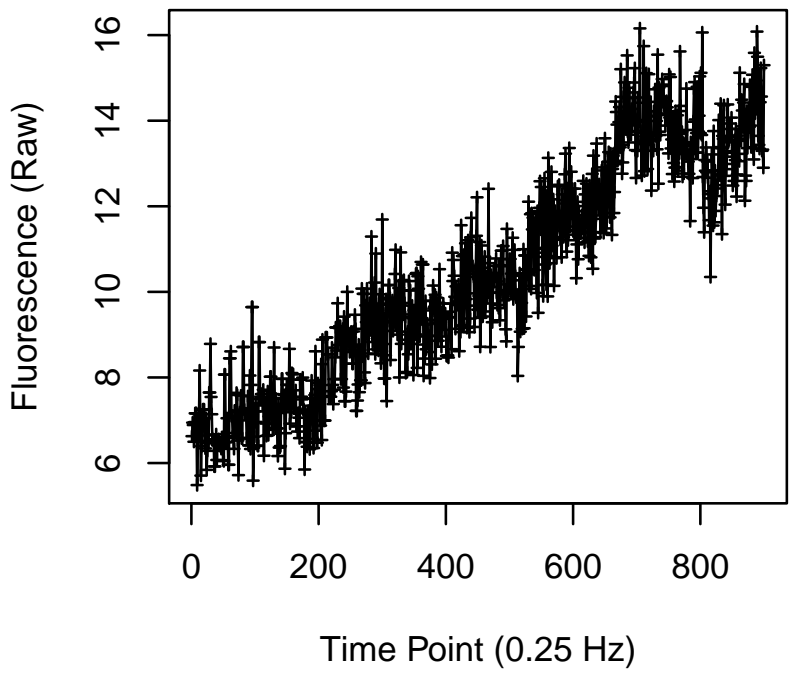

Cell 664

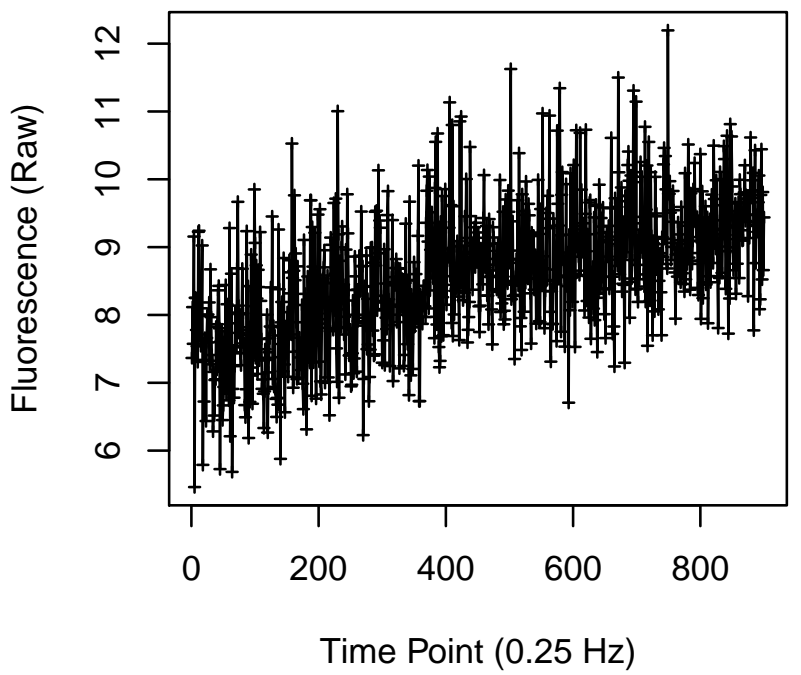




\section{Cell 669}

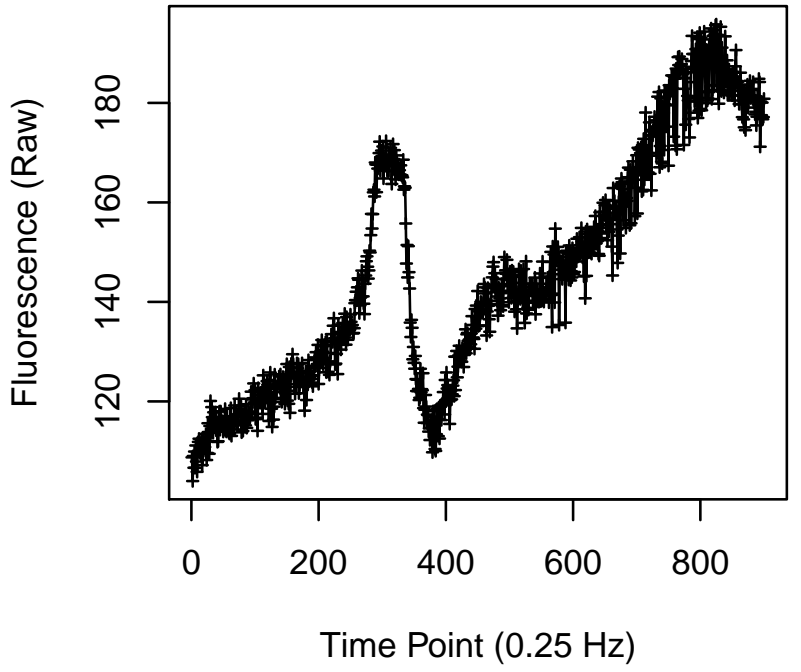

Cell 671

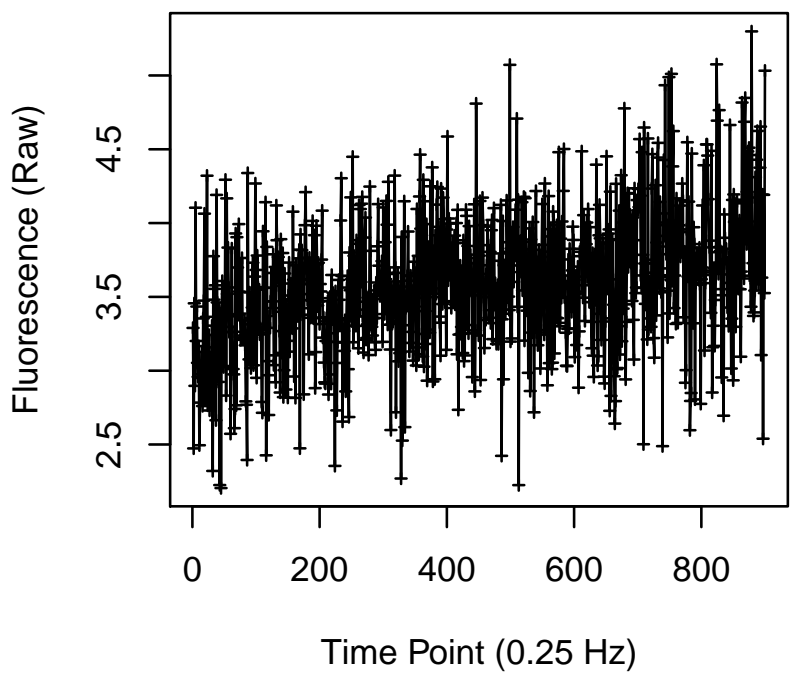

Cell 670

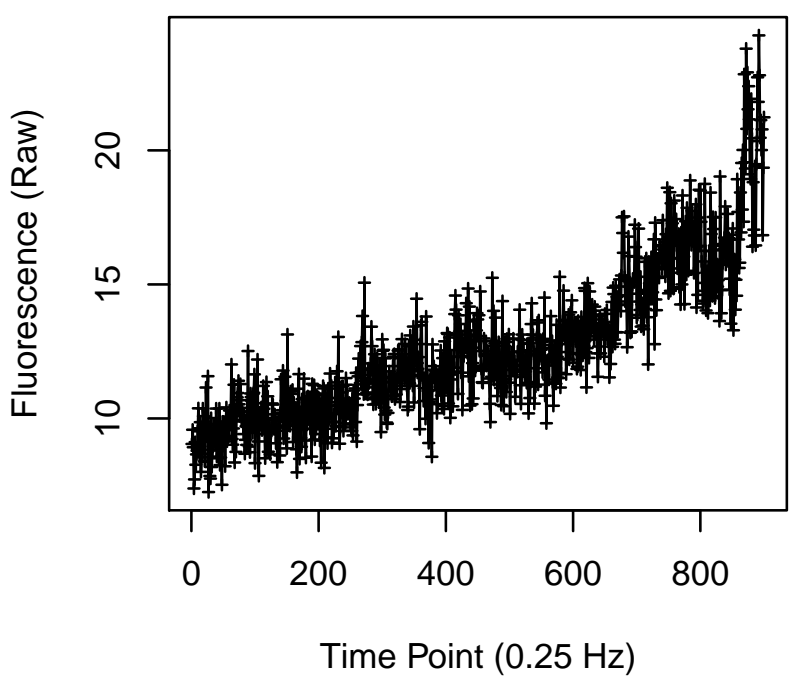

Cell 672

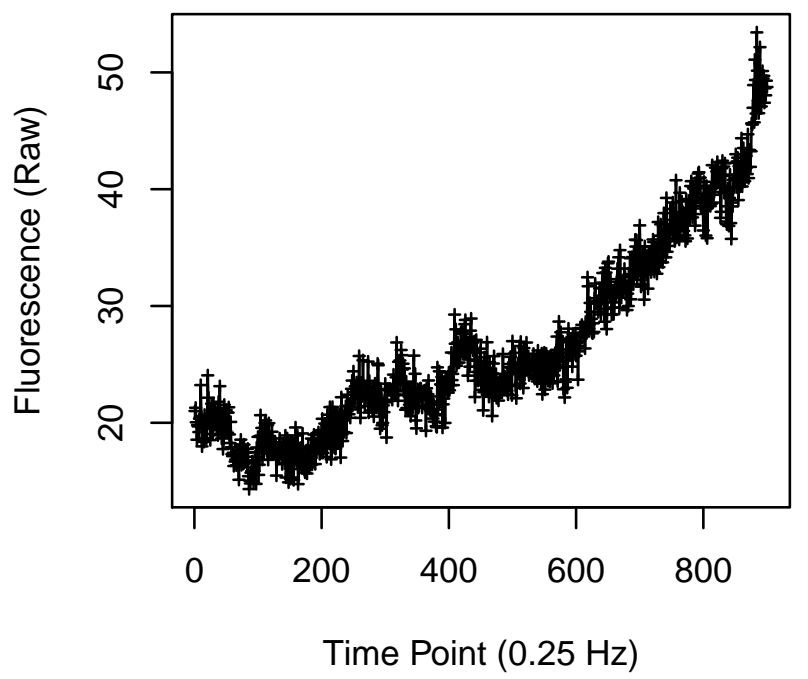




\section{Cell 673}

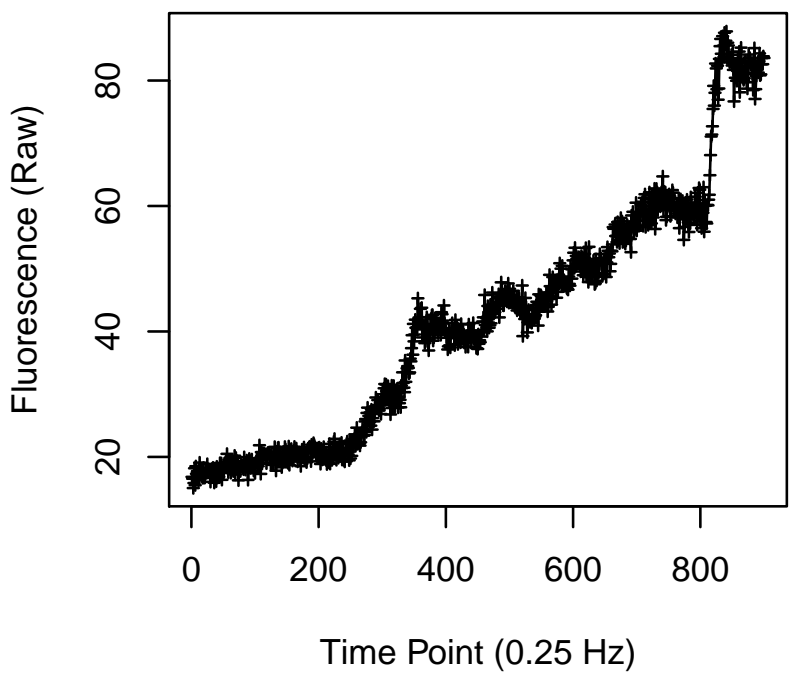

Cell 675

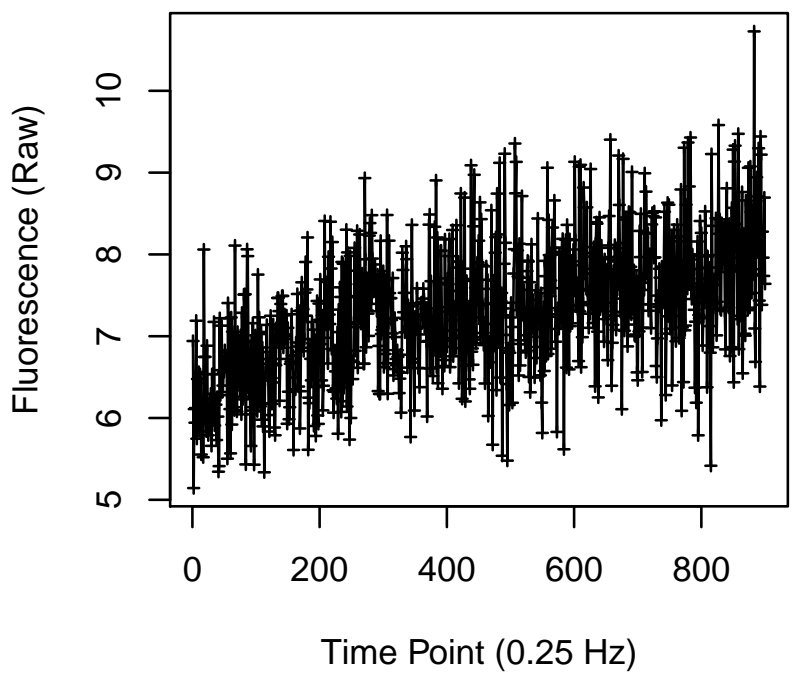

Cell 674

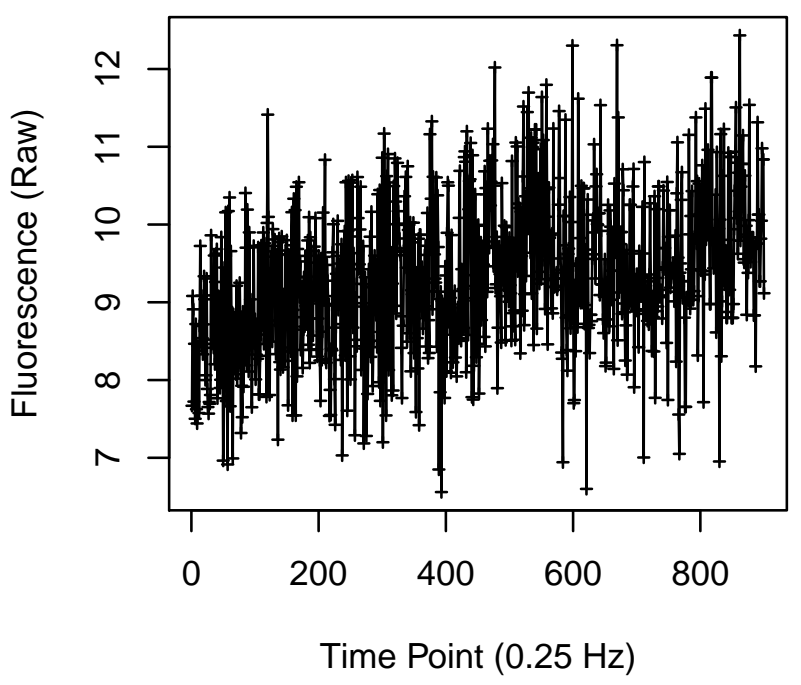

Cell 676

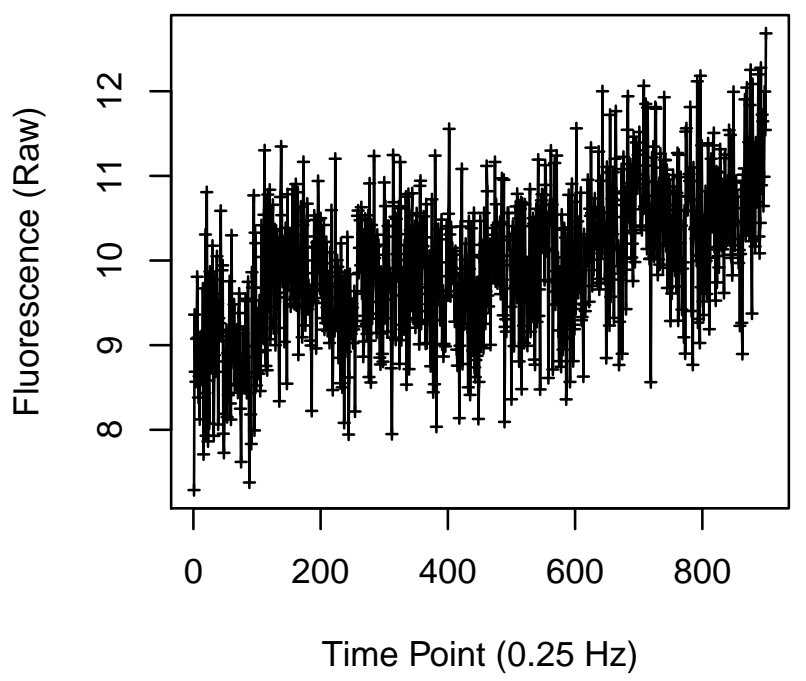


Cell 677

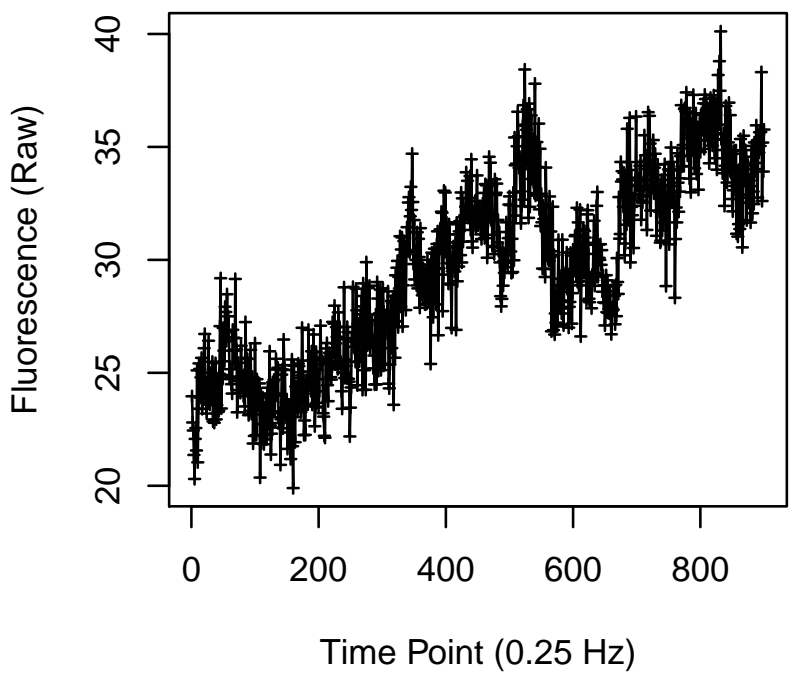

Cell 679

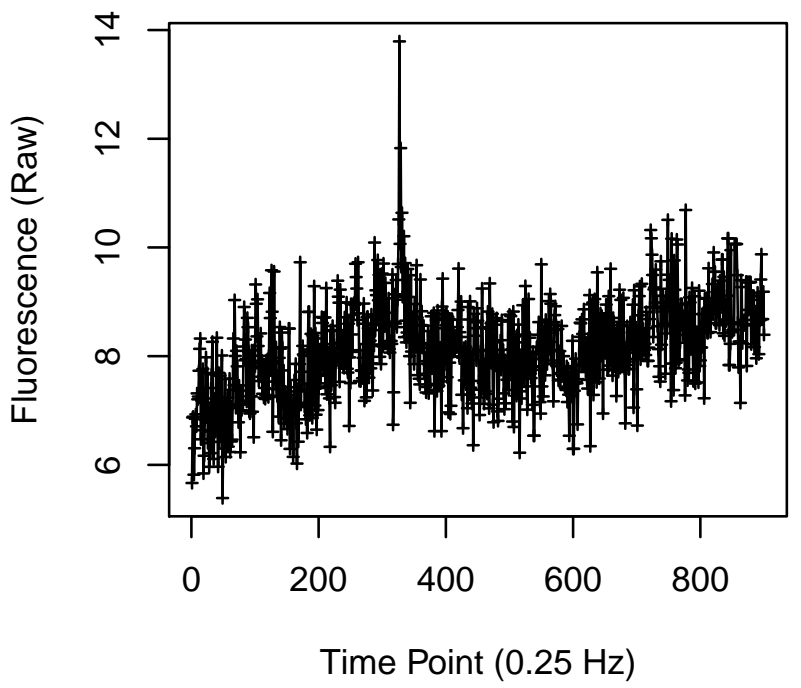

Cell 678

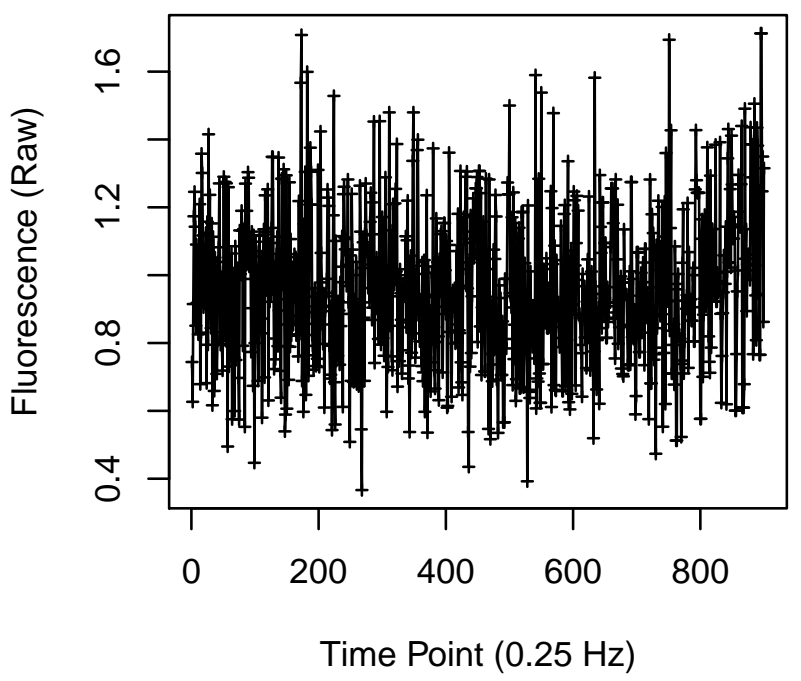

Cell 680

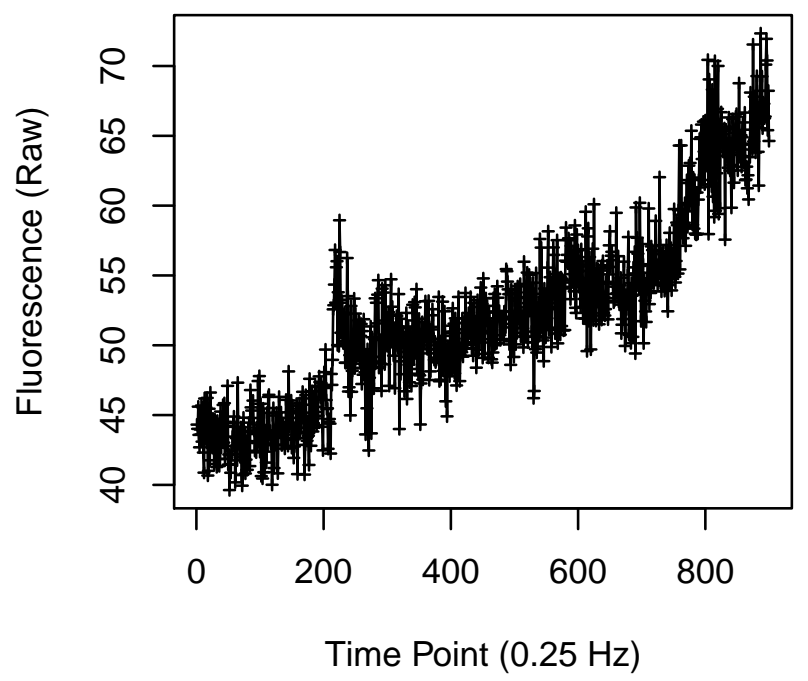


Cell 681

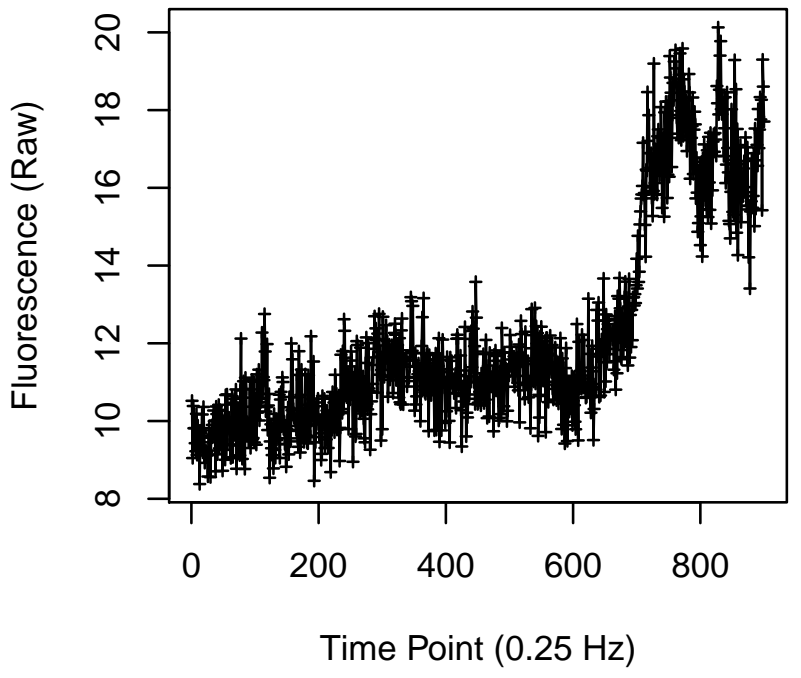

Cell 683

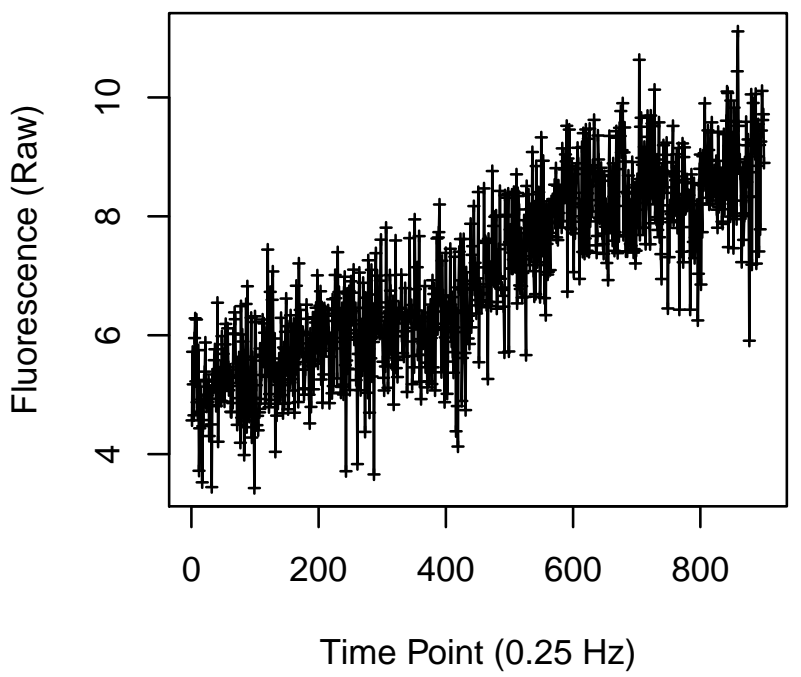

Cell 682

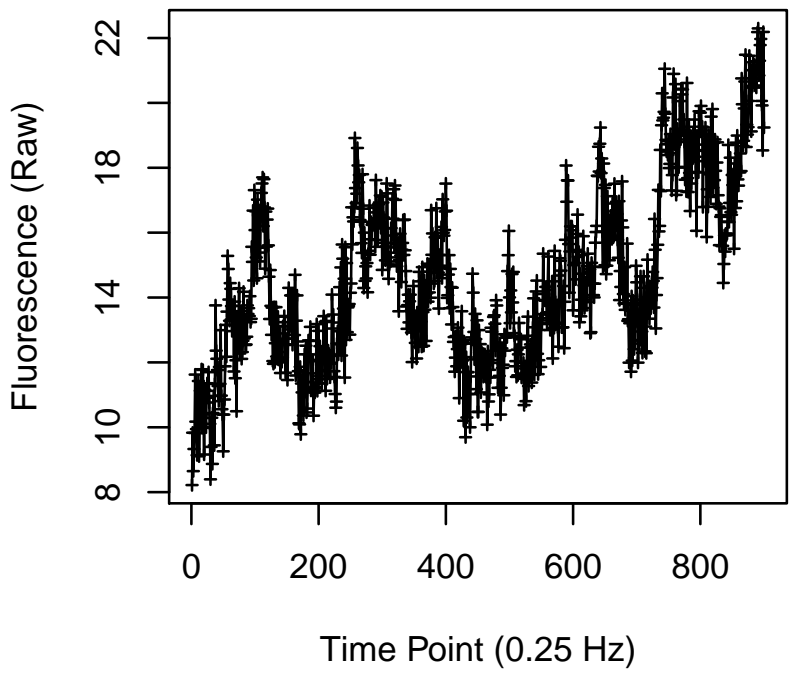

Cell 684

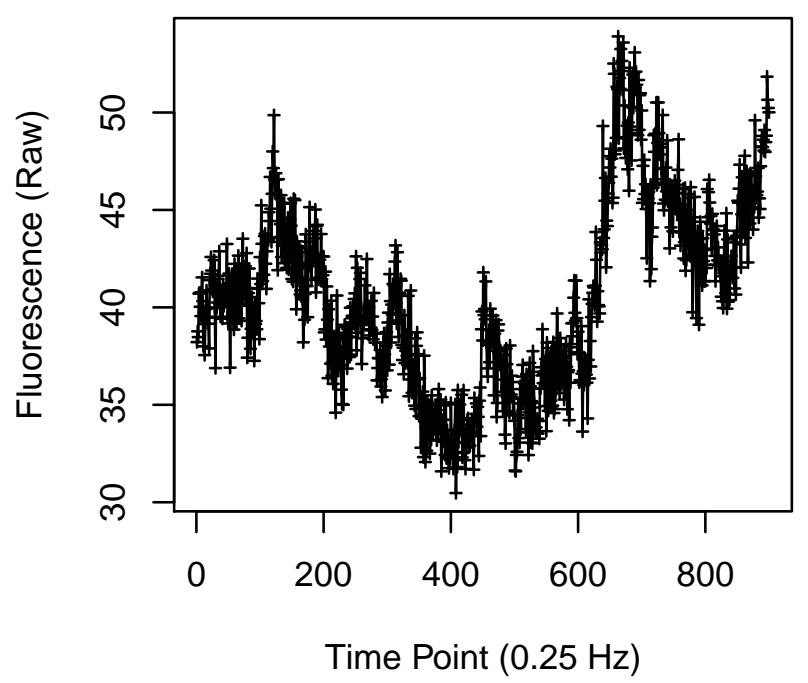




\section{Cell 685}

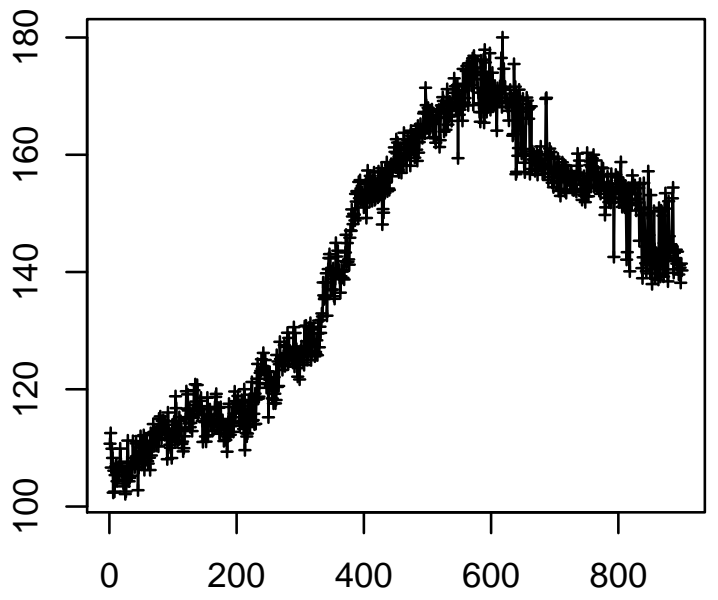

Time Point $(0.25 \mathrm{~Hz})$

Cell 687

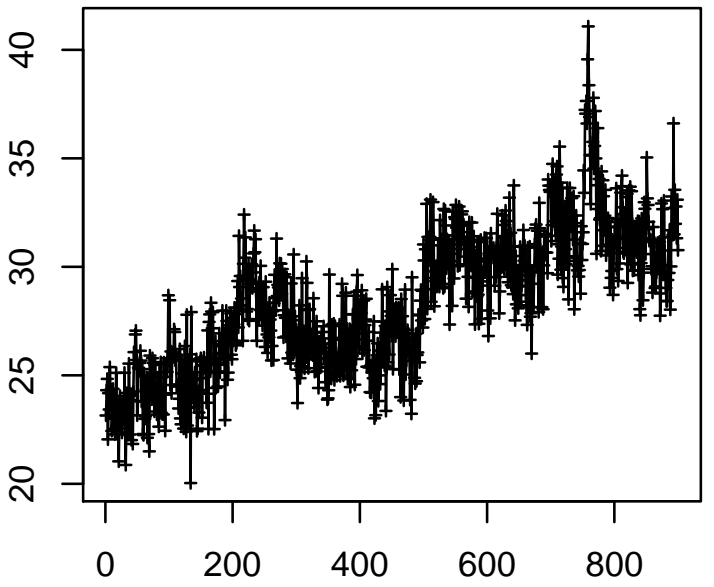

Time Point $(0.25 \mathrm{~Hz})$
Cell 686

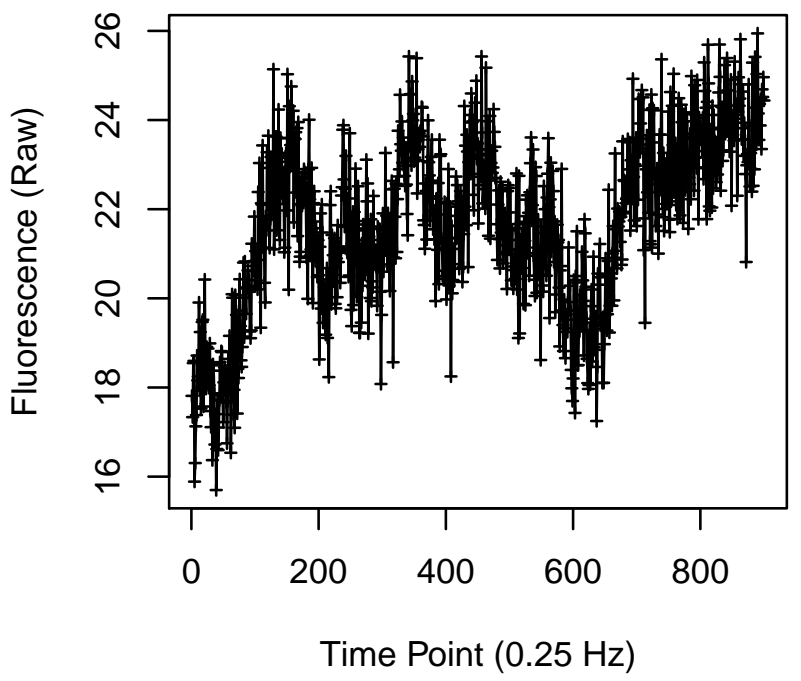

Cell 688

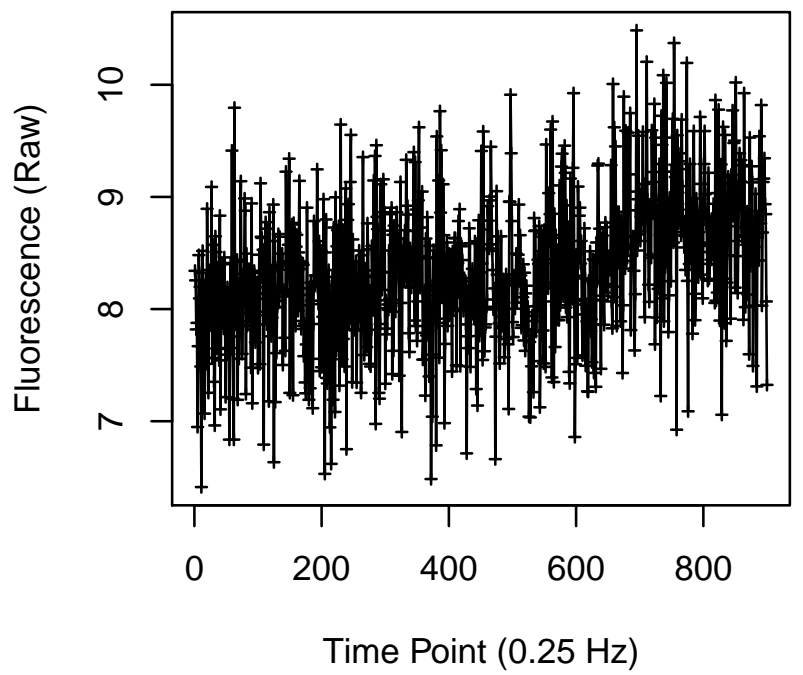


Cell 689

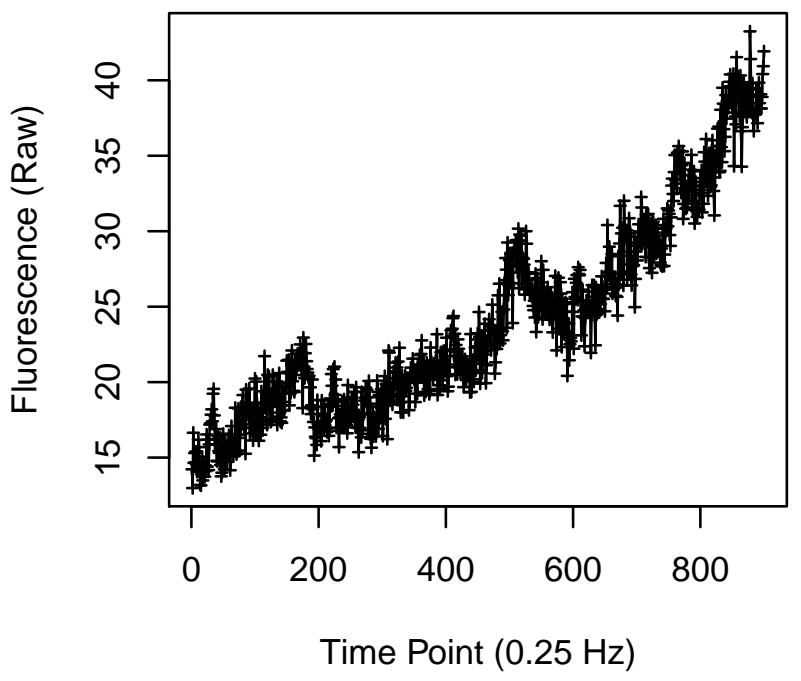

Cell 691

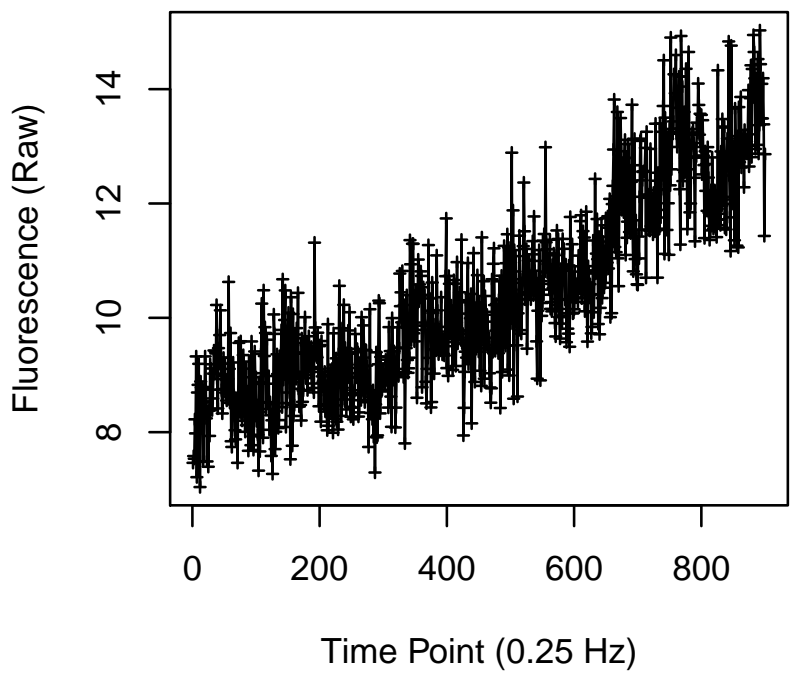

Cell 690

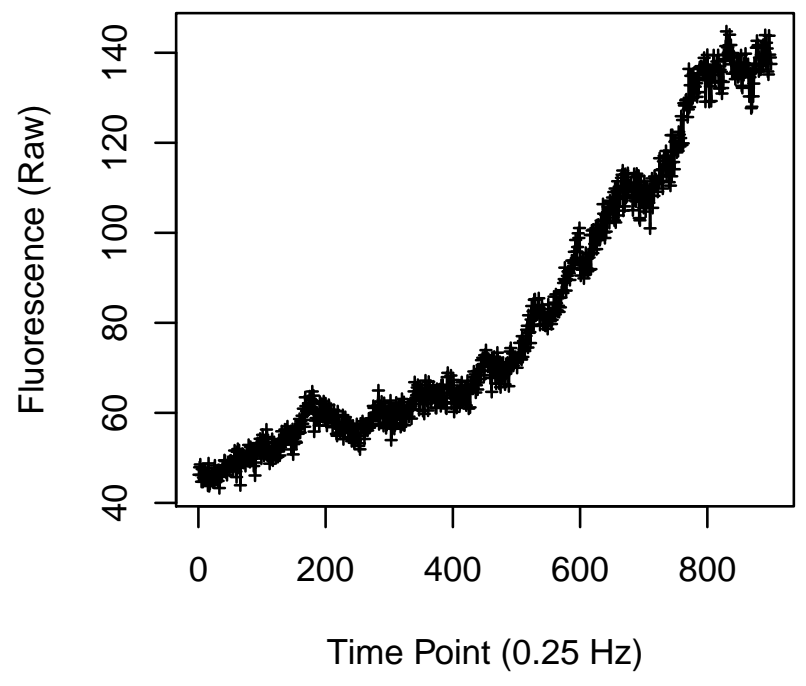

Cell 692

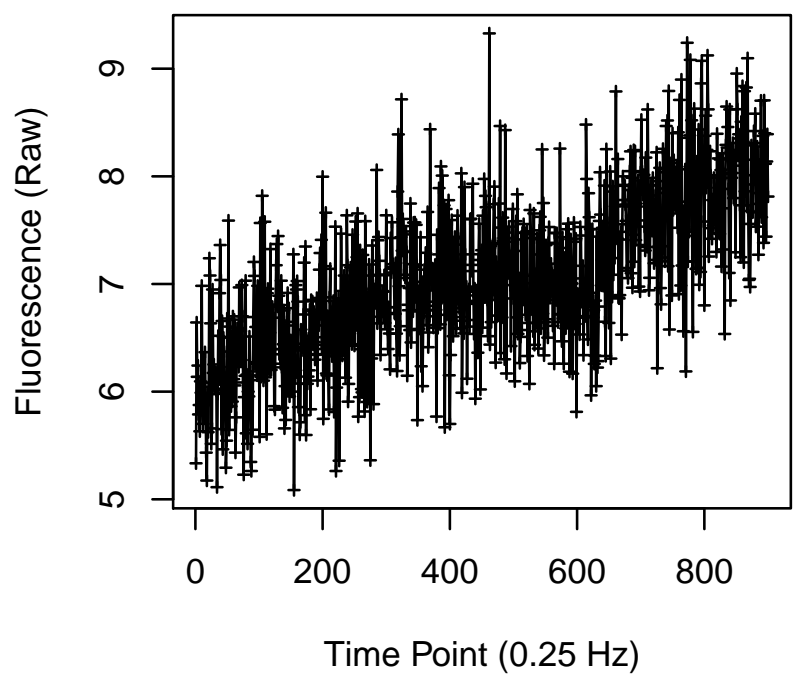


Cell 693

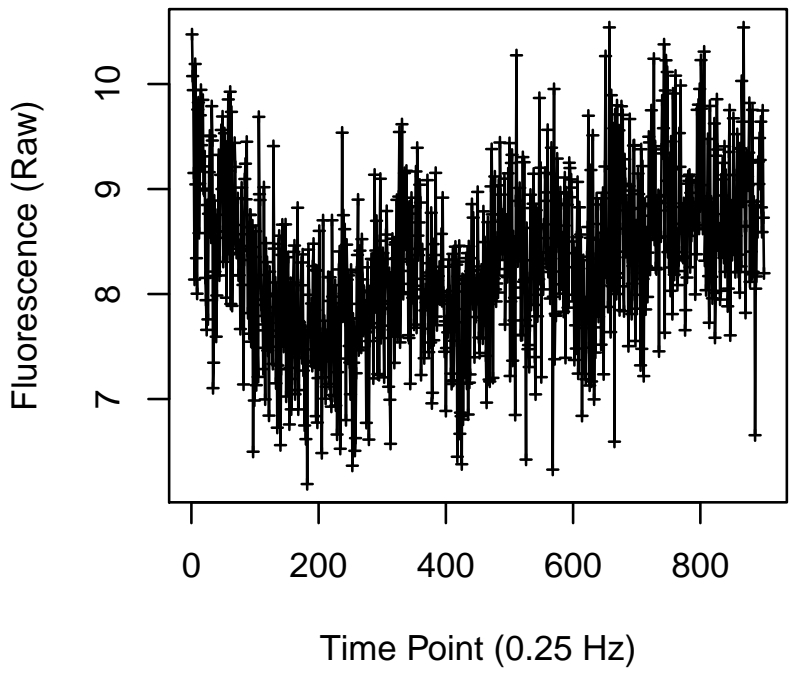

Cell 695

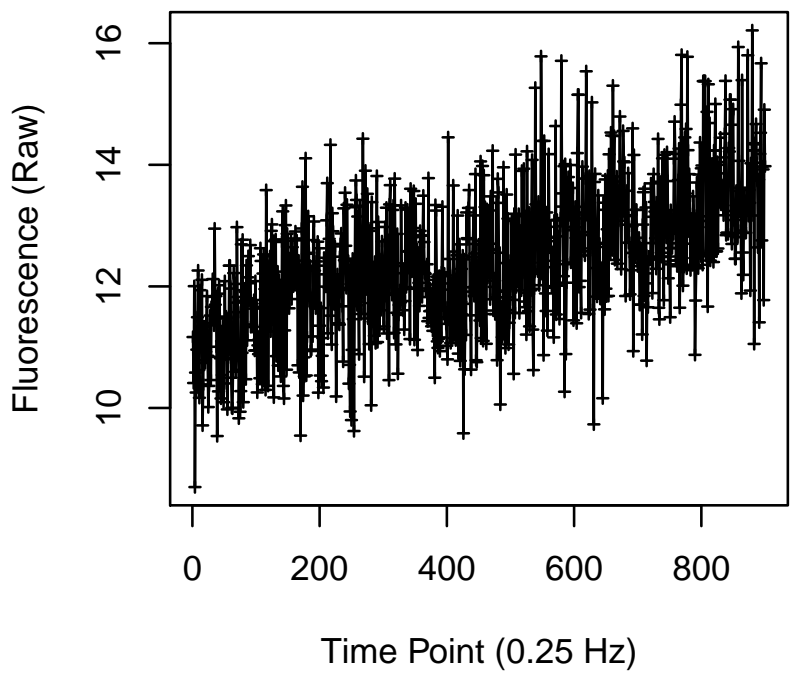

Cell 694

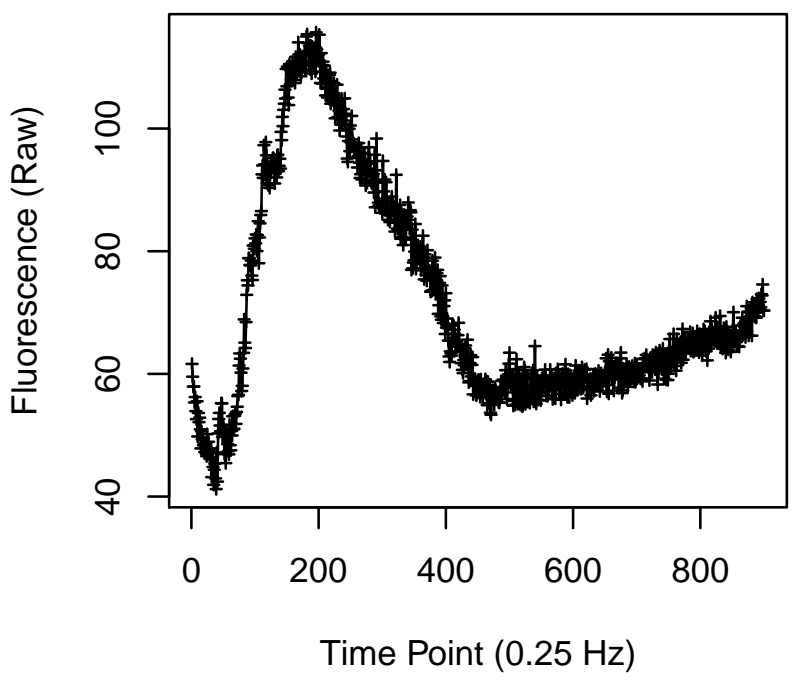

Cell 696

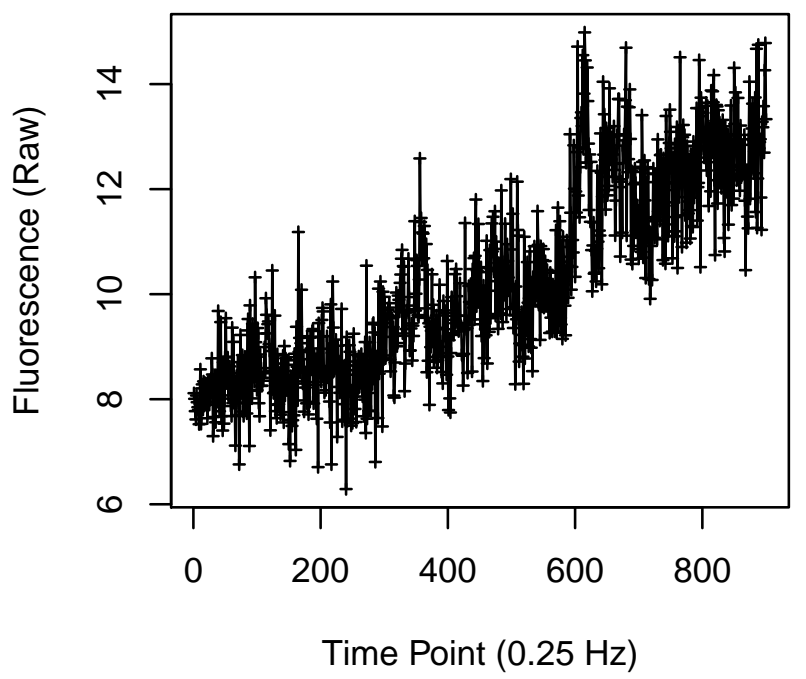




\section{Cell 697}

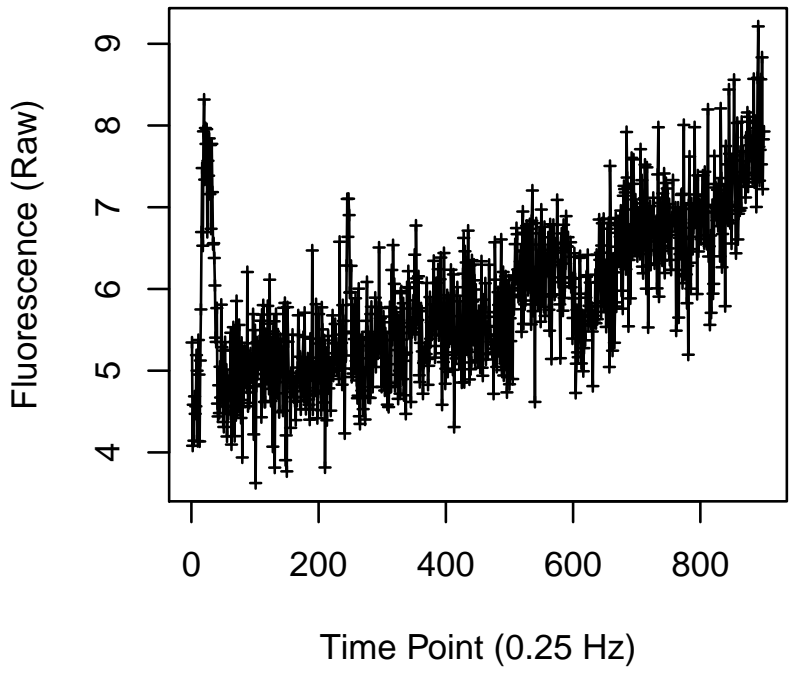

Cell 699

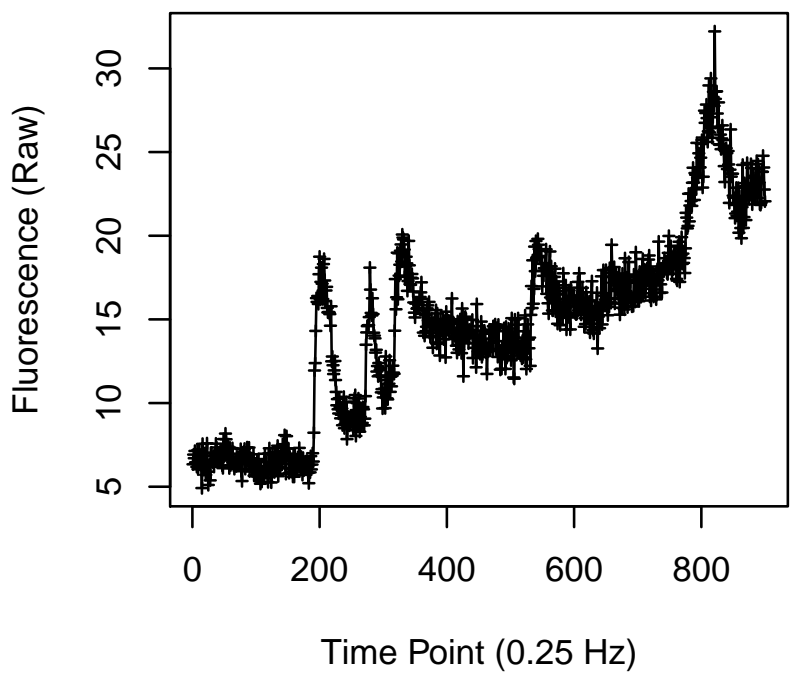

Cell 698

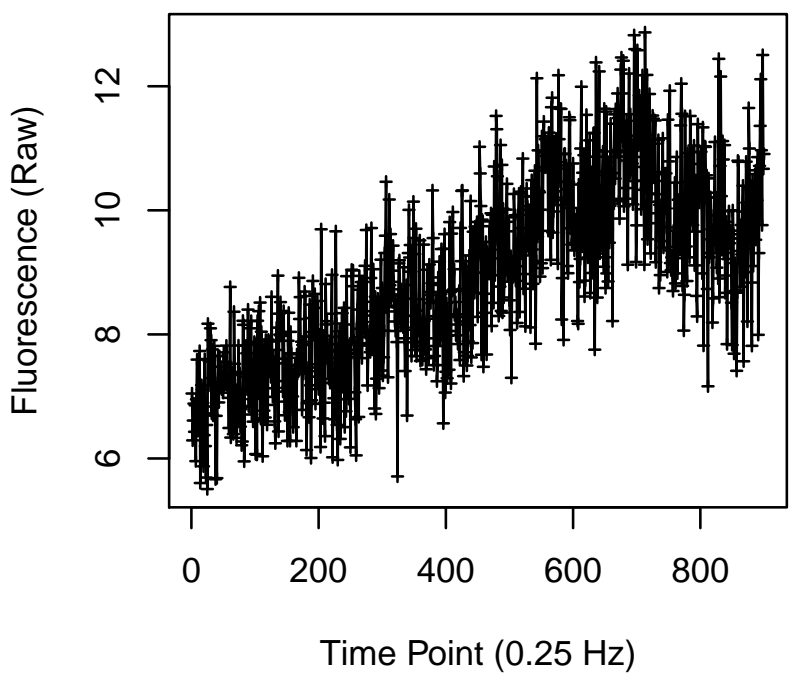

Cell 700

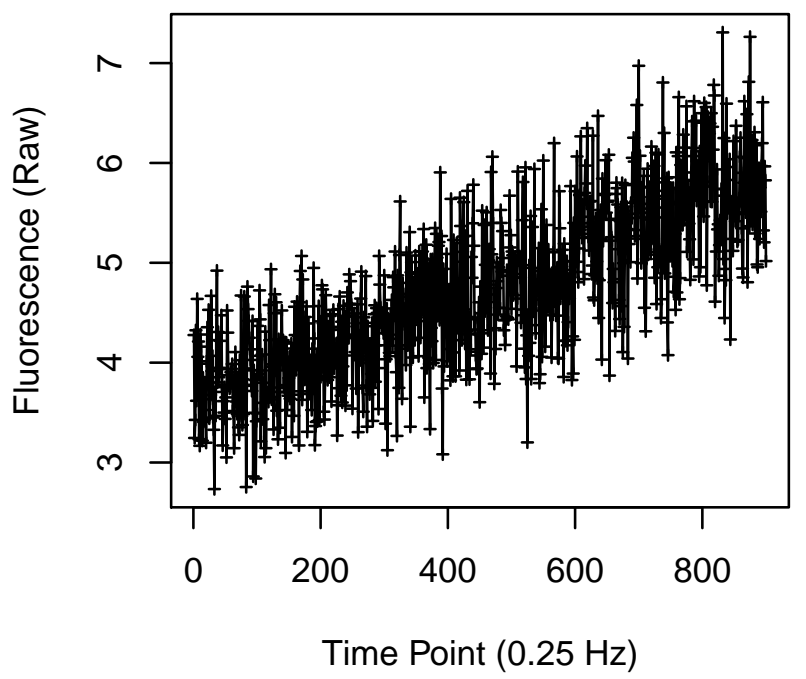


Cell 705

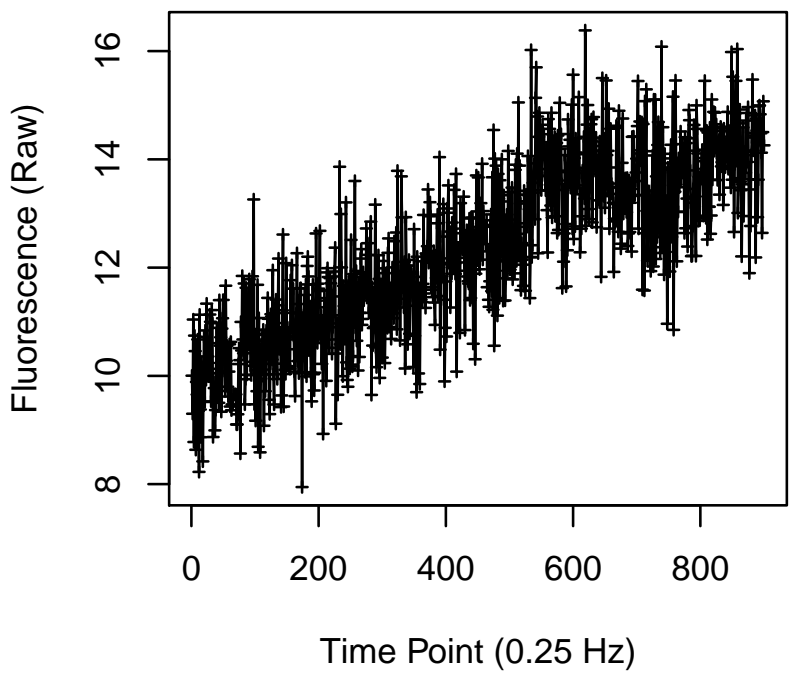

Cell 707

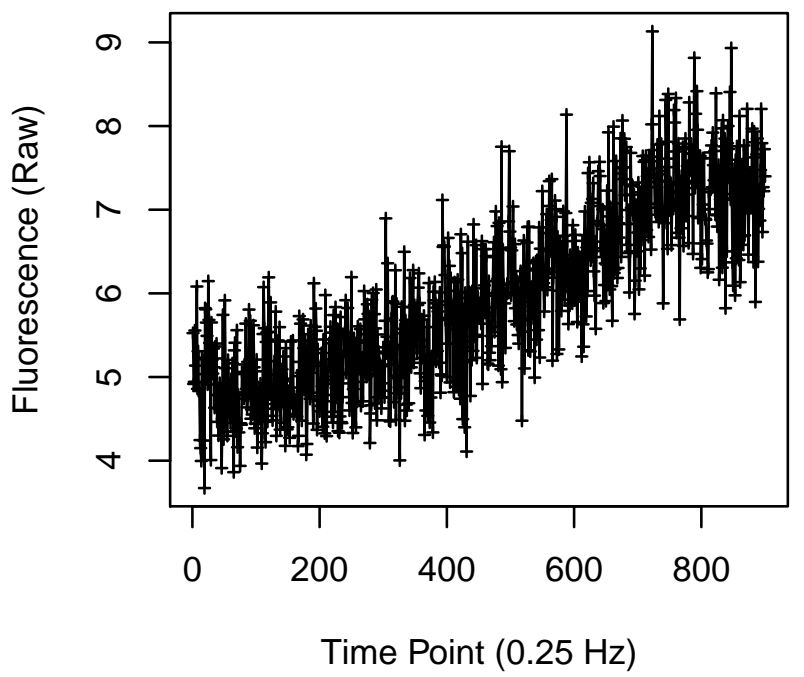

Cell 706

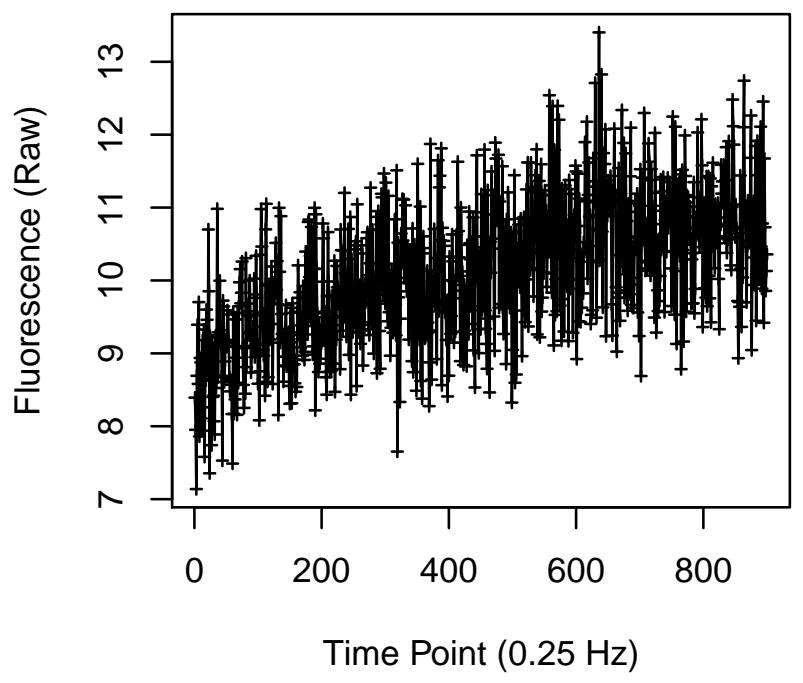

Cell 708

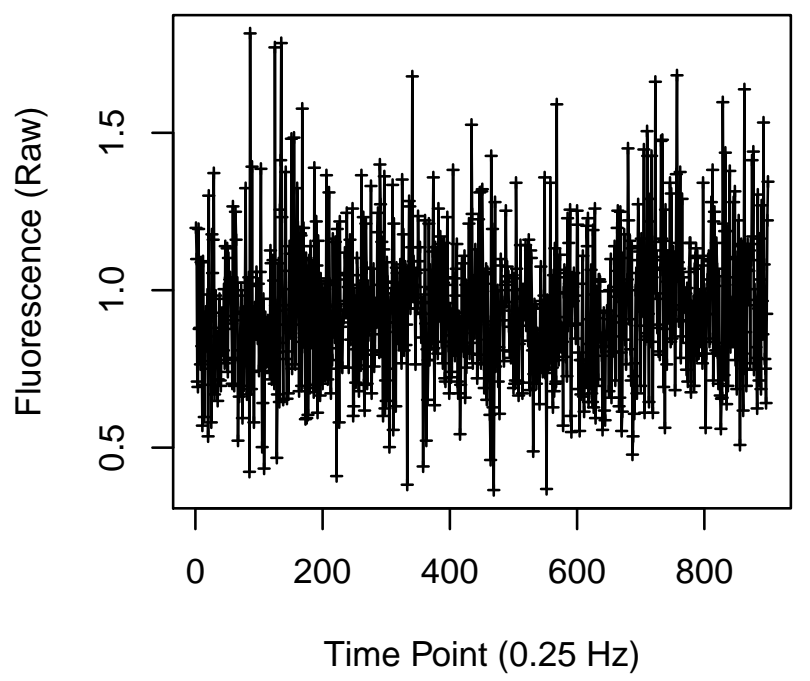




\section{Cell 713}

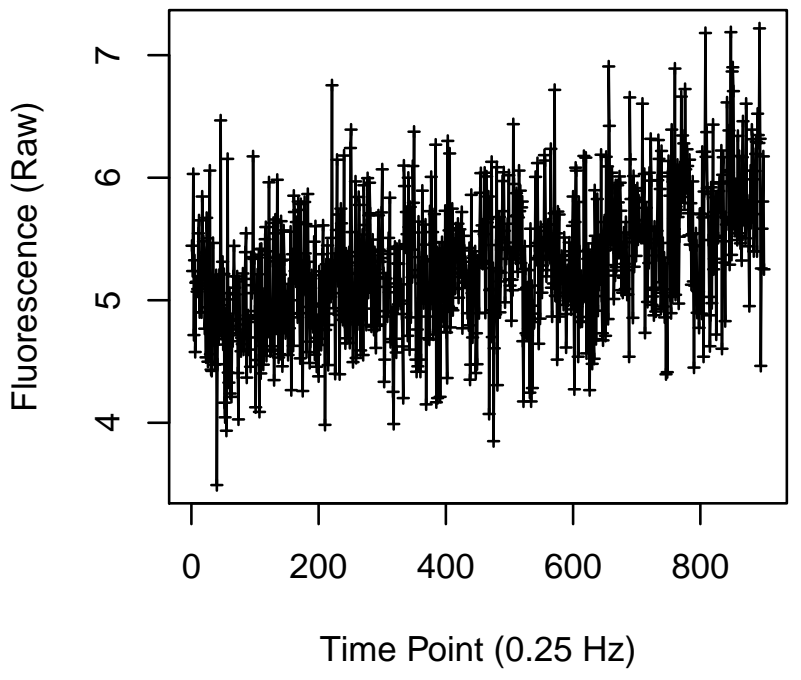

Cell 715

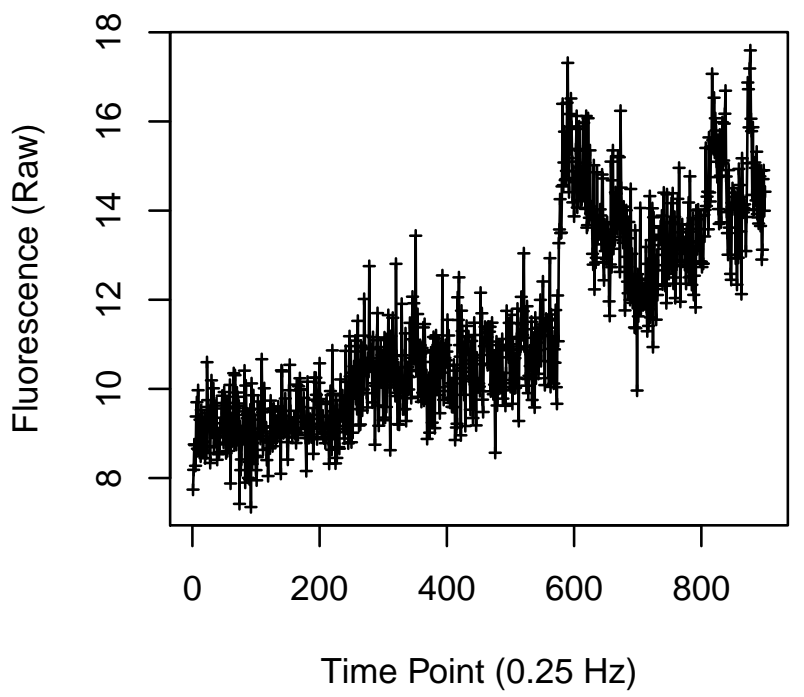

Cell 714

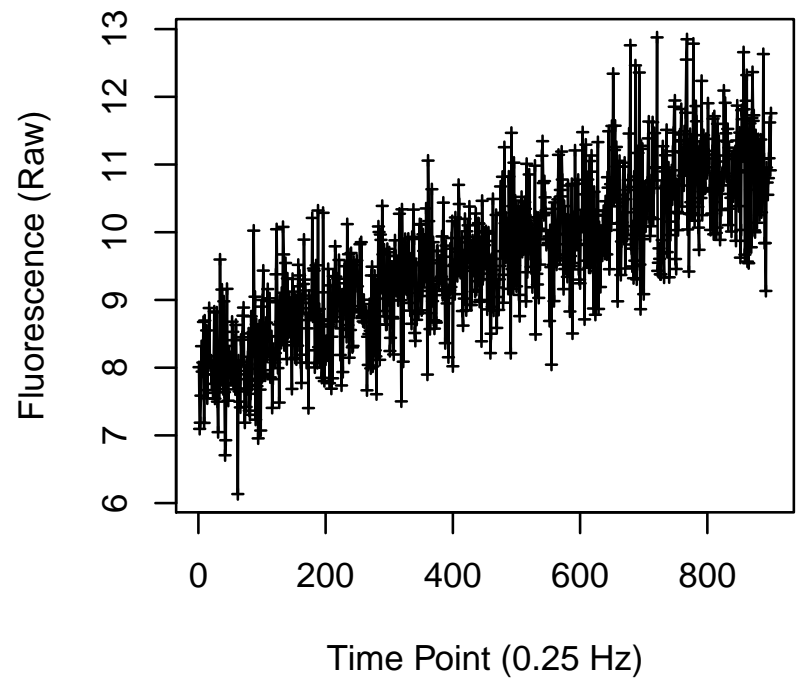

Cell 716

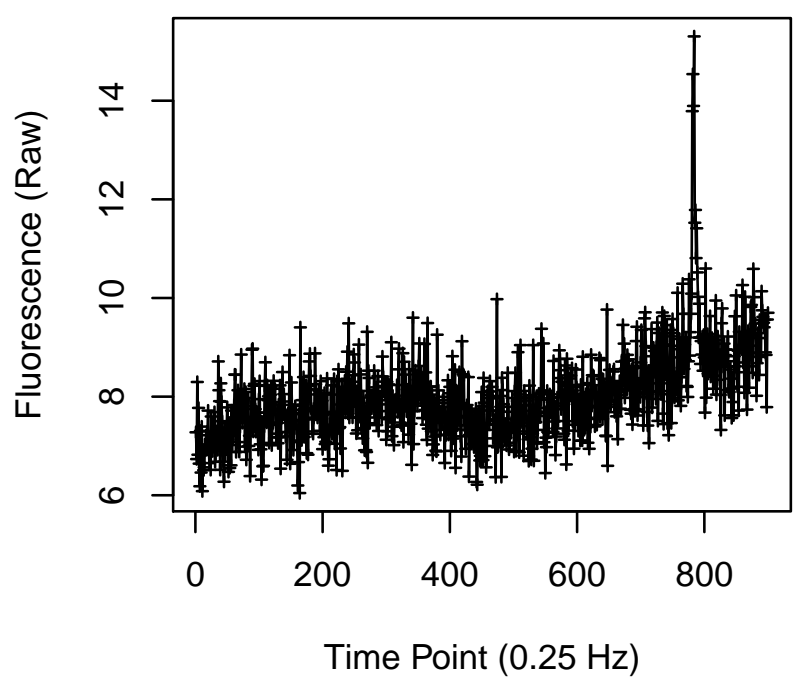


Cell 721

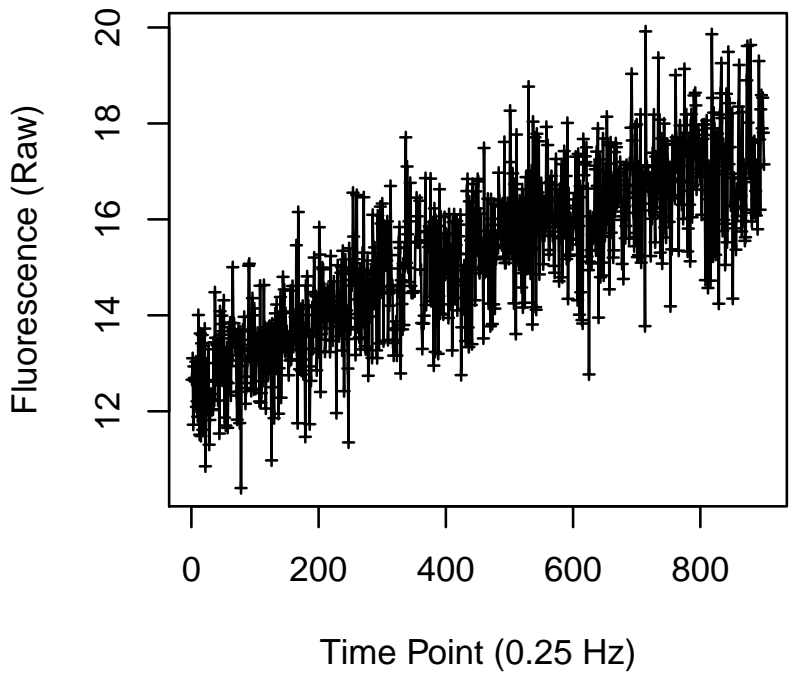

Cell 723

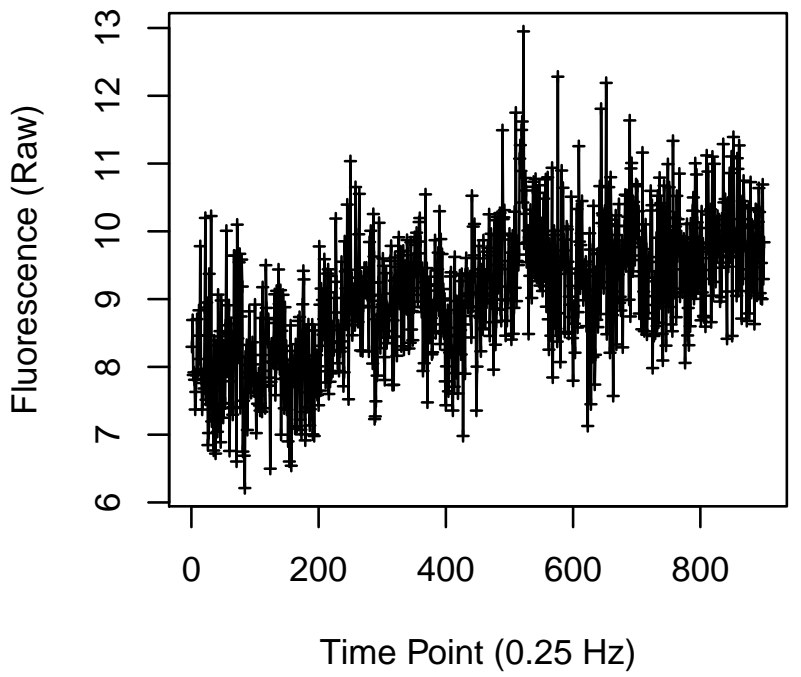

Cell 722

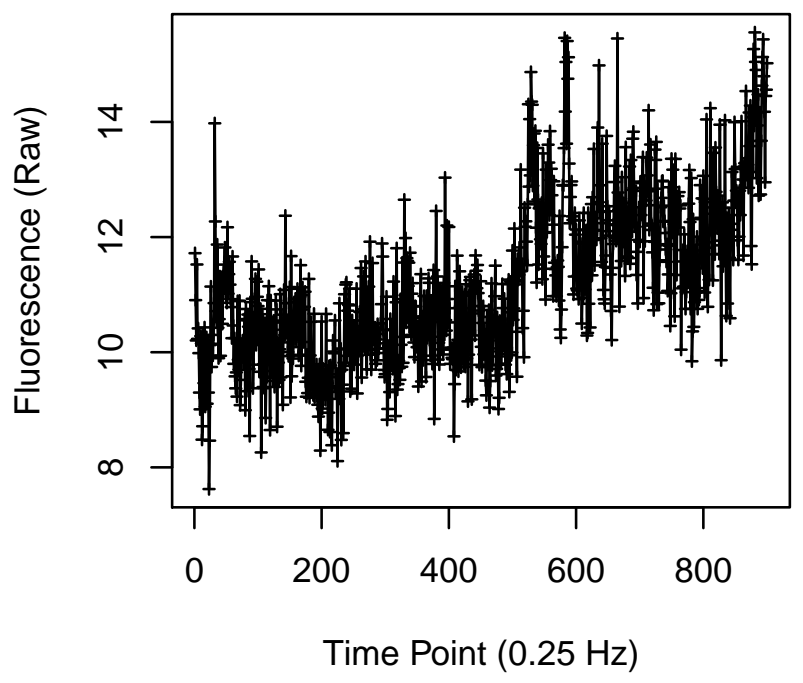

Cell 724

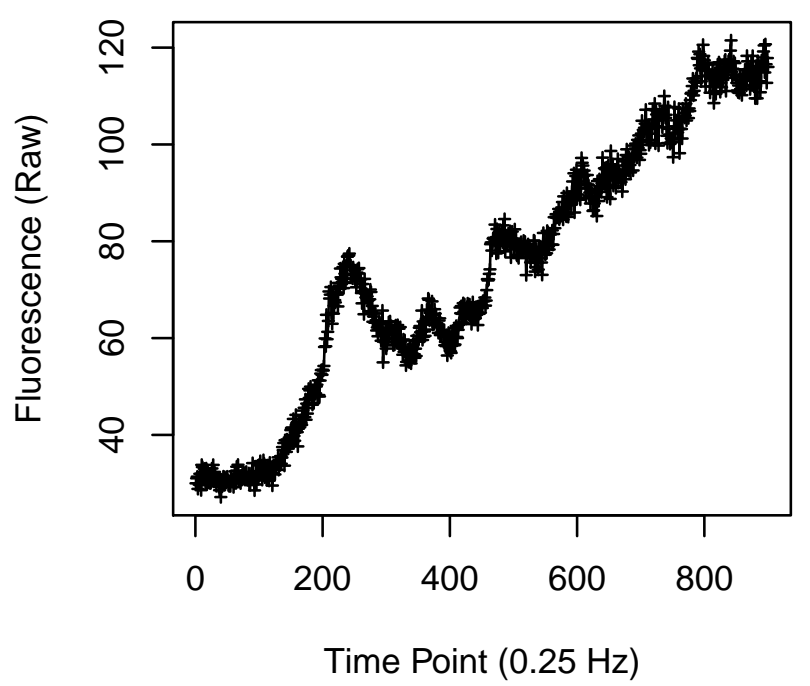


Cell 737

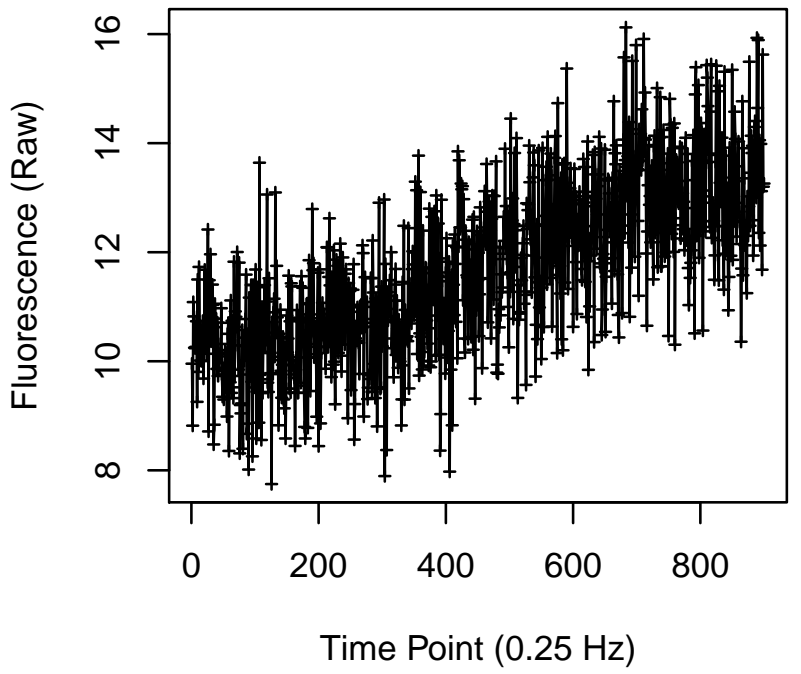

Cell 739

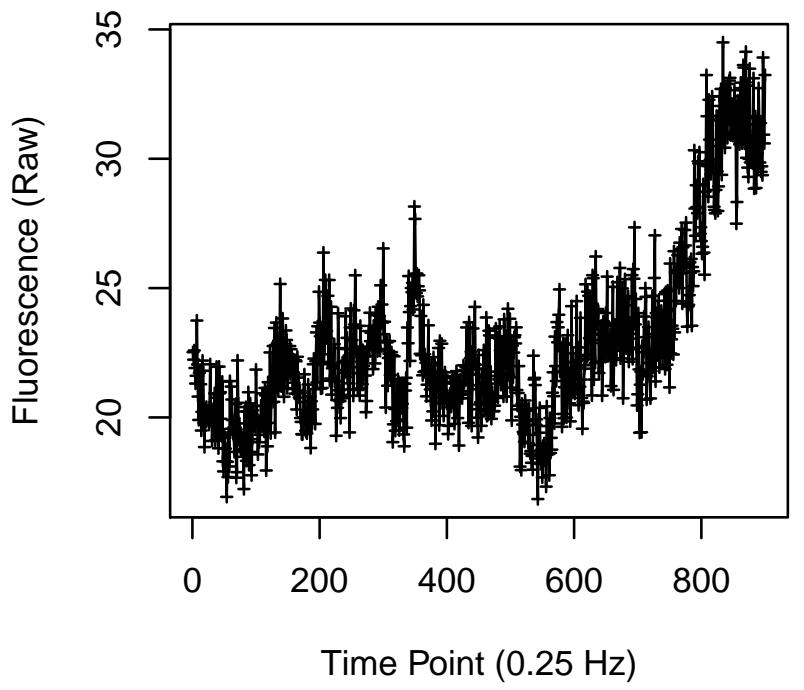

Cell 738

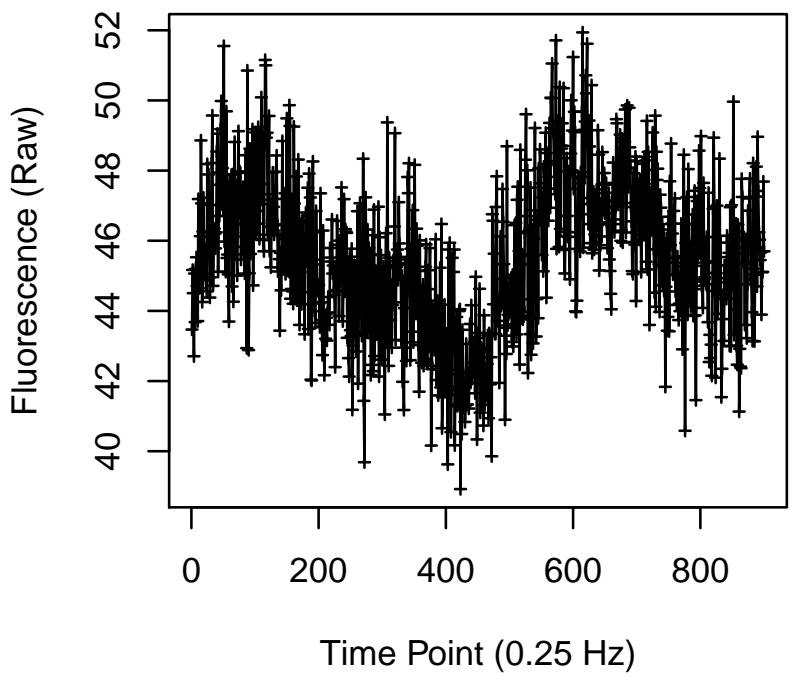

Cell 740

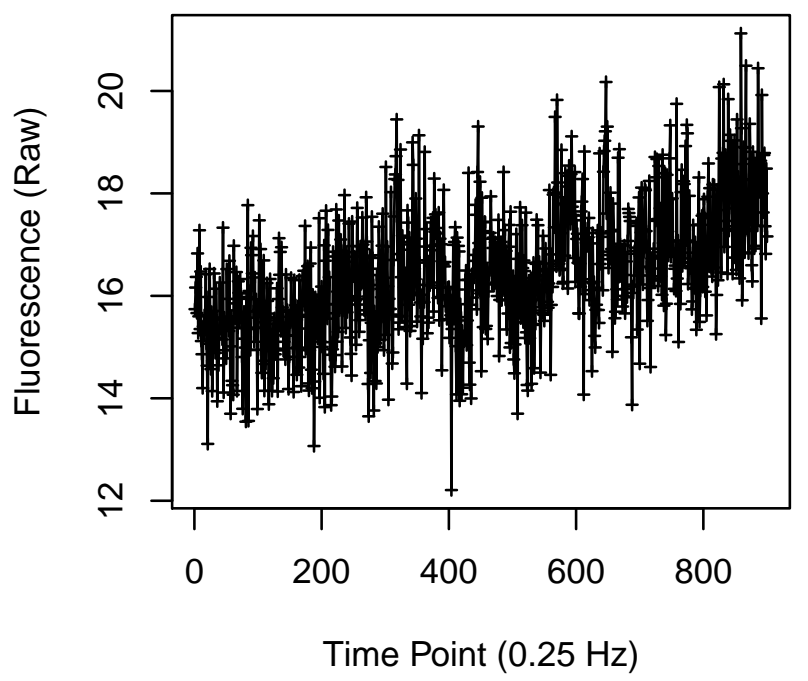


Cell 741

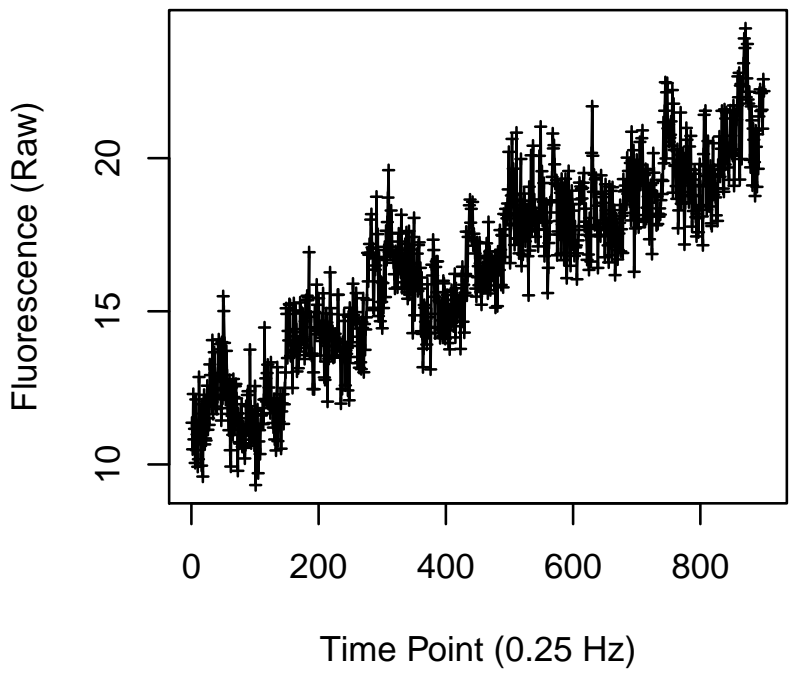

Cell 743

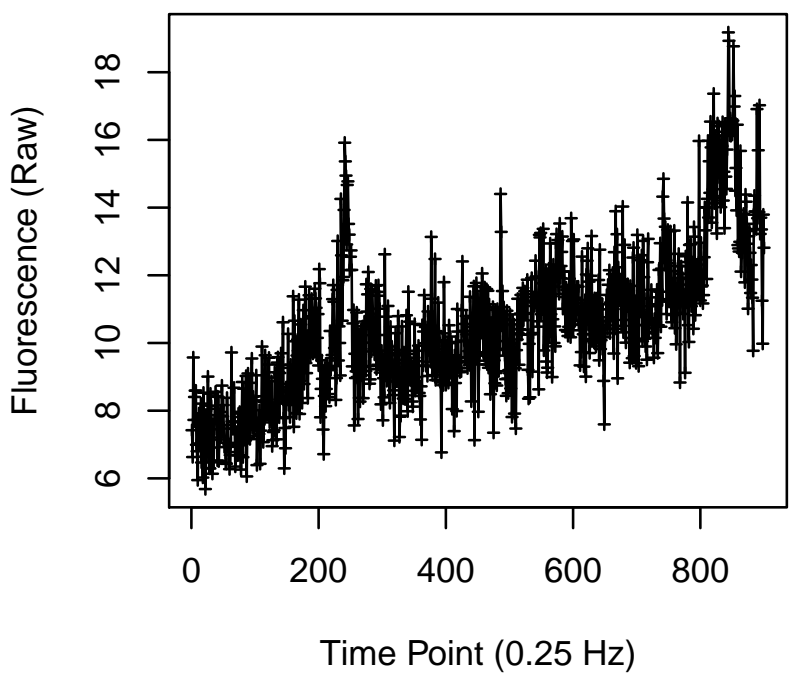

Cell 742

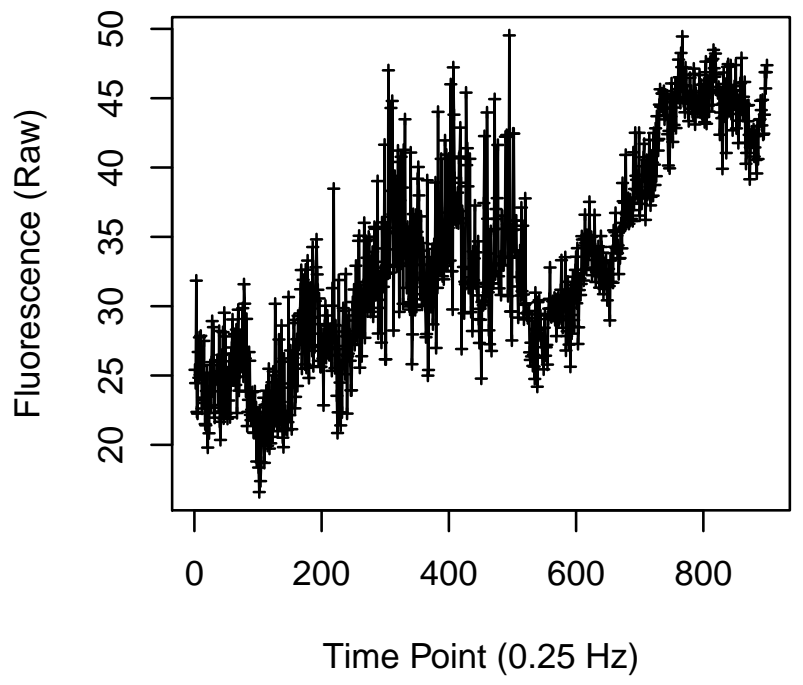

Cell 744

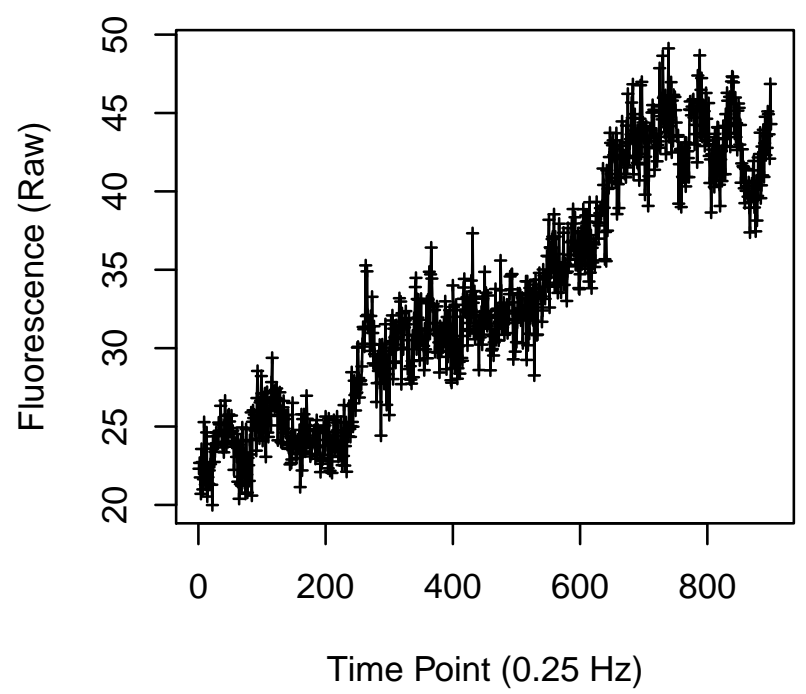




\section{Cell 745}

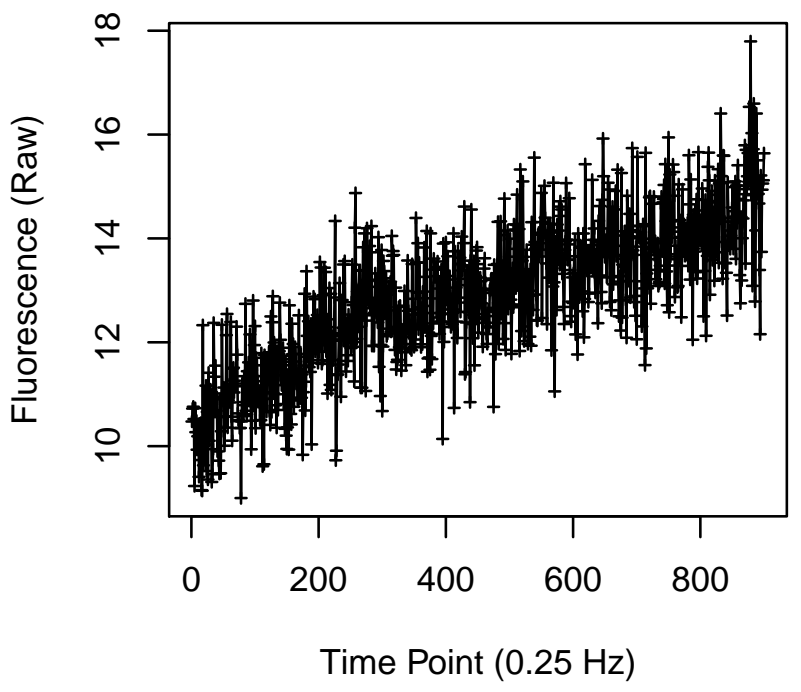

Cell 747

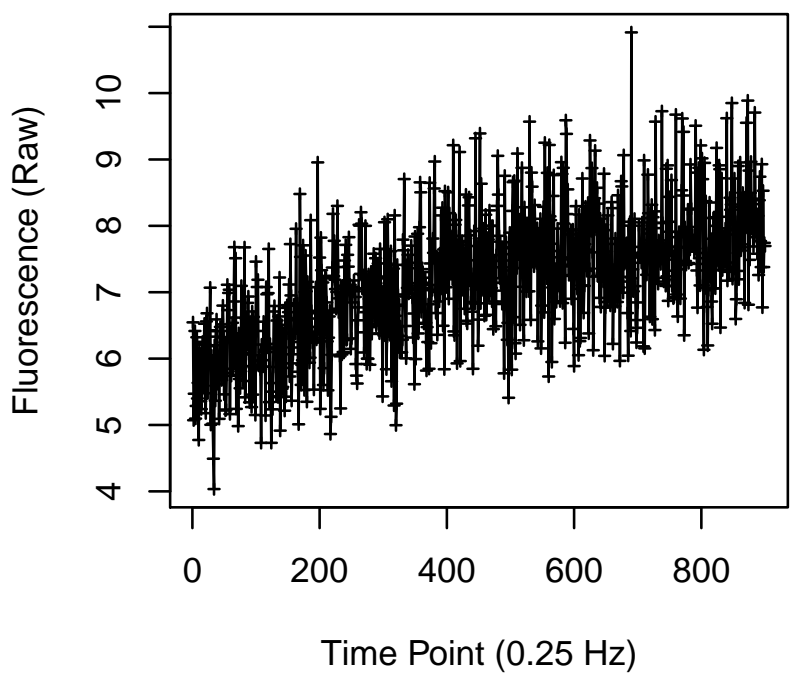

Cell 746

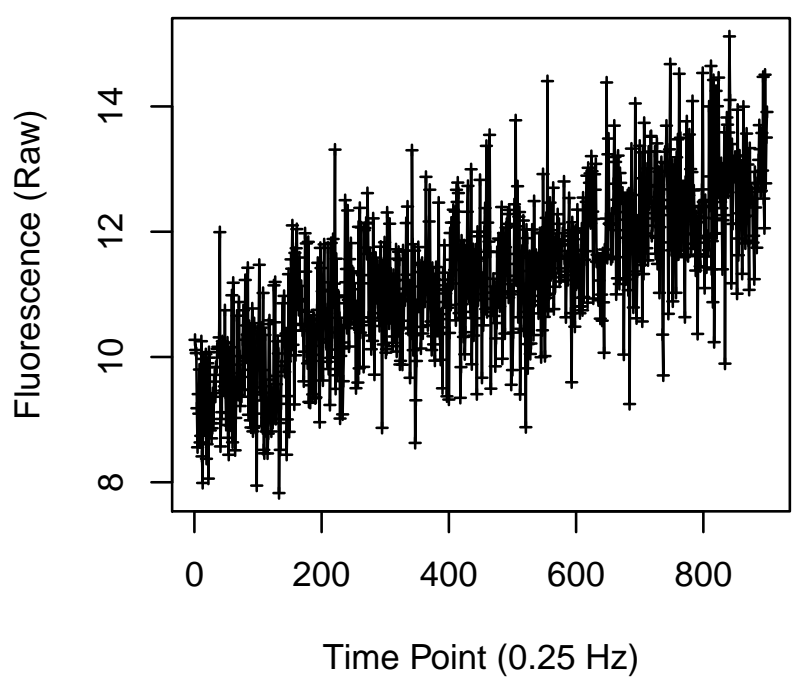

Cell 748

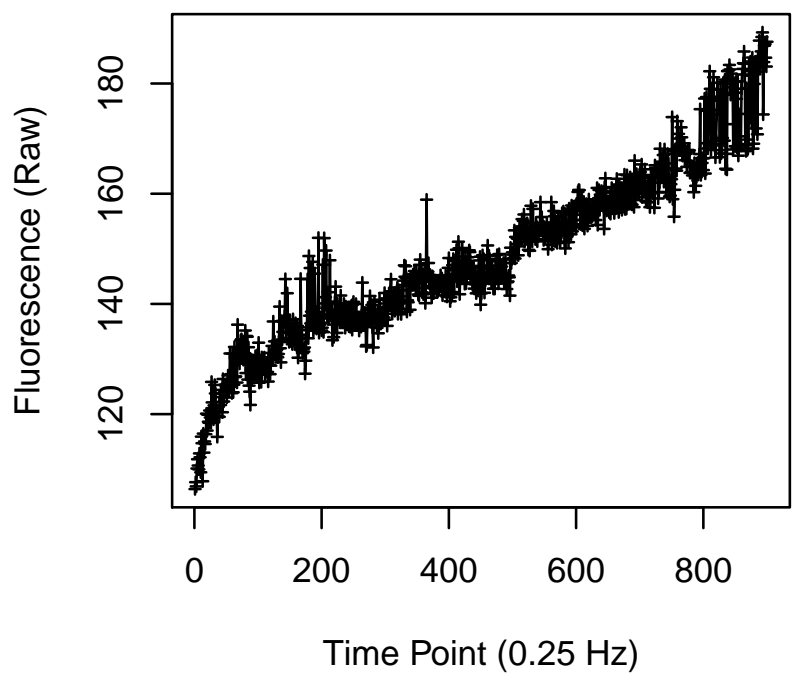


Cell 749

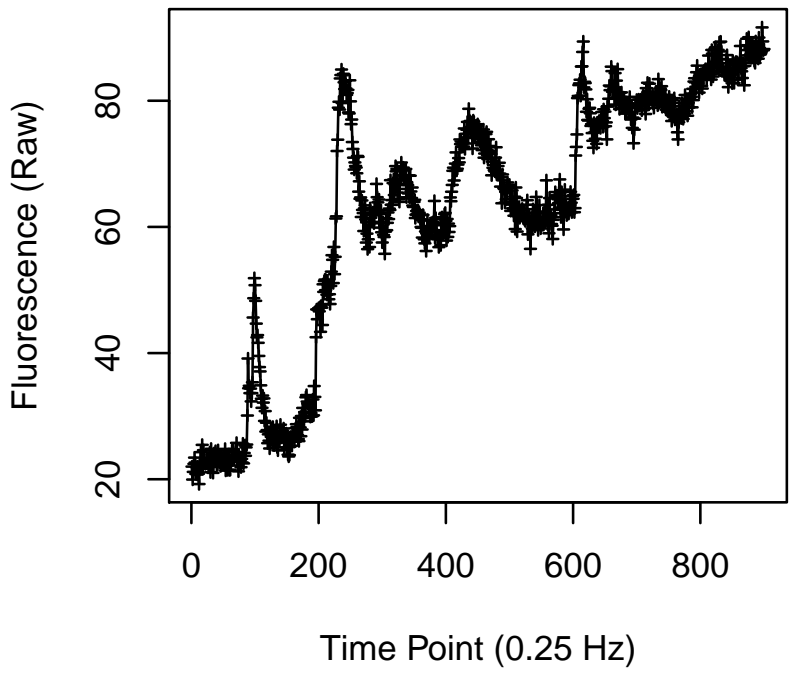

Cell 751

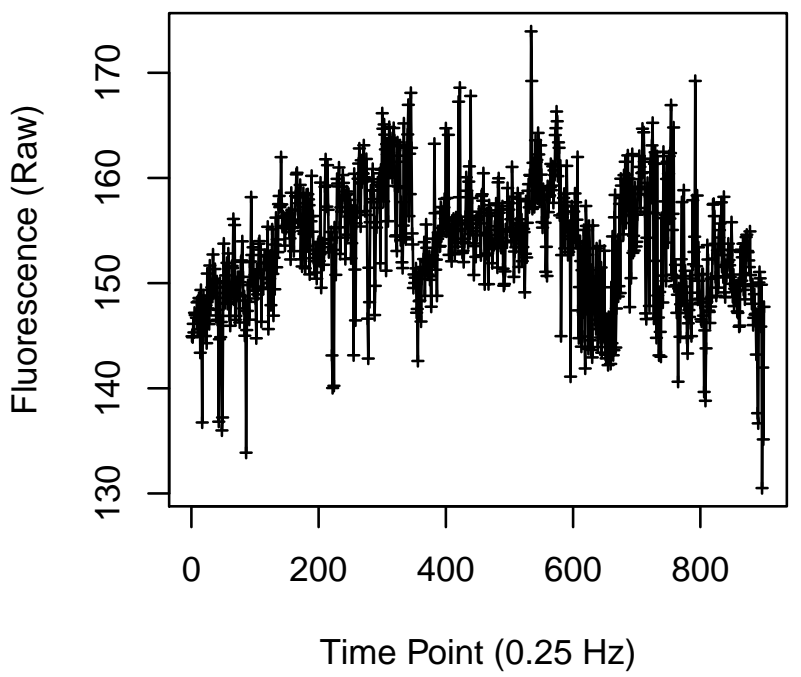

Cell 750

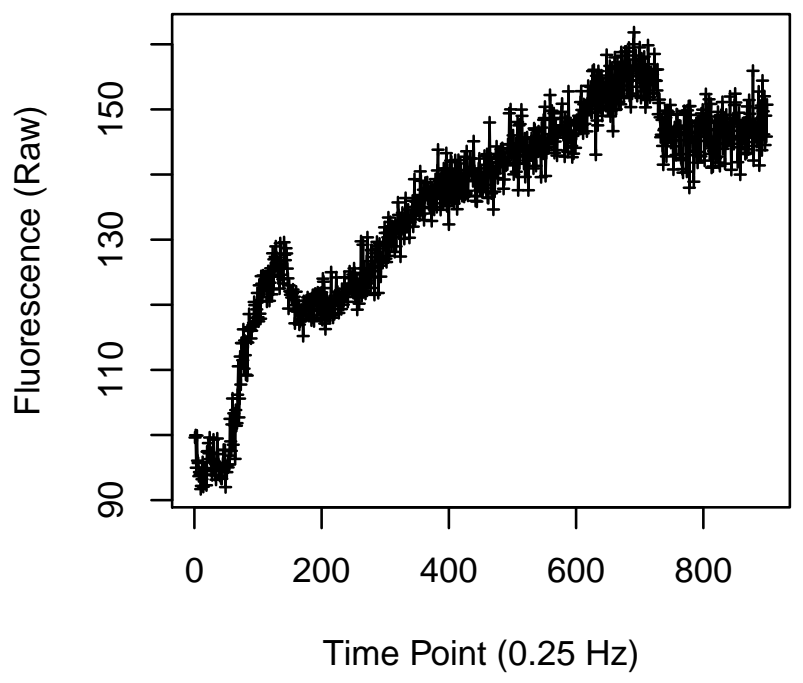

Cell 752

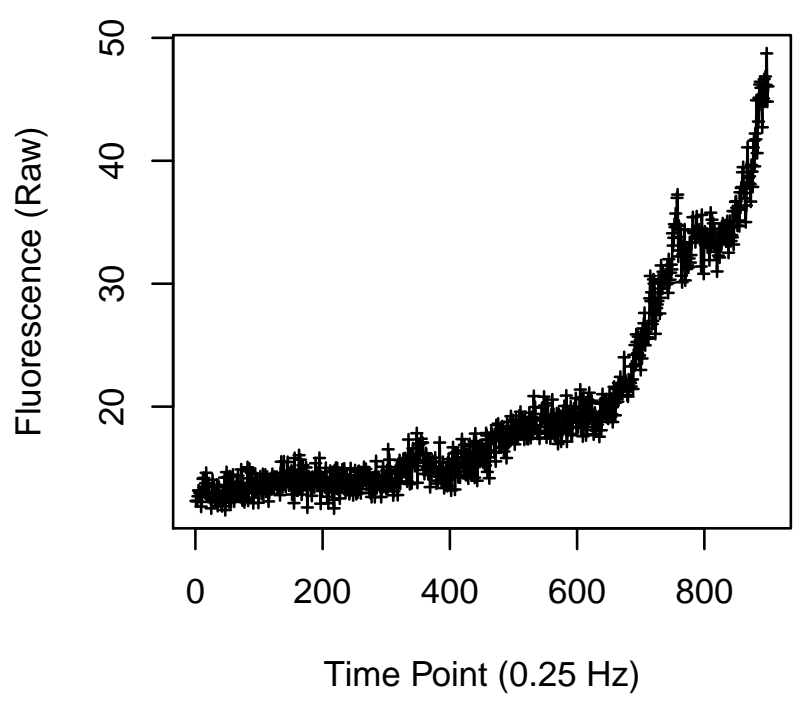


Cell 753

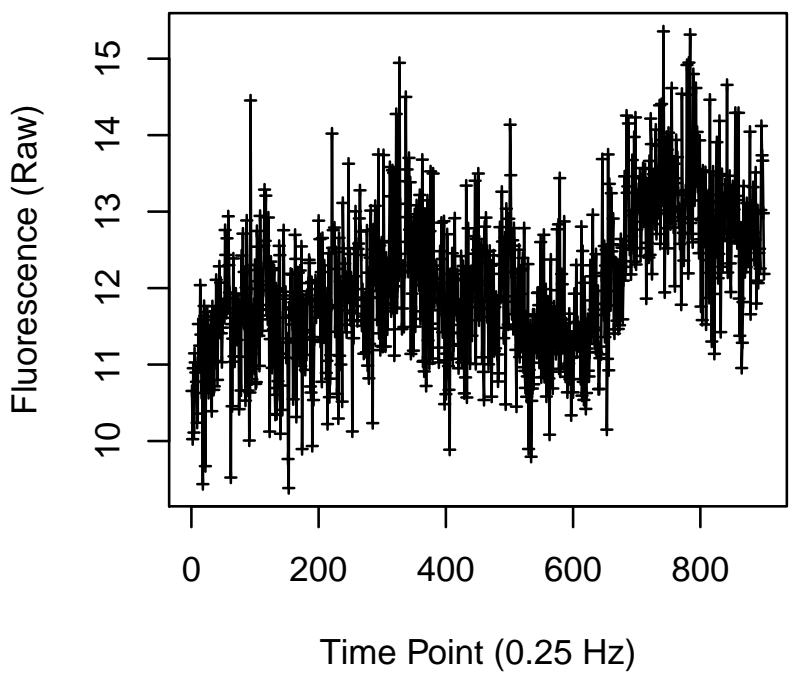

Cell 755

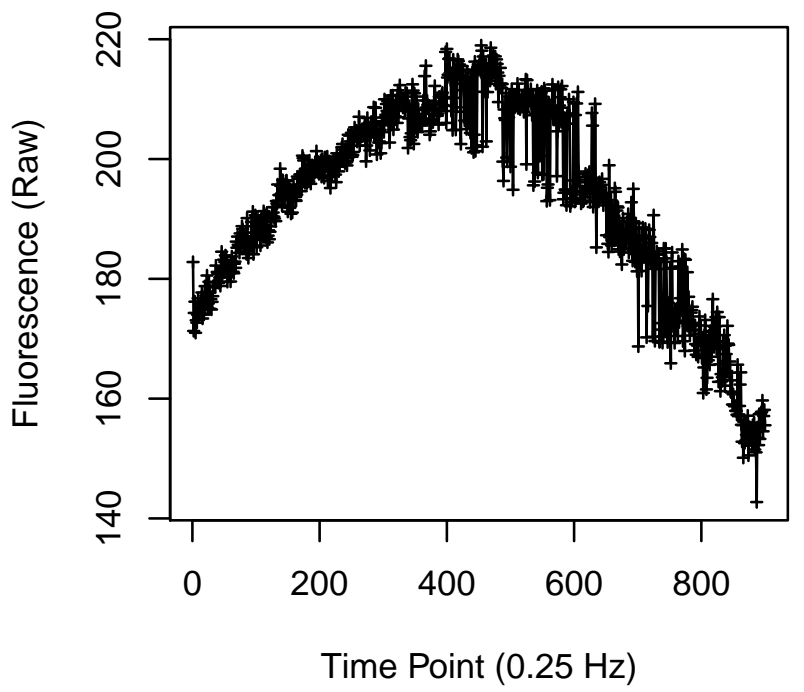

Cell 754

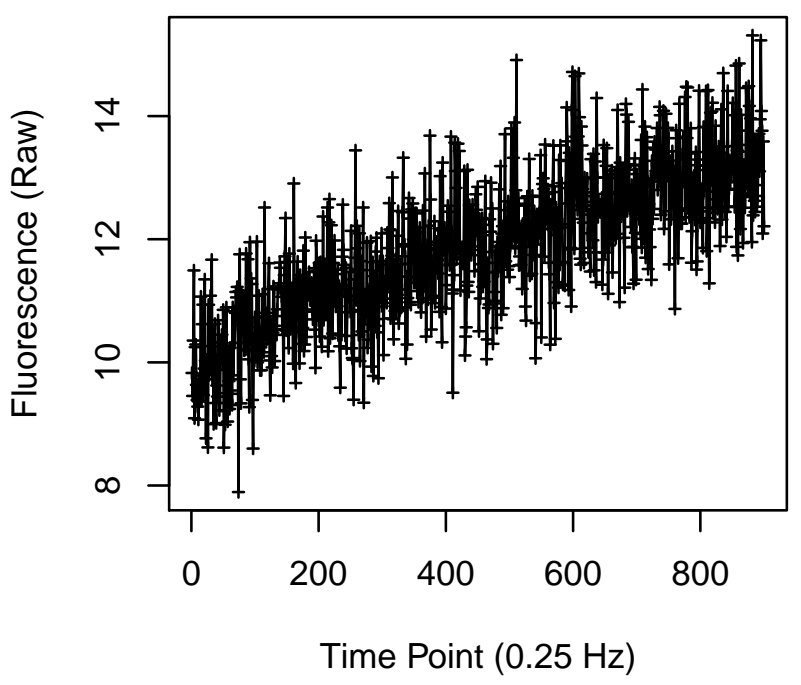

Cell 756

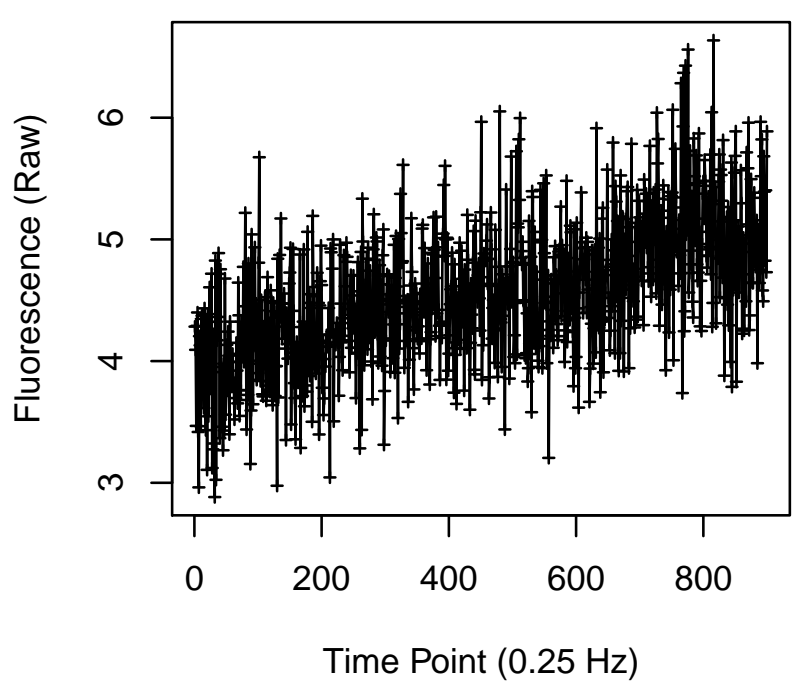


Cell 761

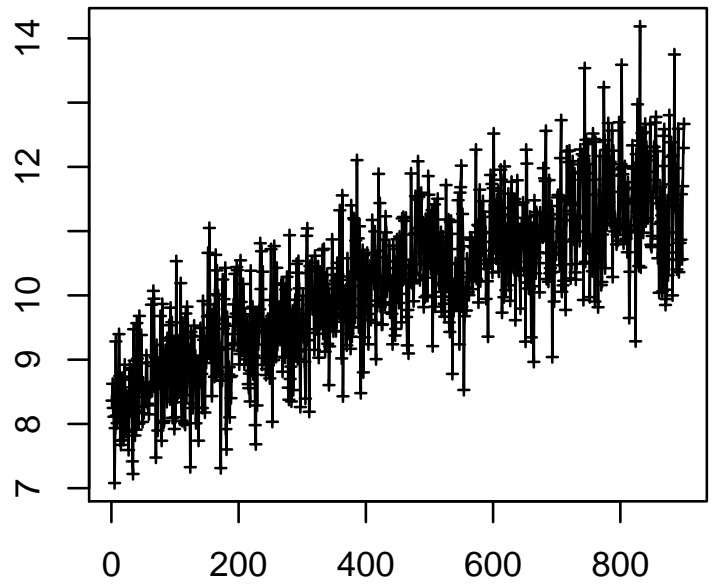

Time Point $(0.25 \mathrm{~Hz})$

\section{Cell 763}

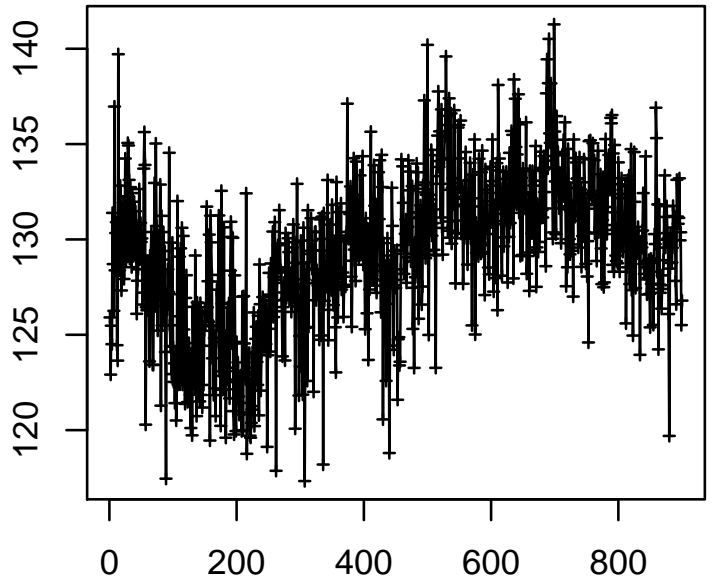

Time Point $(0.25 \mathrm{~Hz})$
Cell 762

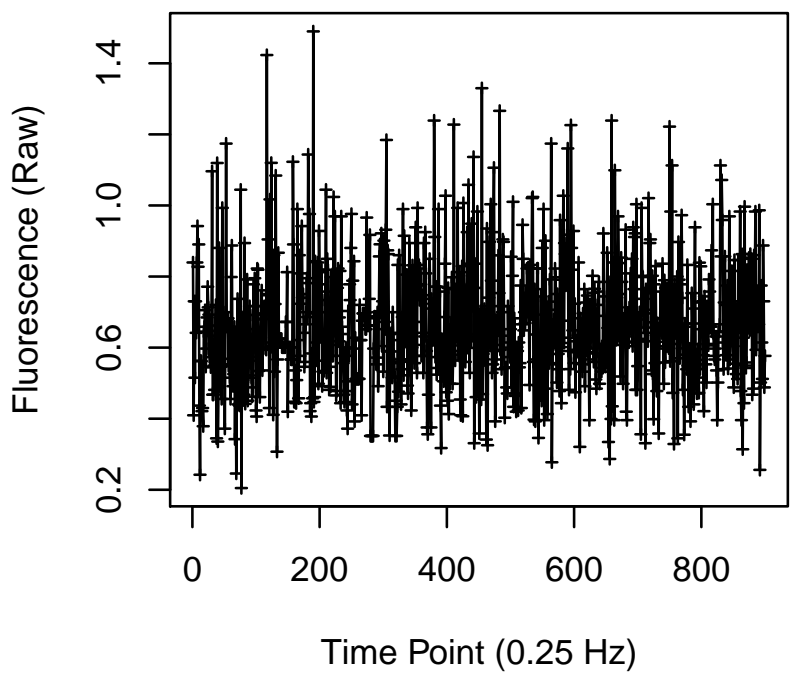

Cell 764

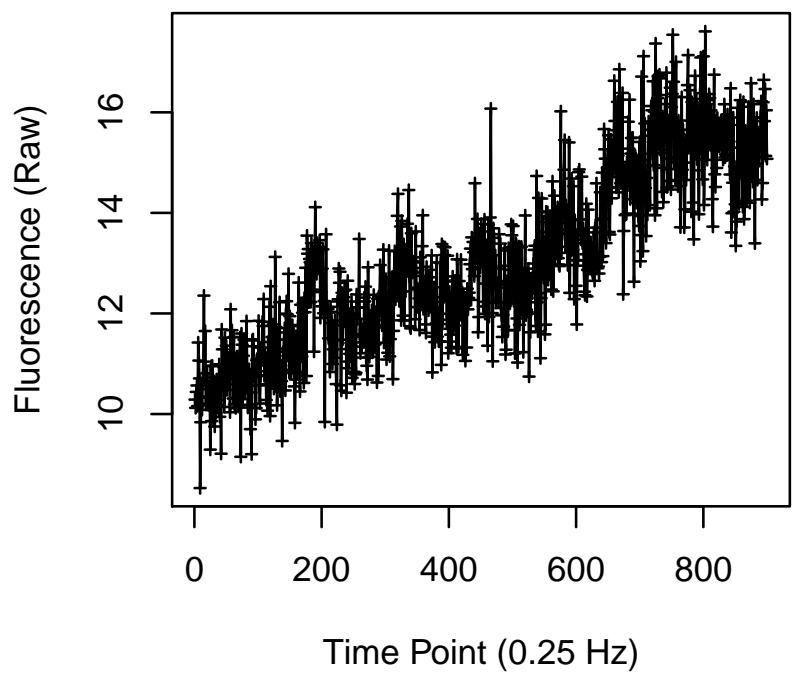


Cell 773

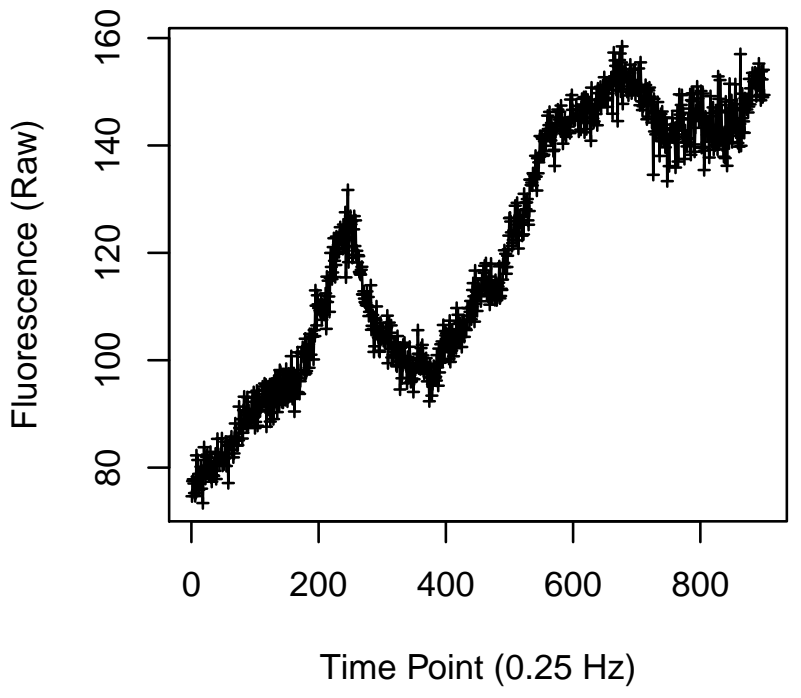

Cell 775

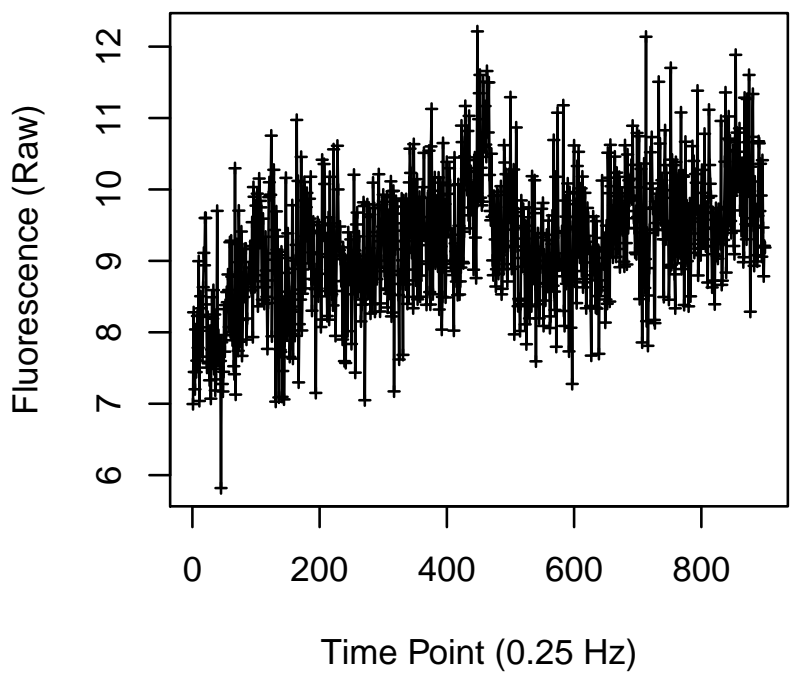

Cell 774

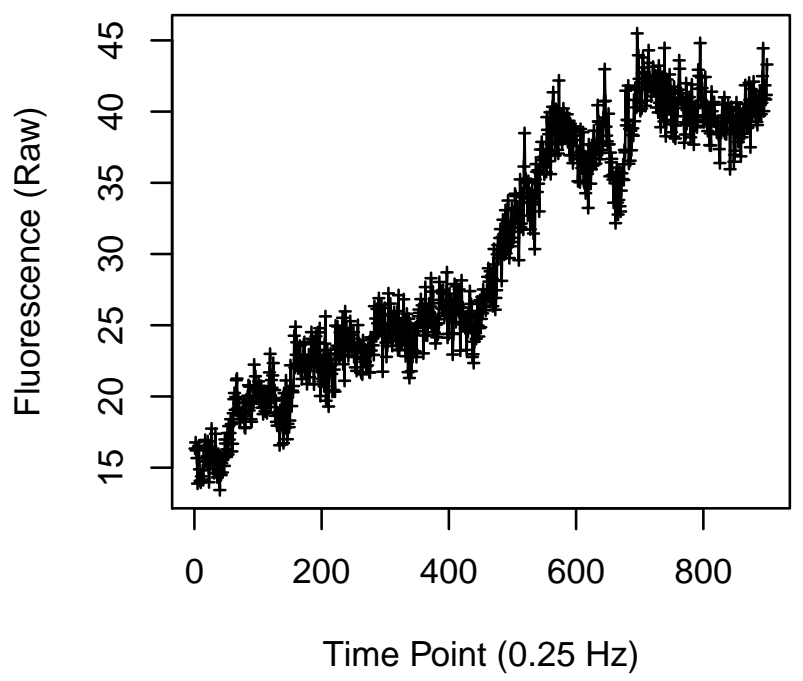

Cell 776

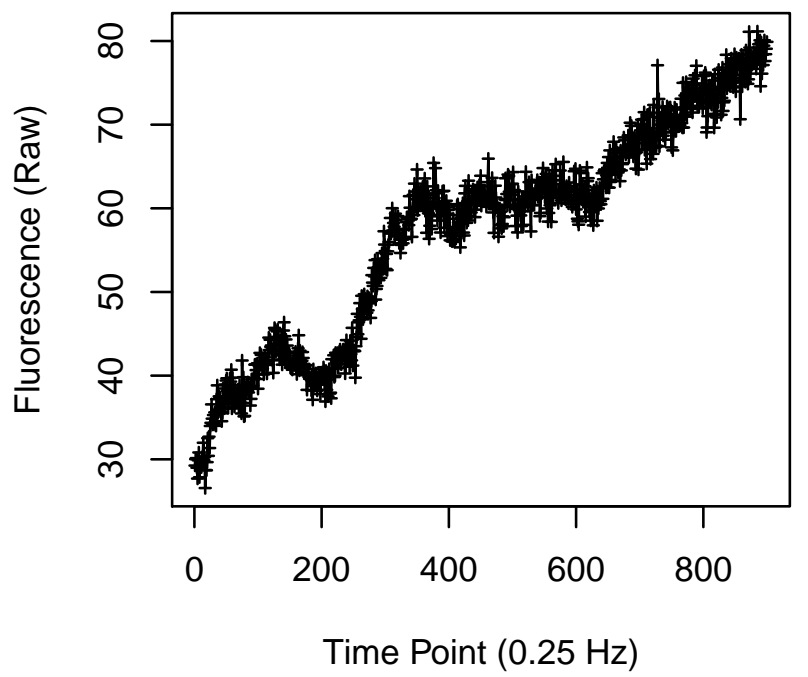




\section{Cell 777}

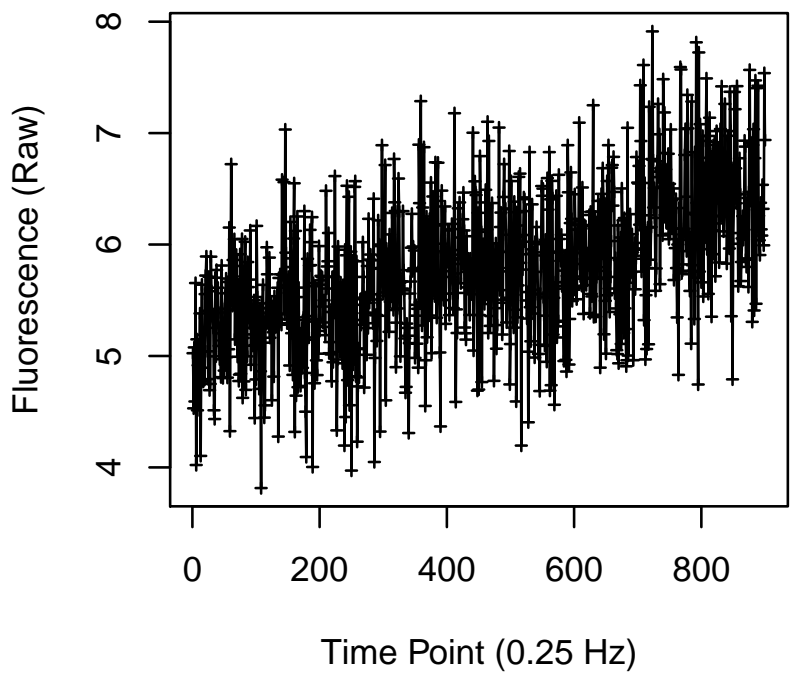

Cell 779

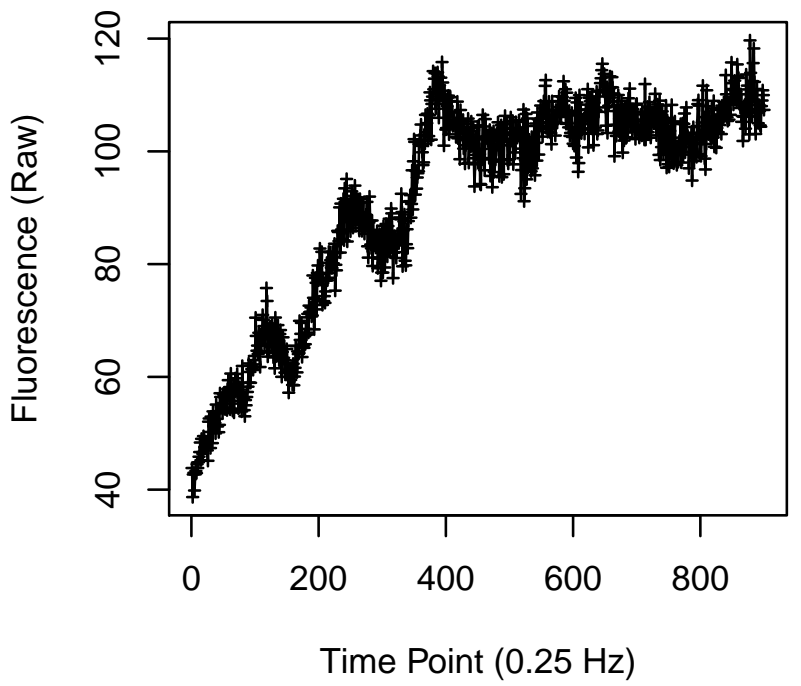

Cell 778

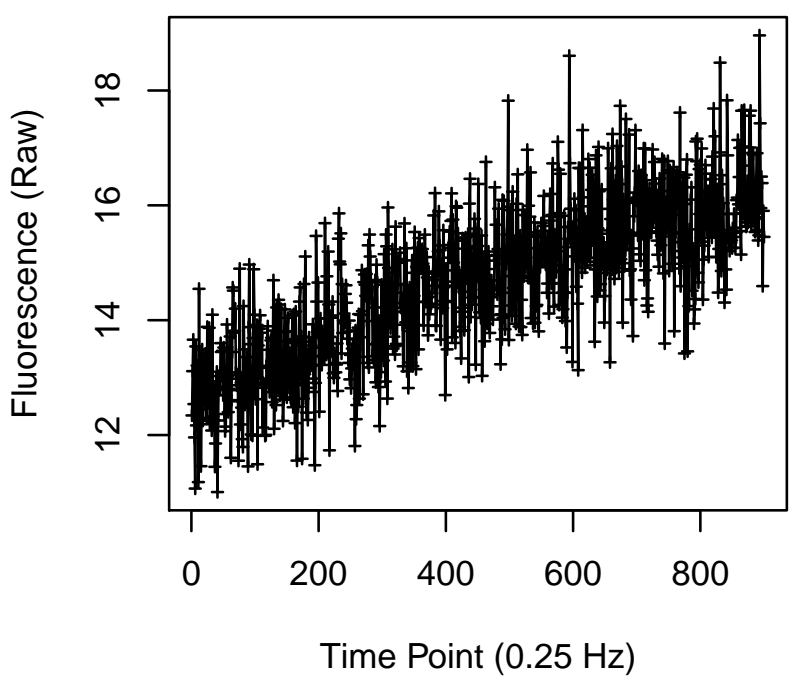

Cell 780

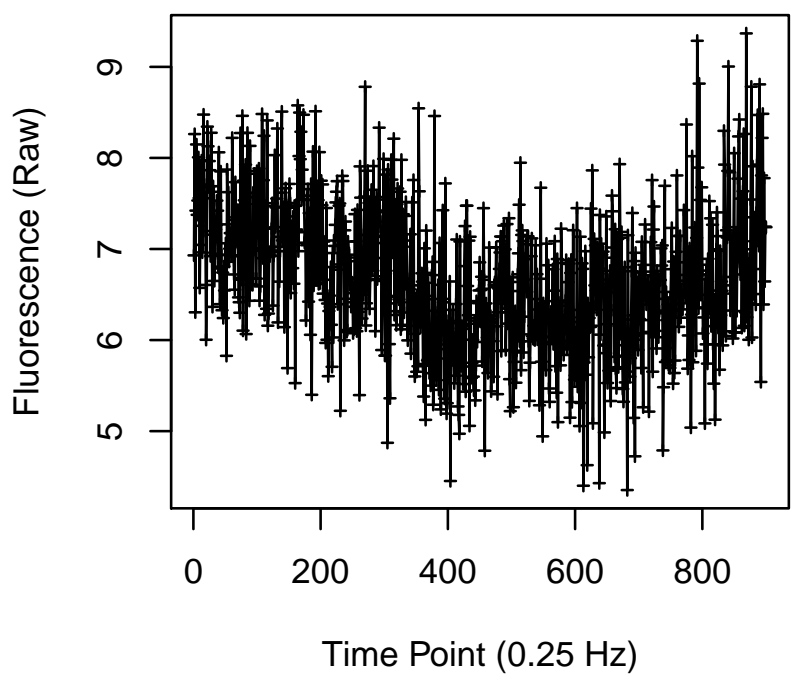


Cell 781

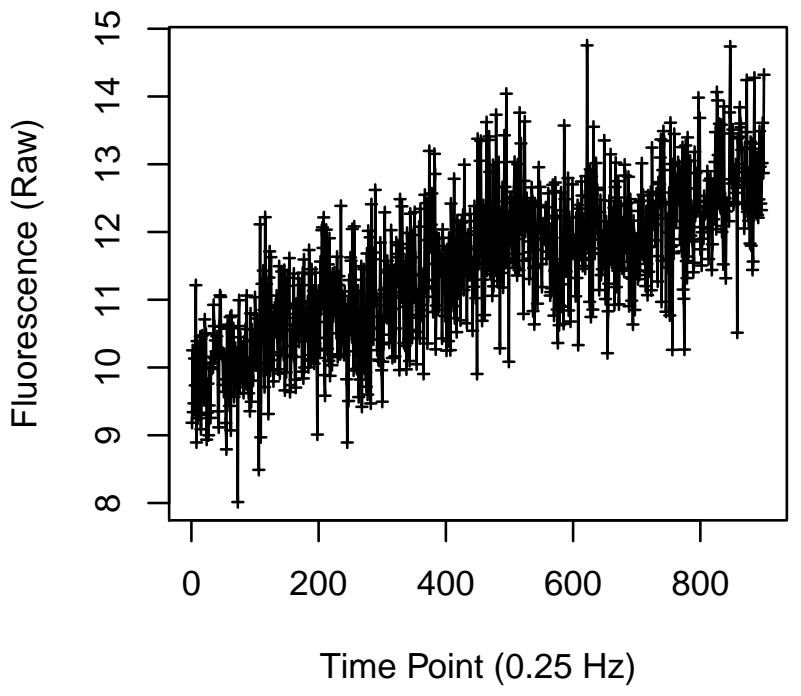

Cell 783

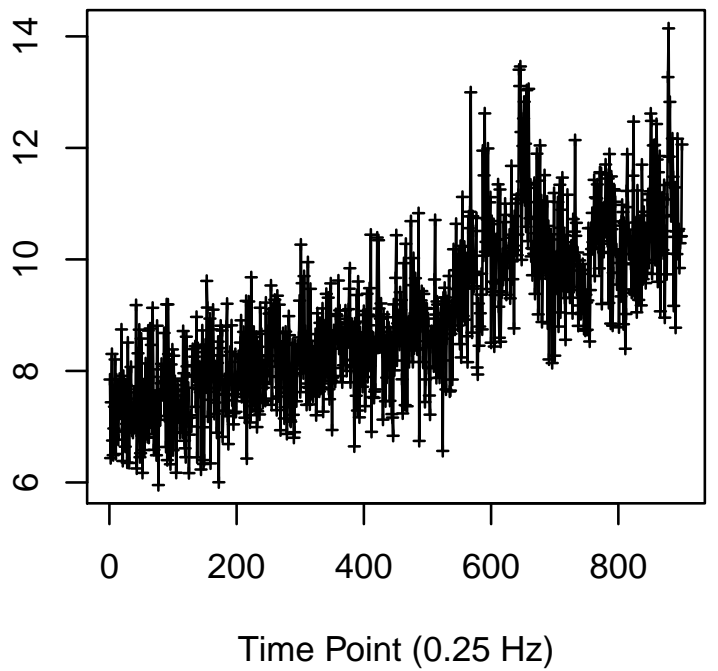

Cell 782

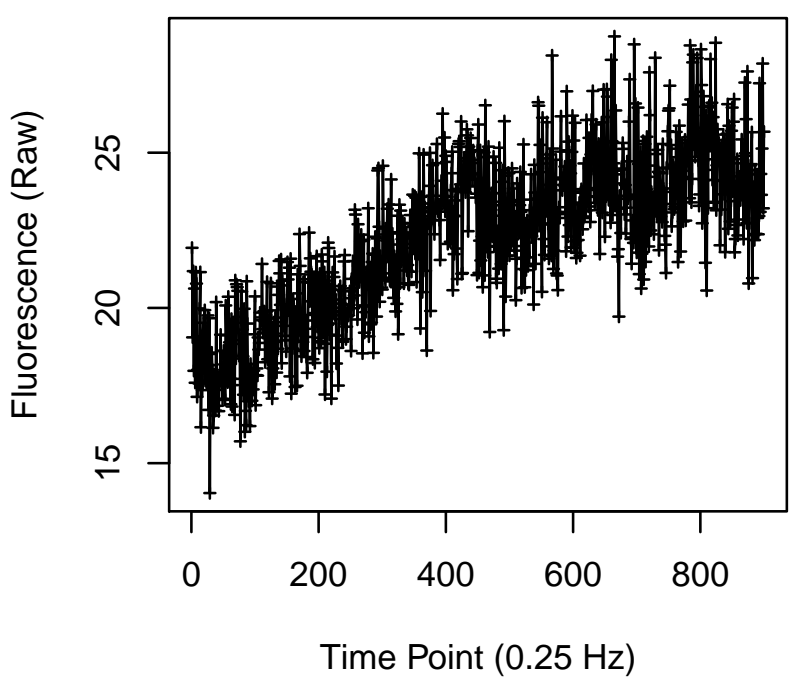

Cell 784

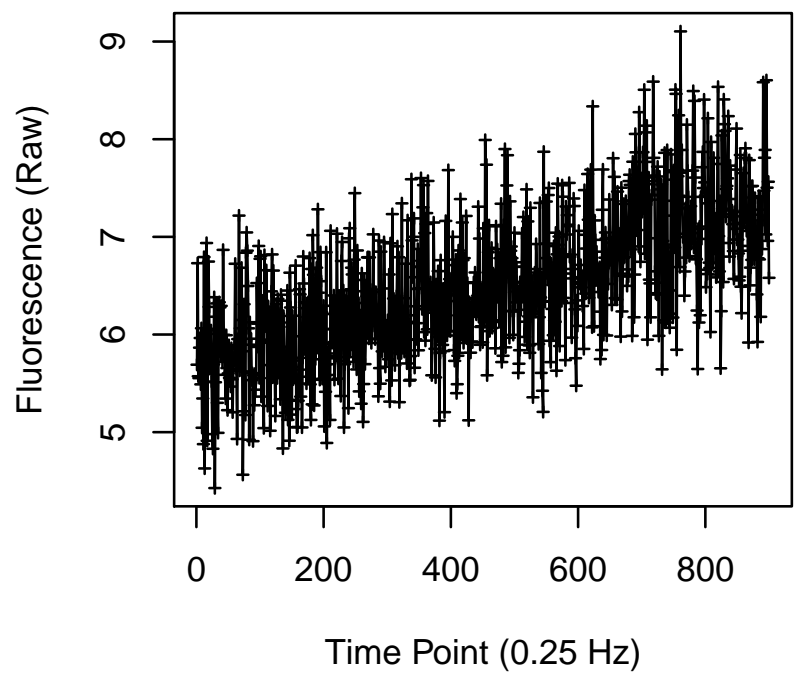


Cell 785

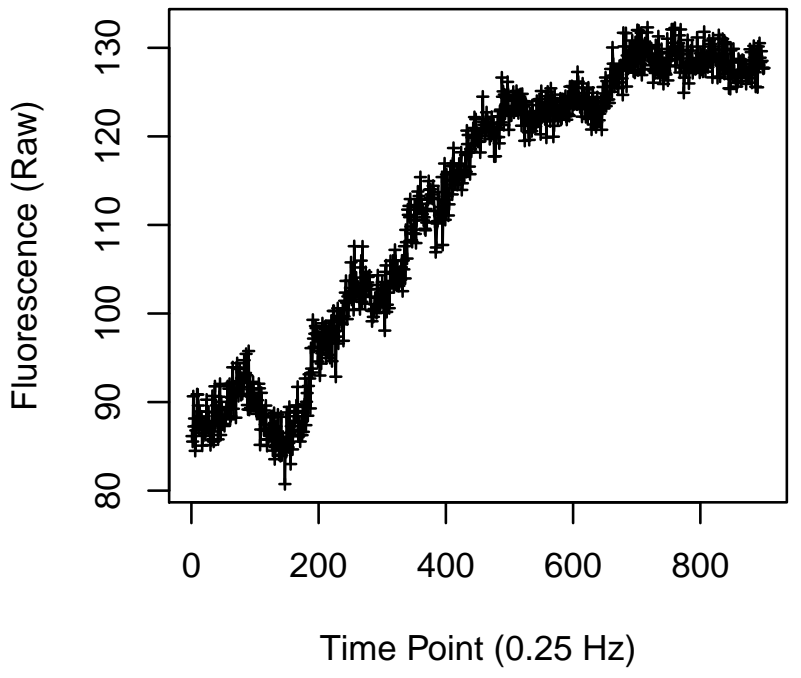

Cell 787

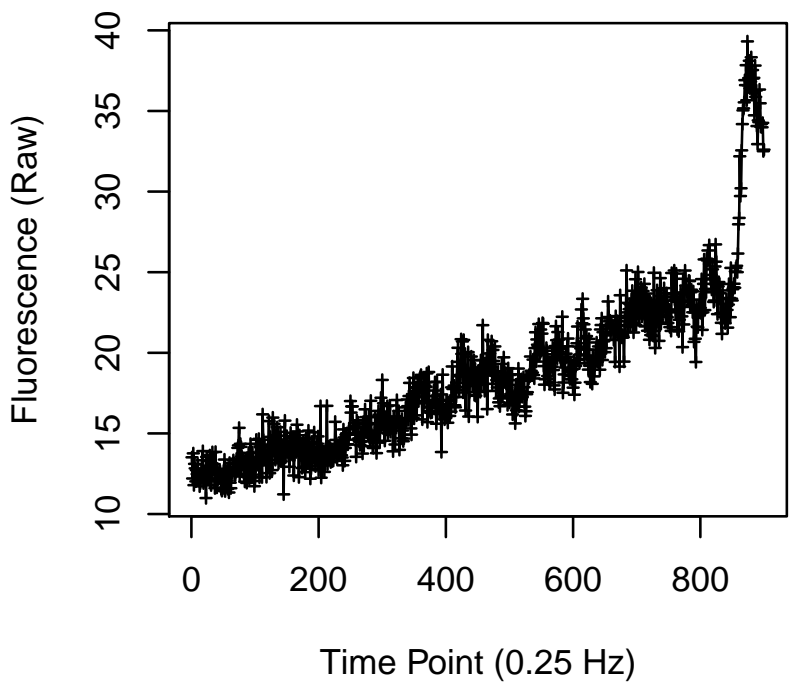

Cell 786

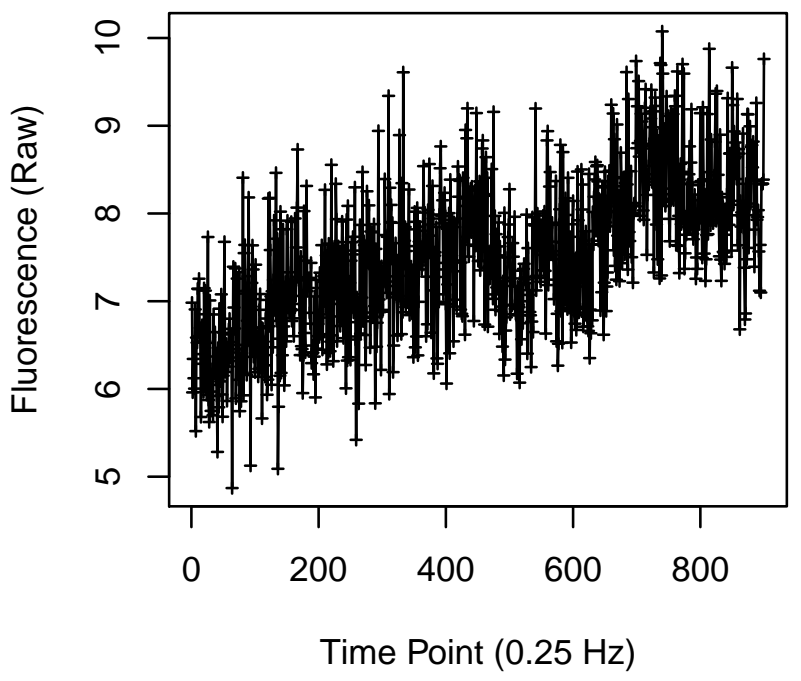

Cell 788

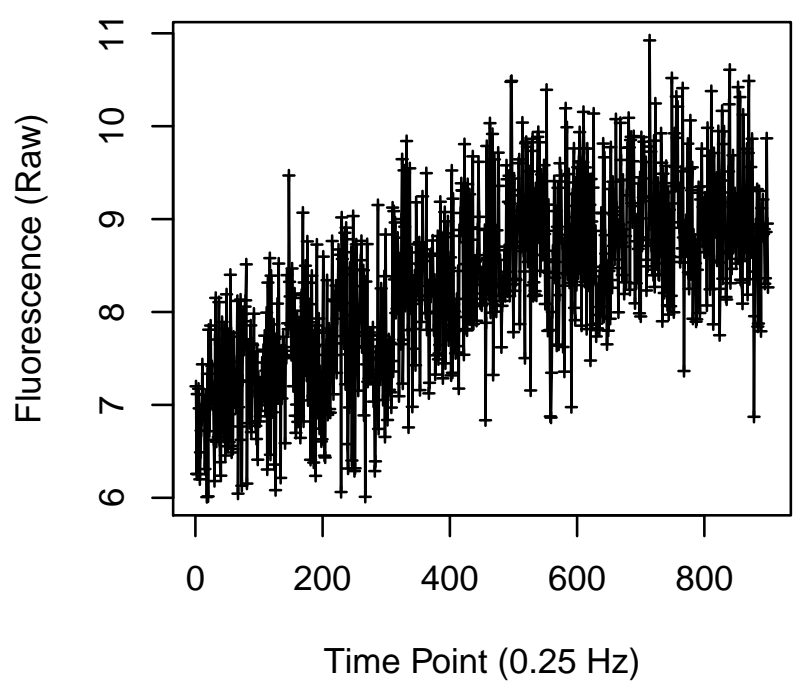


Cell 793

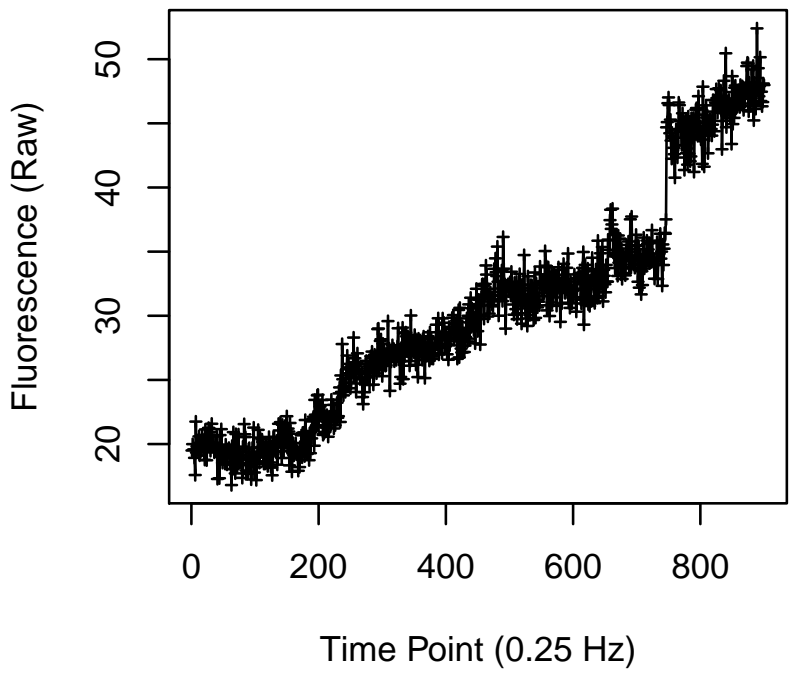

Cell 795

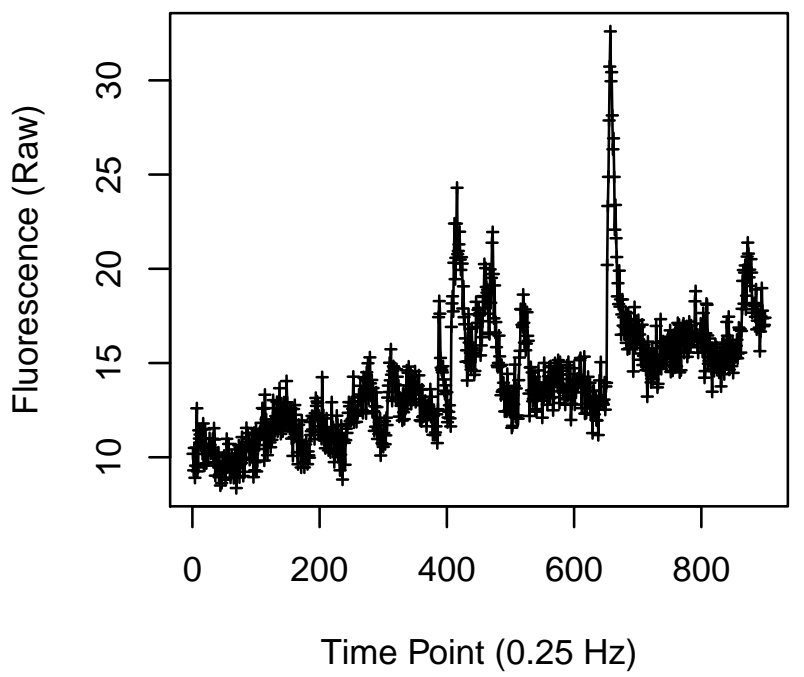

Cell 794

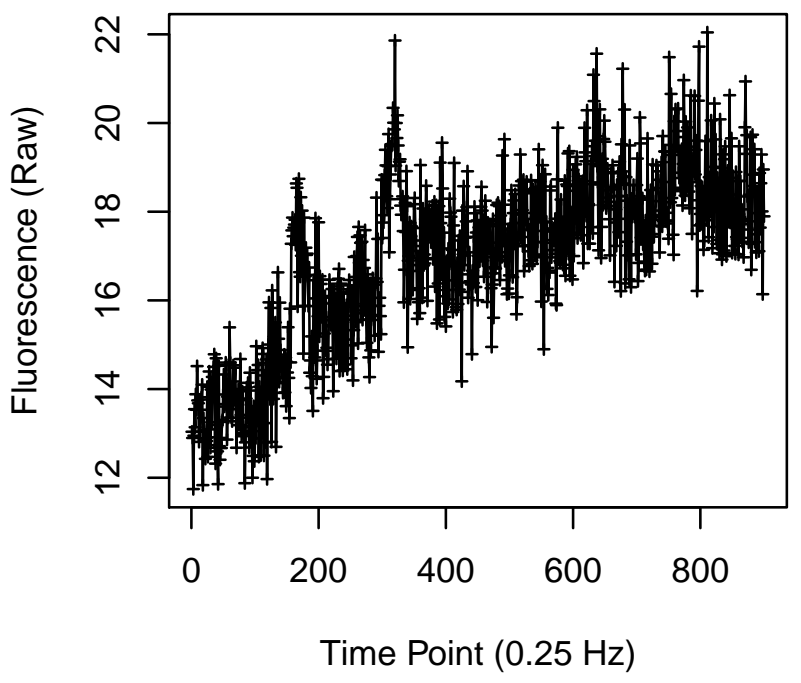

Cell 796

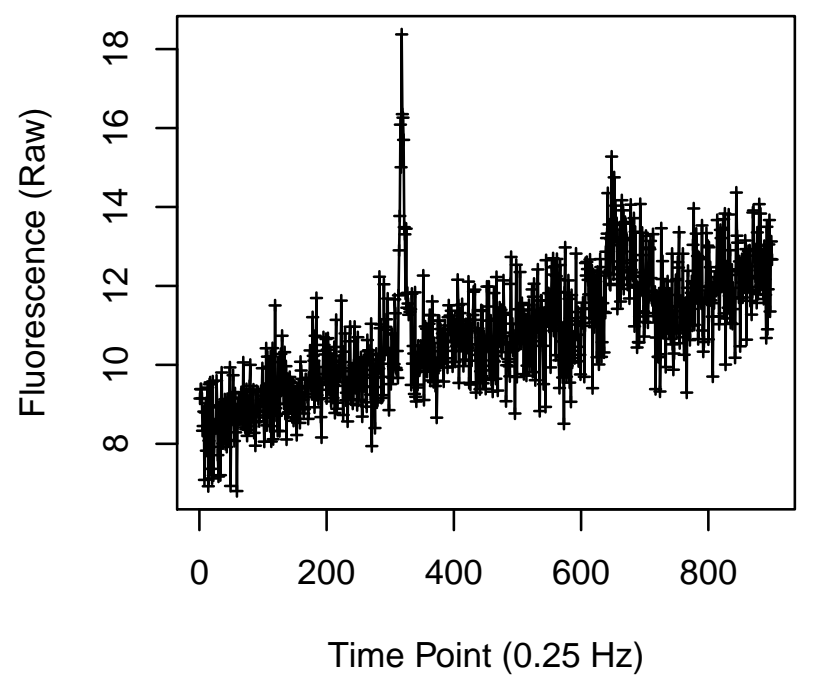


Cell 797

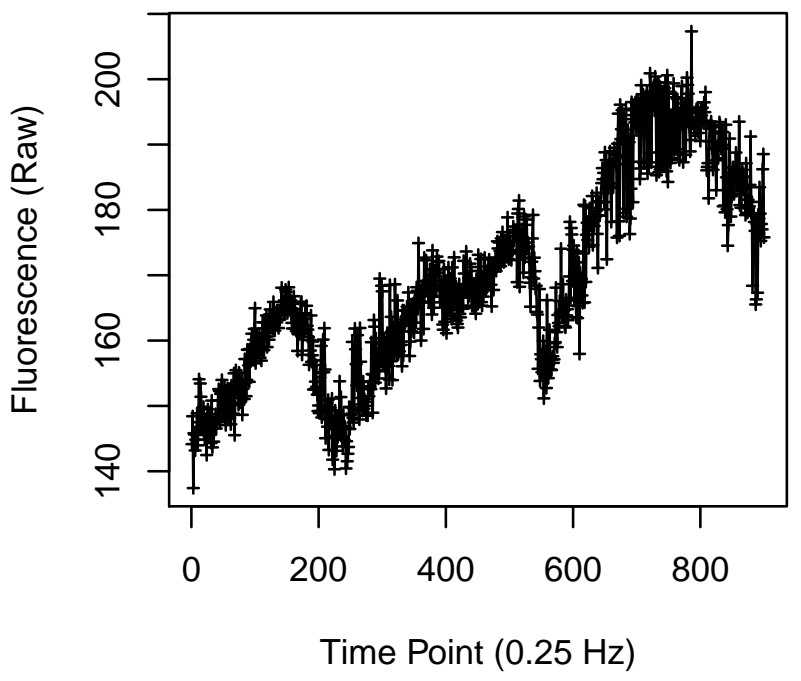

Cell 799

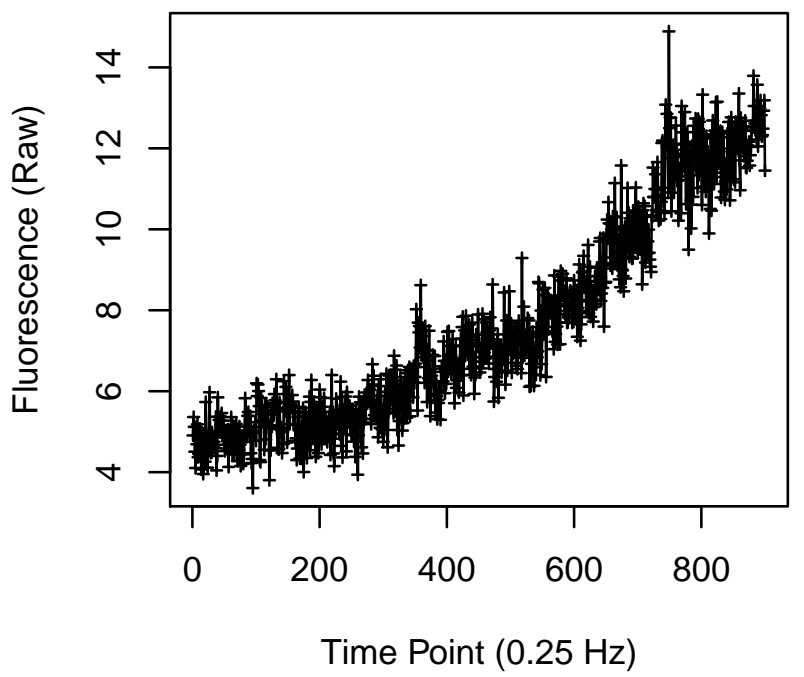

Cell 798

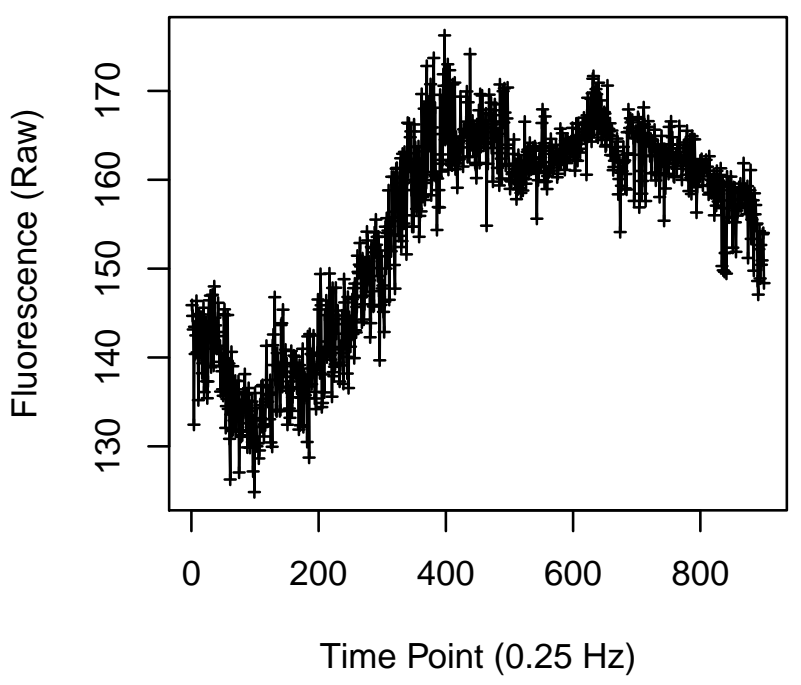

Cell 800

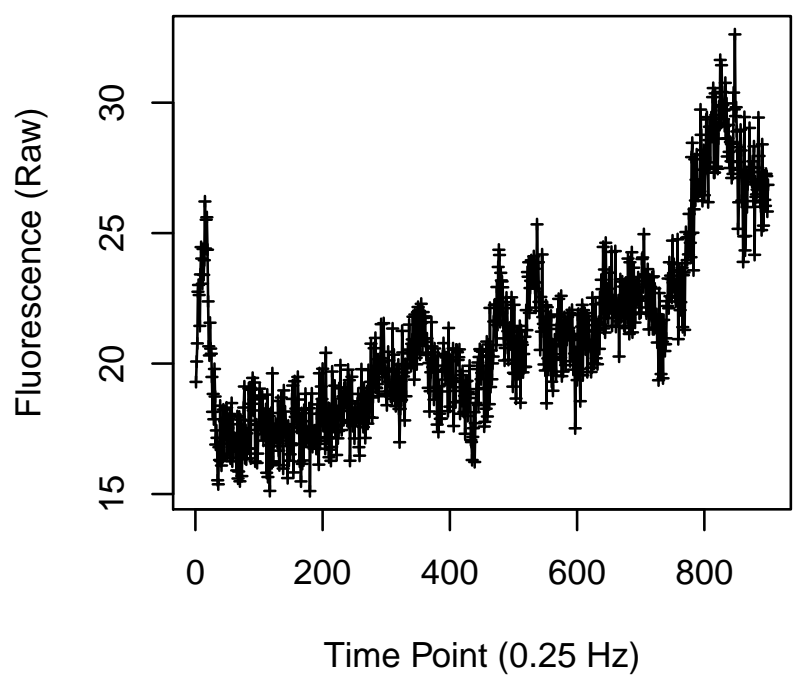




\section{Cell 809}

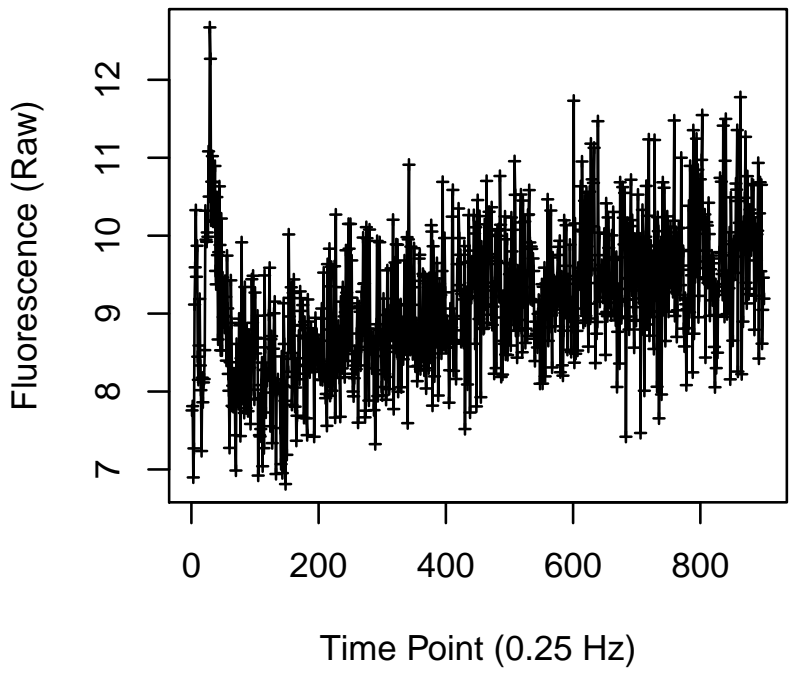

Cell 811

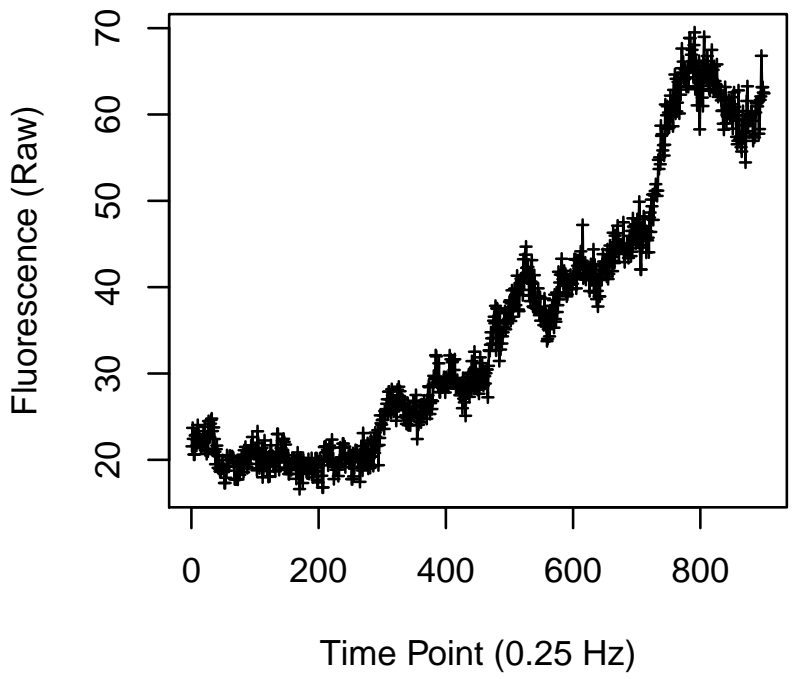

Cell 810

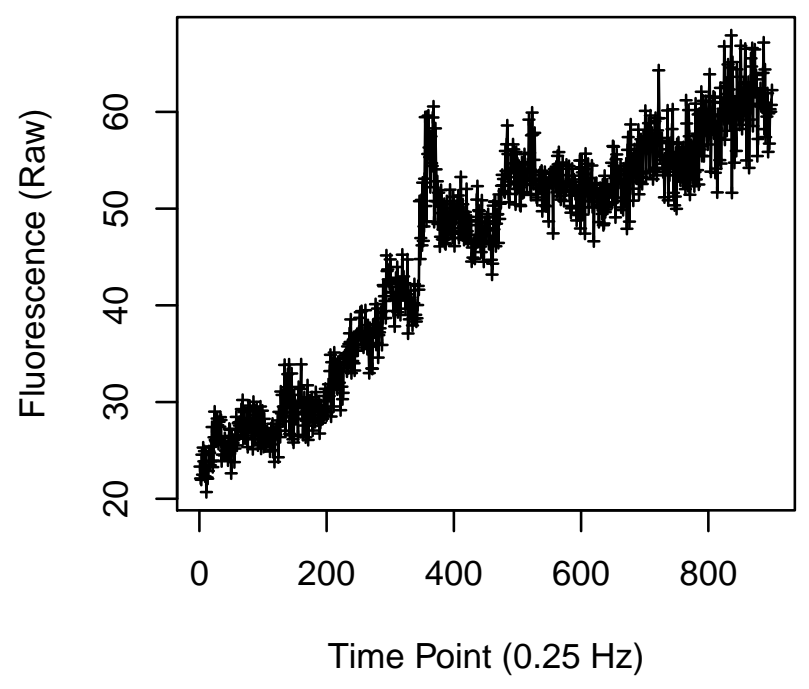

Cell 812

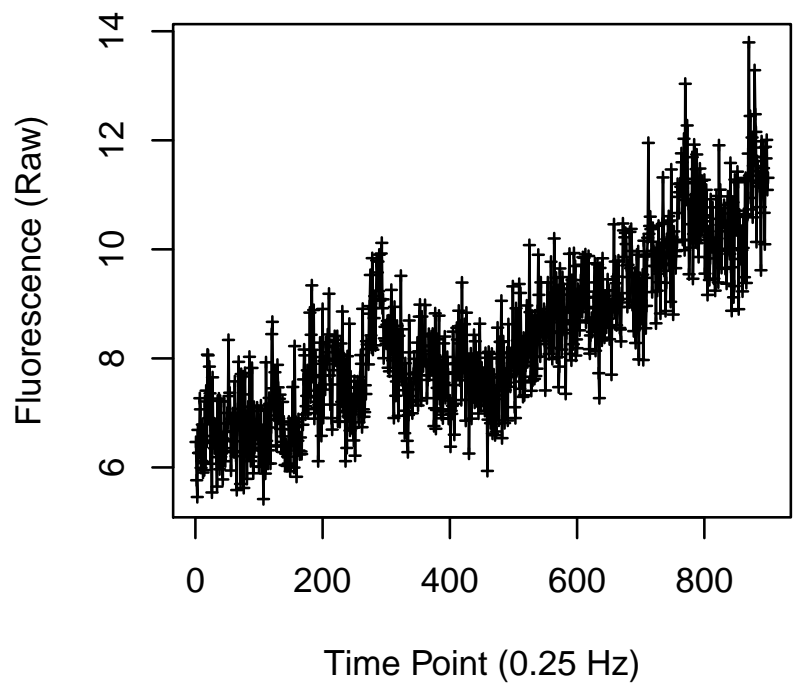


Cell 813

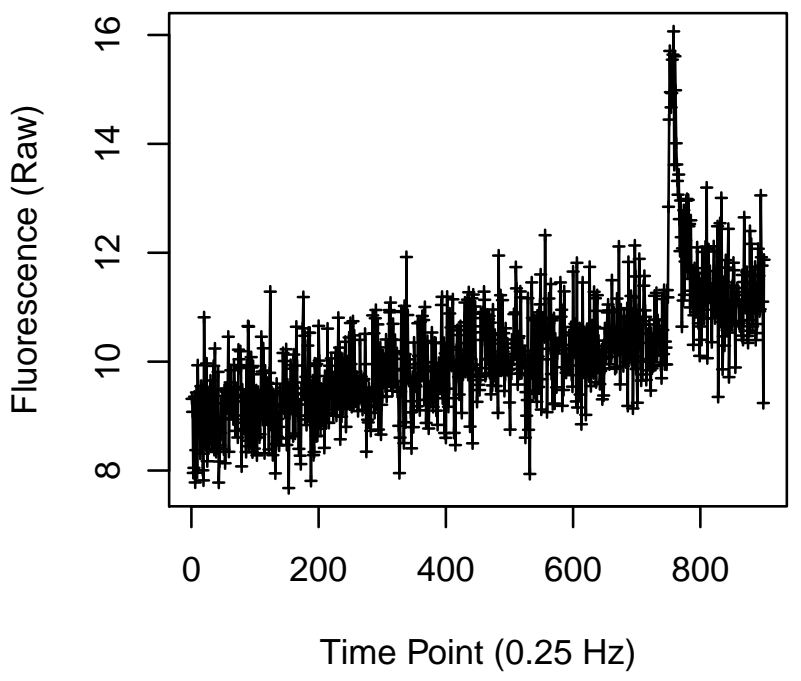

Cell 815

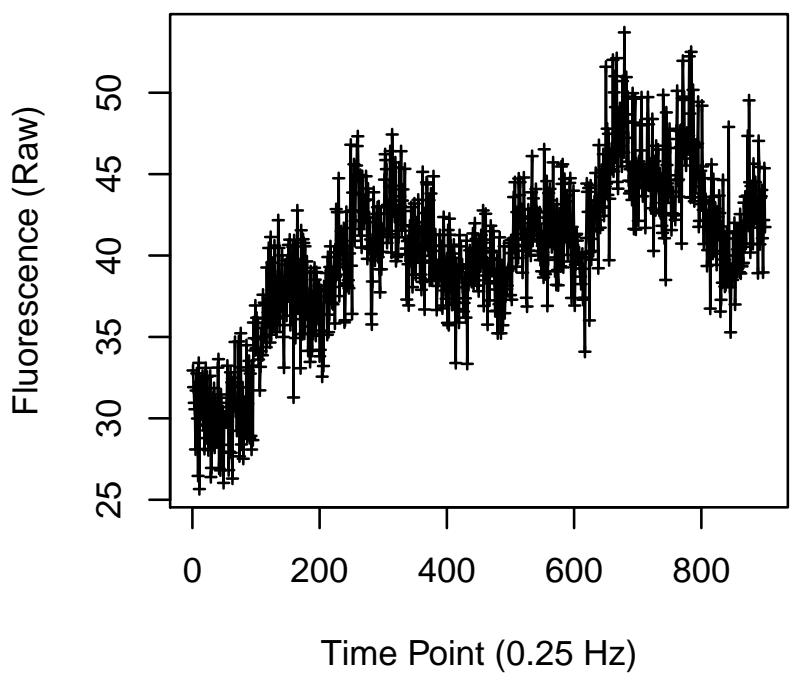

Cell 814

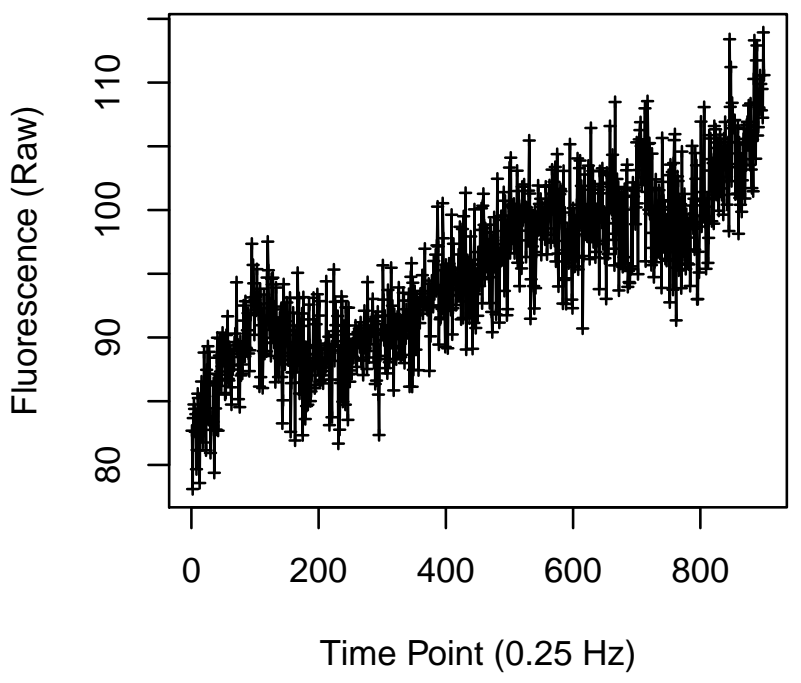

Cell 816

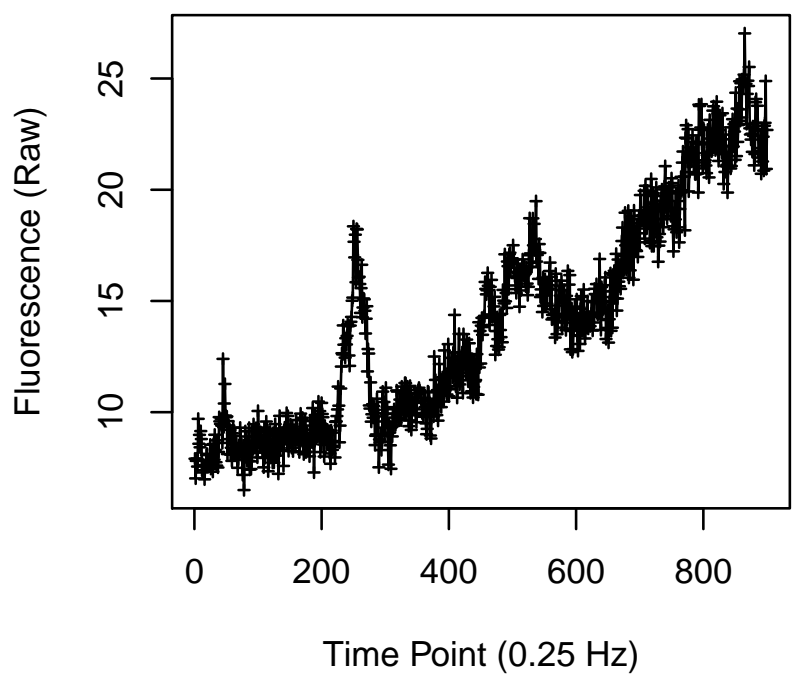


Cell 817

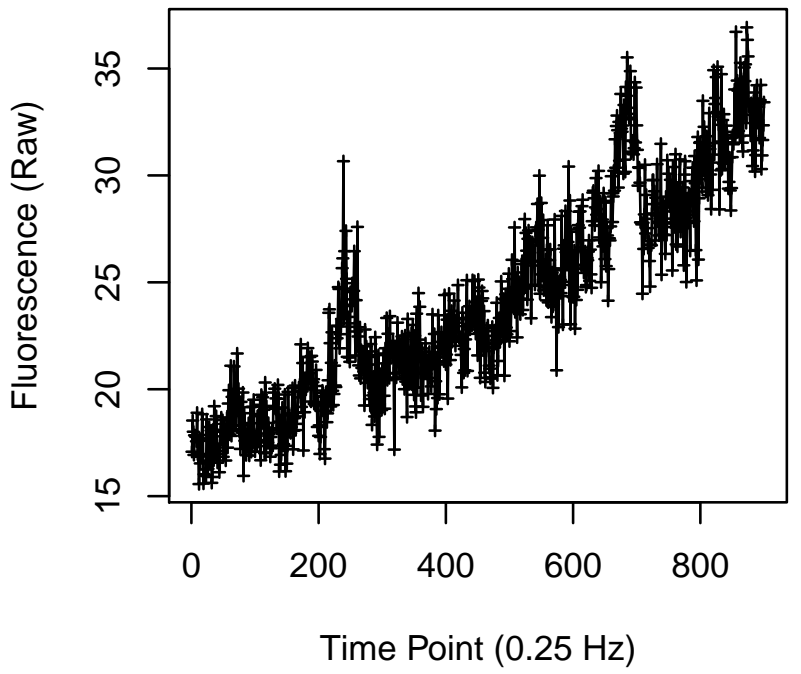

Cell 819

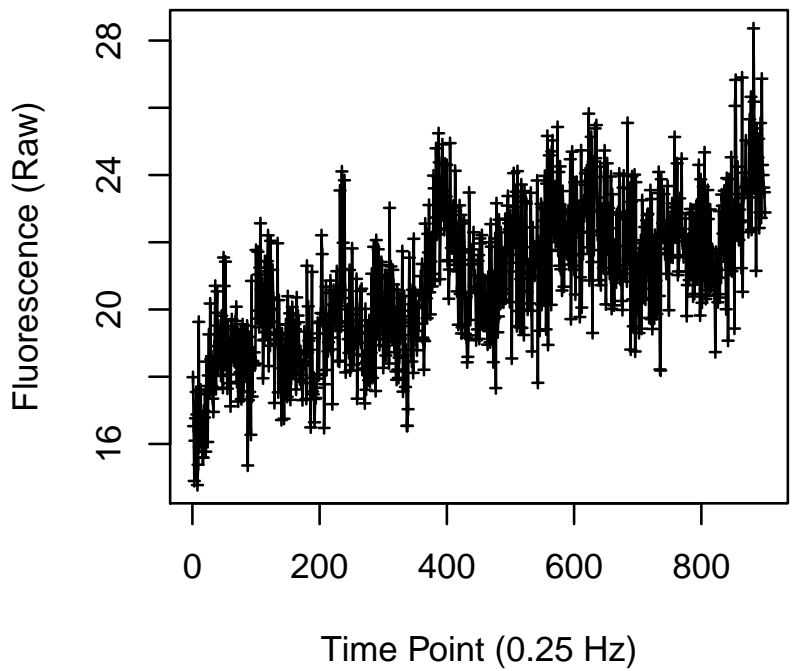

Cell 818

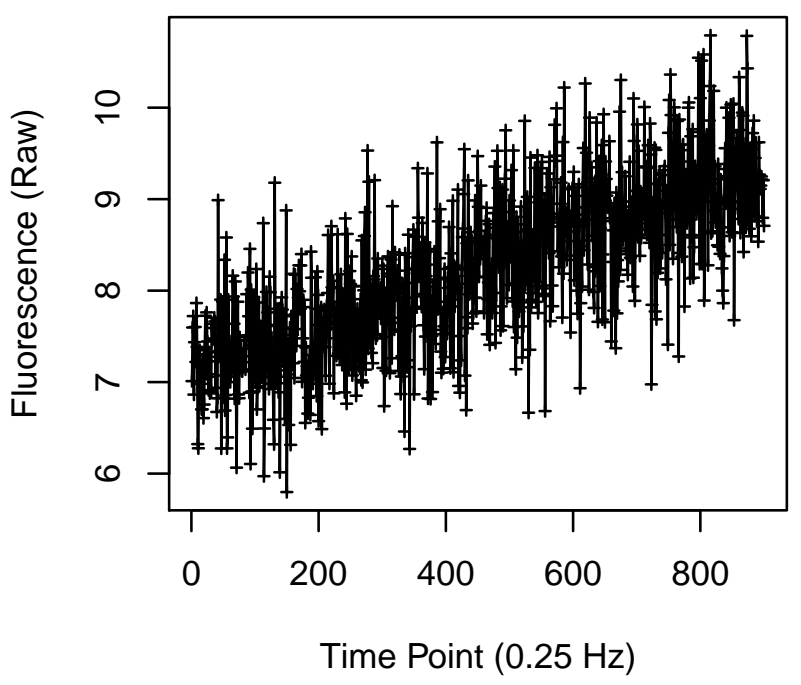

Cell 820

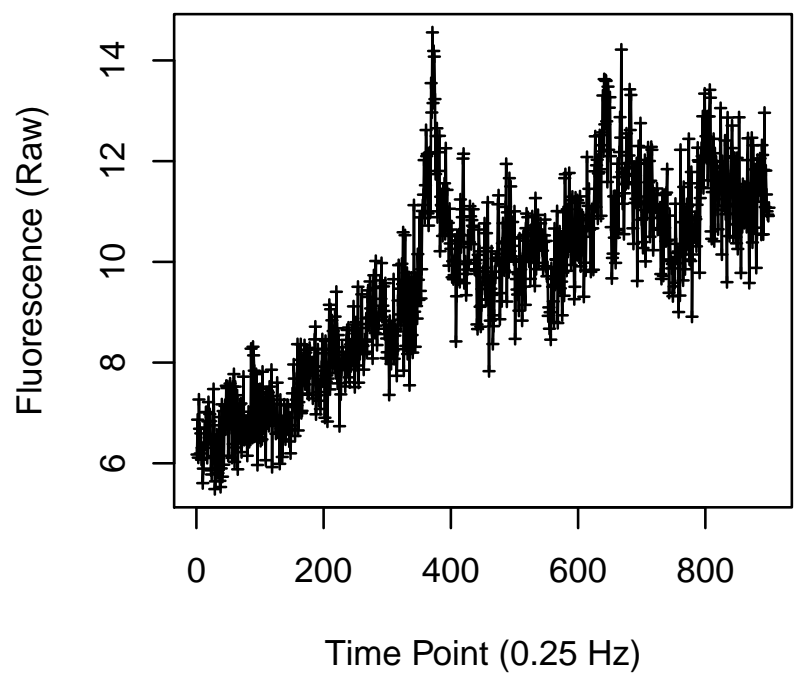


Cell 821

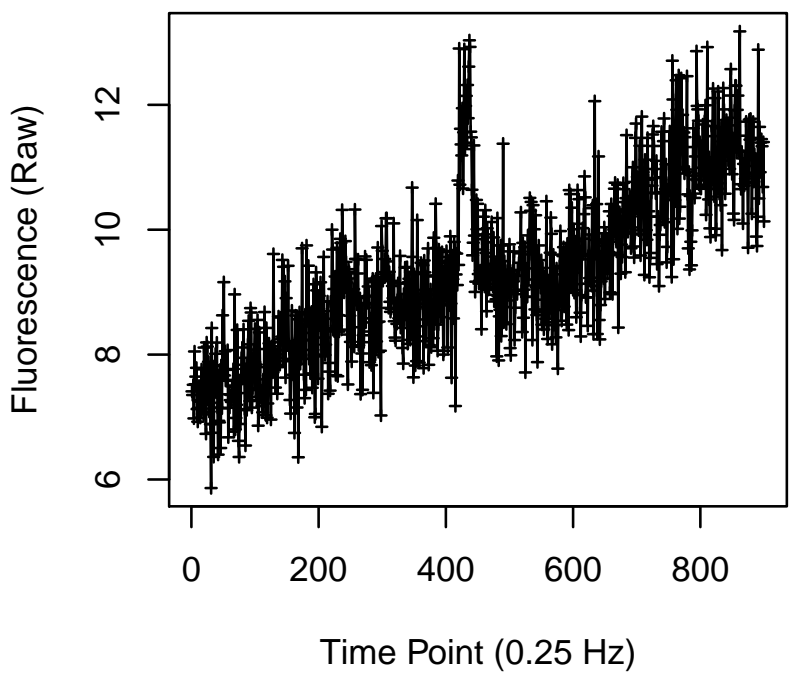

Cell 823

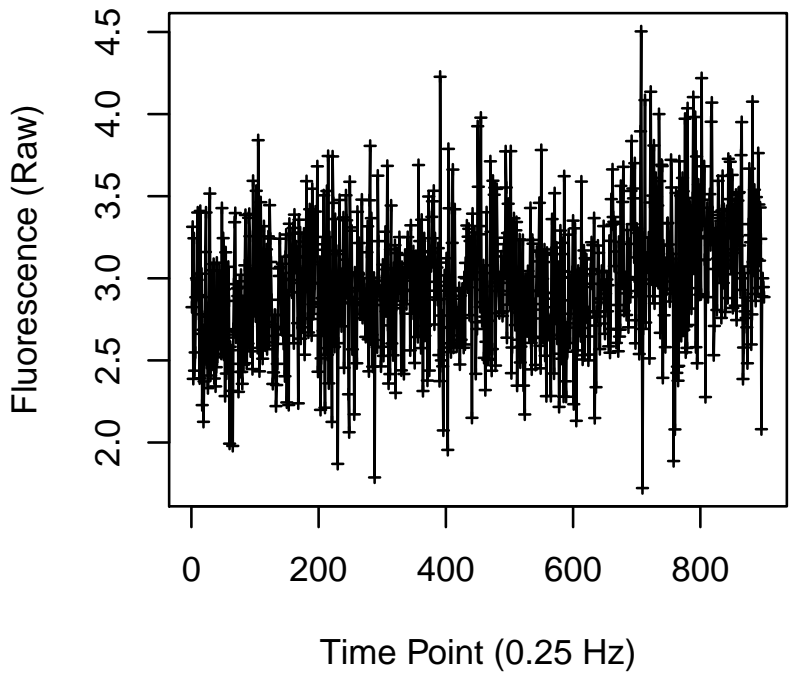

Cell 822

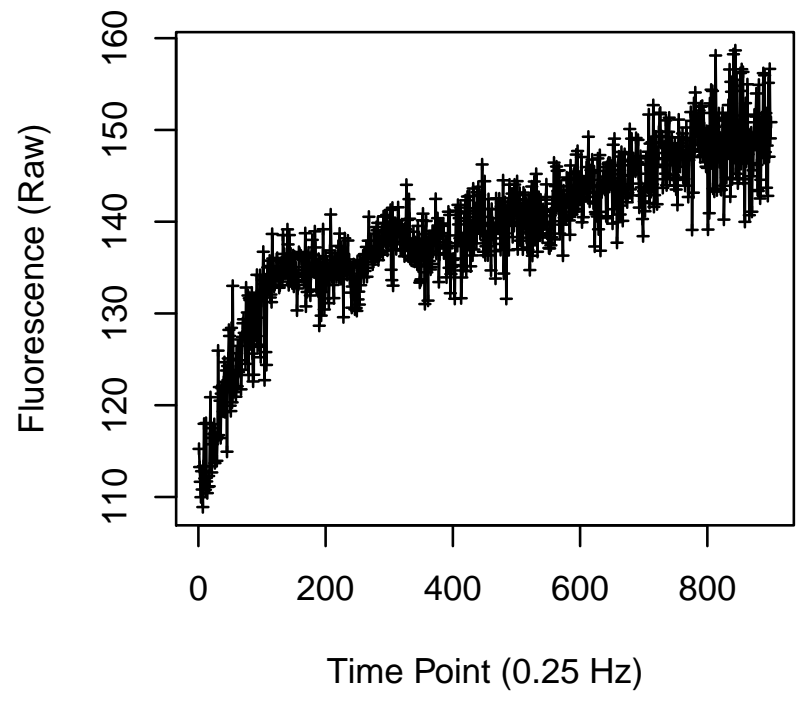

Cell 824

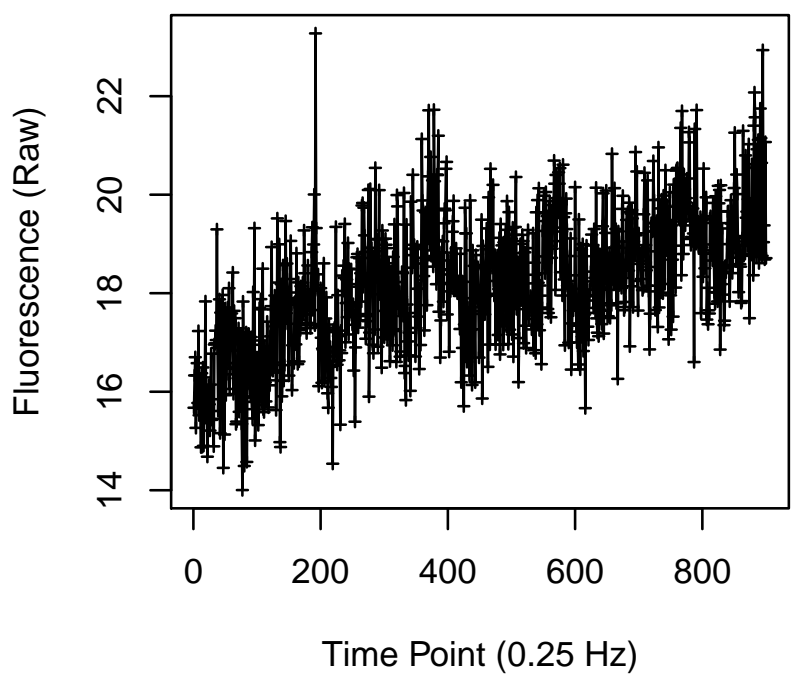




\section{Cell 829}

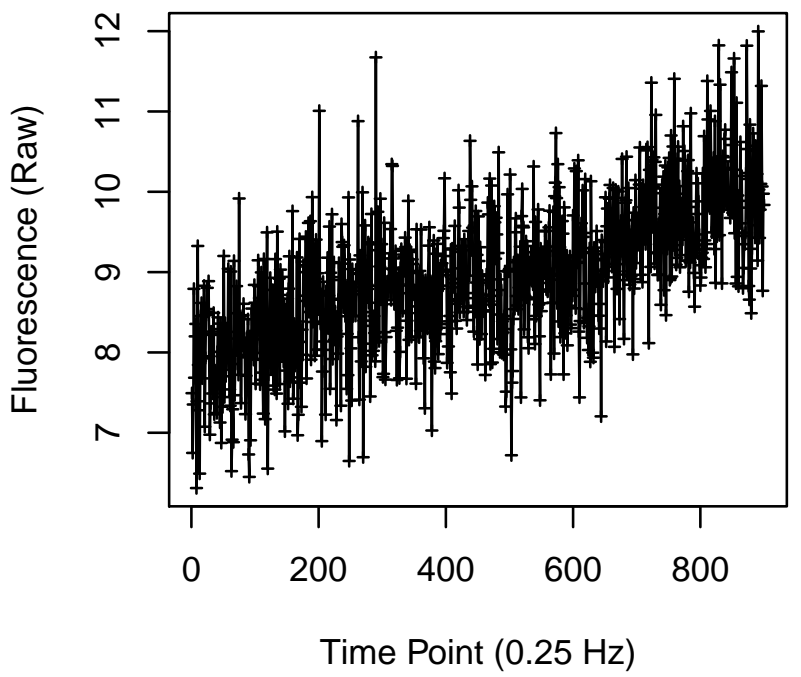

Cell 831

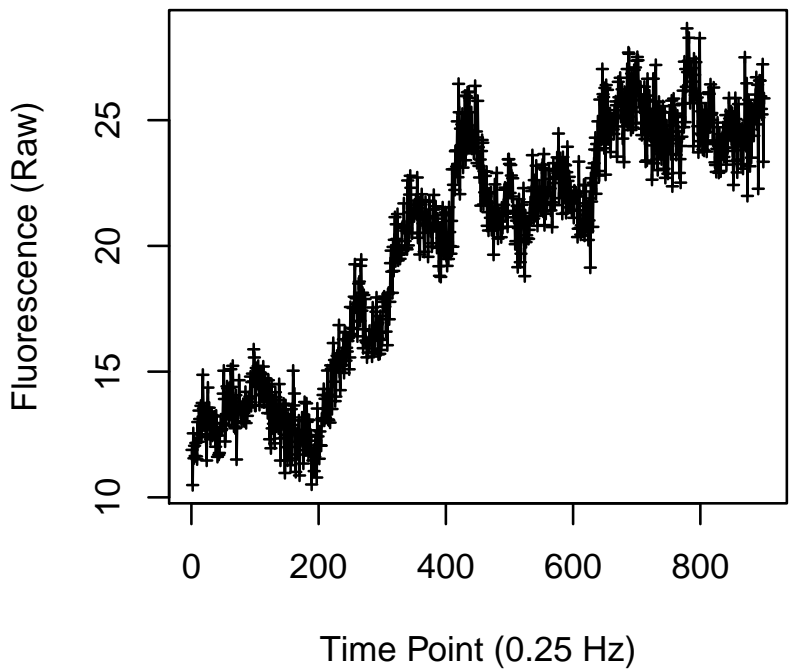

Cell 830

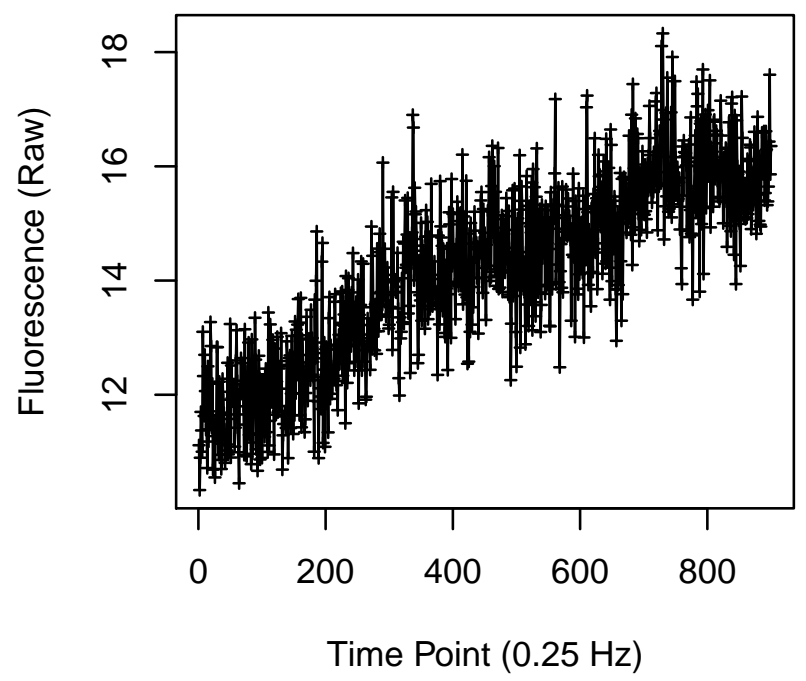

Cell 832

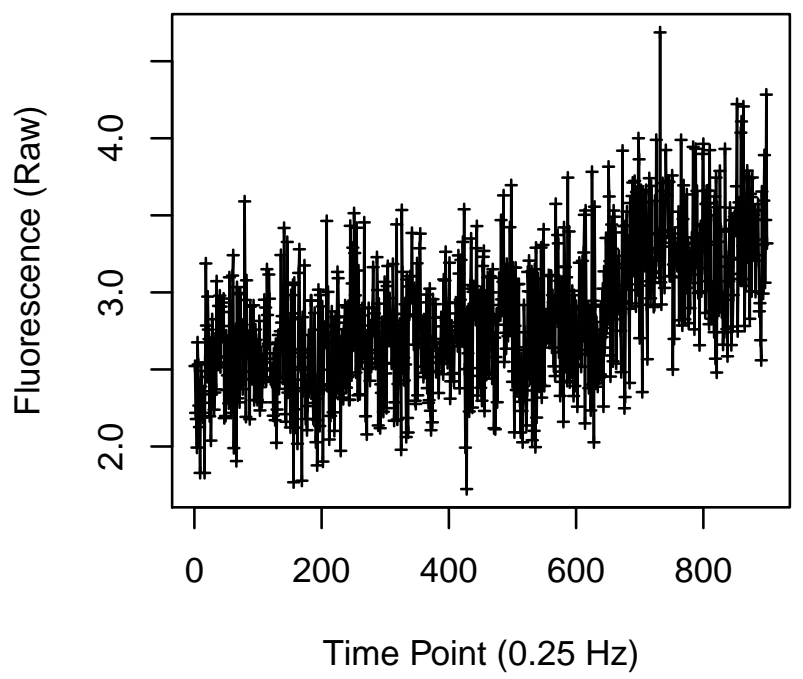




\section{Cell 833}

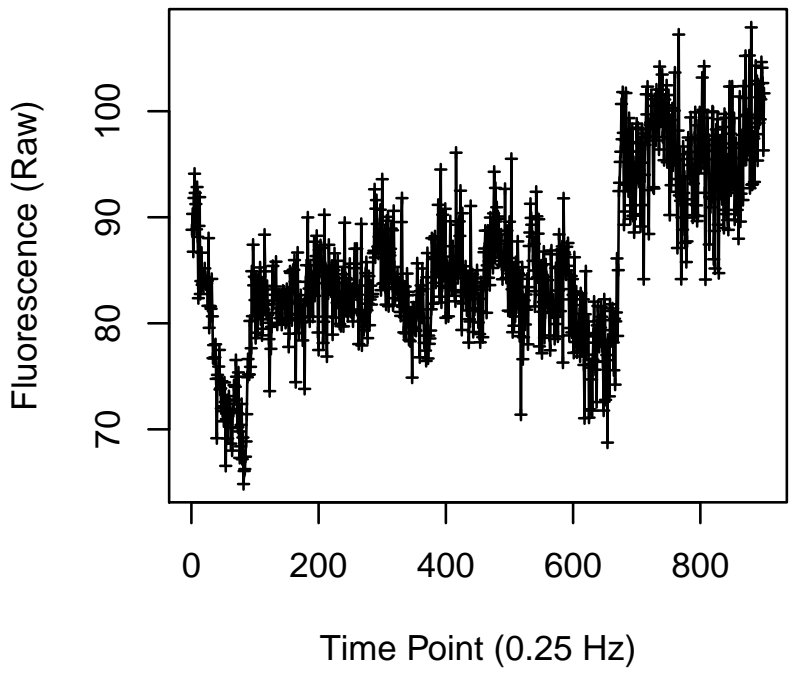

Cell 835

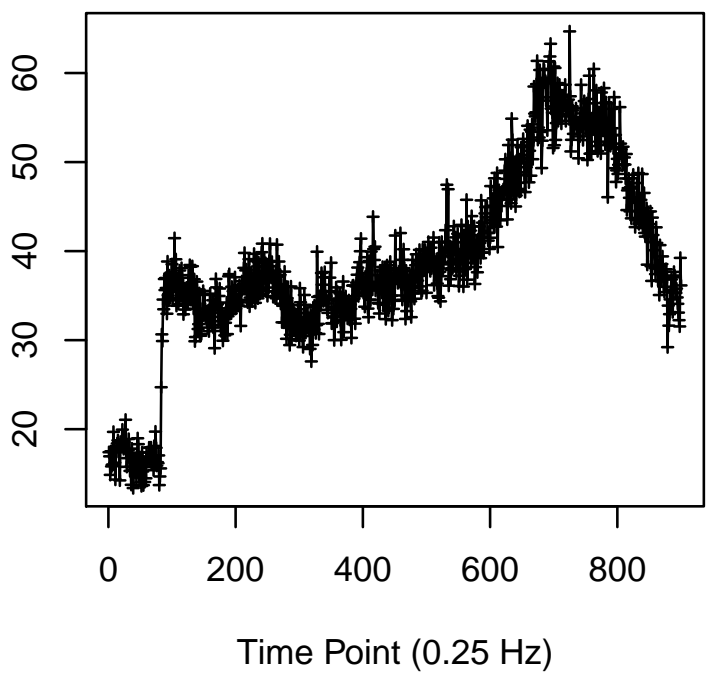

Cell 834

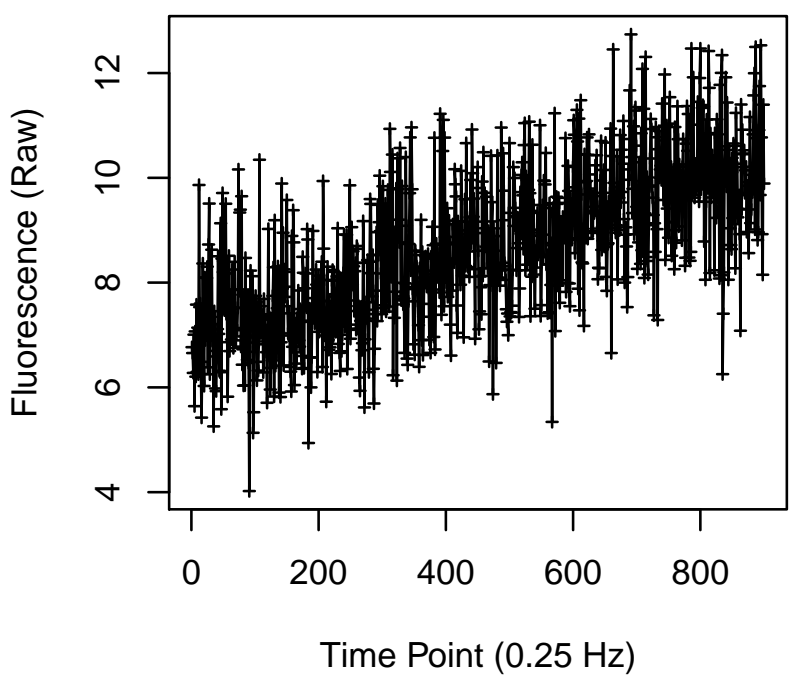

Cell 836

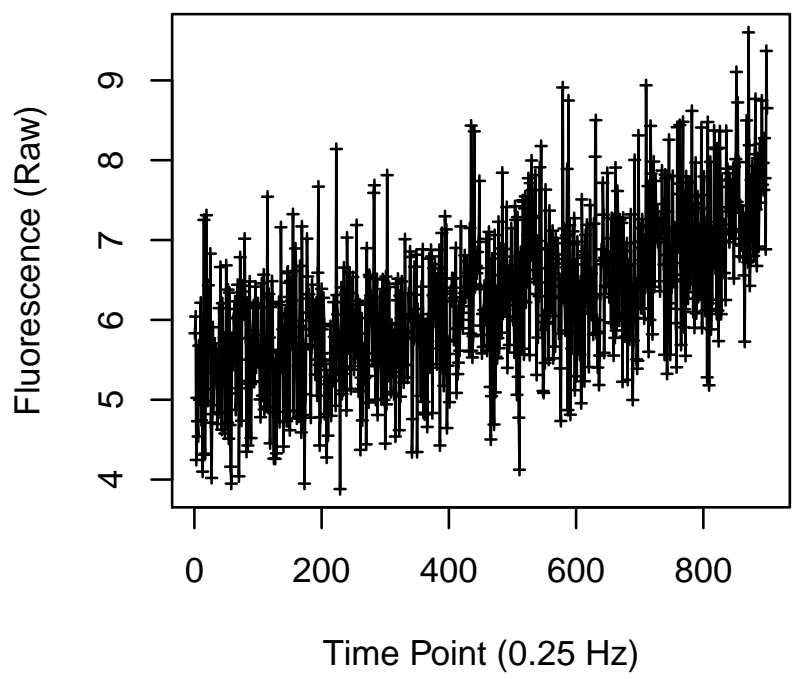


Cell 841

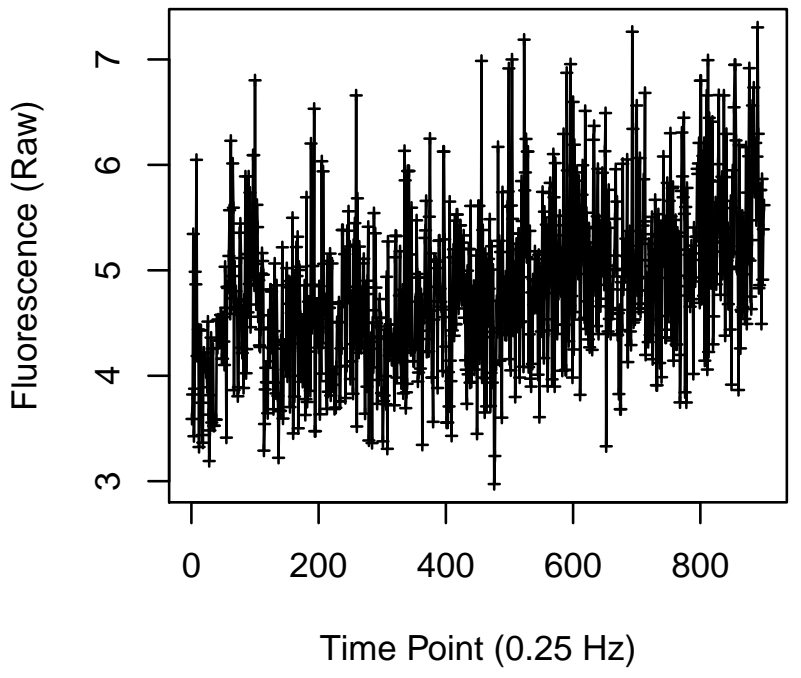

Cell 843

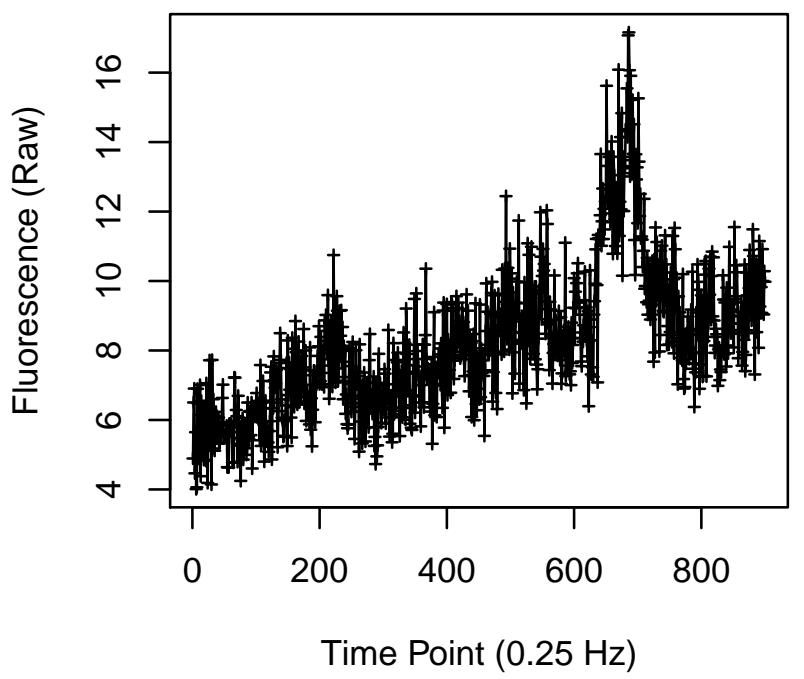

Cell 842

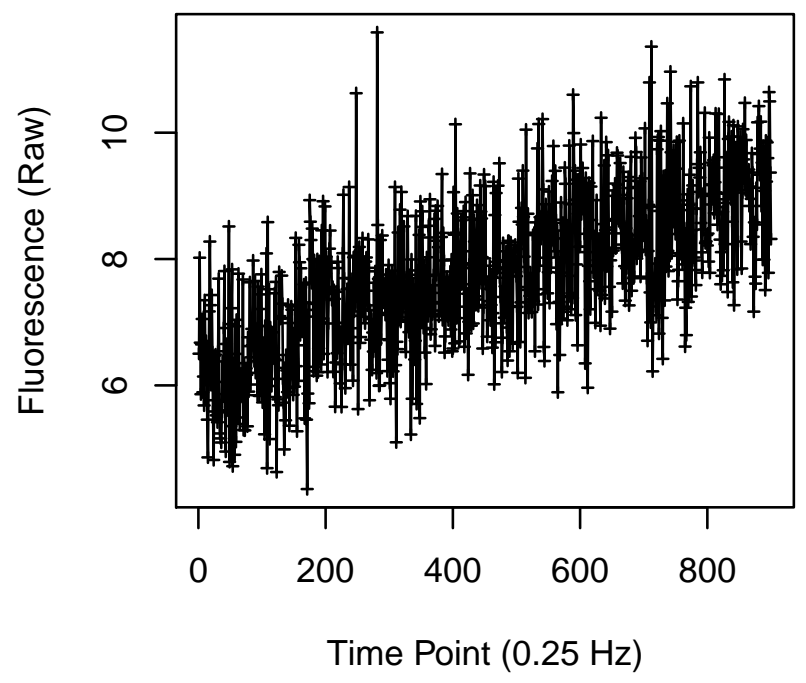

Cell 844

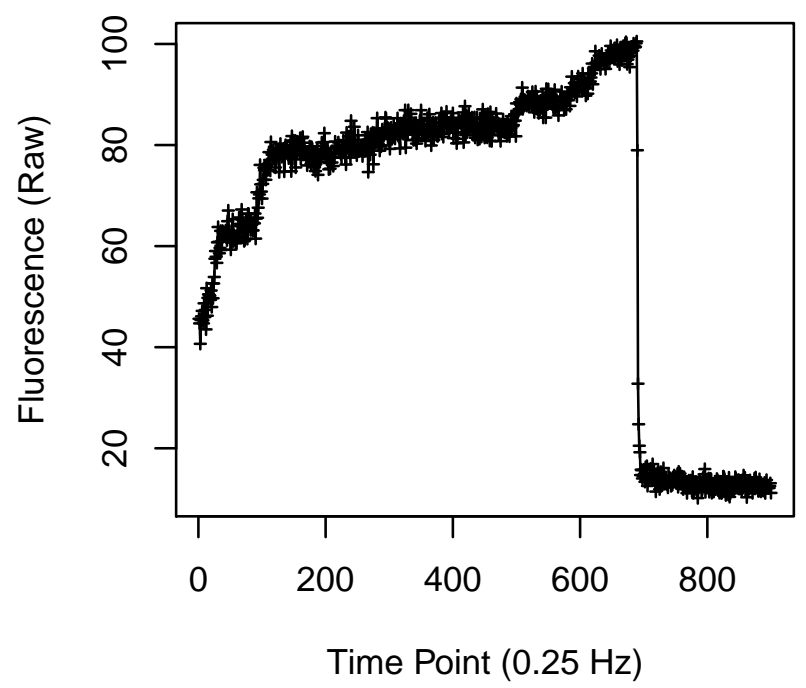




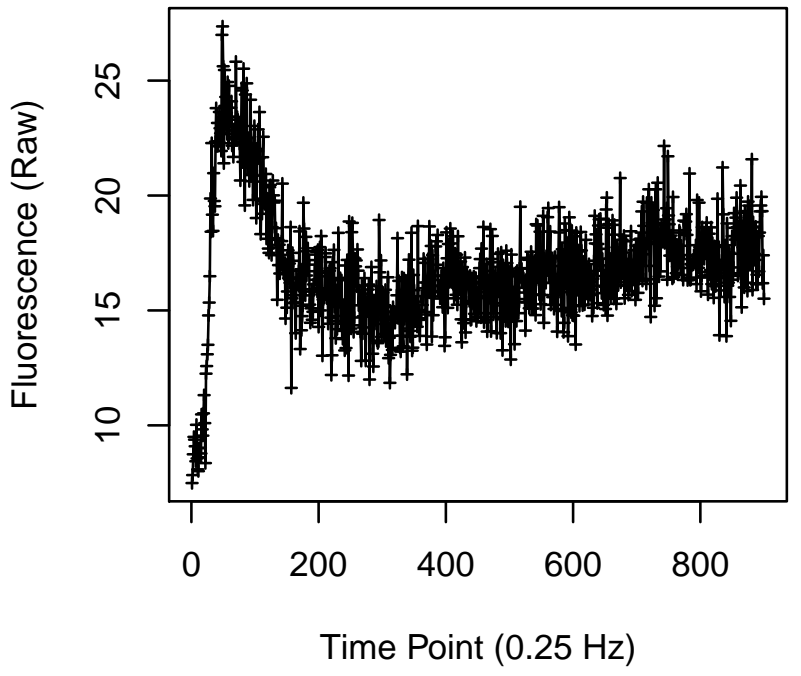

Cell 847

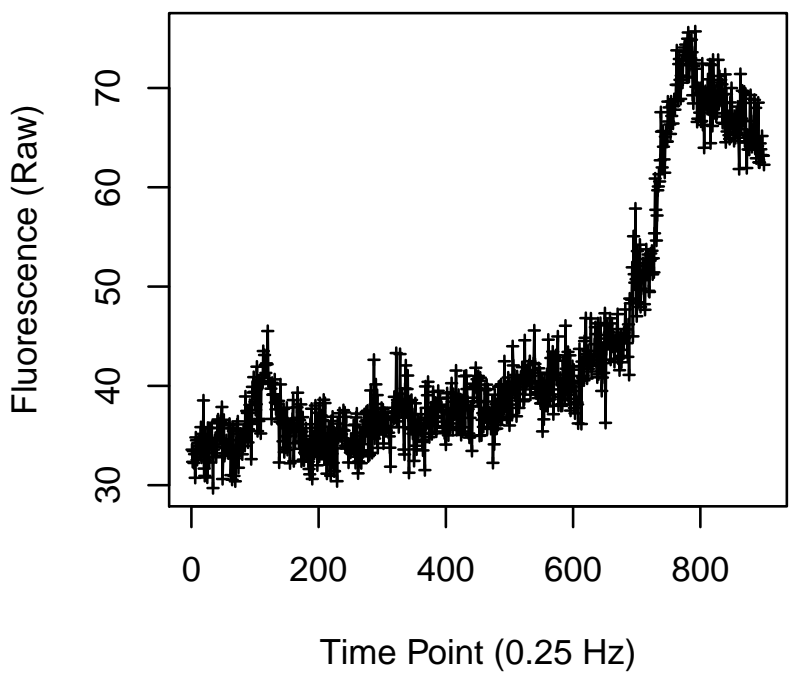

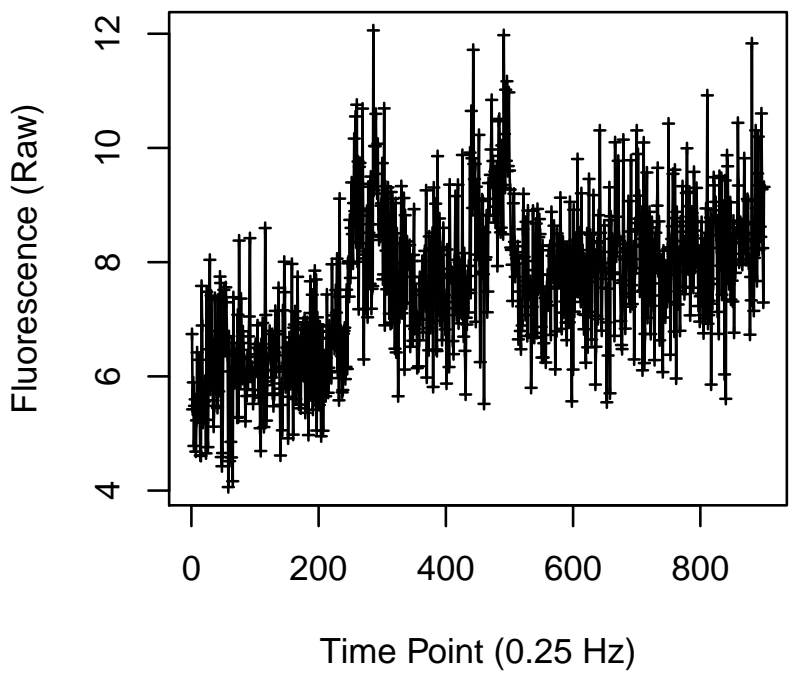

Cell 848

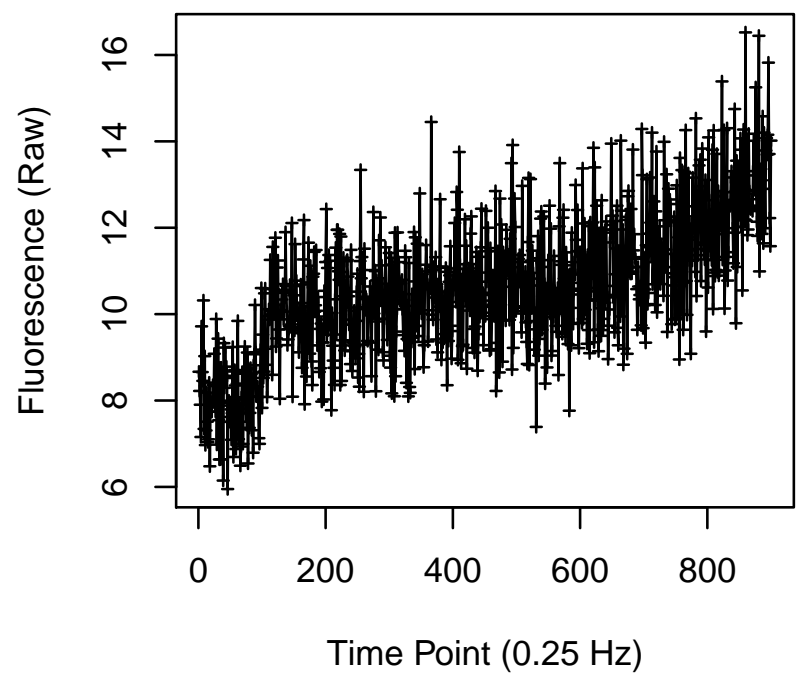




\section{Cell 849}

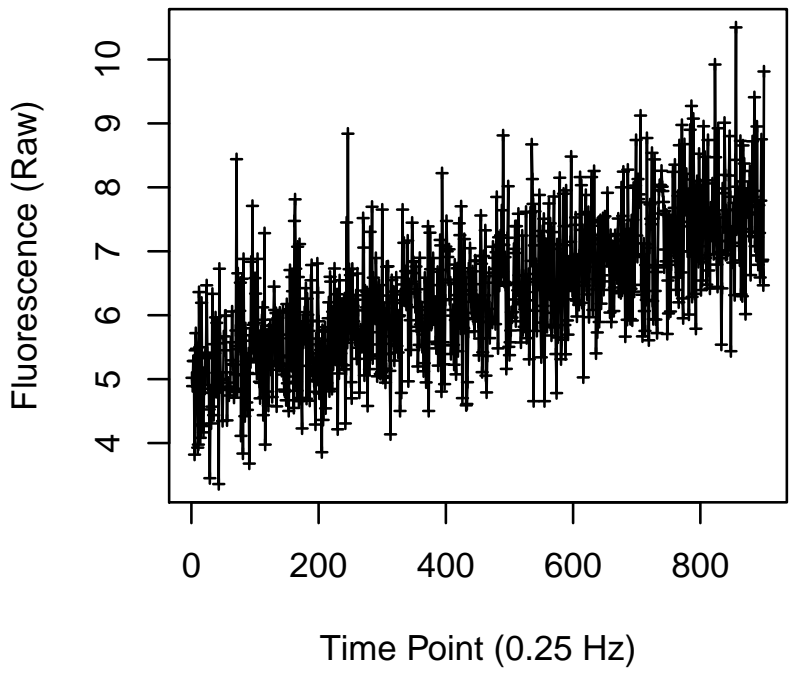

Cell 851

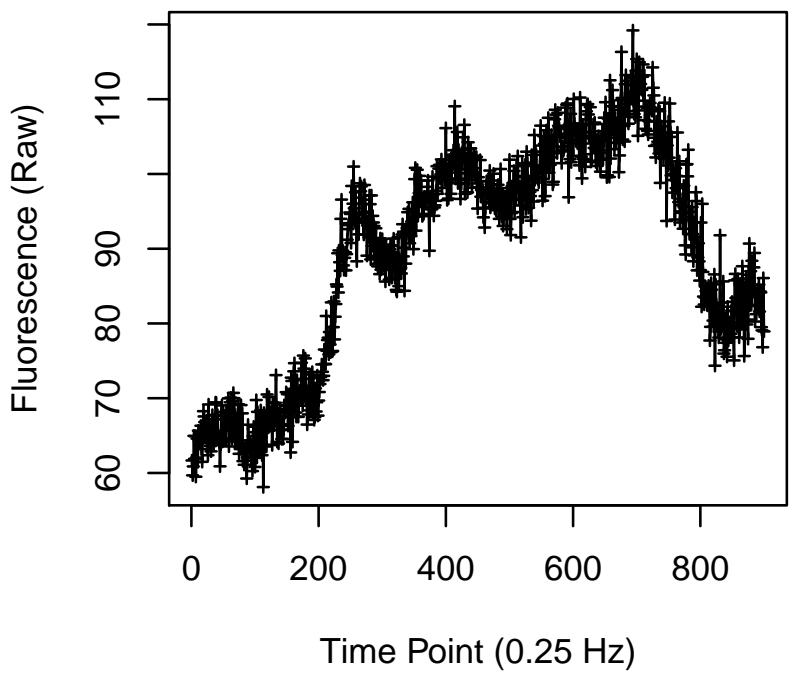

Cell 850

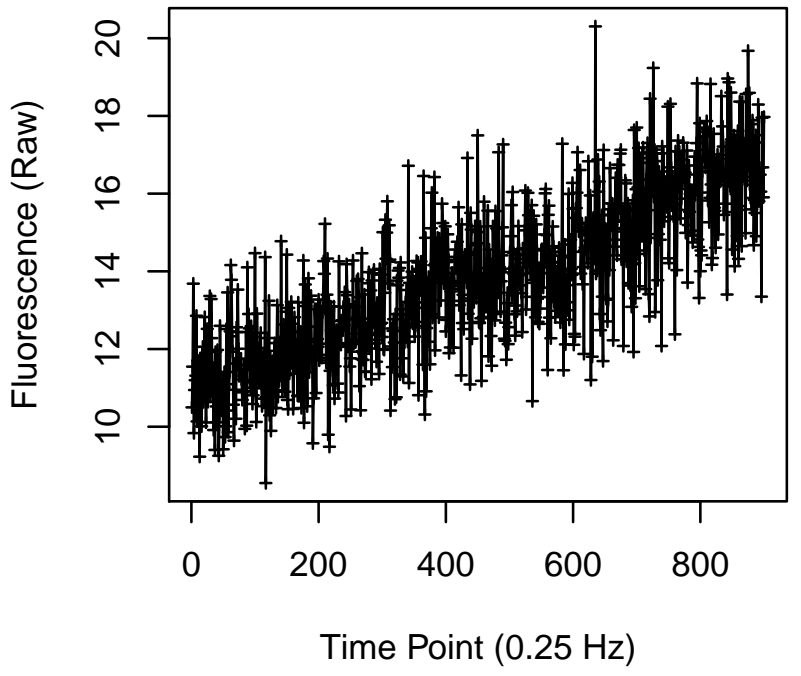

Cell 852

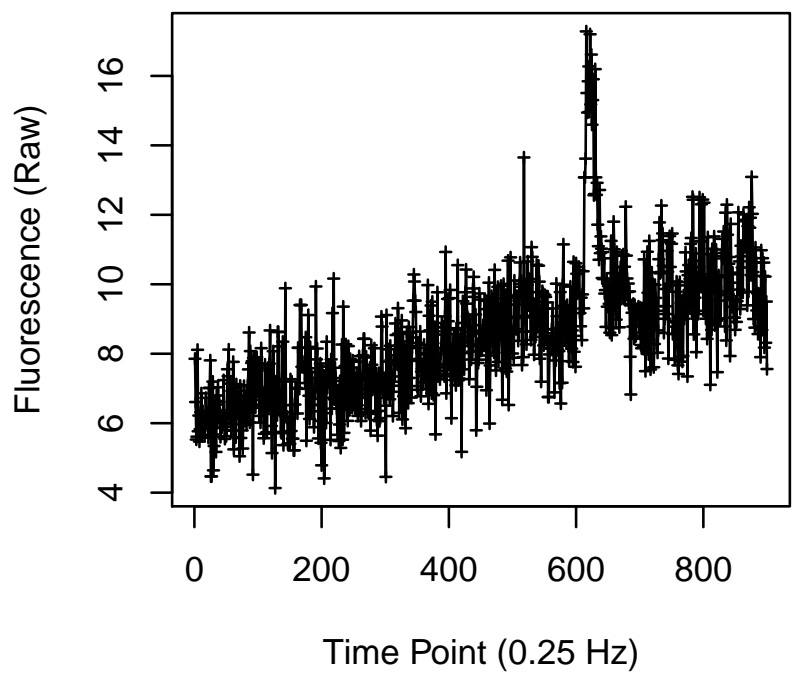




\section{Cell 853}

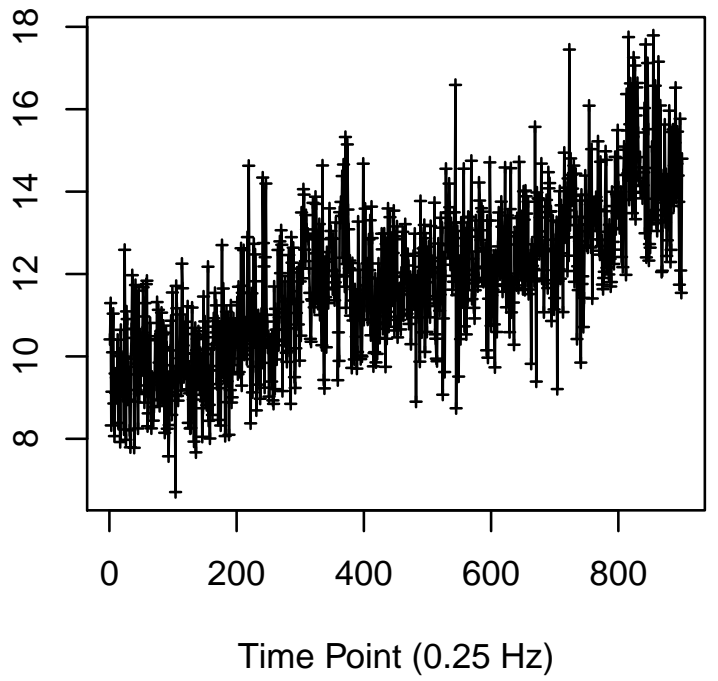

Cell 855

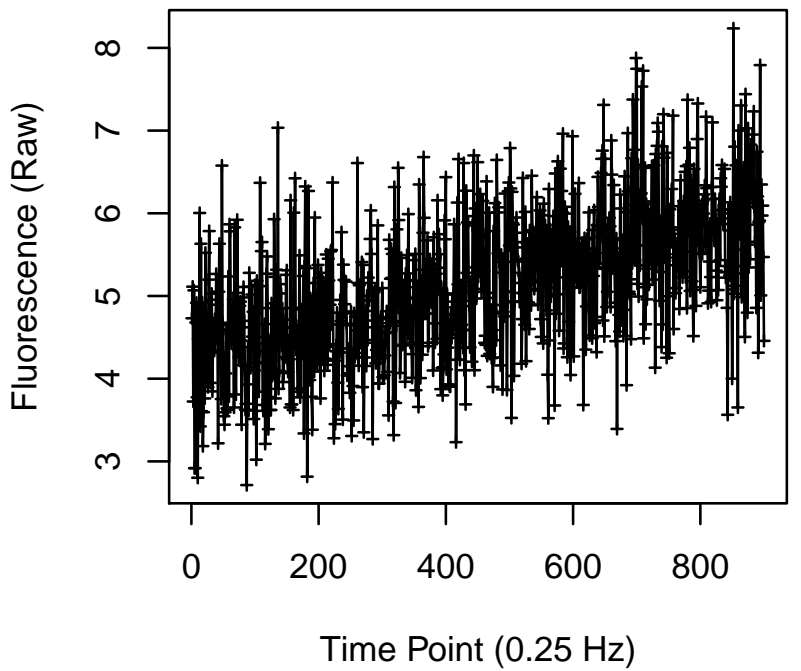

Cell 854

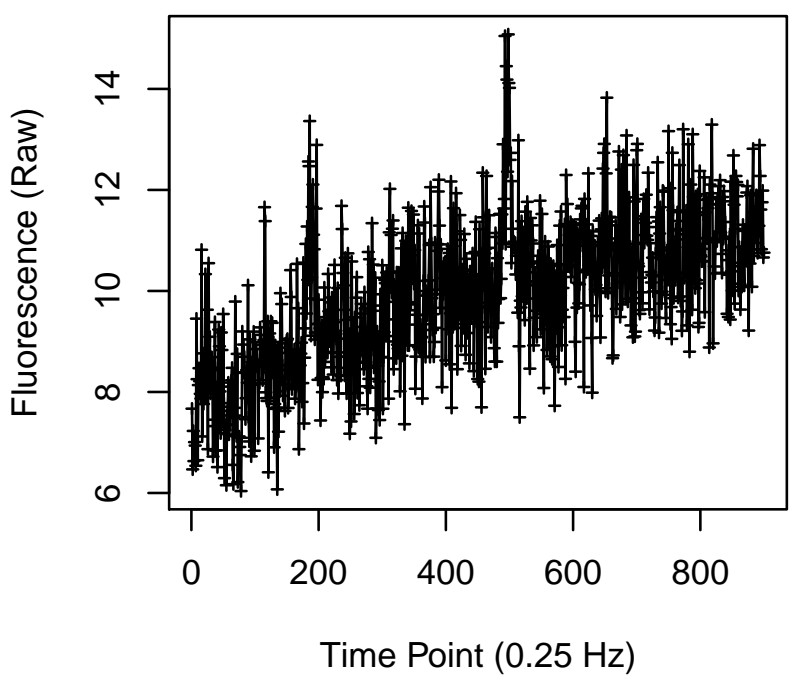

Cell 856

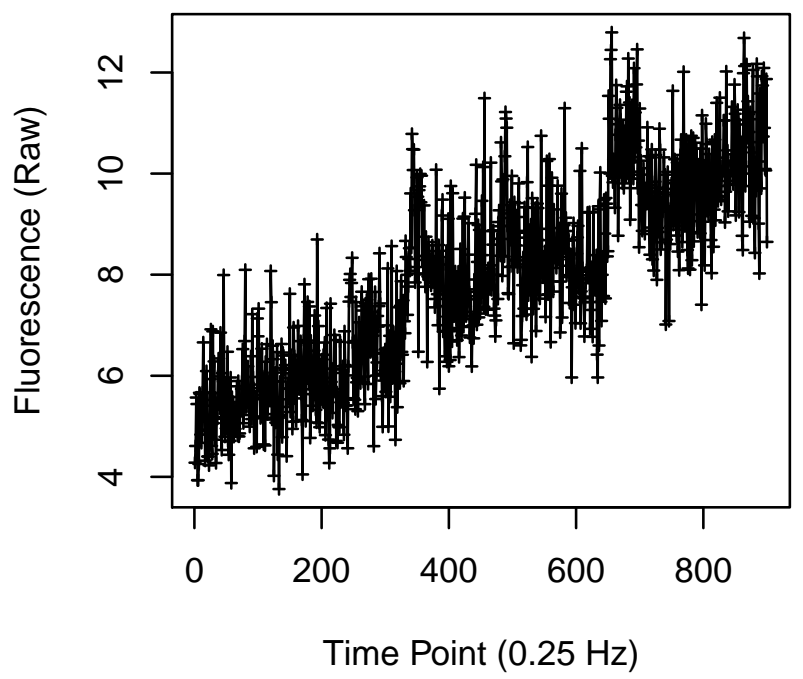


Cell 857

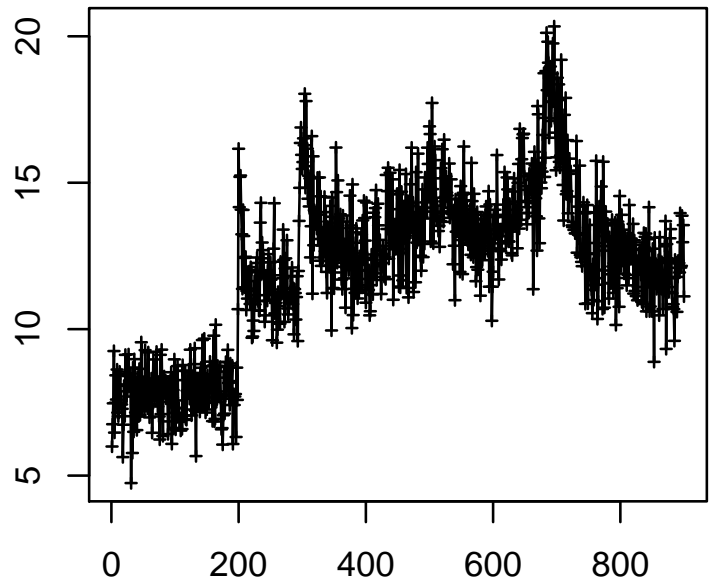

Time Point $(0.25 \mathrm{~Hz})$

\section{Cell 859}

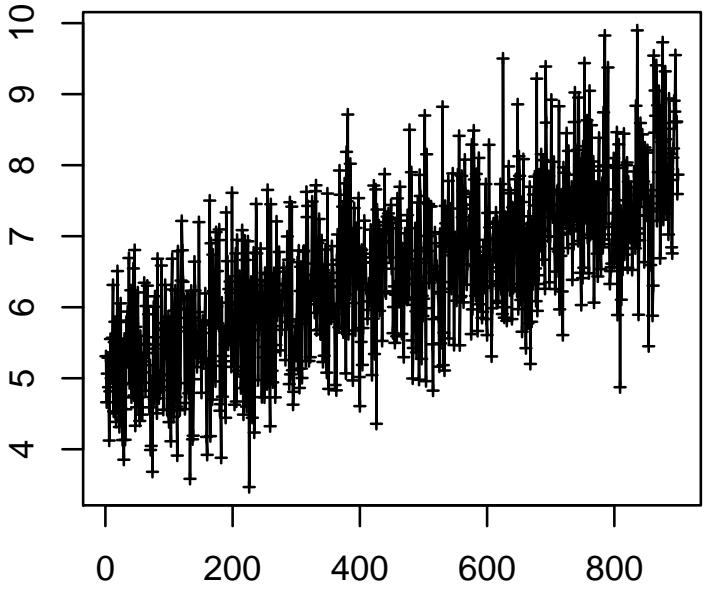

Time Point $(0.25 \mathrm{~Hz})$
Cell 858

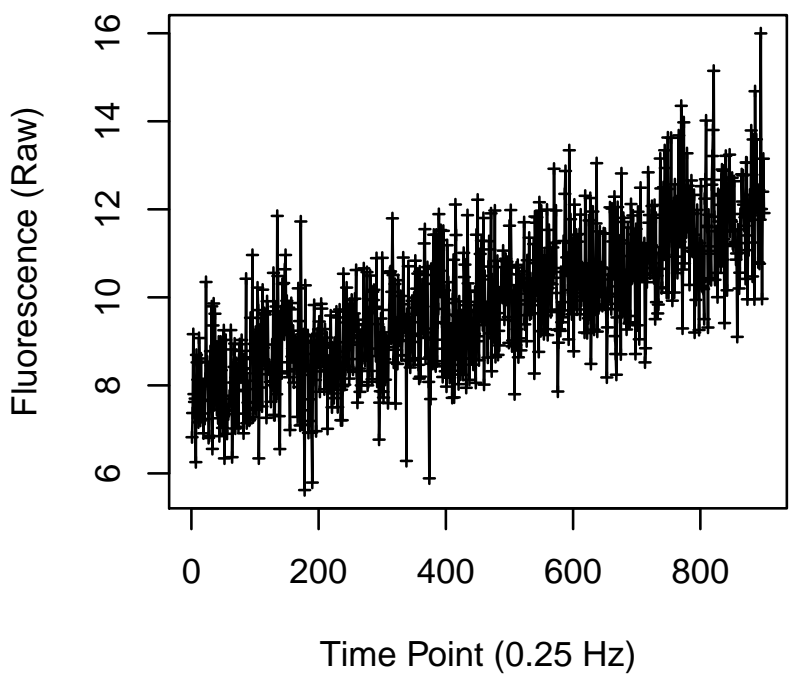

Cell 860

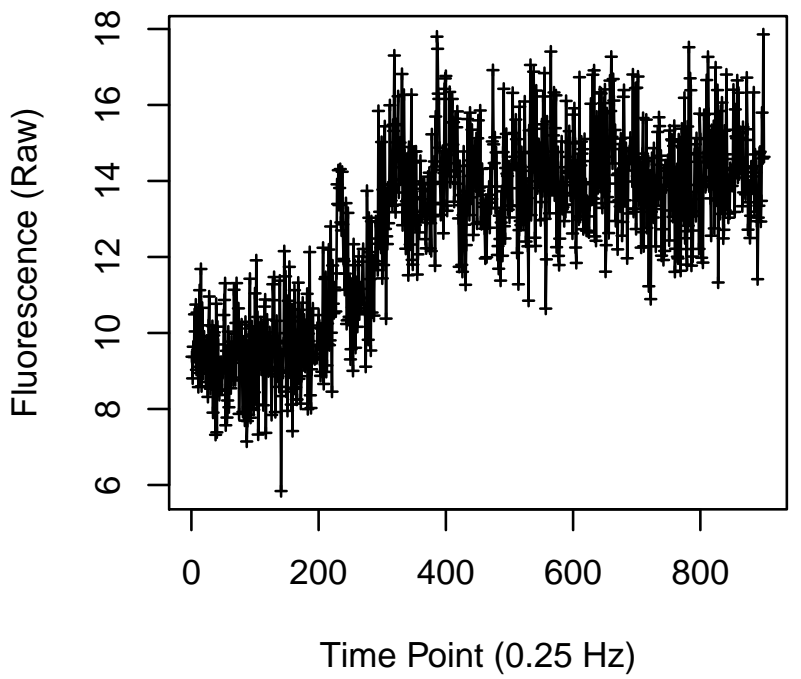


Cell 861

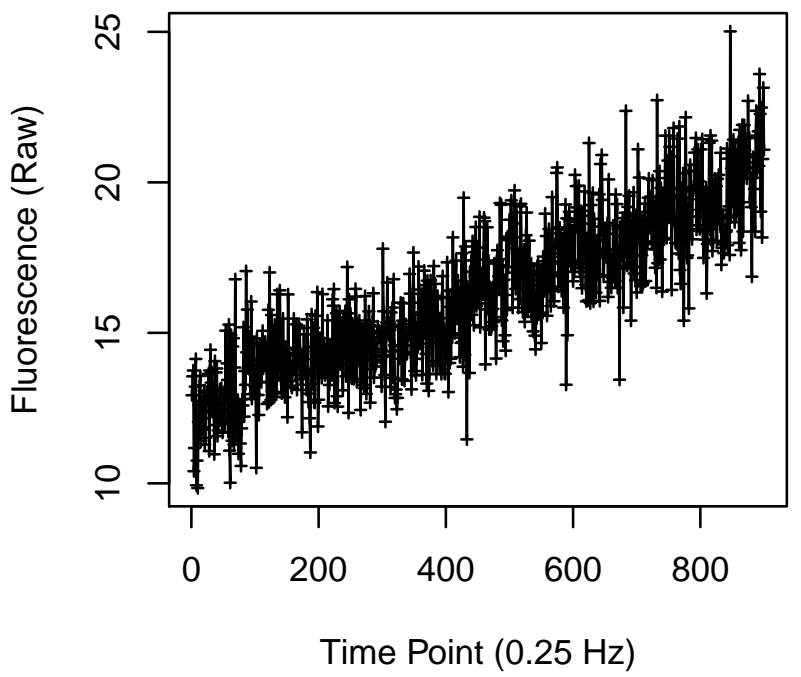

Cell 863

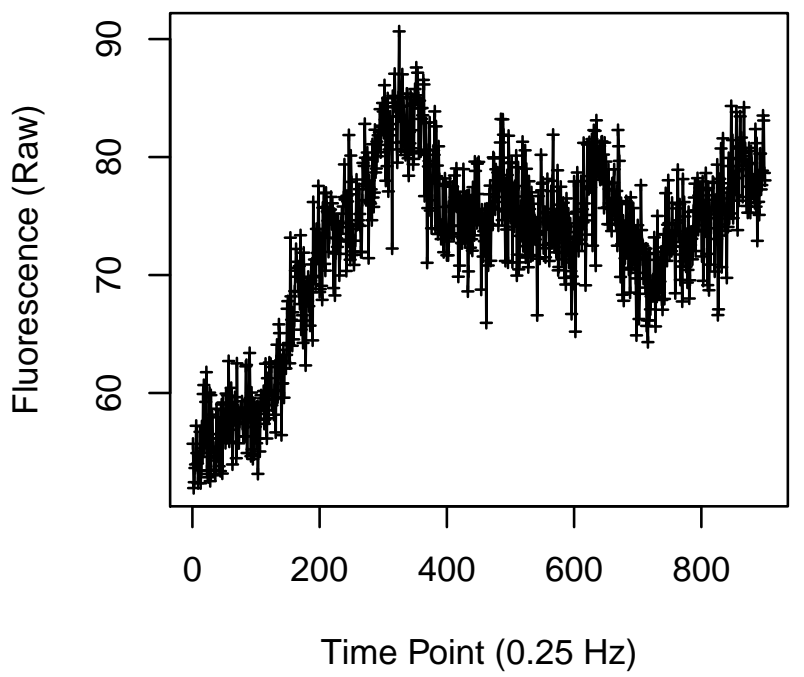

Cell 862

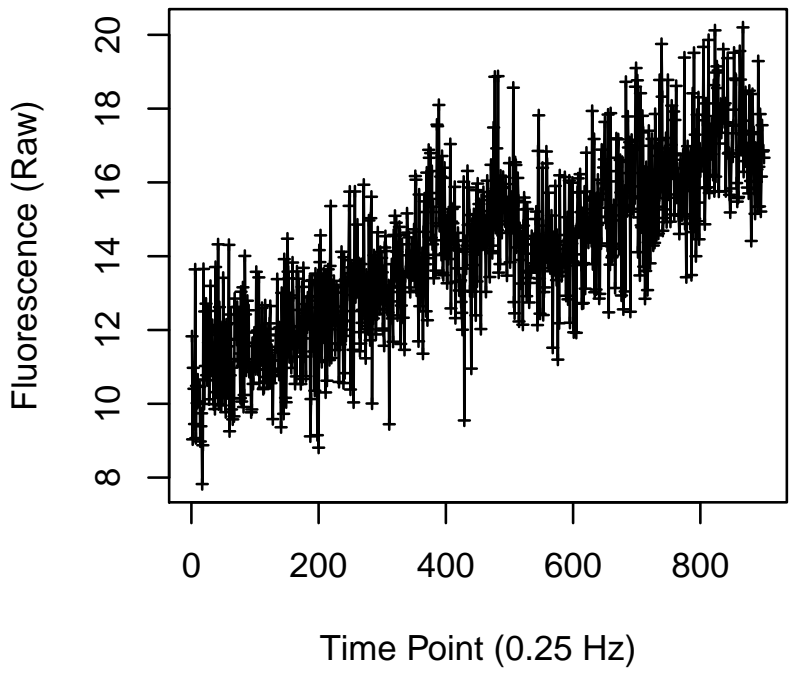

Cell 864

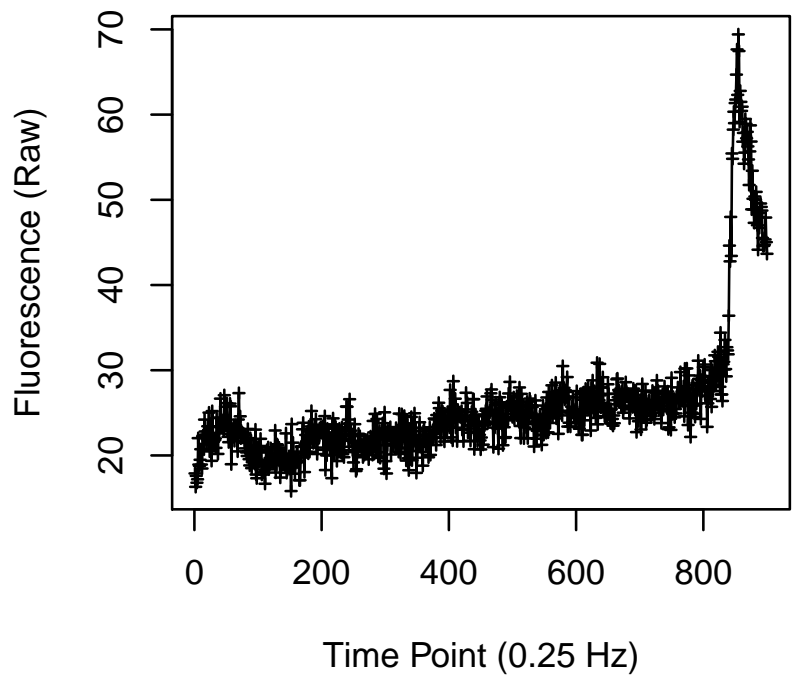




\section{Cell 865}

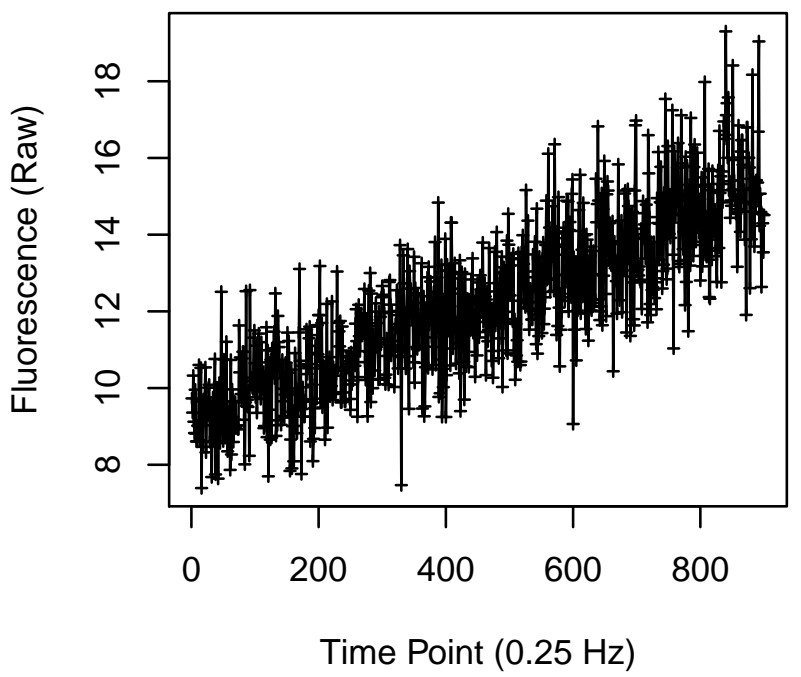

Cell 867

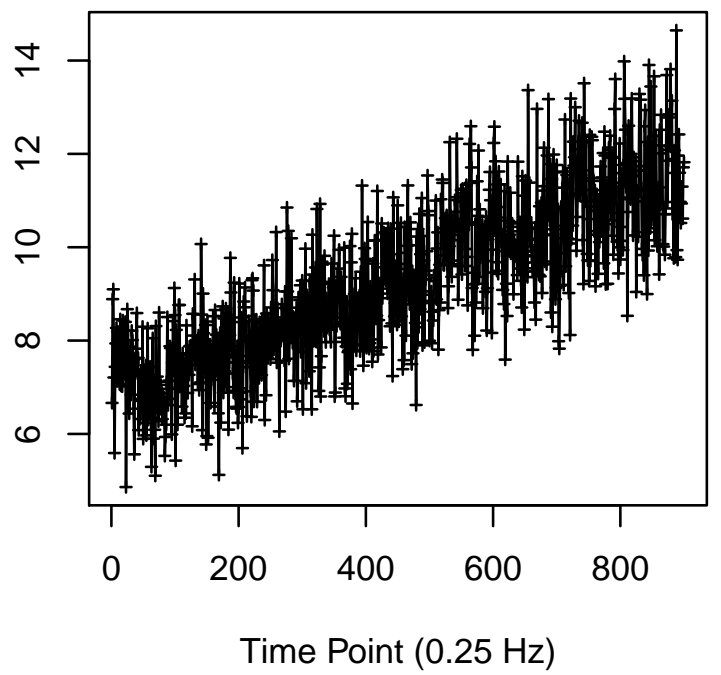

Cell 866

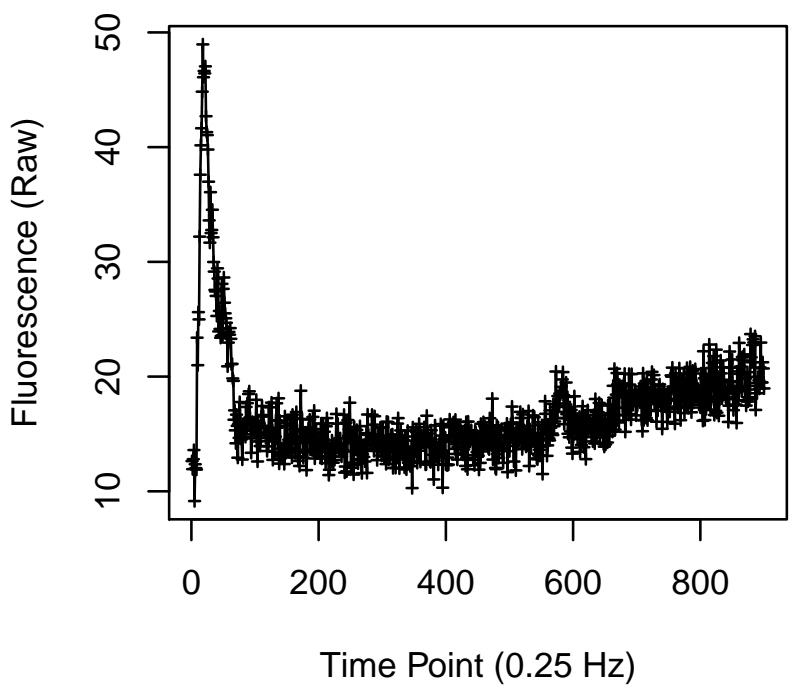

Cell 868

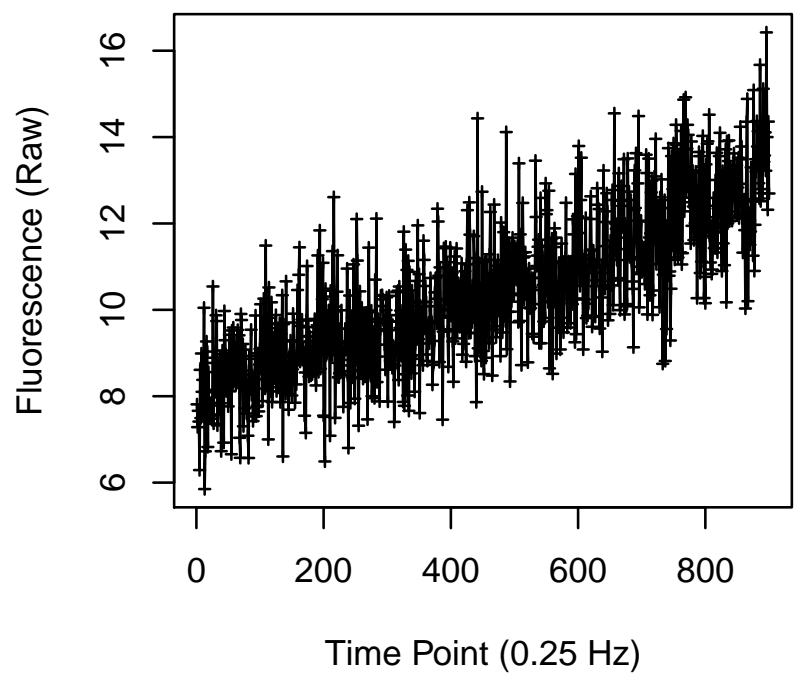


Cell 869

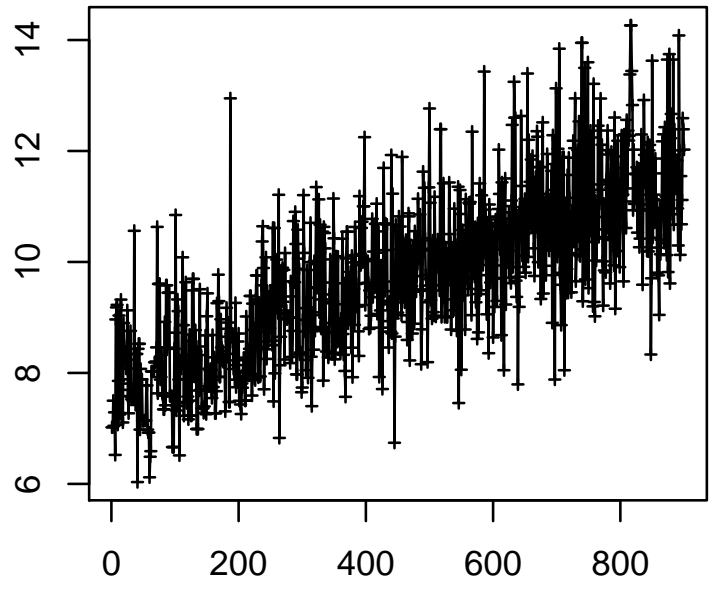

Time Point $(0.25 \mathrm{~Hz})$

Cell 871

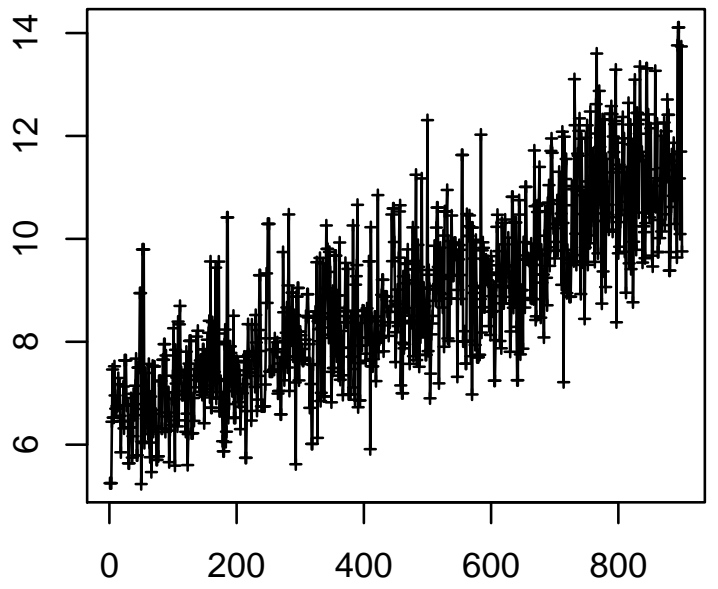

Time Point $(0.25 \mathrm{~Hz})$
Cell 870

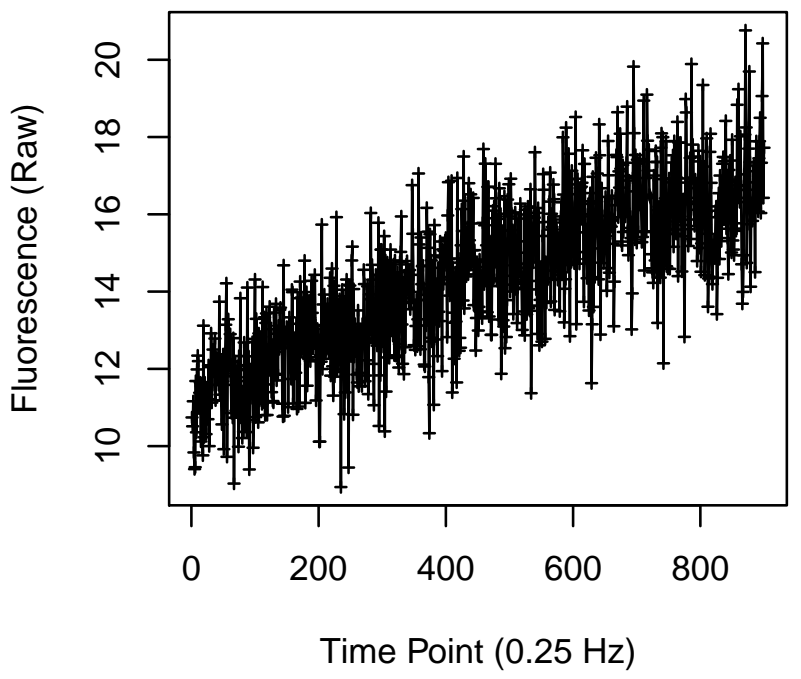

Cell 872

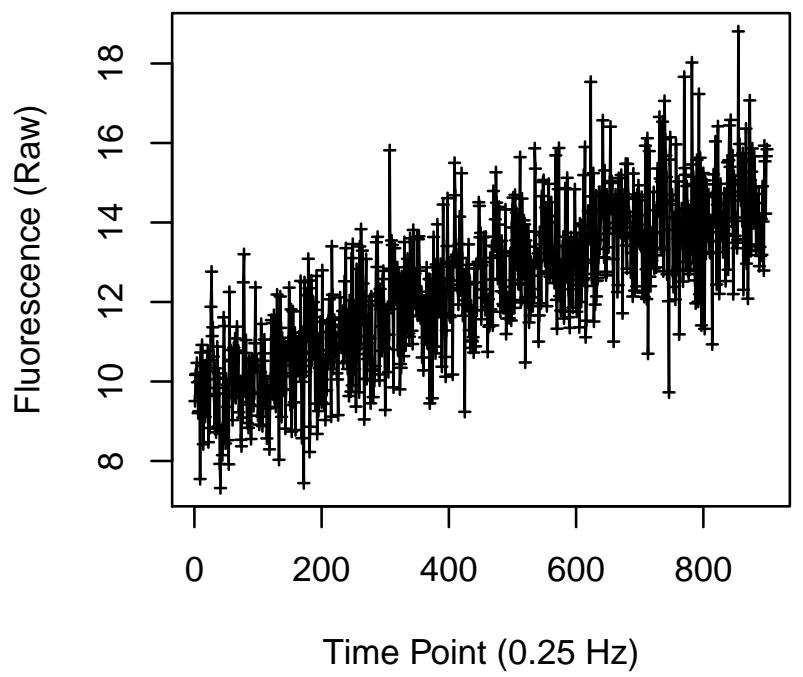


Cell 881

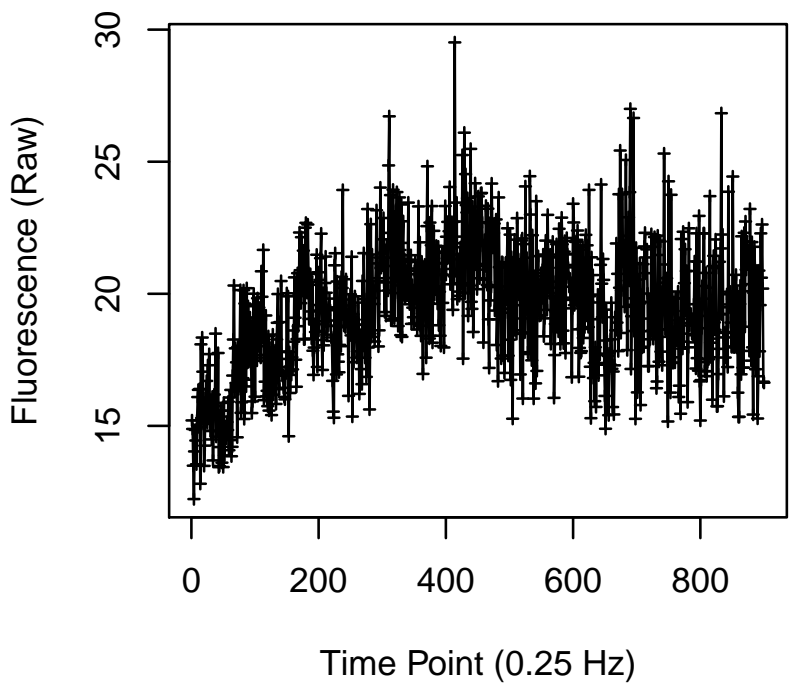

Cell 883

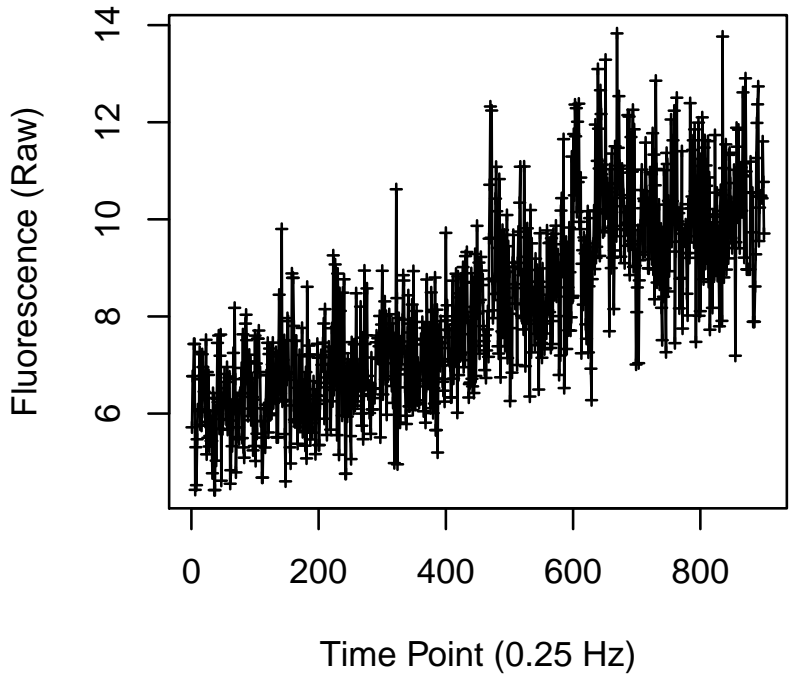

Cell 882

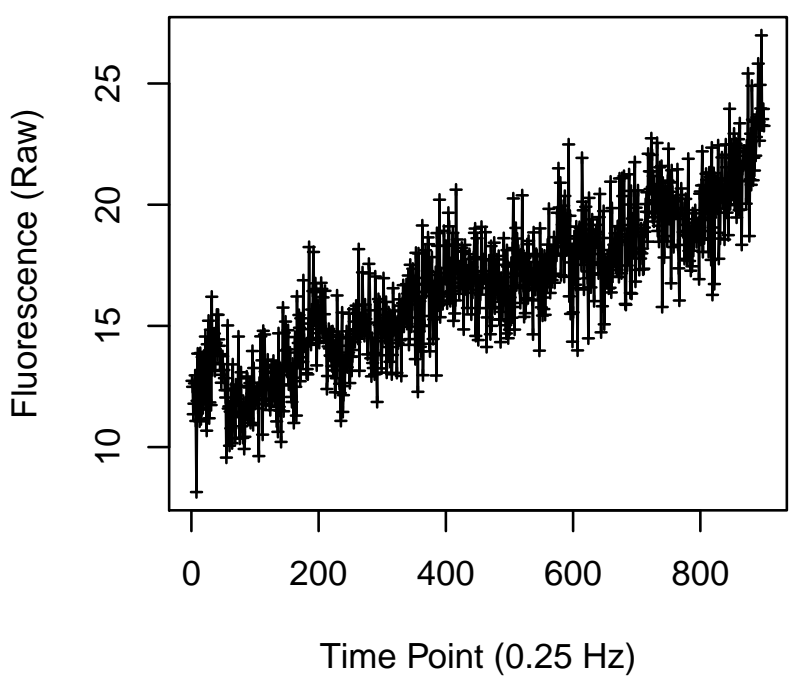

Cell 884

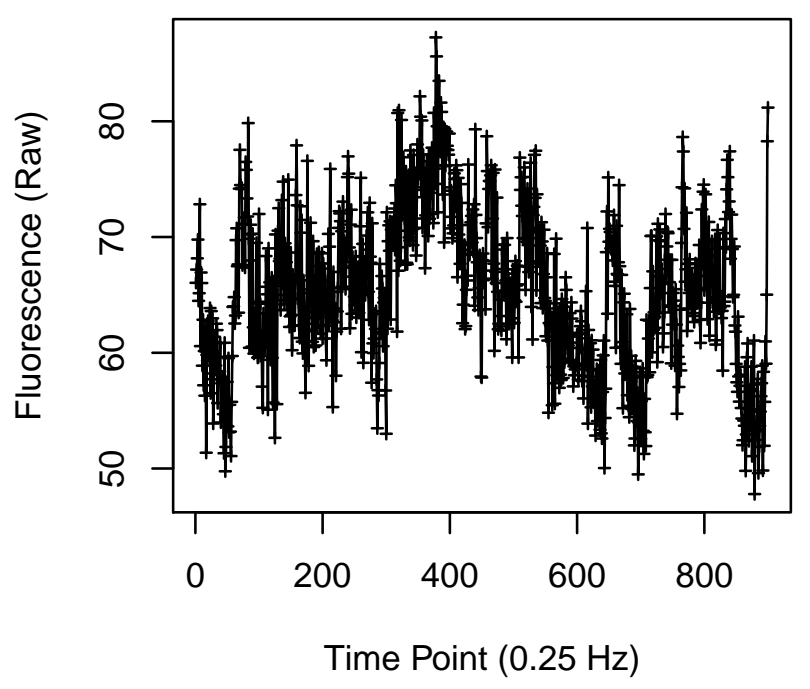


Cell 889

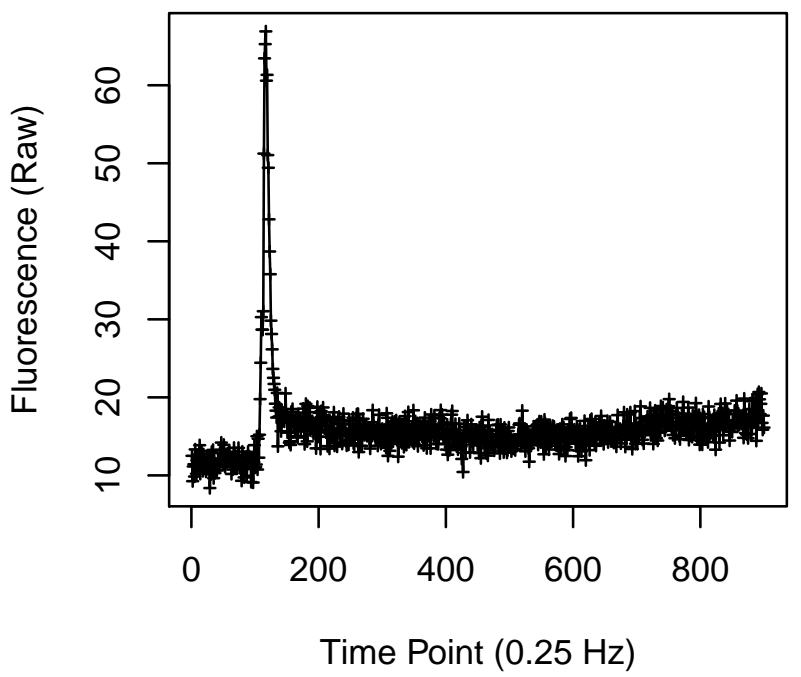

Cell 891

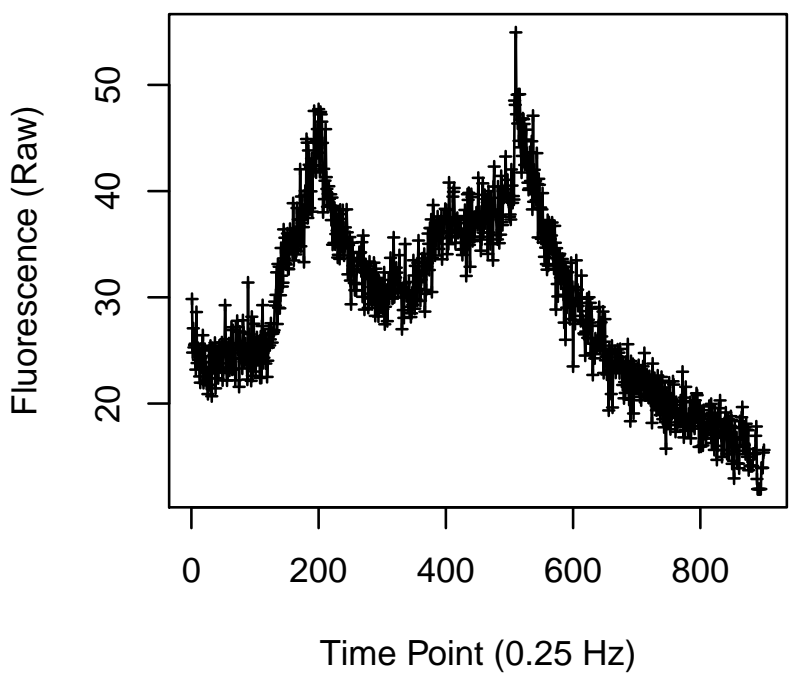

Cell 890

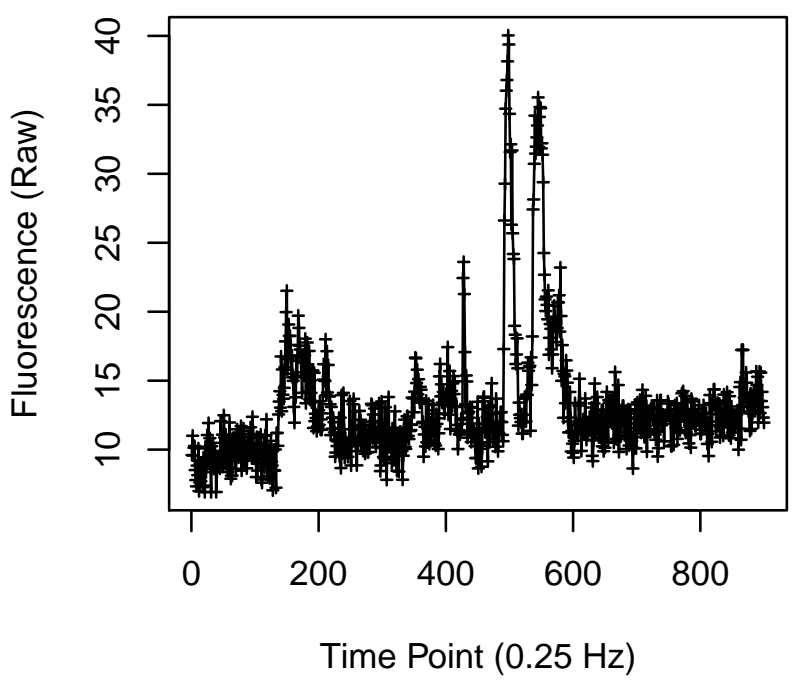

Cell 892

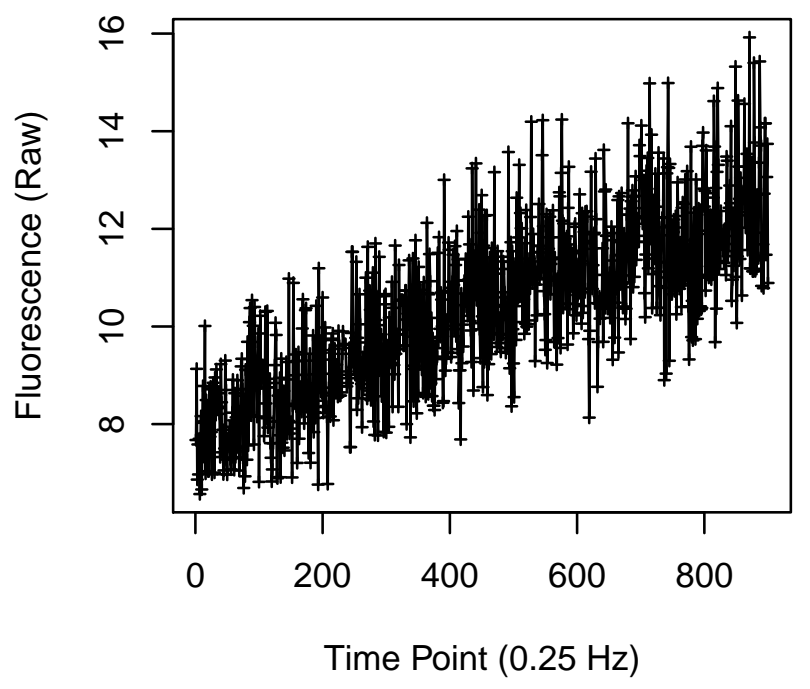


Cell 897

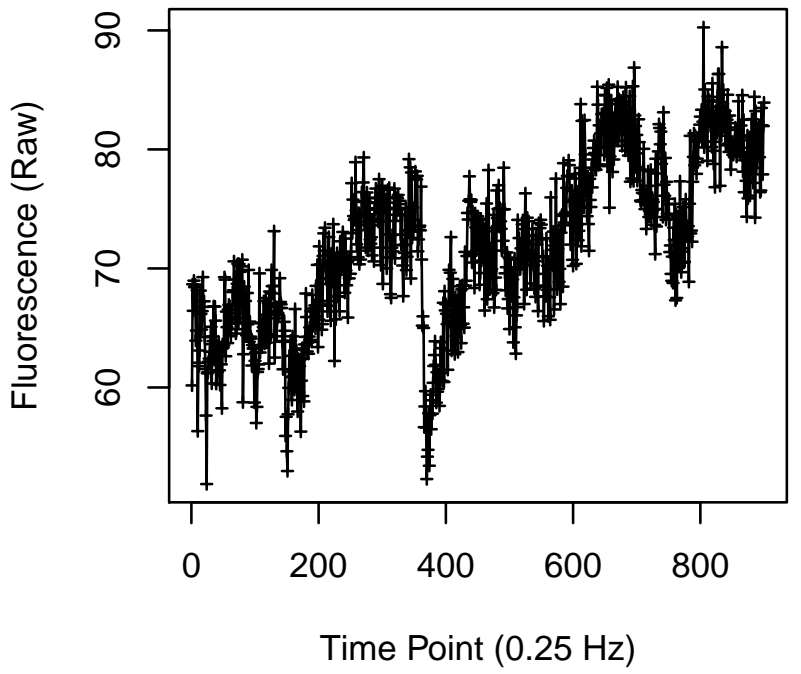

Cell 899

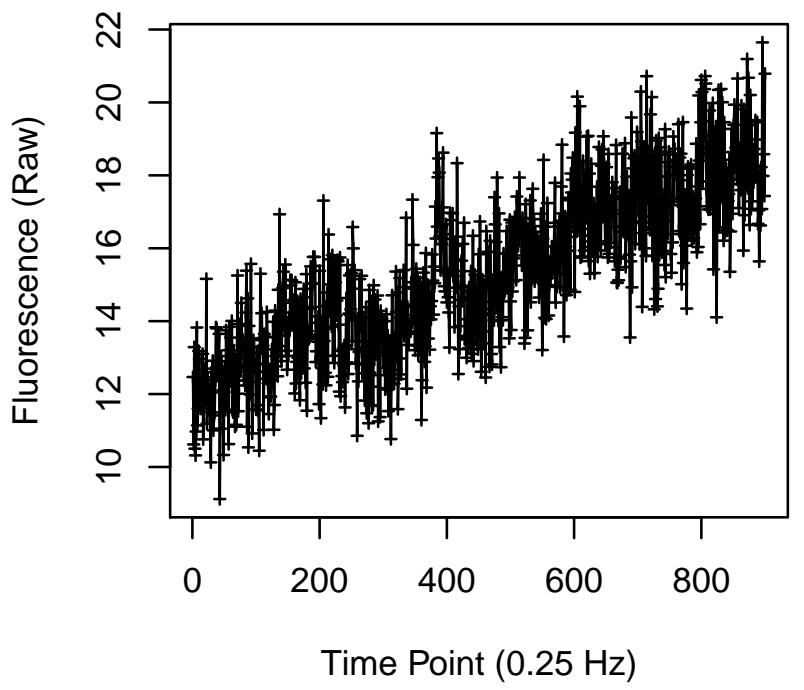

Cell 898

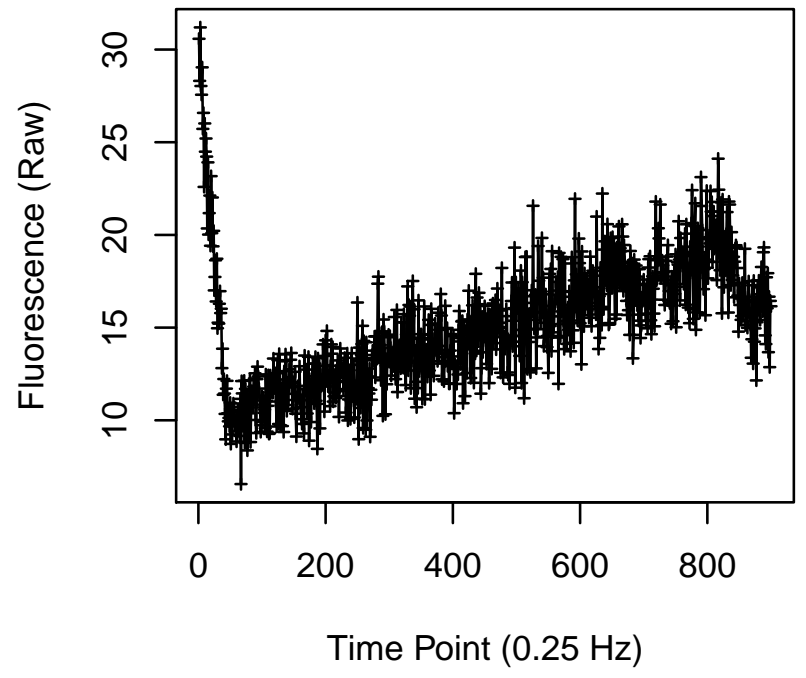

Cell 900

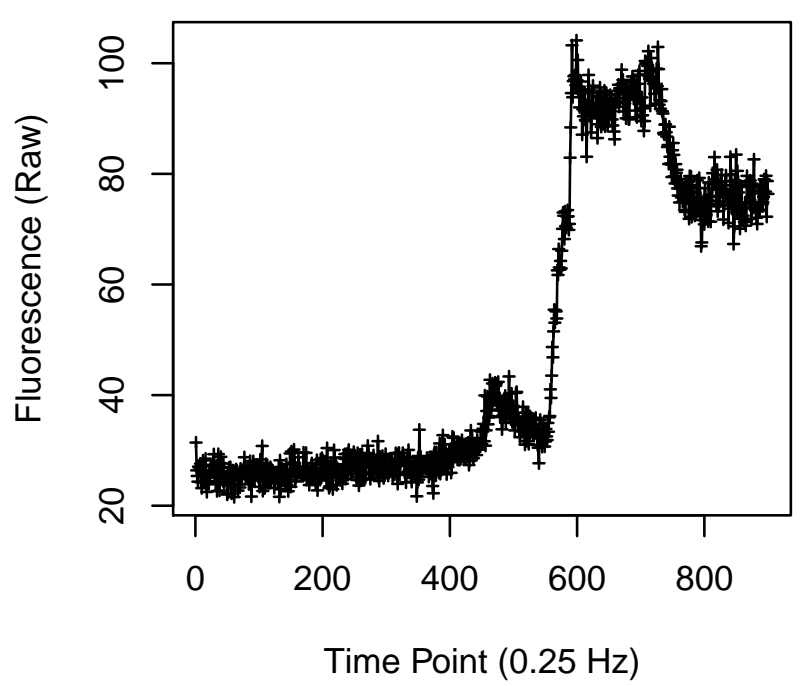


Cell 901

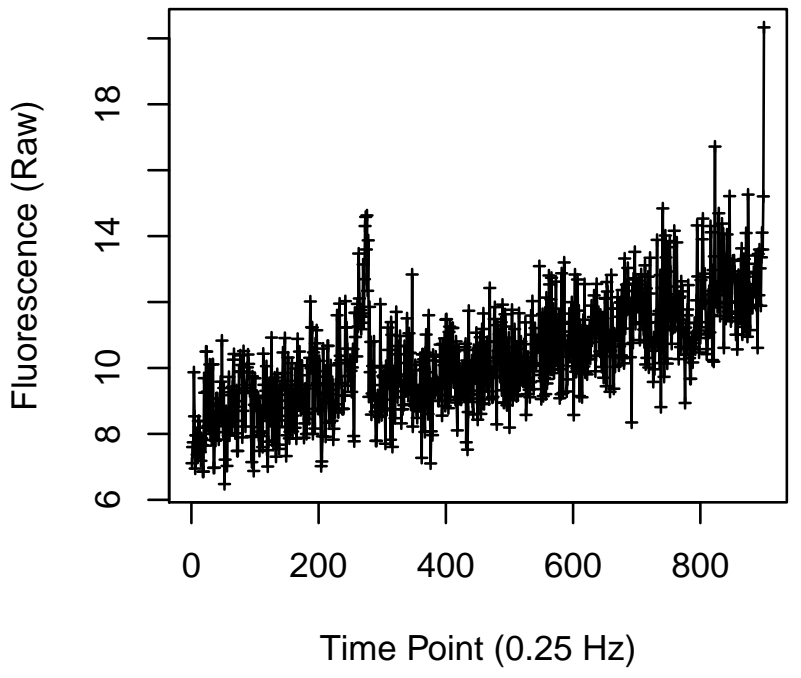

Cell 903

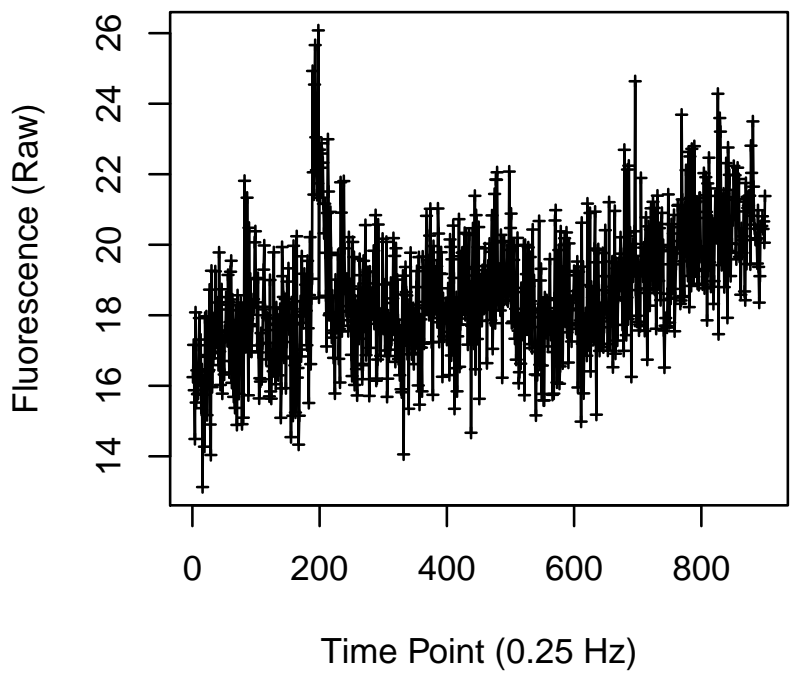

Cell 902

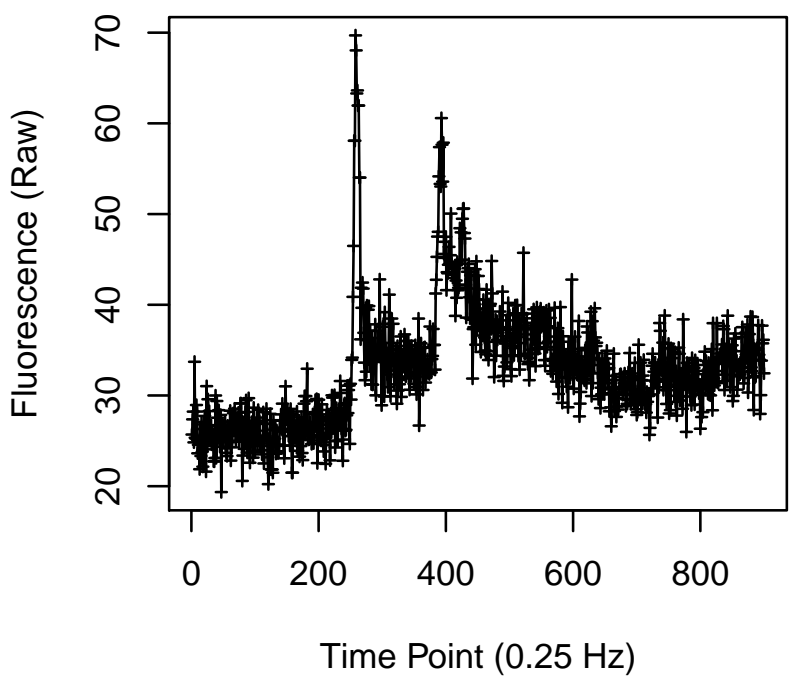

Cell 904

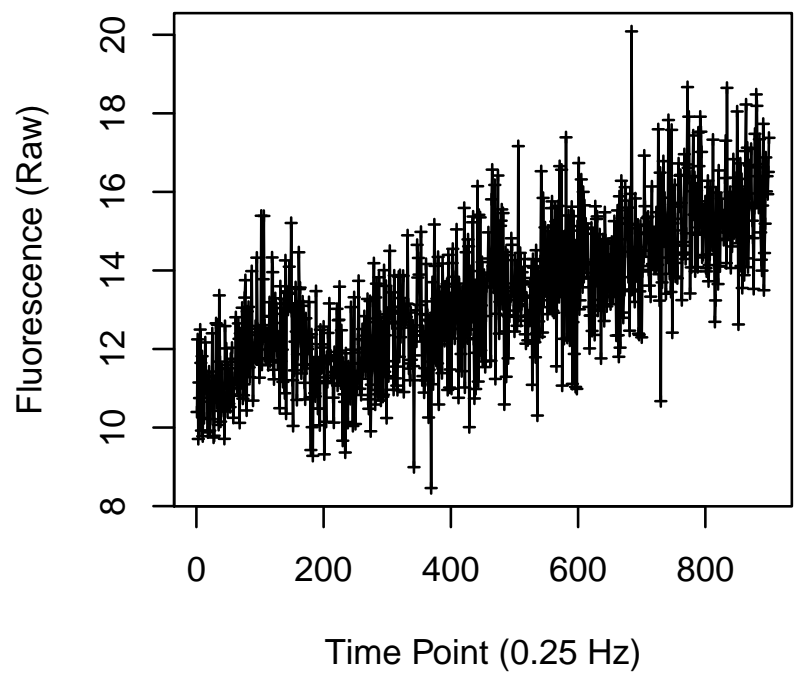




\section{Cell 905}

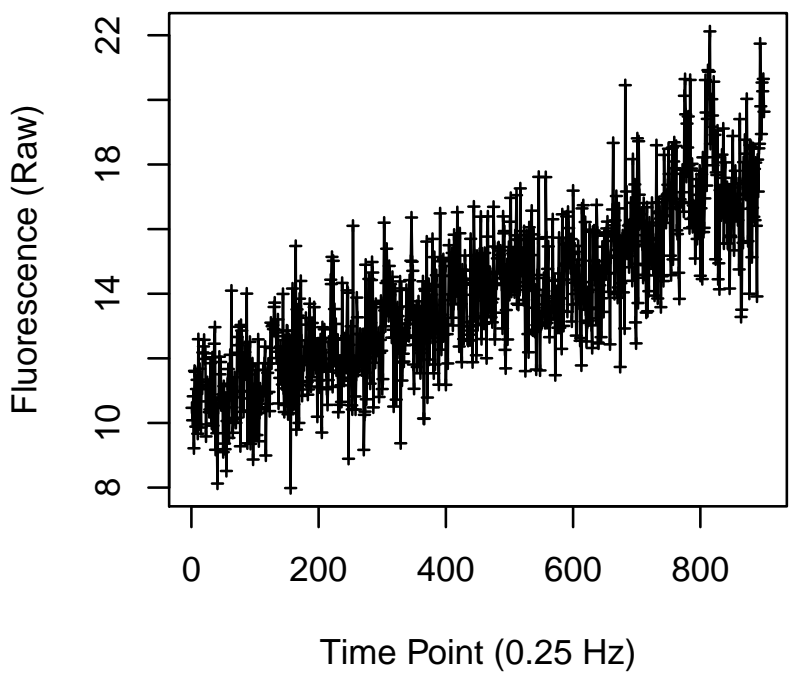

Cell 907

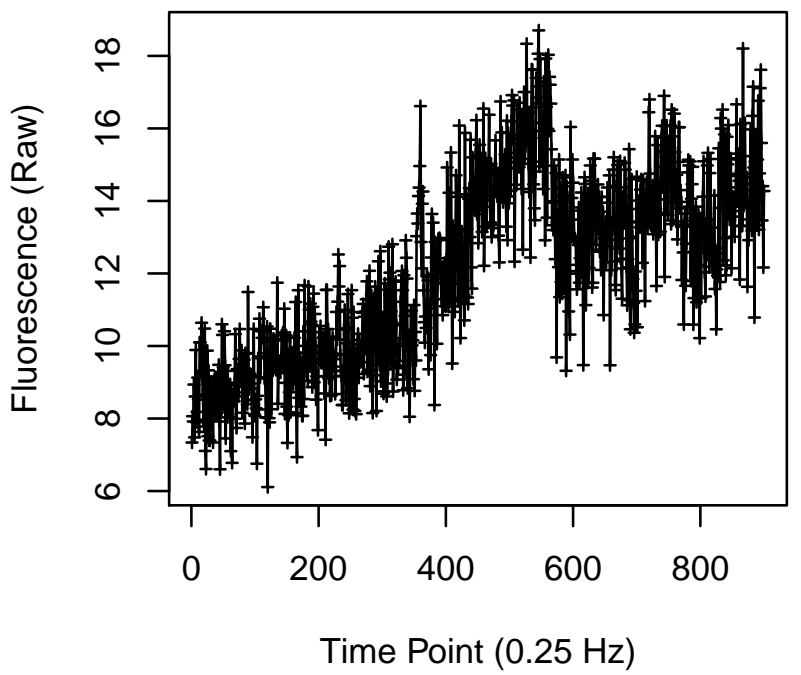

Cell 906

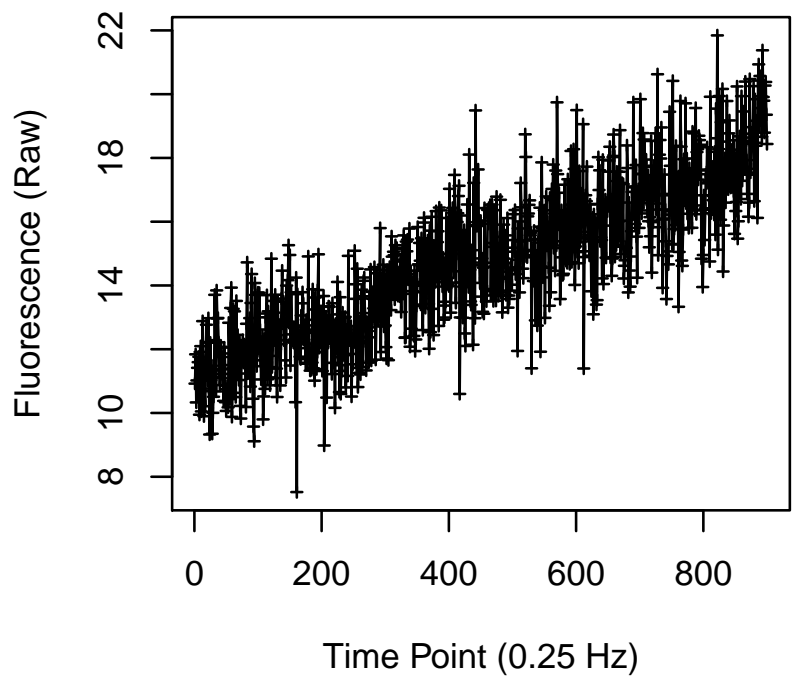

Cell 908

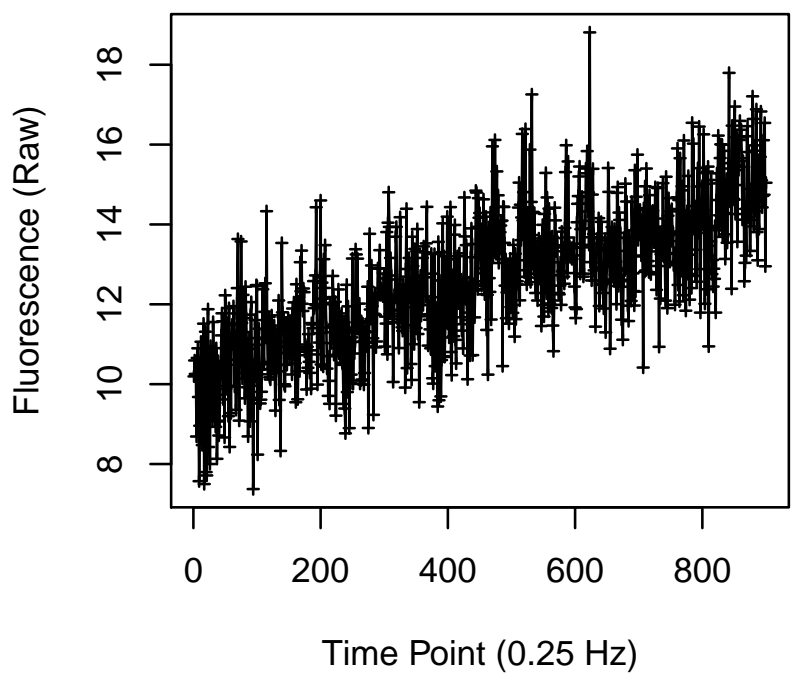




\section{Cell 909}

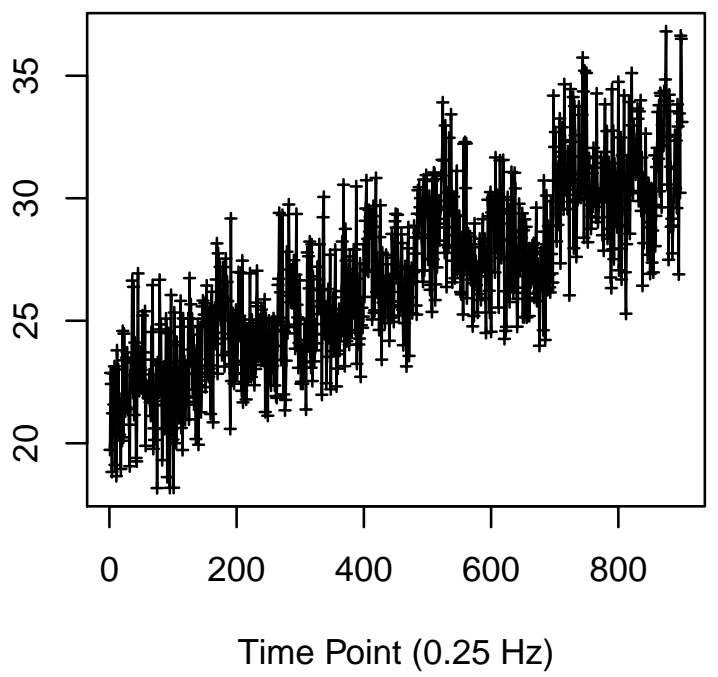

Cell 911

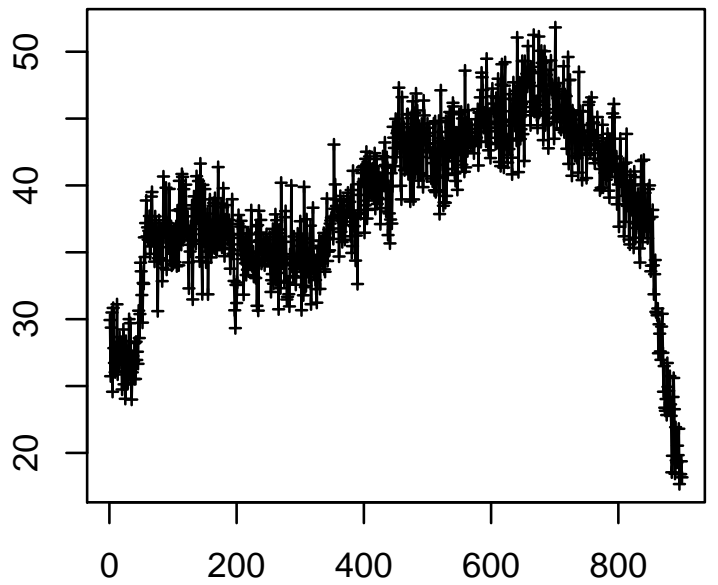

Time Point $(0.25 \mathrm{~Hz})$
Cell 910

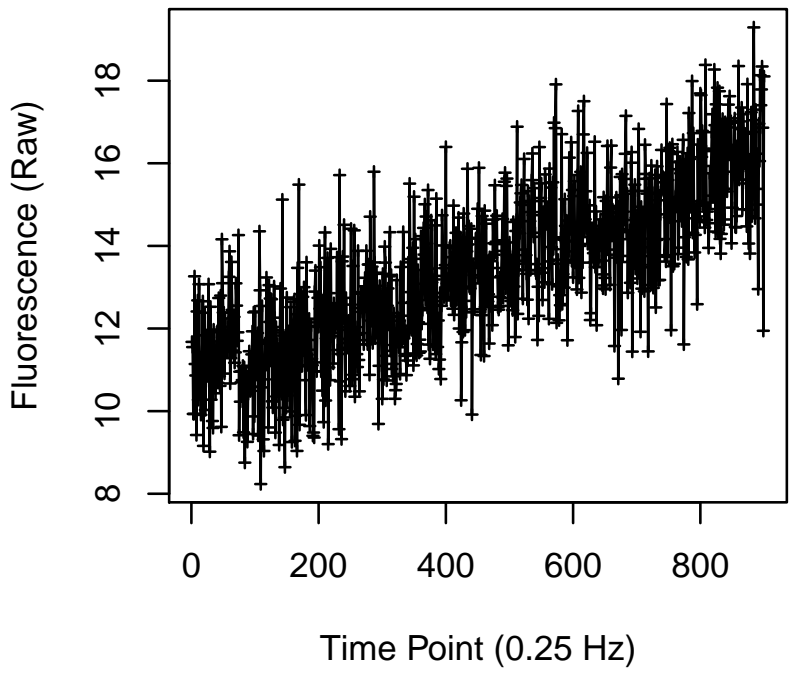

Cell 912

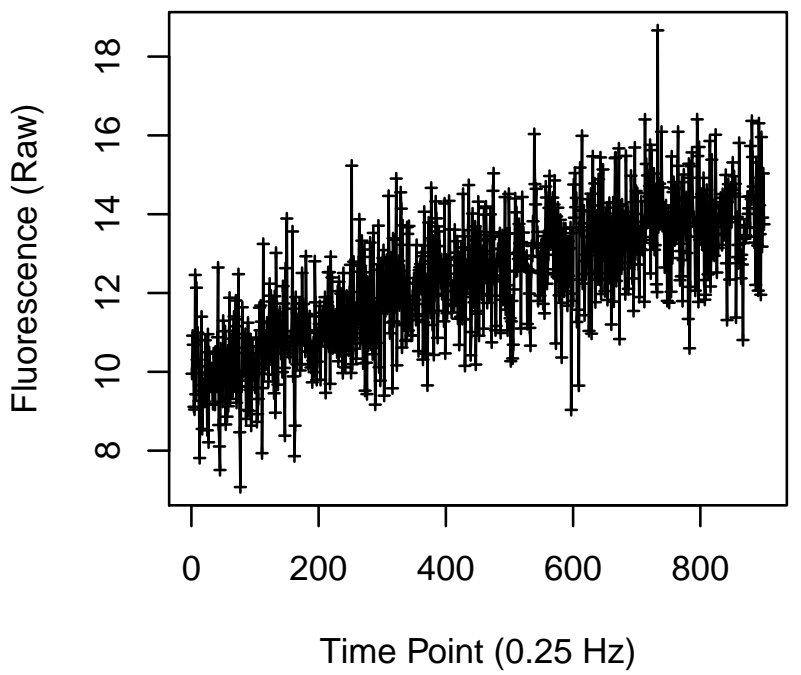




\section{Cell 913}

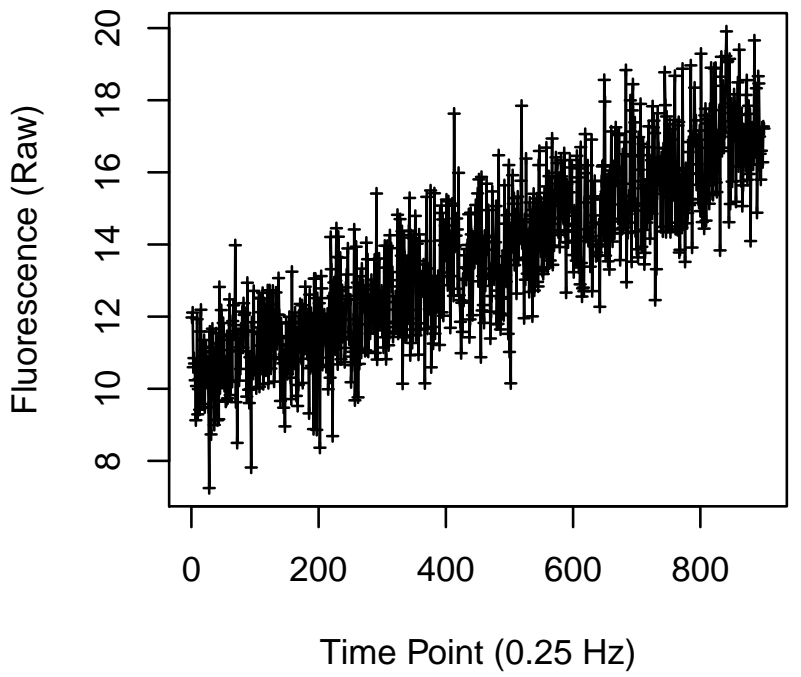

Cell 915

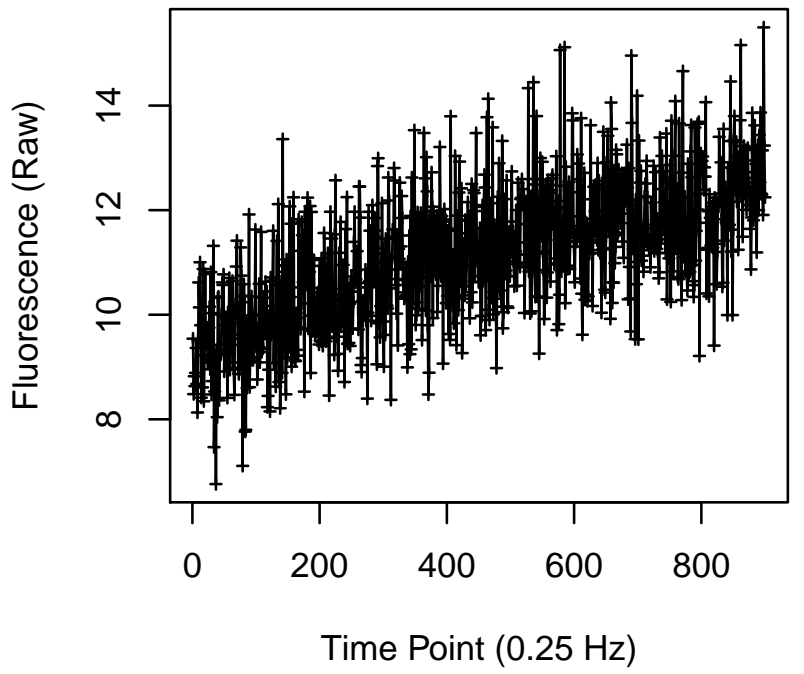

Cell 914

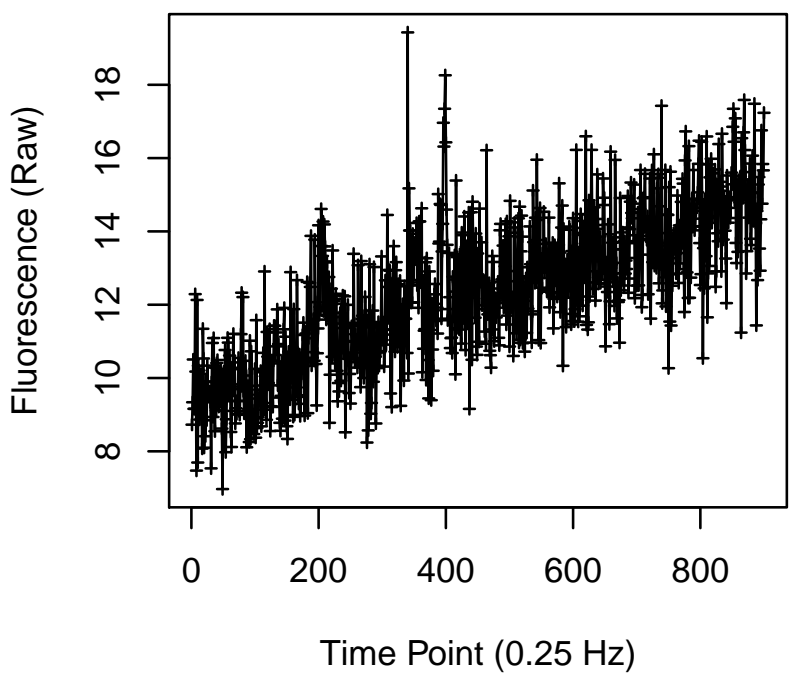

Cell 916

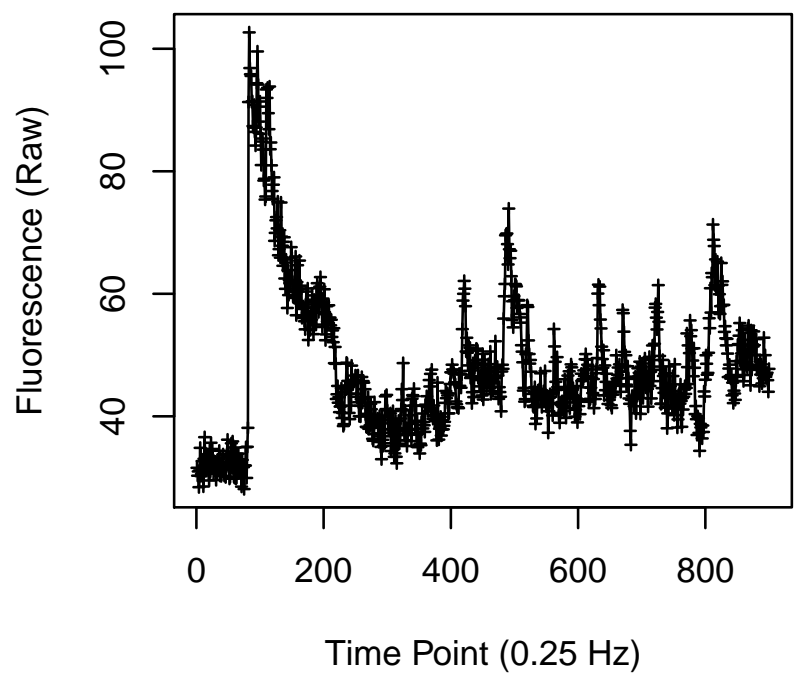


Cell 925

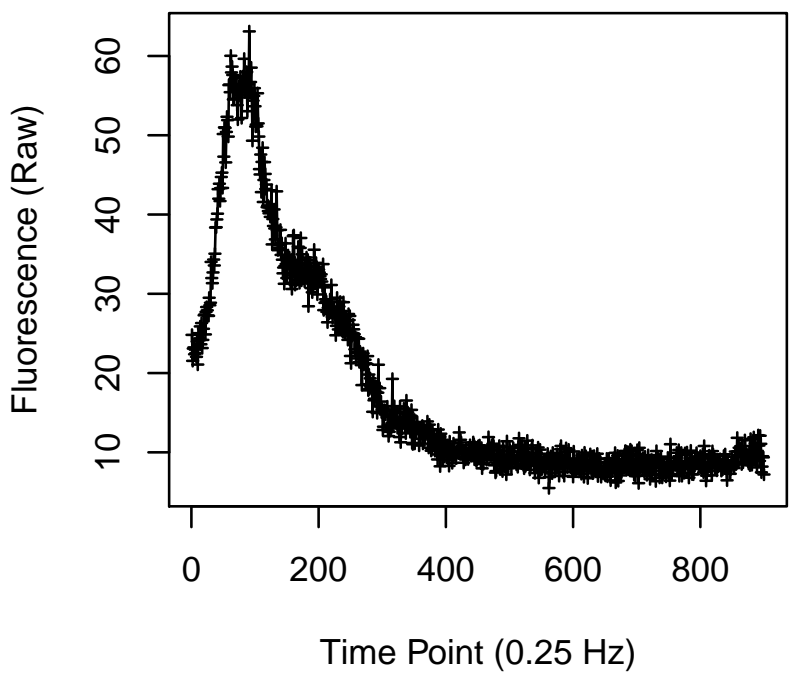

Cell 927

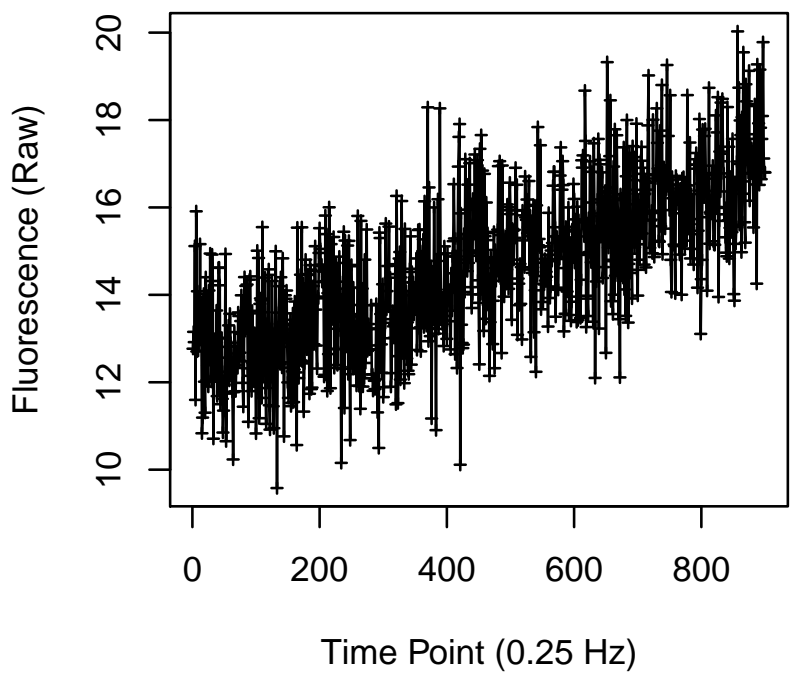

Cell 926

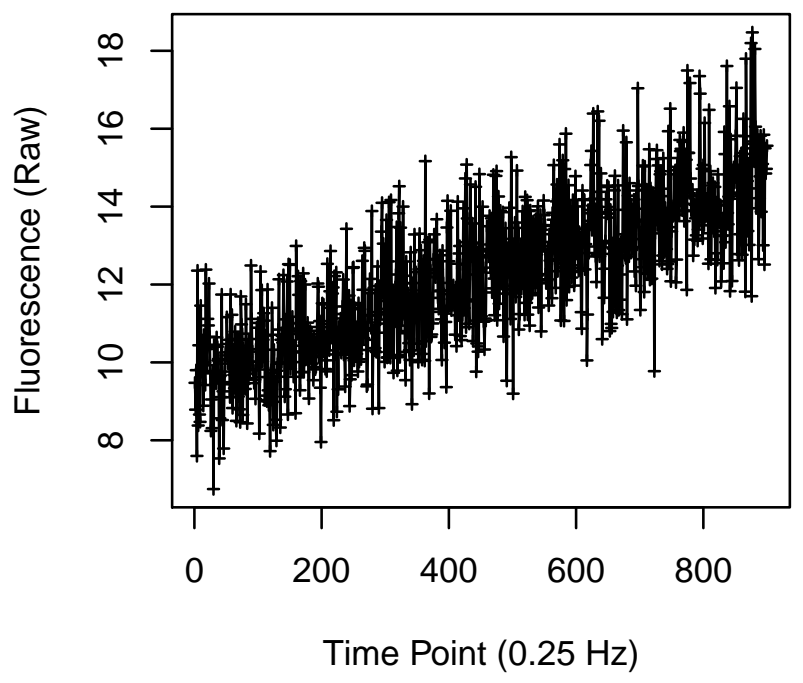

Cell 928

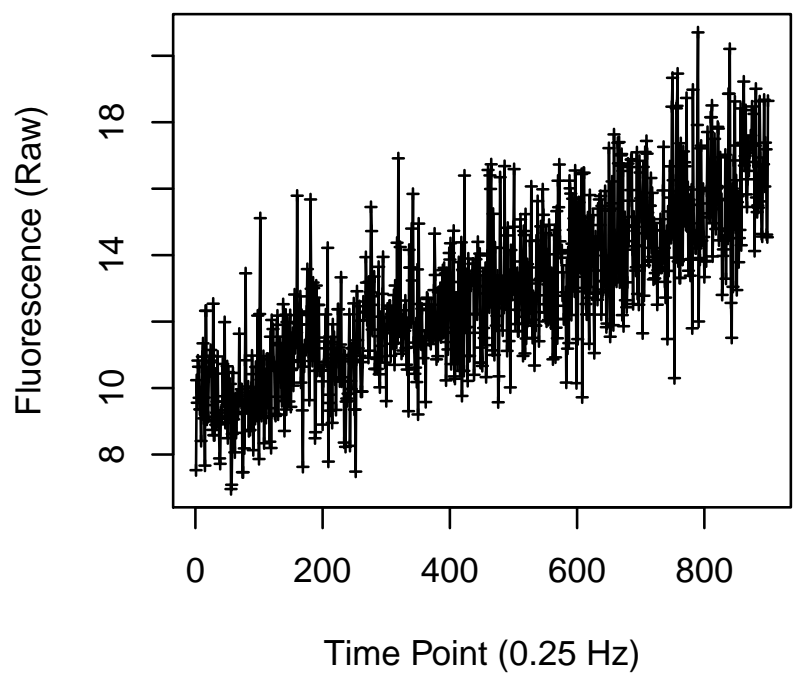


Cell 929

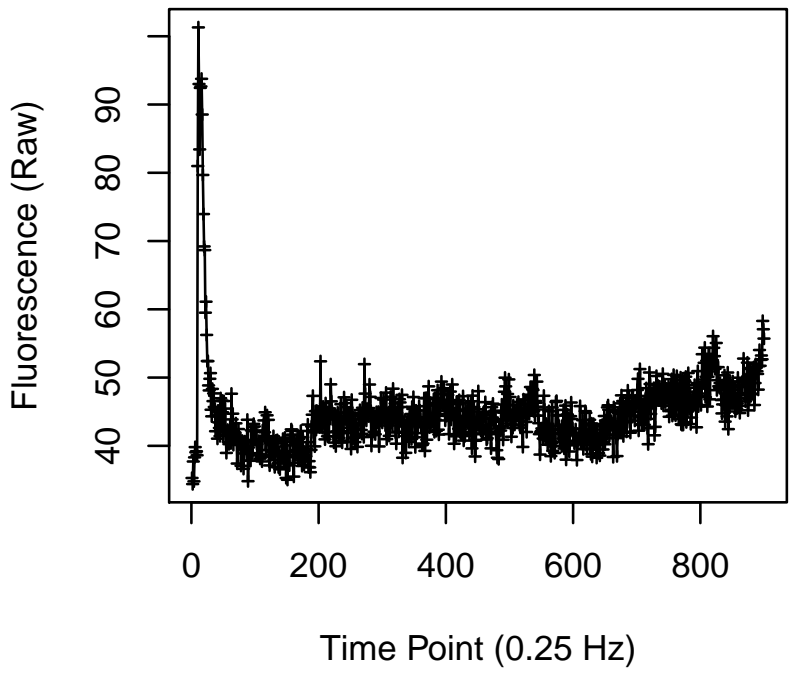

Cell 931

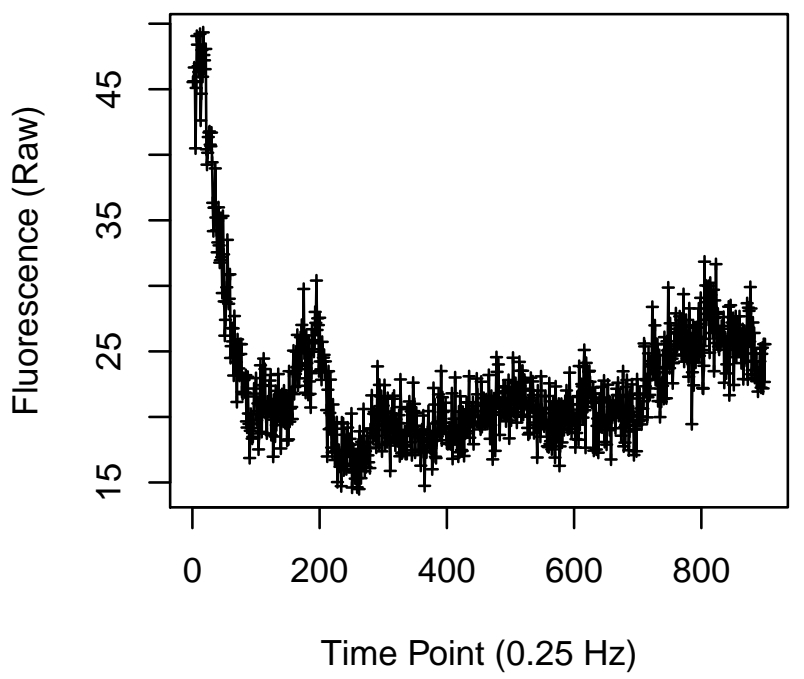

Cell 930

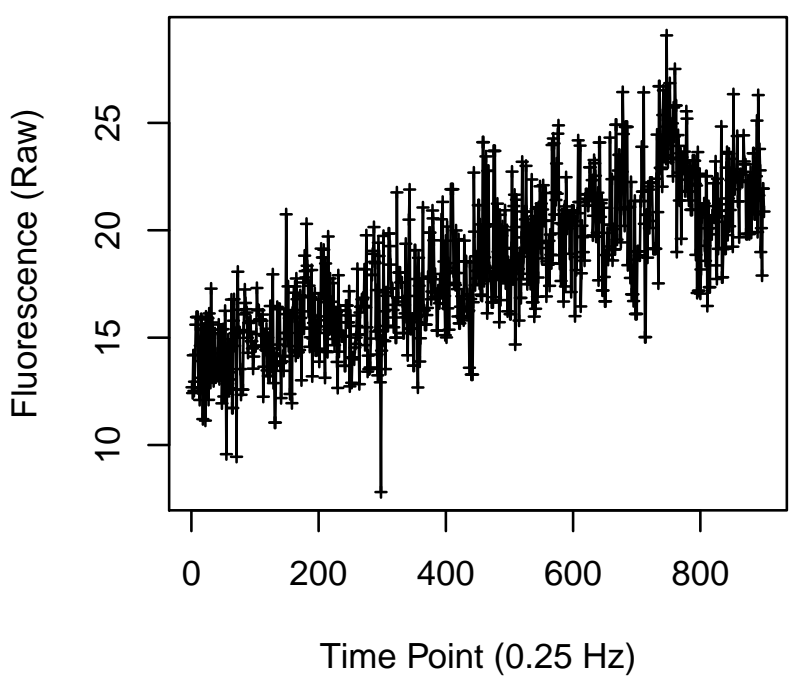

Cell 932

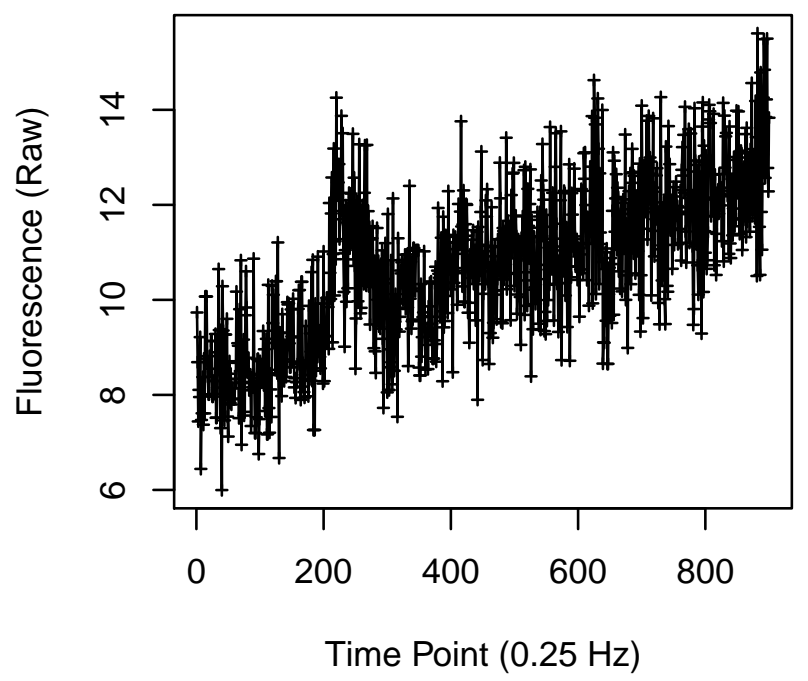




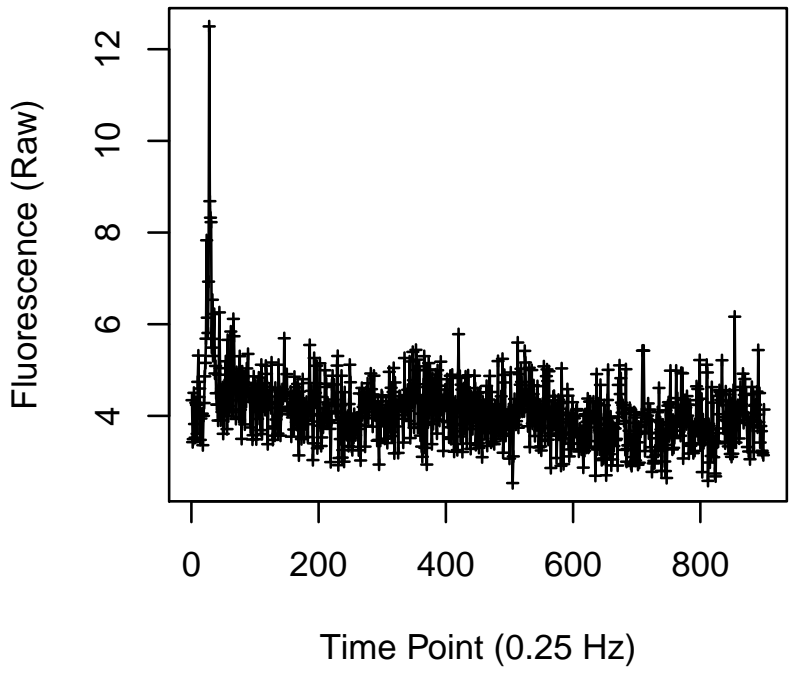

Cell 939

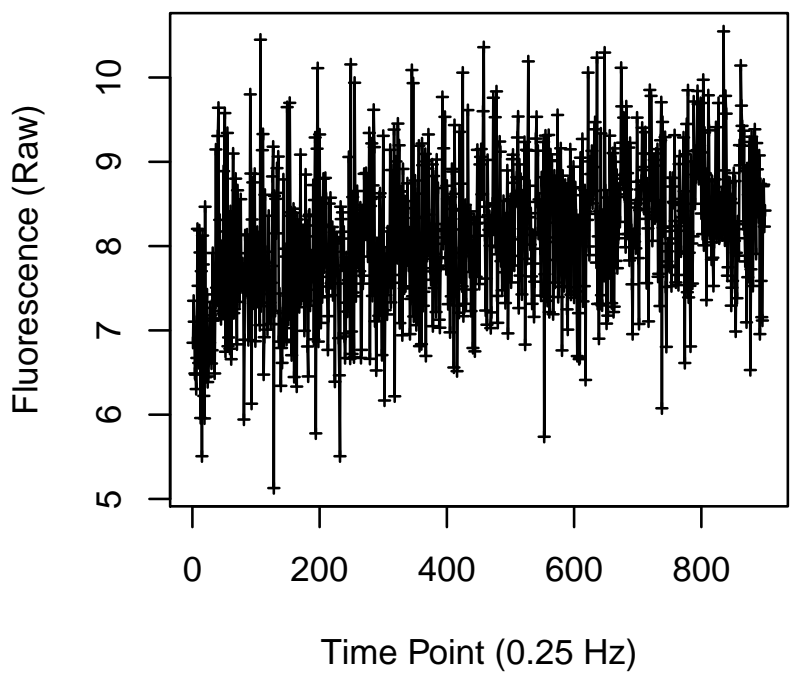

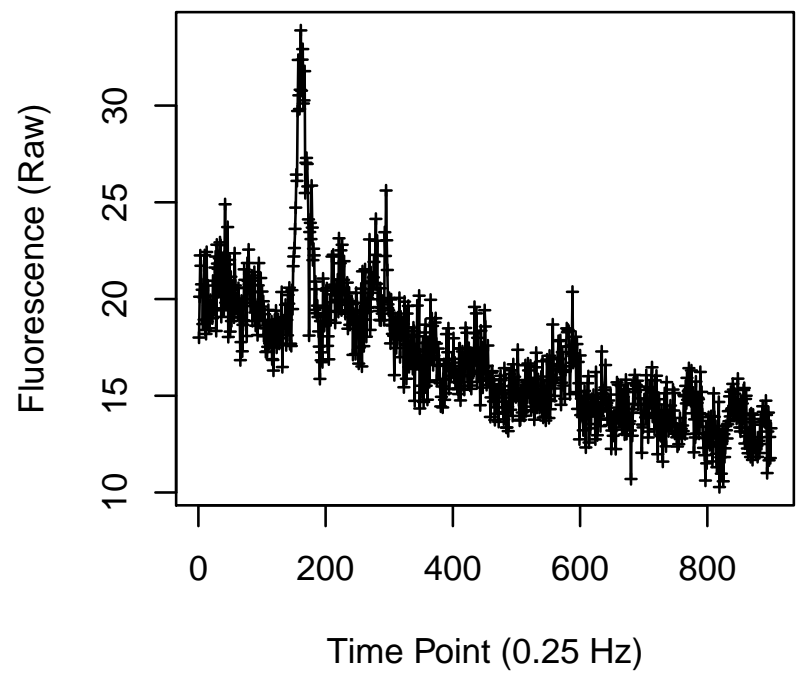

Cell 940

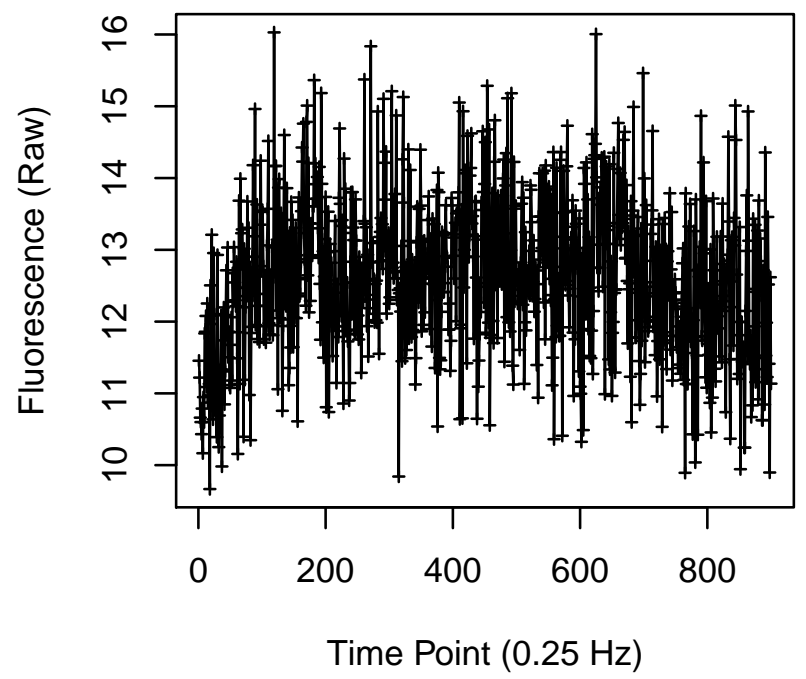


Cell 941

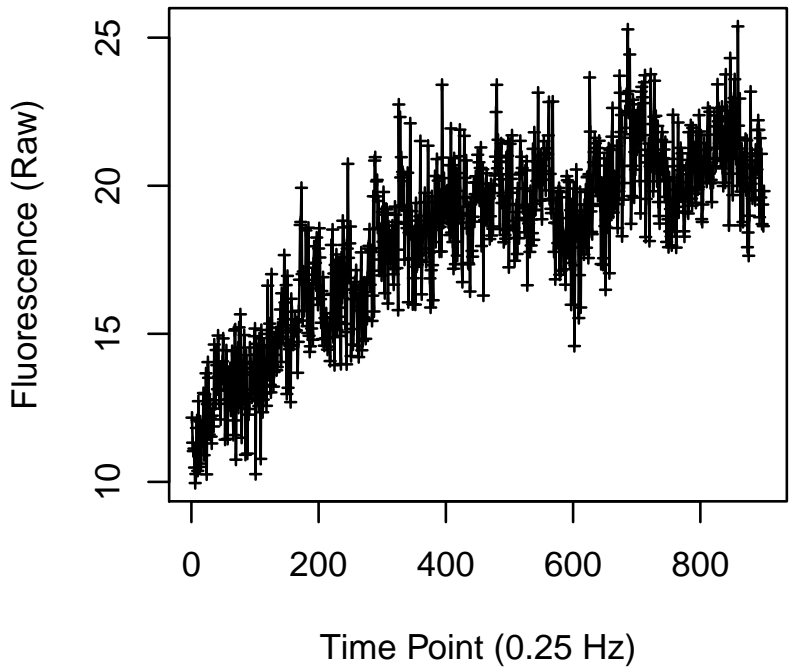

Cell 943

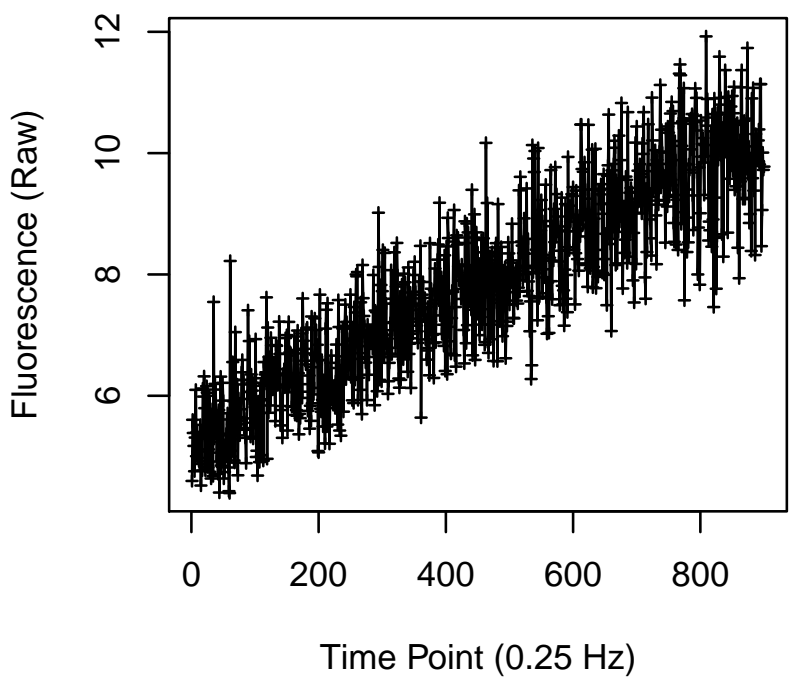

Cell 942

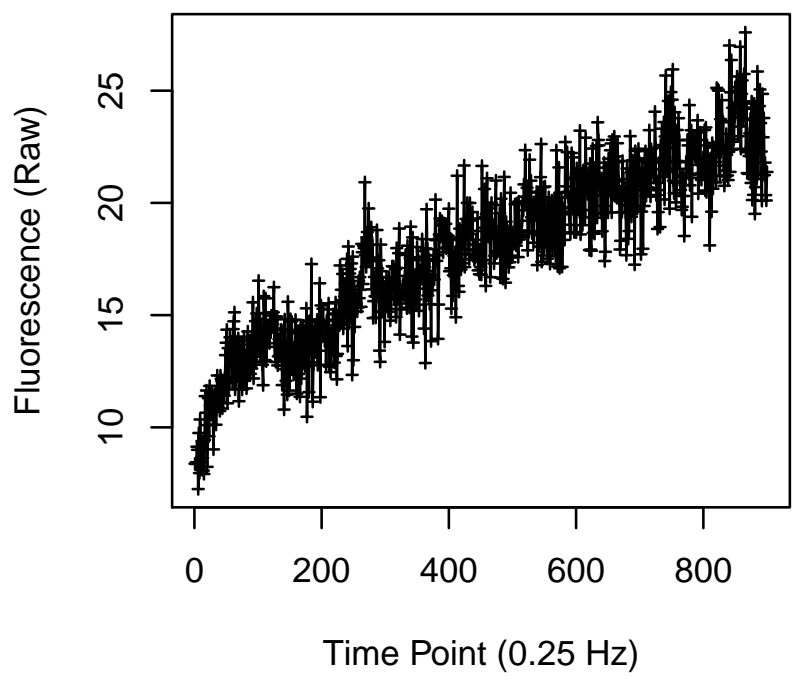

Cell 944

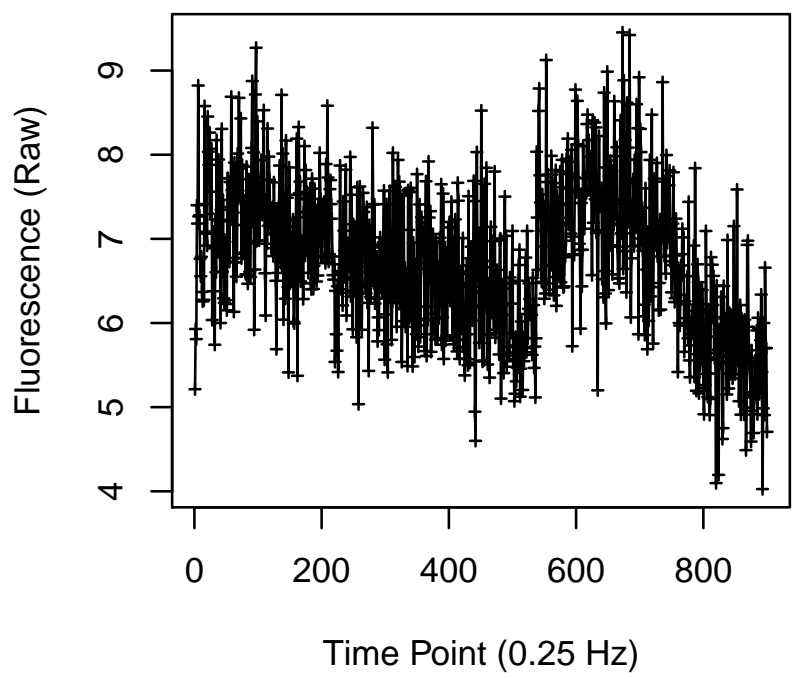




\section{Cell 945}

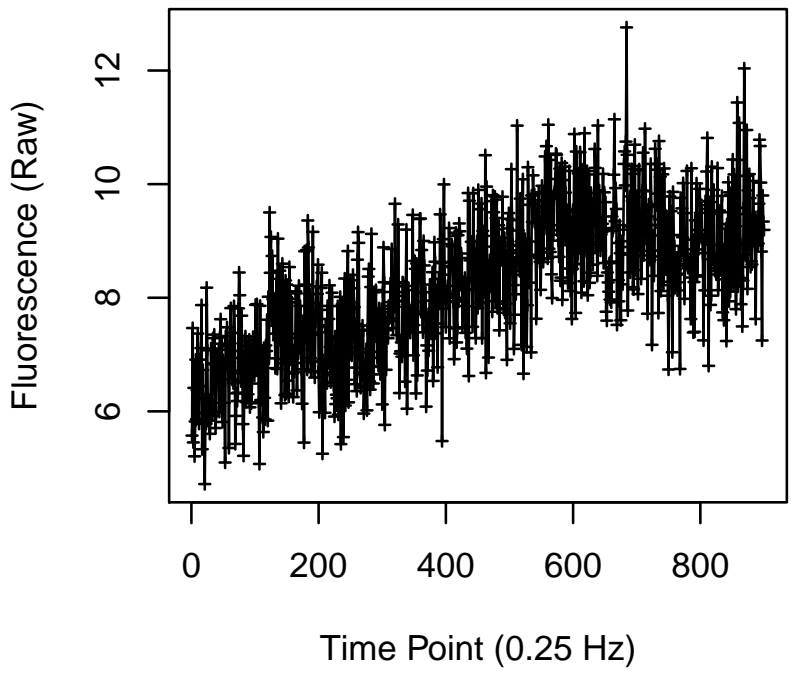

Cell 947

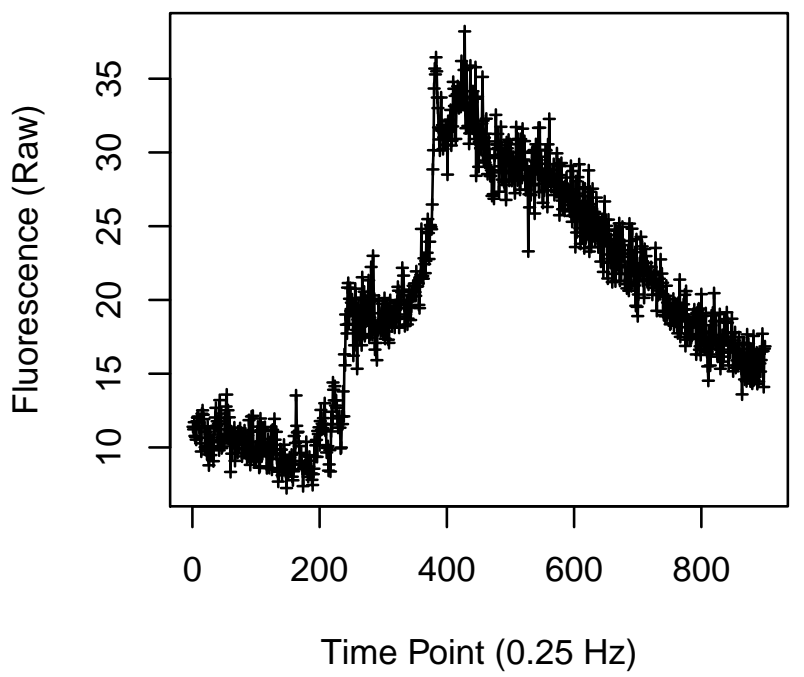

Cell 946

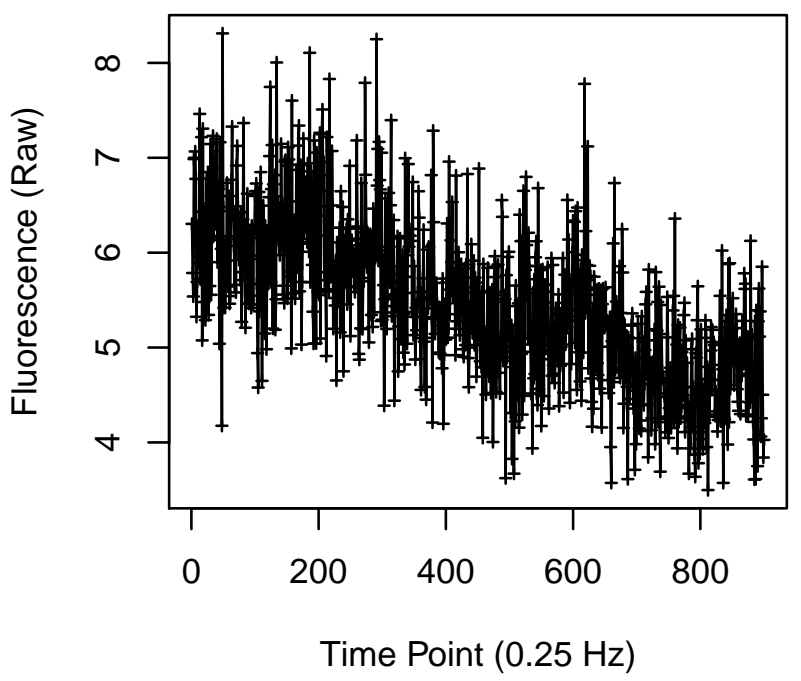

Cell 948

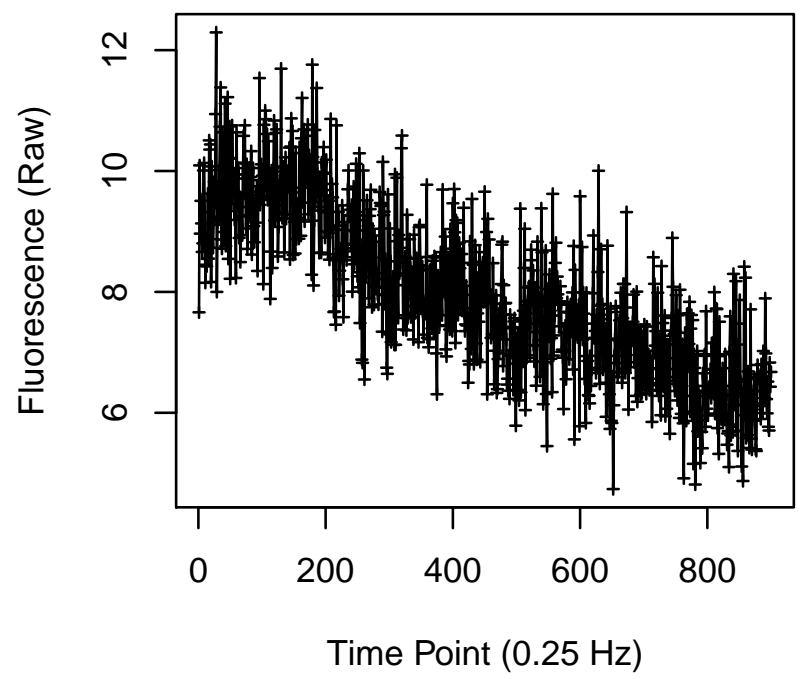


Cell 949

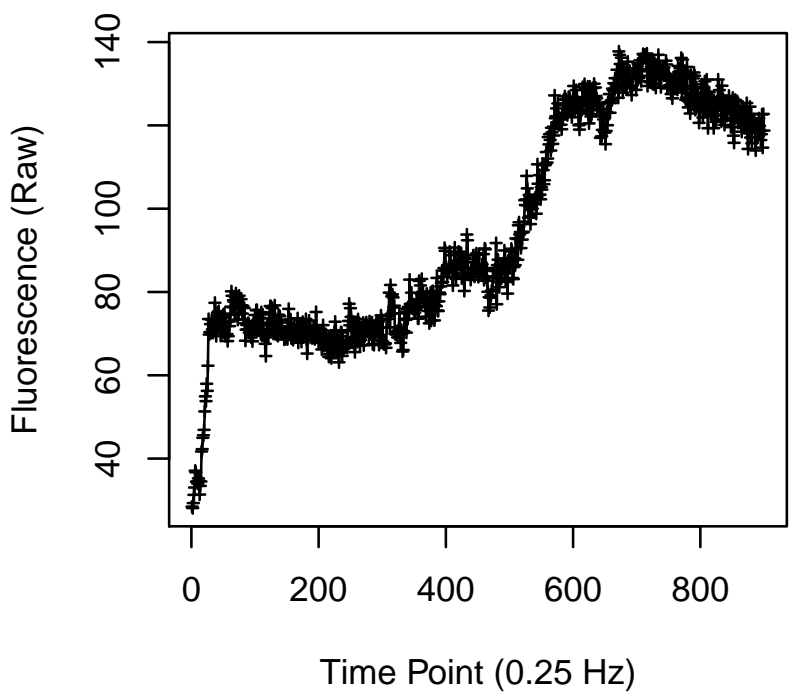

Cell 951

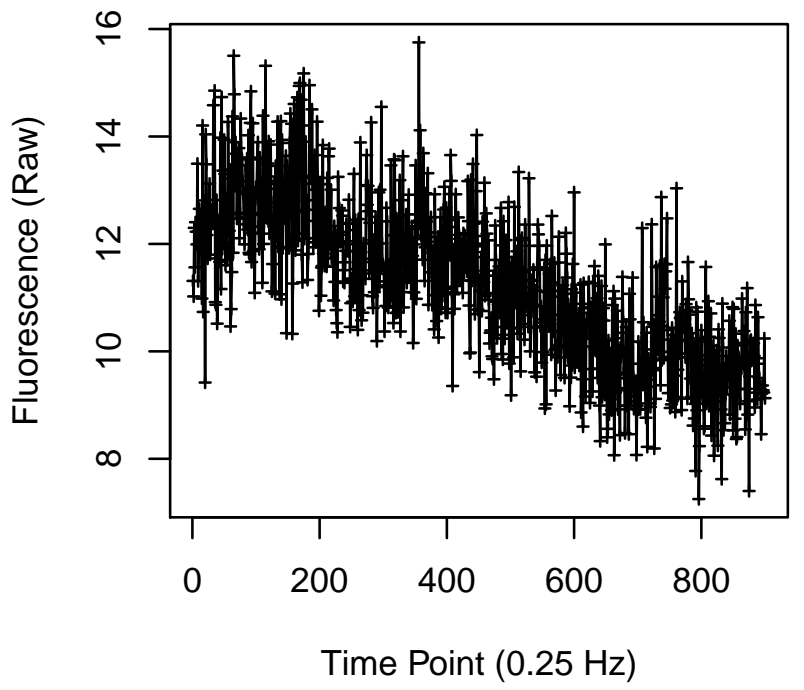

Cell 950

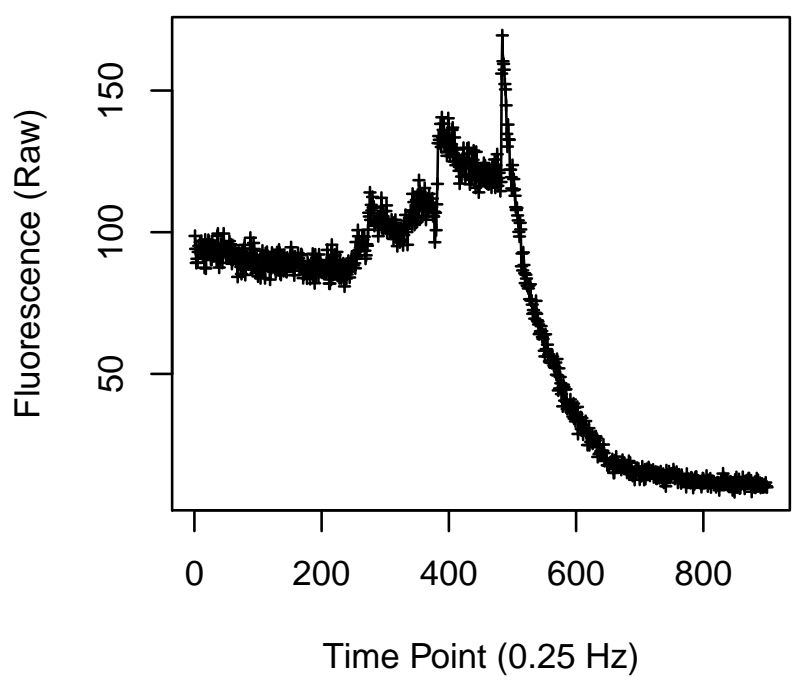

Cell 952

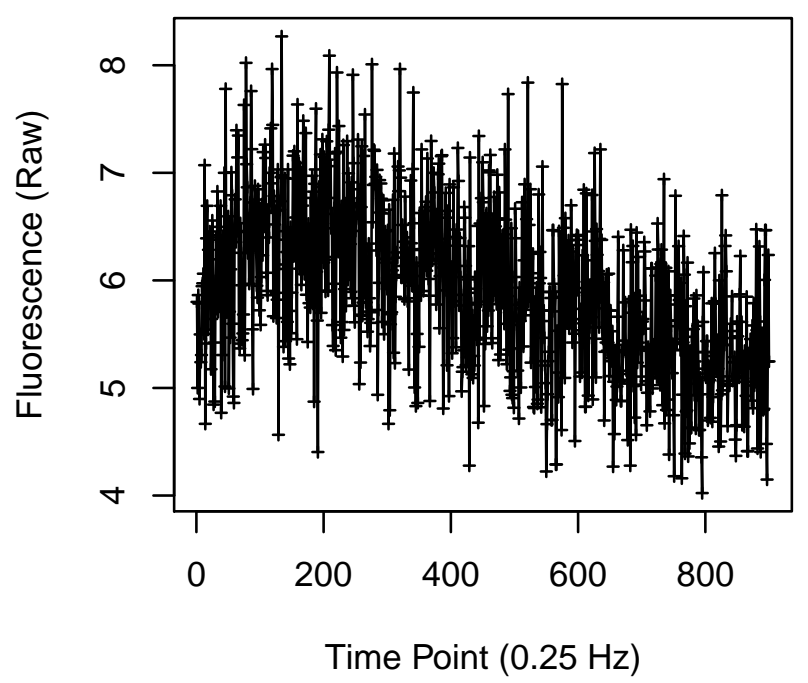




\section{Cell 957}

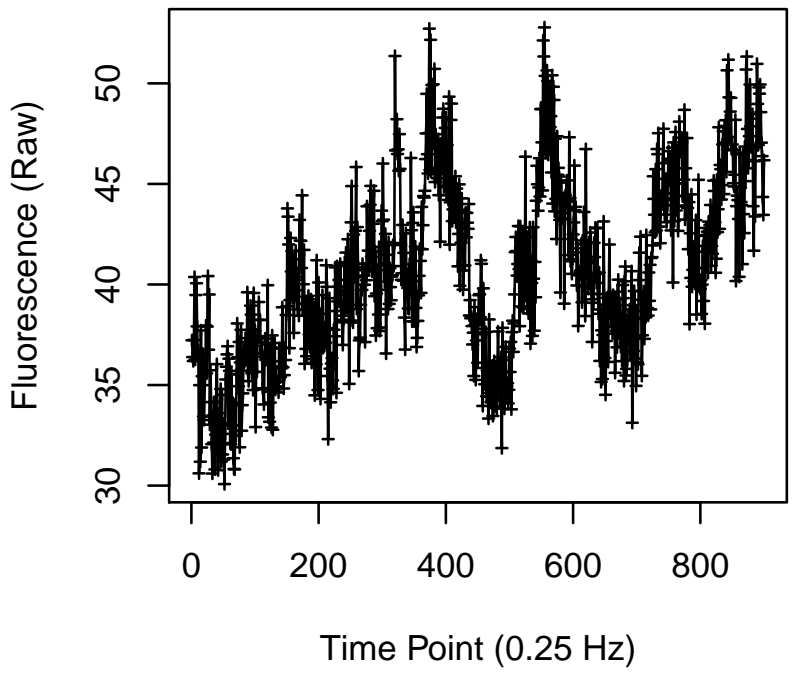

Cell 959

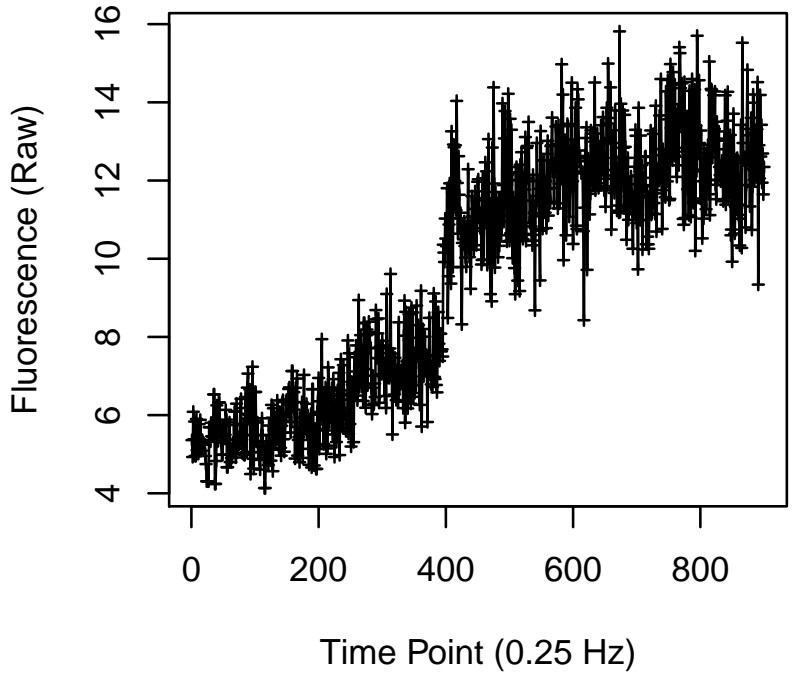

Cell 958

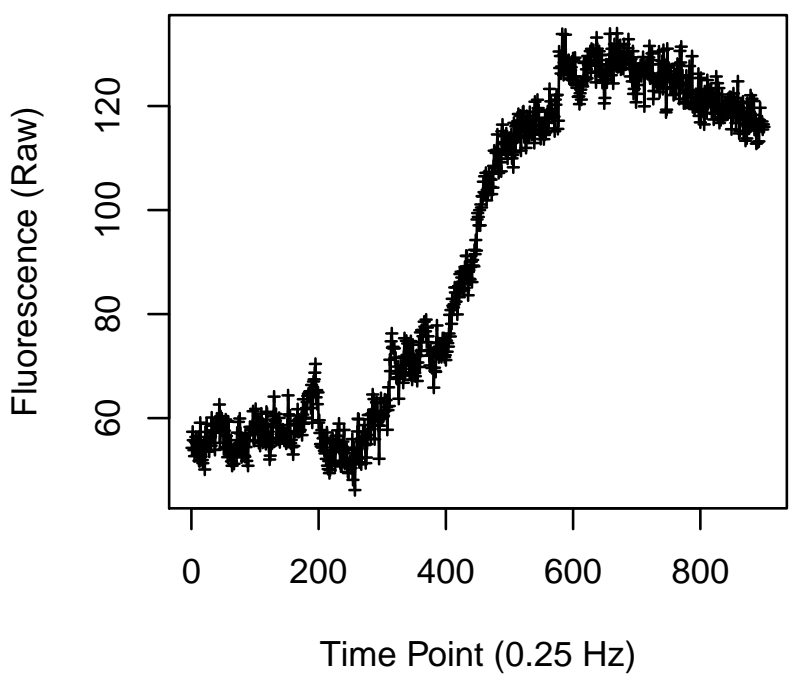

Cell 960

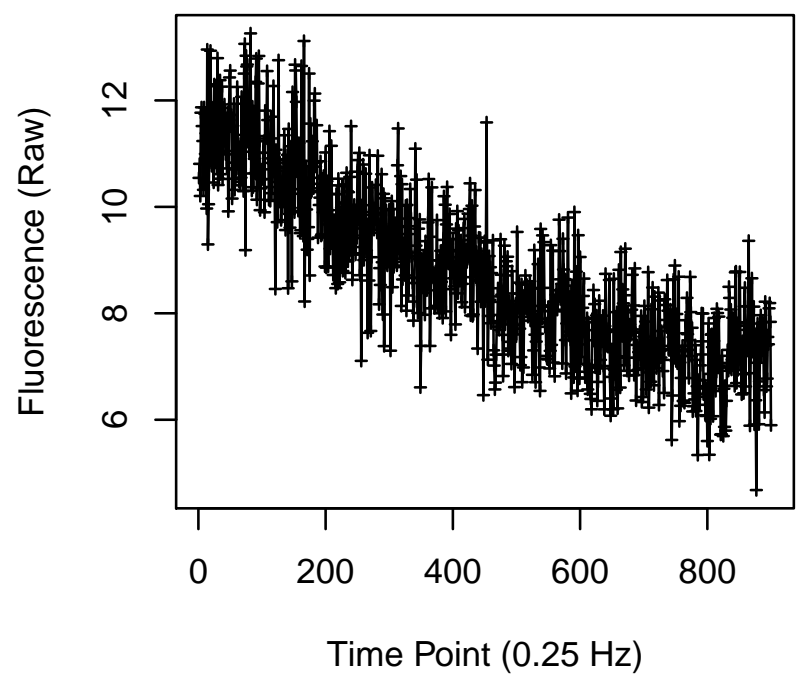




\section{Cell 961}

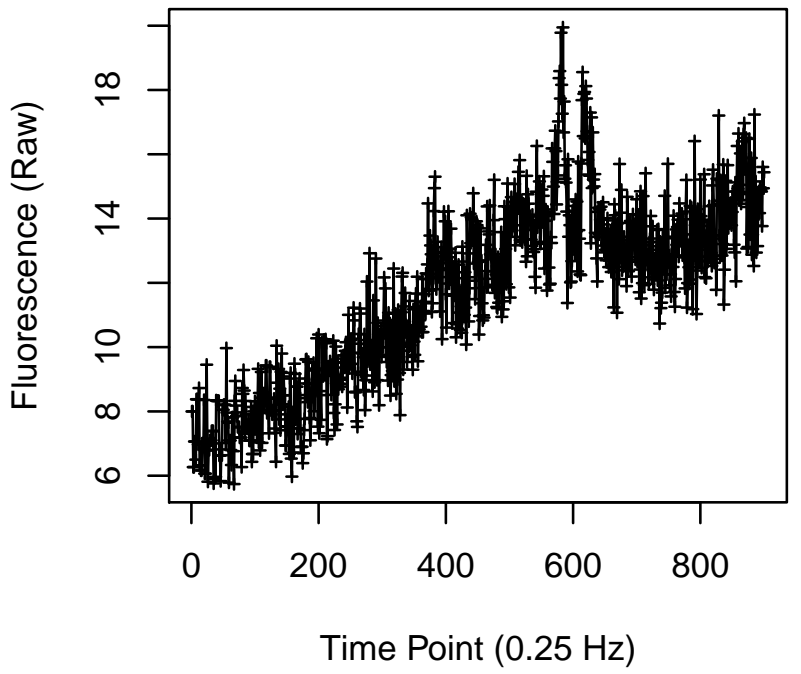

Cell 963

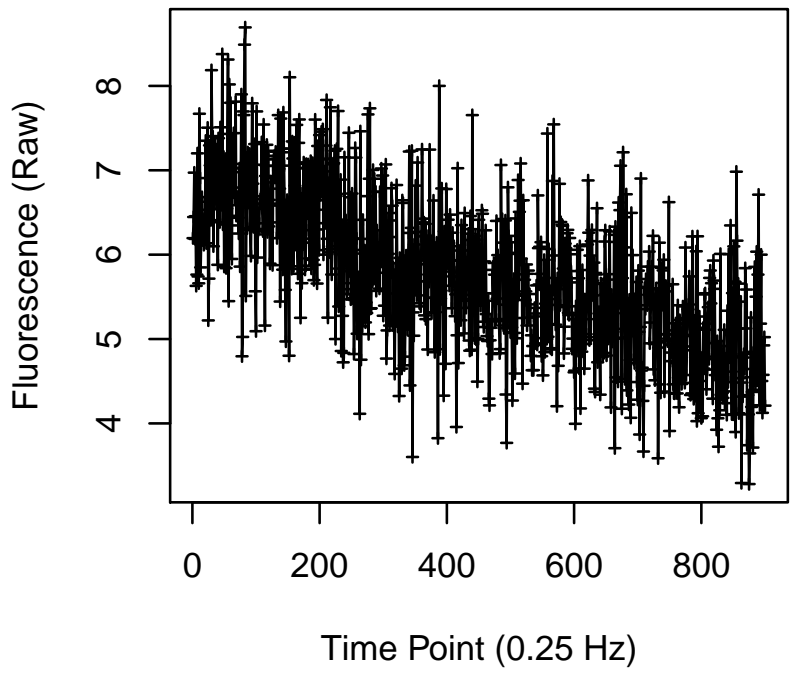

Cell 962

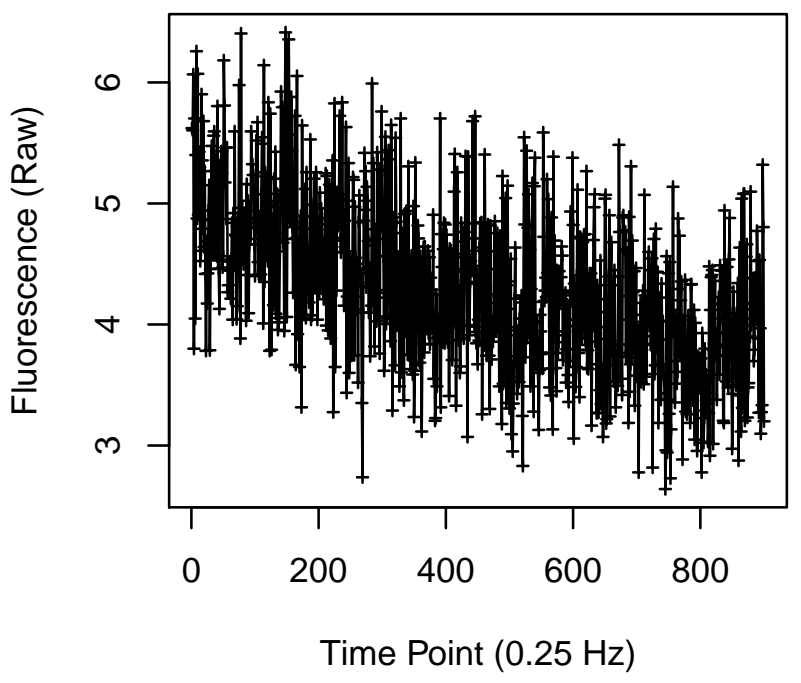

Cell 964

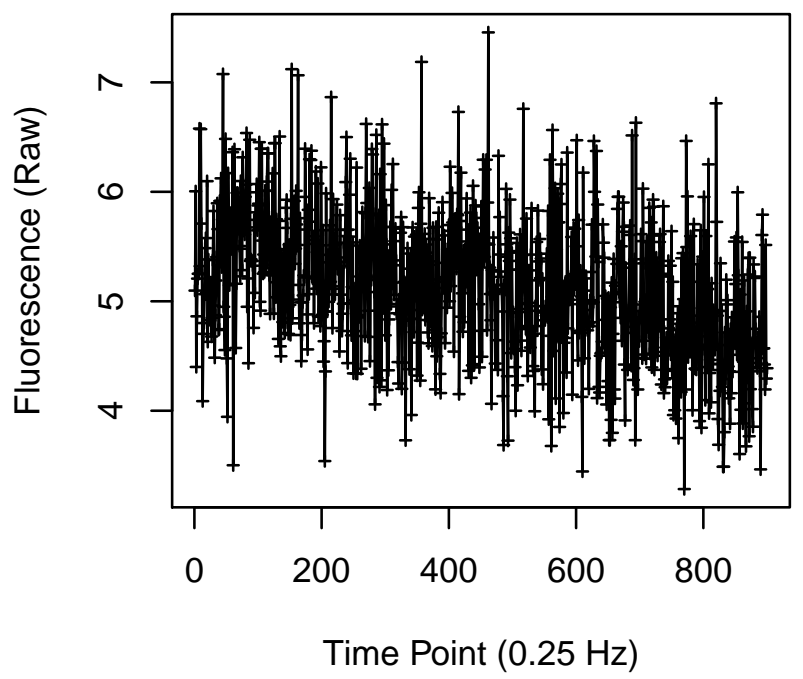




\section{Cell 965}

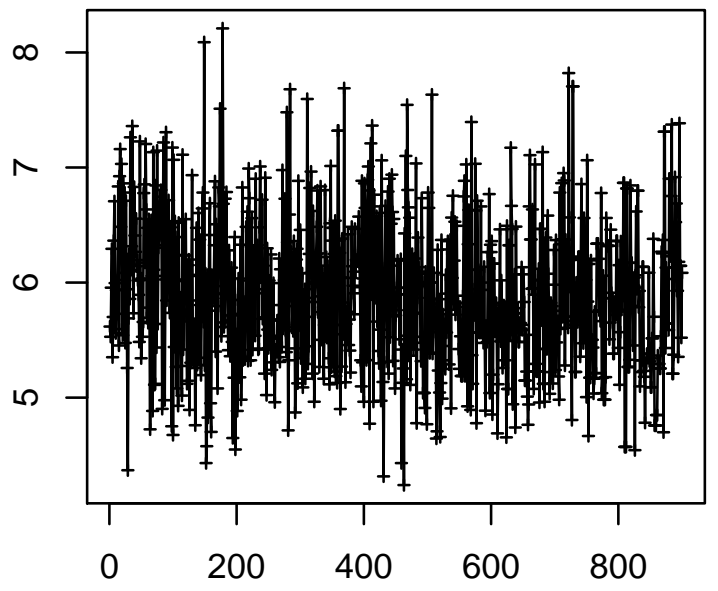

Time Point $(0.25 \mathrm{~Hz})$

\section{Cell 967}

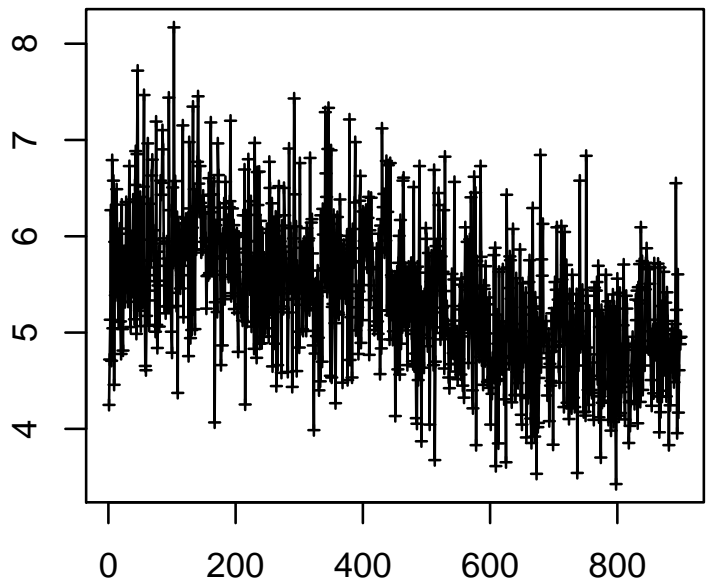

Time Point $(0.25 \mathrm{~Hz})$
Cell 966

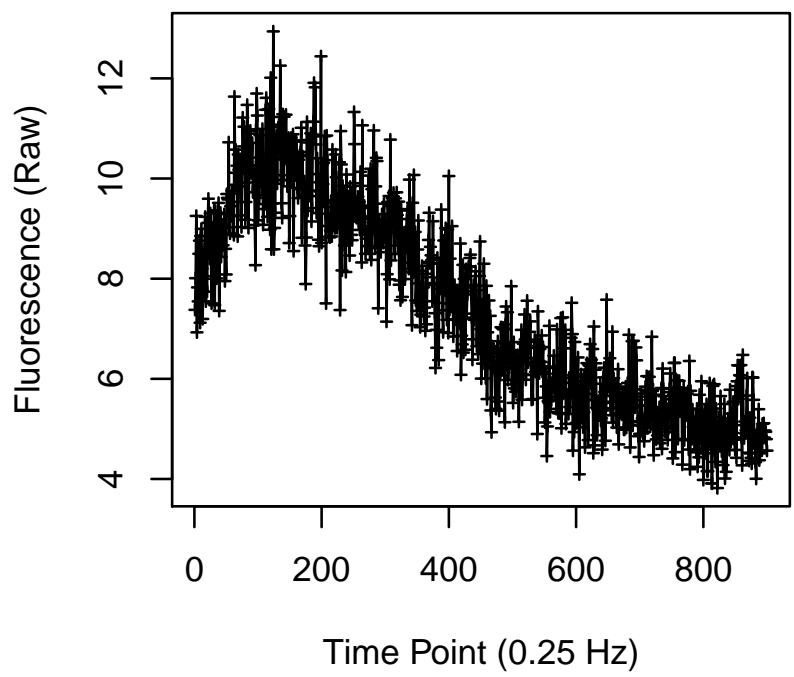

Cell 968

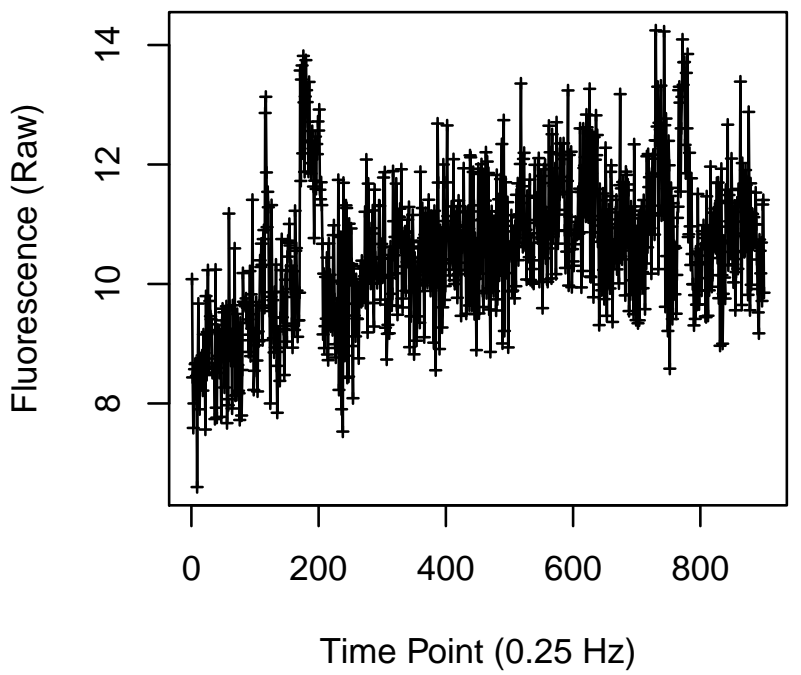




\section{Cell 969}

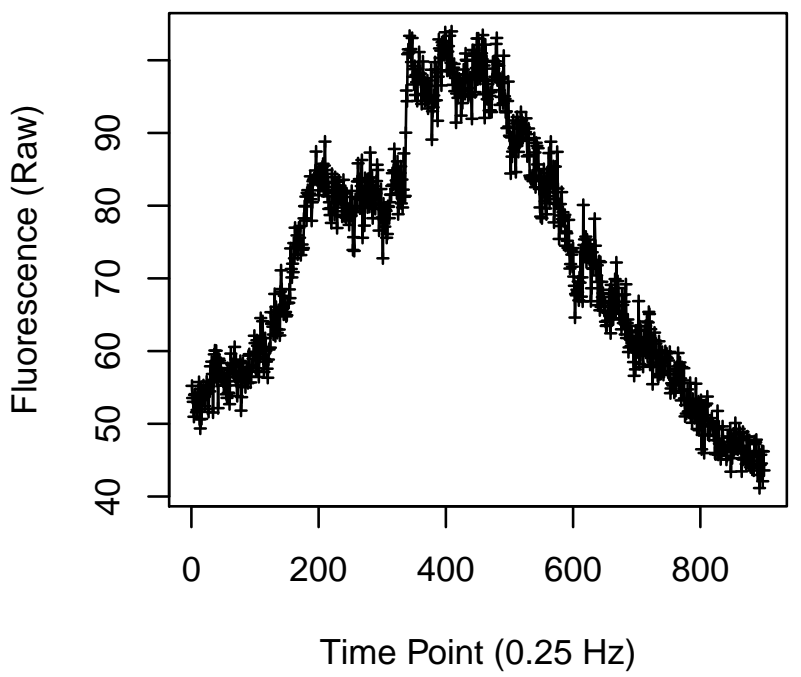

Cell 971

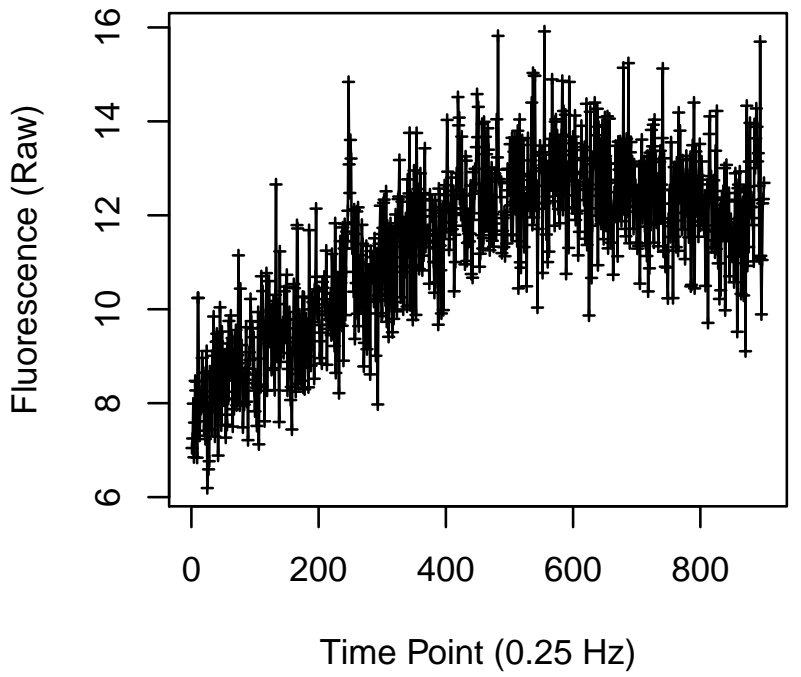

Cell 970

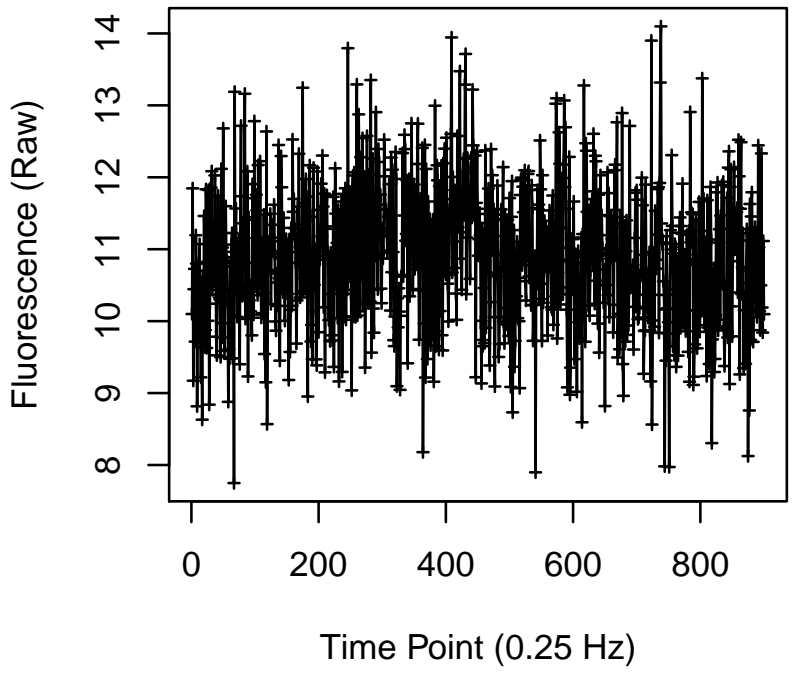

Cell 972

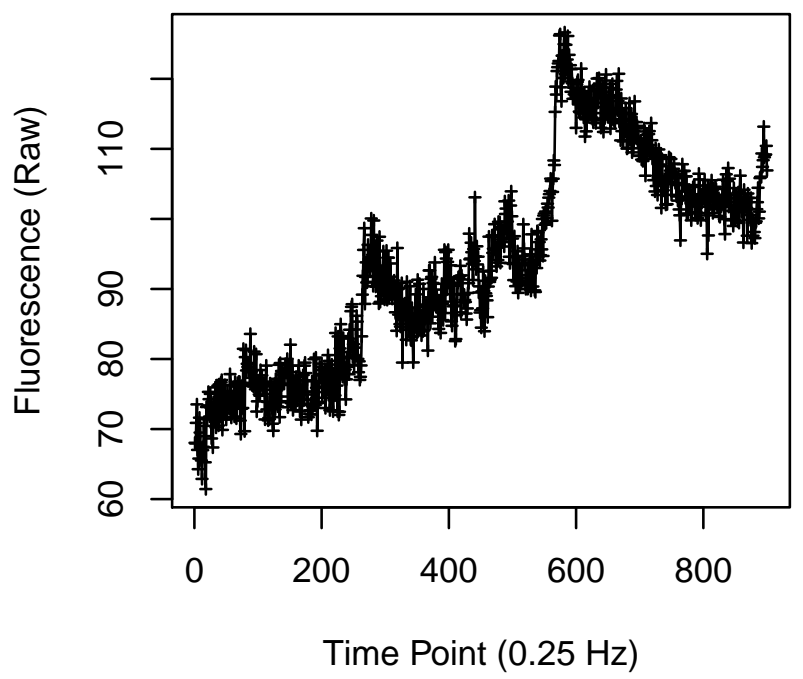




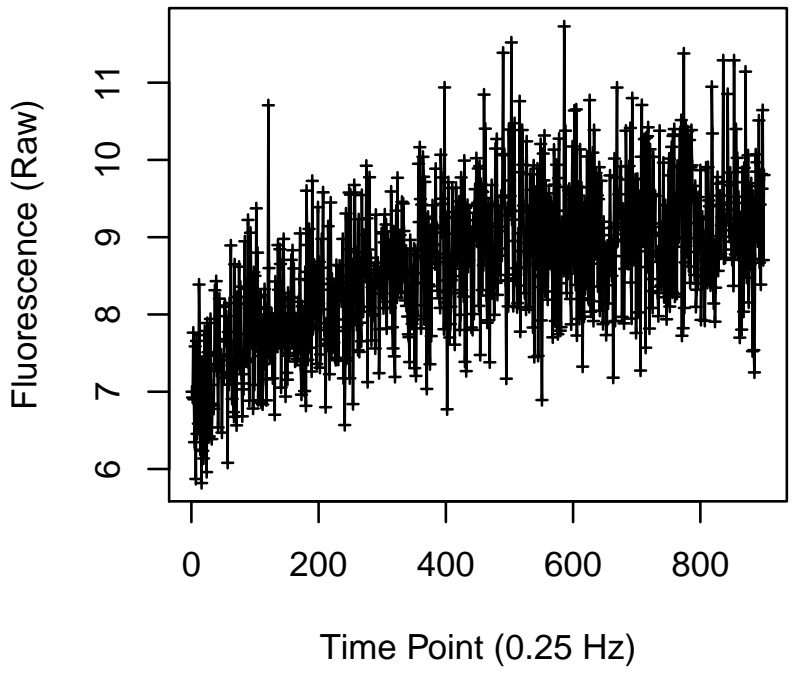

Cell 975

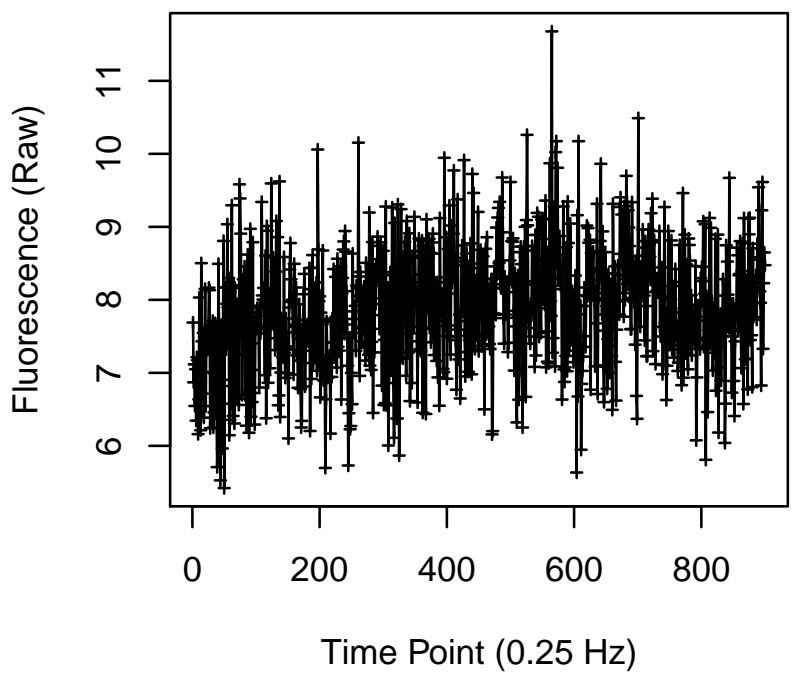

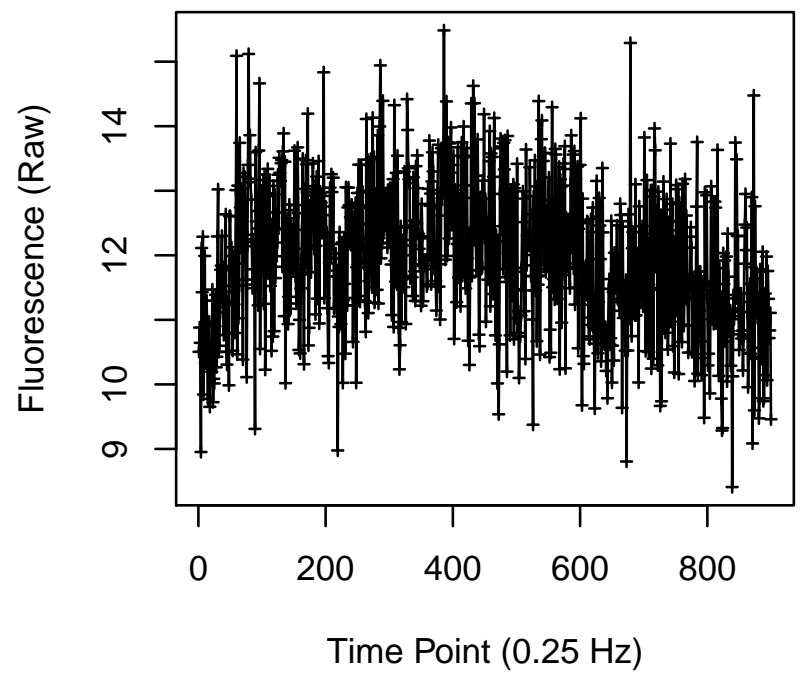

Cell 976

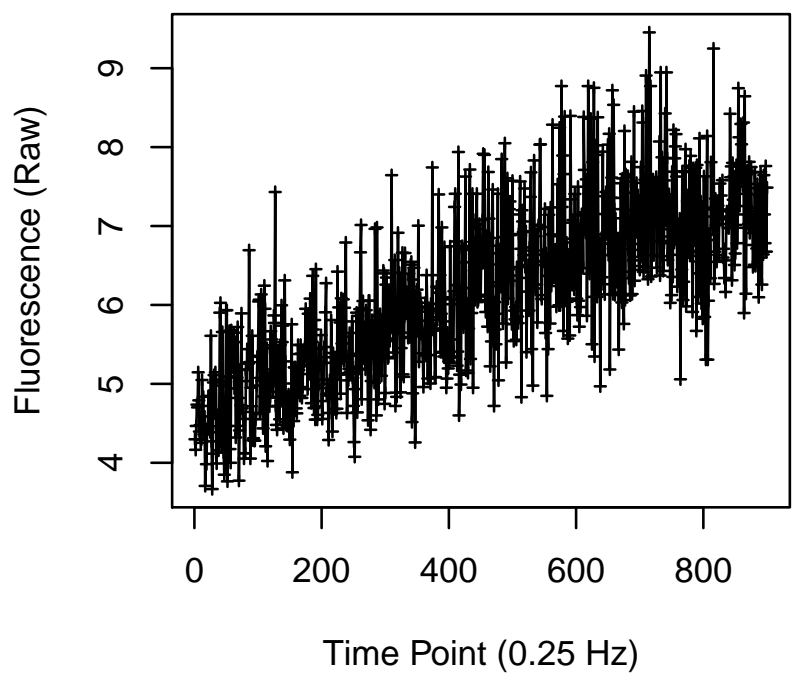


Cell 977

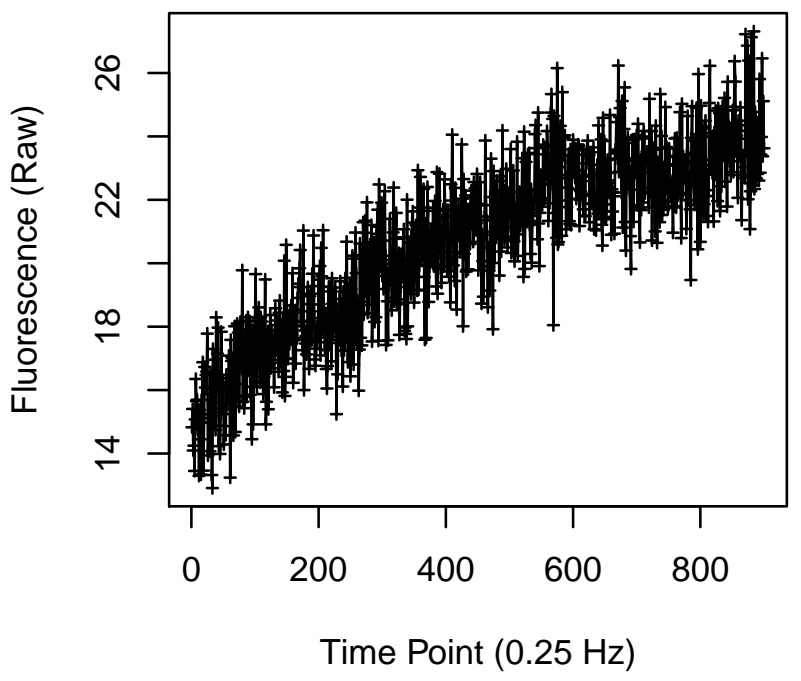

Cell 979

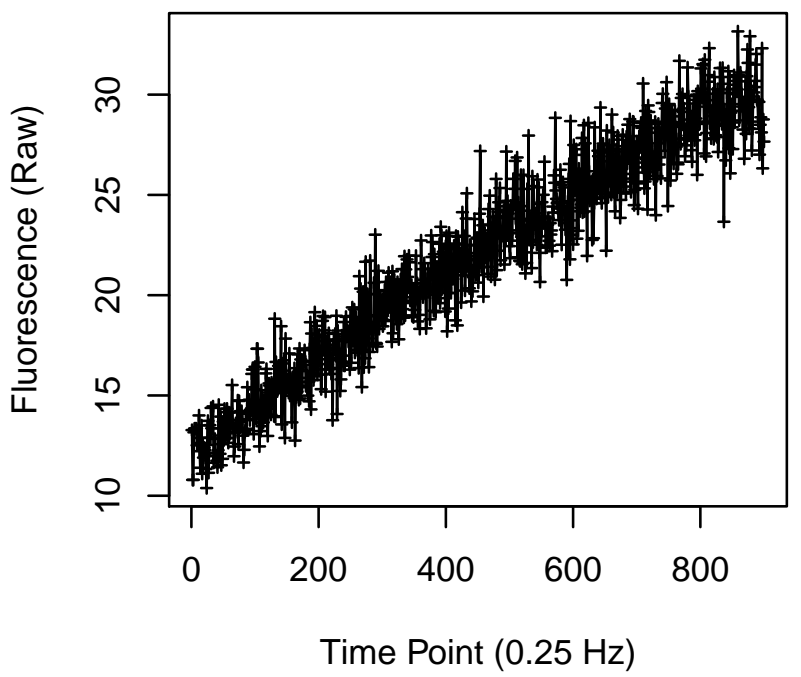

Cell 978

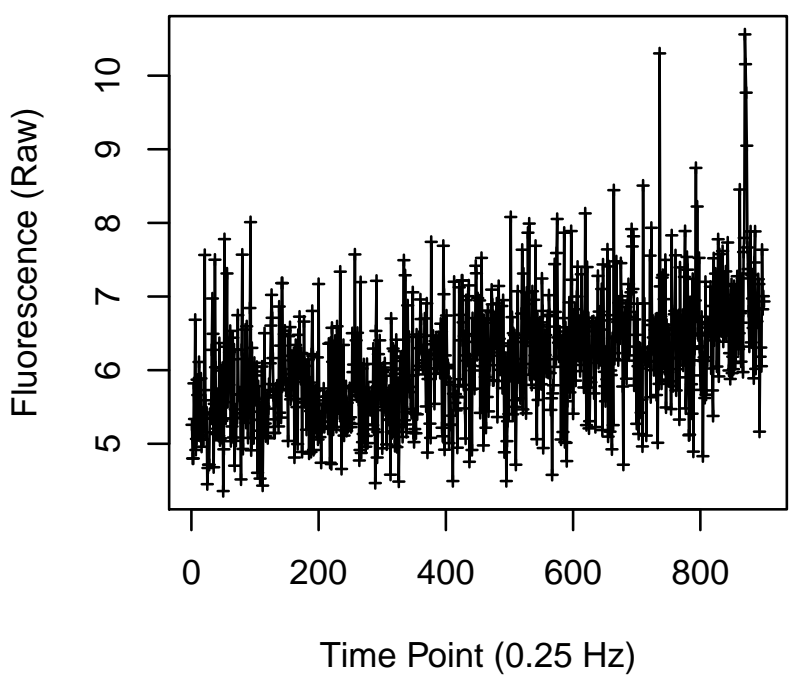

Cell 980

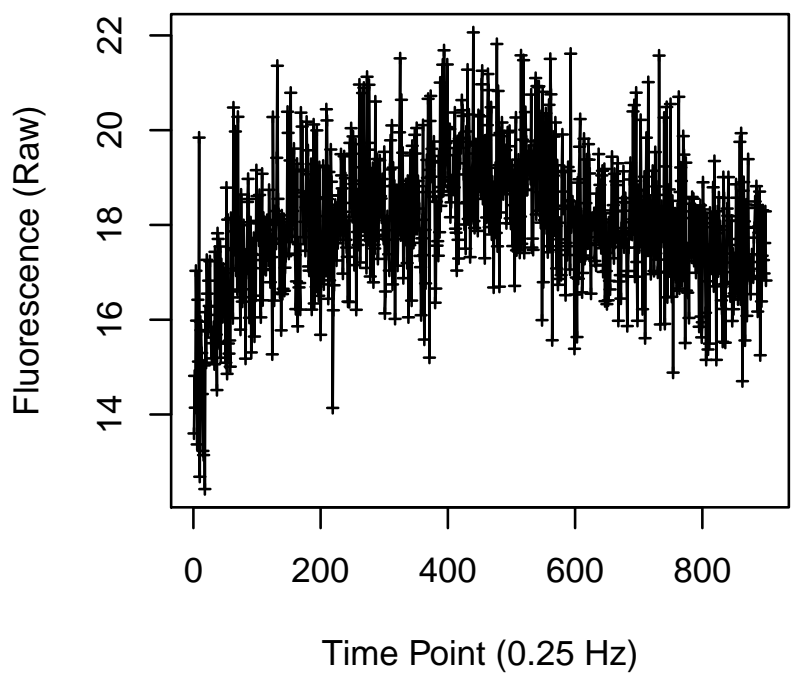




\section{Cell 985}

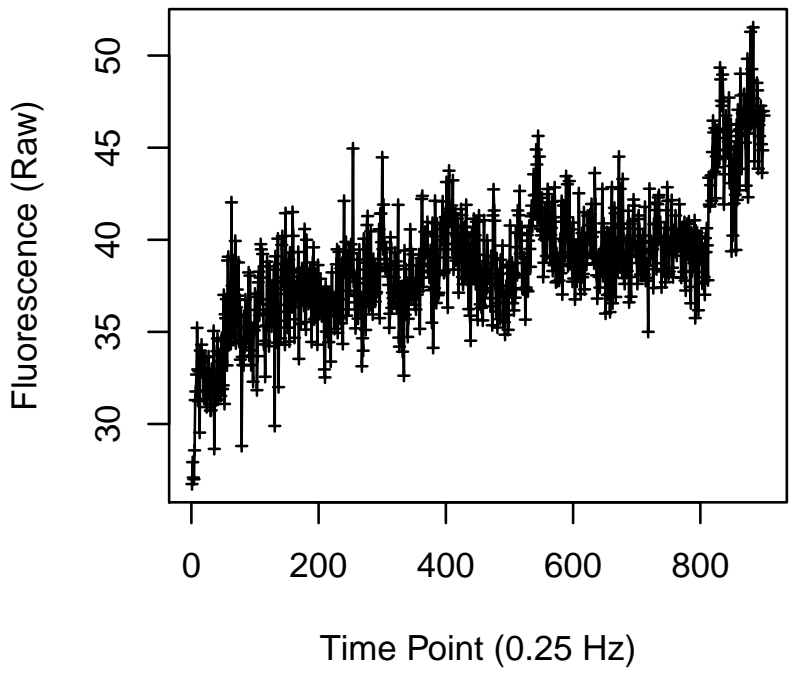

Cell 987

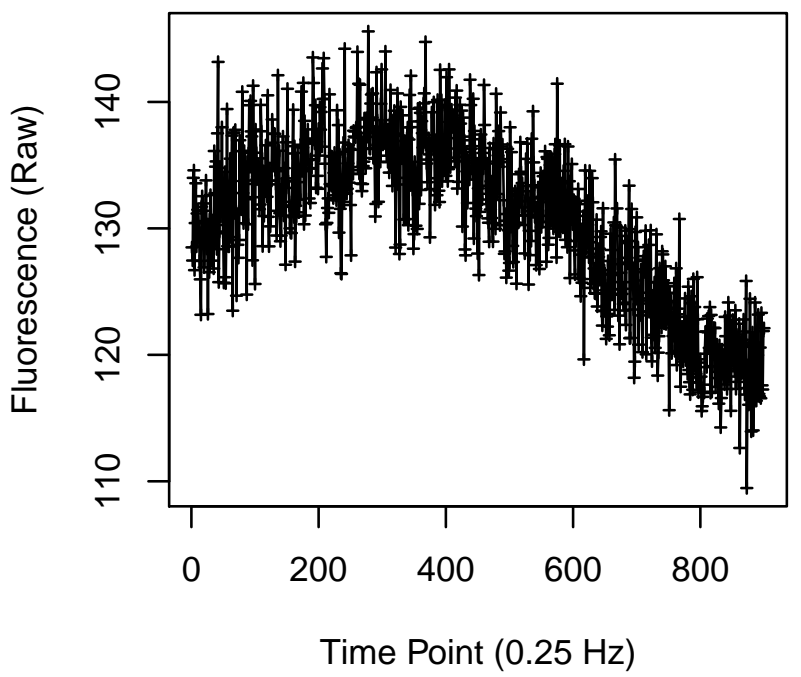

Cell 986

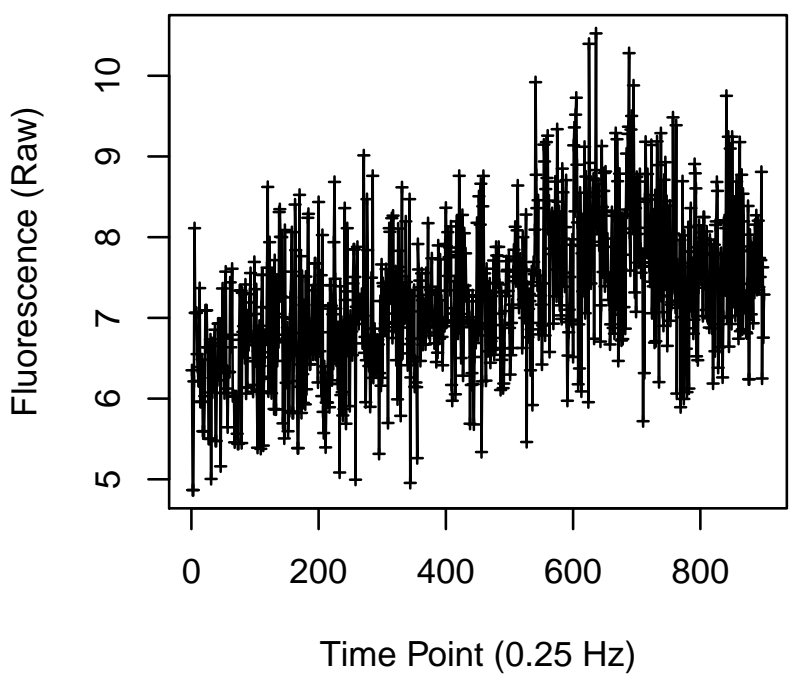

Cell 988

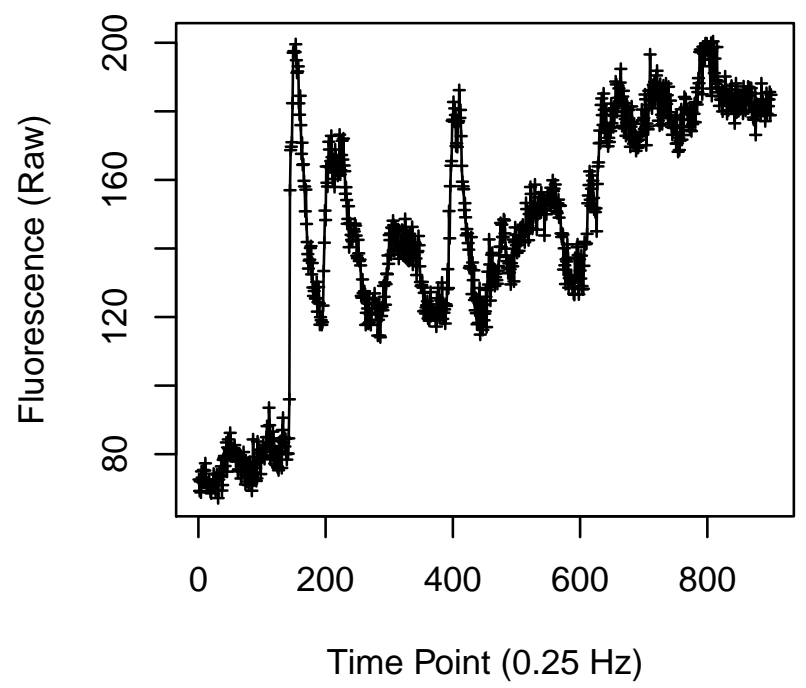




\section{Cell 997}

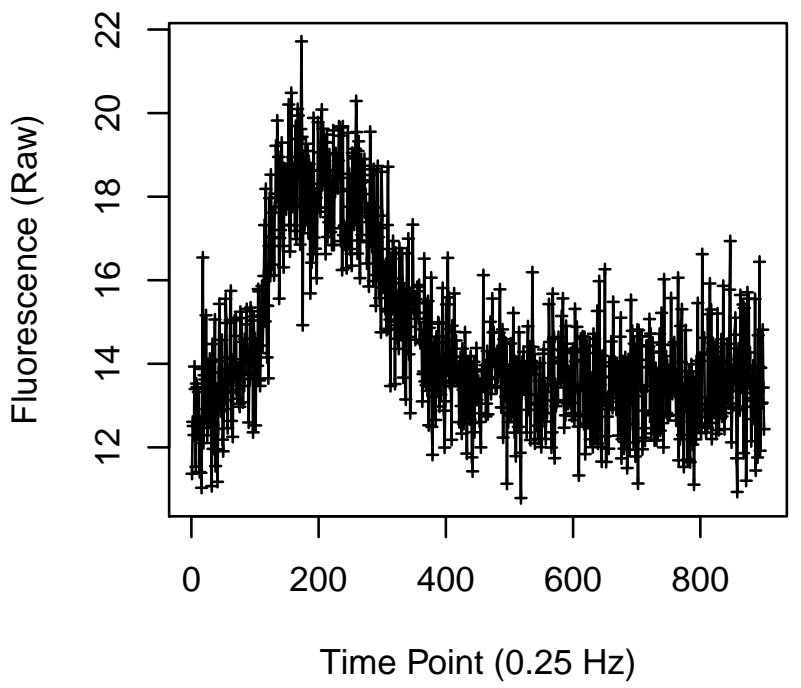

Cell 999

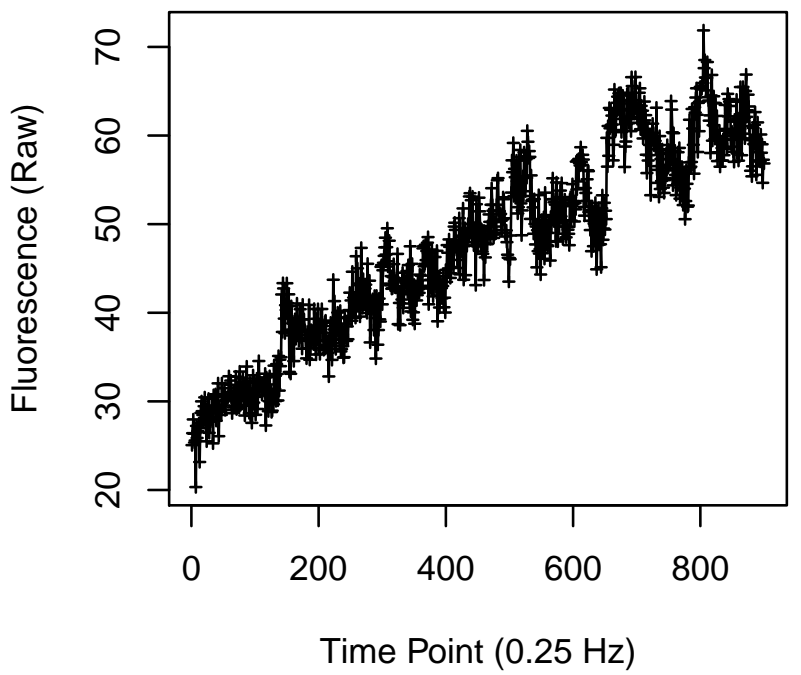

Cell 998

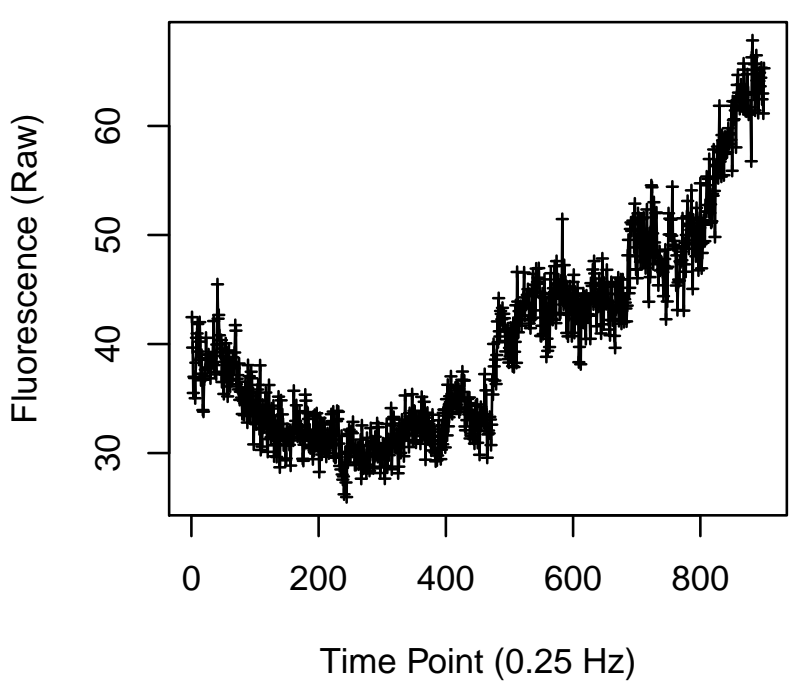

Cell 1000

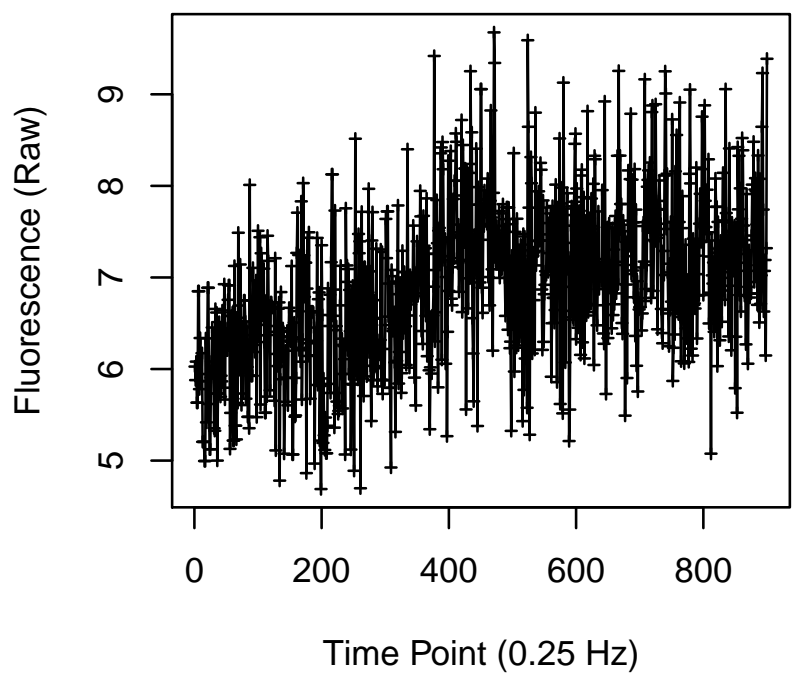


Cell 1001

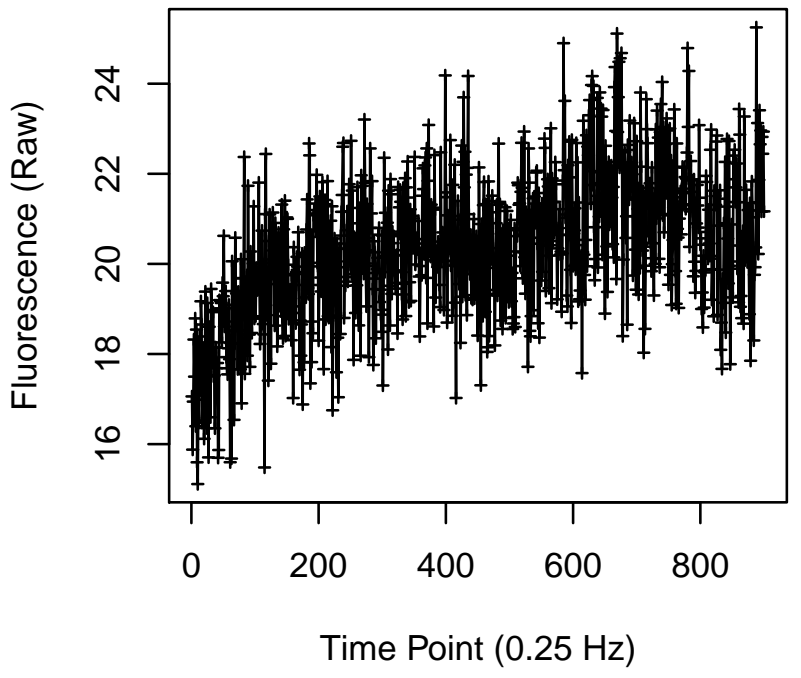

Cell 1003

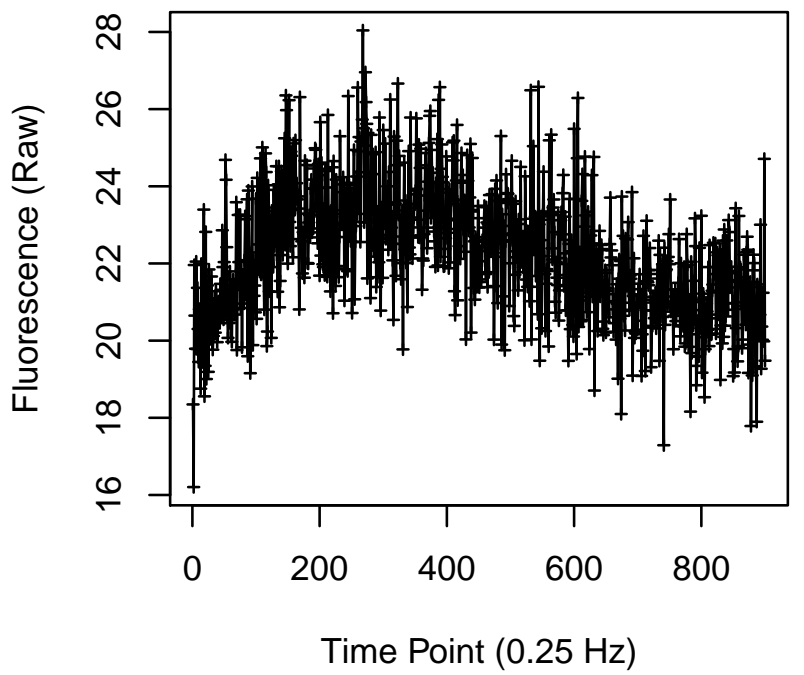

Cell 1002

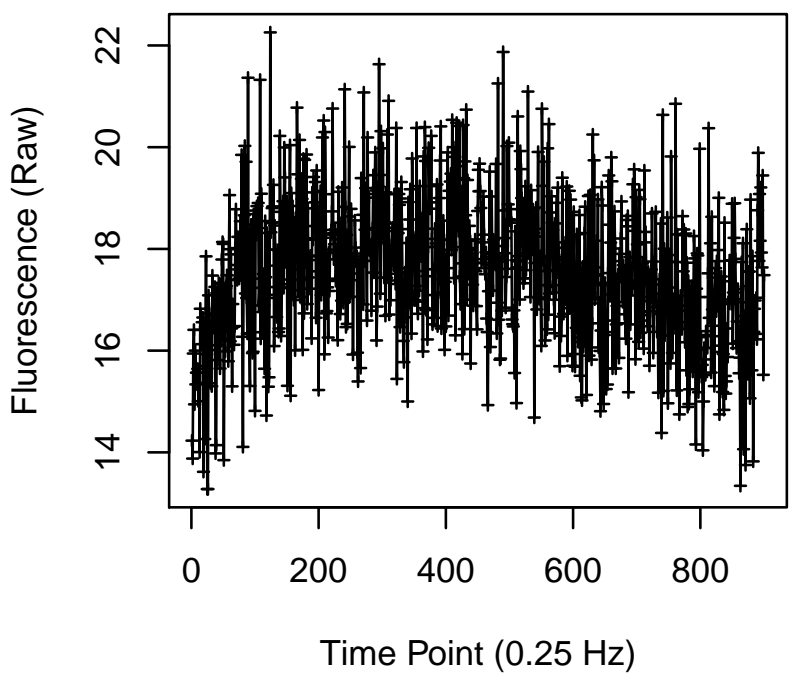

Cell 1004

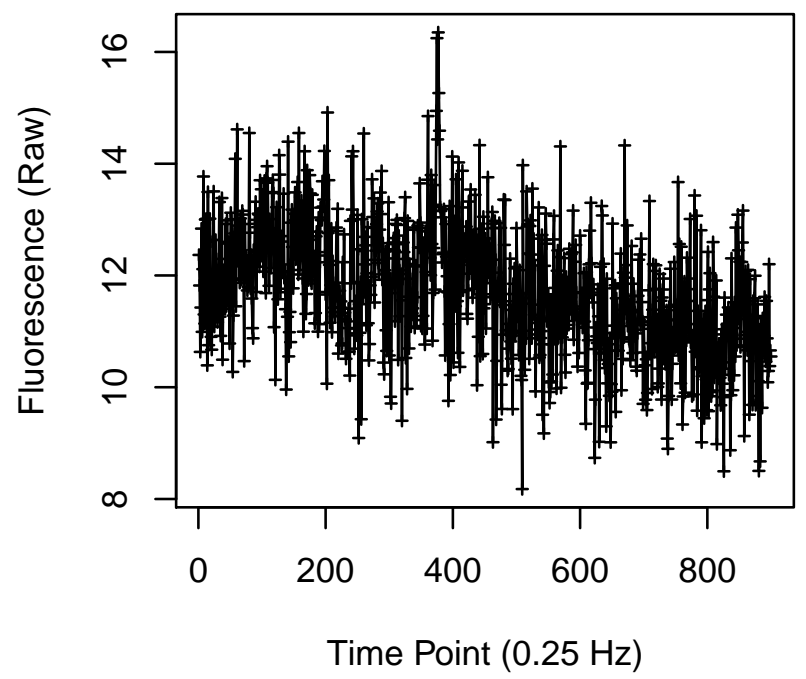


Cell 1005

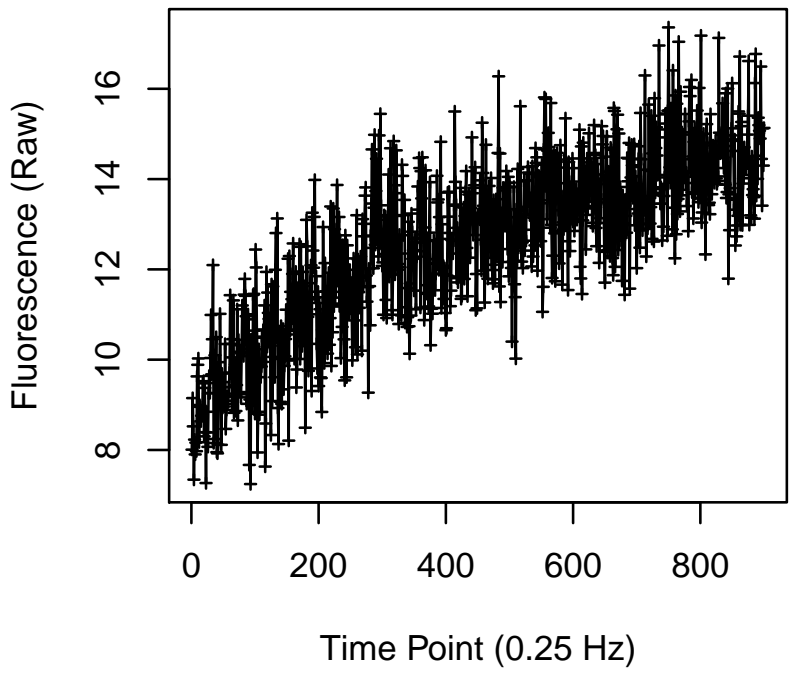

Cell 1007

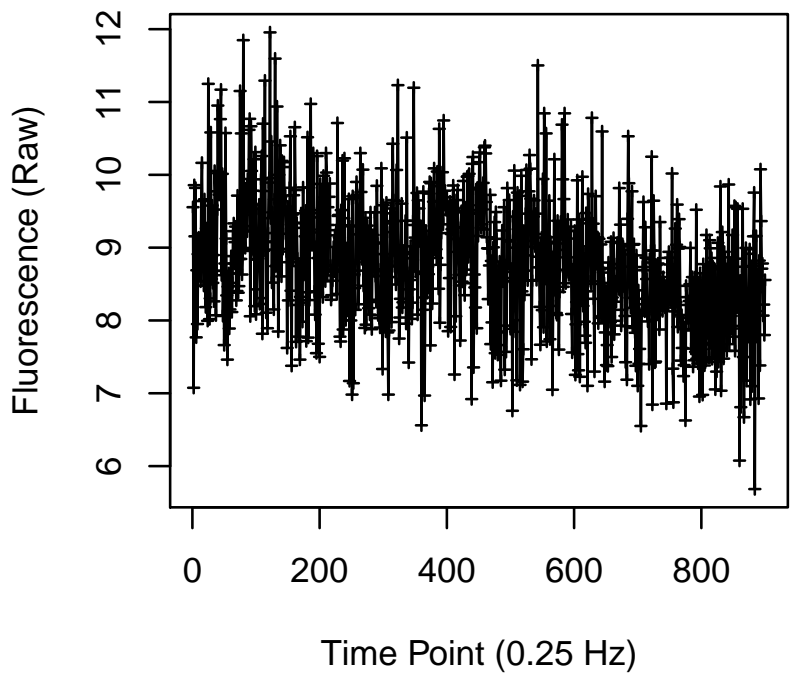

Cell 1006

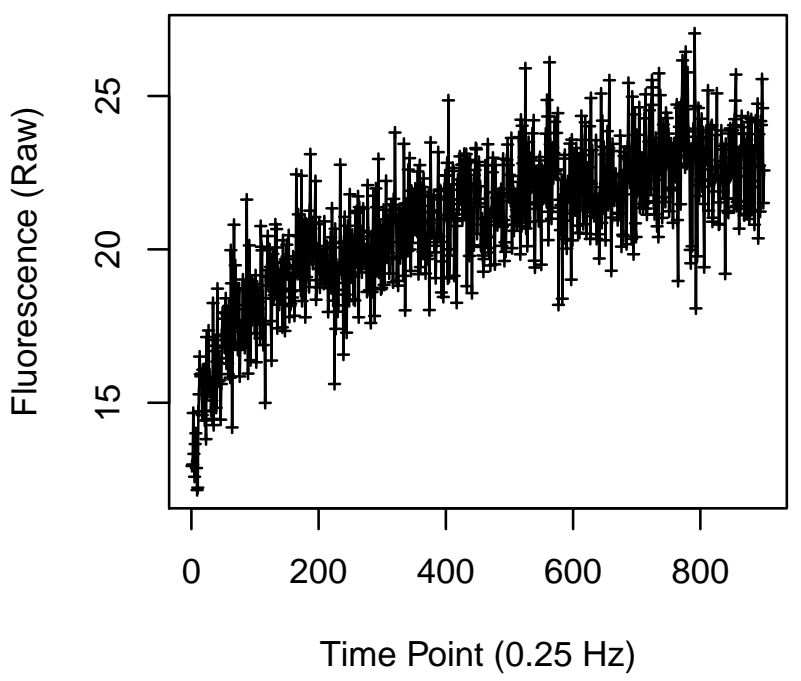

Cell 1008

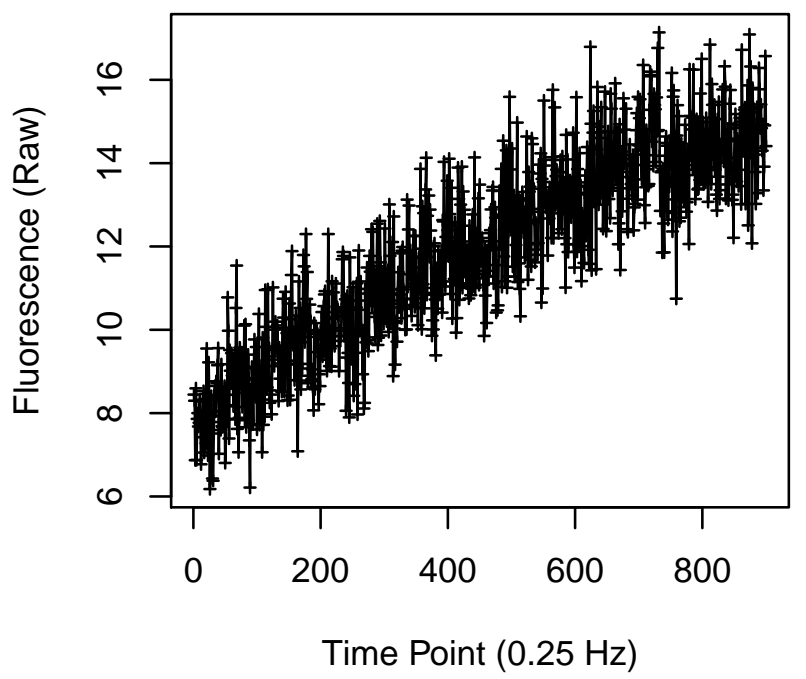


Cell 1009

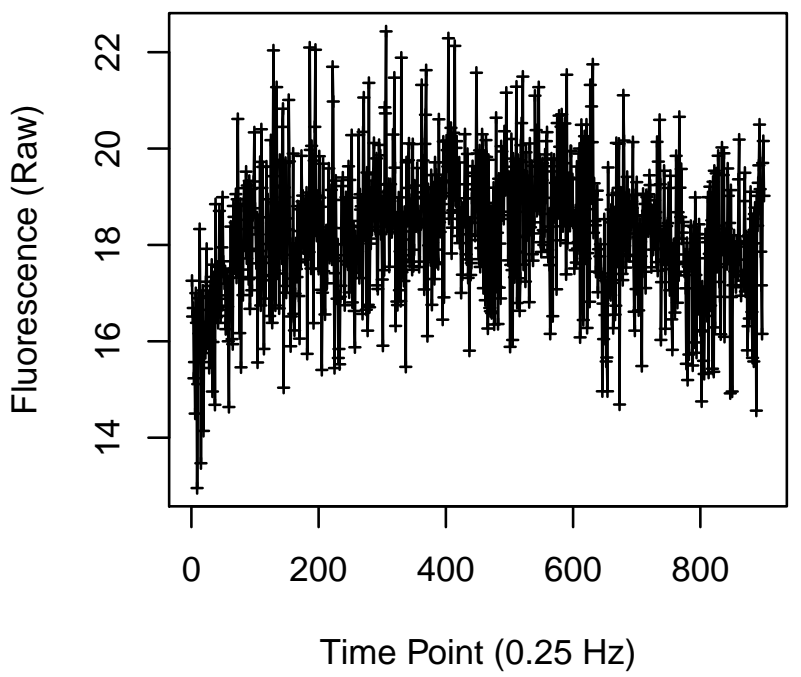

Cell 1011

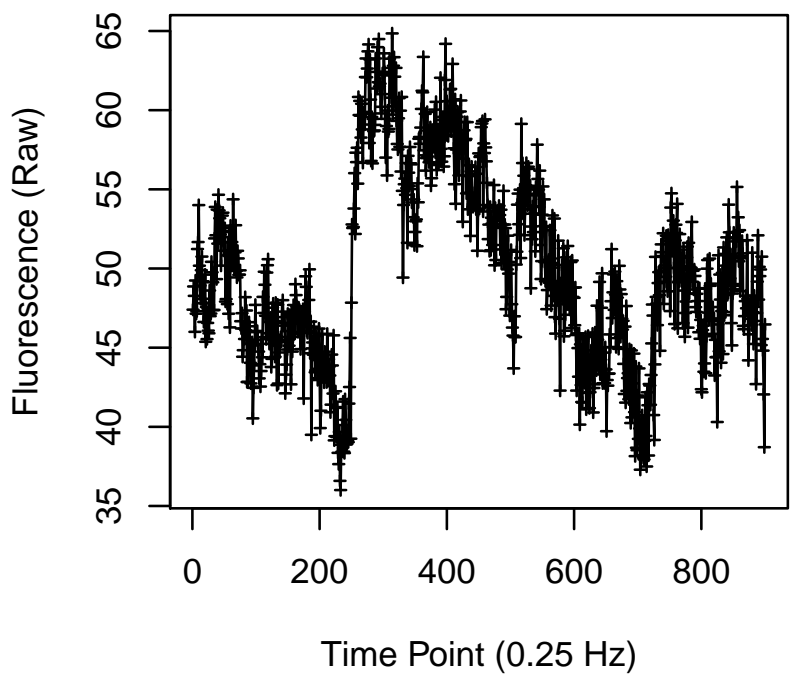

Cell 1010

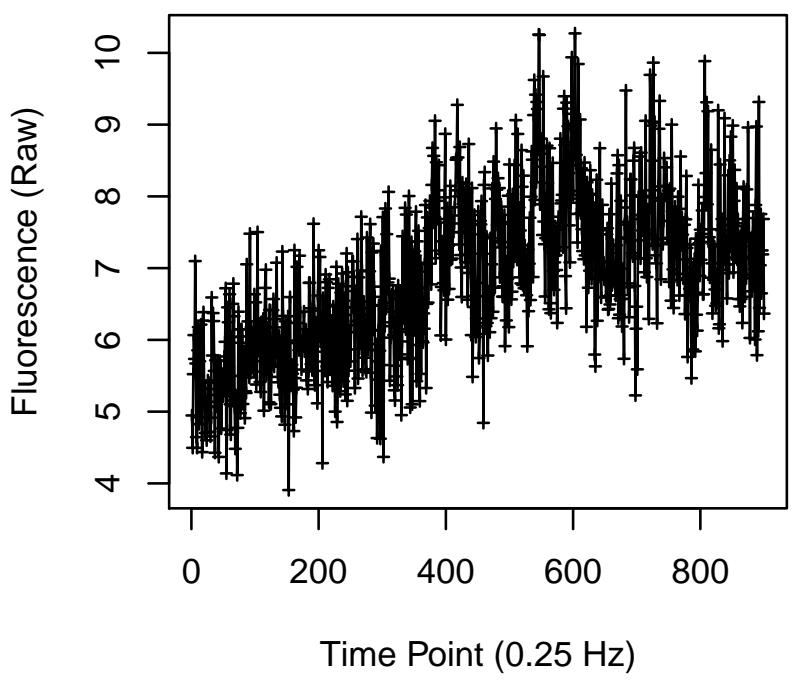

Cell 1012

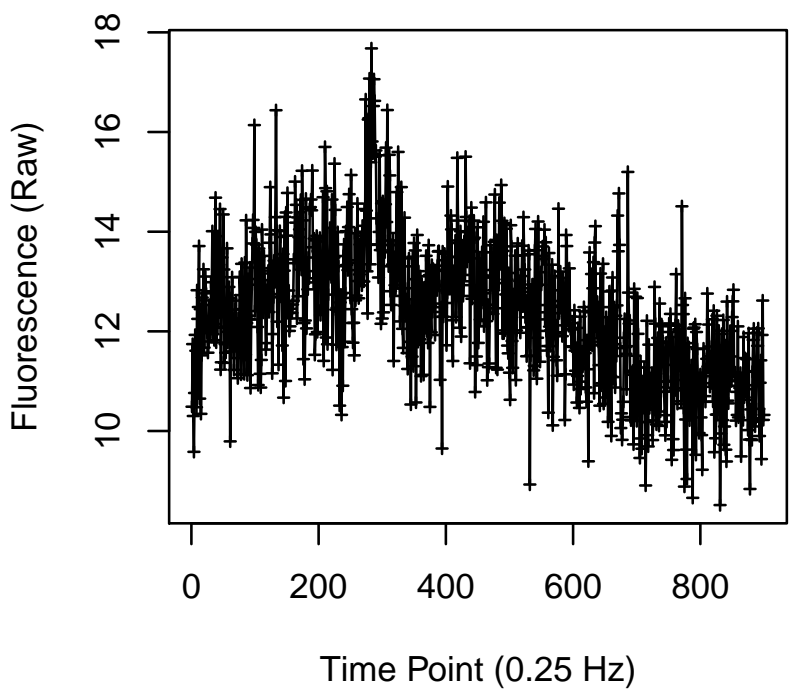


Cell 1013

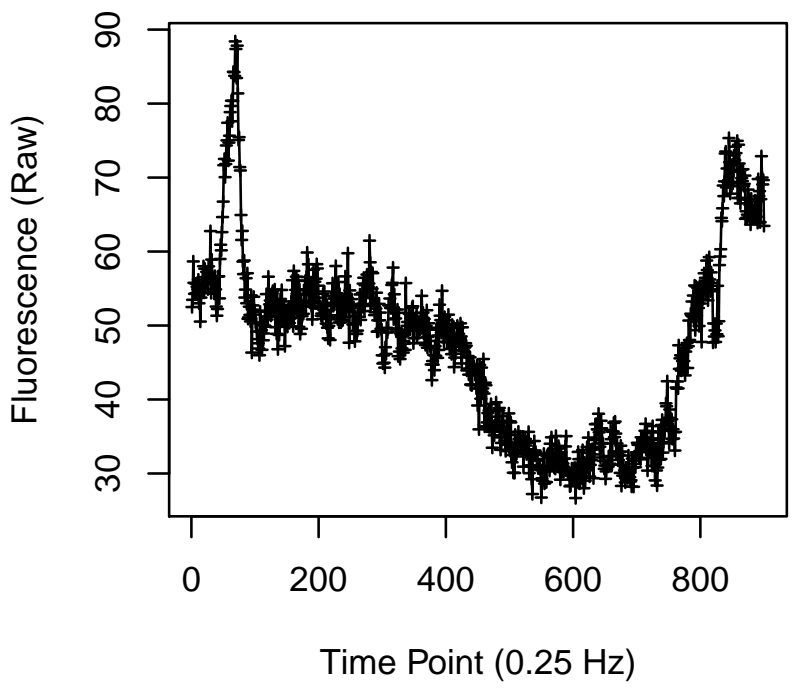

Cell 1015

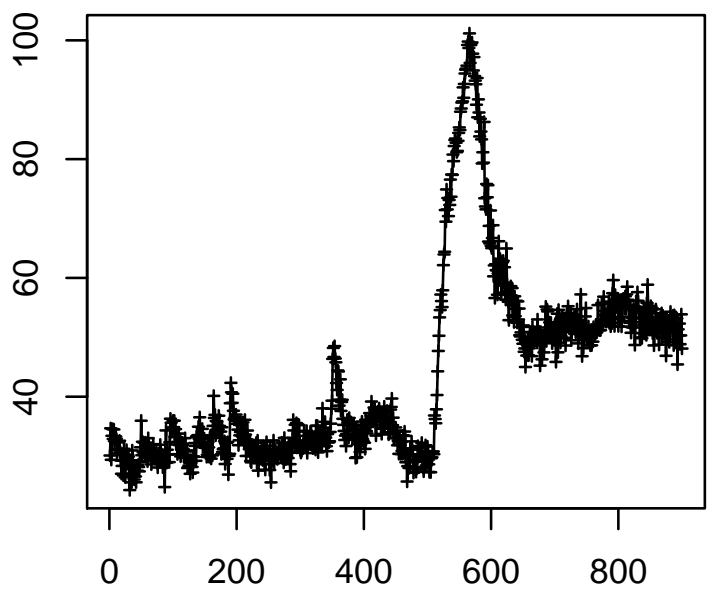

Time Point $(0.25 \mathrm{~Hz})$
Cell 1014

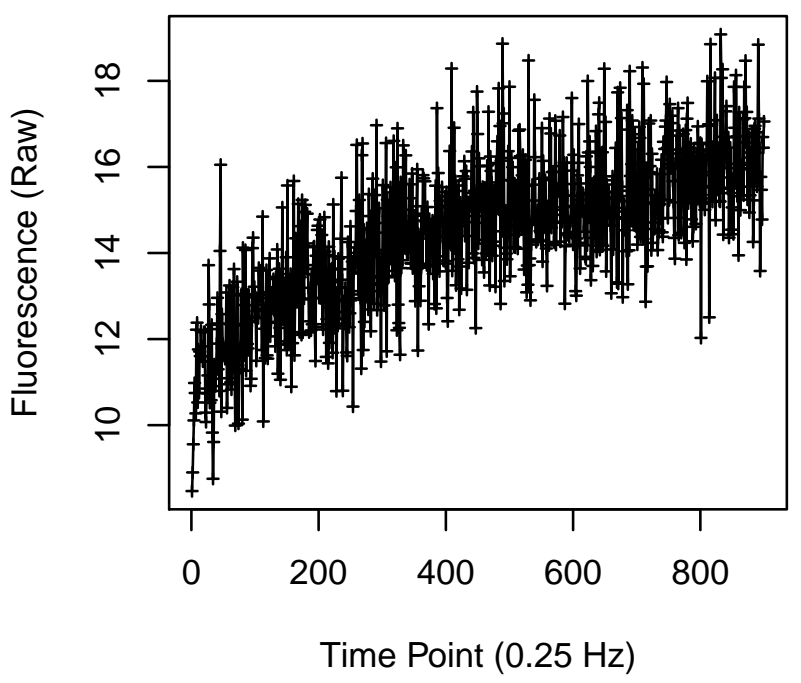

Cell 1016

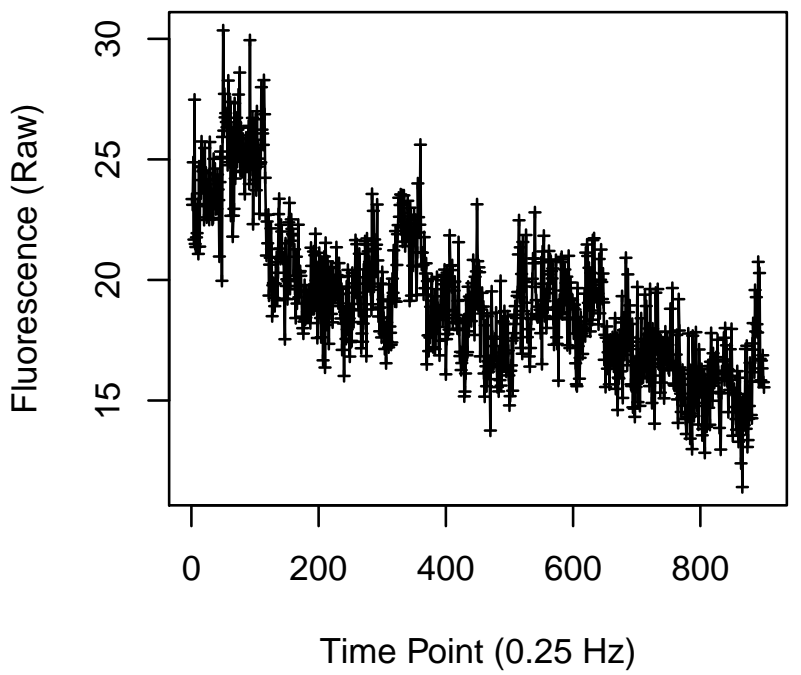


Cell 1017

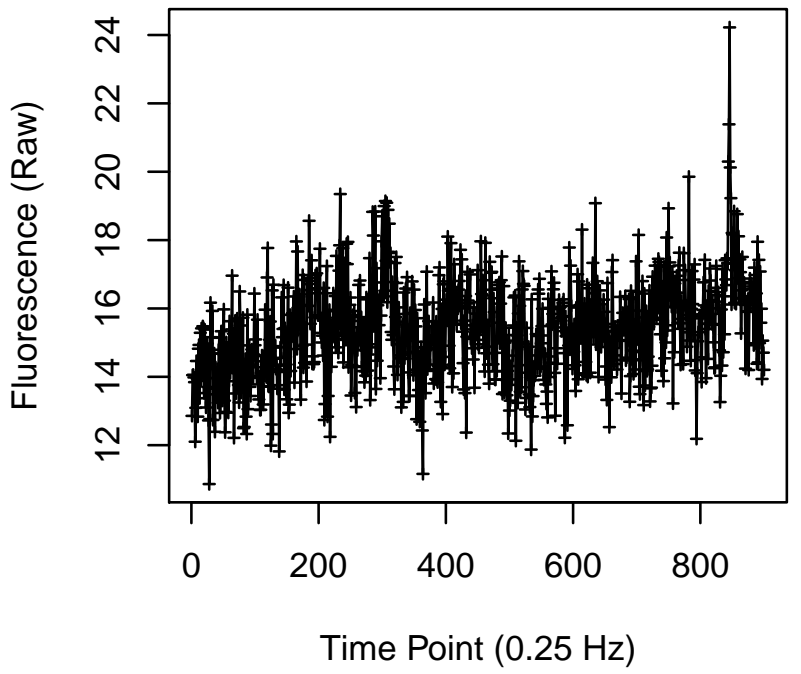

Cell 1019

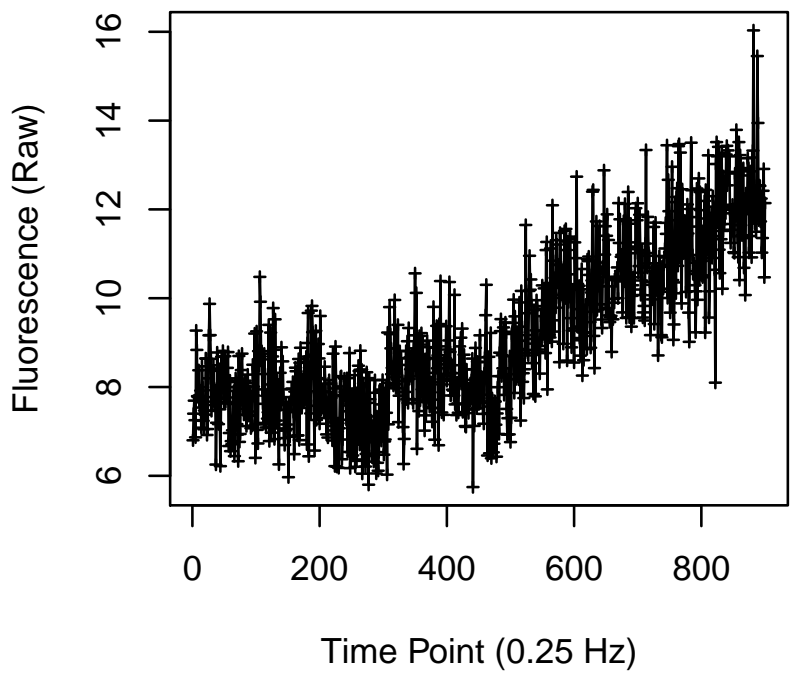

Cell 1018

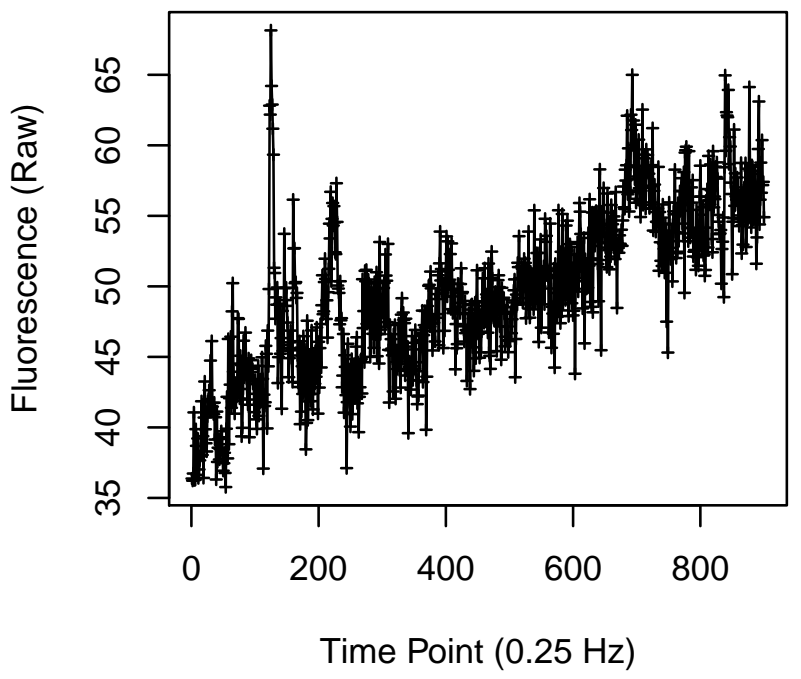

Cell 1020

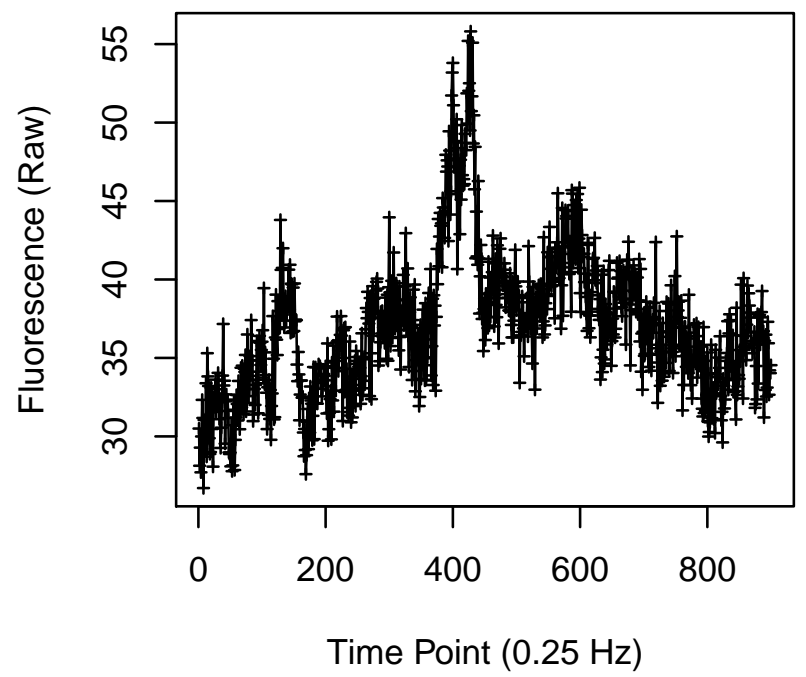


Cell 1021

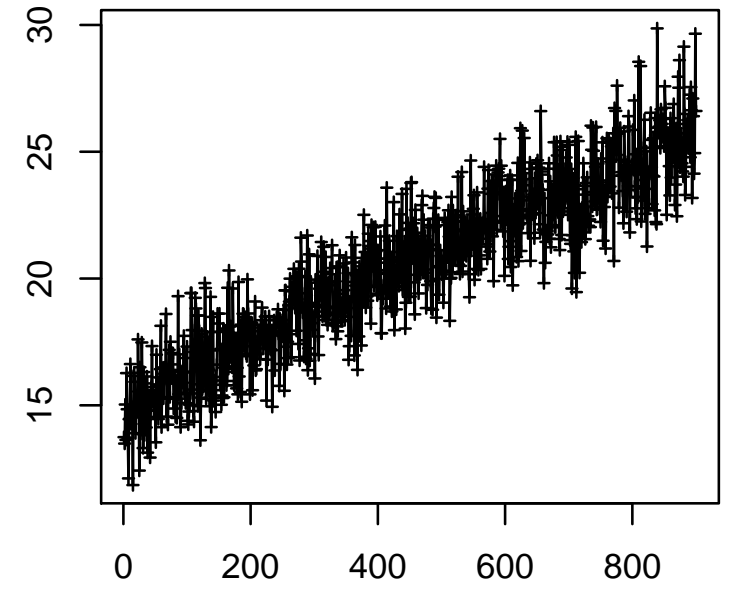

Time Point $(0.25 \mathrm{~Hz})$

Cell 1023

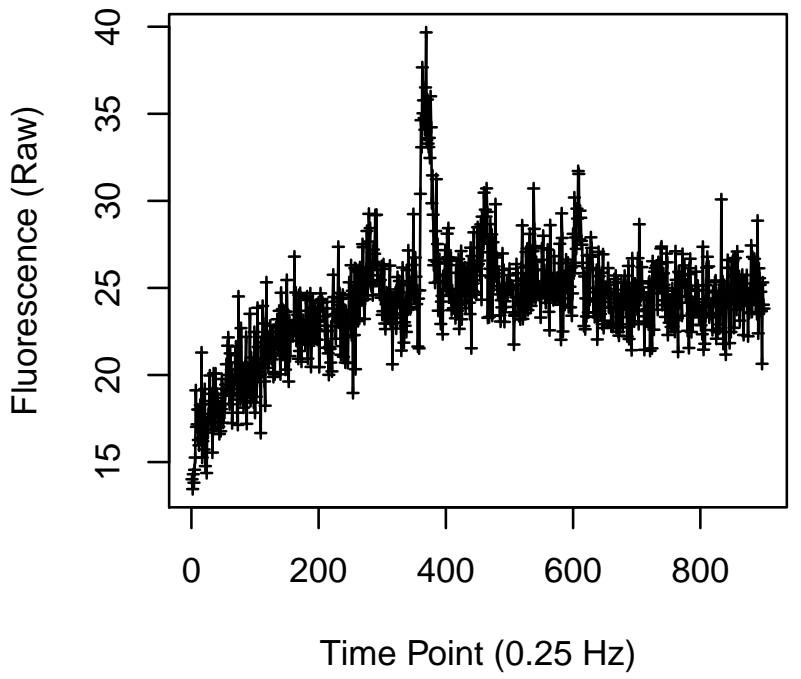

Cell 1022

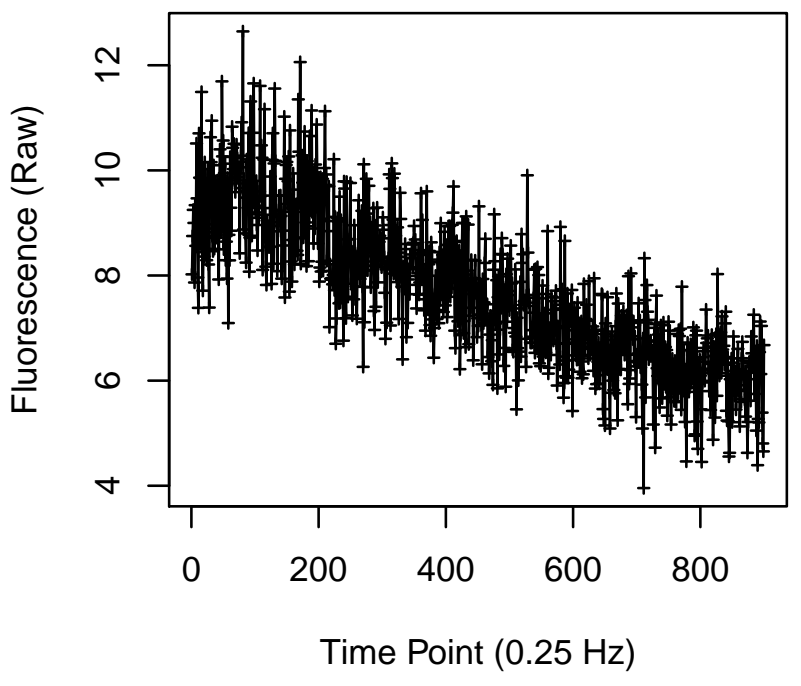

Cell 1024

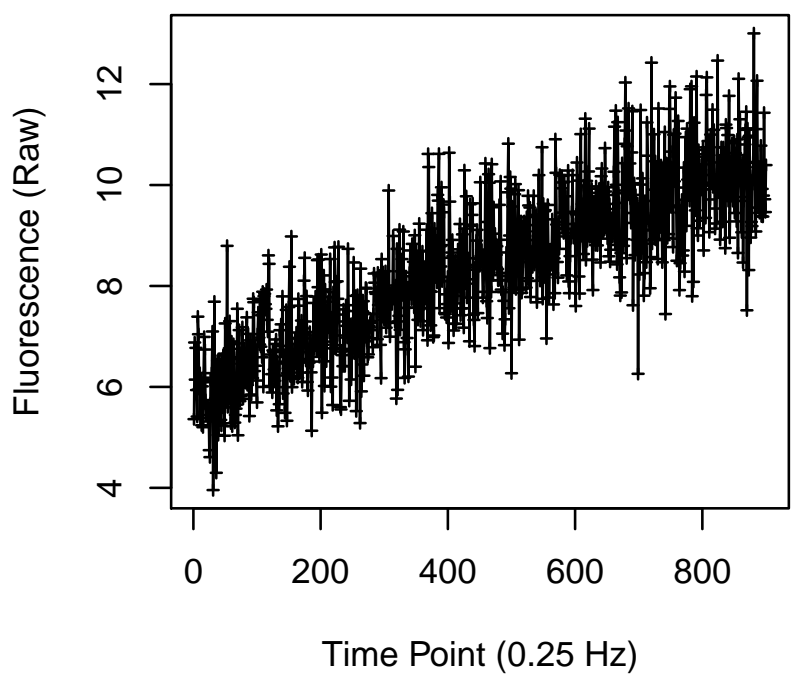


Cell 1025

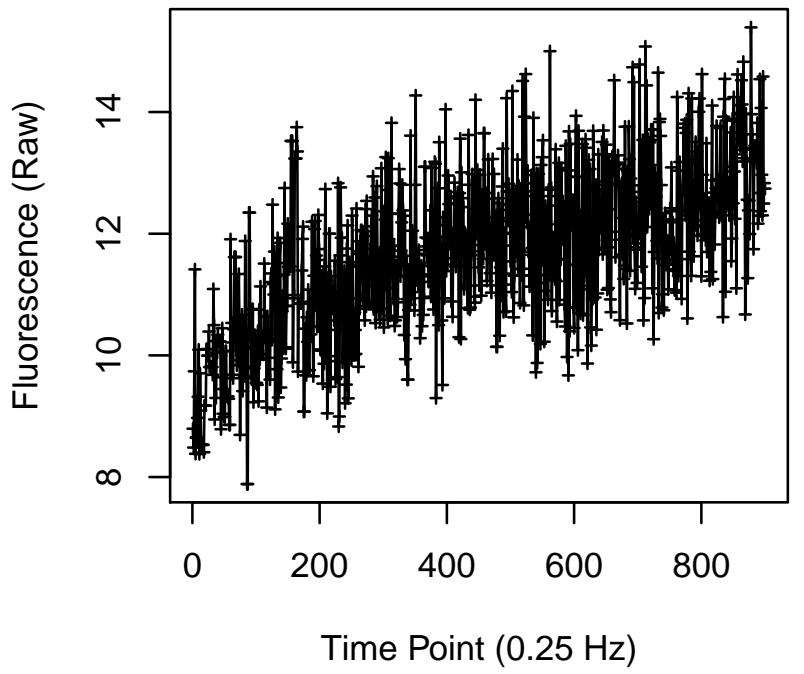

Cell 1027

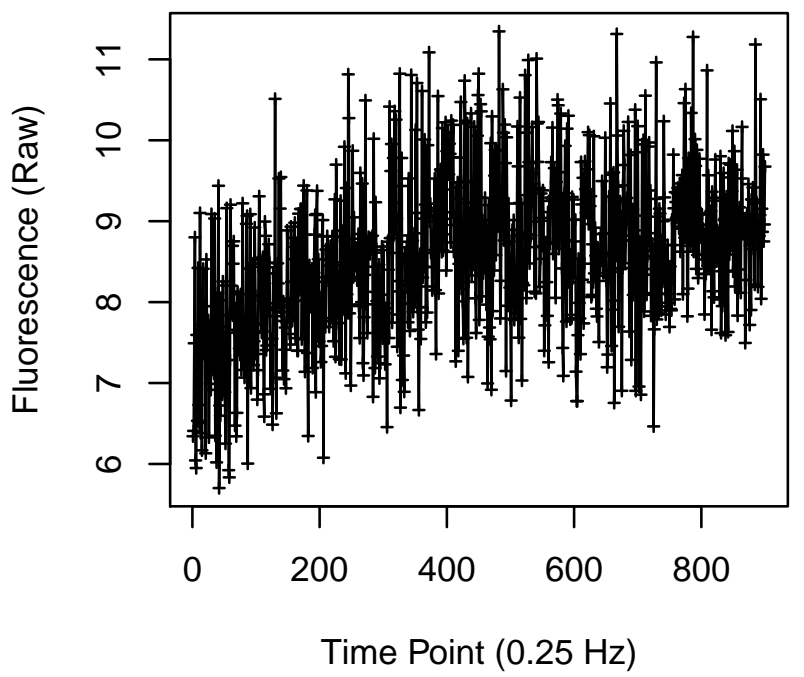

Cell 1026

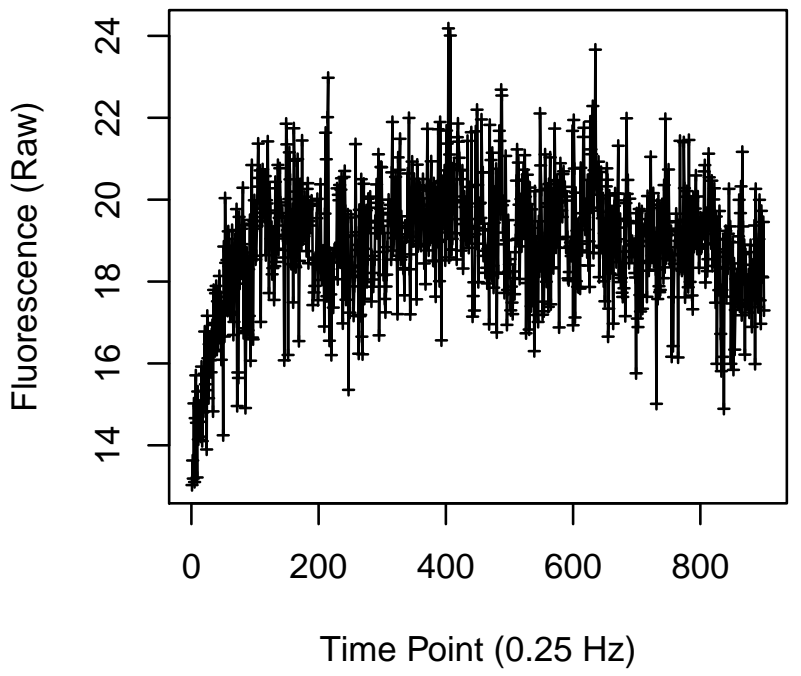

Cell 1028

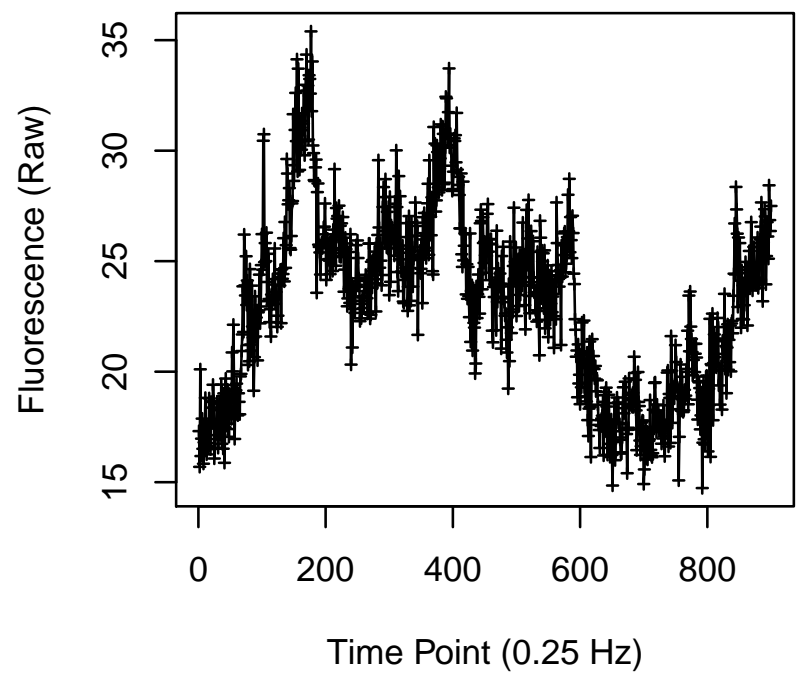


Cell 1029

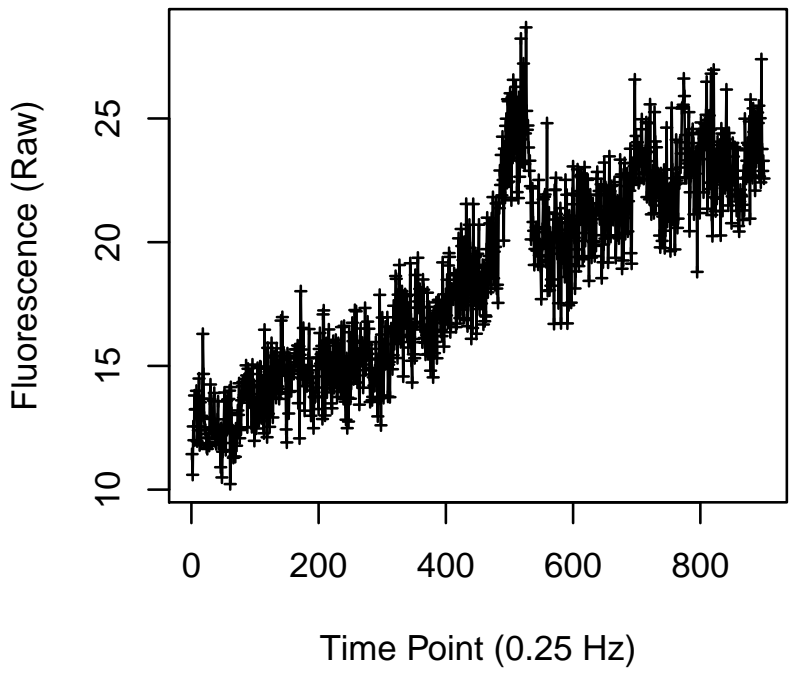

Cell 1031

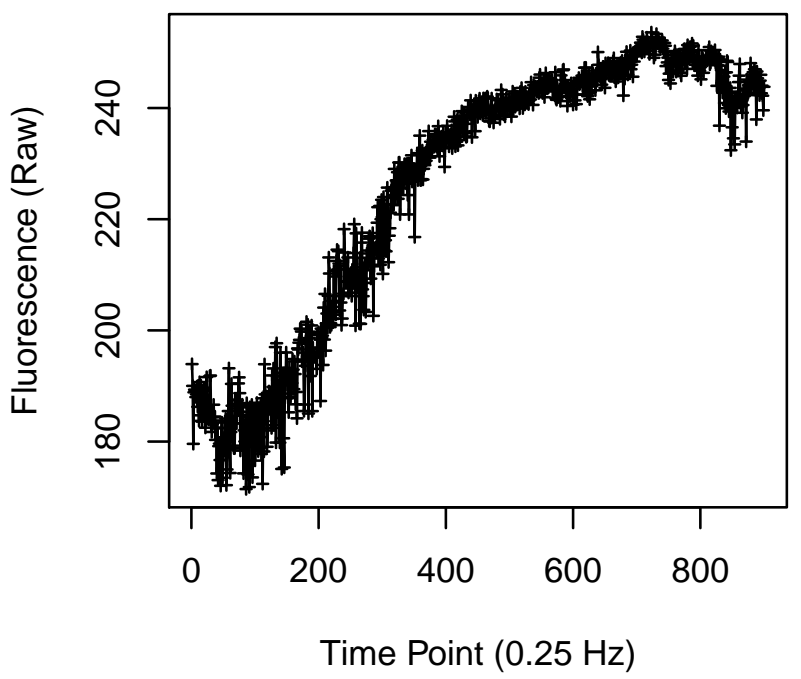

Cell 1030

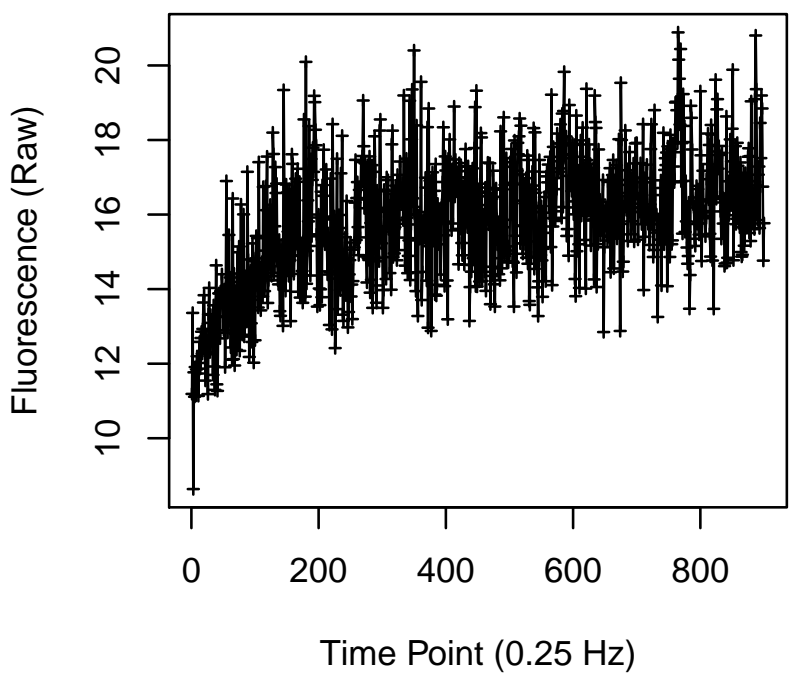

Cell 1032

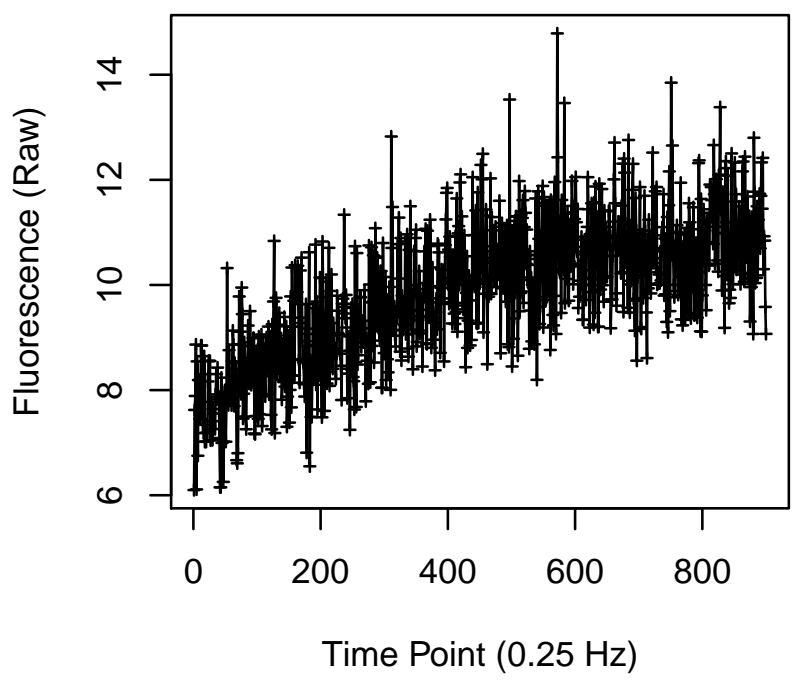


Cell 1033

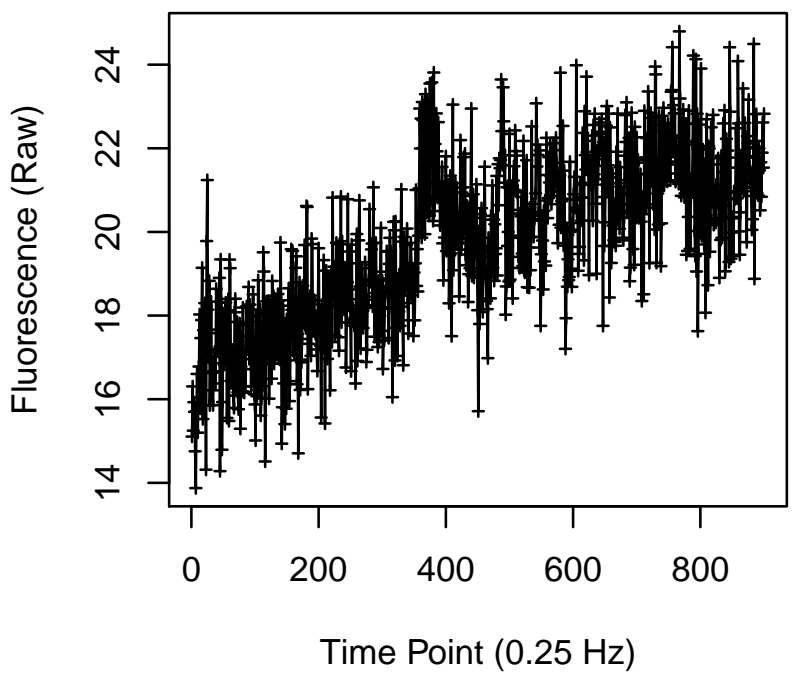

Cell 1035

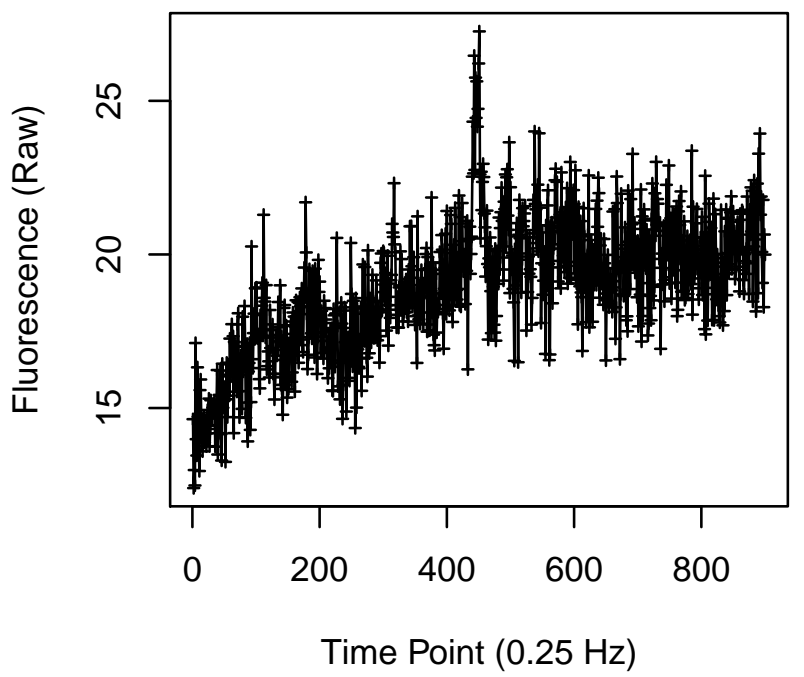

Cell 1034

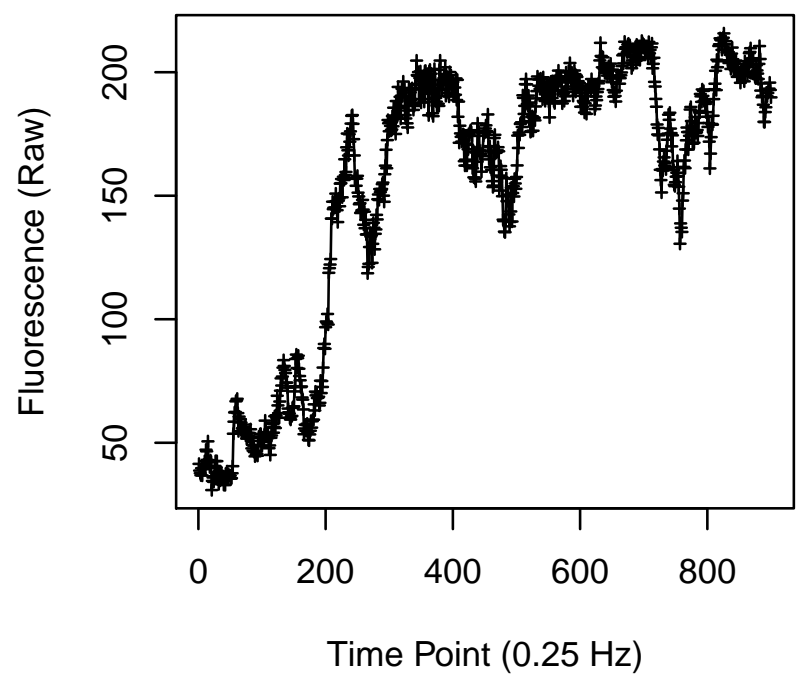

Cell 1036

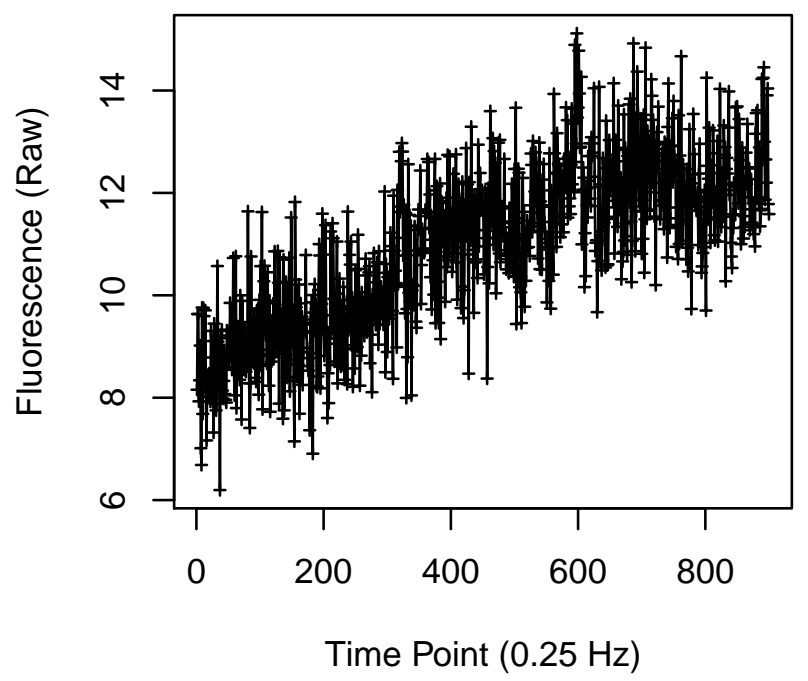


Cell 1037

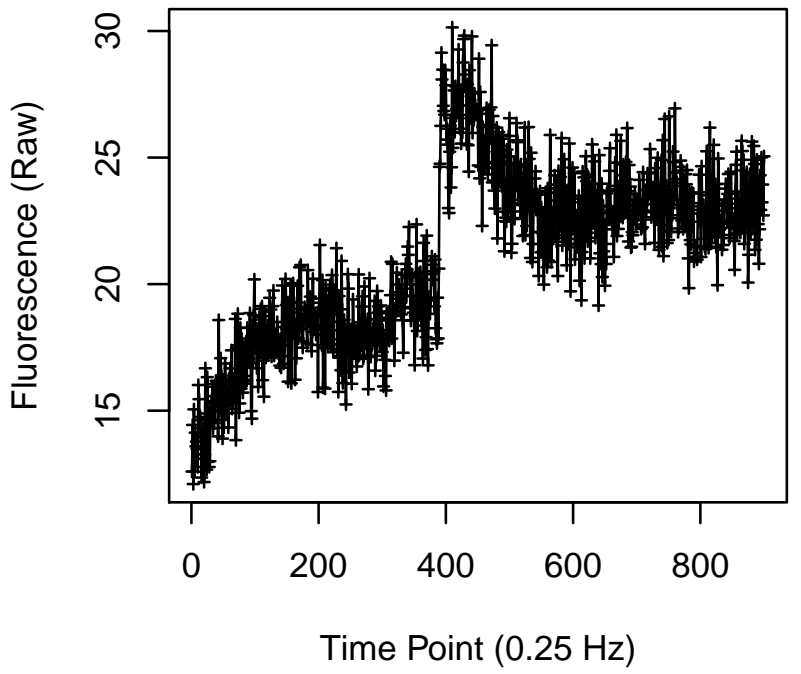

Cell 1039

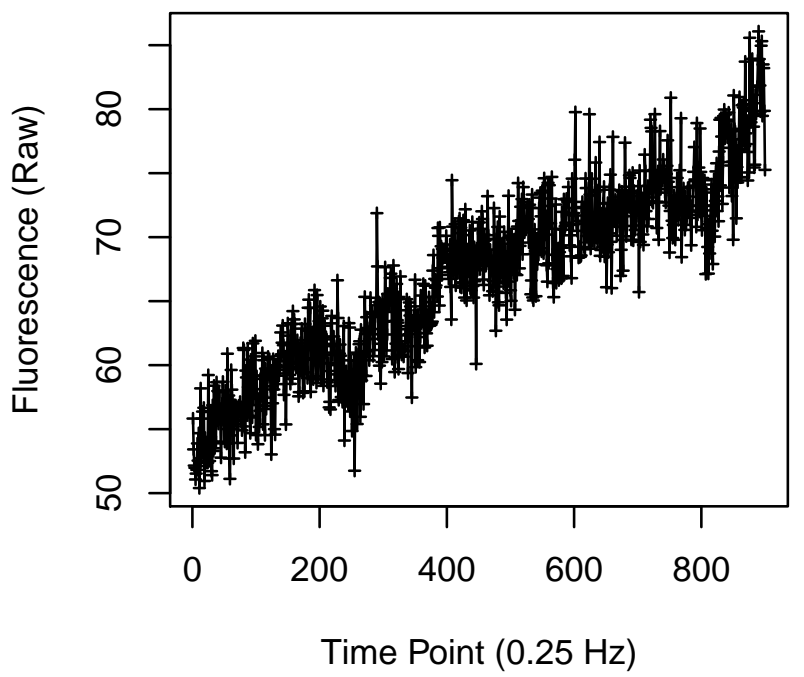

Cell 1038

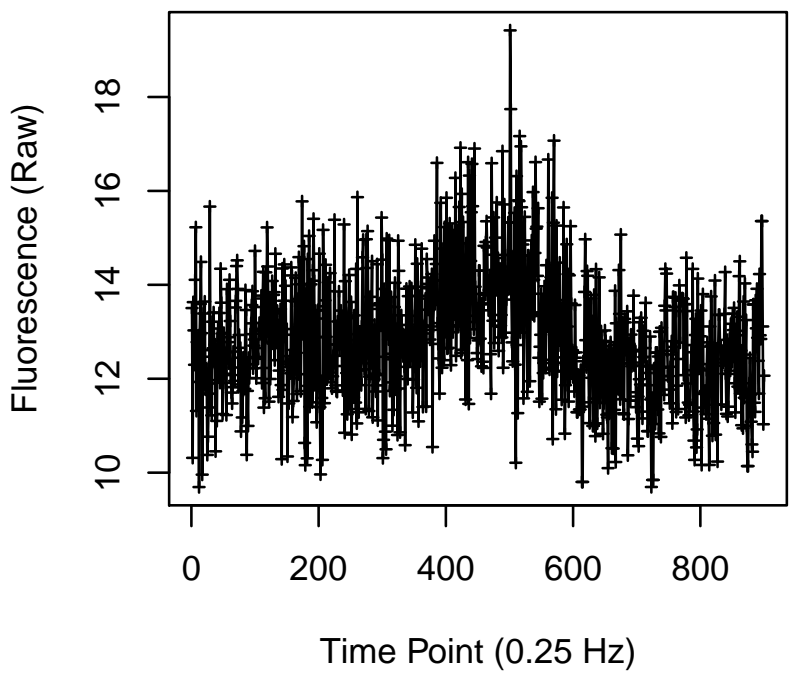

Cell 1040

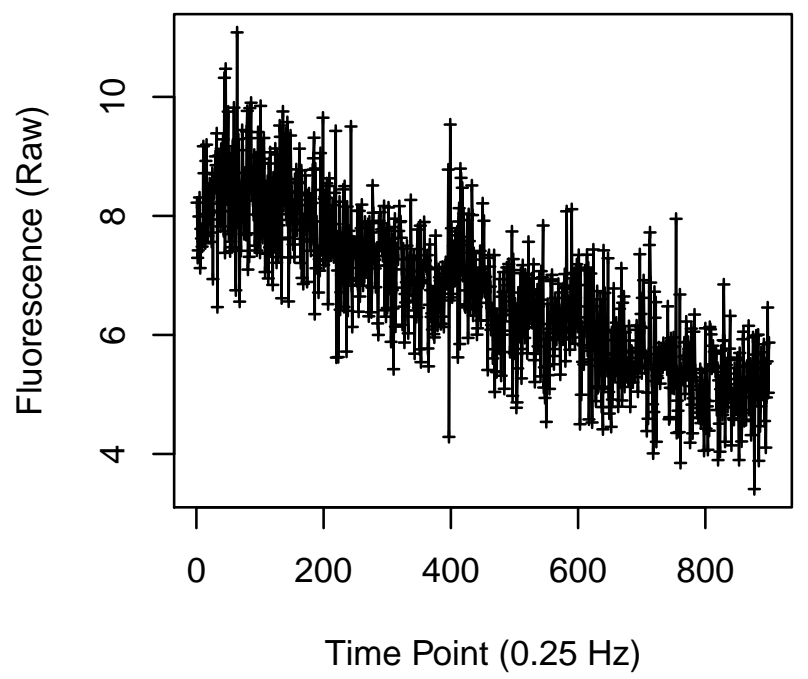


Cell 1041

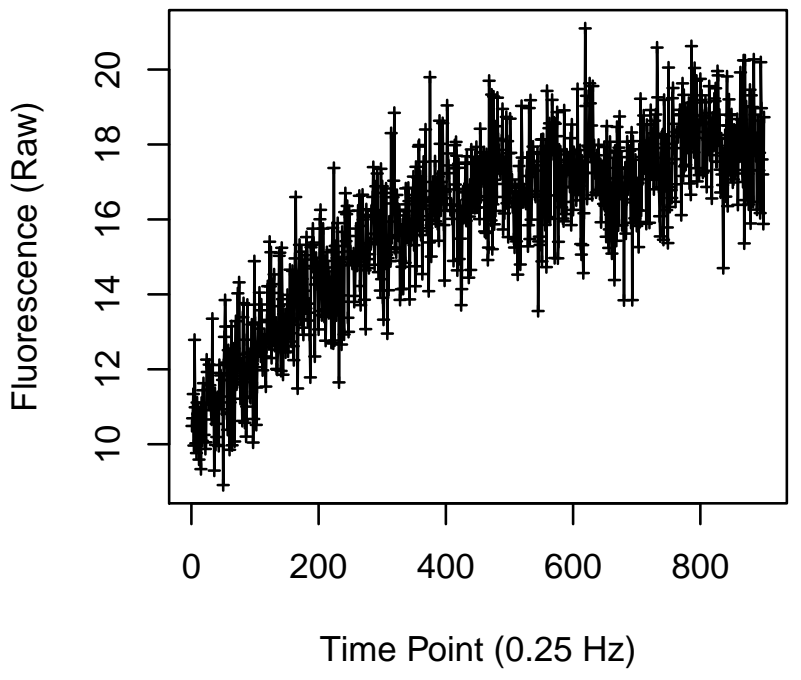

Cell 1043

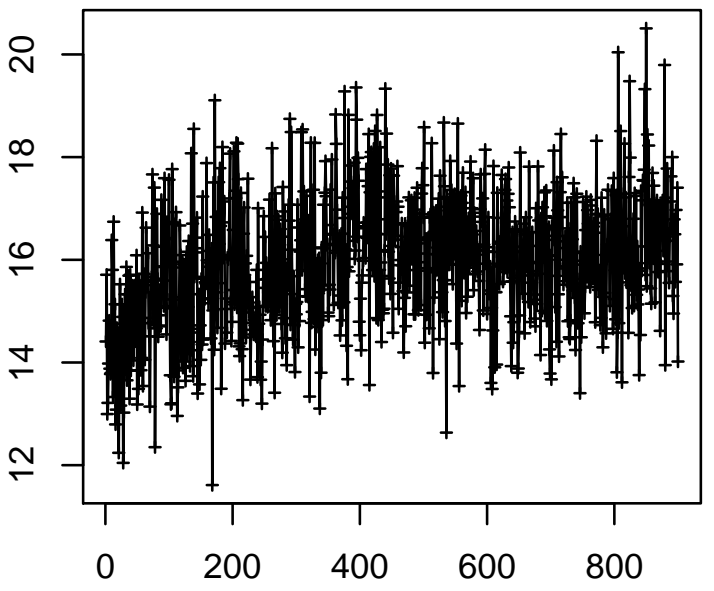

Time Point $(0.25 \mathrm{~Hz})$
Cell 1042

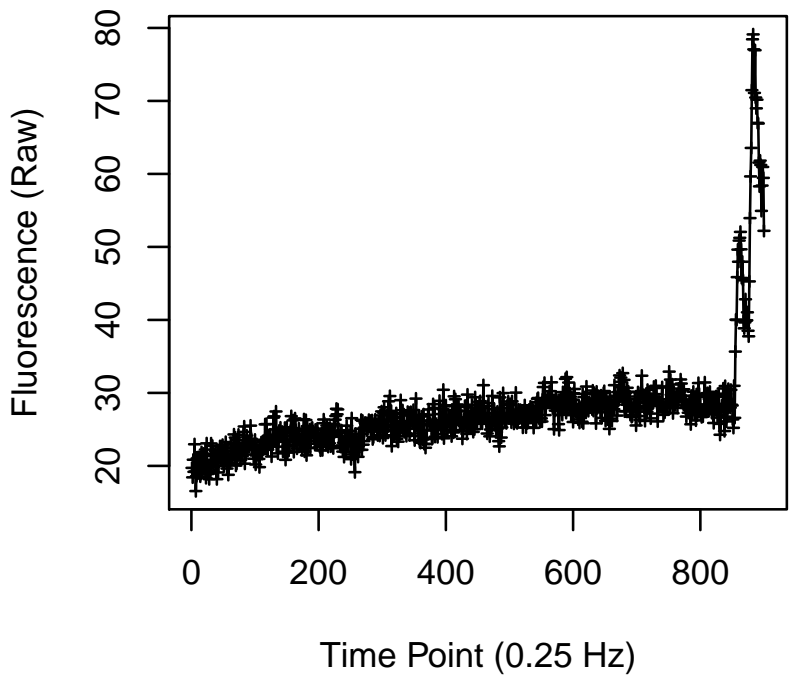

Cell 1044

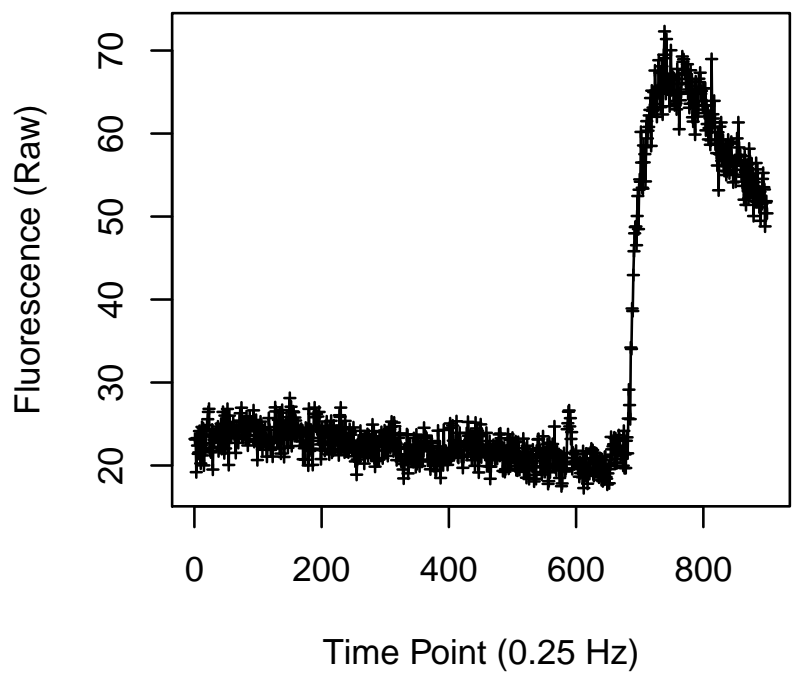


Cell 1045

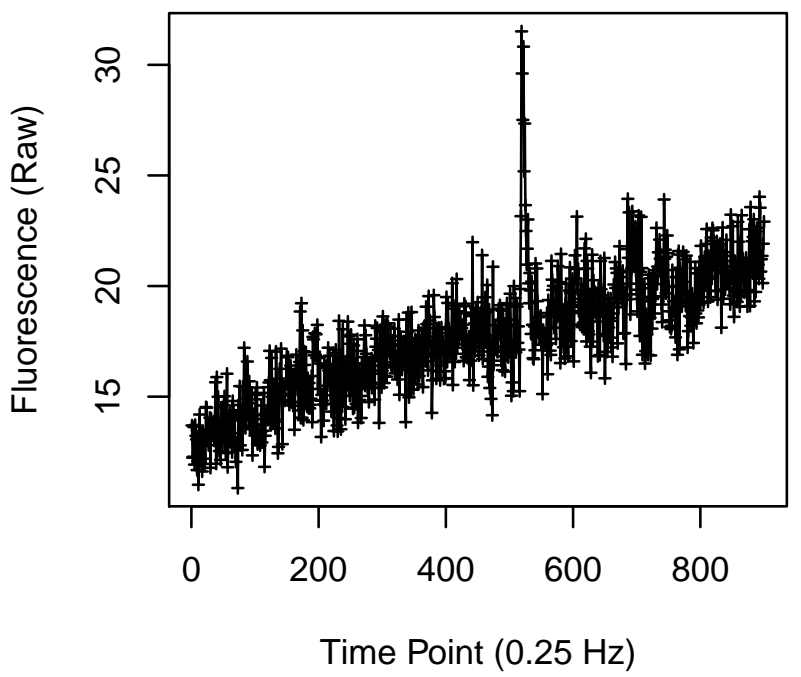

Cell 1047

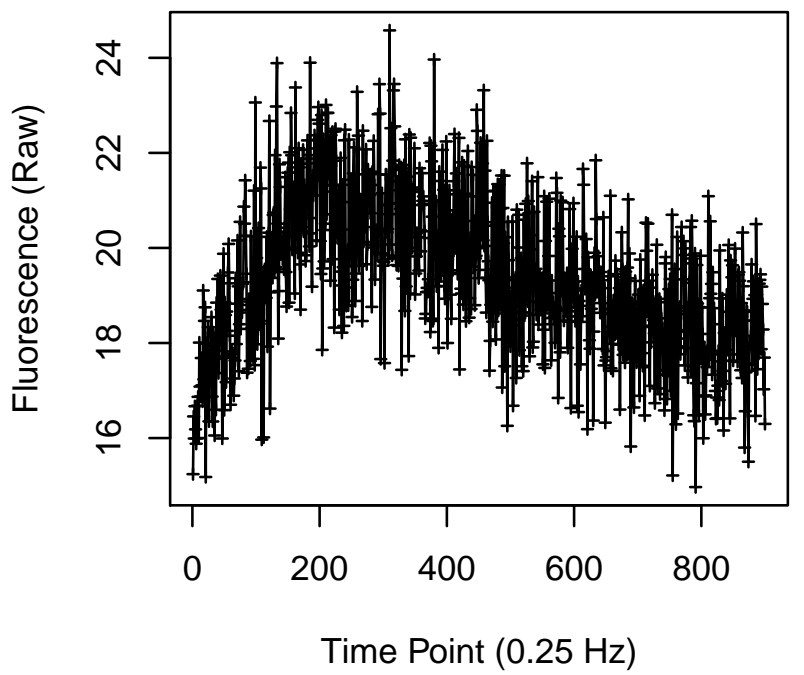

Cell 1046

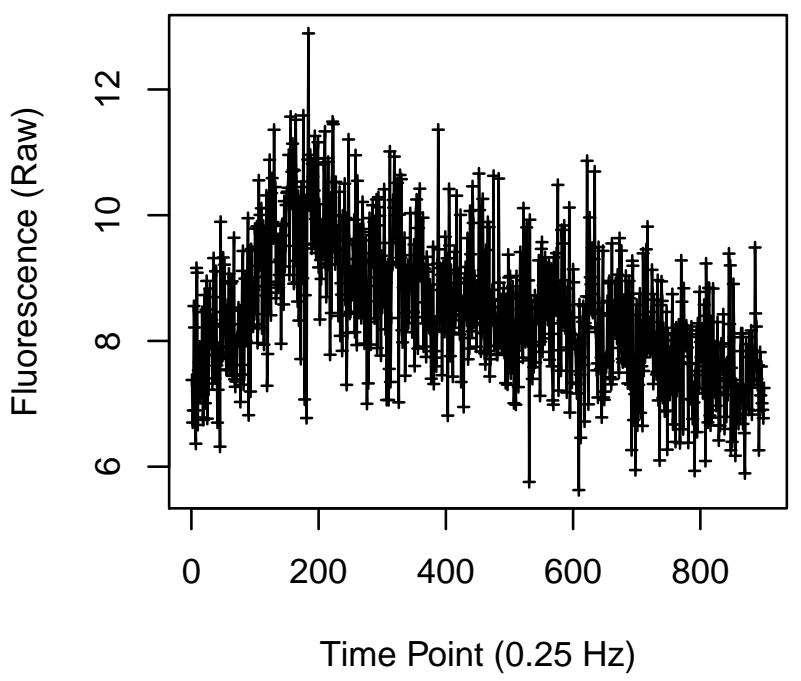

Cell 1048

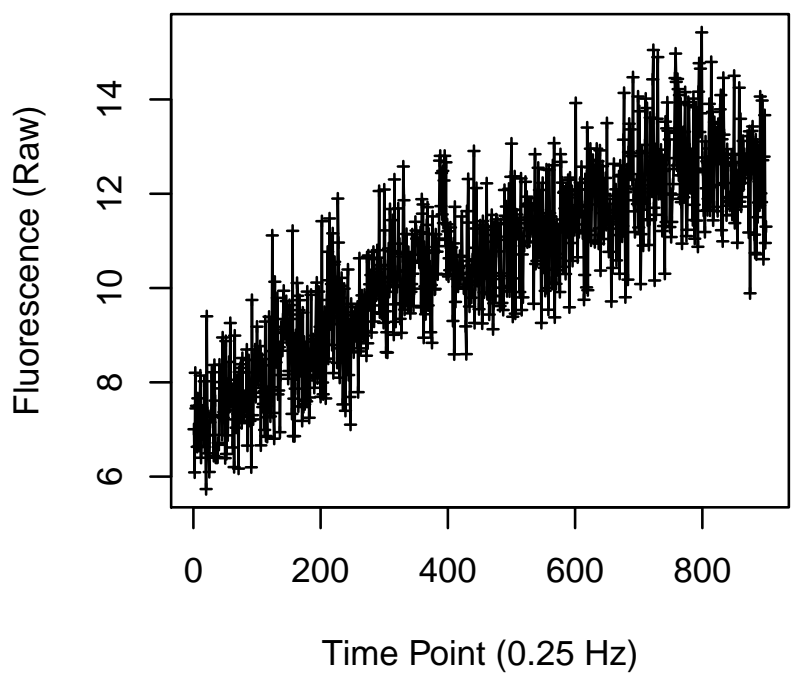


Cell 1049

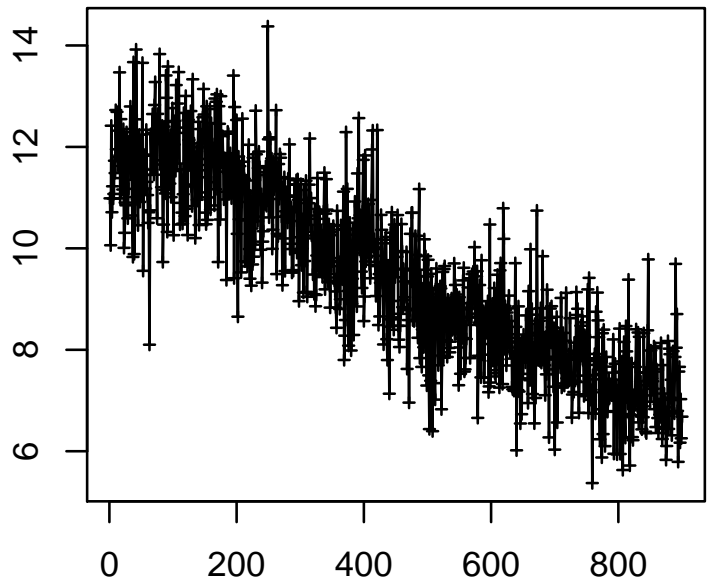

Time Point $(0.25 \mathrm{~Hz})$

Cell 1051

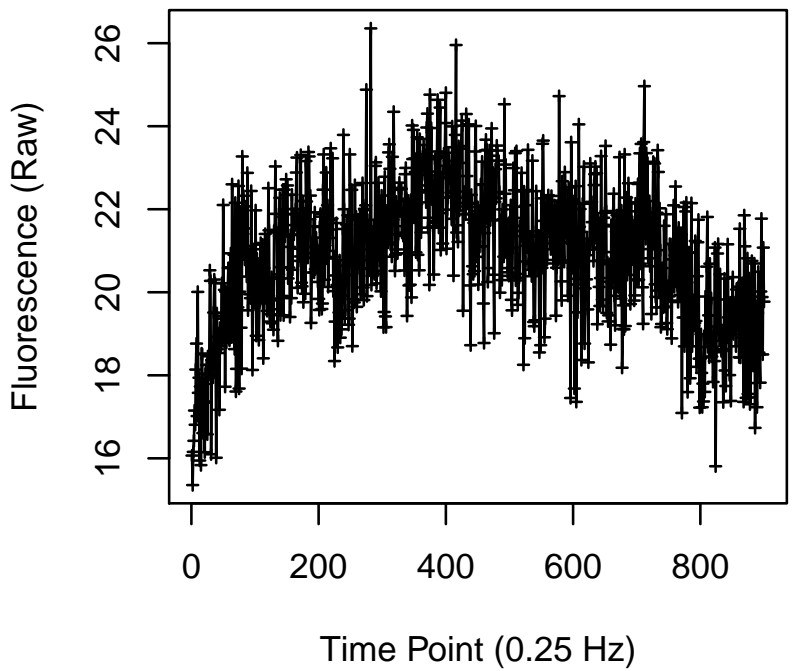

Cell 1050

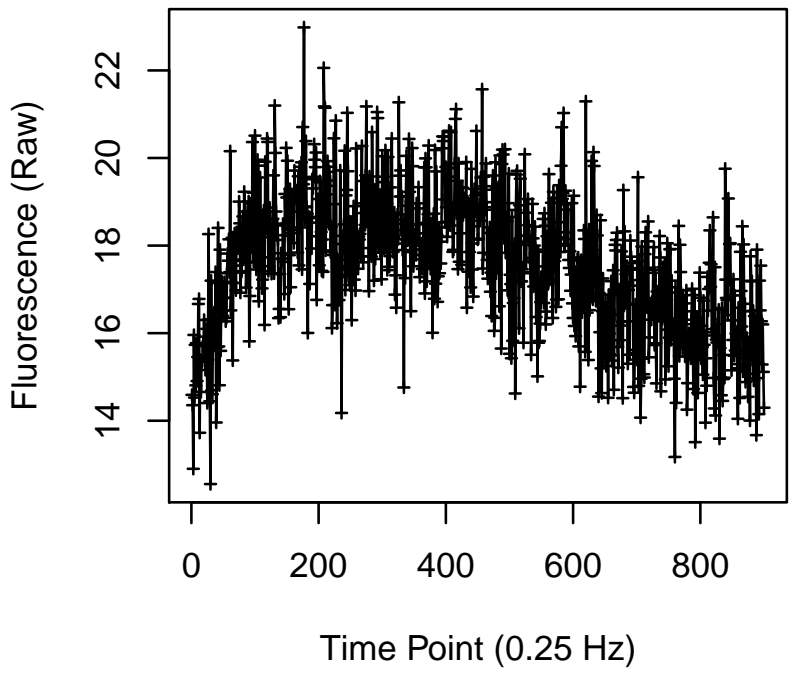

Cell 1052

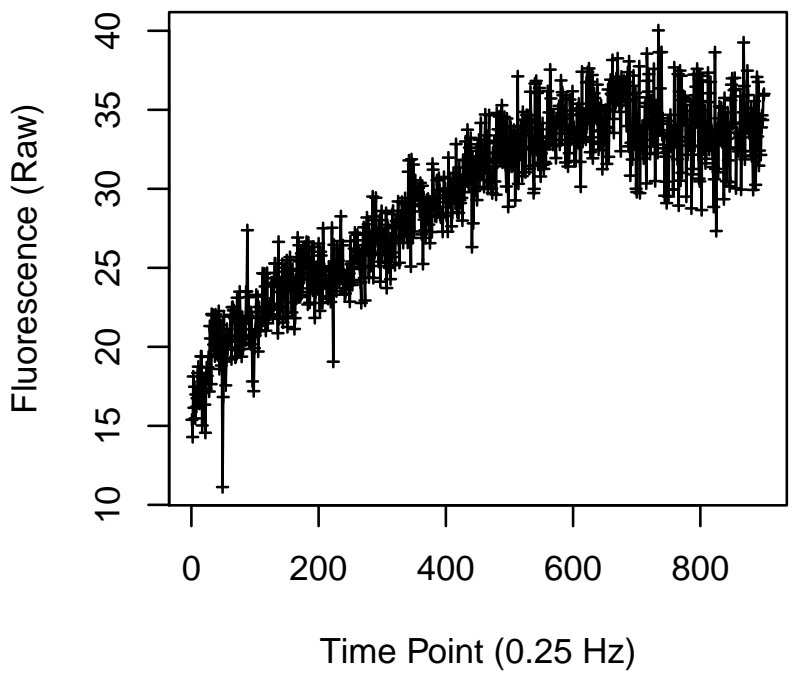


Cell 1057

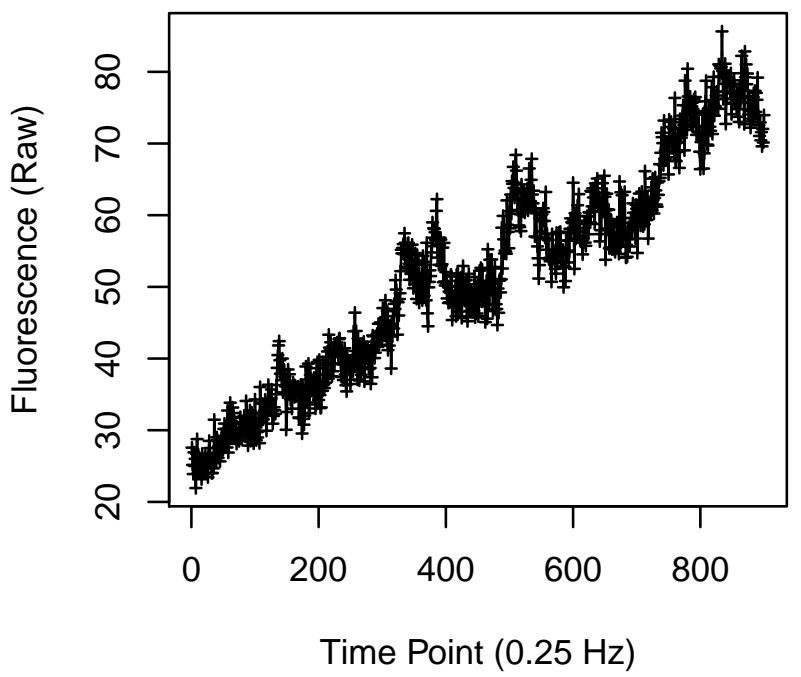

Cell 1059

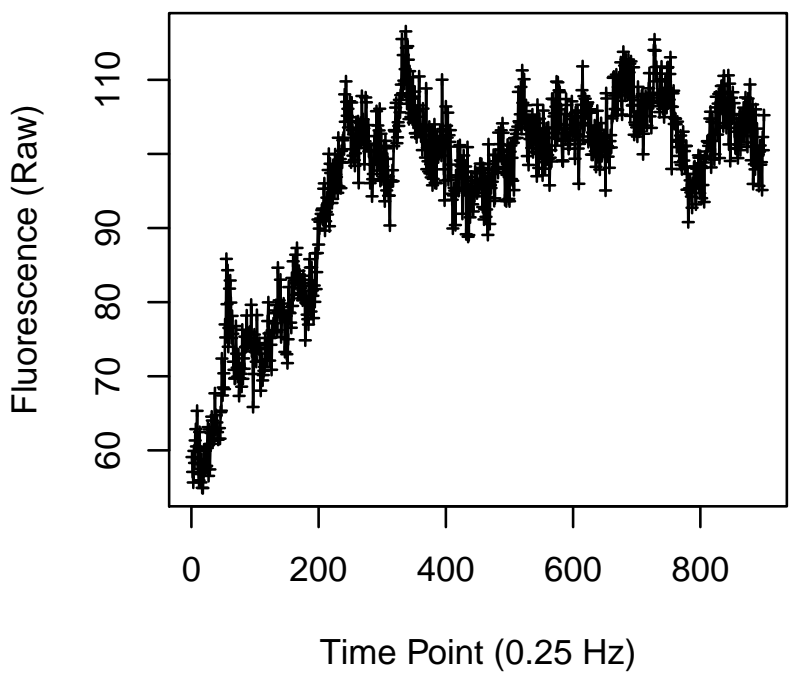

Cell 1058

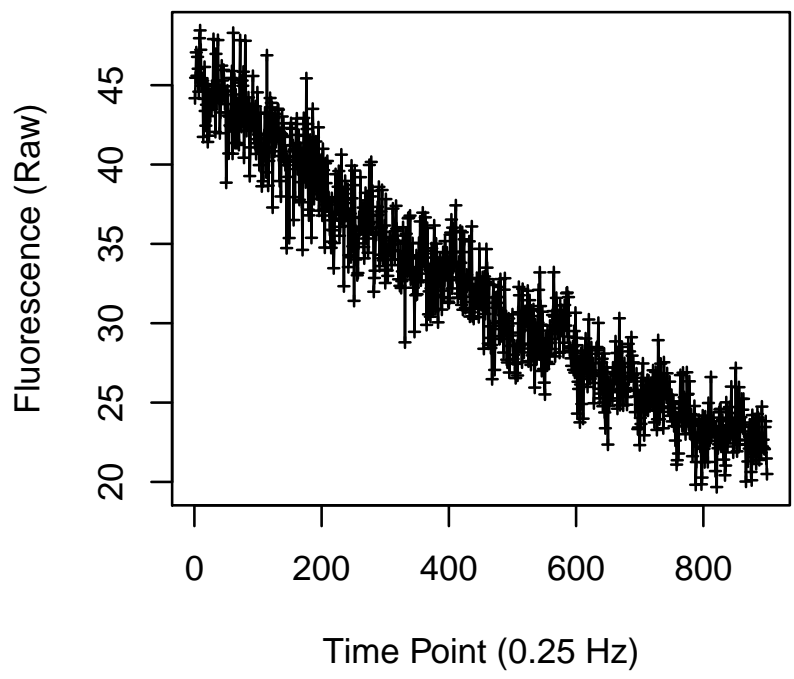

Cell 1060

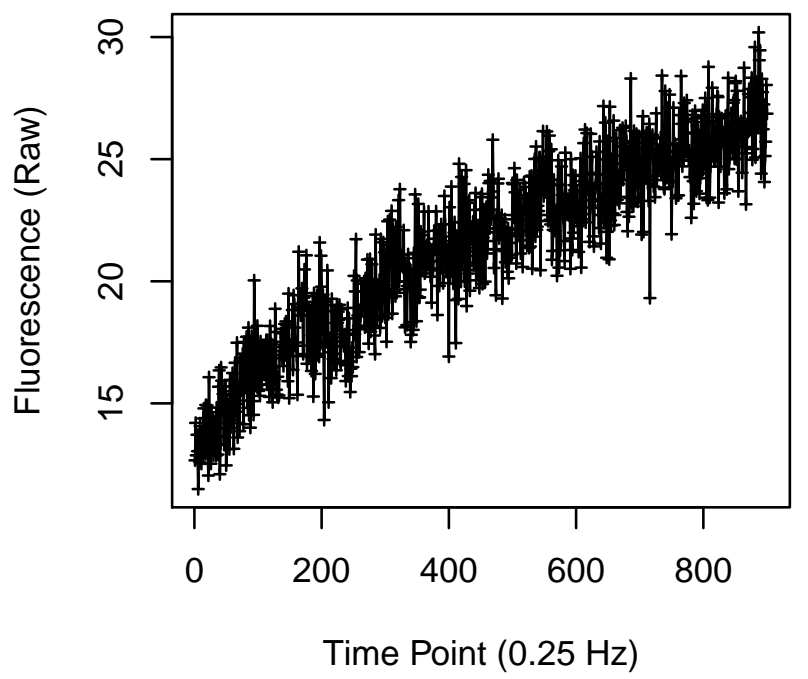


Cell 1065

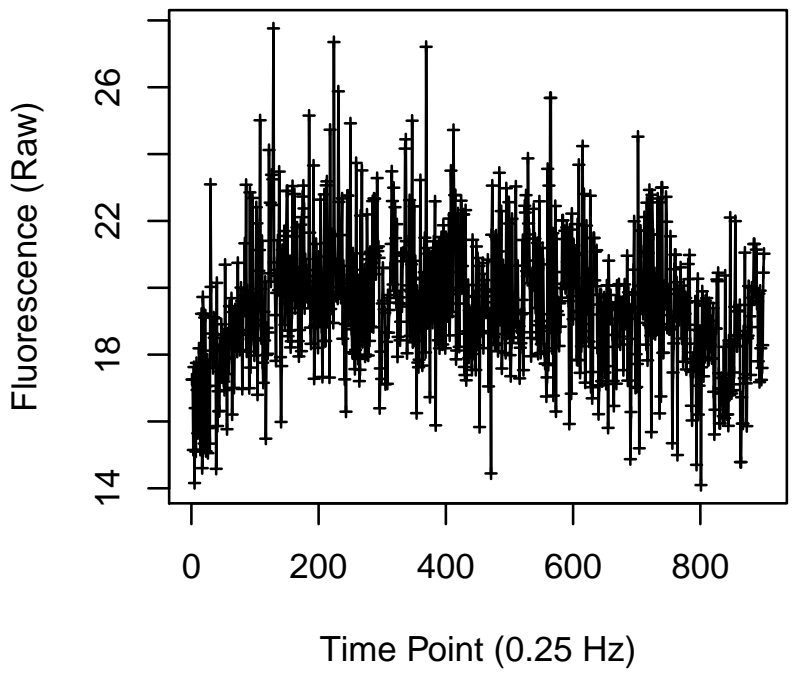

Cell 1067

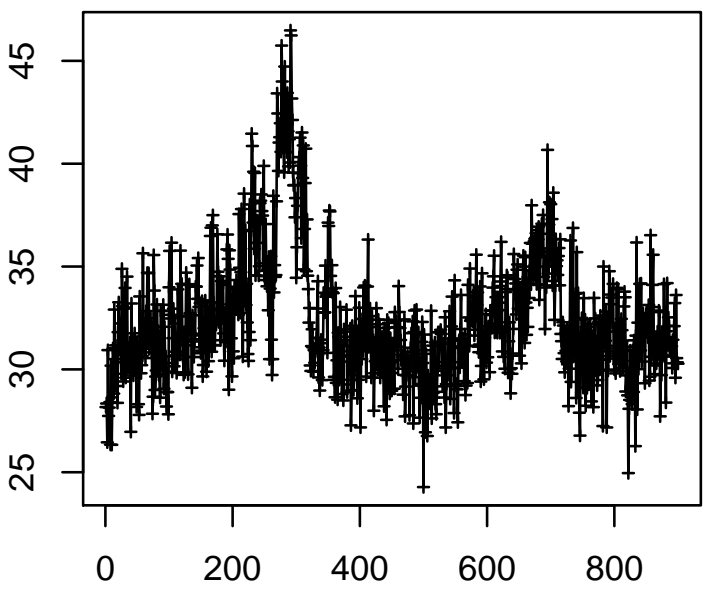

Time Point $(0.25 \mathrm{~Hz})$
Cell 1066

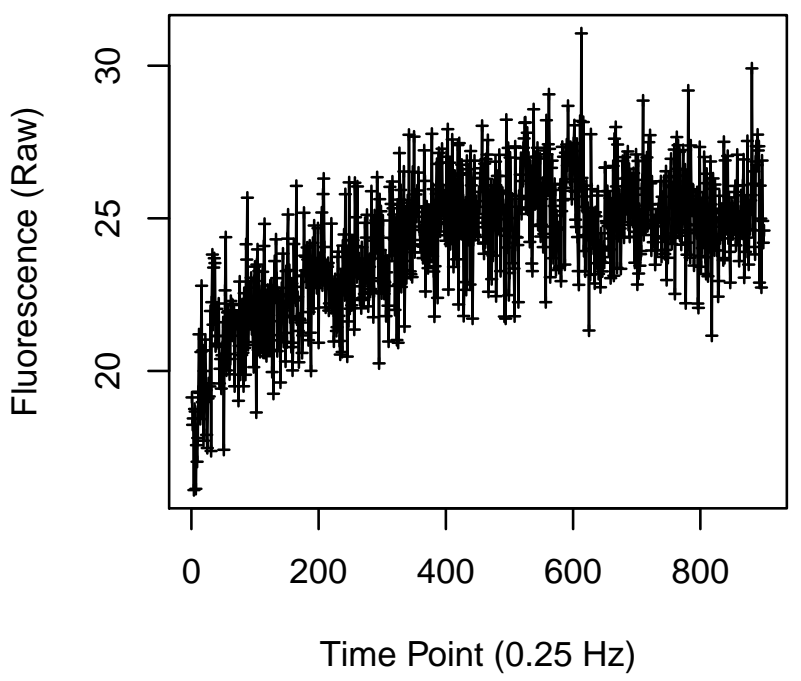

Cell 1068

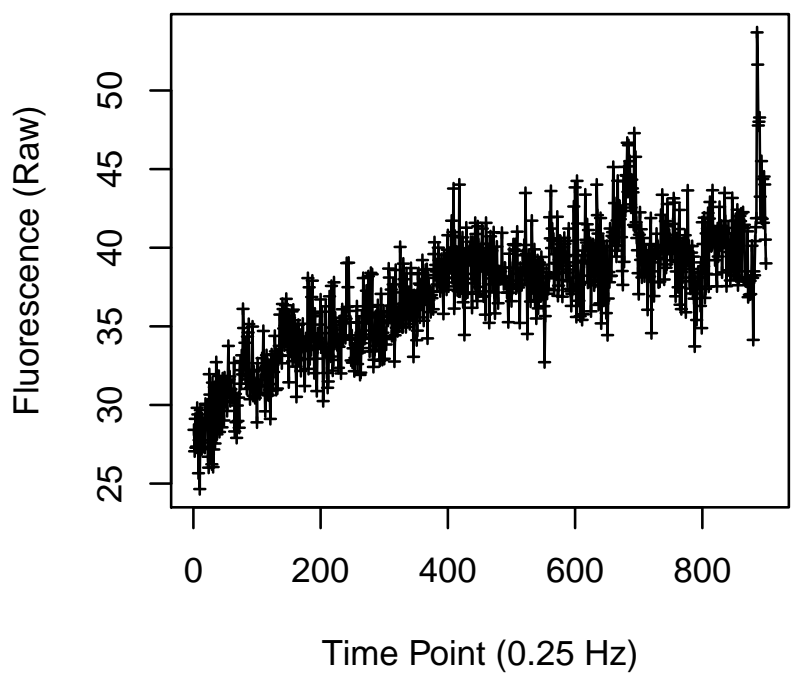


Cell 1069

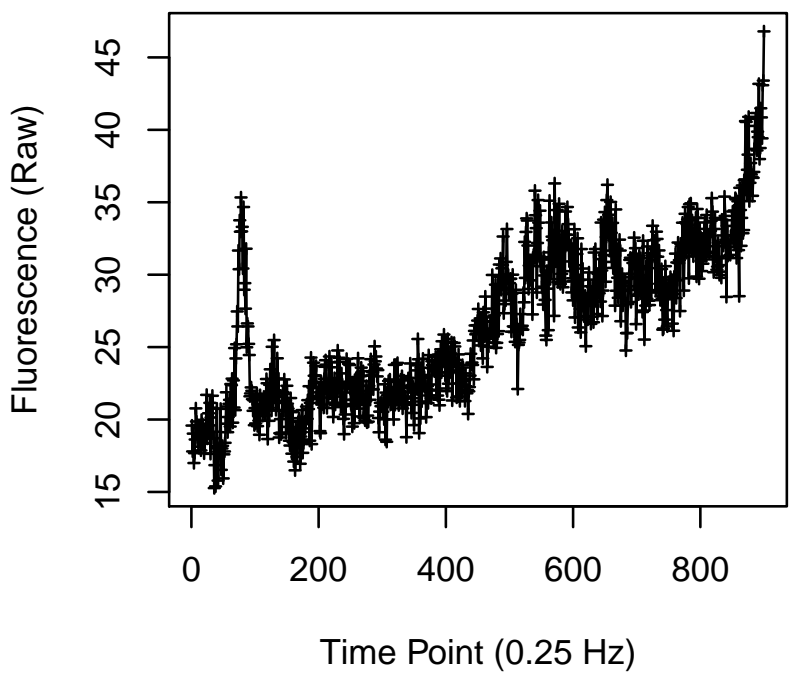

Cell 1071

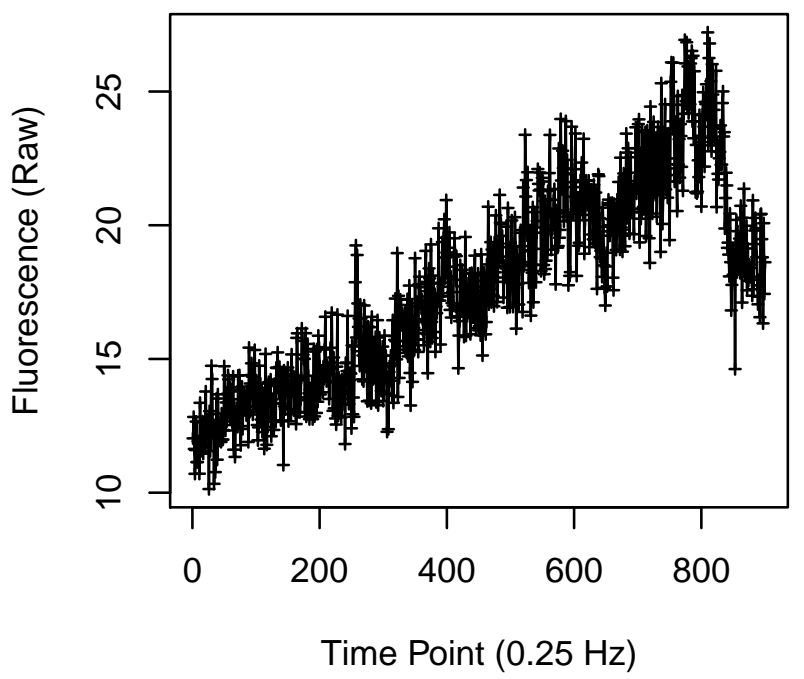

Cell 1070

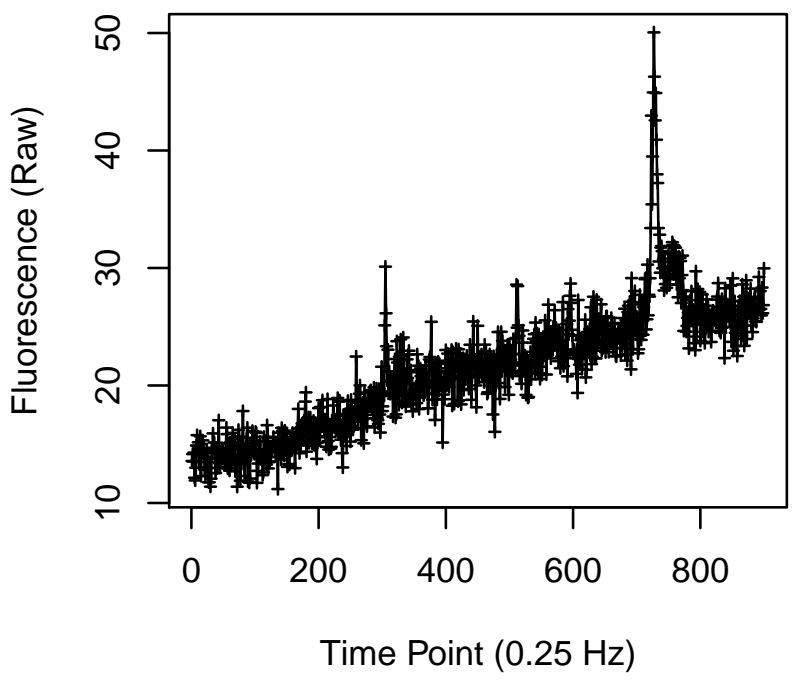

Cell 1072

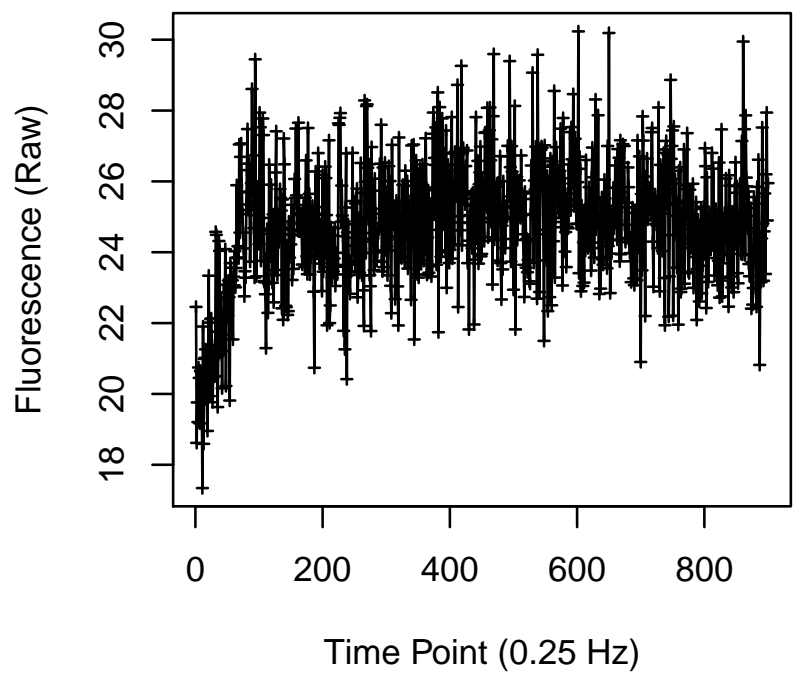


Cell 1073

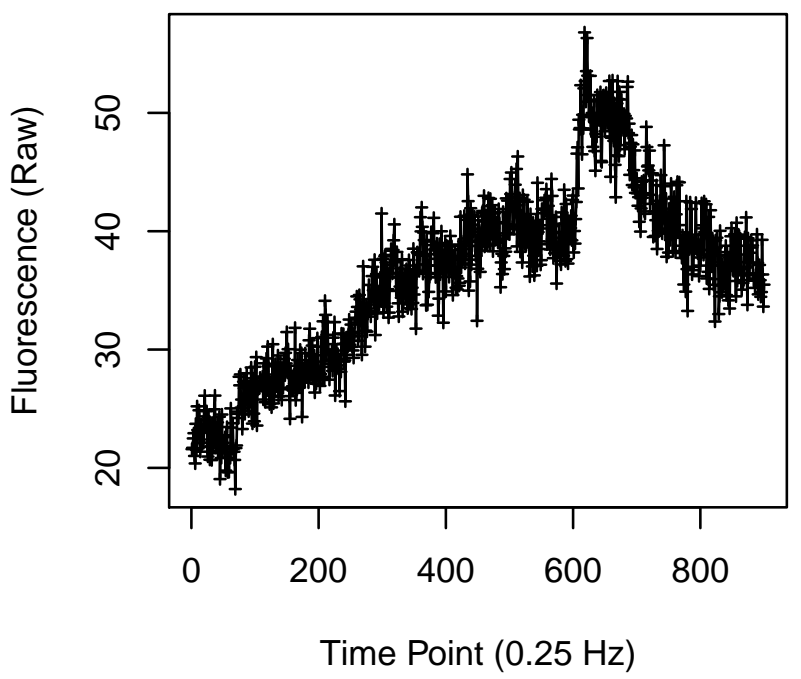

Cell 1075

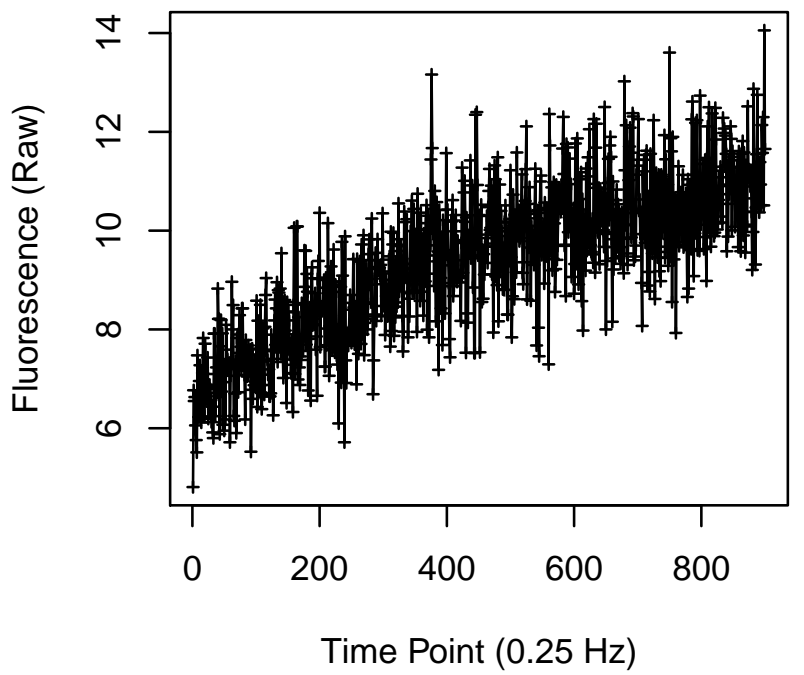

Cell 1074

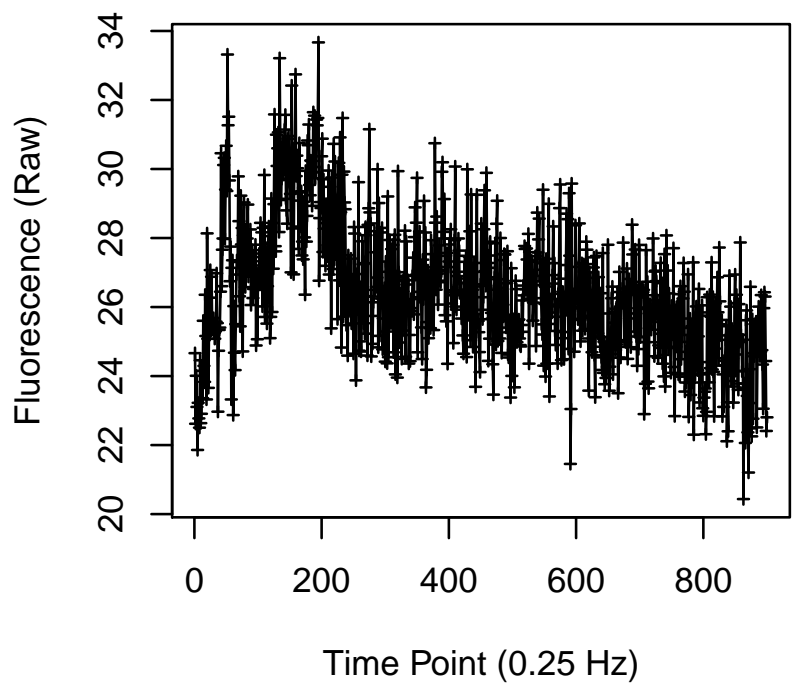

Cell 1076

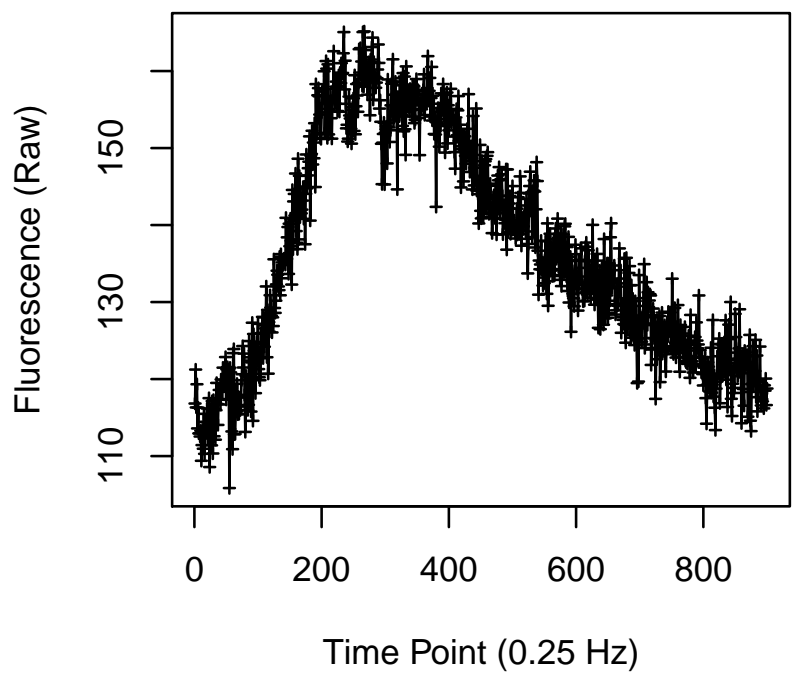


Cell 1081

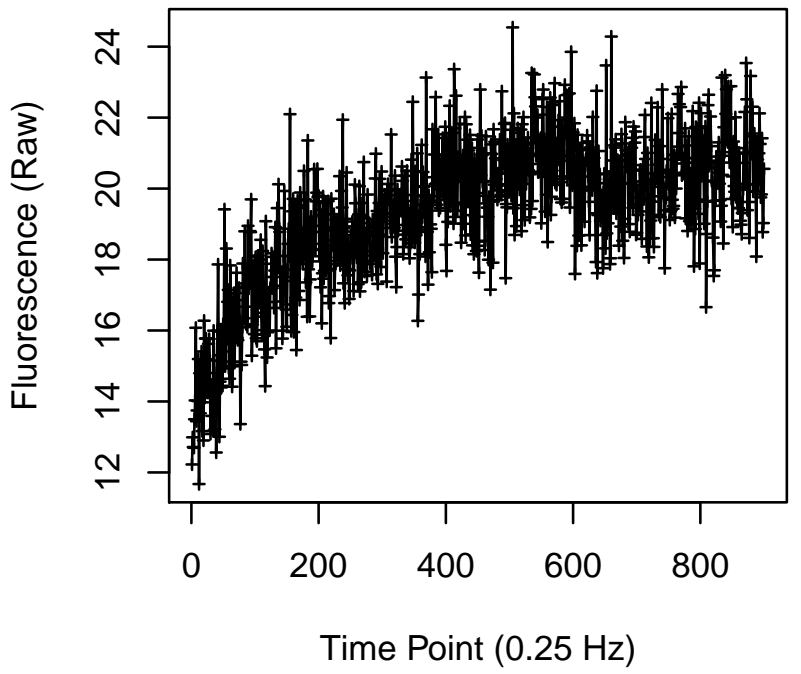

Cell 1083

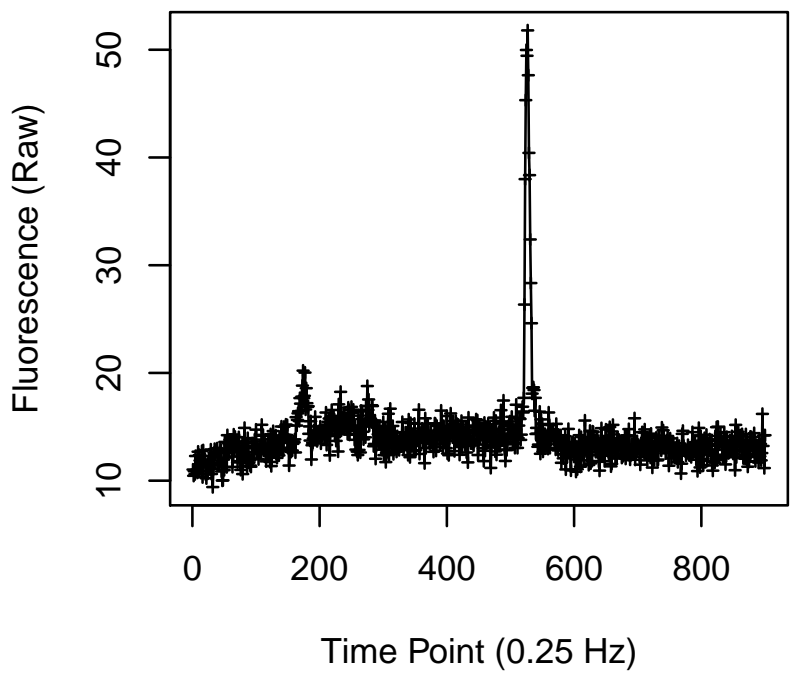

Cell 1082

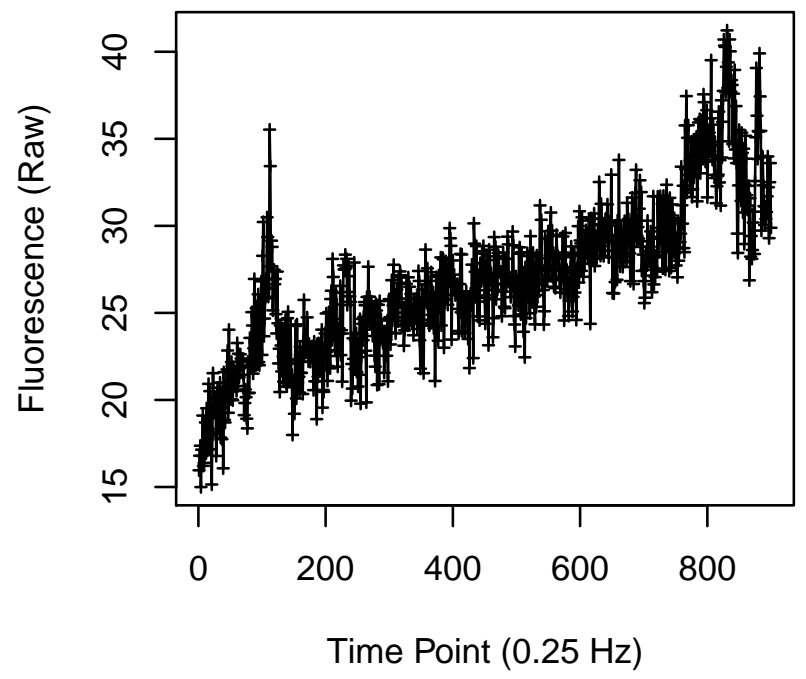

Cell 1084

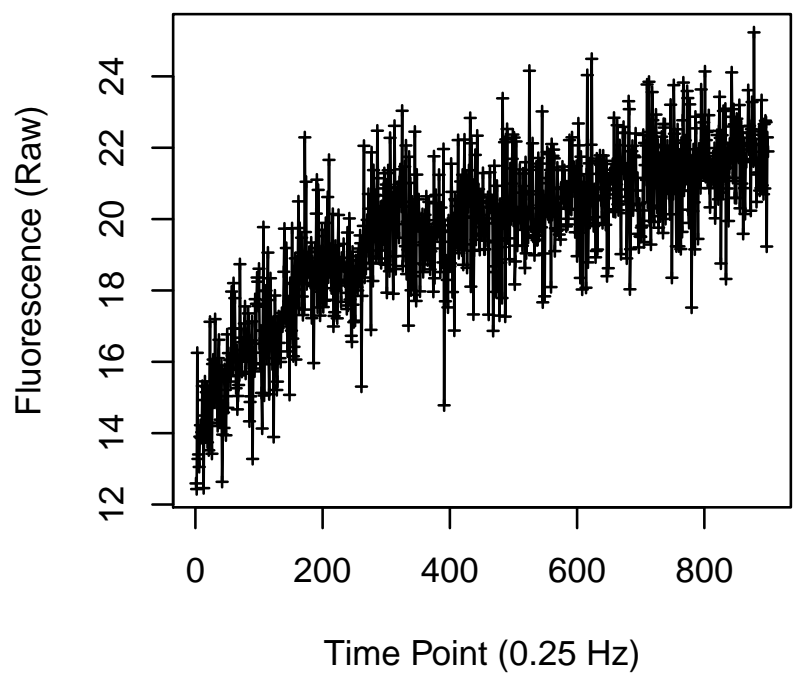


Cell 1085

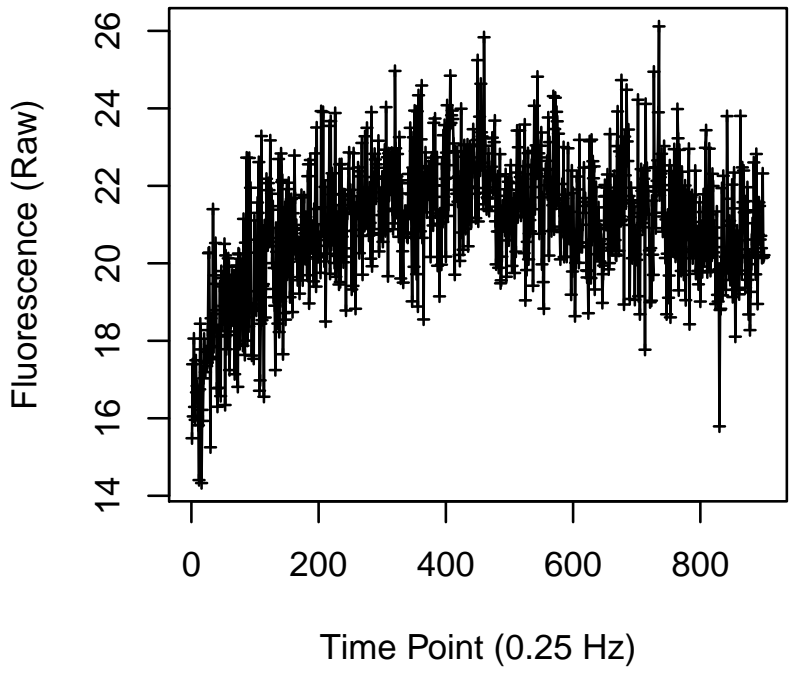

Cell 1087

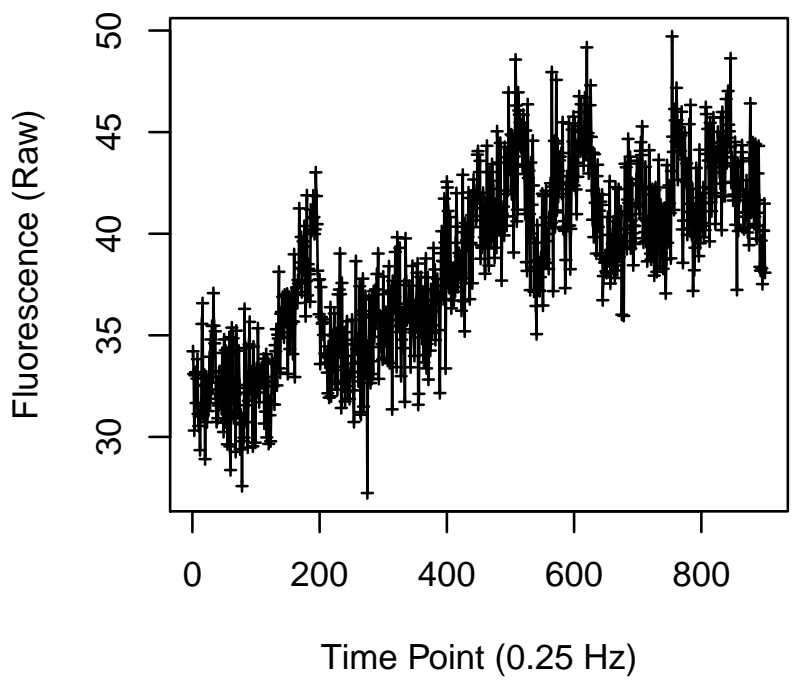

Cell 1086

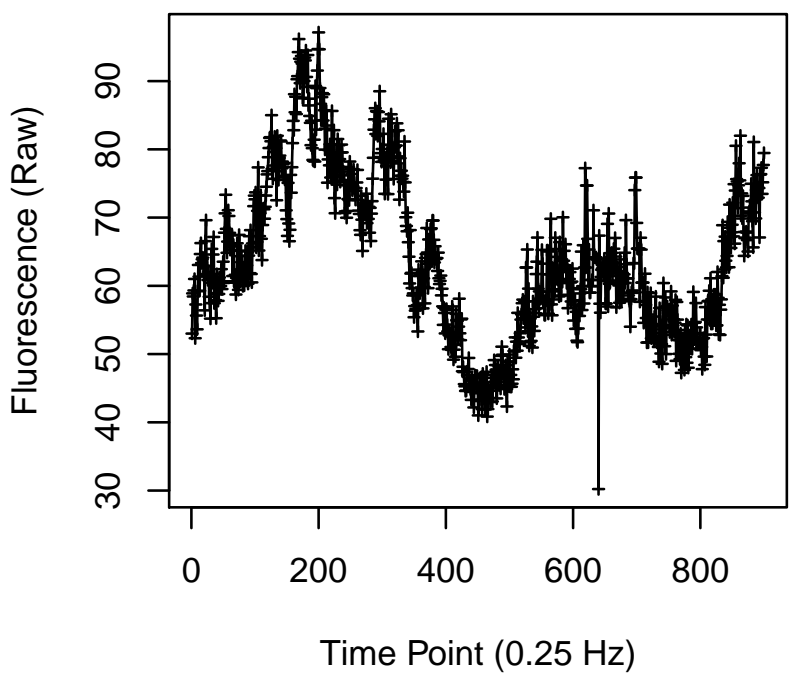

Cell 1088

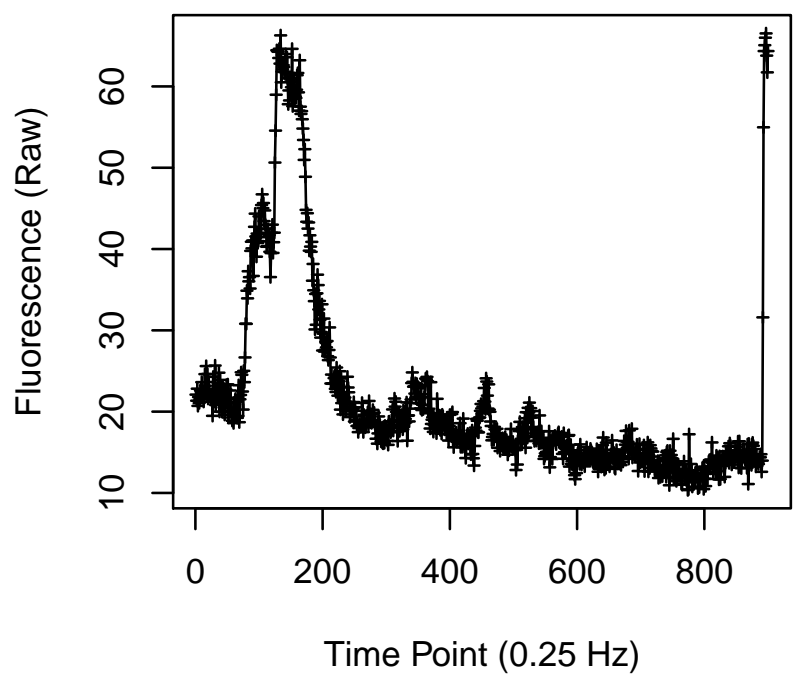


Cell 1089

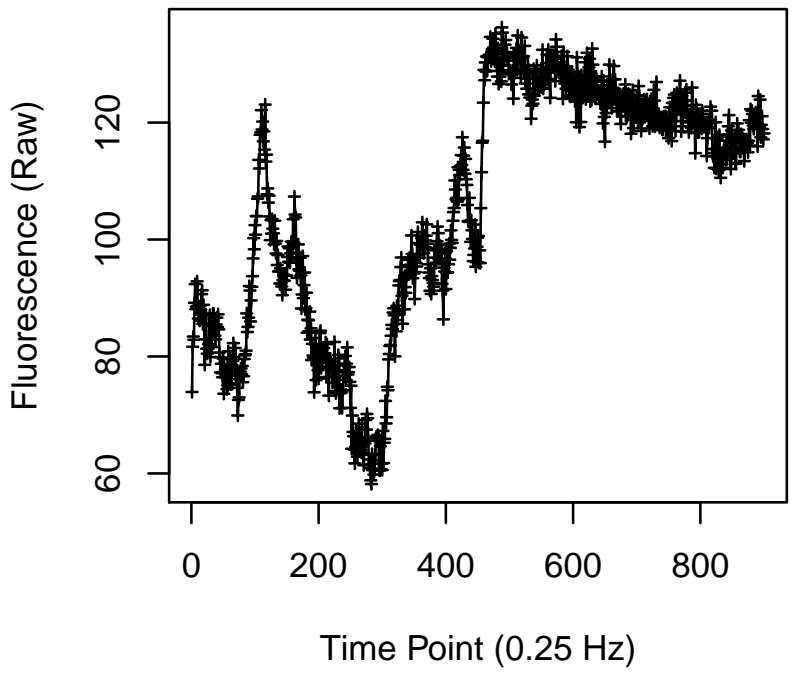

Cell 1091

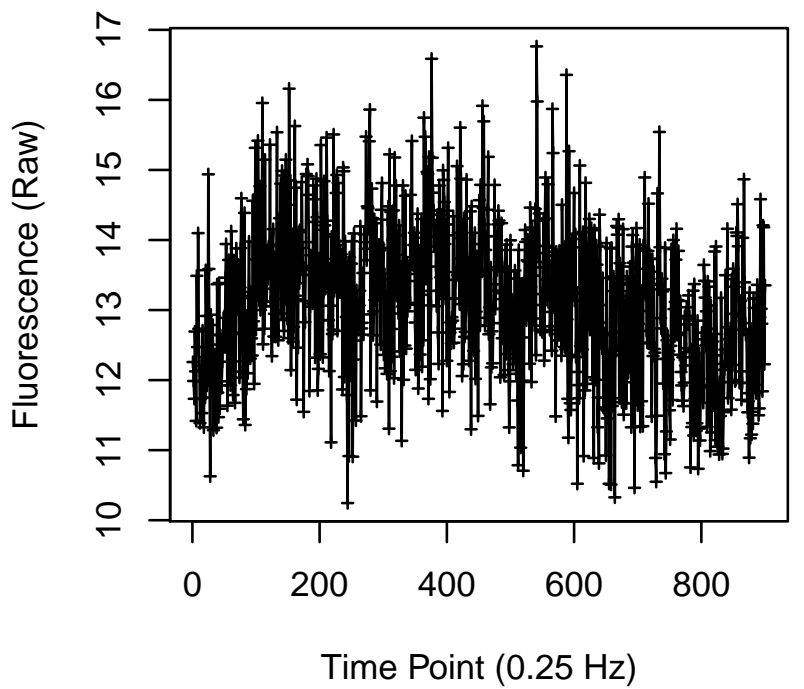

Cell 1090

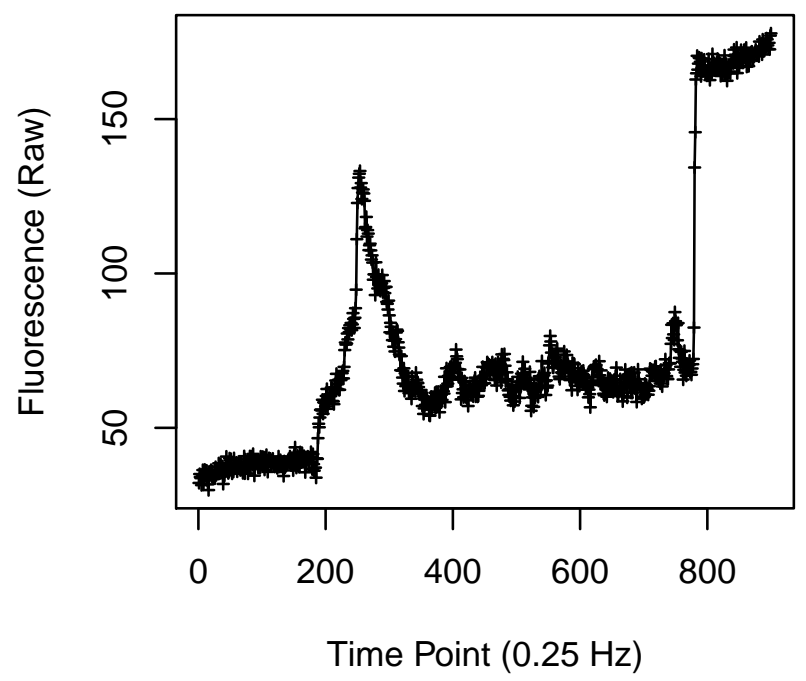

Cell 1092

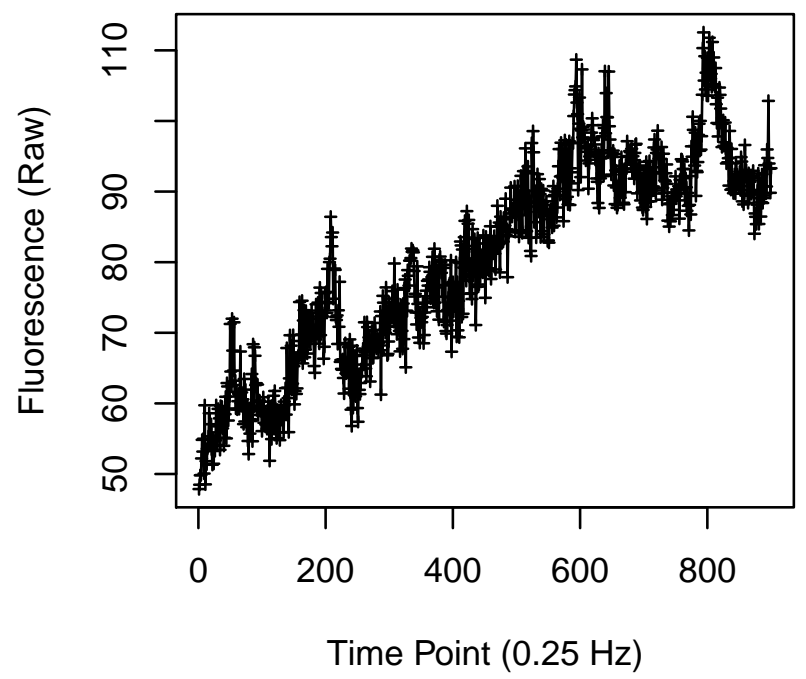


Cell 1093

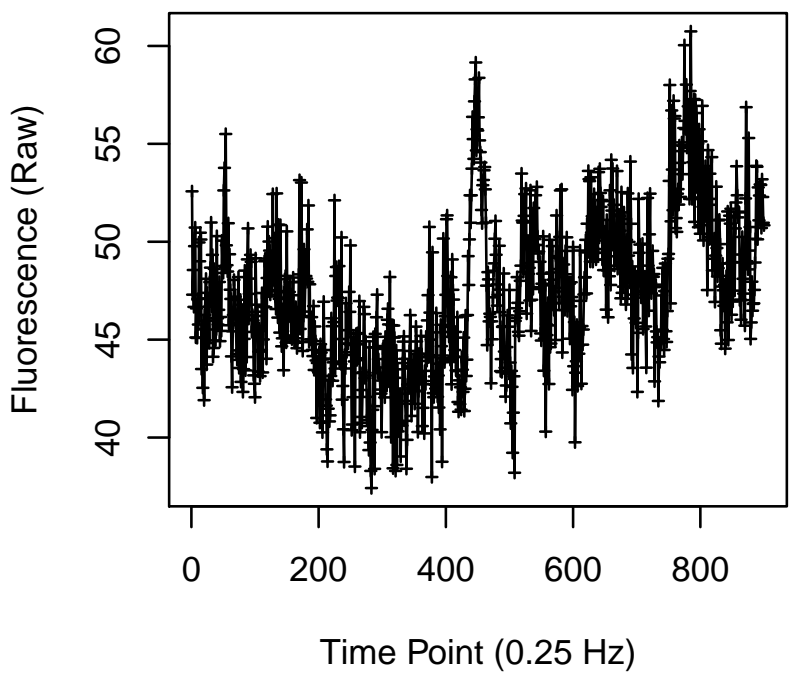

Cell 1095

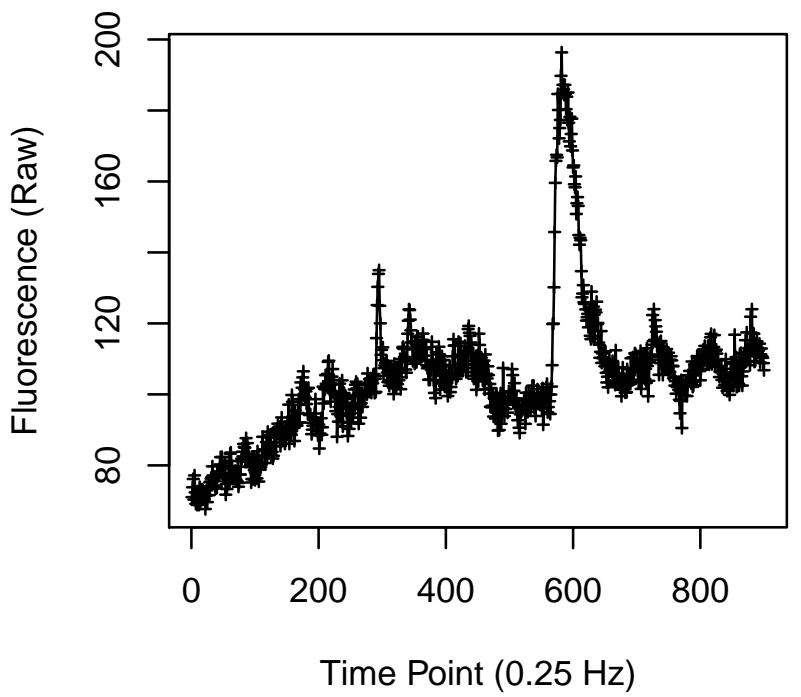

Cell 1094

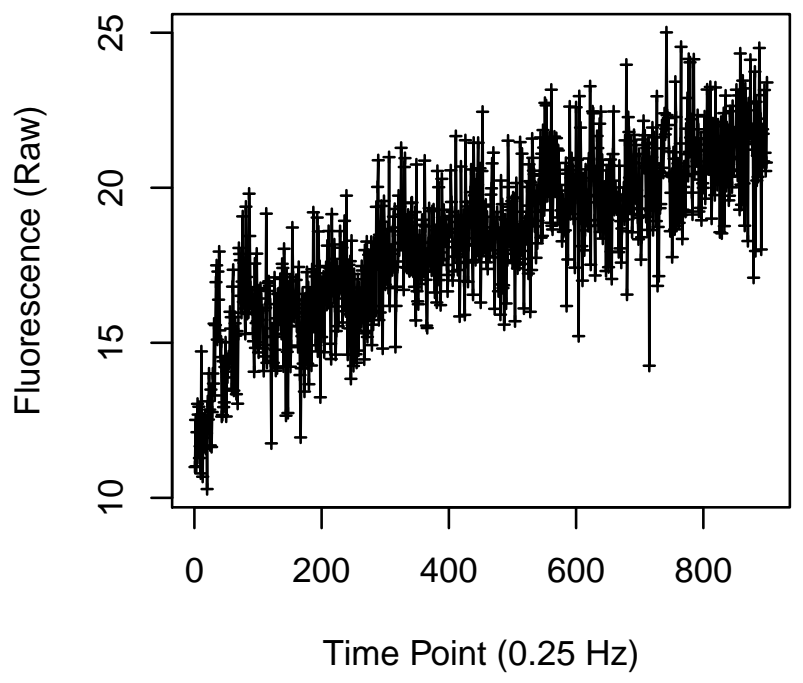

Cell 1096

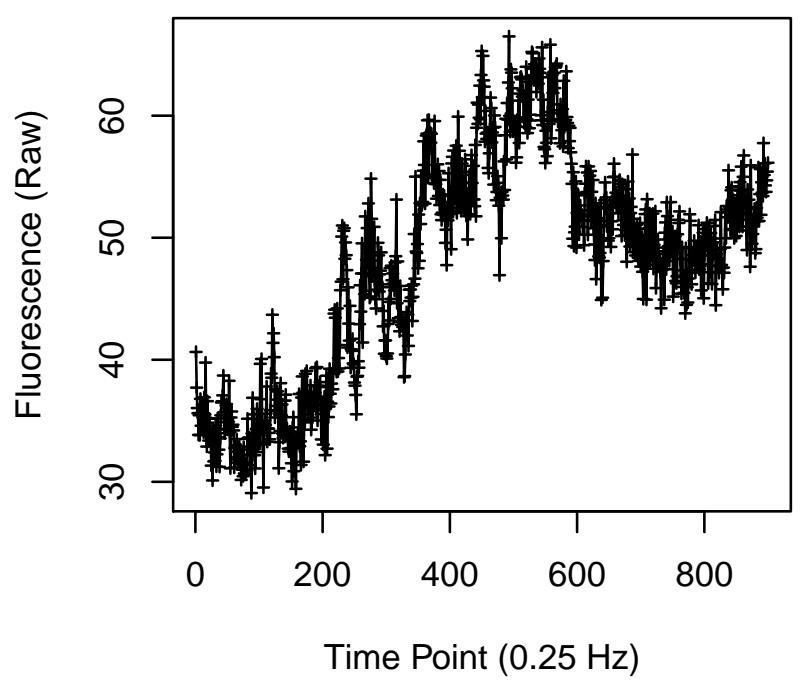


Cell 1097

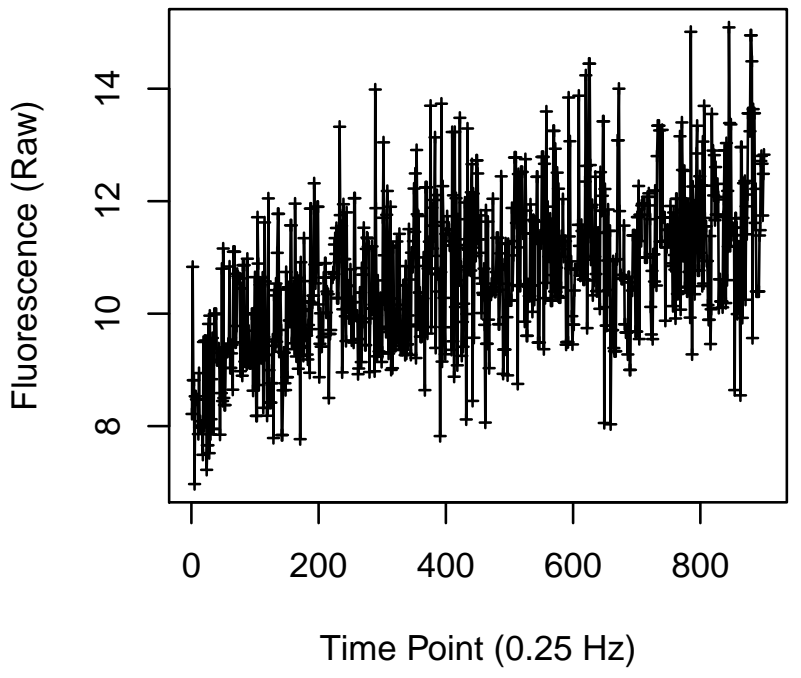

Cell 1099

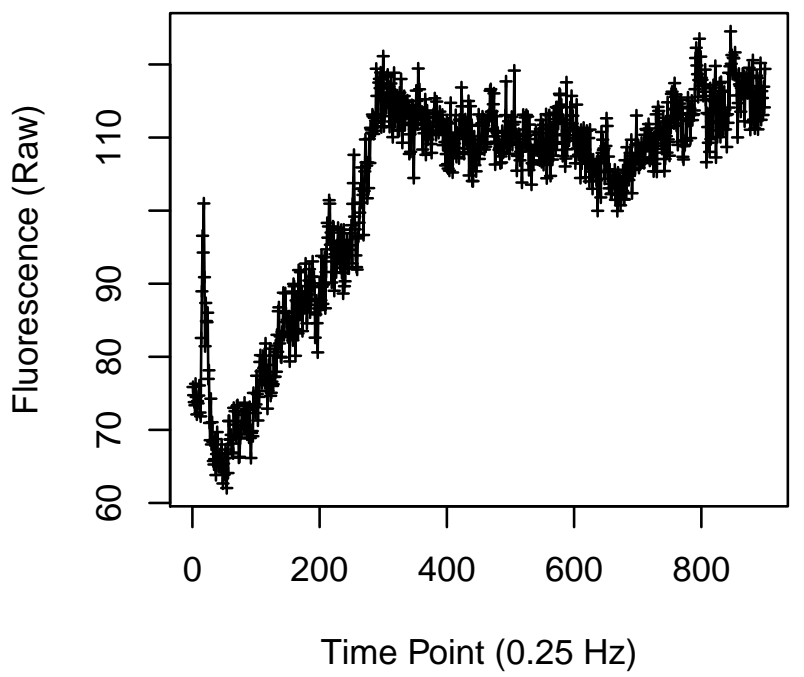

Cell 1098

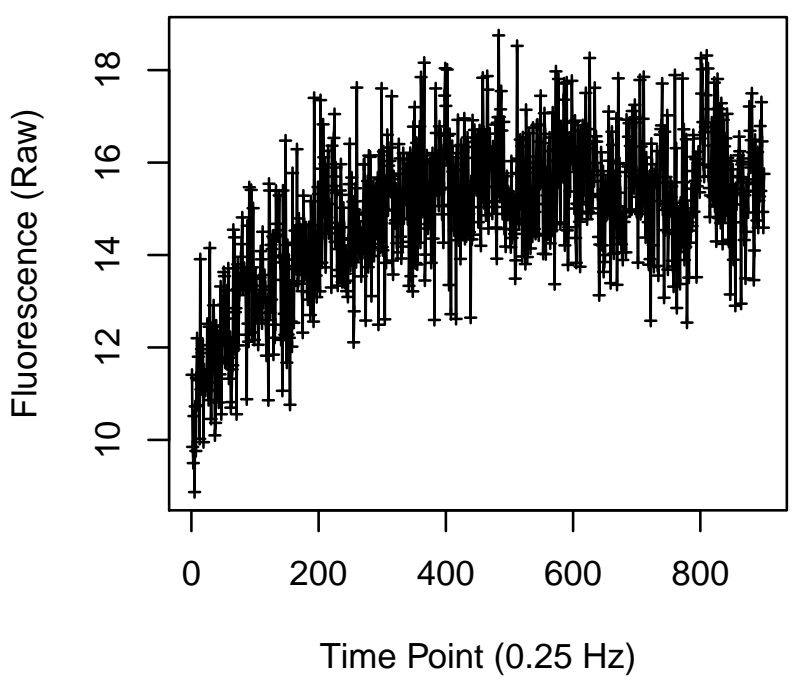

Cell 1100

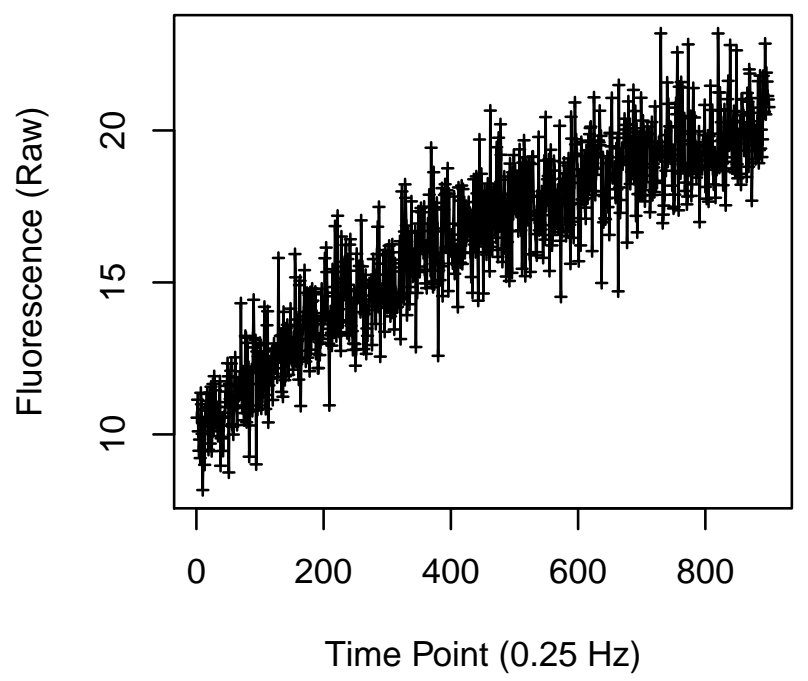


Cell 1101

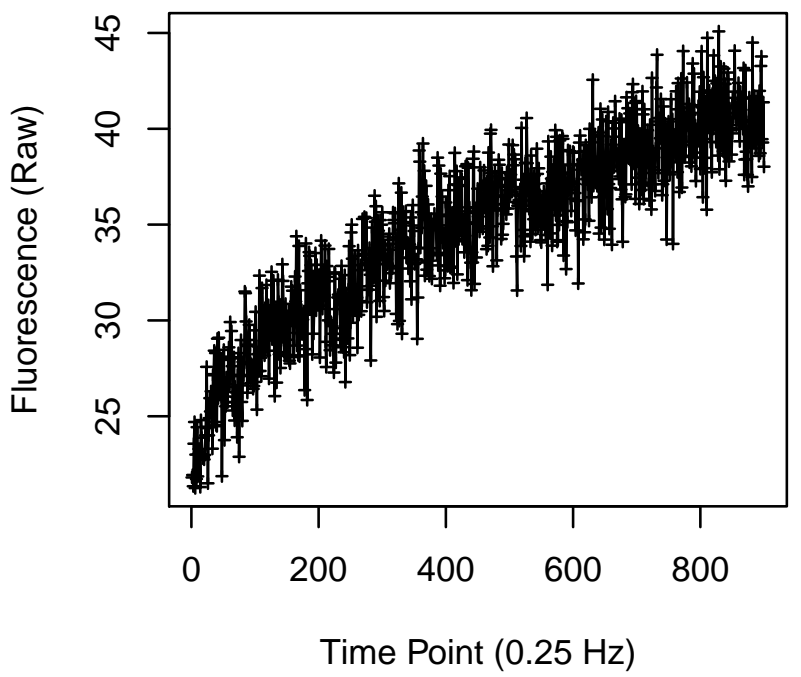

Cell 1103

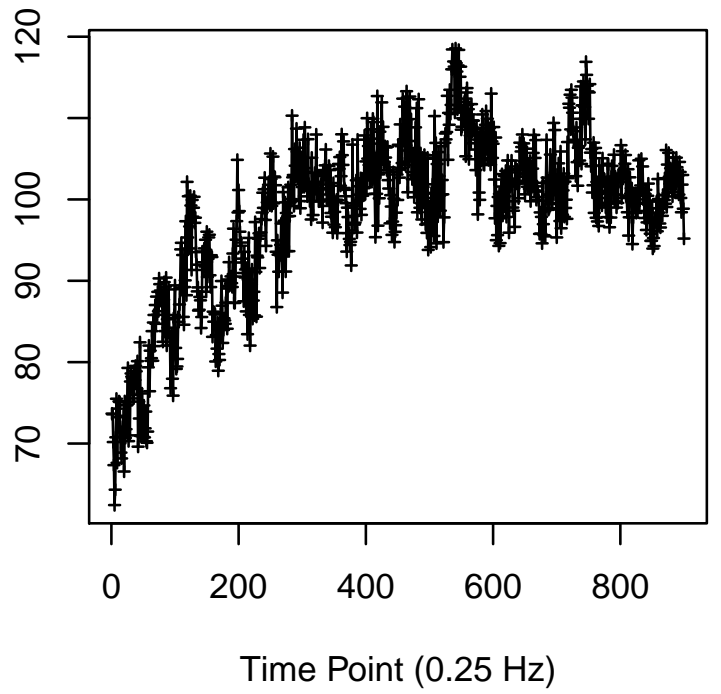

Cell 1102

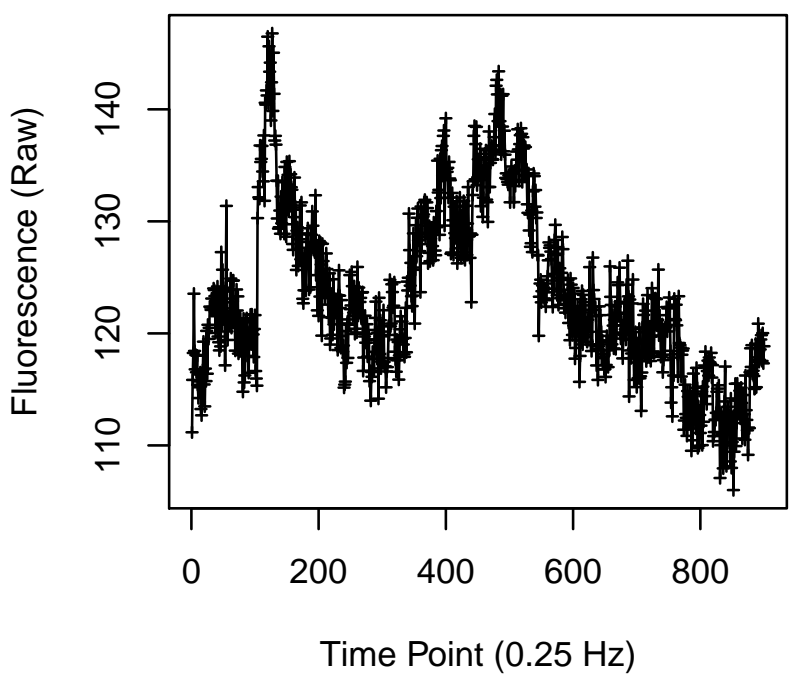

Cell 1104

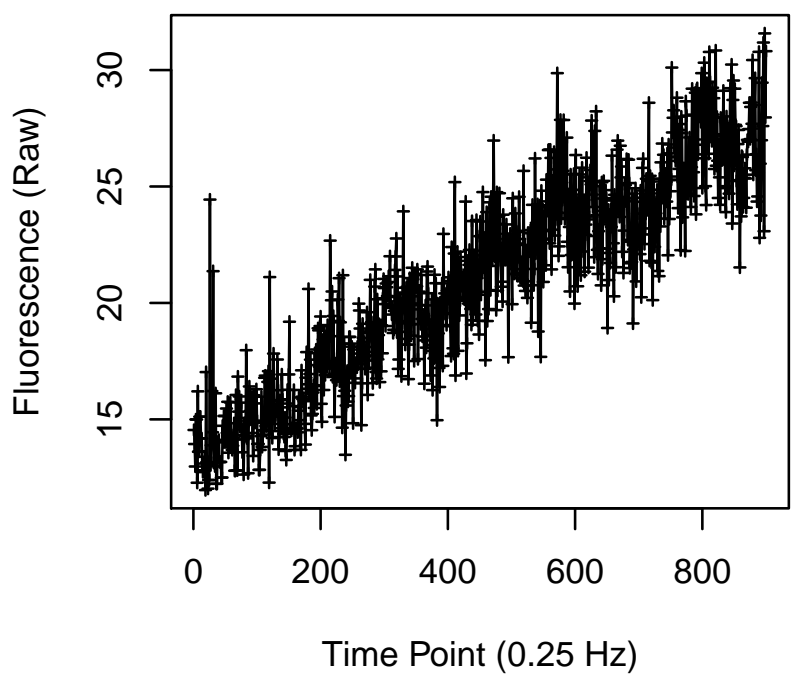


Cell 1105

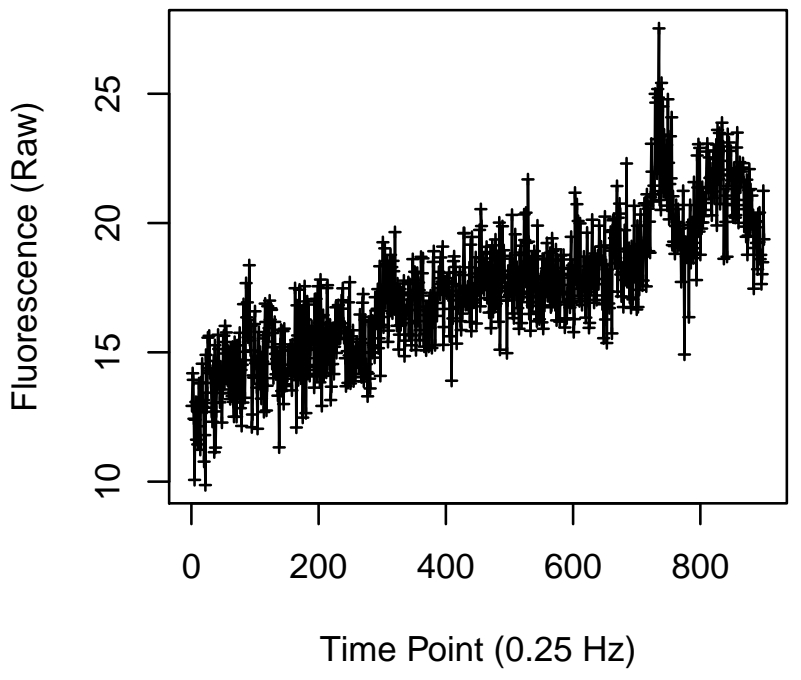

Cell 1107

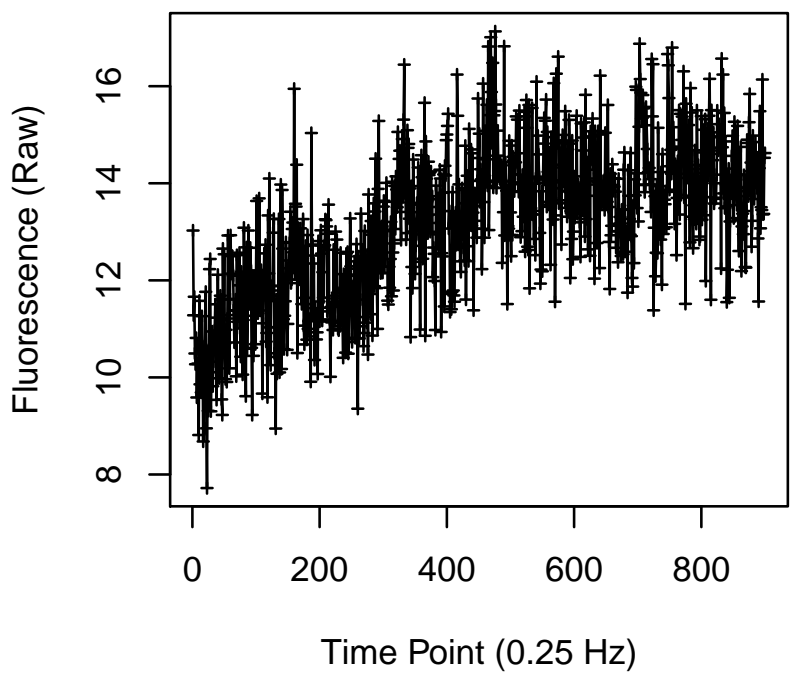

Cell 1106

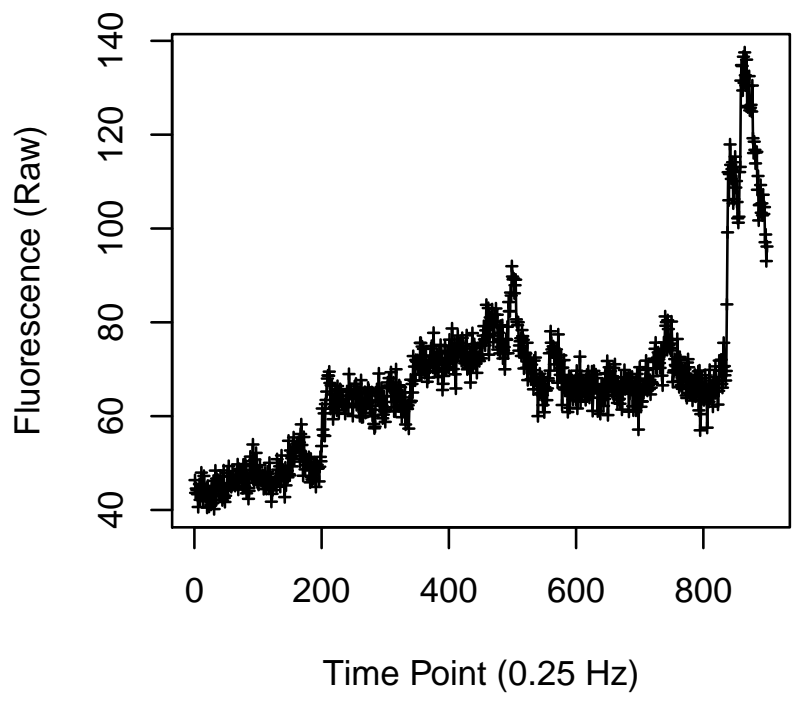

Cell 1108

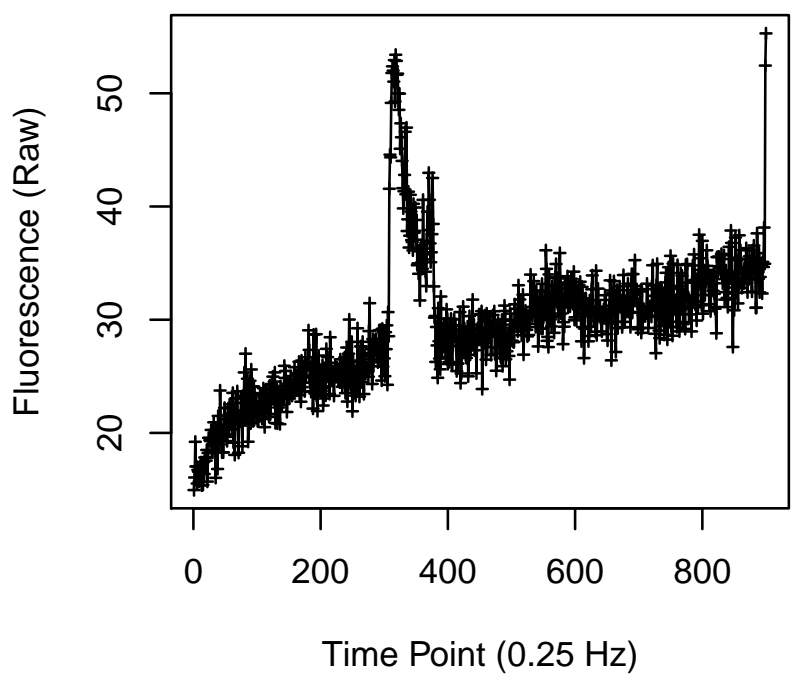


Cell 1109

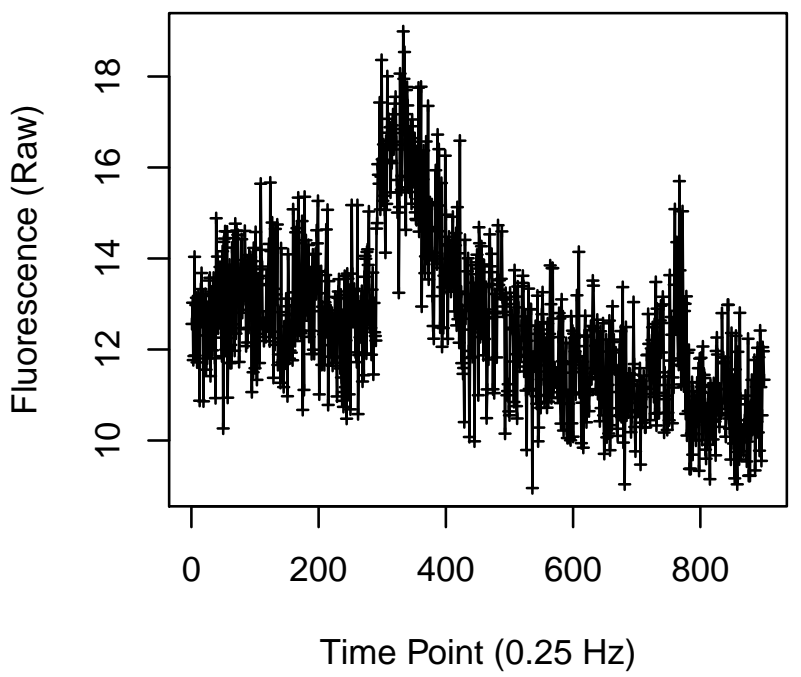

Cell 1111

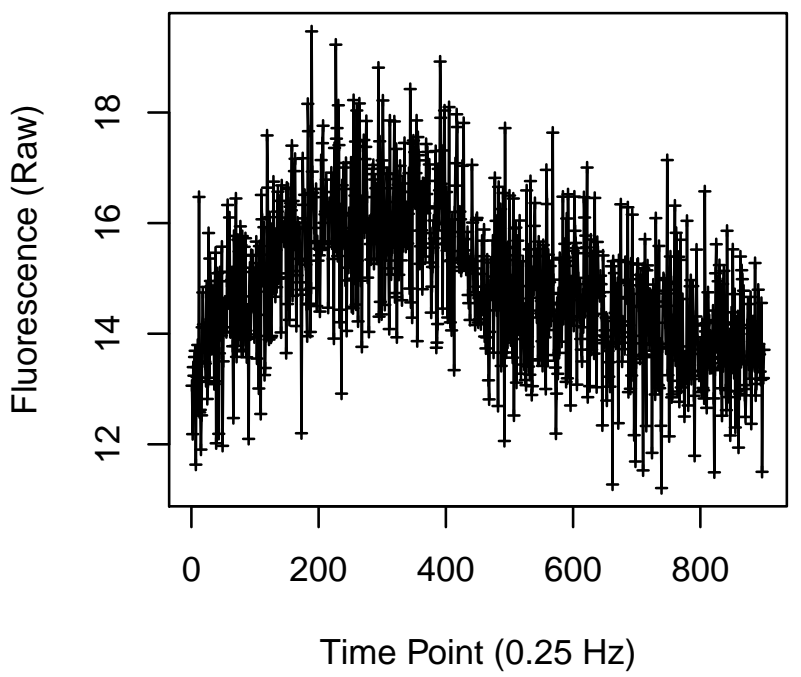

Cell 1110

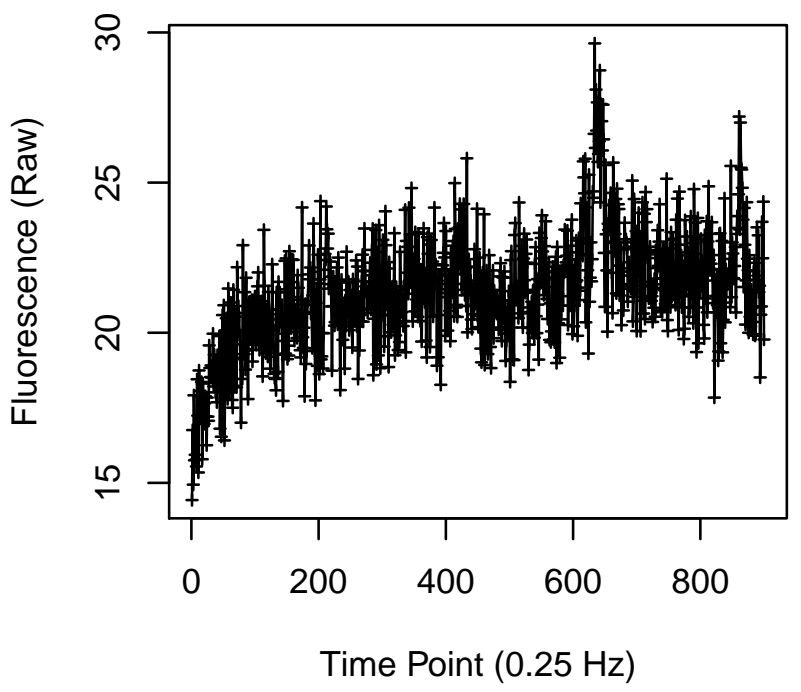

Cell 1112

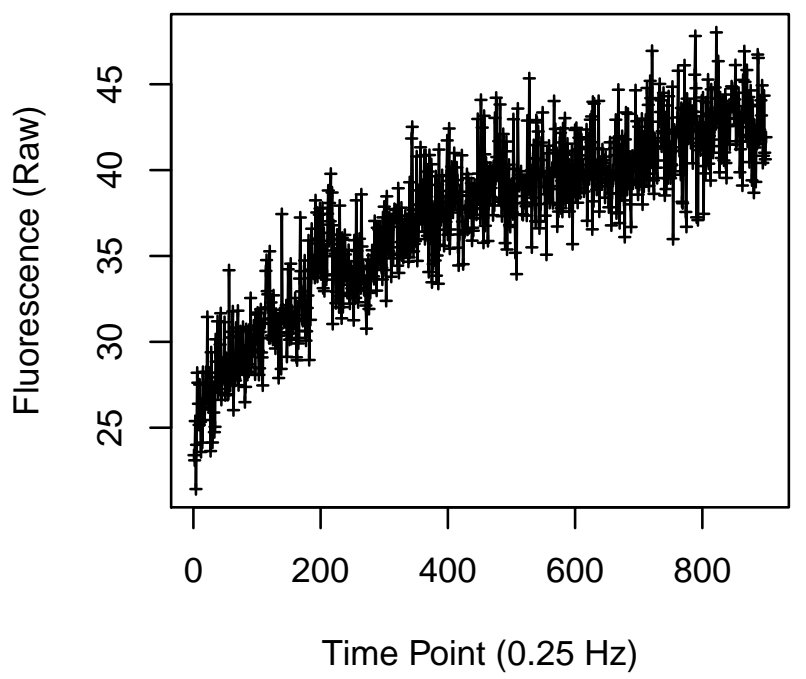


Cell 1113

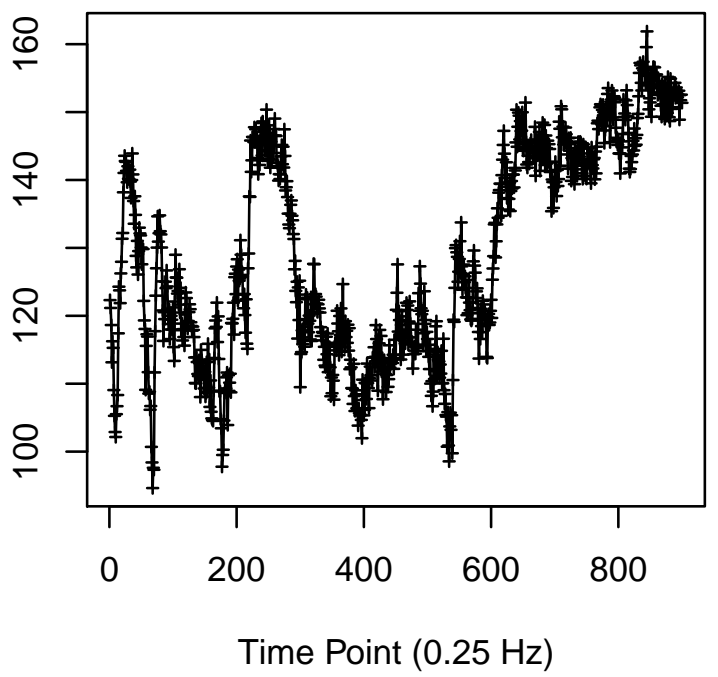

Cell 1115

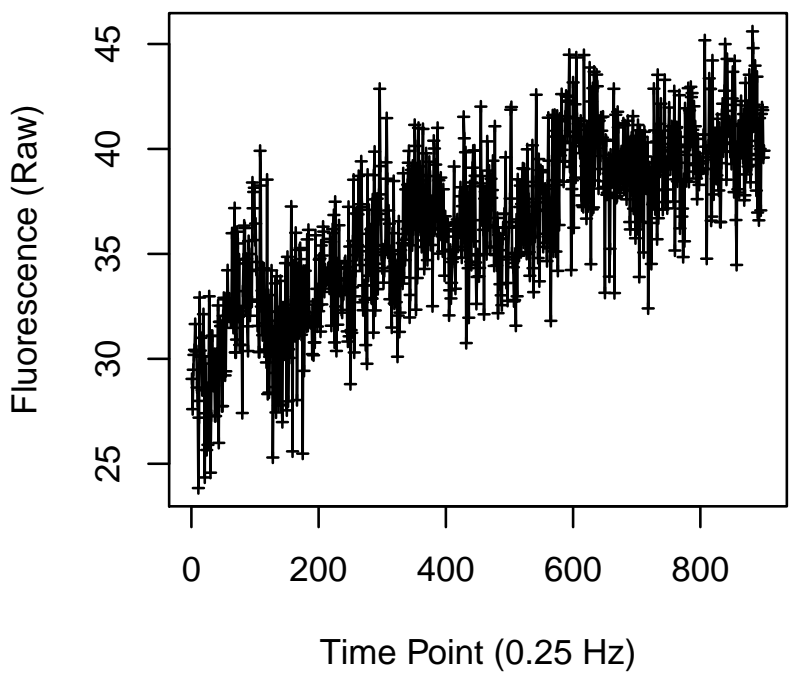

Cell 1114

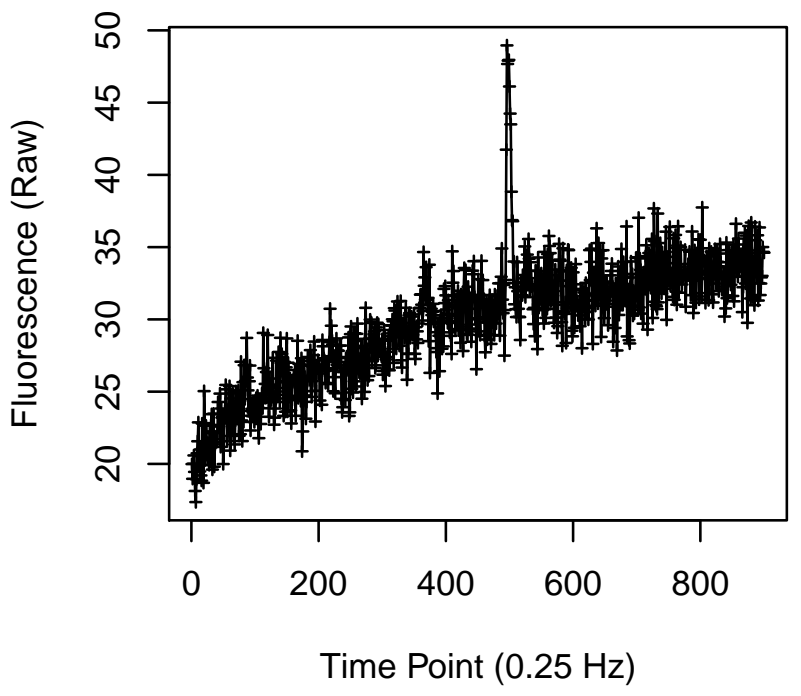

Cell 1116

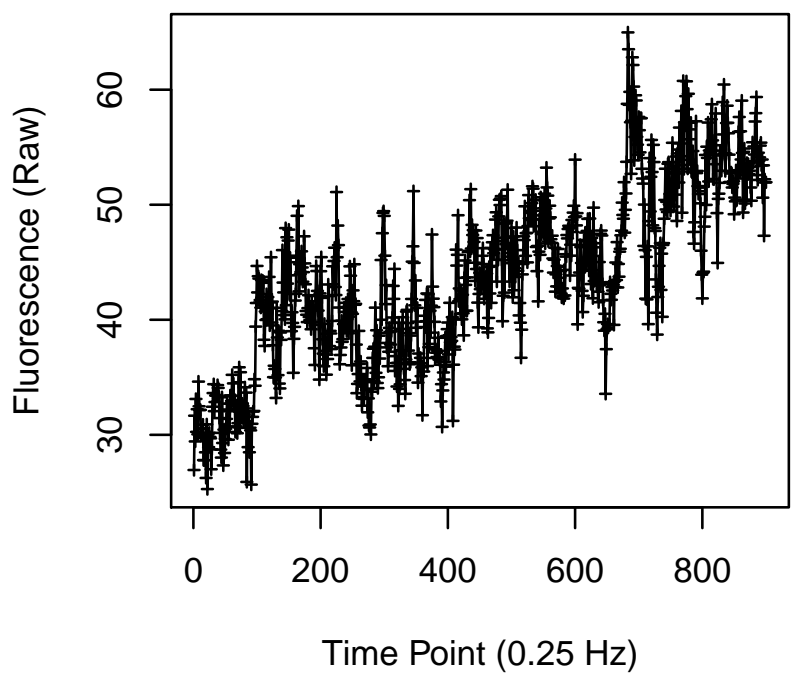


Cell 1121

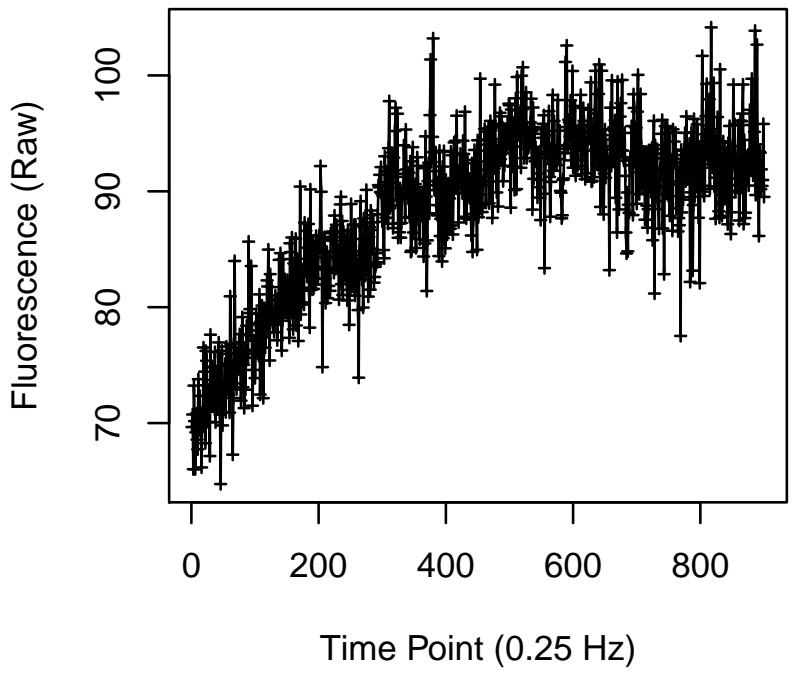

Cell 1123

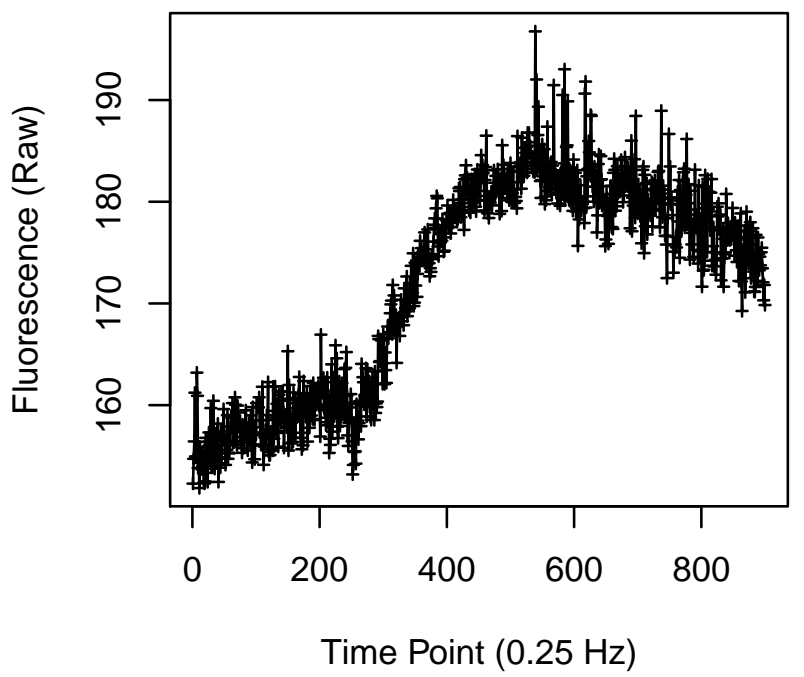

Cell 1122

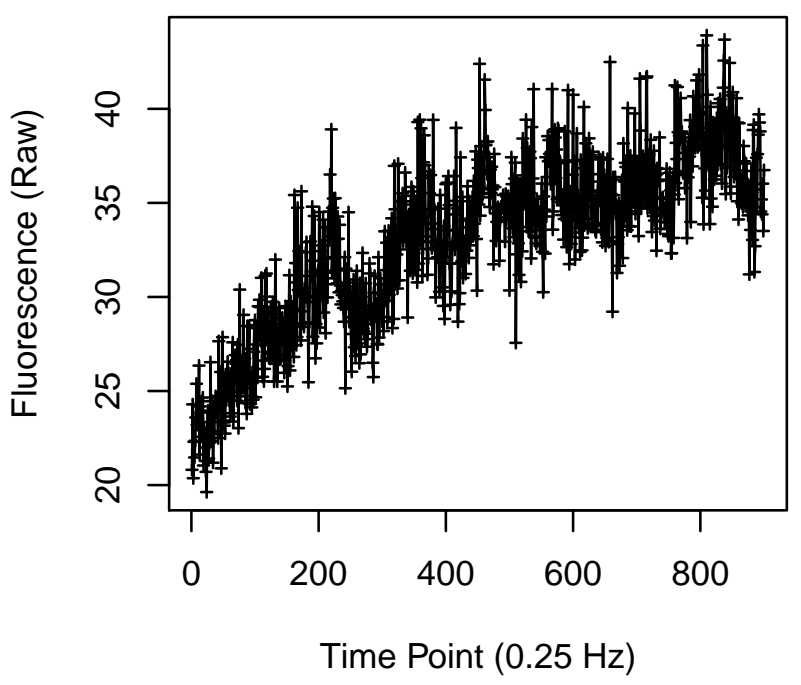

Cell 1124

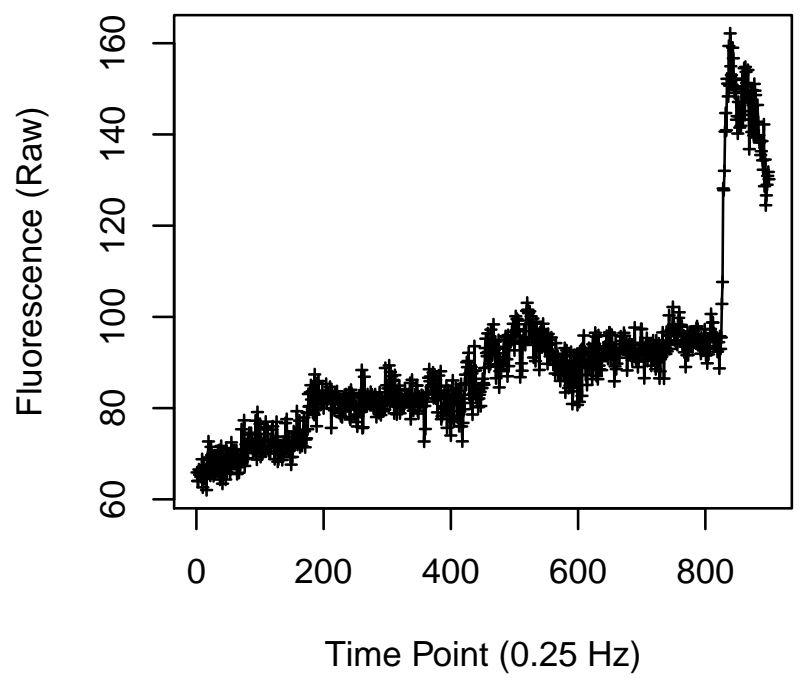


Cell 1125

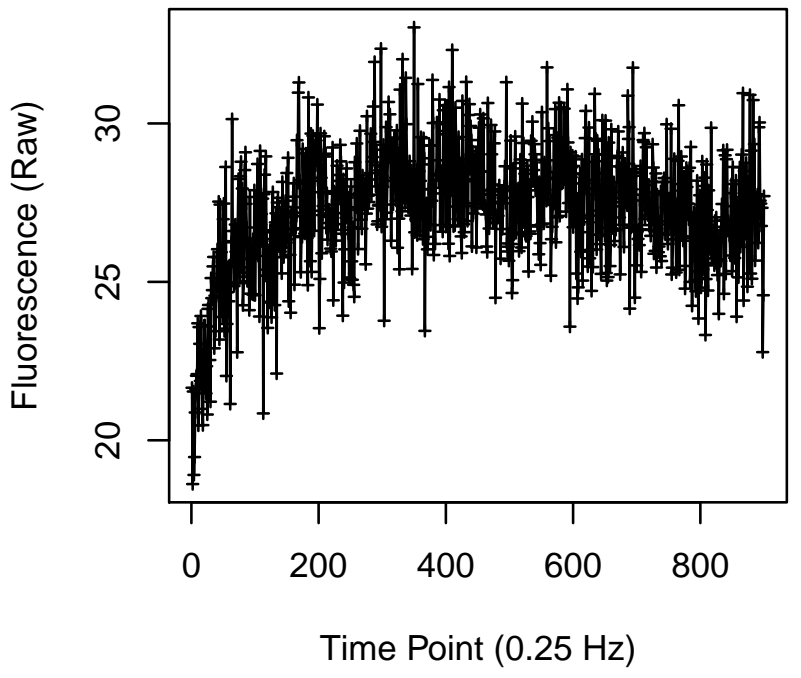

Cell 1127

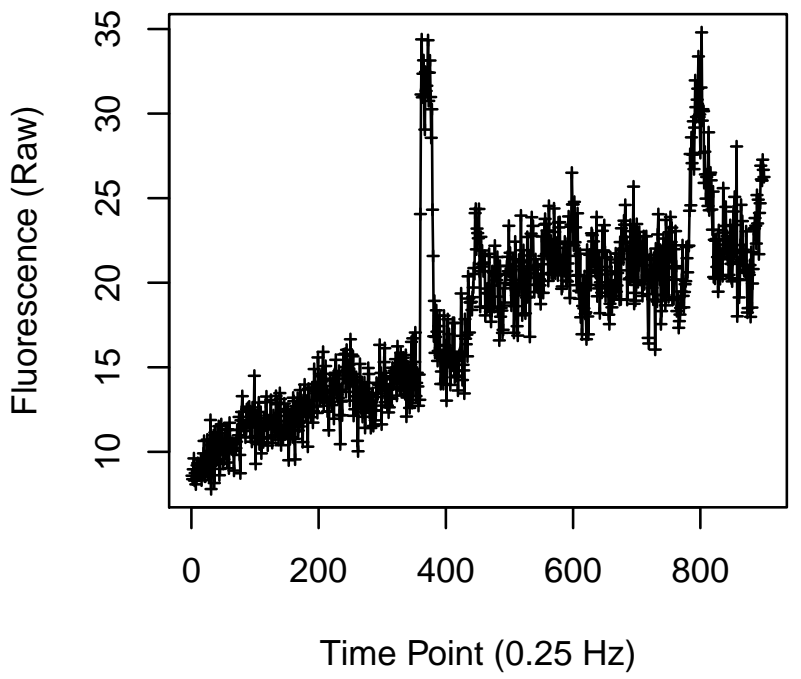

Cell 1126

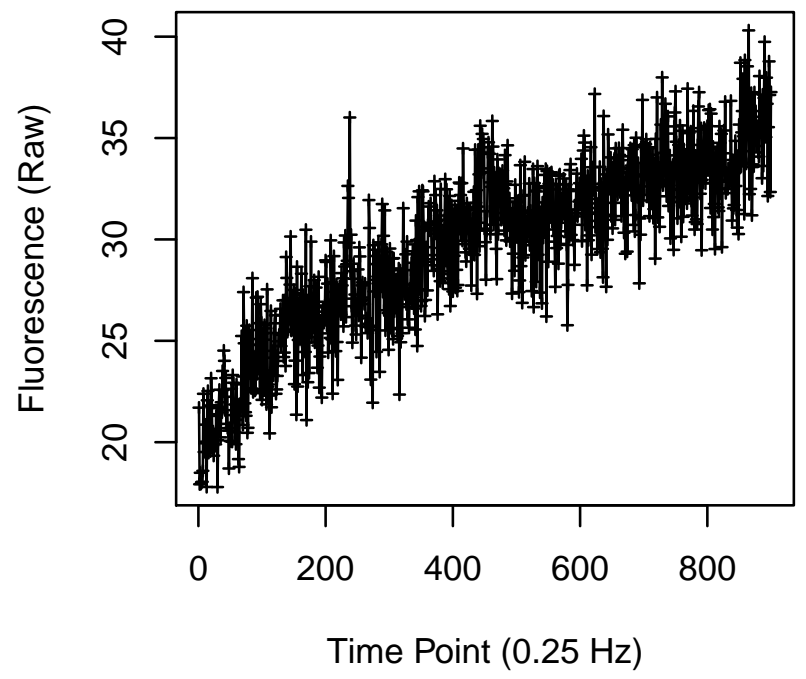

Cell 1128

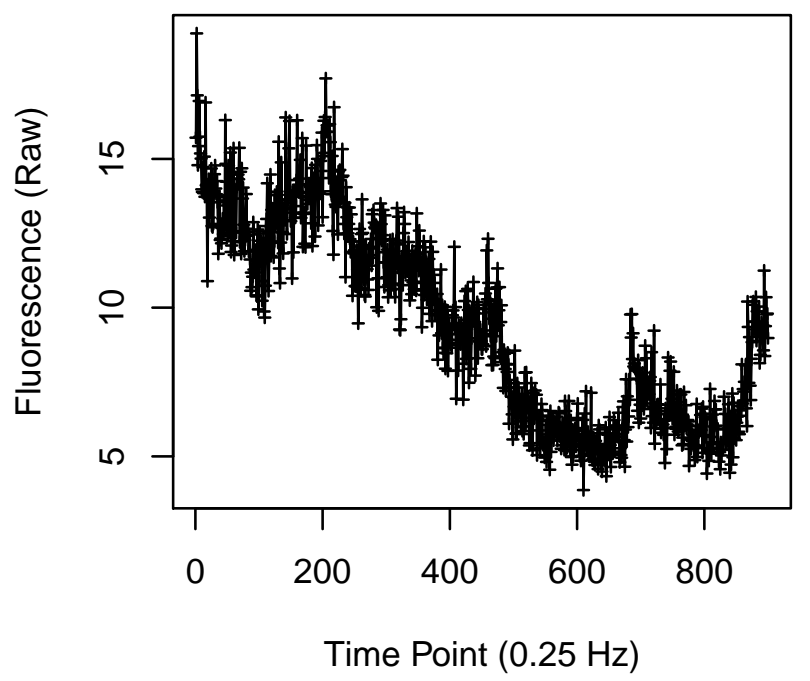


Cell 1129

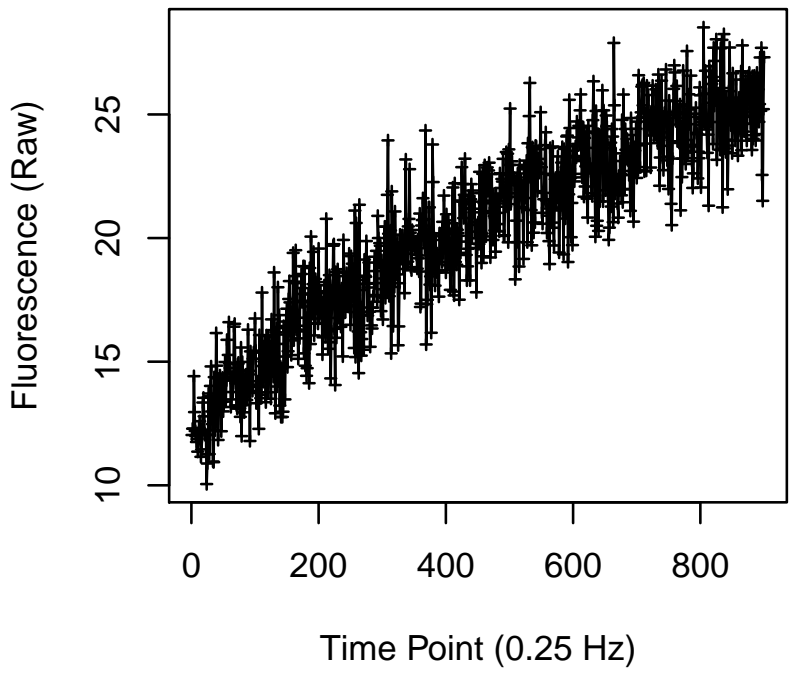

Cell 1131

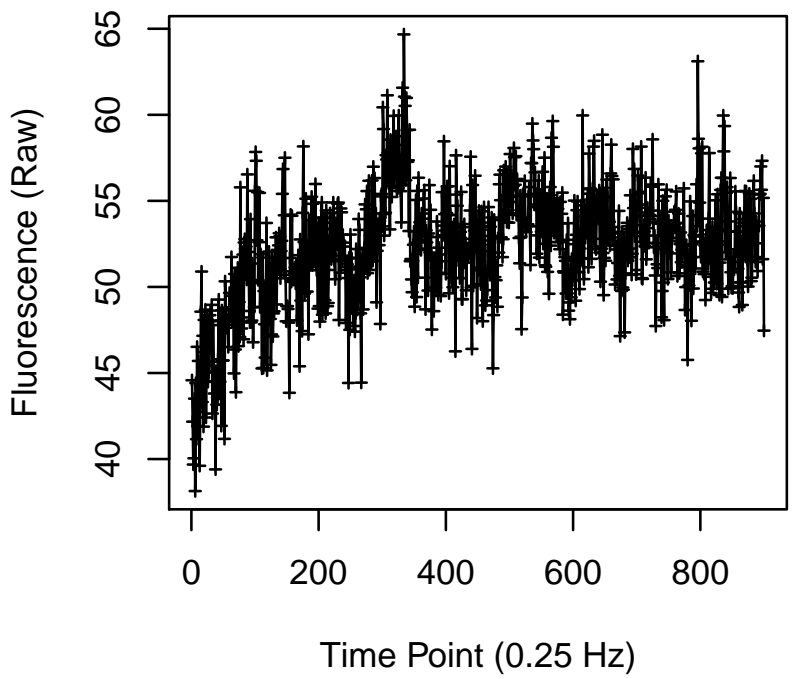

Cell 1130

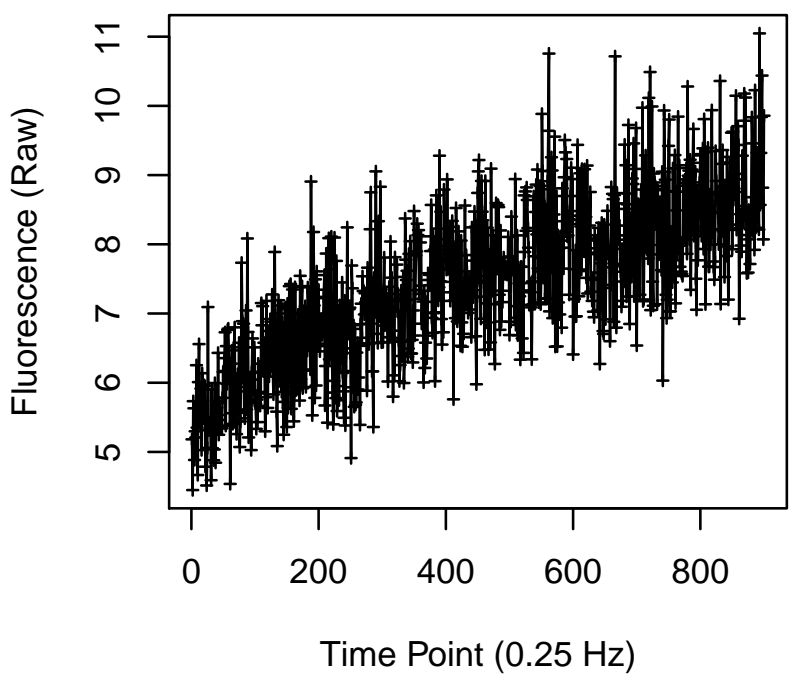

Cell 1132

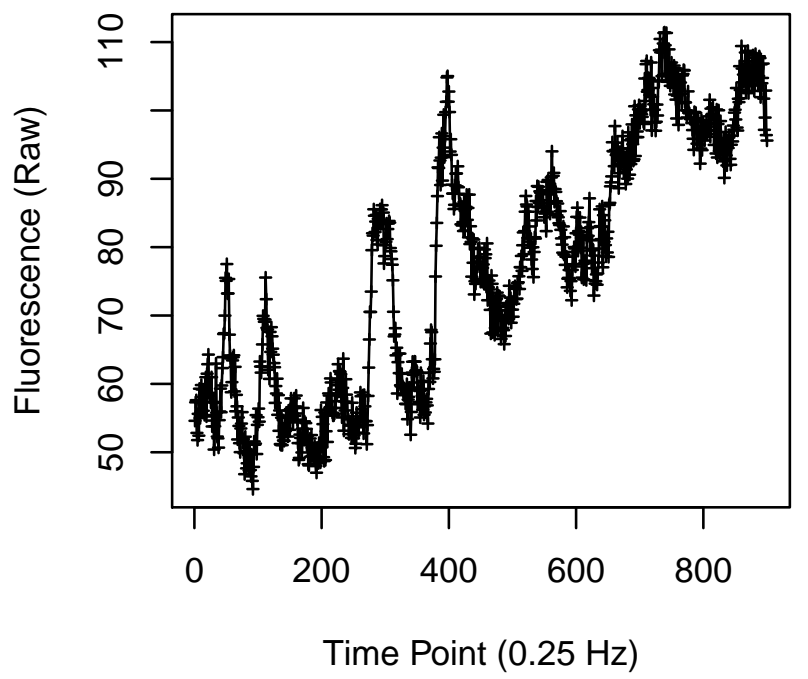


Cell 1133

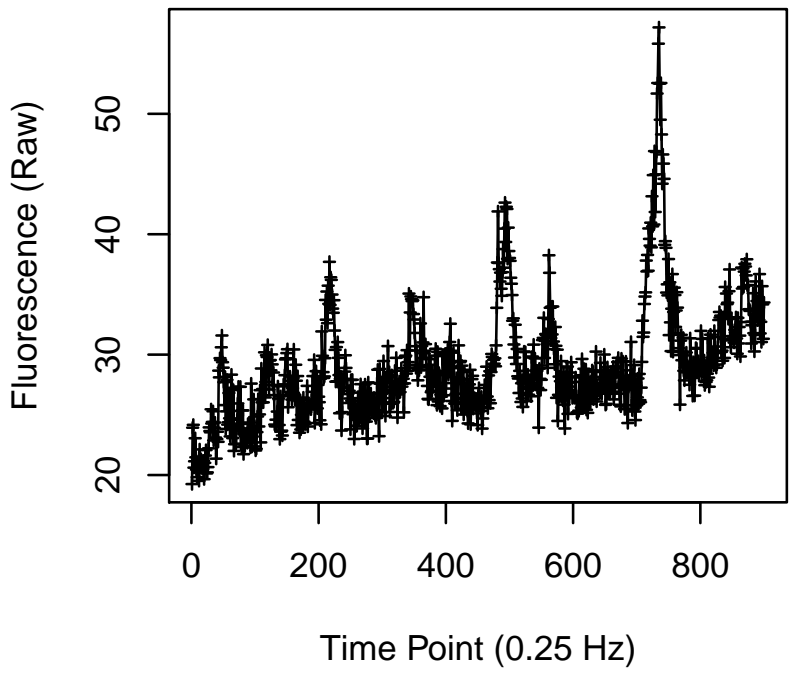

Cell 1135

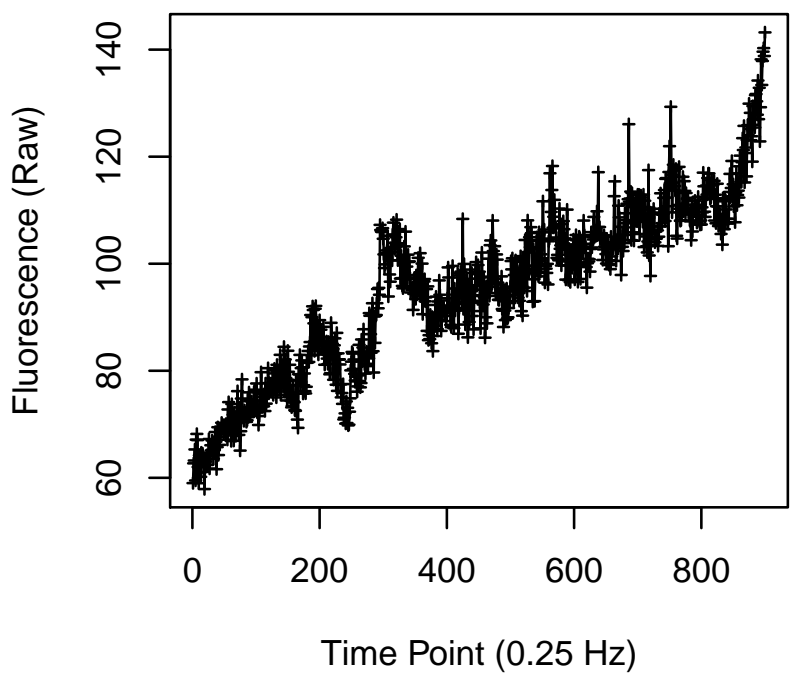

Cell 1134

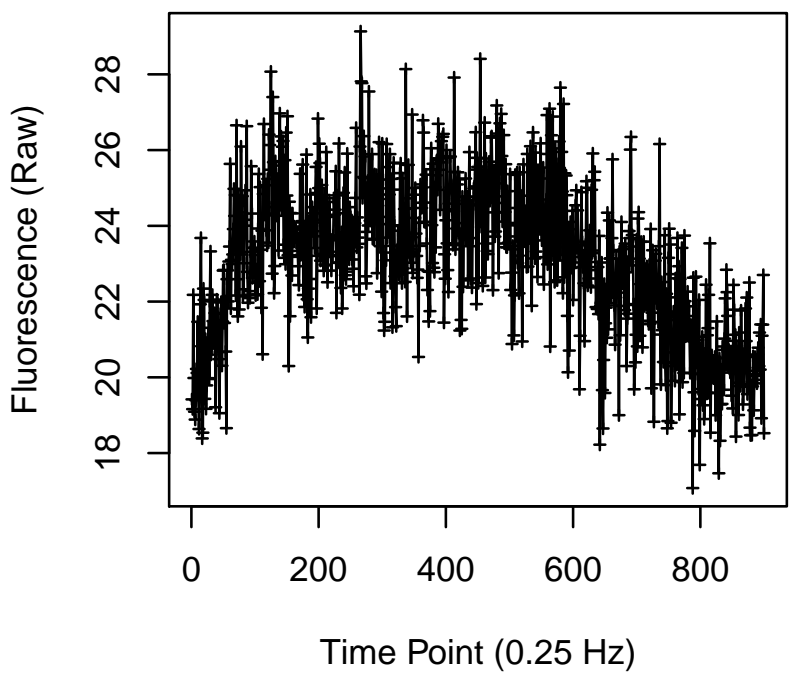

Cell 1136

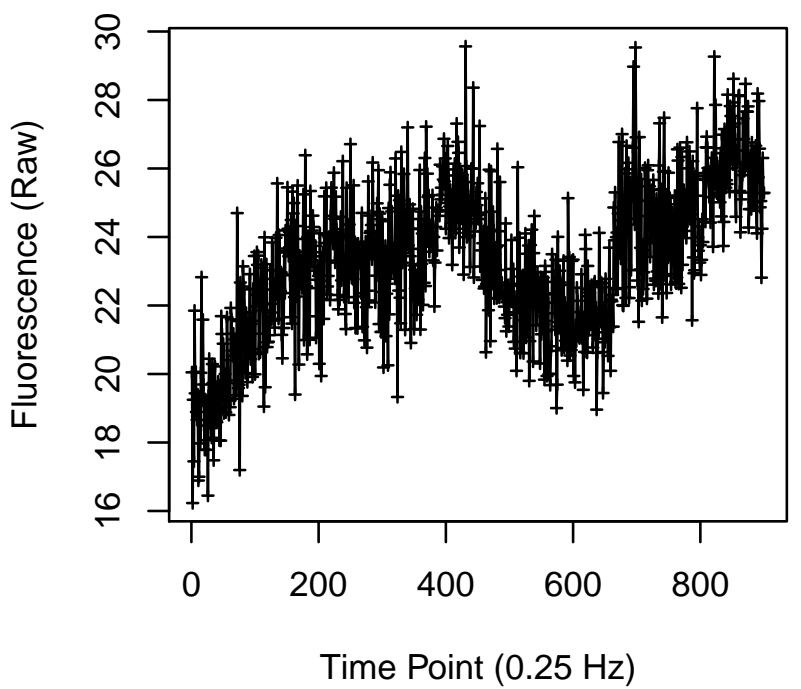


Cell 1137

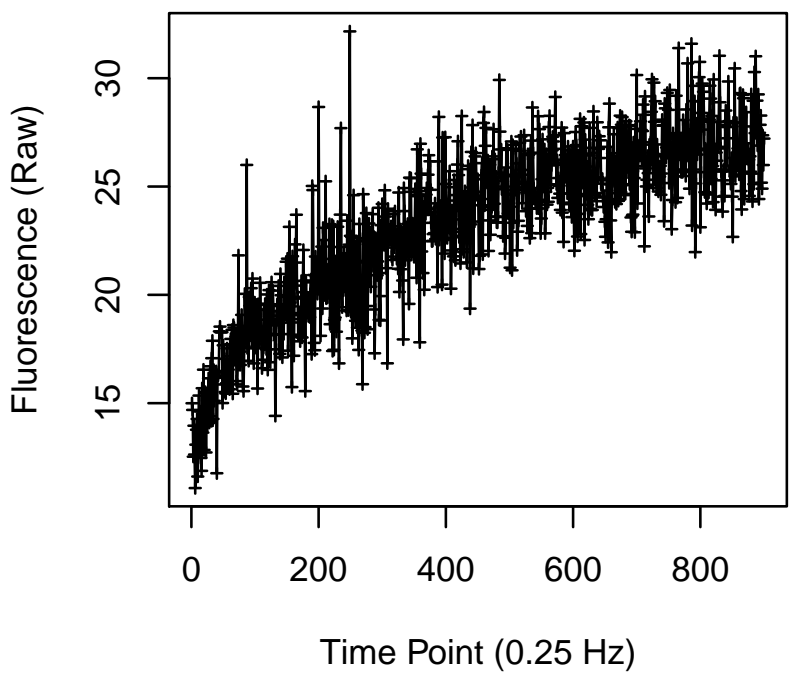

Cell 1139

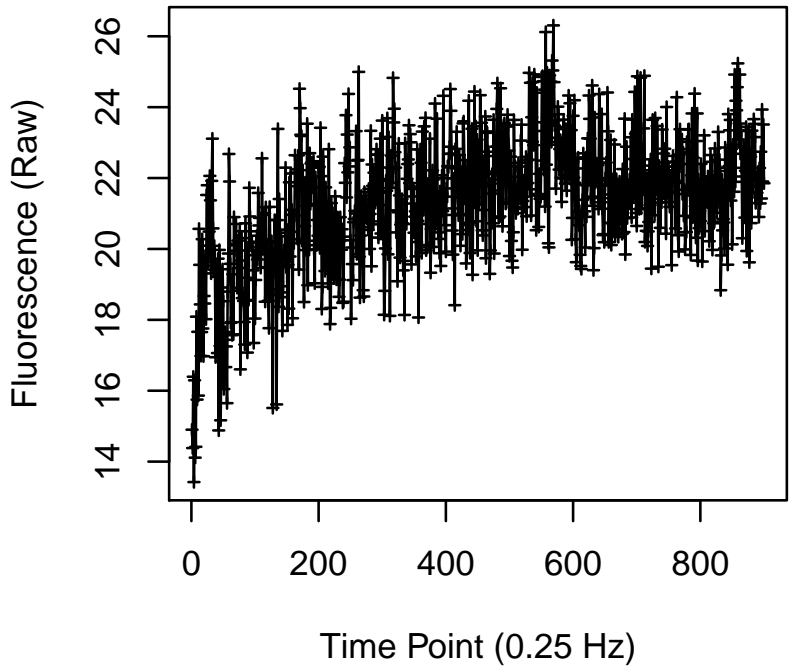

Cell 1138

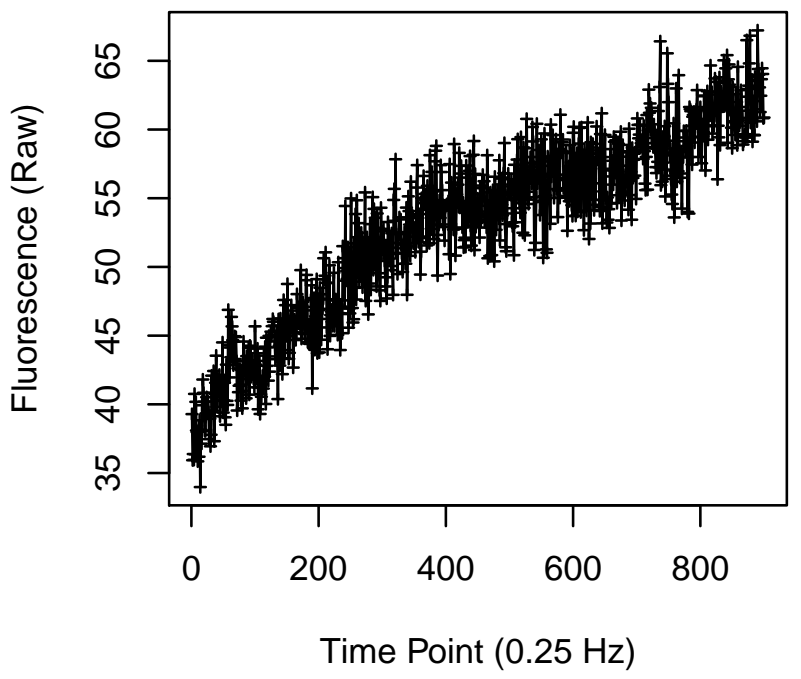

Cell 1140

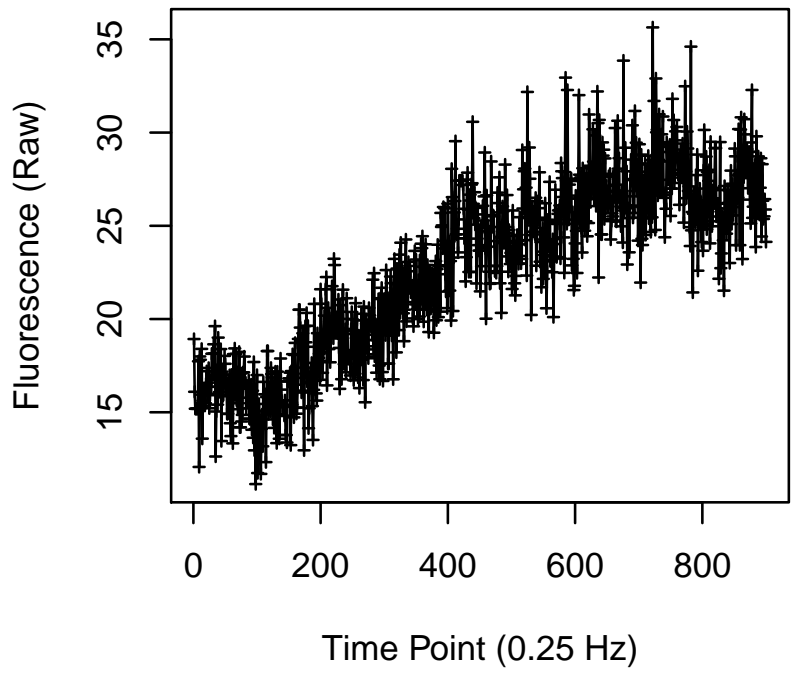




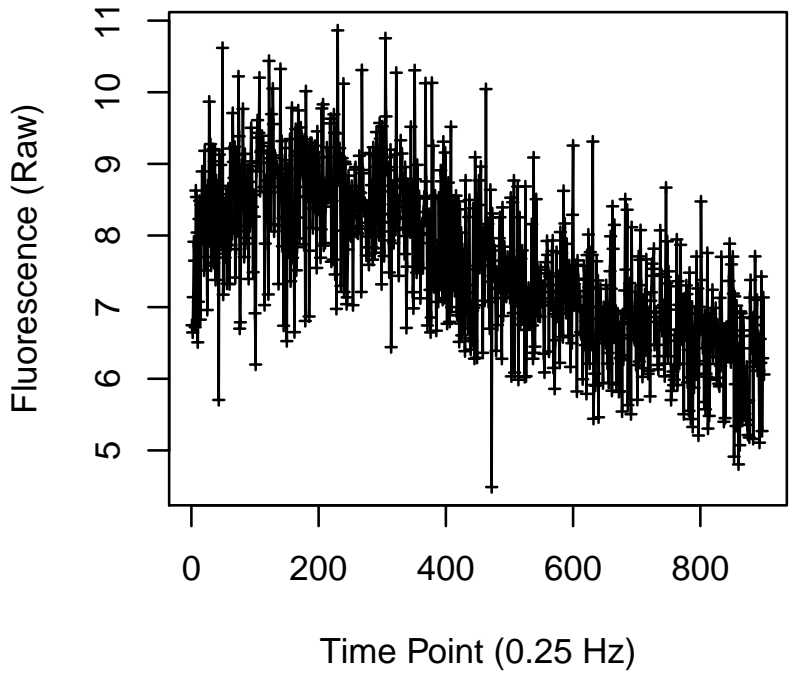

Cell 1151

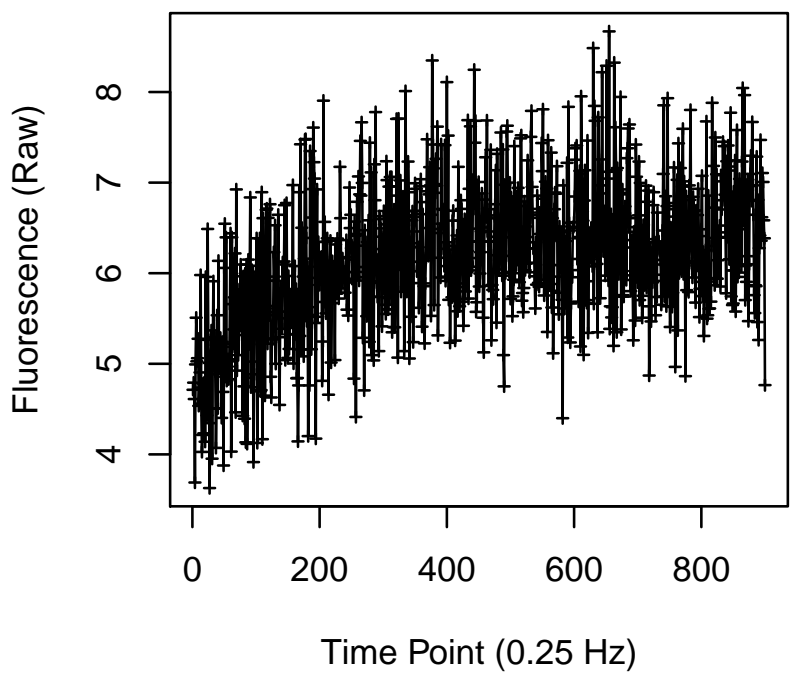

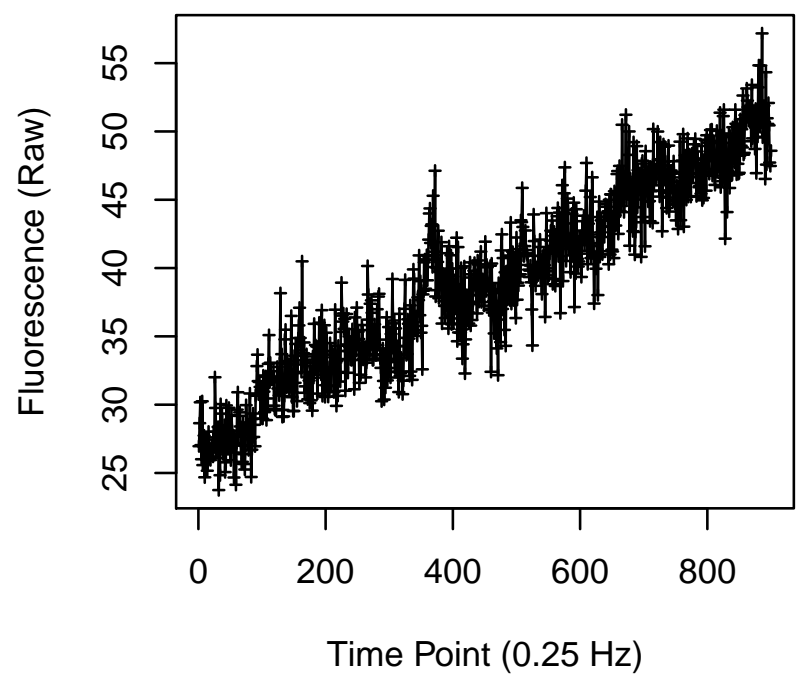

Cell 1152

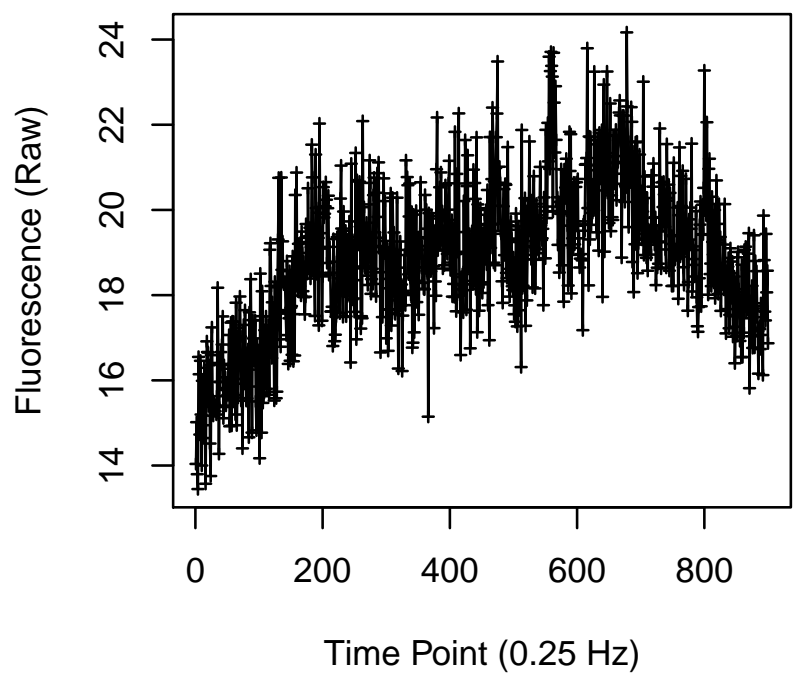




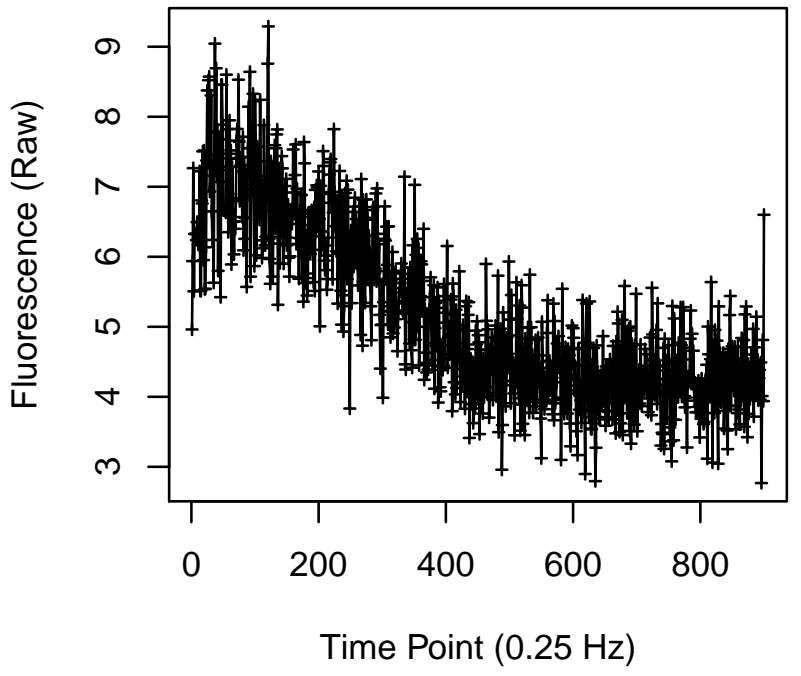

Cell 1159

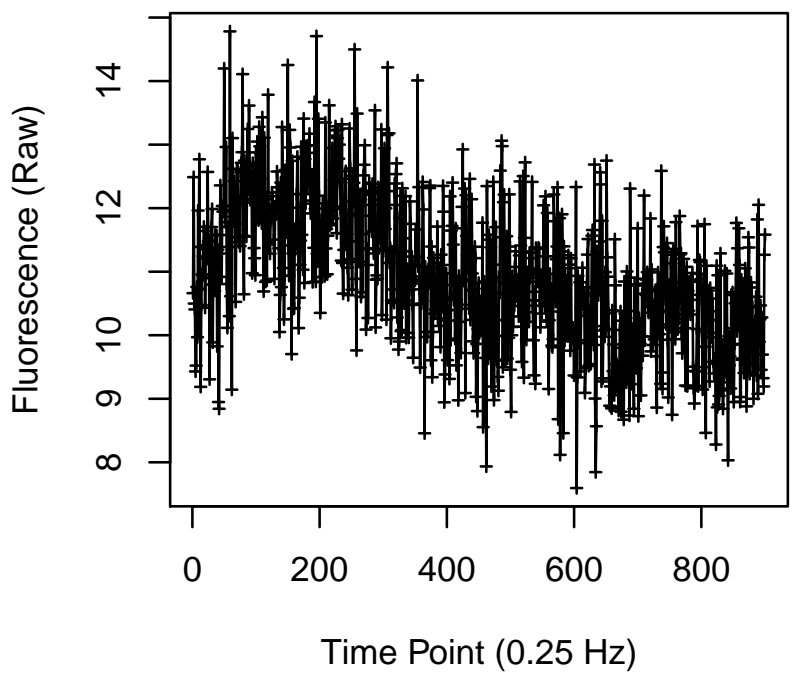

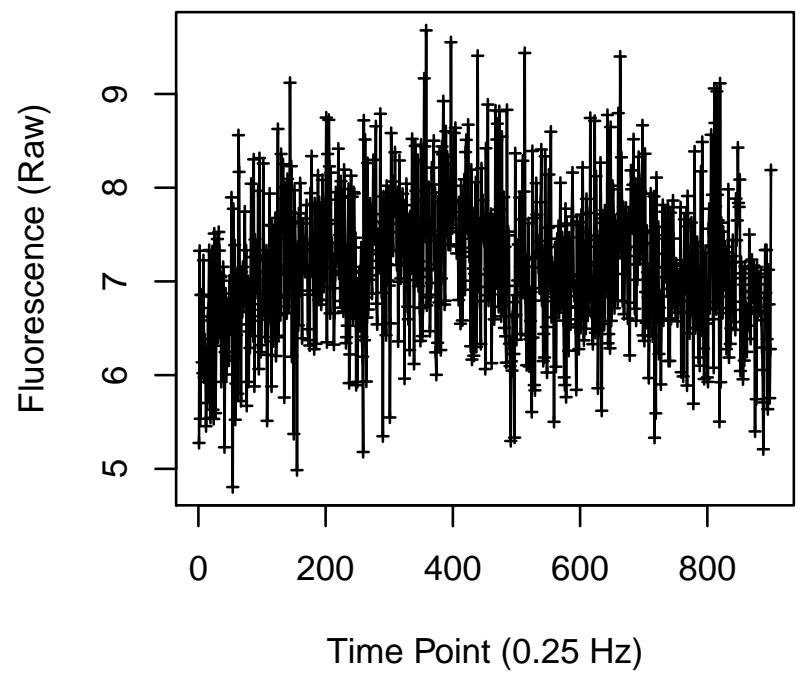

Cell 1160

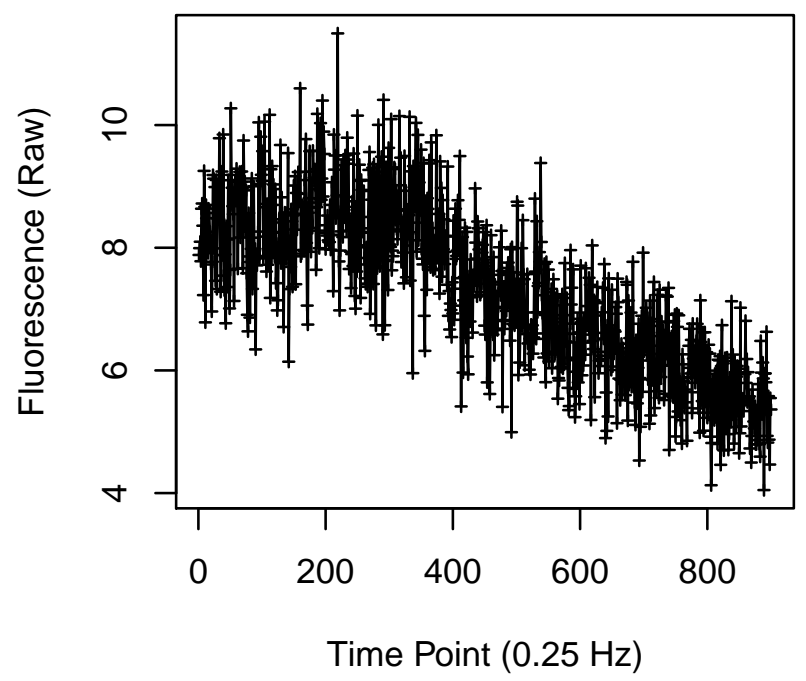


Cell 1165

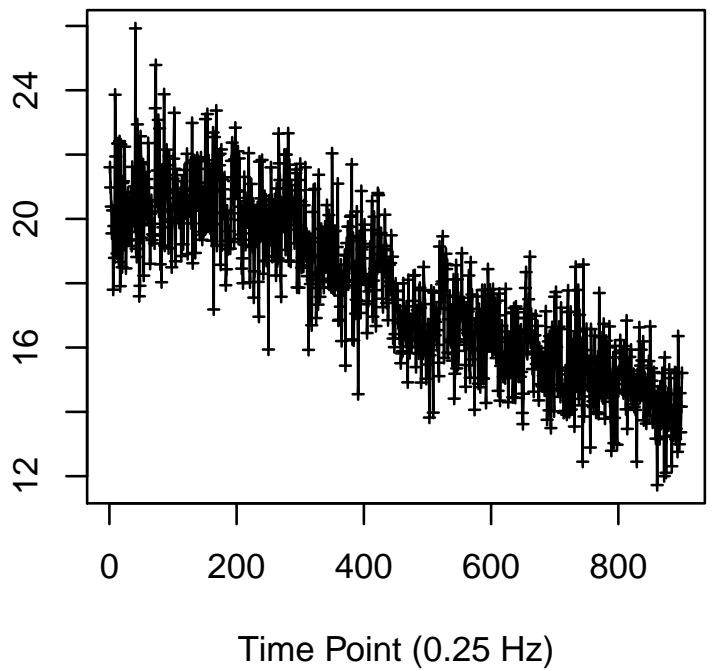

Cell 1167

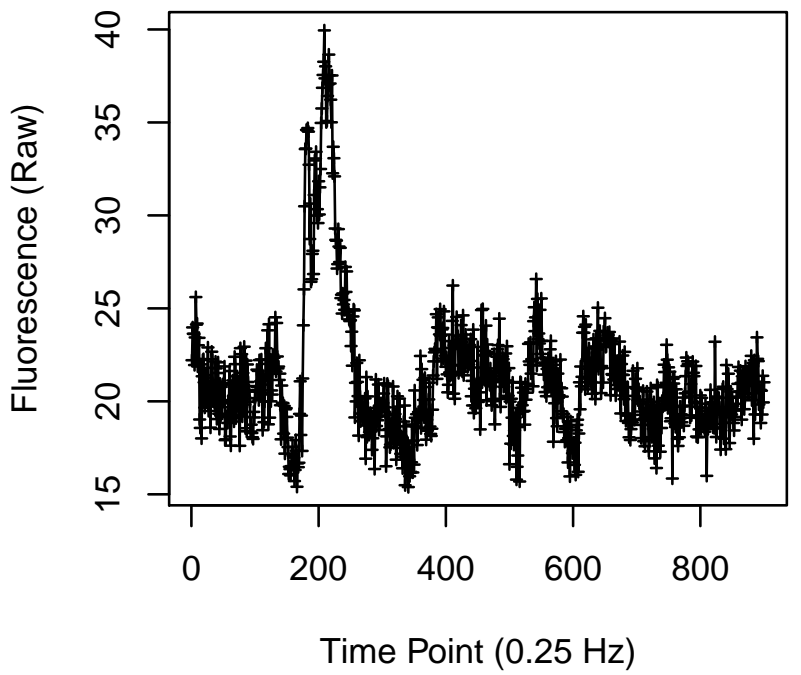

Cell 1166

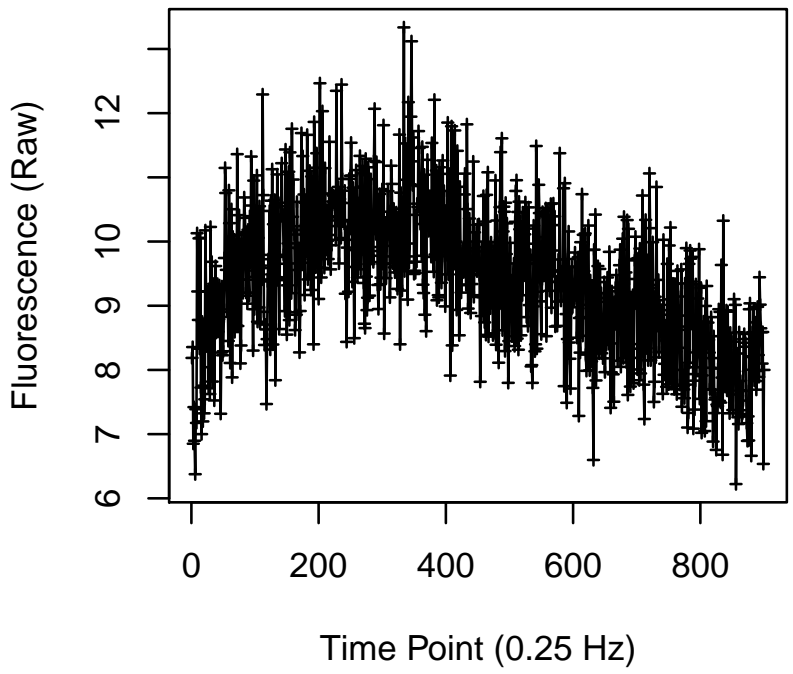

Cell 1168

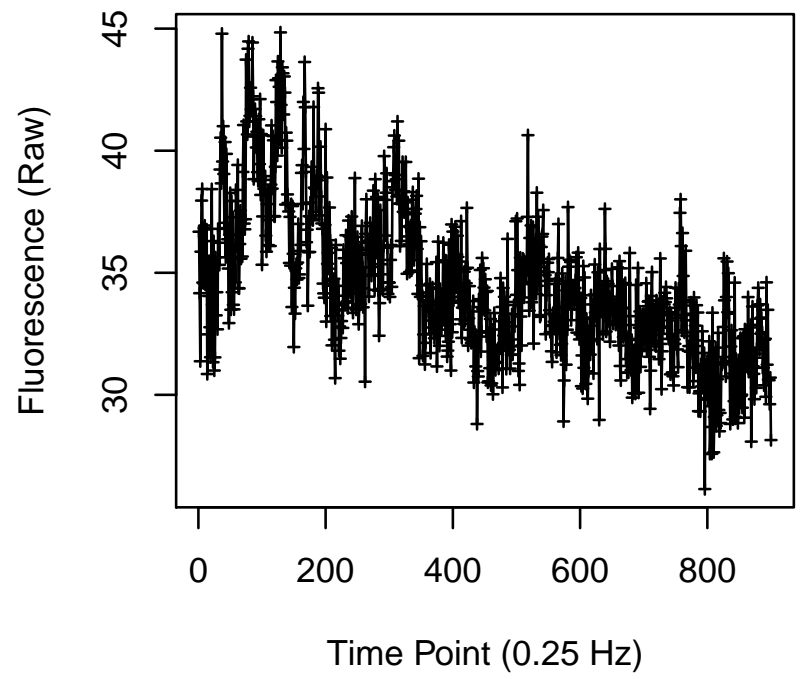


Cell 1173

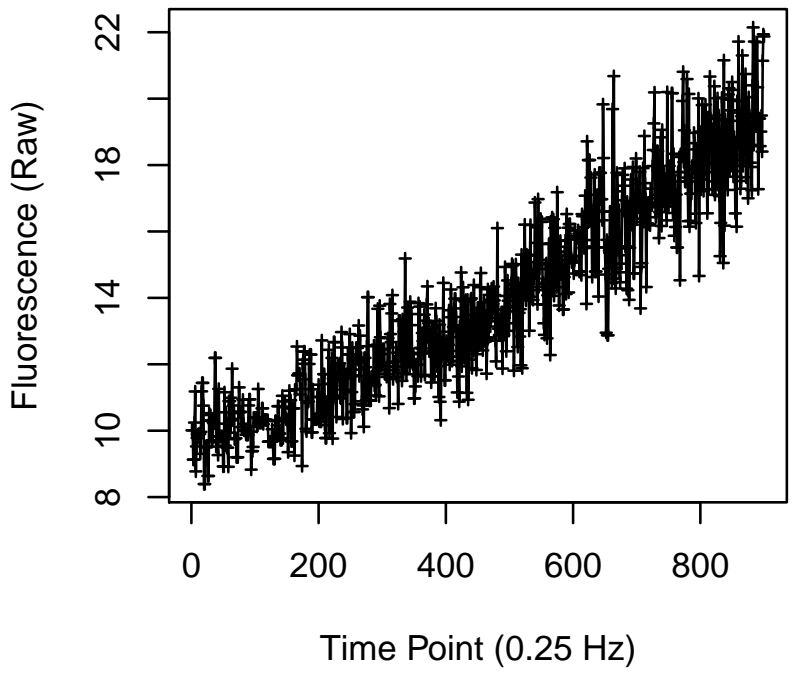

Cell 1175

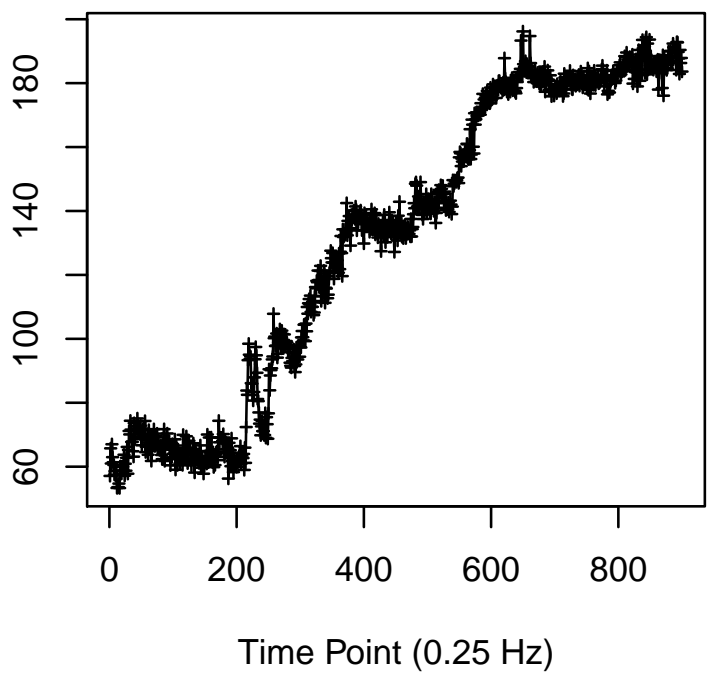

Cell 1174

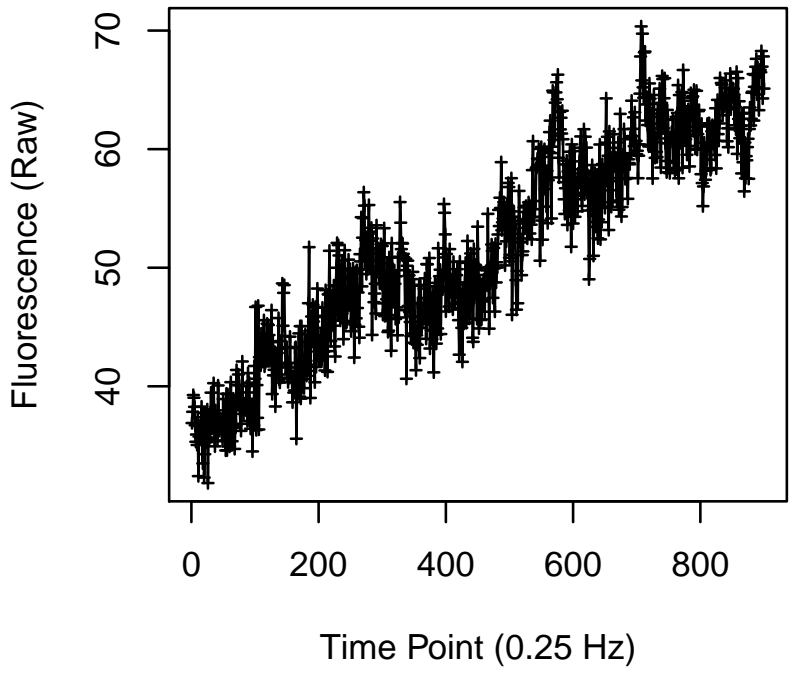

Cell 1176

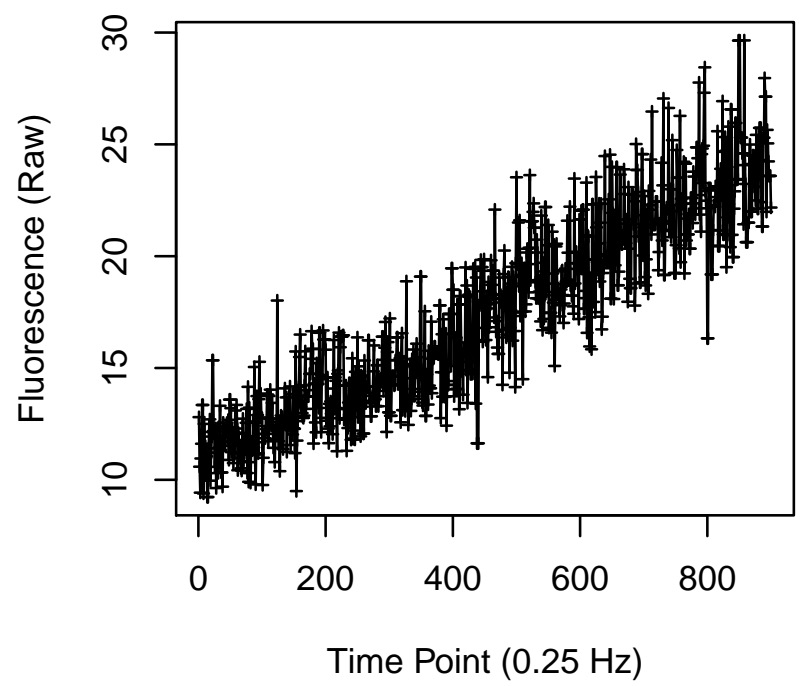


Cell 1177

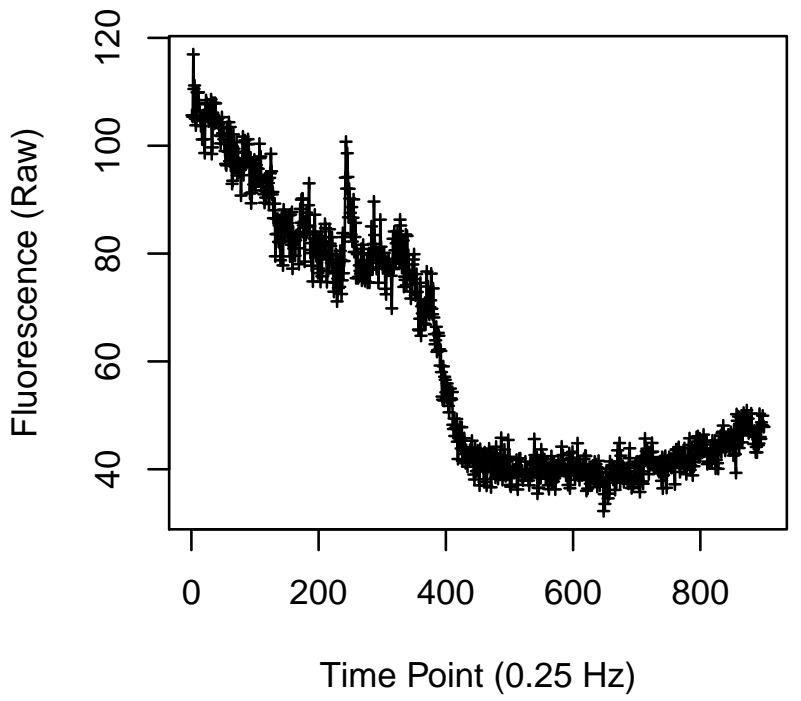

Cell 1179

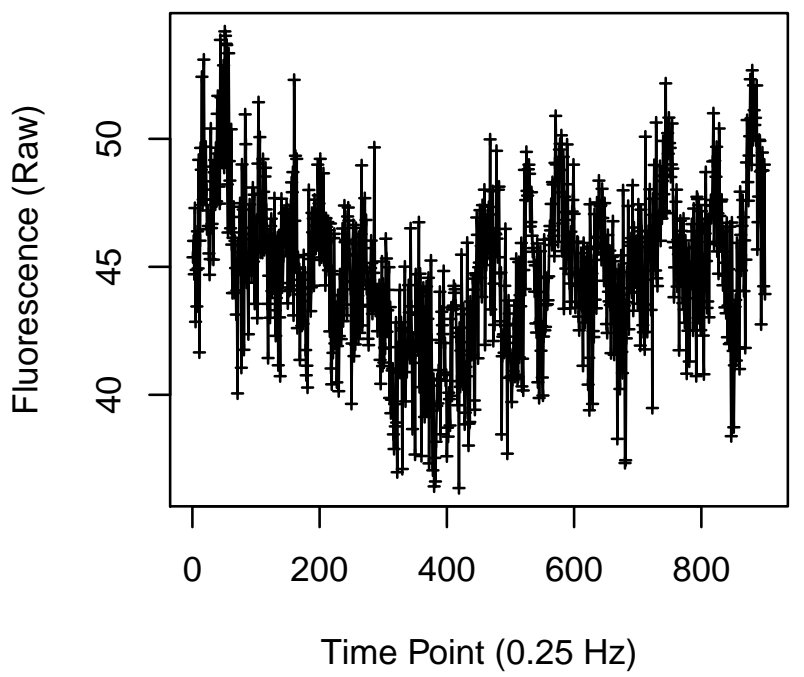

Cell 1178

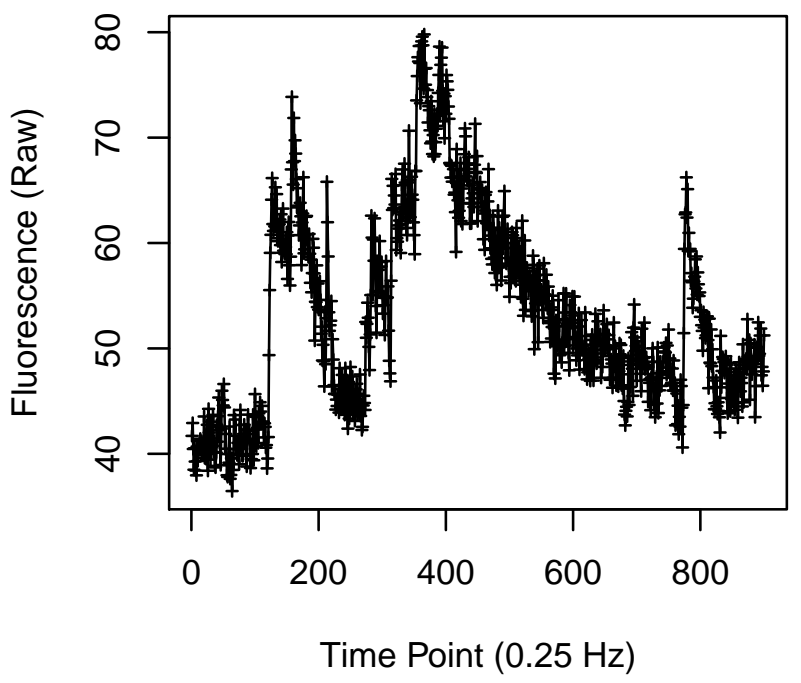

Cell 1180

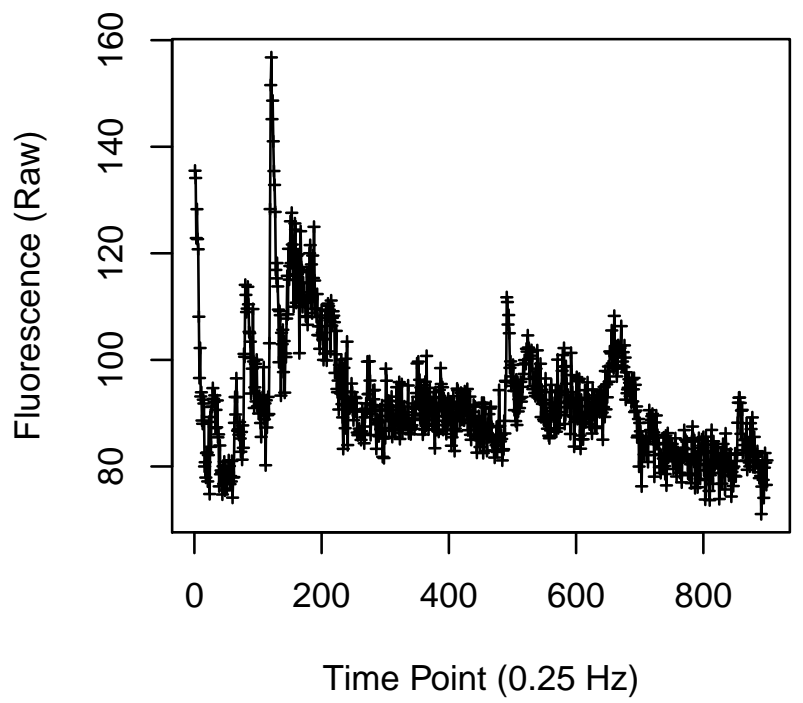


Cell 1185

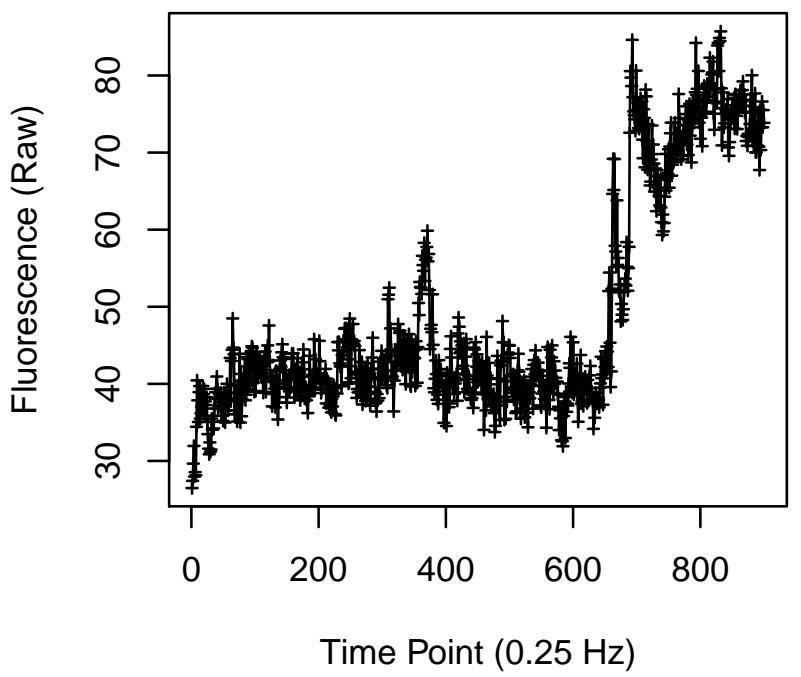

Cell 1187

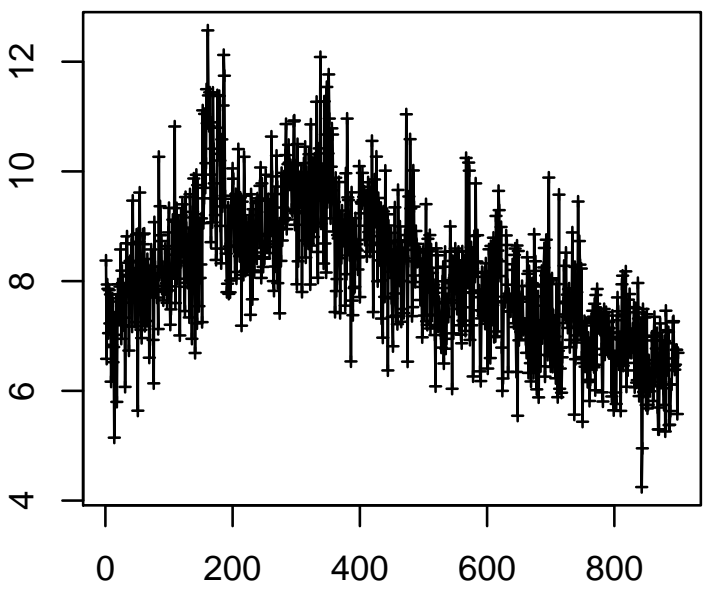

Time Point $(0.25 \mathrm{~Hz})$
Cell 1186

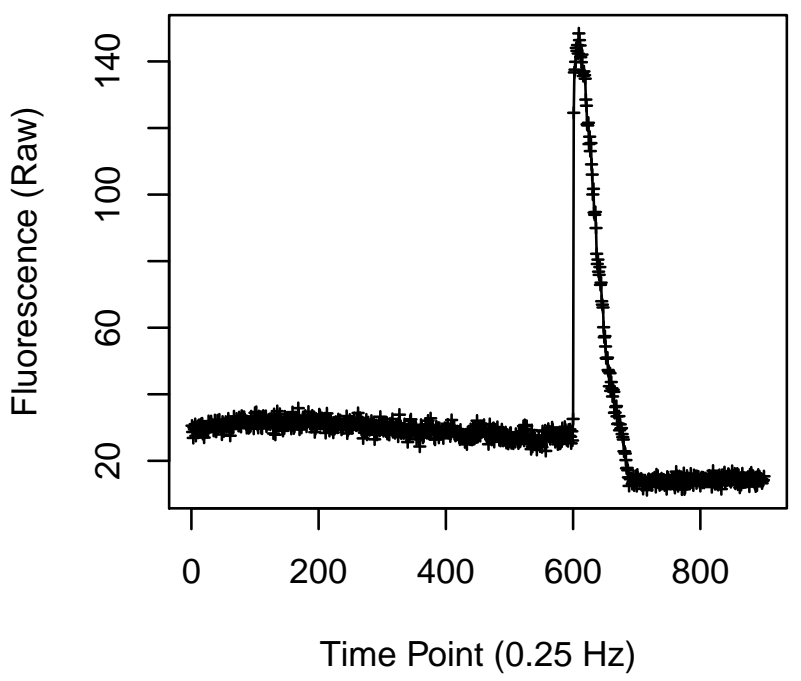

Cell 1188

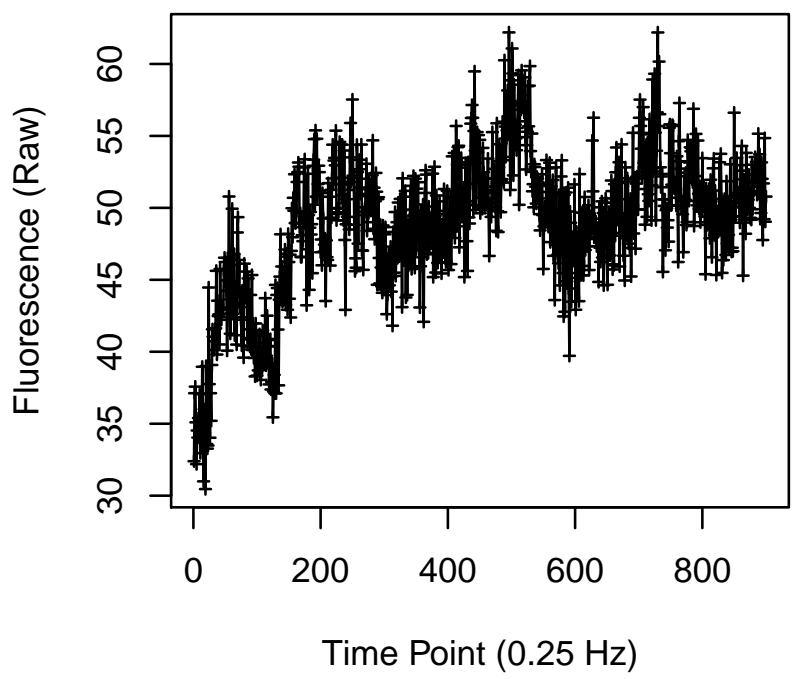


Cell 1189

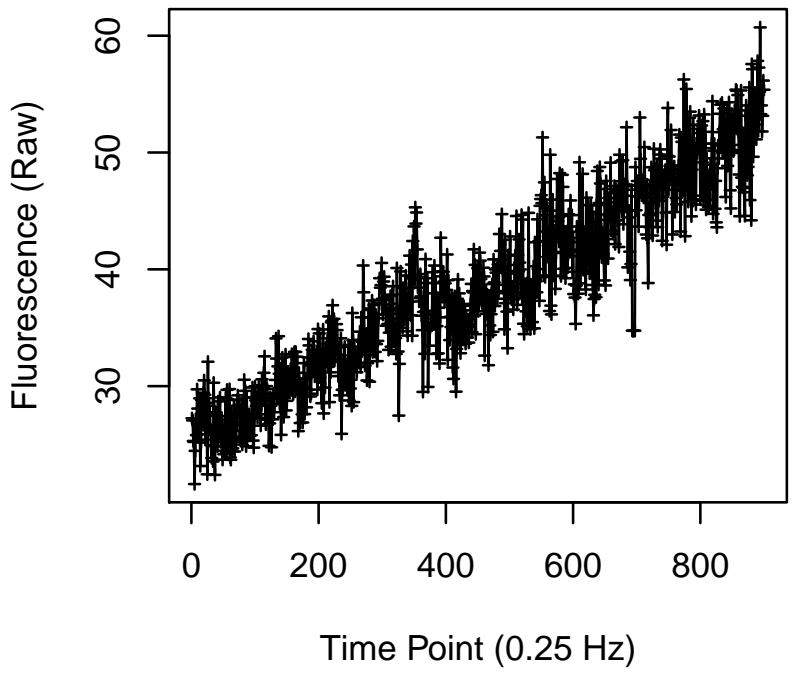

Cell 1191

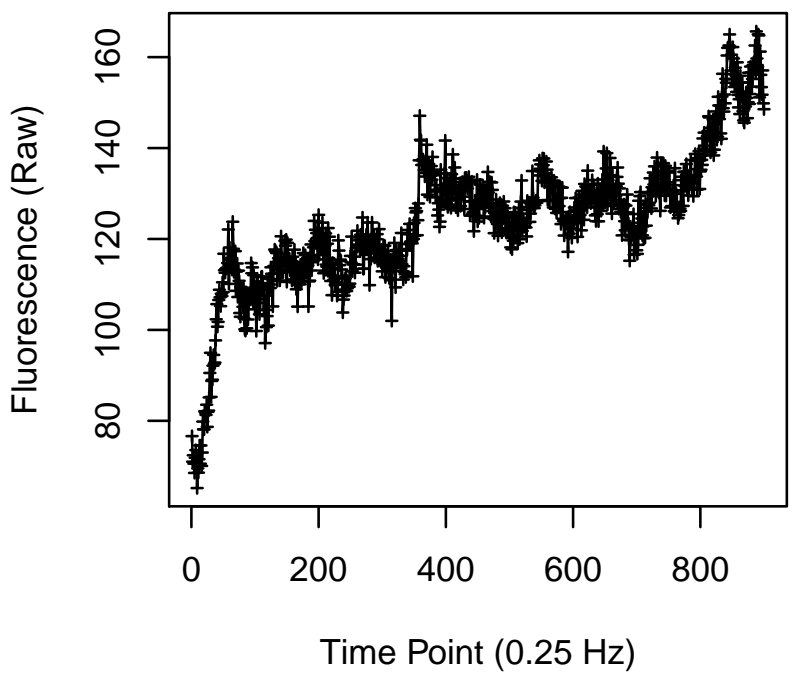

Cell 1190

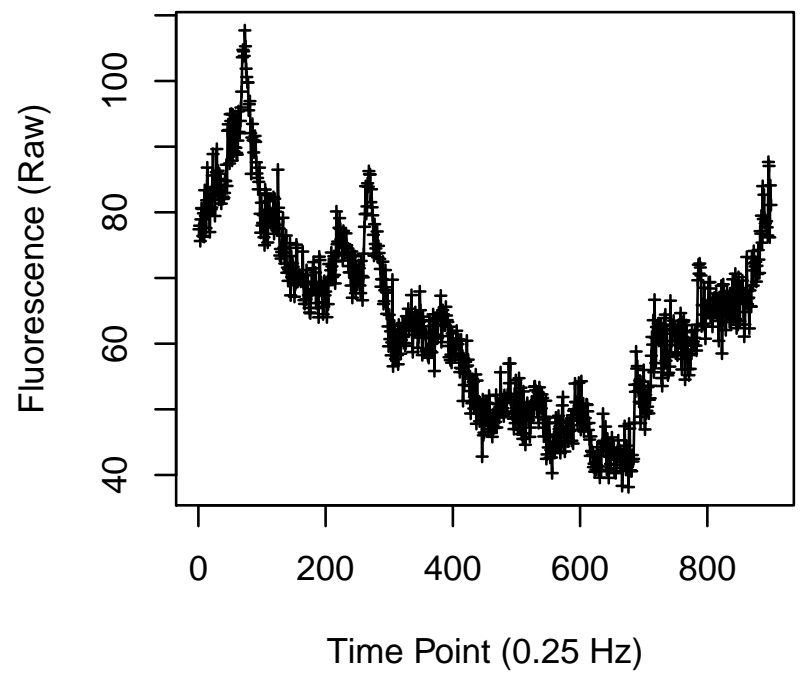

Cell 1192

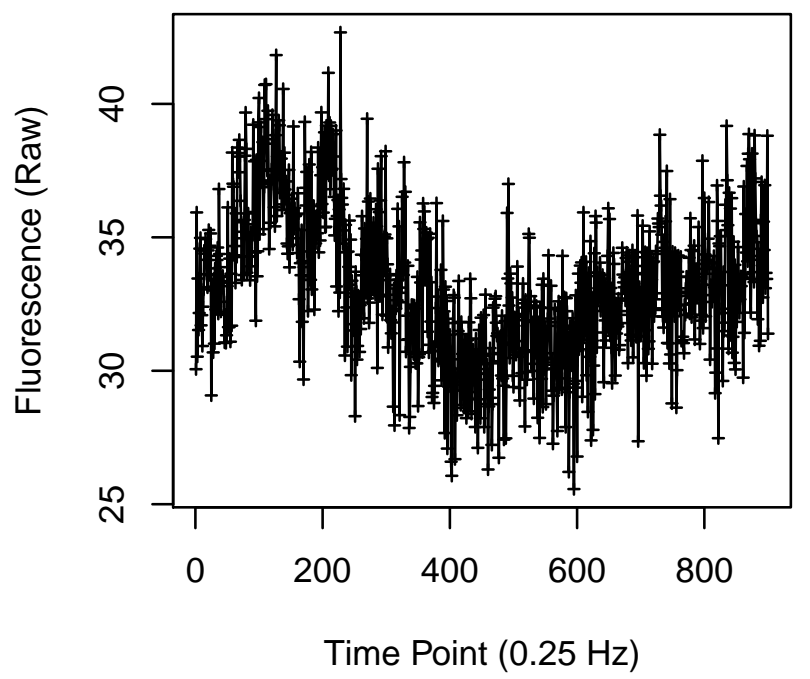


Cell 1193

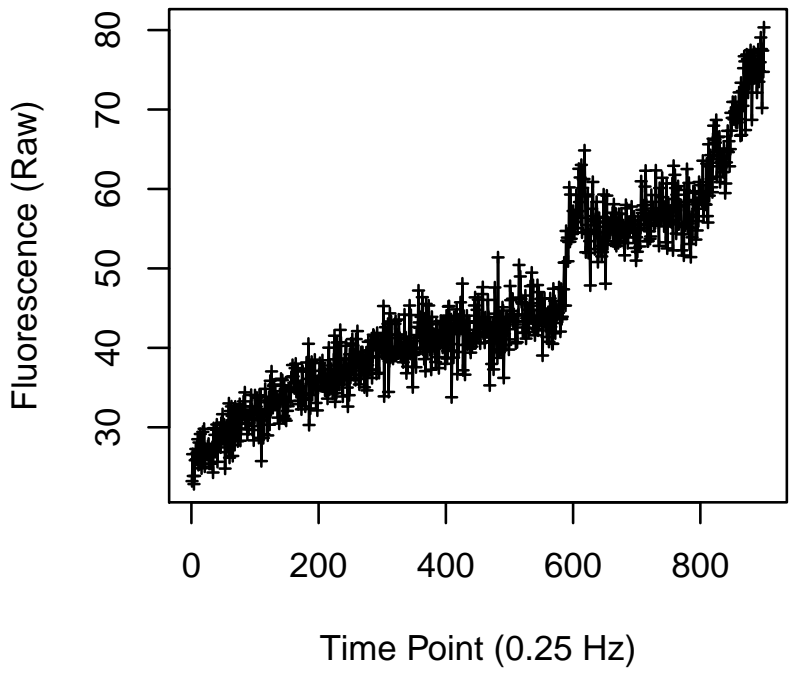

Cell 1195

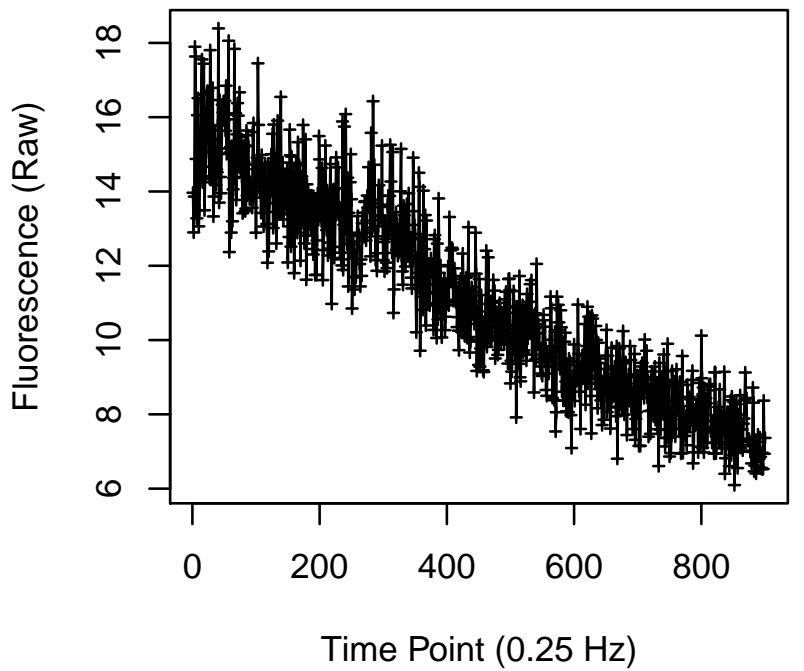

Cell 1194

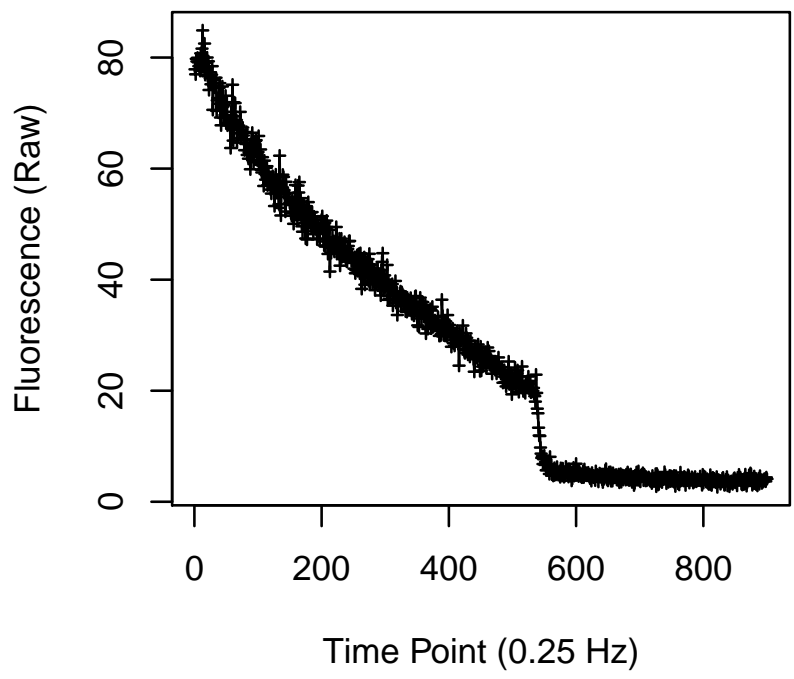

Cell 1196

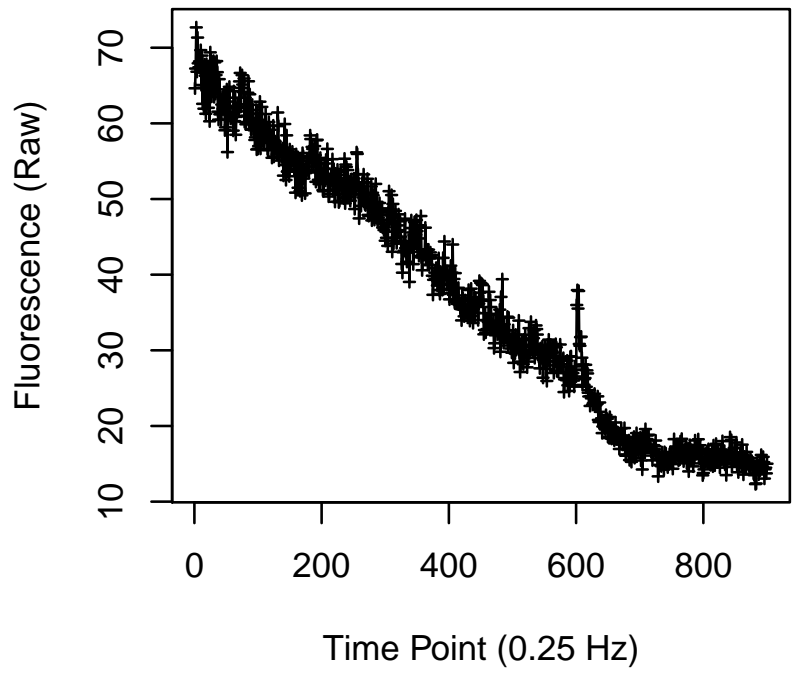


Cell 1197

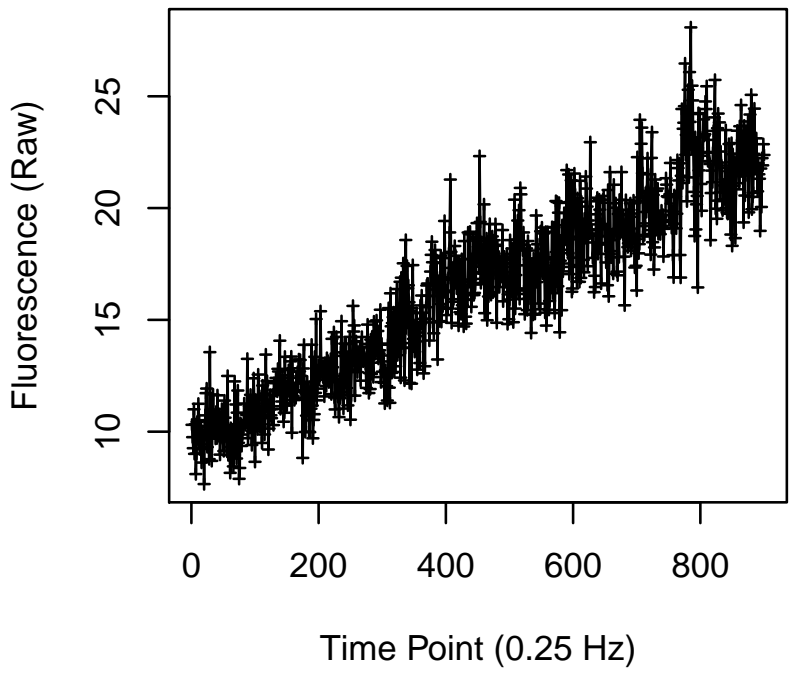

Cell 1199

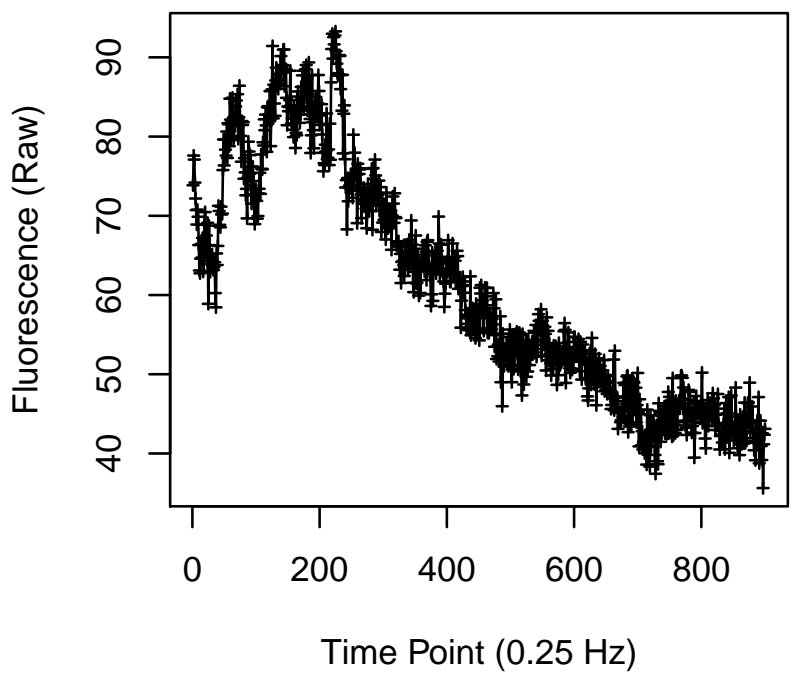

Cell 1198

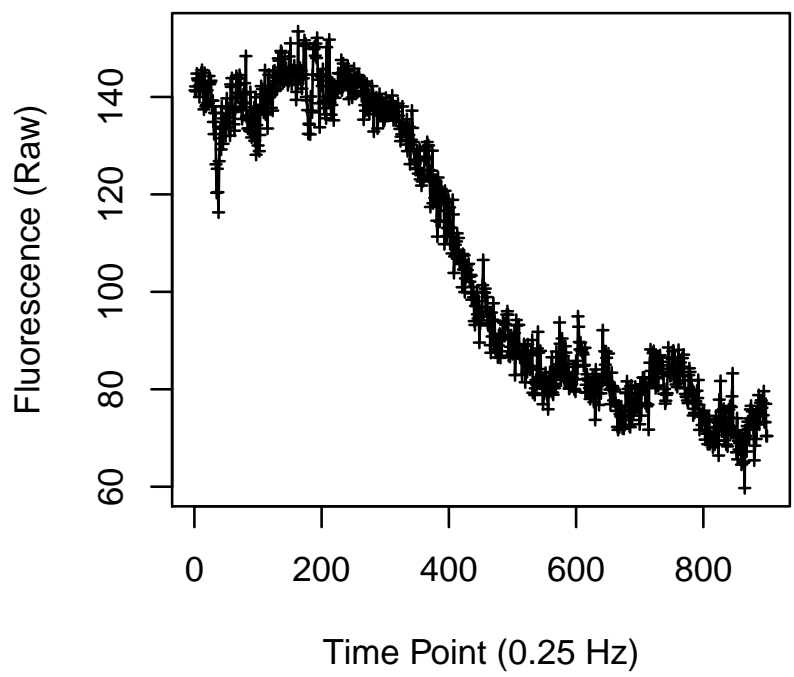

Cell 1200

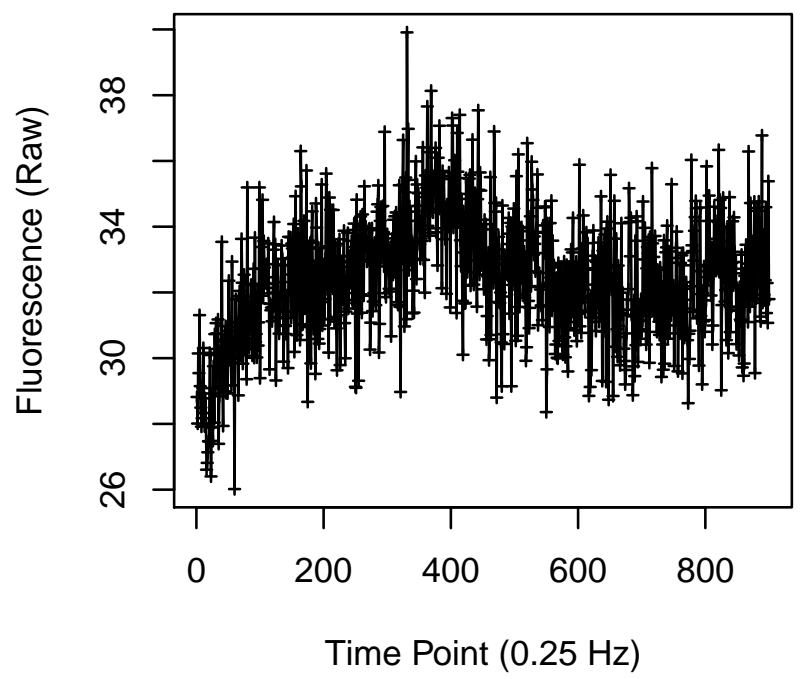


Cell 1201

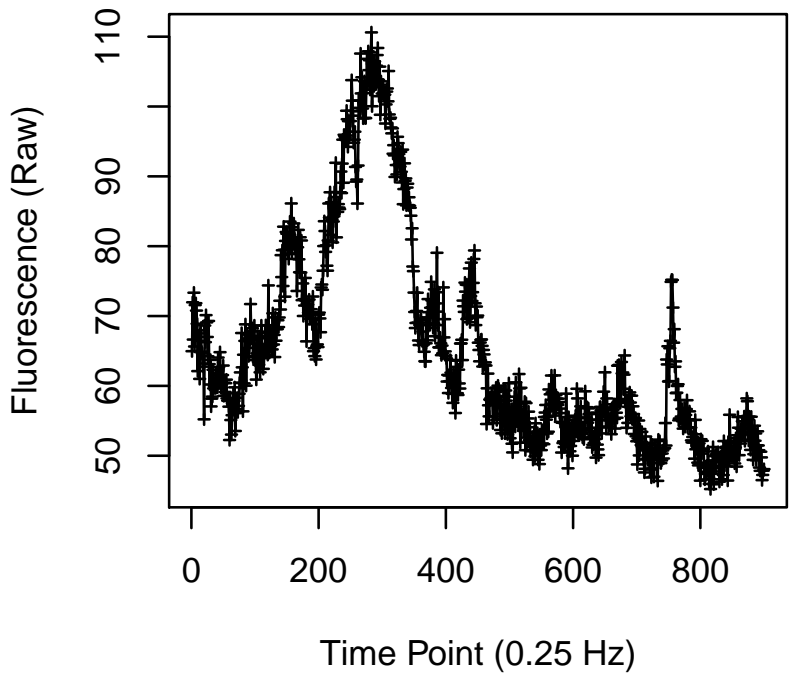

Cell 1203

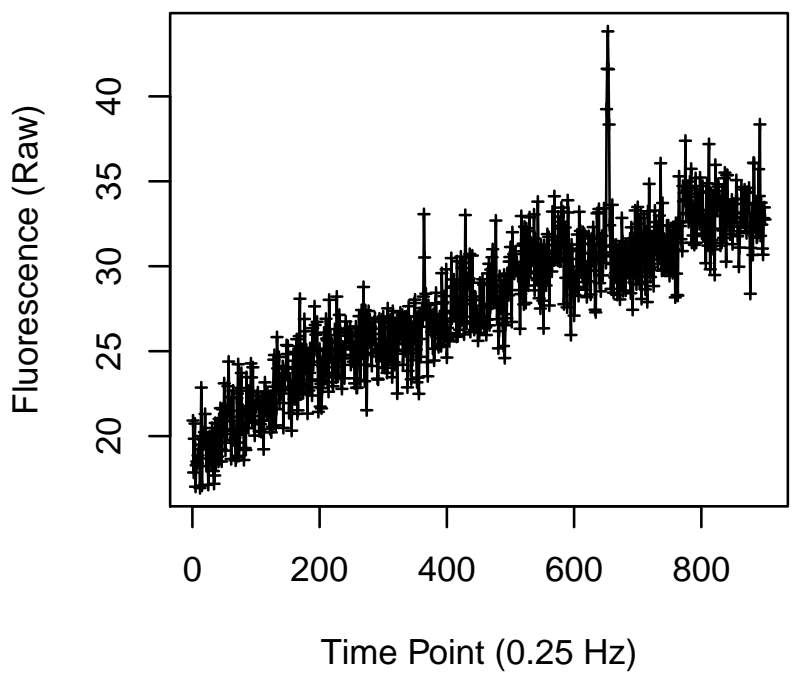

Cell 1202

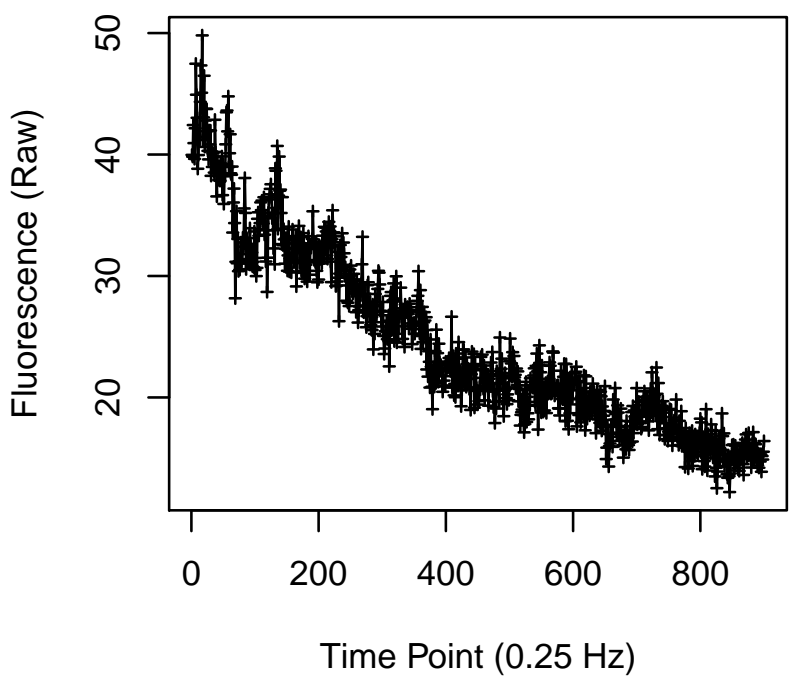

Cell 1204

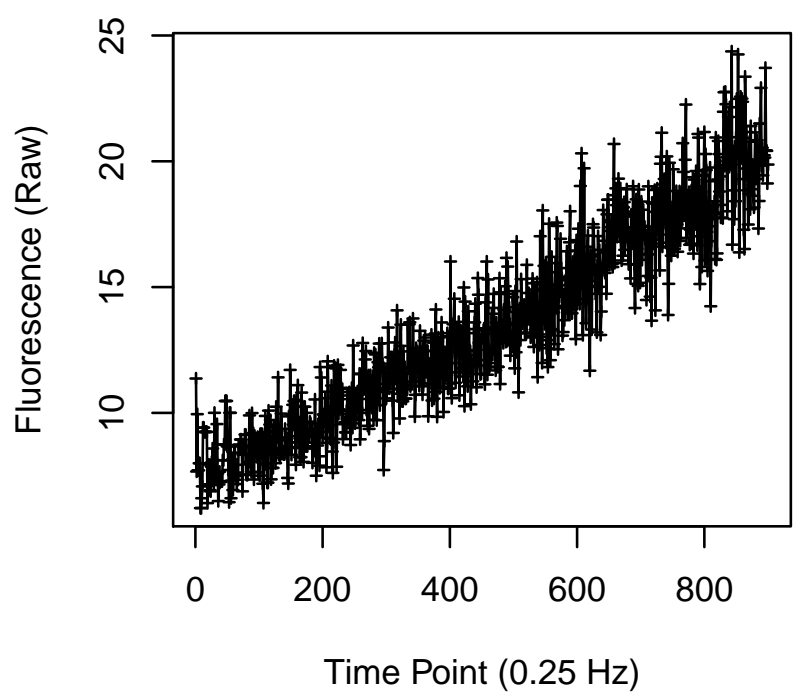


Cell 1205

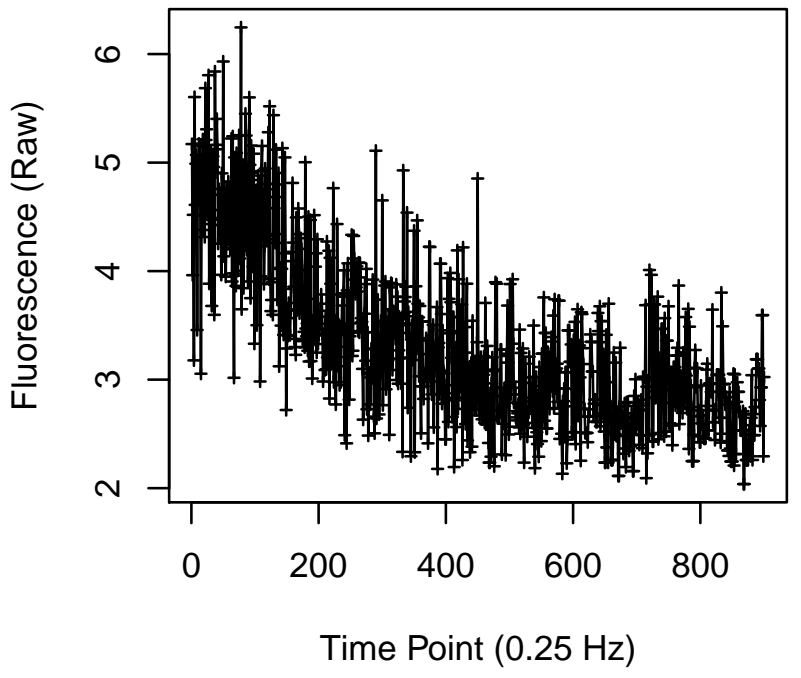

Cell 1207

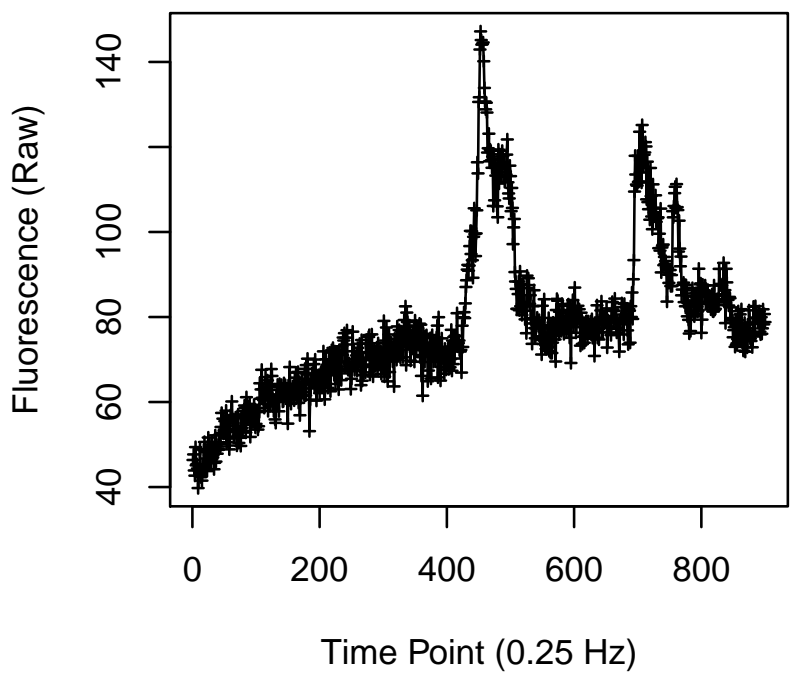

Cell 1206

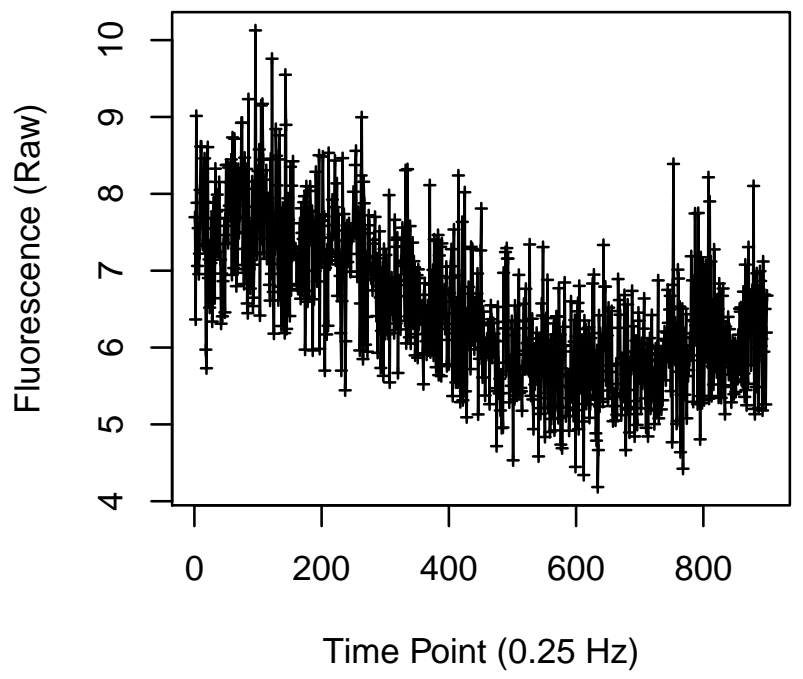

Cell 1208

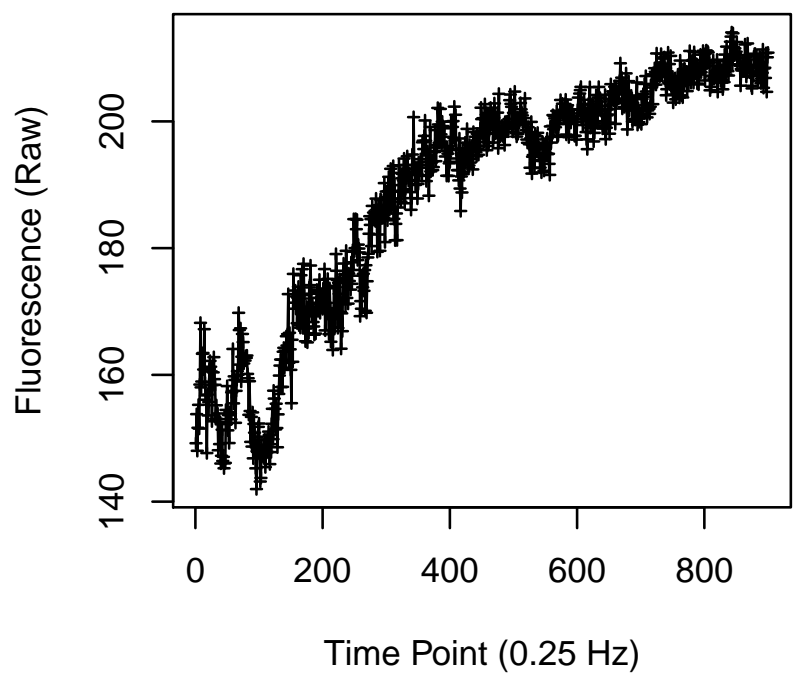


Cell 1213

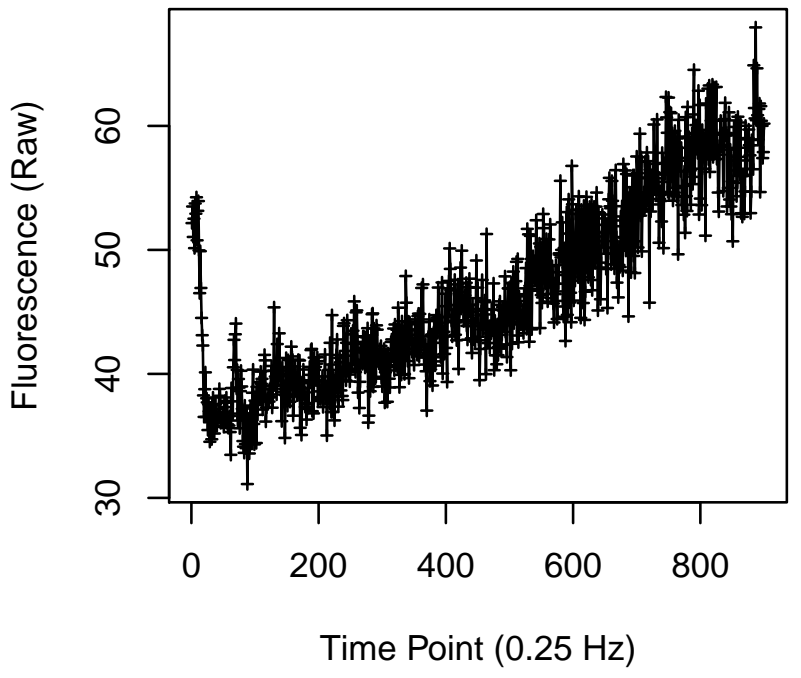

Cell 1215

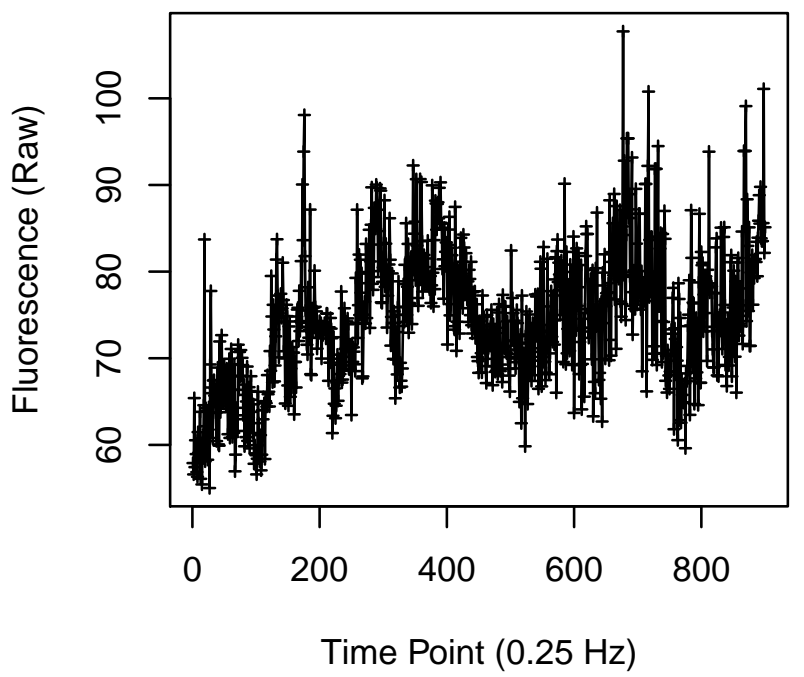

Cell 1214

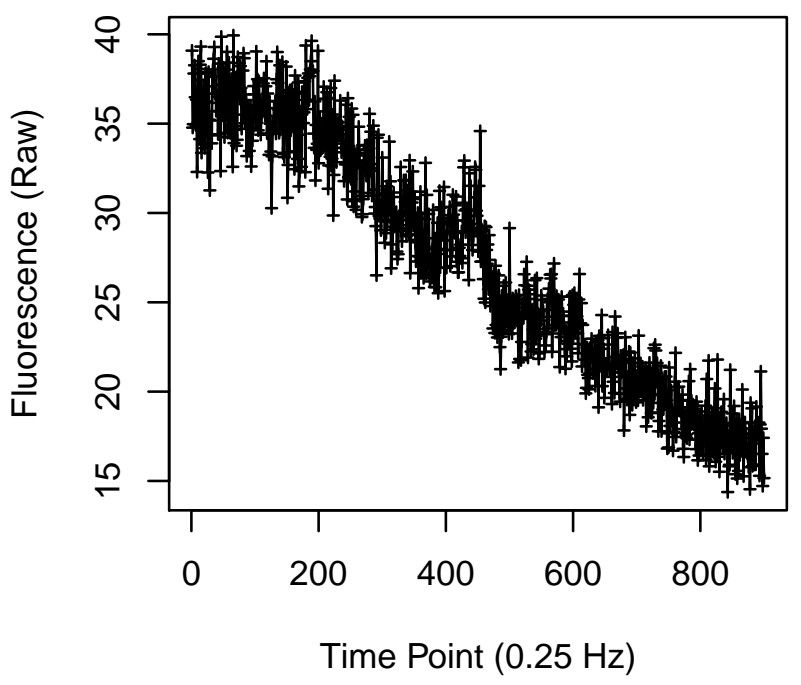

Cell 1216

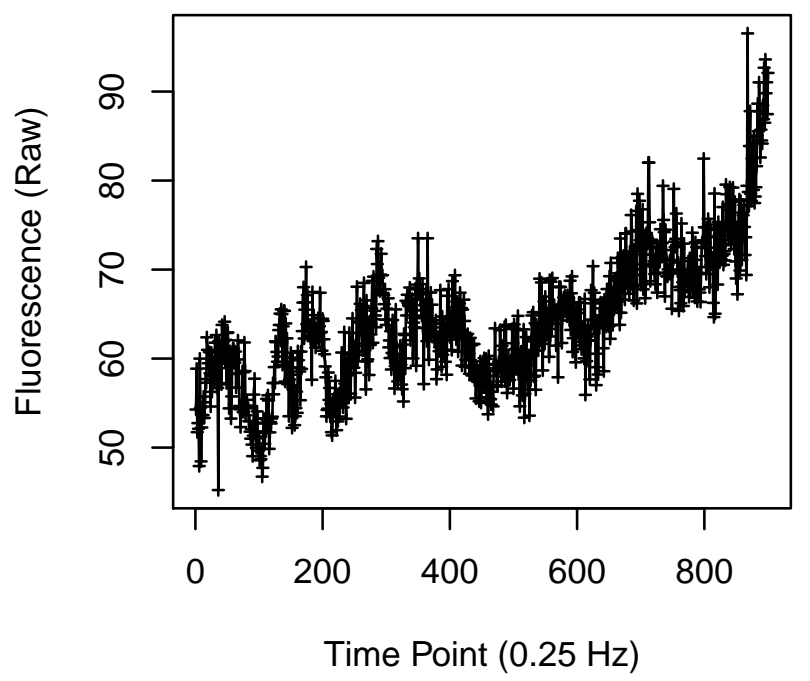


Cell 1217

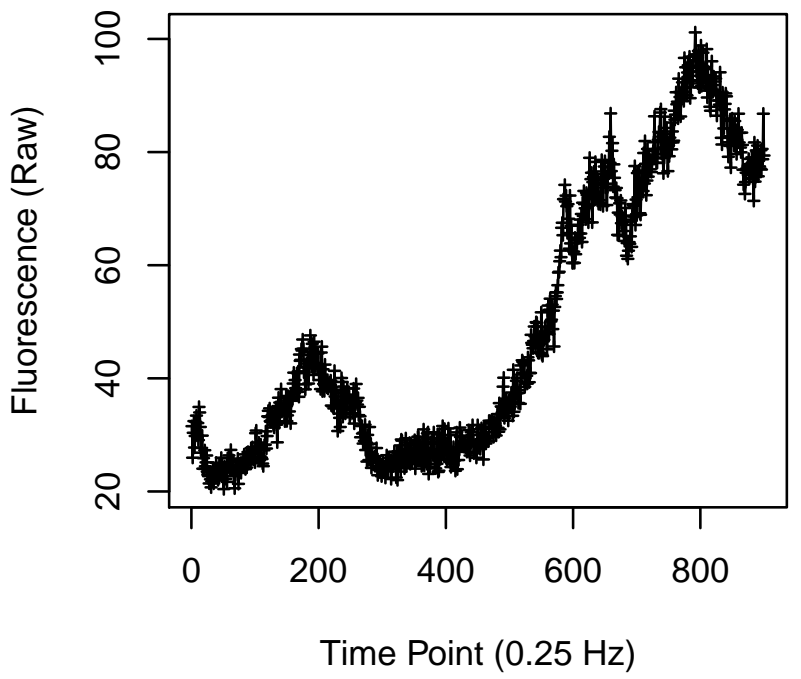

Cell 1219

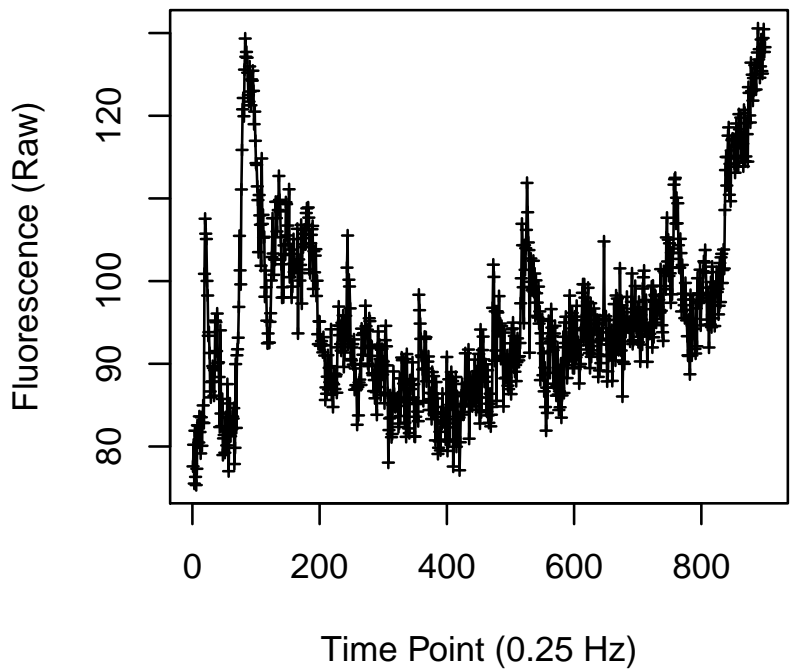

Cell 1218

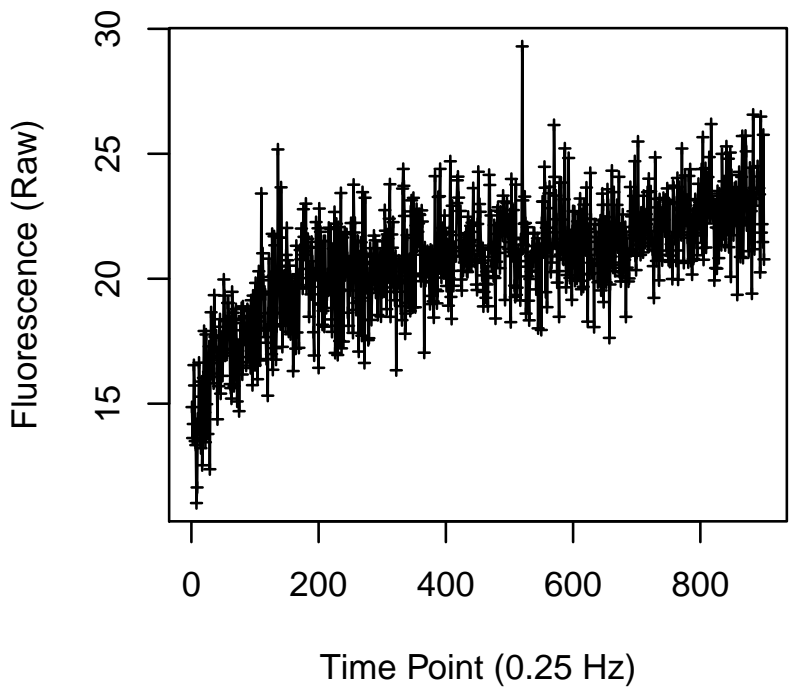

Cell 1220

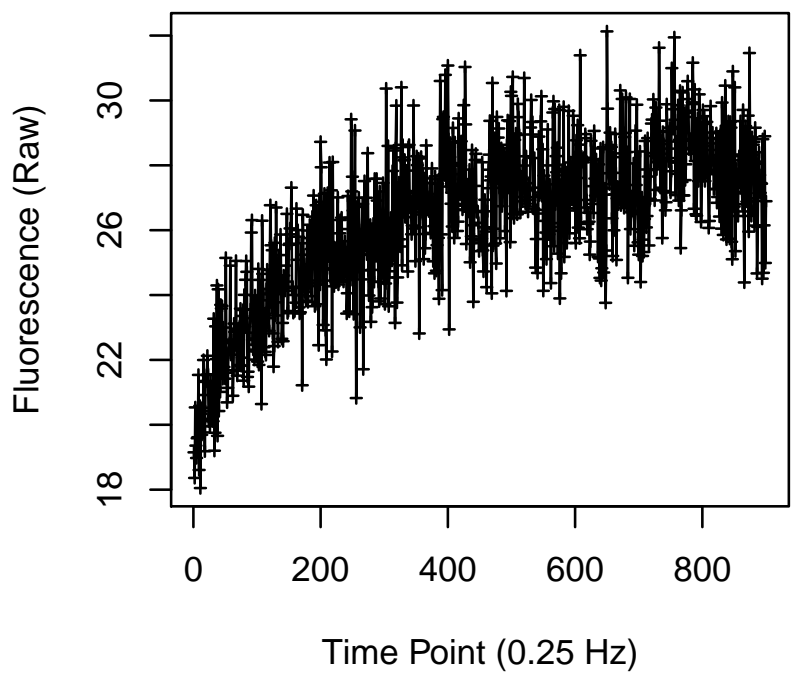


Cell 1221

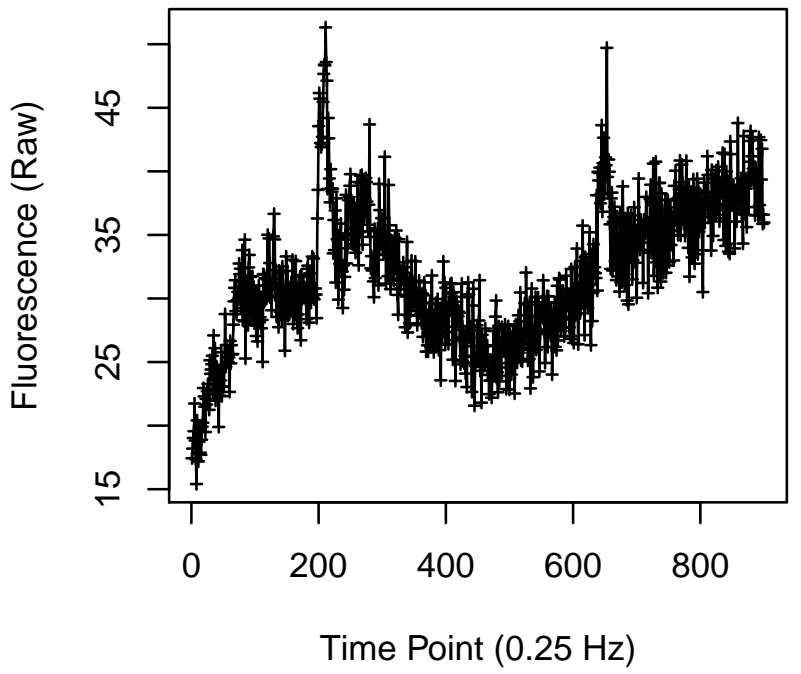

Cell 1223

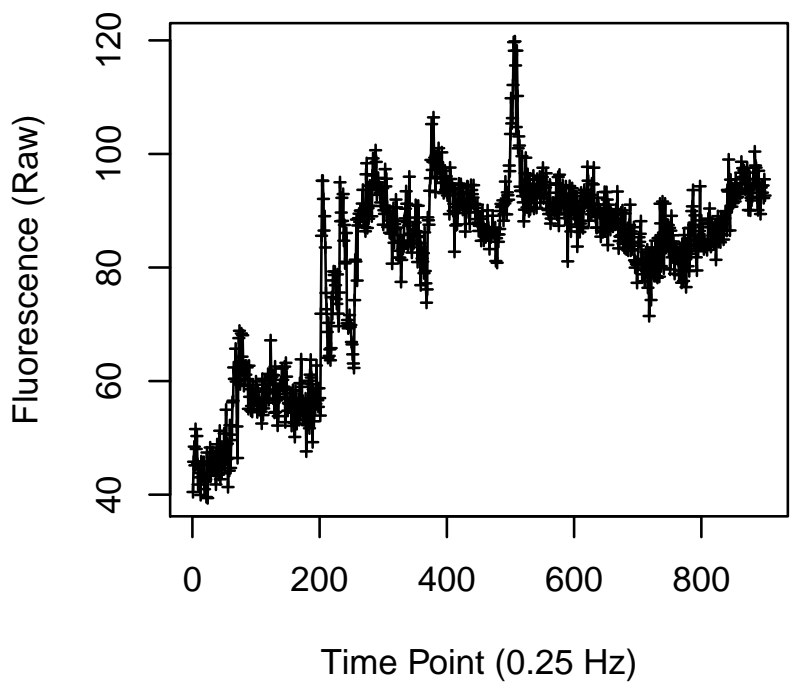

Cell 1222

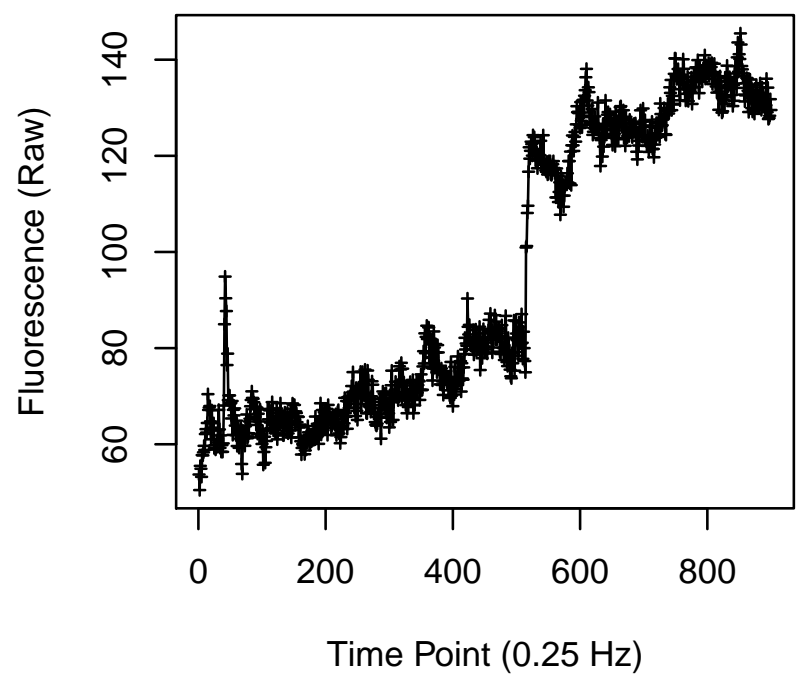

Cell 1224

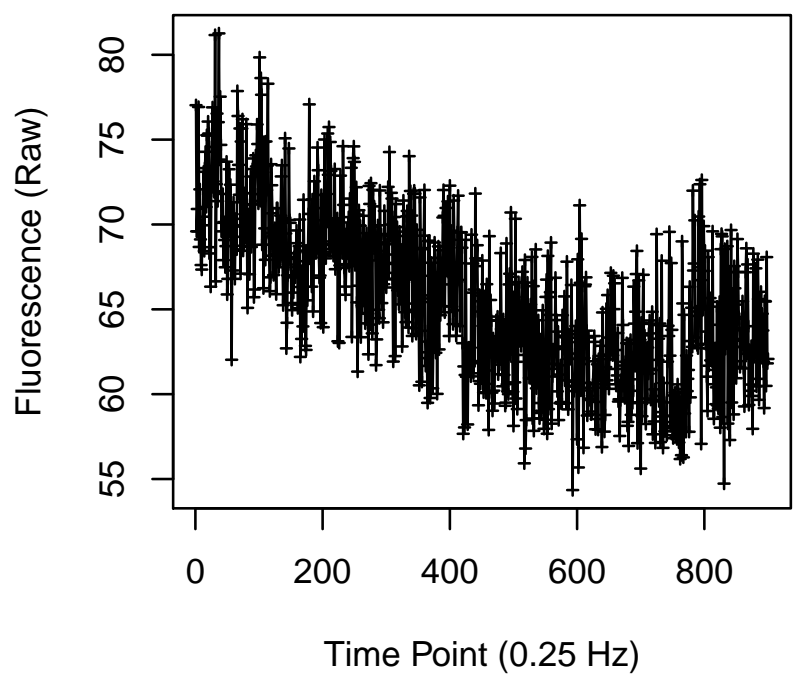


Cell 1225

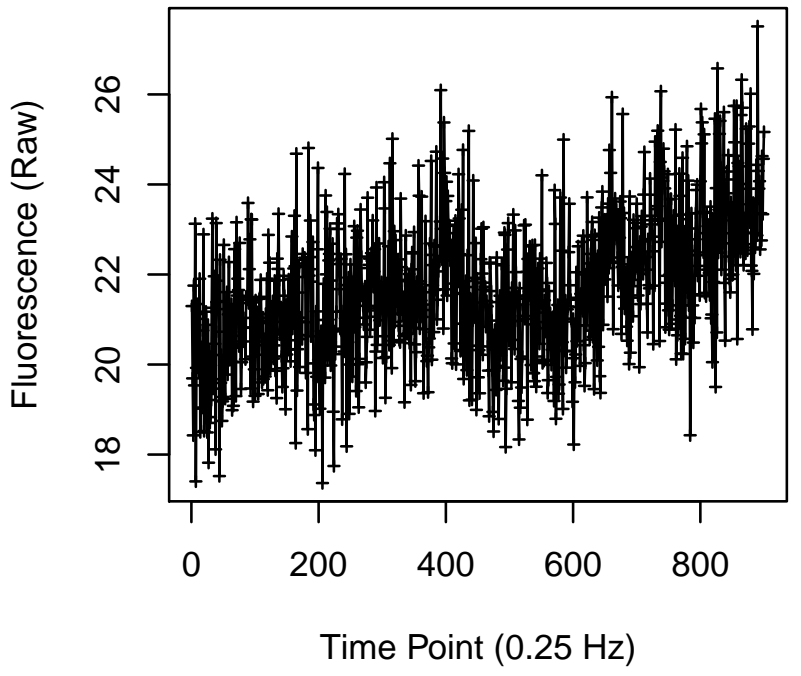

Cell 1227

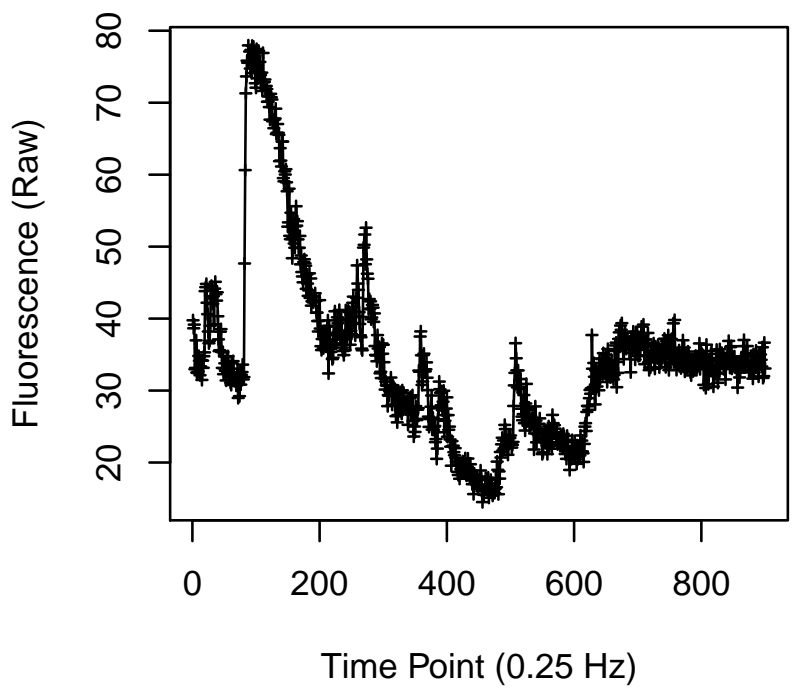

Cell 1226

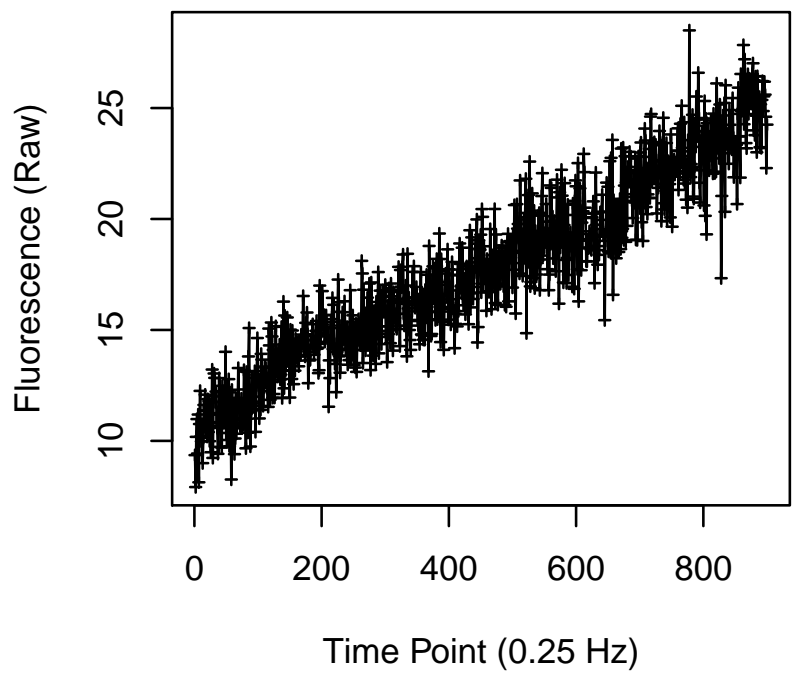

Cell 1228

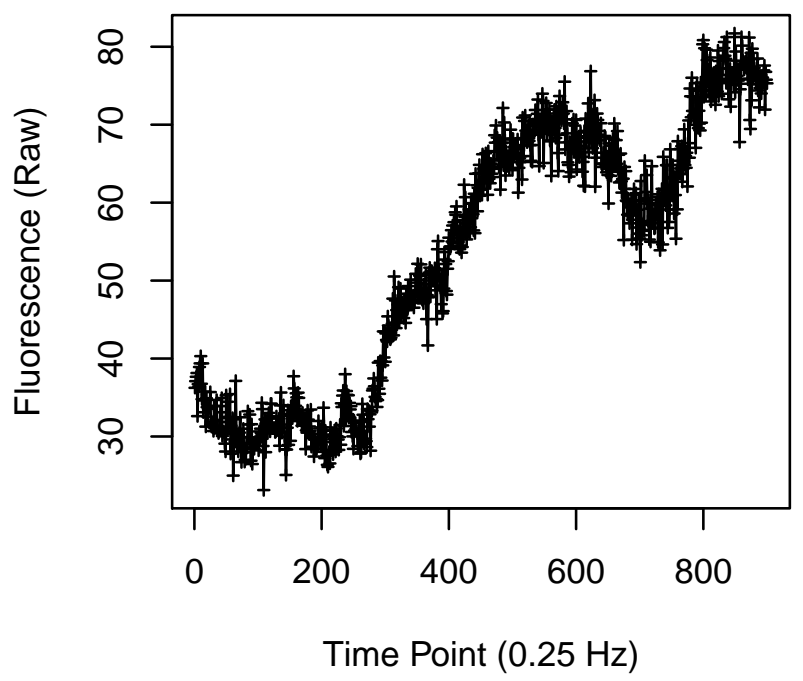


Cell 1229

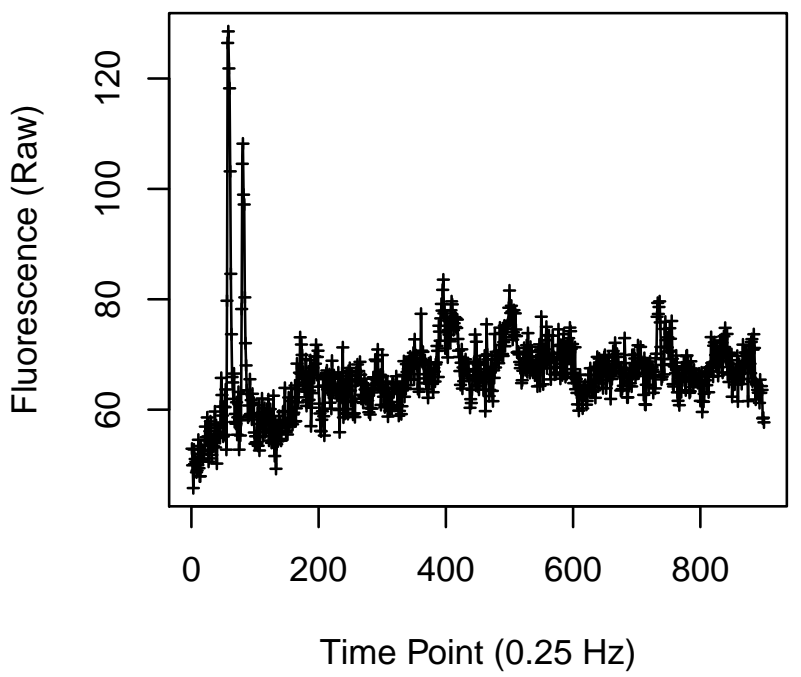

Cell 1231

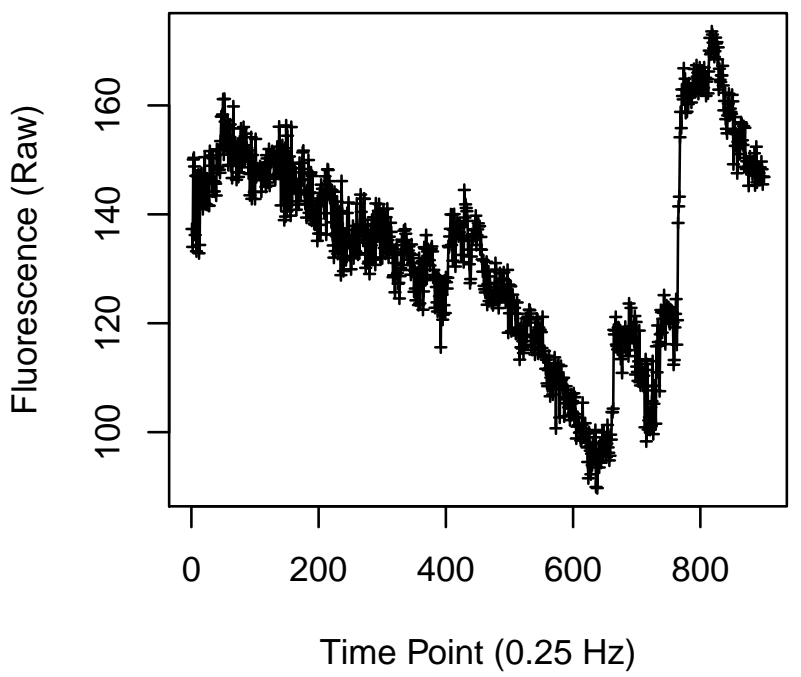

Cell 1230

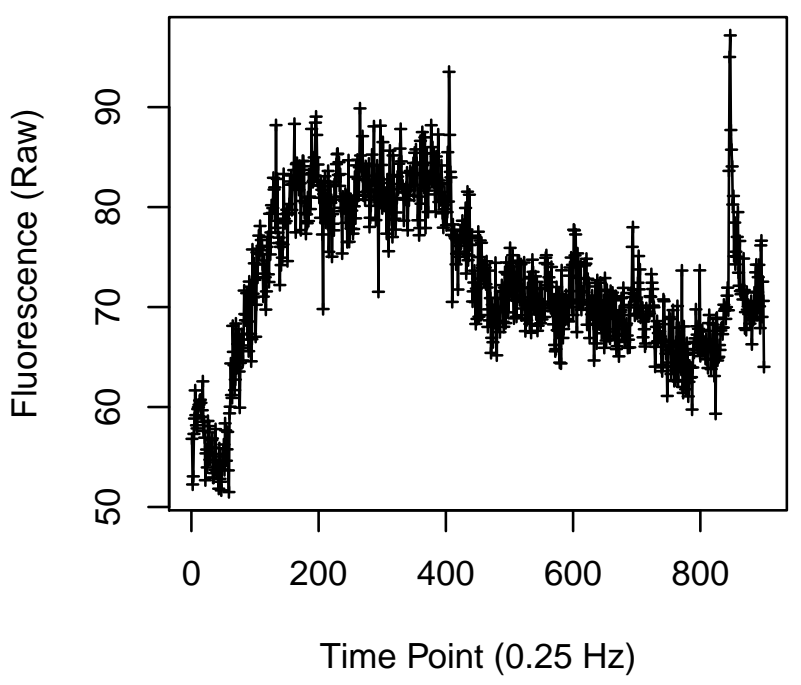

Cell 1232

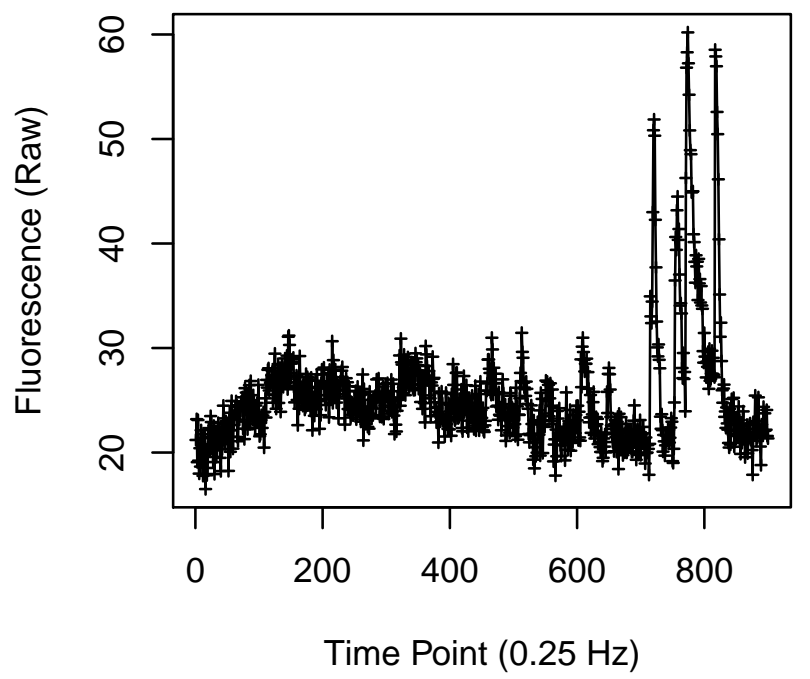


Cell 1233

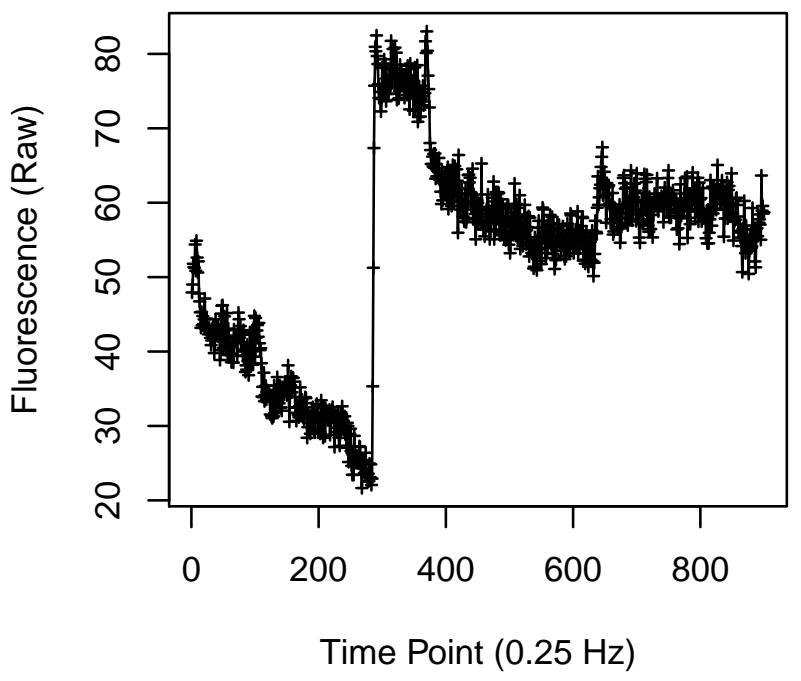

Cell 1235

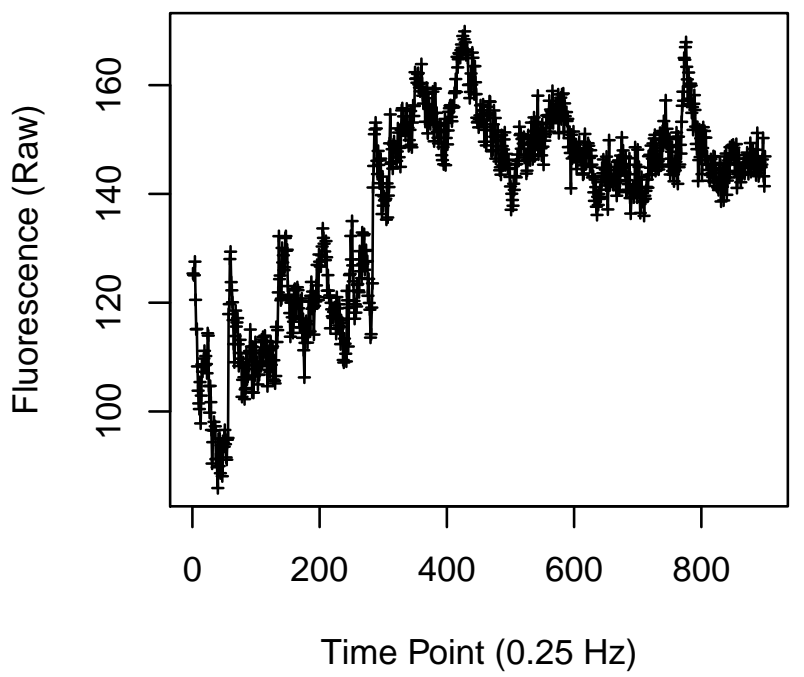

Cell 1234

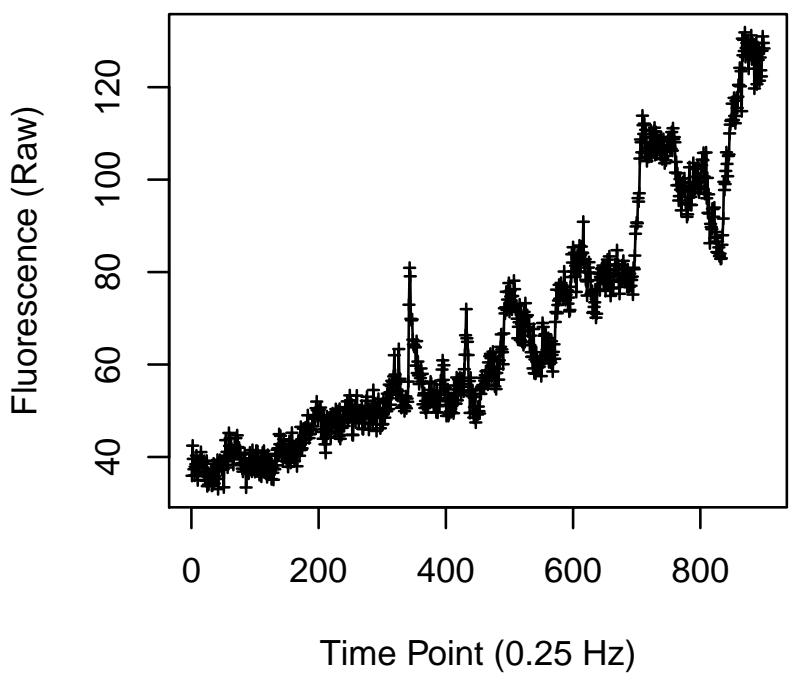

Cell 1236

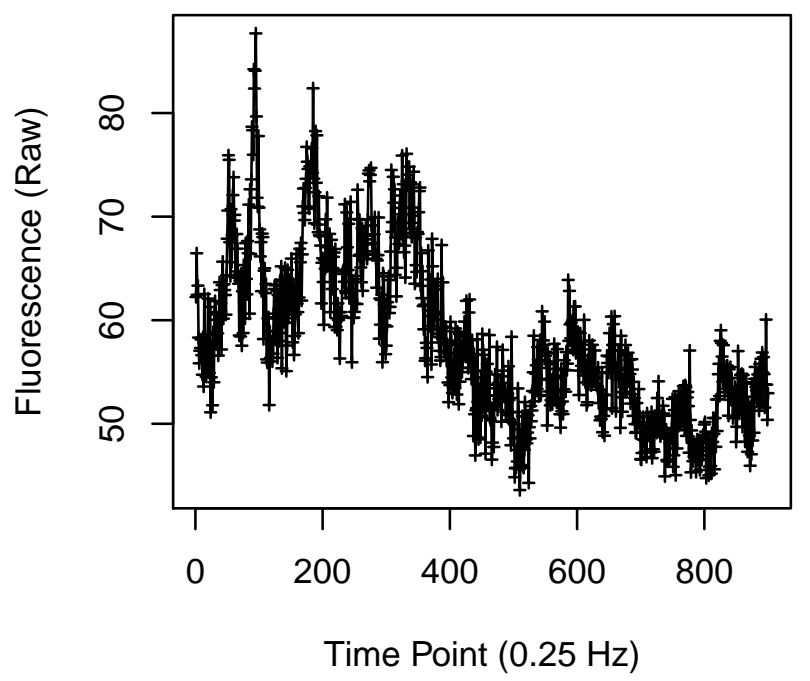


Cell 1237

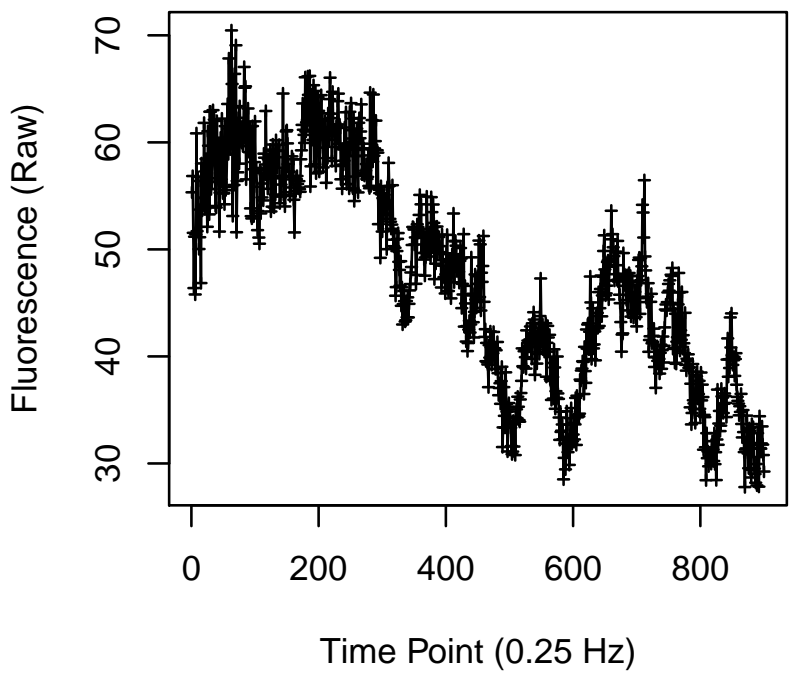

Cell 1239

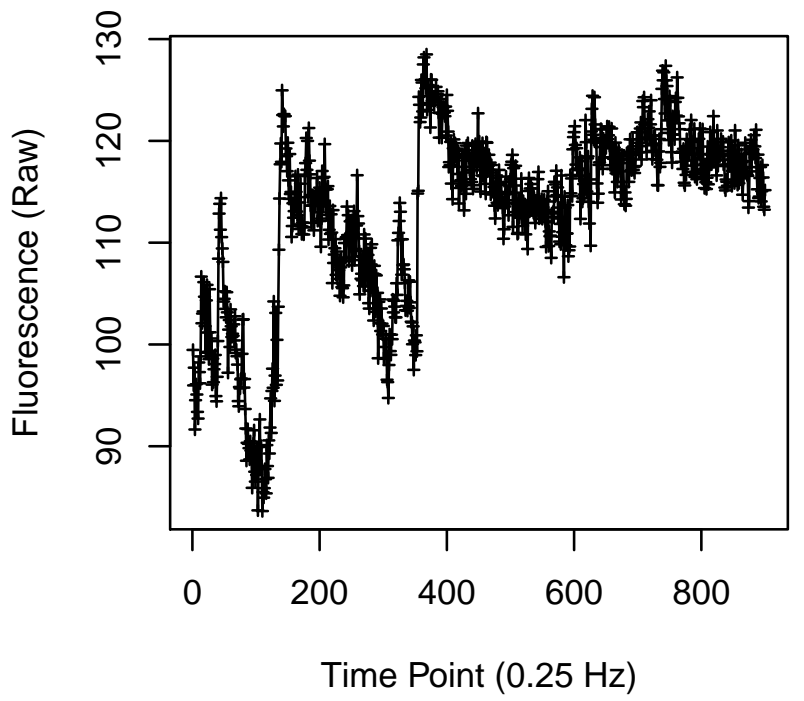

Cell 1238

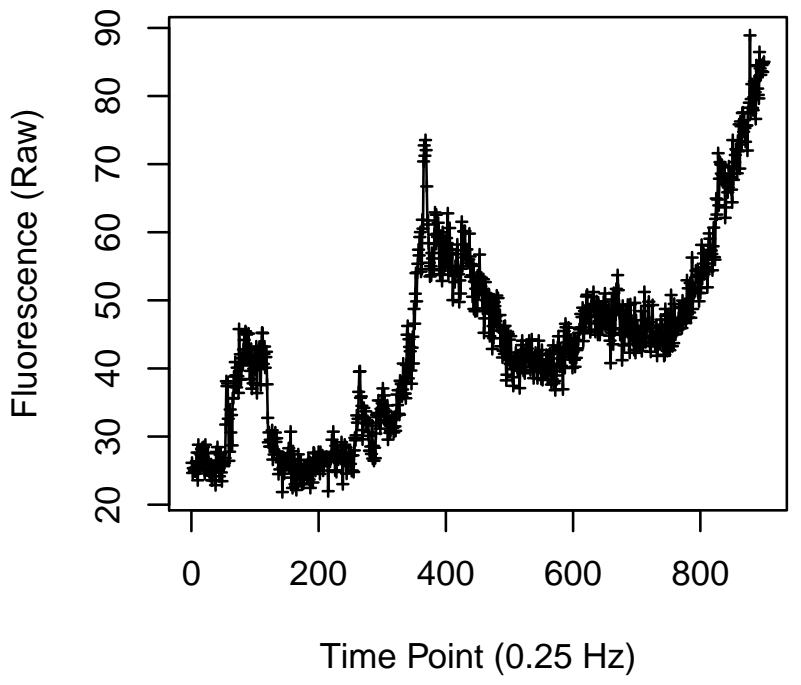

Cell 1240

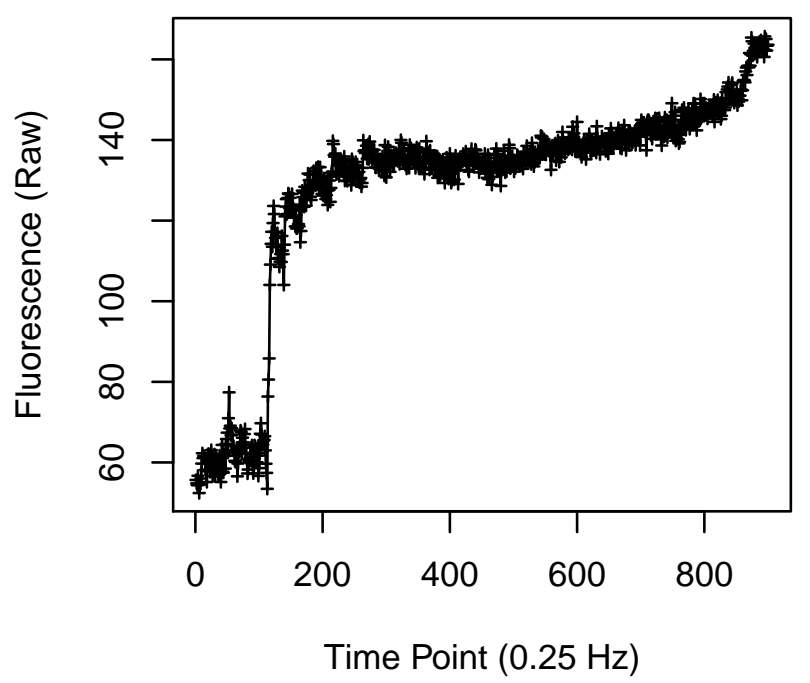


Cell 1241

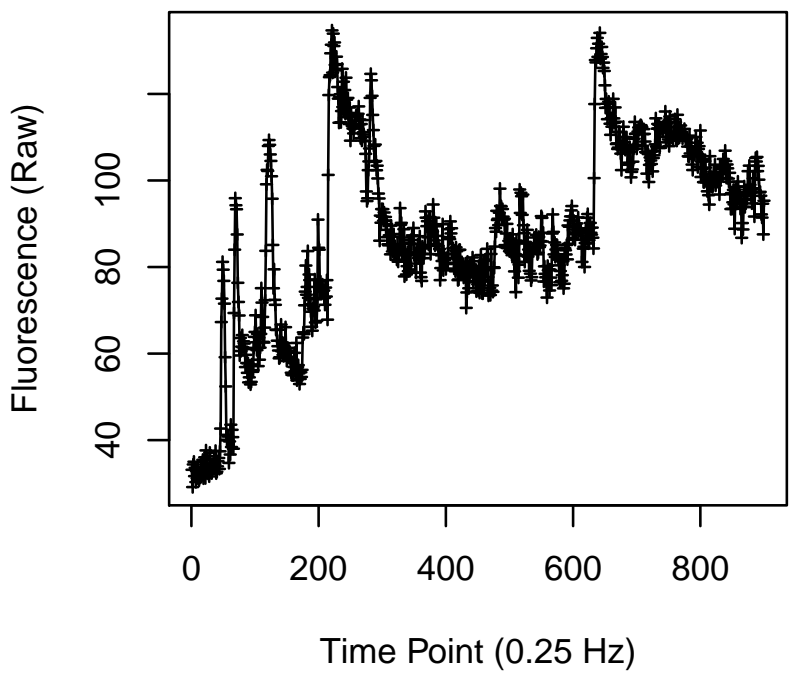

Cell 1243

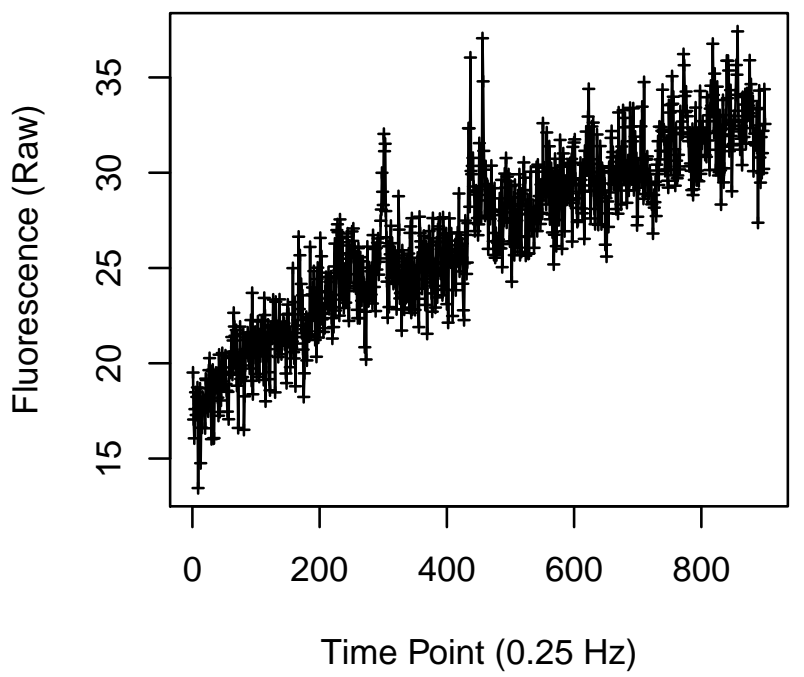

Cell 1242

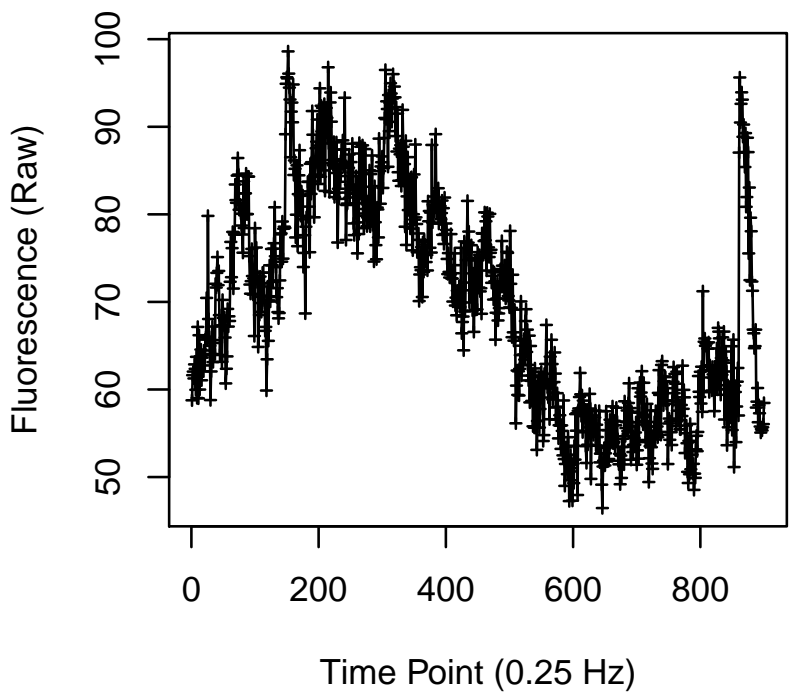

Cell 1244

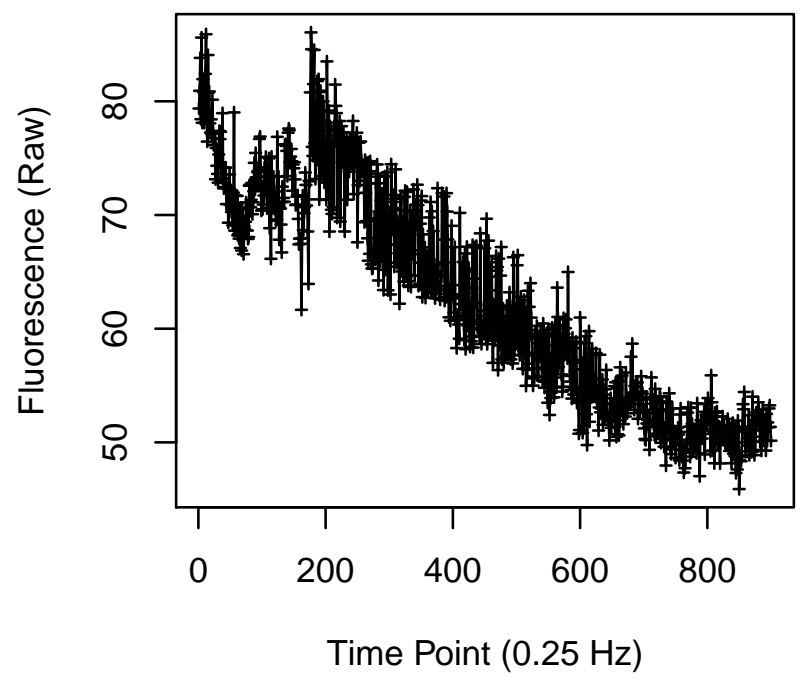


Cell 1245

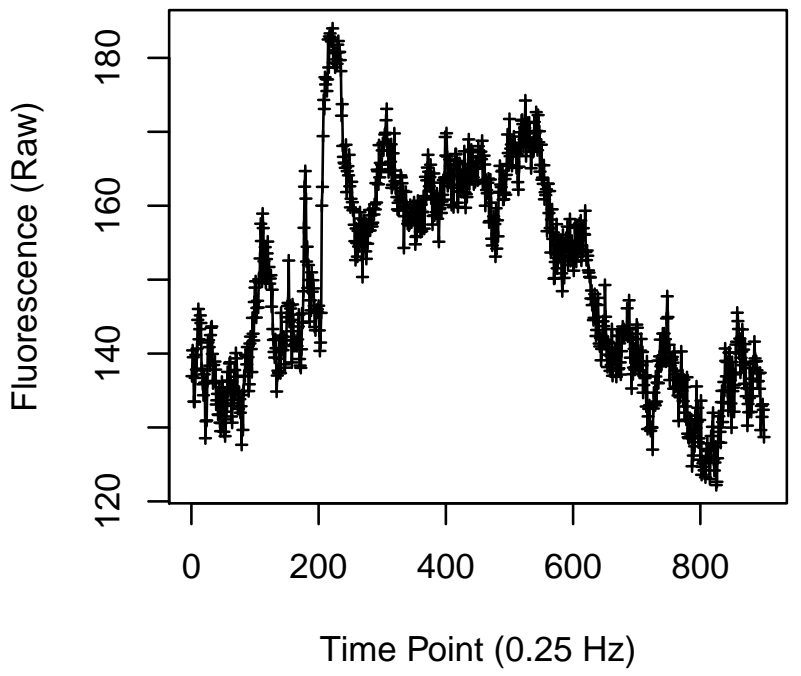

Cell 1247

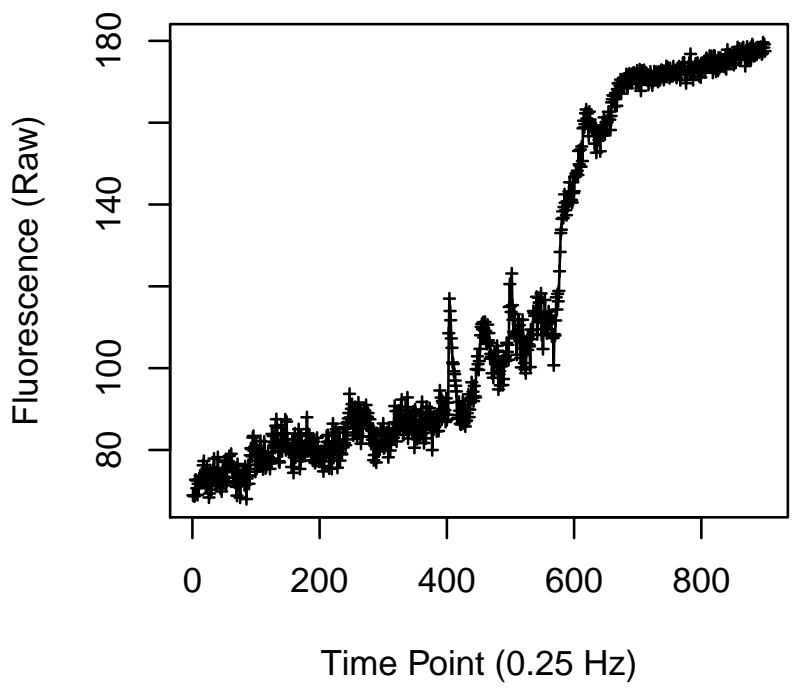

Cell 1246

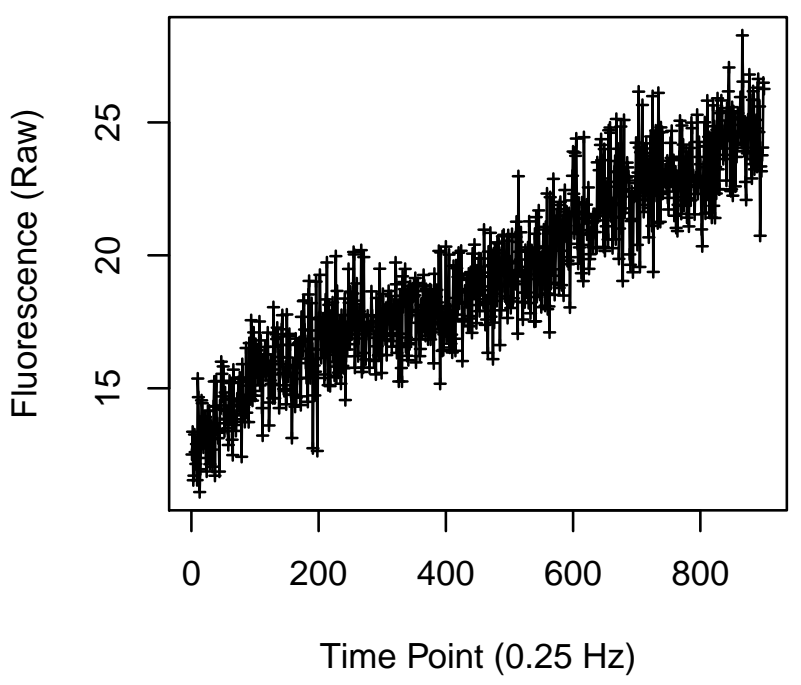

Cell 1248

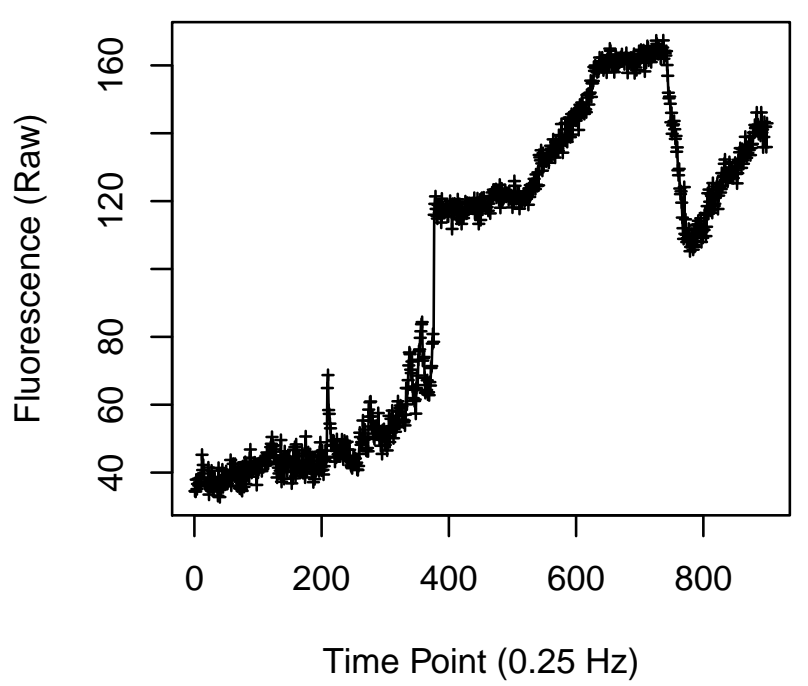


Cell 1249

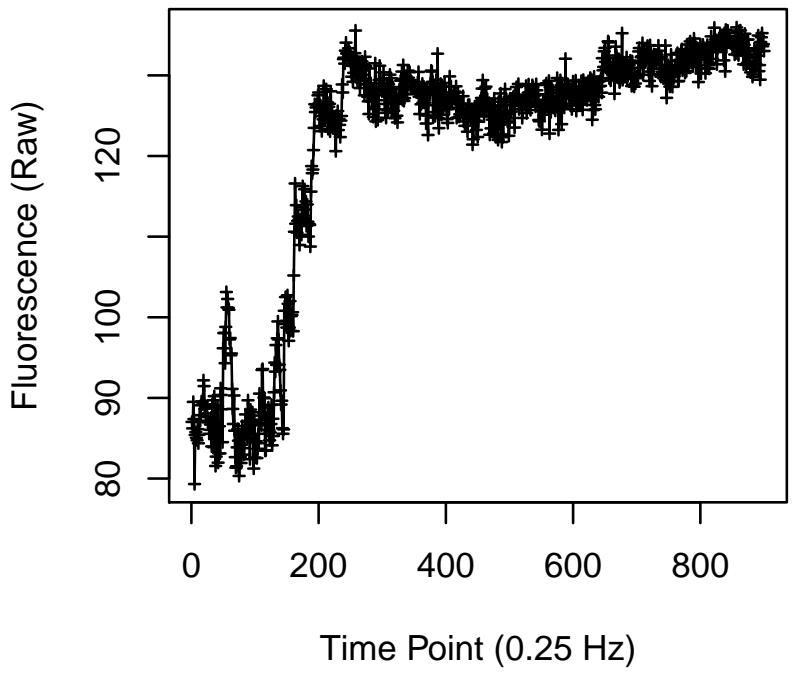

Cell 1251

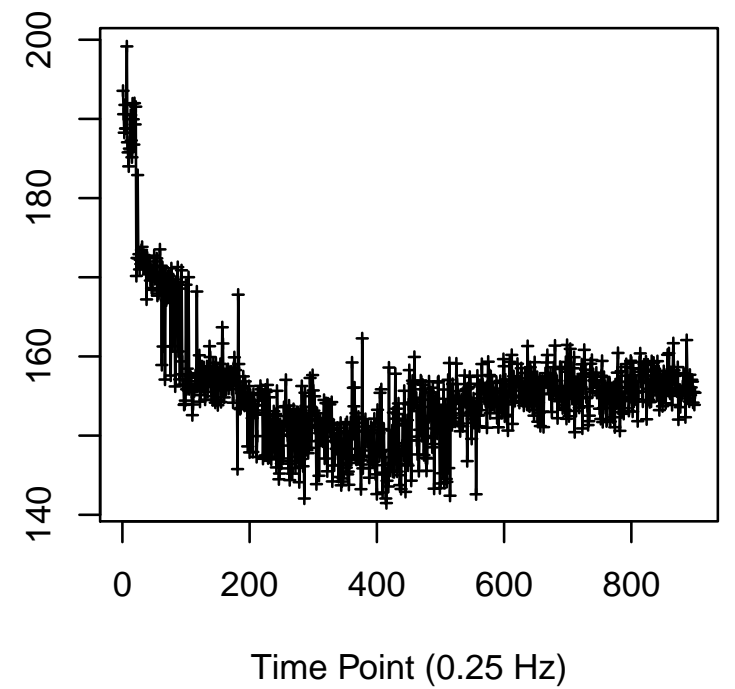

Cell 1250

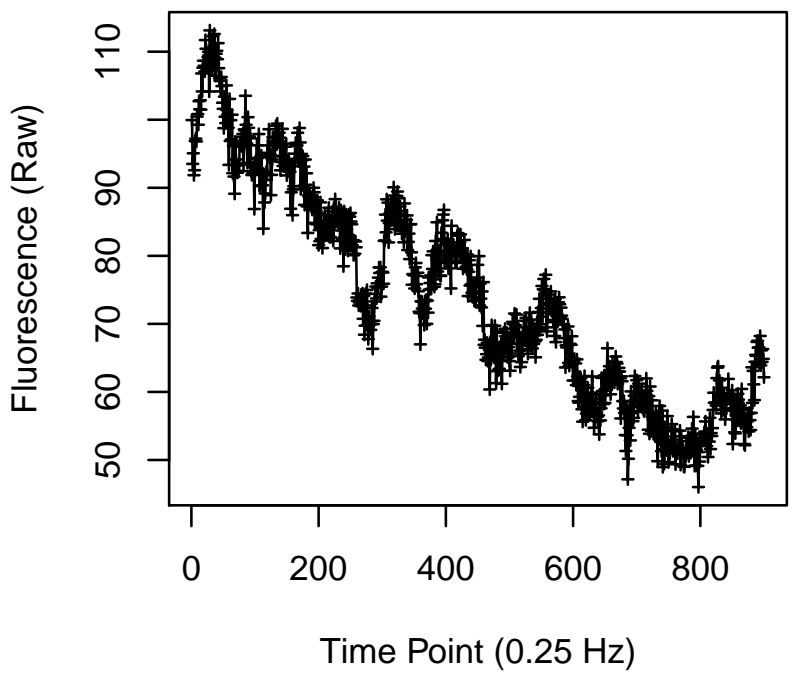

Cell 1252

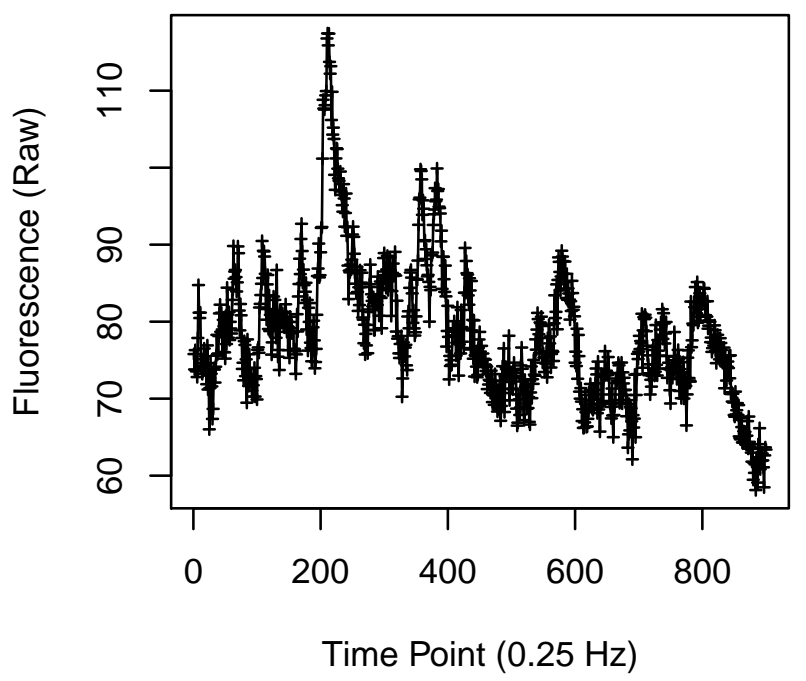


Cell 1253

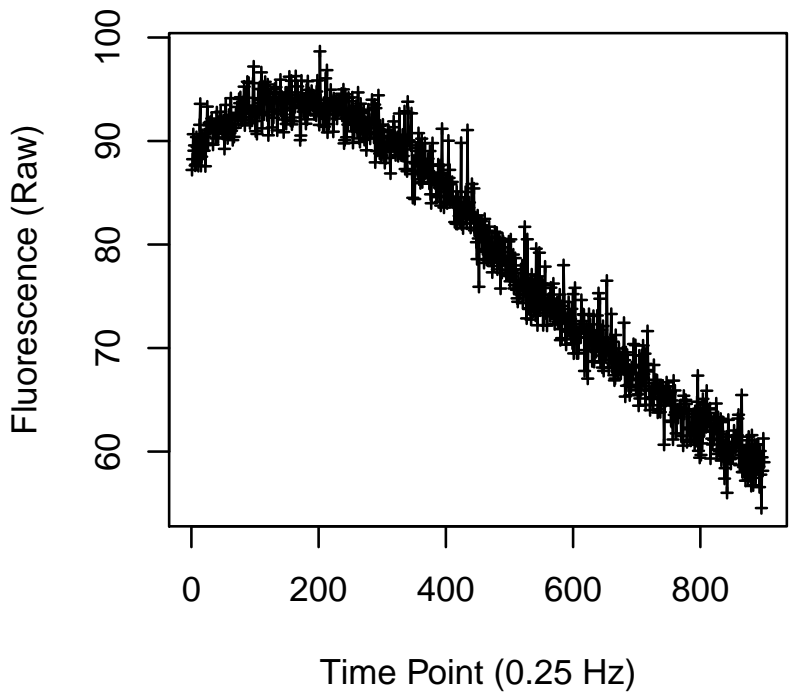

Cell 1255

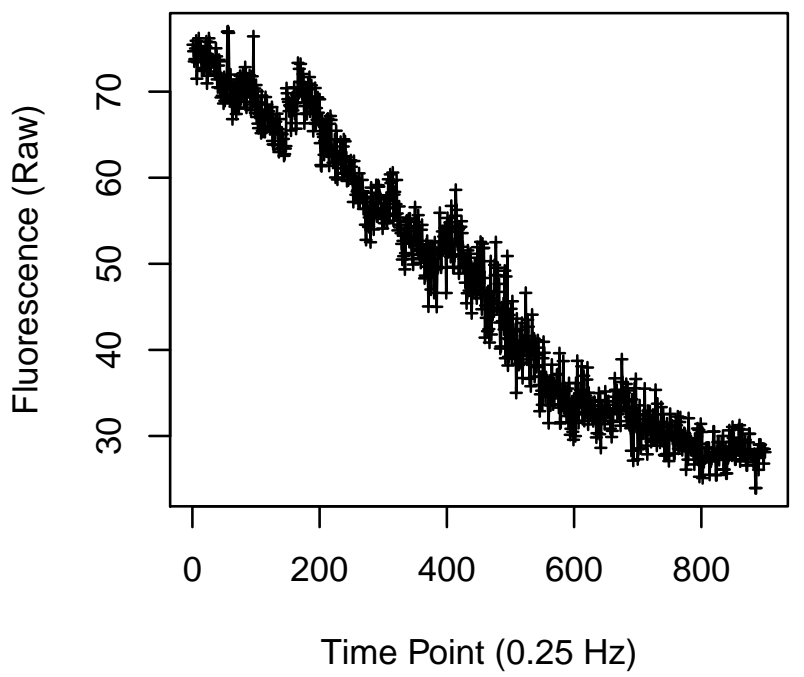

Cell 1254

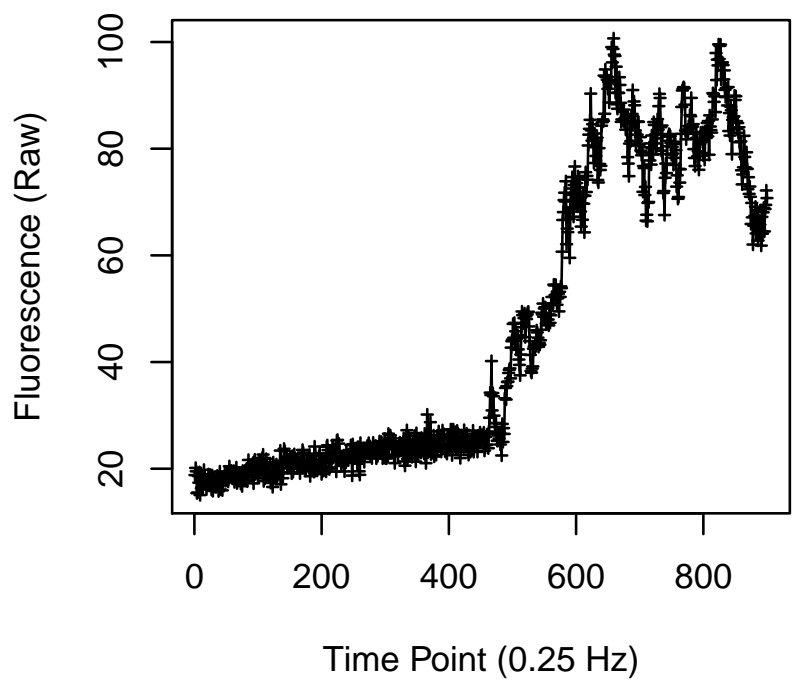

Cell 1256

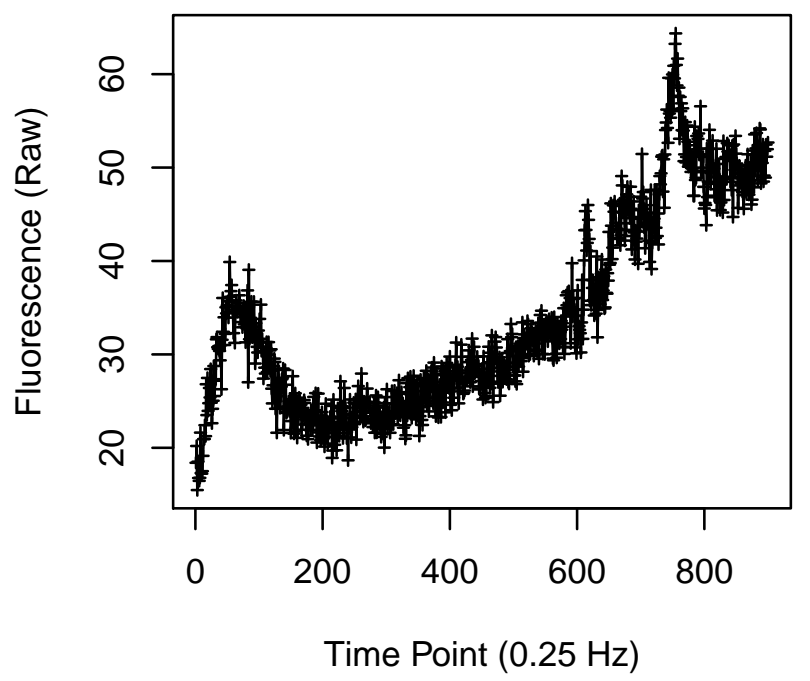


Cell 1265

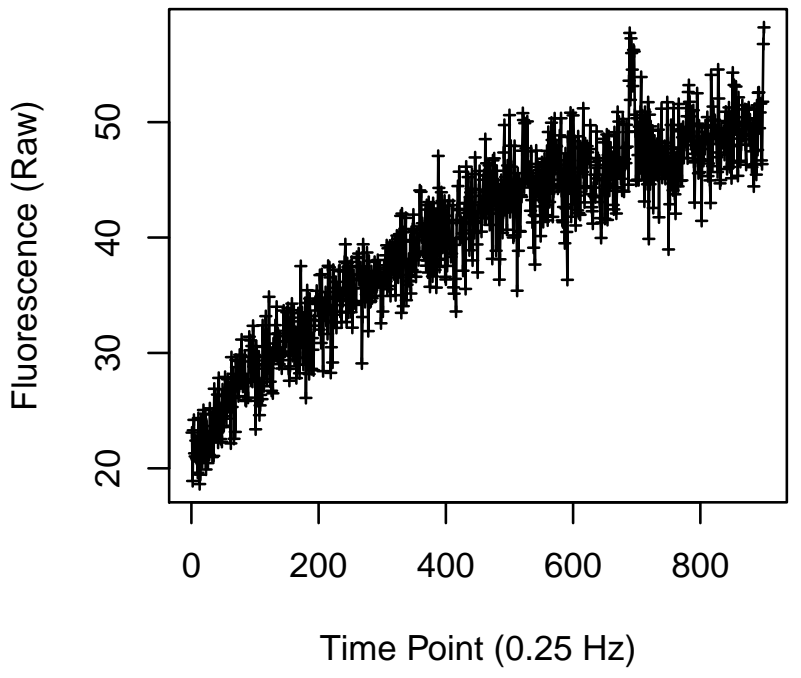

Cell 1267

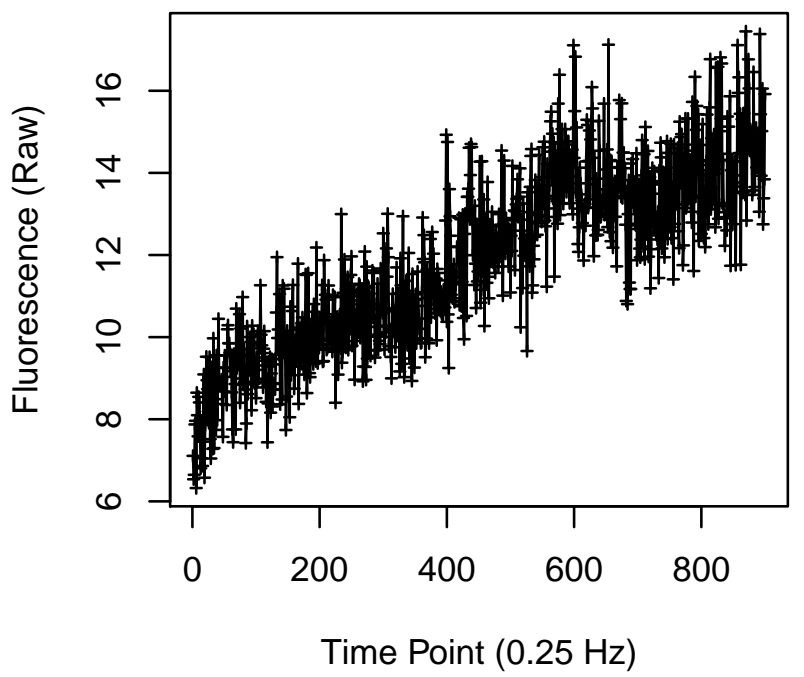

Cell 1266

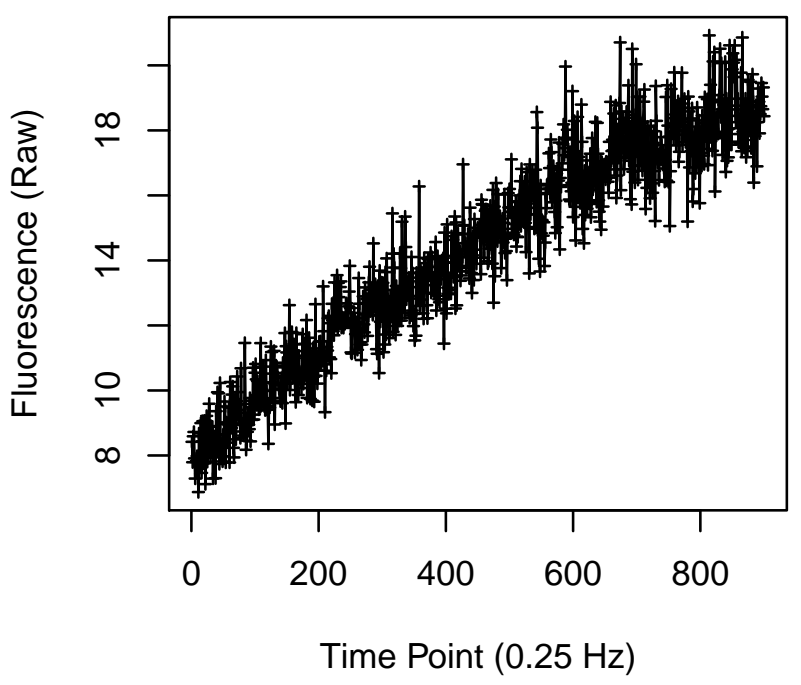

Cell 1268

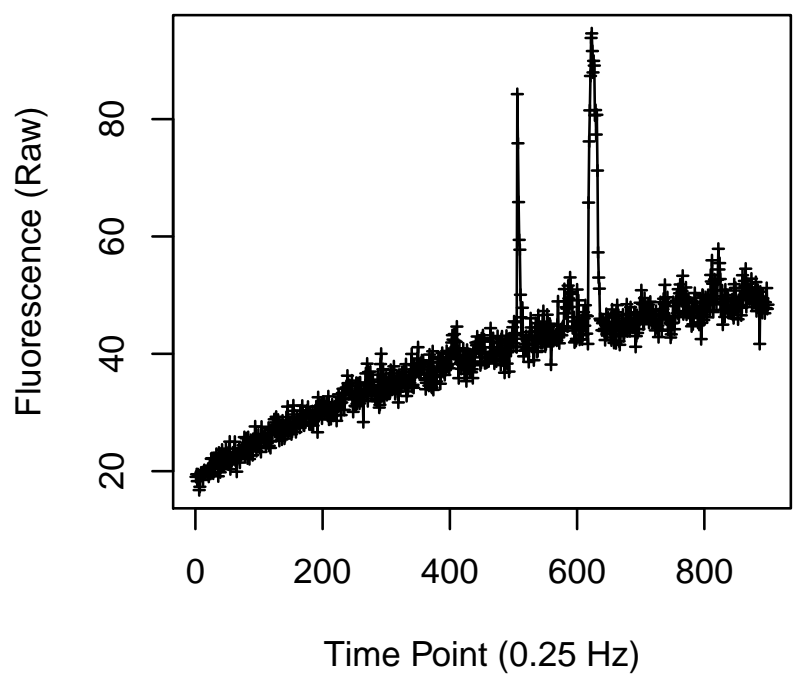


Cell 1269

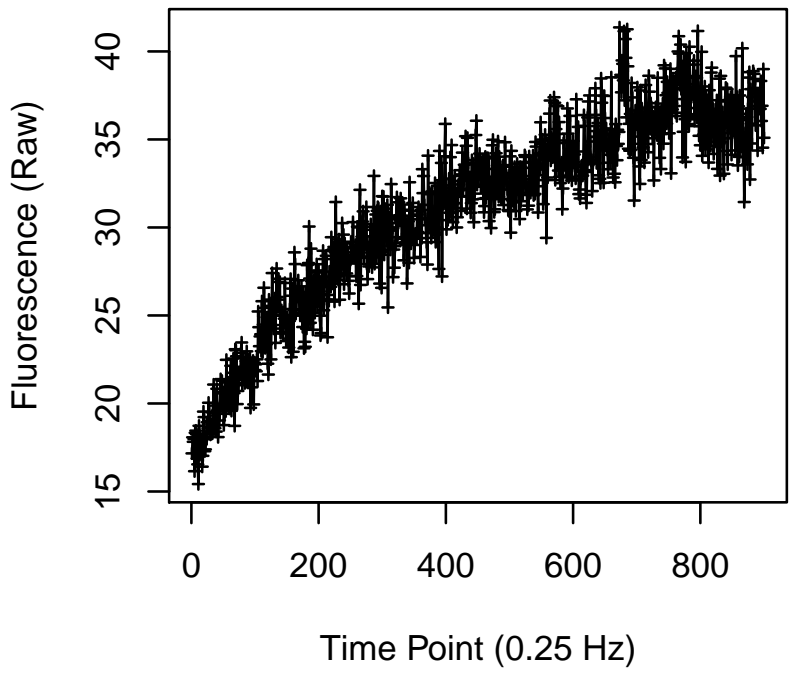

Cell 1271

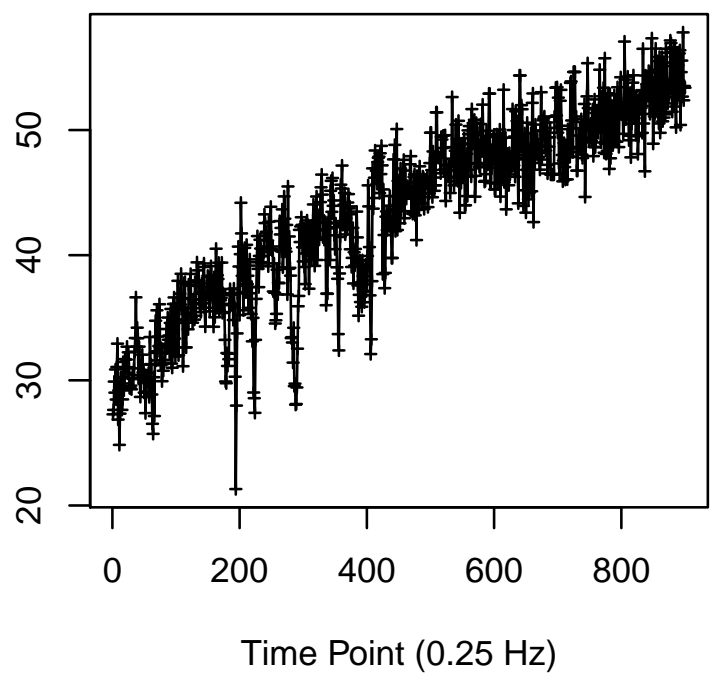

Cell 1270

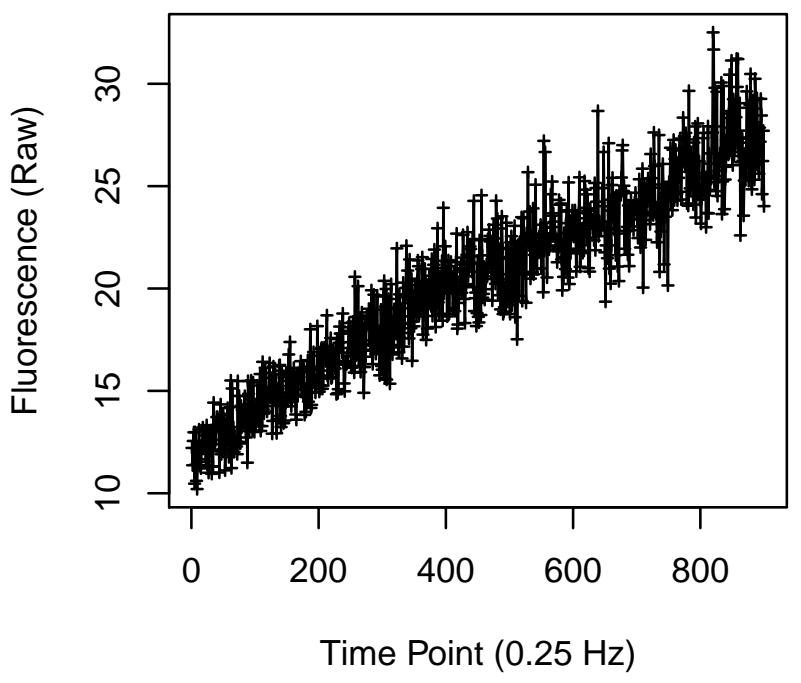

Cell 1272

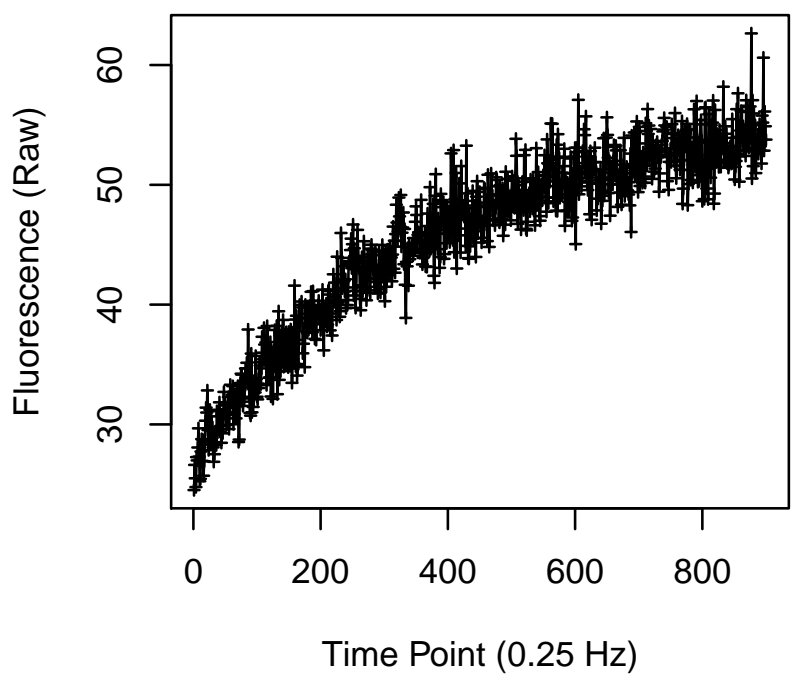


Cell 1273

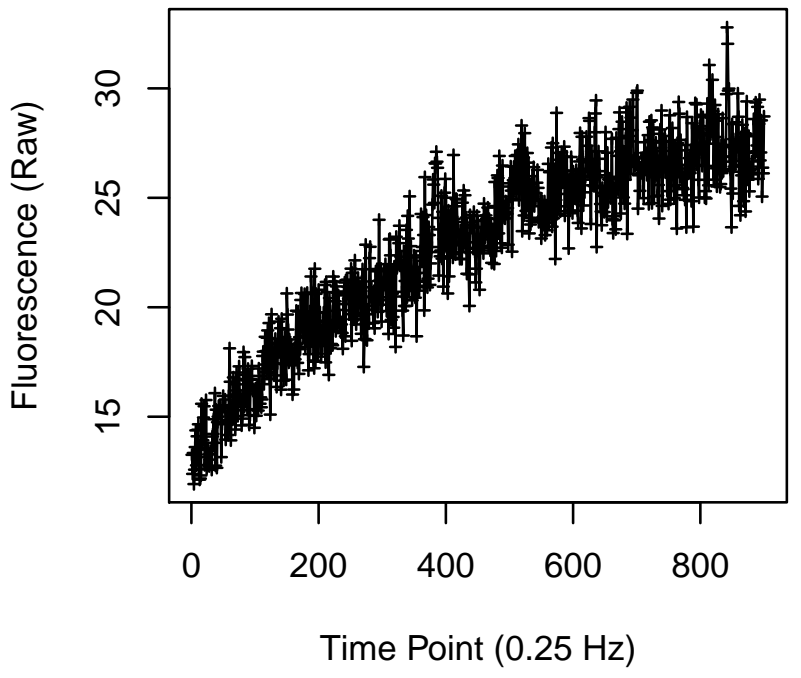

Cell 1275

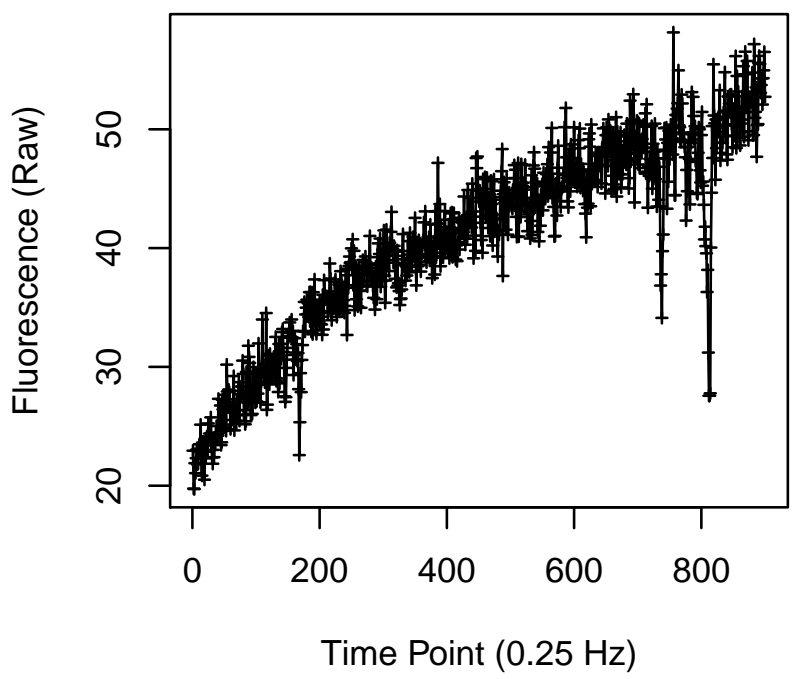

Cell 1274

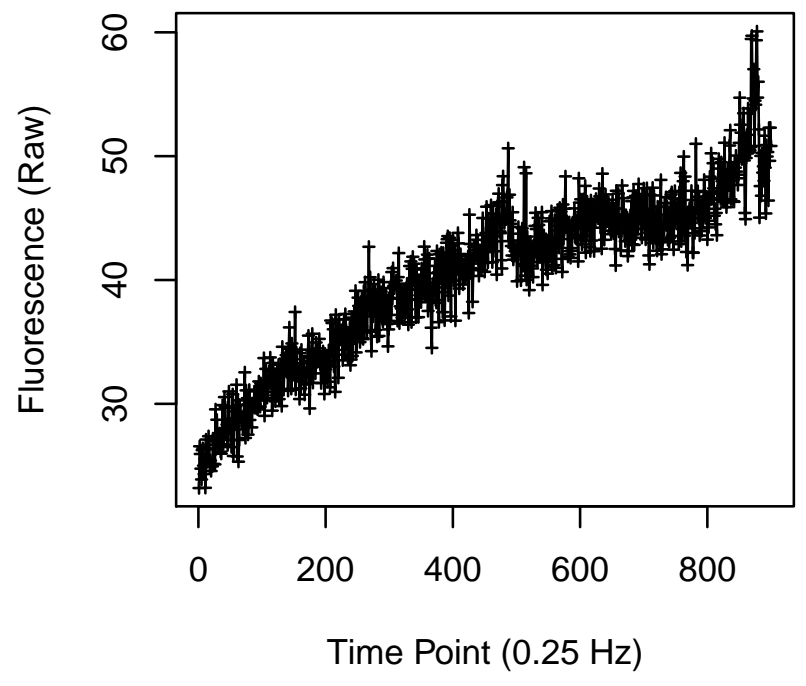

Cell 1276

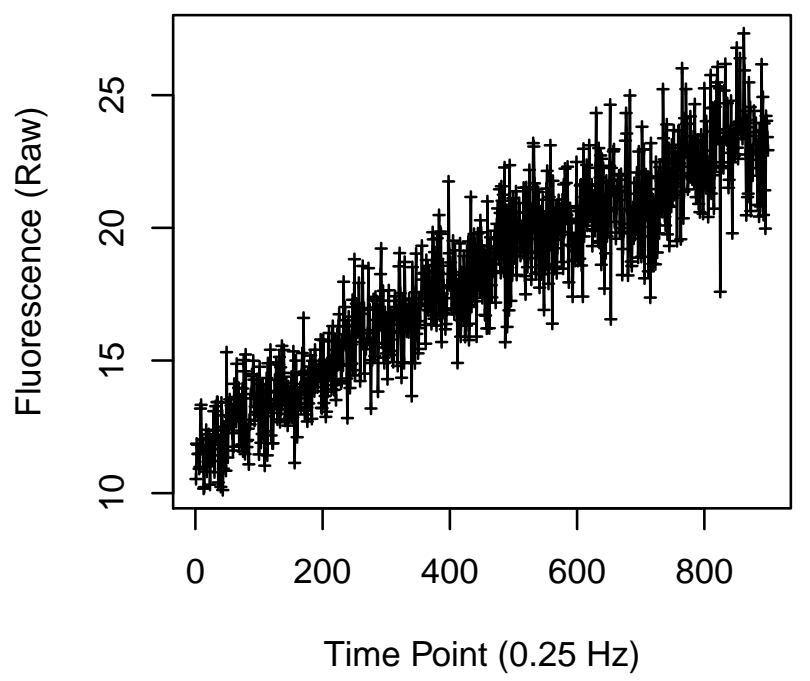


Cell 1277

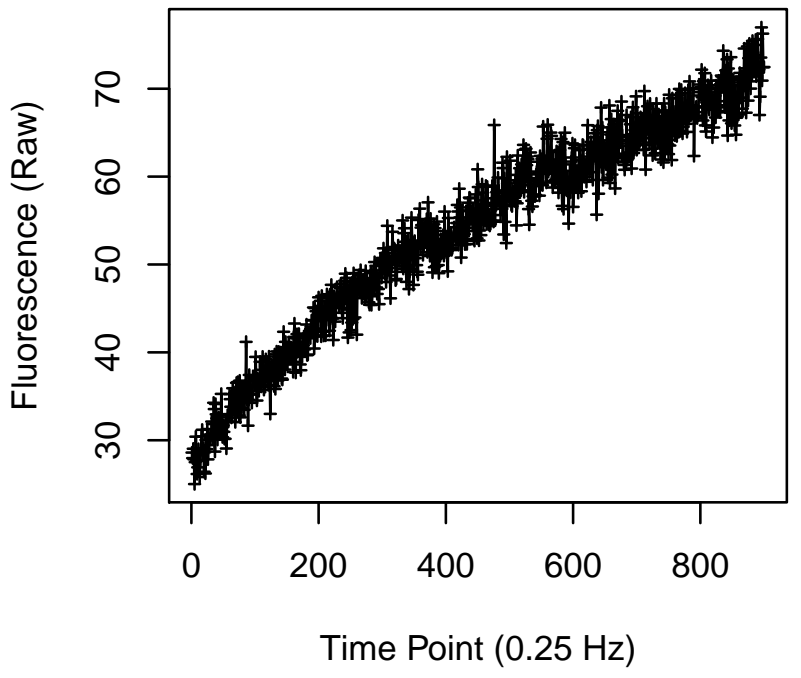

Cell 1279

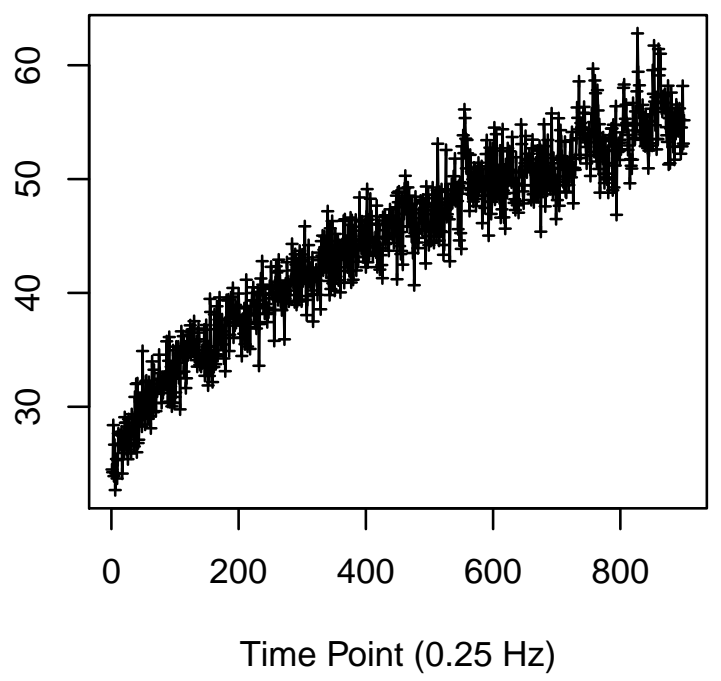

Cell 1278

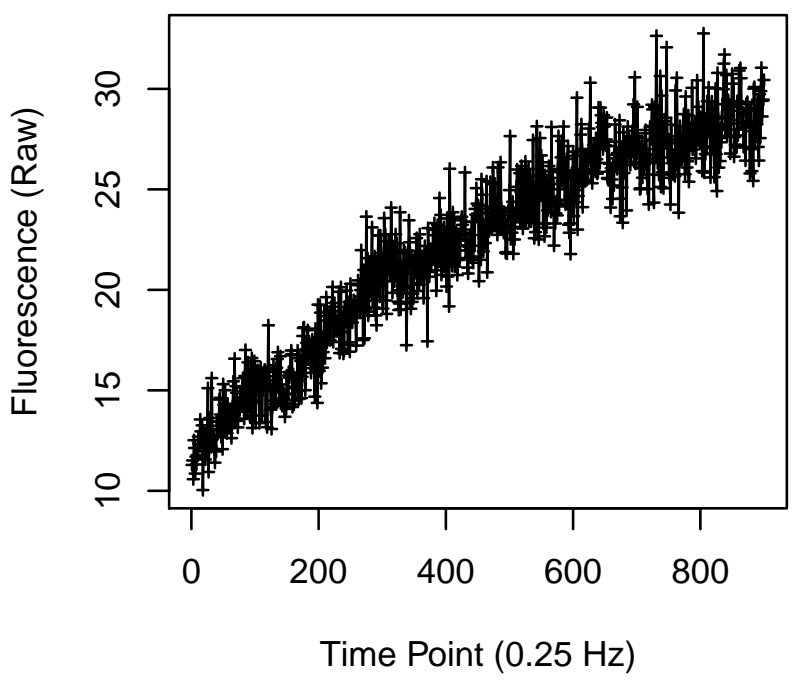

Cell 1280

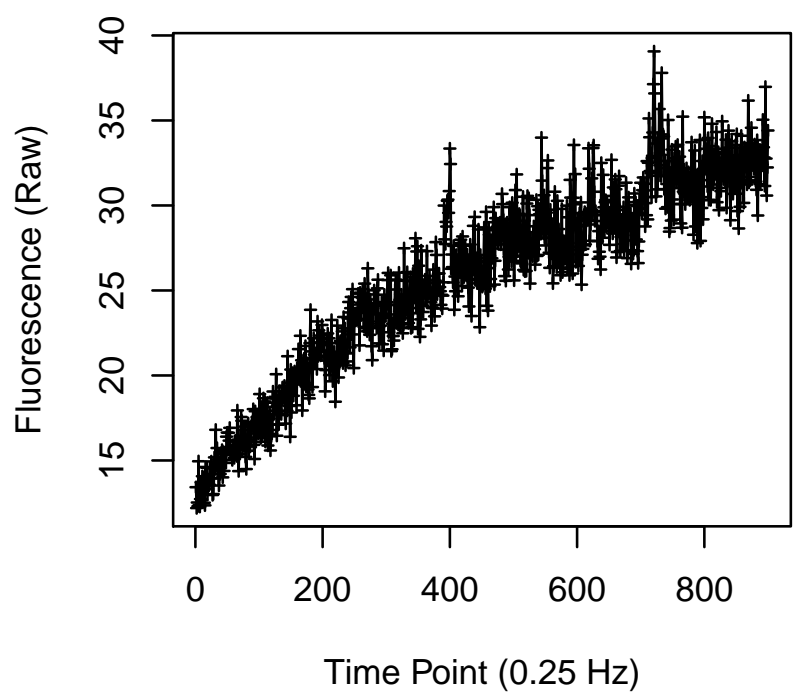


Cell 1281

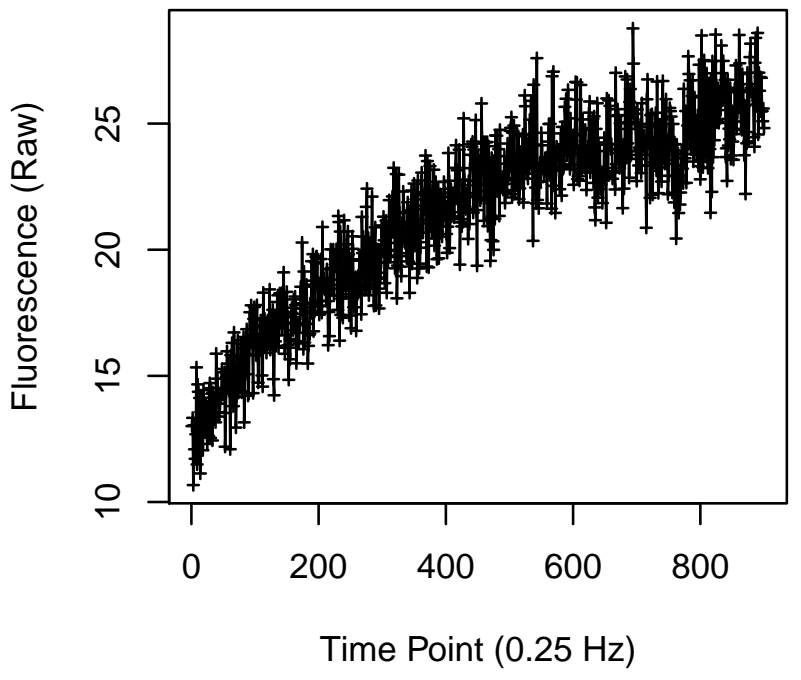

Cell 1283

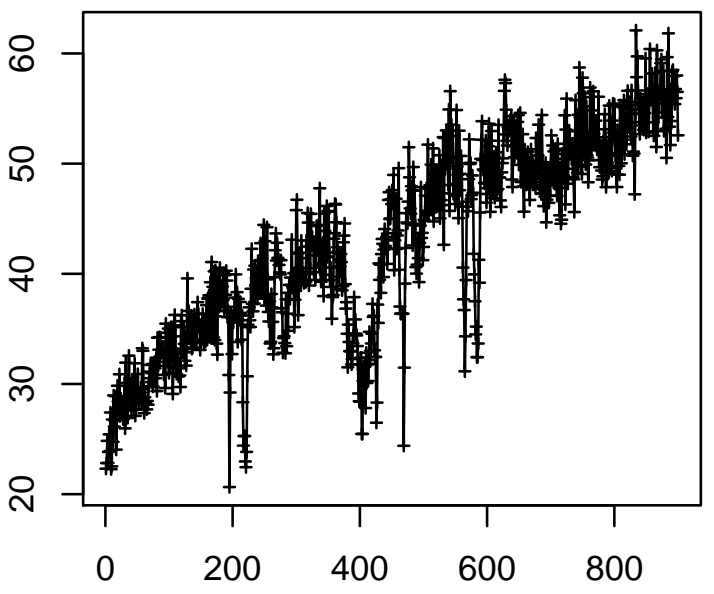

Time Point $(0.25 \mathrm{~Hz})$
Cell 1282

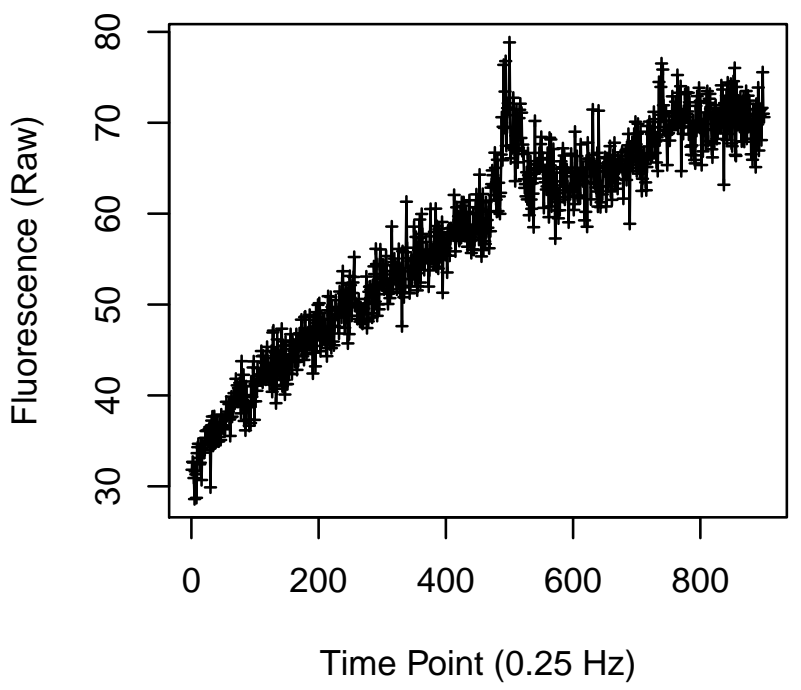

Cell 1284

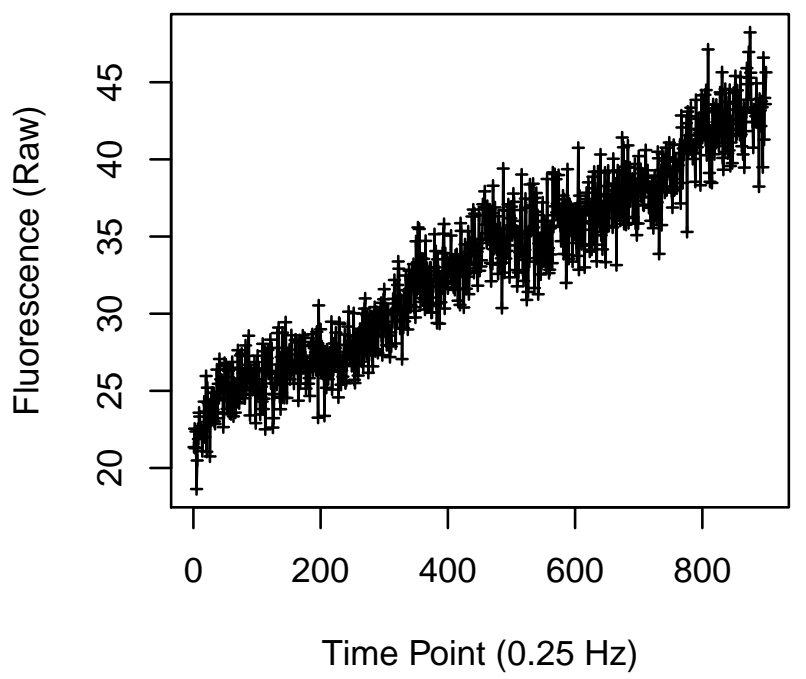


Cell 1285

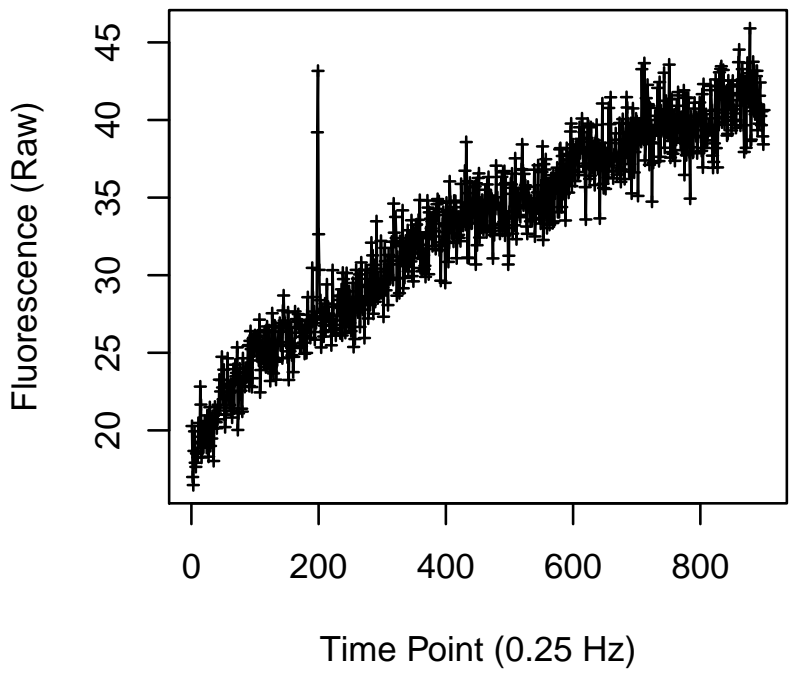

Cell 1287

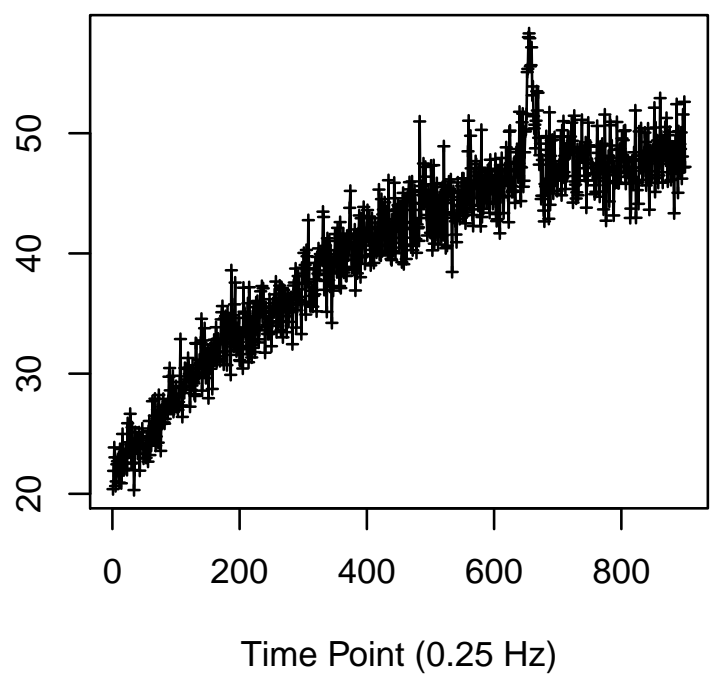

Cell 1286

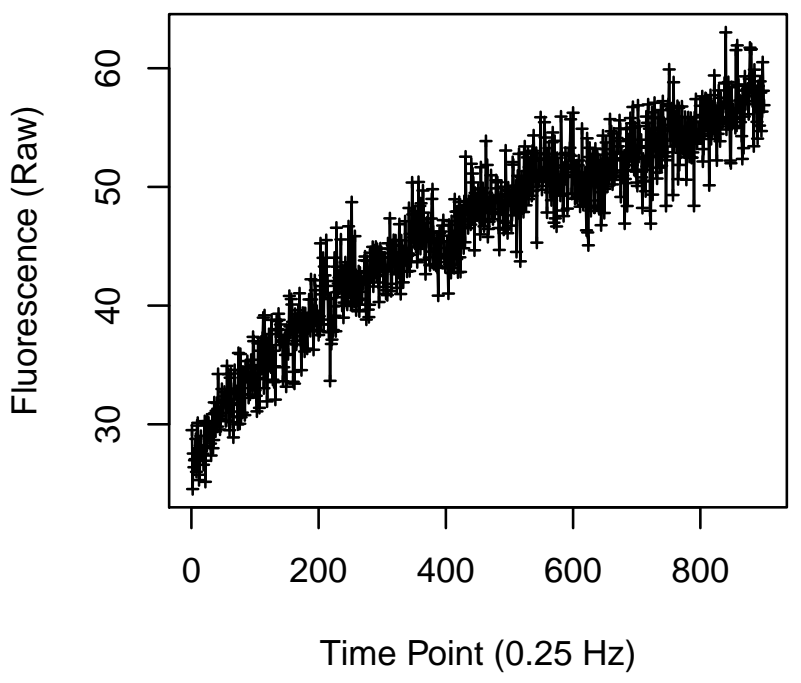

Cell 1288

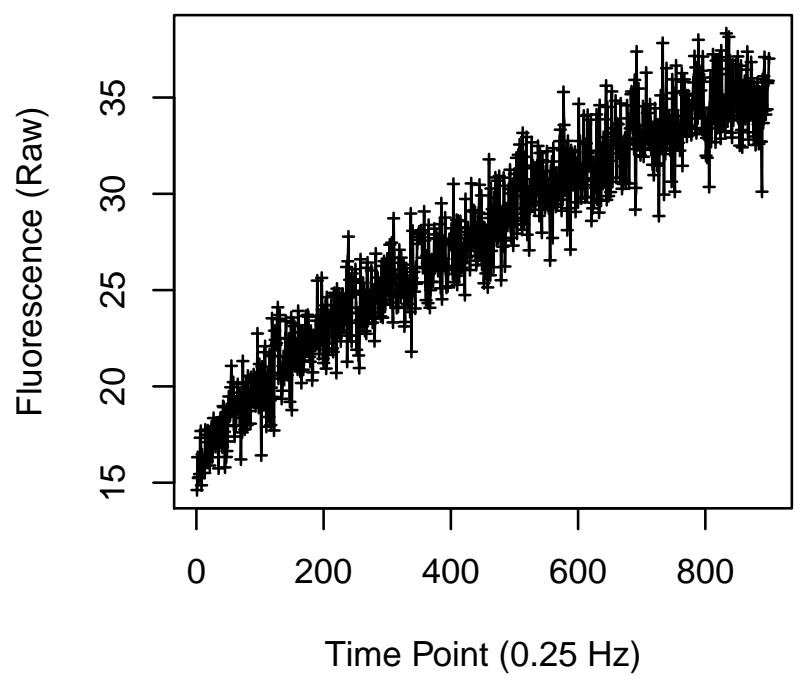


Cell 1289

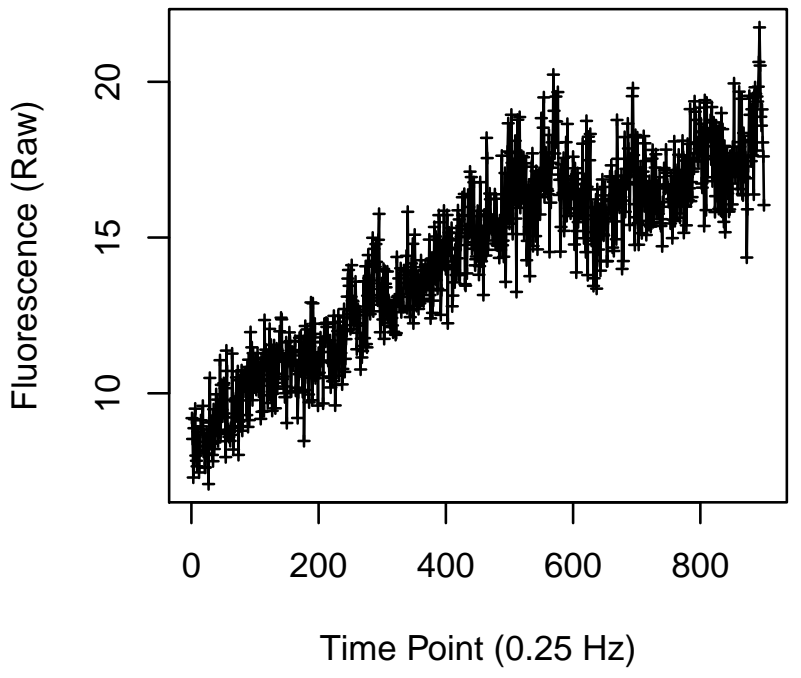

Cell 1291

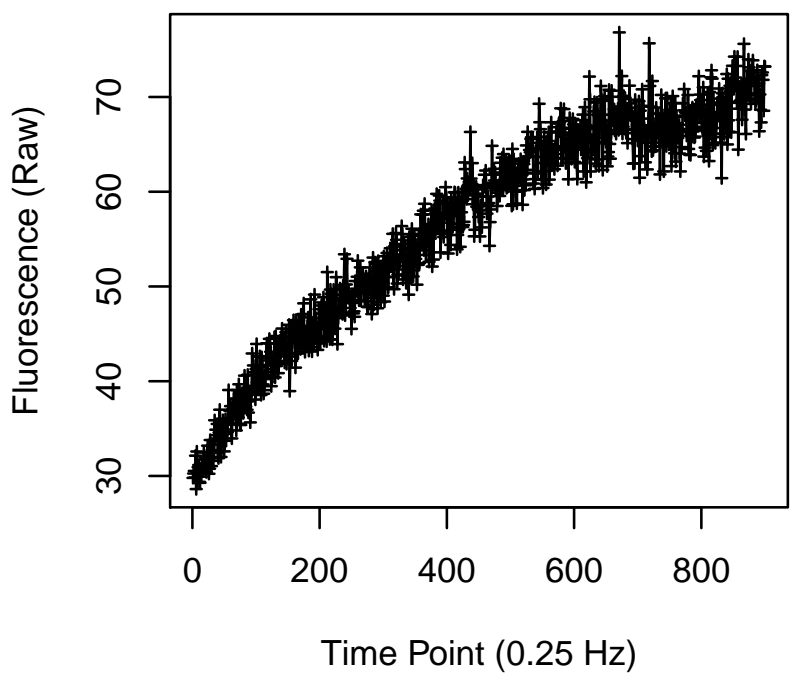

Cell 1290

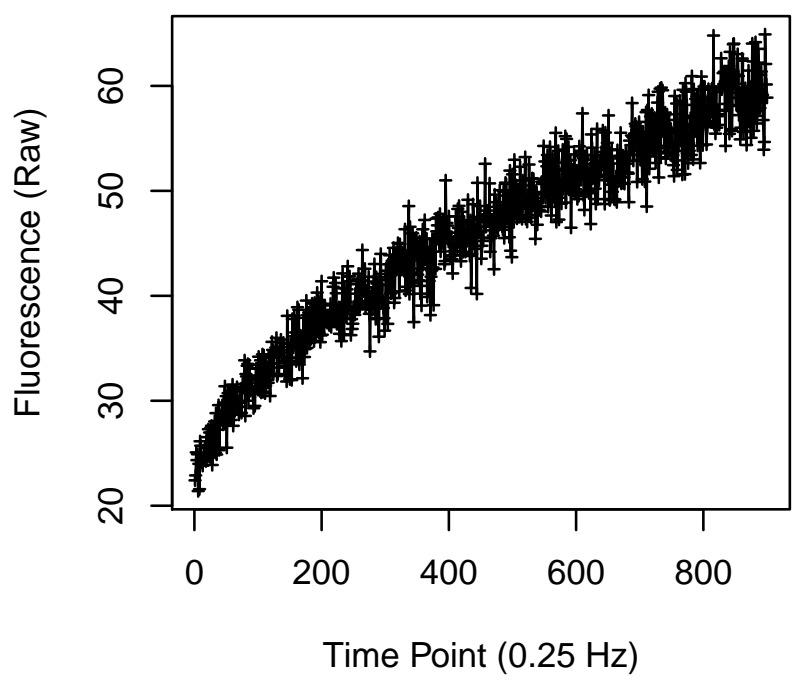

Cell 1292

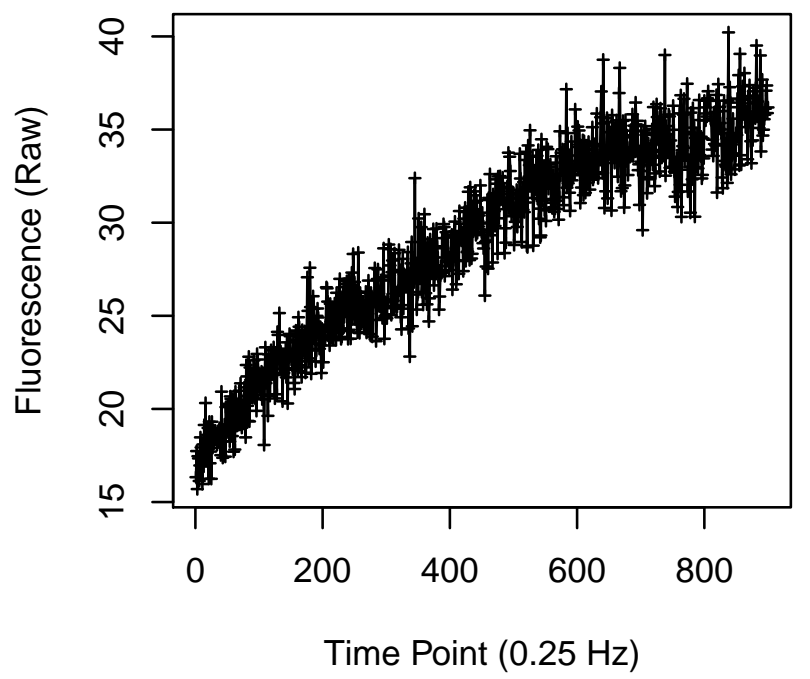


Cell 1293

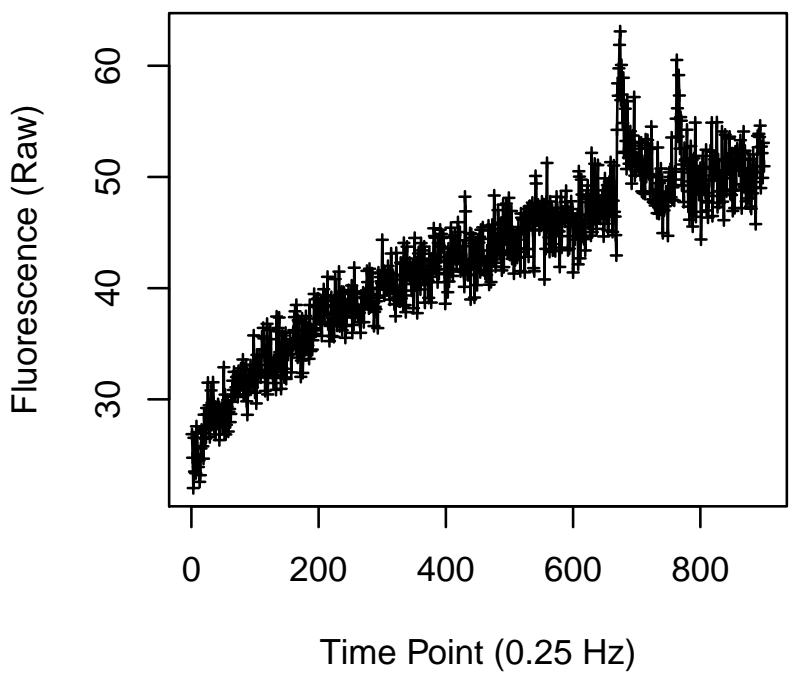

Cell 1295

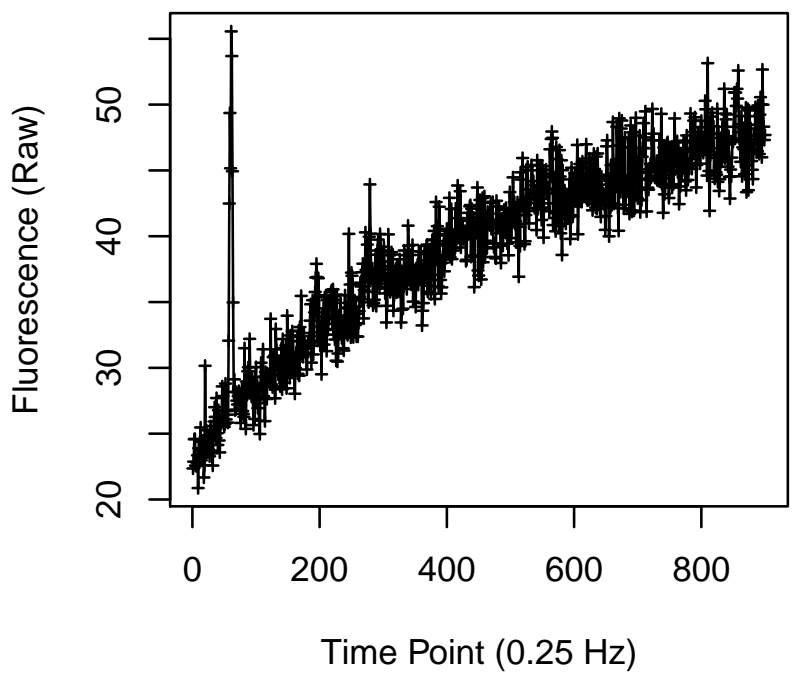

Cell 1294

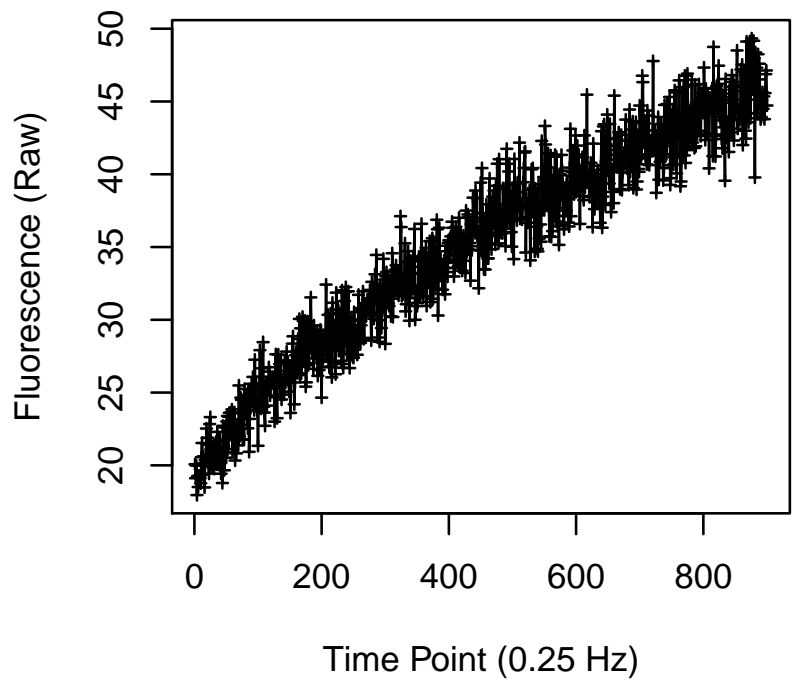

Cell 1296

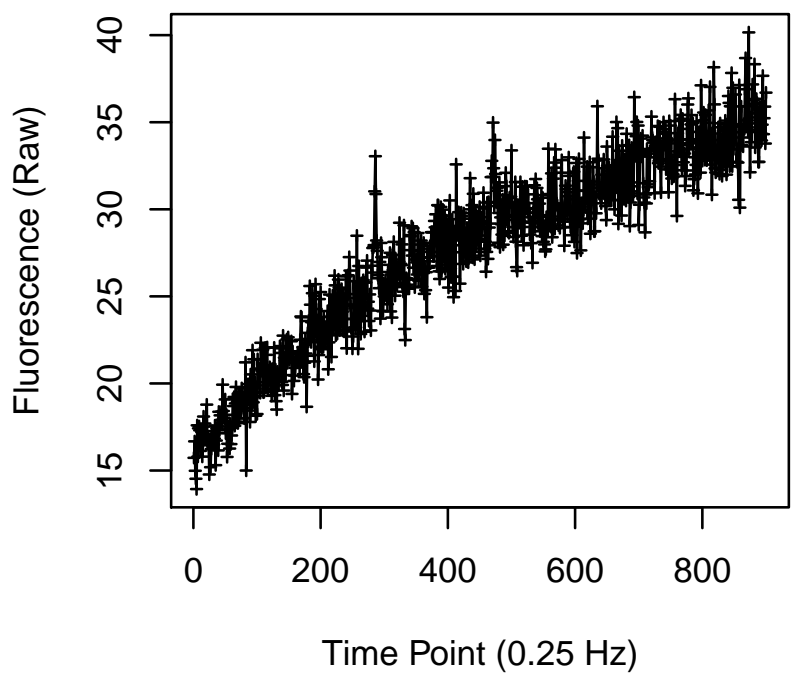


Cell 1297

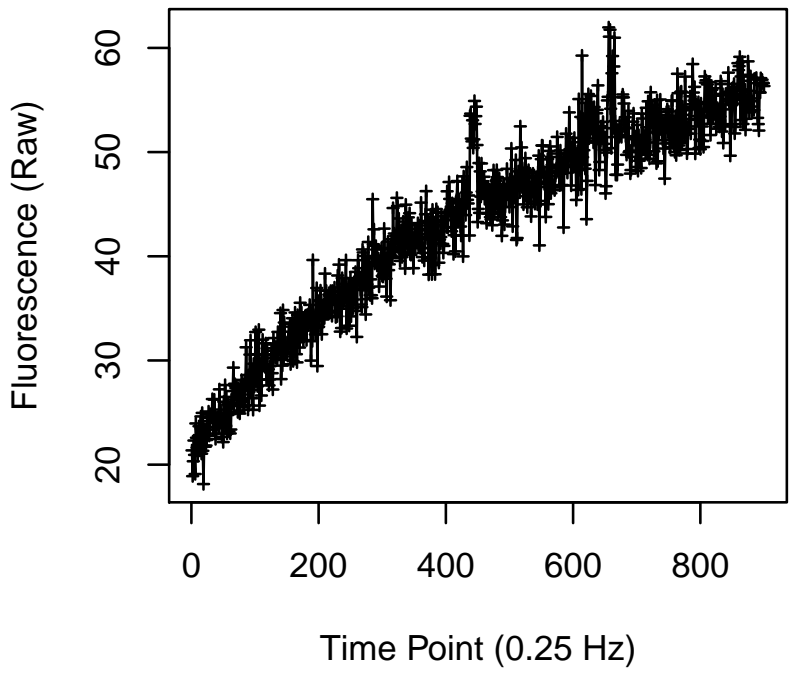

Cell 1299

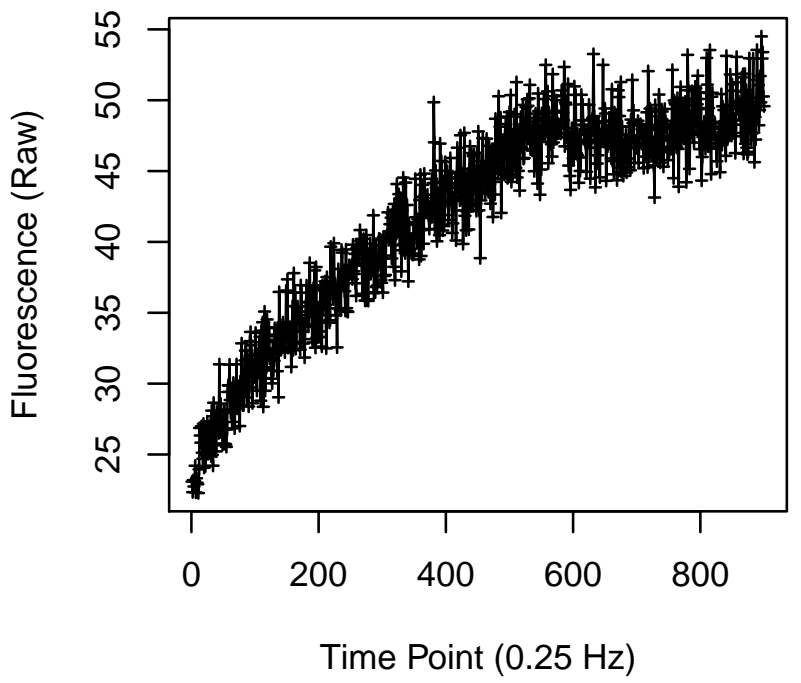

Cell 1298

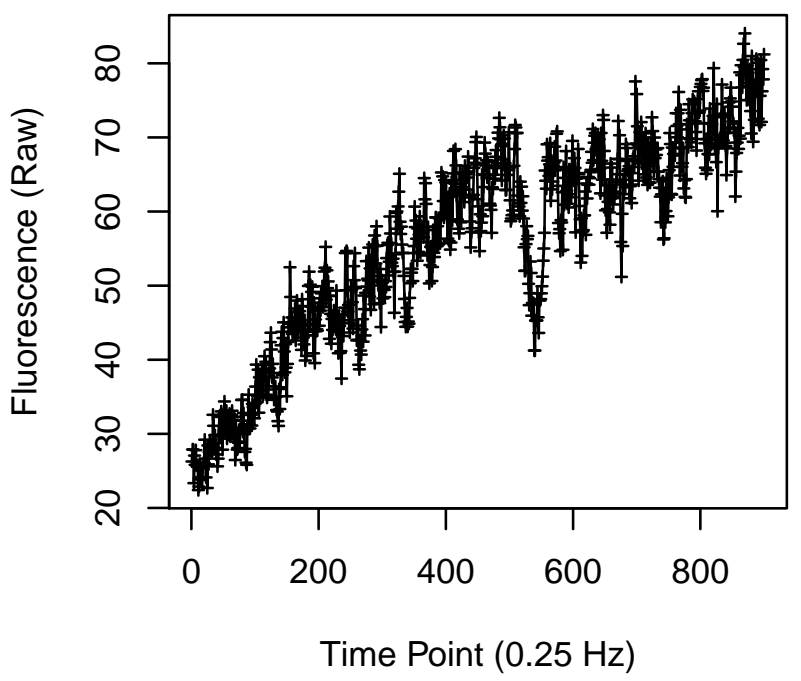

Cell 1300

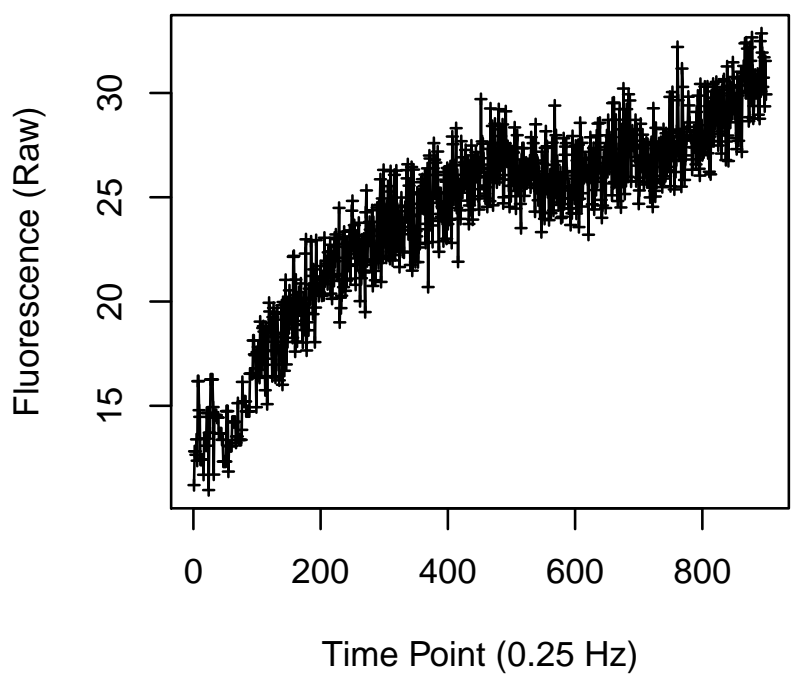


Cell 1301

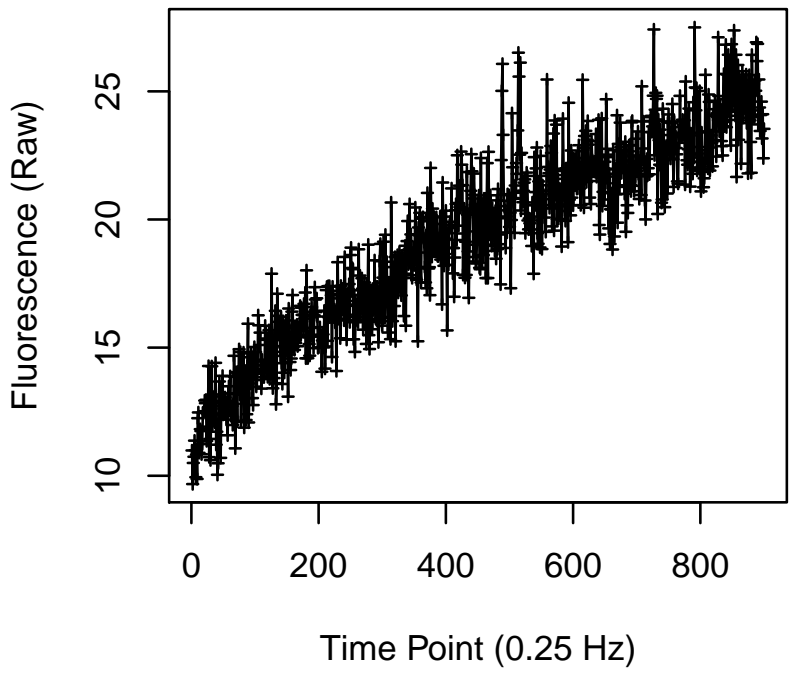

Cell 1303

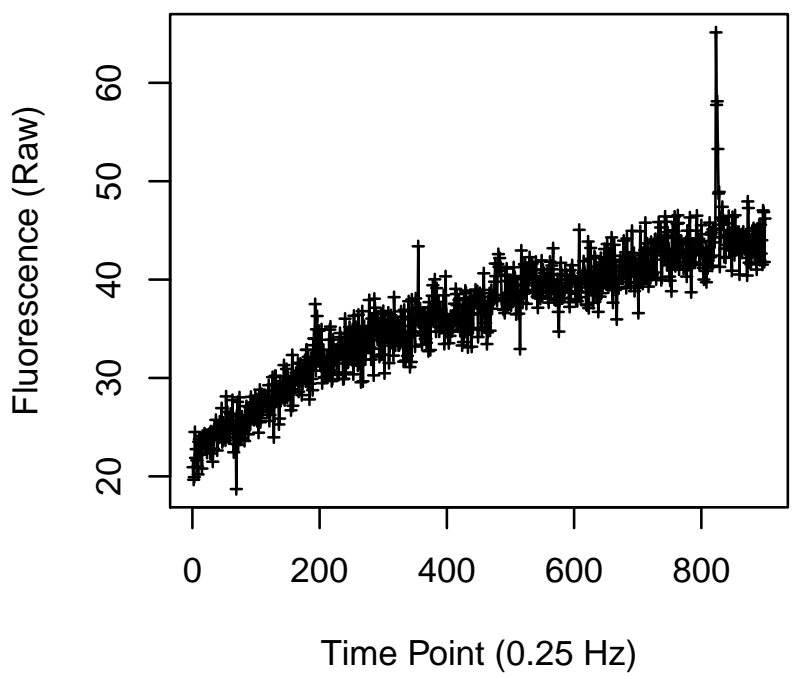

Cell 1302

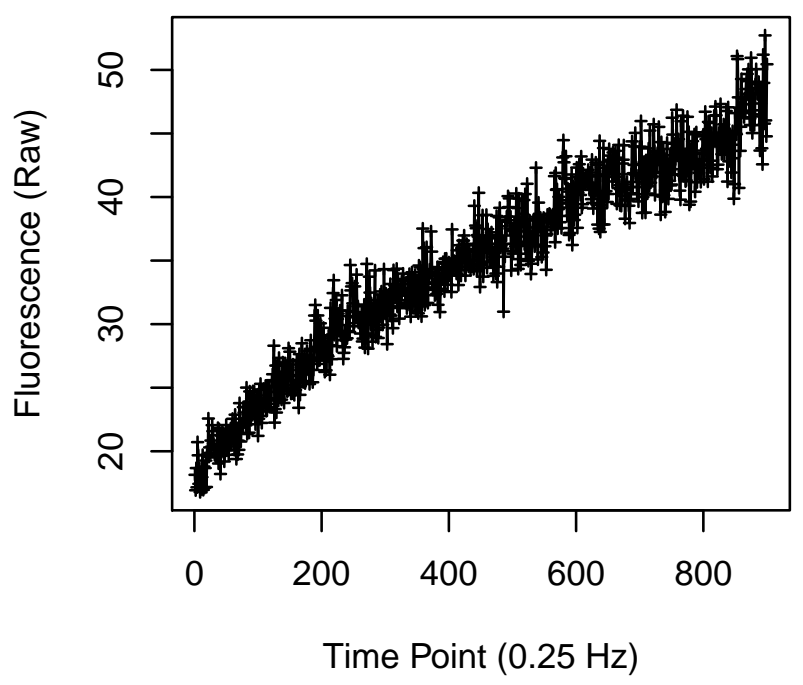

Cell 1304

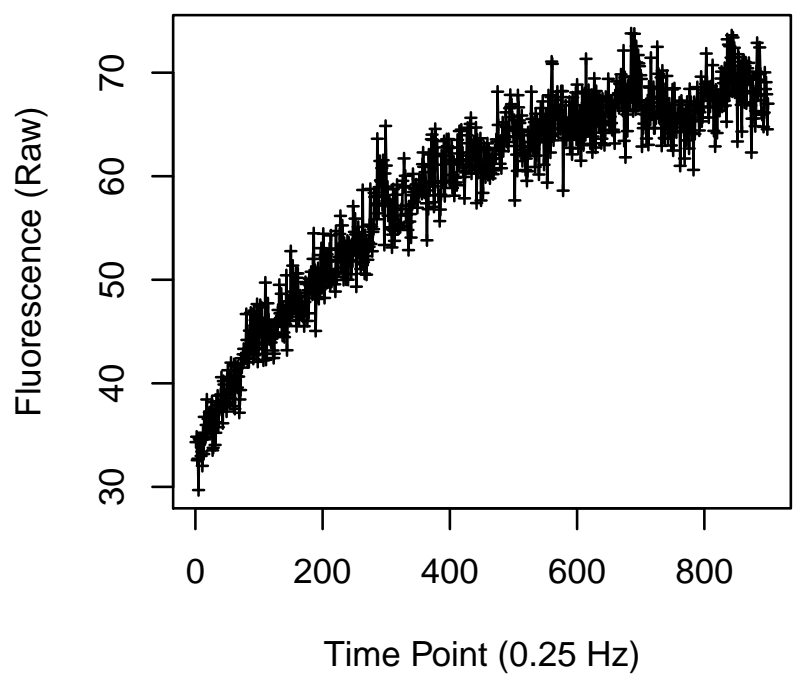


Cell 1305

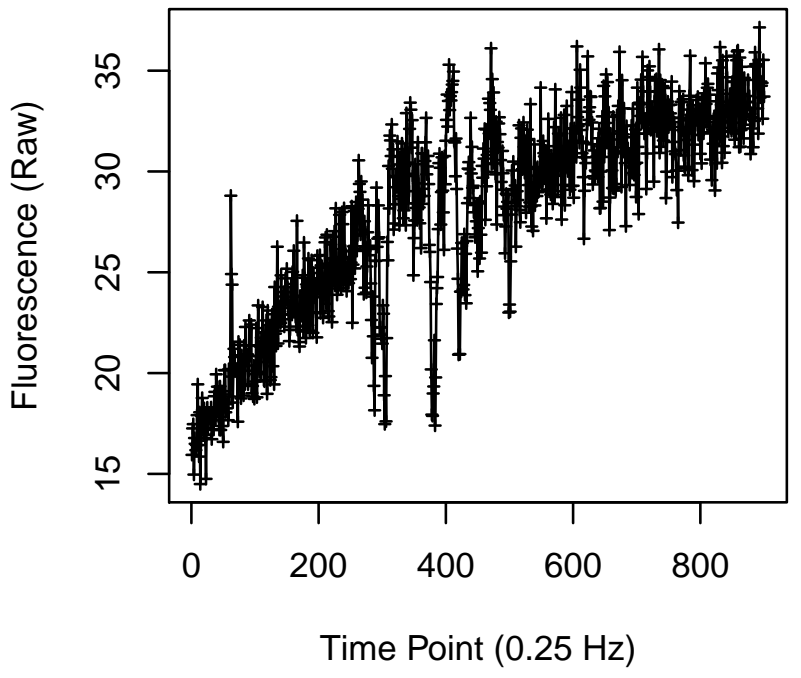

Cell 1307

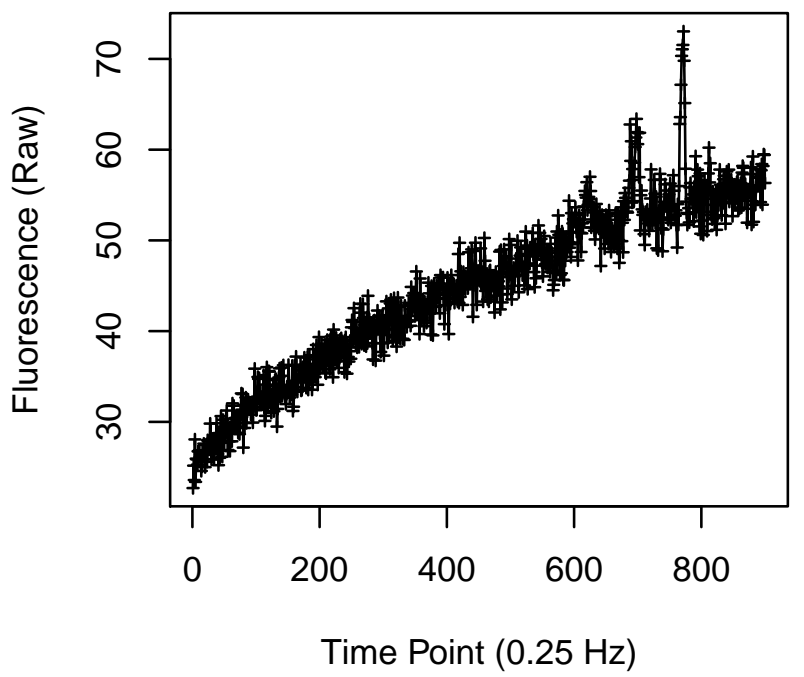

Cell 1306

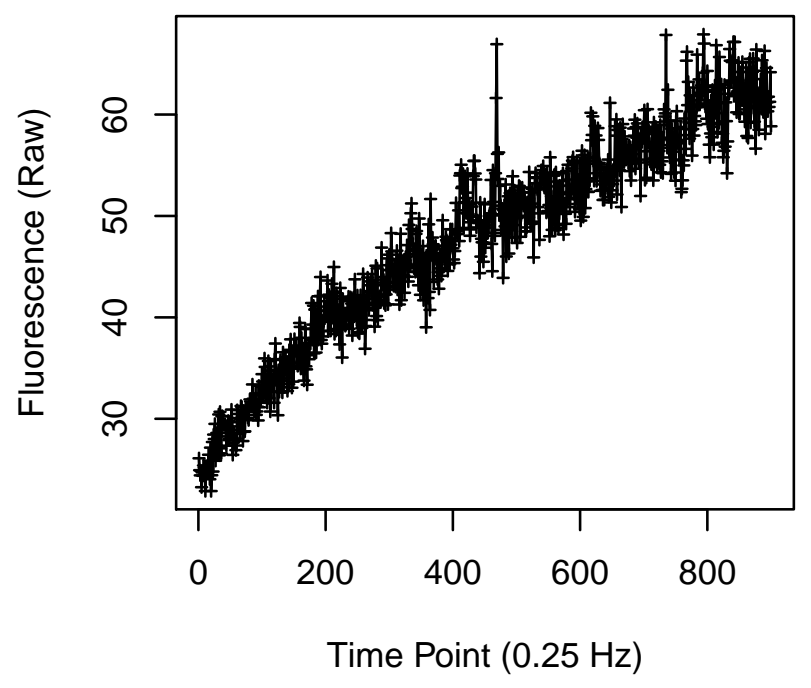

Cell 1308

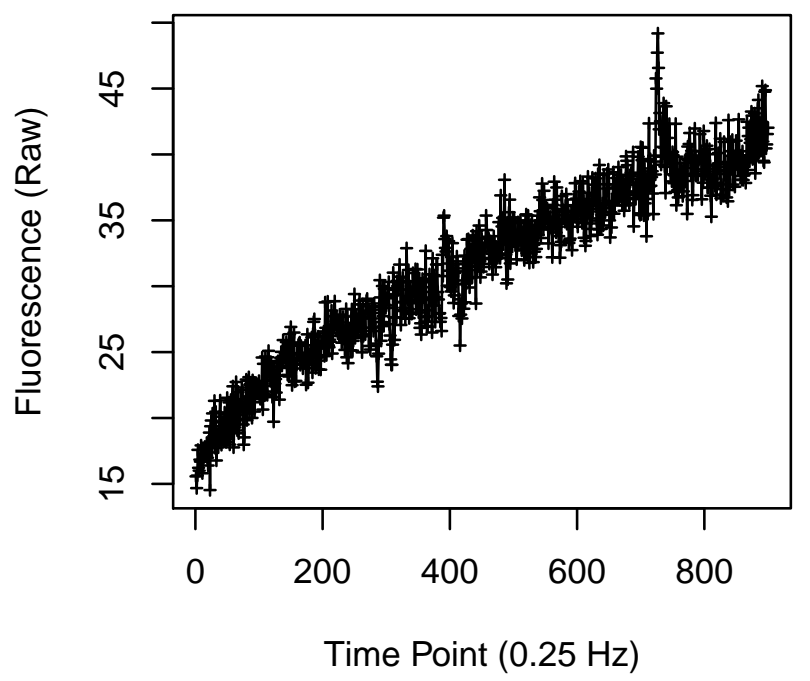


Cell 1309

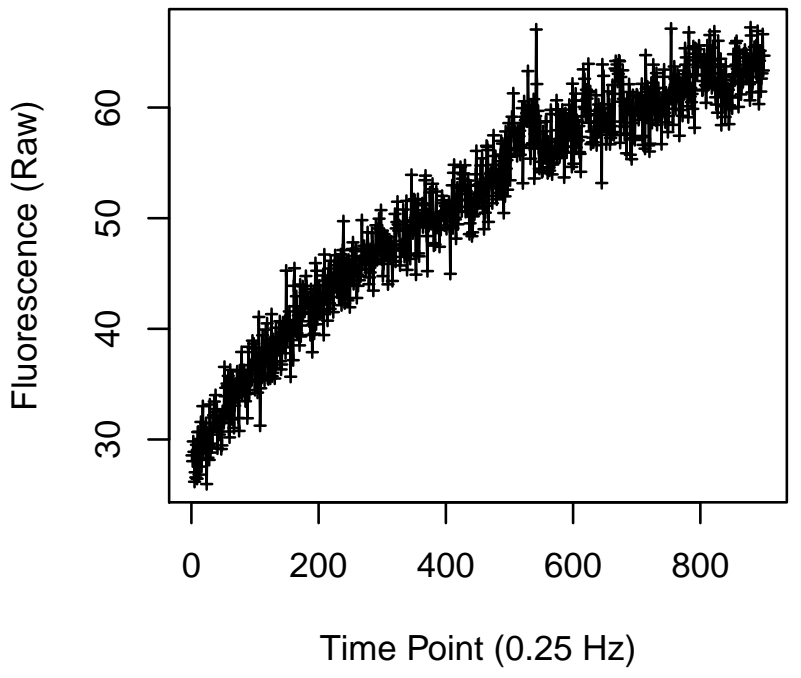

Cell 1311

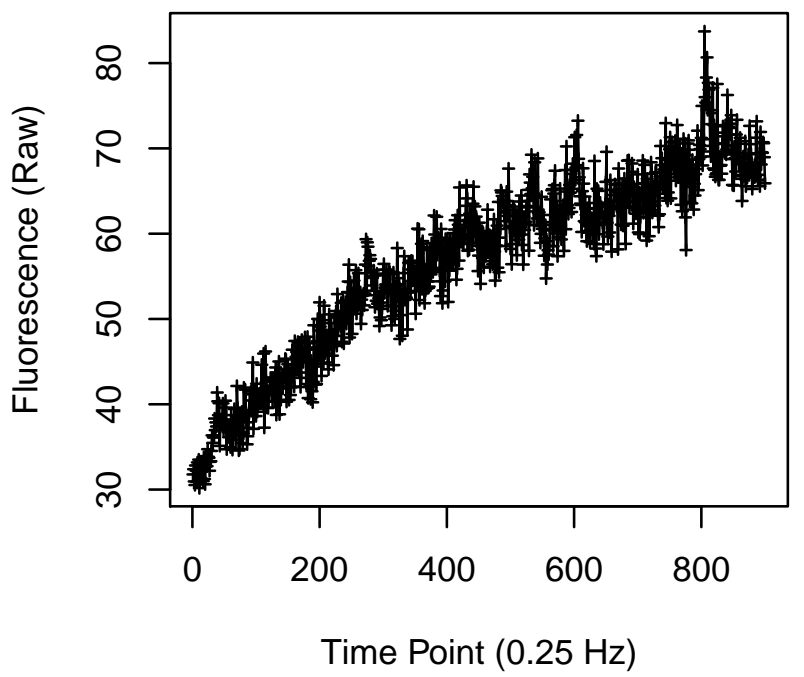

Cell 1310

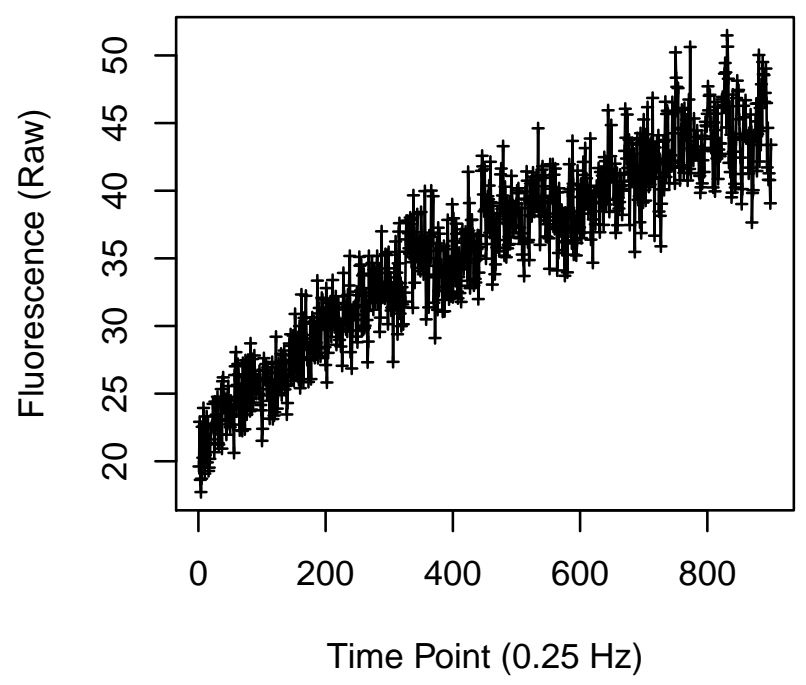

Cell 1312

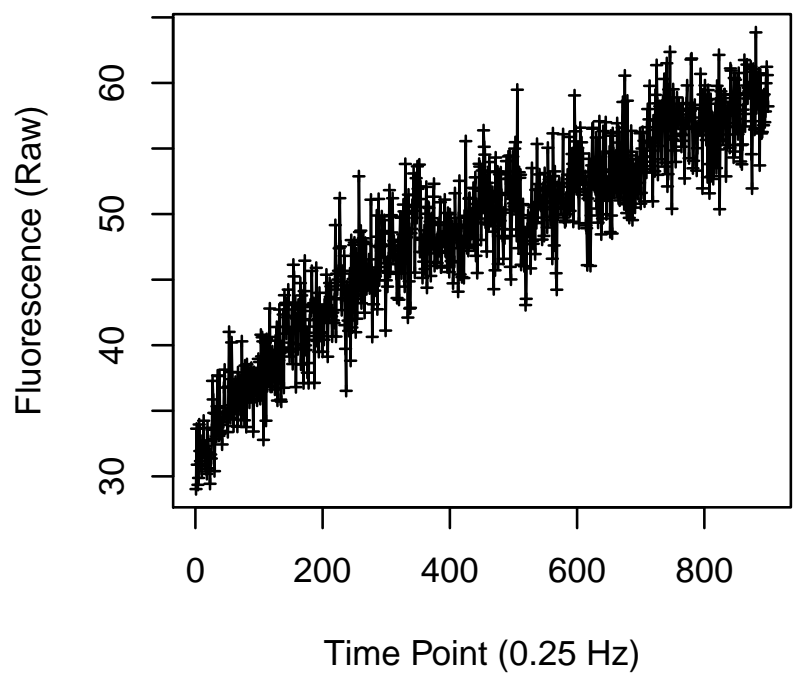


Cell 1321

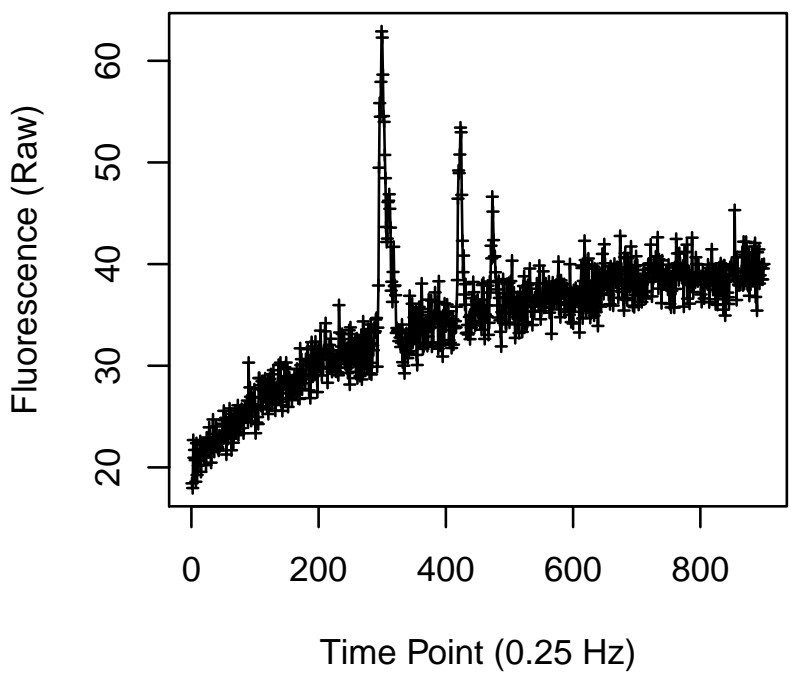

Cell 1323

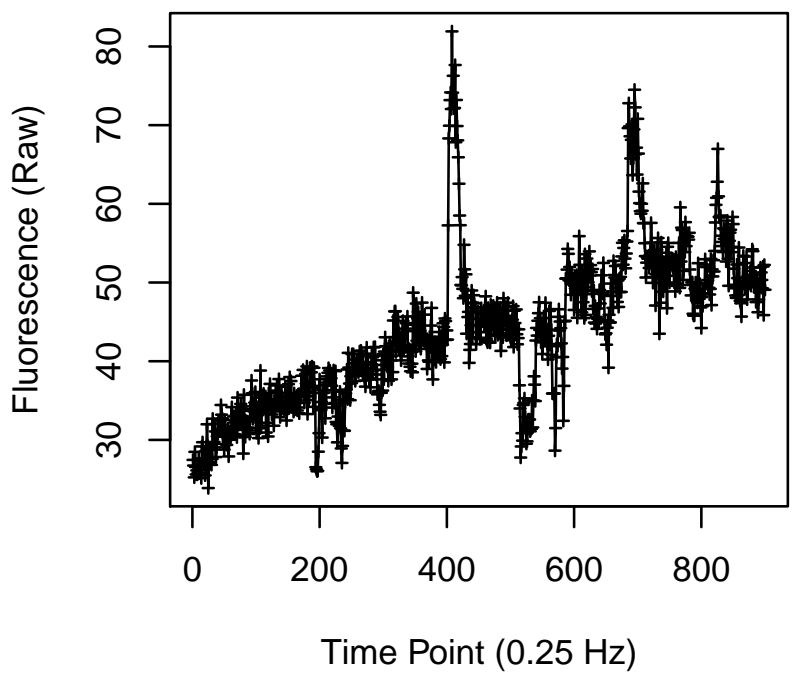

Cell 1322

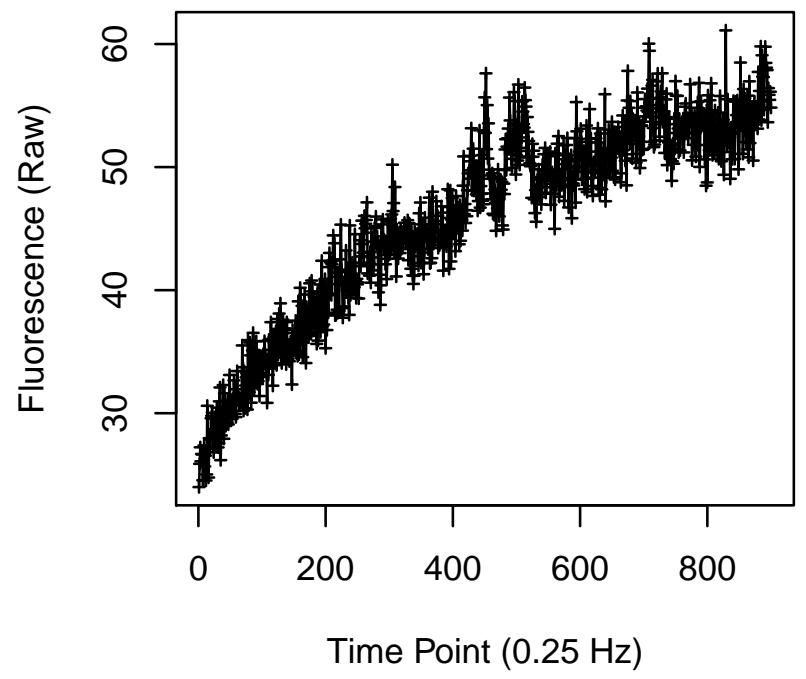

Cell 1324

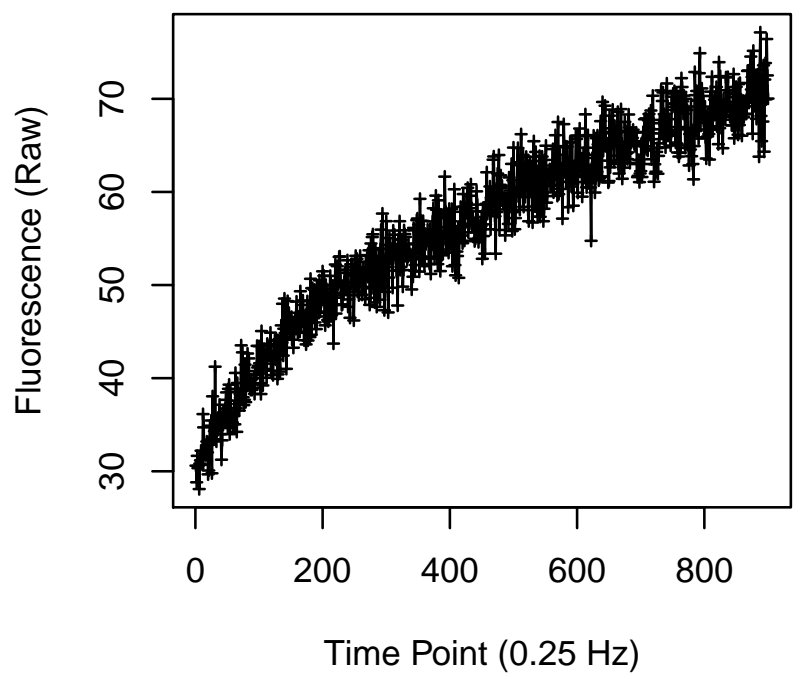


Cell 1325

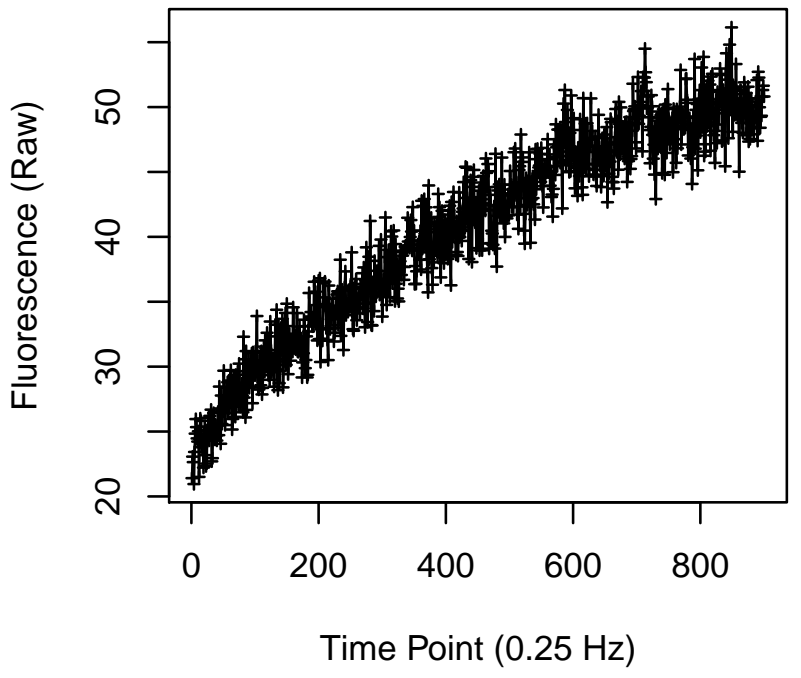

Cell 1327

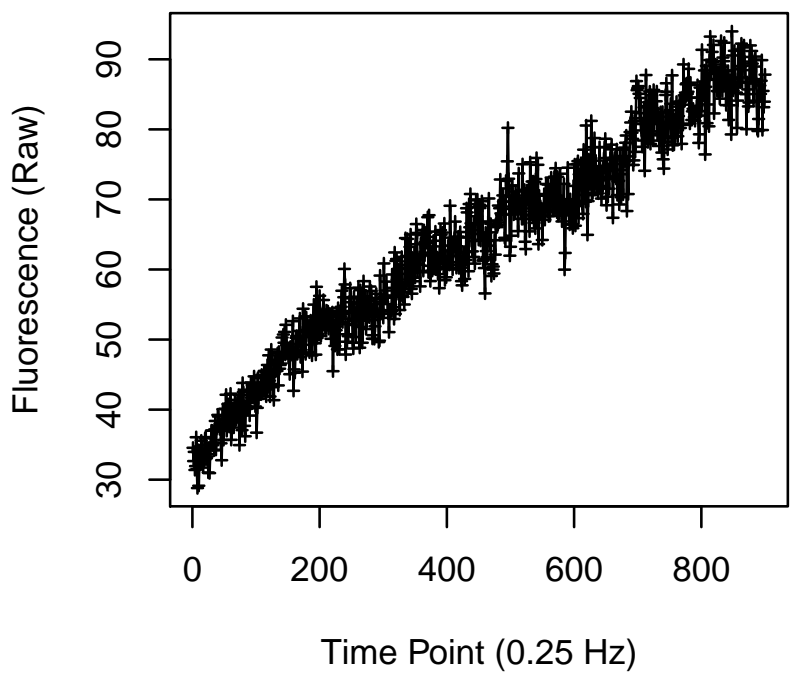

Cell 1326

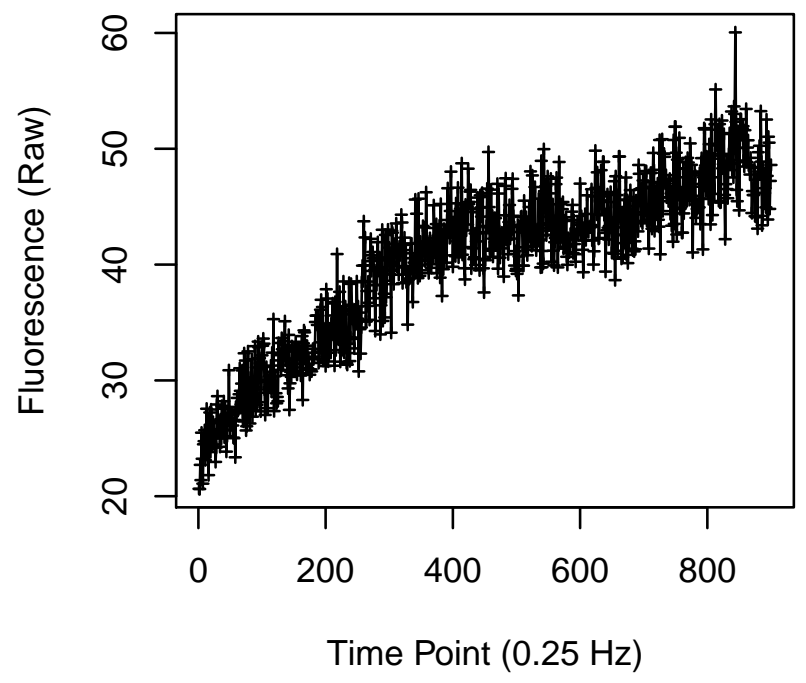

Cell 1328

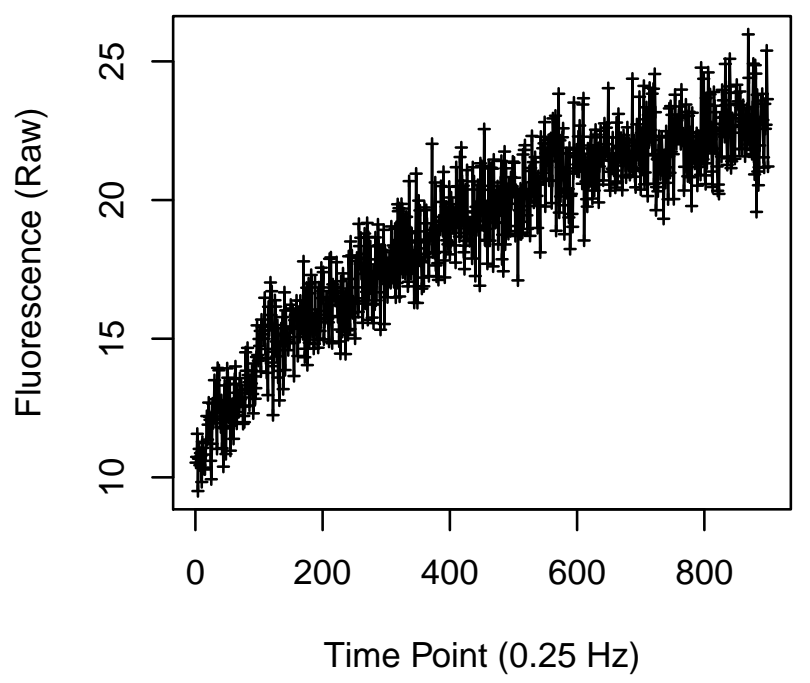


Cell 1329

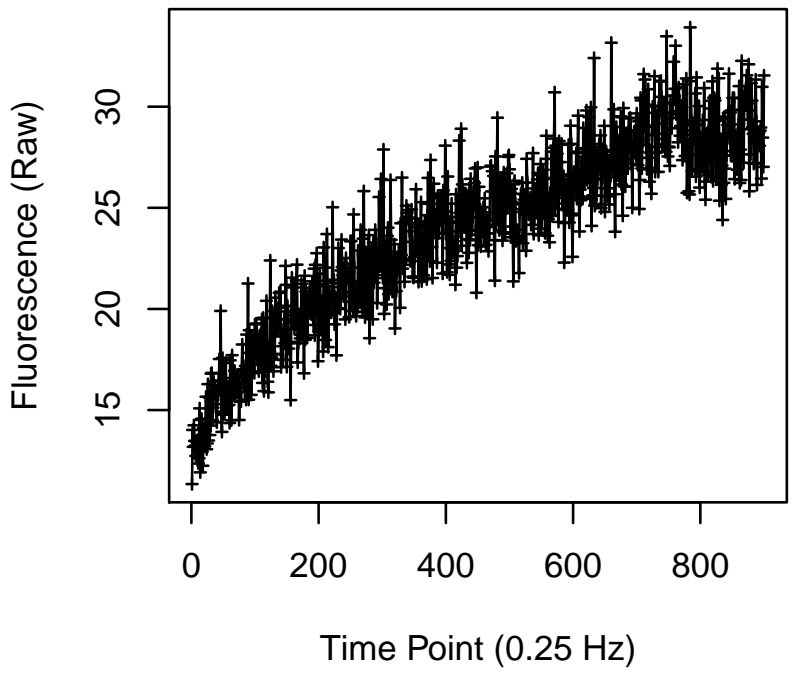

Cell 1331

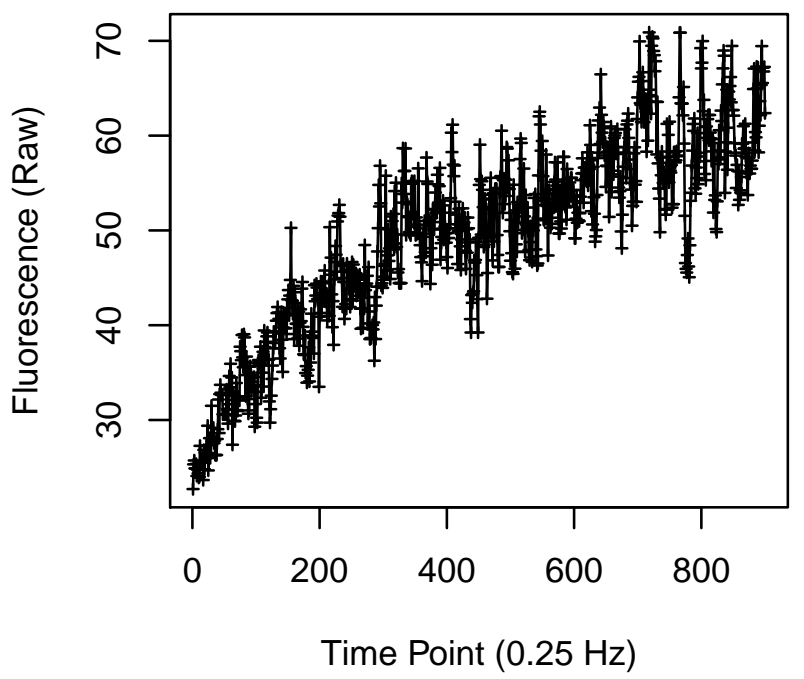

Cell 1330

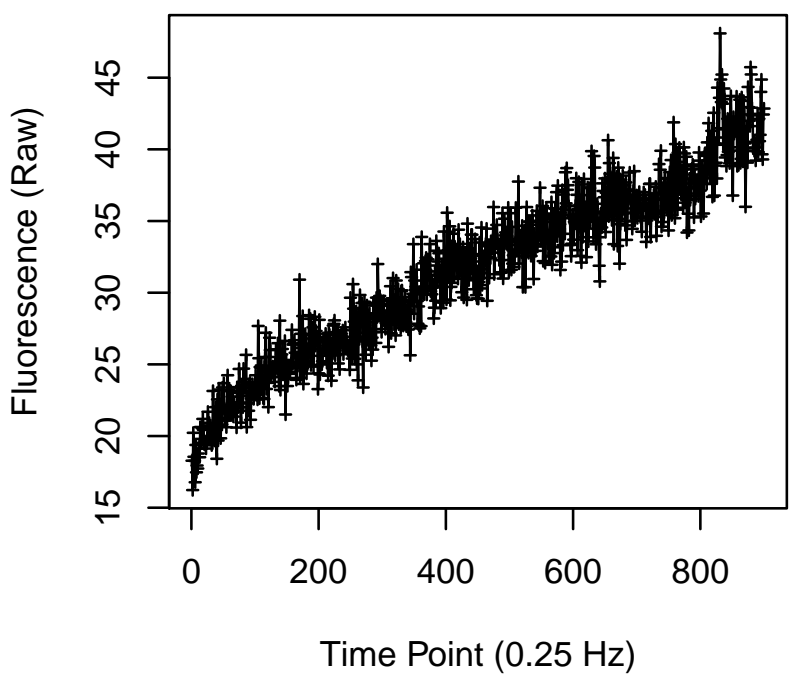

Cell 1332

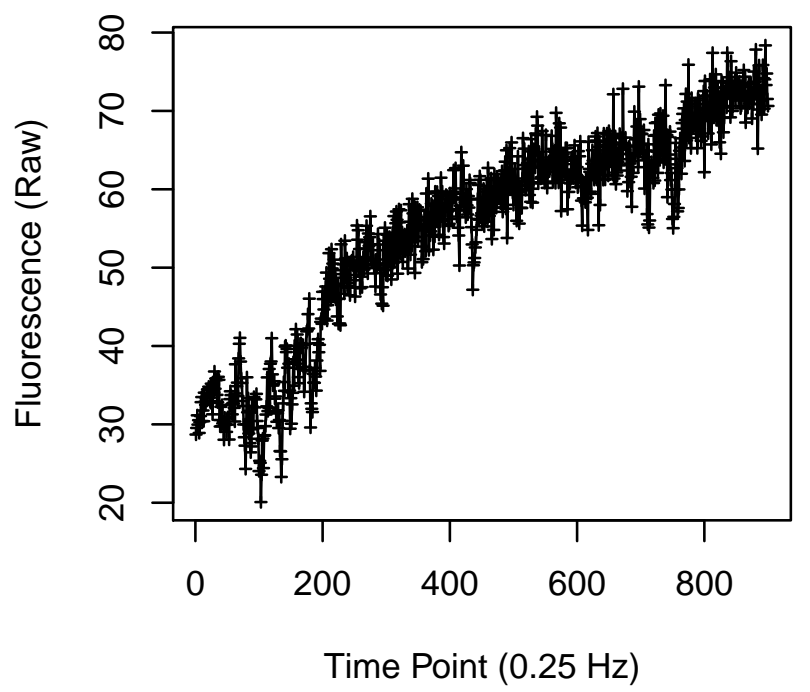


Cell 1333

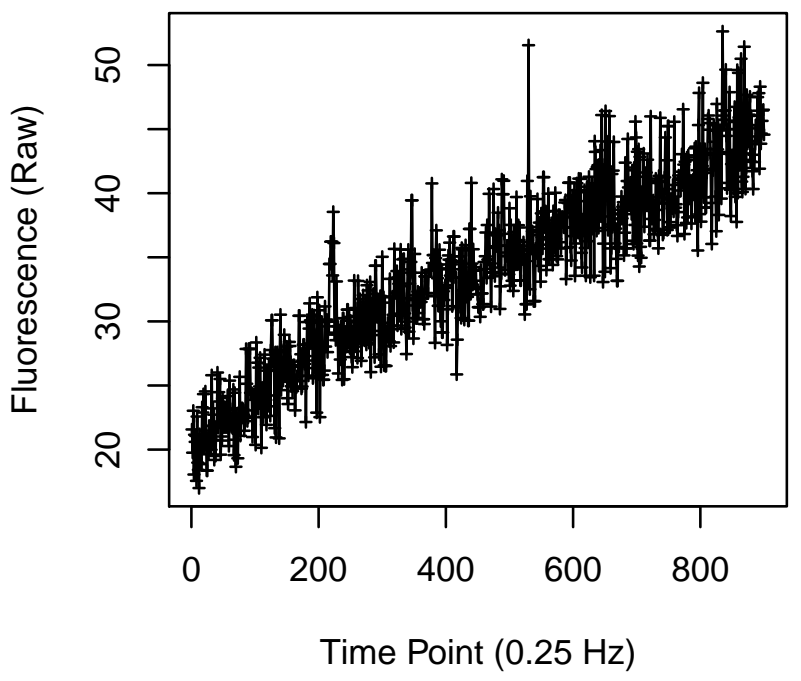

Cell 1335

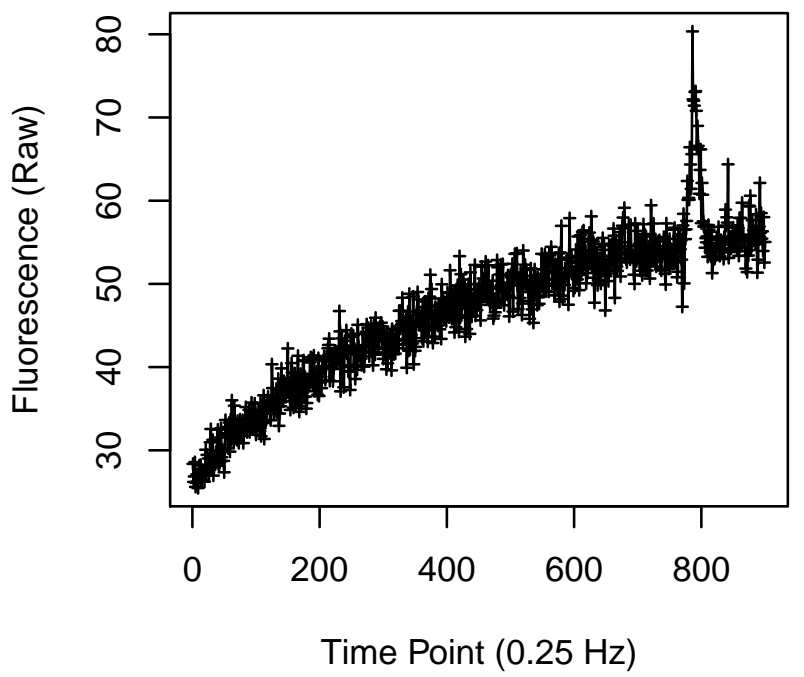

Cell 1334

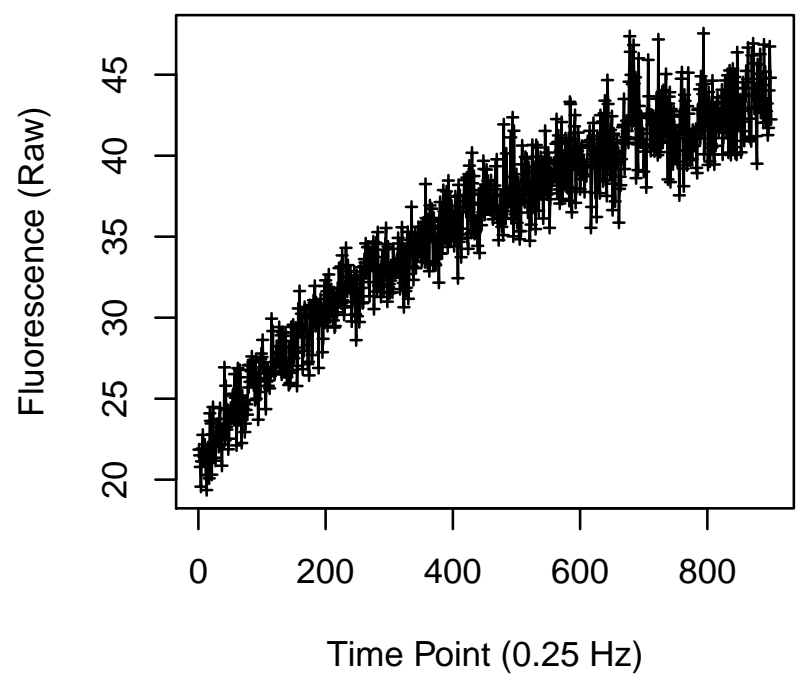

Cell 1336

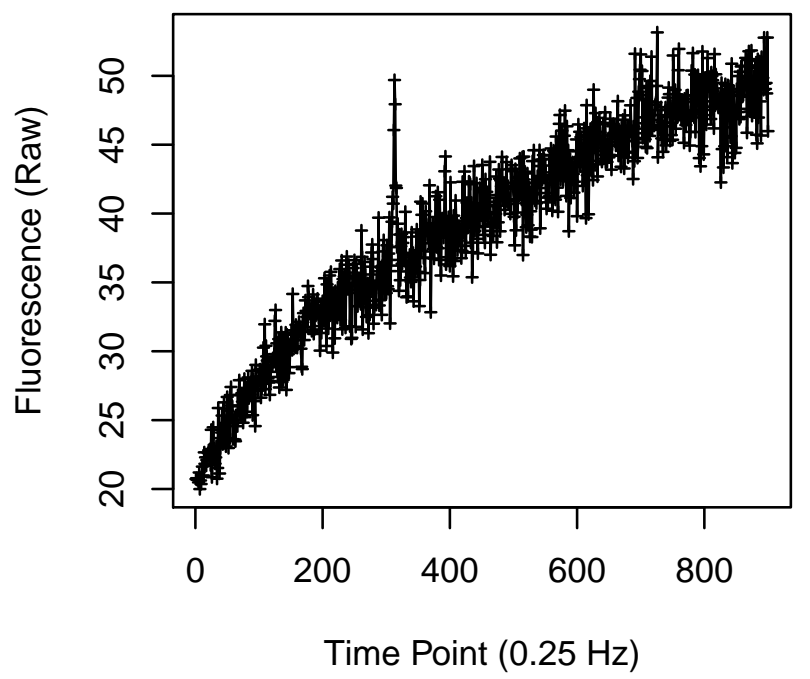


Cell 1337

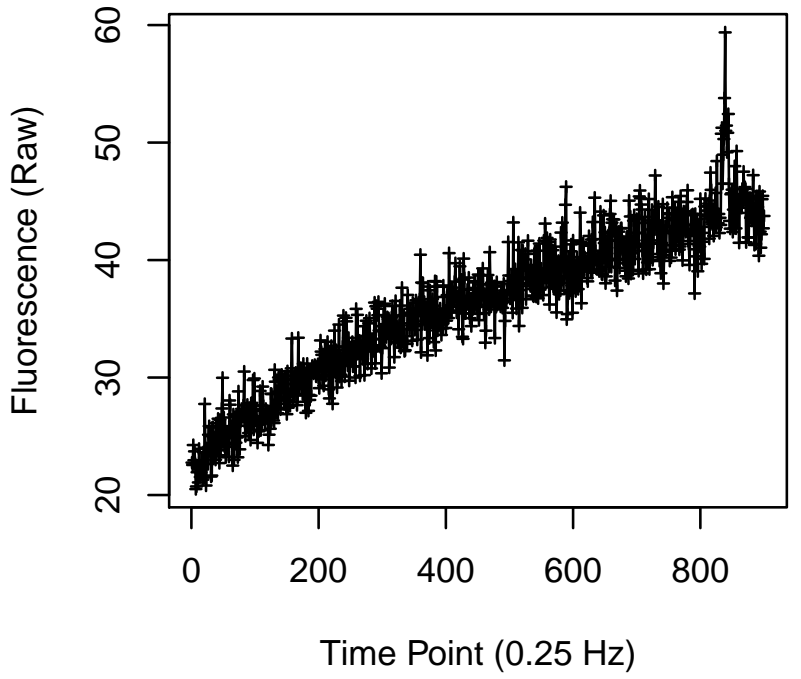

Cell 1339

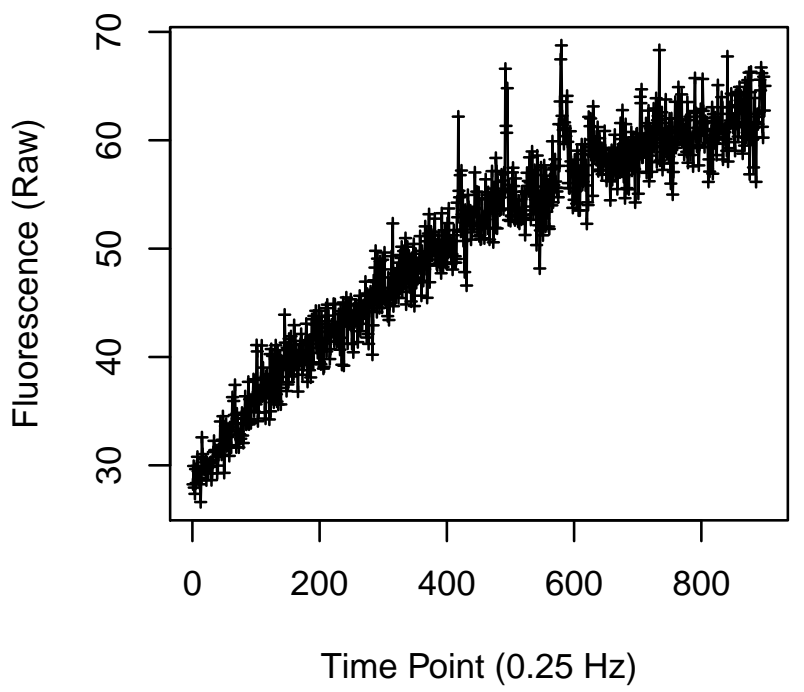

Cell 1338

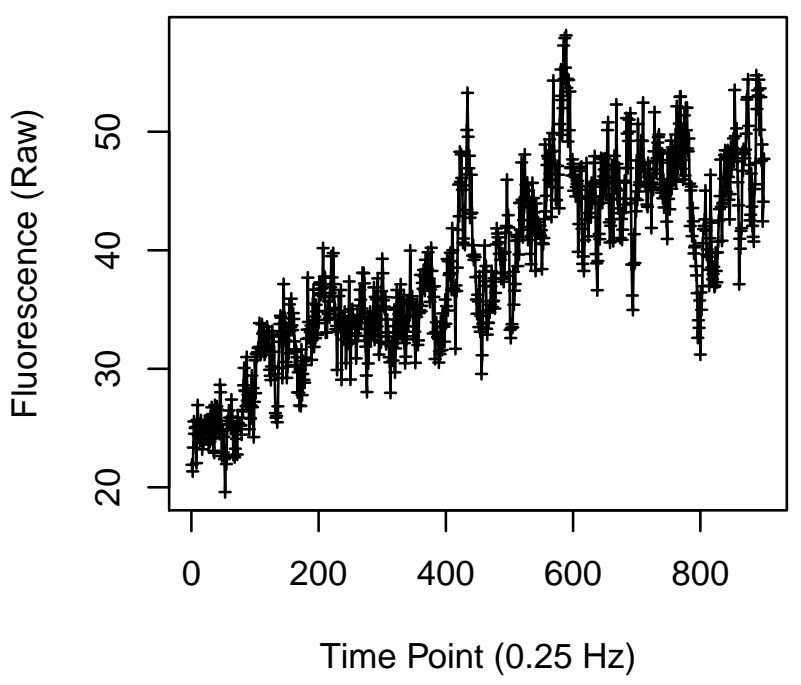

Cell 1340

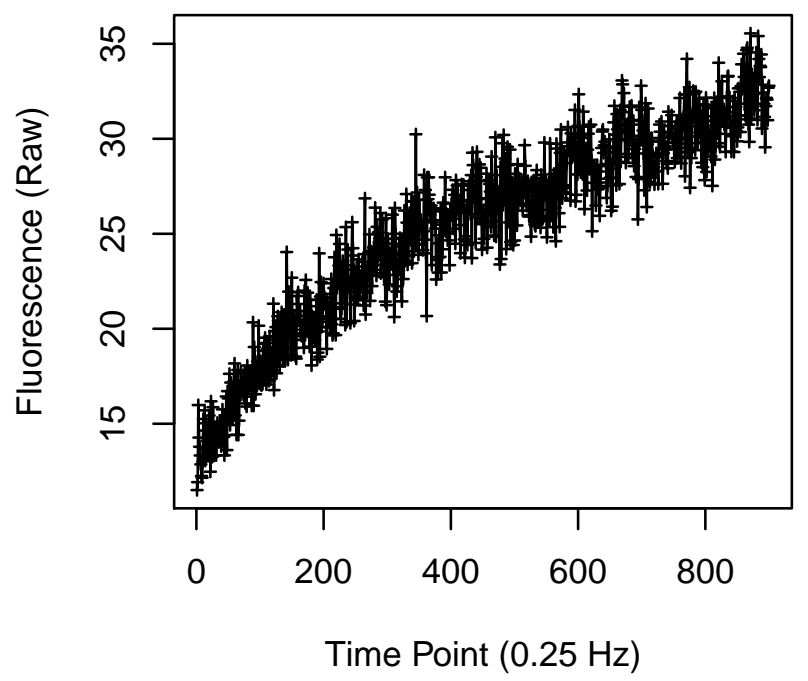


Cell 1349

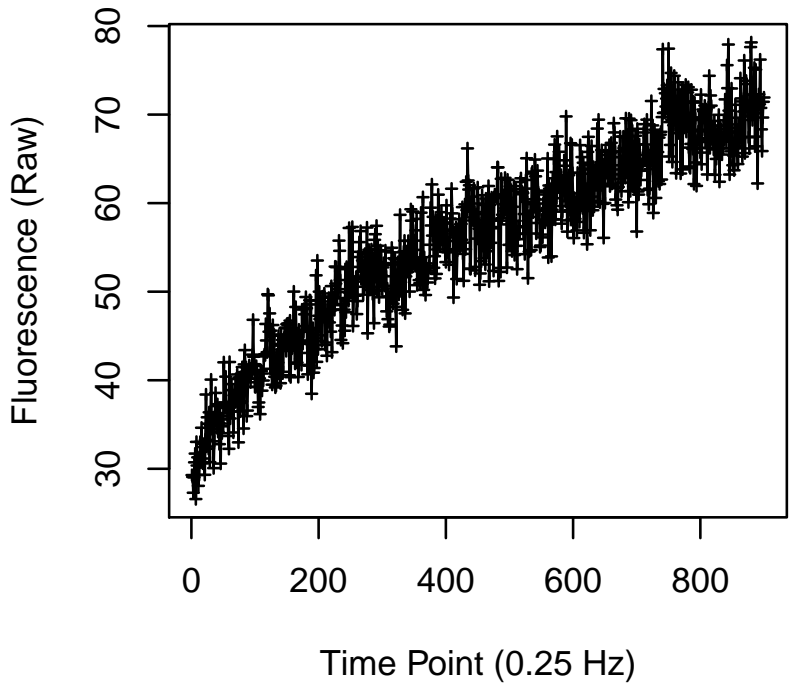

Cell 1351

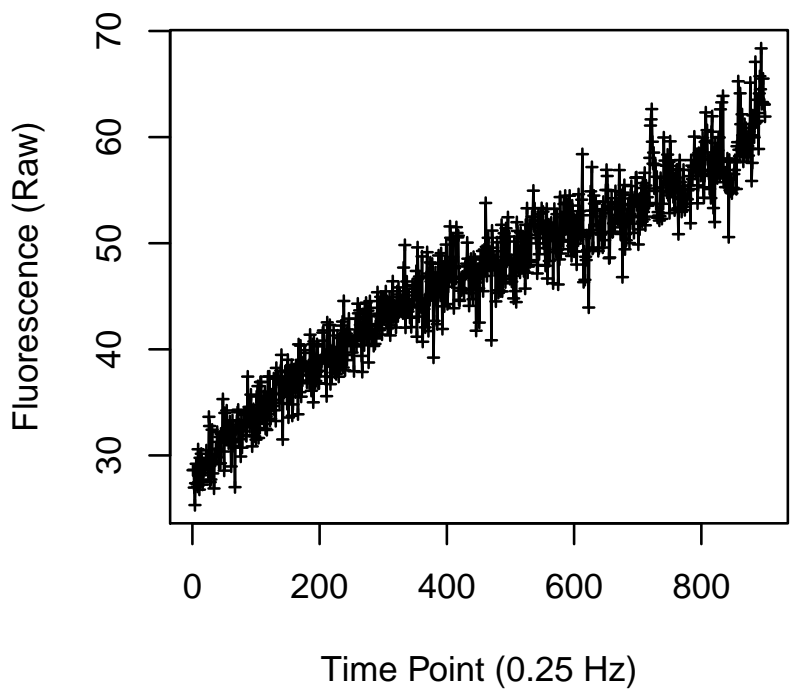

Cell 1350

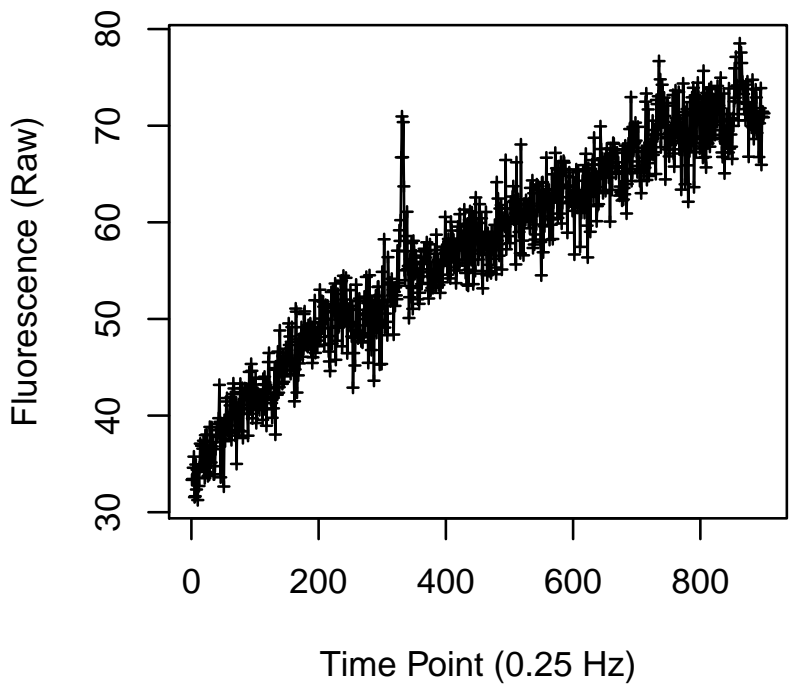

Cell 1352

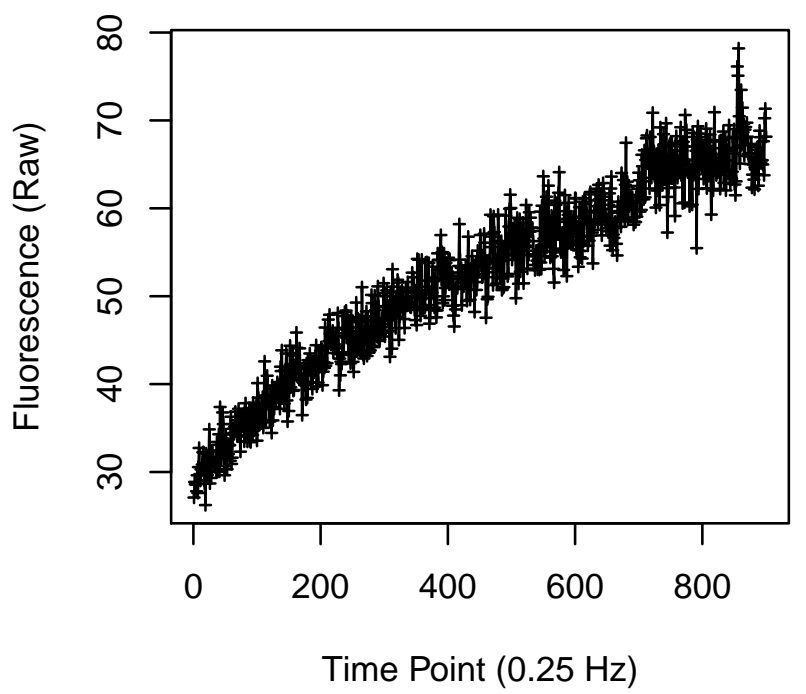


Cell 1353

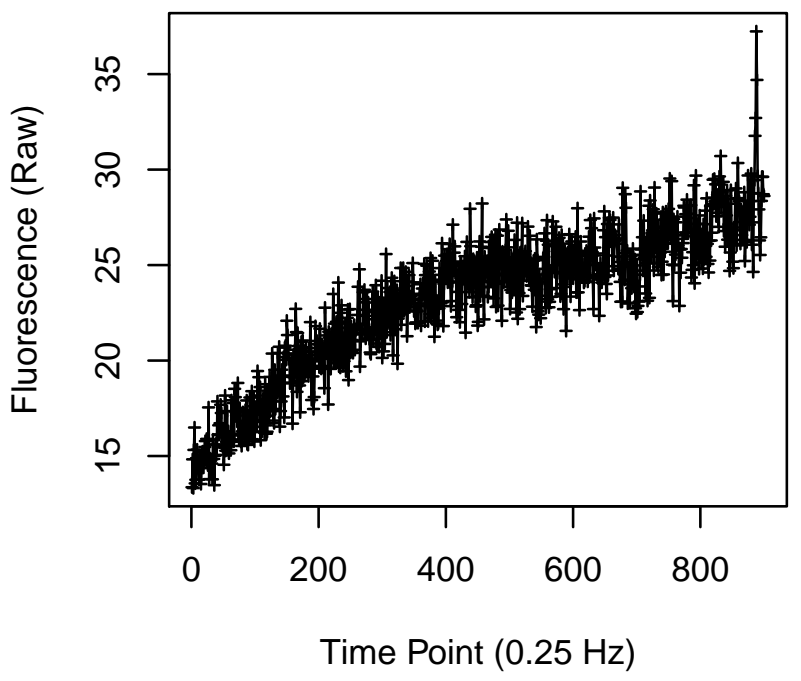

Cell 1355

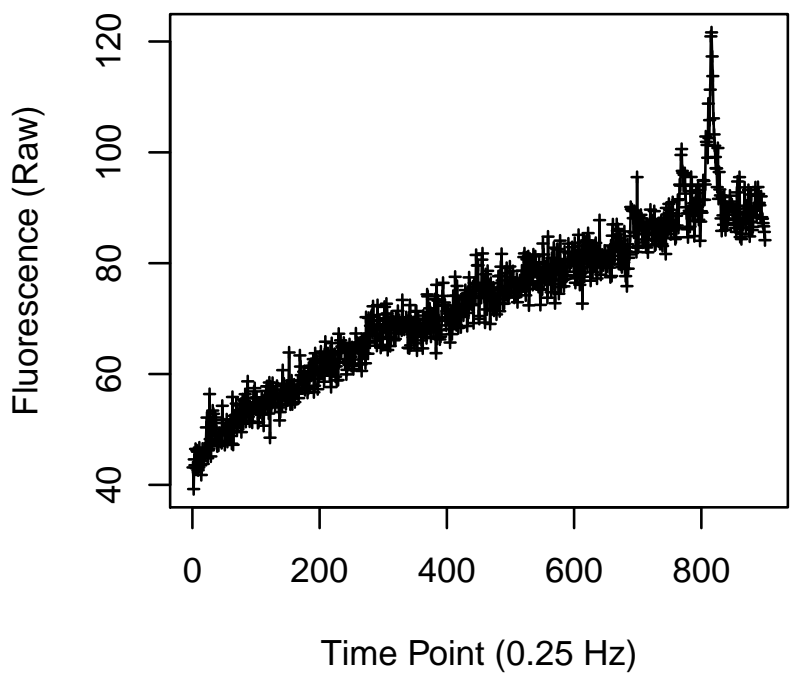

Cell 1354

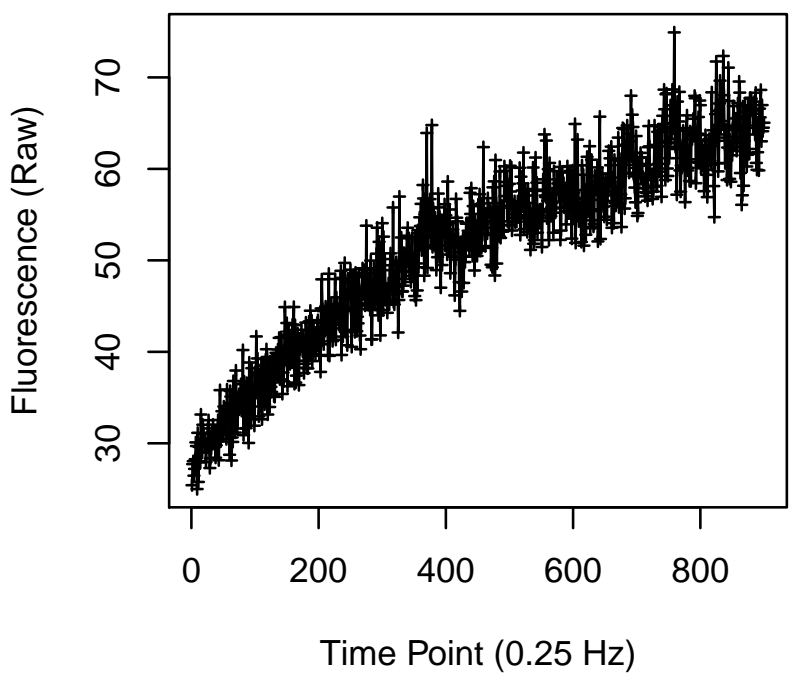

Cell 1356

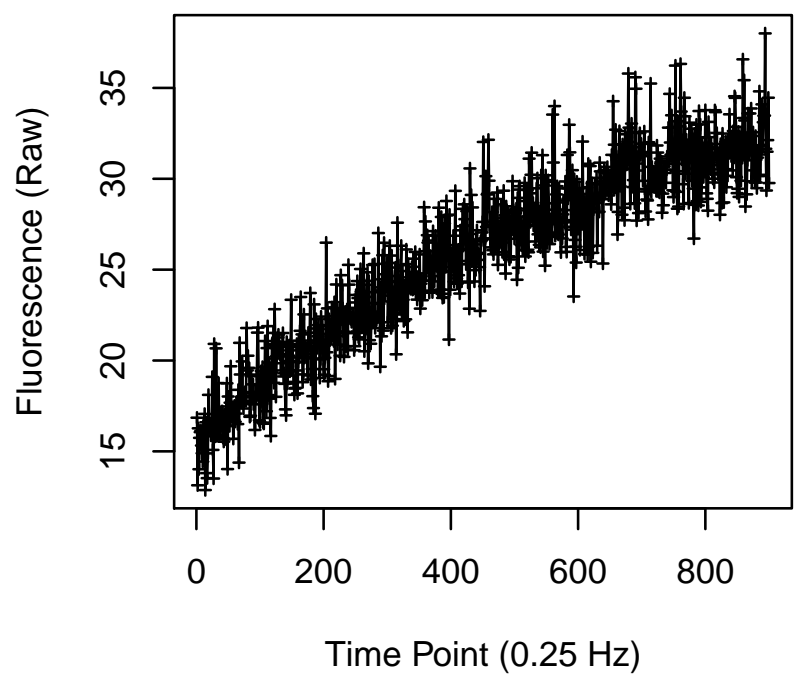


Cell 1357

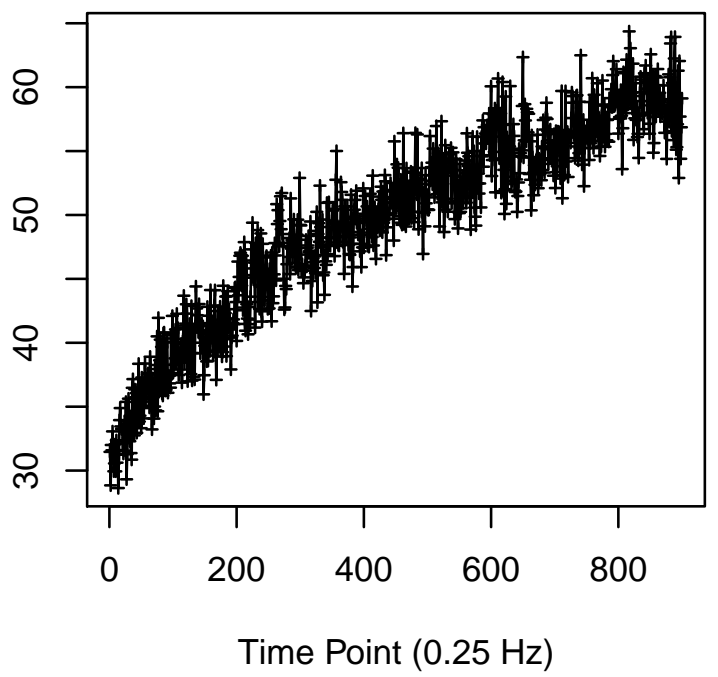

Cell 1359

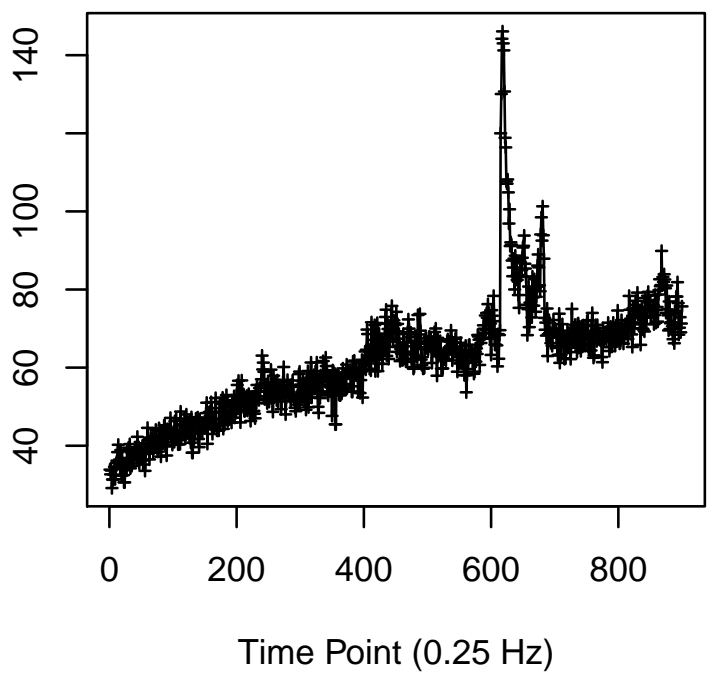

Cell 1358

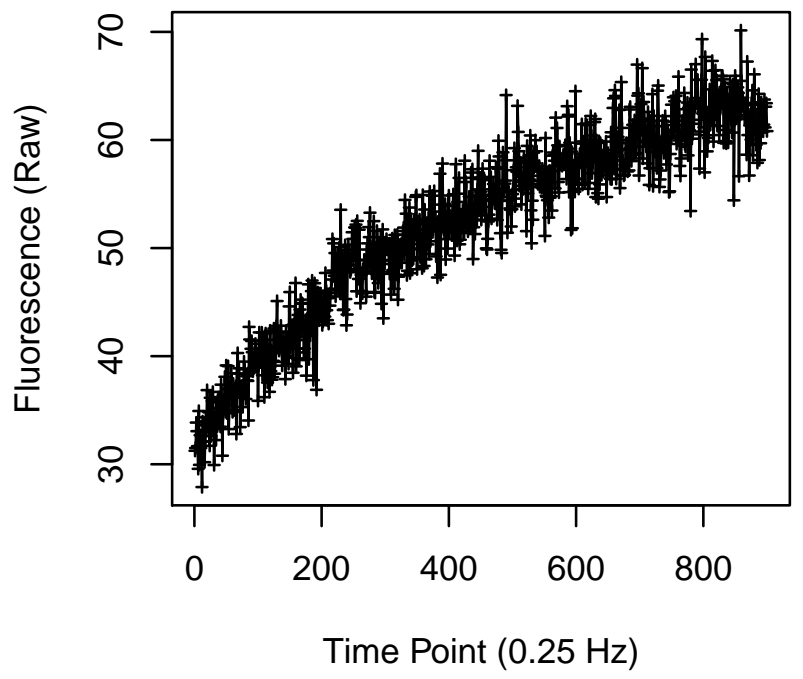

Cell 1360

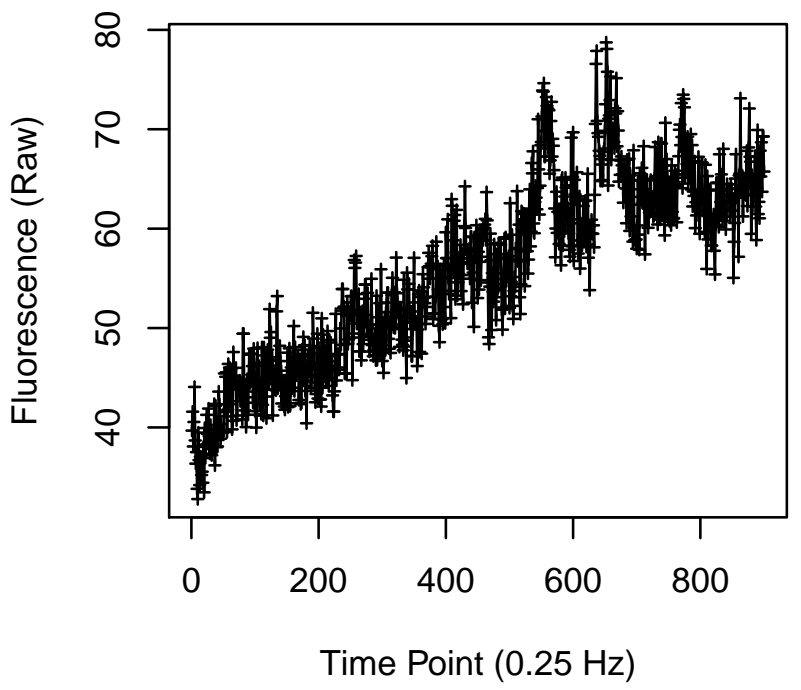


Cell 1361

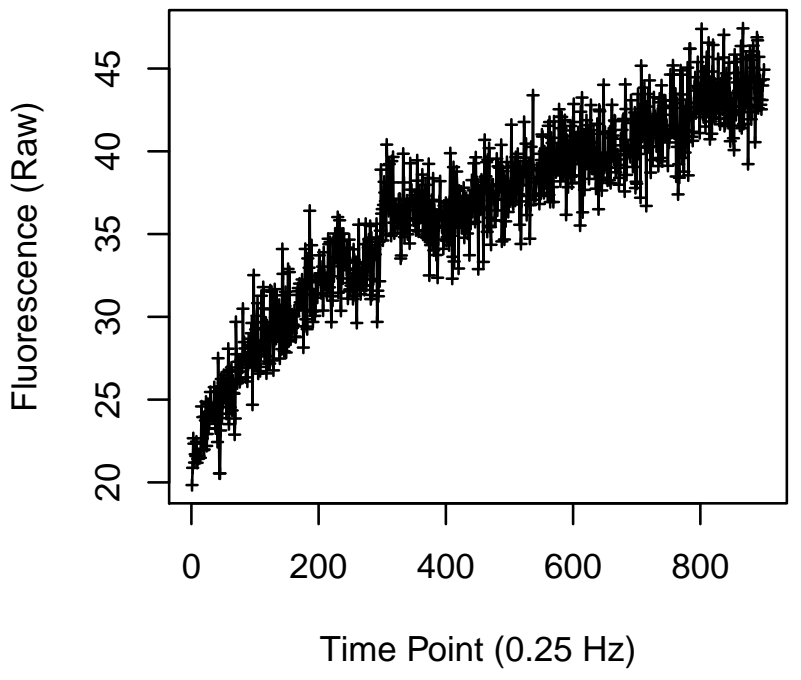

Cell 1363

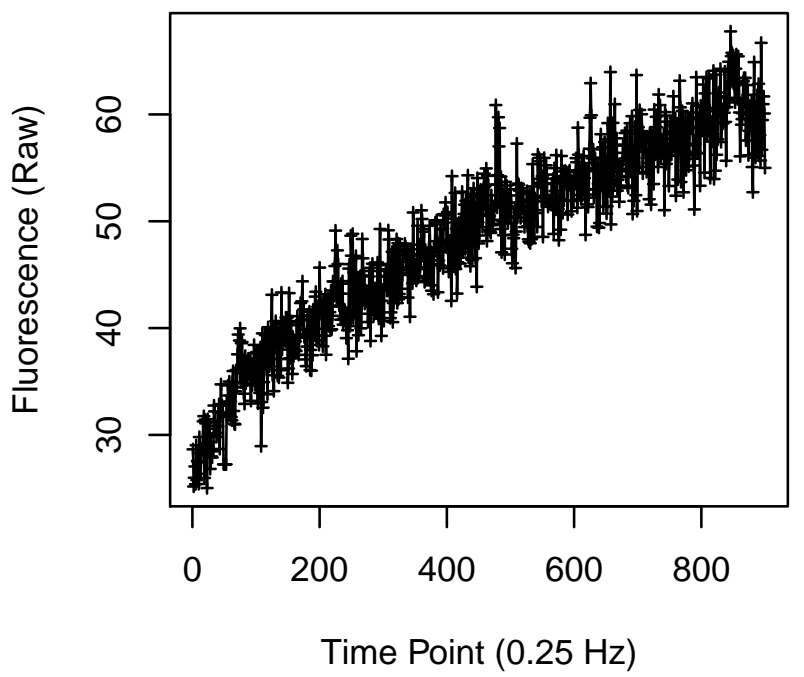

Cell 1362

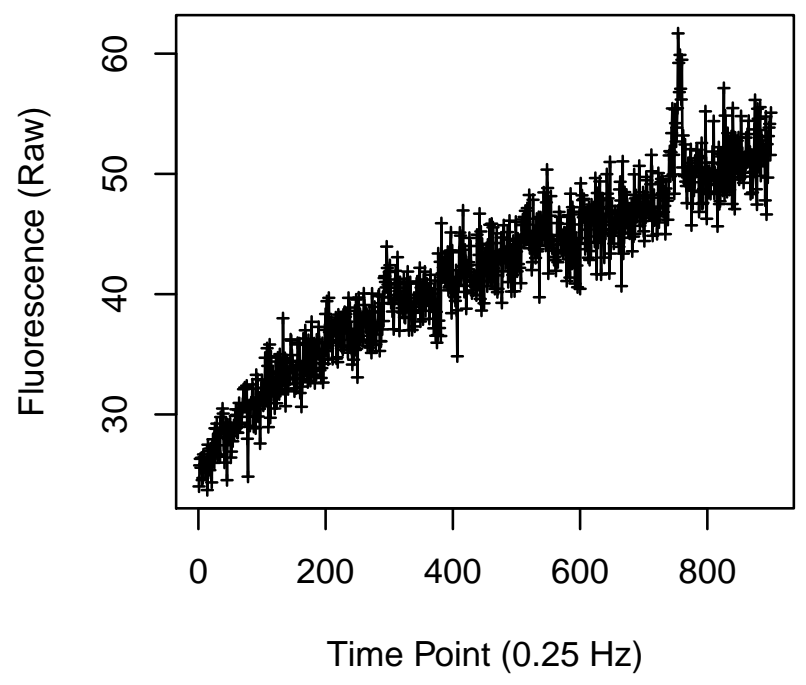

Cell 1364

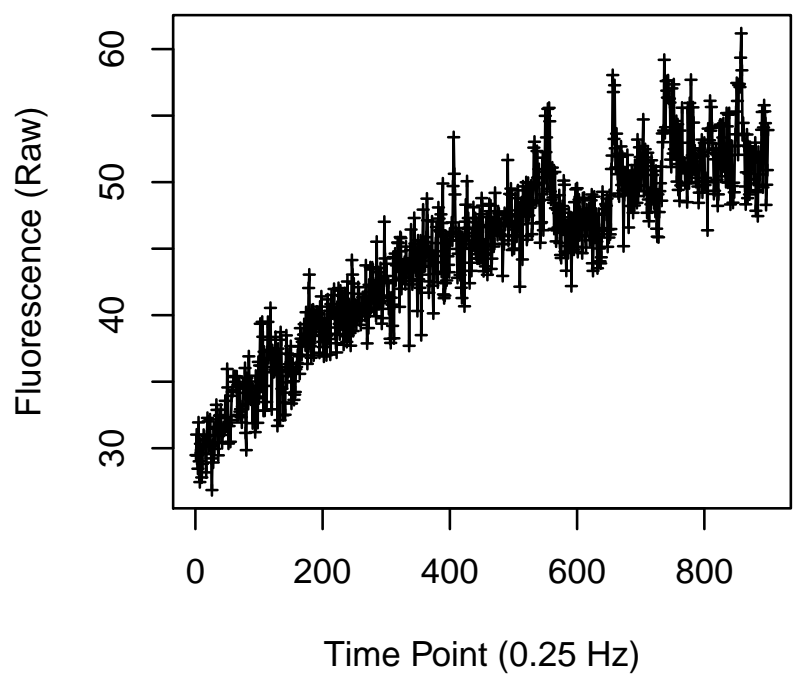


Cell 1365

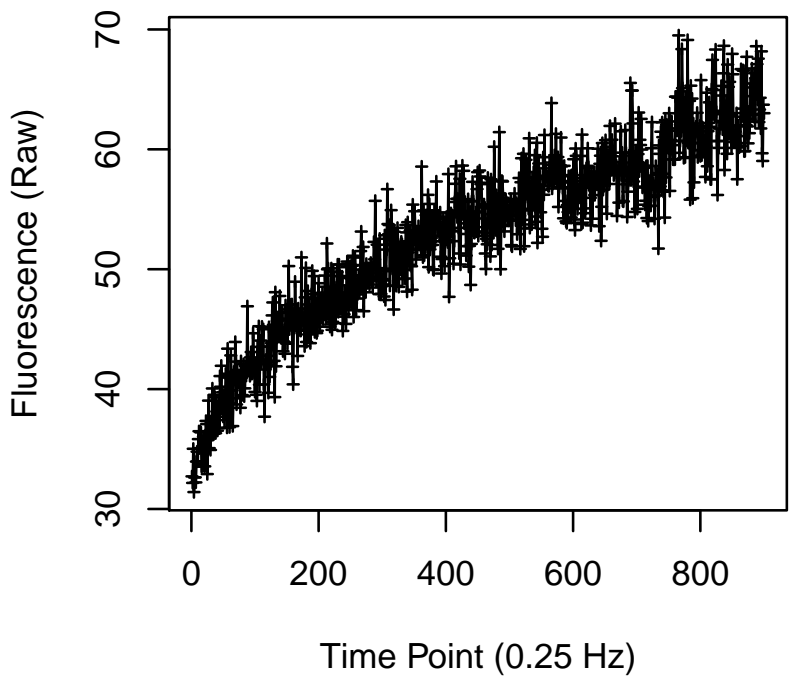

Cell 1367

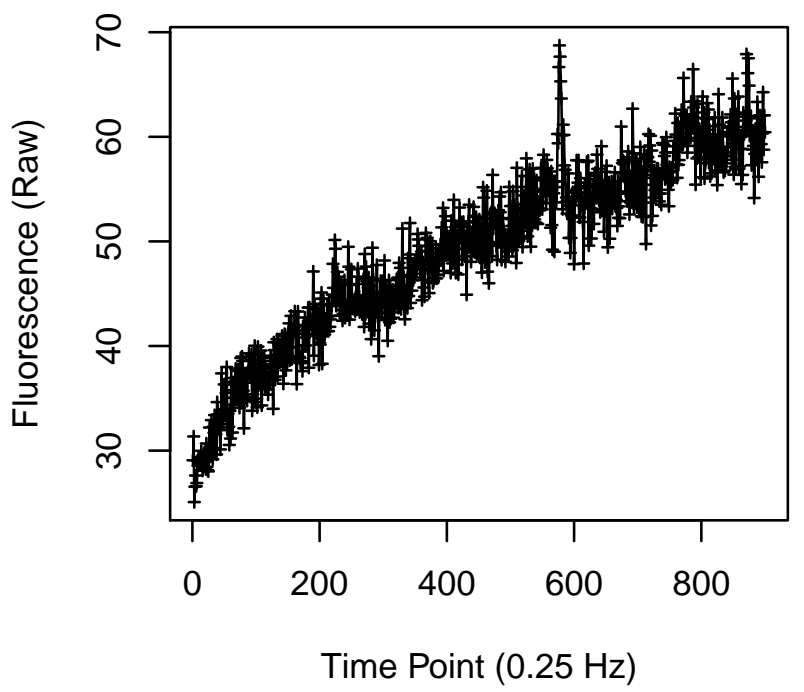

Cell 1366

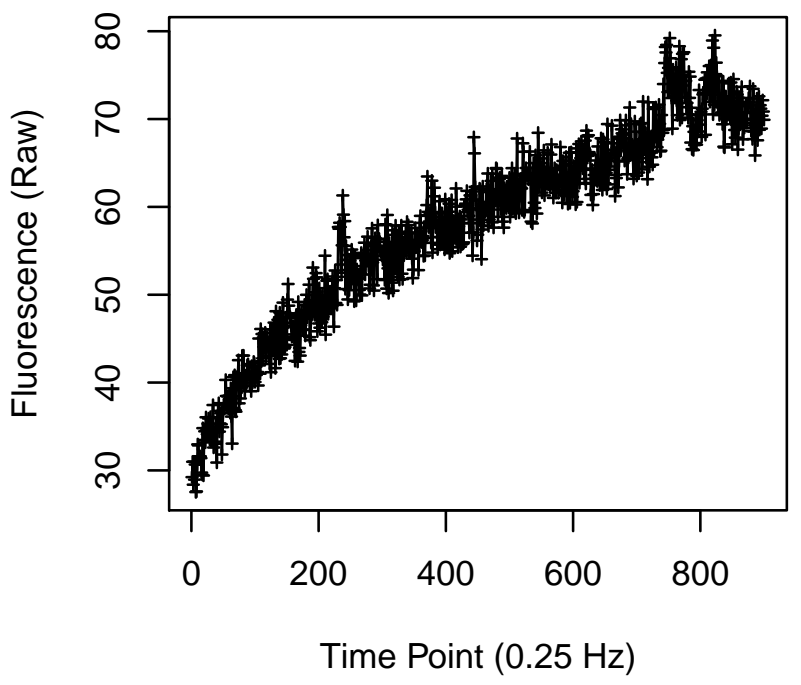

Cell 1368

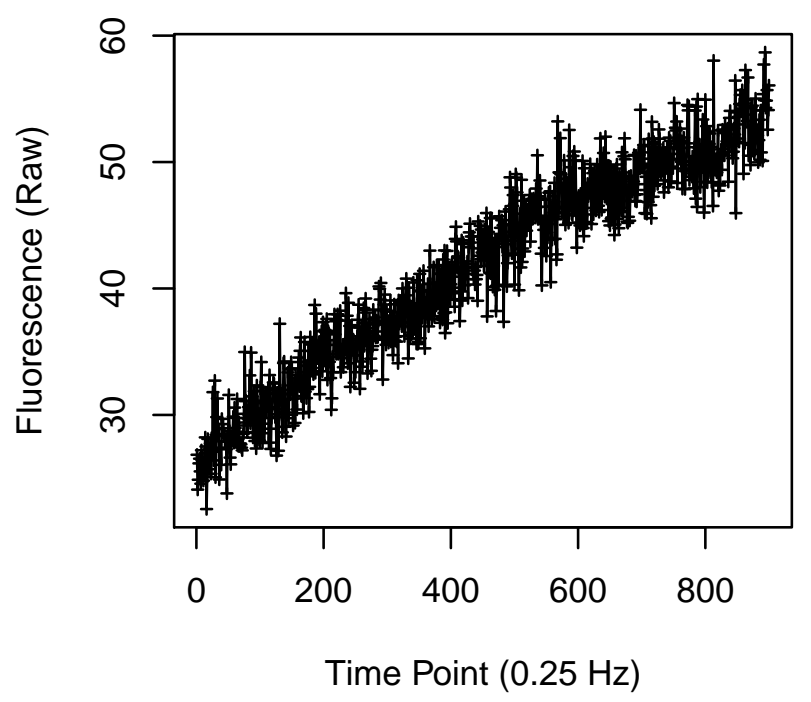


Cell 1369

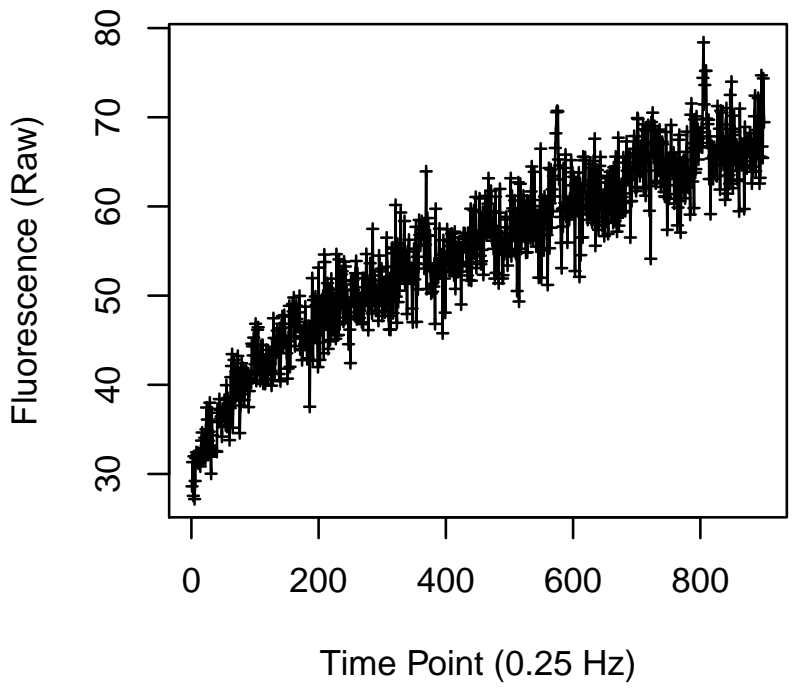

Cell 1371

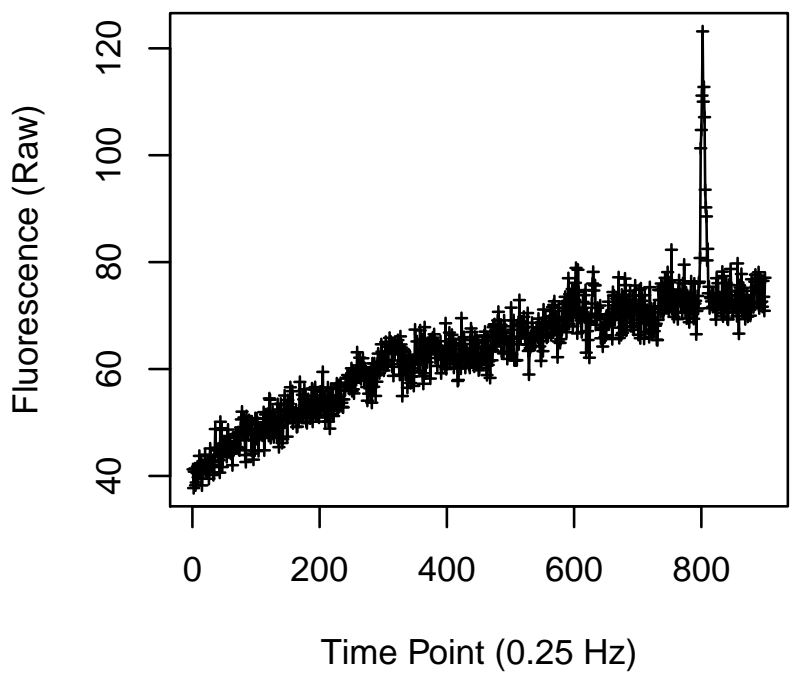

Cell 1370

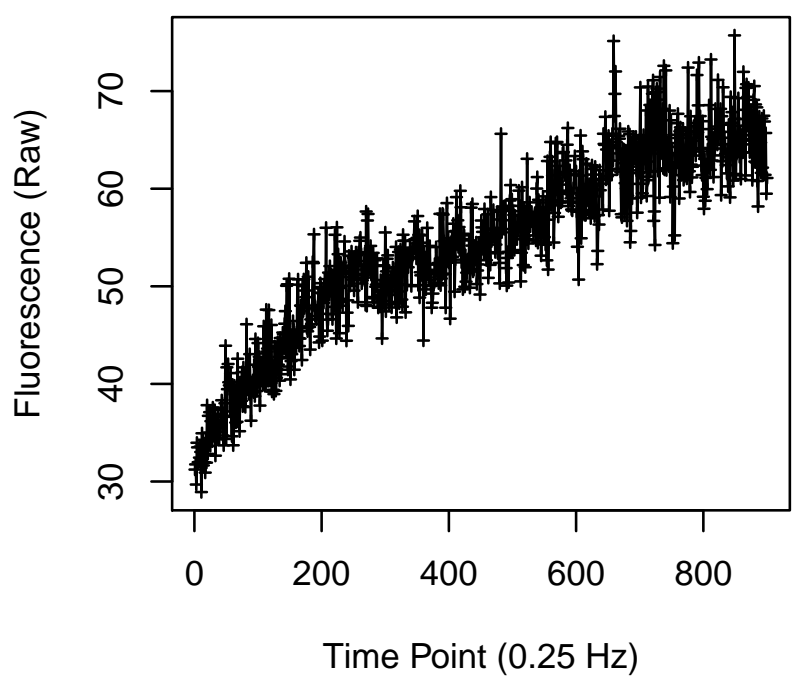

Cell 1372

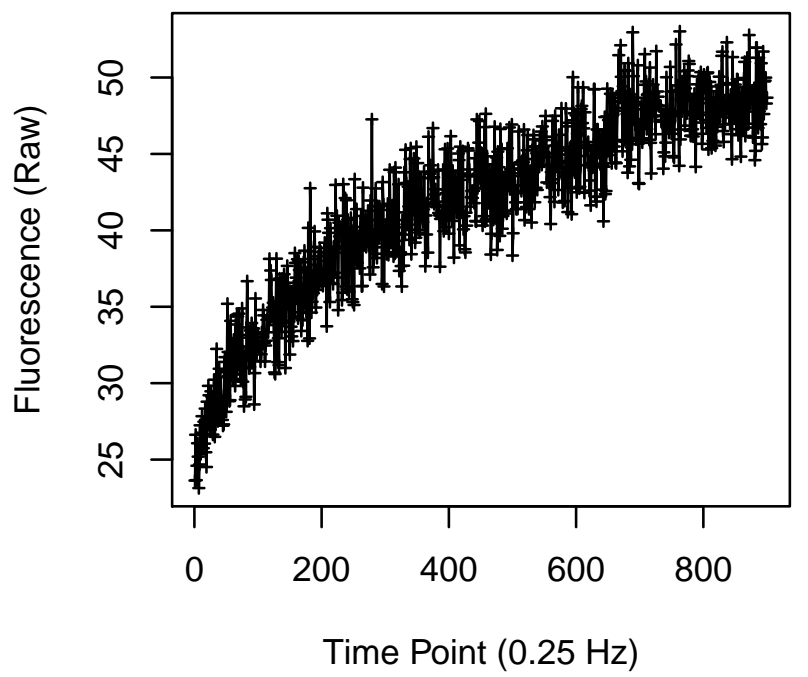


Cell 1373

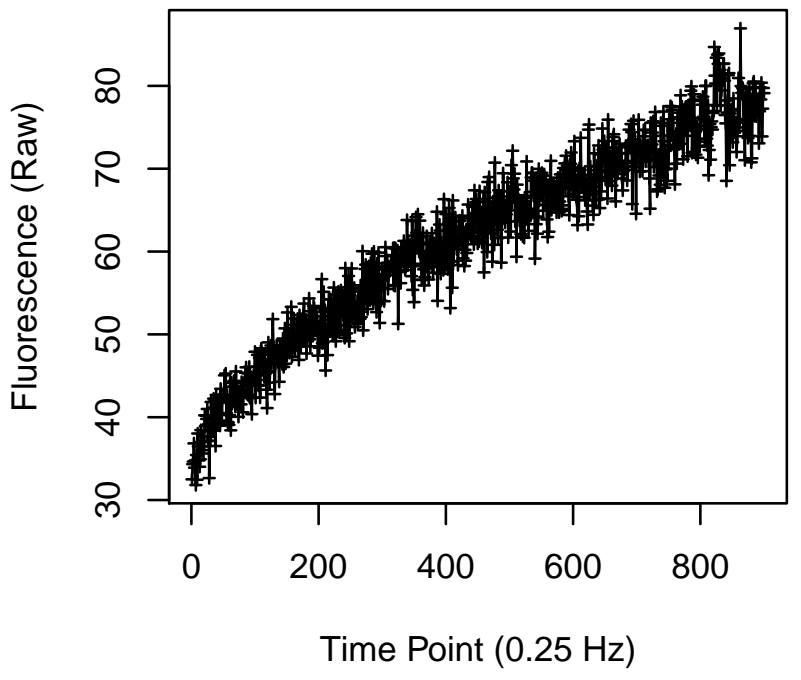

Cell 1375

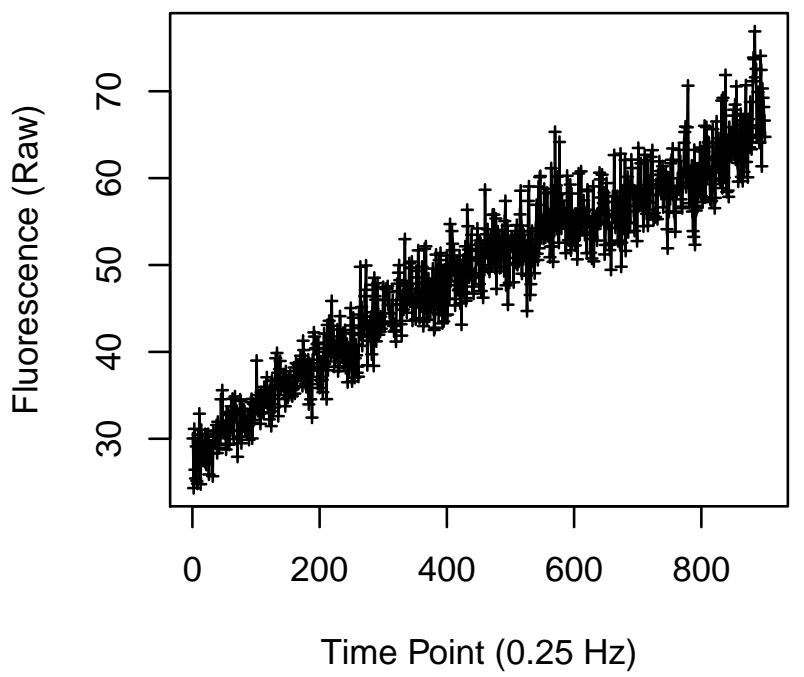

Cell 1374

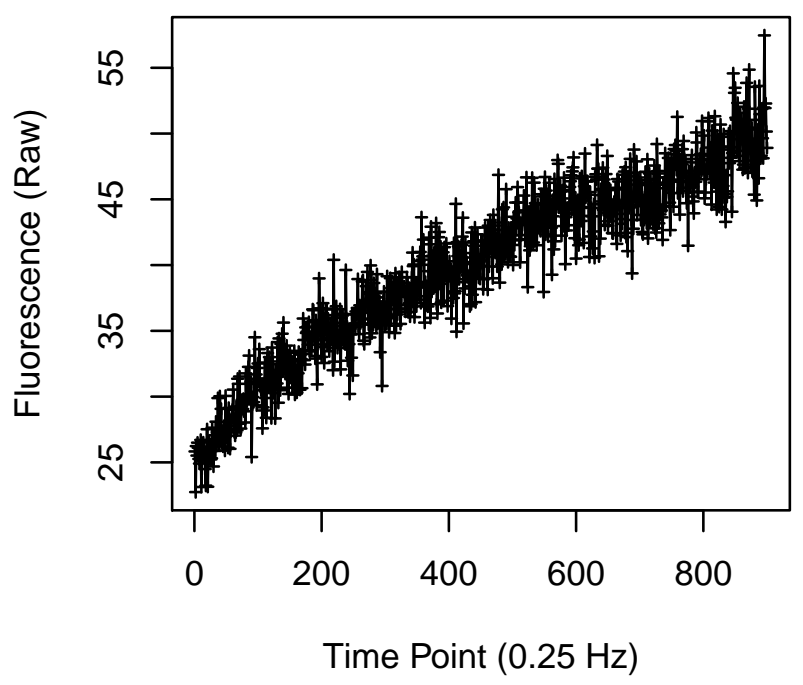

Cell 1376

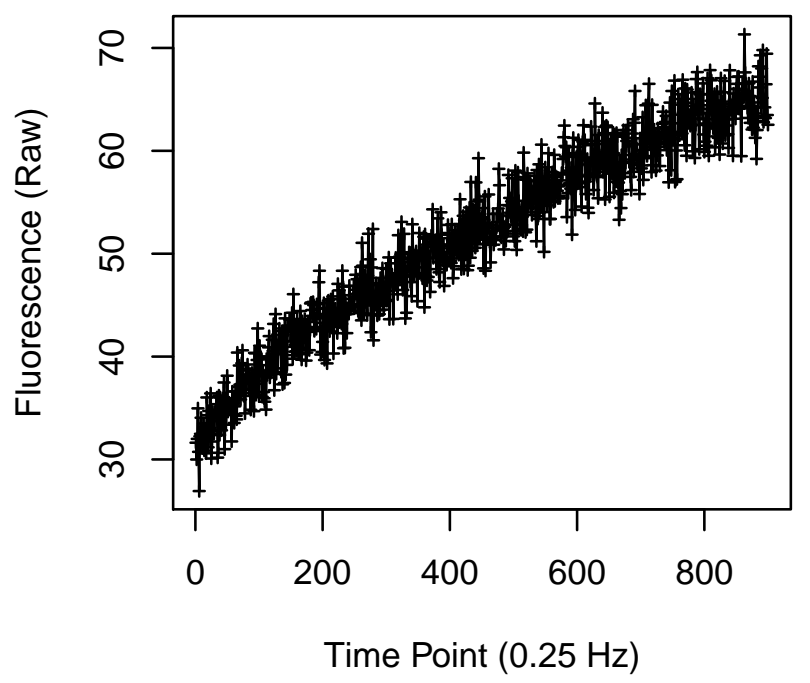


Cell 1377

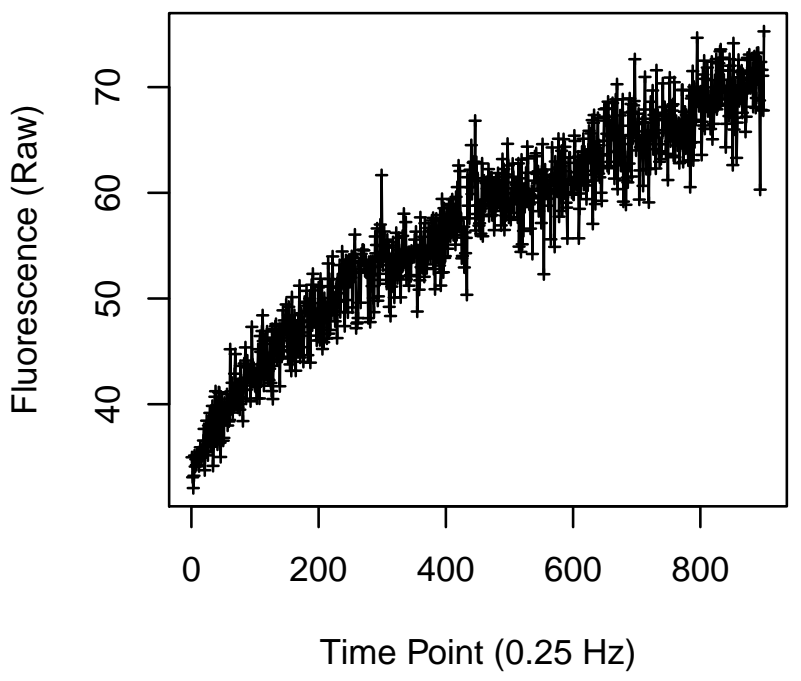

Cell 1379

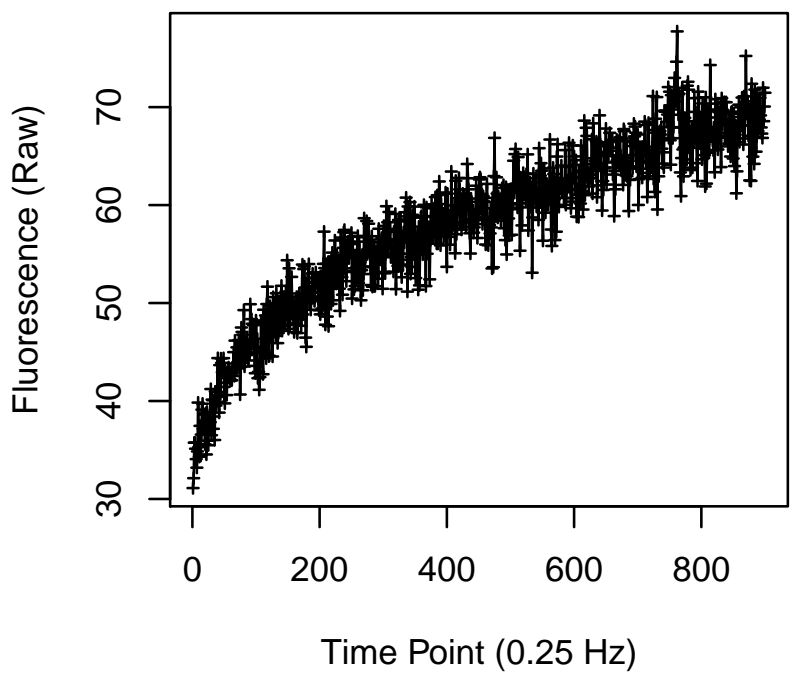

Cell 1378

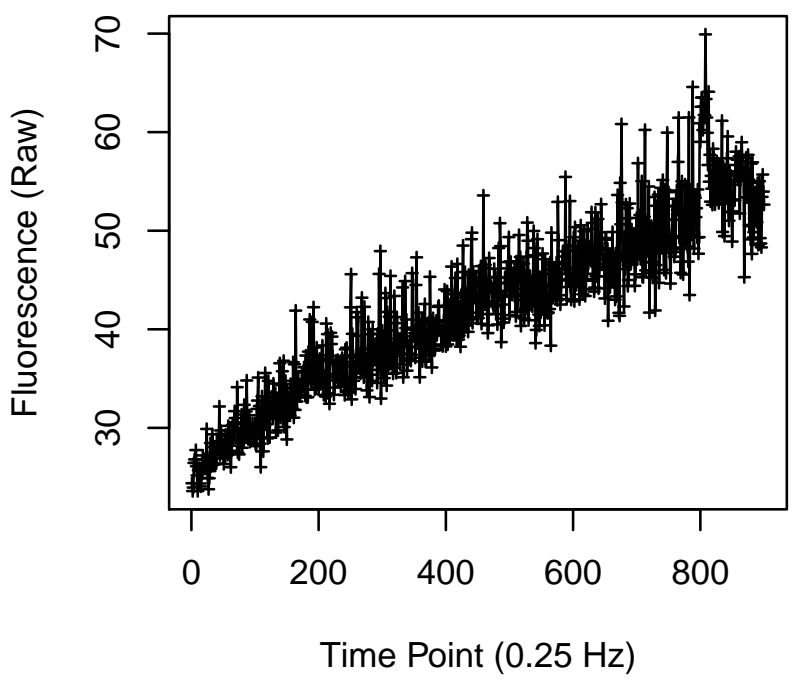

Cell 1380

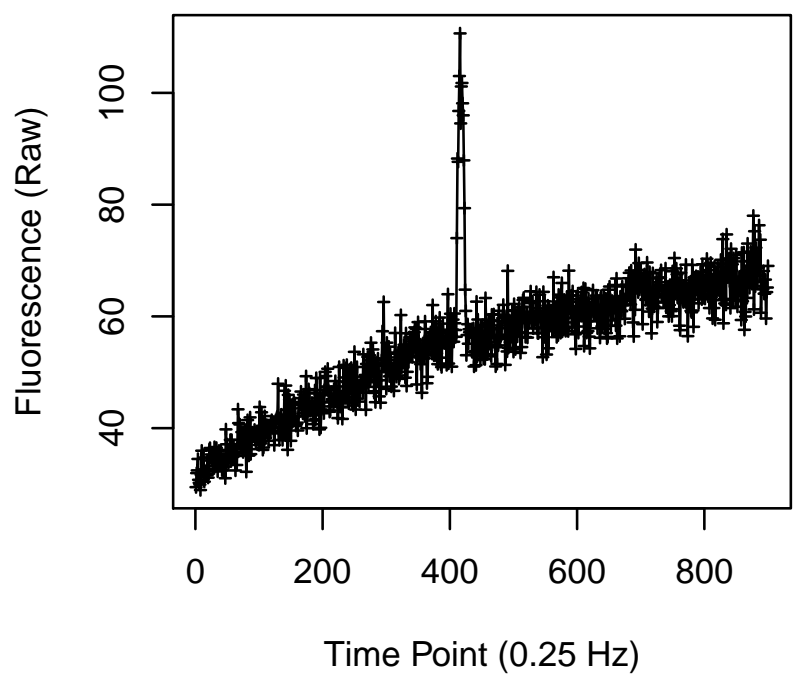


Cell 1385

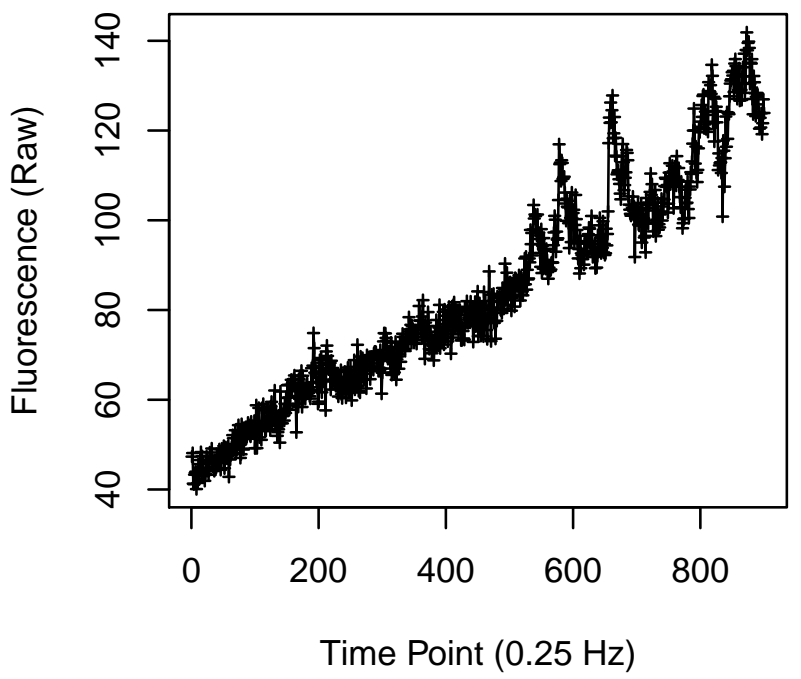

Cell 1387

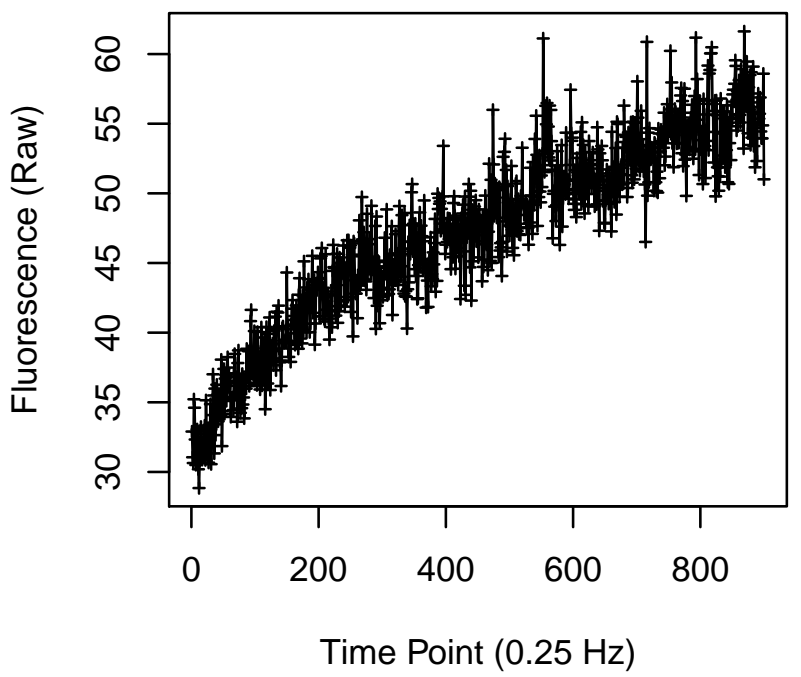

Cell 1386

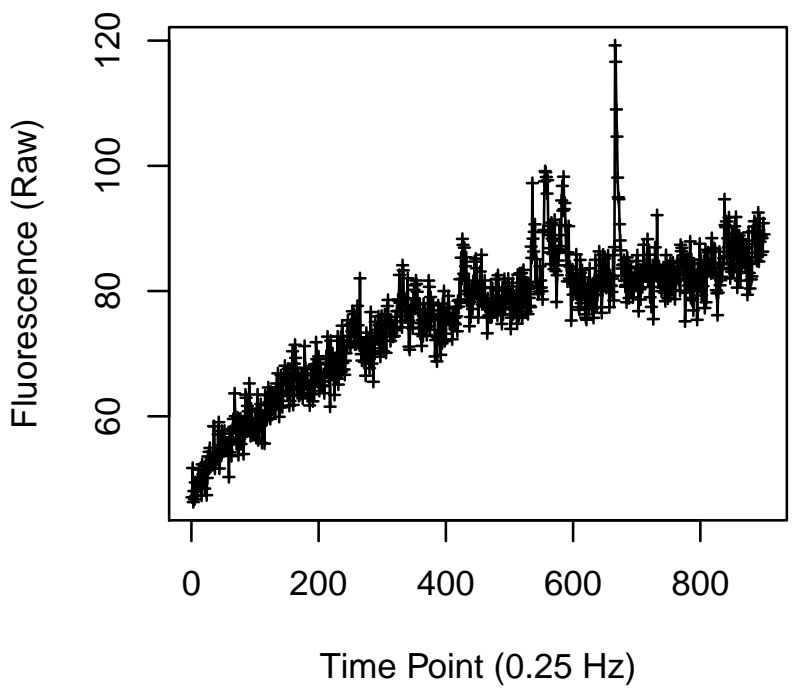

Cell 1388

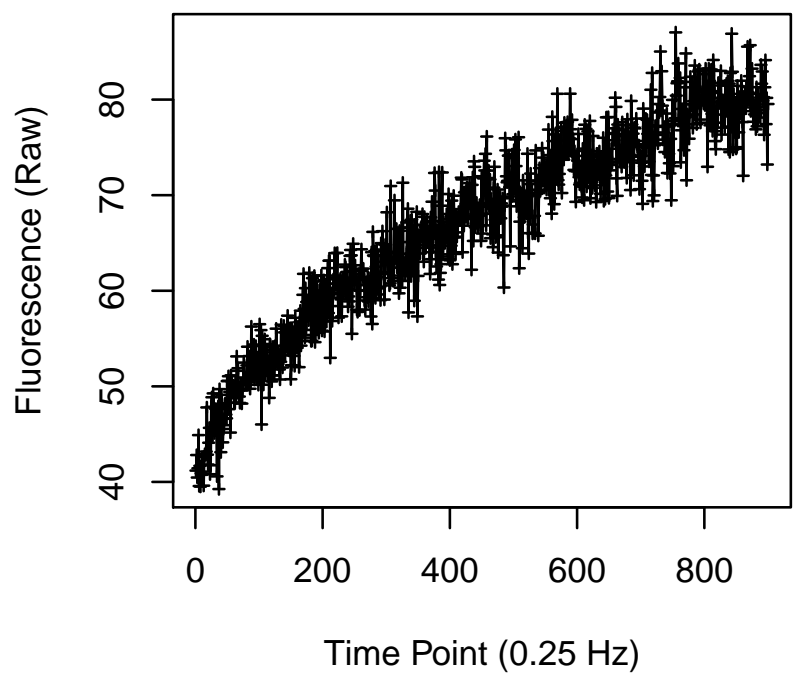


Cell 1389

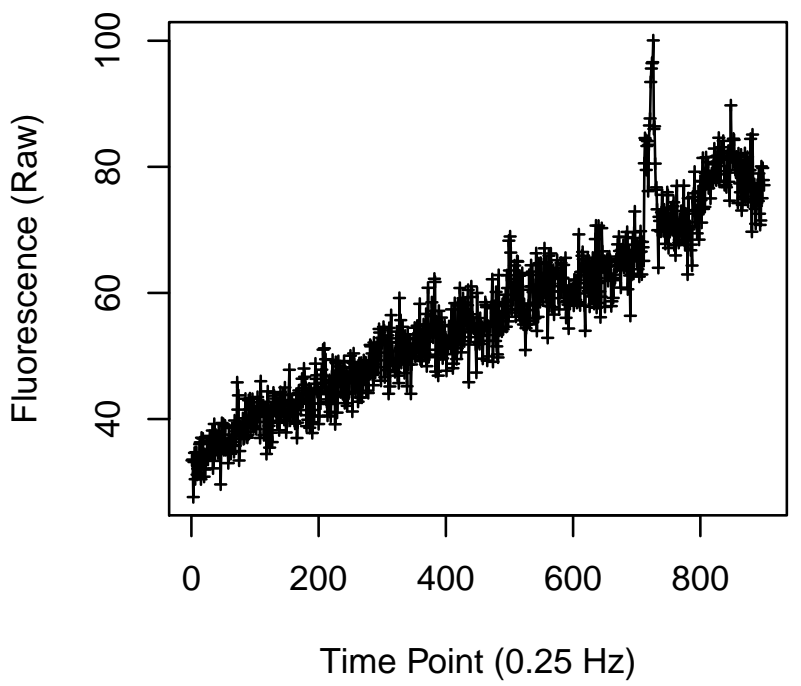

Cell 1391

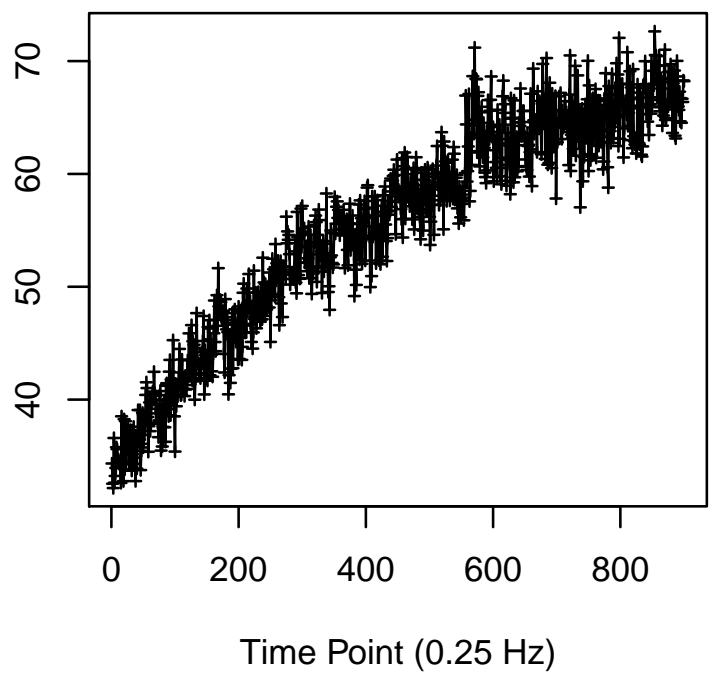

Cell 1390

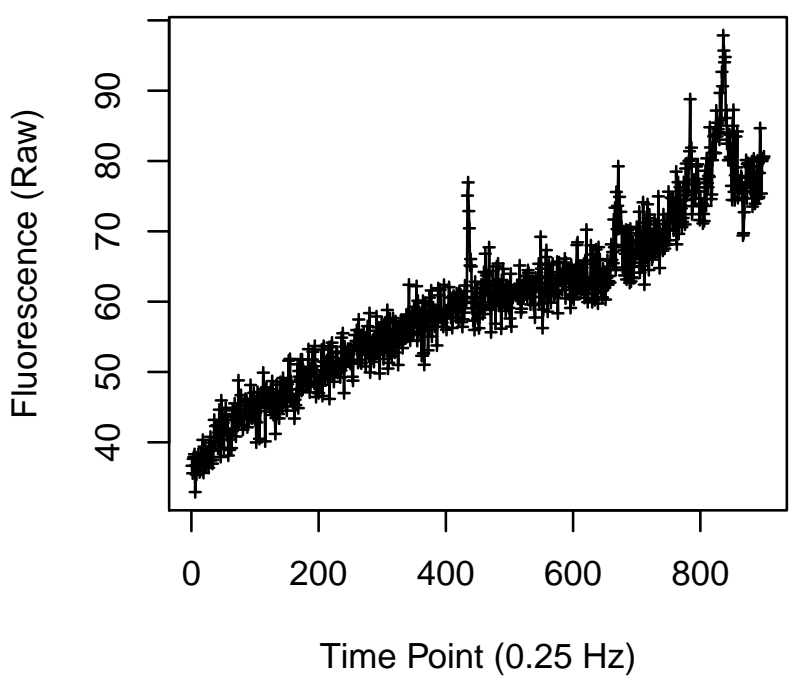

Cell 1392

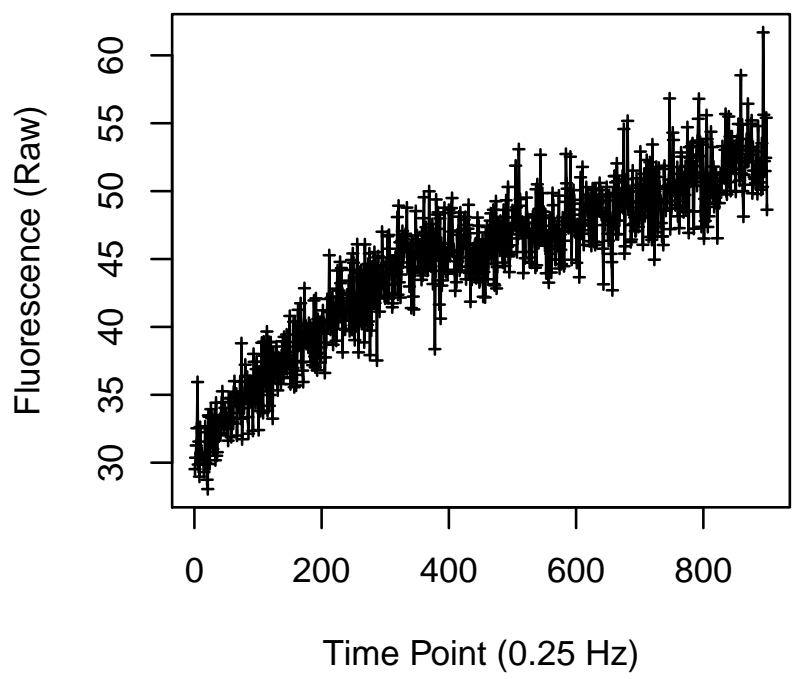


Cell 1393

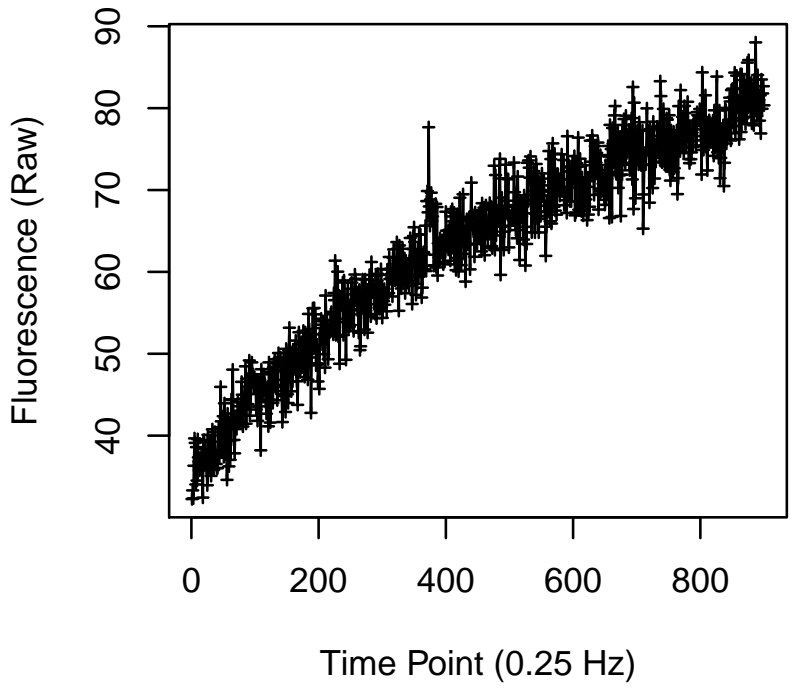

Cell 1395

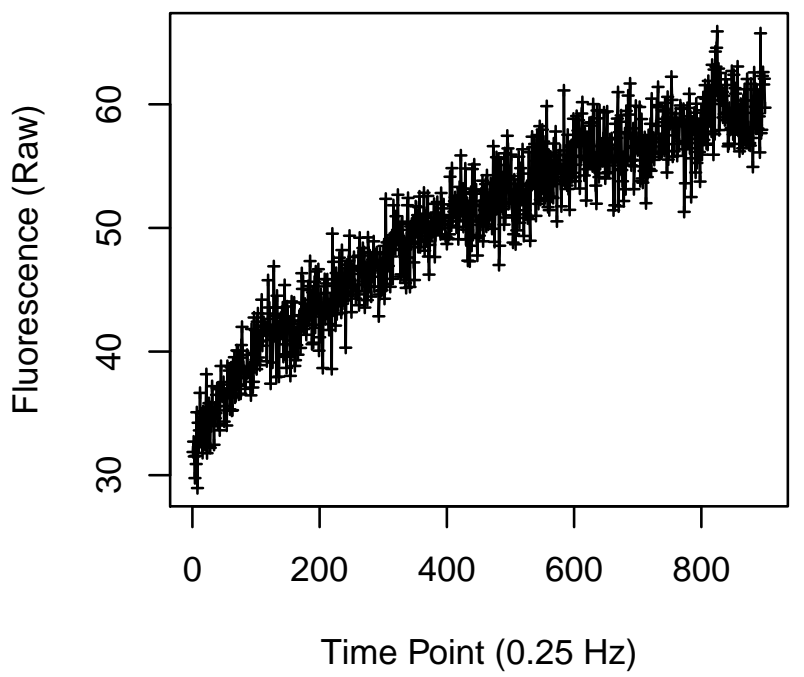

Cell 1394

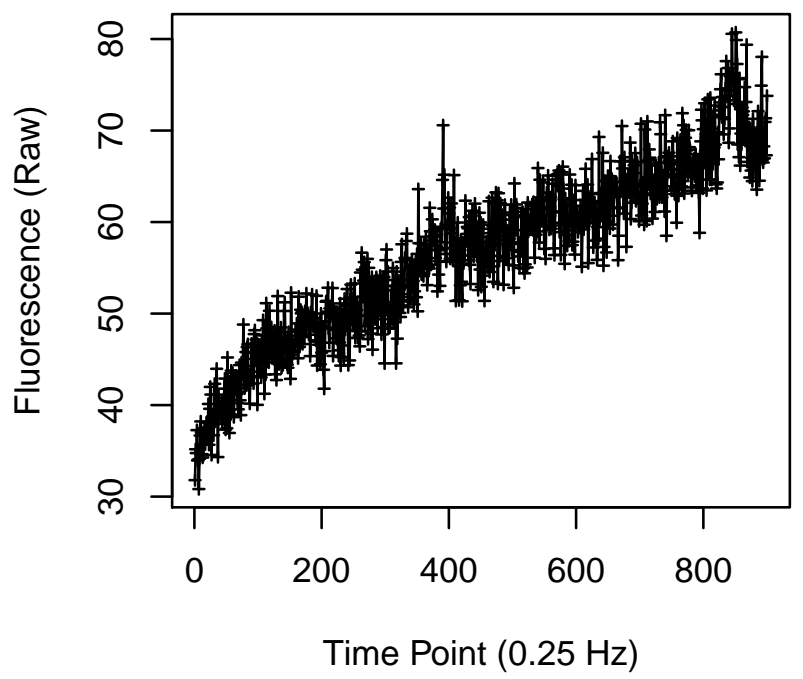

Cell 1396

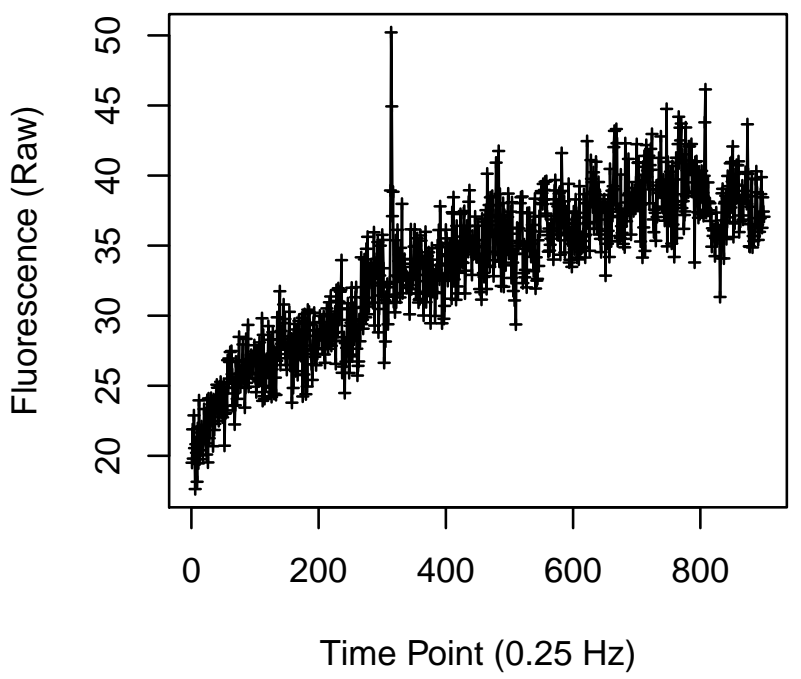


Cell 1397

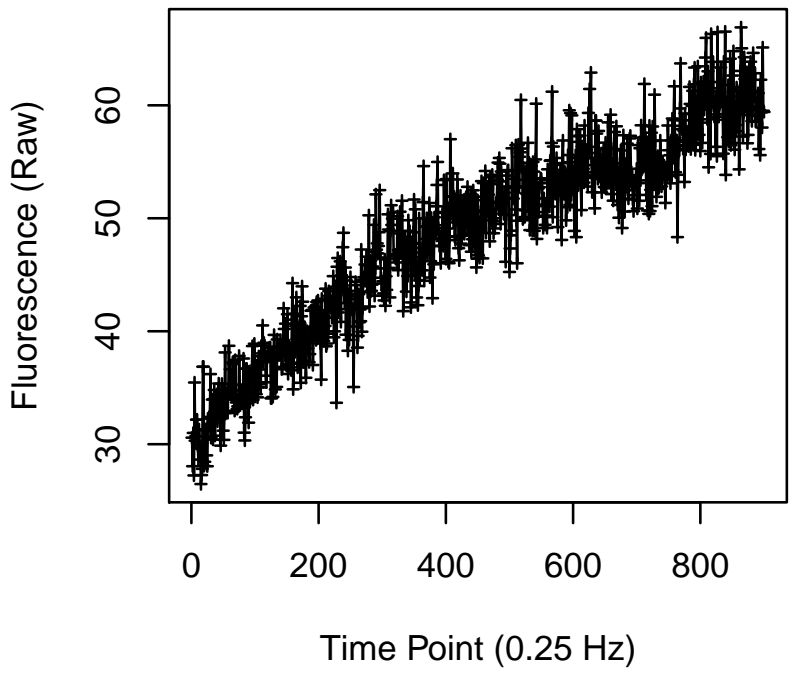

Cell 1399

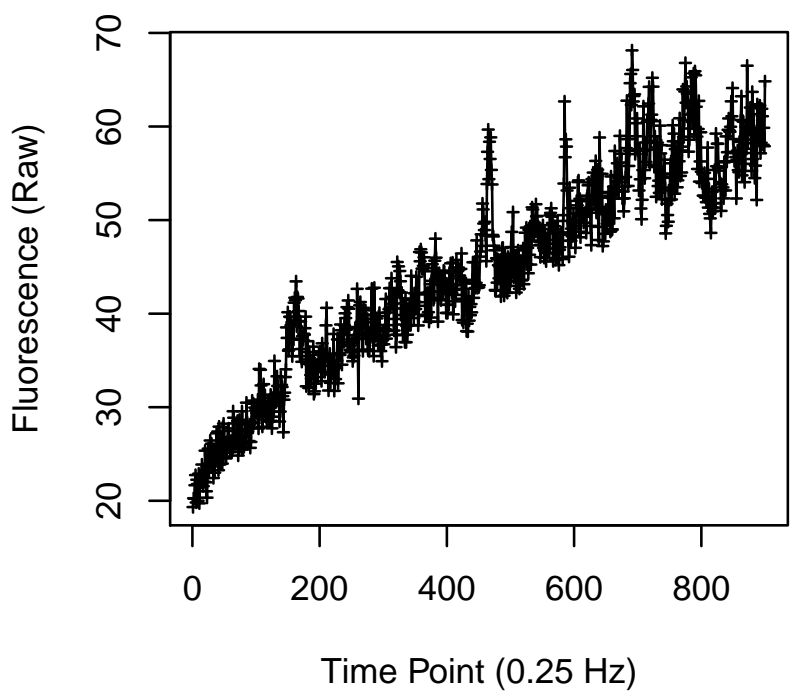

Cell 1398

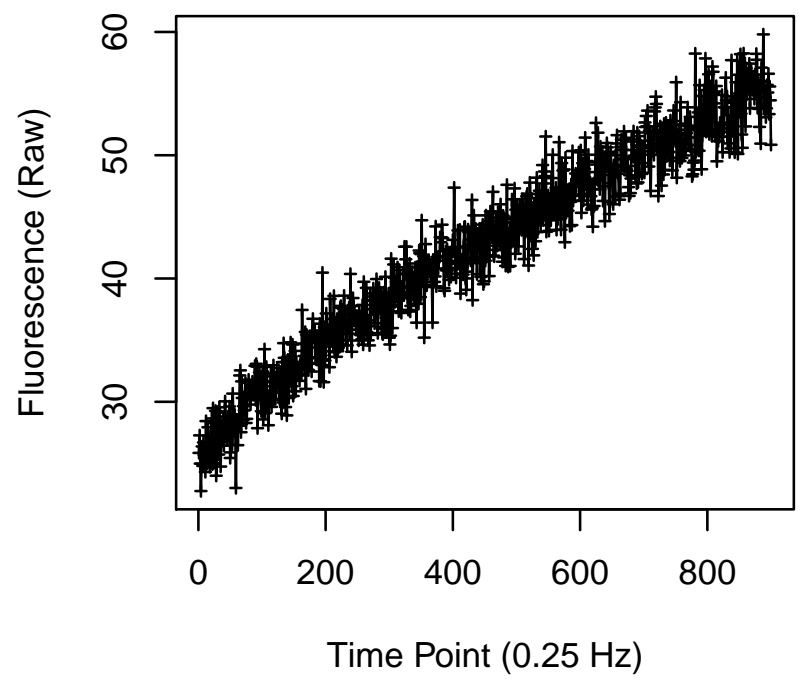

Cell 1400

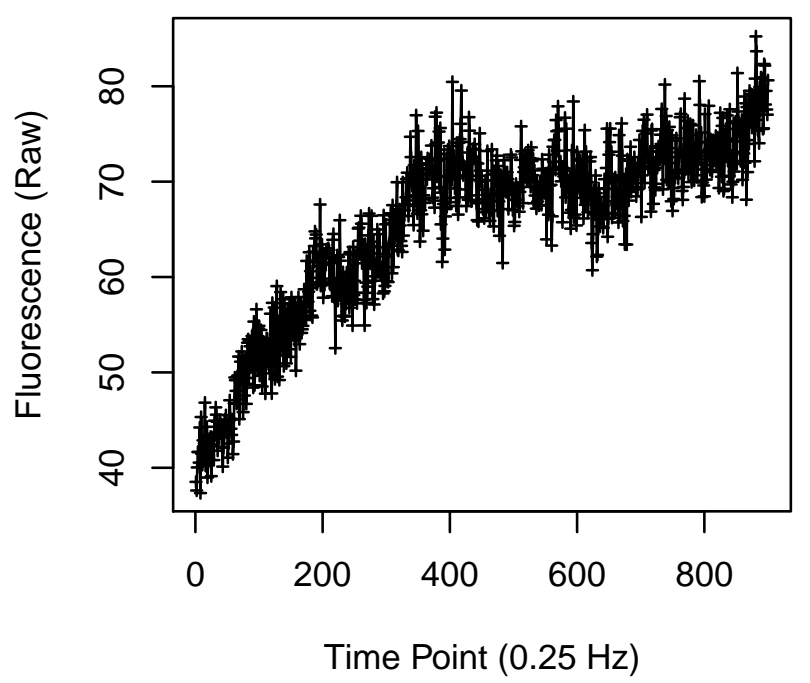


Cell 1401

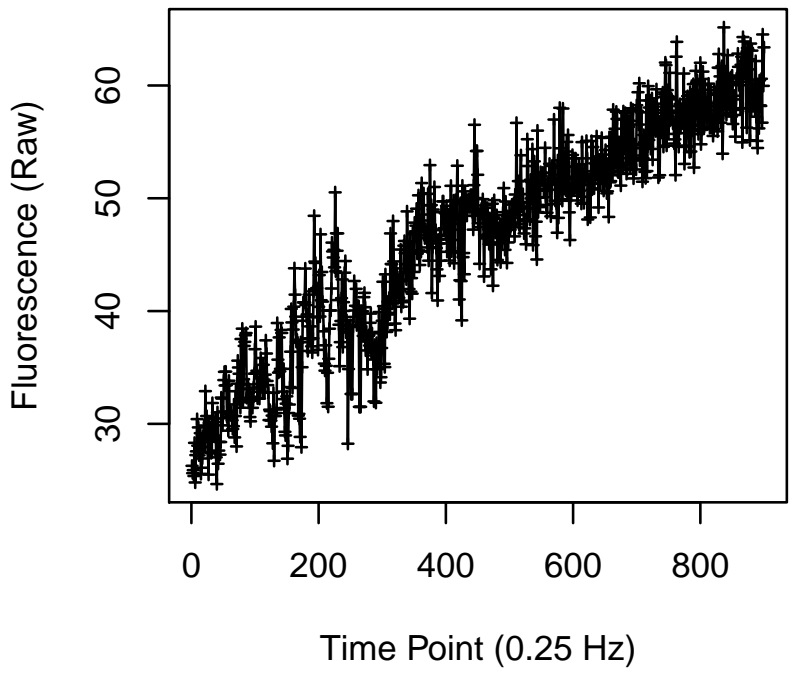

Cell 1403

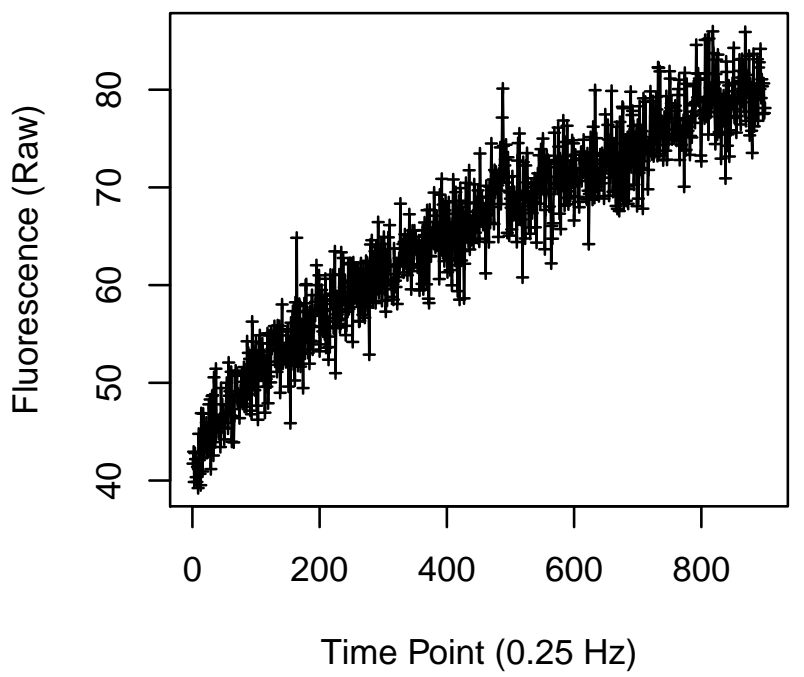

Cell 1402

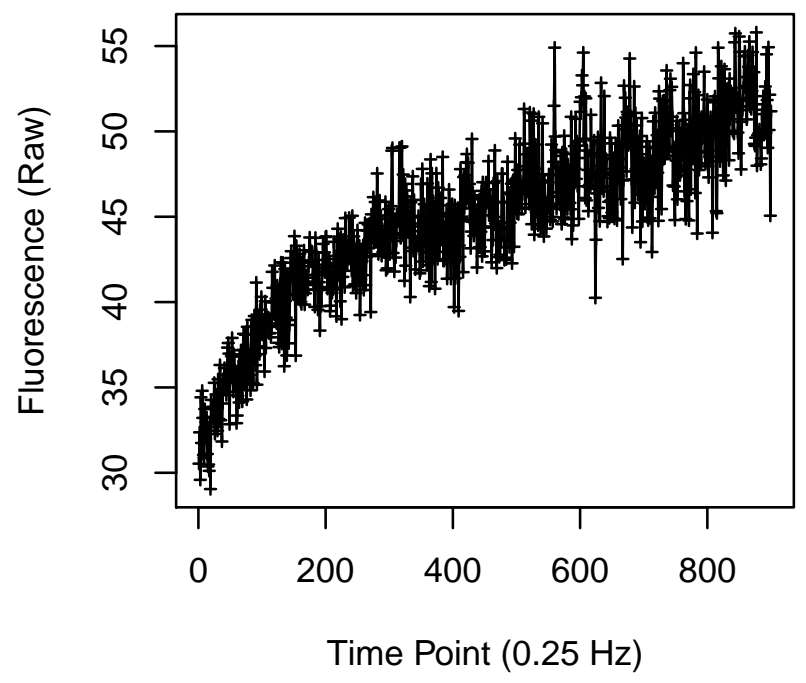

Cell 1404

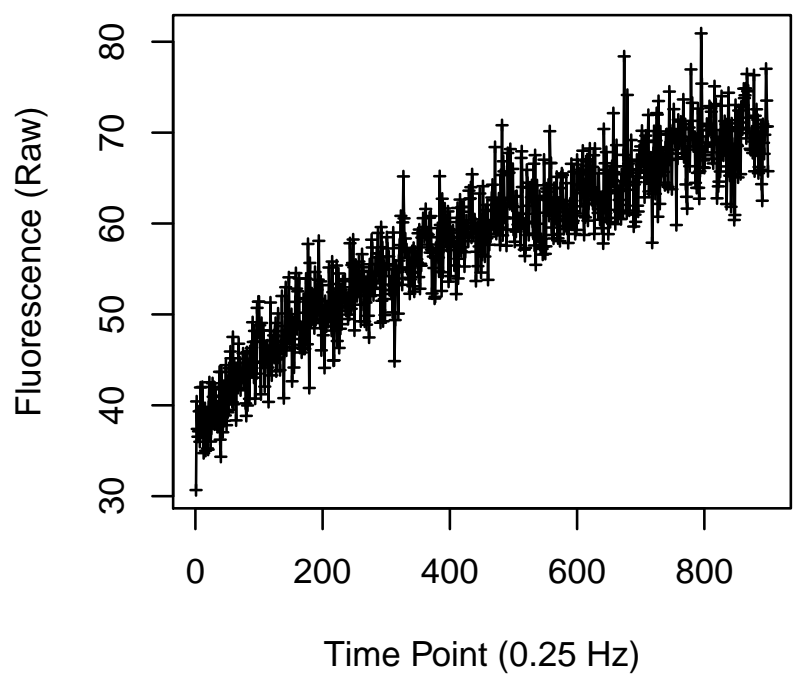


Cell 1405

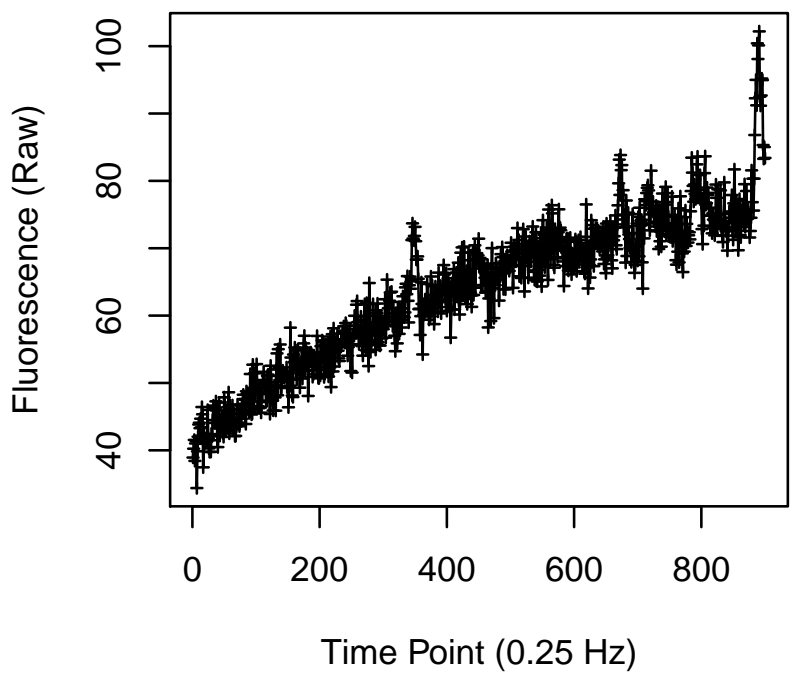

Cell 1407

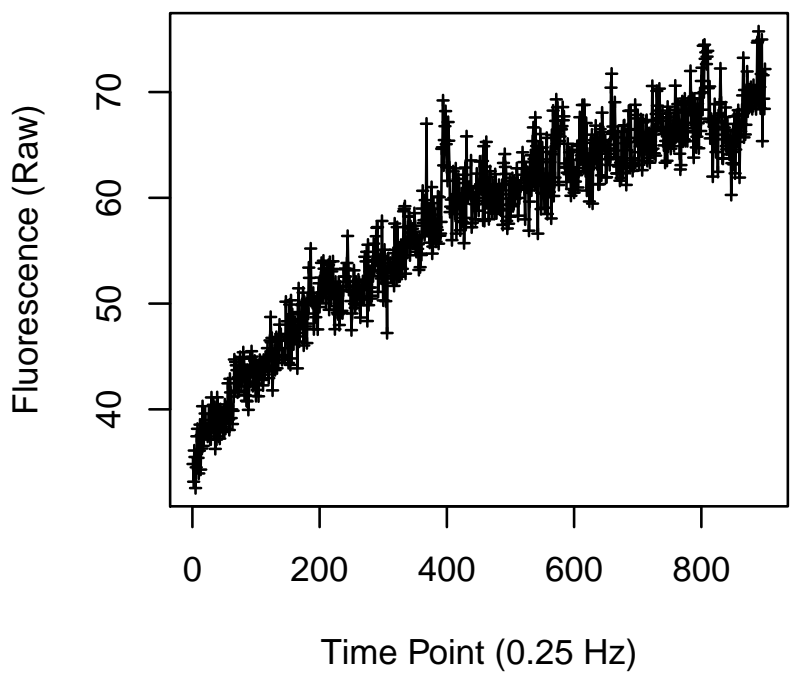

Cell 1406

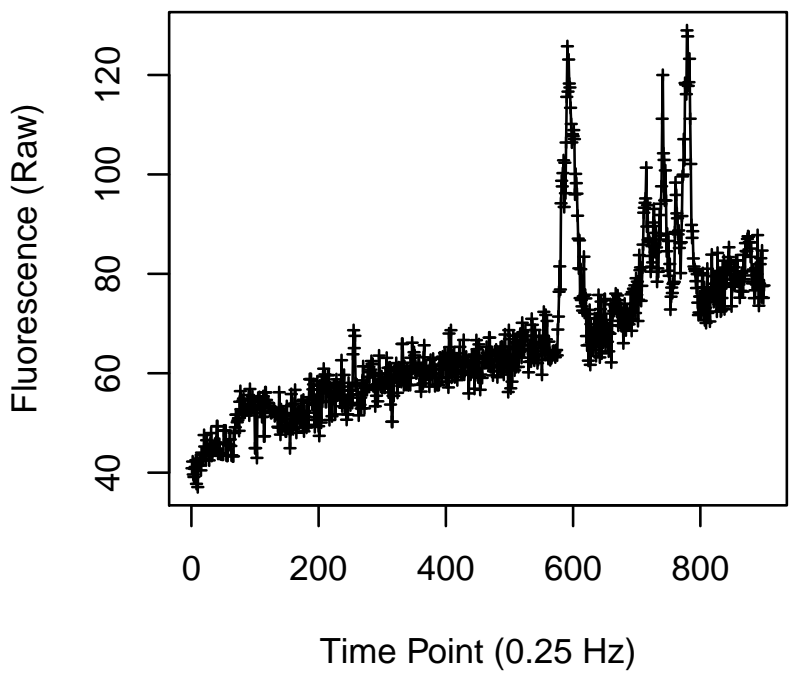

Cell 1408

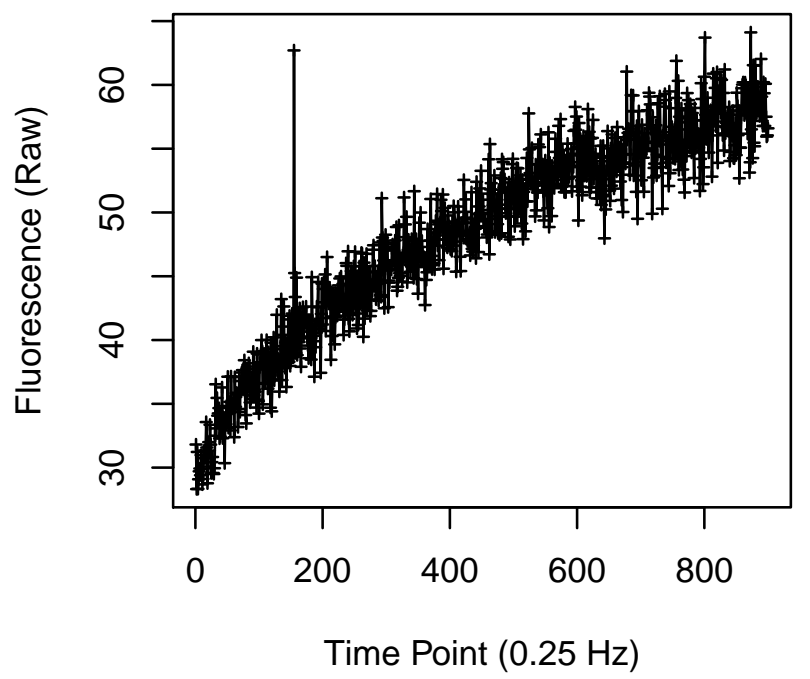


Cell 1409

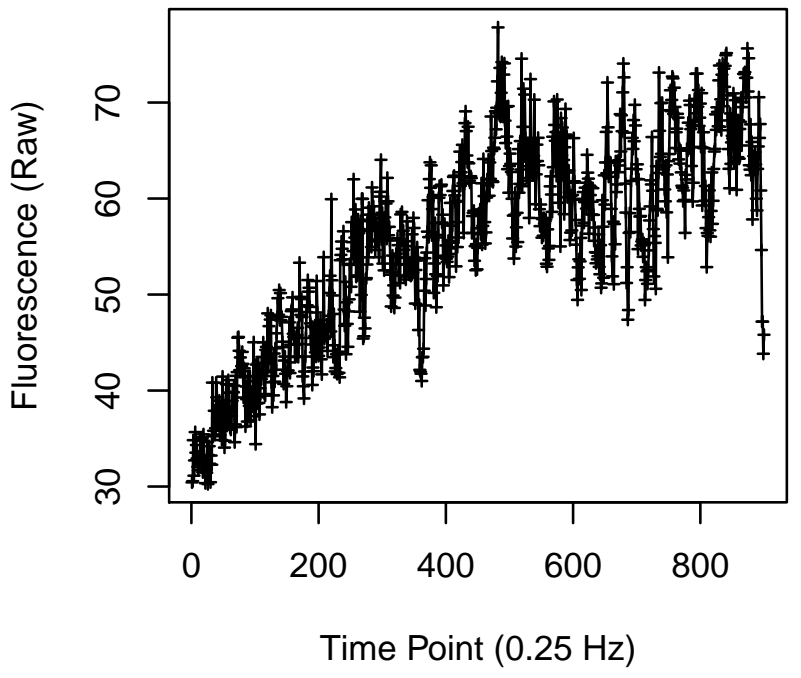

Cell 1411

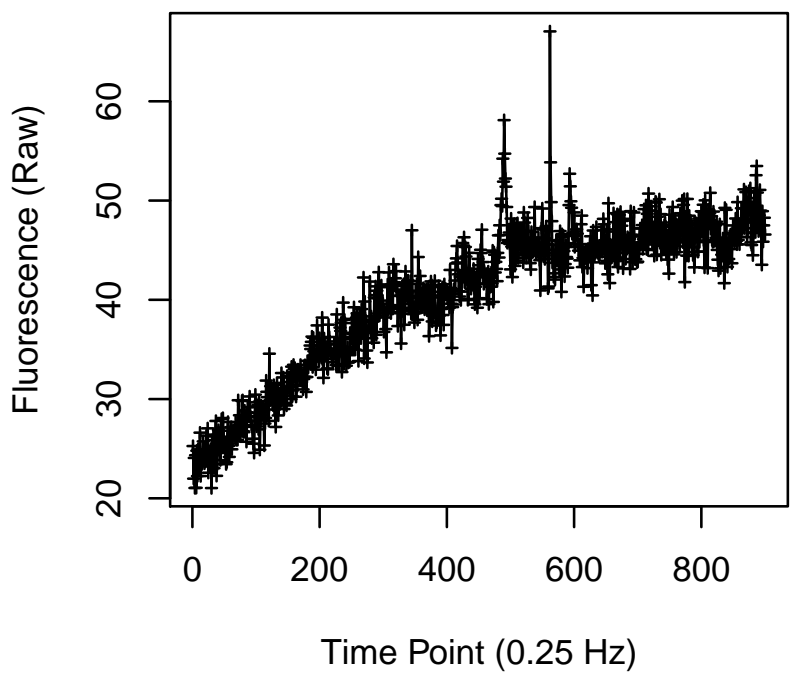

Cell 1410

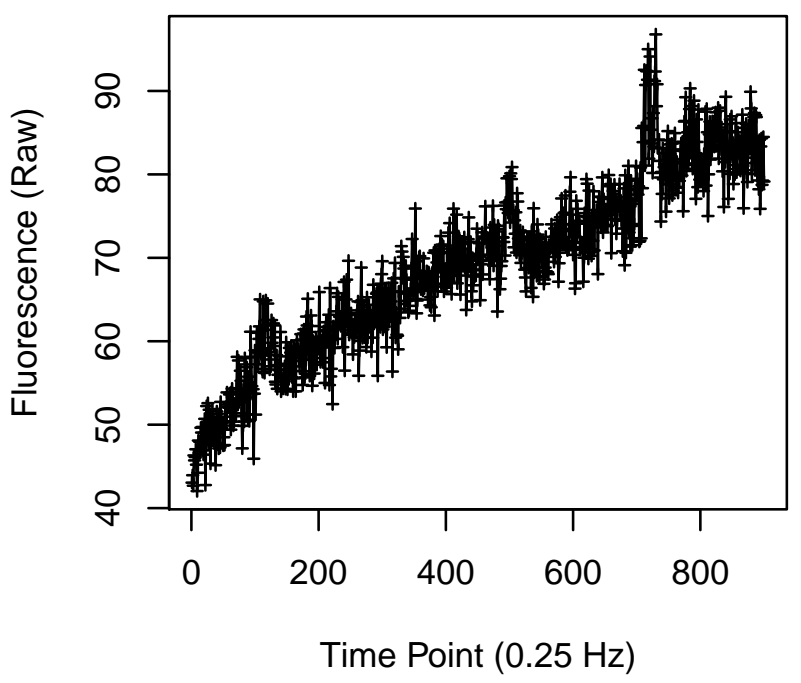

Cell 1412

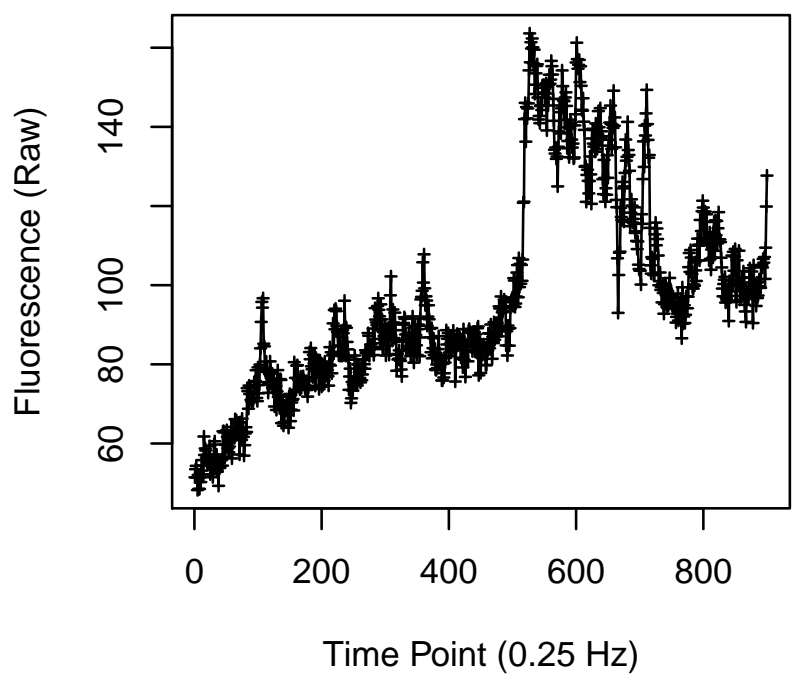


Cell 1413

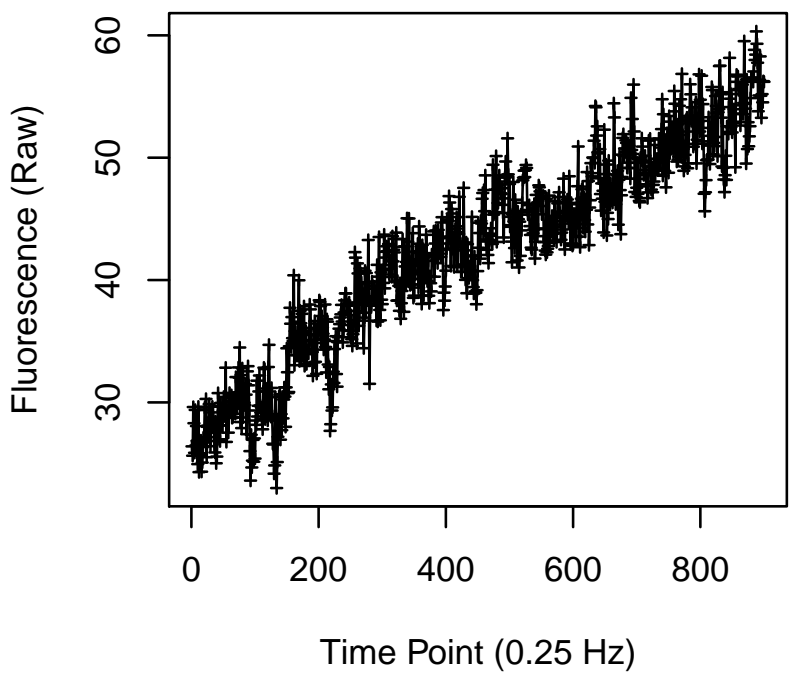

Cell 1415

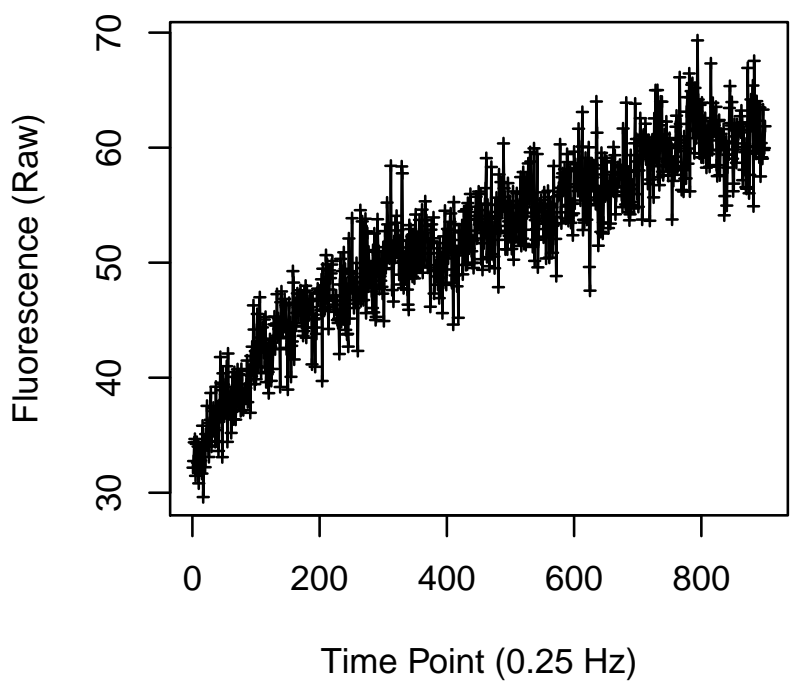

Cell 1414

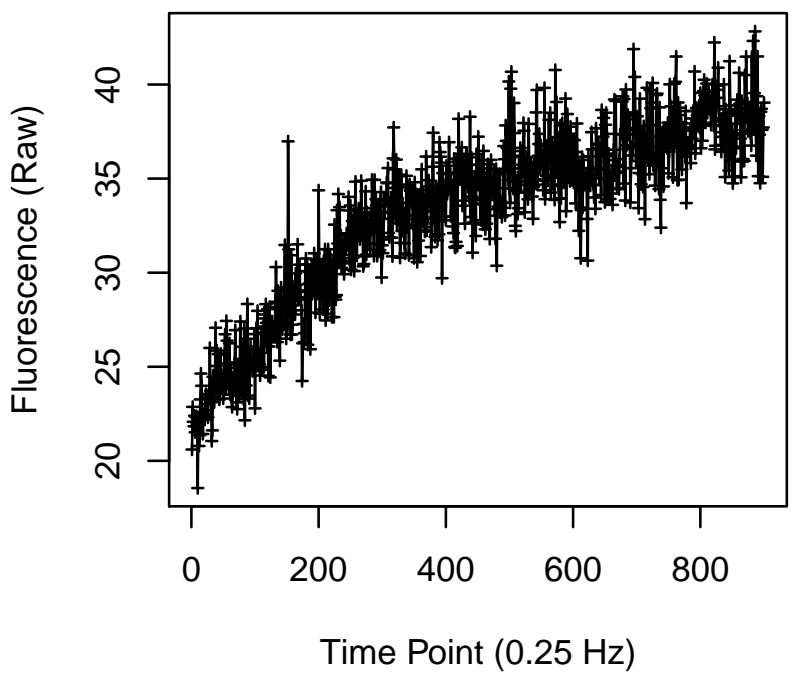

Cell 1416

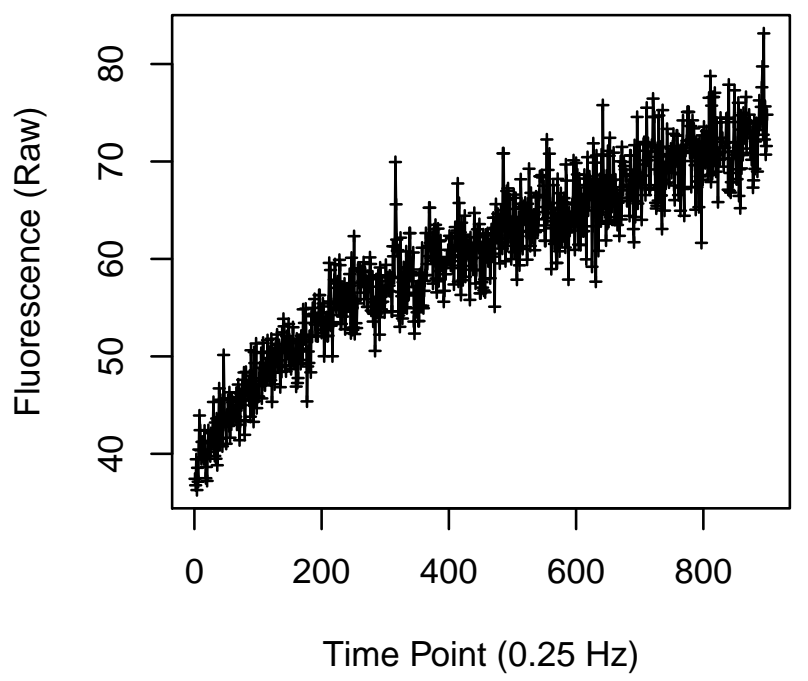


Cell 1417

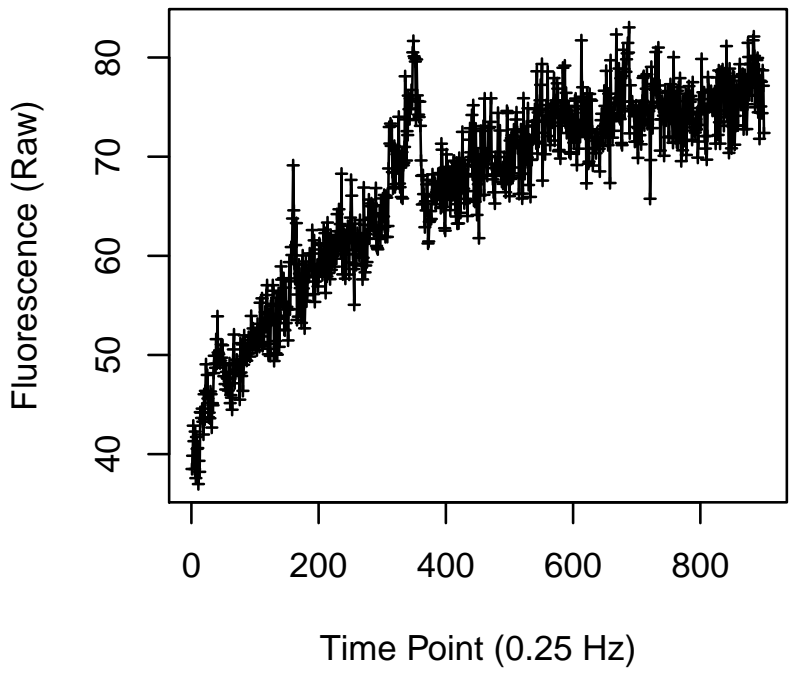

Cell 1419

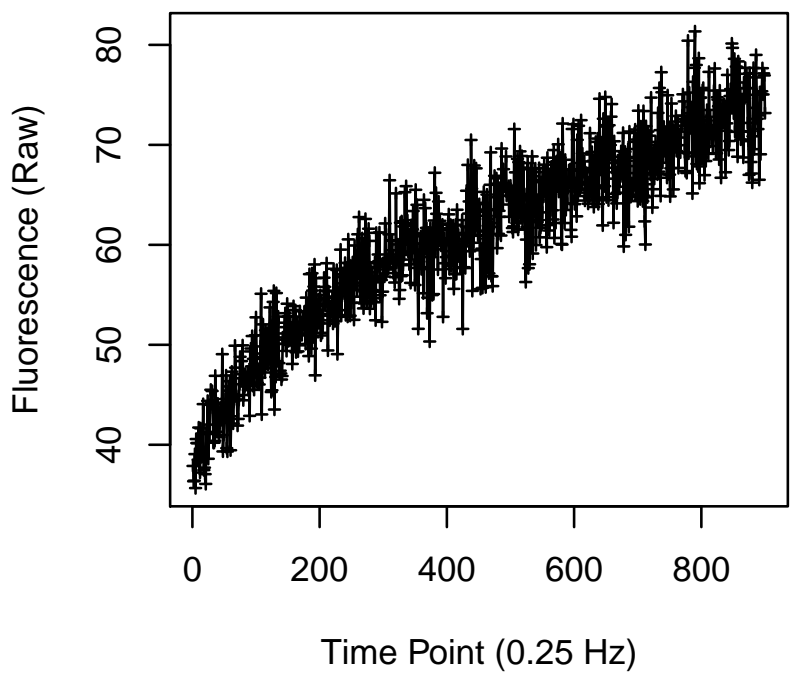

Cell 1418

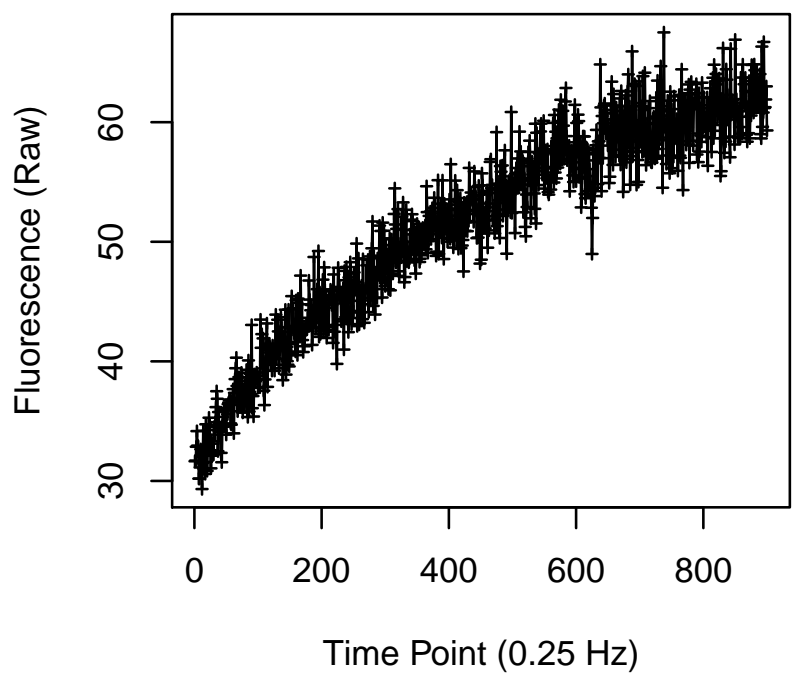

Cell 1420

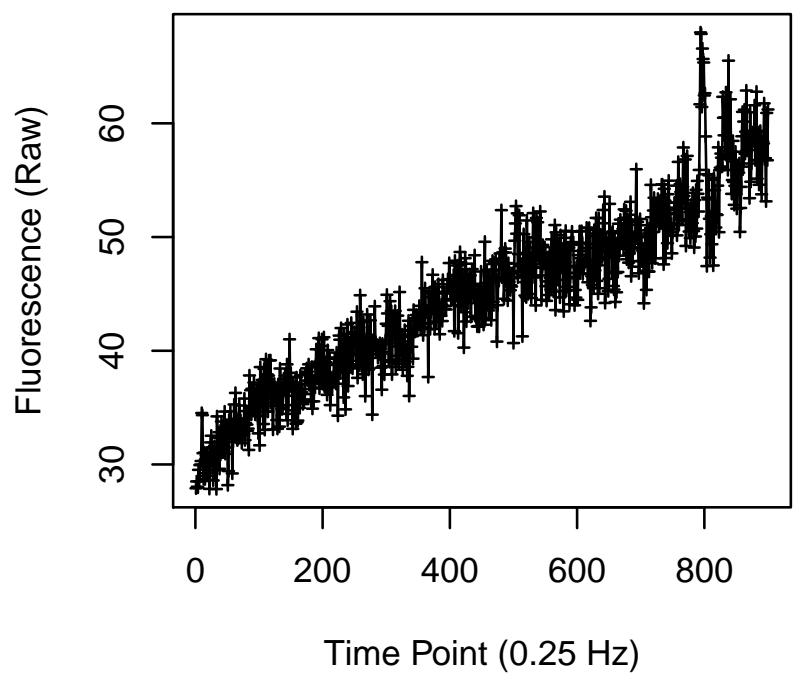


Cell 1421

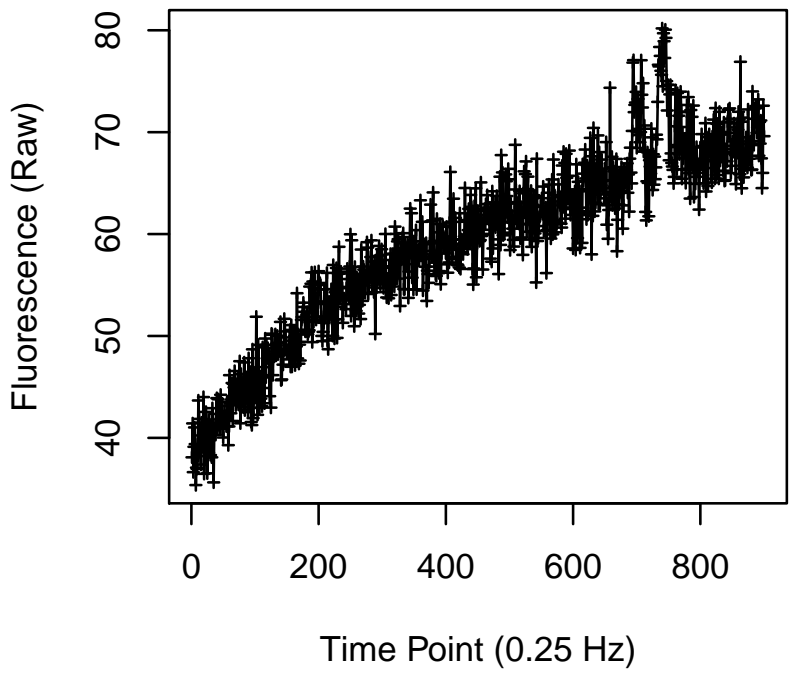

Cell 1423

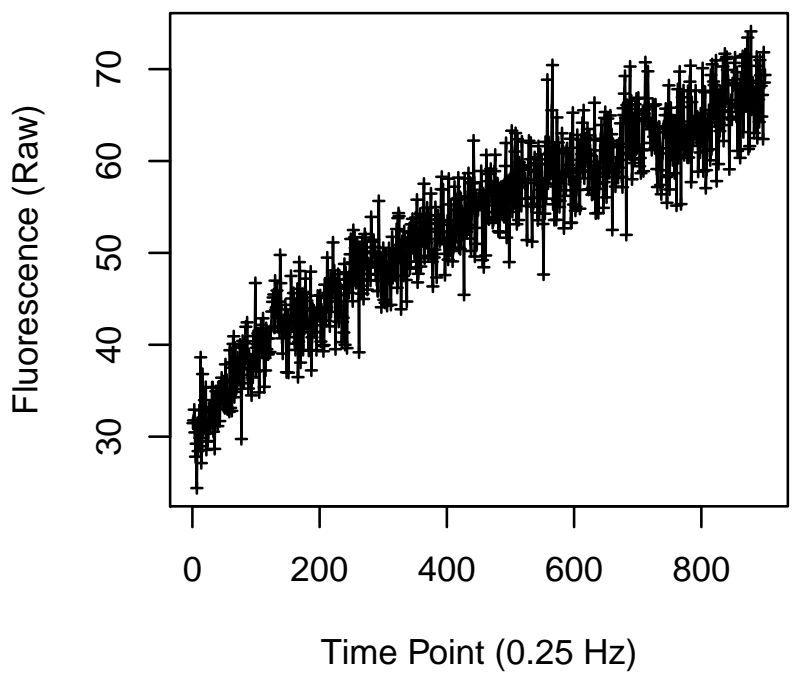

Cell 1422

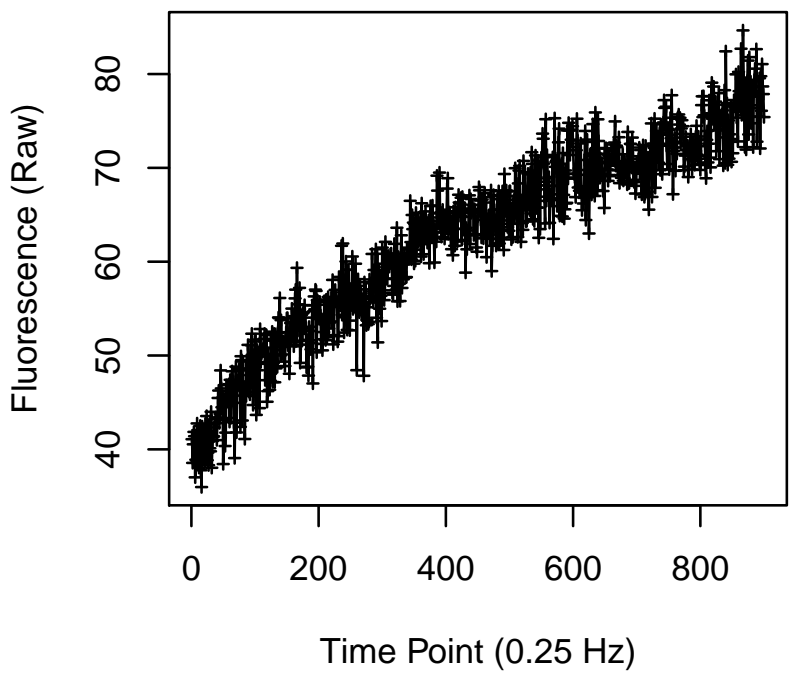

Cell 1424

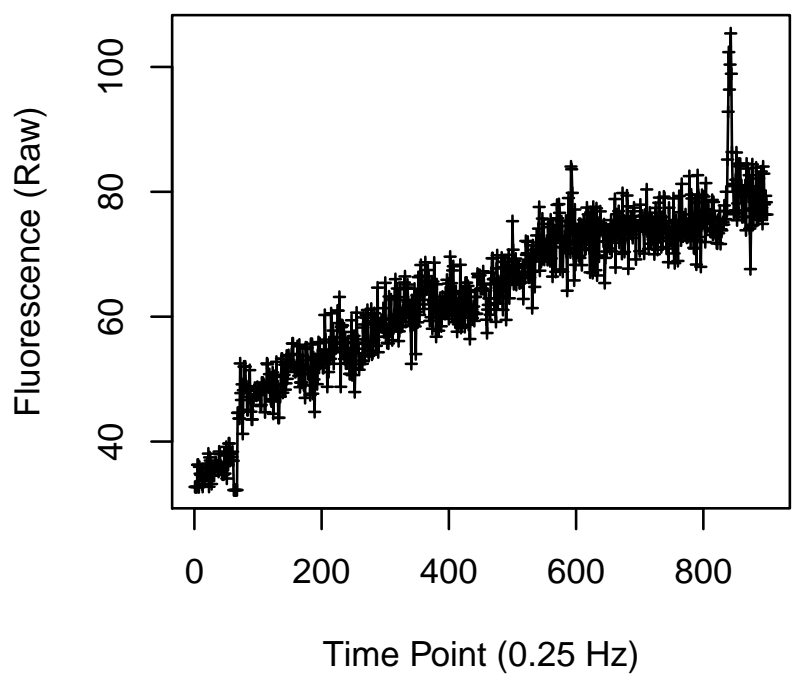


Cell 1425

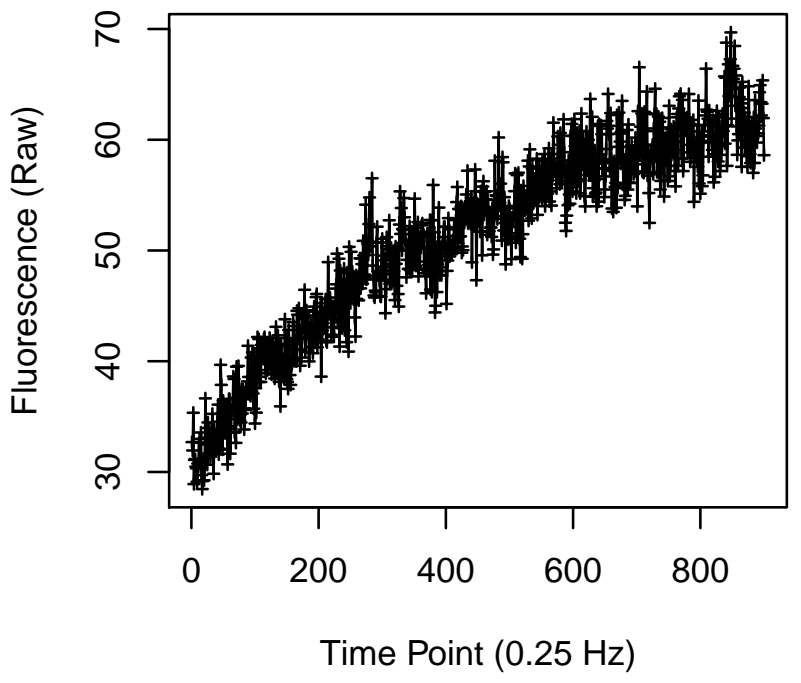

Cell 1427

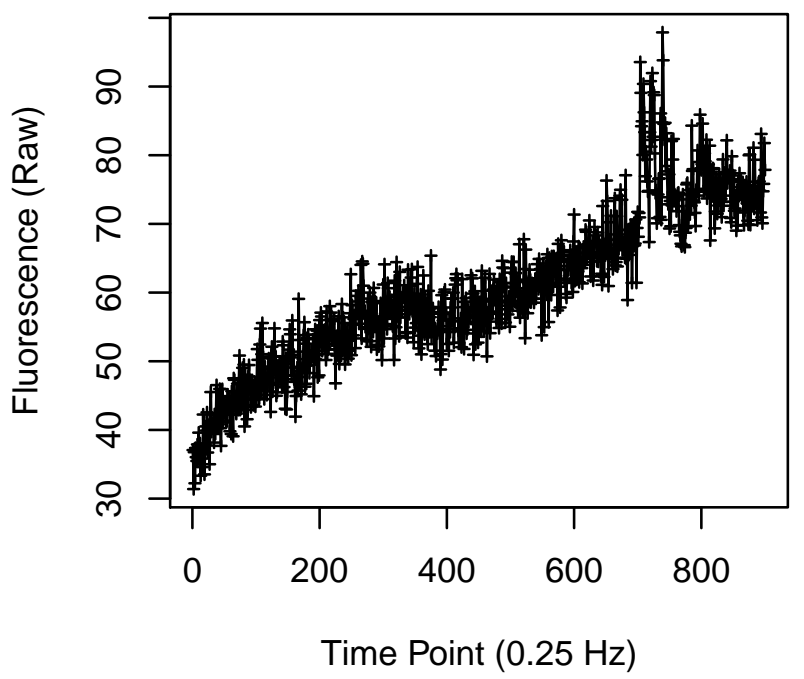

Cell 1426

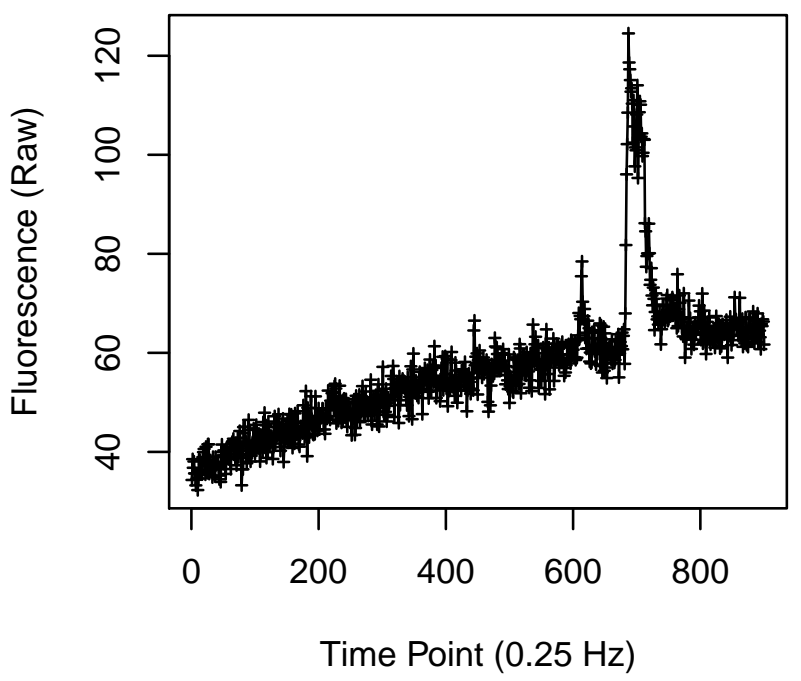

Cell 1428

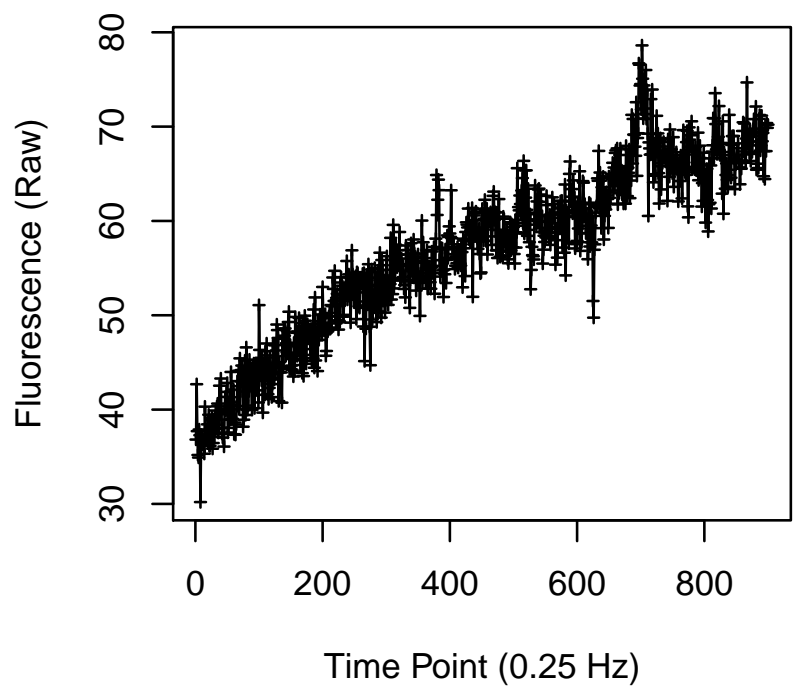


Cell 1429

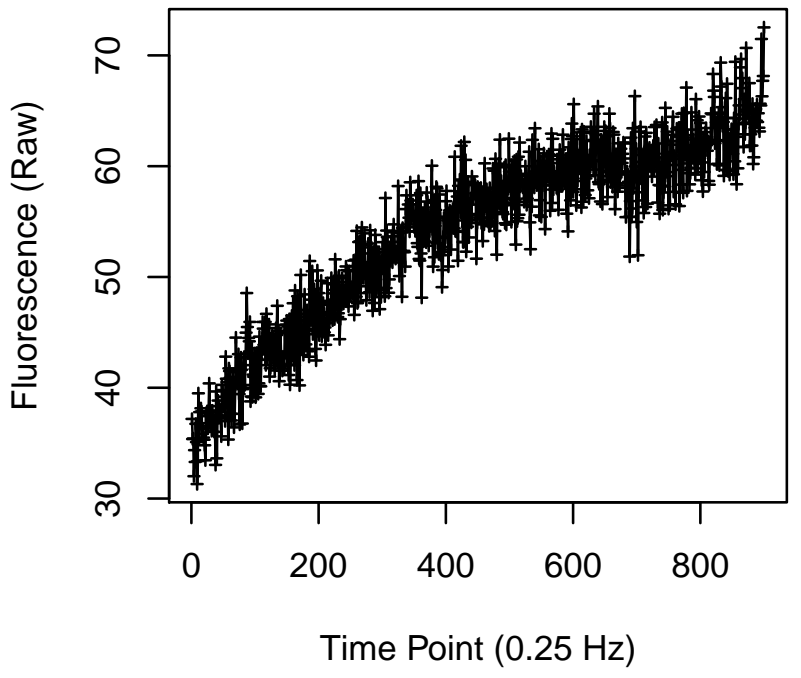

Cell 1431

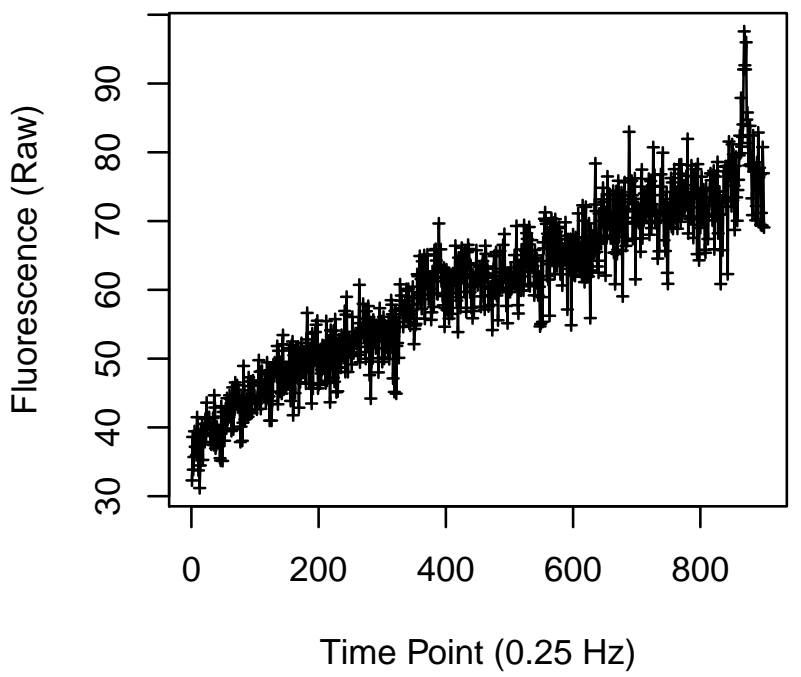

Cell 1430

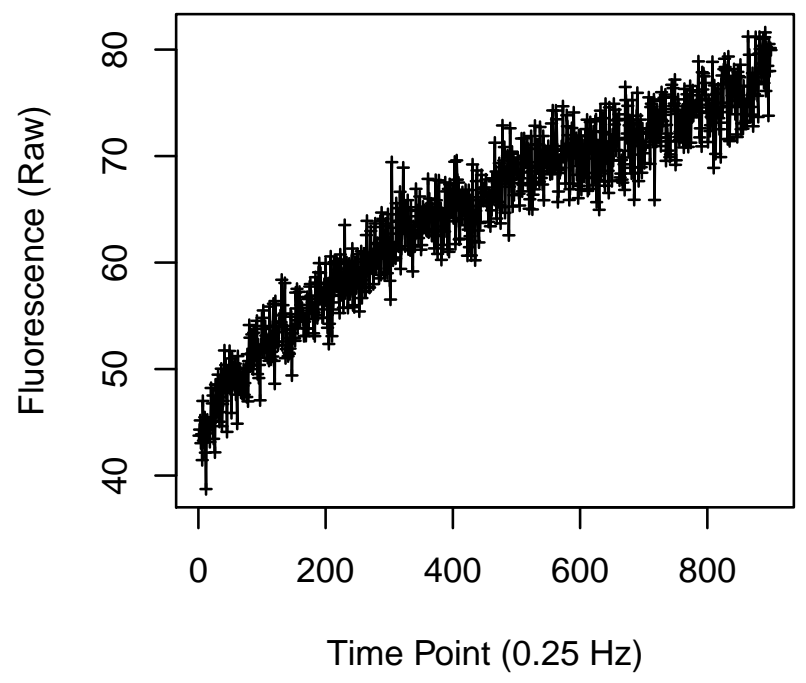

Cell 1432

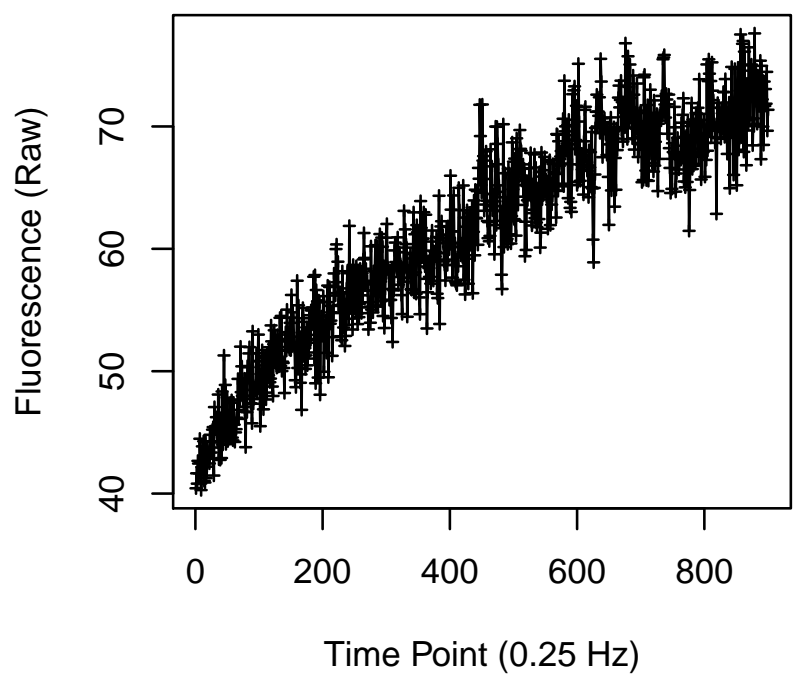


Cell 1433

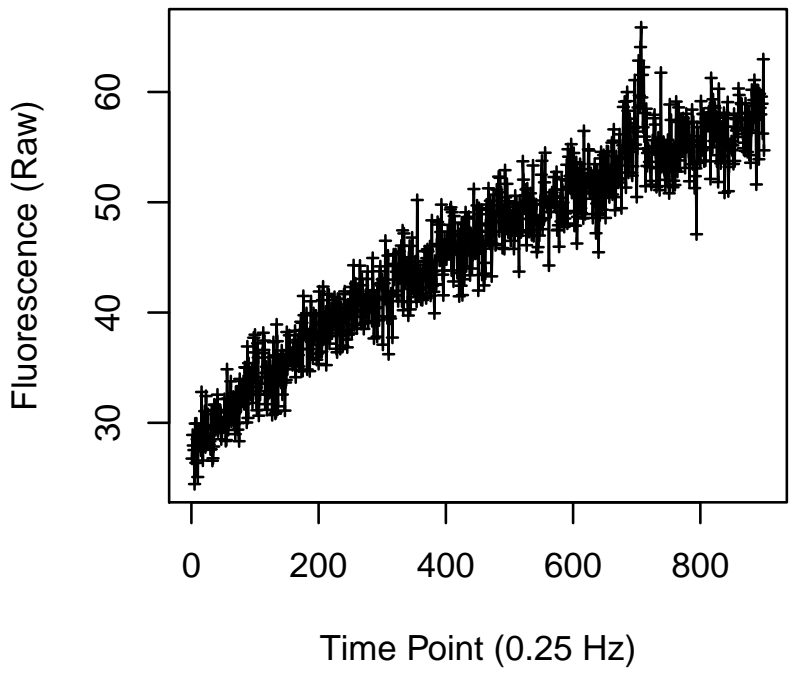

Cell 1435

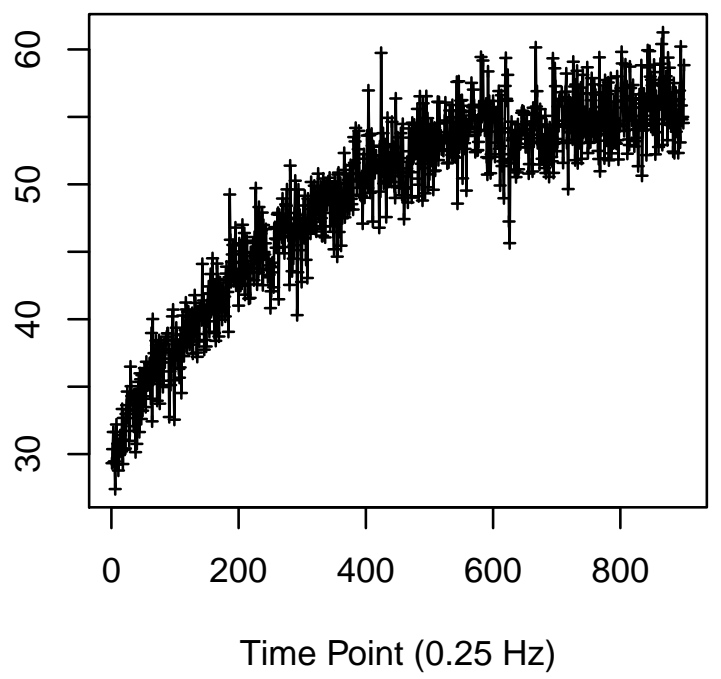

Cell 1434

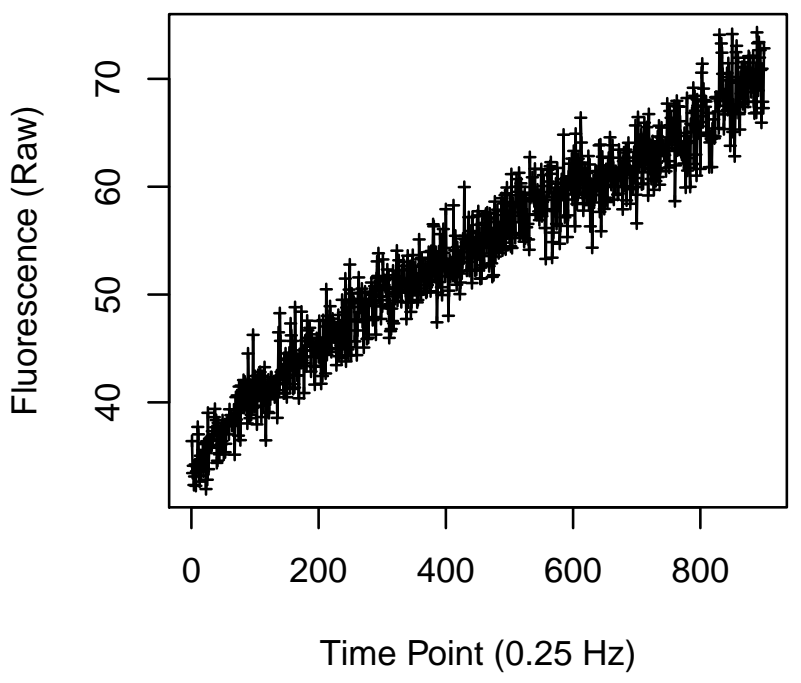

Cell 1436

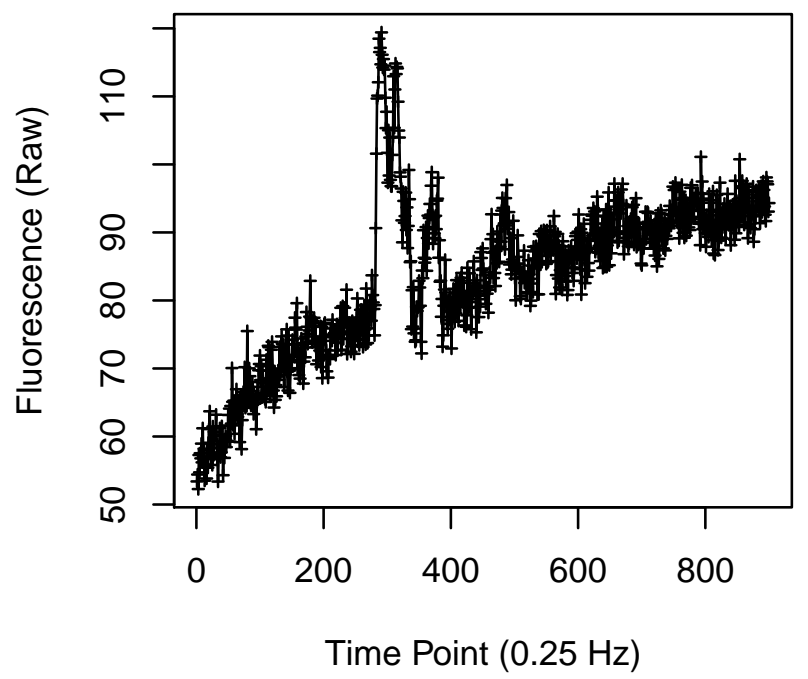


Cell 1441

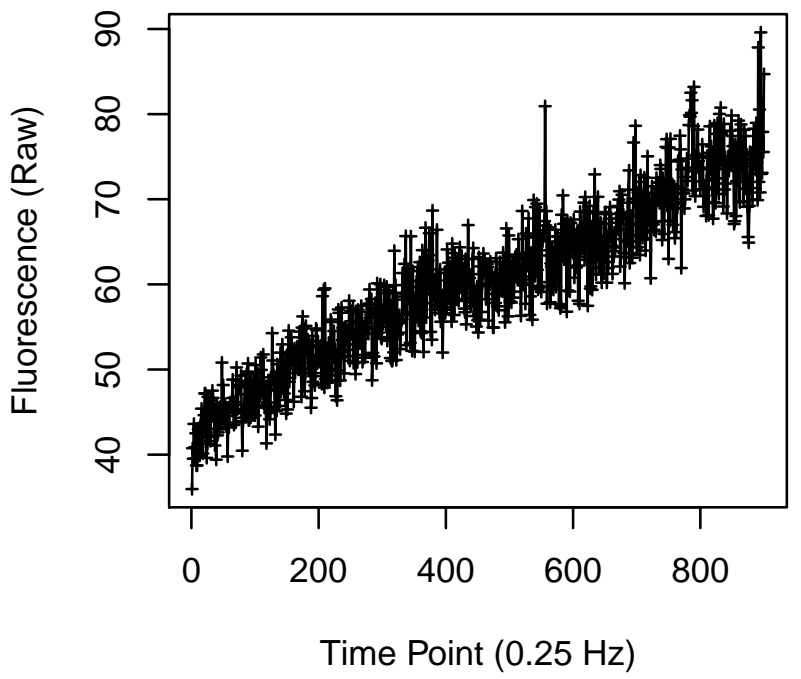

Cell 1443

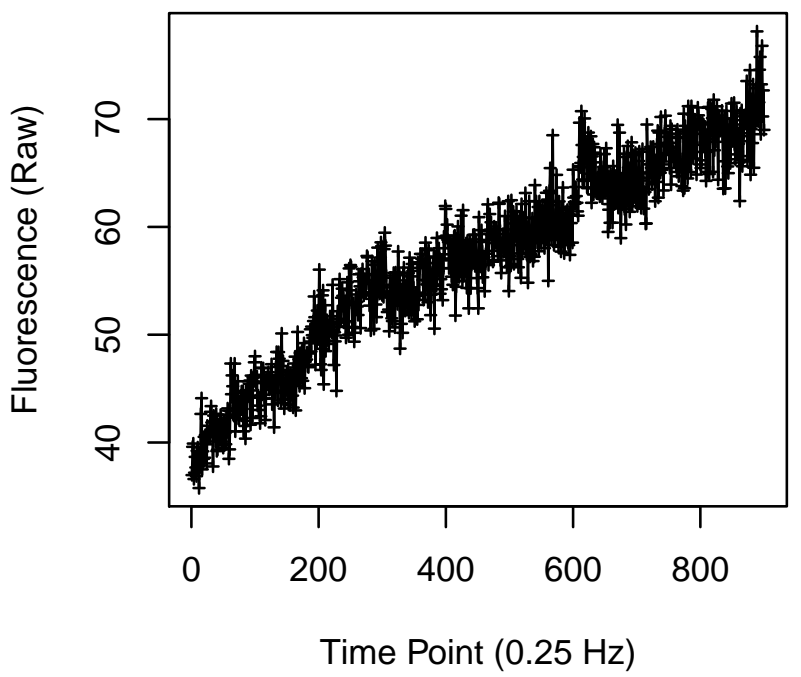

Cell 1442

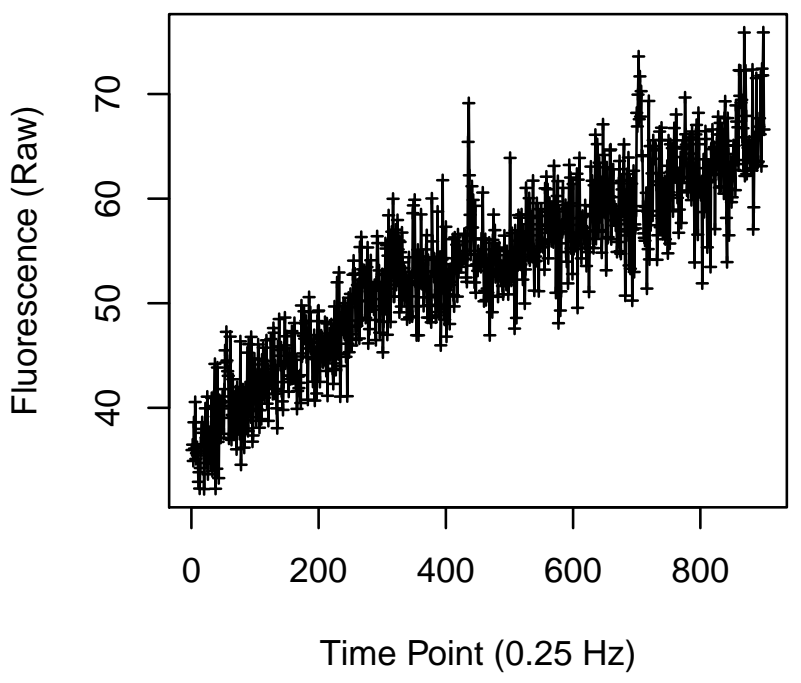

Cell 1444

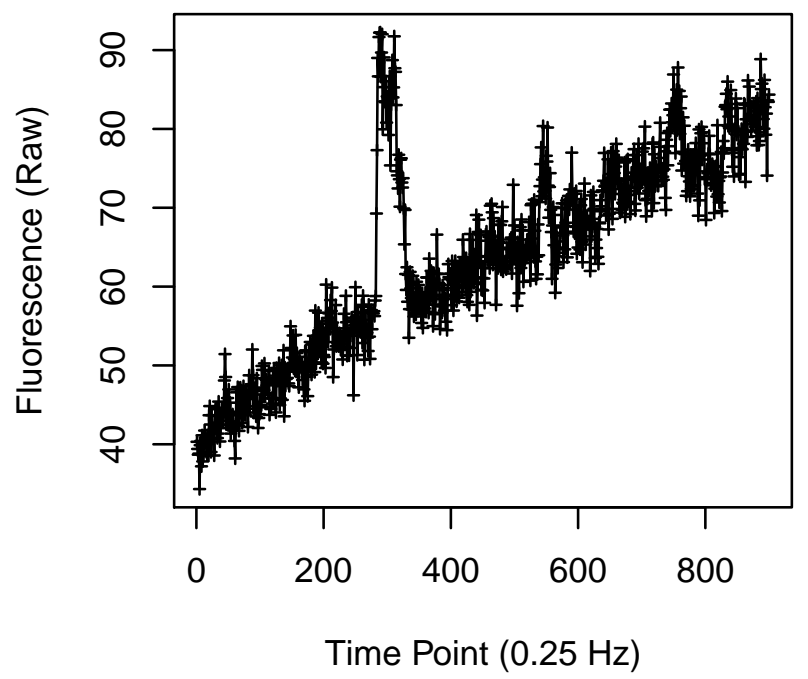


Cell 1449

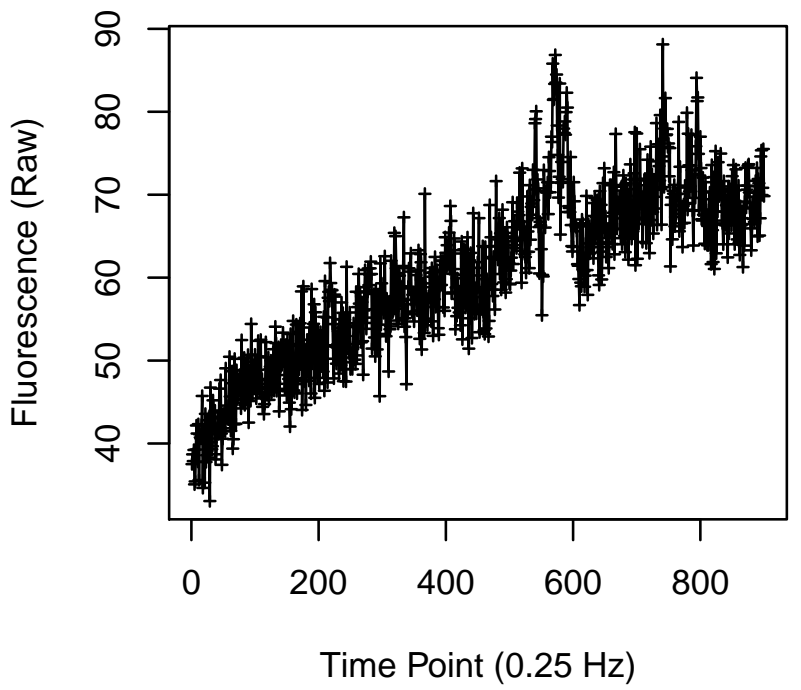

Cell 1451

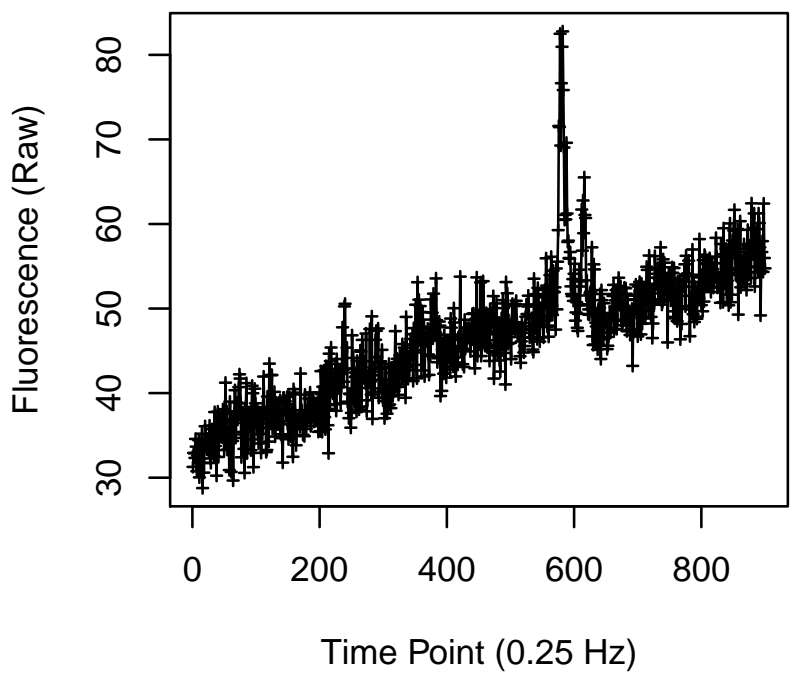

Cell 1450

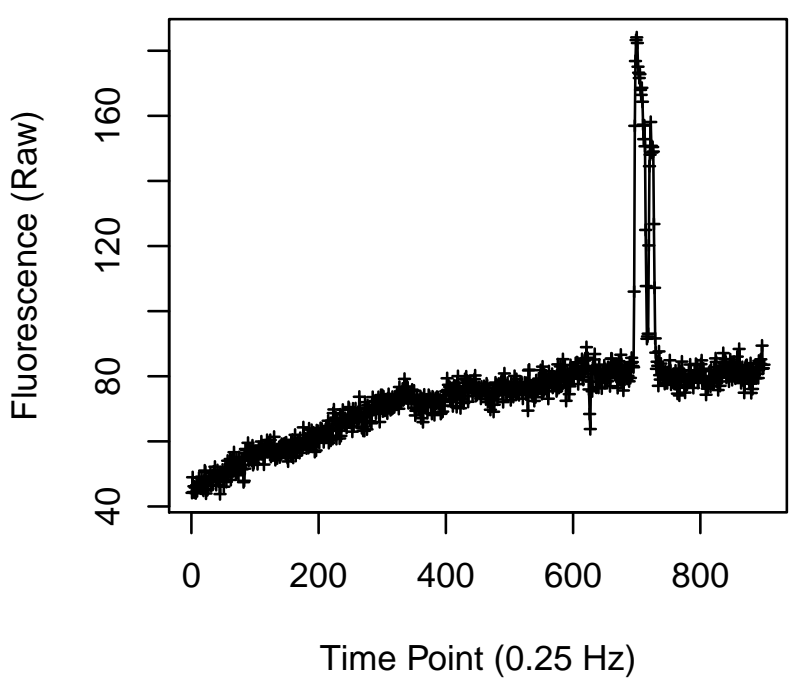

Cell 1452

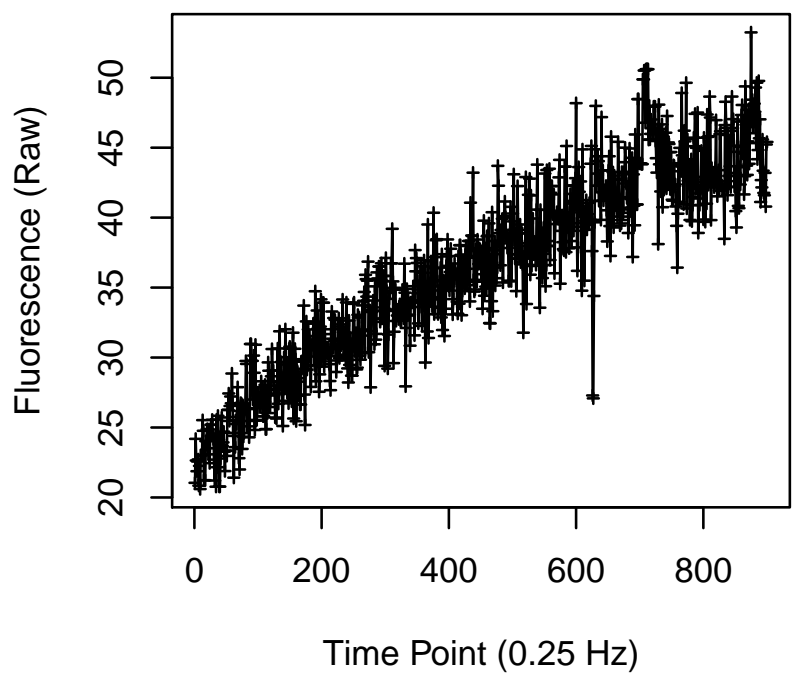


Cell 1453

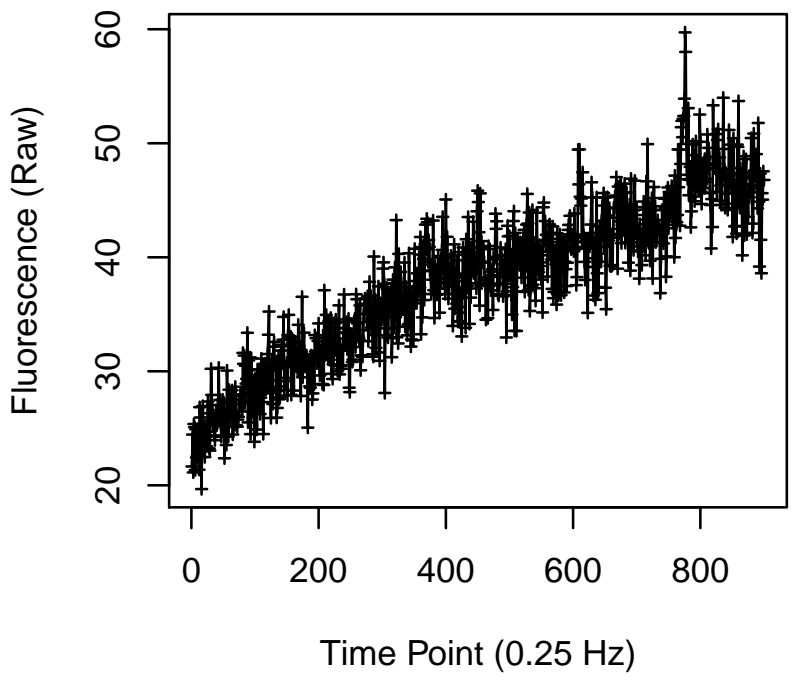

Cell 1455

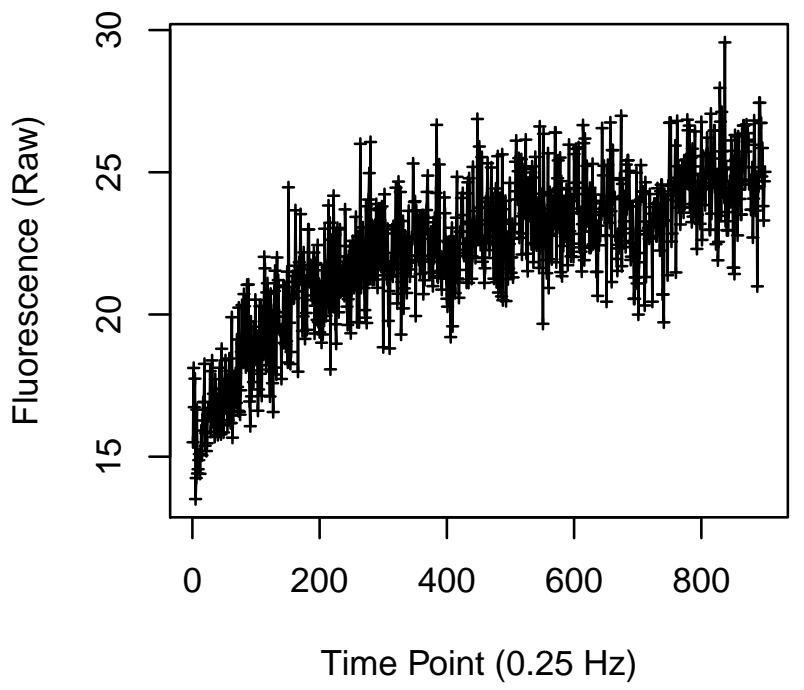

Cell 1454

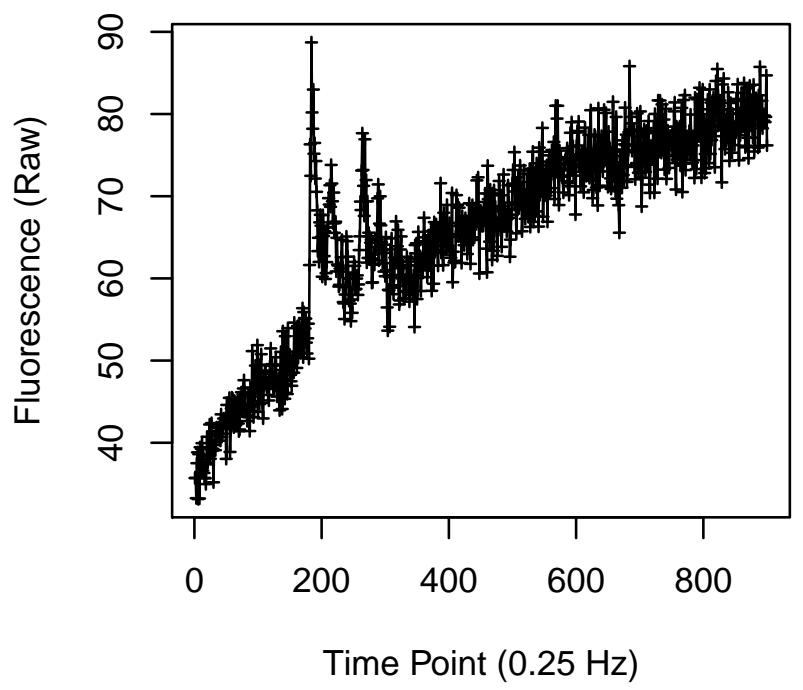

Cell 1456

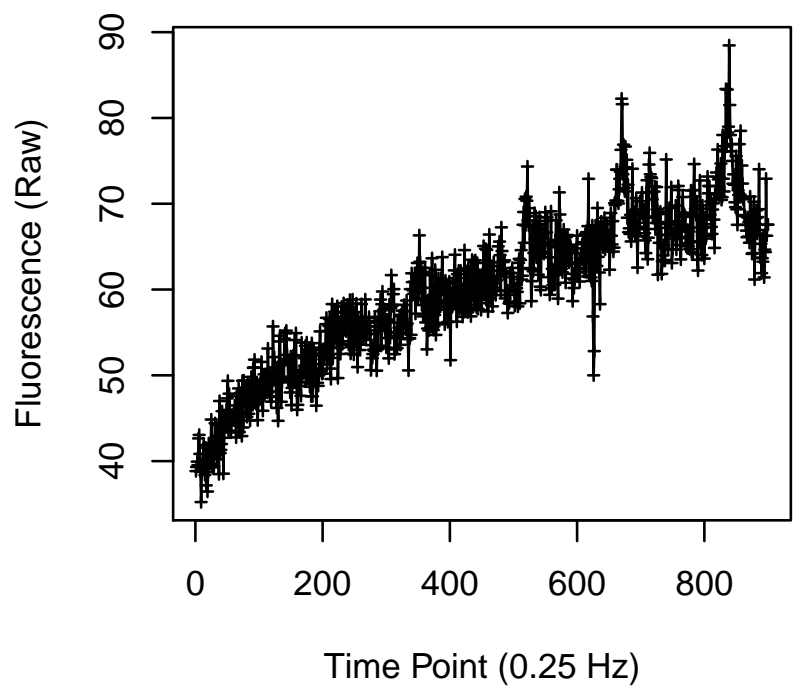


Cell 1457

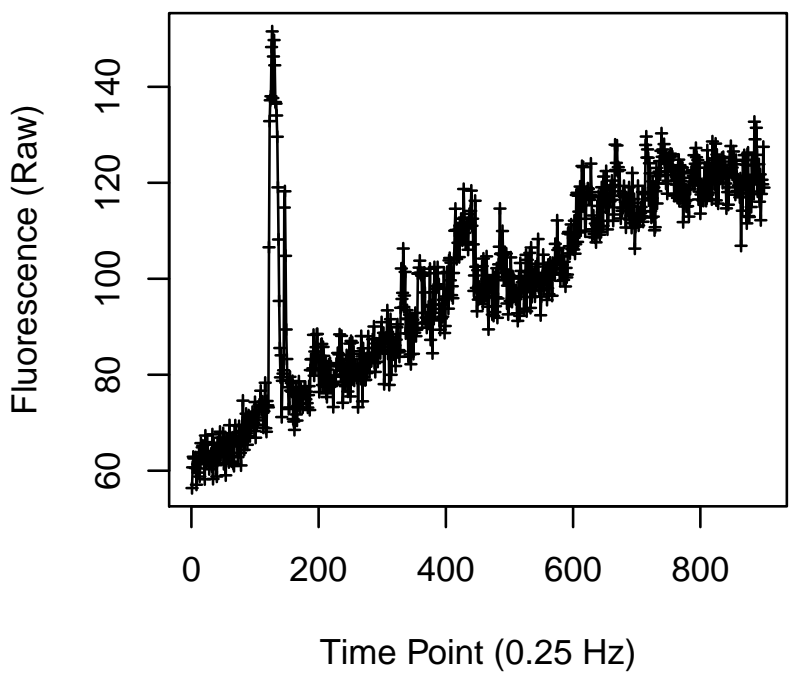

Cell 1459

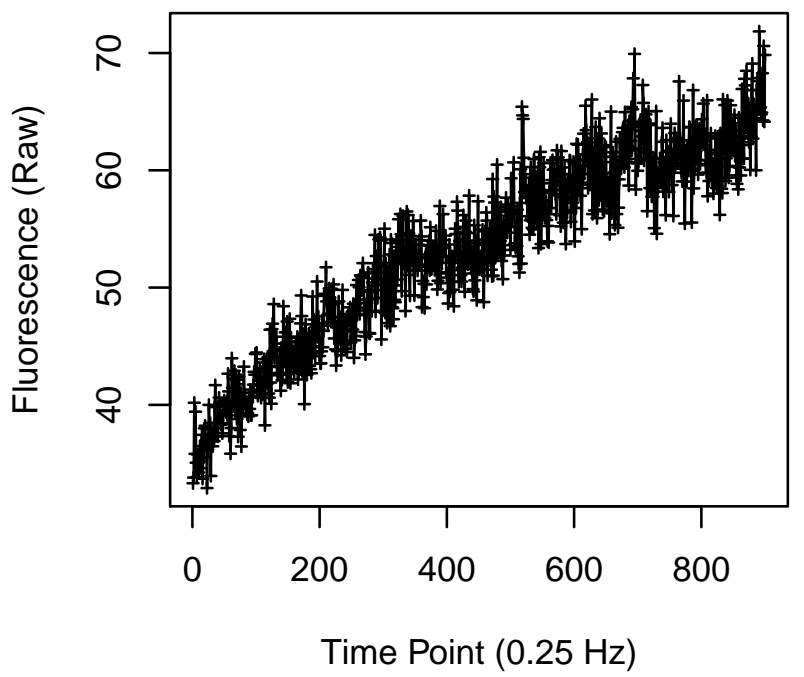

Cell 1458

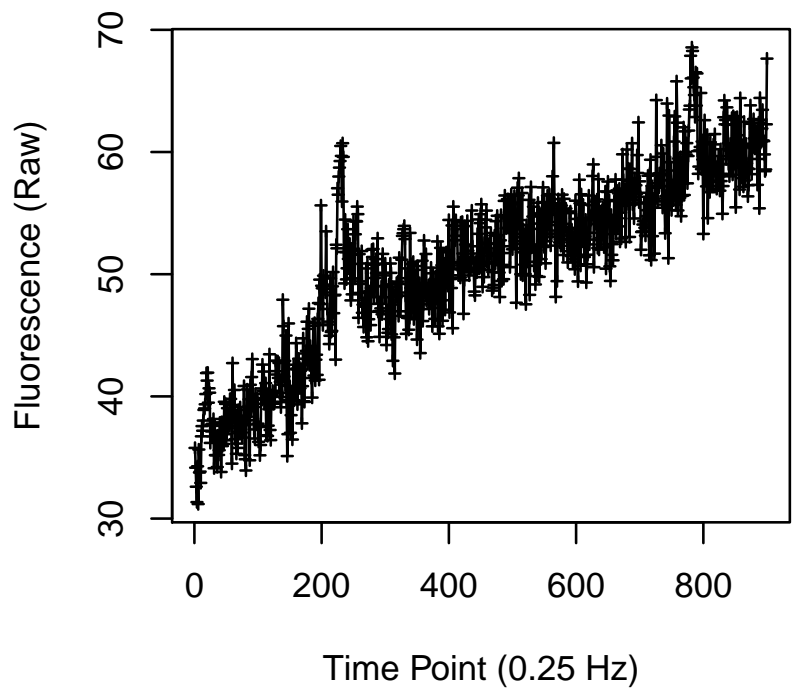

Cell 1460

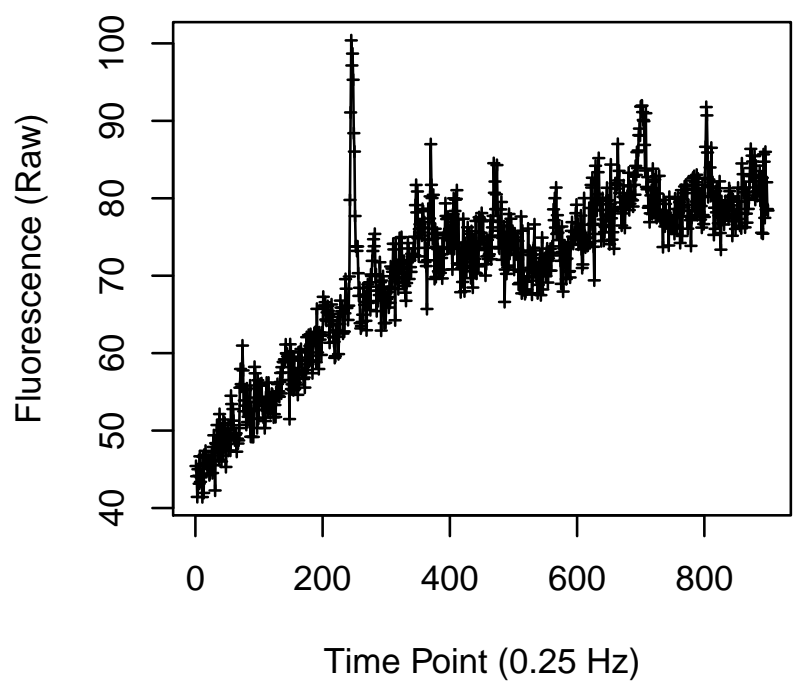


Cell 1461

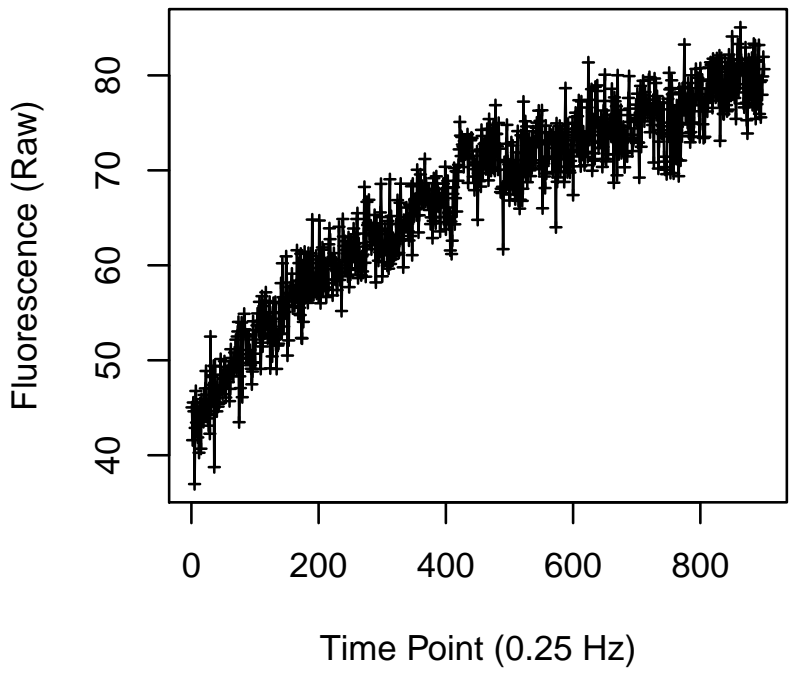

Cell 1463

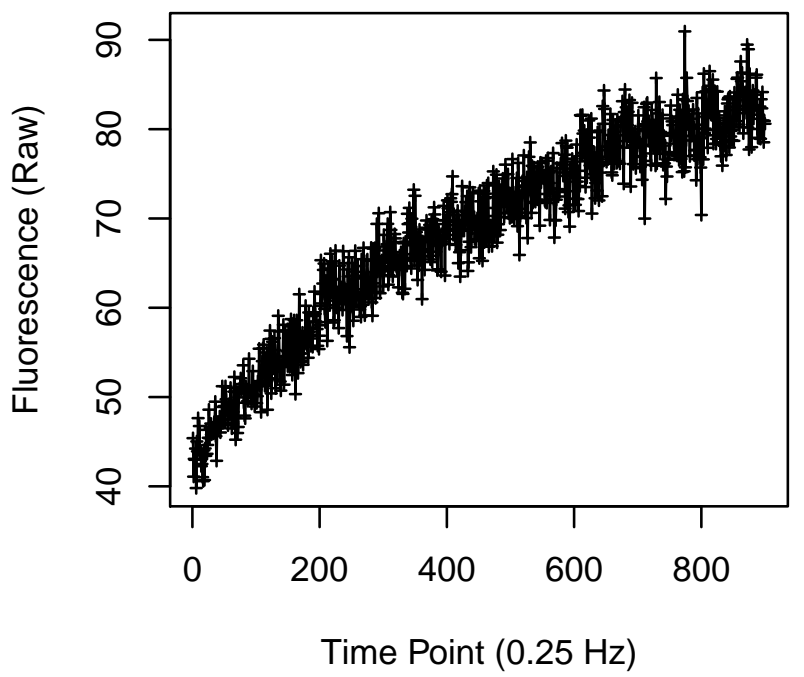

Cell 1462

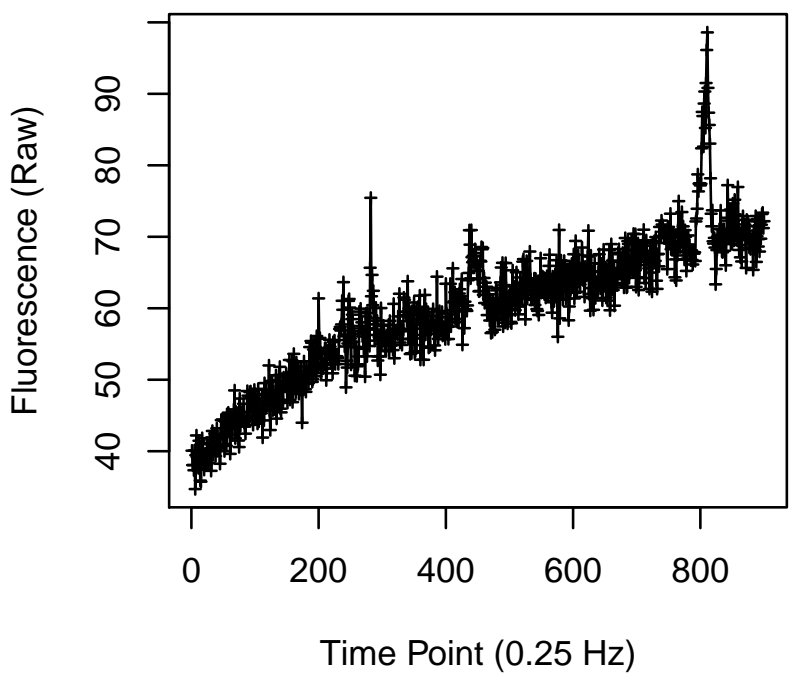

Cell 1464

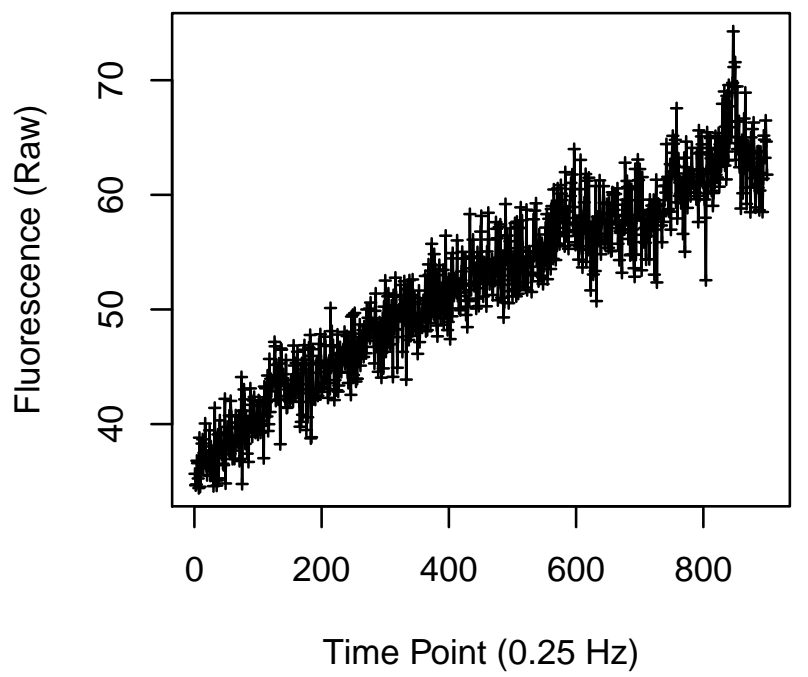


Cell 1465

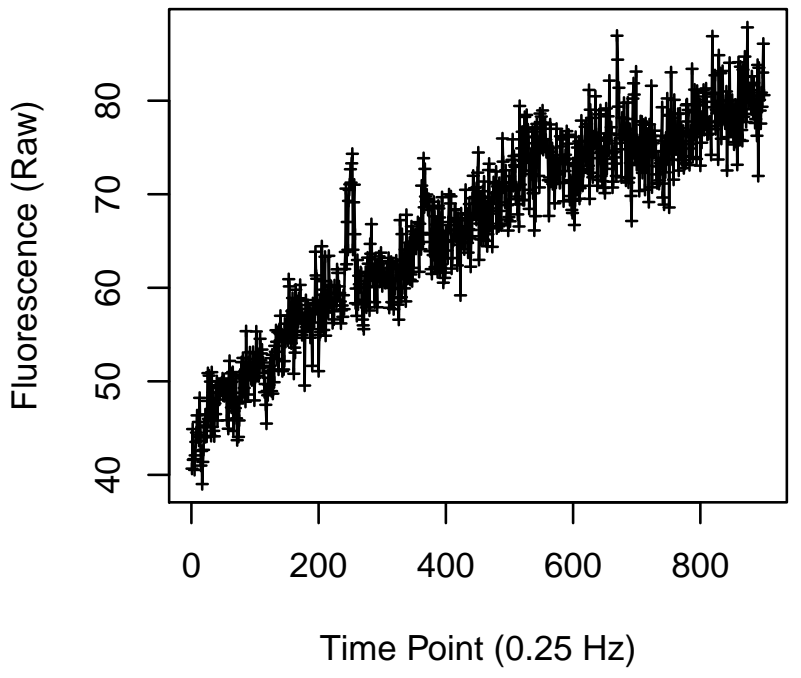

Cell 1467

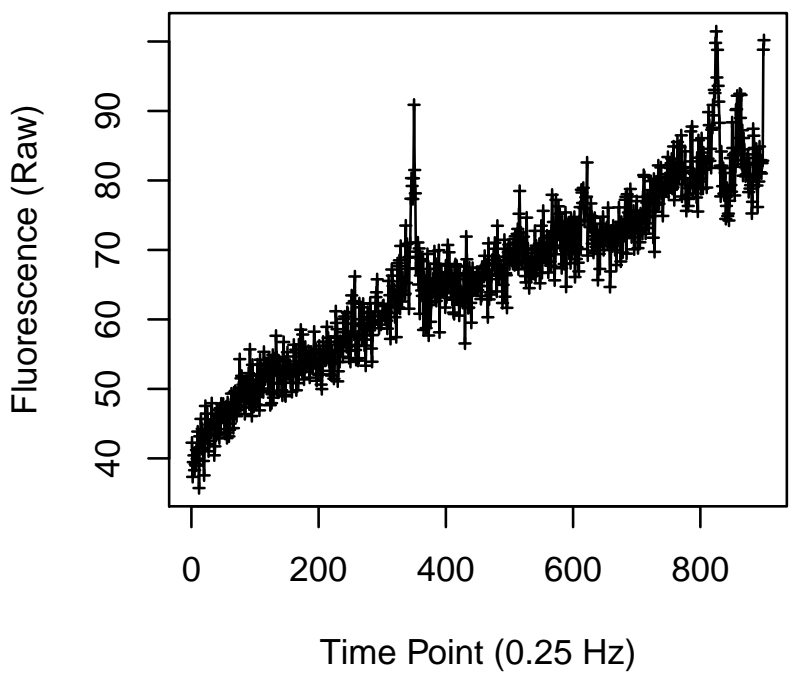

Cell 1466

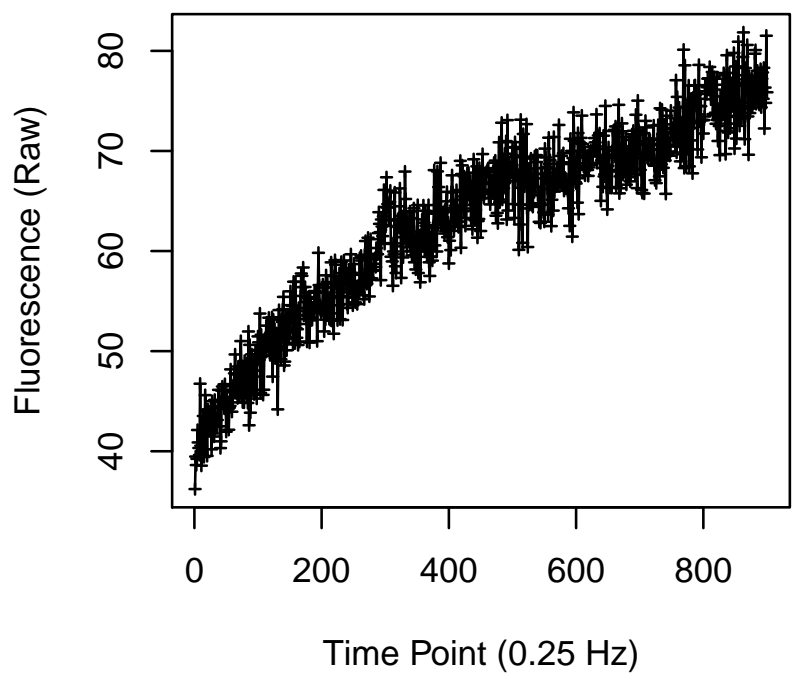

Cell 1468

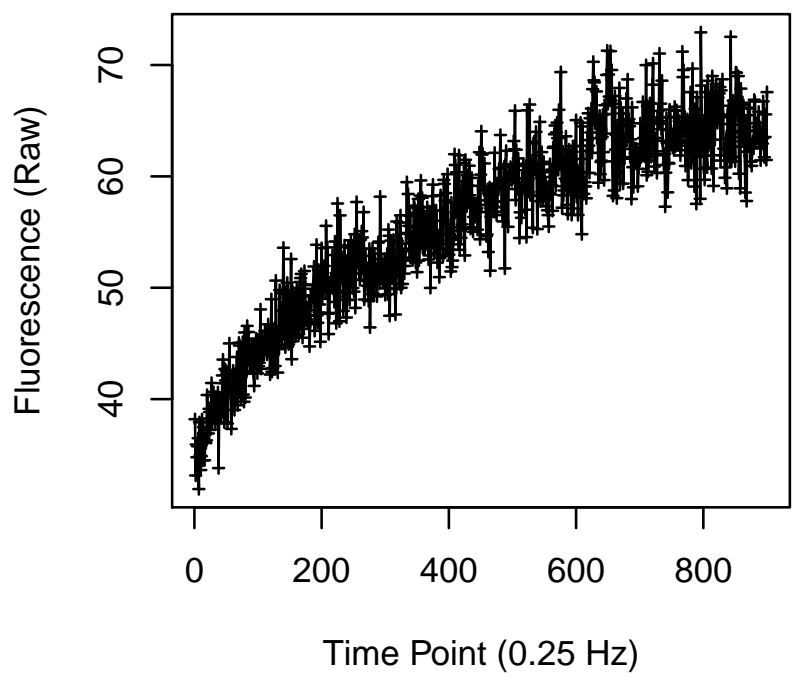


Cell 1473

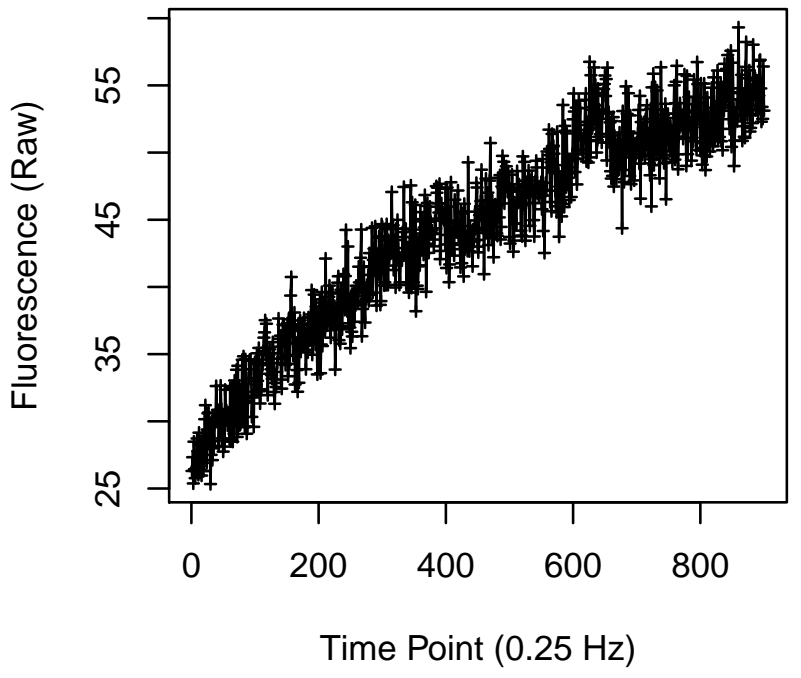

Cell 1475

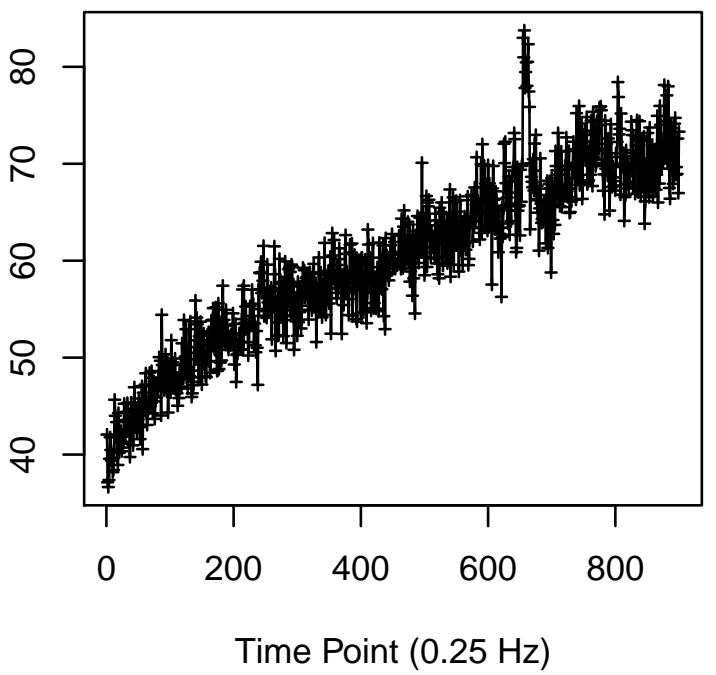

Cell 1474

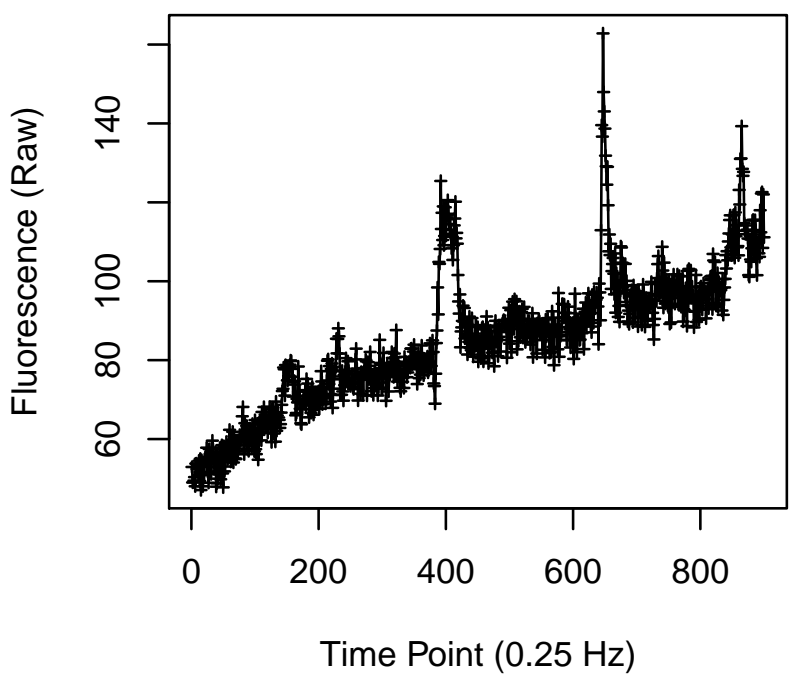

Cell 1476

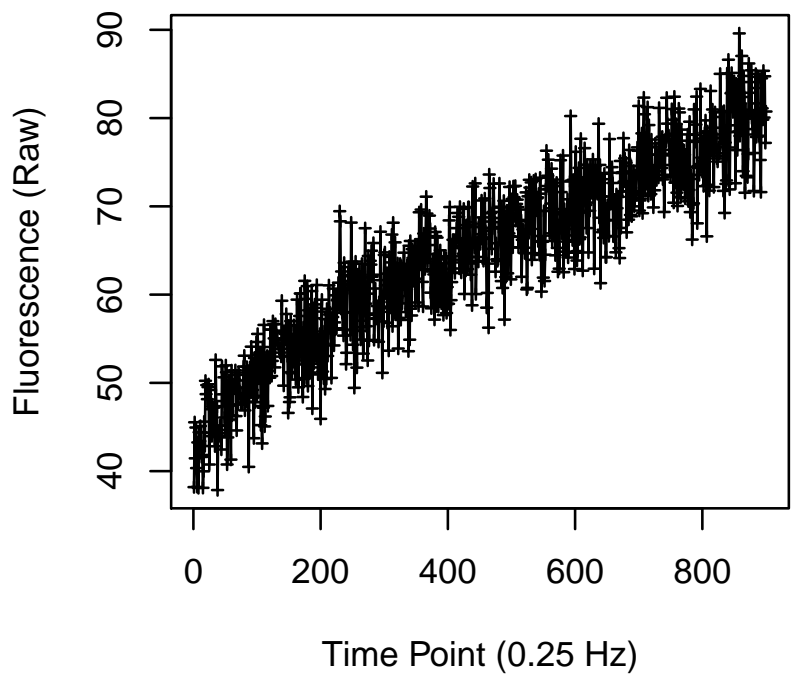


Cell 1481

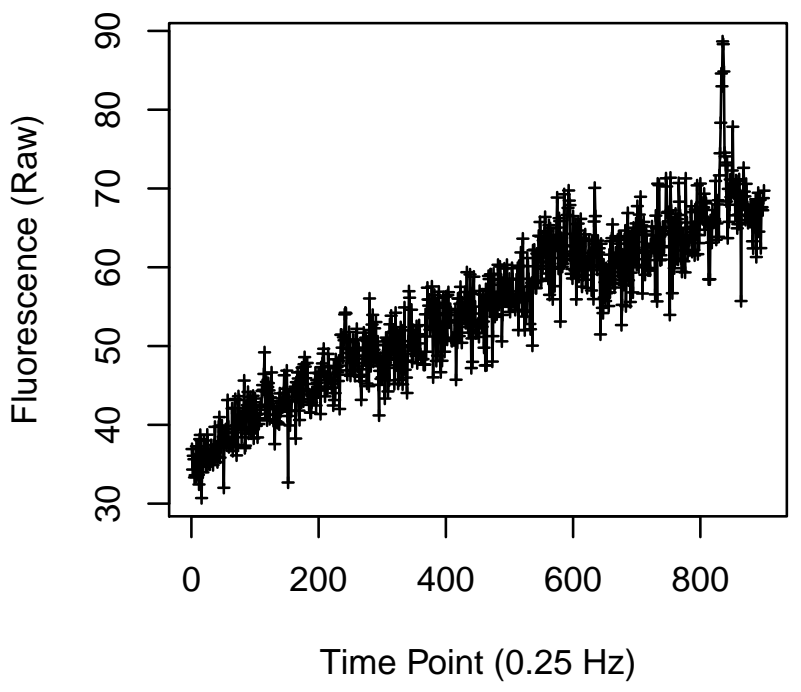

Cell 1483

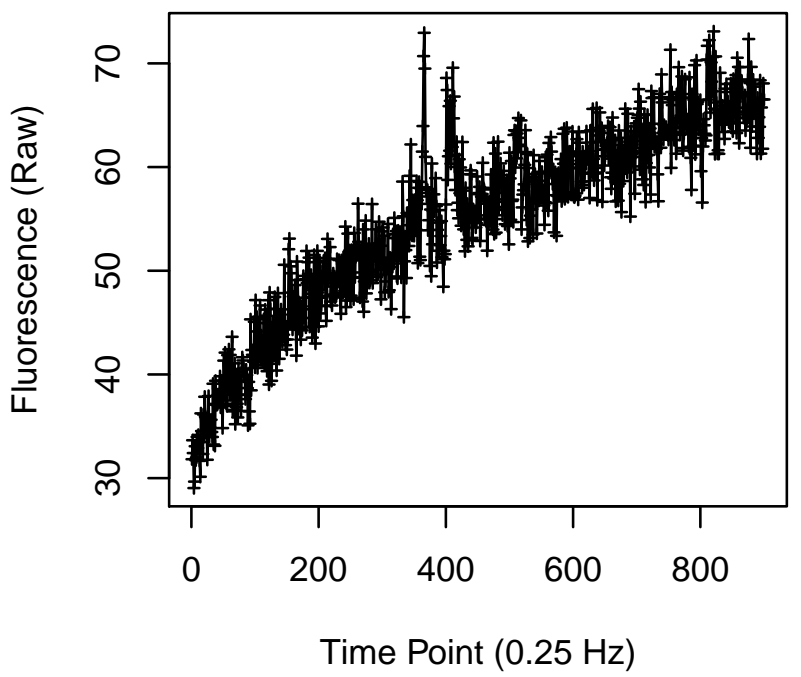

Cell 1482

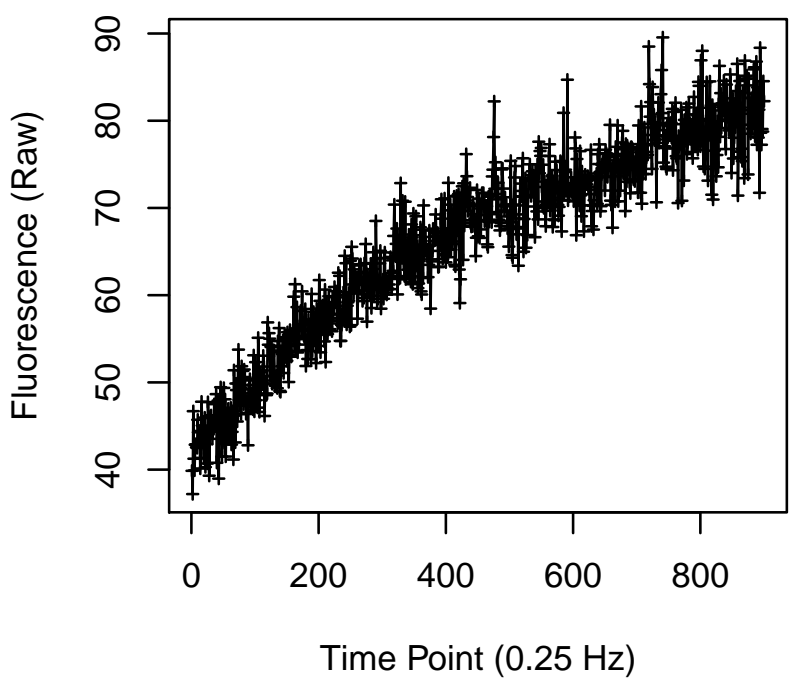

Cell 1484

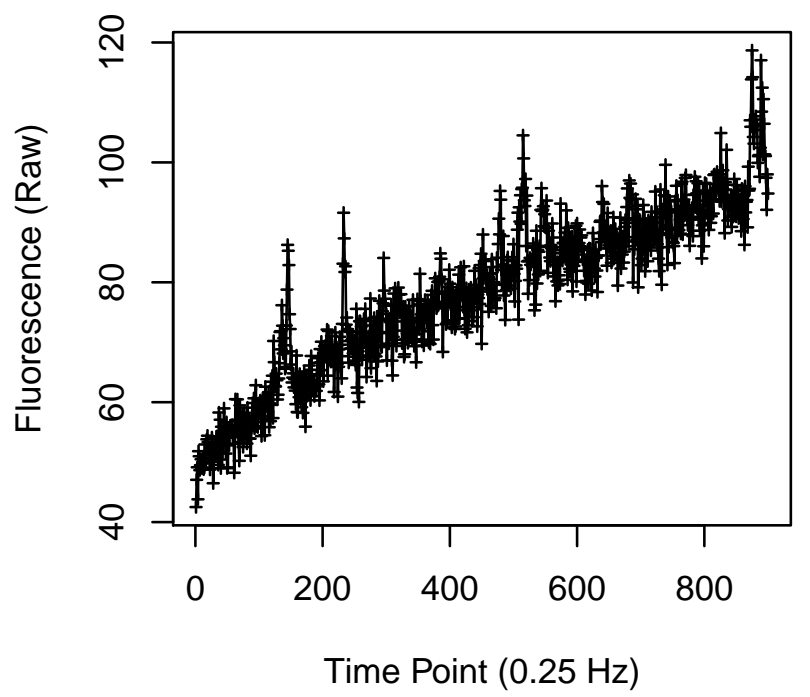


Cell 1493

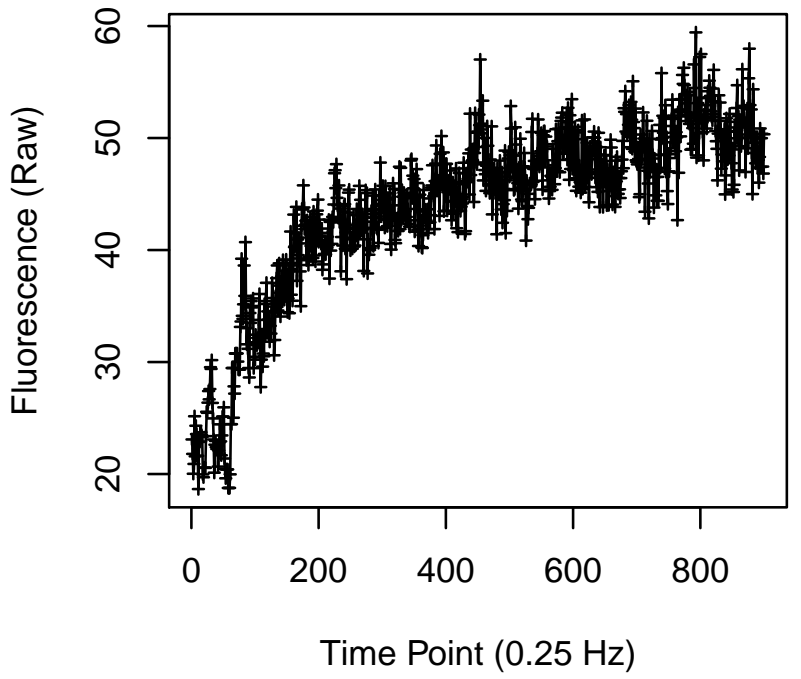

Cell 1495

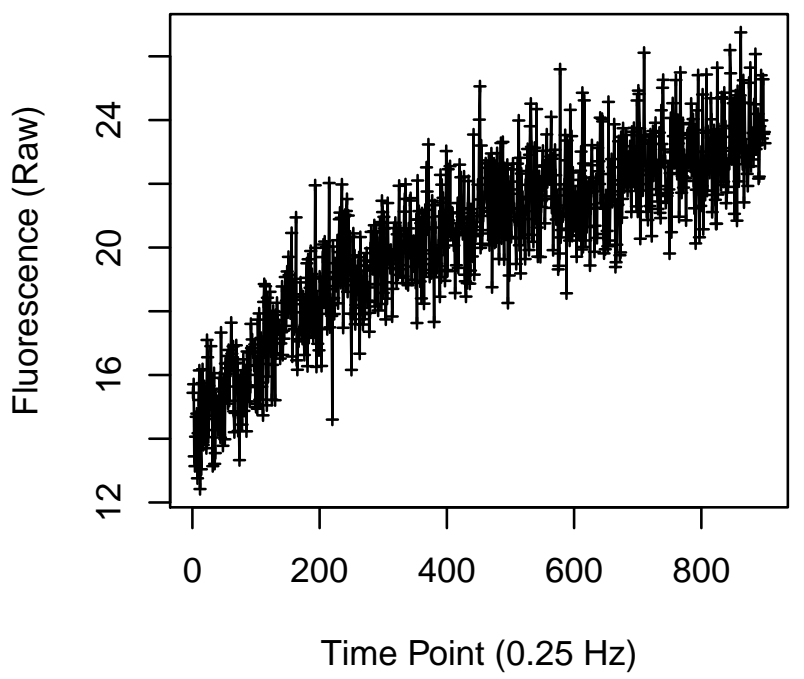

Cell 1494

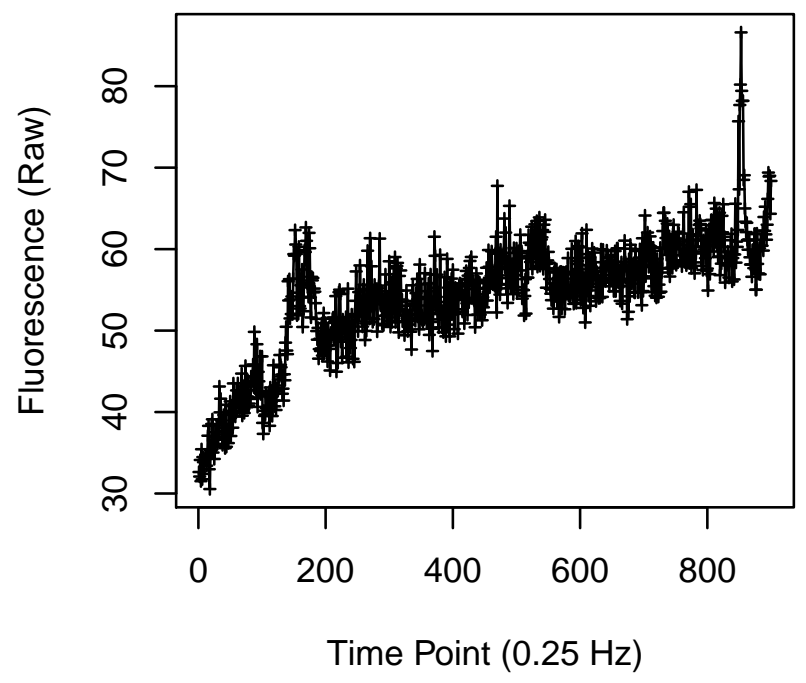

Cell 1496

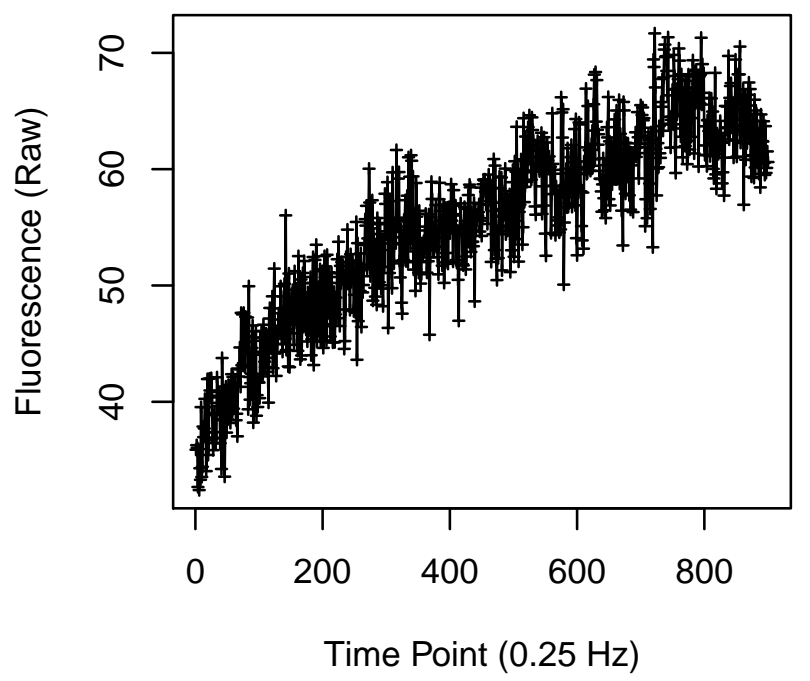


Cell 1497

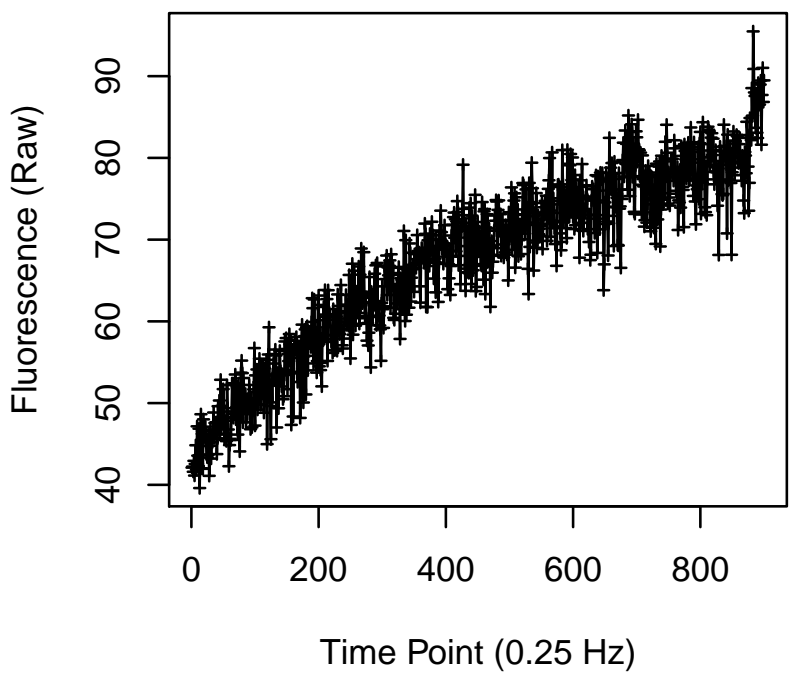

Cell 1499

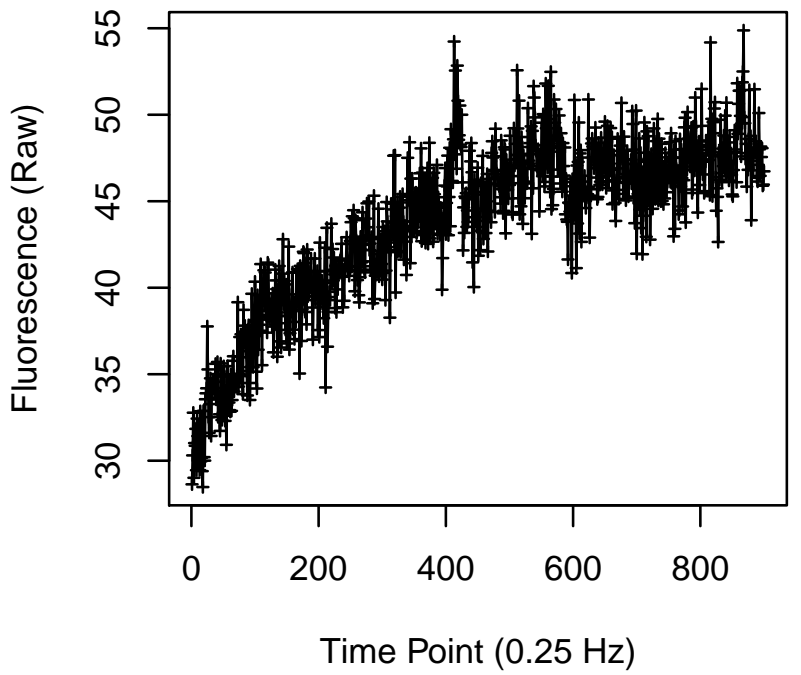

Cell 1498

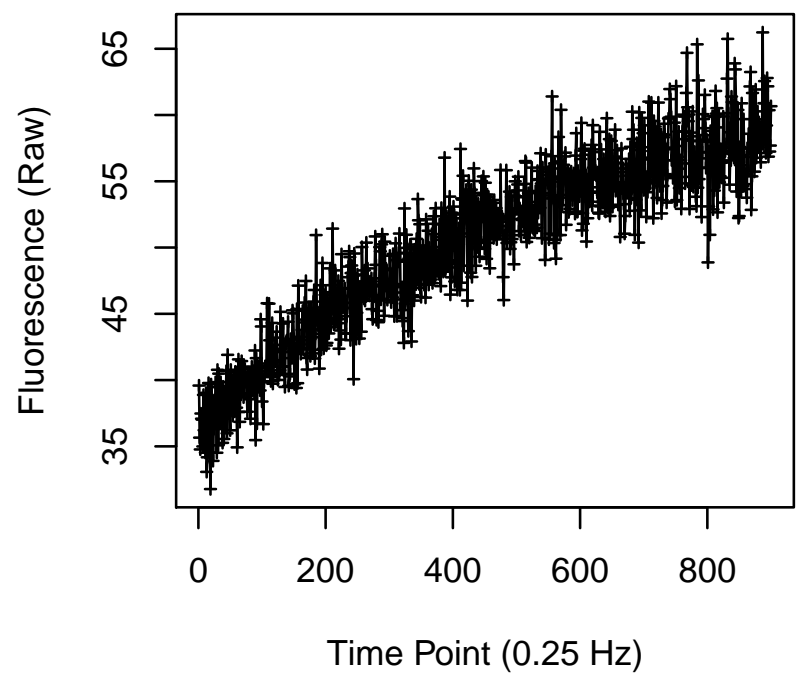

Cell 1500

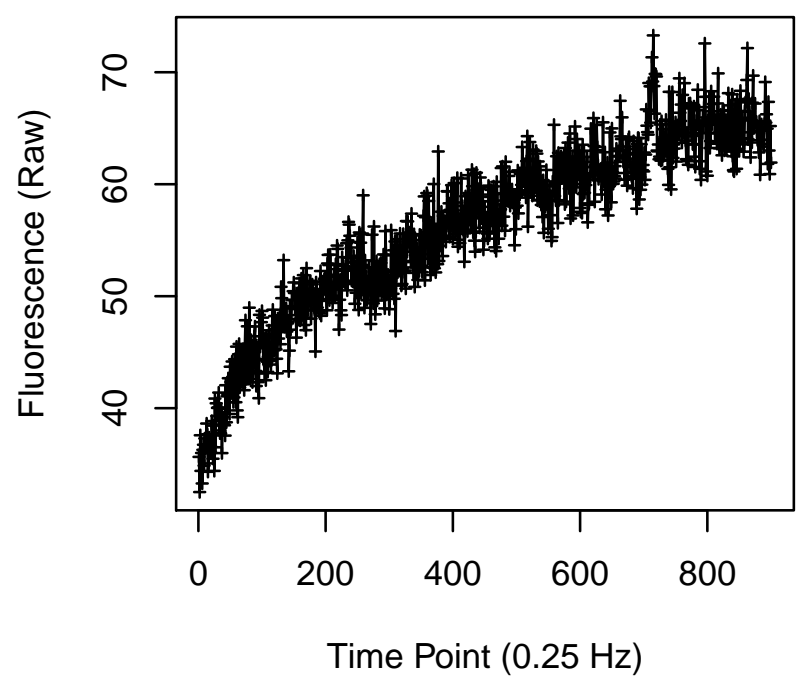


Cell 1501

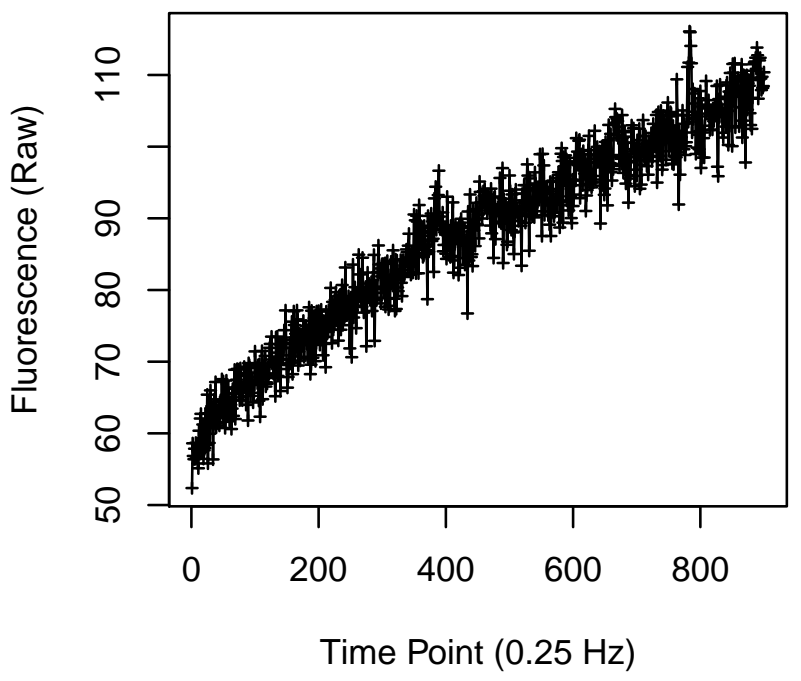

Cell 1503

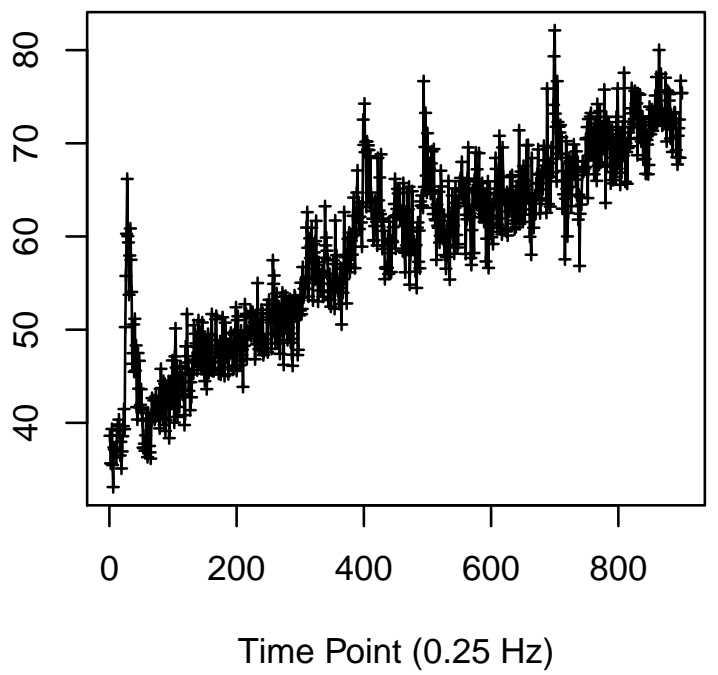

Cell 1502

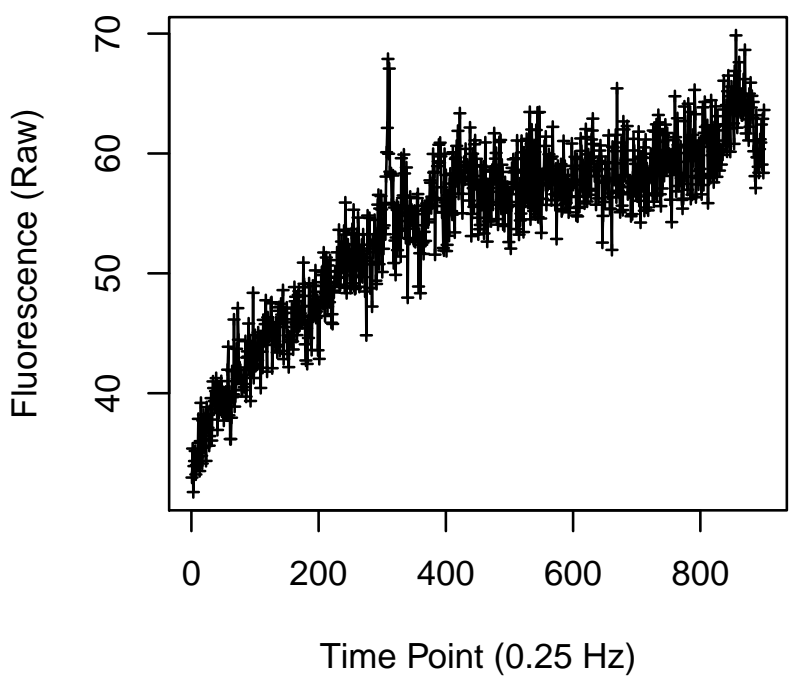

Cell 1504

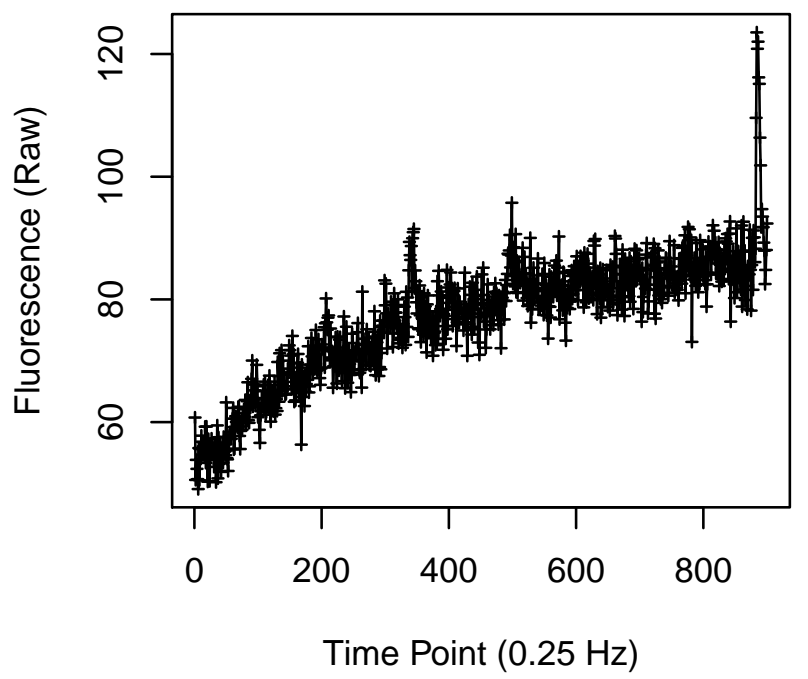


Cell 1505

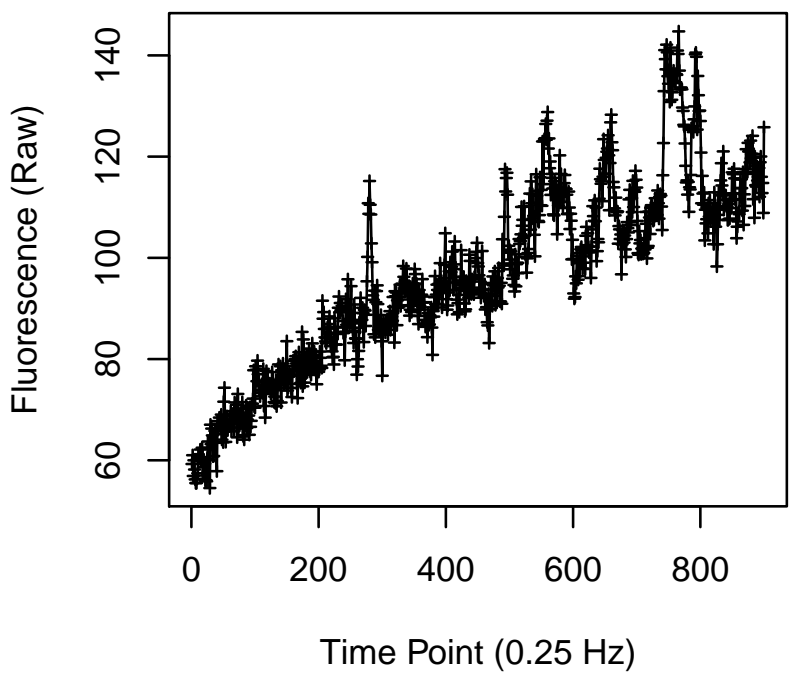

Cell 1507

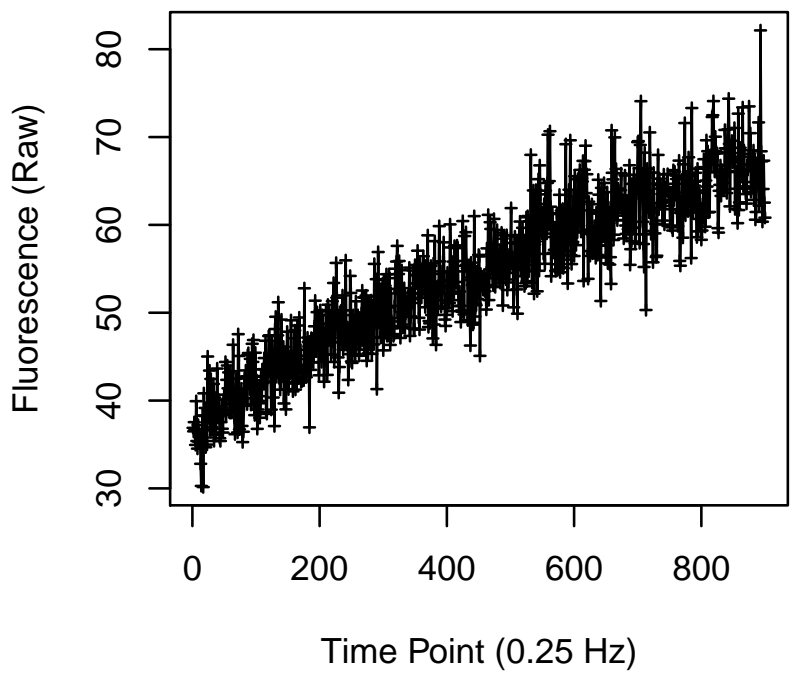

Cell 1506

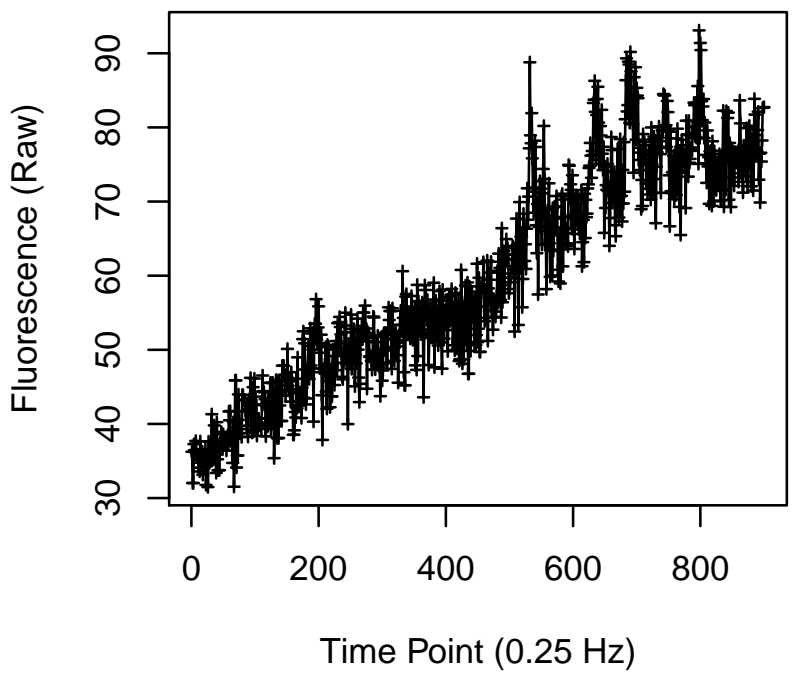

Cell 1508

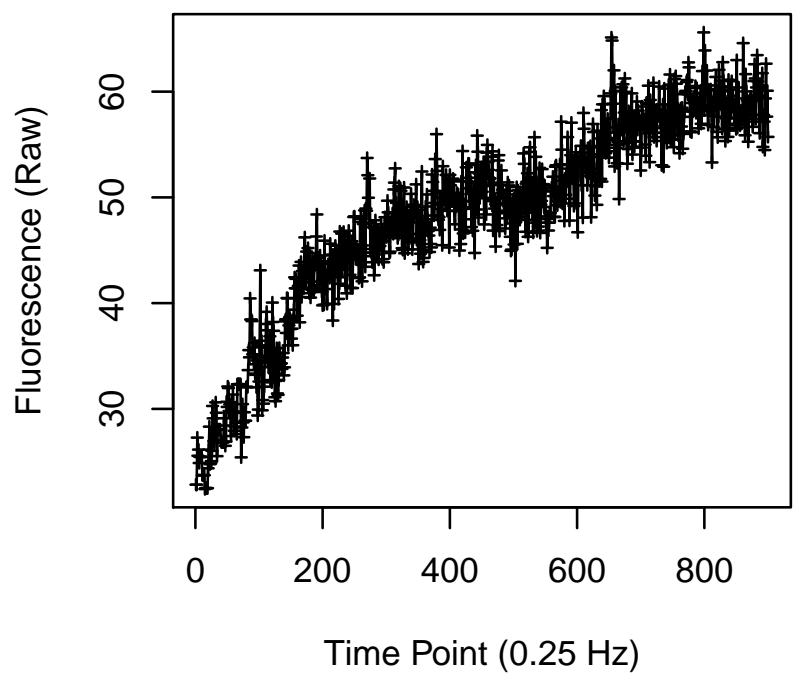


Cell 1509

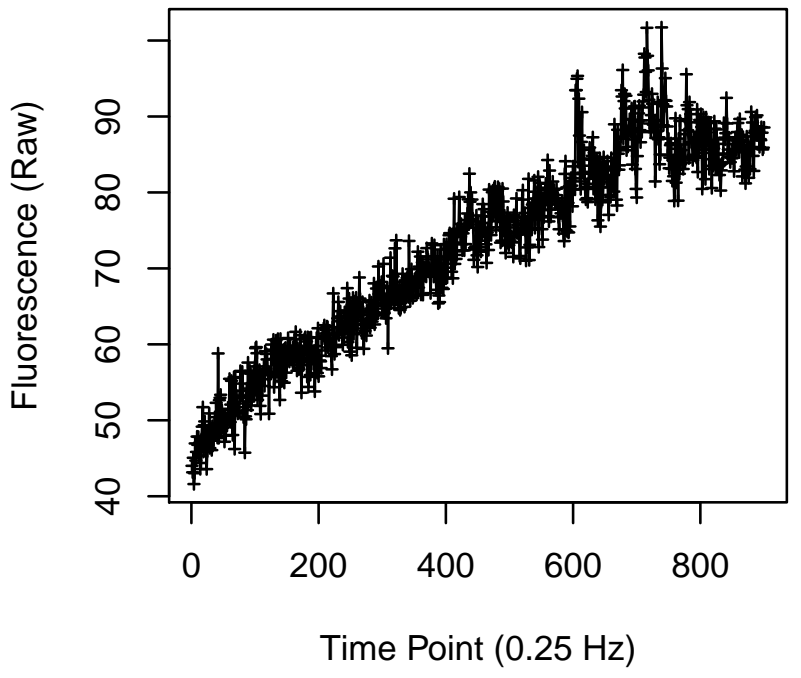

Cell 1511

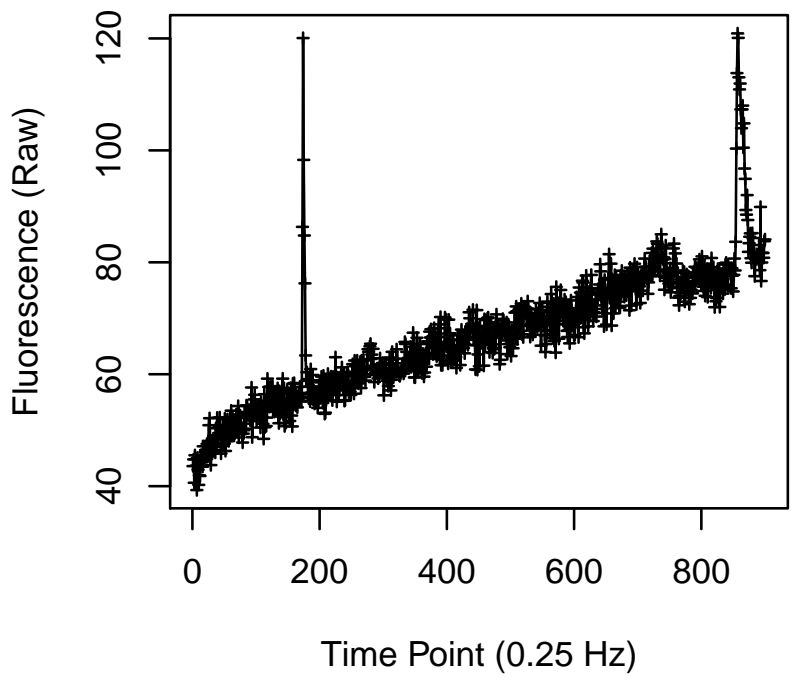

Cell 1510

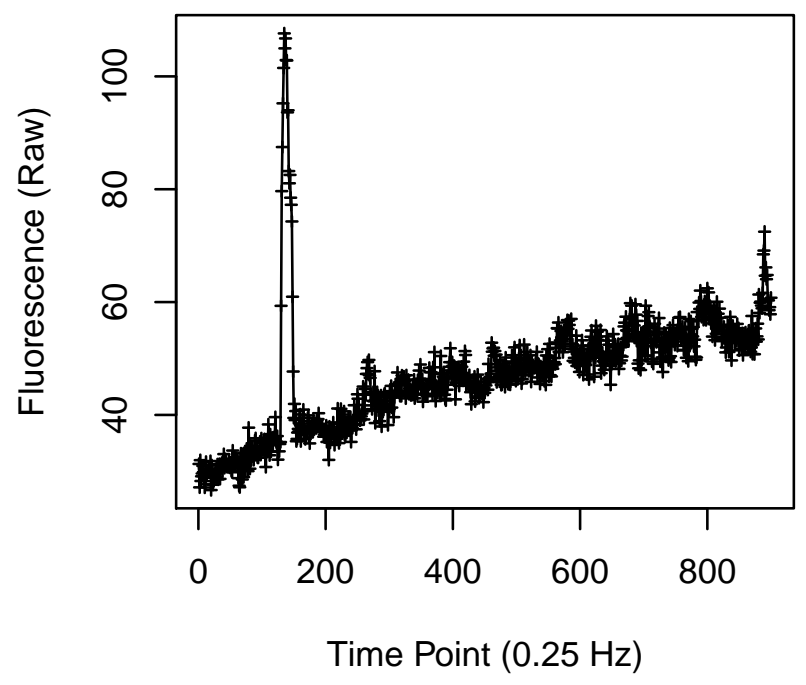

Cell 1512

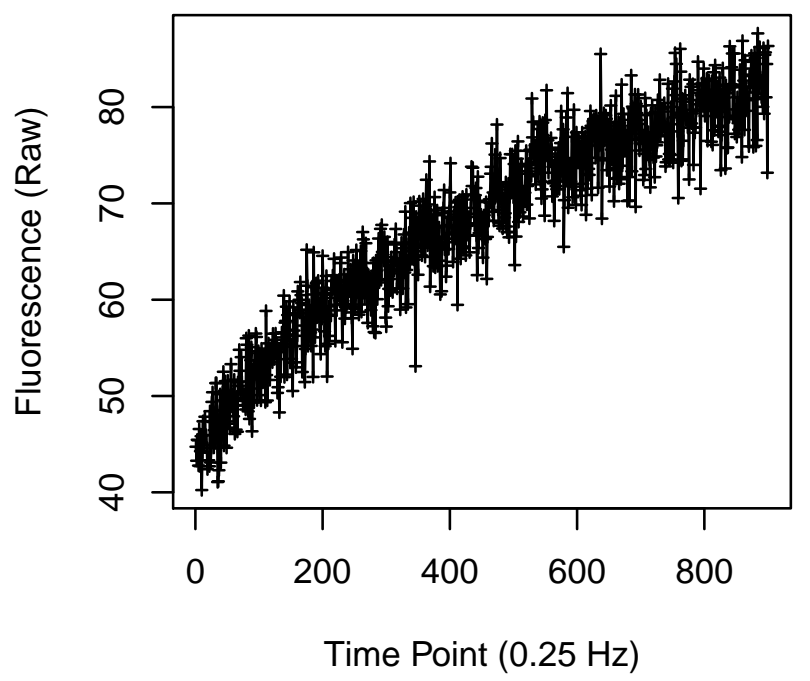


Cell 1513

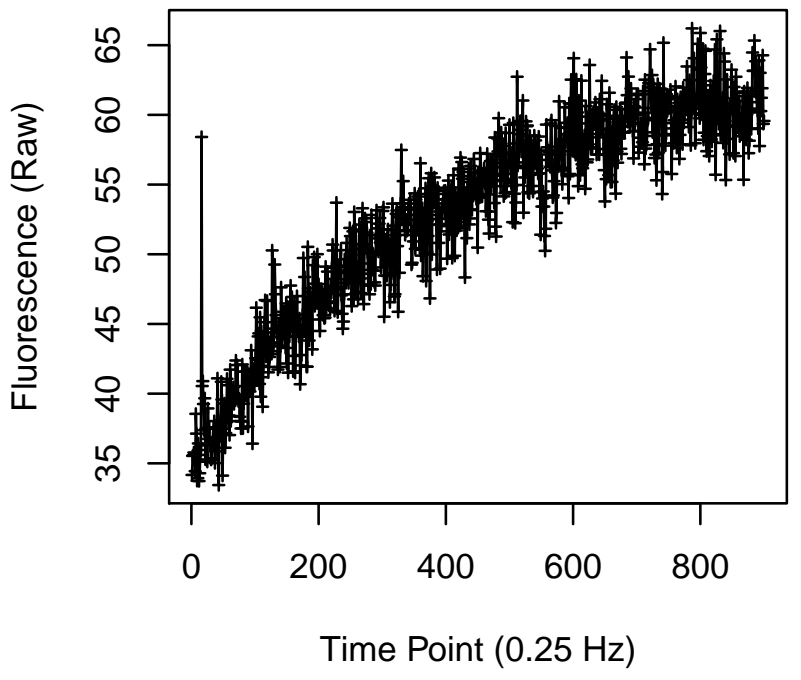

Cell 1515

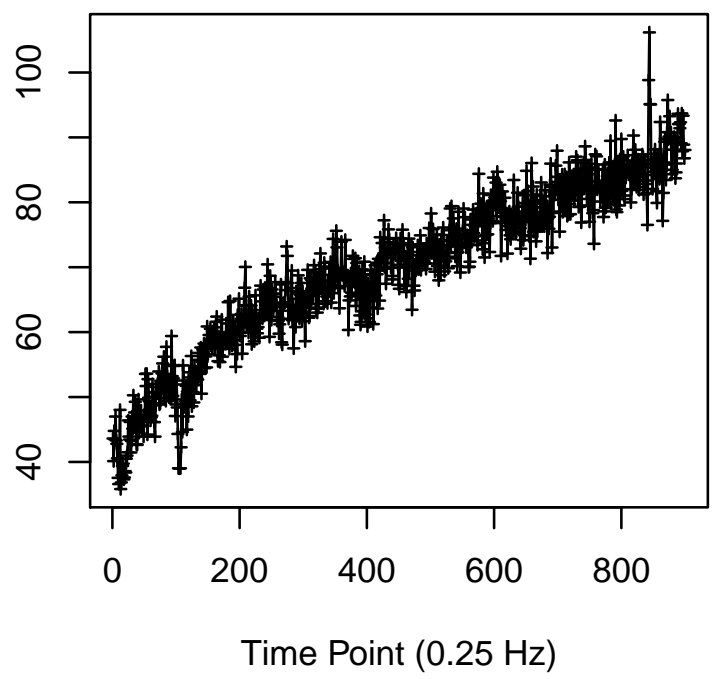

Cell 1514

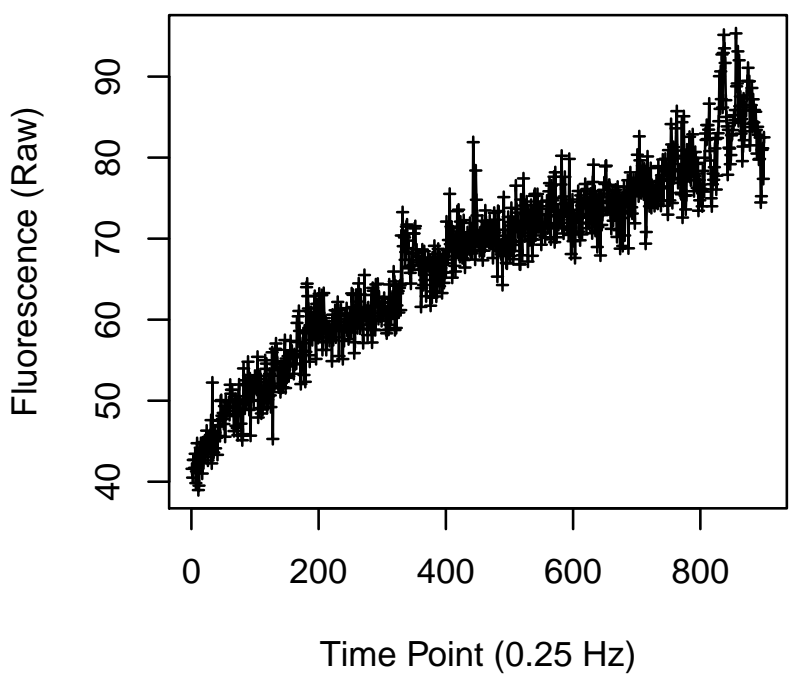

Cell 1516

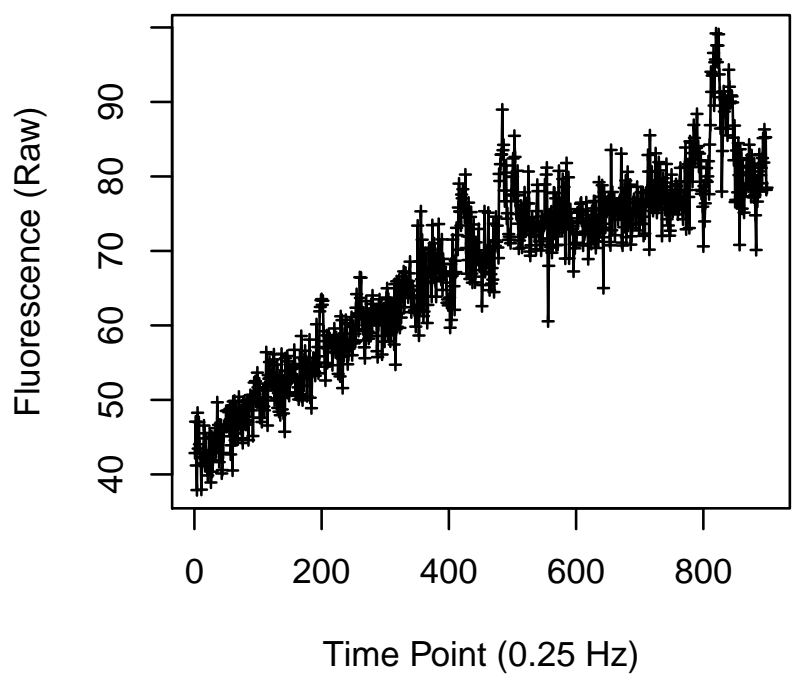


Cell 1517

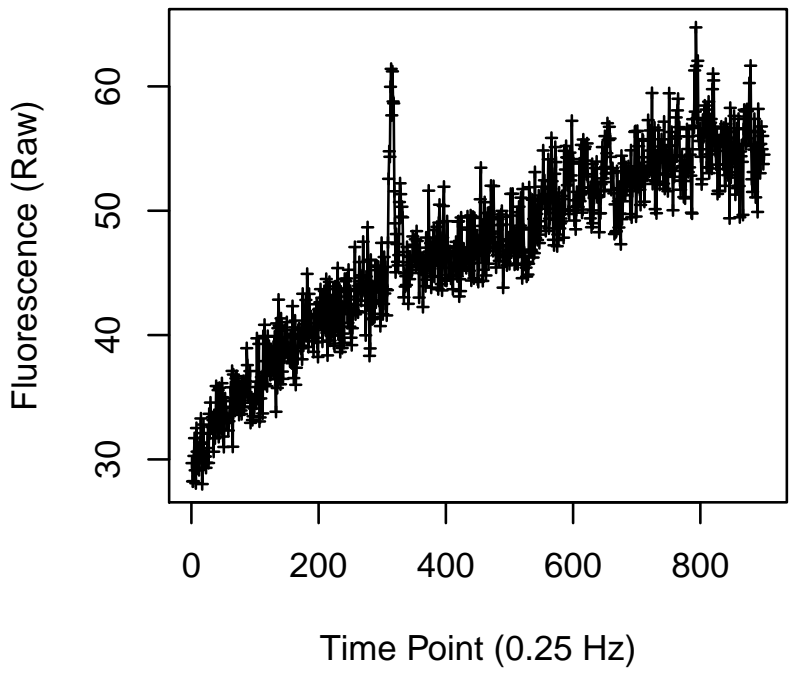

Cell 1519

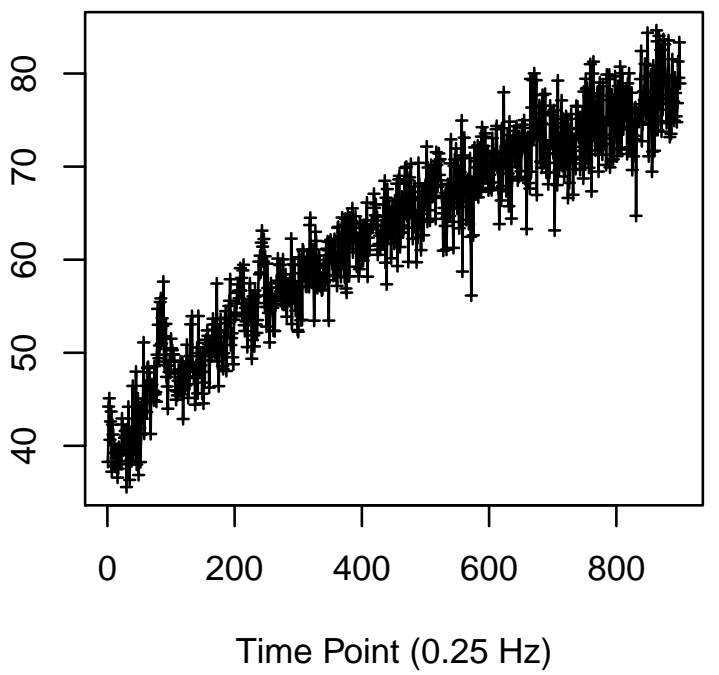

Cell 1518

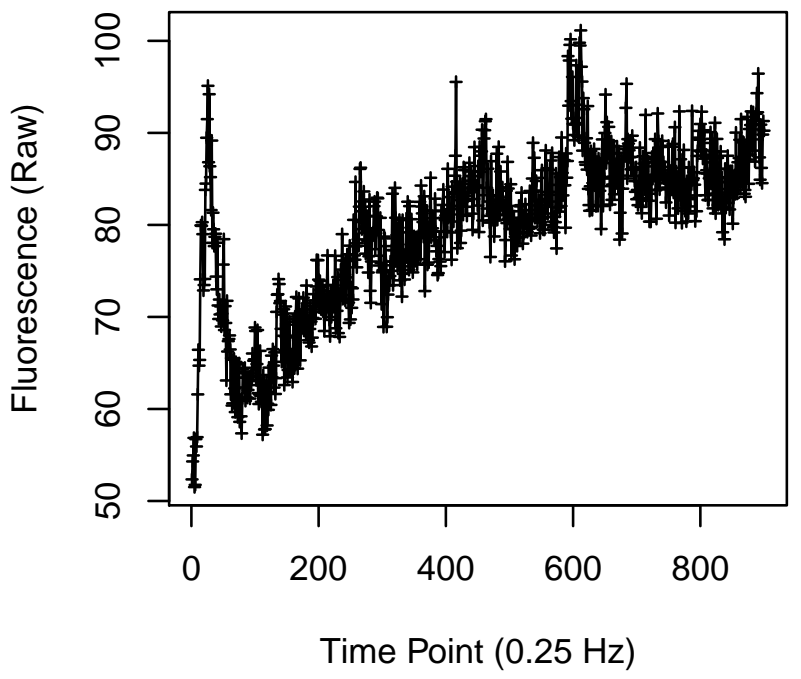

Cell 1520

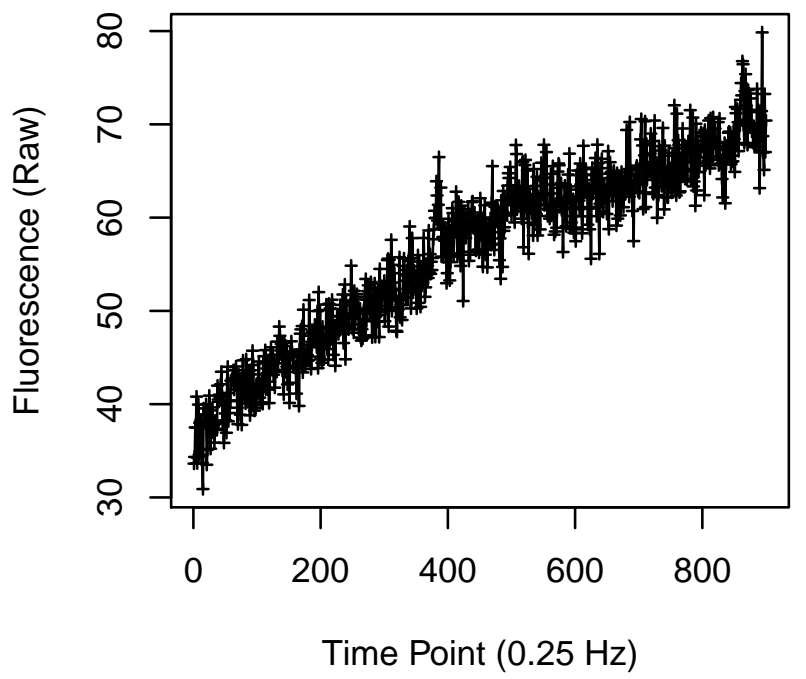


Cell 1521

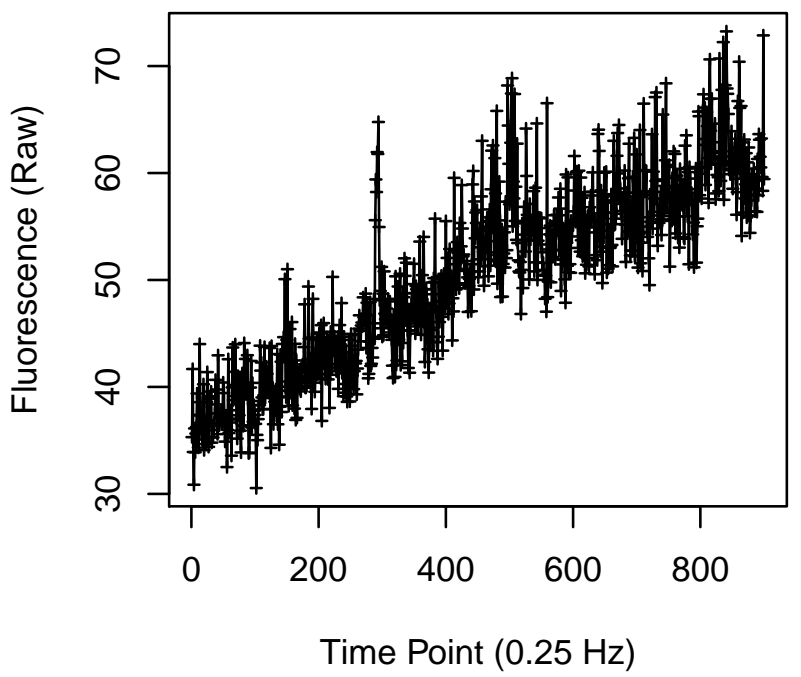

Cell 1523

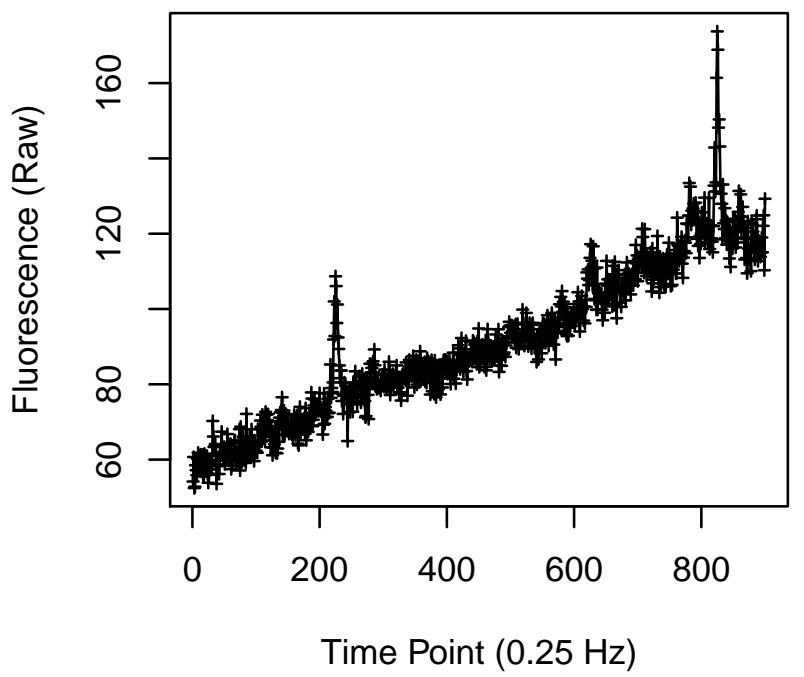

Cell 1522

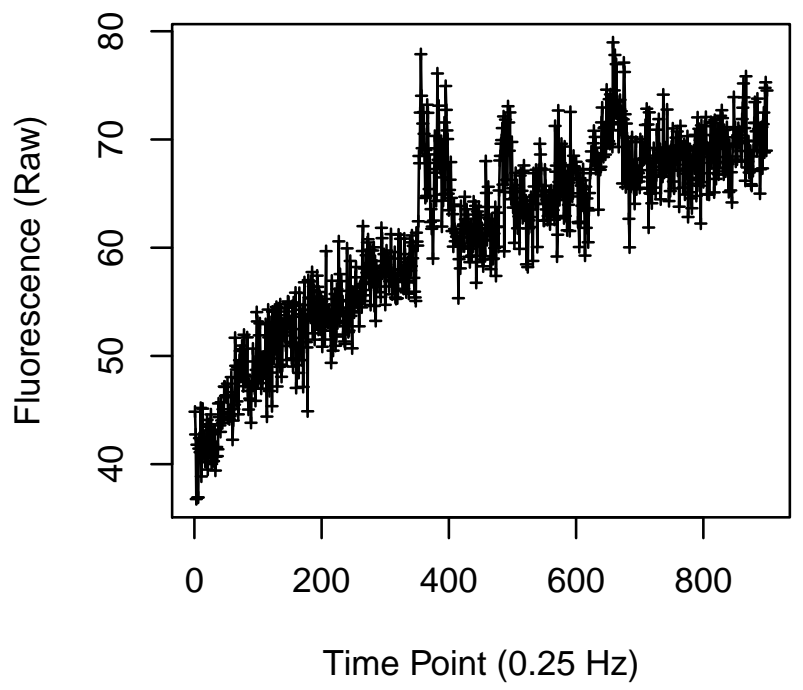

Cell 1524

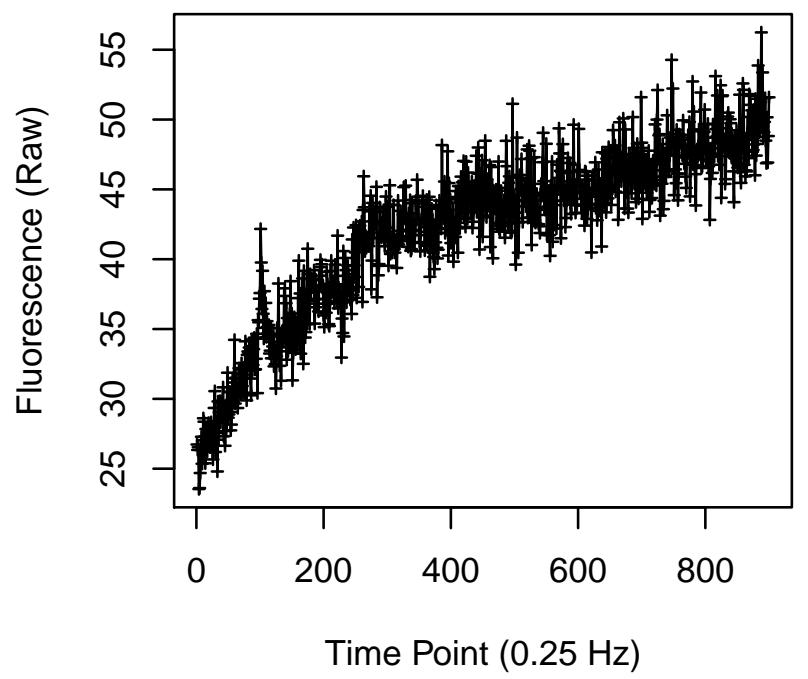


Cell 1529

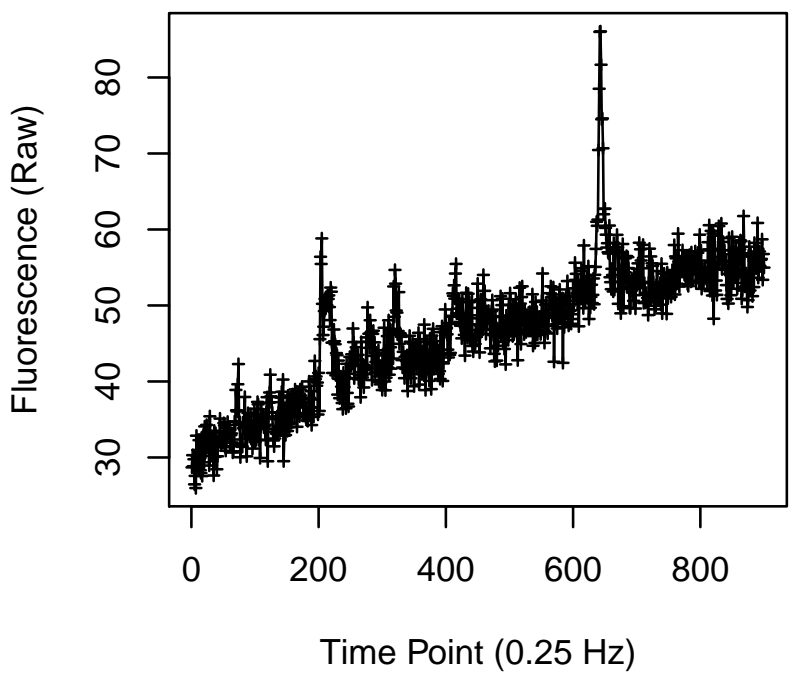

Cell 1531

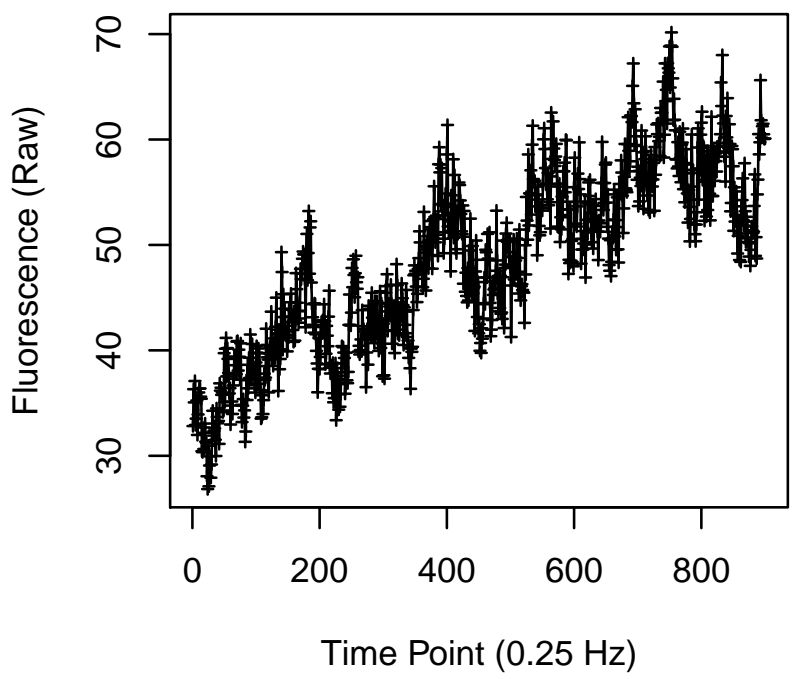

Cell 1530

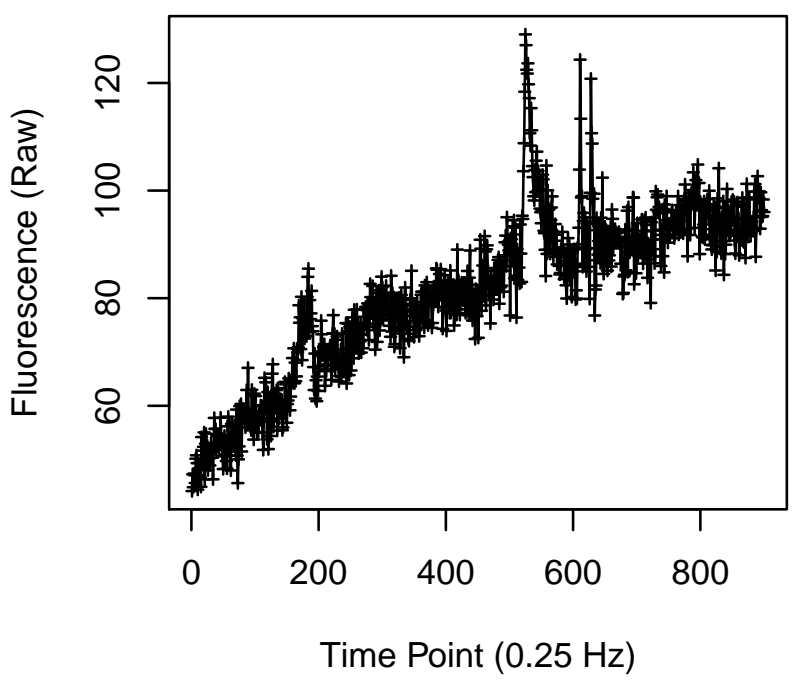

Cell 1532

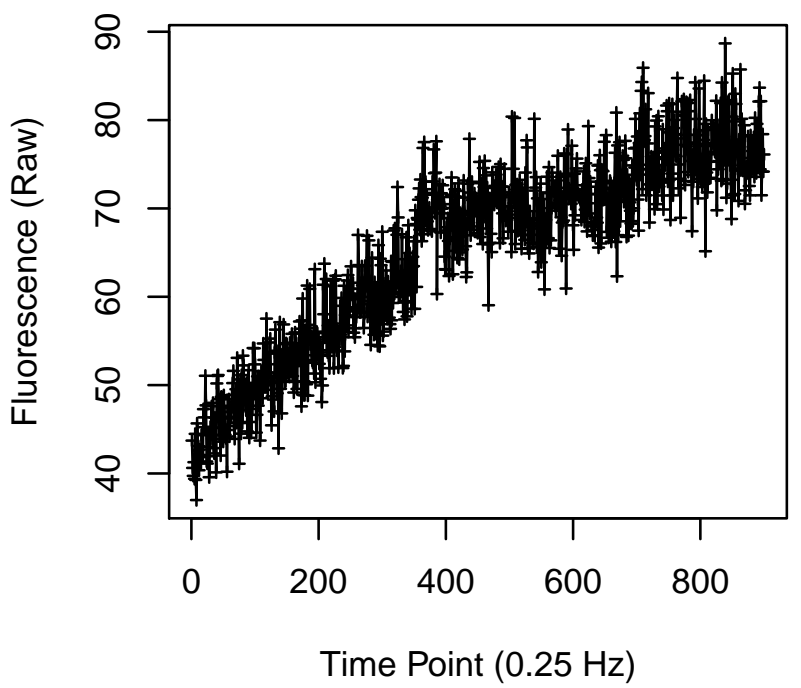


Cell 1533

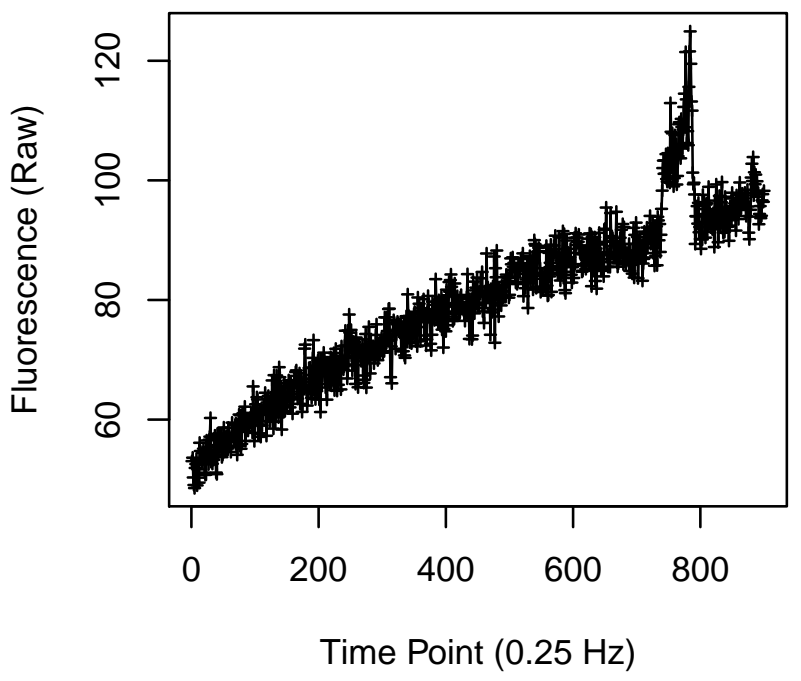

Cell 1535

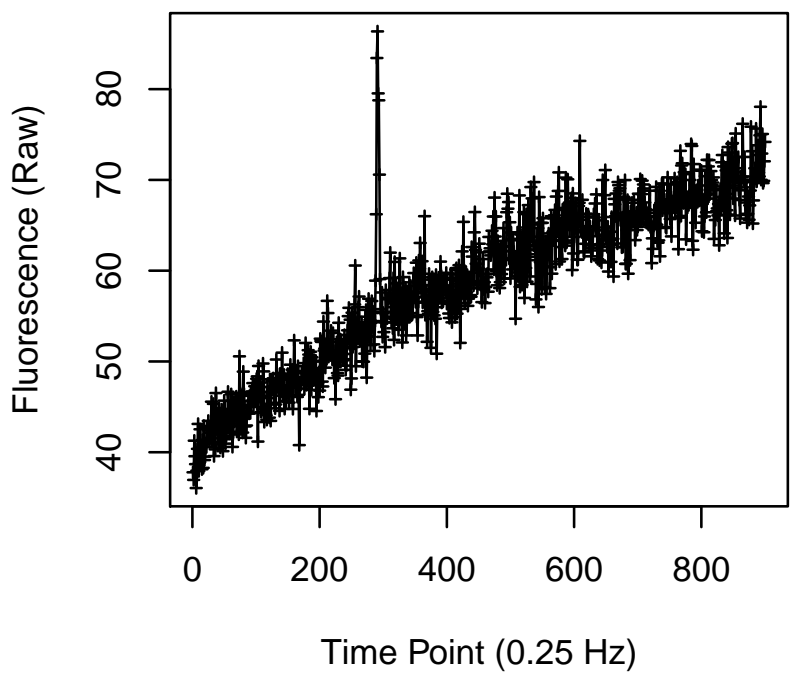

Cell 1534

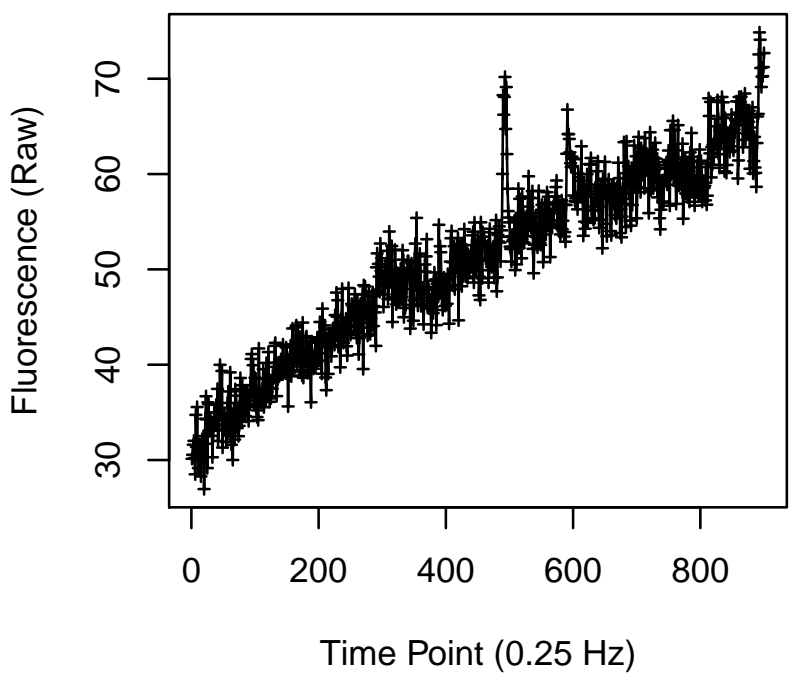

Cell 1536

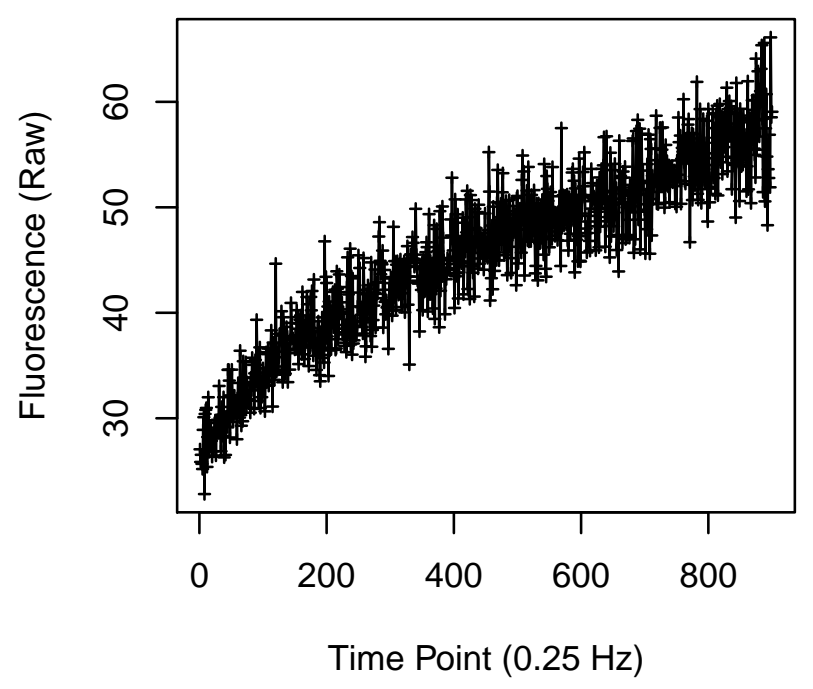


Cell 1537

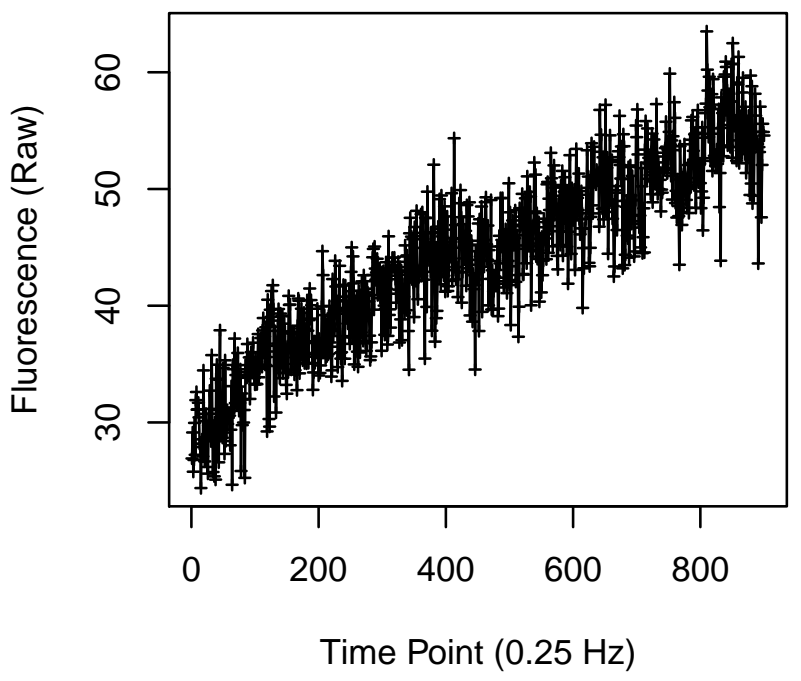

Cell 1539

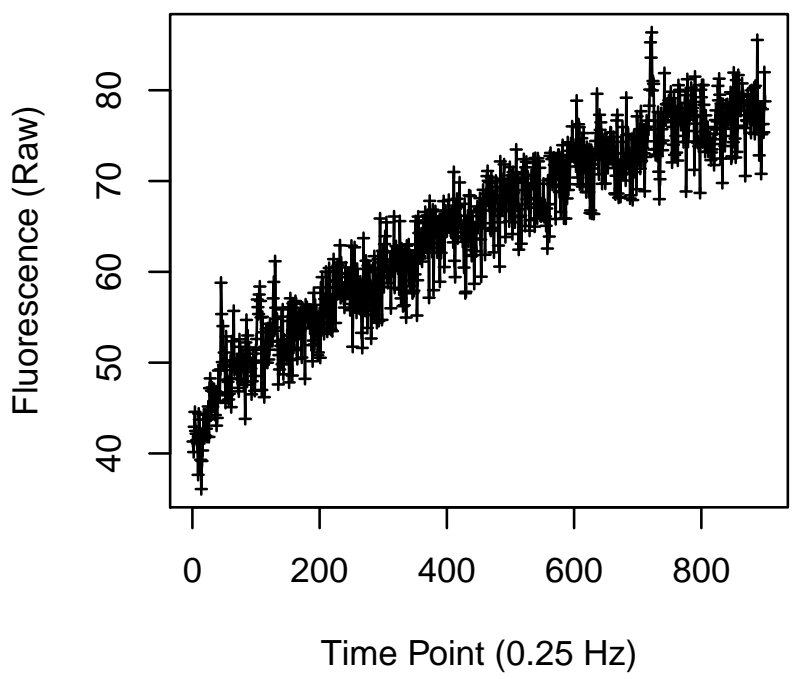

Cell 1538

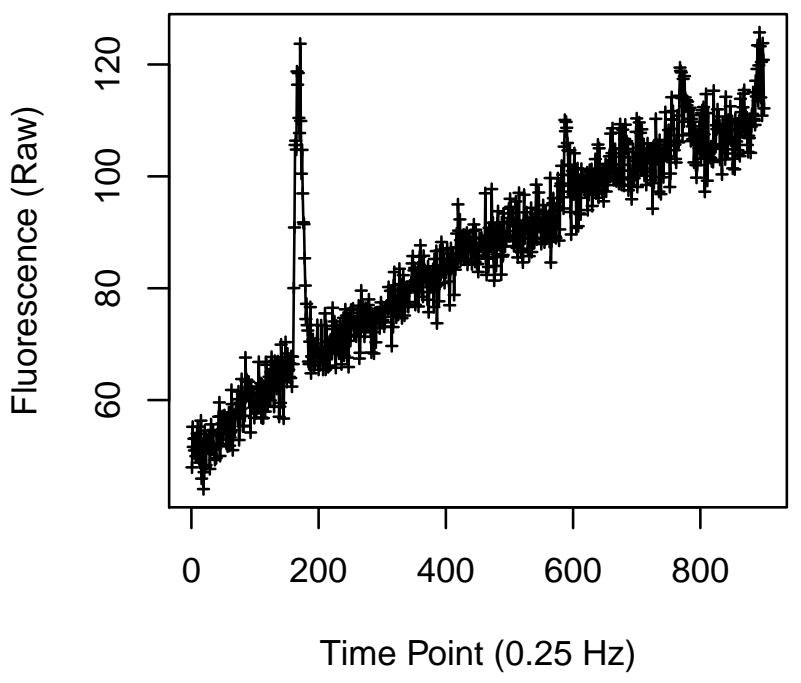

Cell 1540

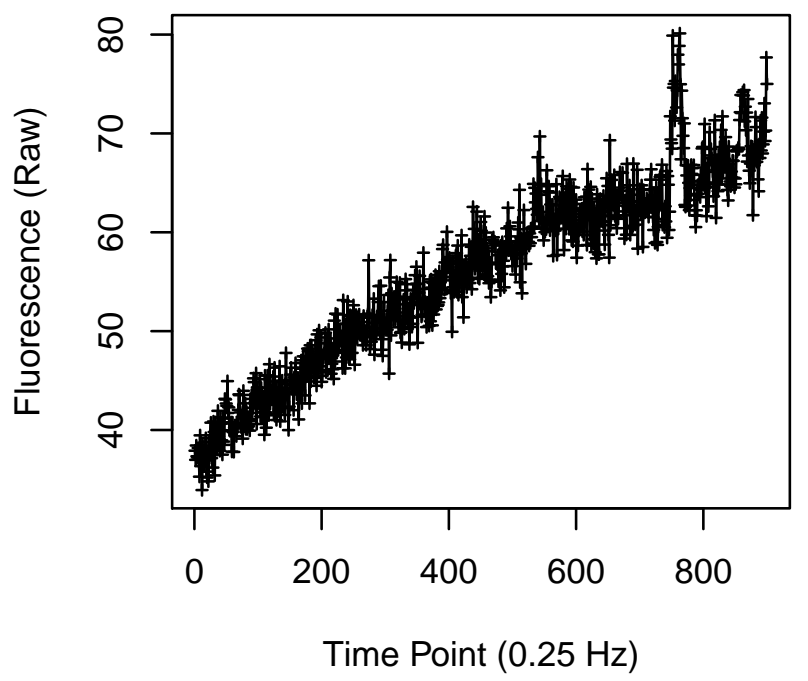


Cell 1541

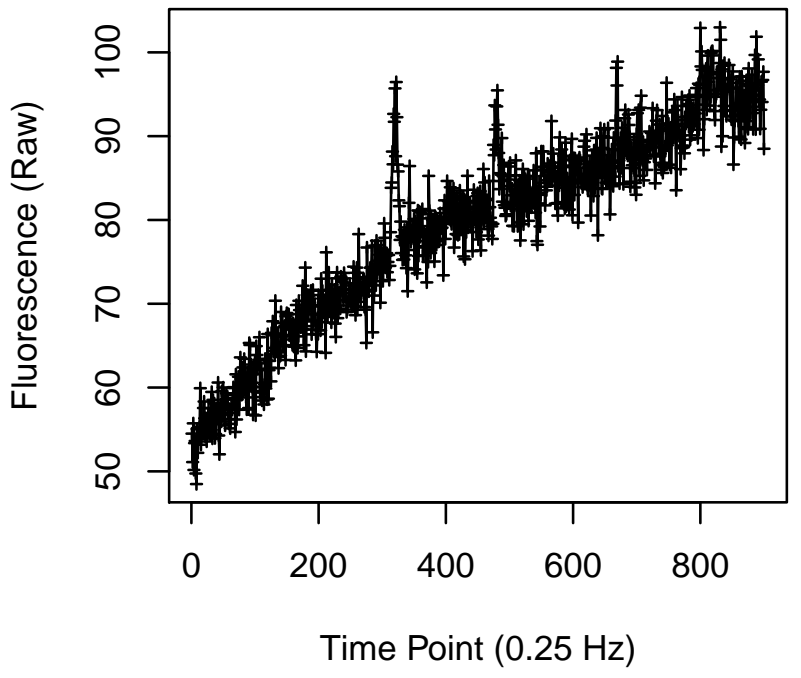

Cell 1543

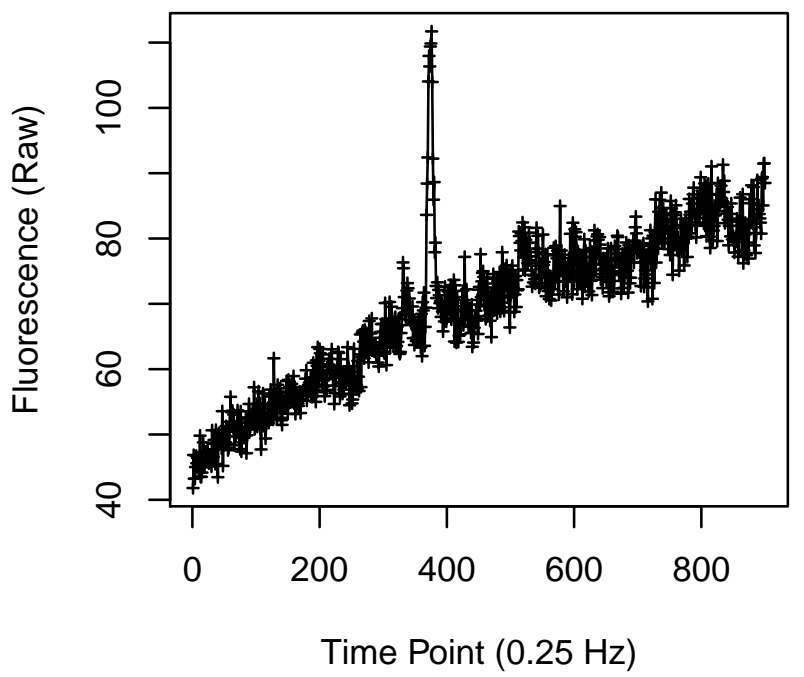

Cell 1542

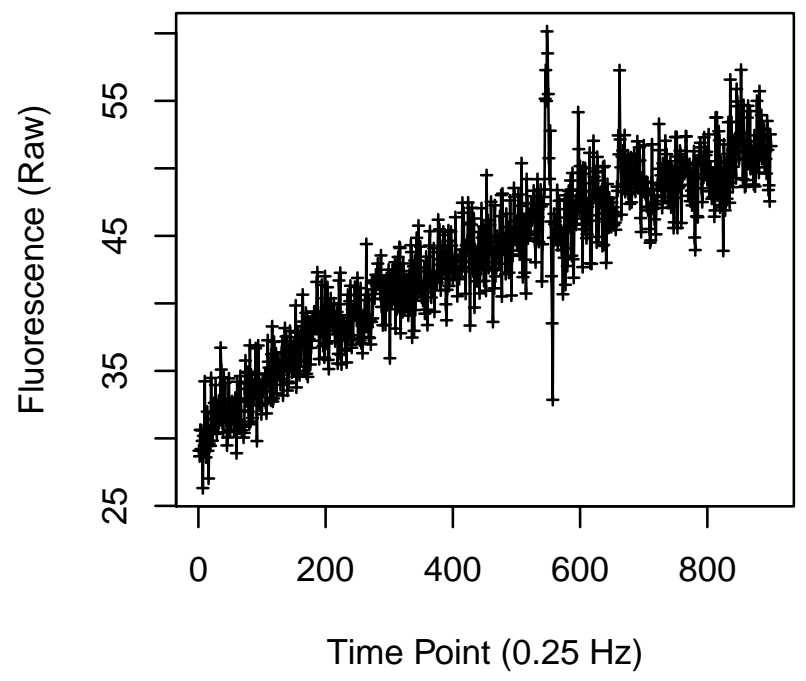

Cell 1544

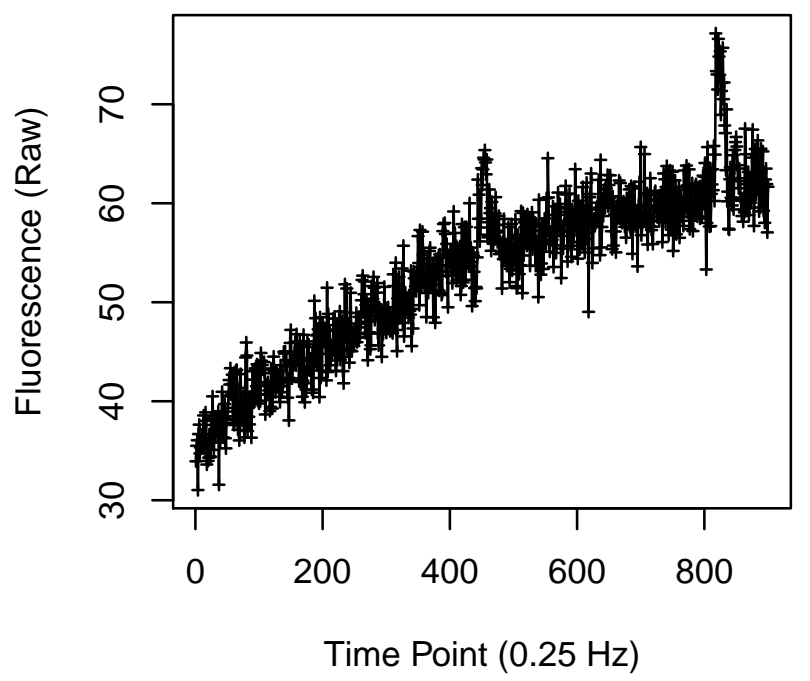


Cell 1545

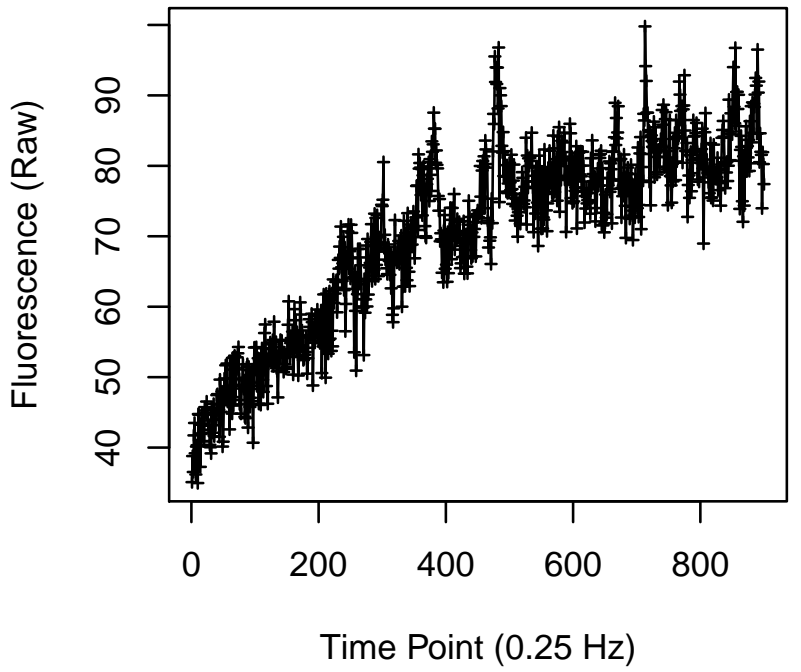

Cell 1547

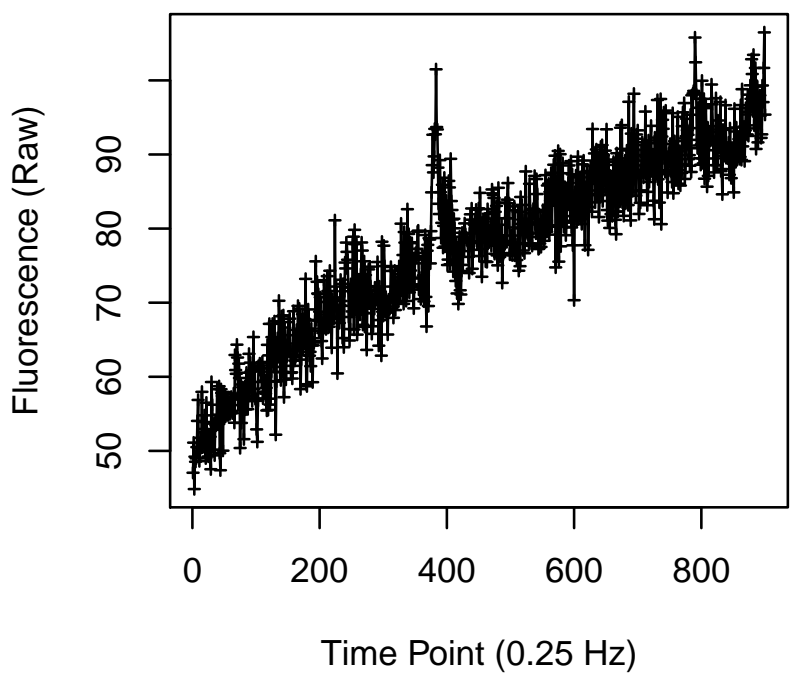

Cell 1546

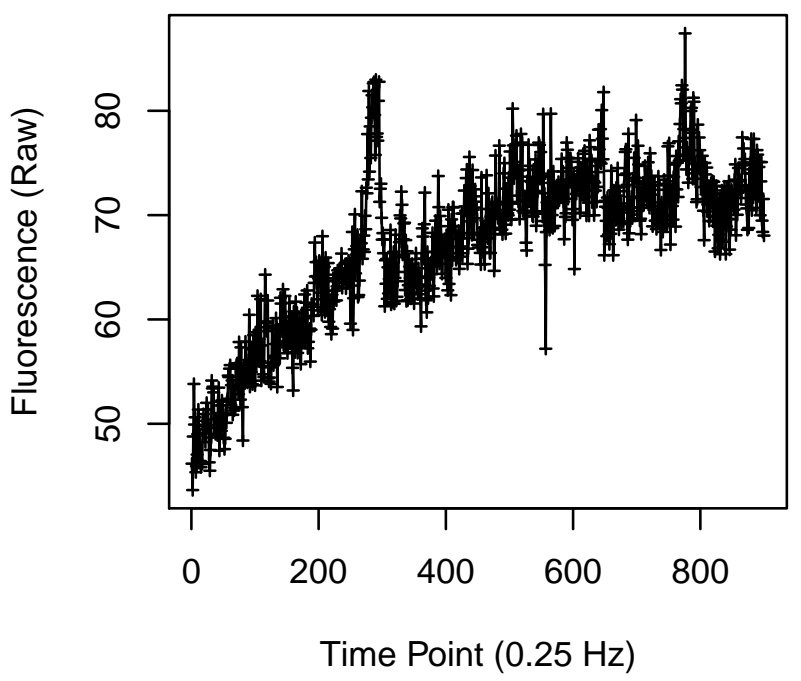

Cell 1548

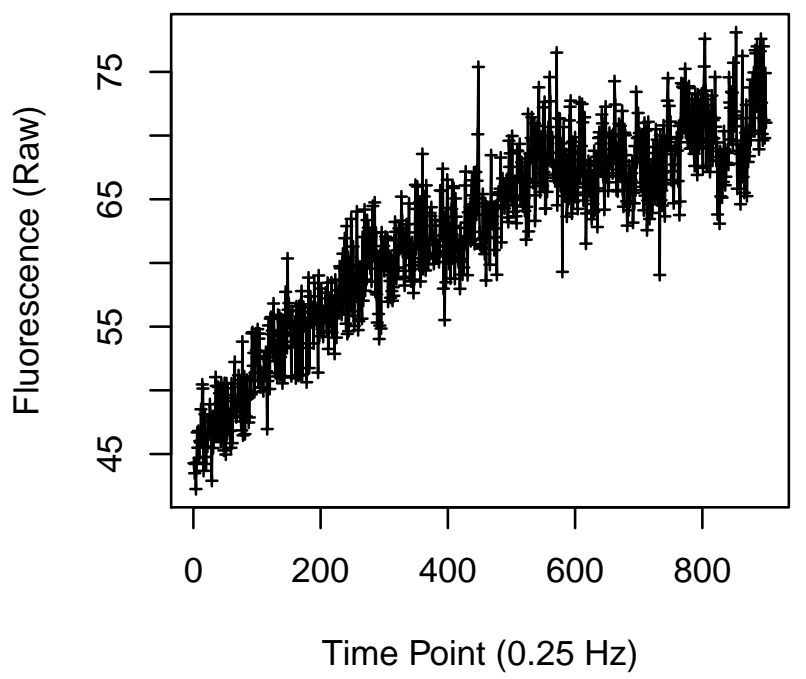


Cell 1553

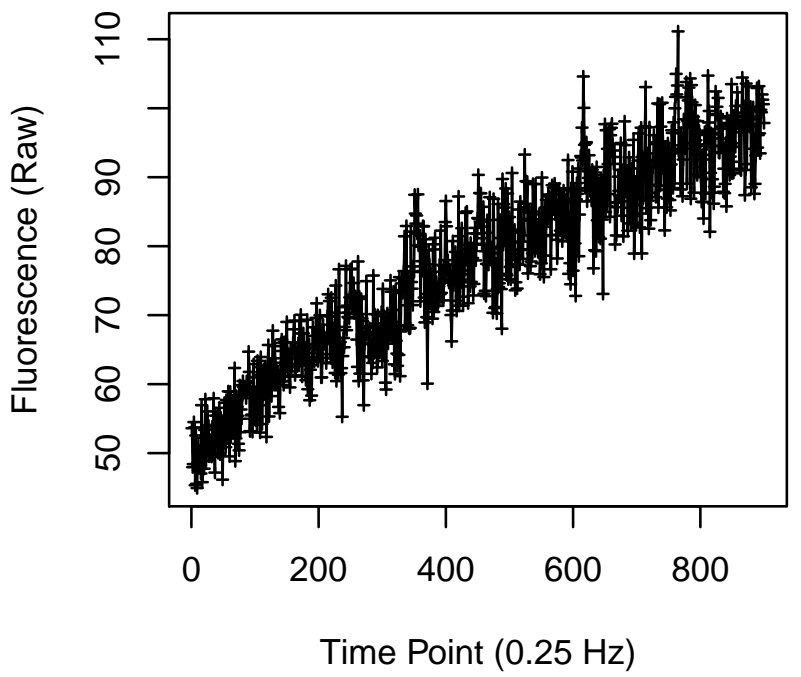

Cell 1555

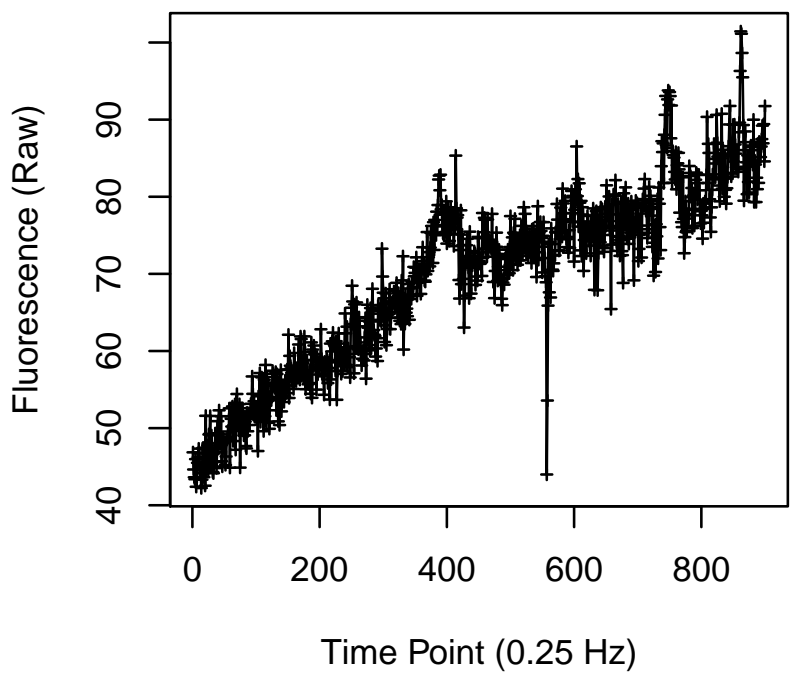

Cell 1554

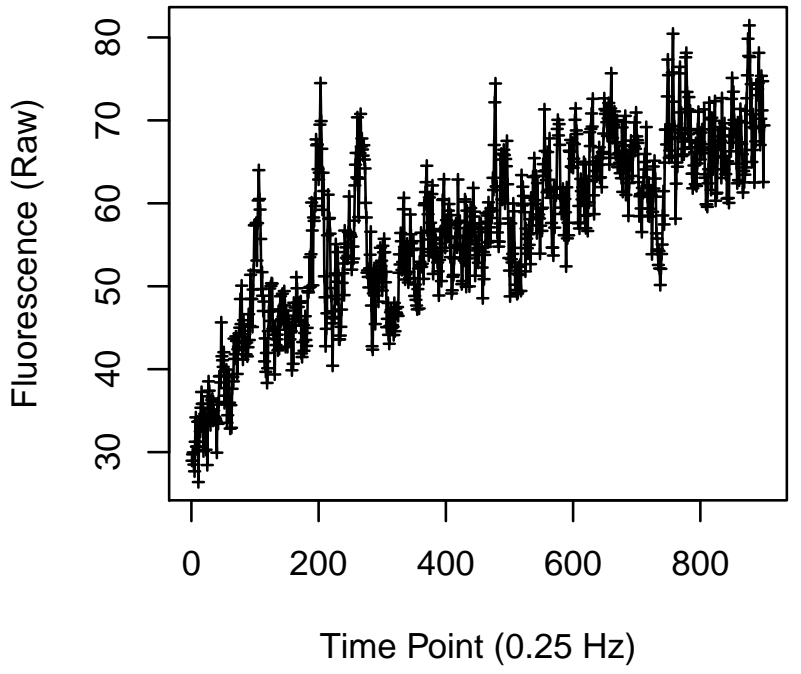

Cell 1556

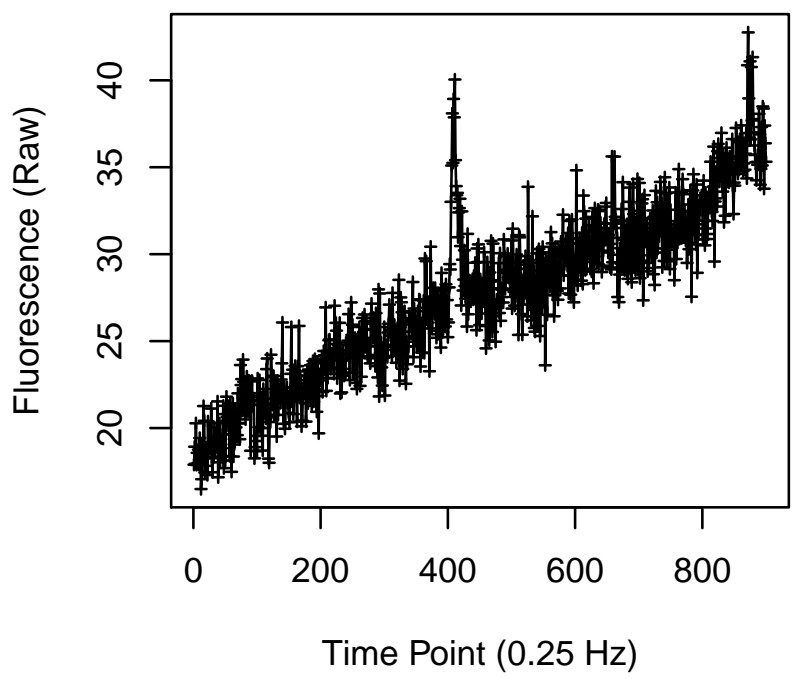


Cell 1557

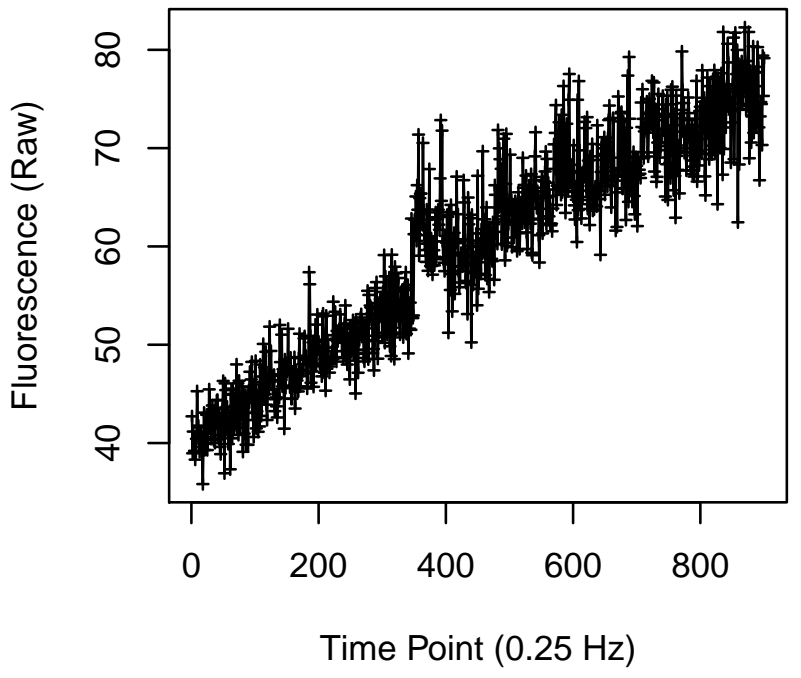

Cell 1559

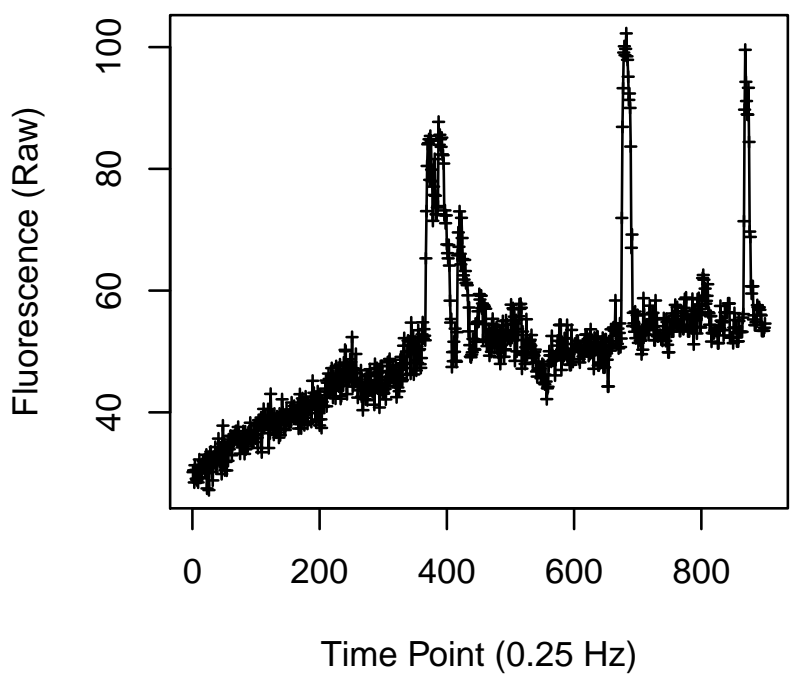

Cell 1558

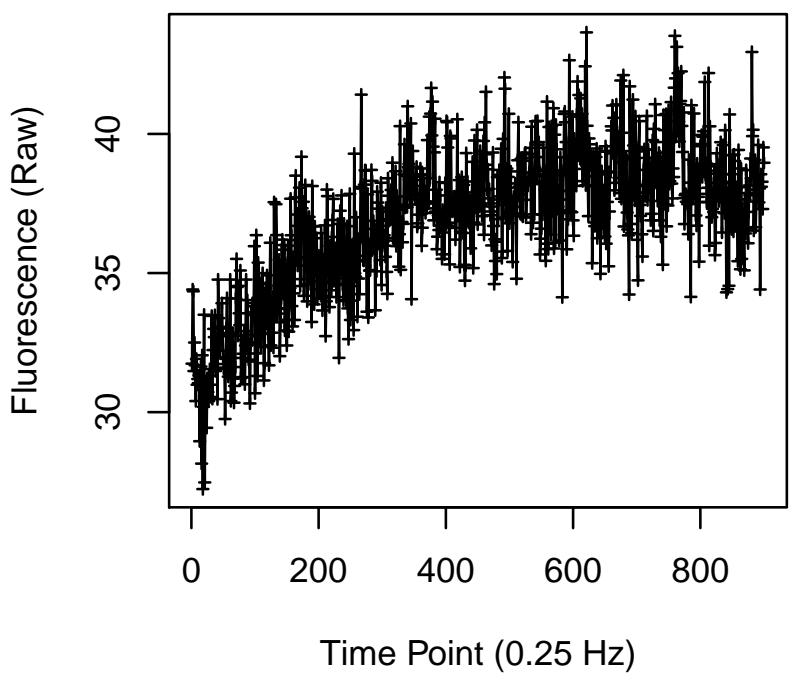

Cell 1560

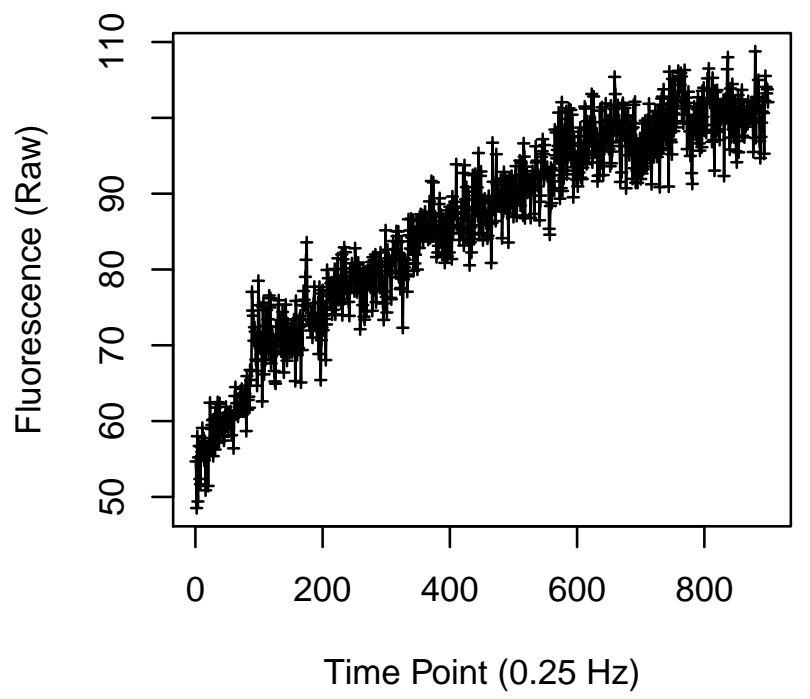


Cell 1561

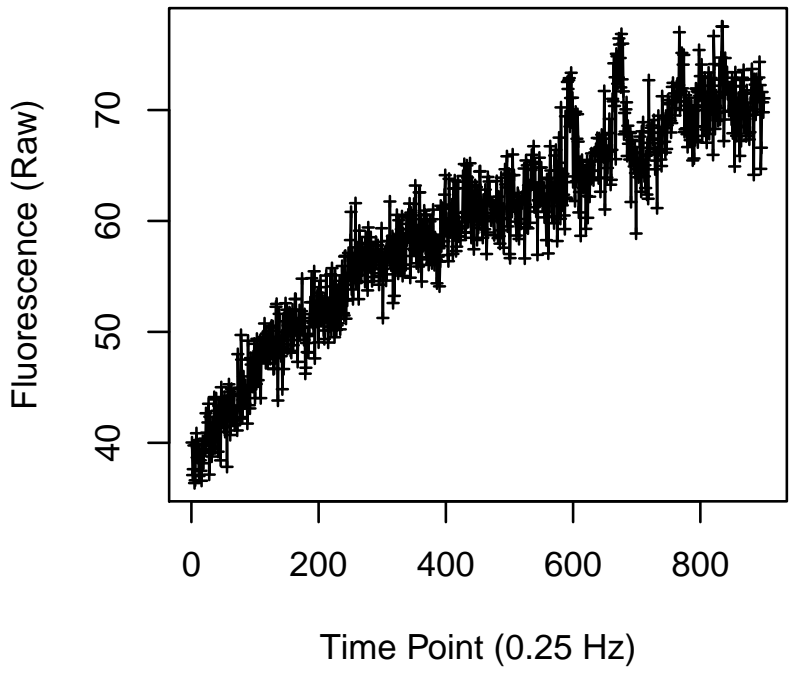

Cell 1563

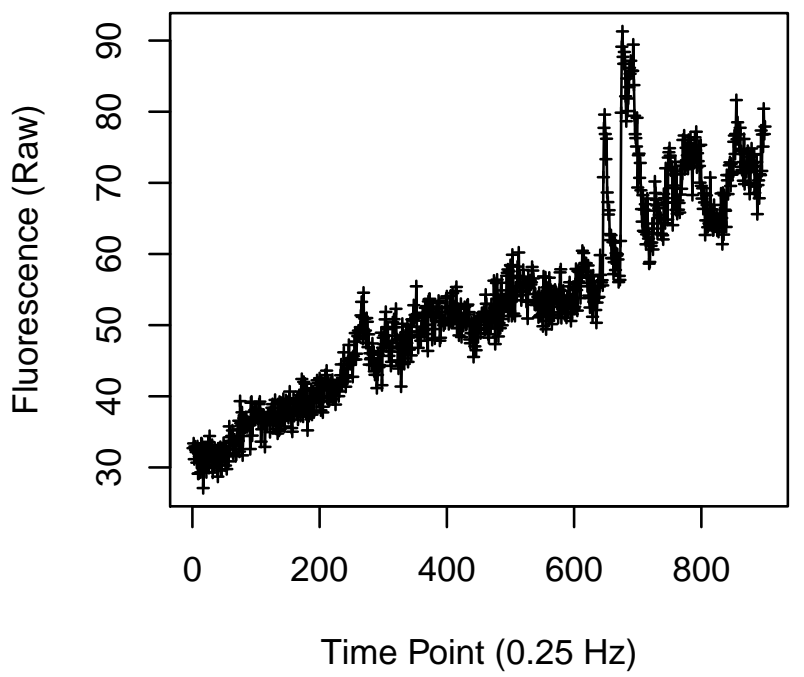

Cell 1562

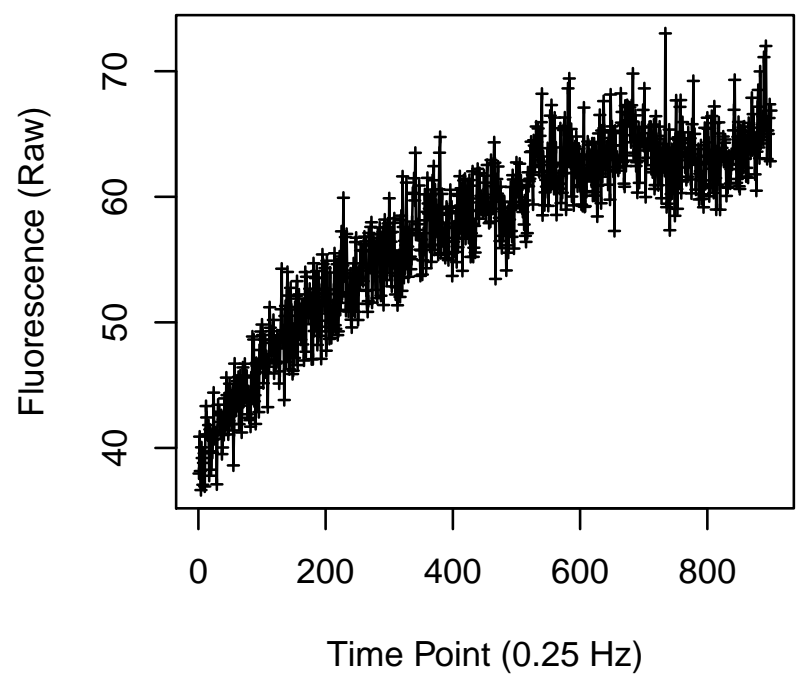

Cell 1564

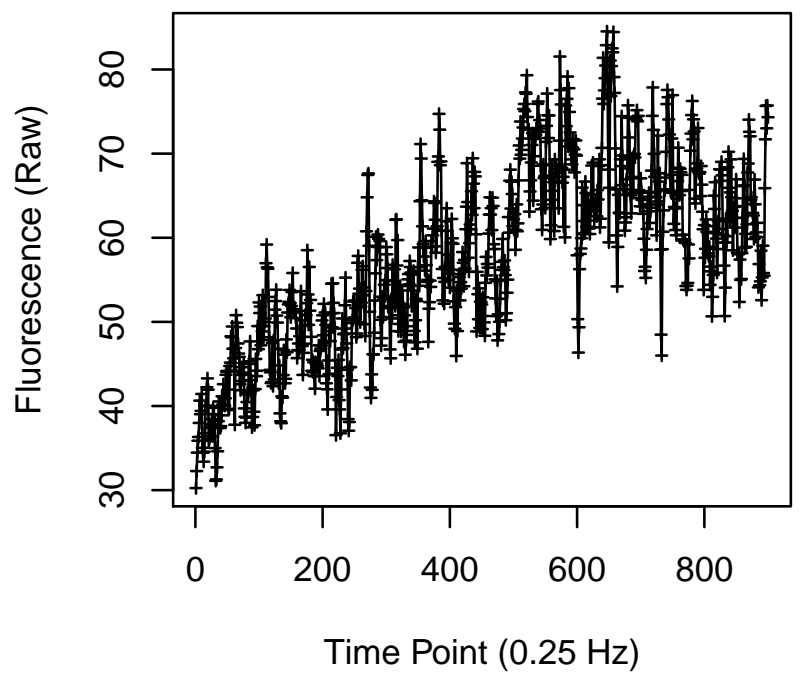


Cell 1565

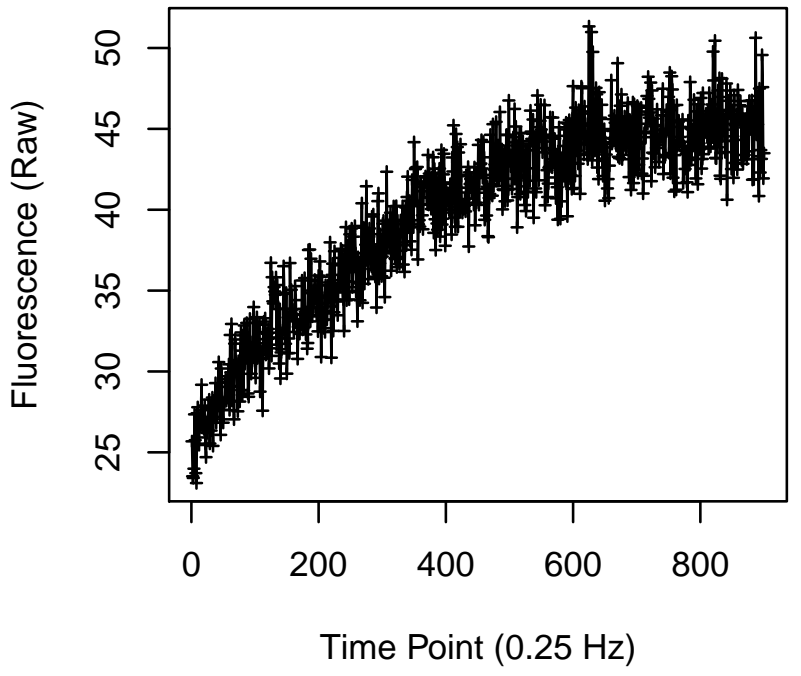

Cell 1567

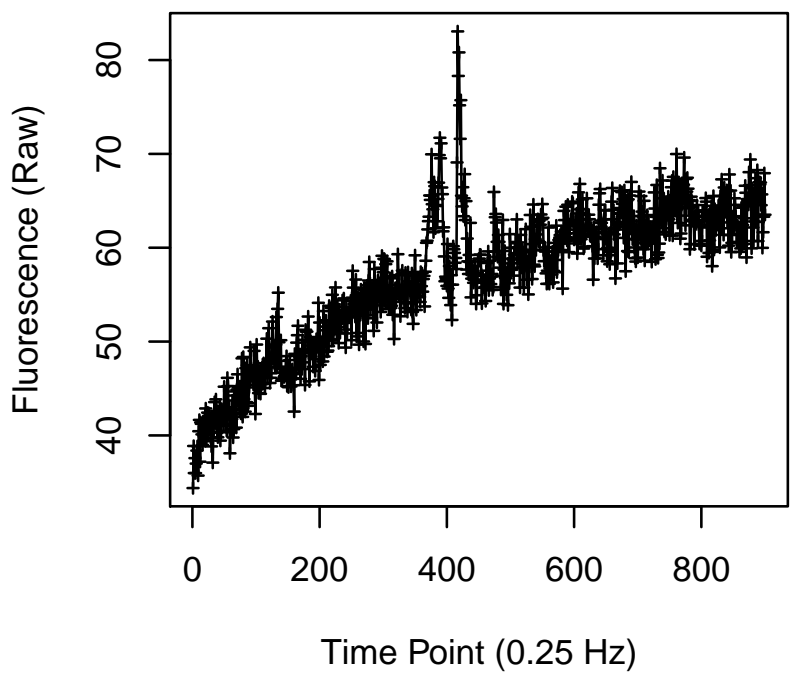

Cell 1566

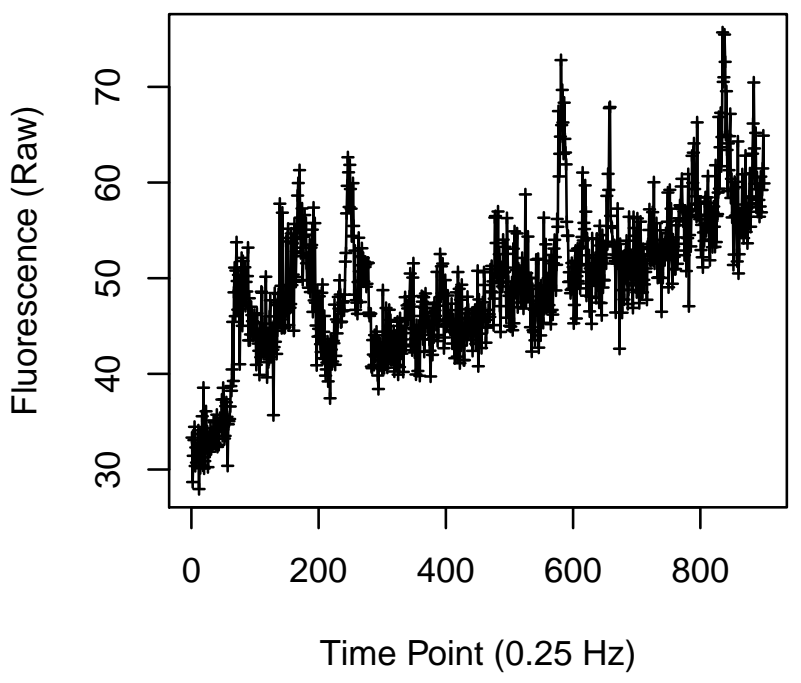

Cell 1568

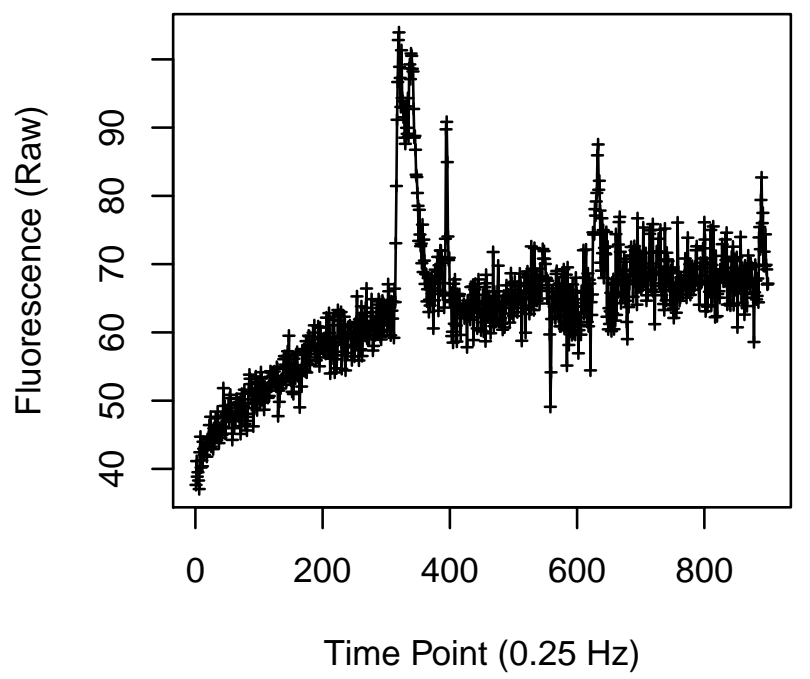


Cell 1573

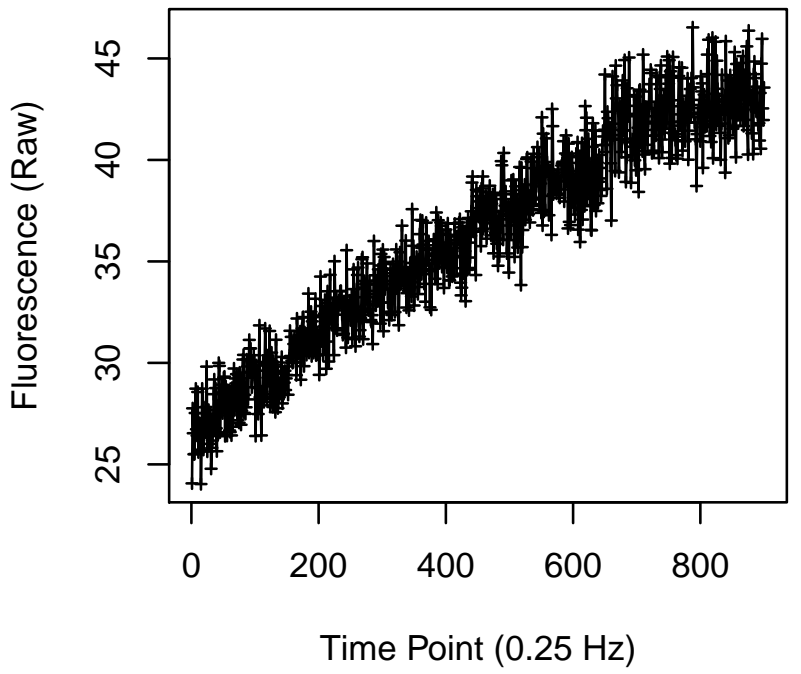

Cell 1575

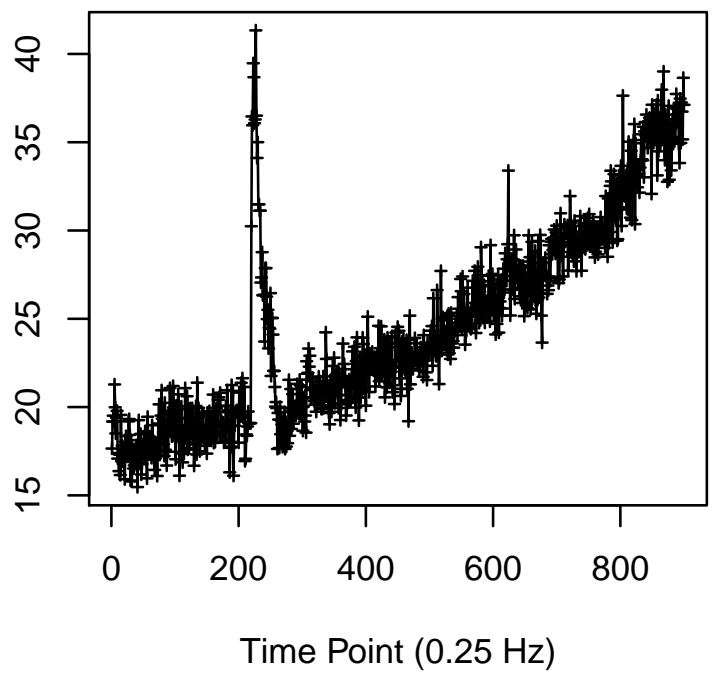

Cell 1574

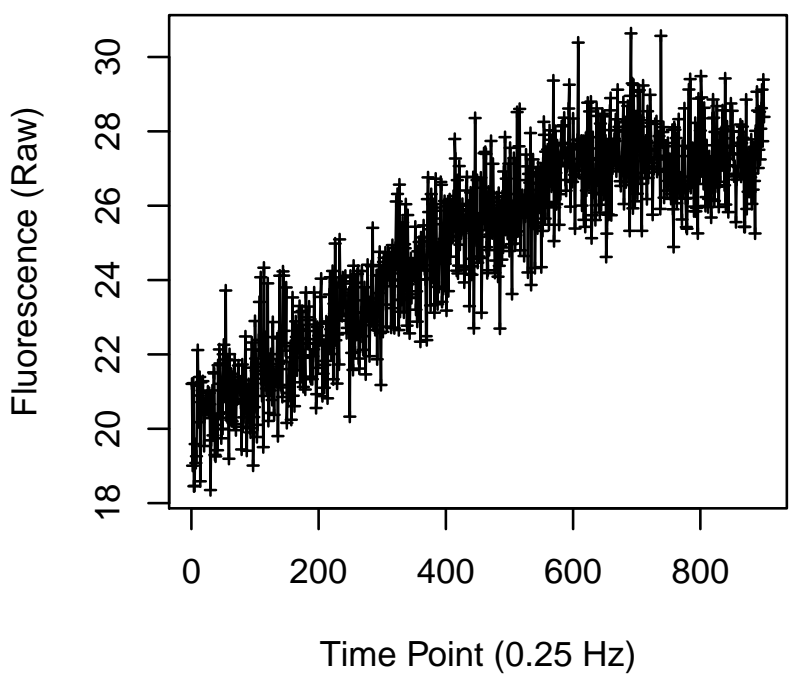

Cell 1576

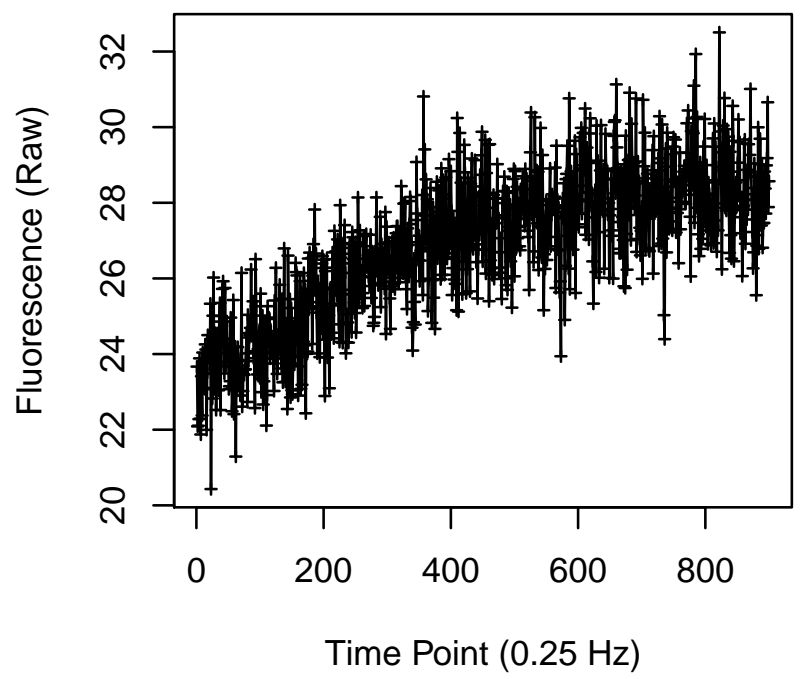


Cell 1577

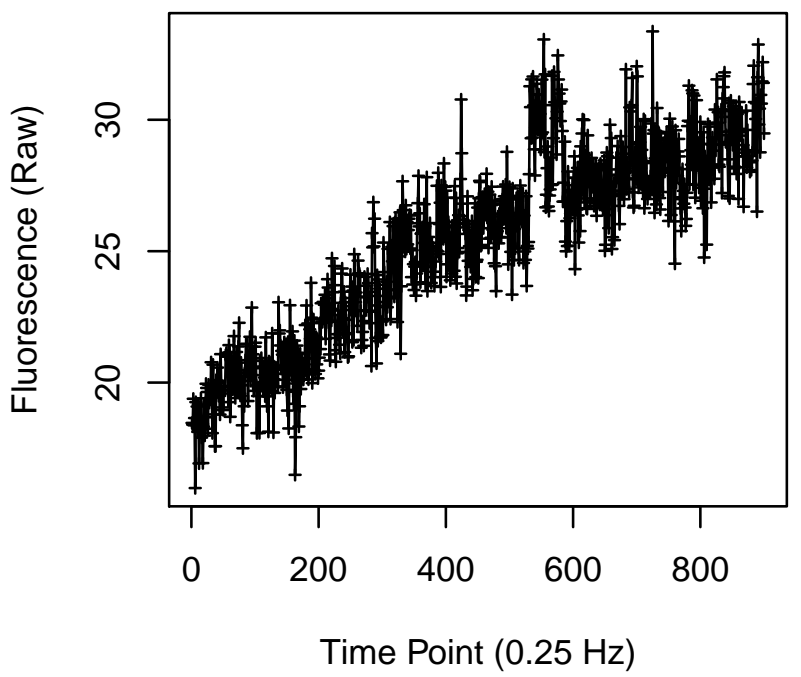

Cell 1579

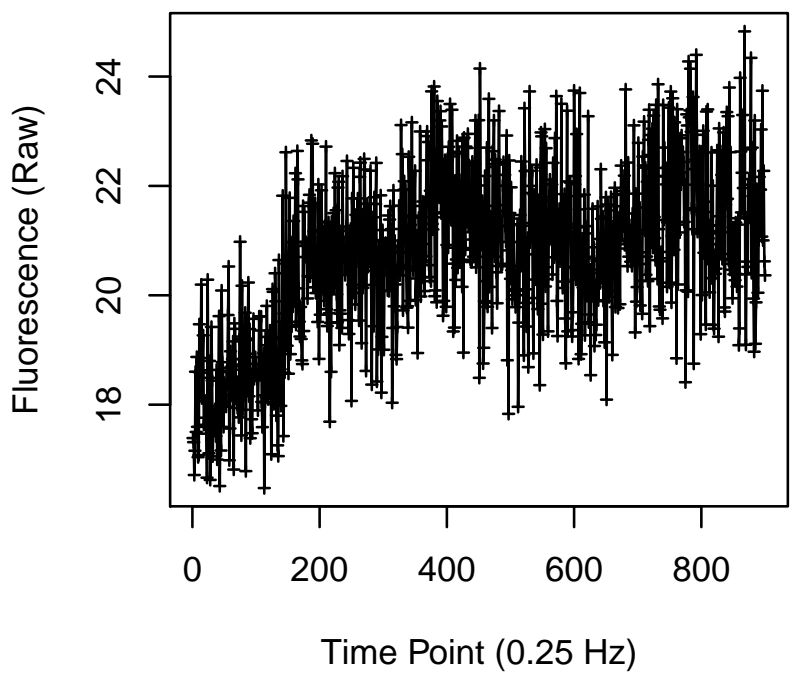

Cell 1578

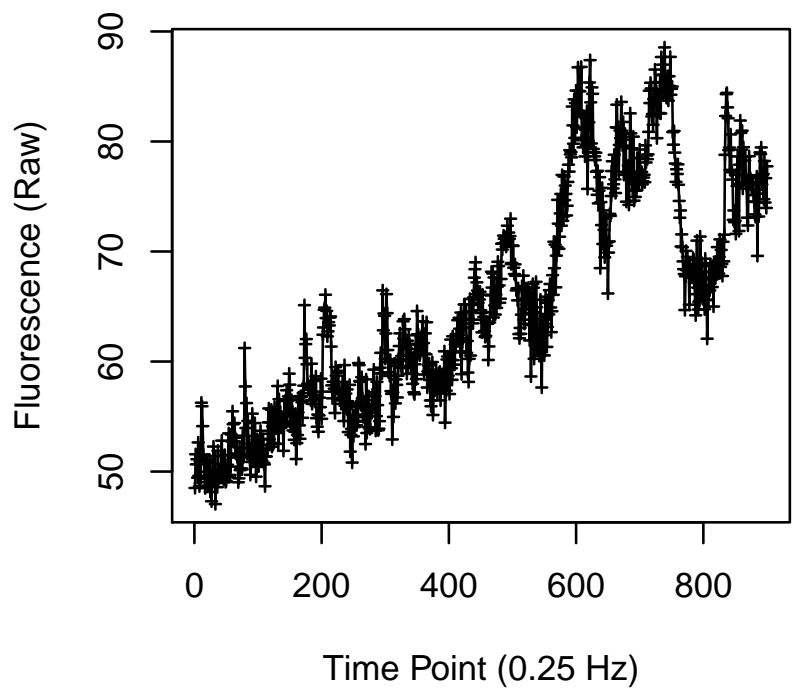

Cell 1580

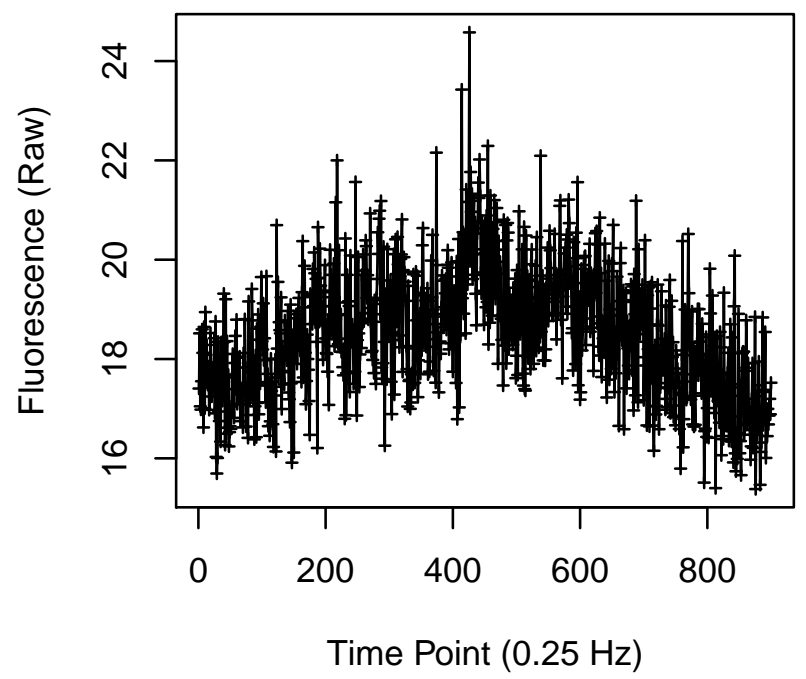


Cell 1581

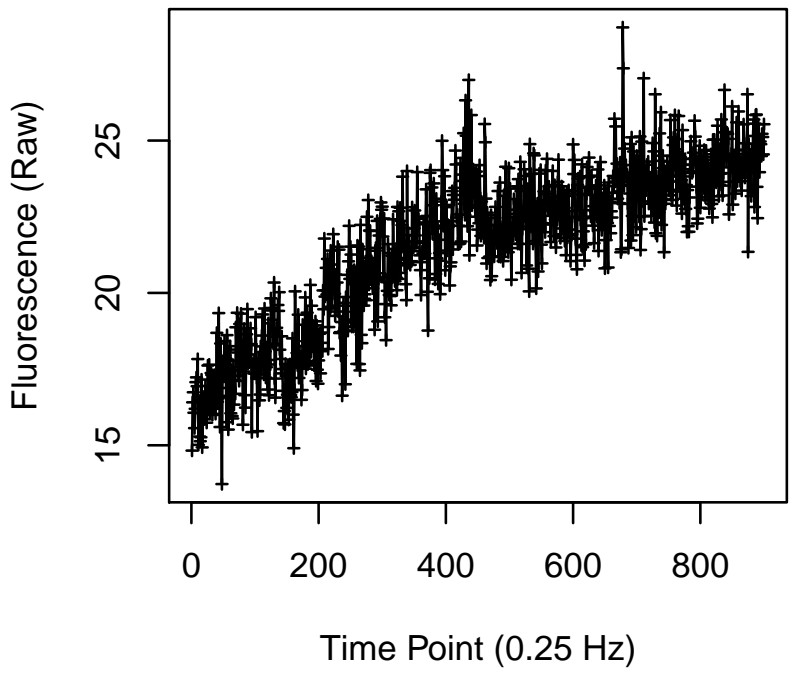

Cell 1583

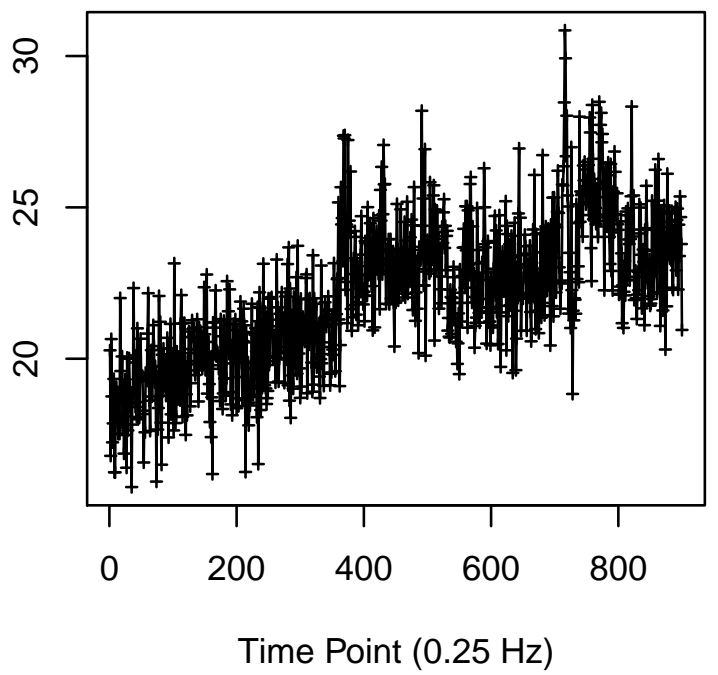

Cell 1582

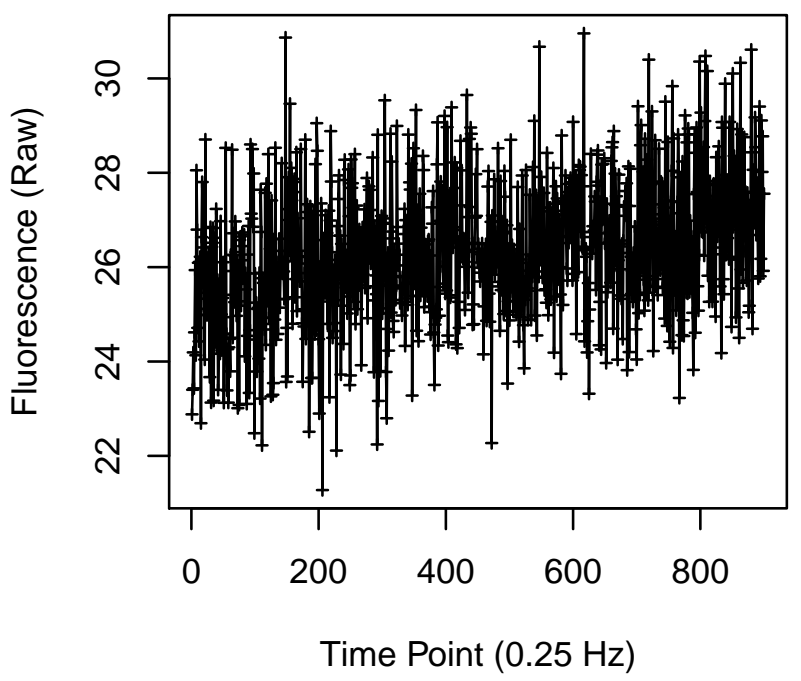

Cell 1584

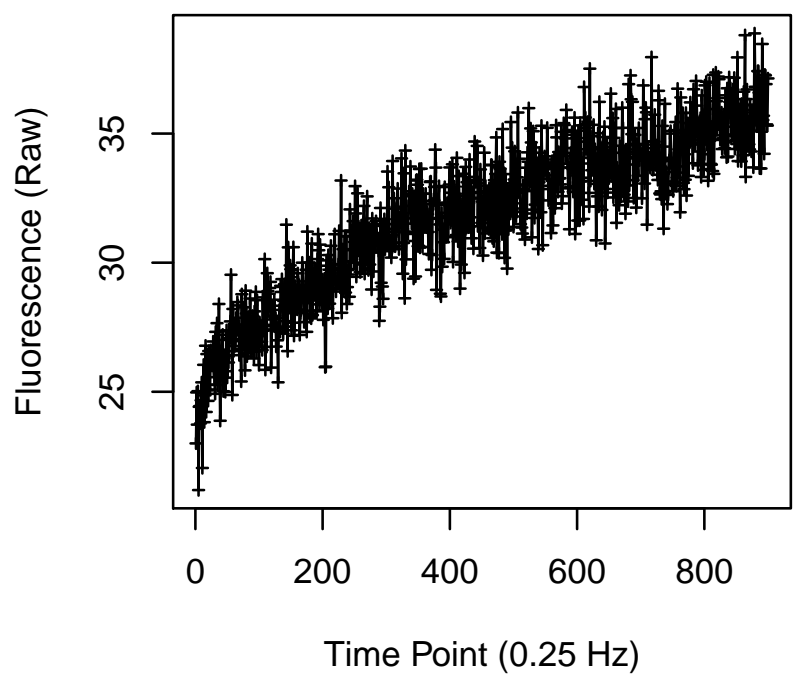


Cell 1589

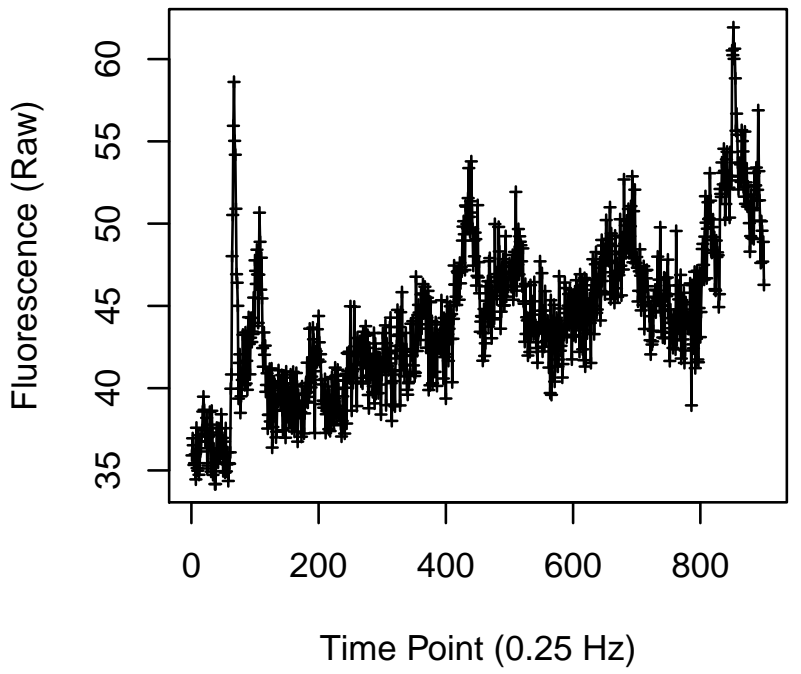

Cell 1591

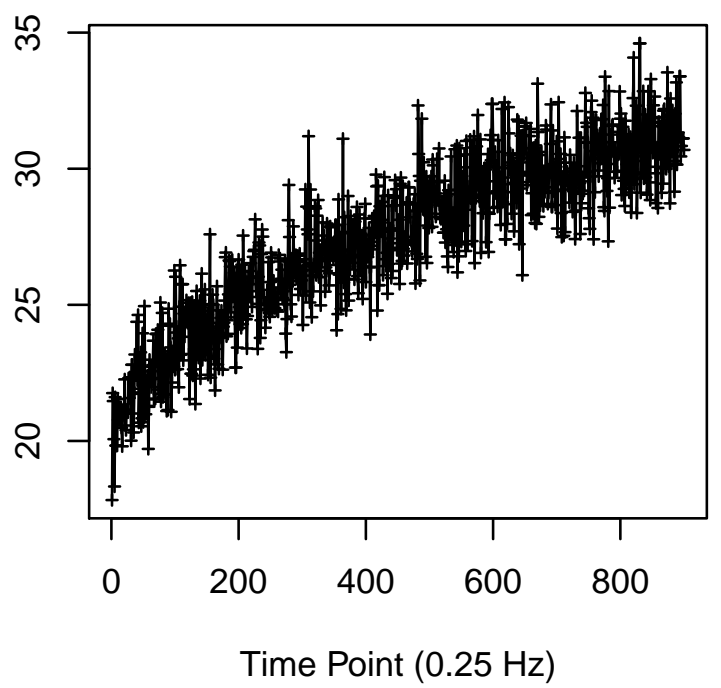

Cell 1590

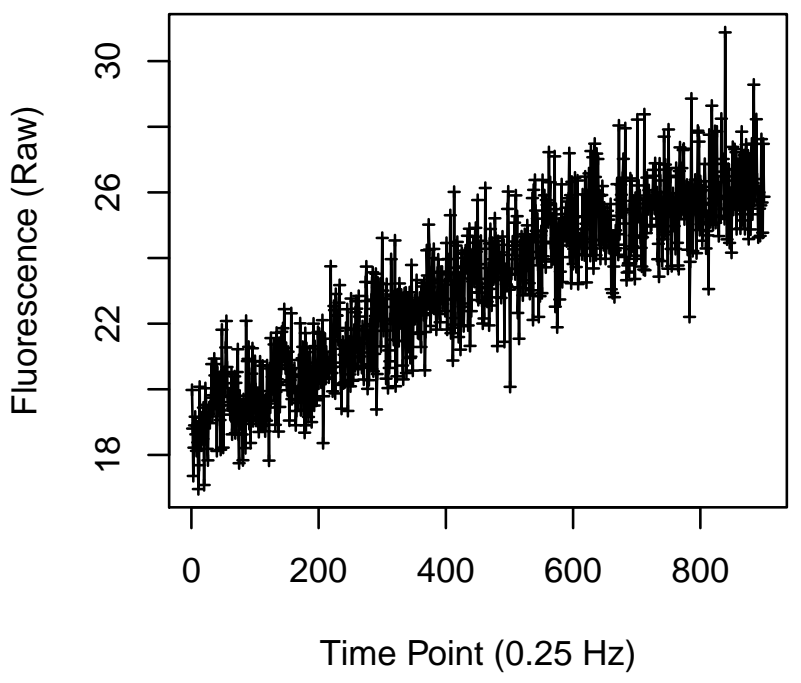

Cell 1592

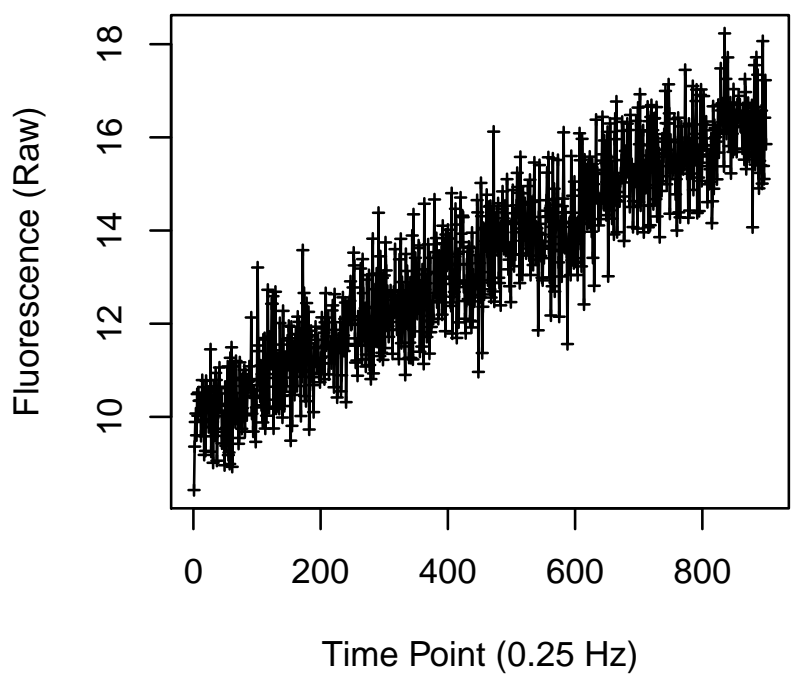


Cell 1593

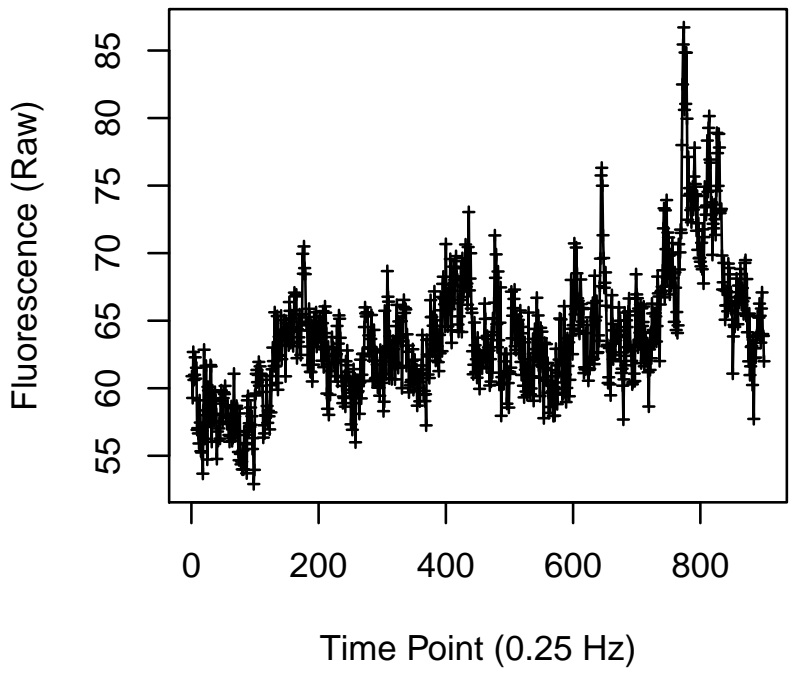

Cell 1595

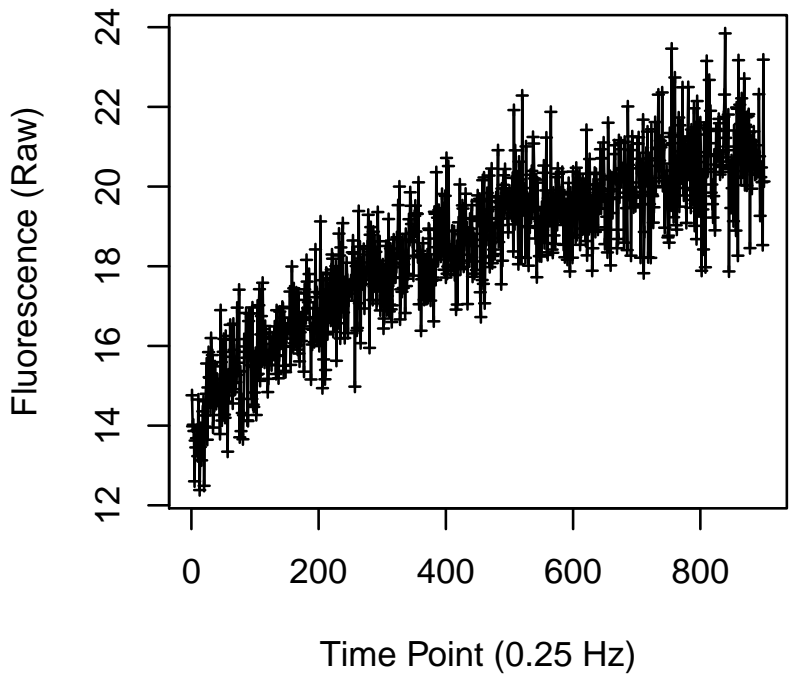

Cell 1594

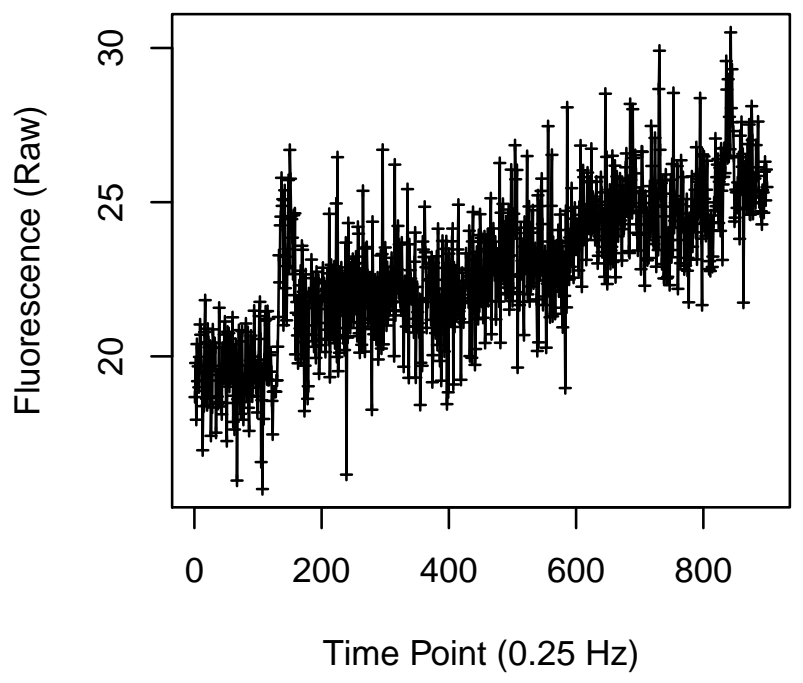

Cell 1596

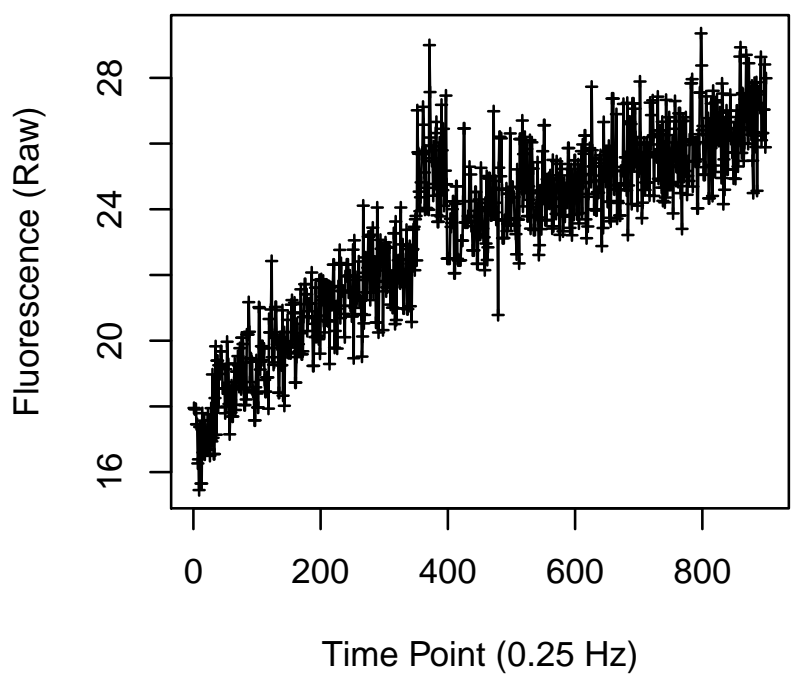


Cell 1597

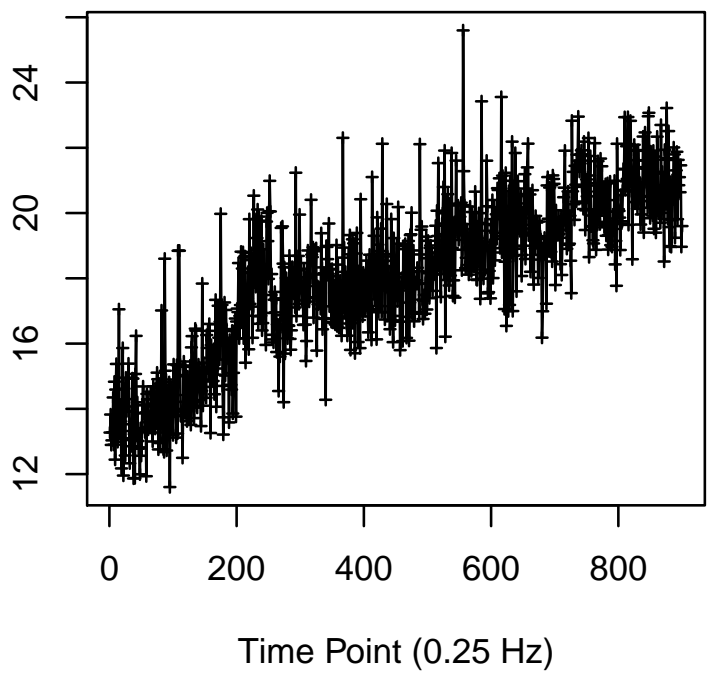

Cell 1599

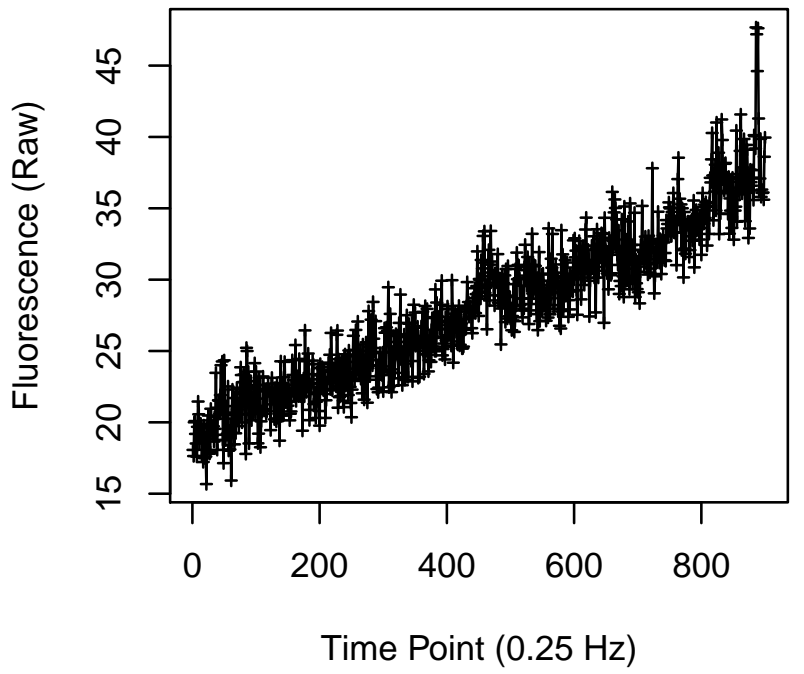

Cell 1598

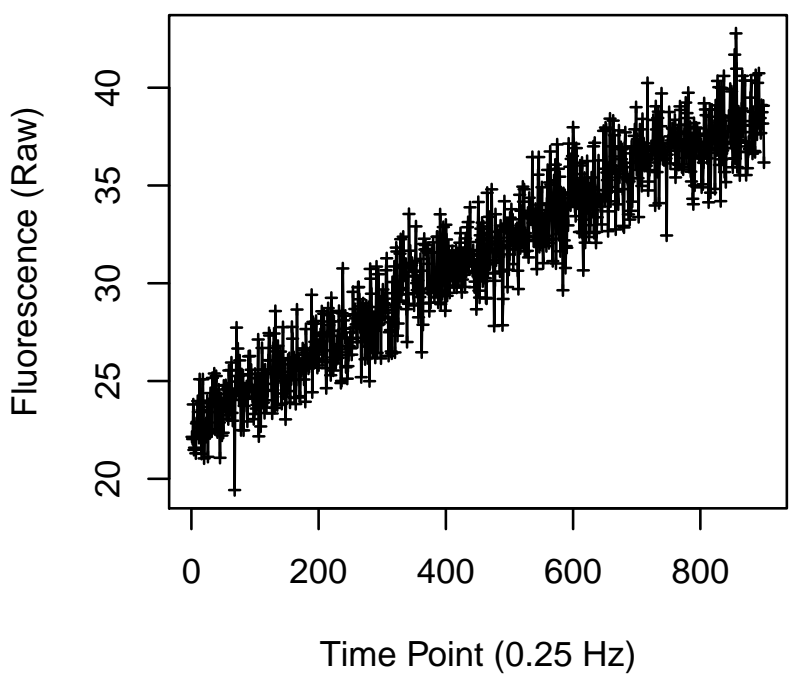

Cell 1600

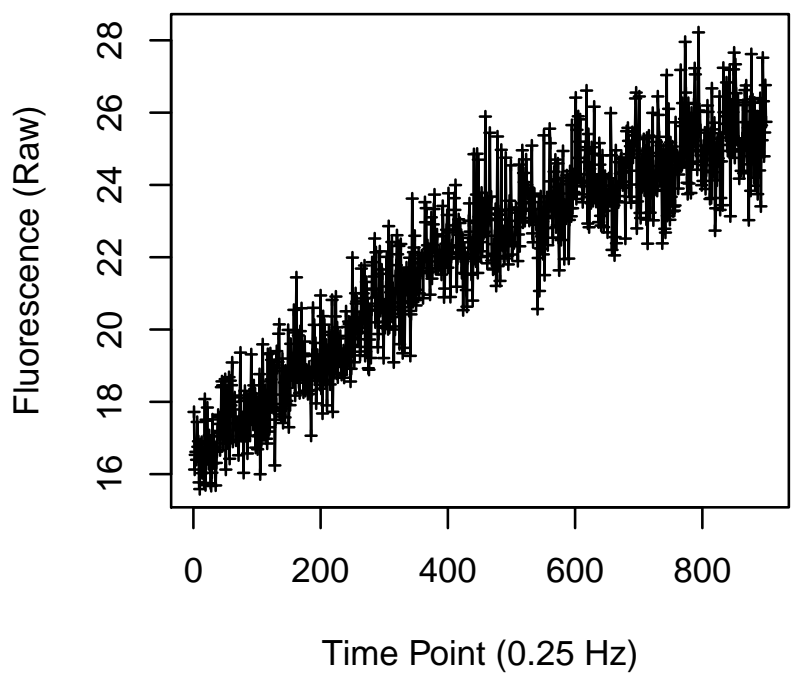


Cell 1601

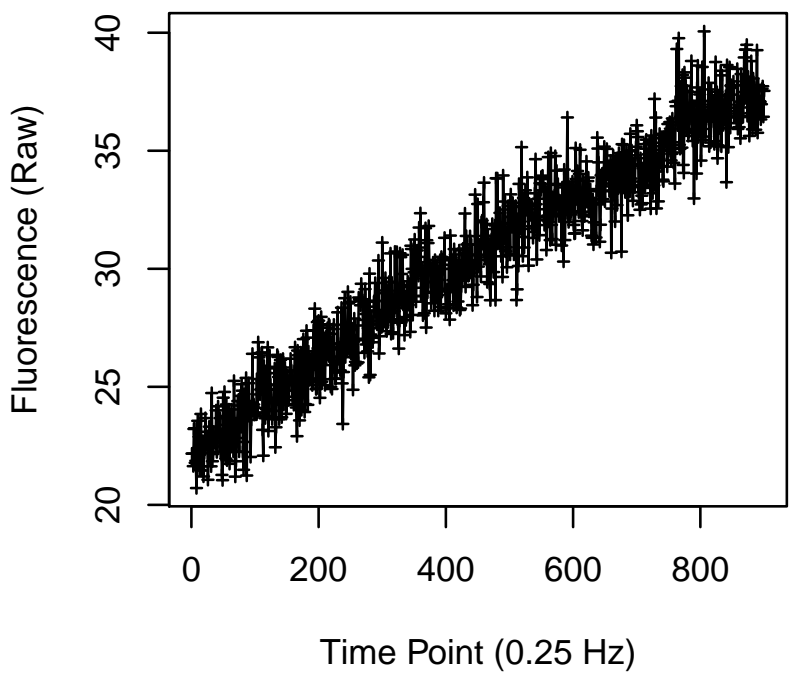

Cell 1603

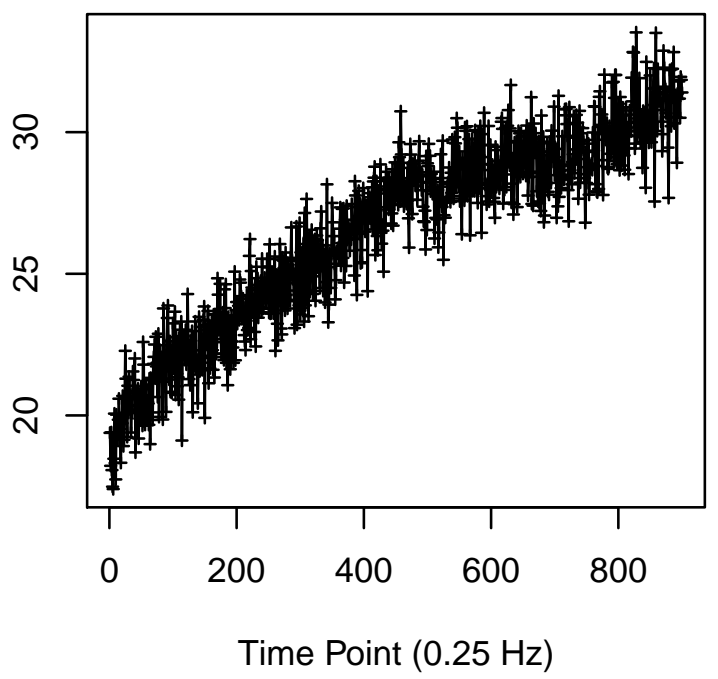

Cell 1602

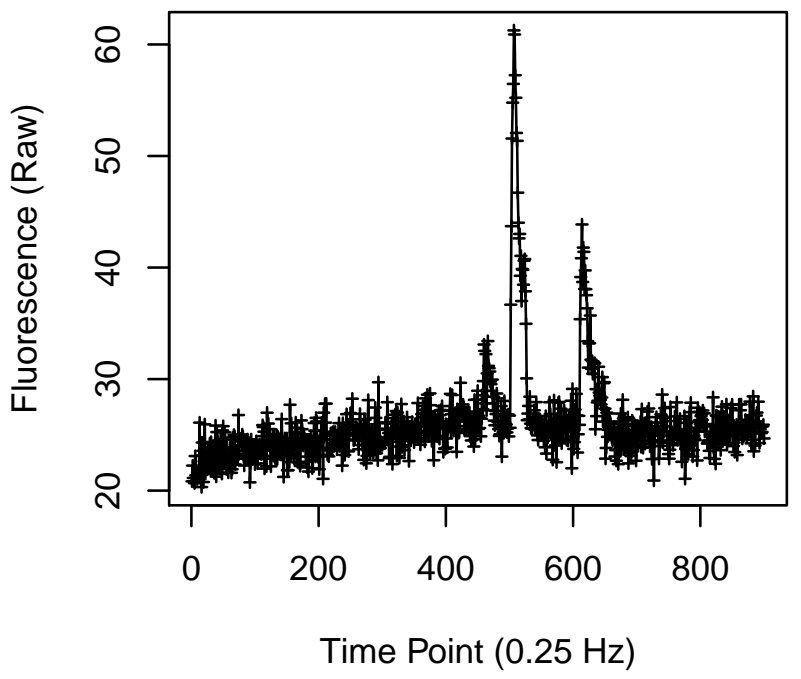

Cell 1604

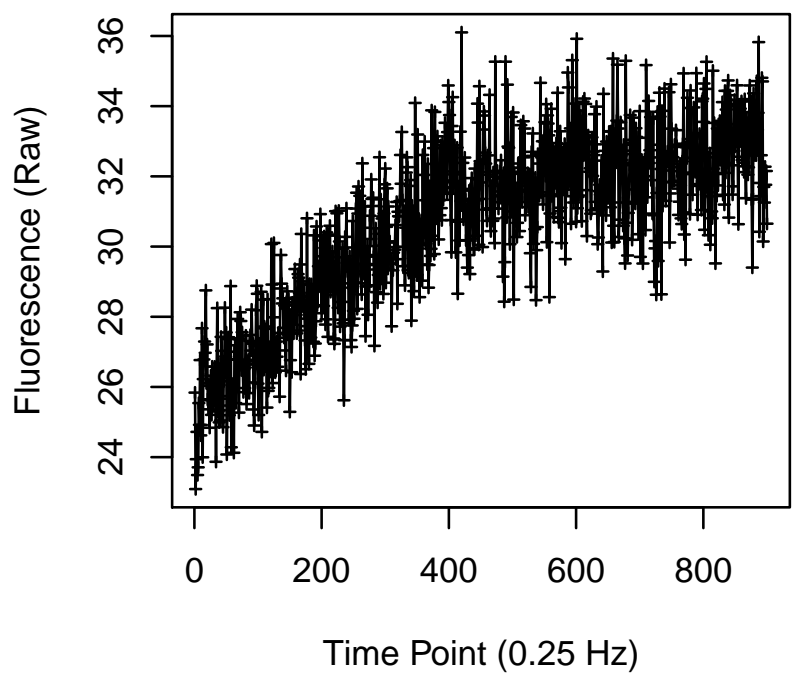


Cell 1605

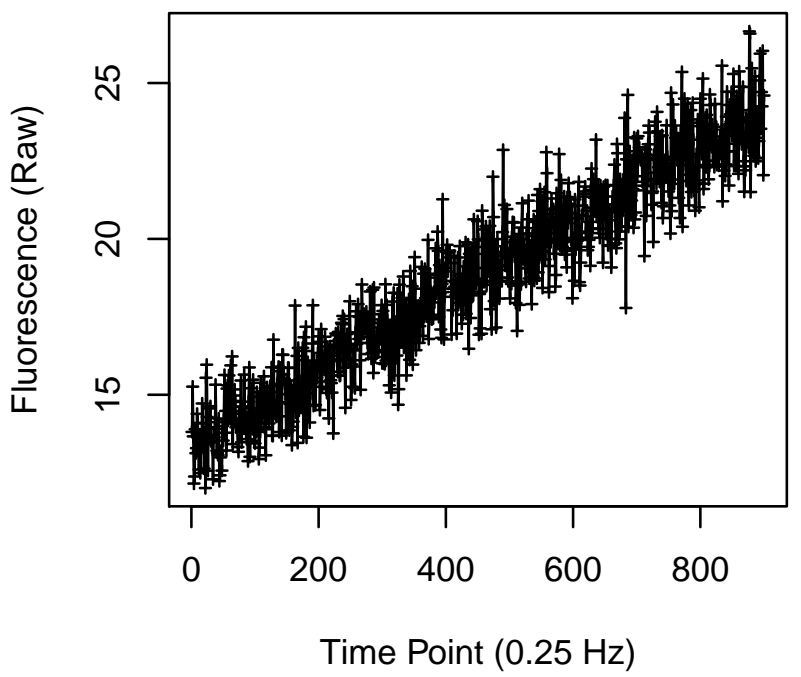

Cell 1607

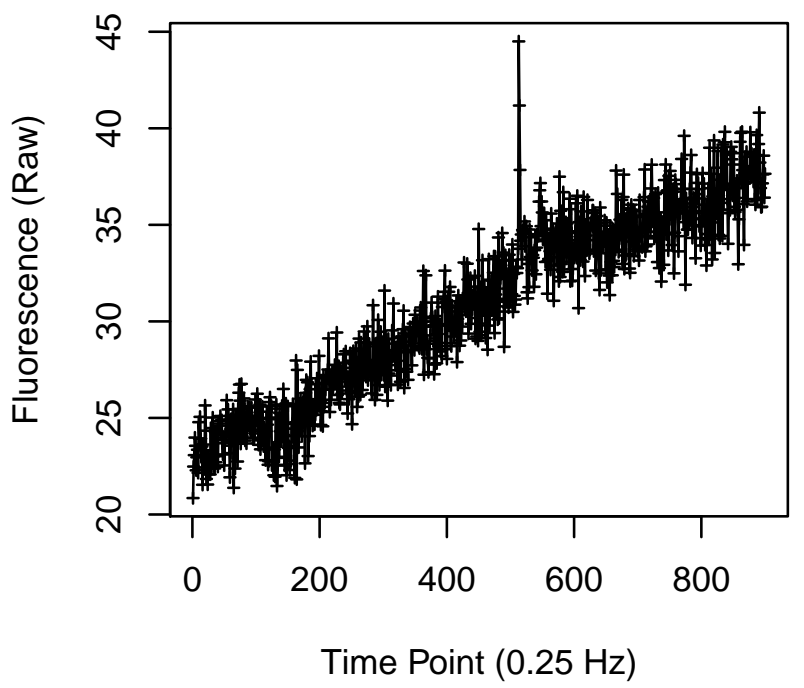

Cell 1606

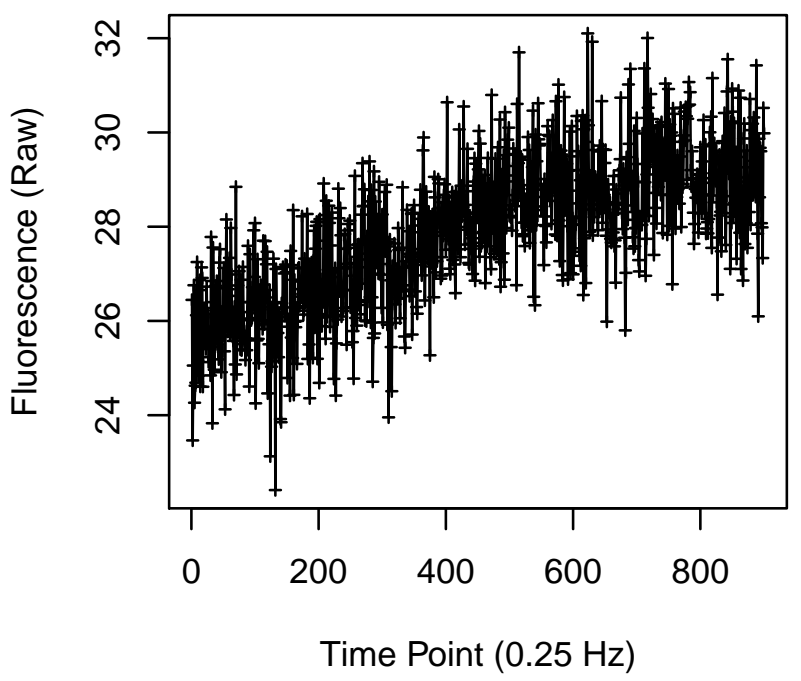

Cell 1608

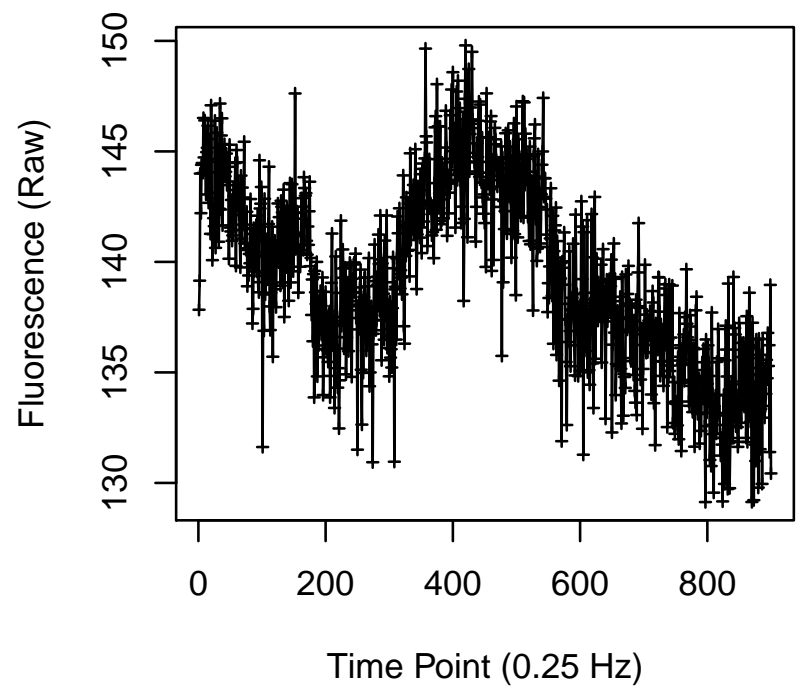


Cell 1609

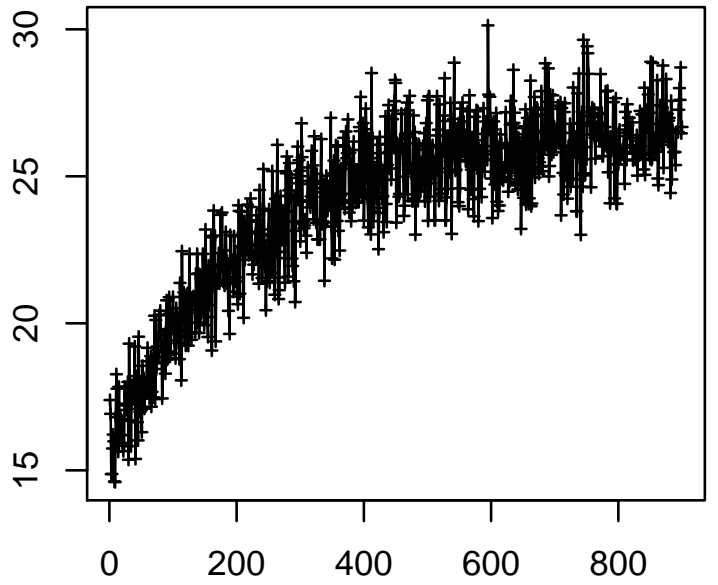

Time Point $(0.25 \mathrm{~Hz})$

Cell 1611

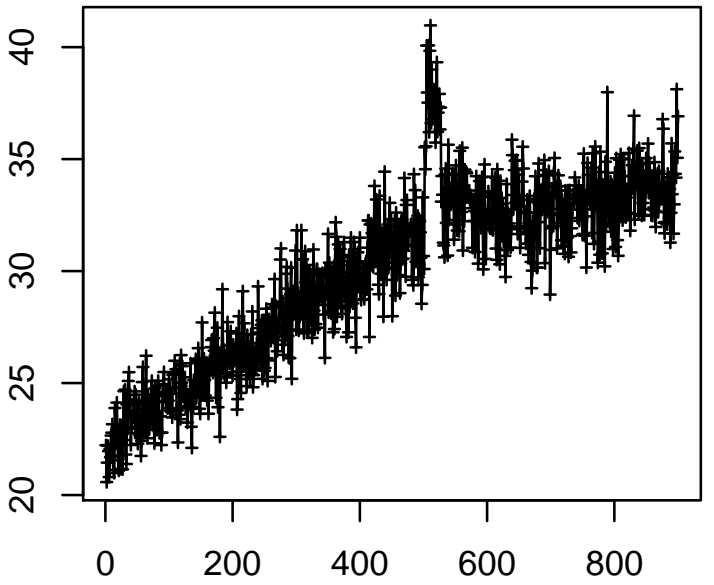

Time Point $(0.25 \mathrm{~Hz})$
Cell 1610

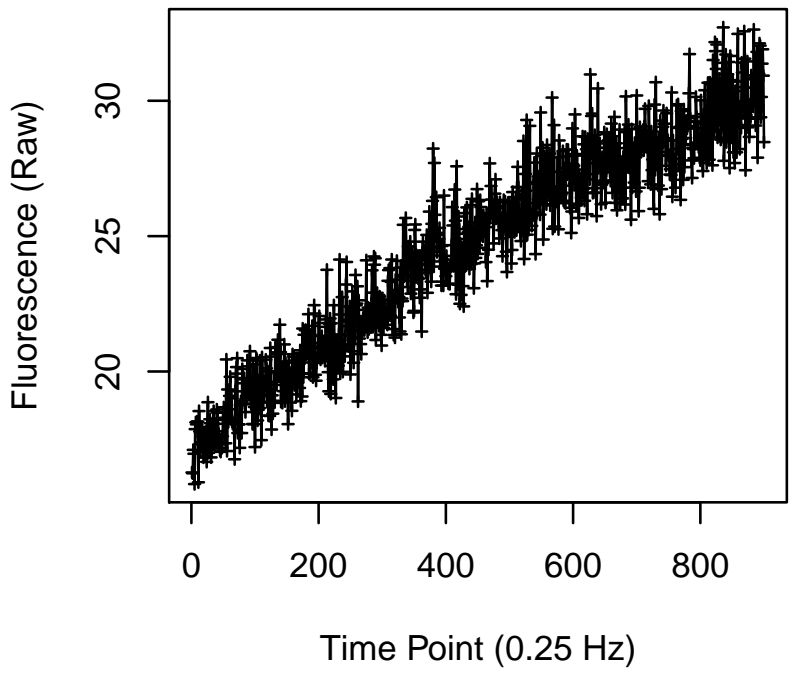

Cell 1612

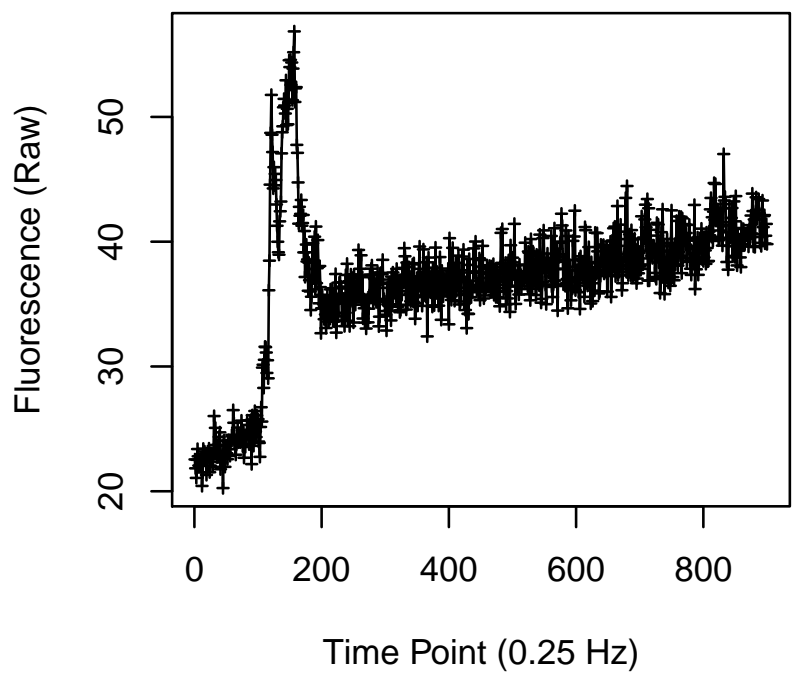


Cell 1613

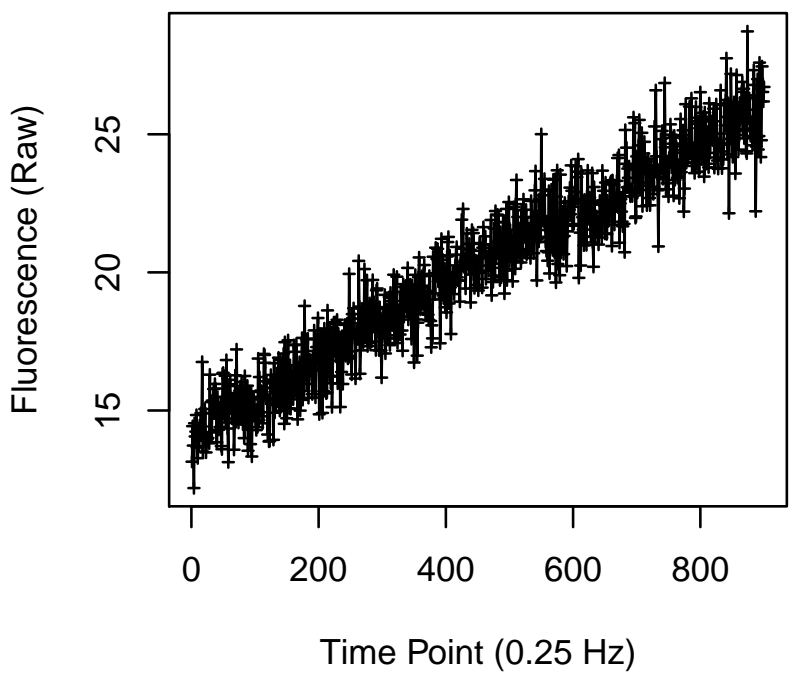

Cell 1615

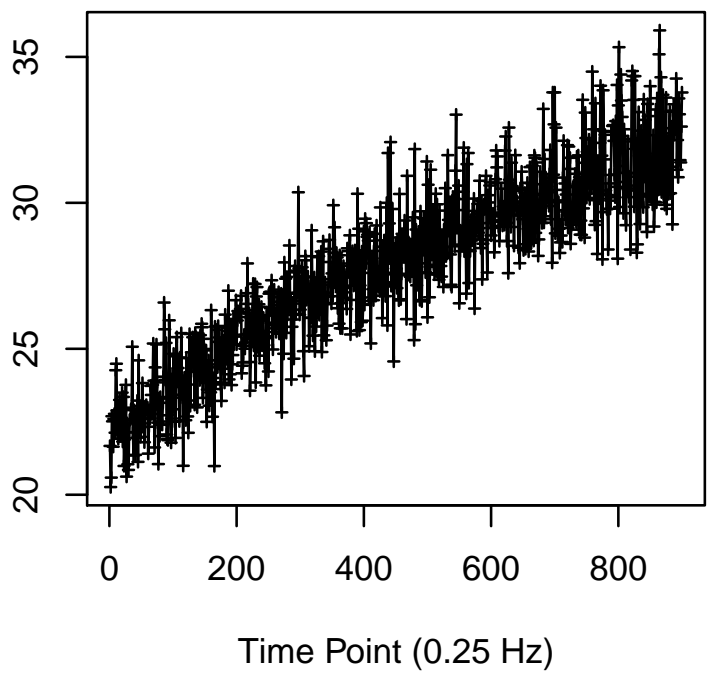

Cell 1614

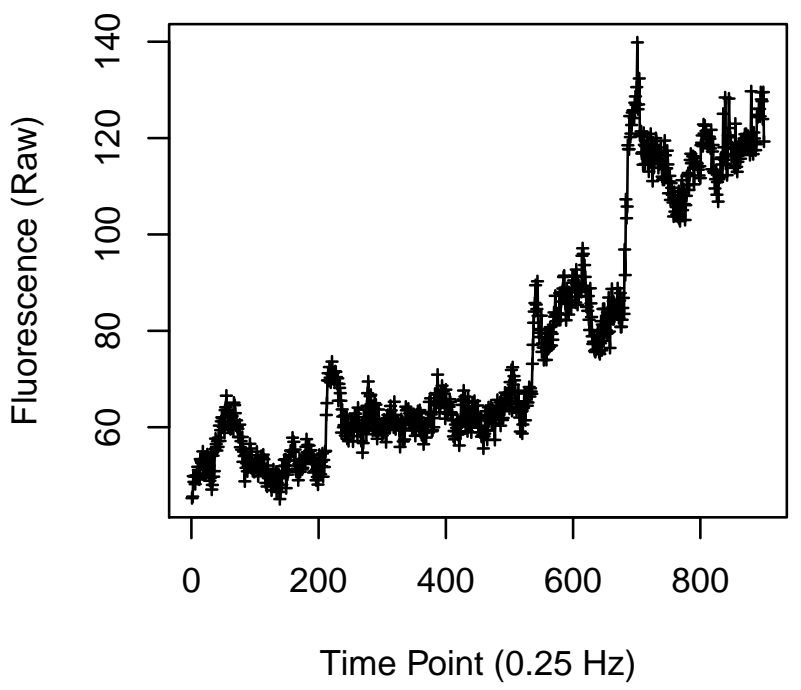

Cell 1616

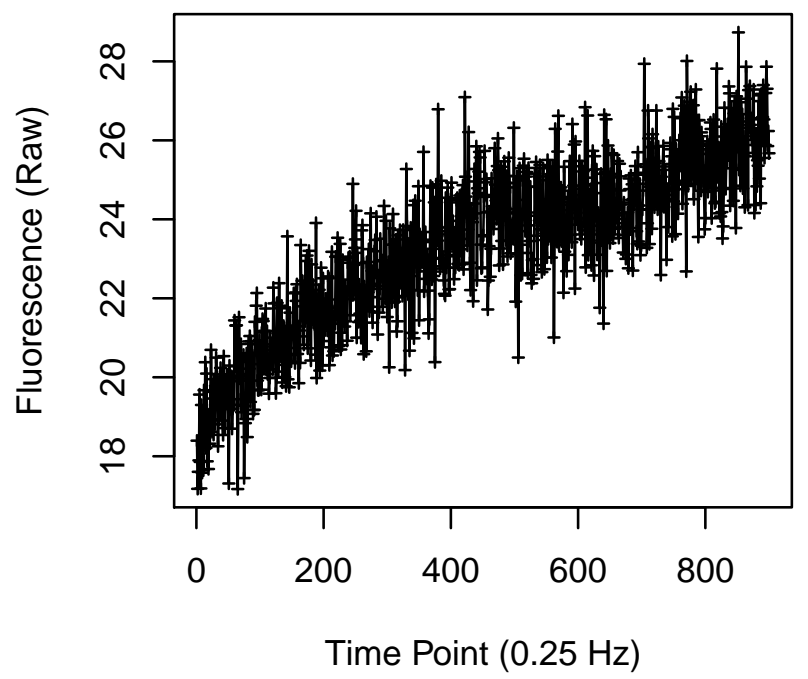


Cell 1621

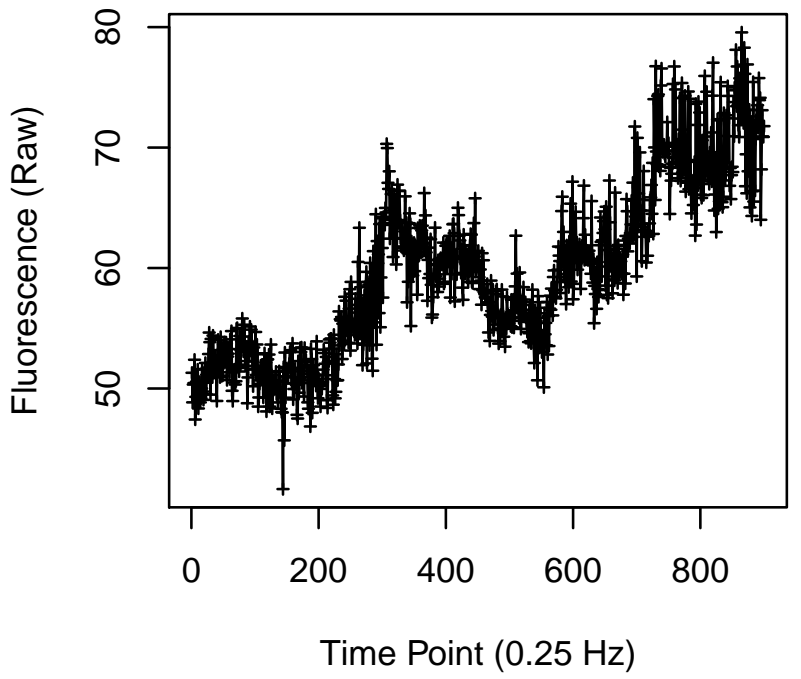

Cell 1623

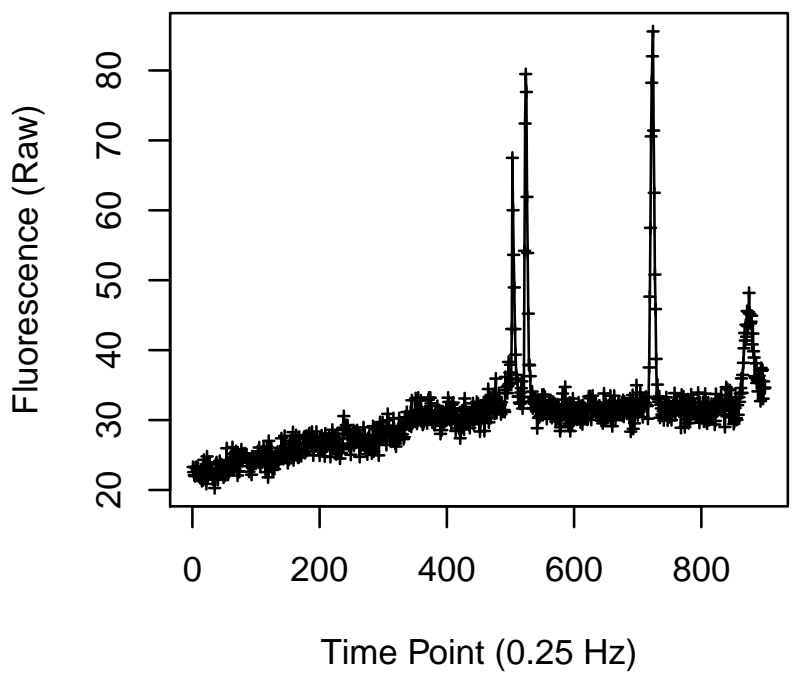

Cell 1622

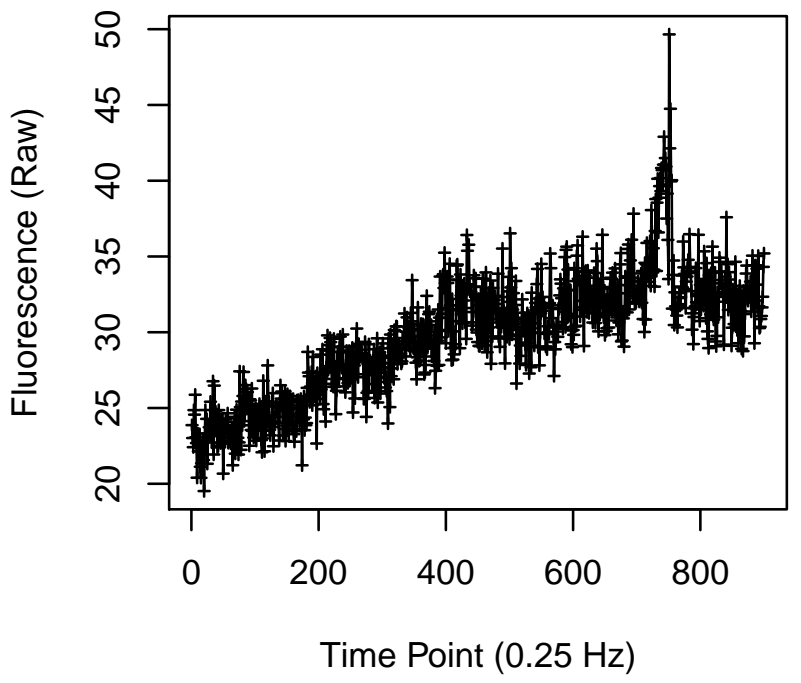

Cell 1624

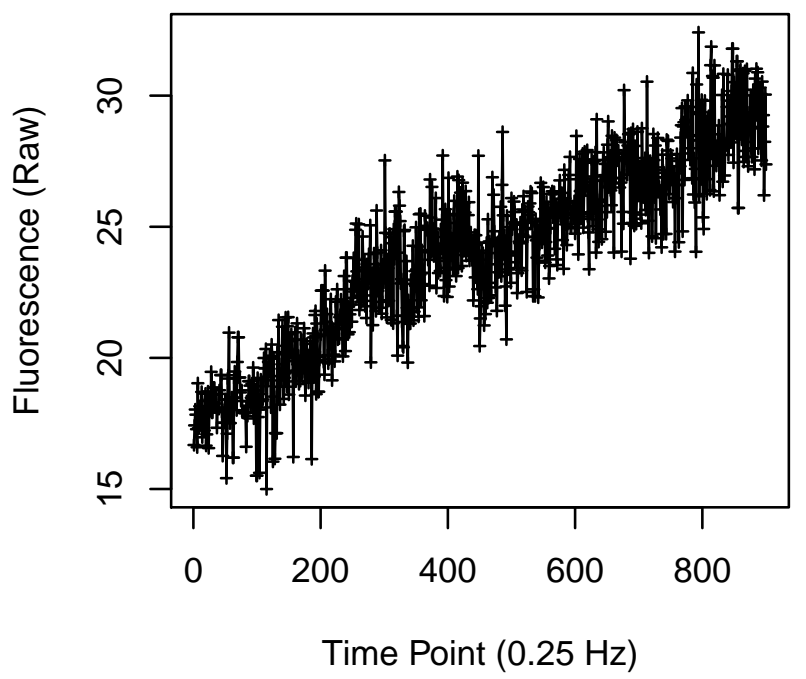


Cell 1625

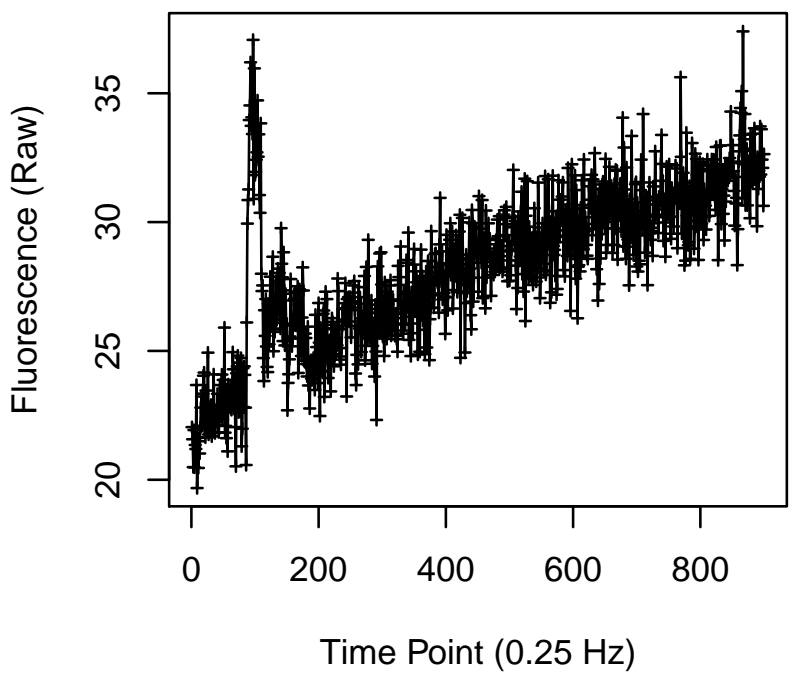

Cell 1627

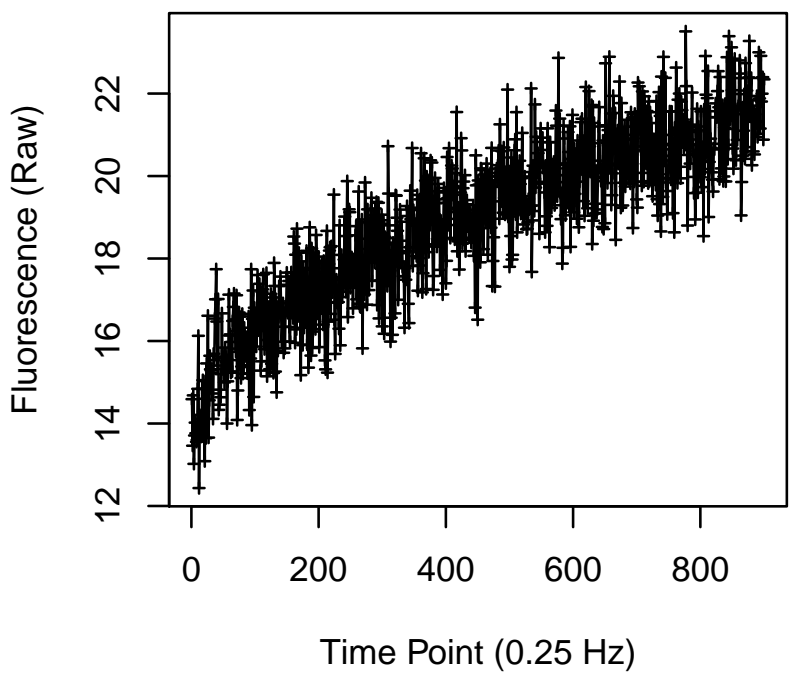

Cell 1626

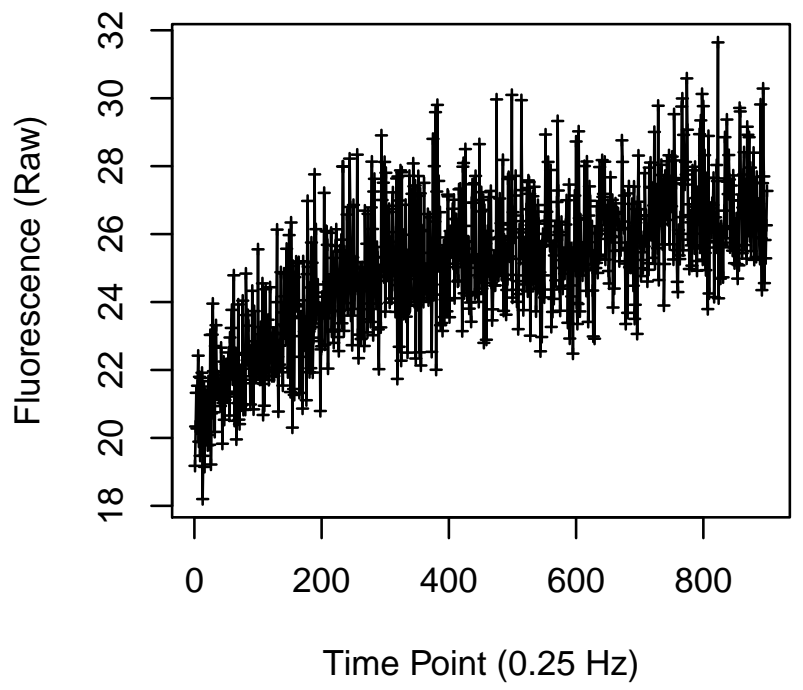

Cell 1628

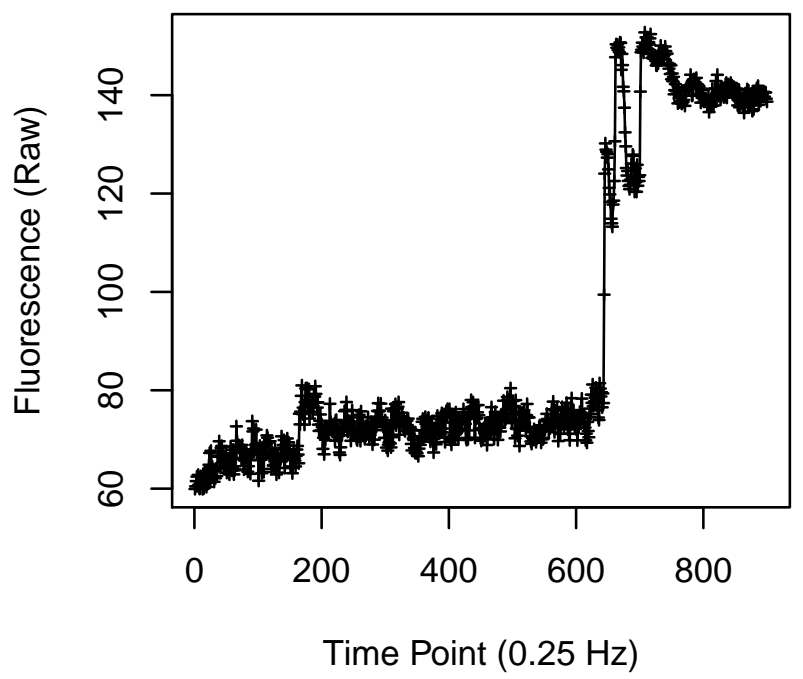


Cell 1629

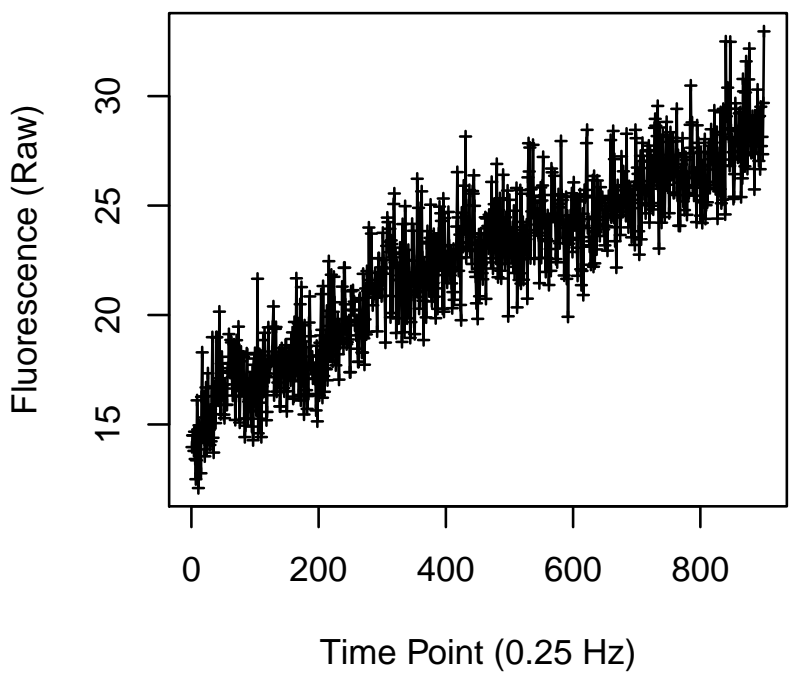

Cell 1631

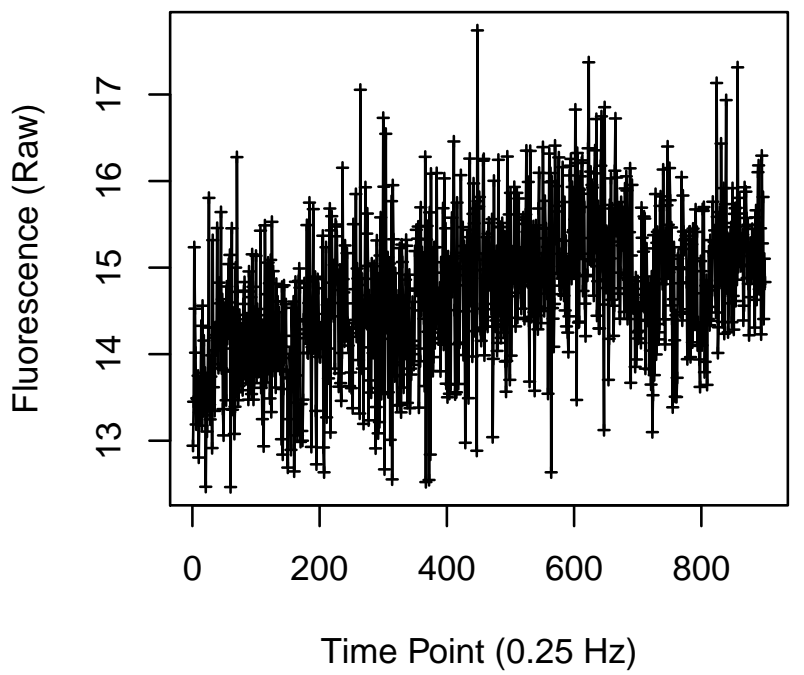

Cell 1630

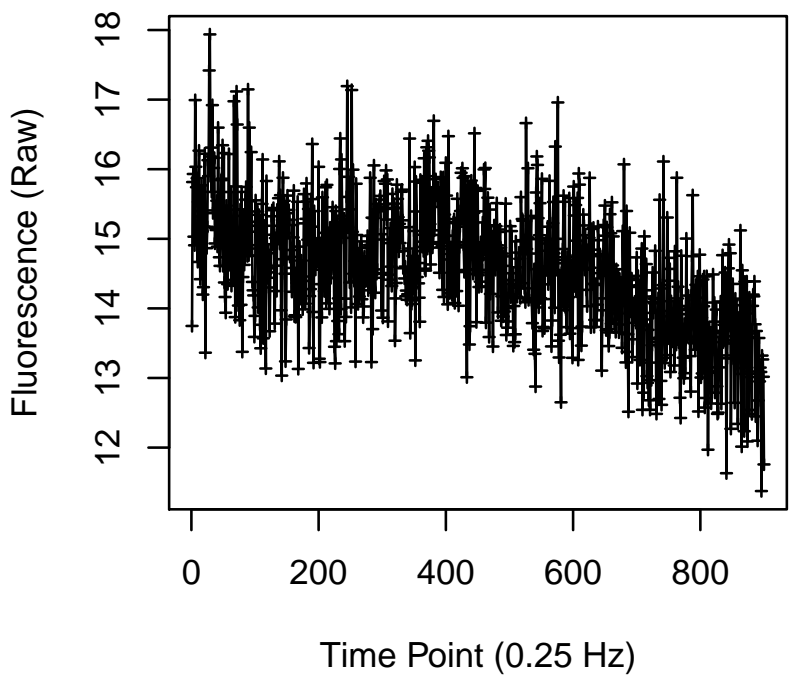

Cell 1632

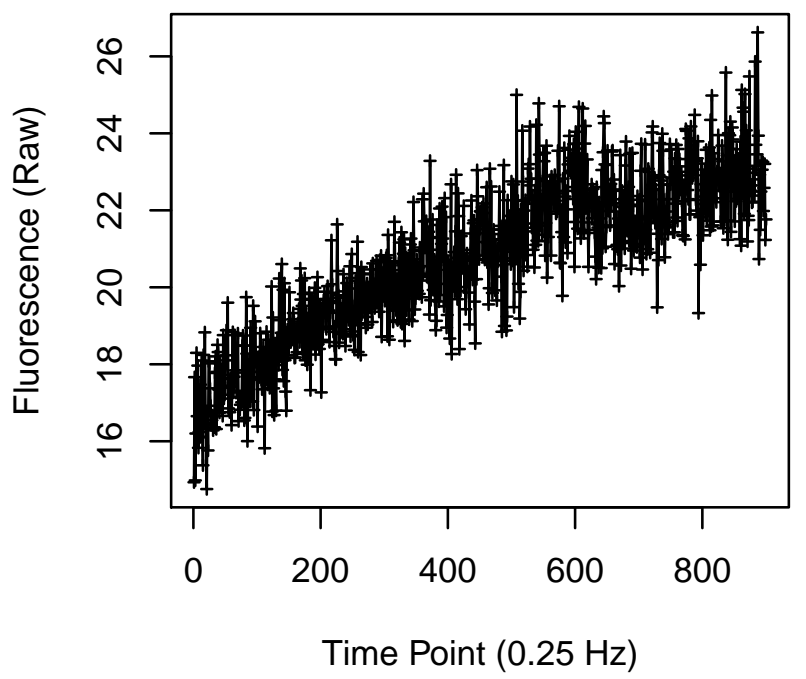


Cell 1637

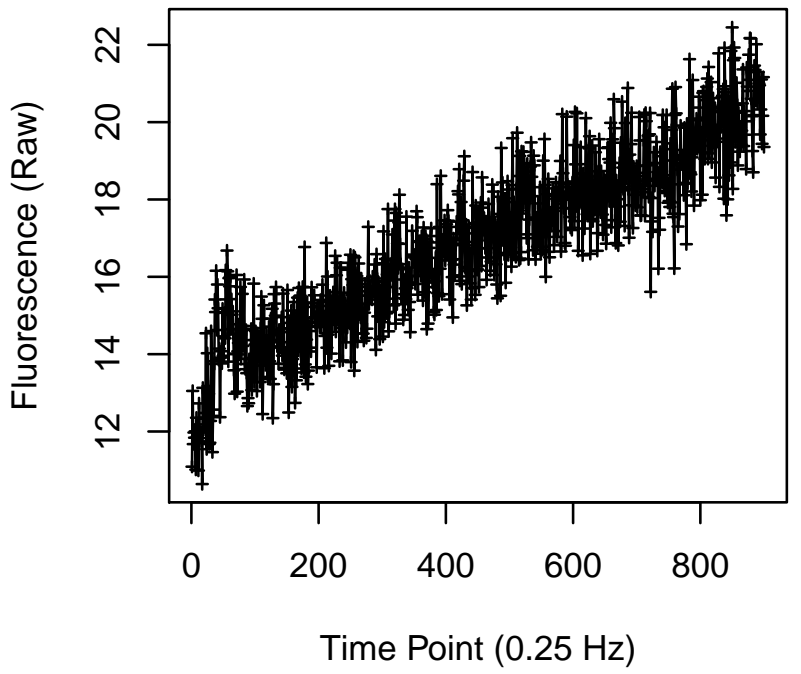

Cell 1639

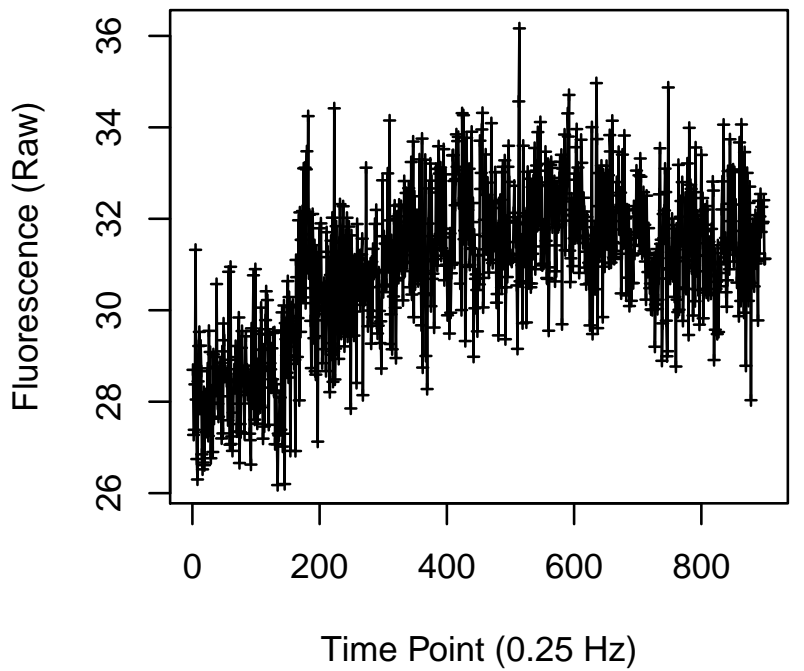

Cell 1638

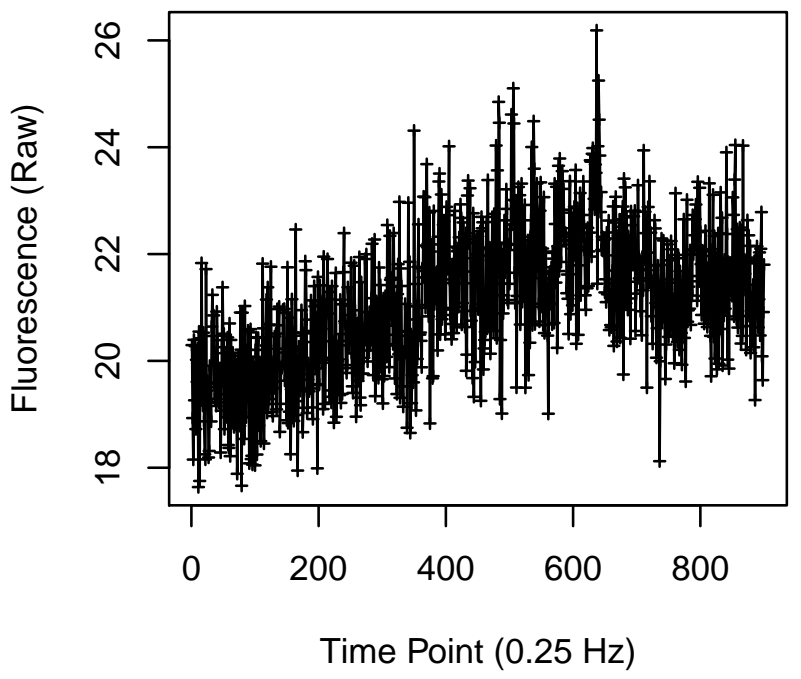

Cell 1640

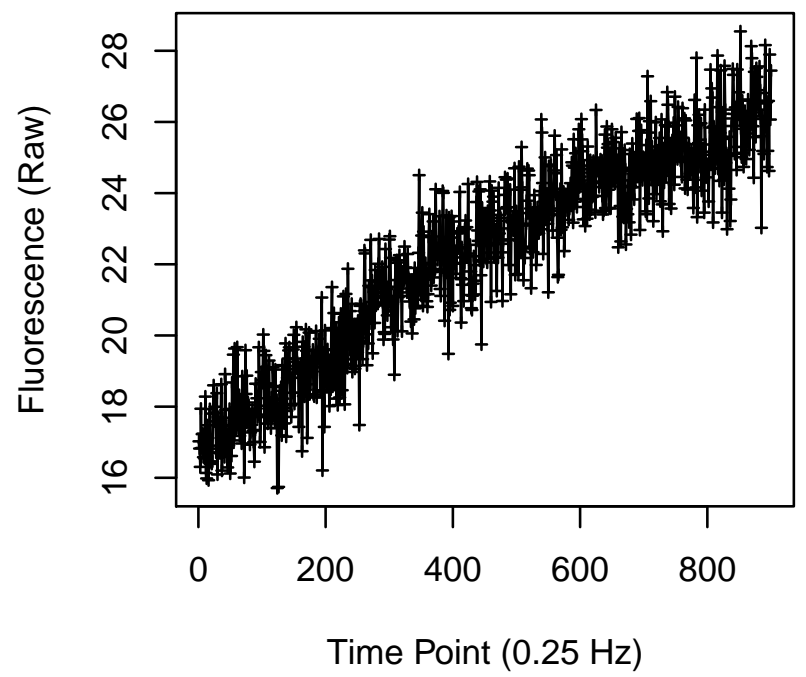


Cell 1641

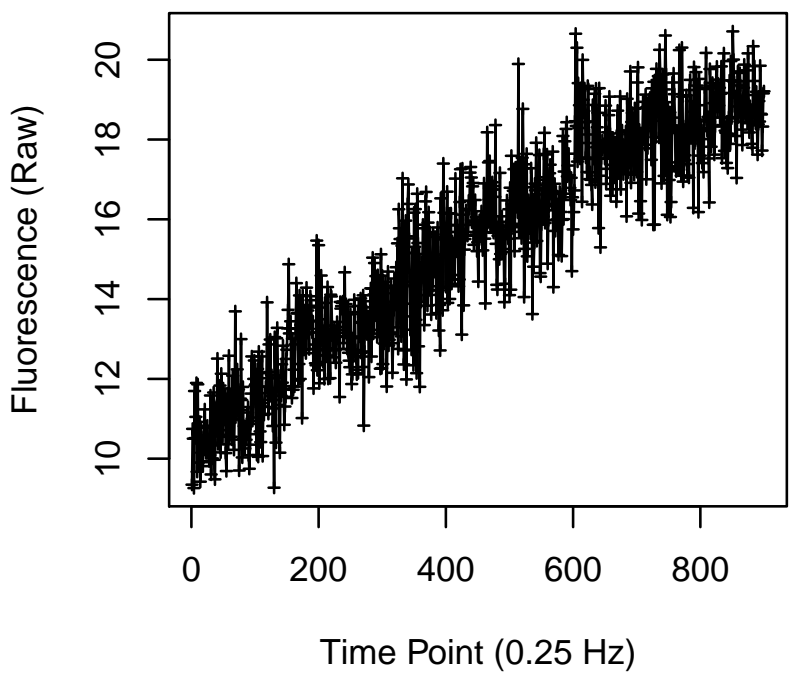

Cell 1643

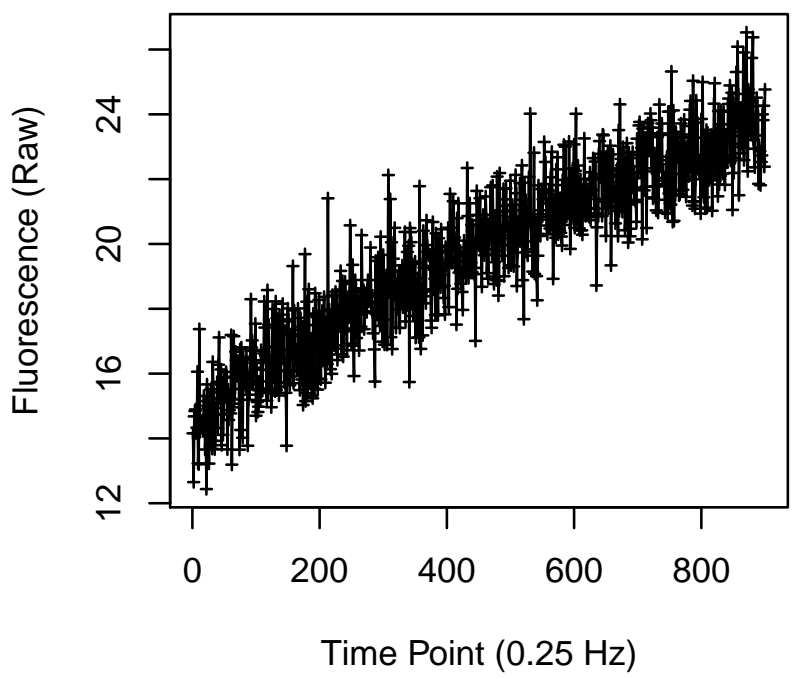

Cell 1642

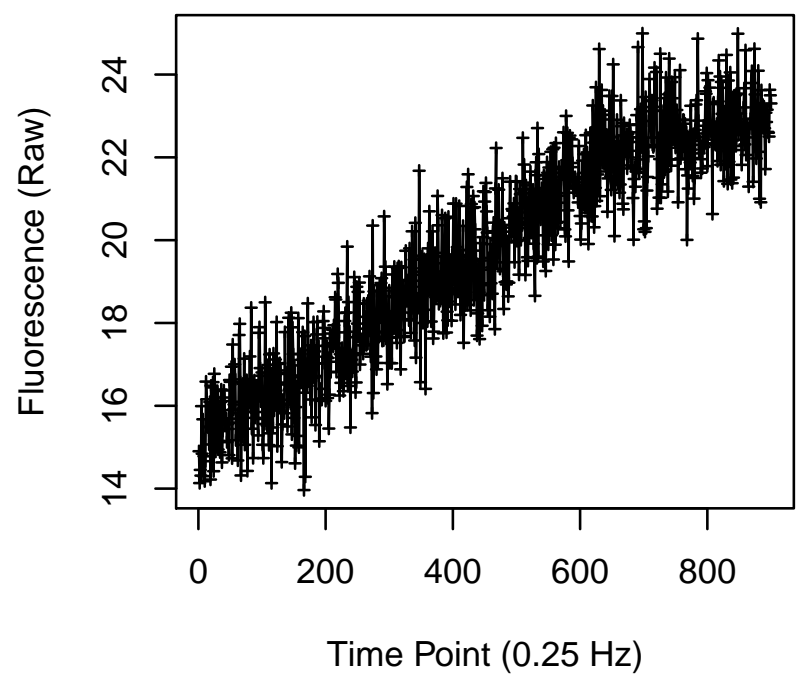

Cell 1644

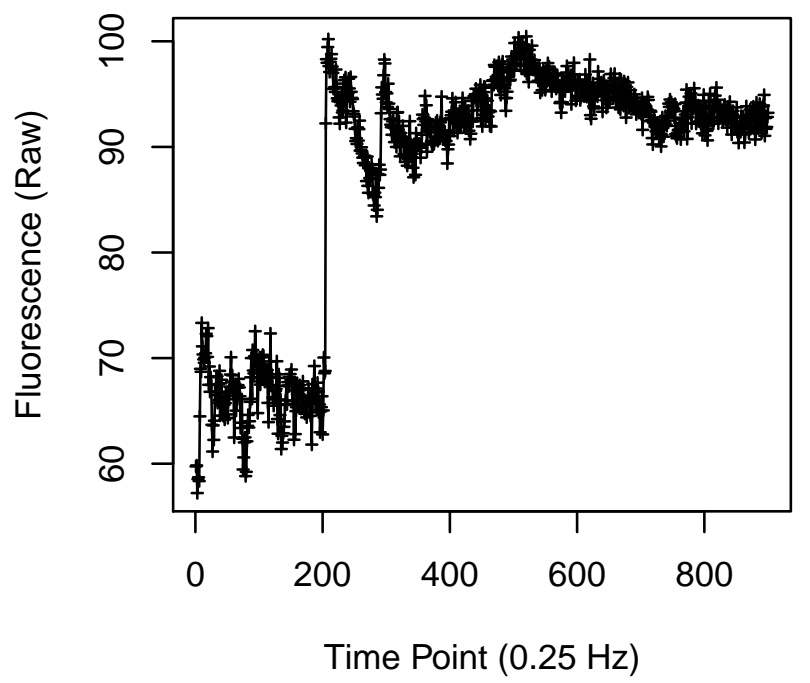


Cell 1645

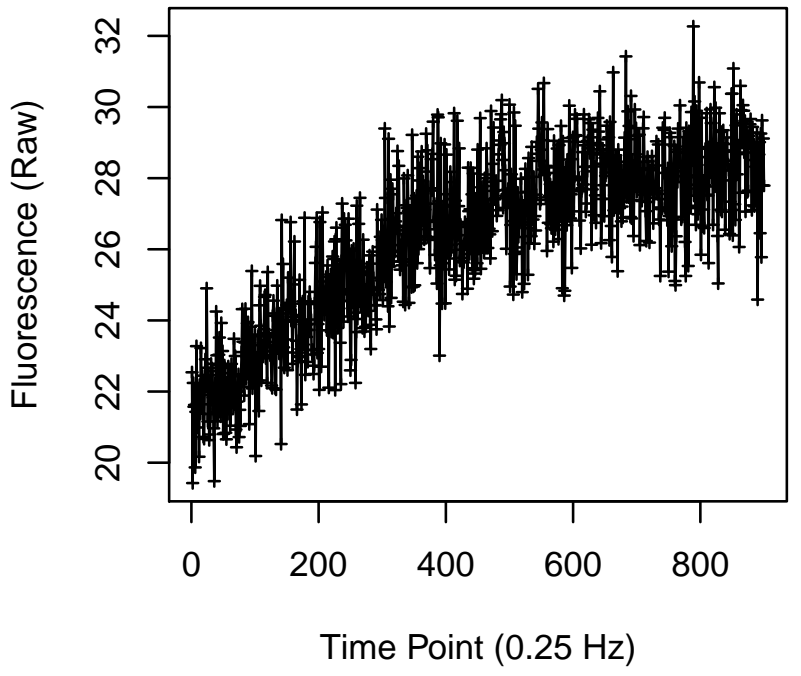

Cell 1647

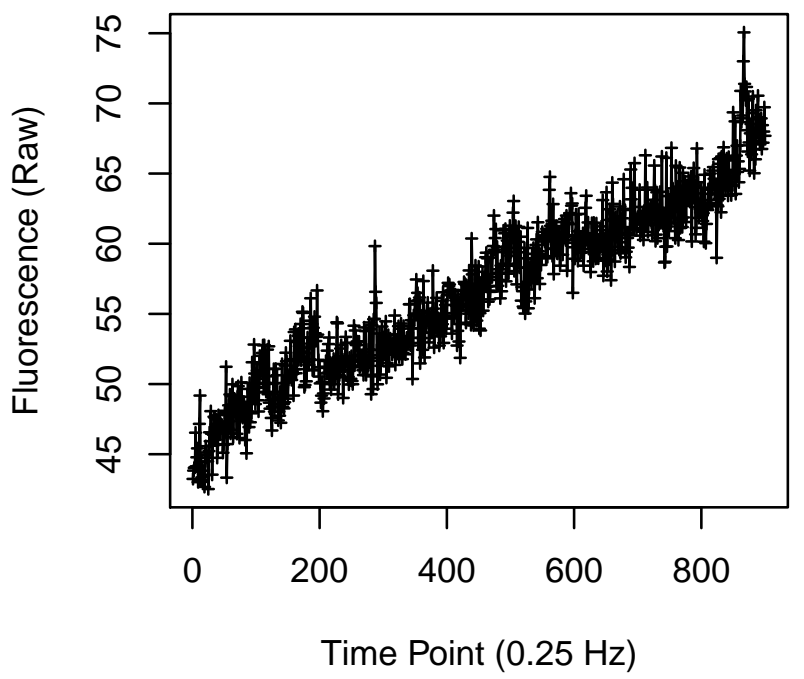

Cell 1646

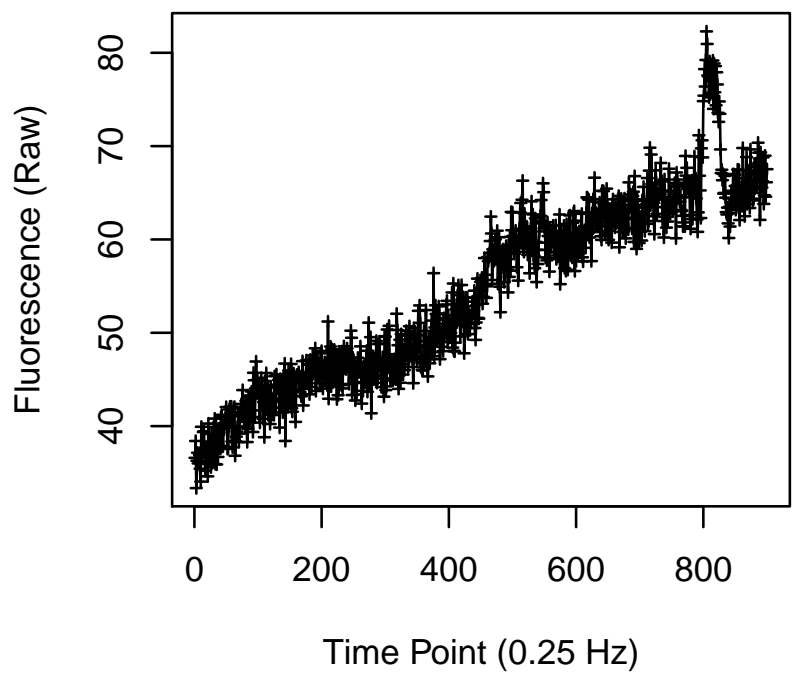

Cell 1648

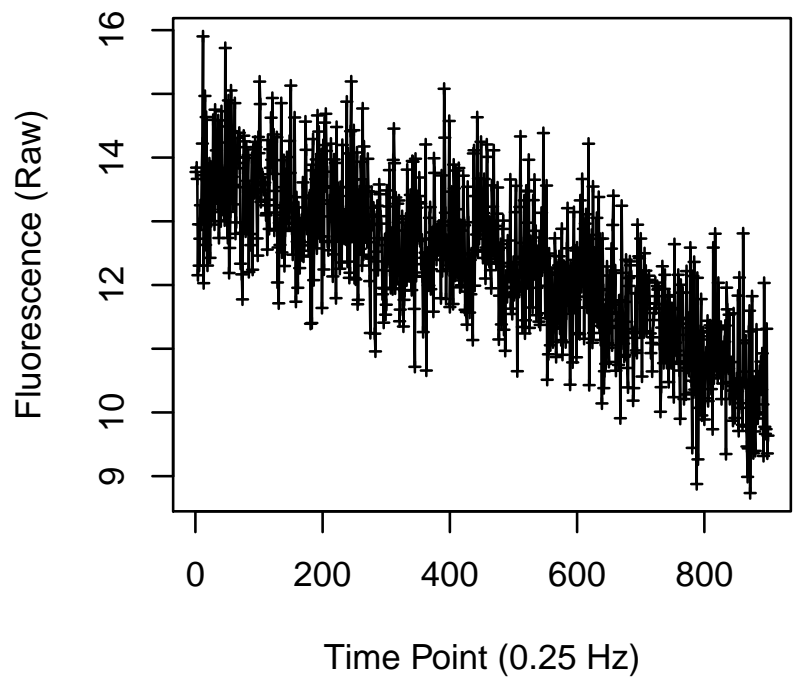


Cell 1649

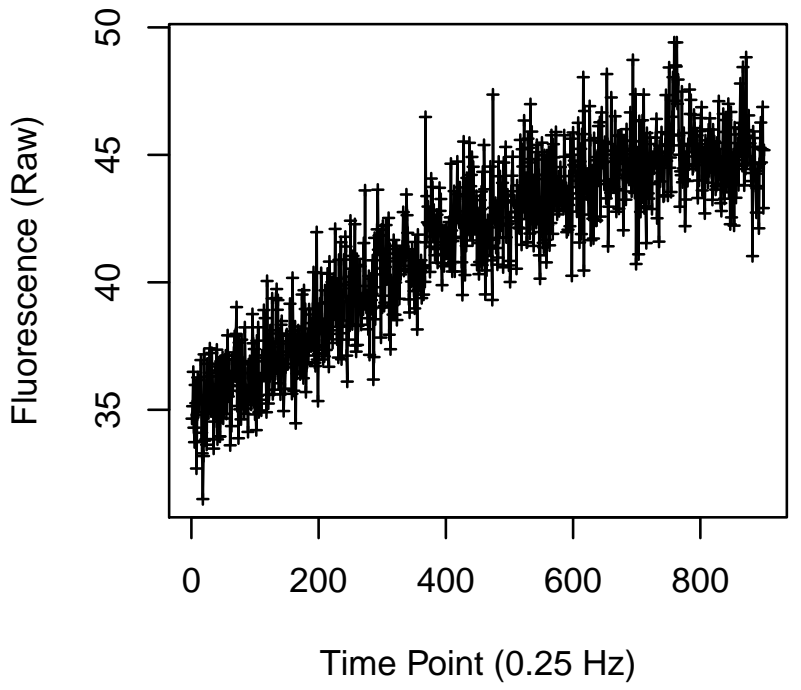

Cell 1651

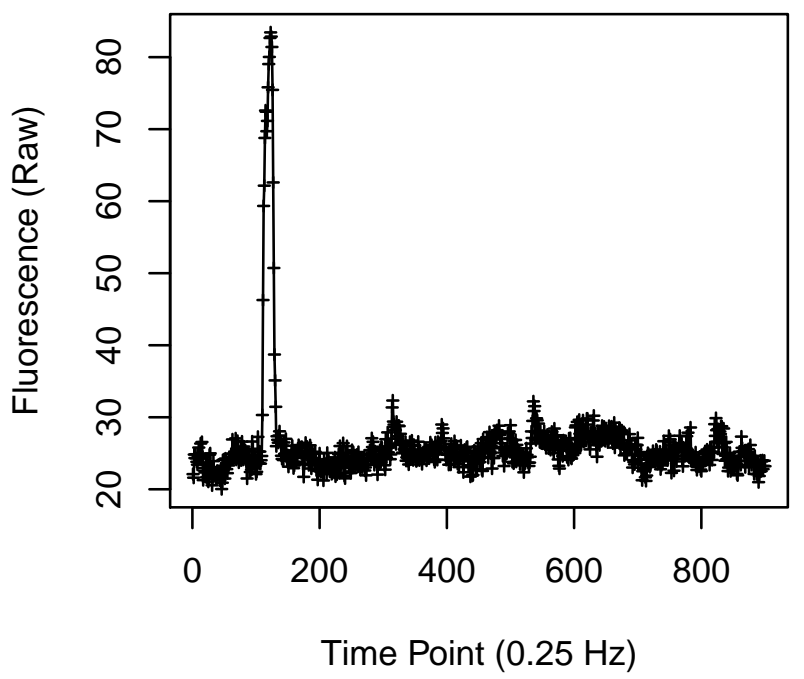

Cell 1650

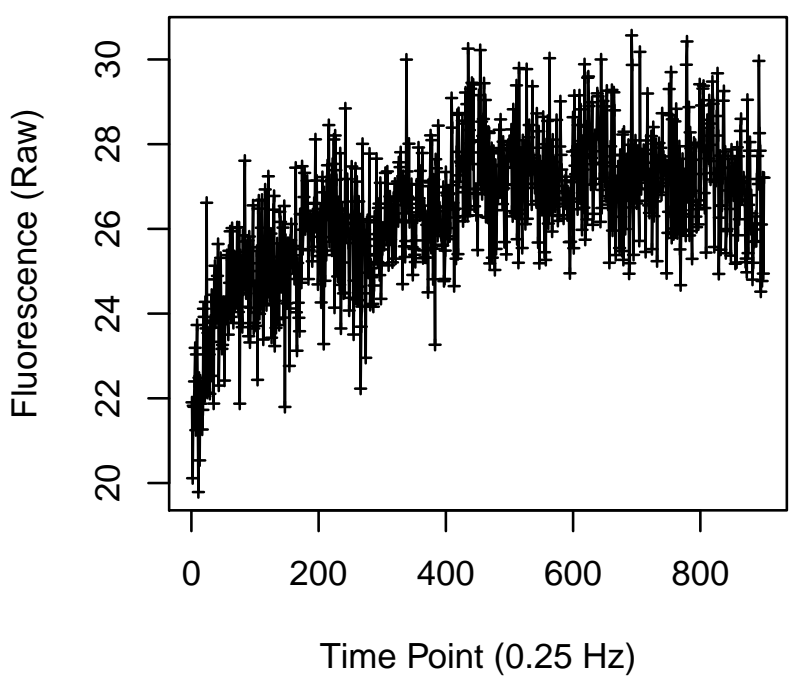

Cell 1652

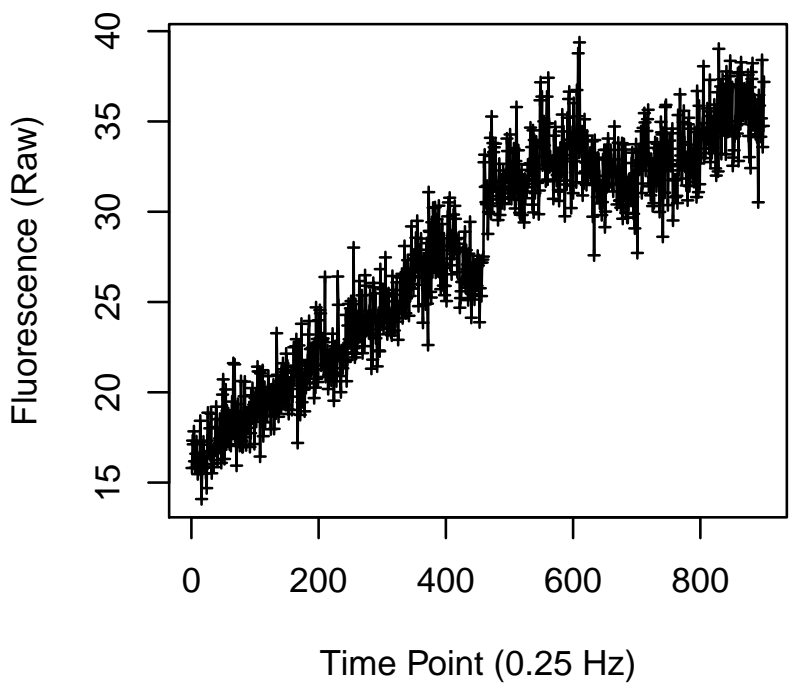


Cell 1653

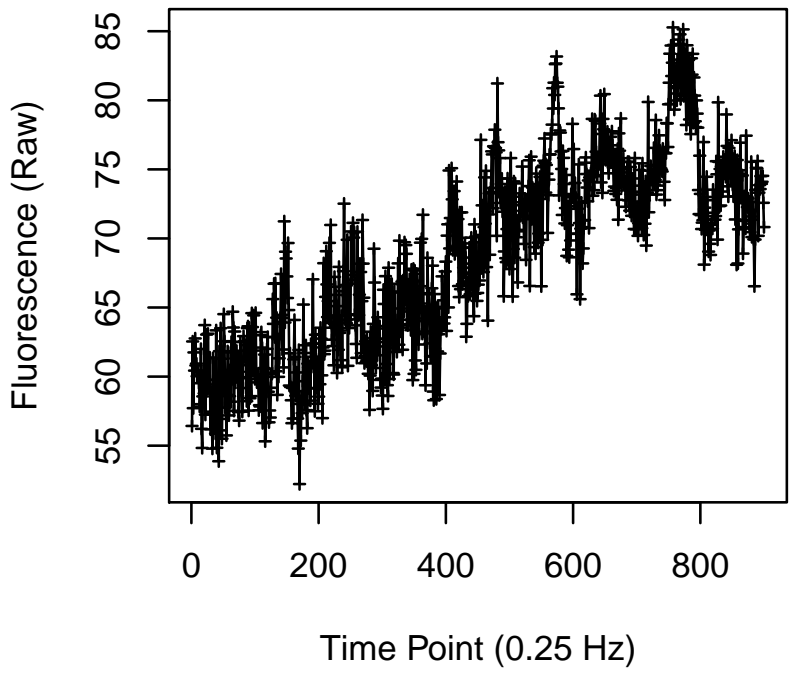

Cell 1655

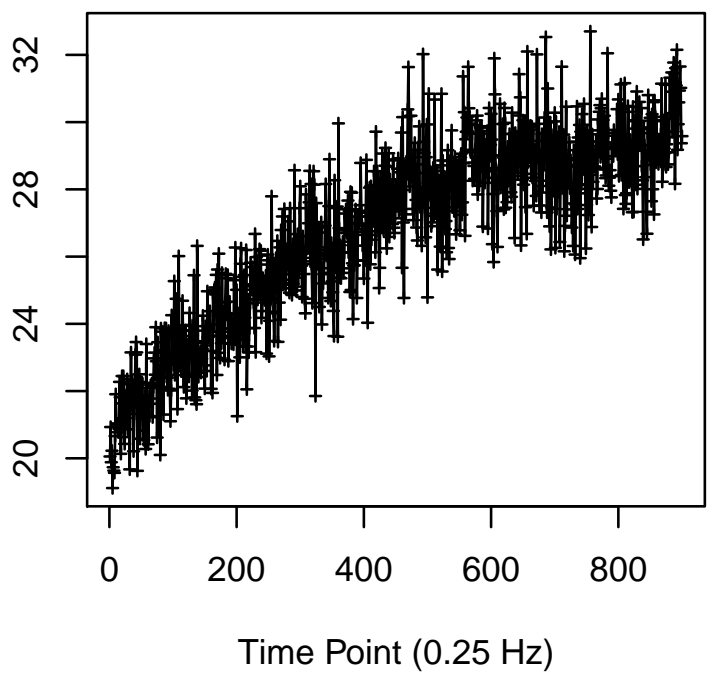

Cell 1654

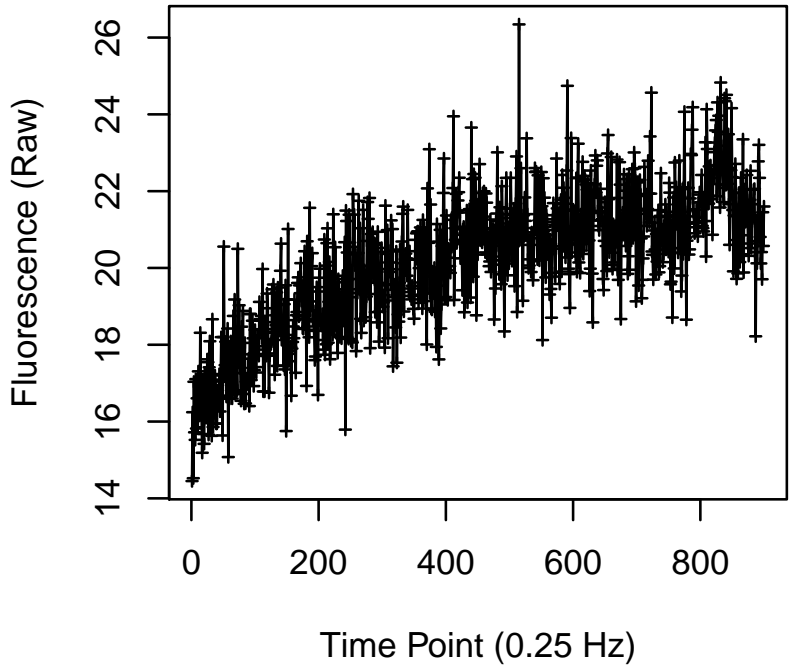

Cell 1656

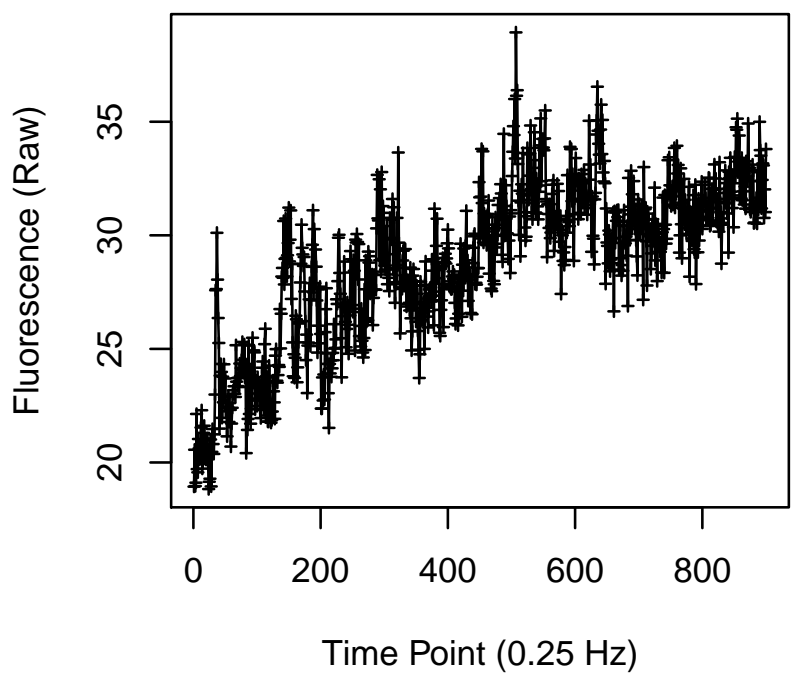


Cell 1657

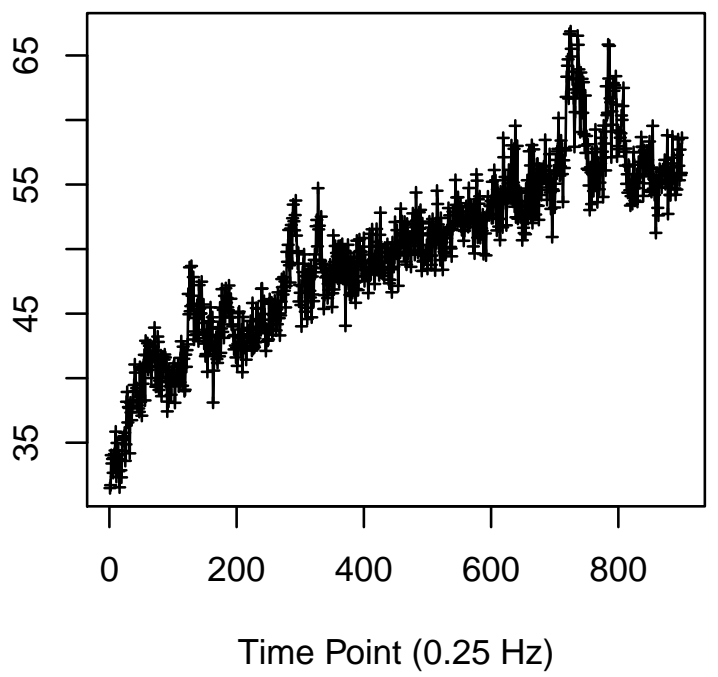

Cell 1659

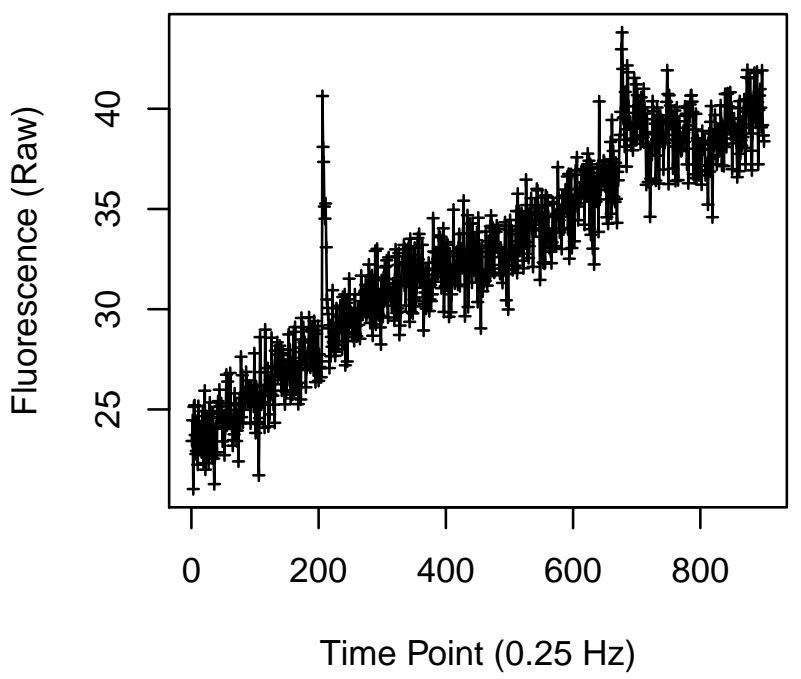

Cell 1658

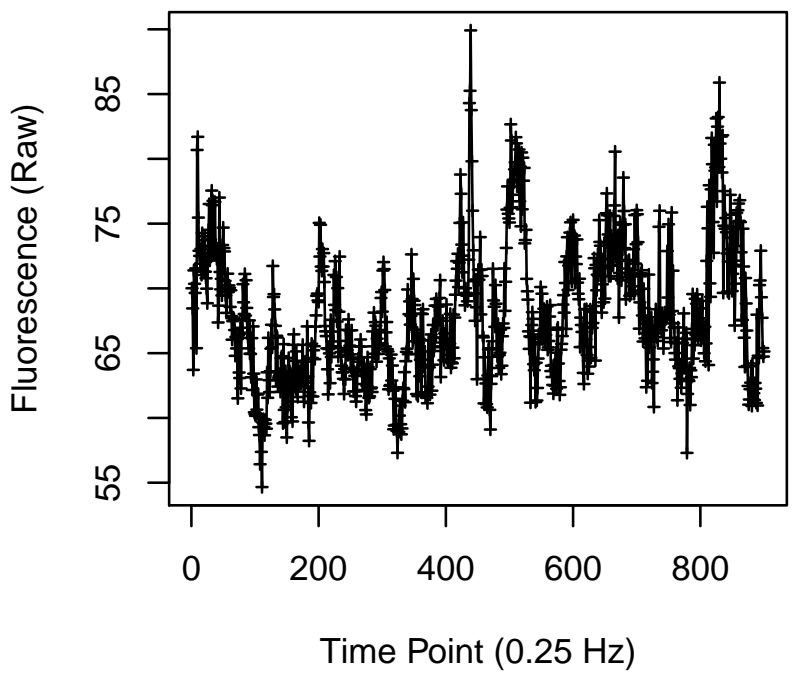

Cell 1660

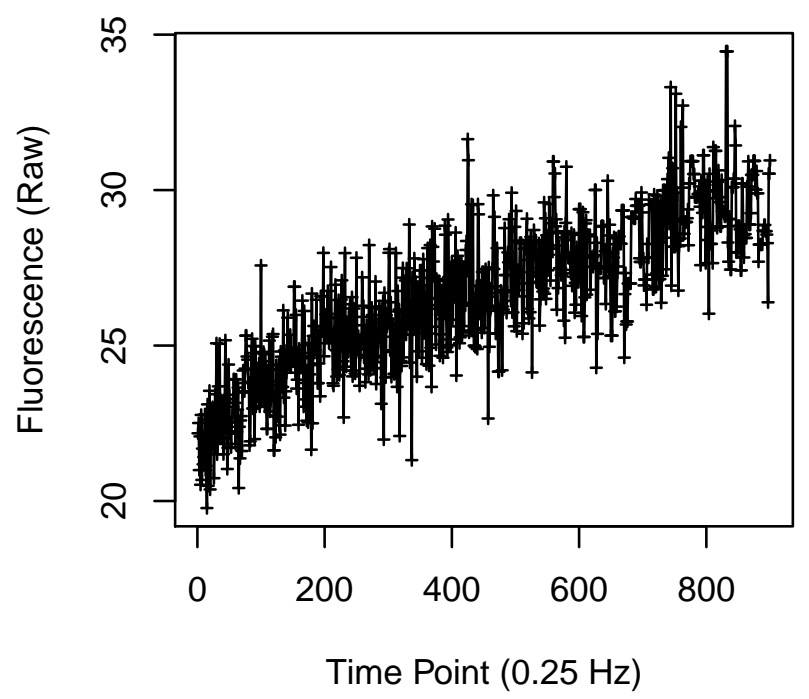


Cell 1661

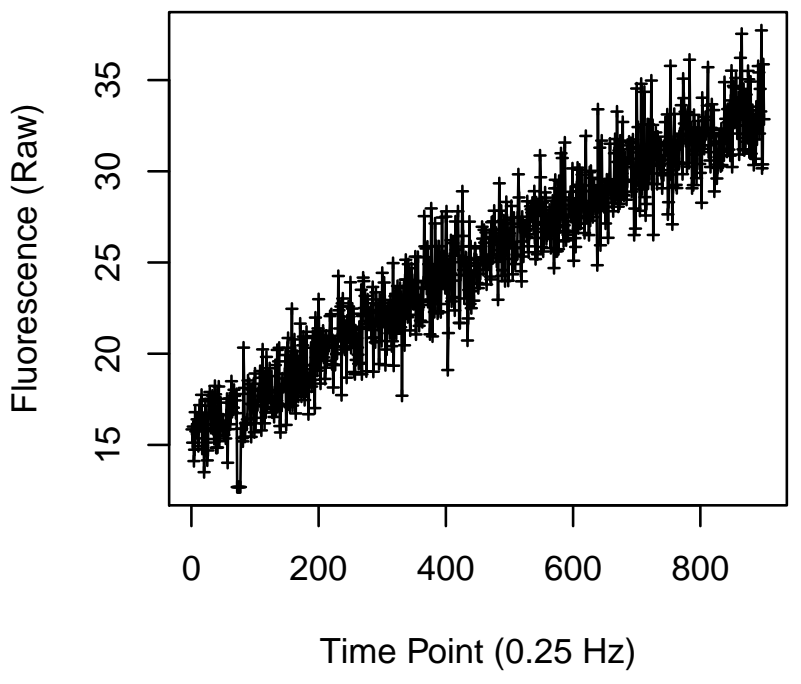

Cell 1663

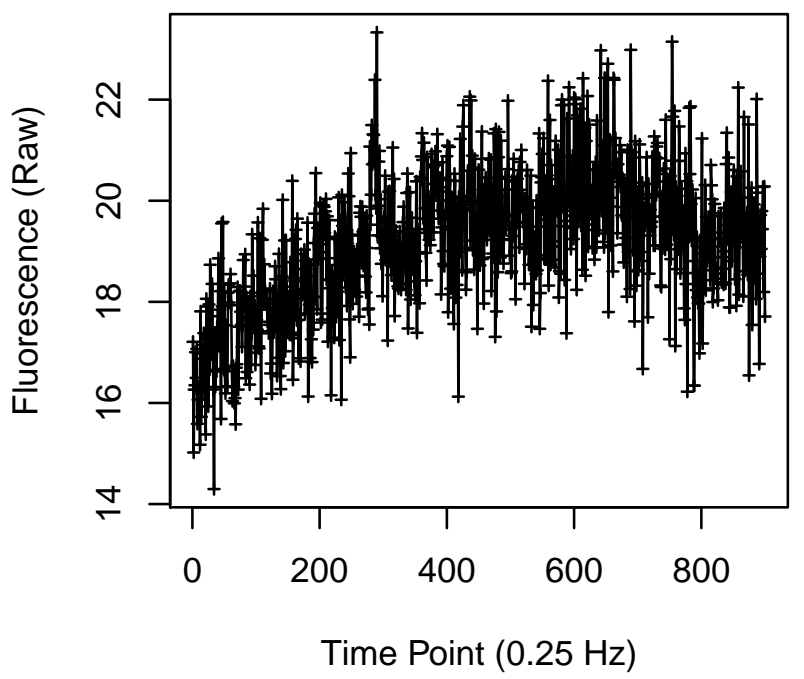

Cell 1662

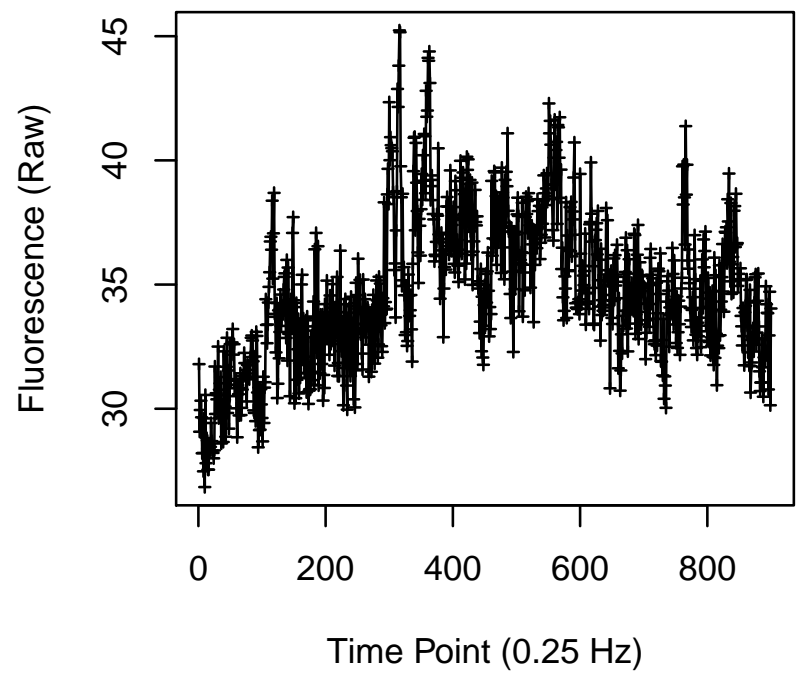

Cell 1664

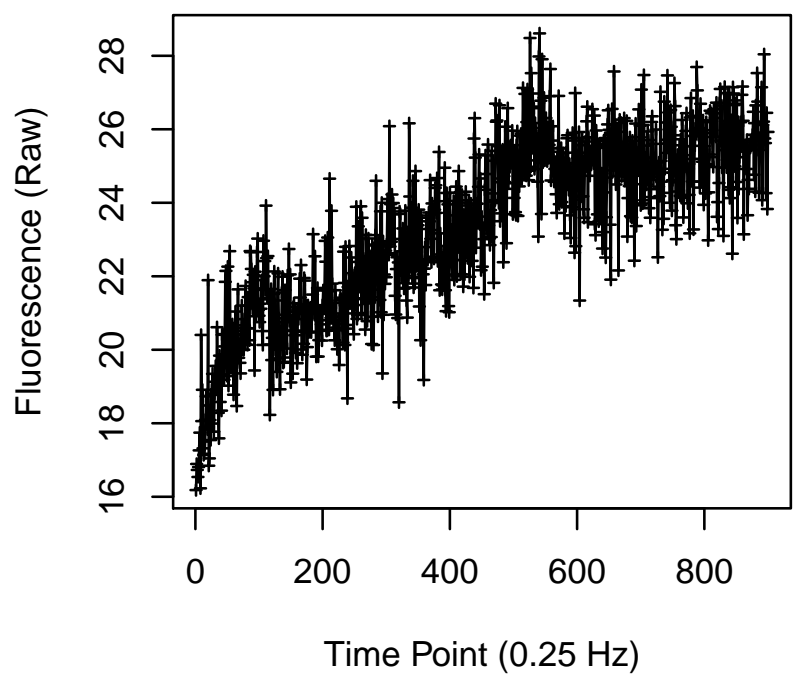


Cell 1669

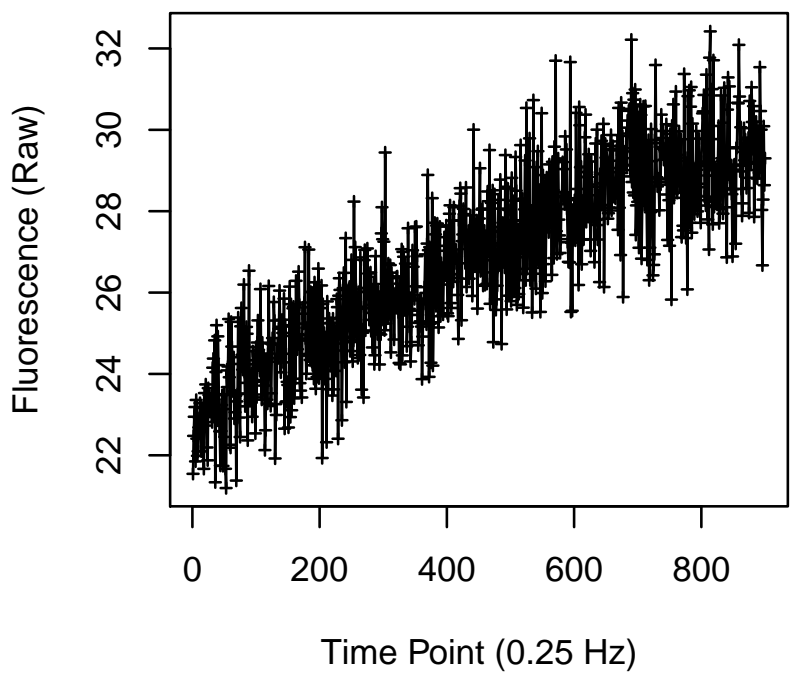

Cell 1671

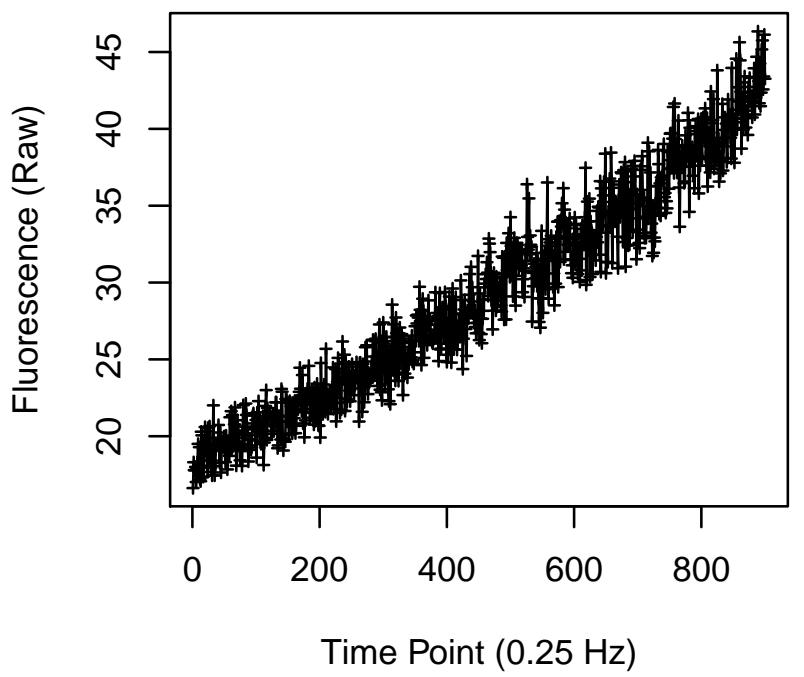

Cell 1670

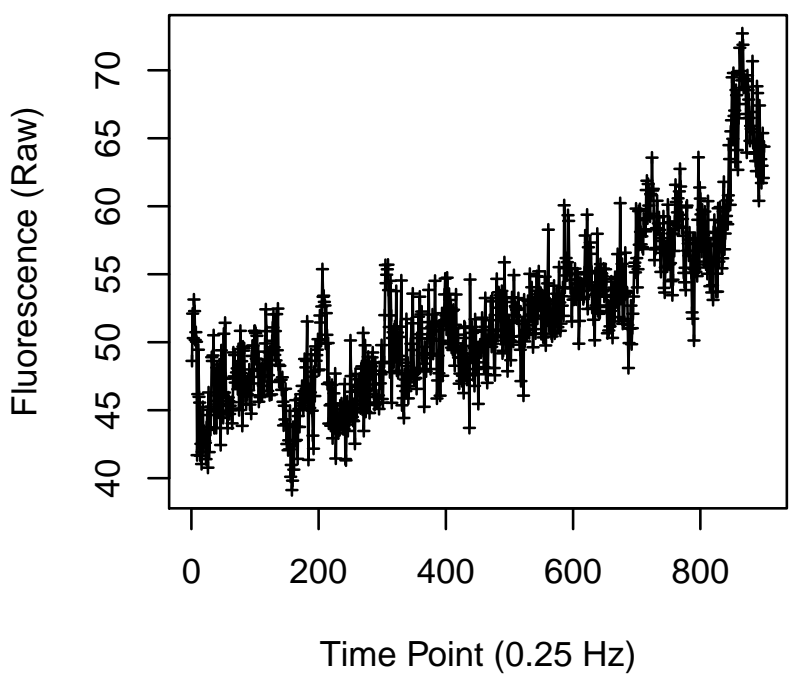

Cell 1672

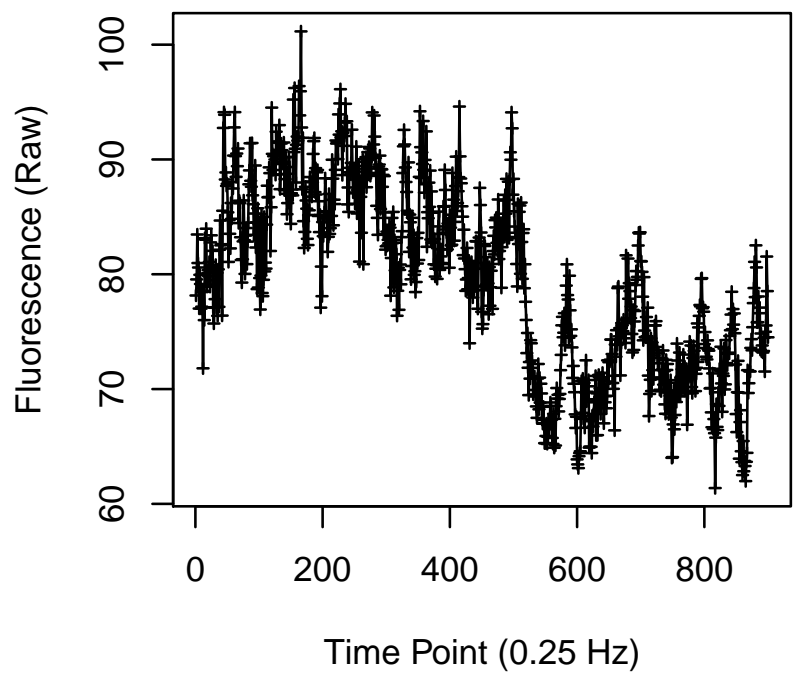


Cell 1673

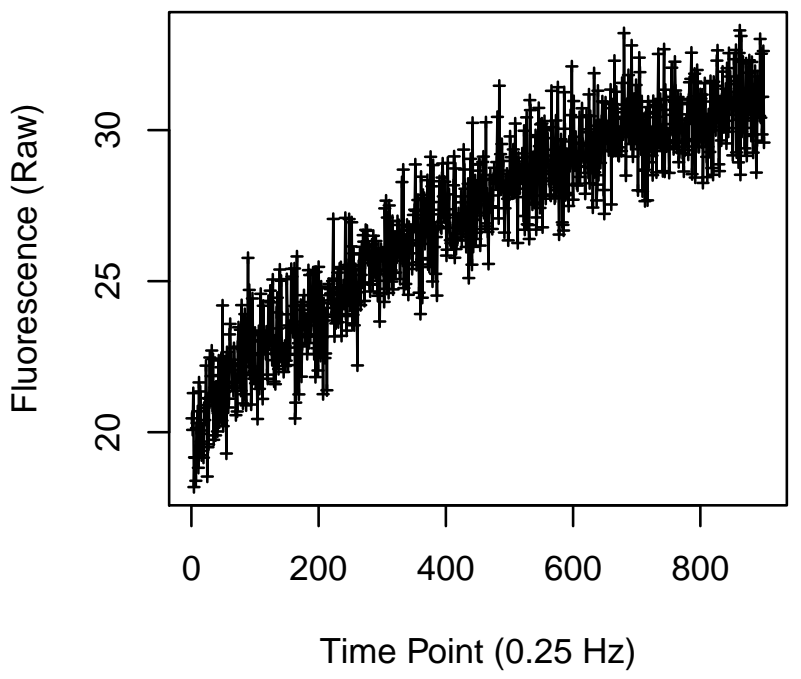

Cell 1675

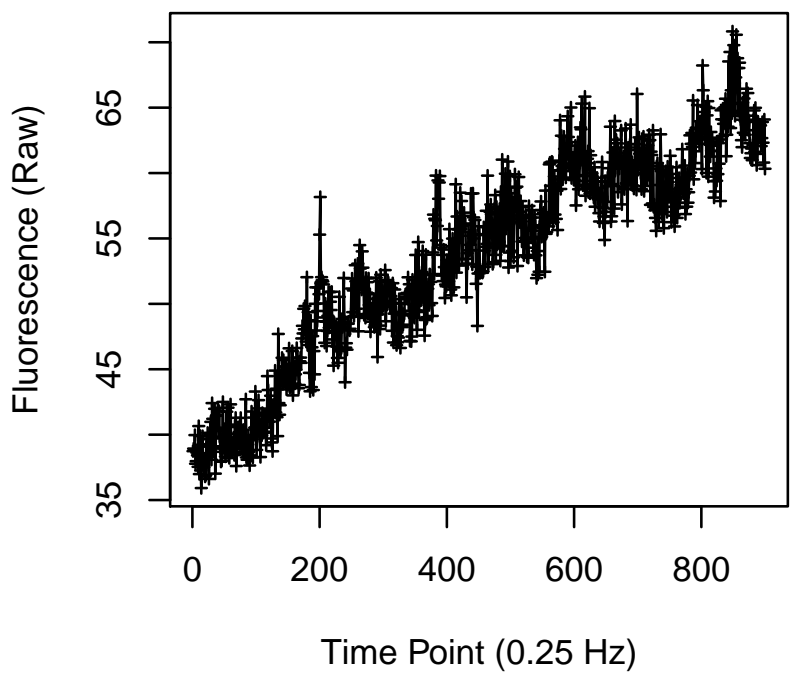

Cell 1674

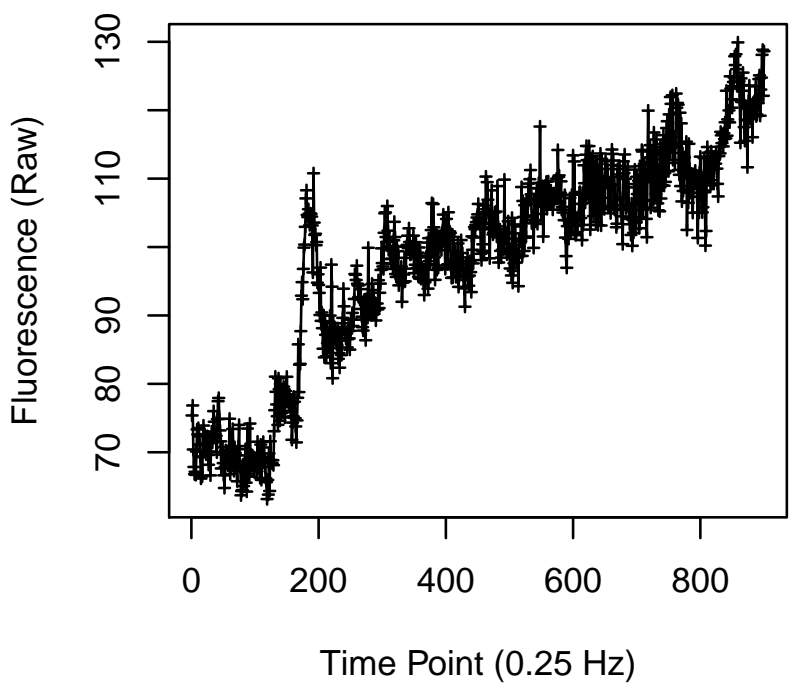

Cell 1676

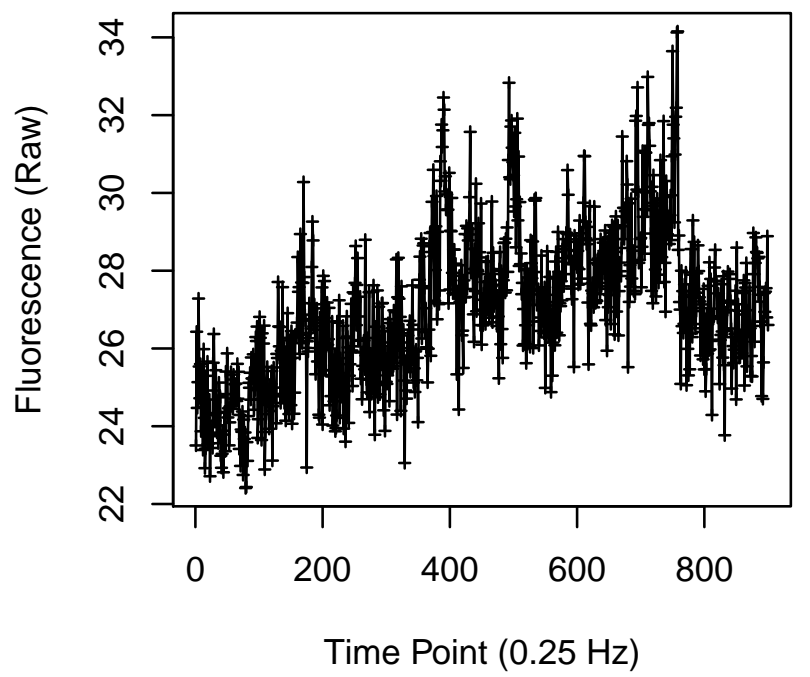


Cell 1677

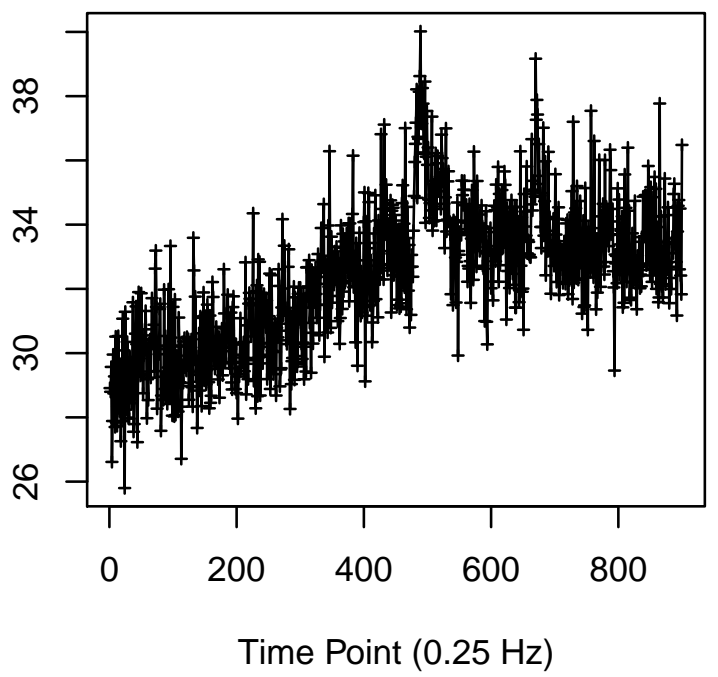

Cell 1679

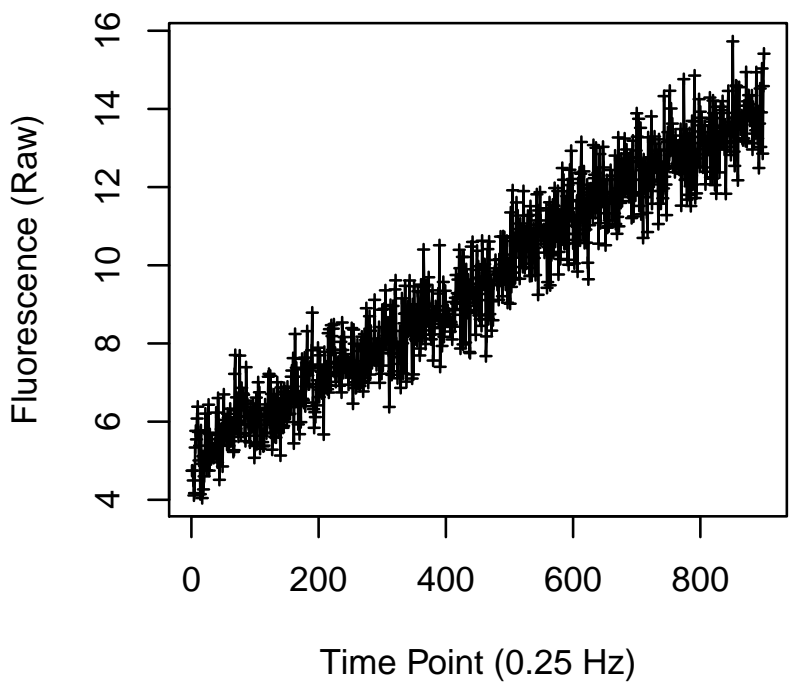

Cell 1678

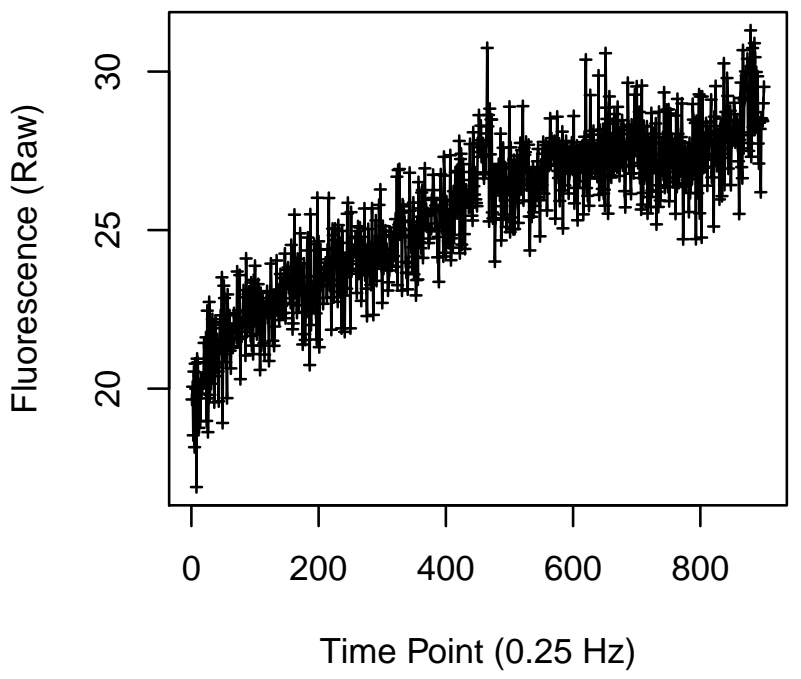

Cell 1680

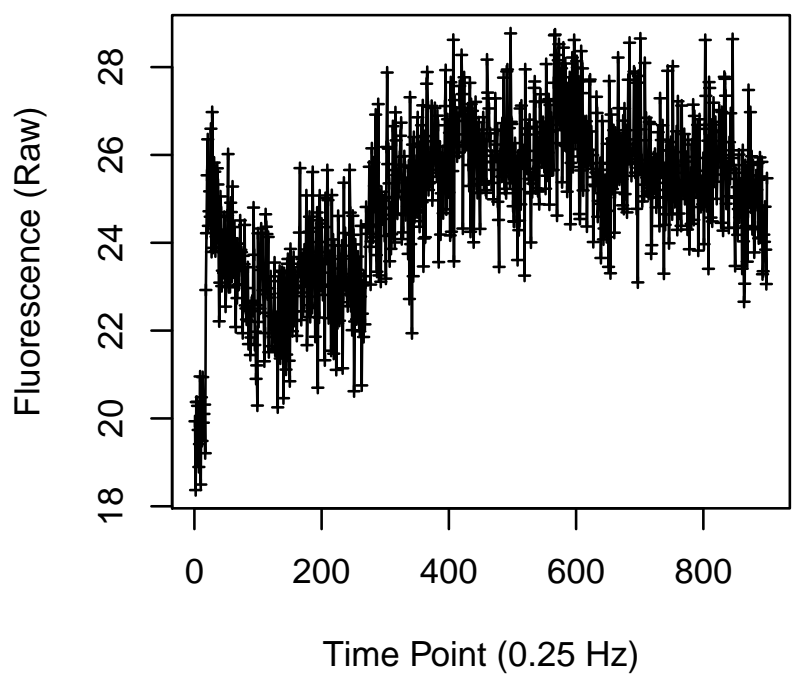


Cell 1681

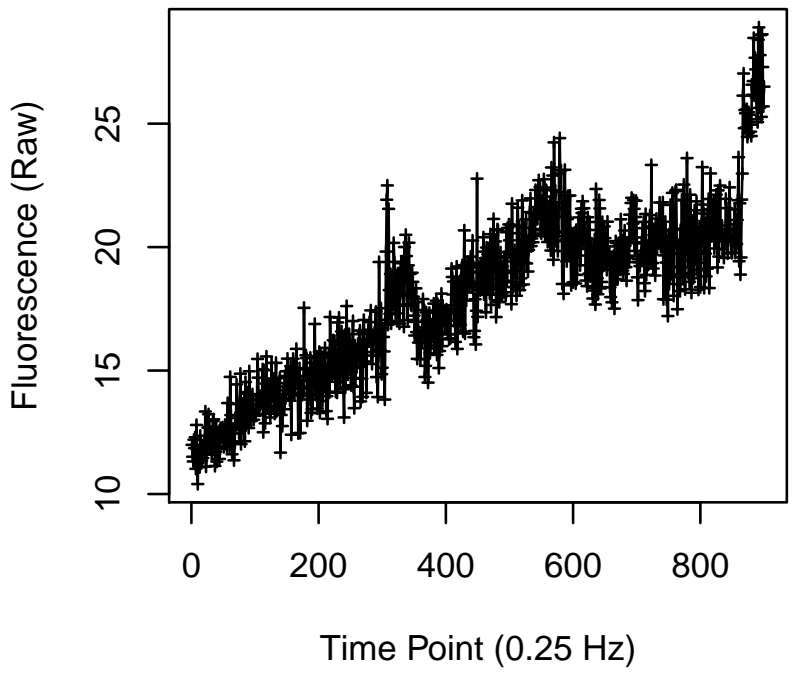

Cell 1683

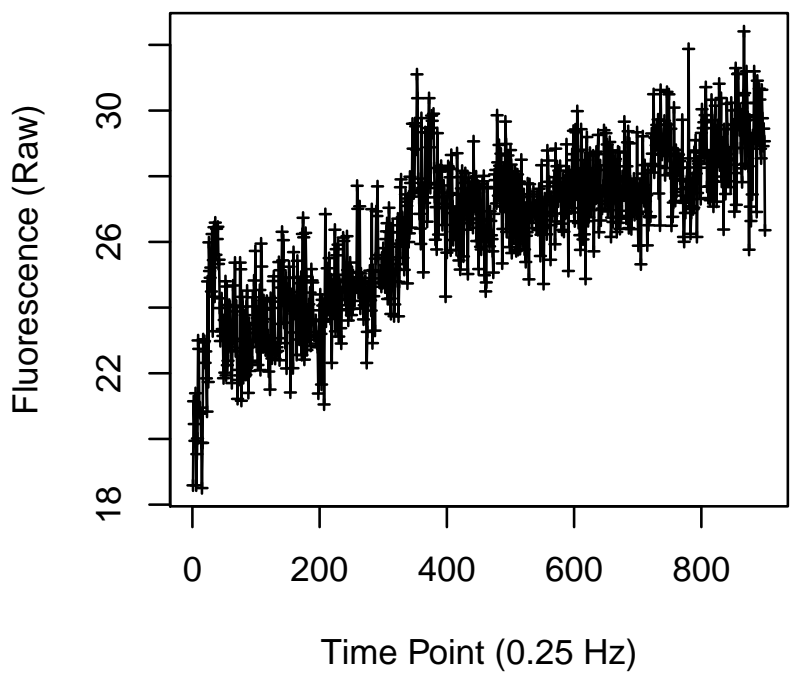

Cell 1682

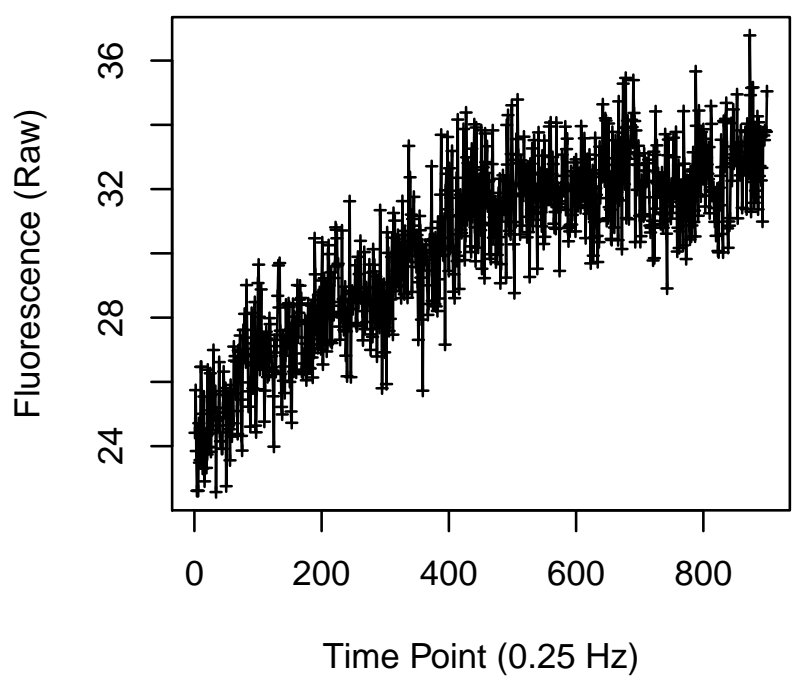

Cell 1684

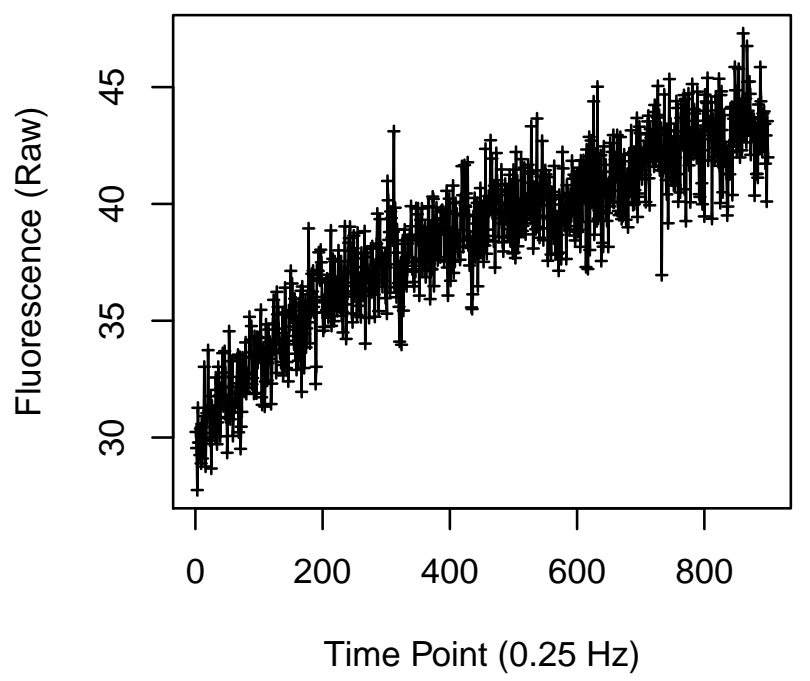


Cell 1685

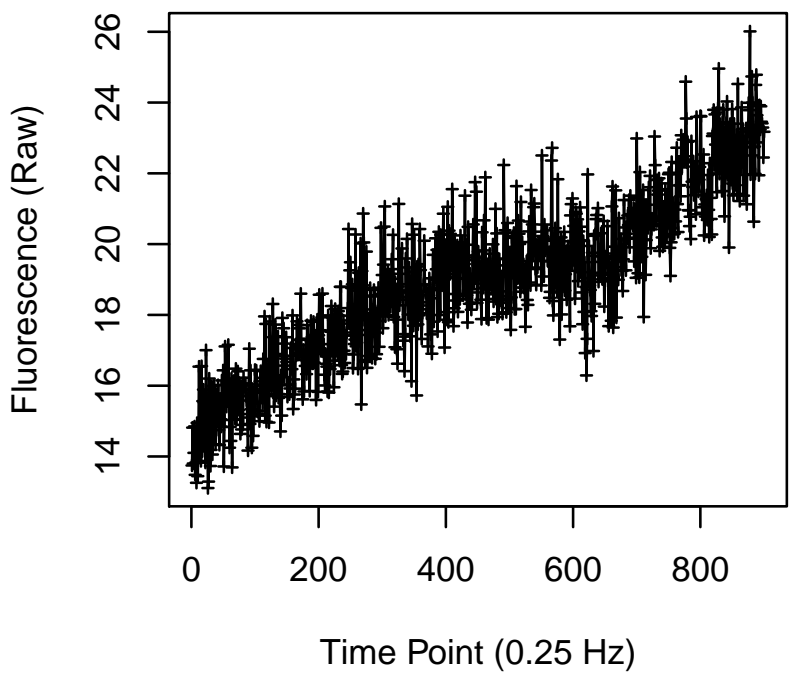

Cell 1687

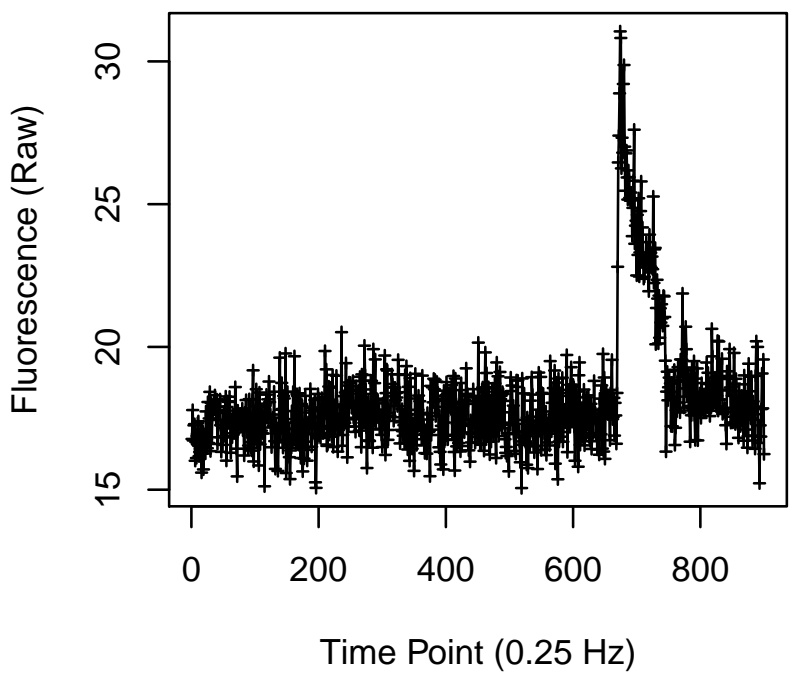

Cell 1686

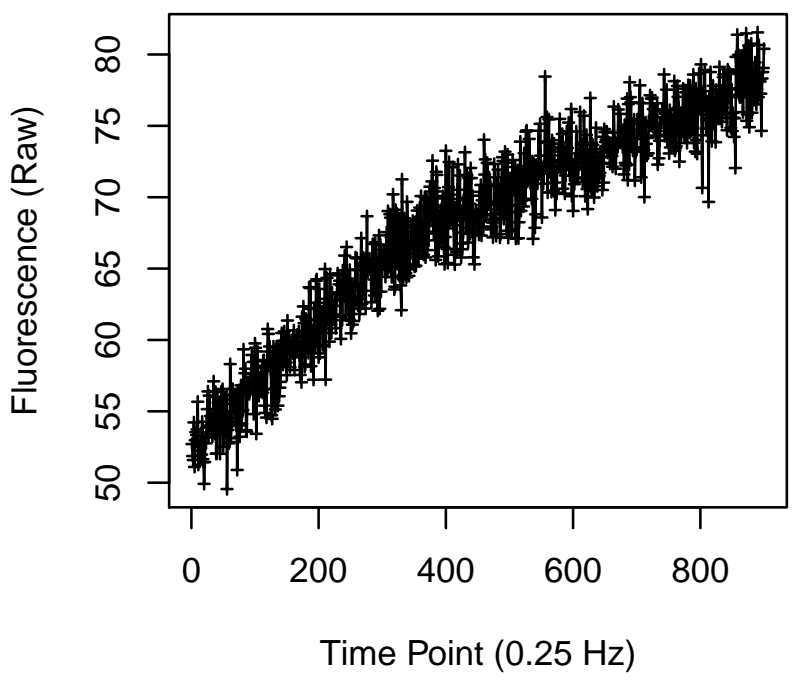

Cell 1688

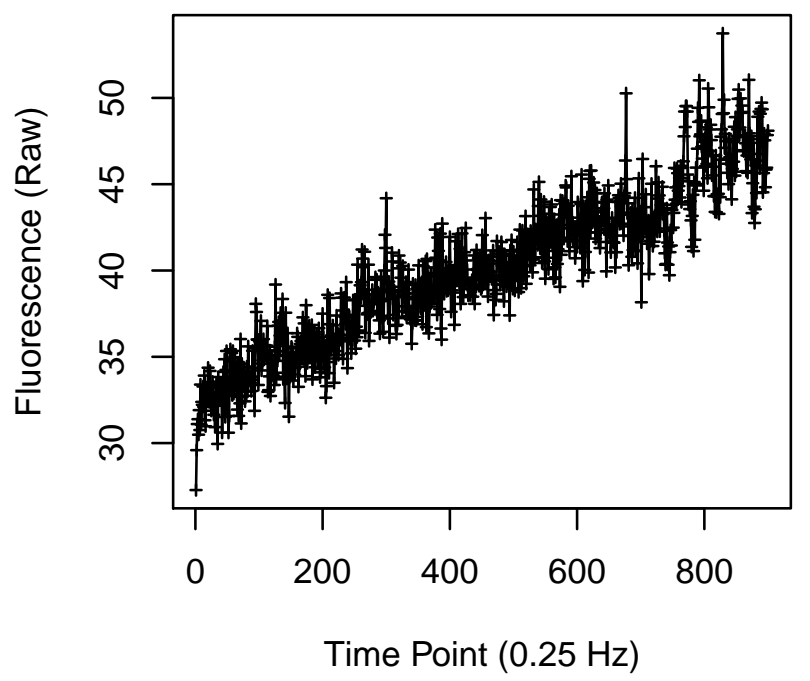


Cell 1689

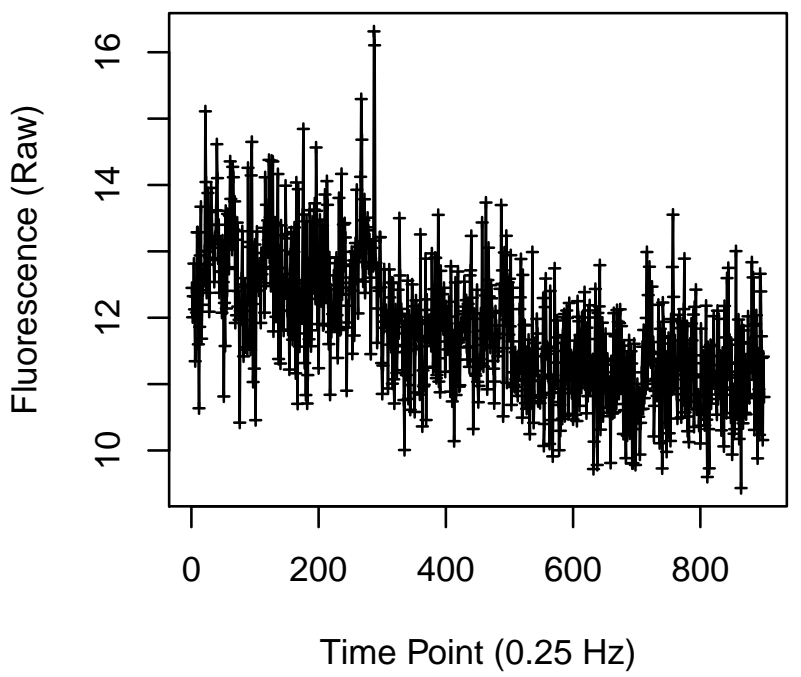

Cell 1691

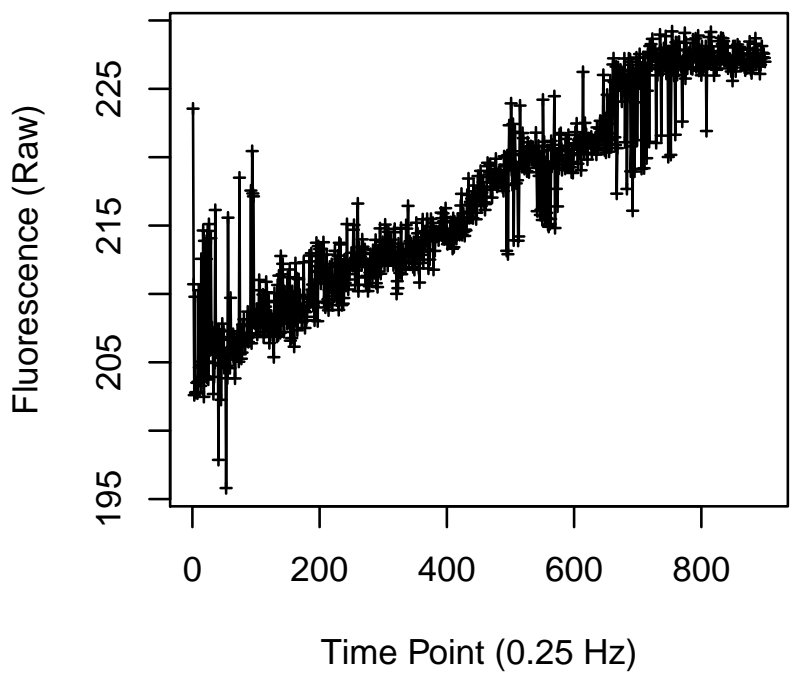

Cell 1690

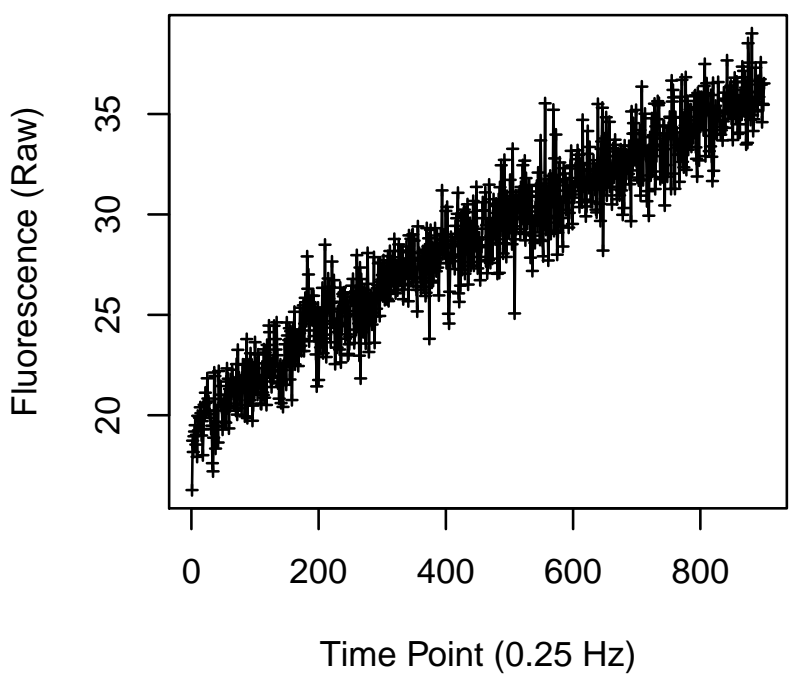

Cell 1692

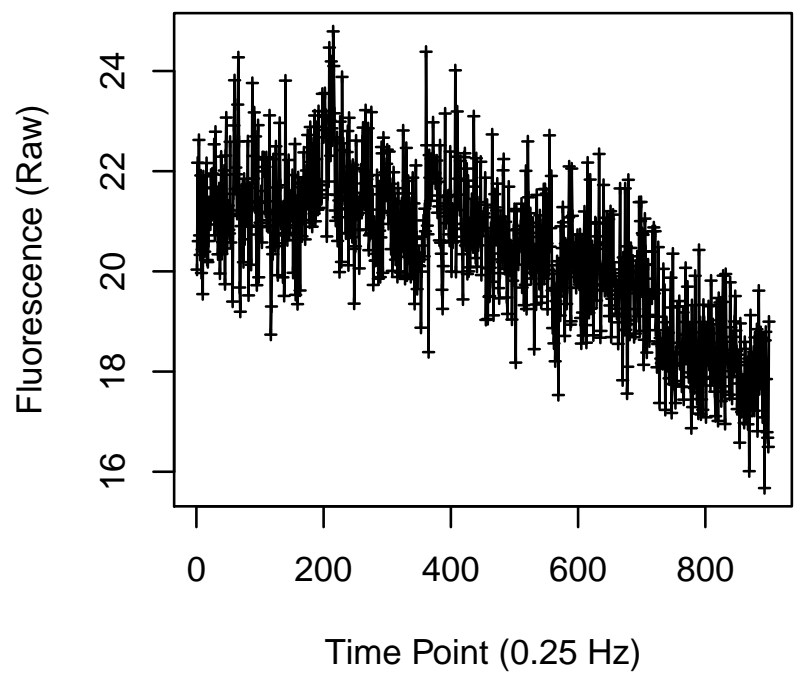


Cell 1693

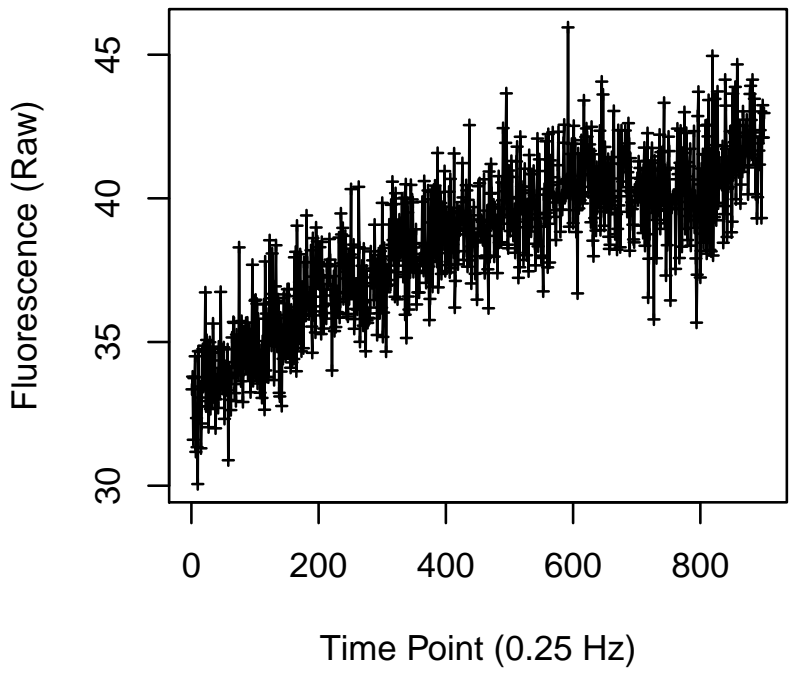

Cell 1695

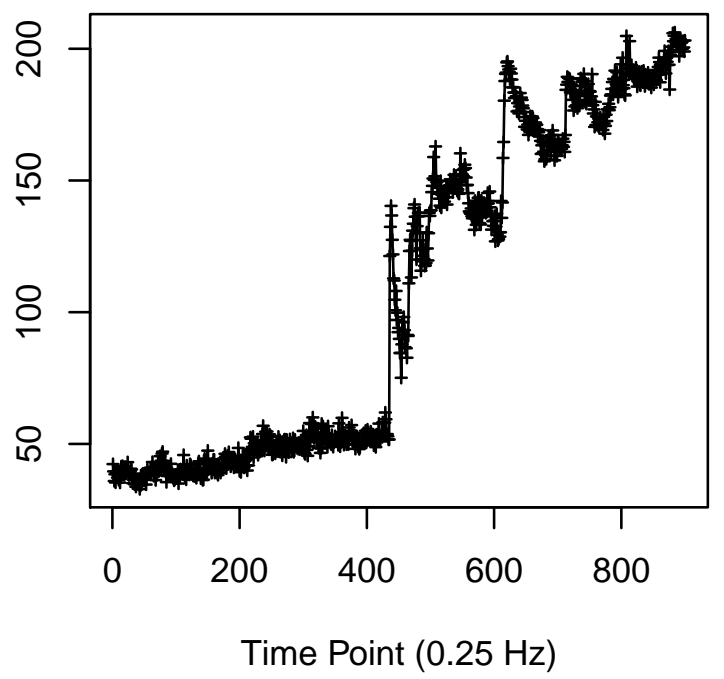

Cell 1694

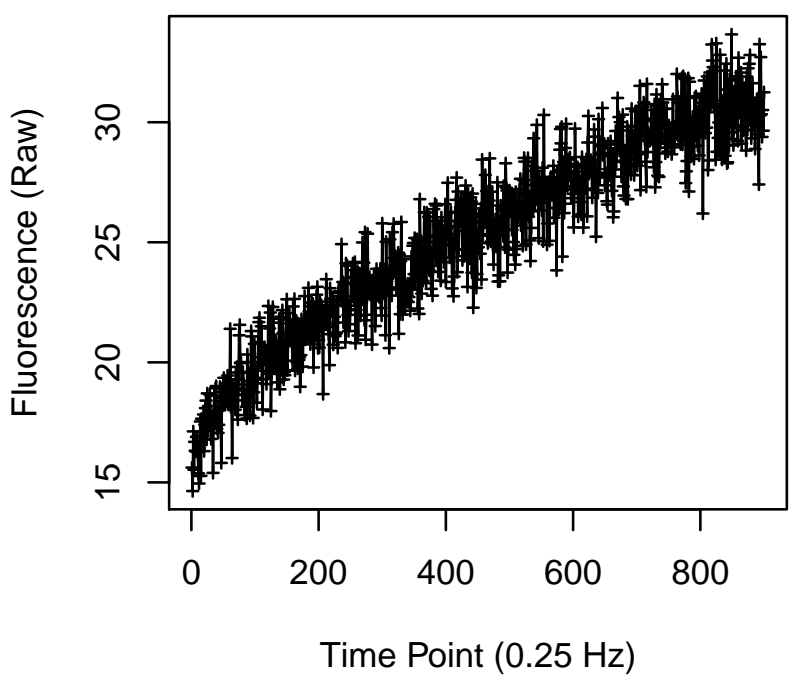

Cell 1696

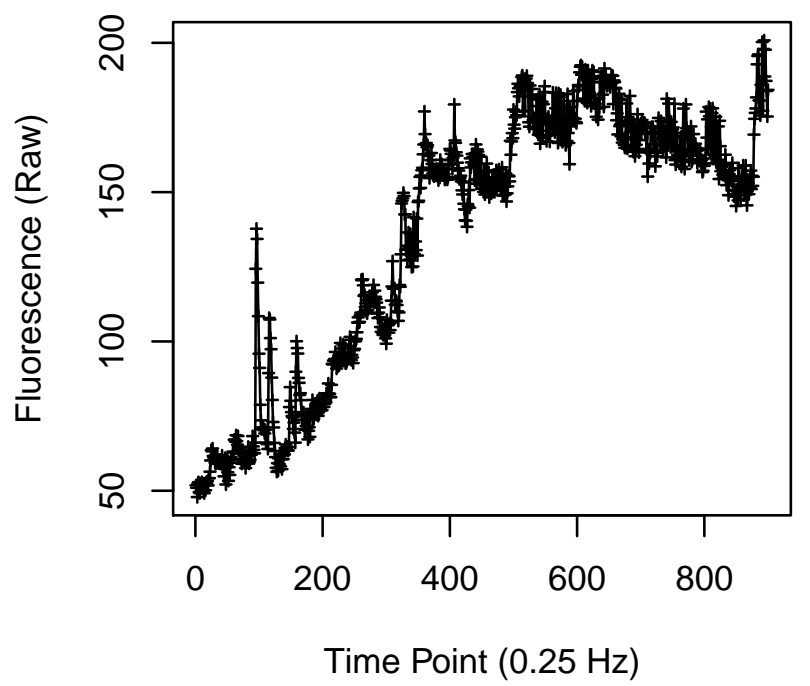


Cell 1697

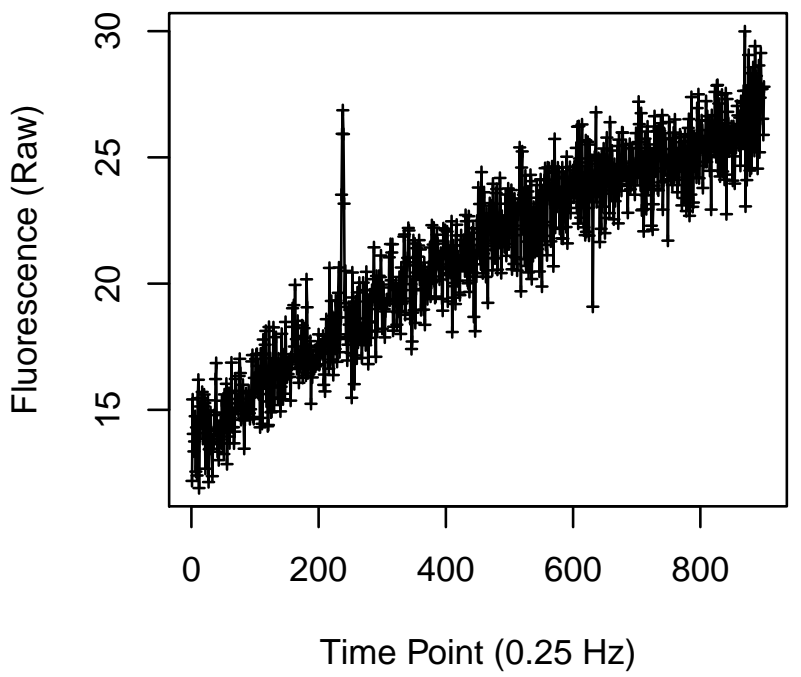

Cell 1699

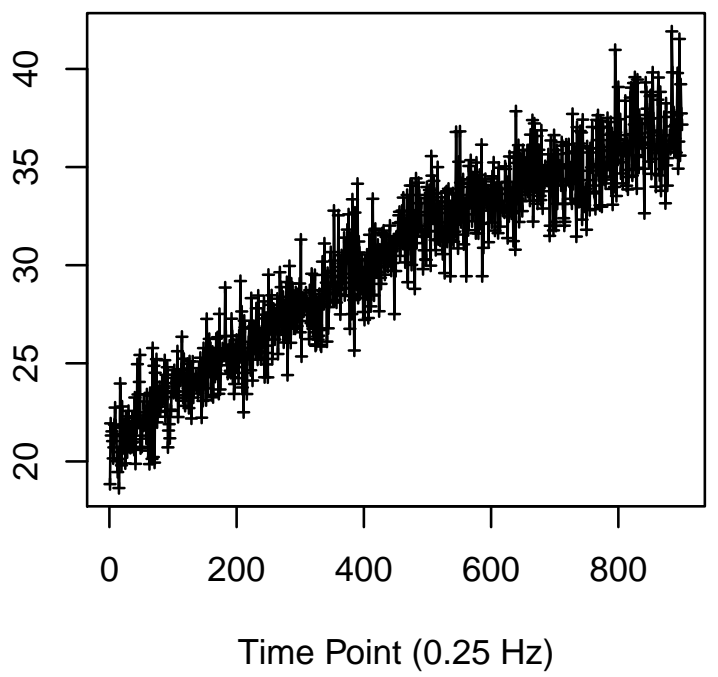

Cell 1698

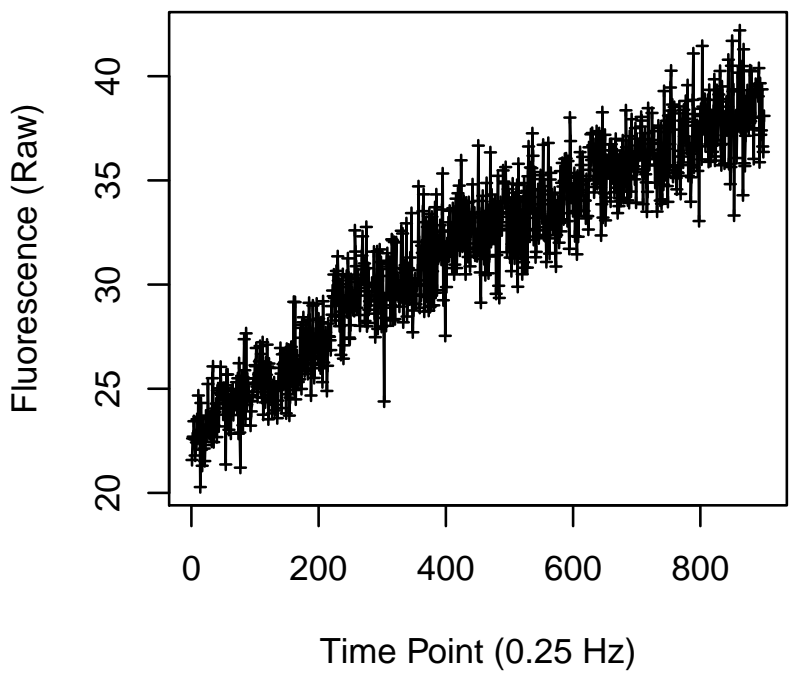

Cell 1700

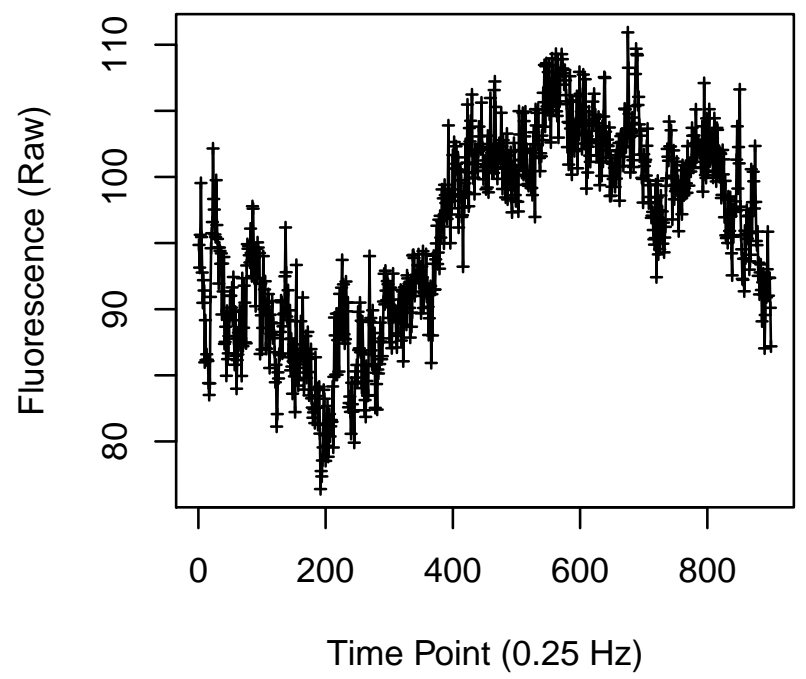


Cell 1701

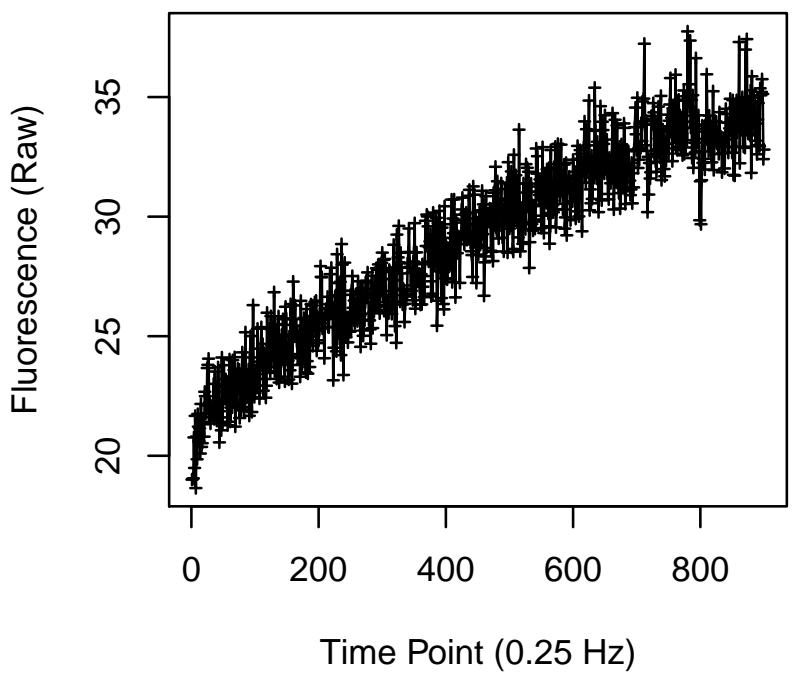

Cell 1703

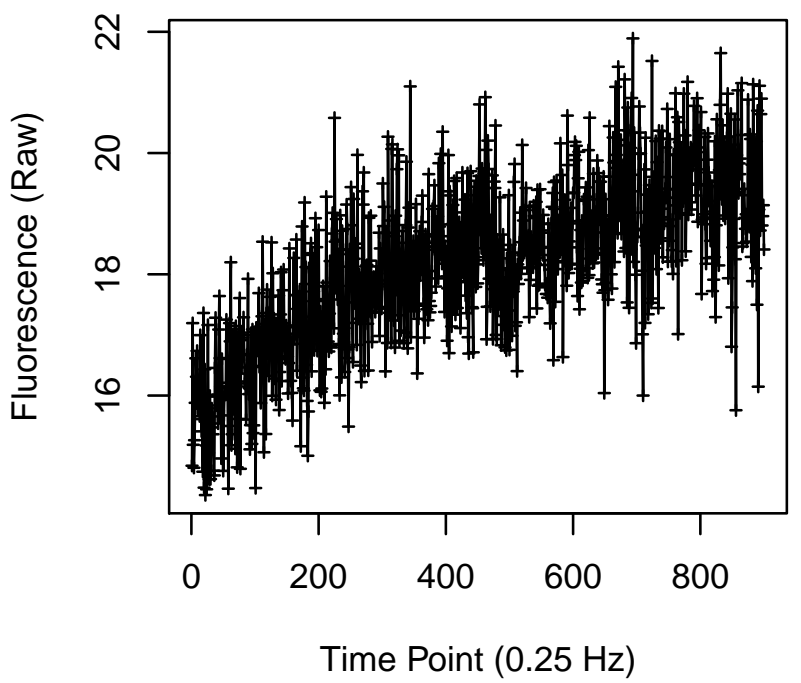

Cell 1702

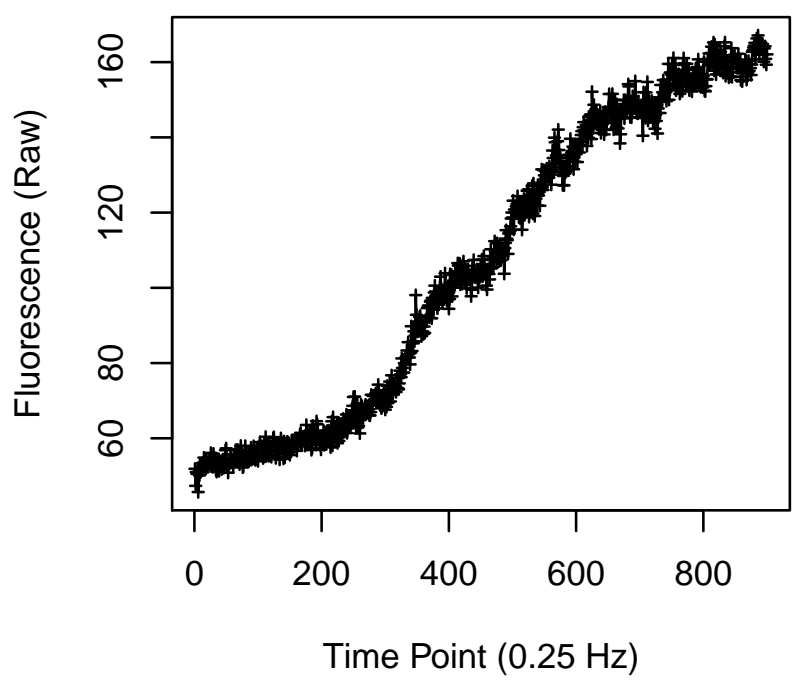

Cell 1704

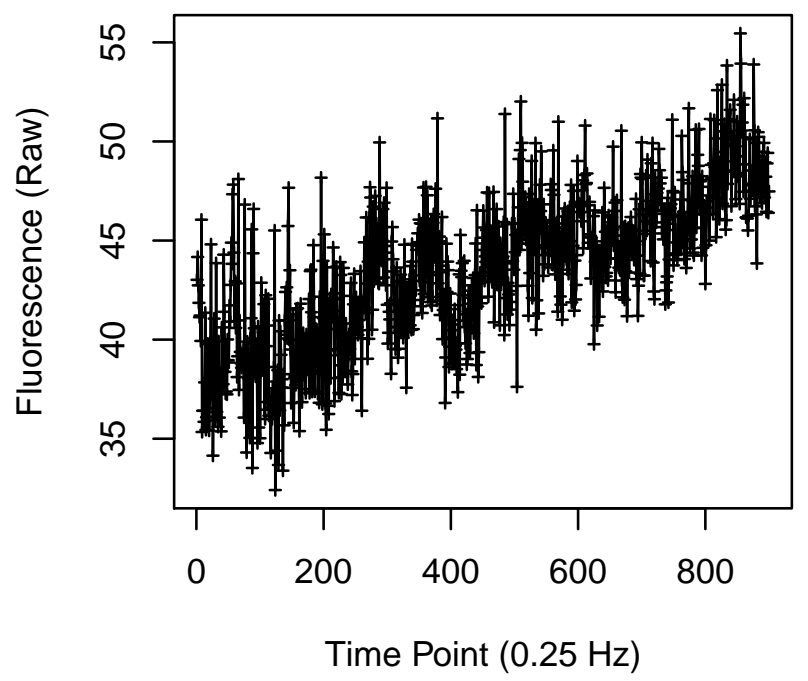


Cell 1705

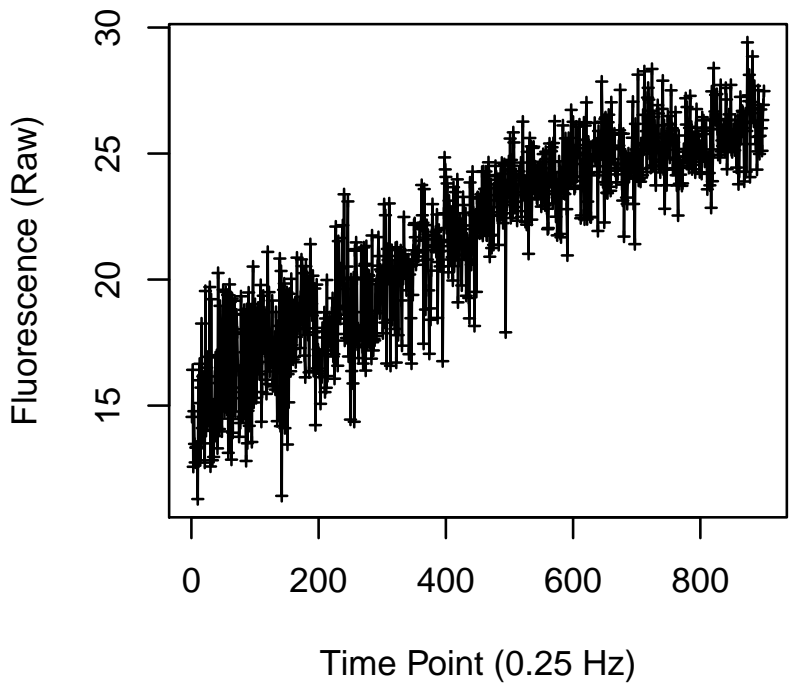

Cell 1707

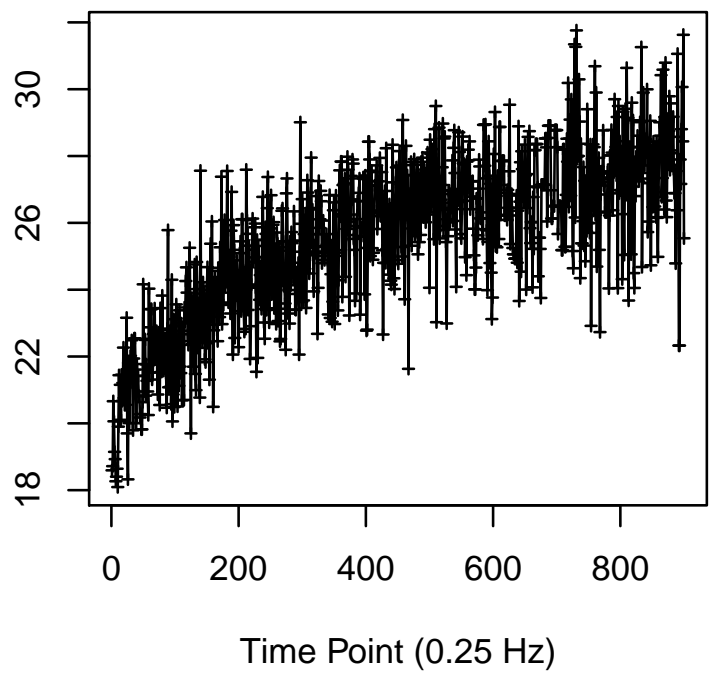

Cell 1706

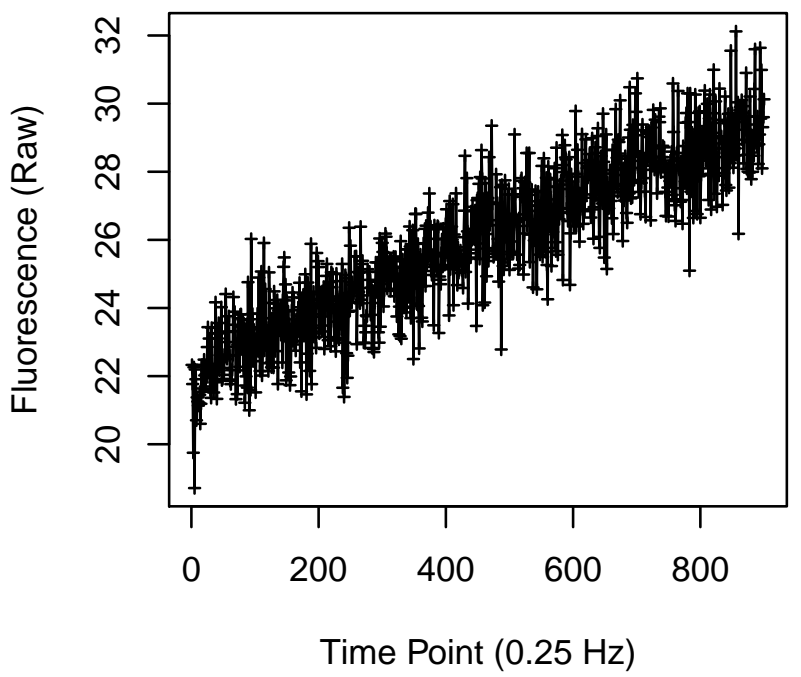

Cell 1708

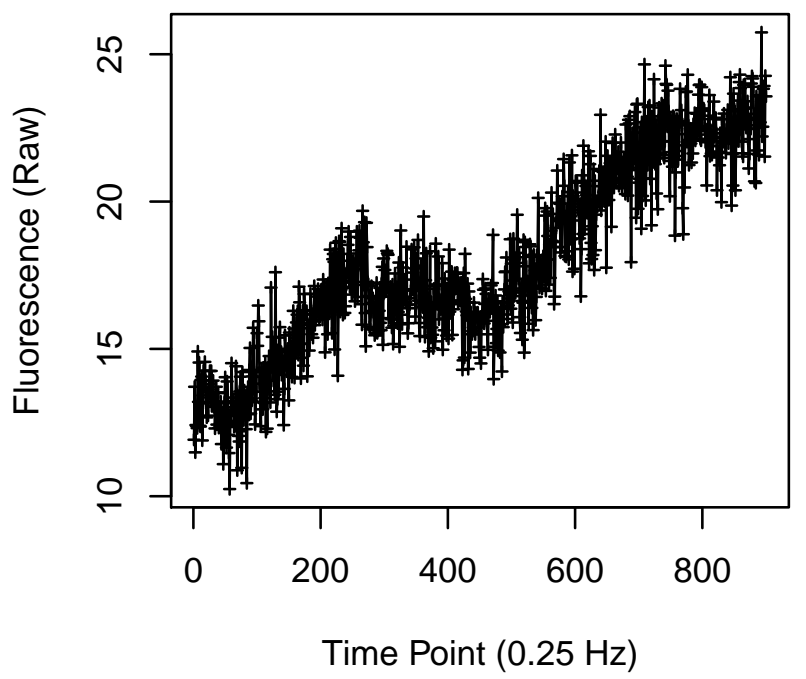


Cell 1709

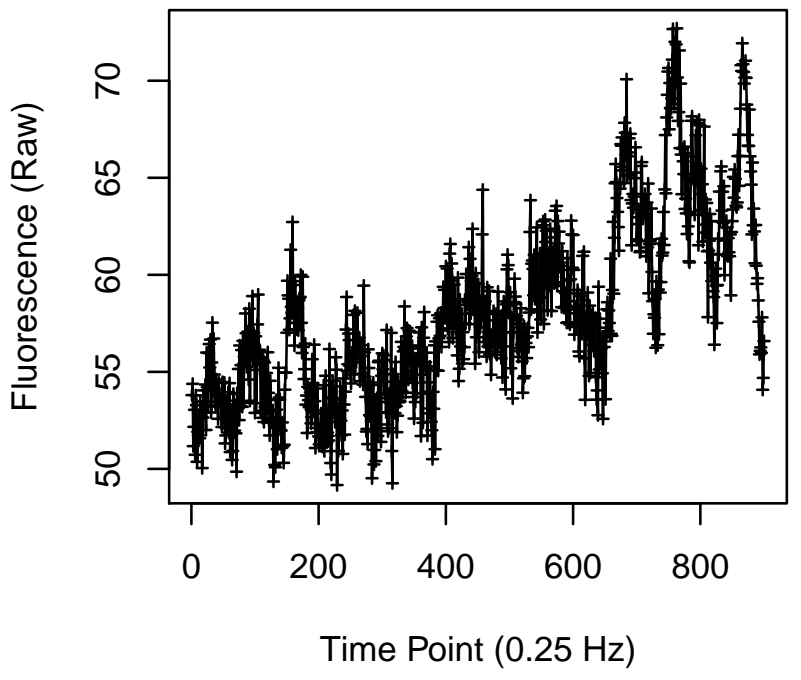

Cell 1711

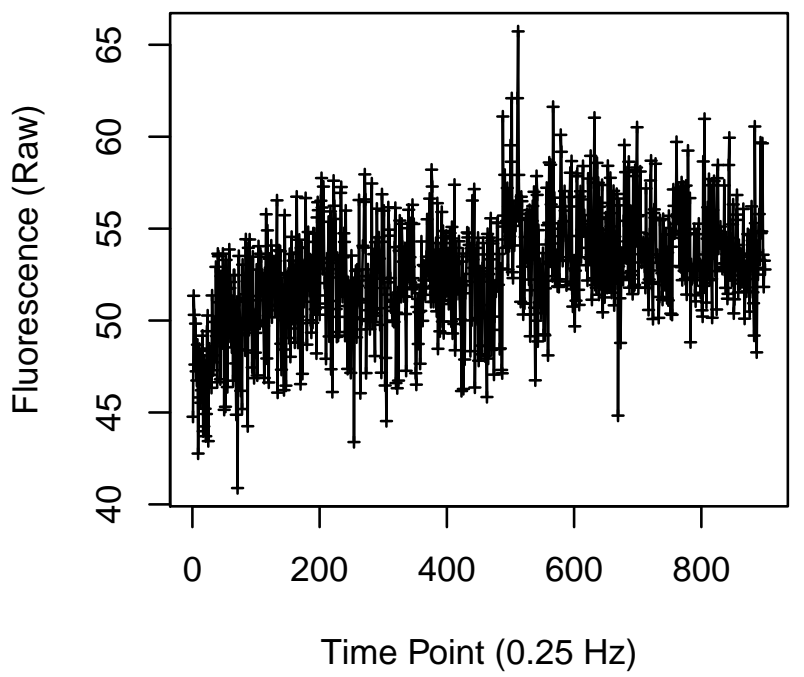

Cell 1710

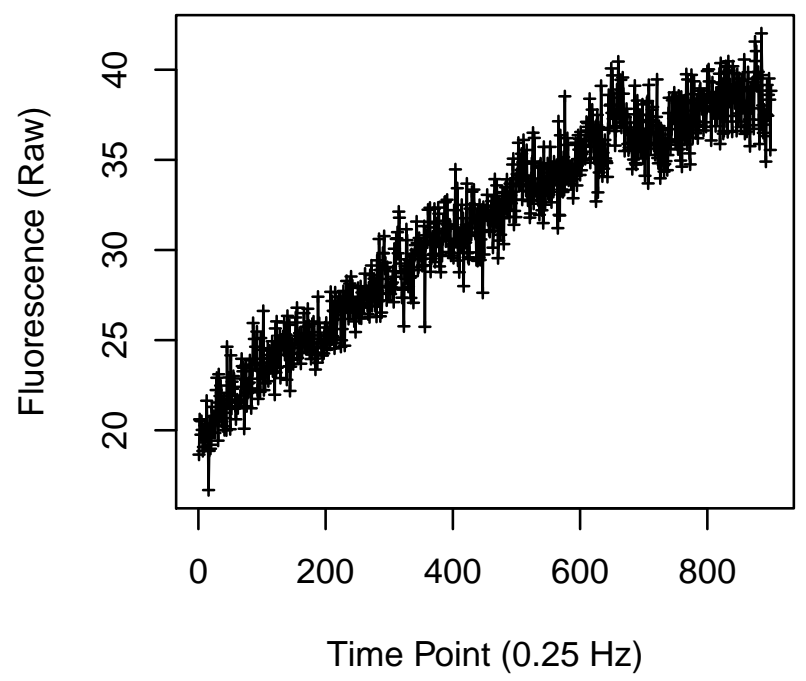

Cell 1712

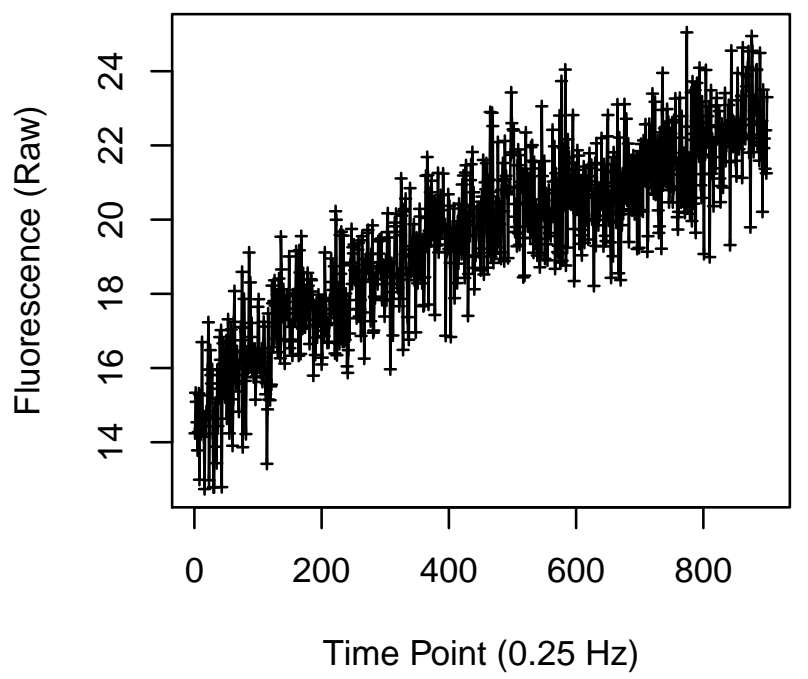


Cell 1713

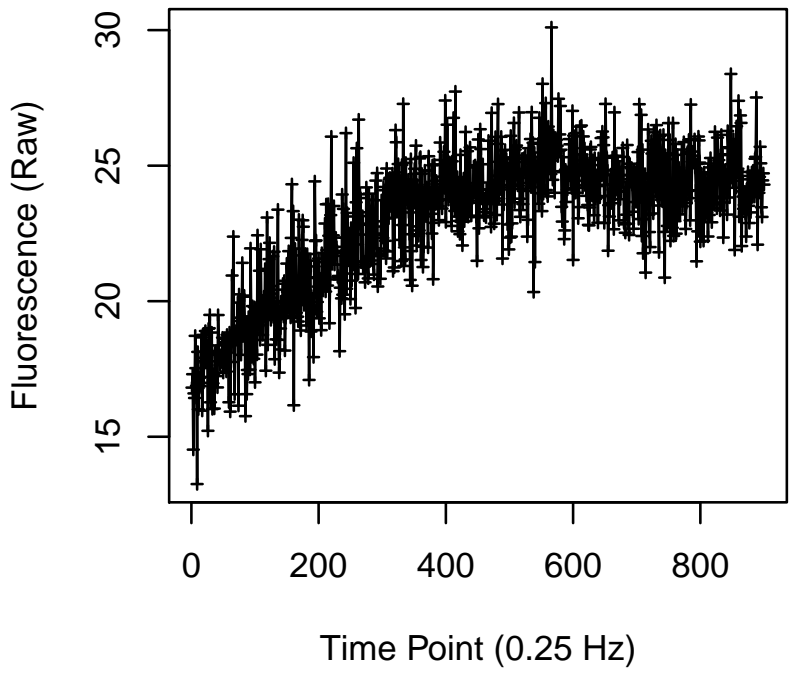

Cell 1715

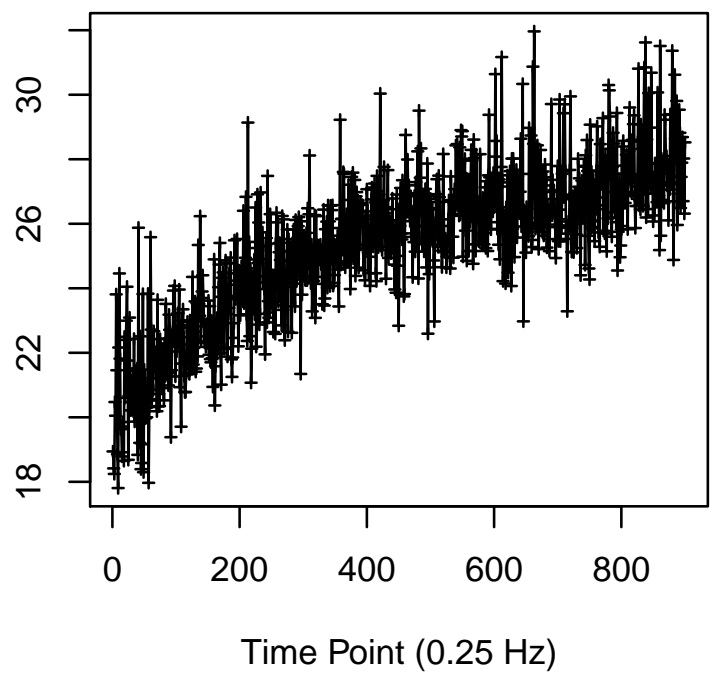

Cell 1714

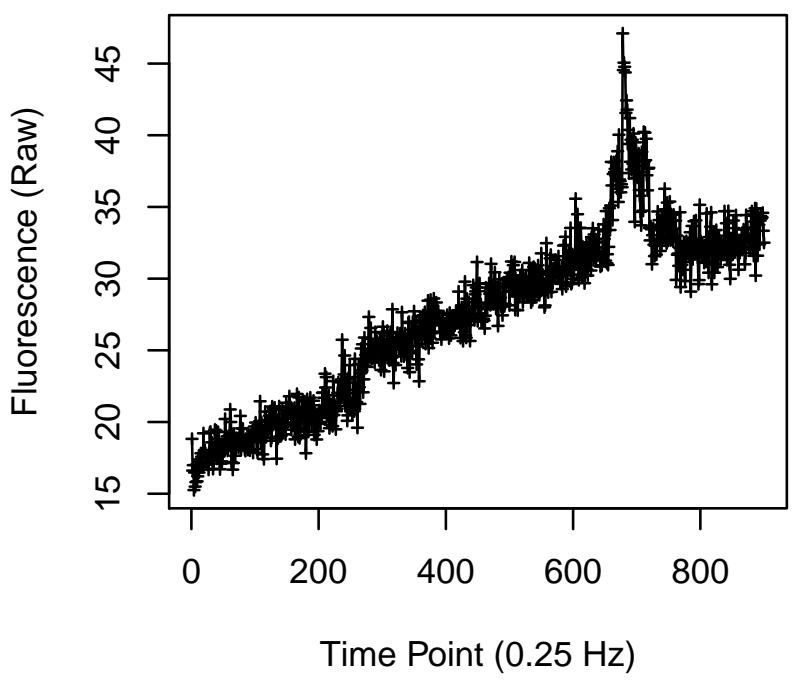

Cell 1716

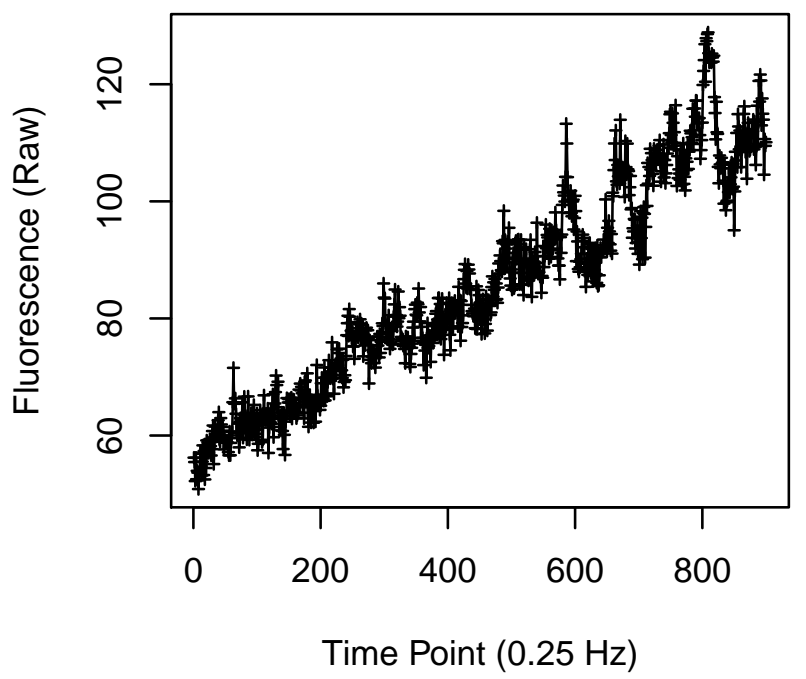


Cell 1717

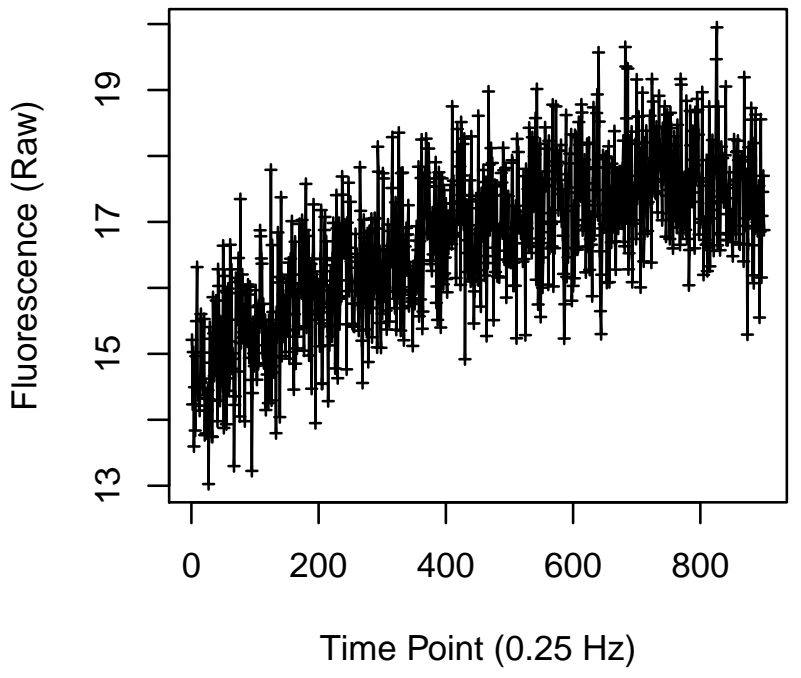

Cell 1719

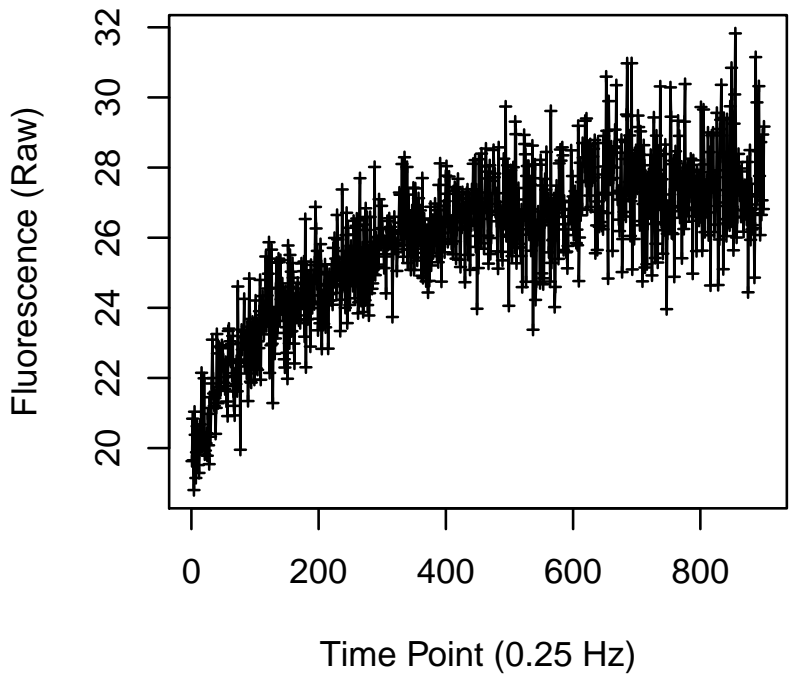

Cell 1718

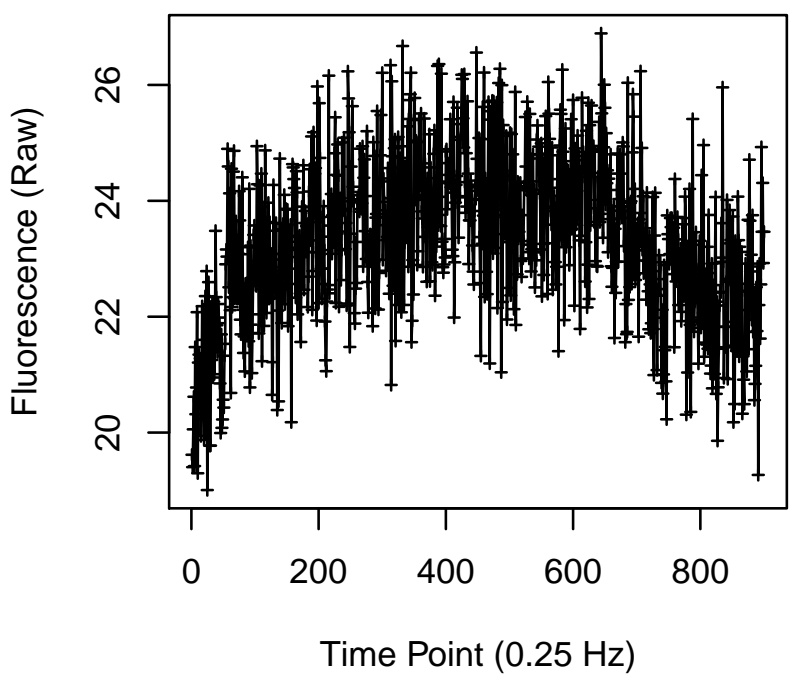

Cell 1720

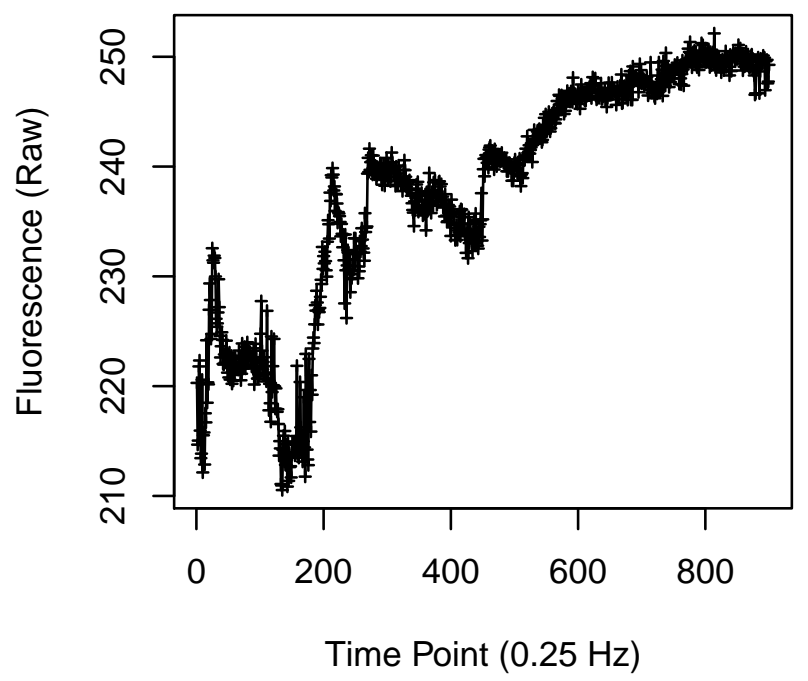


Cell 1721

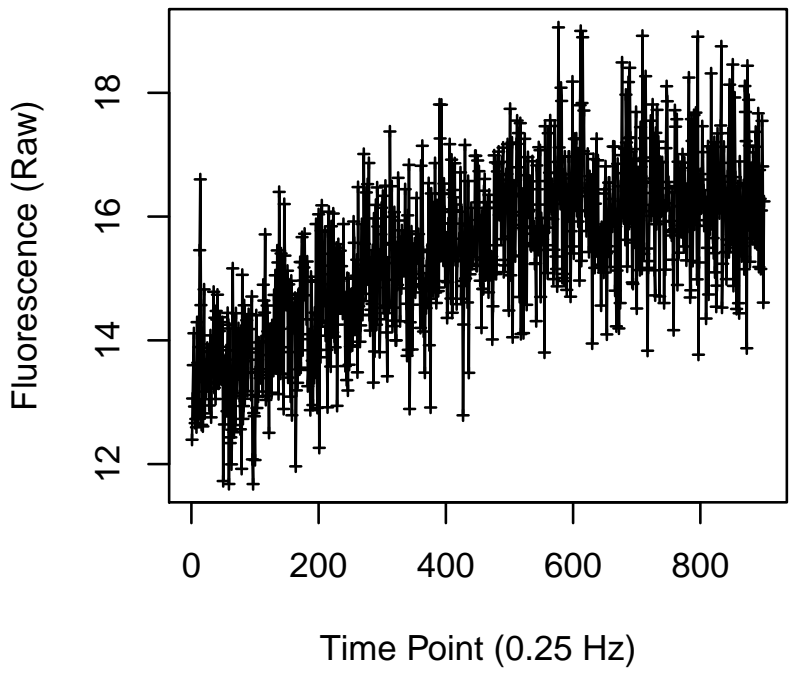

Cell 1723

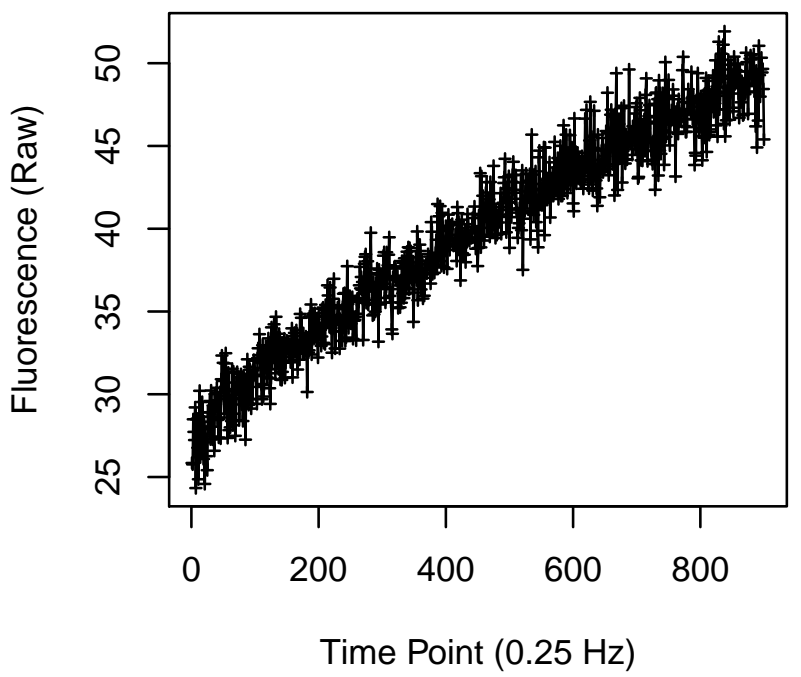

Cell 1722

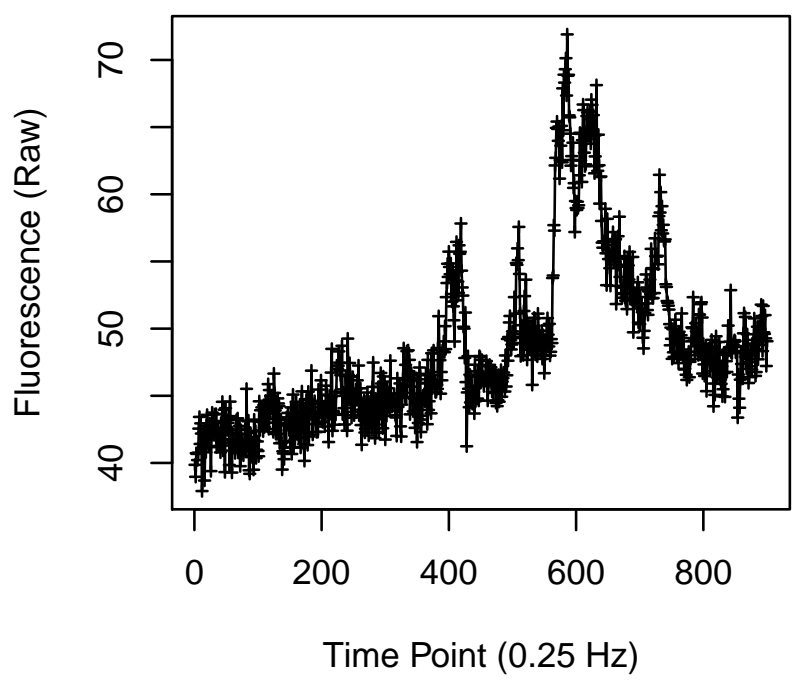

Cell 1724

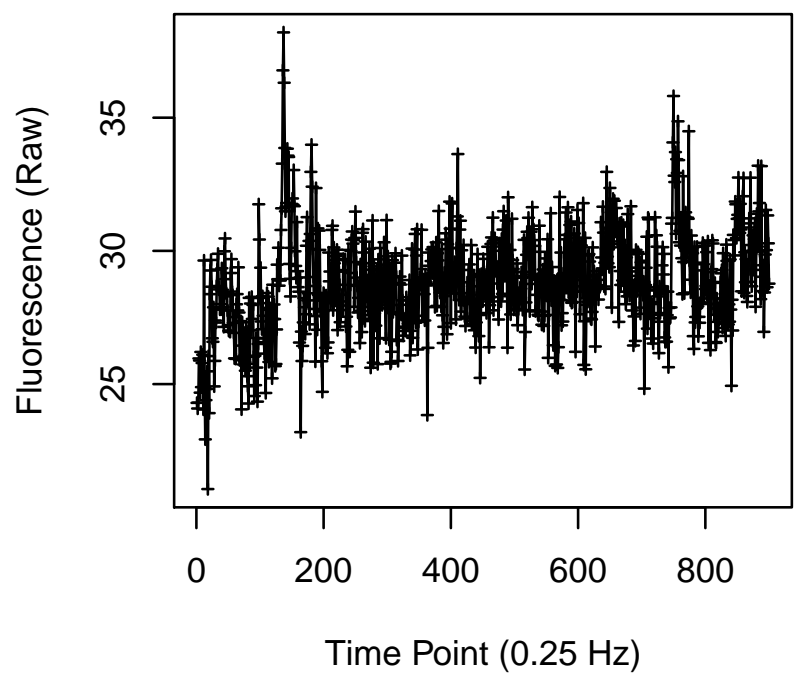


Cell 1725

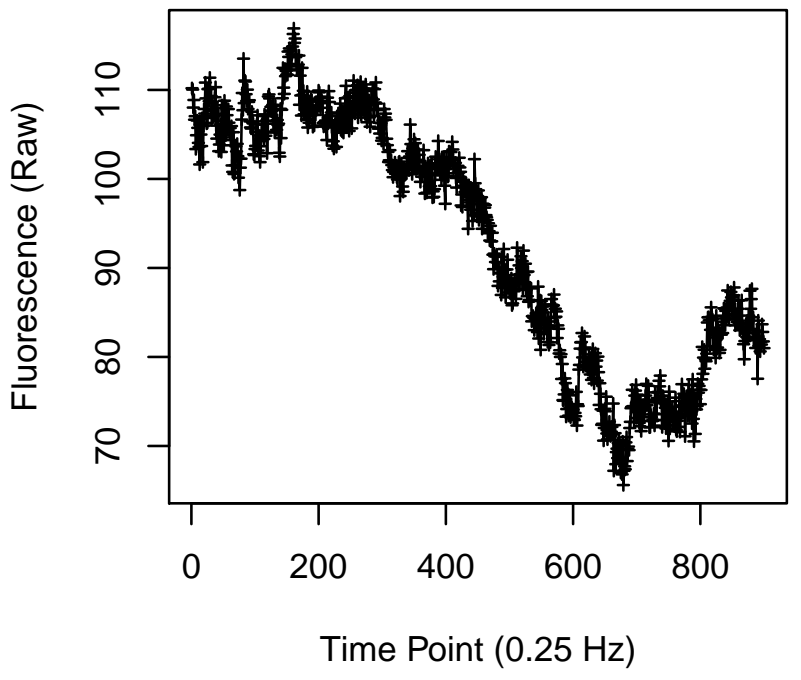

Cell 1727

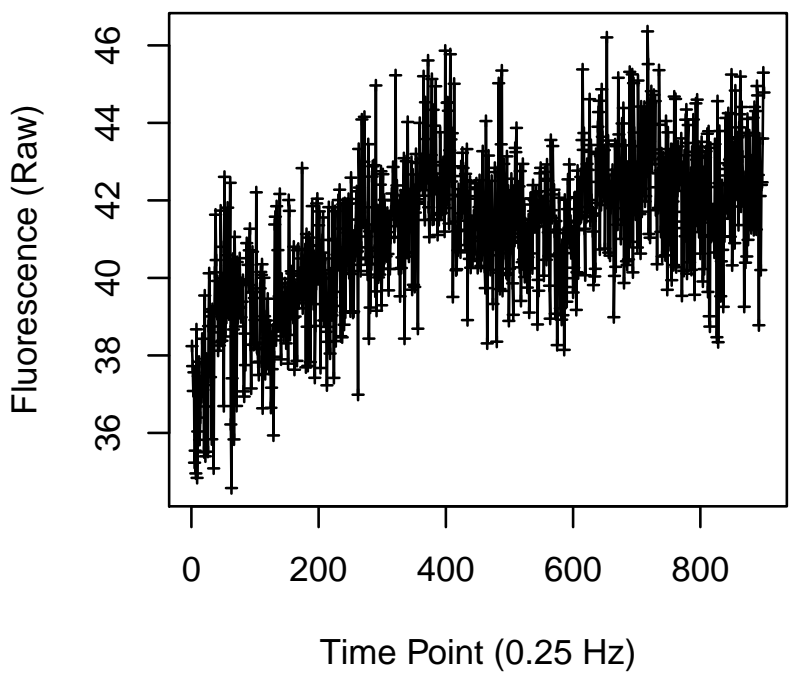

Cell 1726

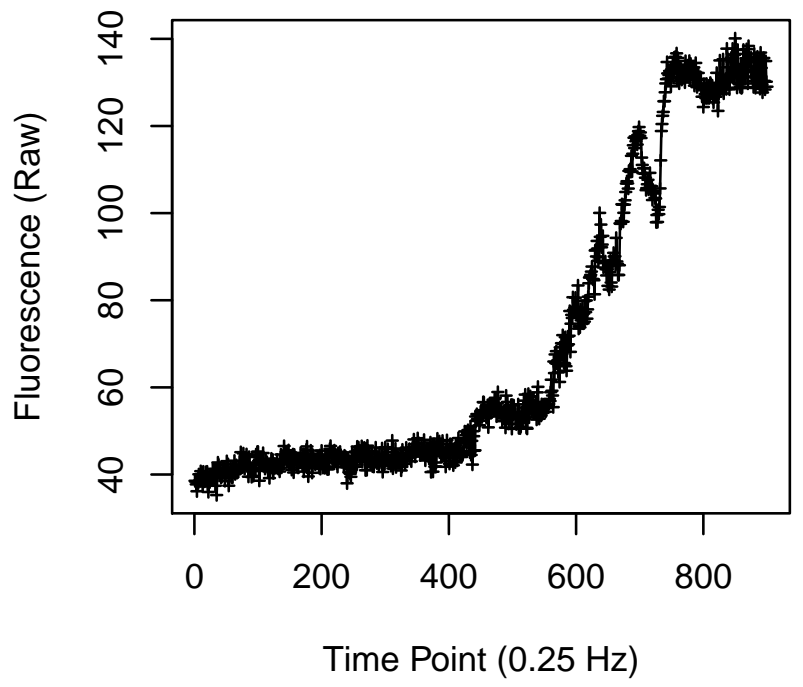

Cell 1728

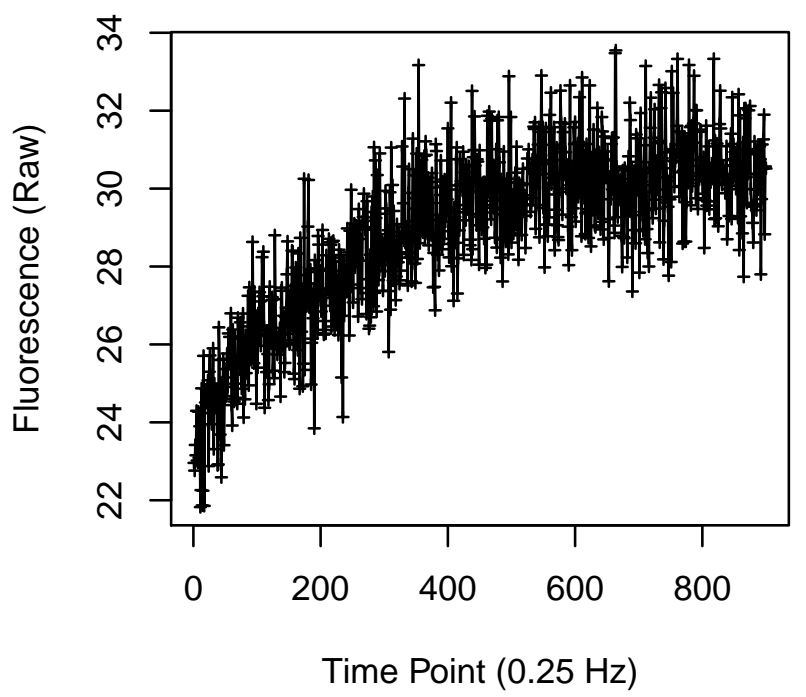


Cell 1733

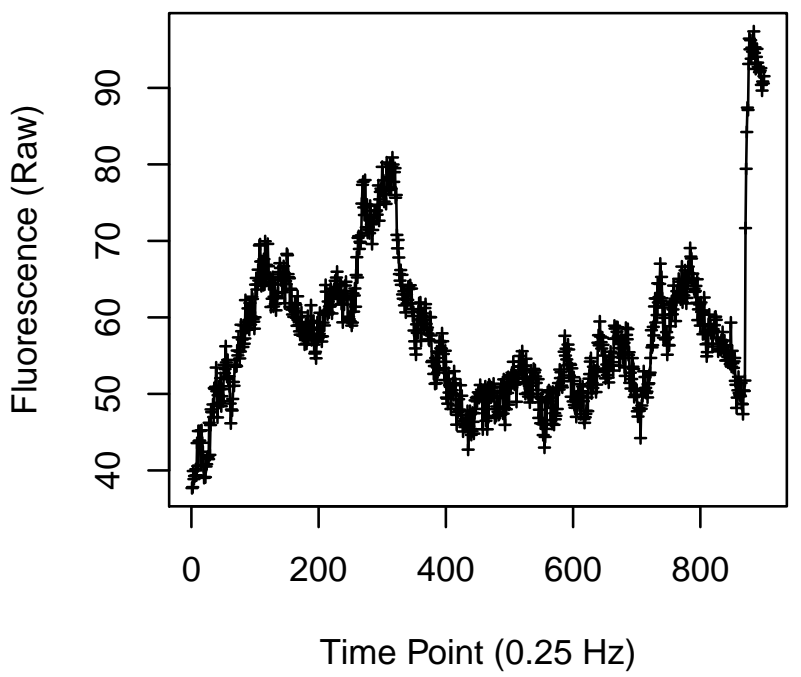

Cell 1735

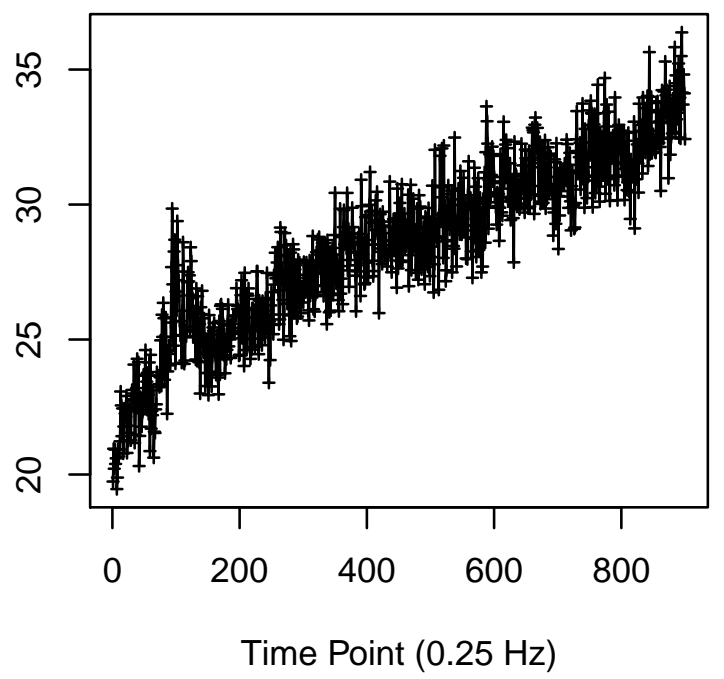

Cell 1734

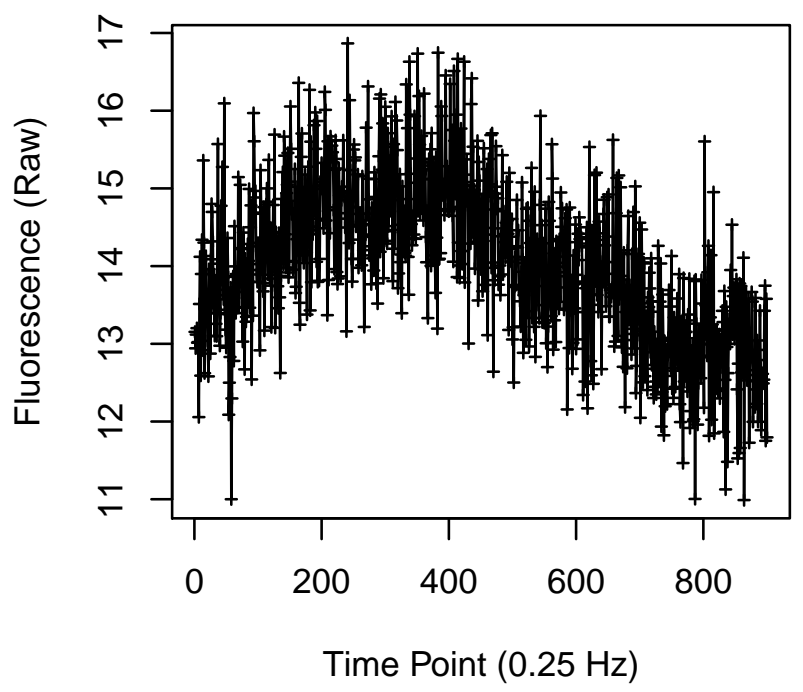

Cell 1736

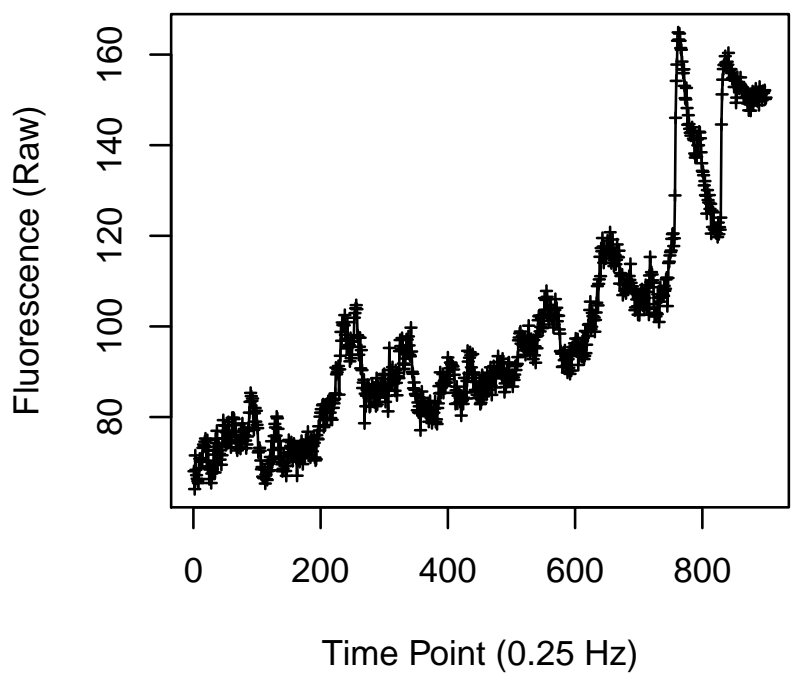


Cell 1737

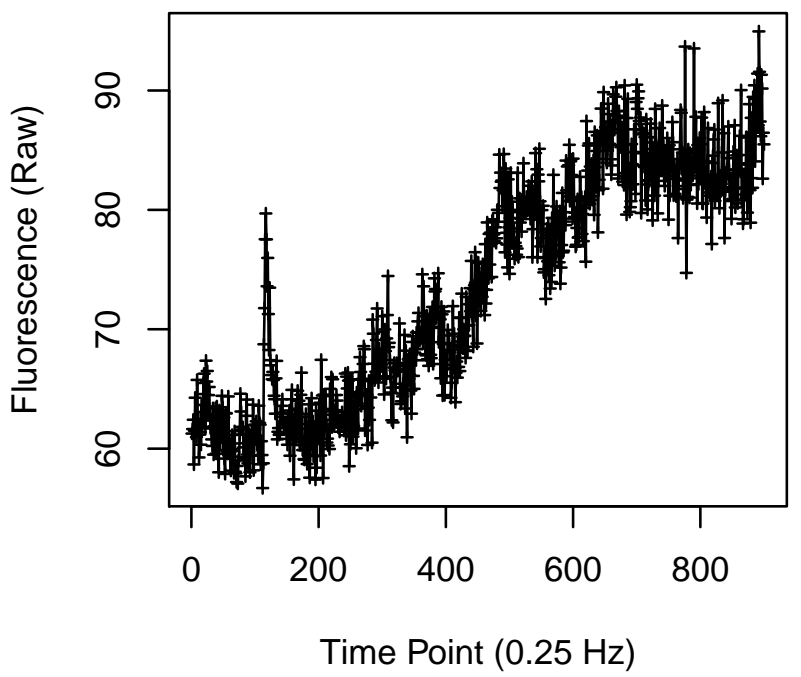

Cell 1739

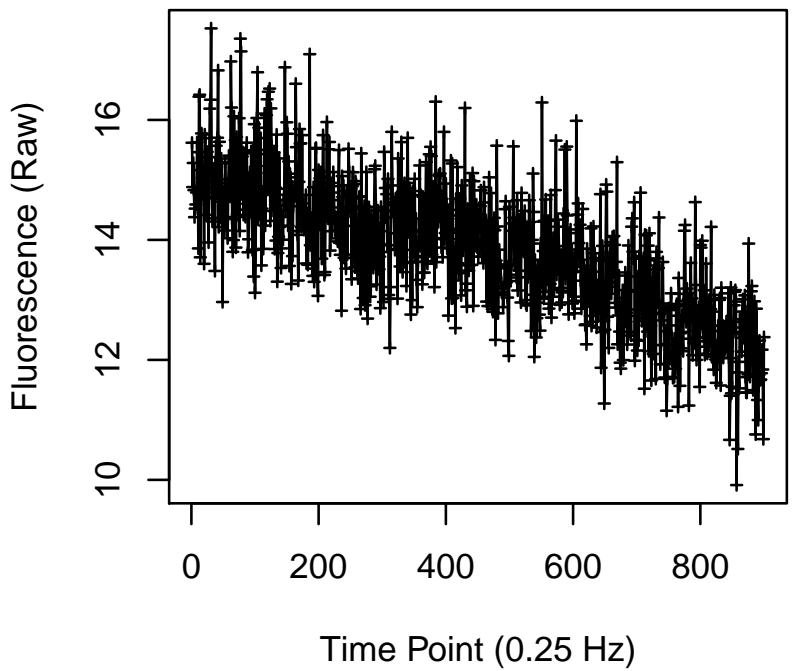

Cell 1738

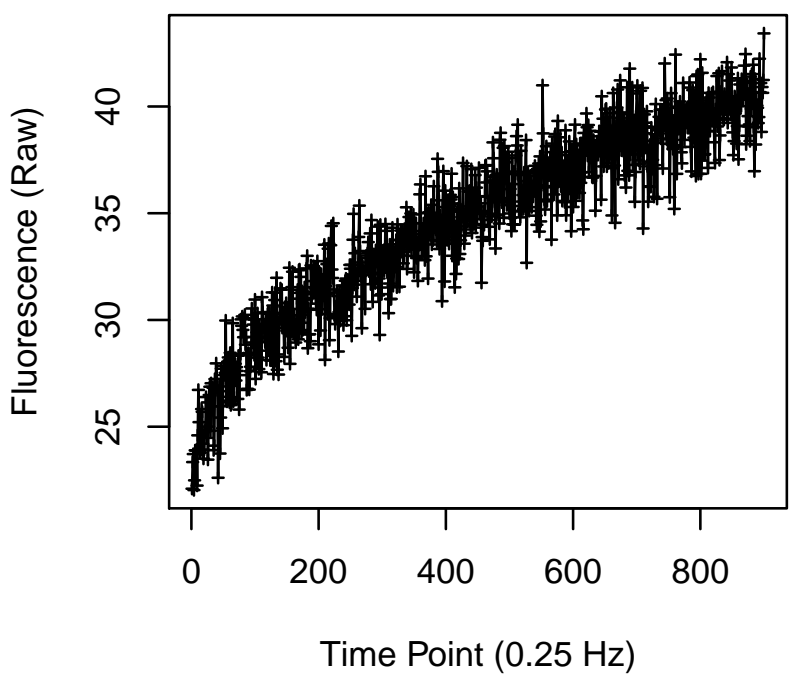

Cell 1740

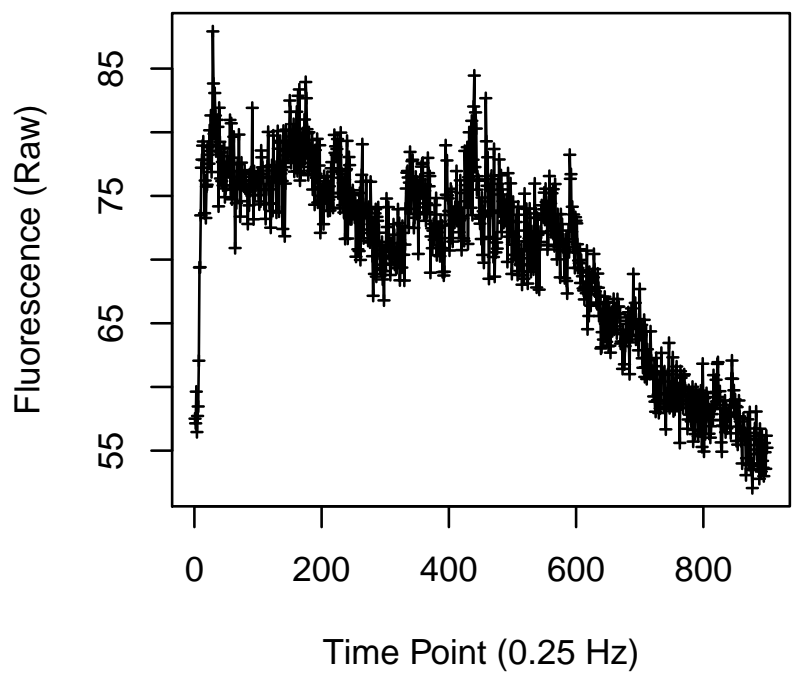


Cell 1753

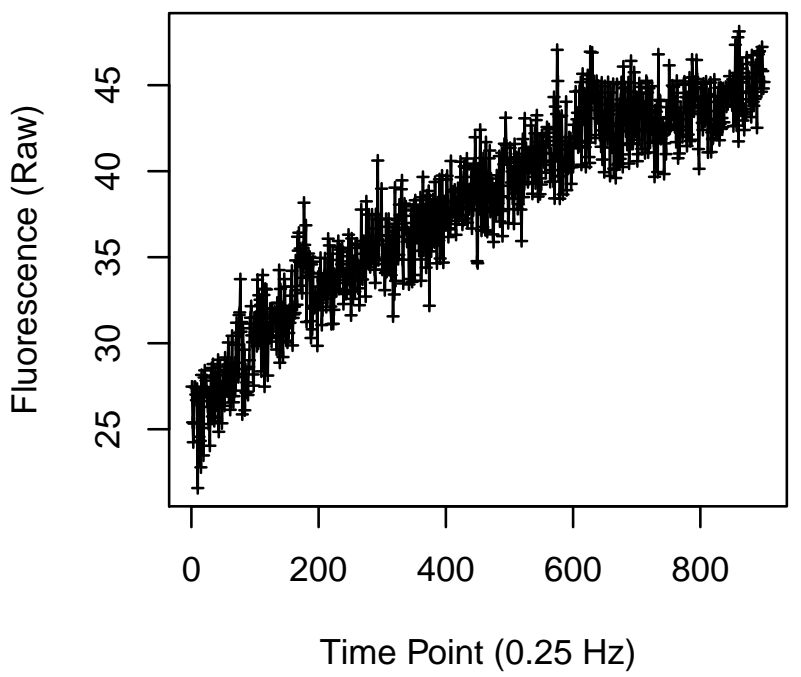

Cell 1755

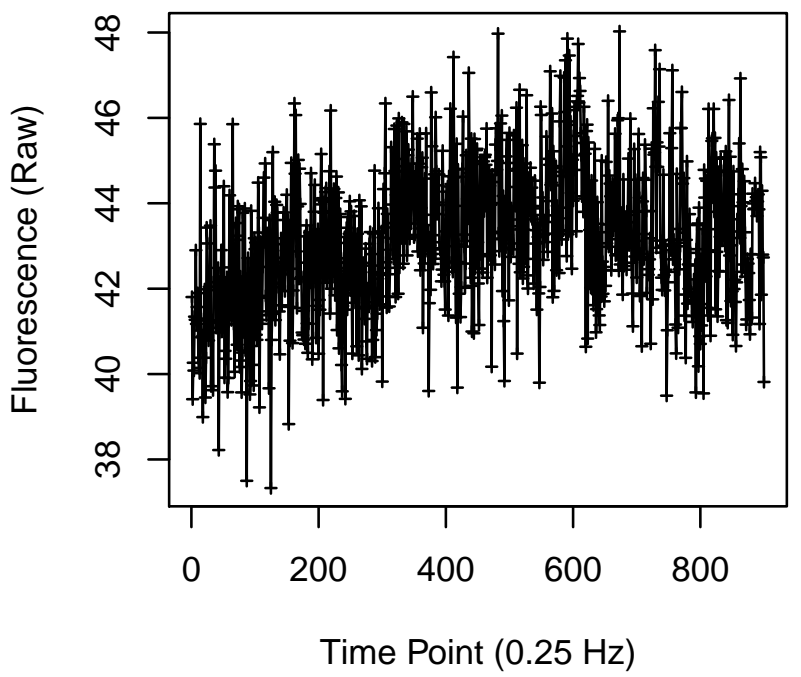

Cell 1754

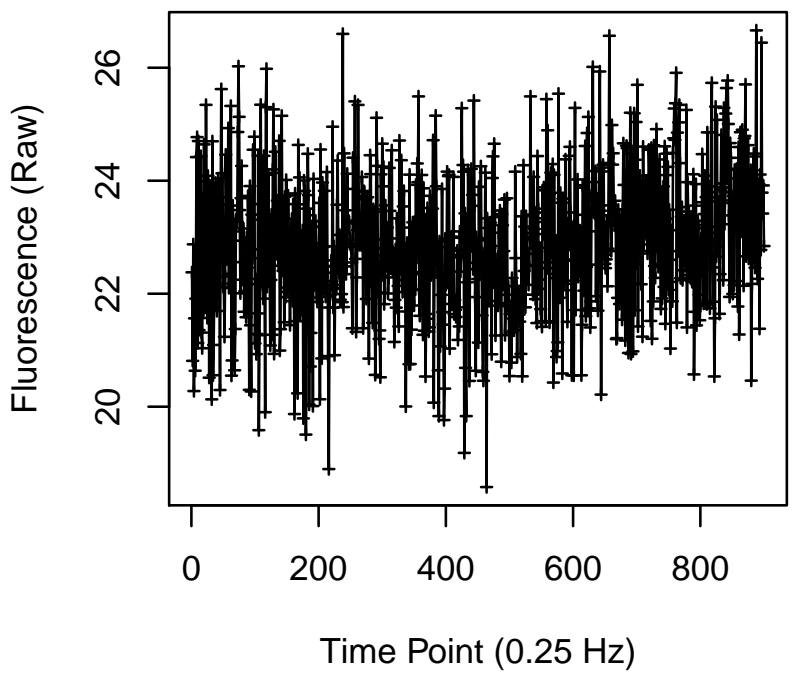

Cell 1756

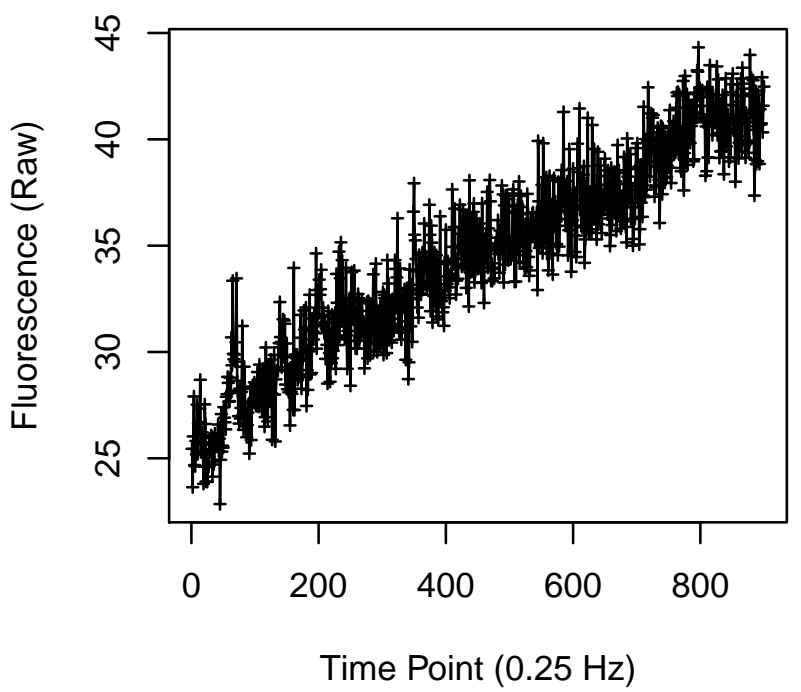


Cell 1761

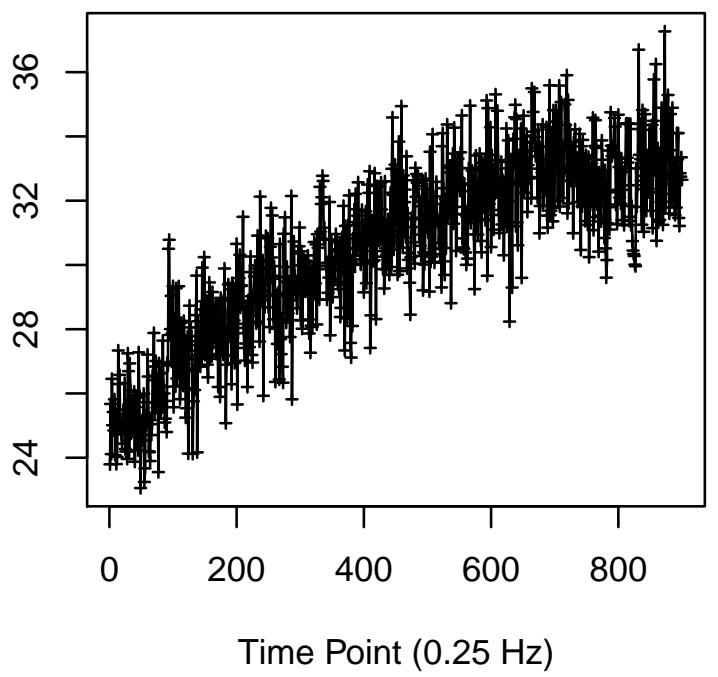

Cell 1763

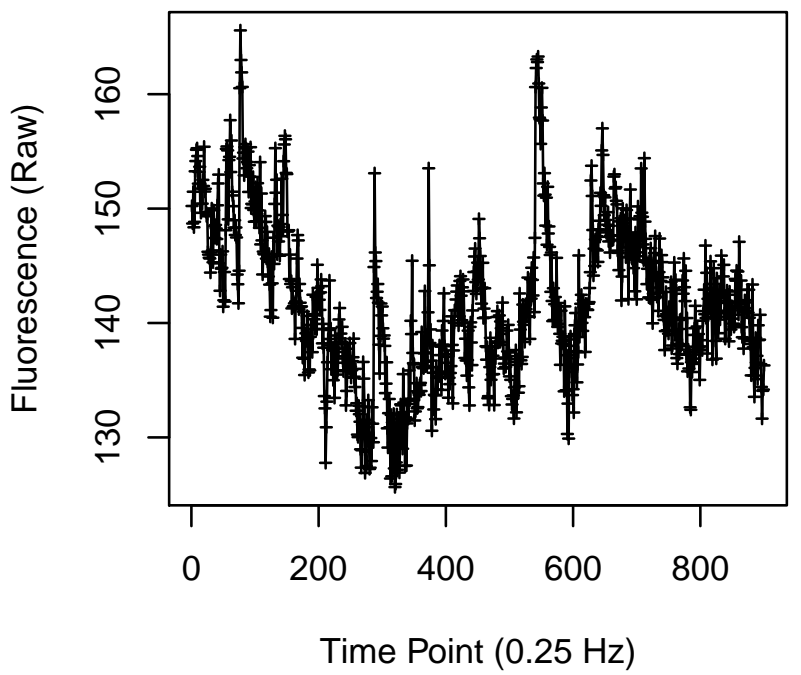

Cell 1762

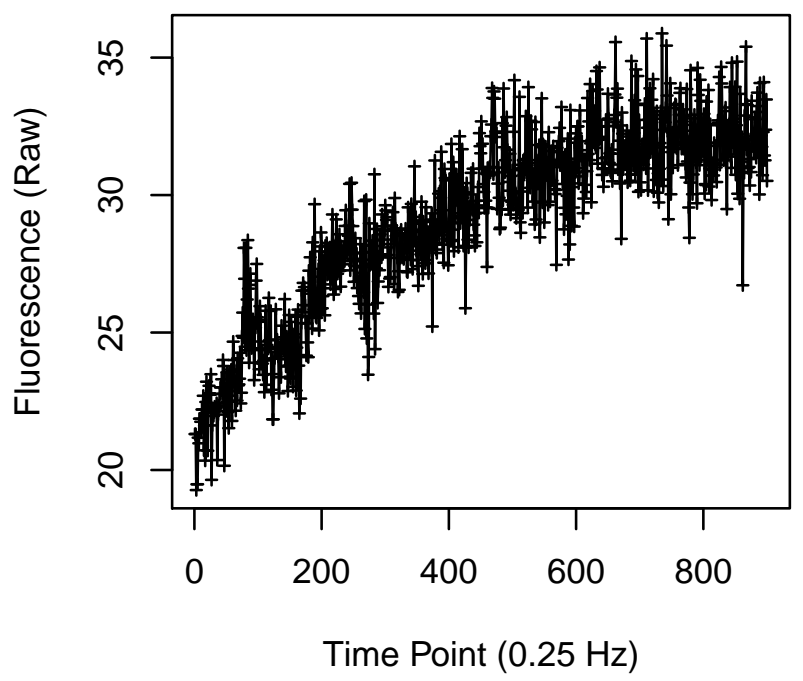

Cell 1764

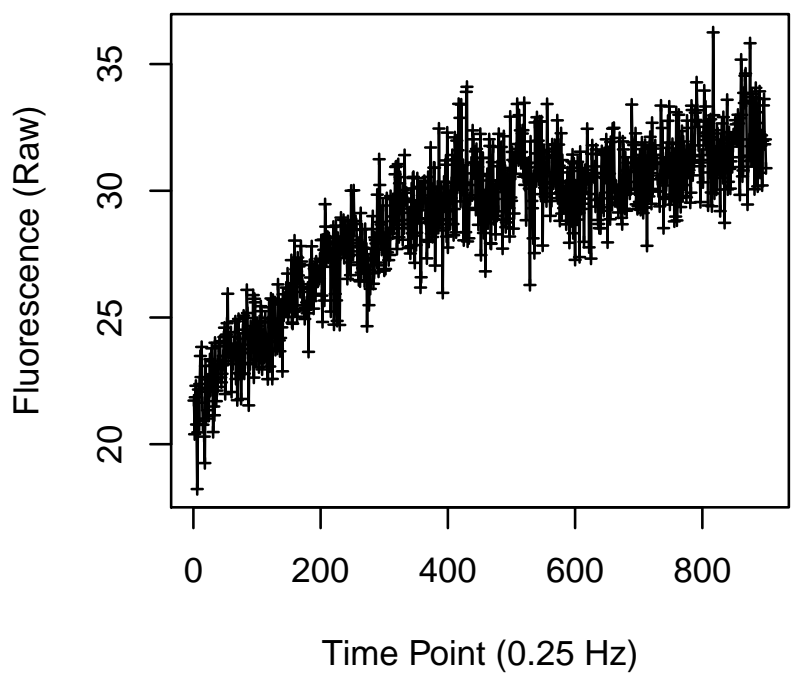


Cell 1765

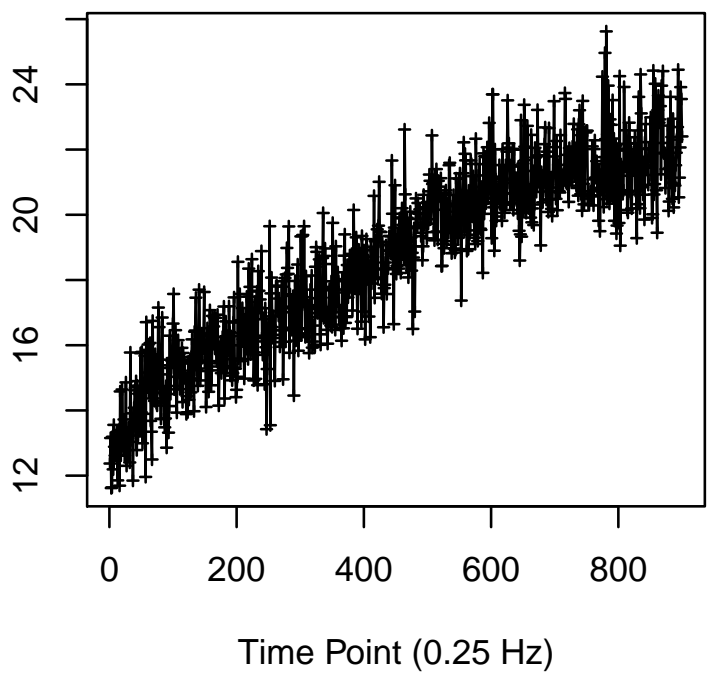

Cell 1767

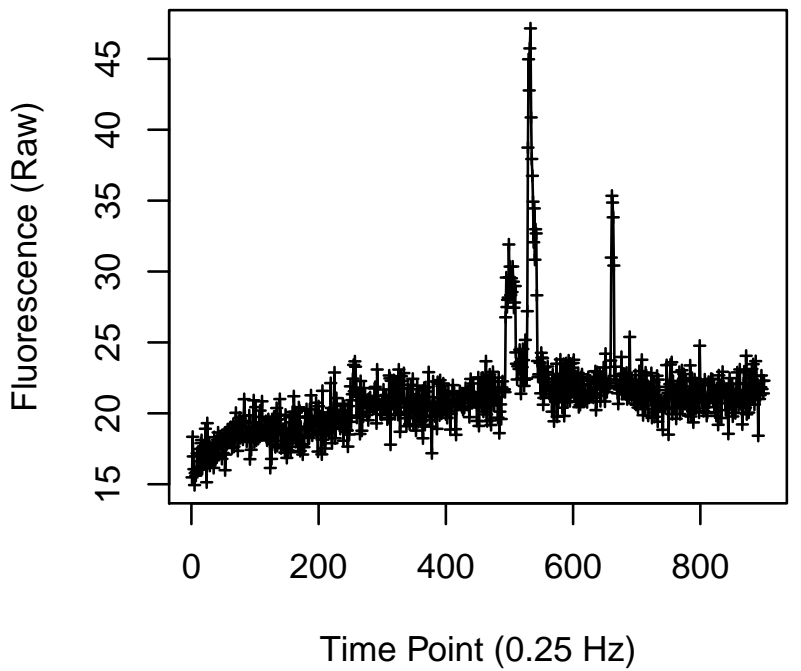

Cell 1766

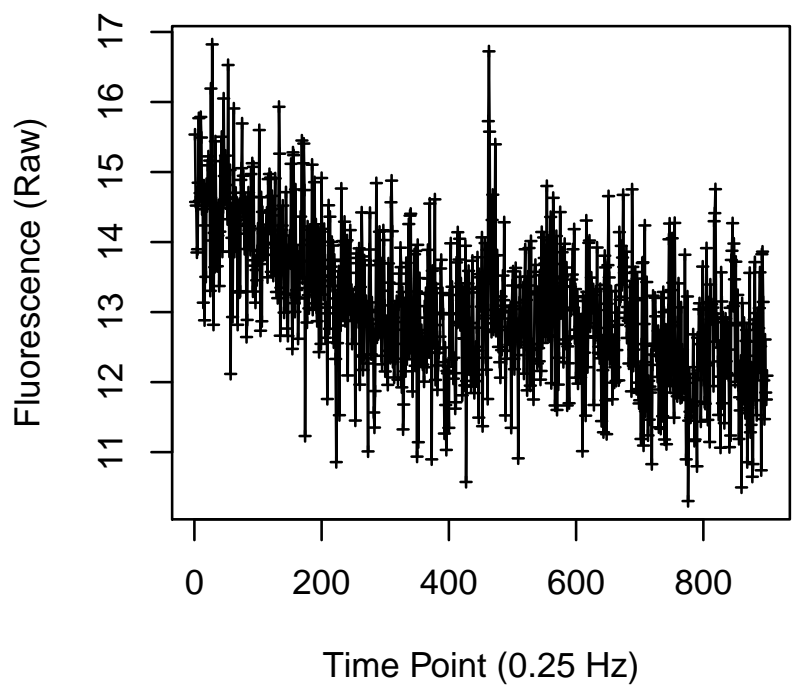

Cell 1768

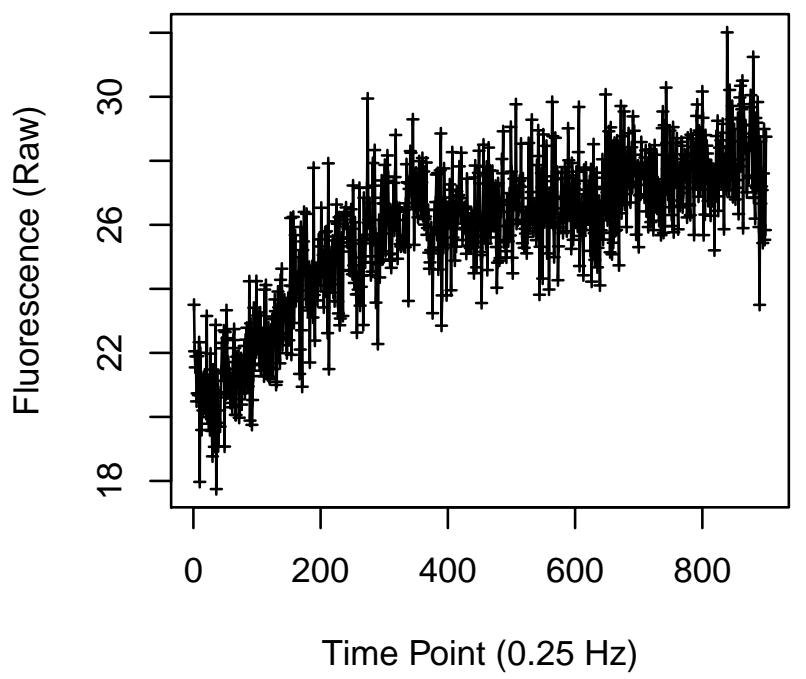


Cell 1769

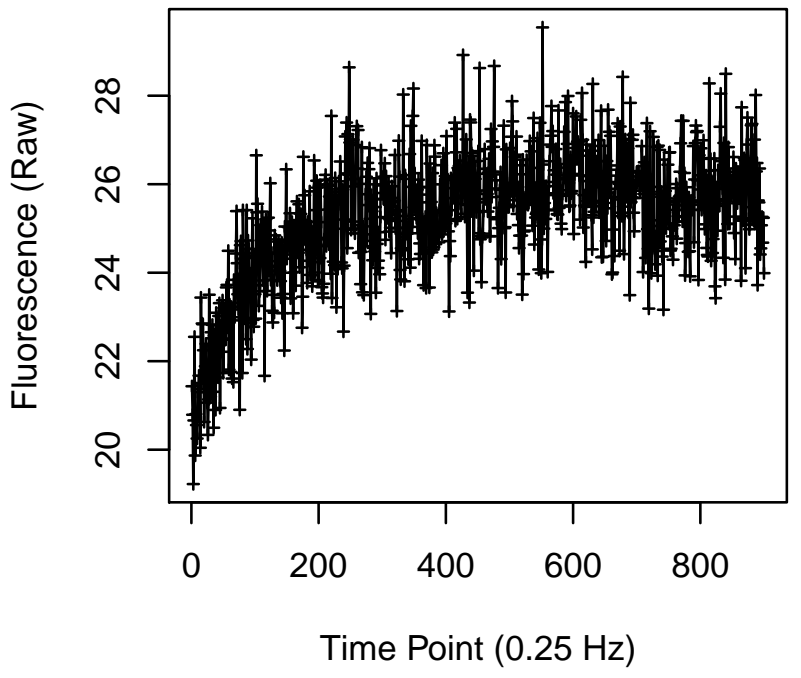

Cell 1771

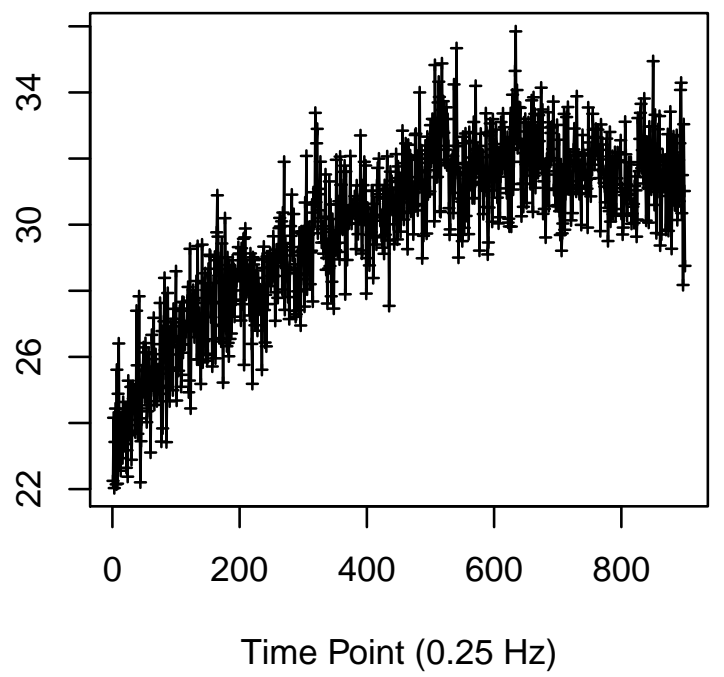

Cell 1770

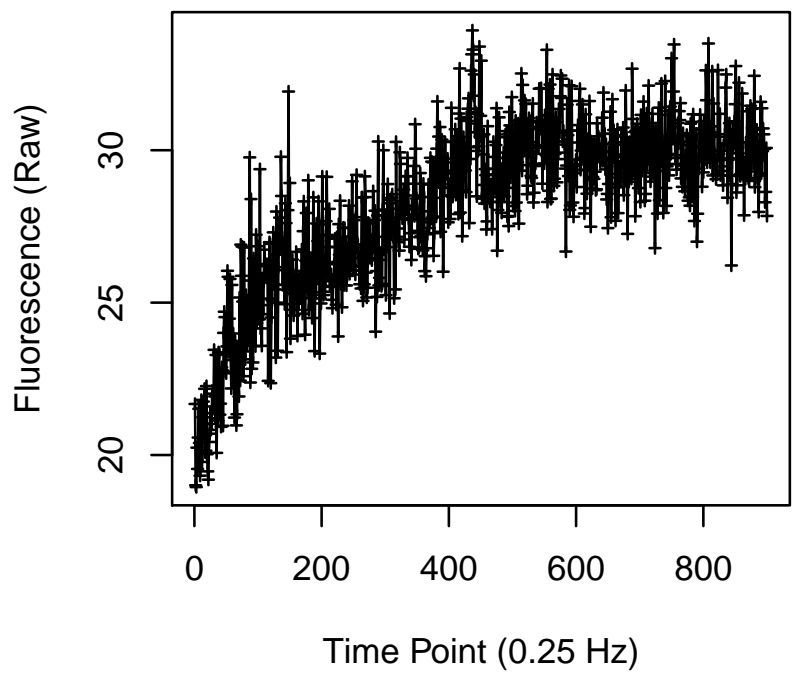

Cell 1772

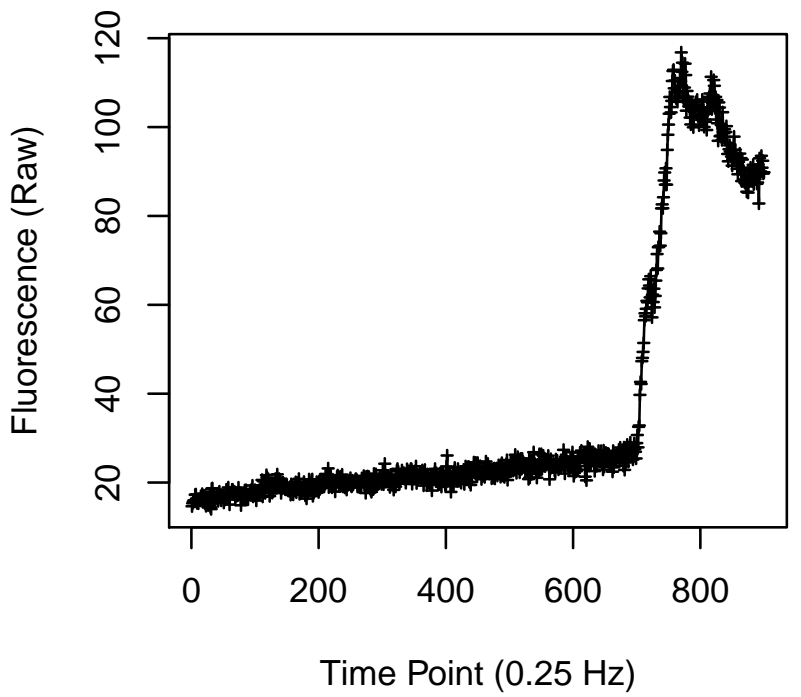


Cell 1773

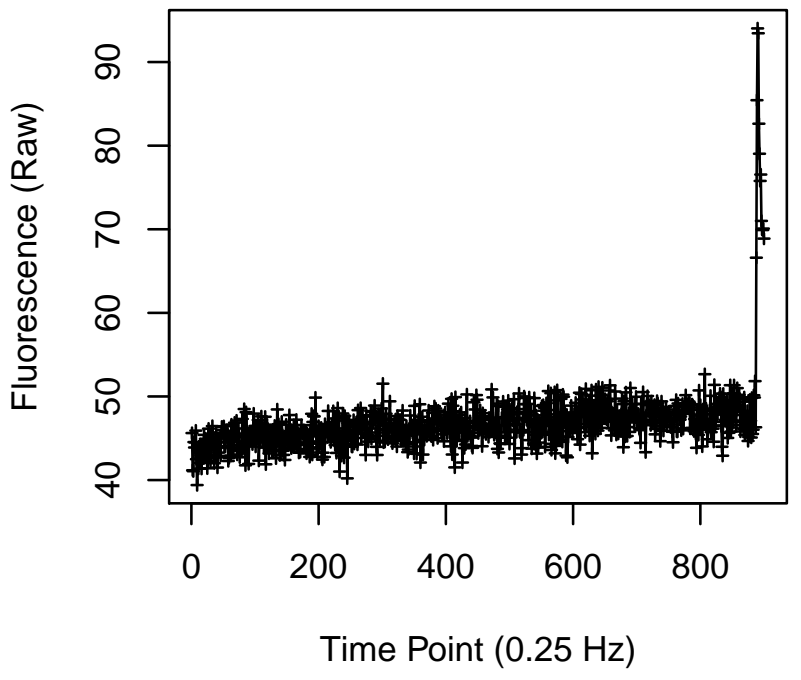

Cell 1775

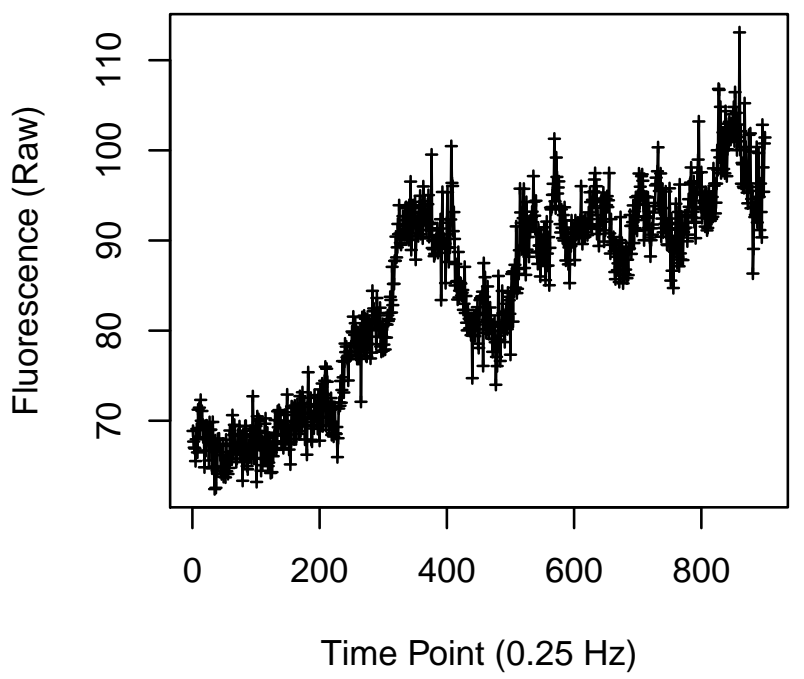

Cell 1774

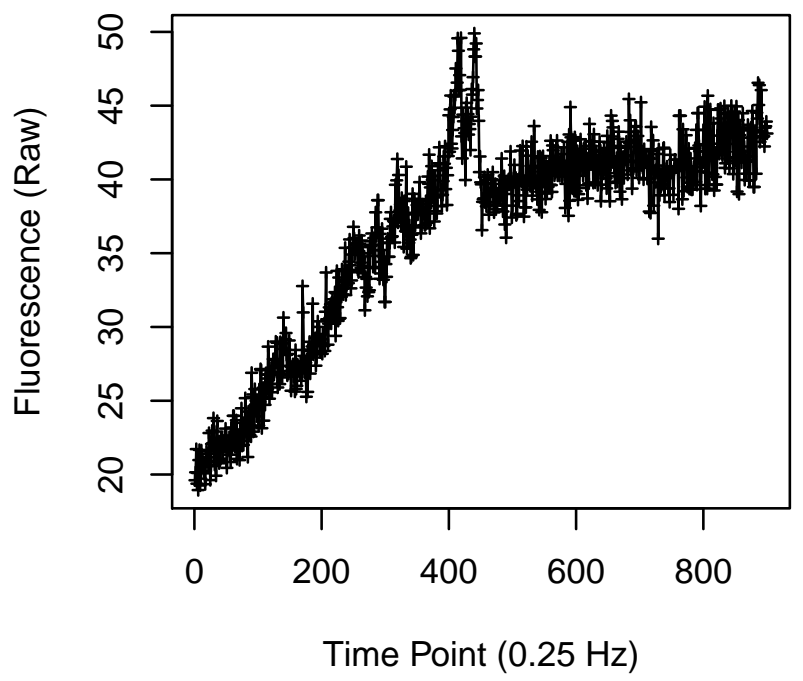

Cell 1776

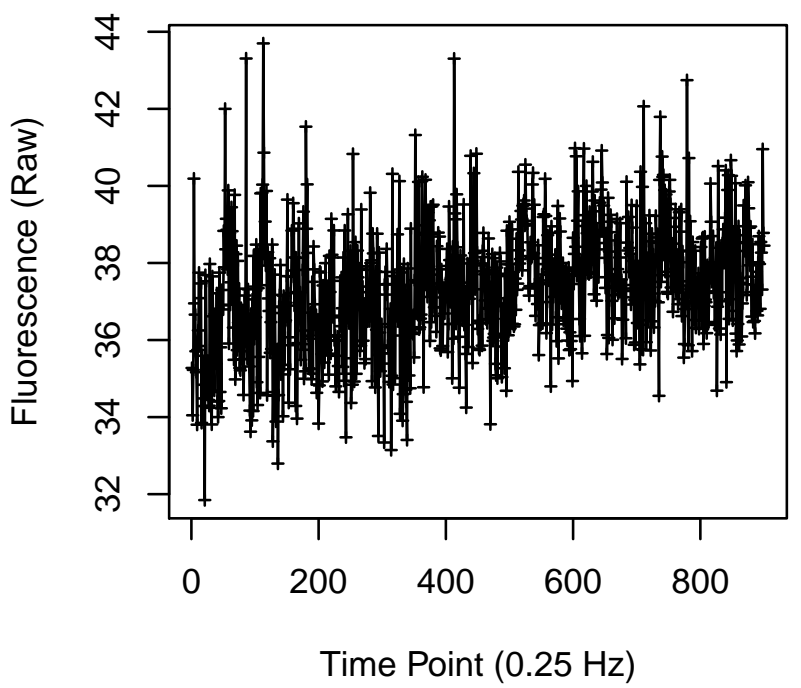


Cell 1777

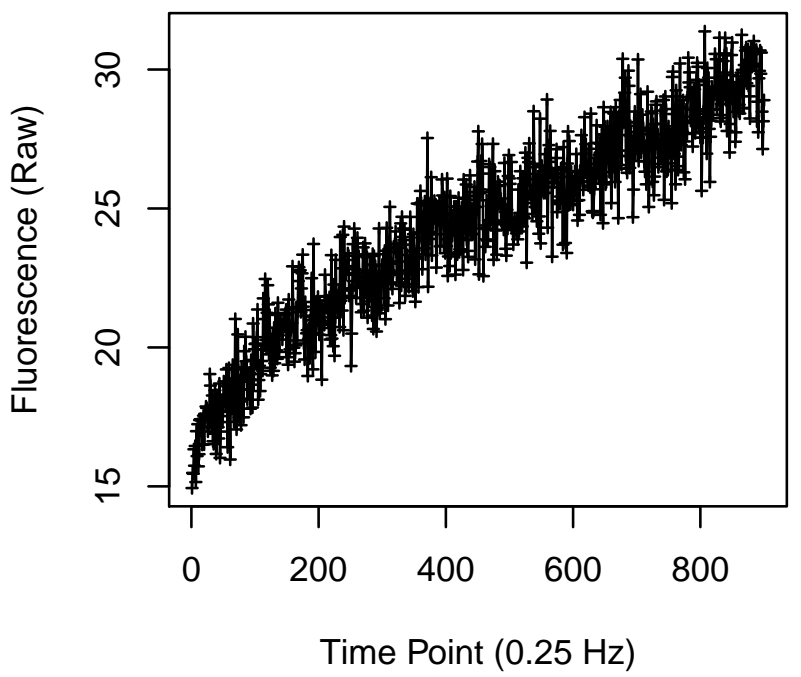

Cell 1779

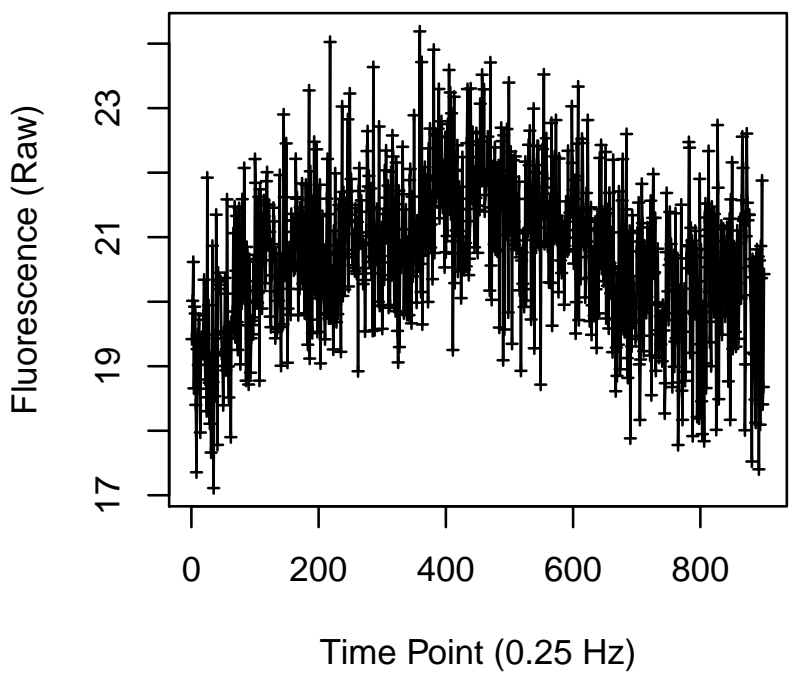

Cell 1778

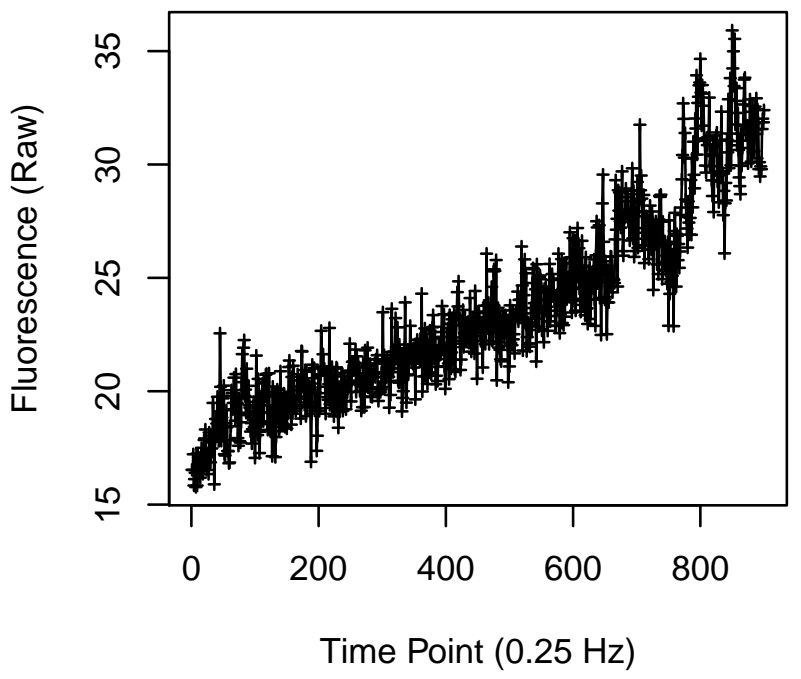

Cell 1780

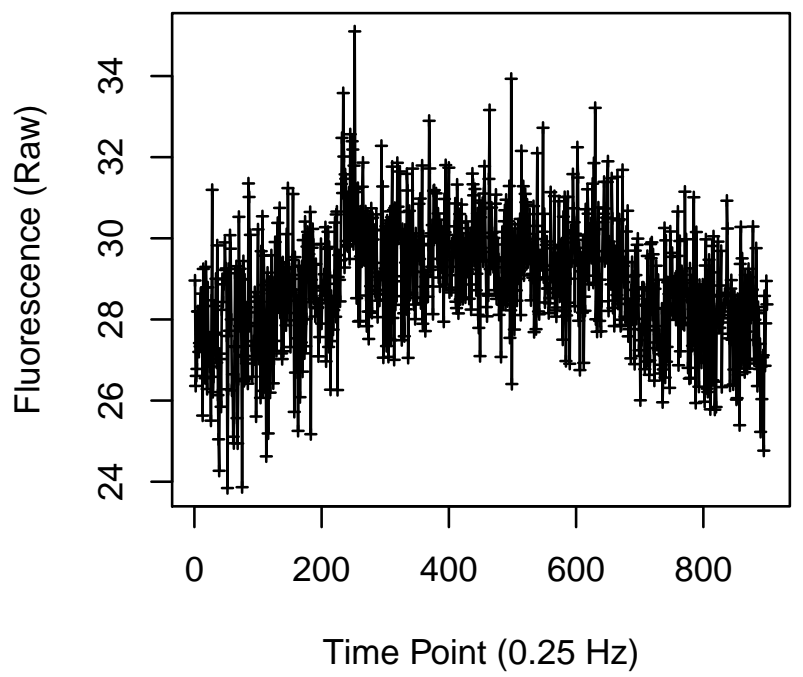


Cell 1781

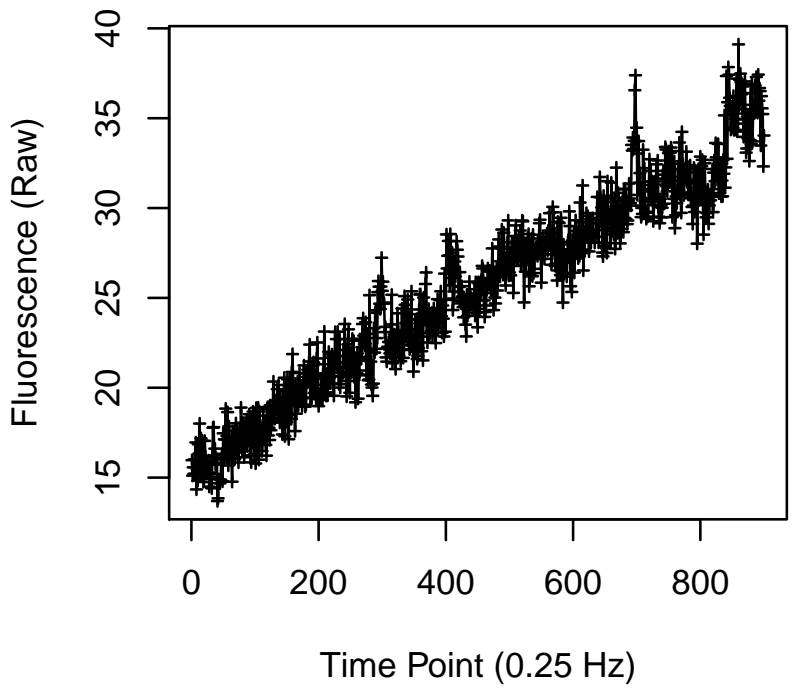

Cell 1783

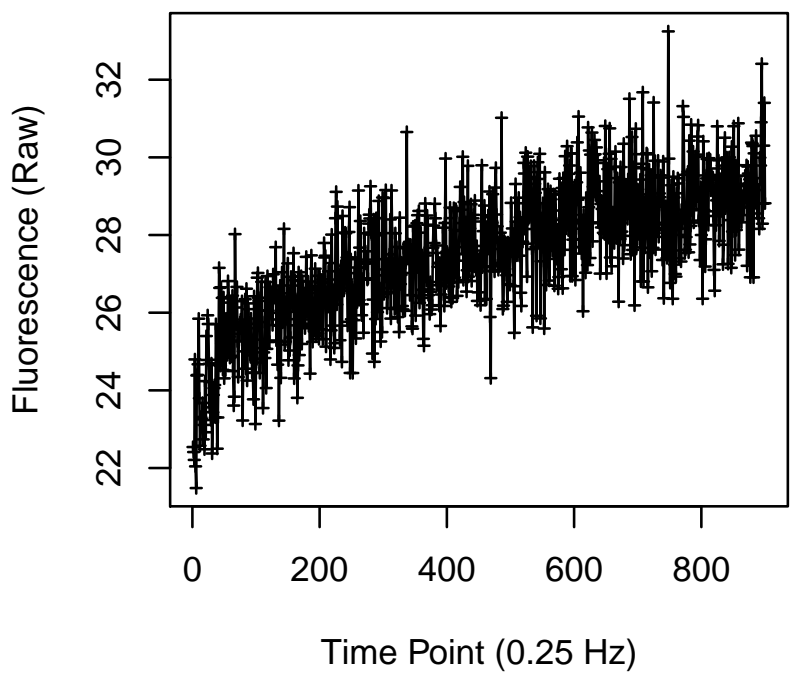

Cell 1782

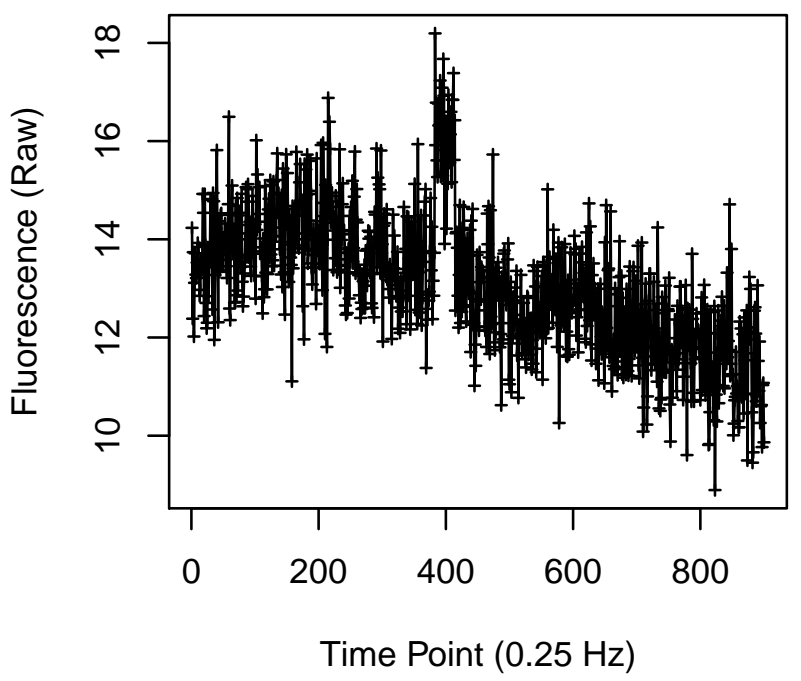

Cell 1784

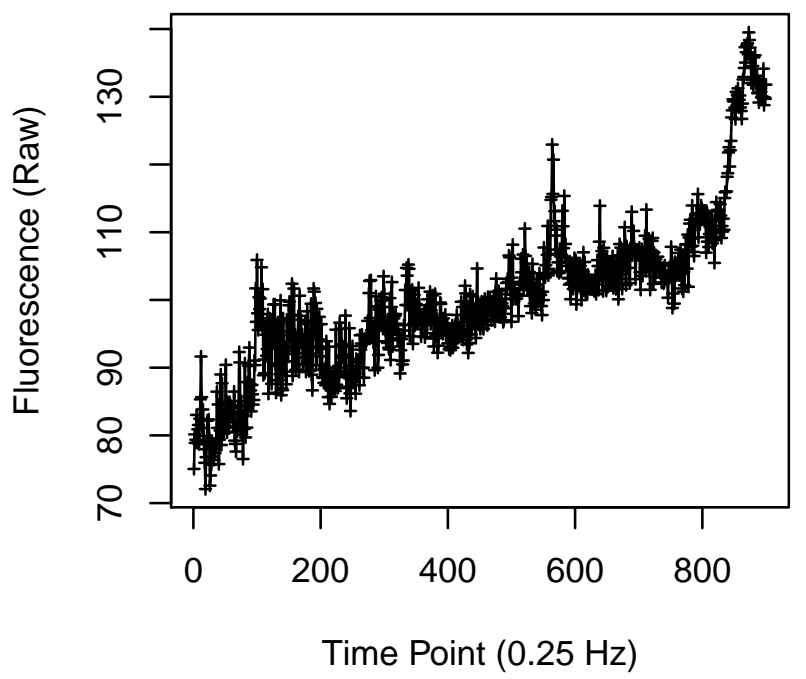


Cell 1789

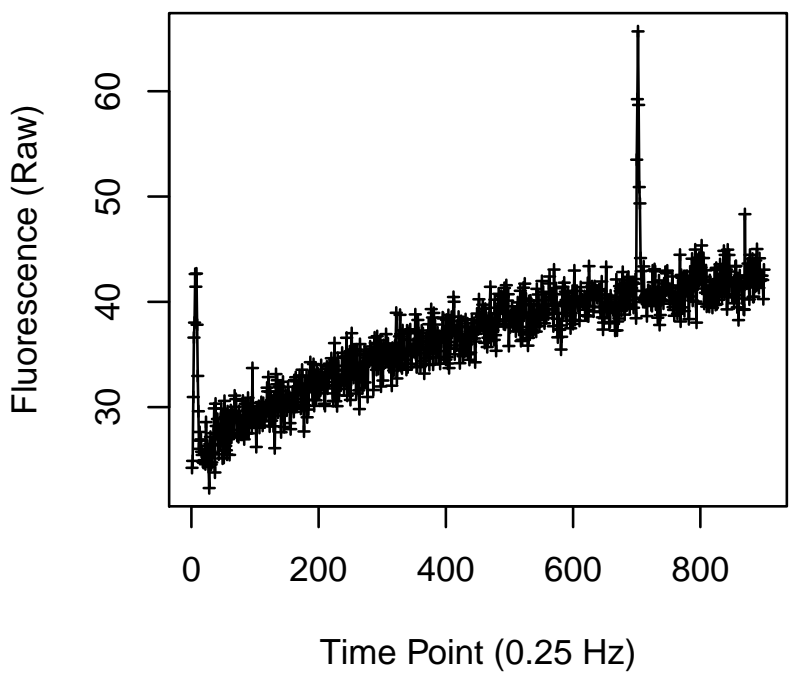

Cell 1791

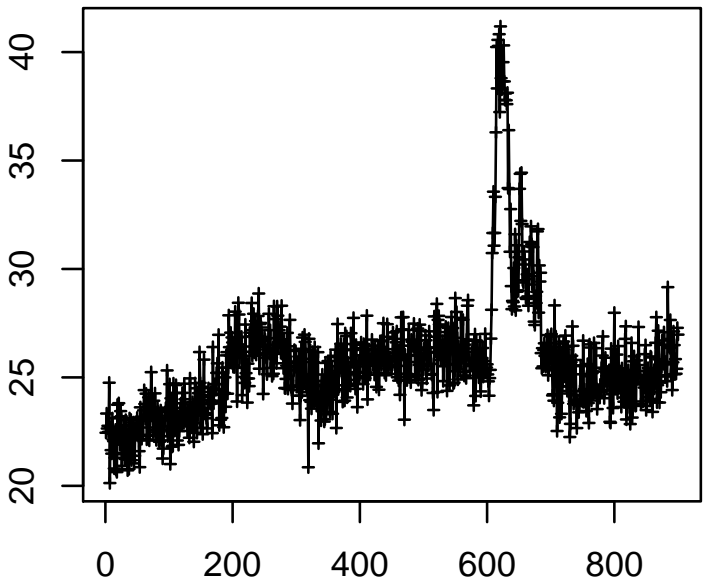

Time Point $(0.25 \mathrm{~Hz})$
Cell 1790

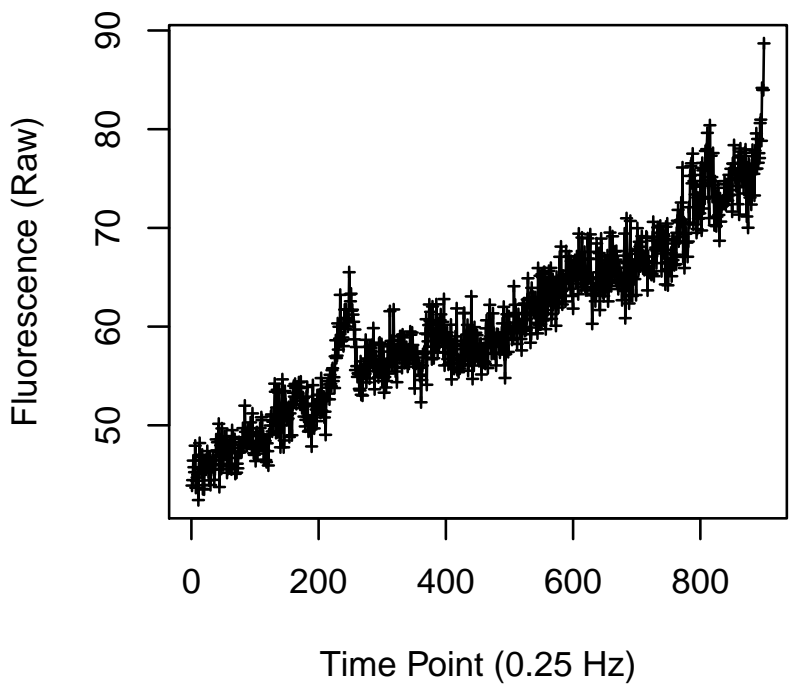

Cell 1792

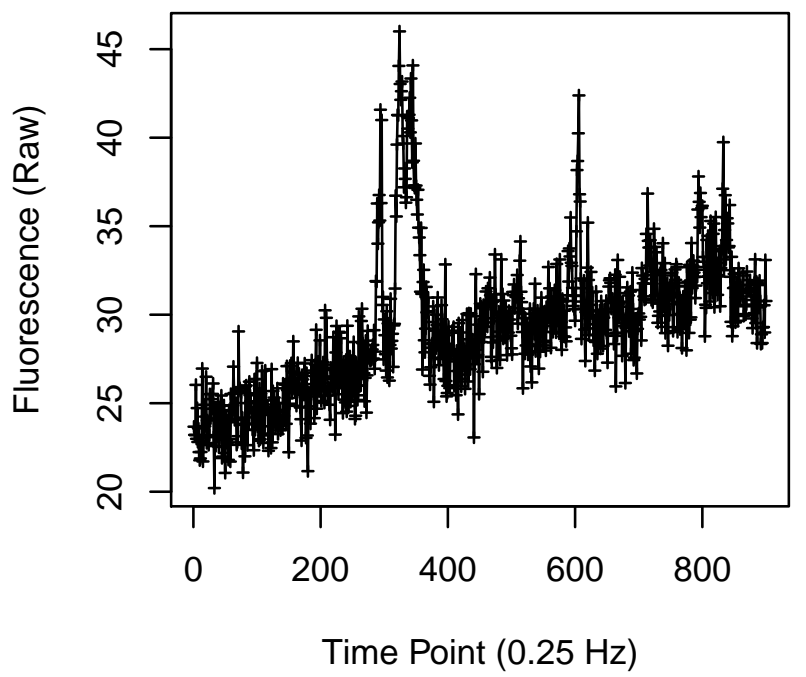


Cell 1793

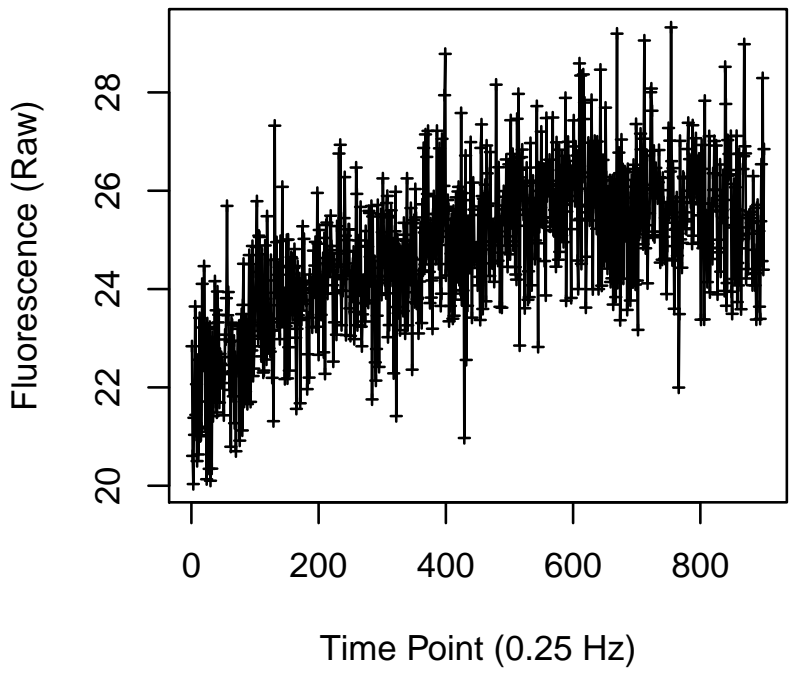

Cell 1795

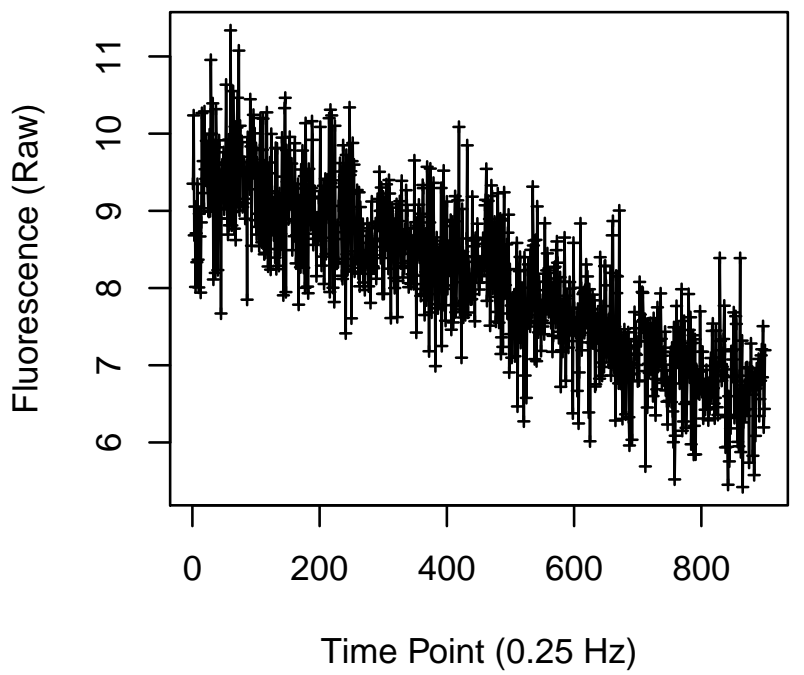

Cell 1794

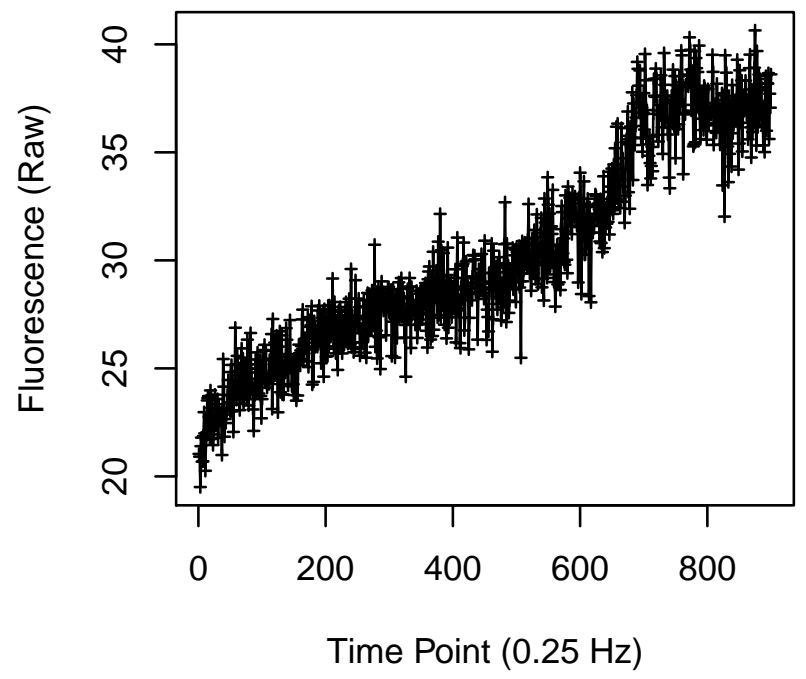

Cell 1796

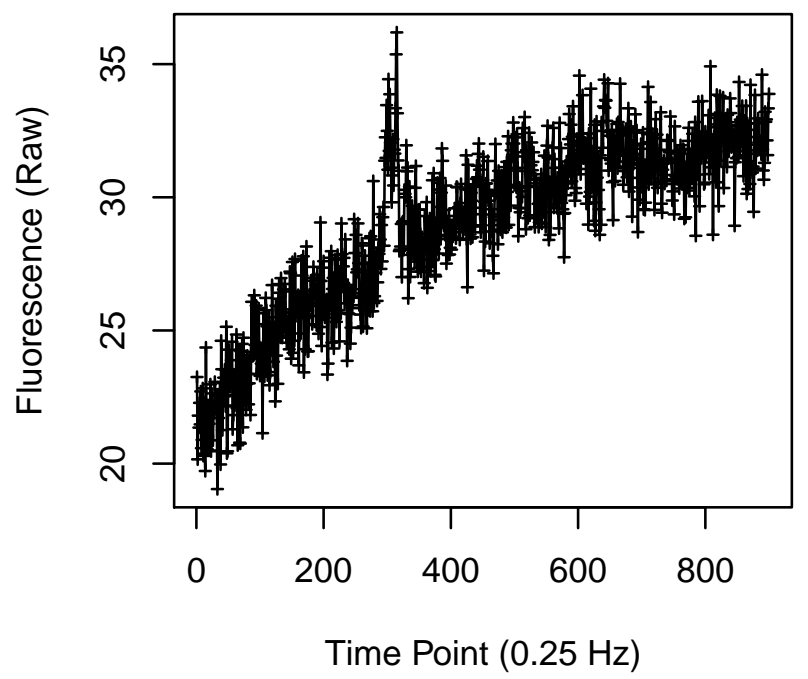


Cell 1797

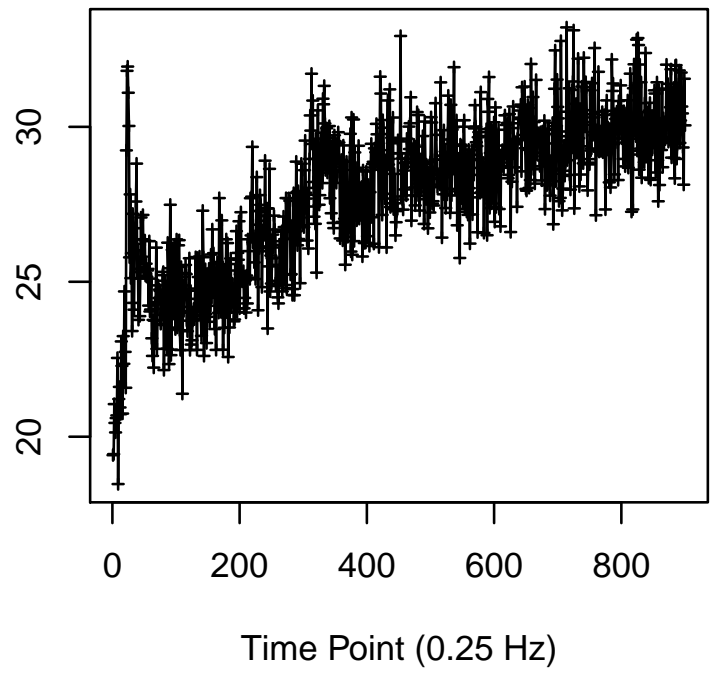

Cell 1799

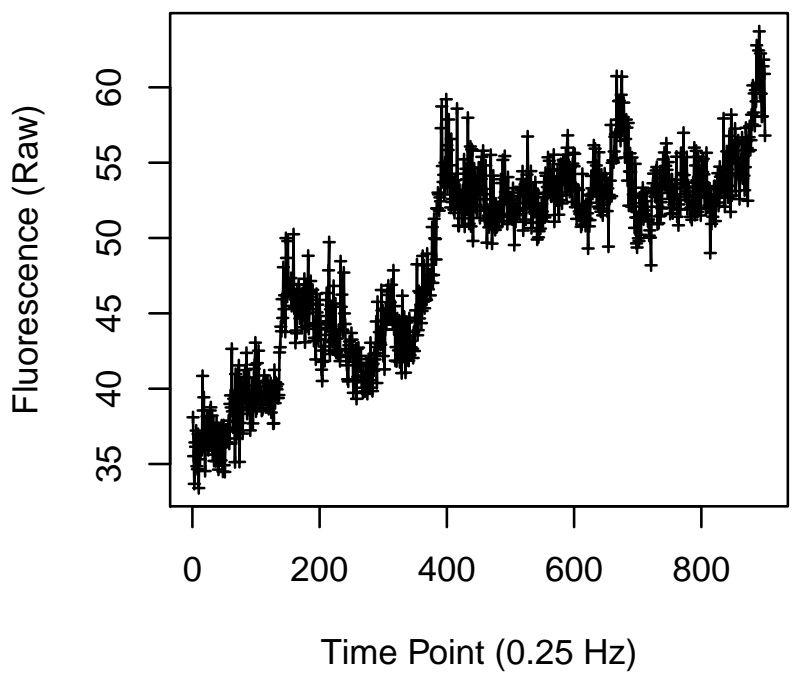

Cell 1798

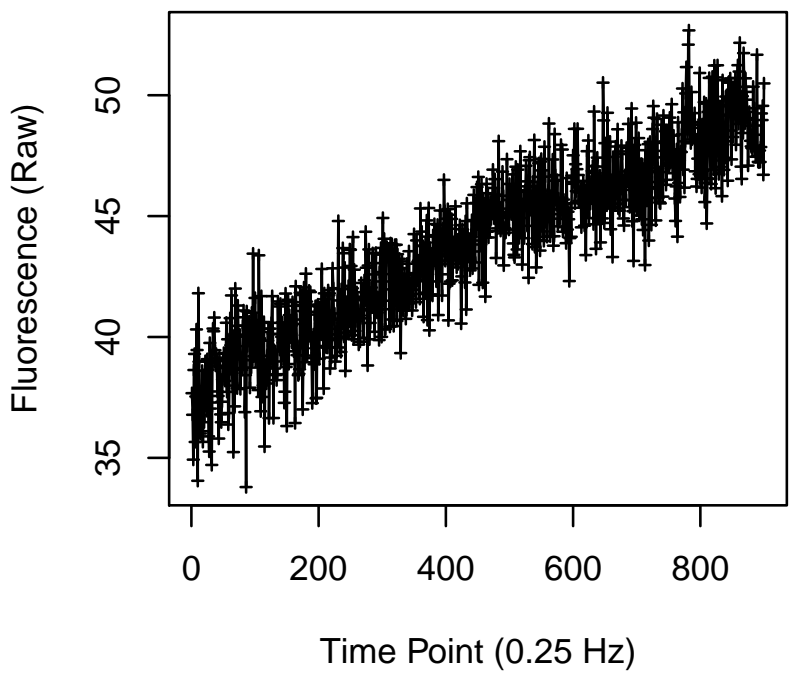

Cell 1800

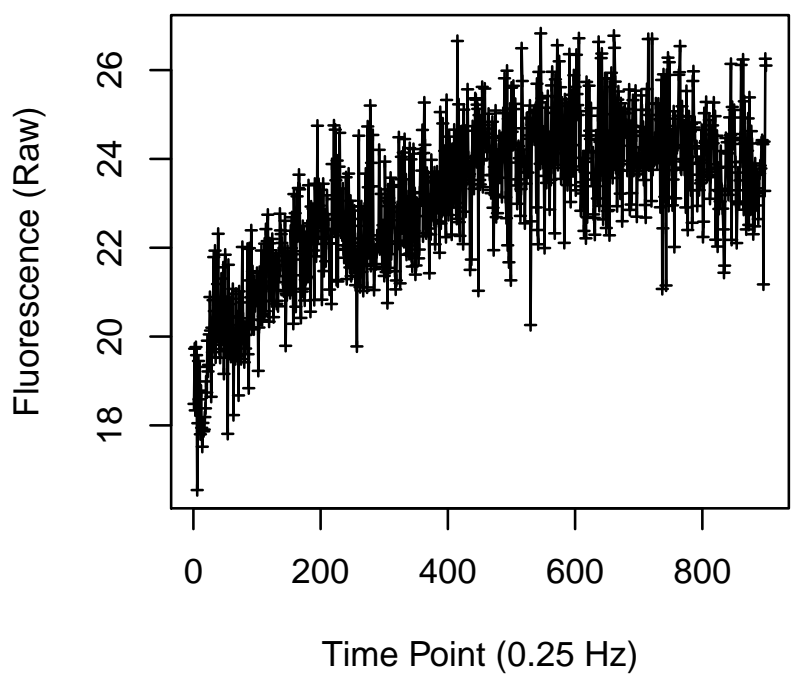


Cell 1801

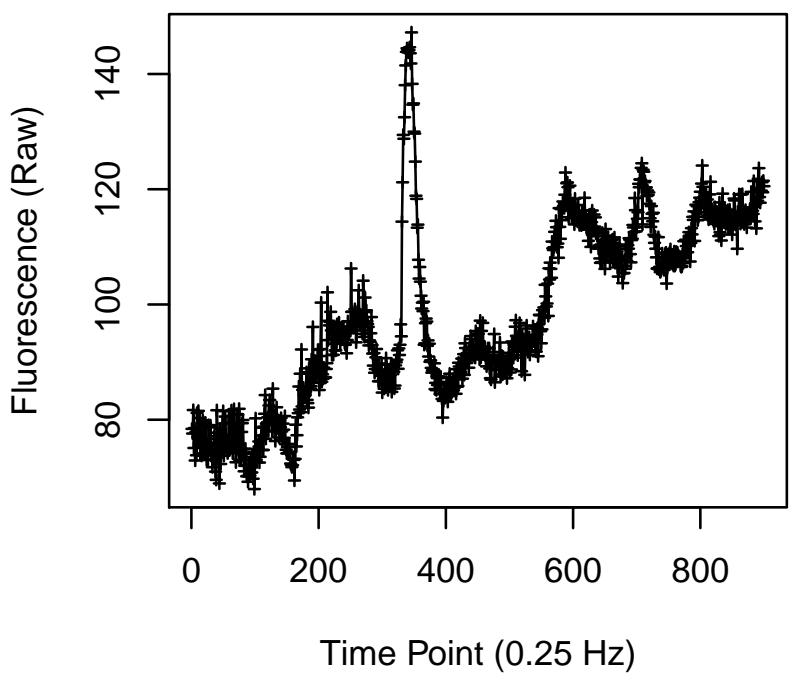

Cell 1803

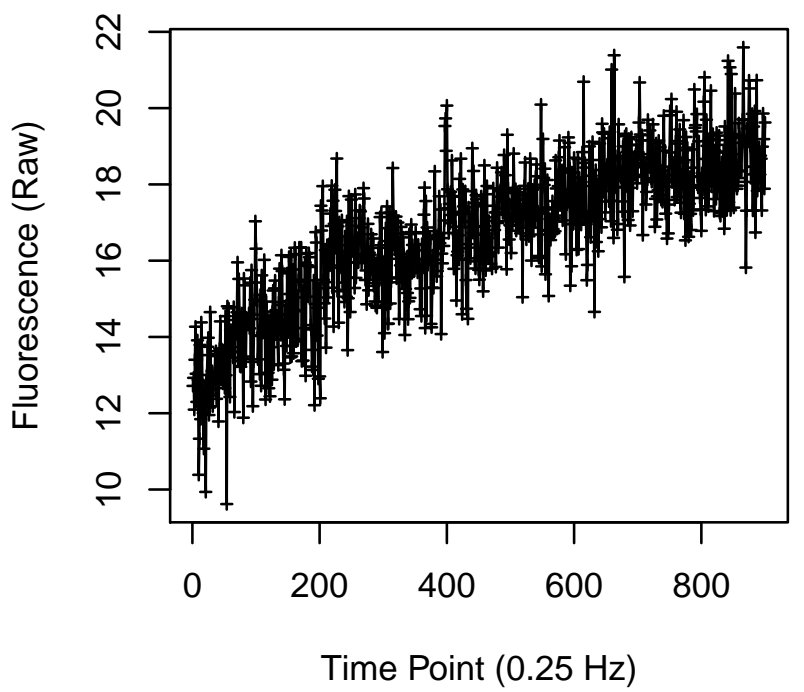

Cell 1802

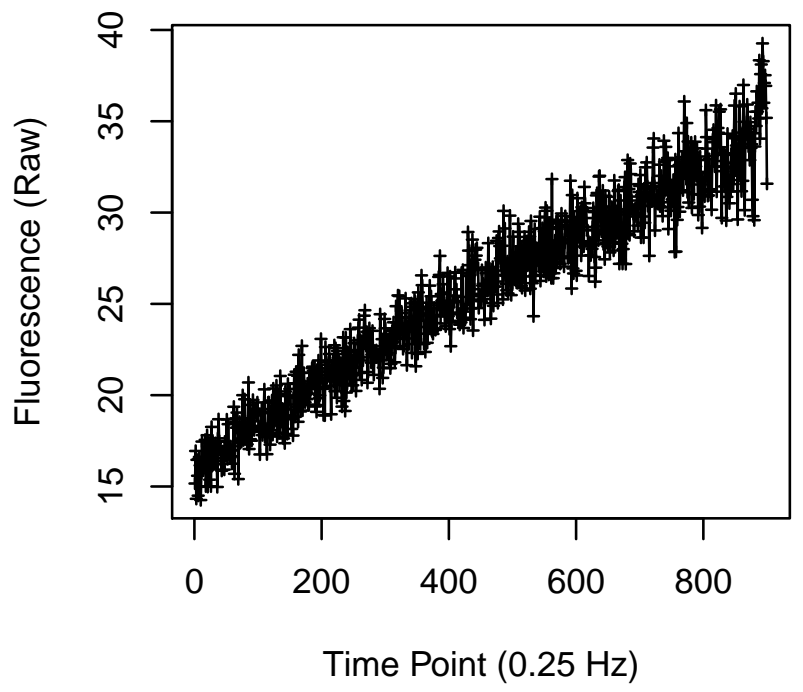

Cell 1804

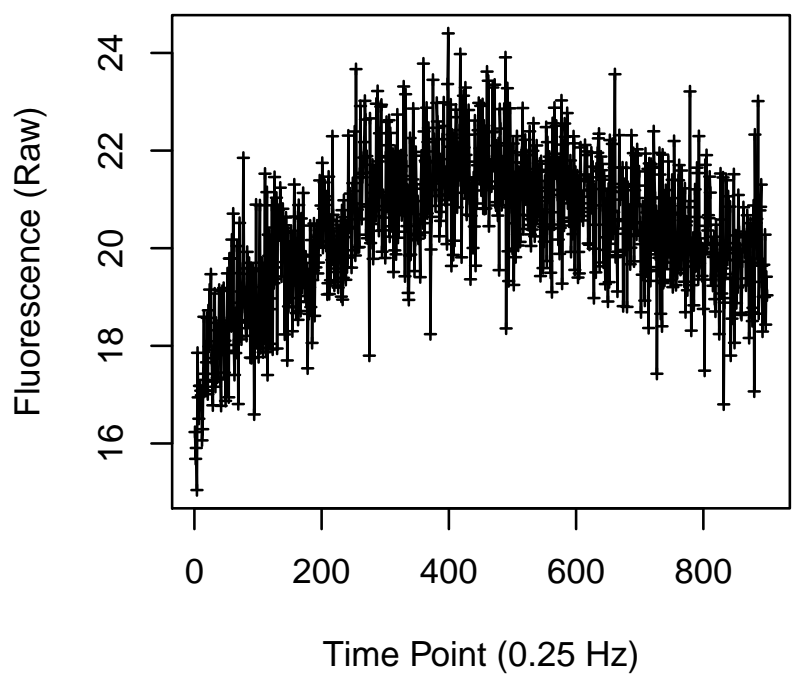


Cell 1805

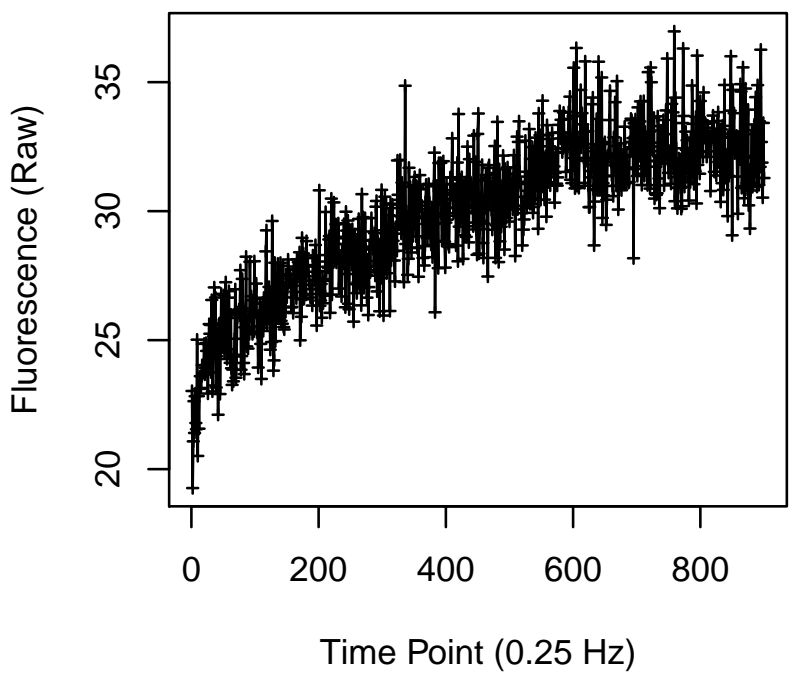

Cell 1807

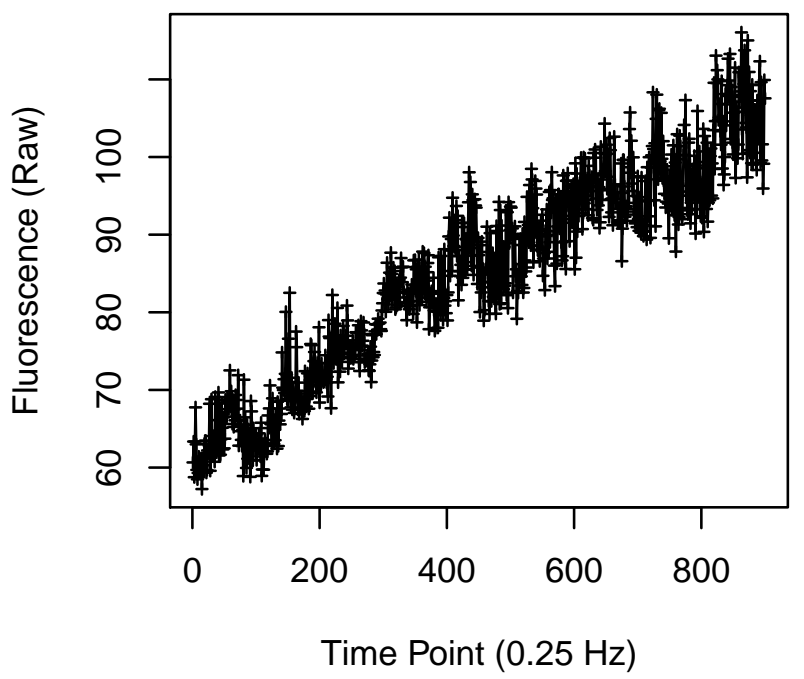

Cell 1806

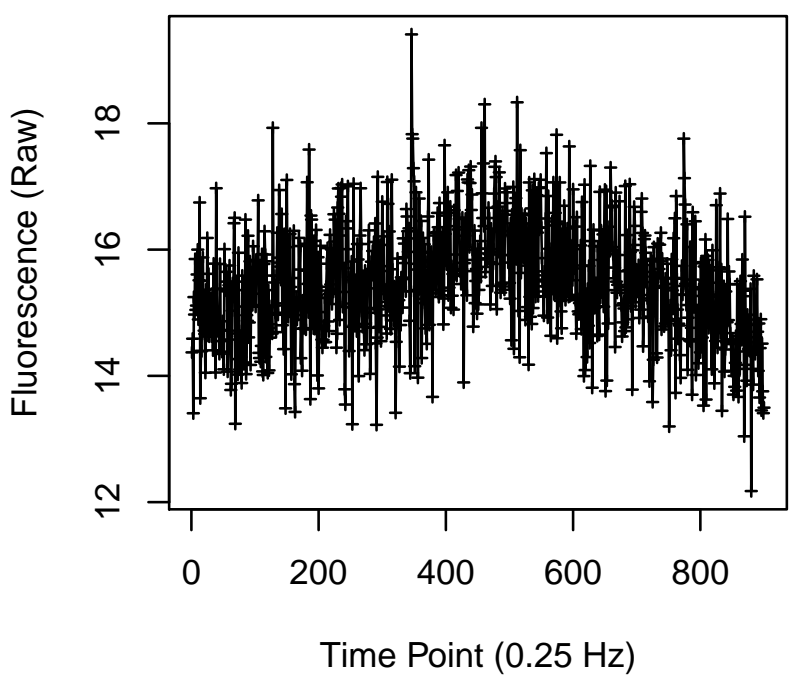

Cell 1808

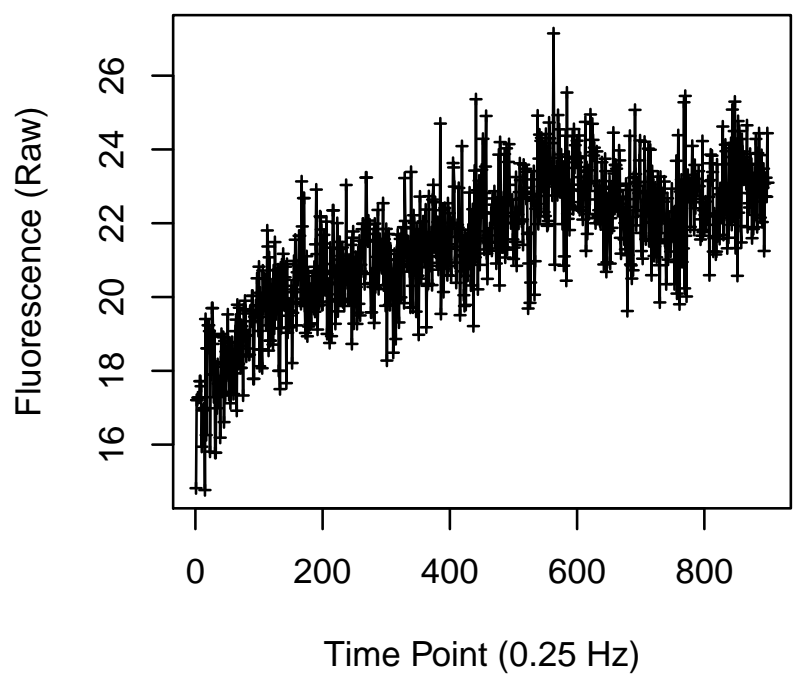


Cell 1813

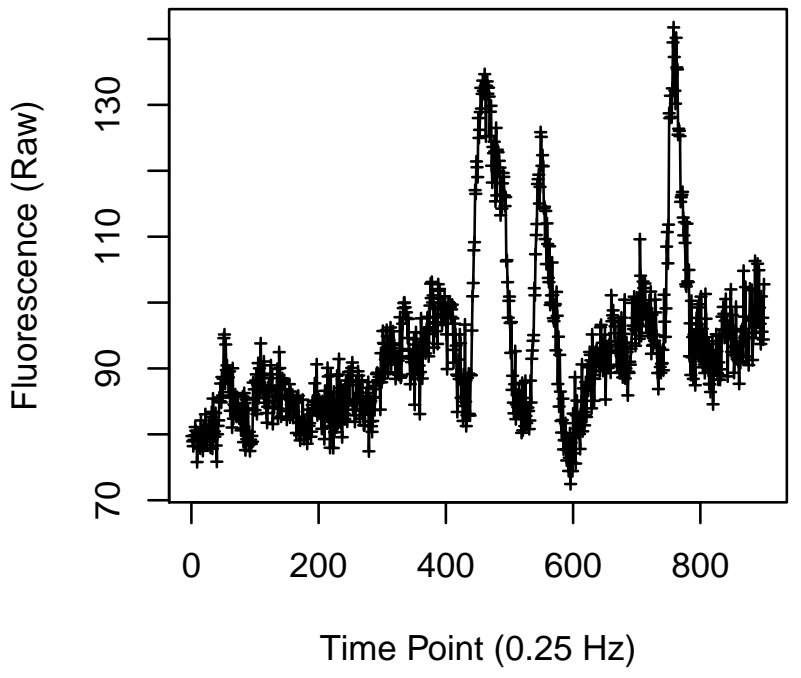

Cell 1815

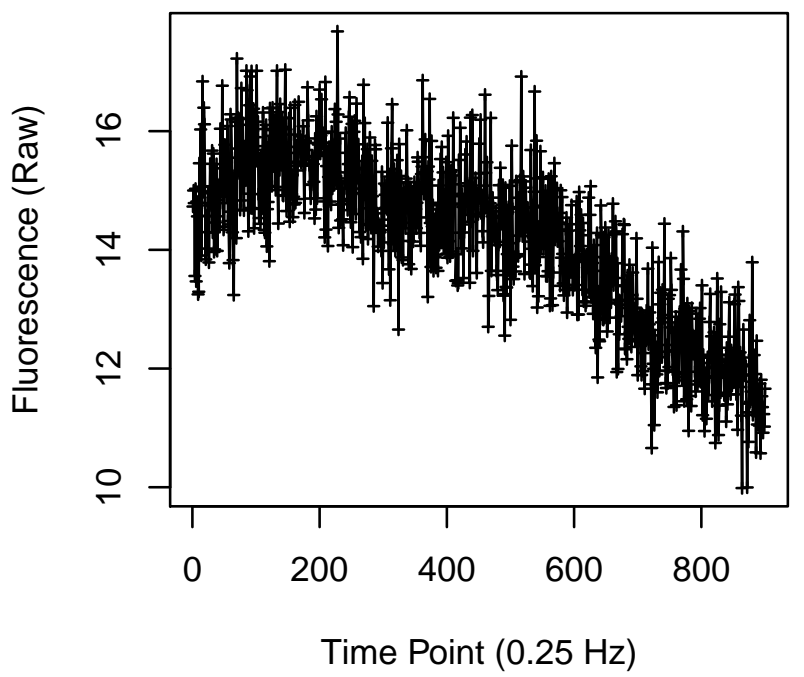

Cell 1814

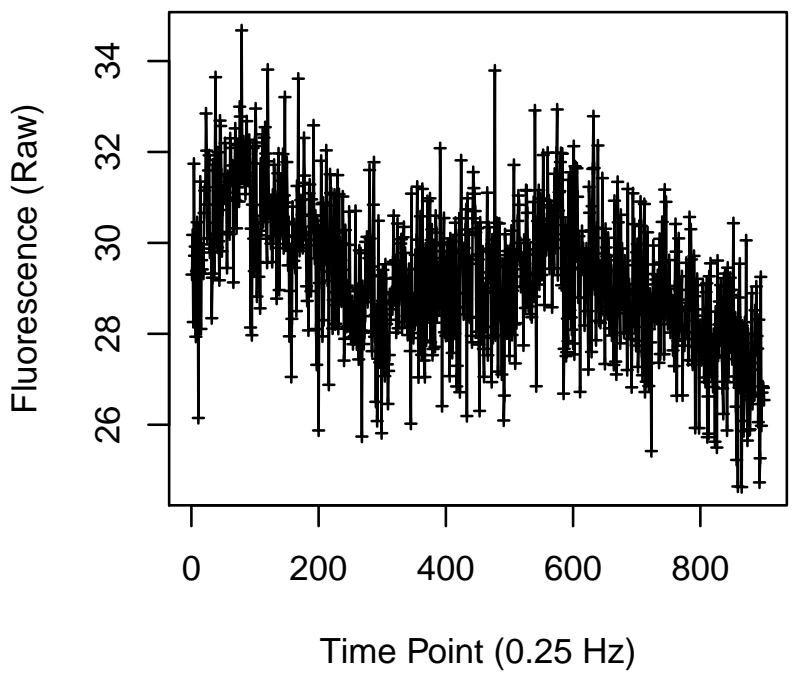

Cell 1816

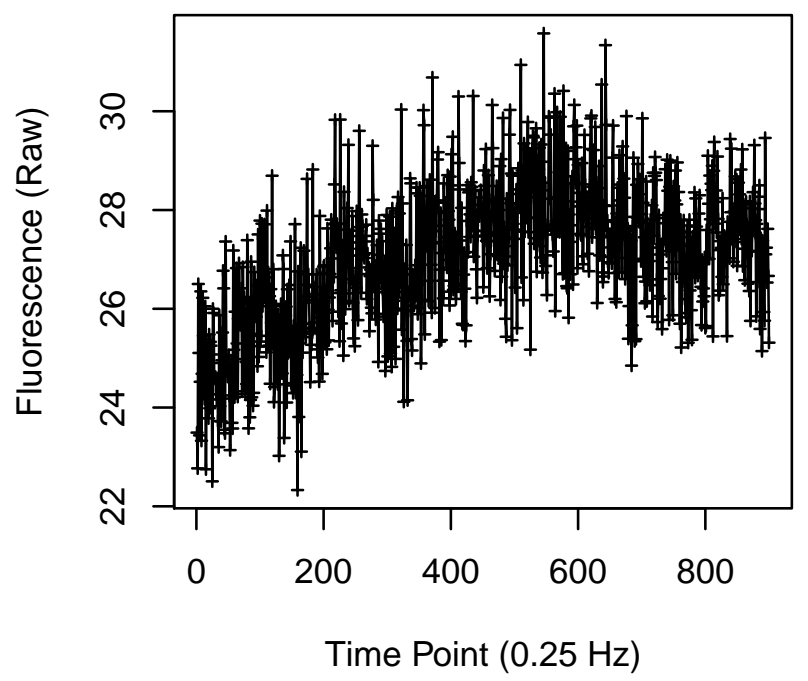


Cell 1817

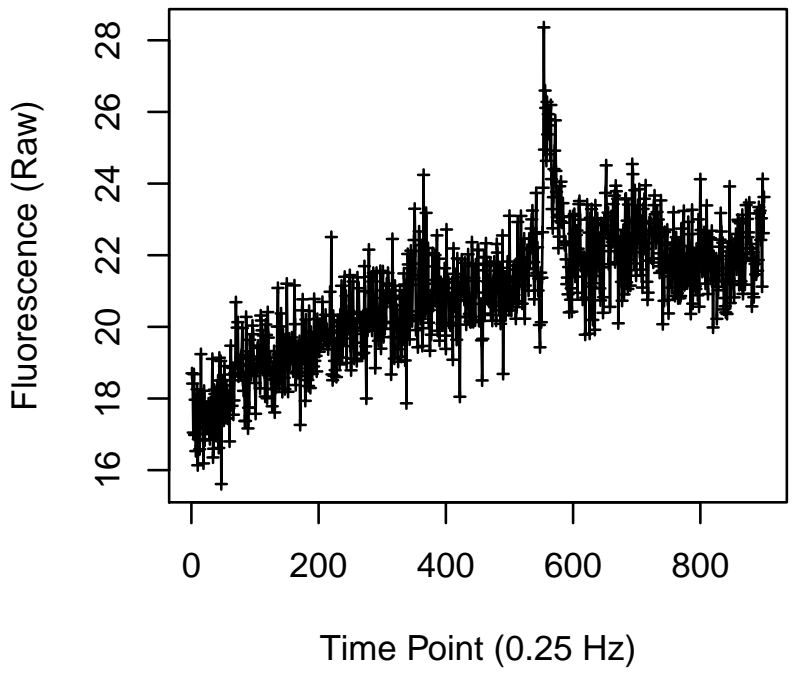

Cell 1819

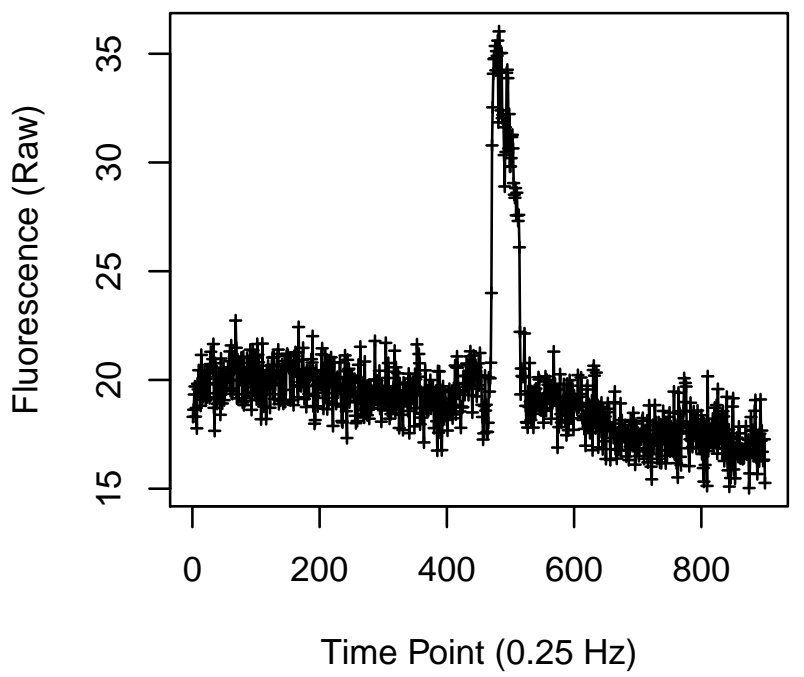

Cell 1818

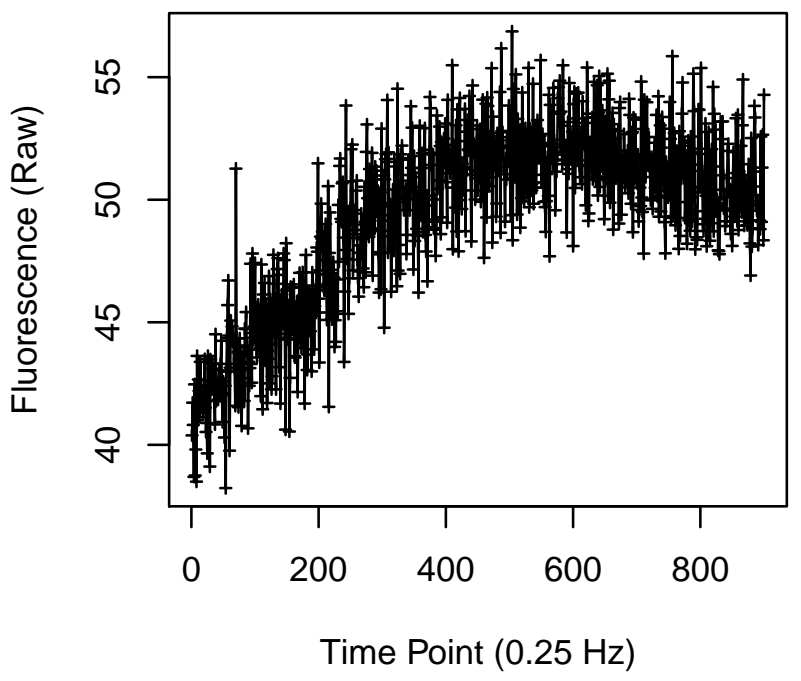

Cell 1820

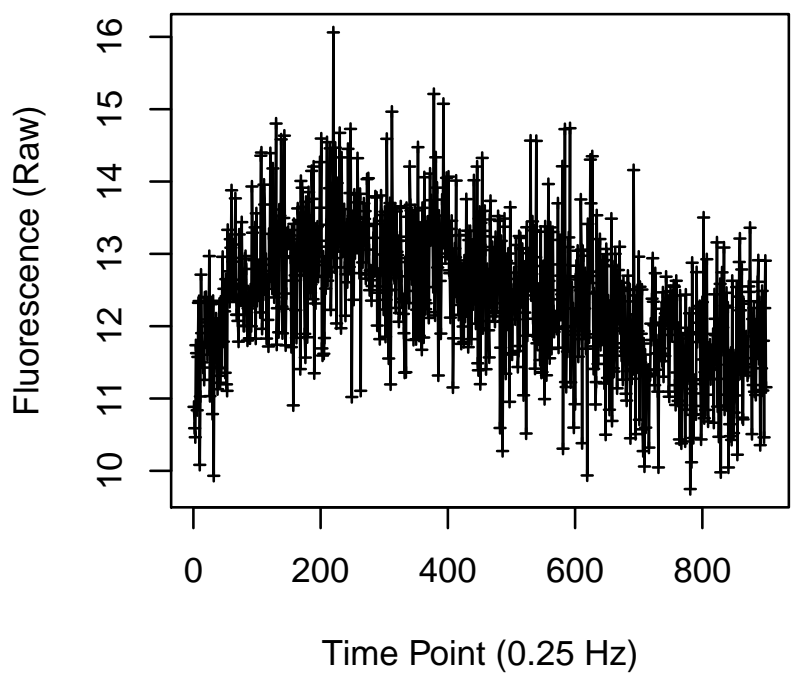


Cell 1821

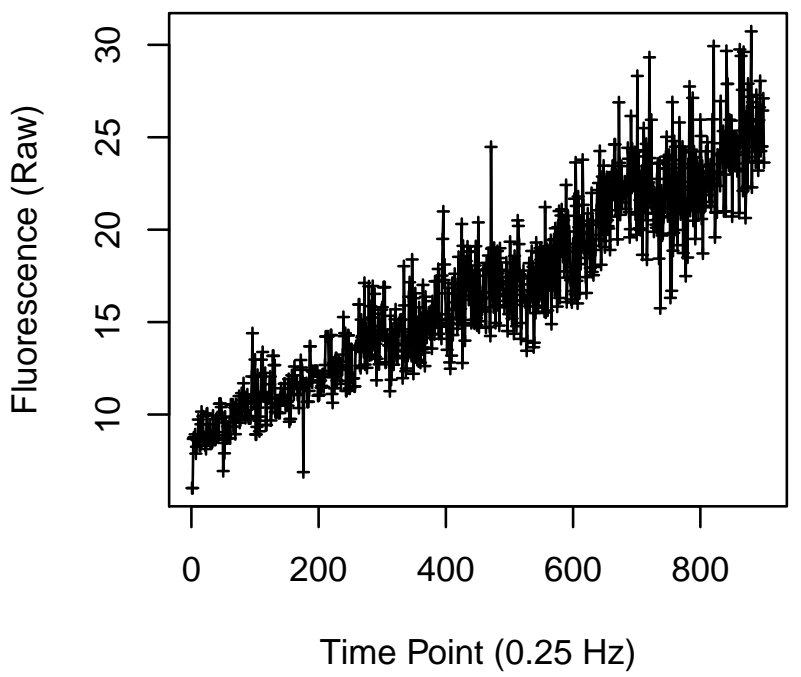

Cell 1823

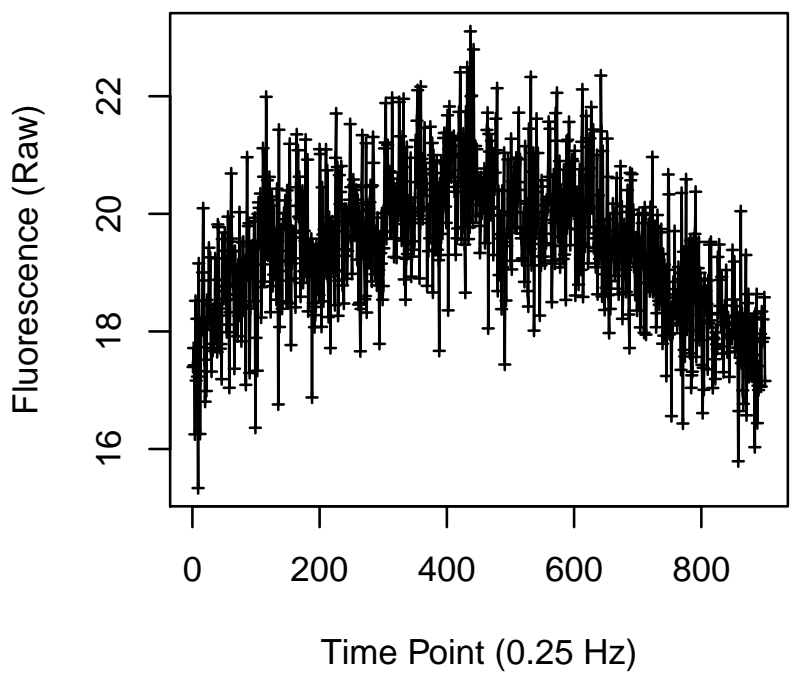

Cell 1822

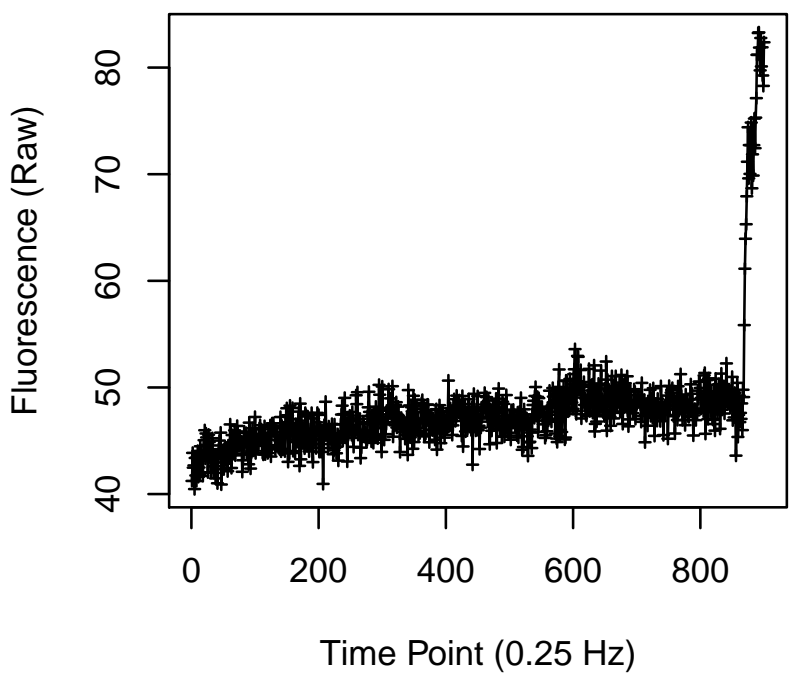

Cell 1824

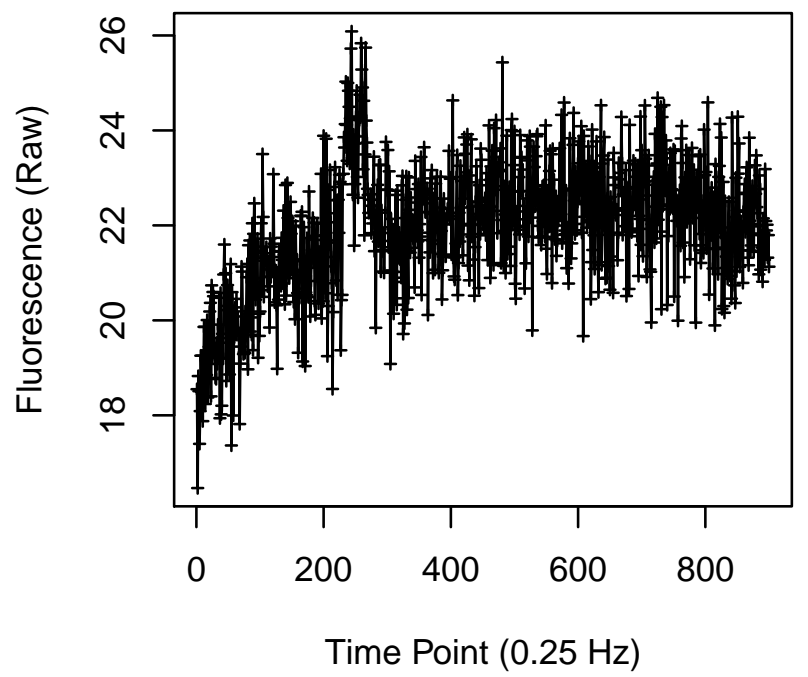


Cell 1825

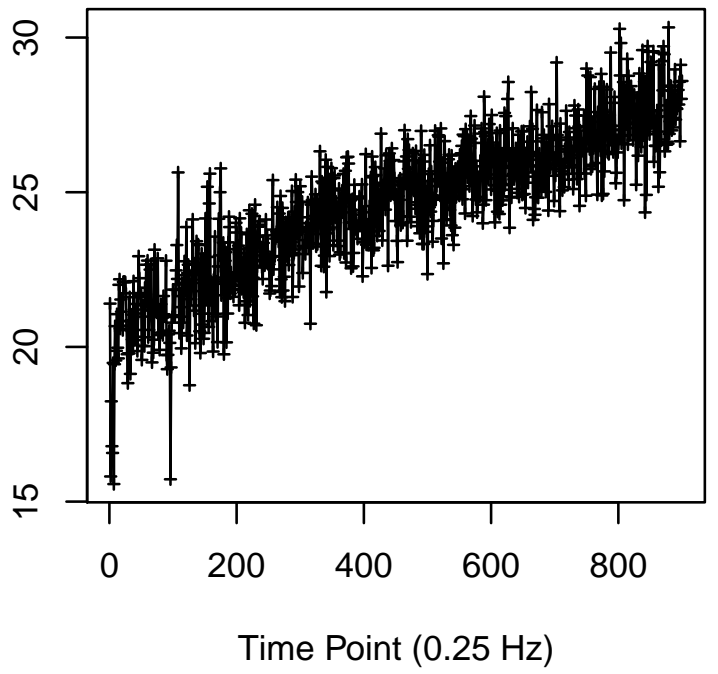

Cell 1827

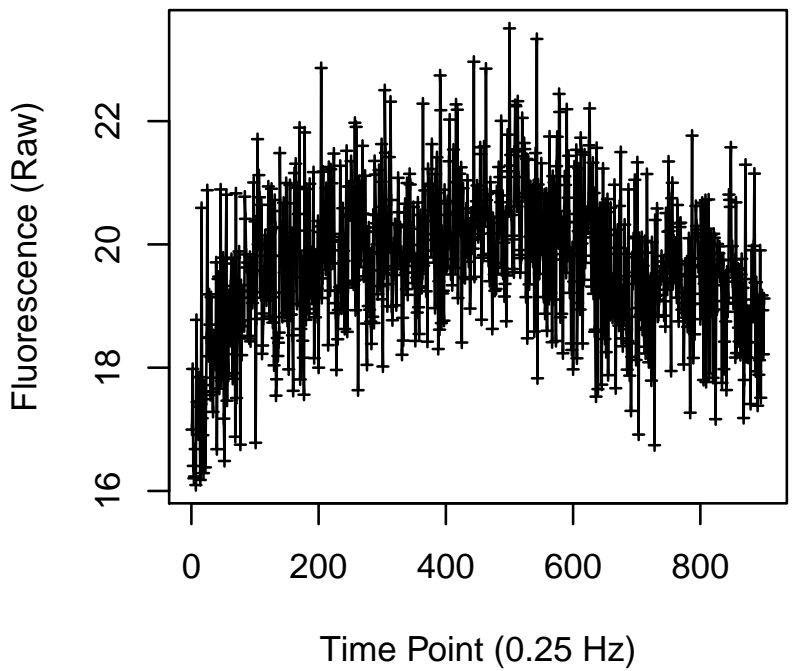

Cell 1826

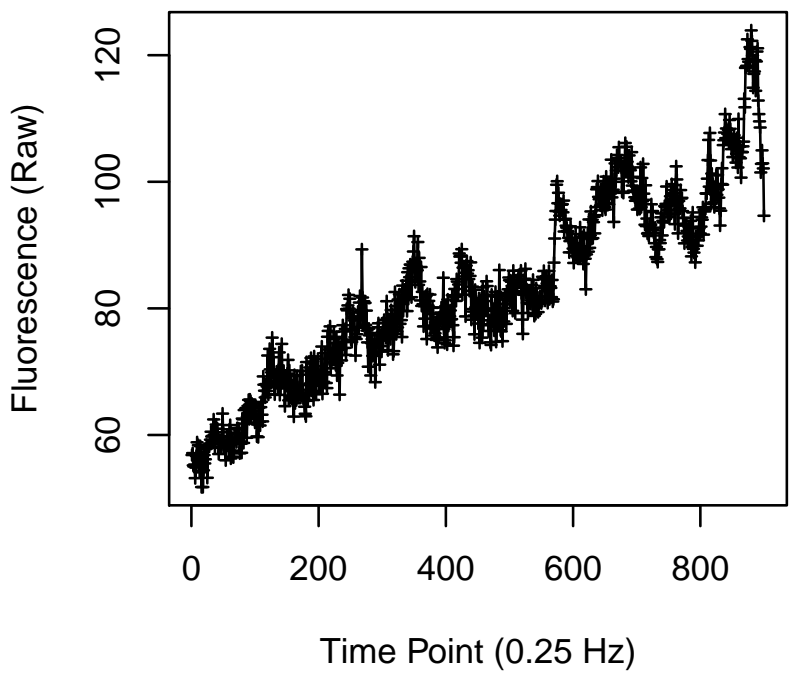

Cell 1828

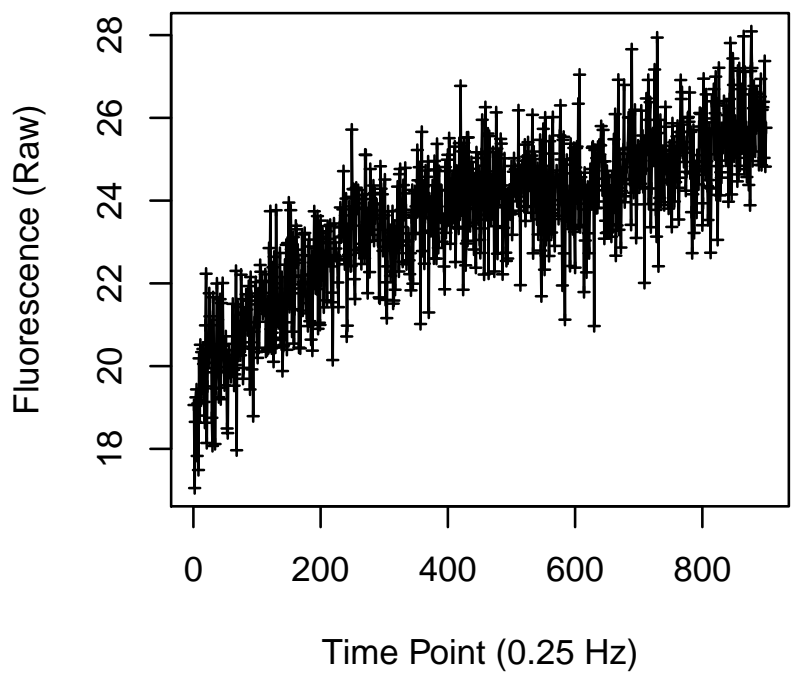


Cell 1833

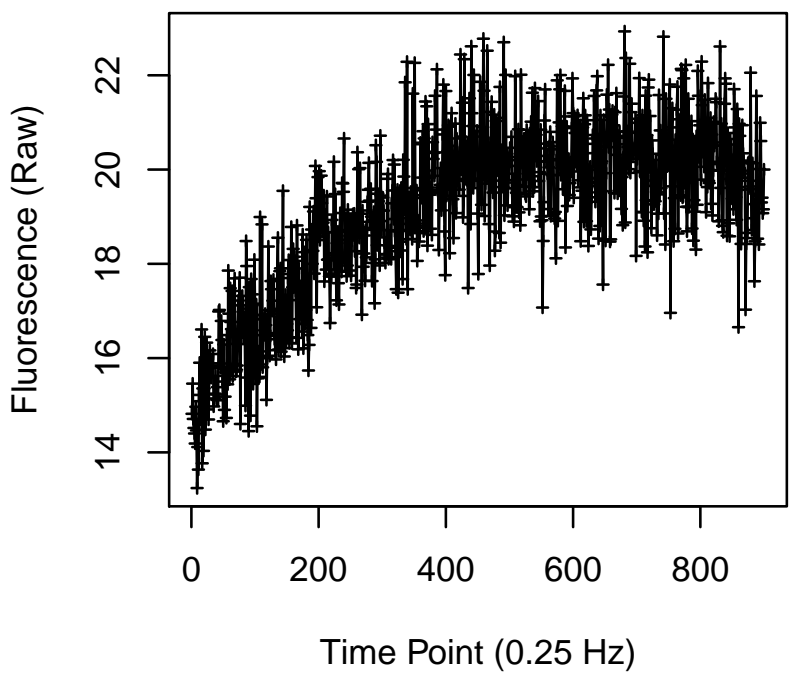

Cell 1835

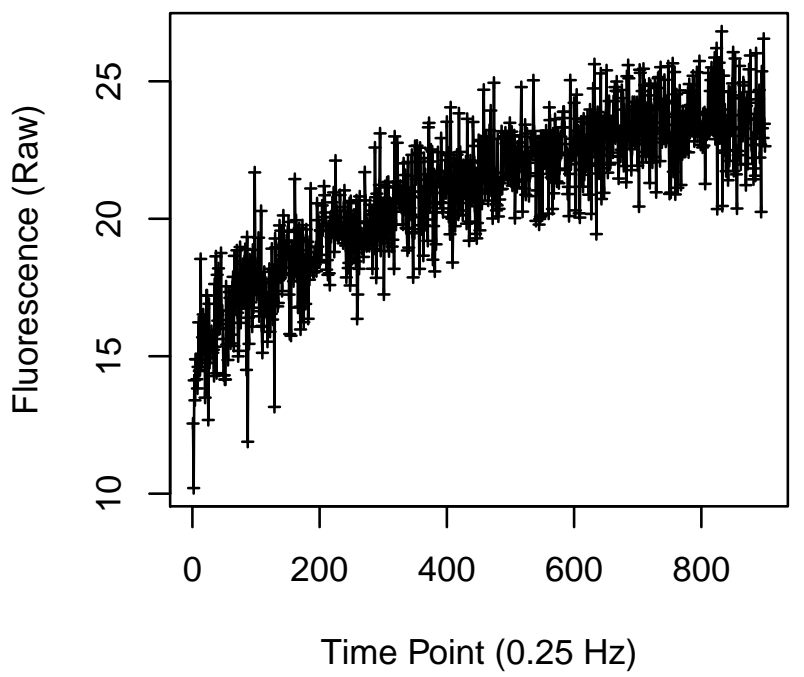

Cell 1834

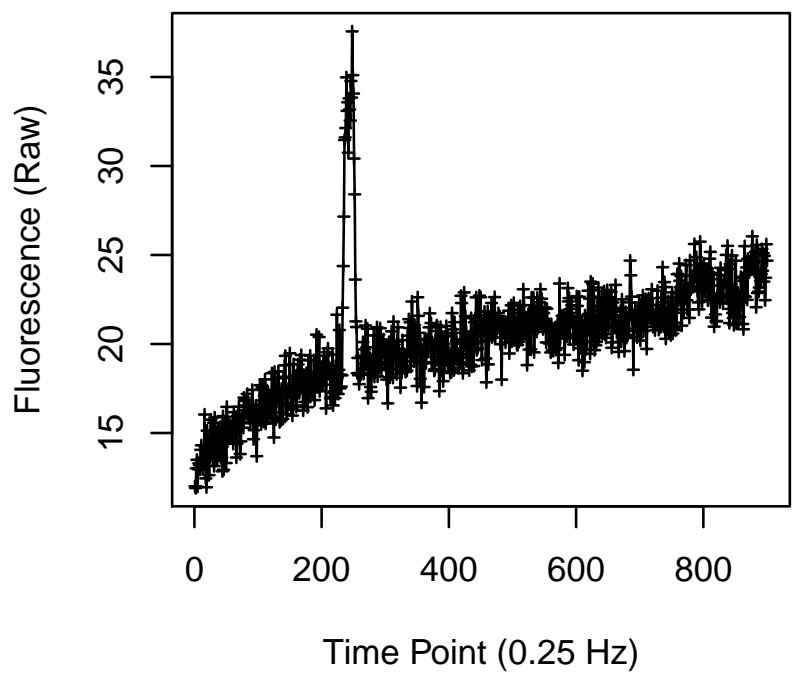

Cell 1836

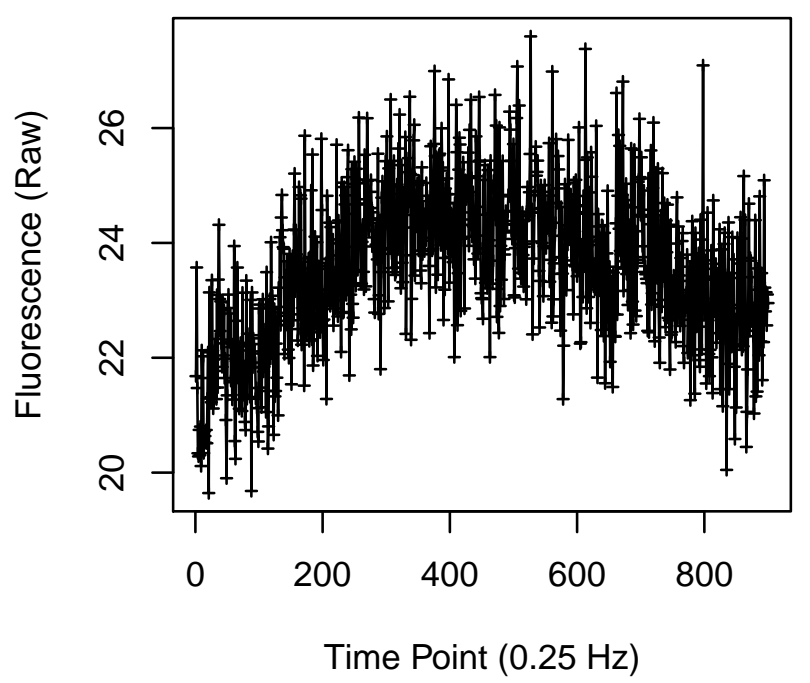


Cell 1837

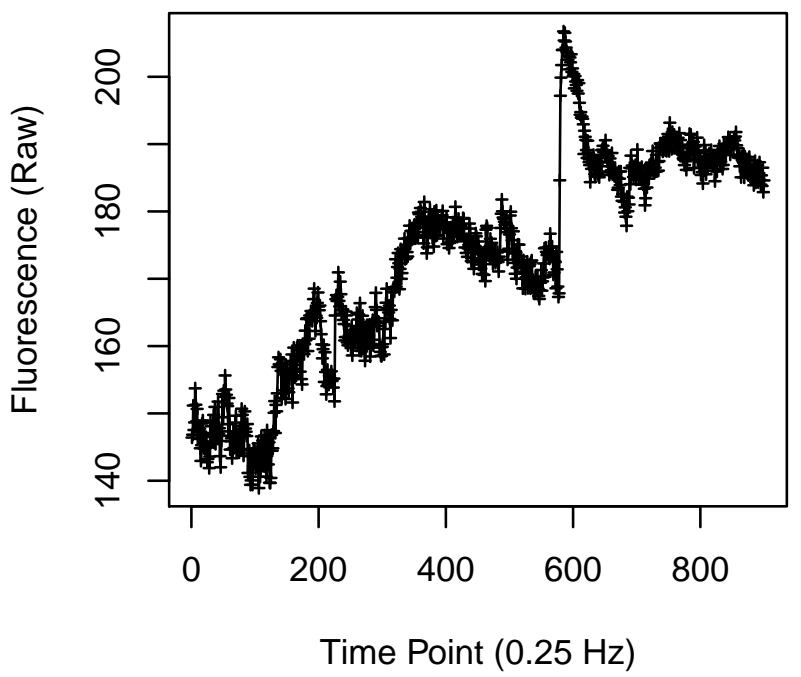

Cell 1839

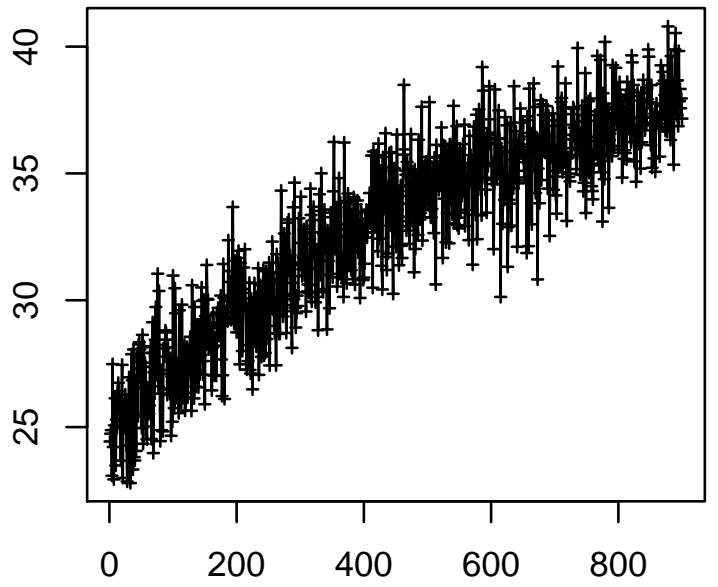

Time Point $(0.25 \mathrm{~Hz})$
Cell 1838

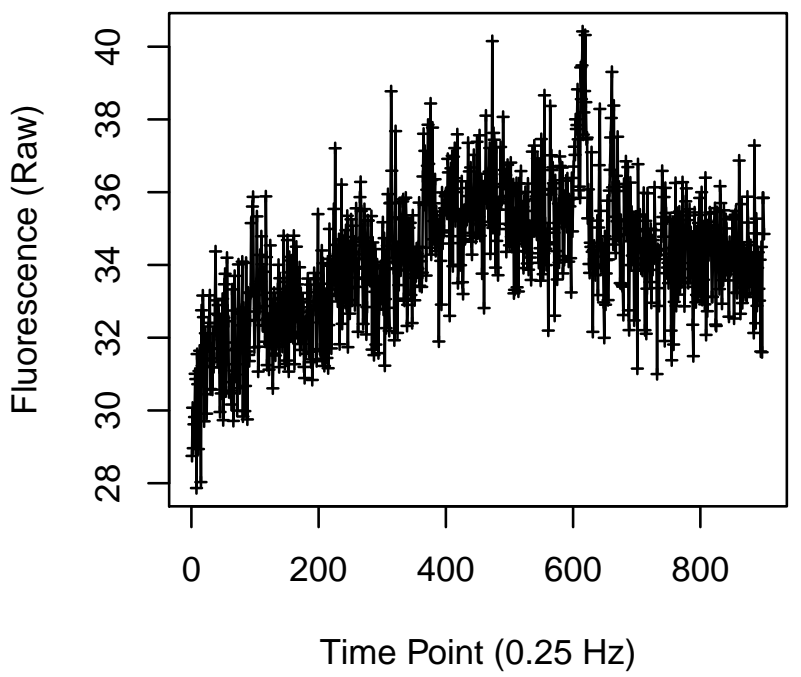

Cell 1840

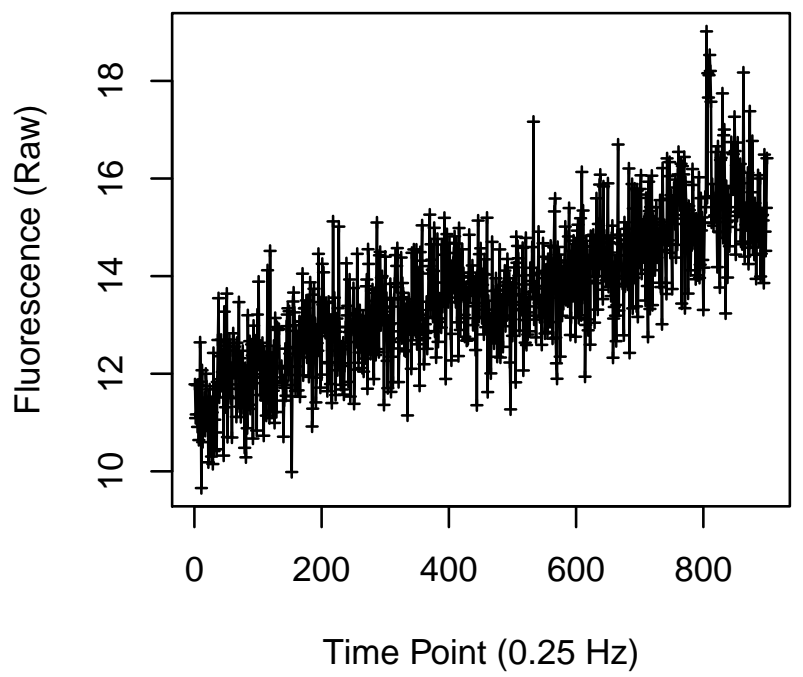


Cell 1845

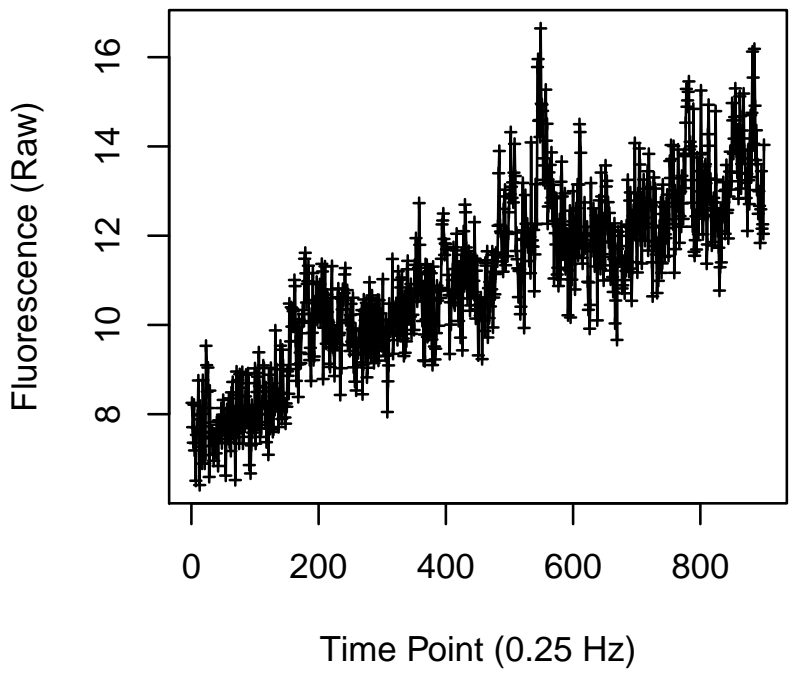

Cell 1847

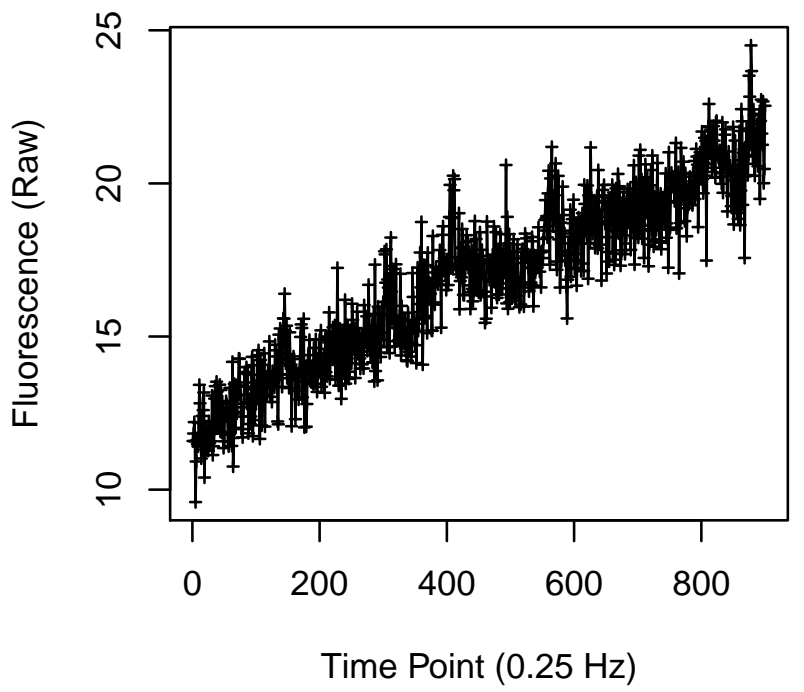

Cell 1846

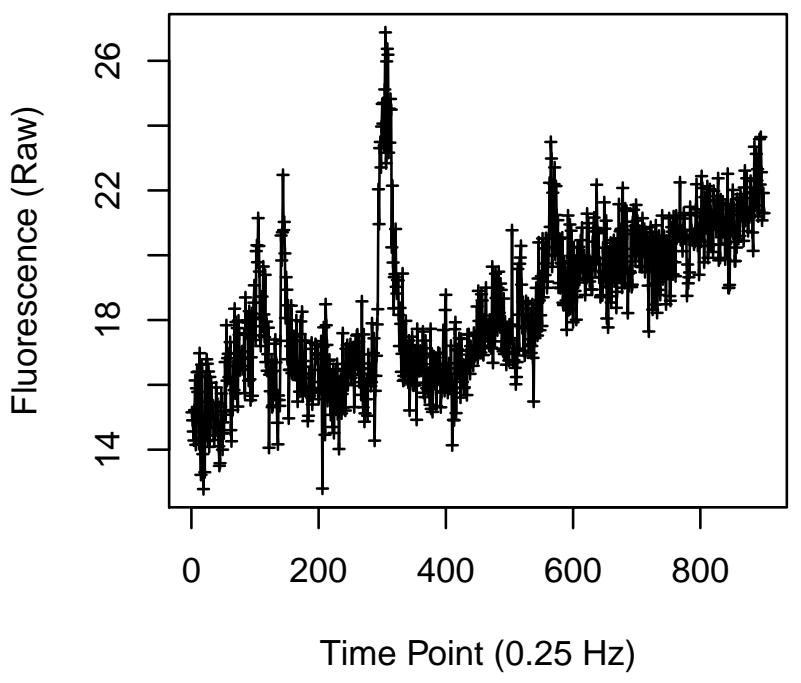

Cell 1848

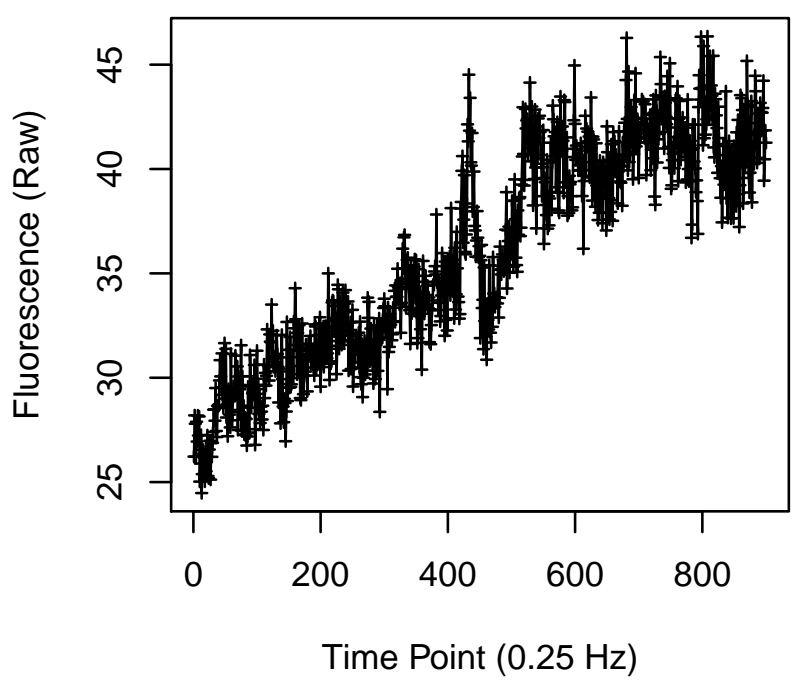


Cell 1849

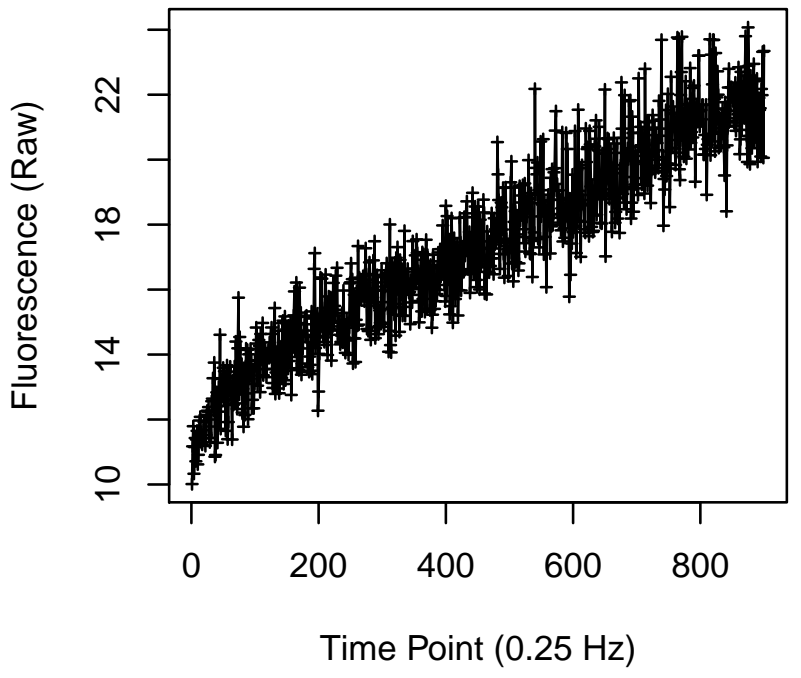

Cell 1851

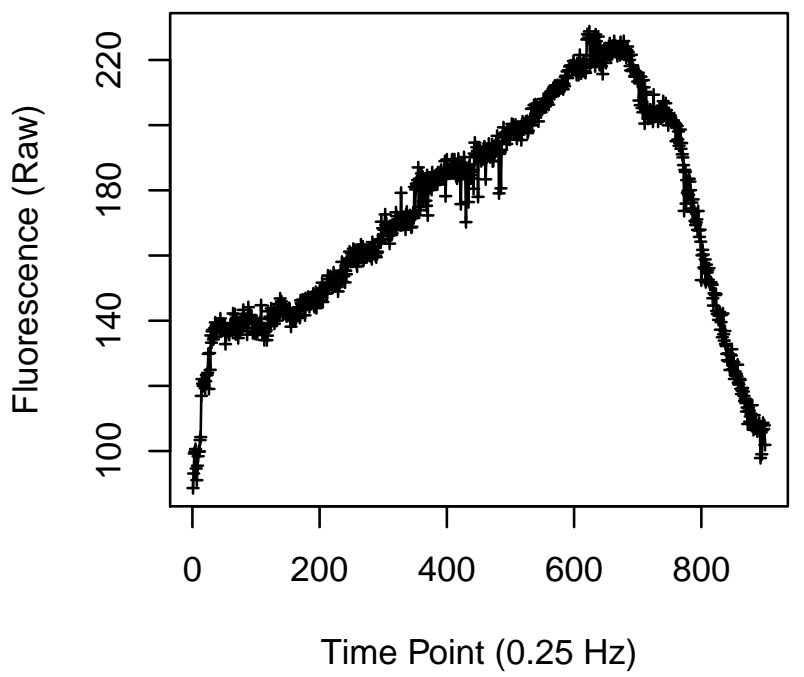

Cell 1850

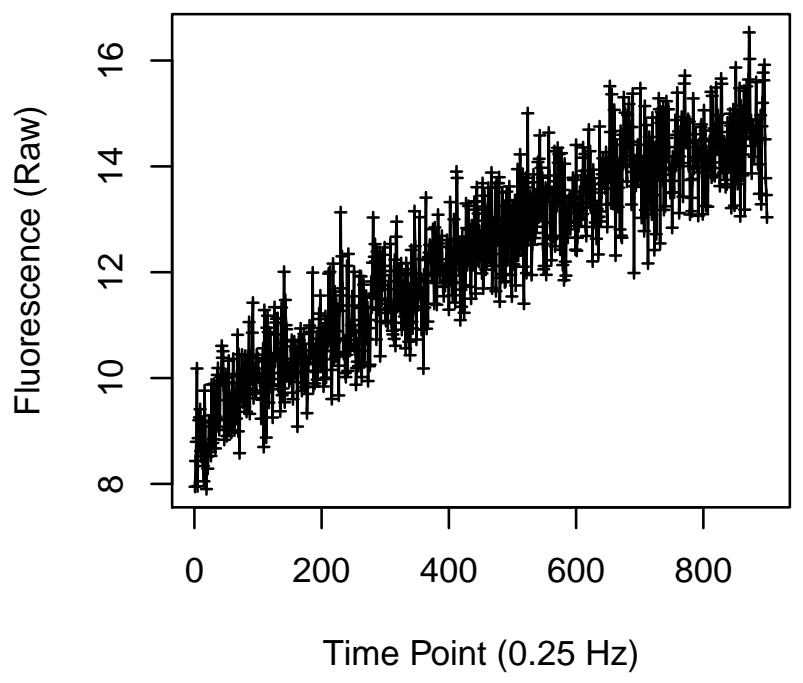

Cell 1852

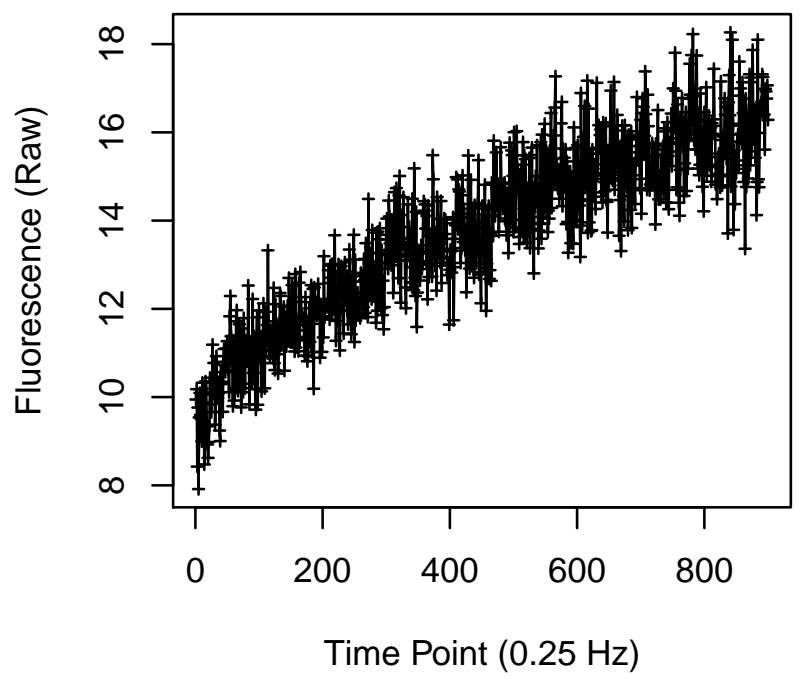


Cell 1853

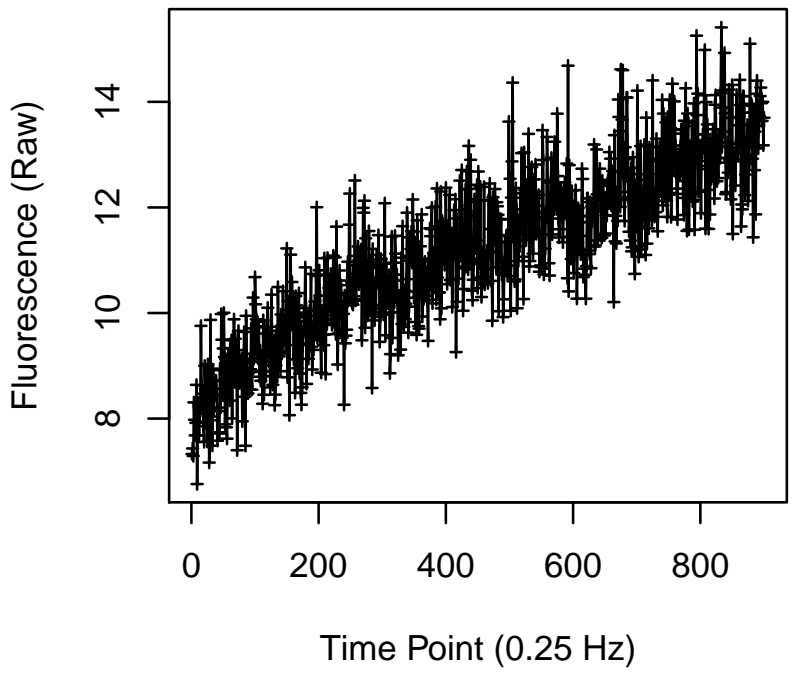

Cell 1855

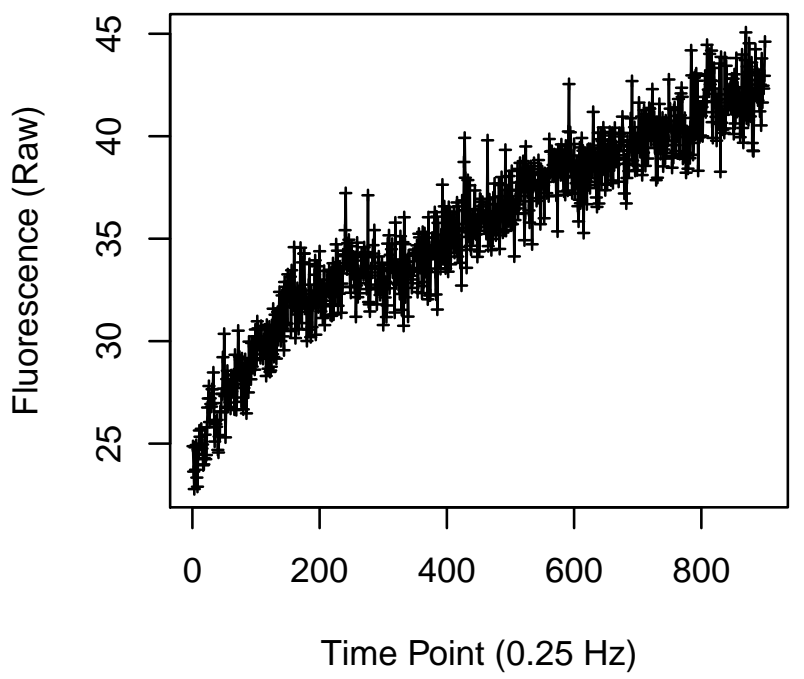

Cell 1854

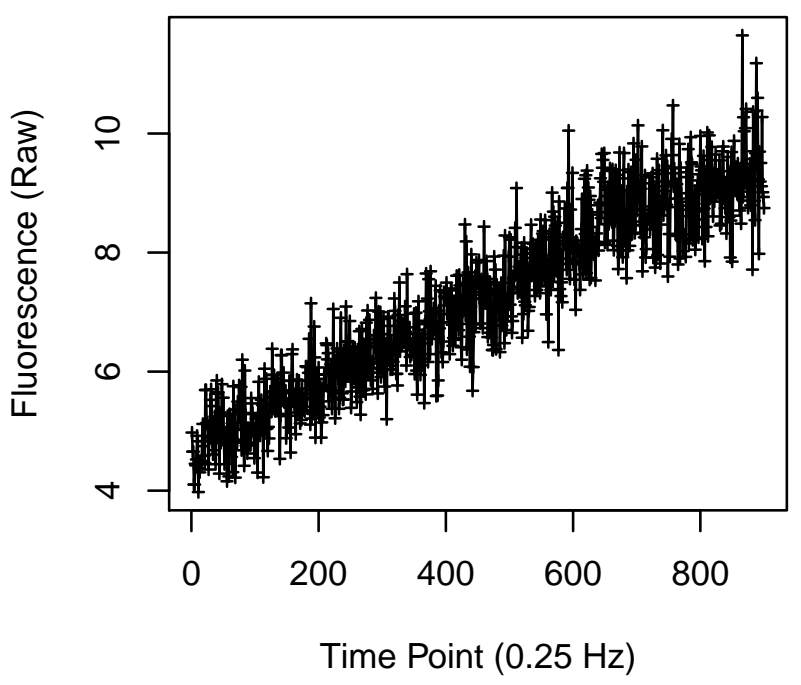

Cell 1856

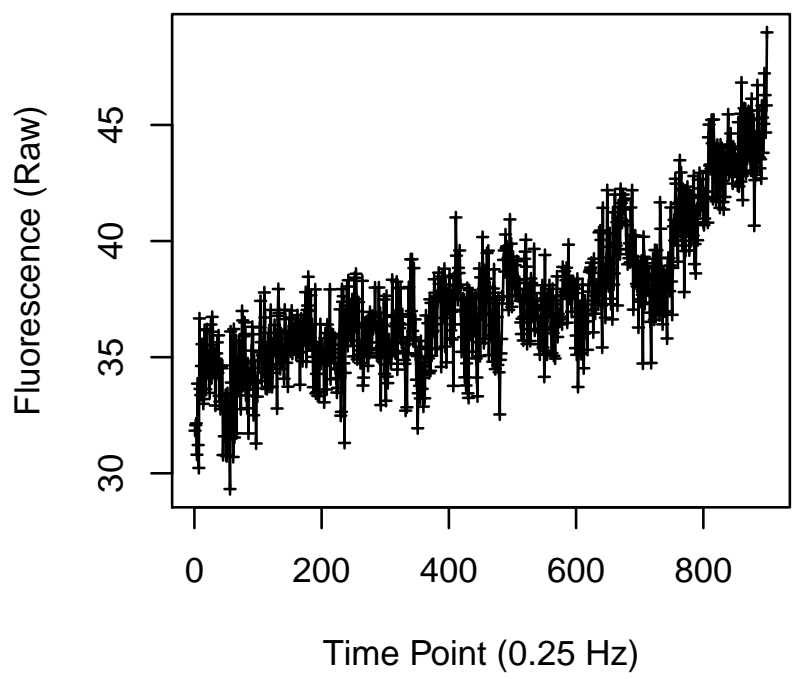


Cell 1869

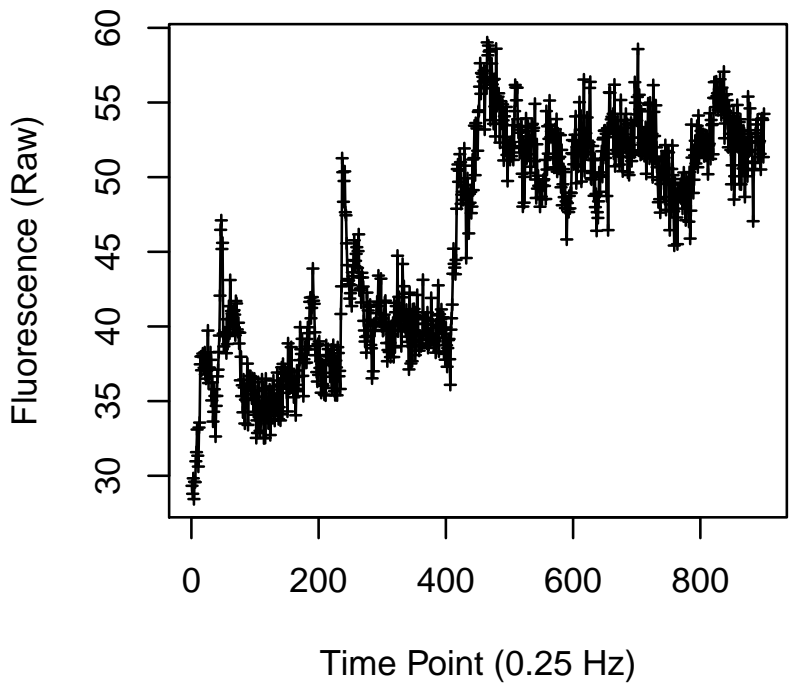

Cell 1871

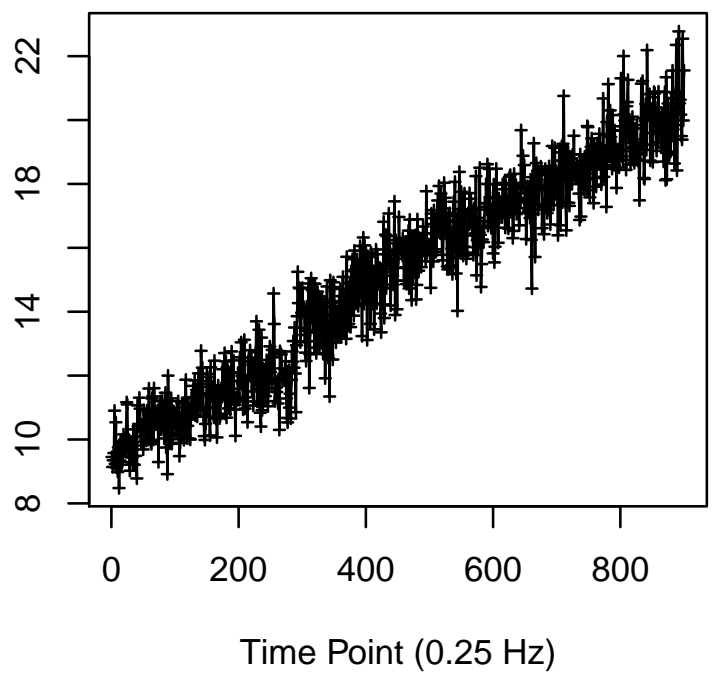

Cell 1870

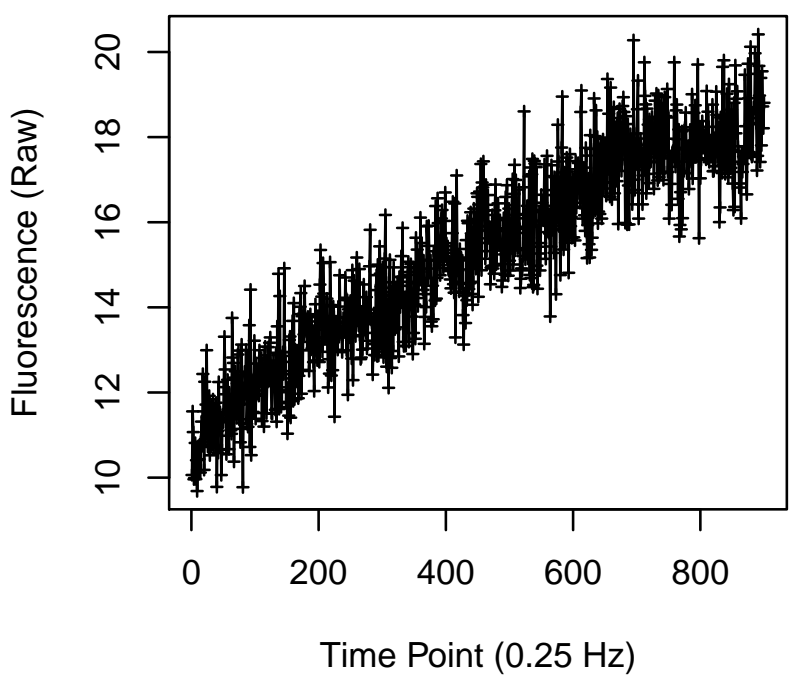

Cell 1872

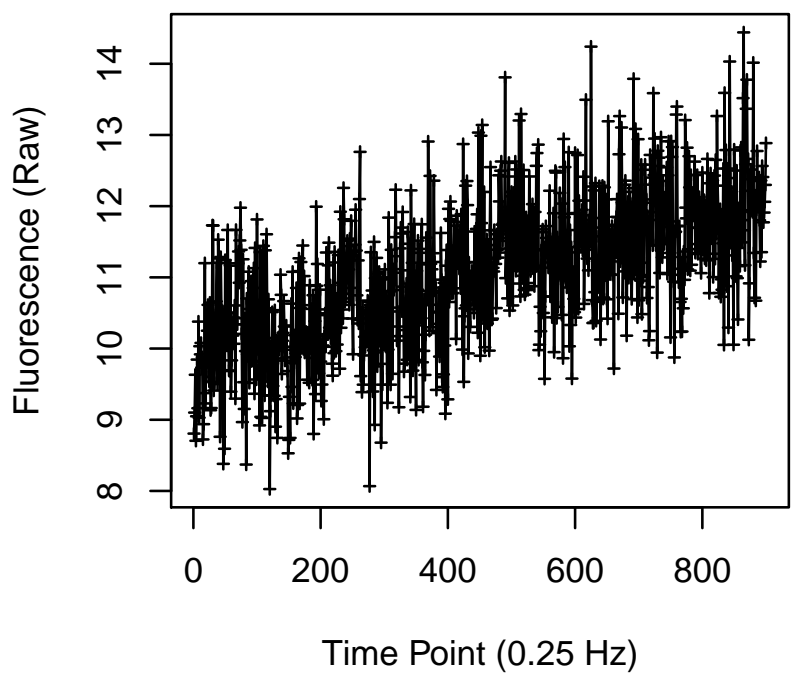


Cell 1877

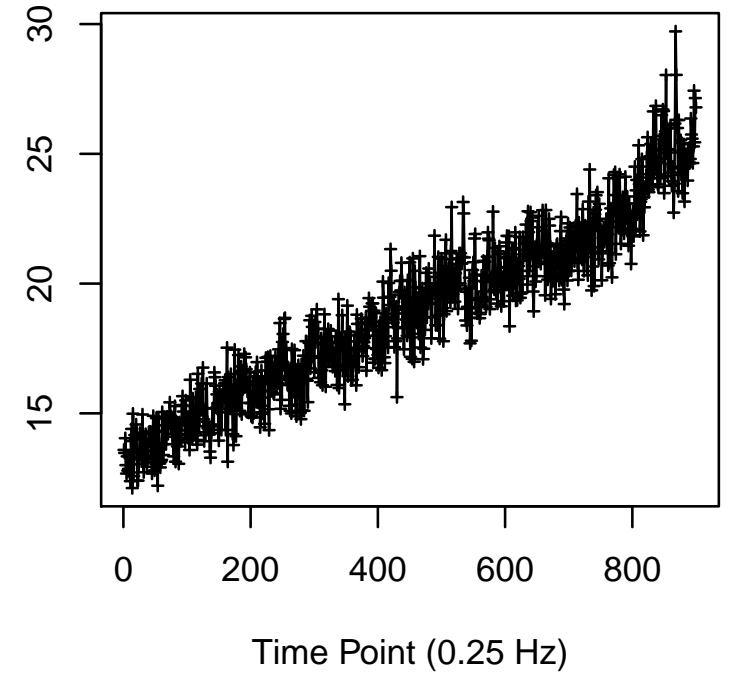

Cell 1879

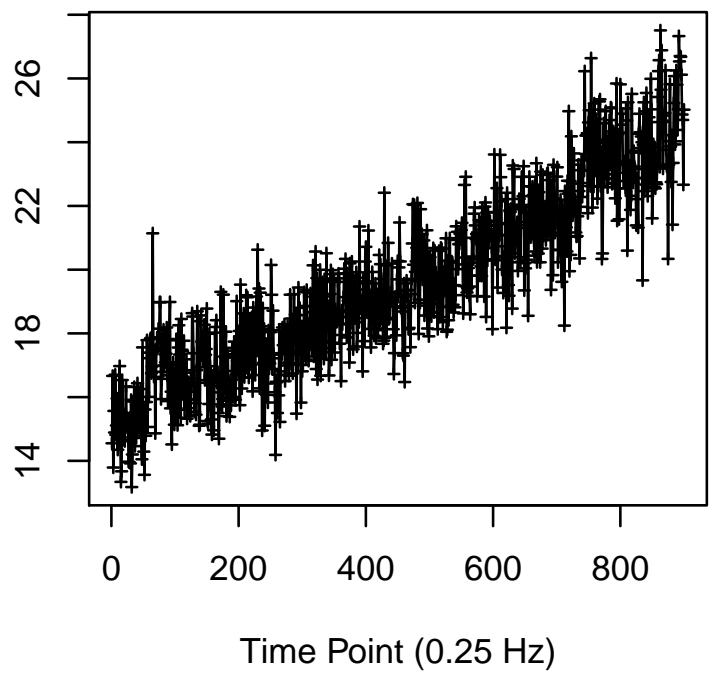

Cell 1878

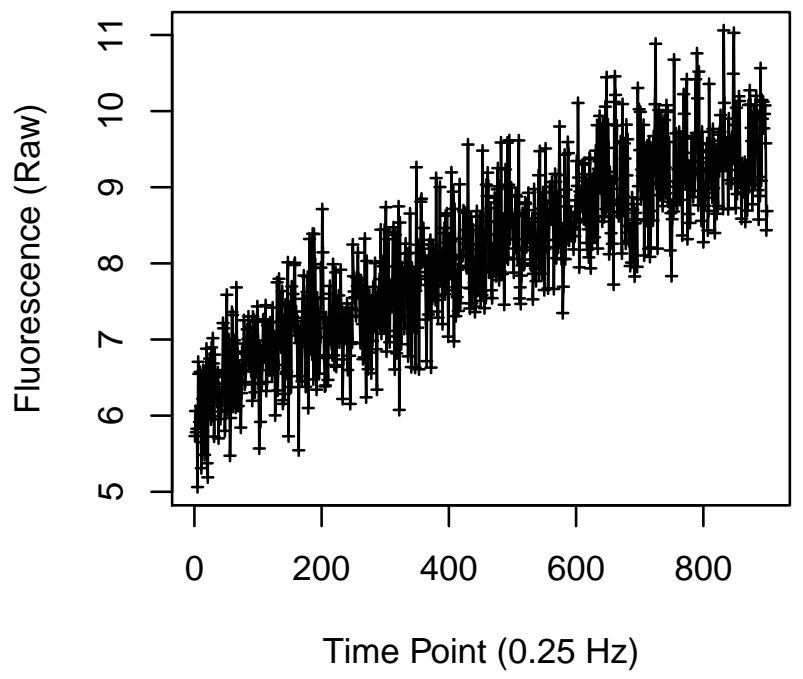

Cell 1880

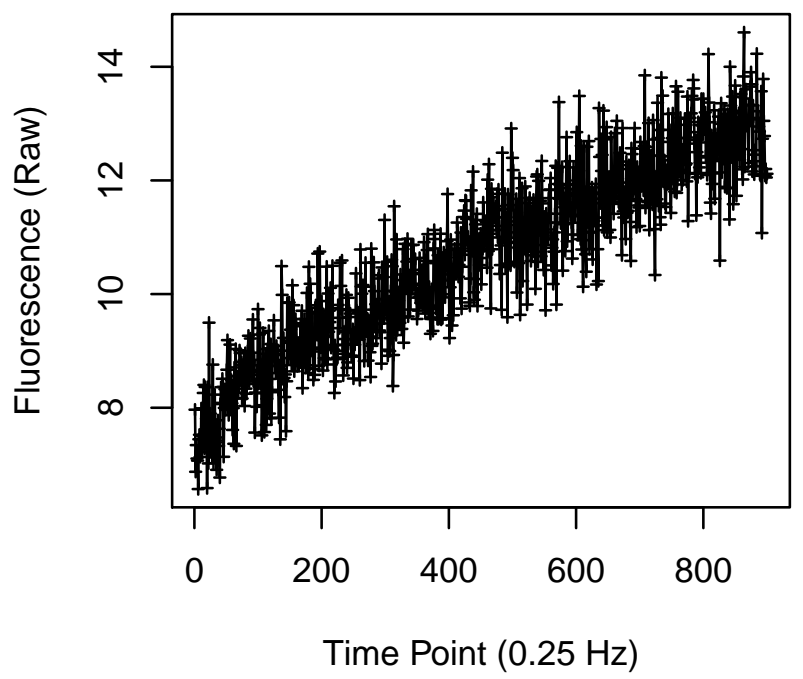


Cell 1881

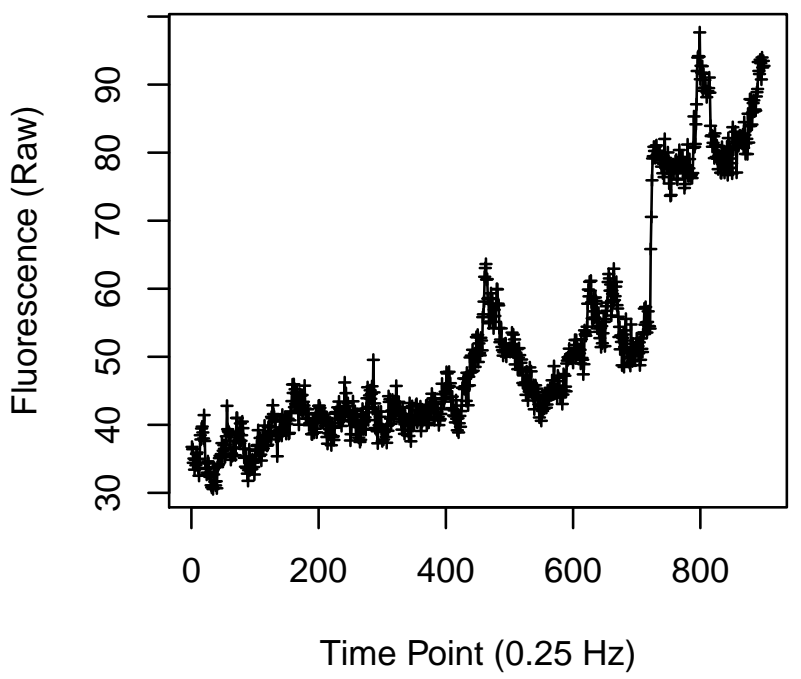

Cell 1883

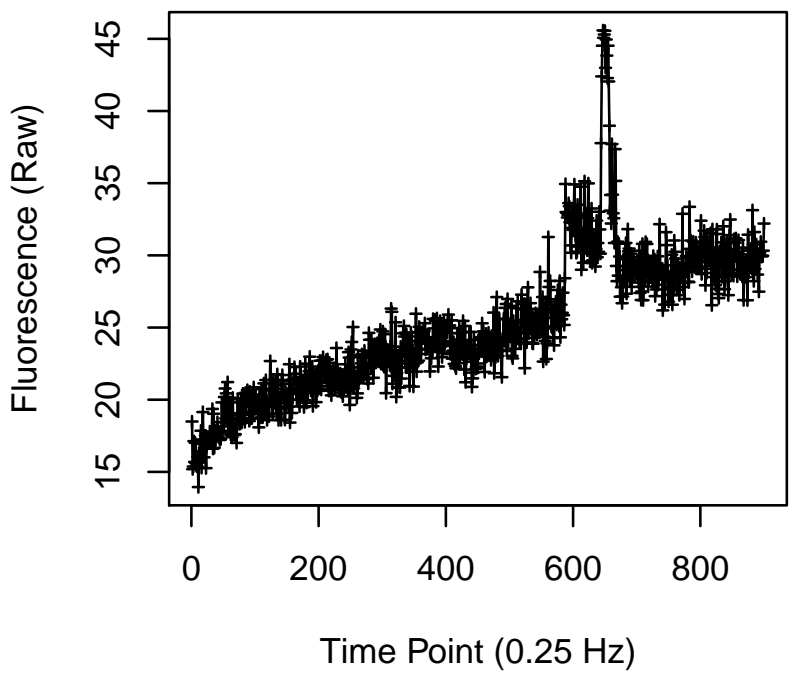

Cell 1882

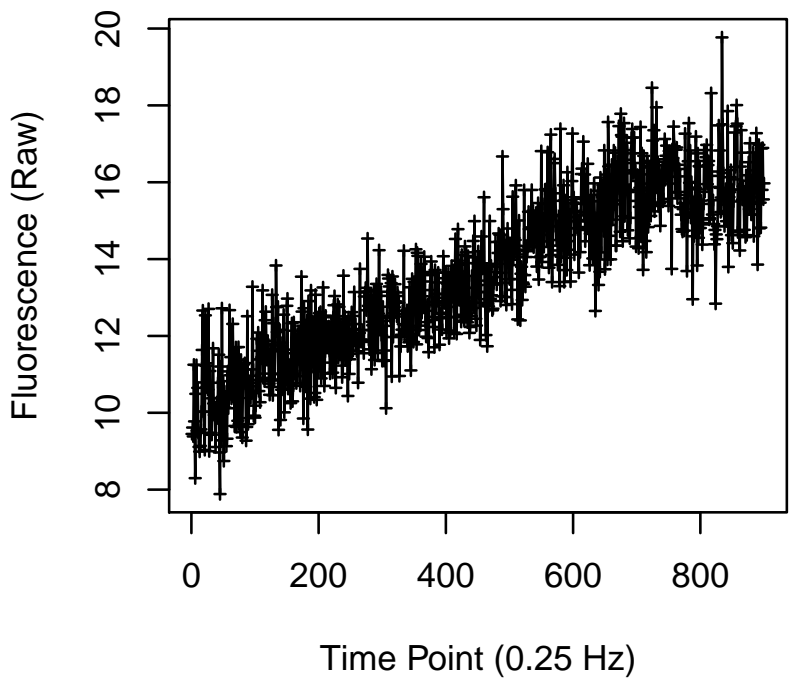

Cell 1884

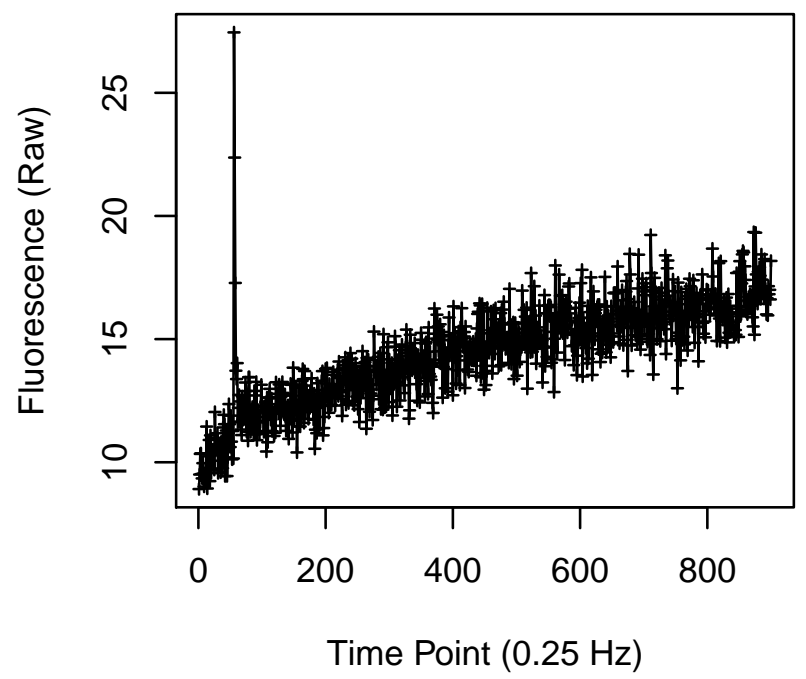


Cell 1885

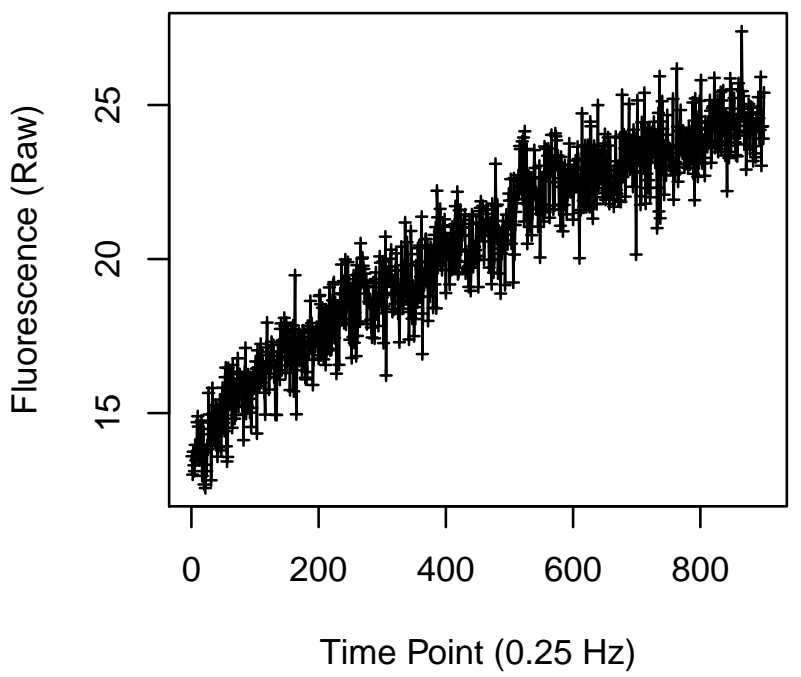

Cell 1887

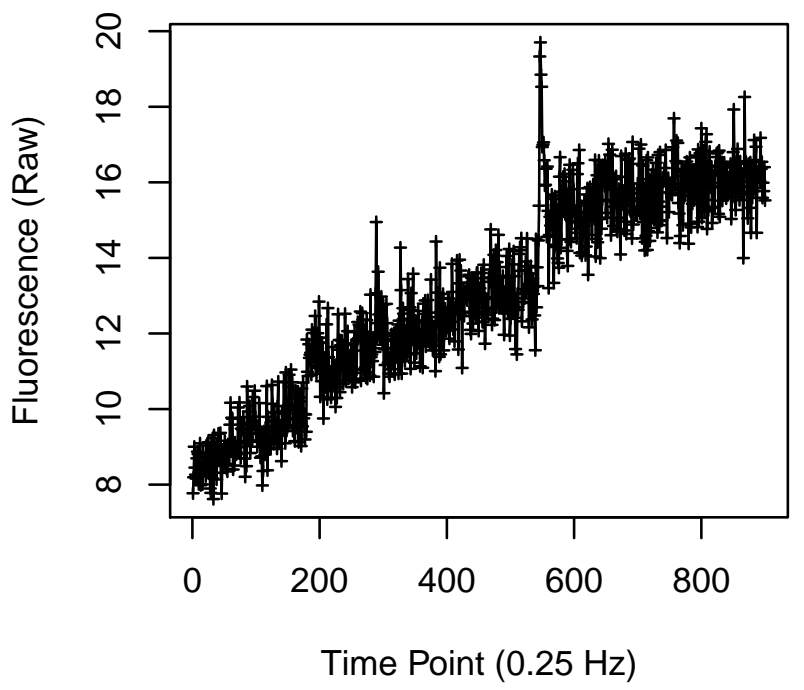

Cell 1886

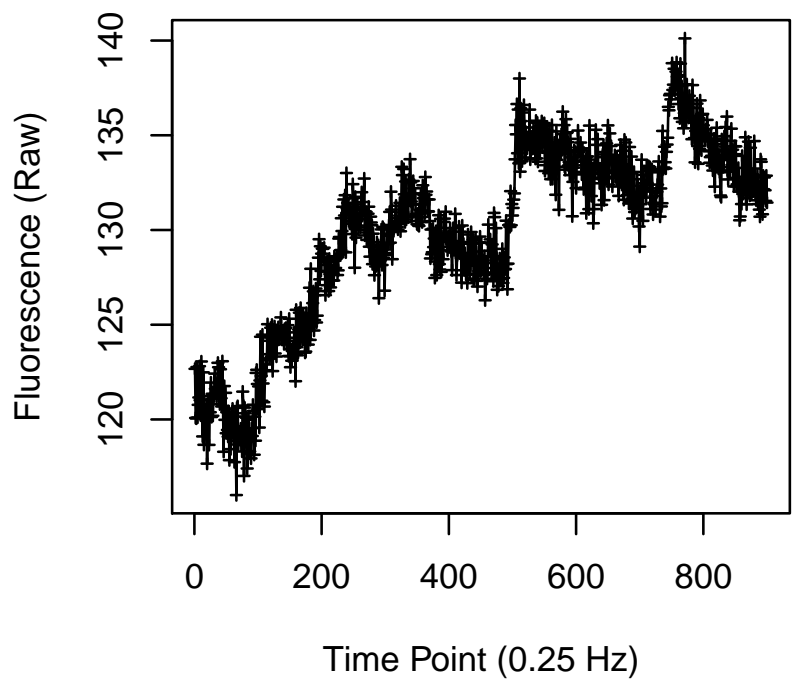

Cell 1888

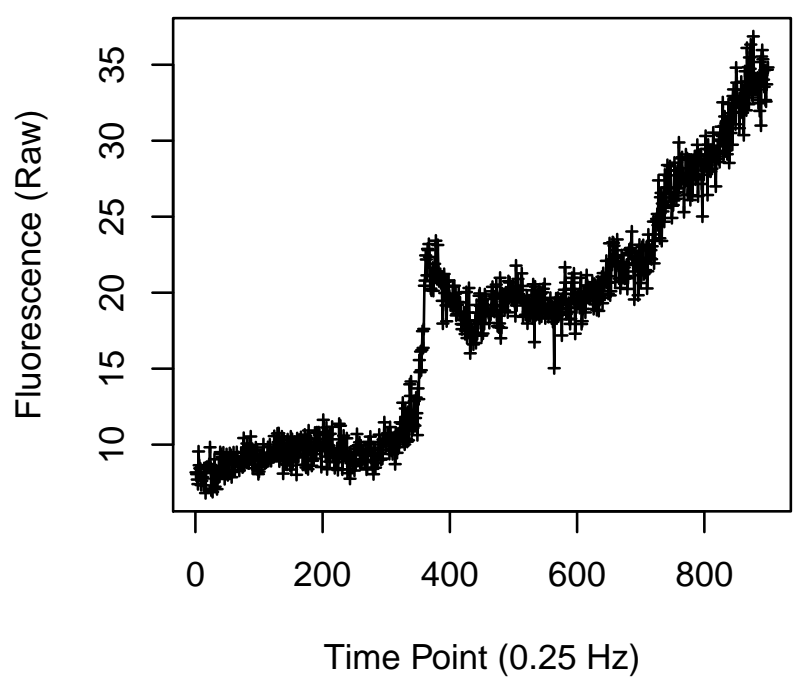


Cell 1889

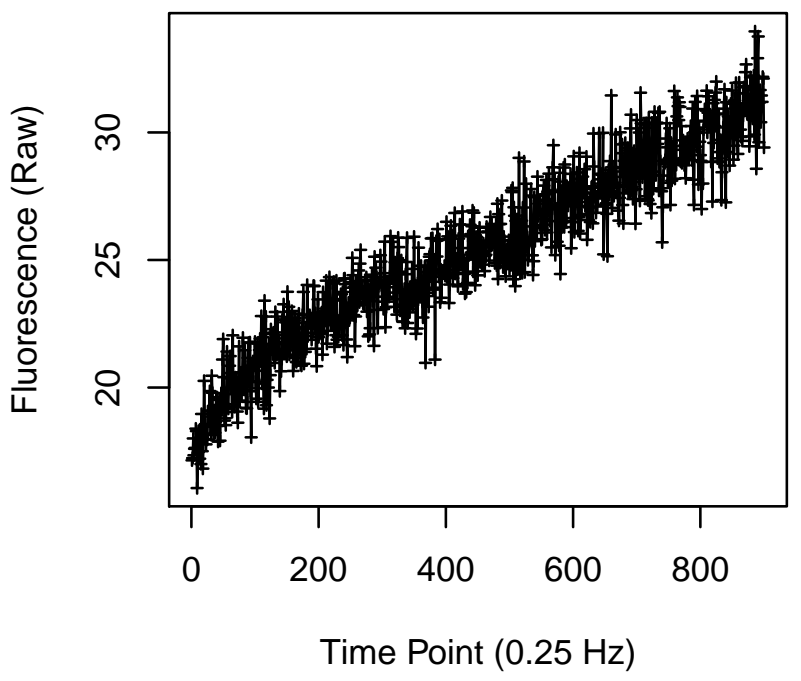

Cell 1891

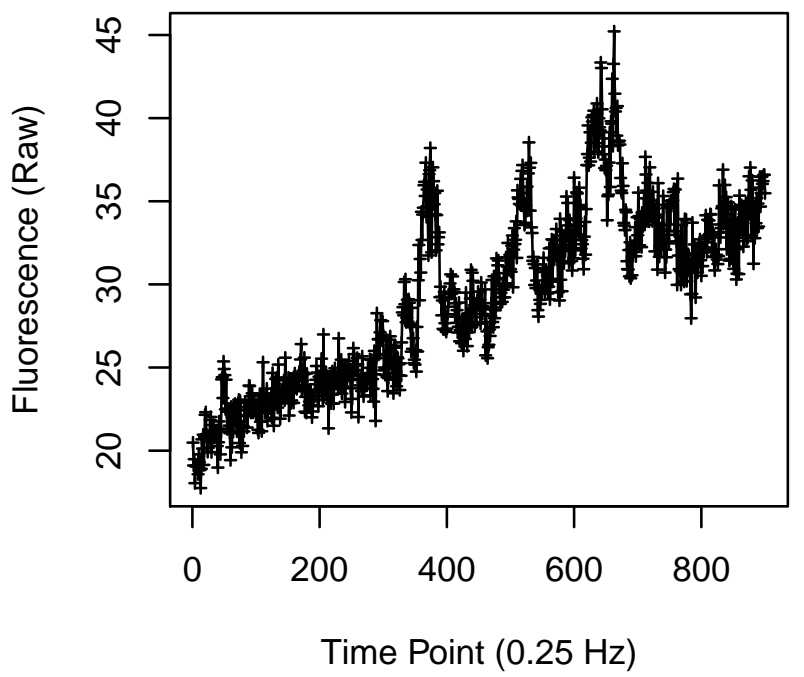

Cell 1890

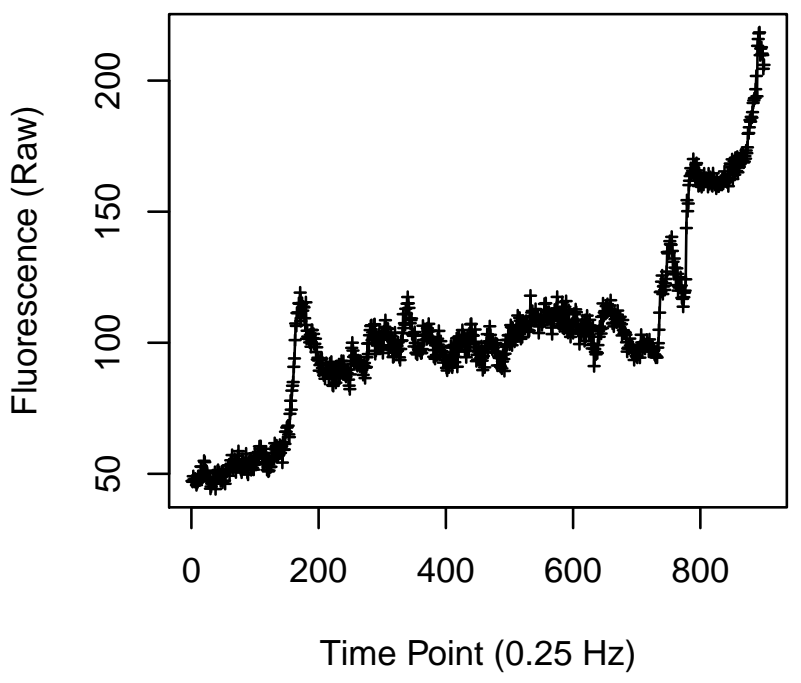

Cell 1892

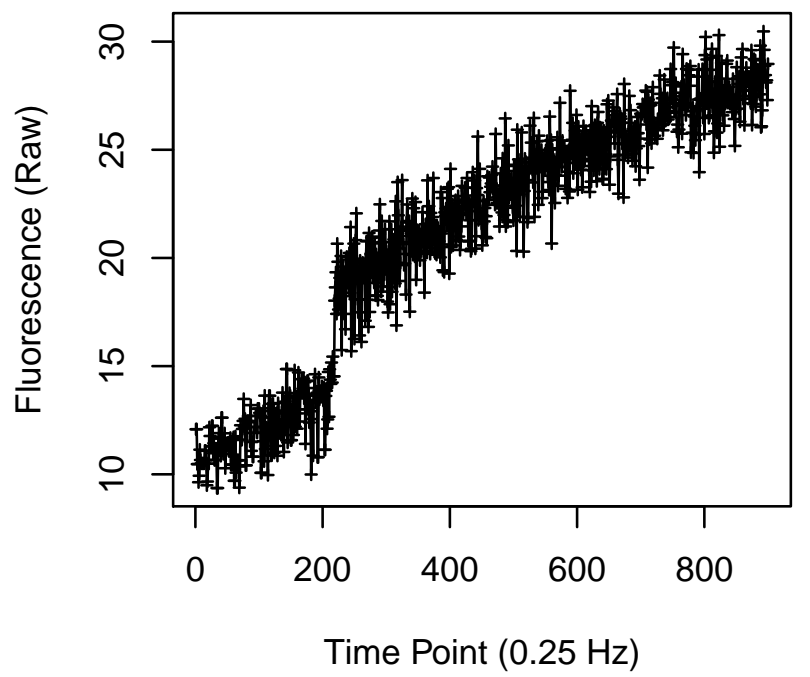


Cell 1893

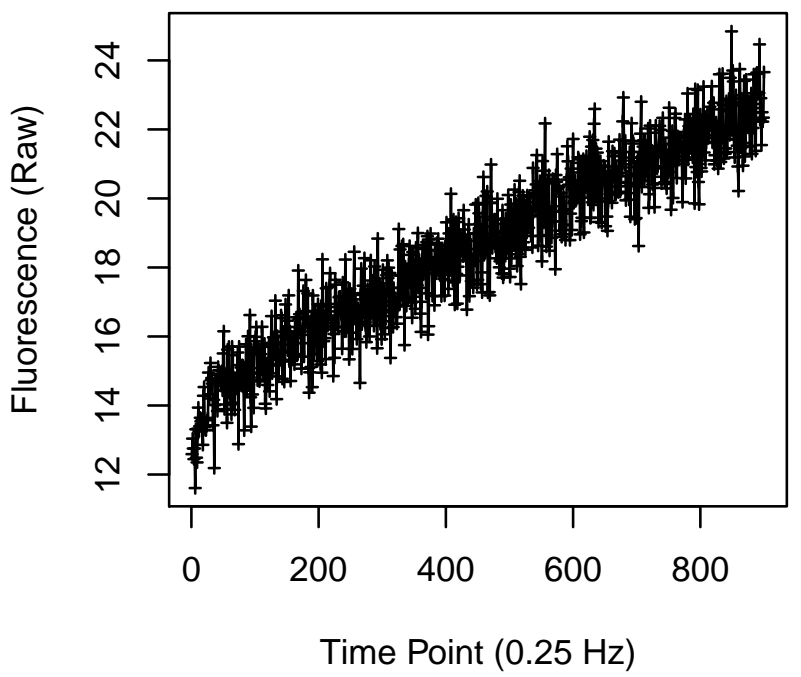

Cell 1895

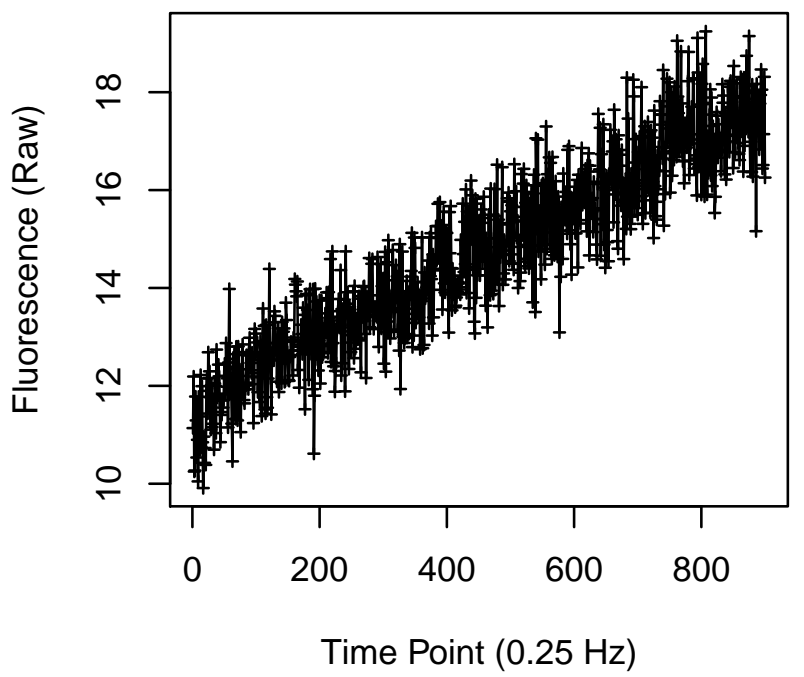

Cell 1894

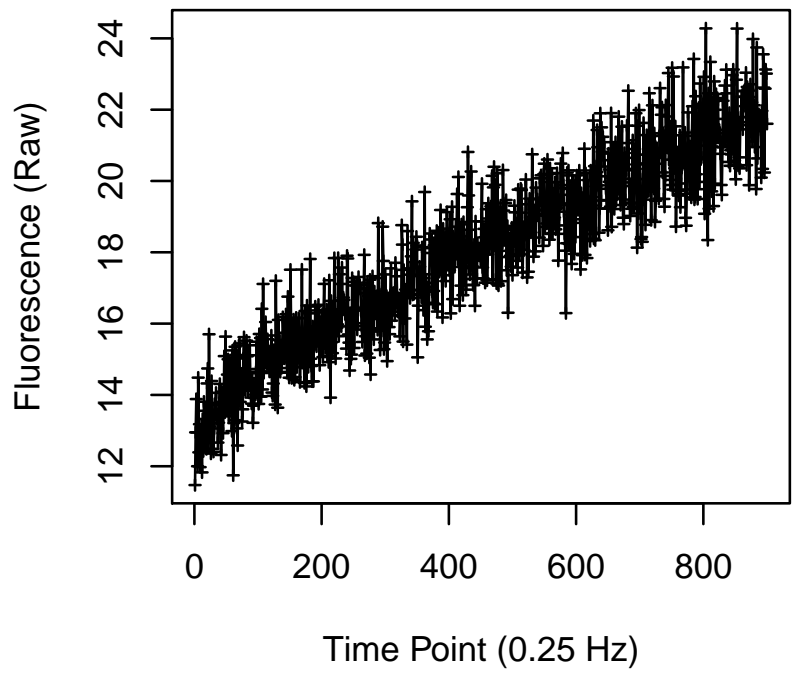

Cell 1896

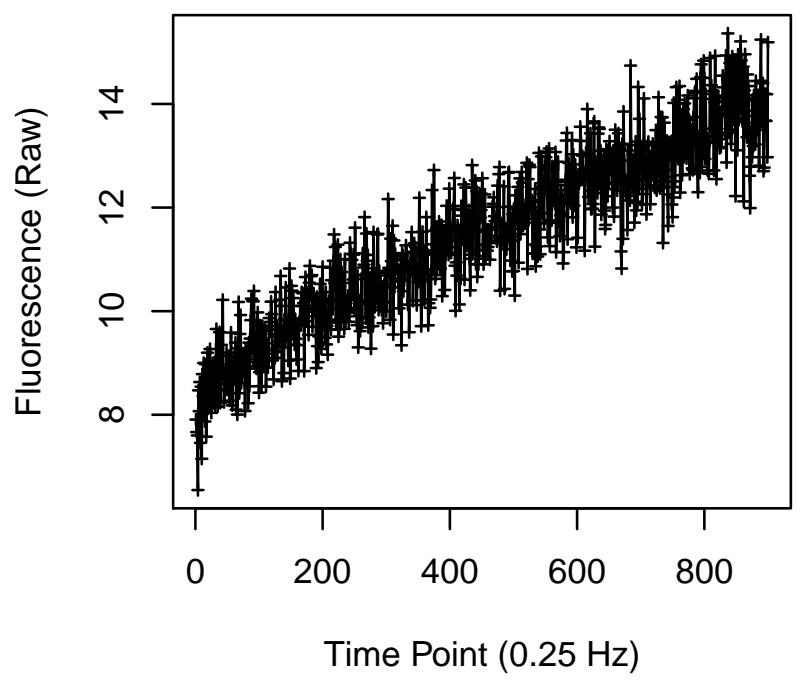


Cell 1897

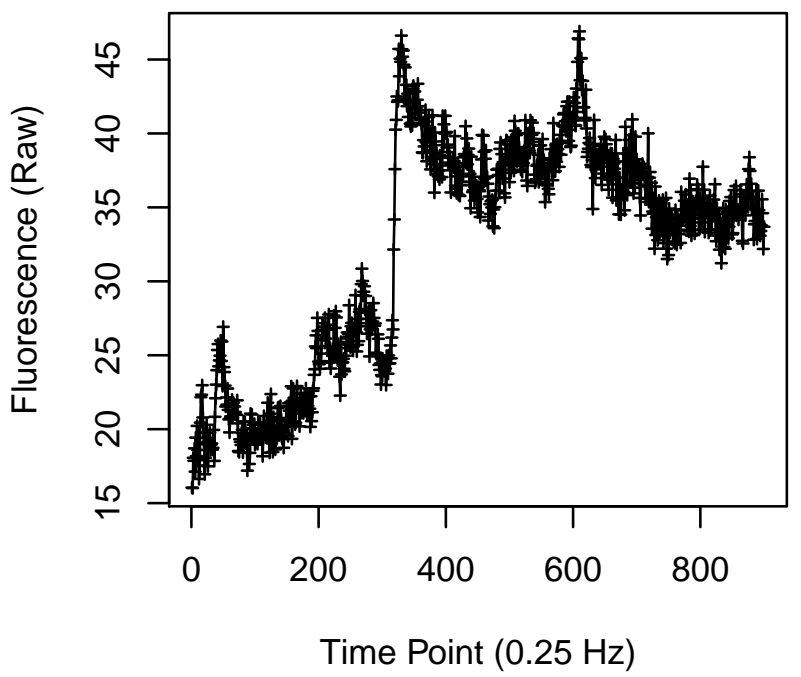

Cell 1899

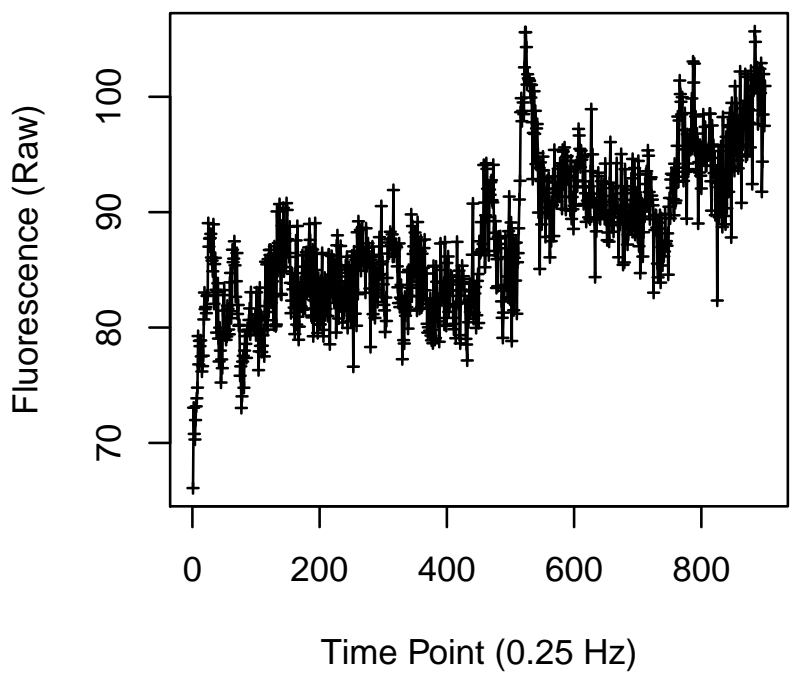

Cell 1898

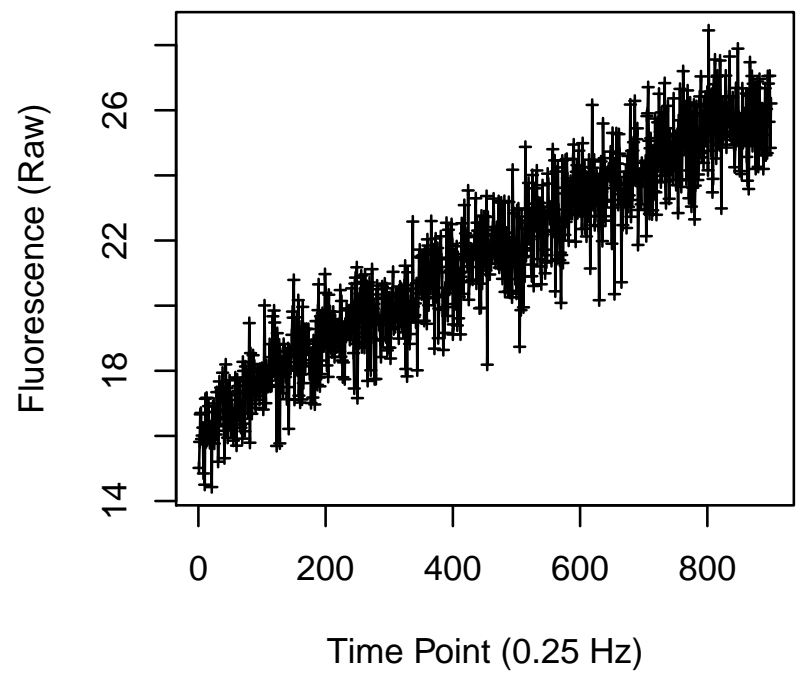

Cell 1900

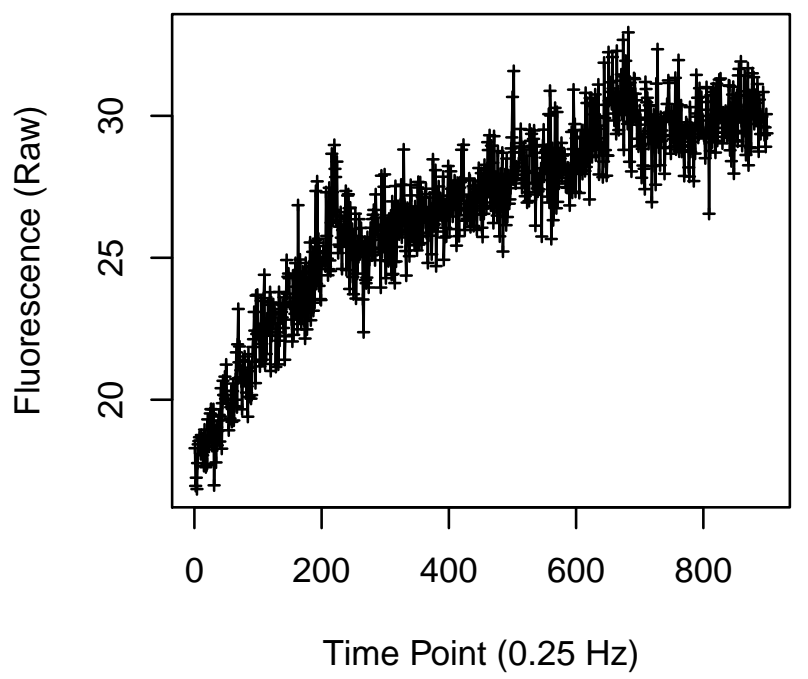


Cell 1901

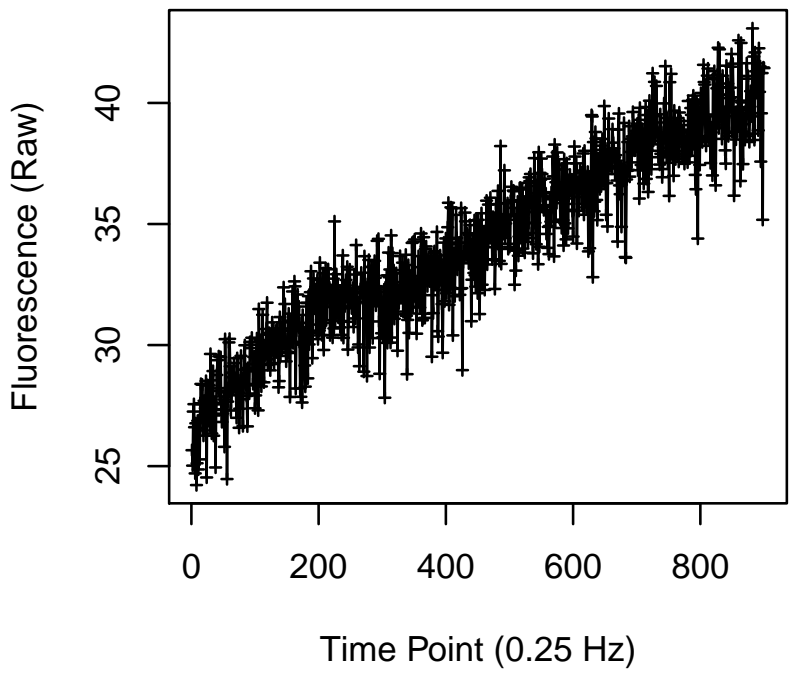

Cell 1903

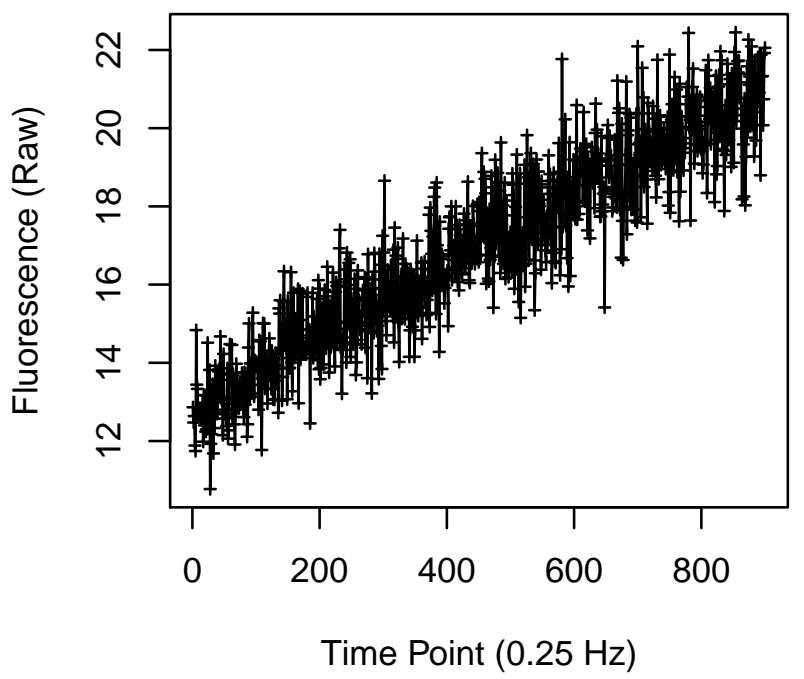

Cell 1902

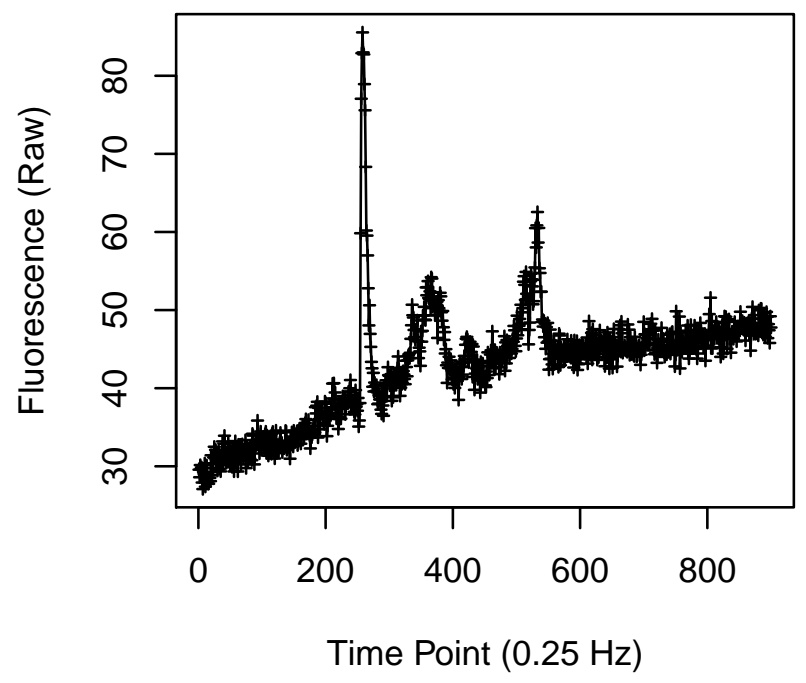

Cell 1904

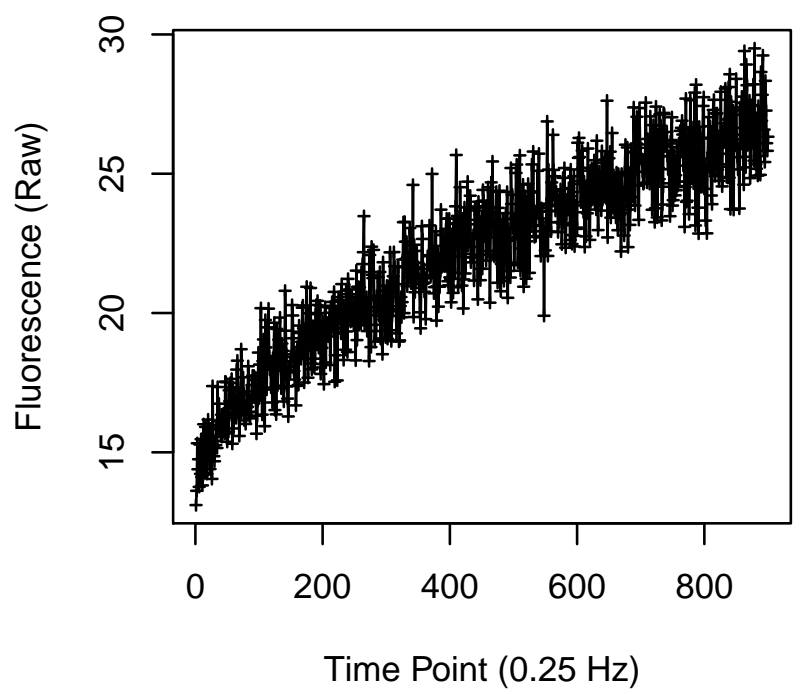


Cell 1905

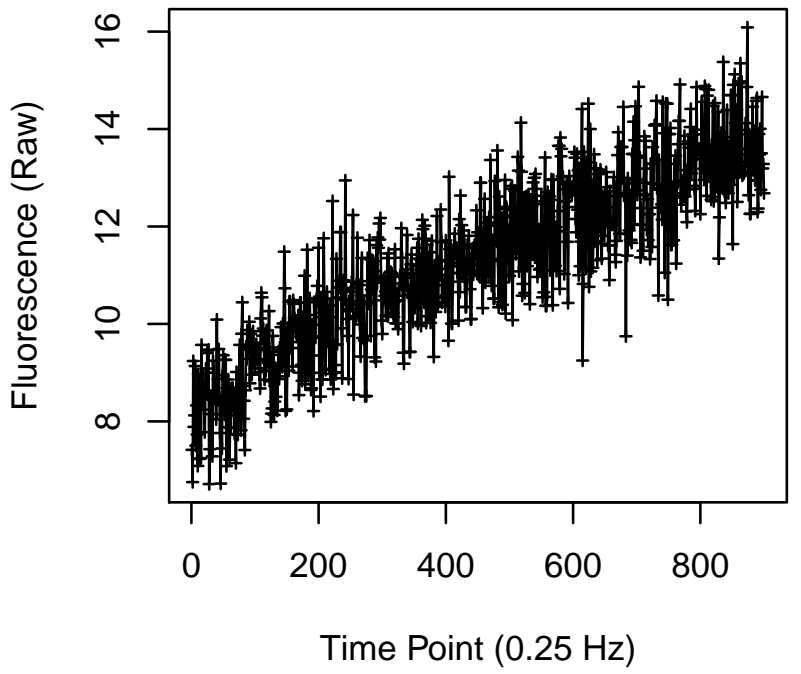

Cell 1907

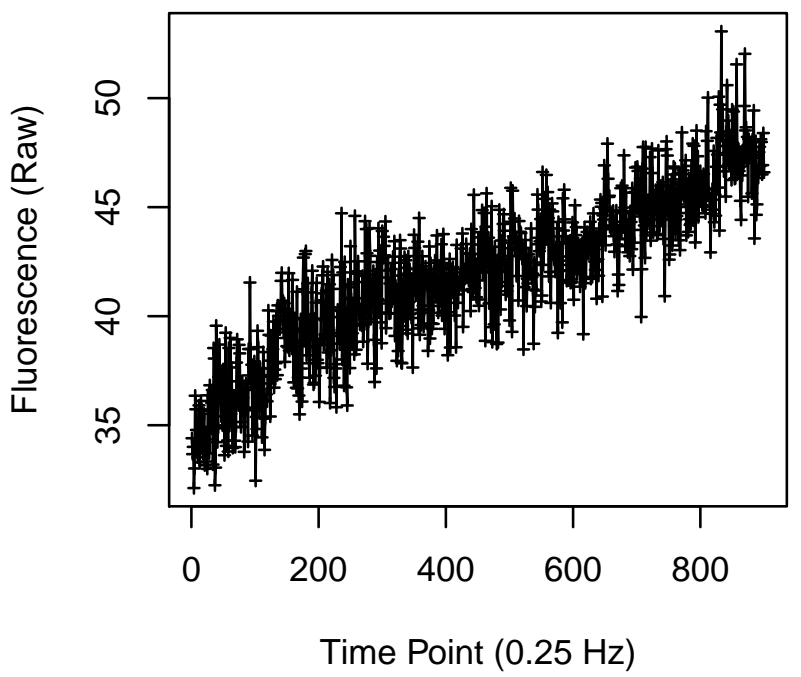

Cell 1906

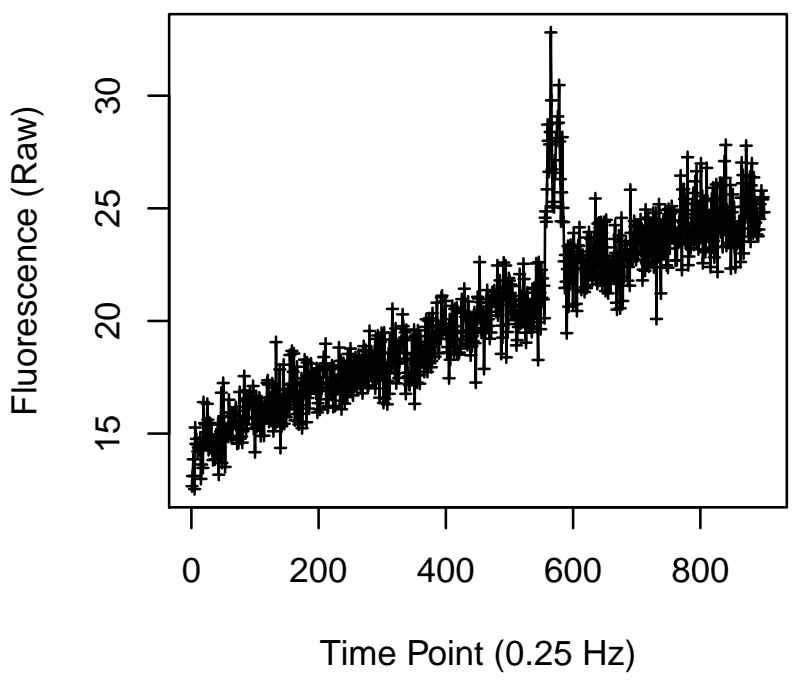

Cell 1908

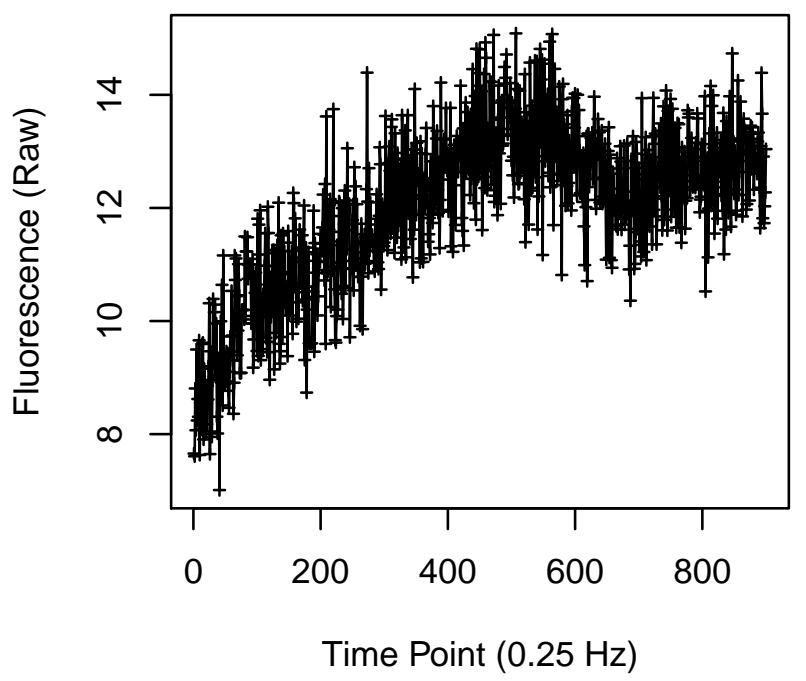


Cell 1909

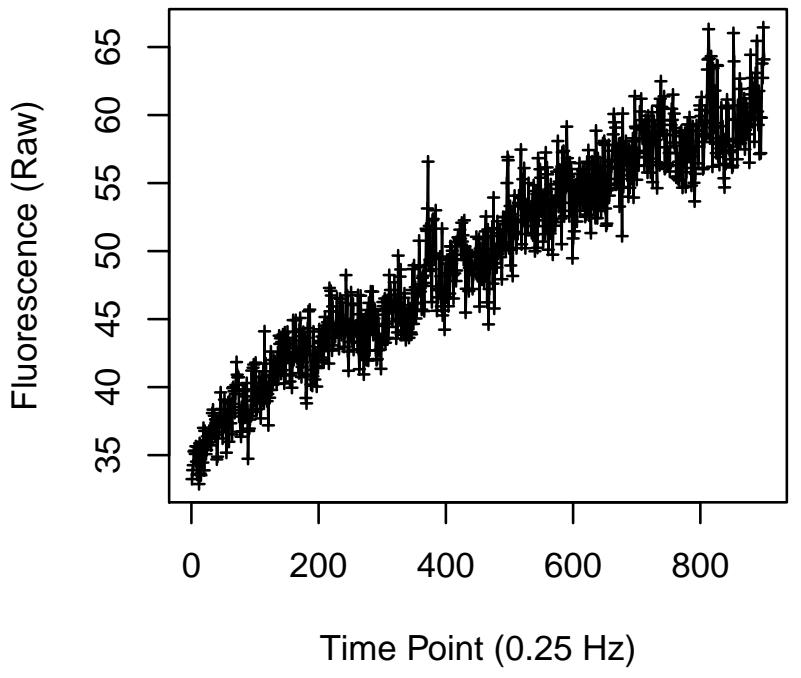

Cell 1911

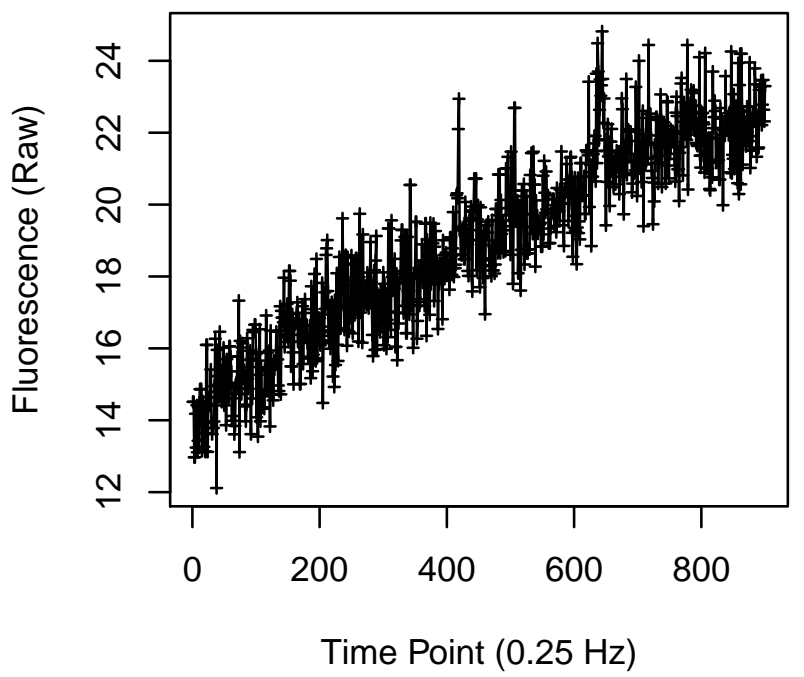

Cell 1910

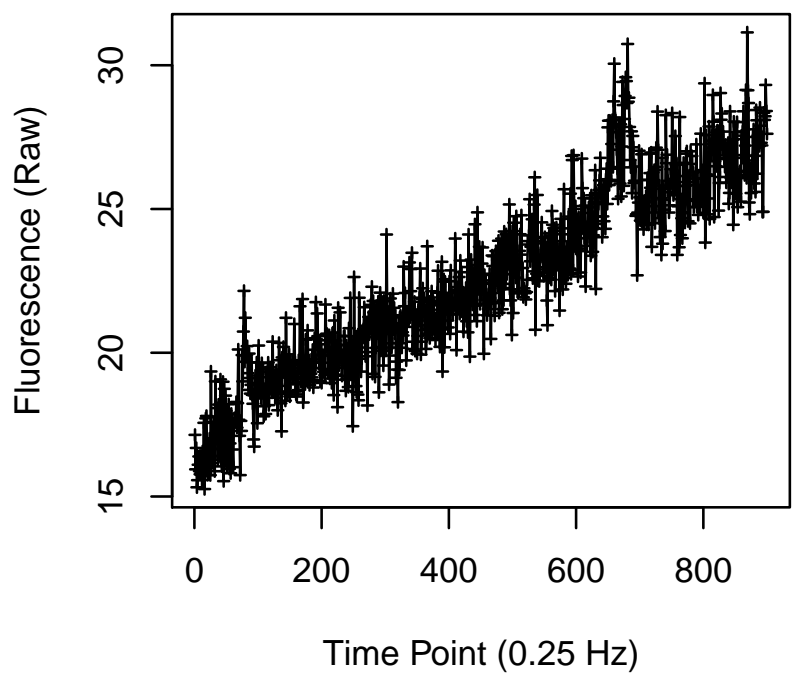

Cell 1912

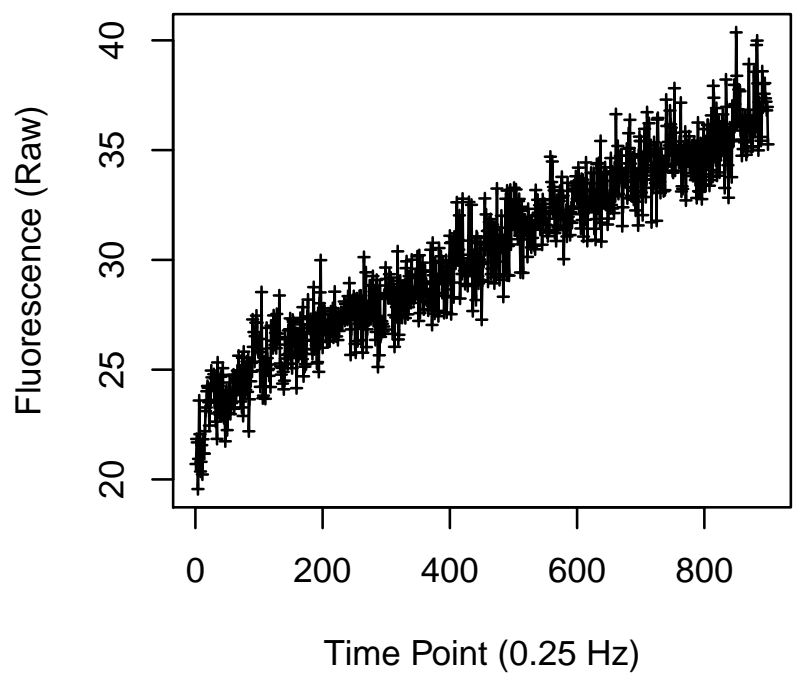


Cell 1921

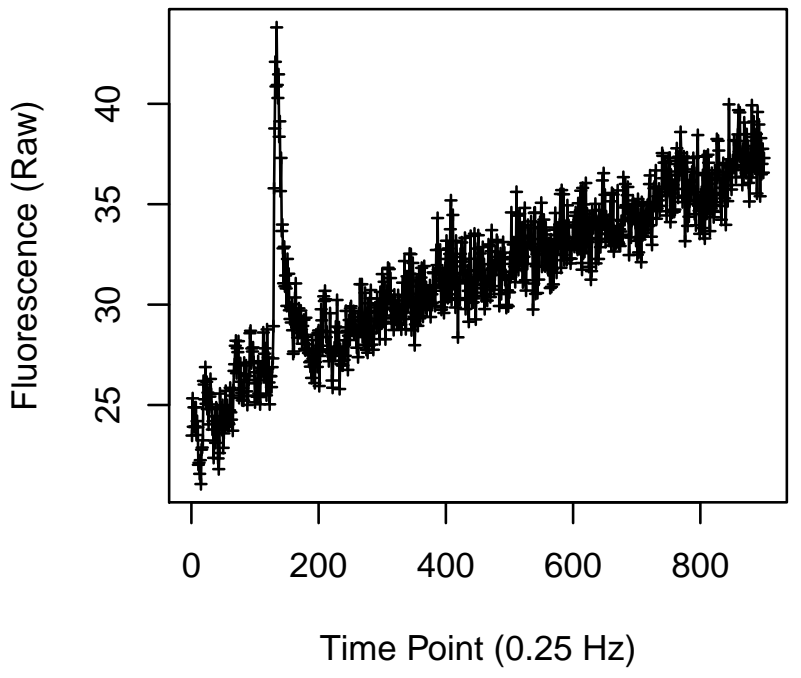

Cell 1923

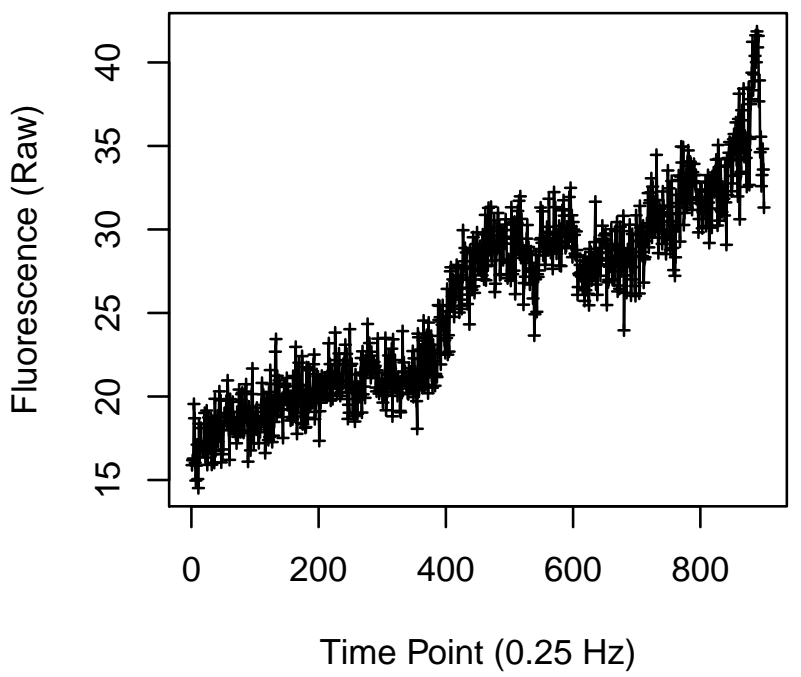

Cell 1922

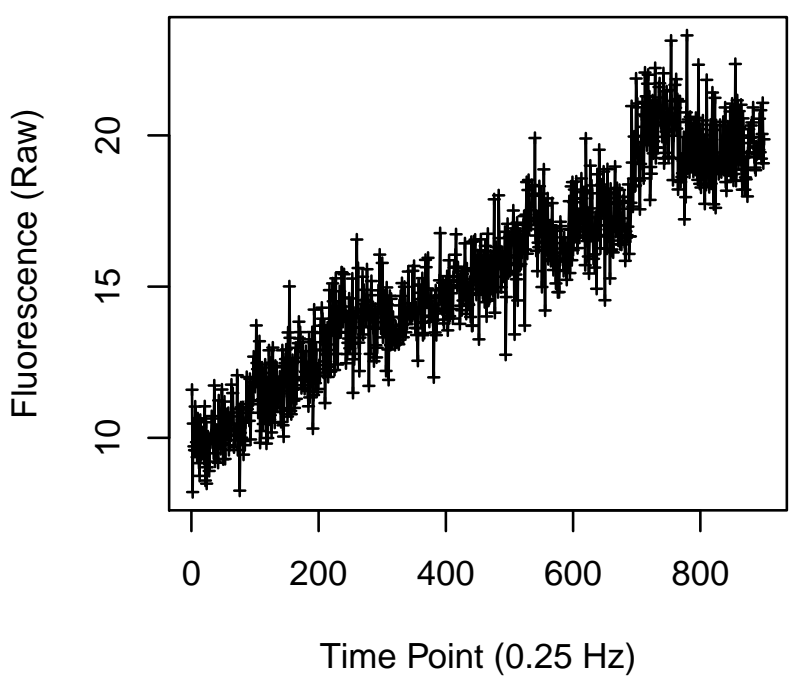

Cell 1924

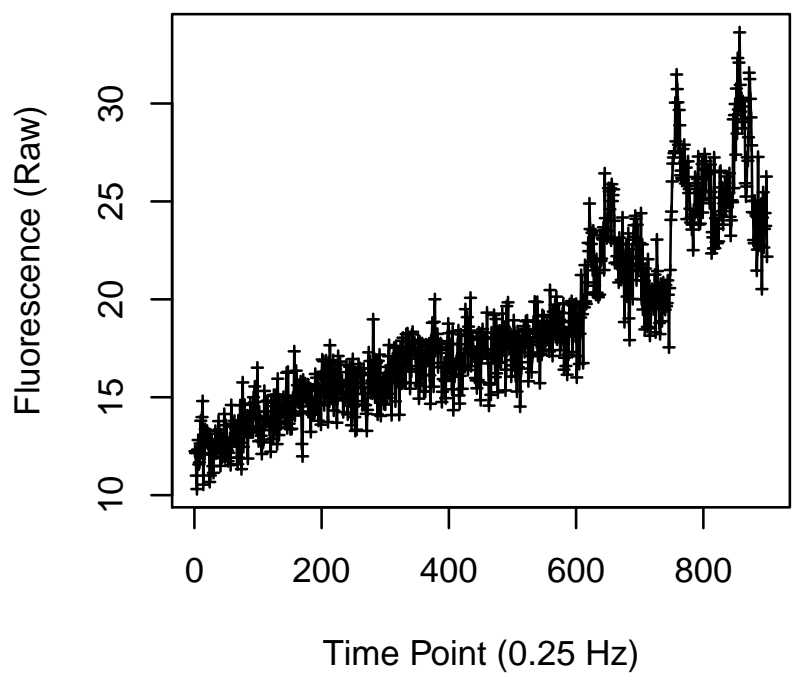


Cell 1925

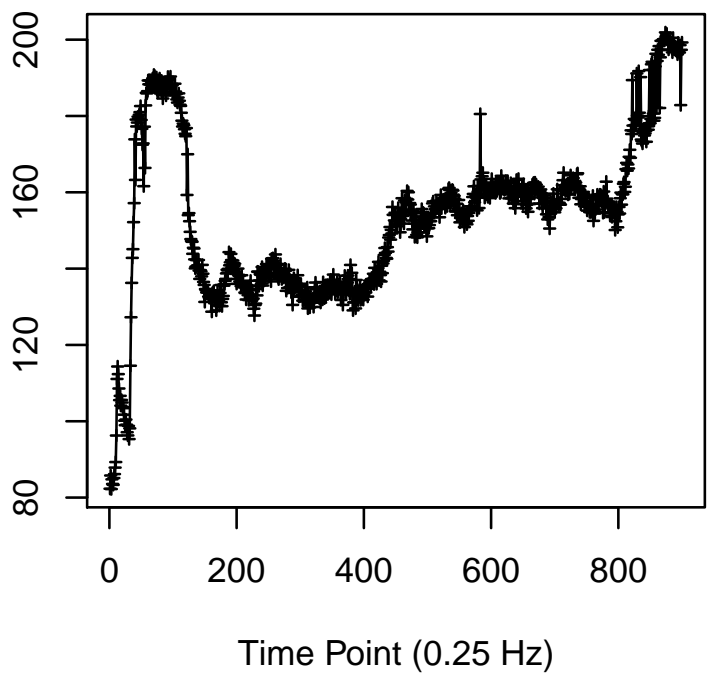

Cell 1927

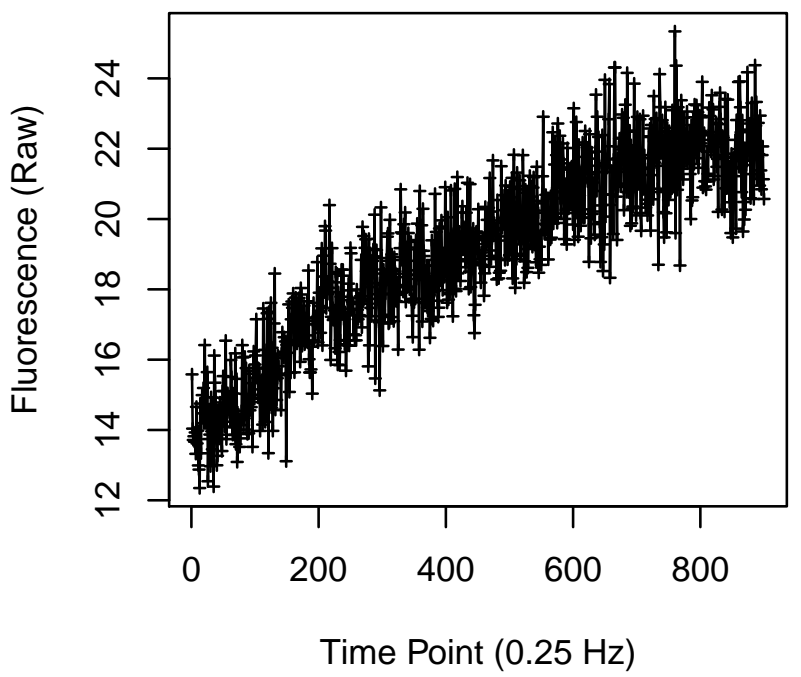

Cell 1926

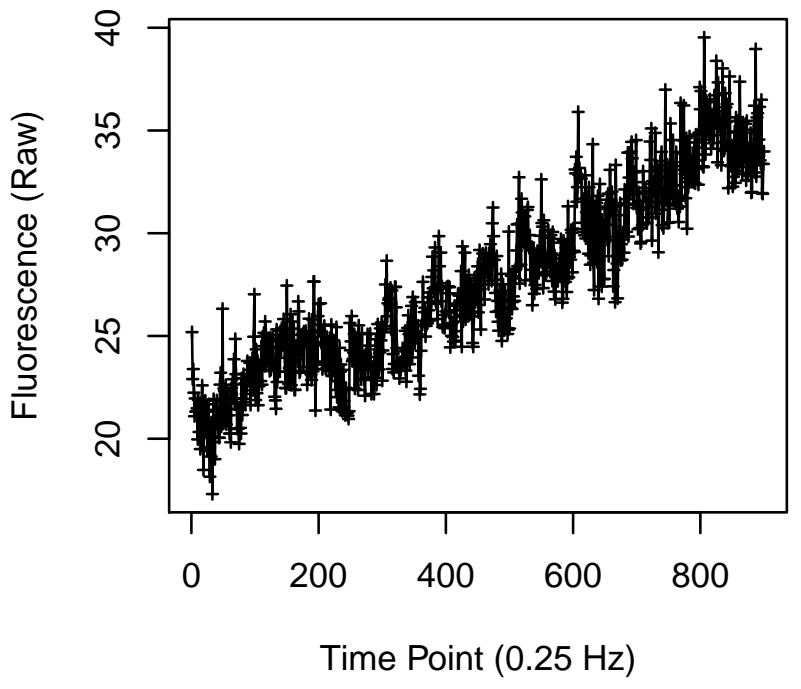

Cell 1928

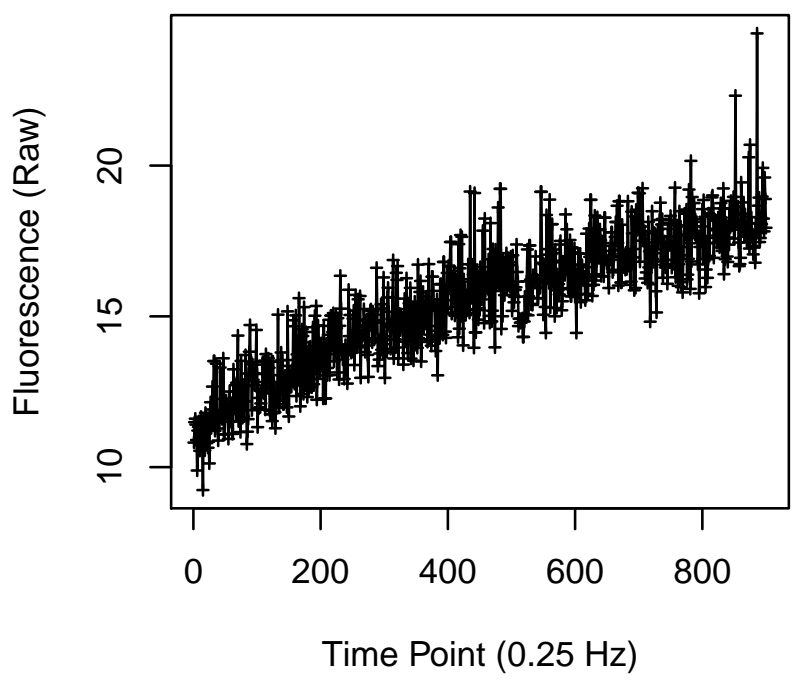


Cell 1929

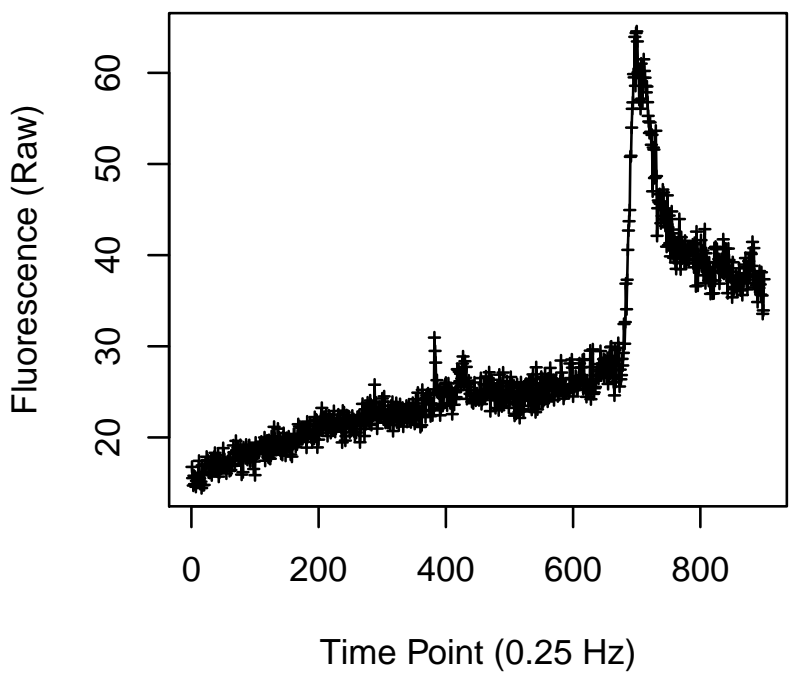

Cell 1931

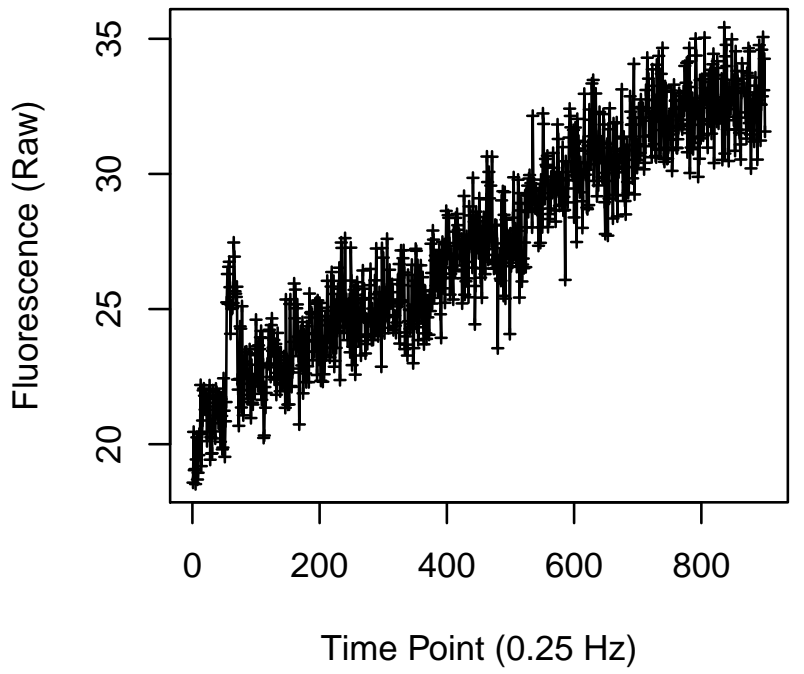

Cell 1930

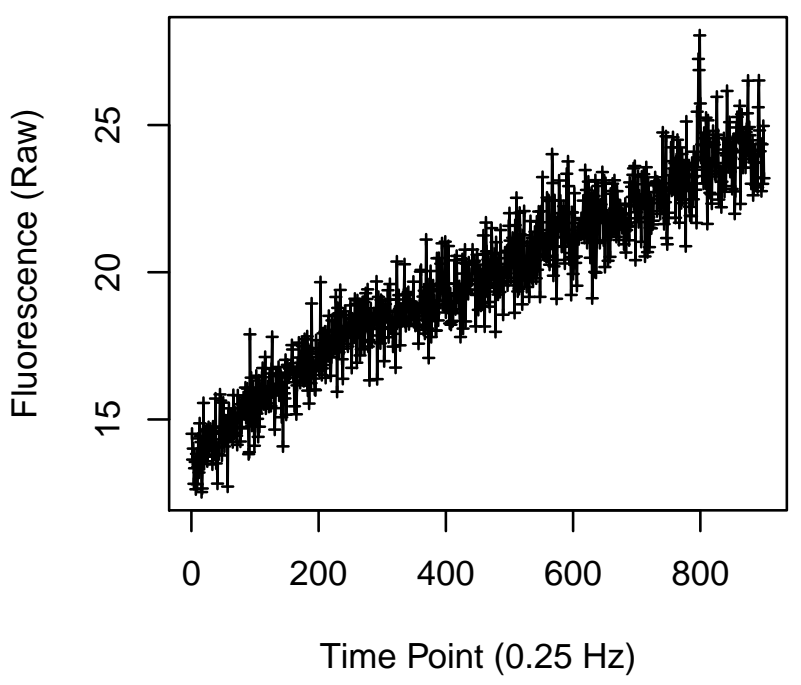

Cell 1932

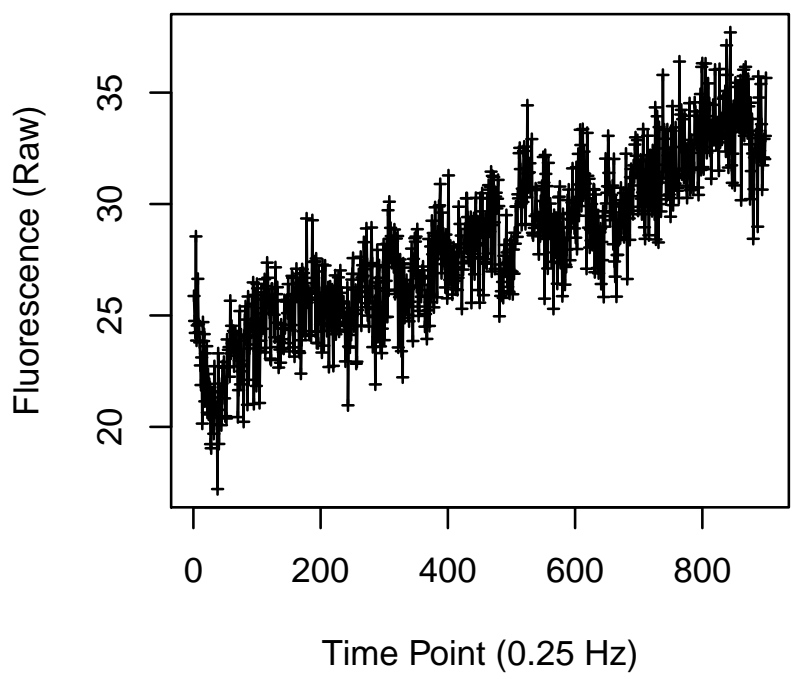


Cell 1933

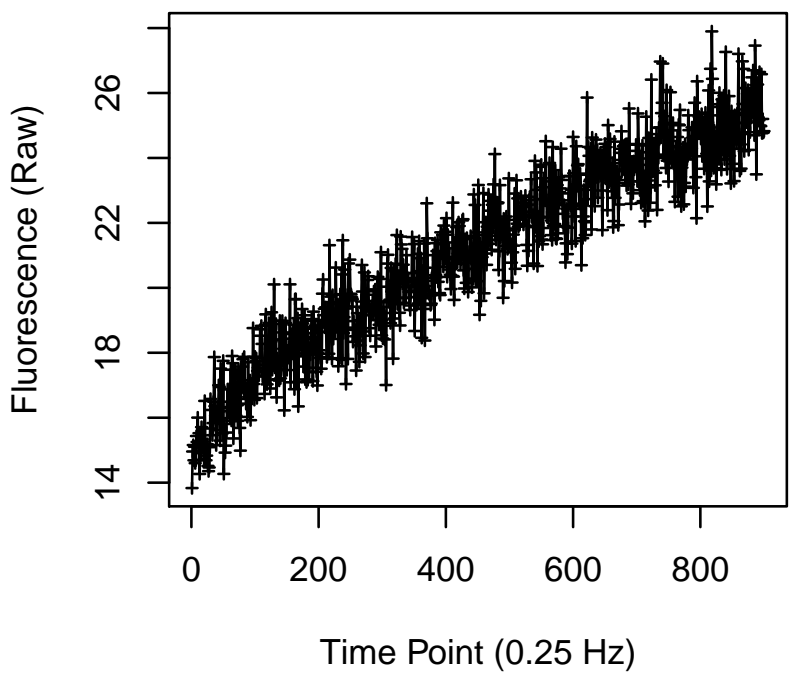

Cell 1935

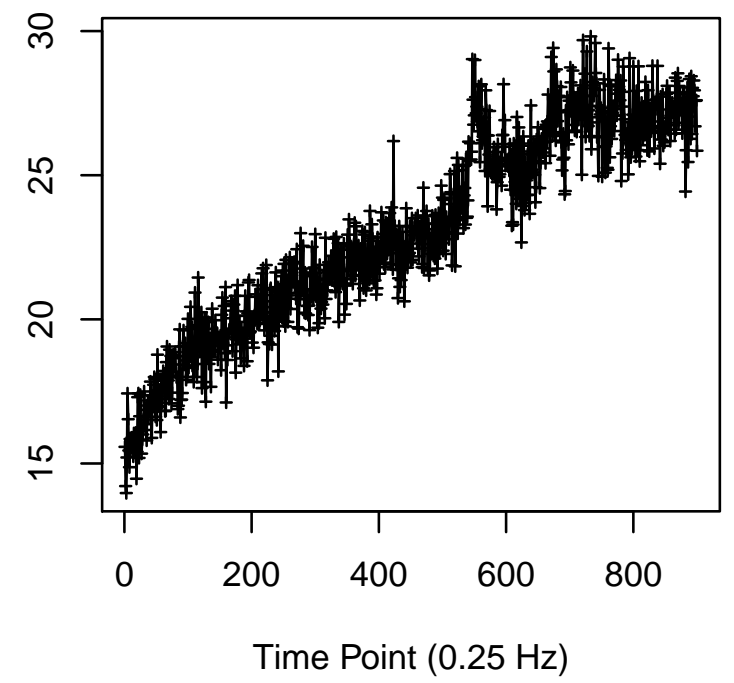

Cell 1934

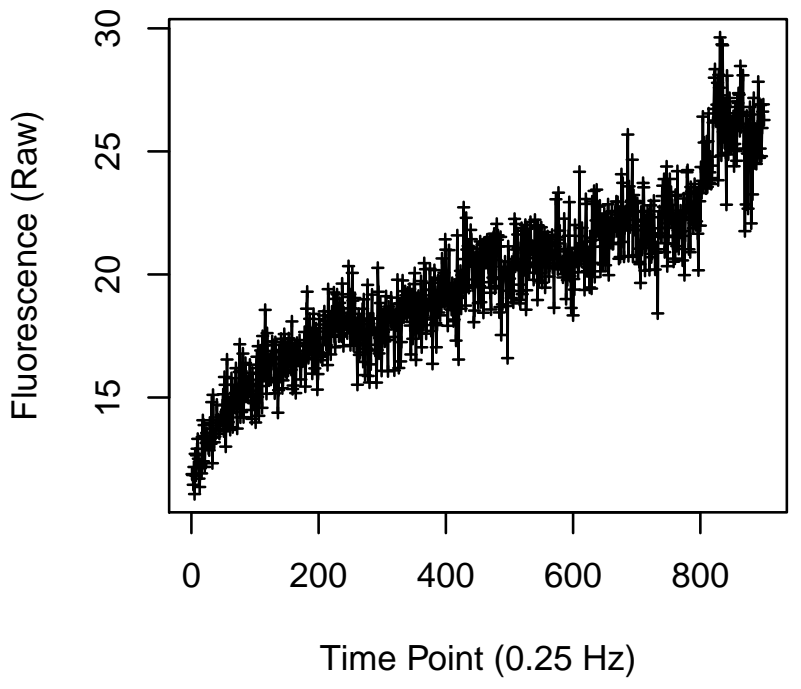

Cell 1936

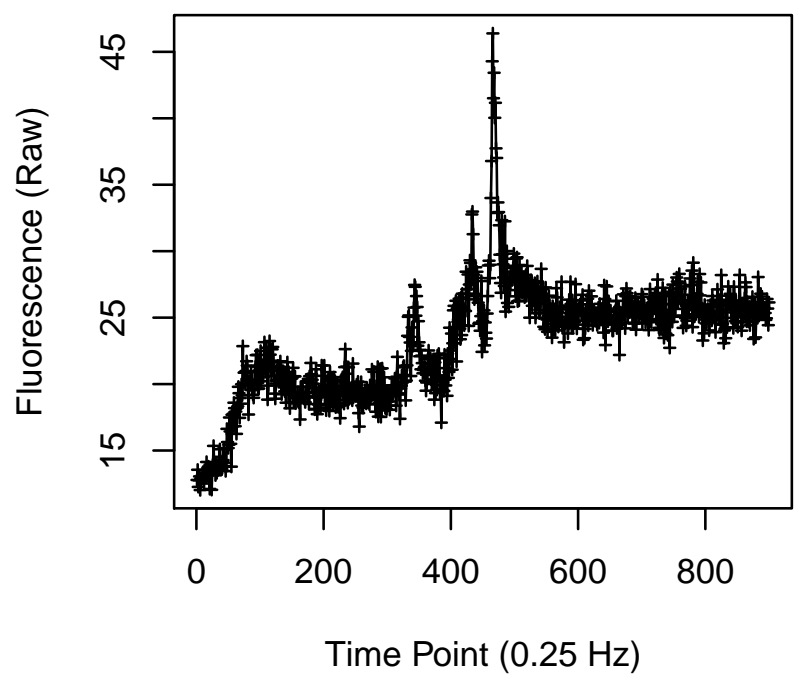


Cell 1937

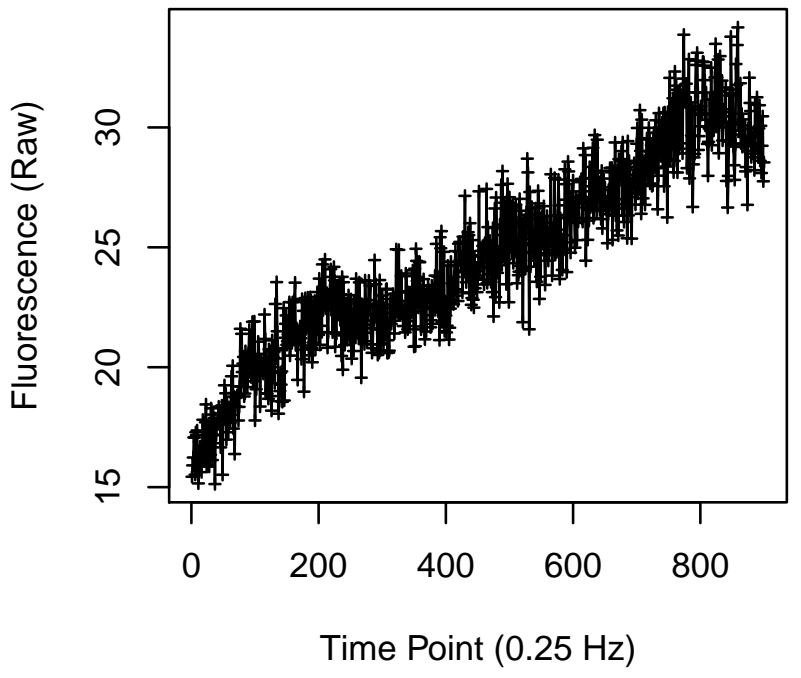

Cell 1939

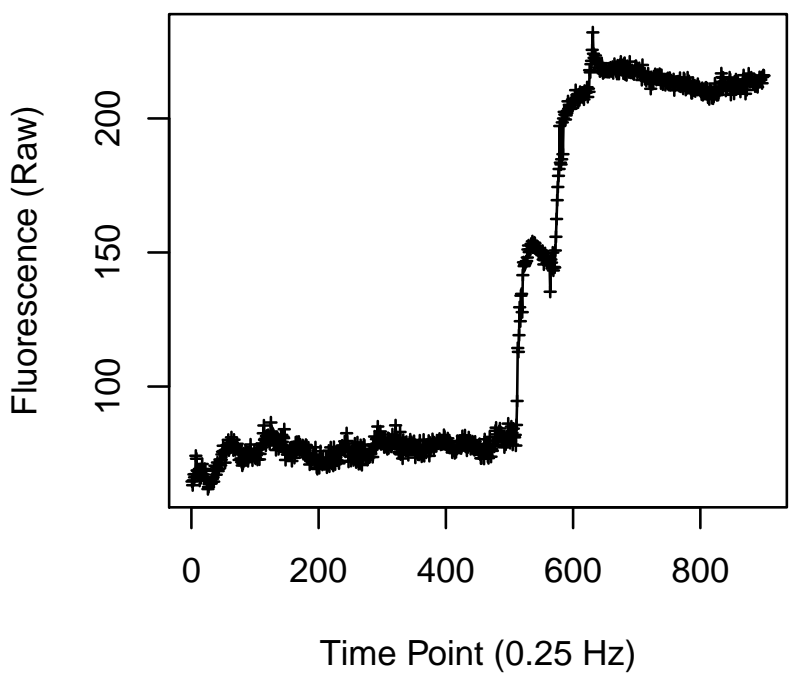

Cell 1938

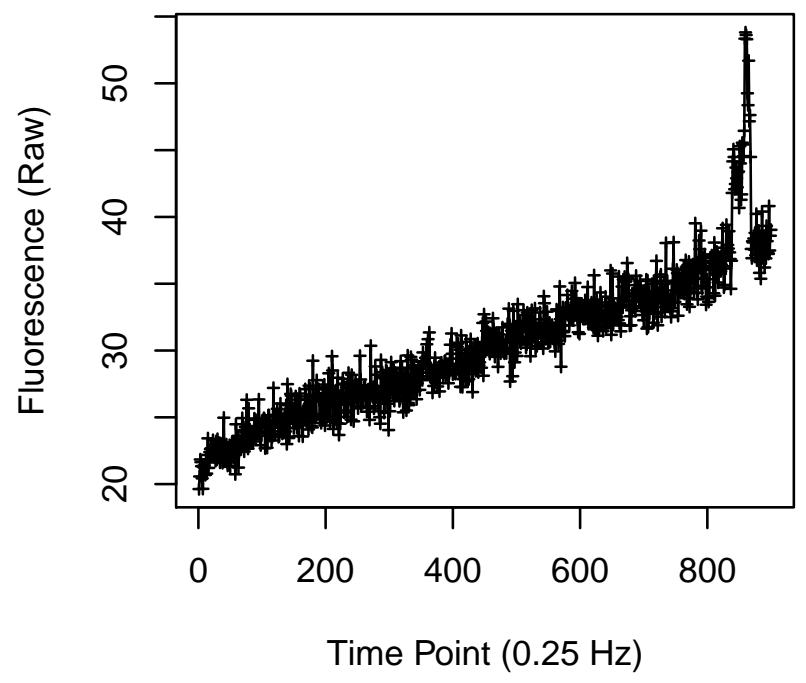

Cell 1940

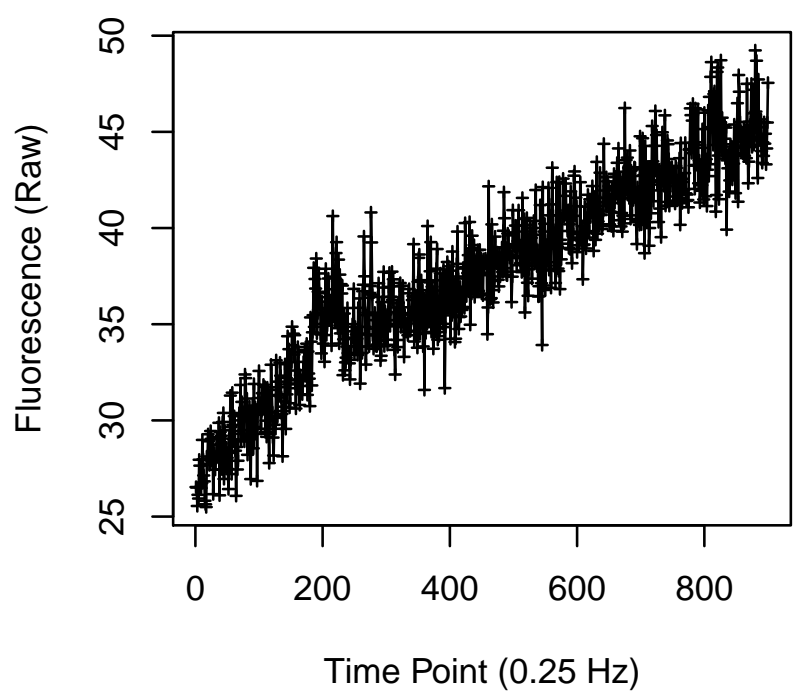


Cell 1941

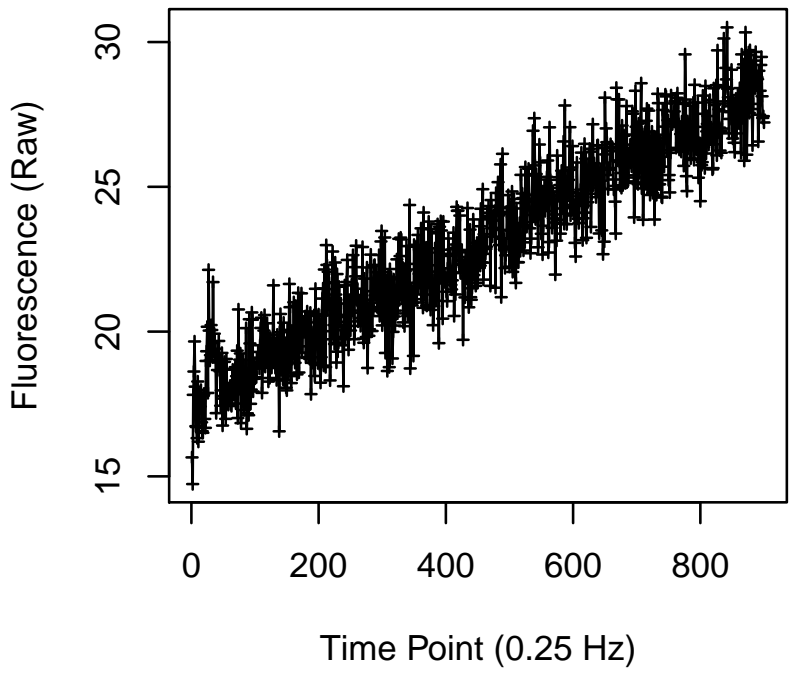

Cell 1943

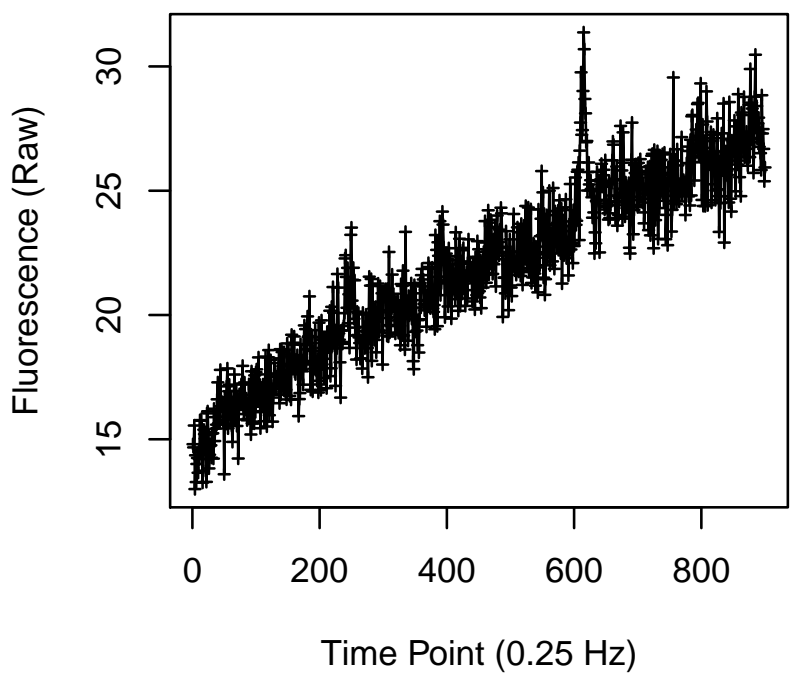

Cell 1942

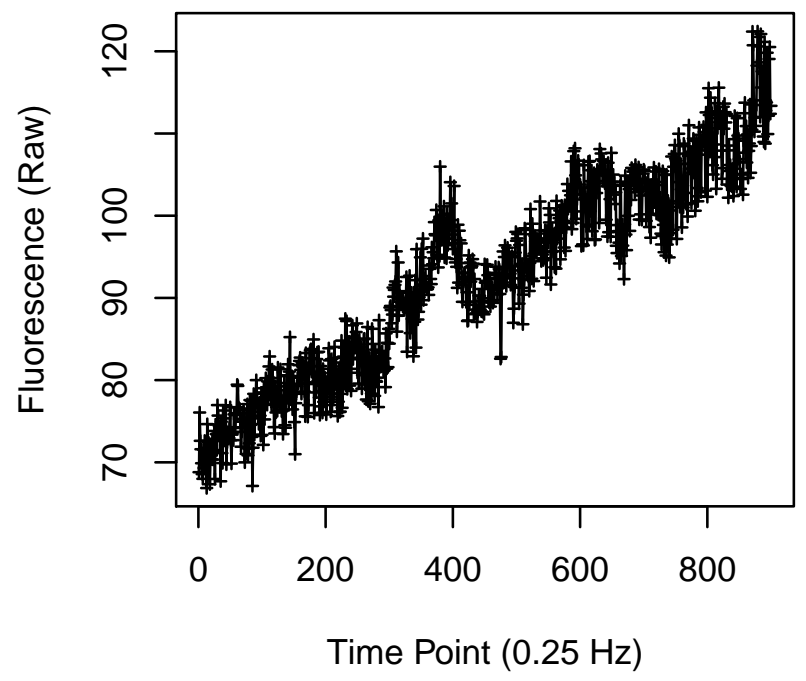

Cell 1944

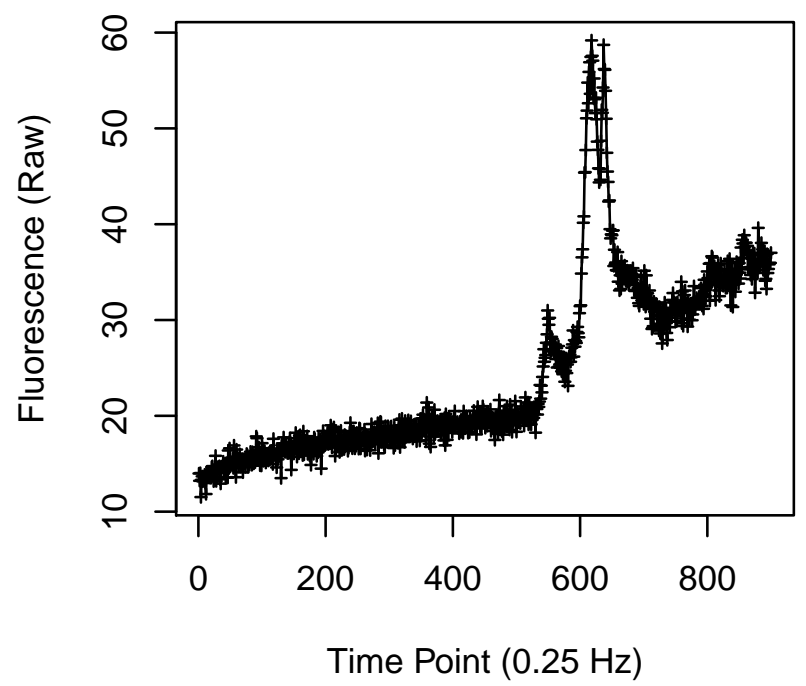


Cell 1945

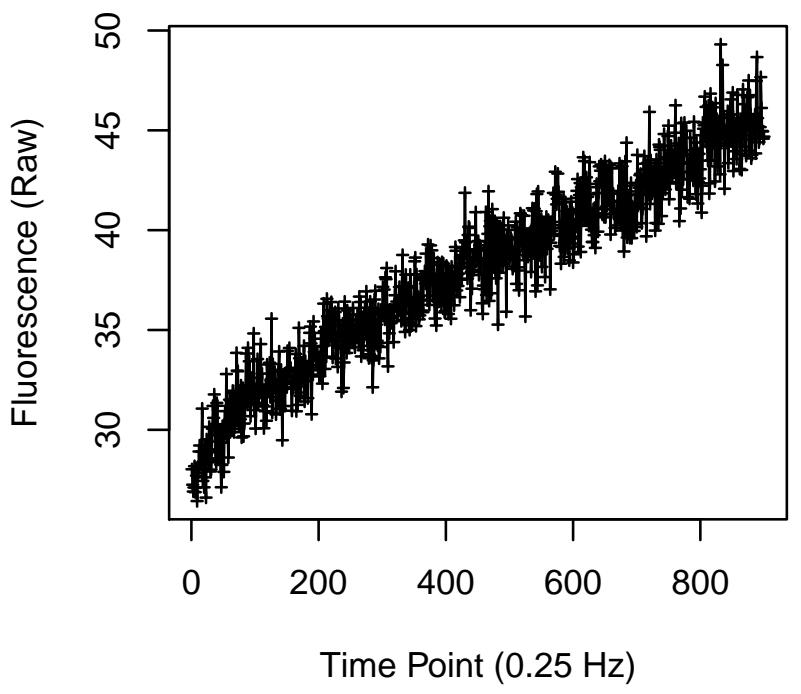

Cell 1947

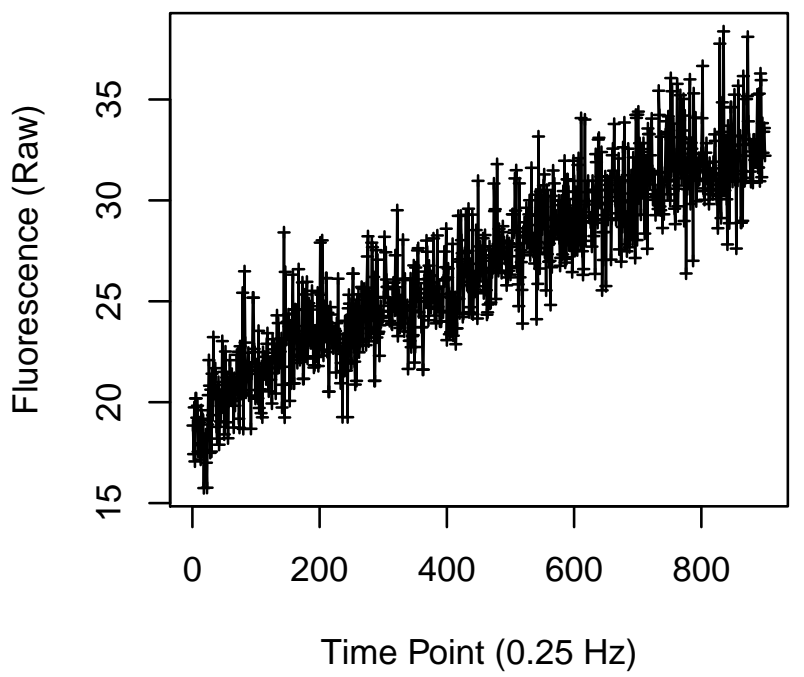

Cell 1946

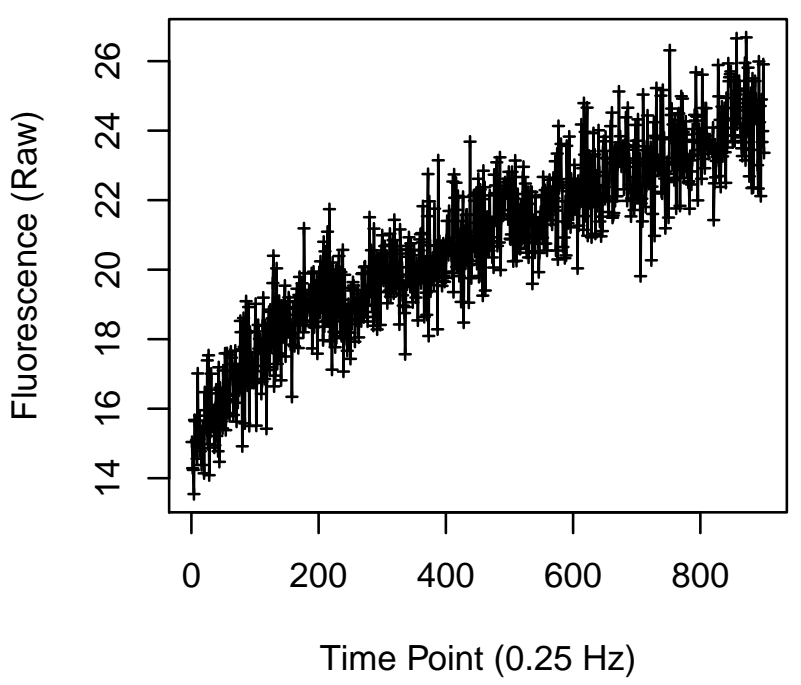

Cell 1948

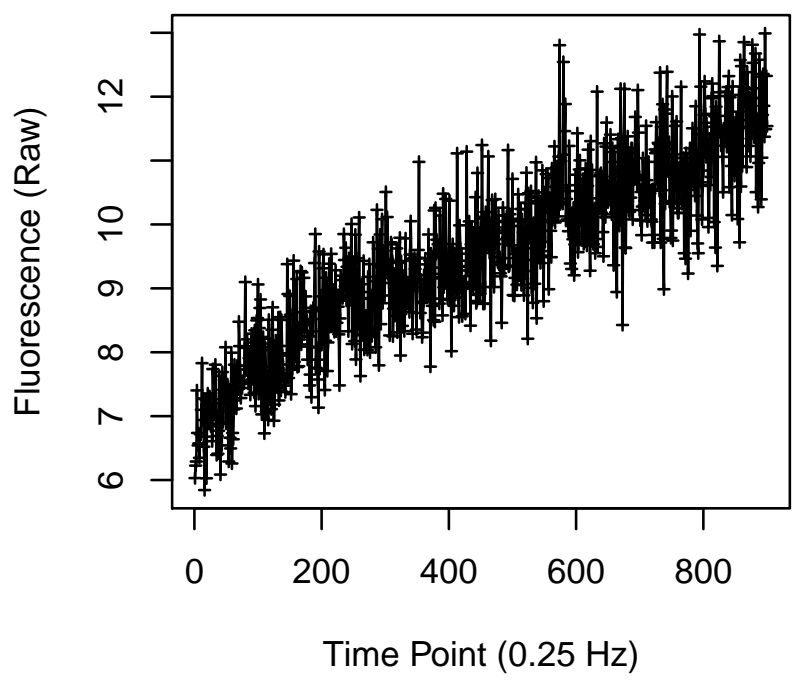


Cell 1949

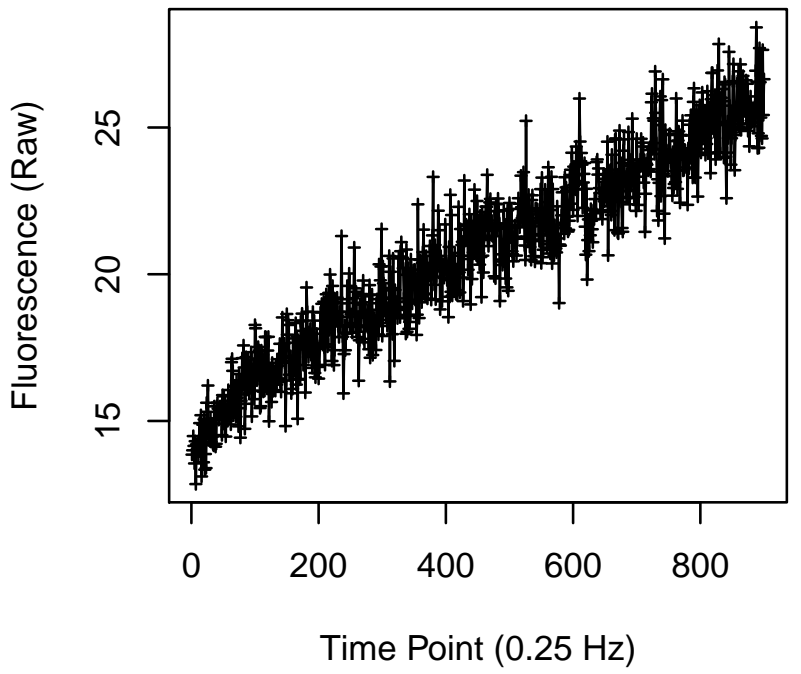

Cell 1951

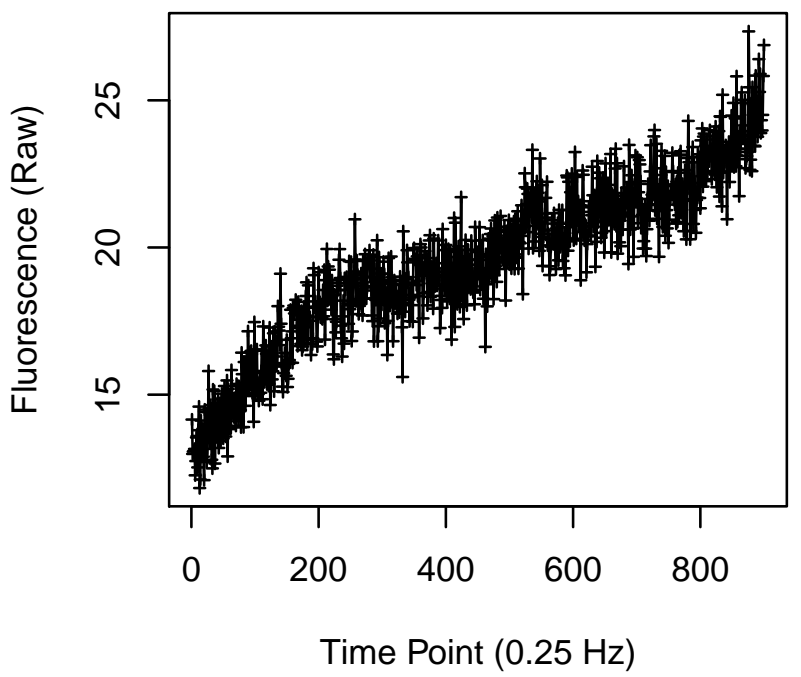

Cell 1950

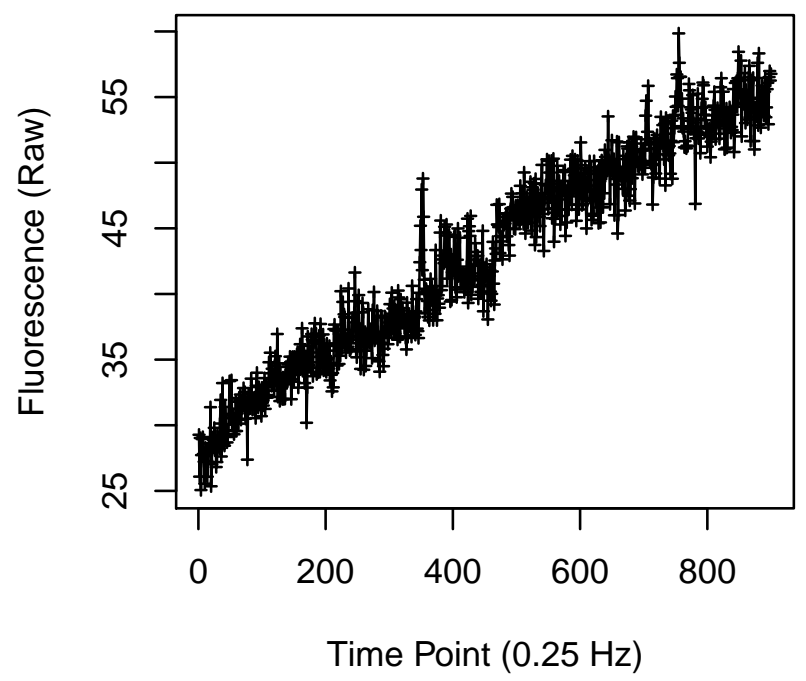

Cell 1952

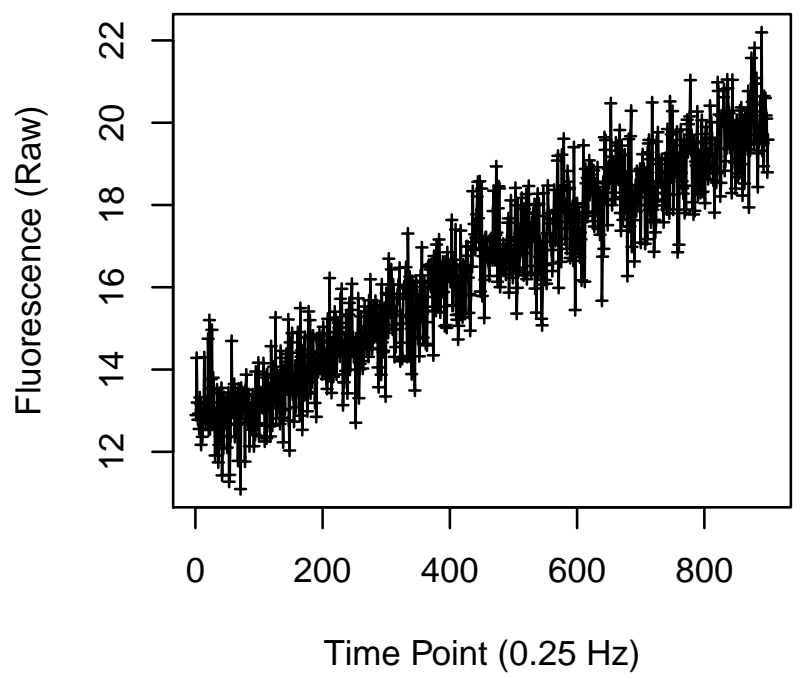


Cell 1957

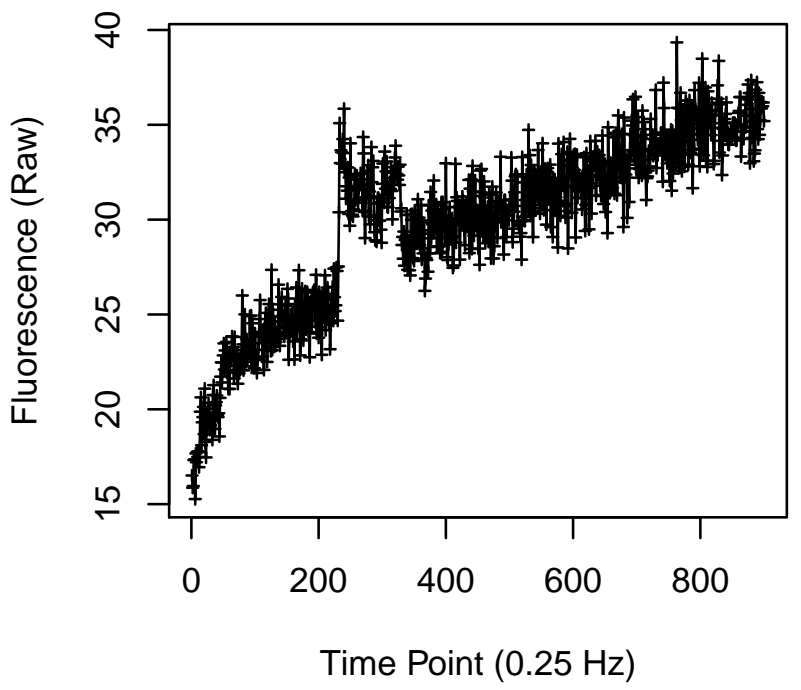

Cell 1959

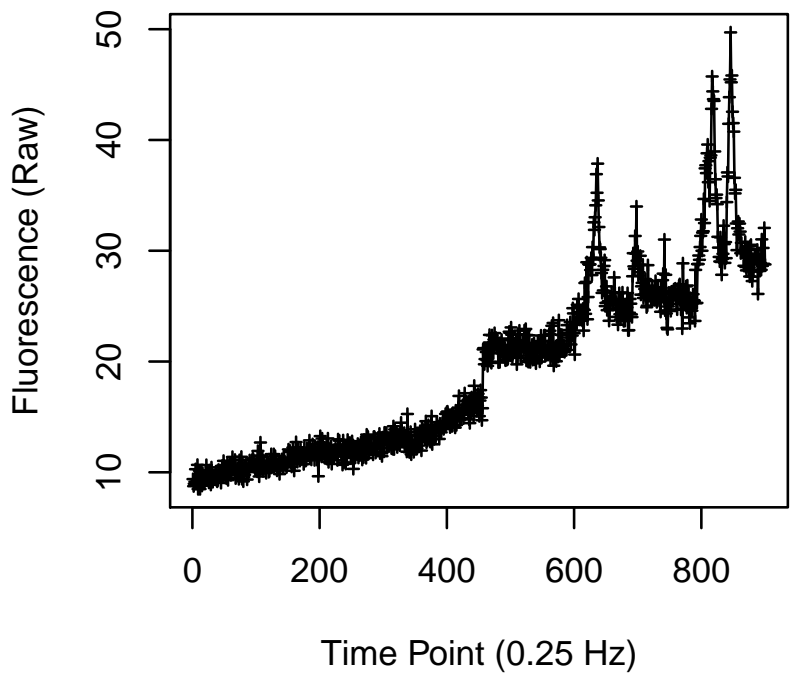

Cell 1958

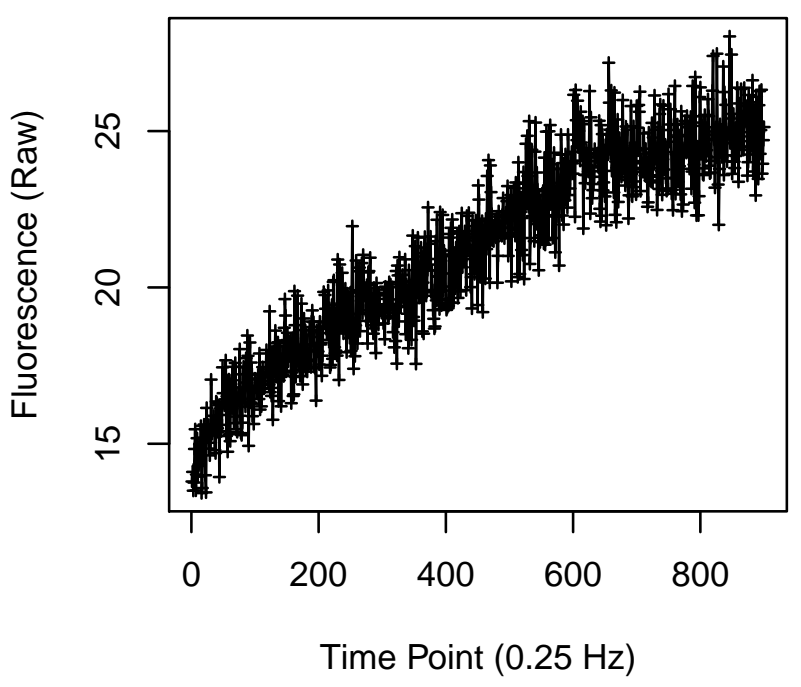

Cell 1960

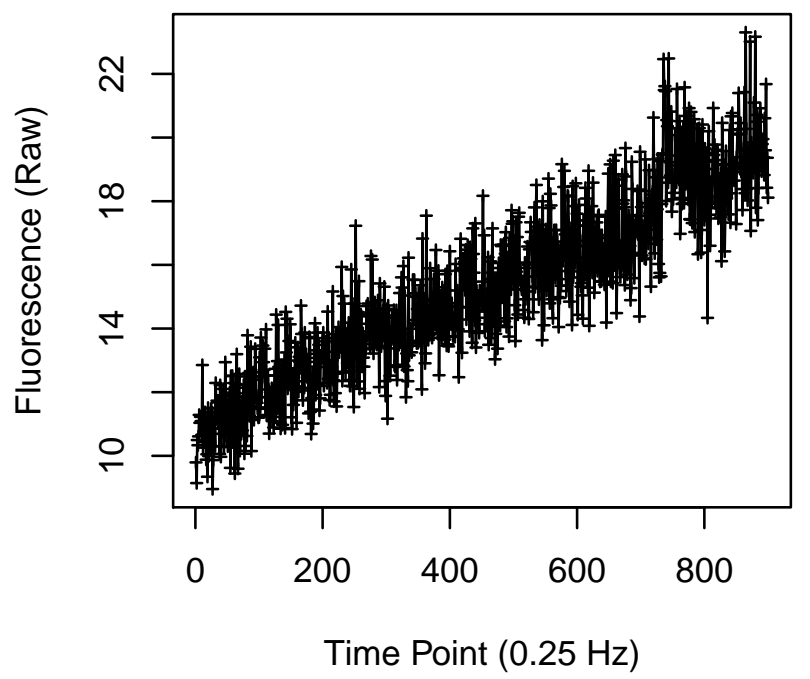


Cell 1965

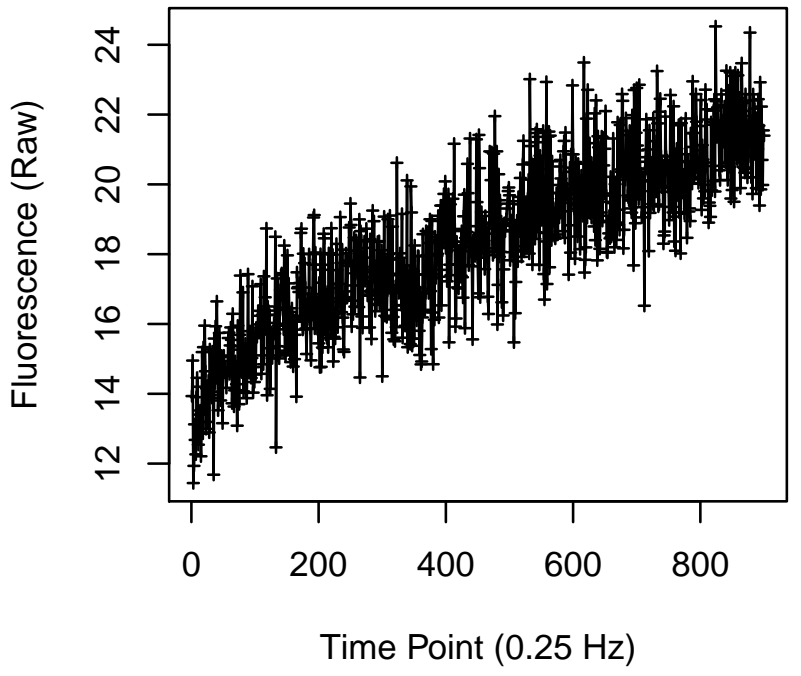

Cell 1967

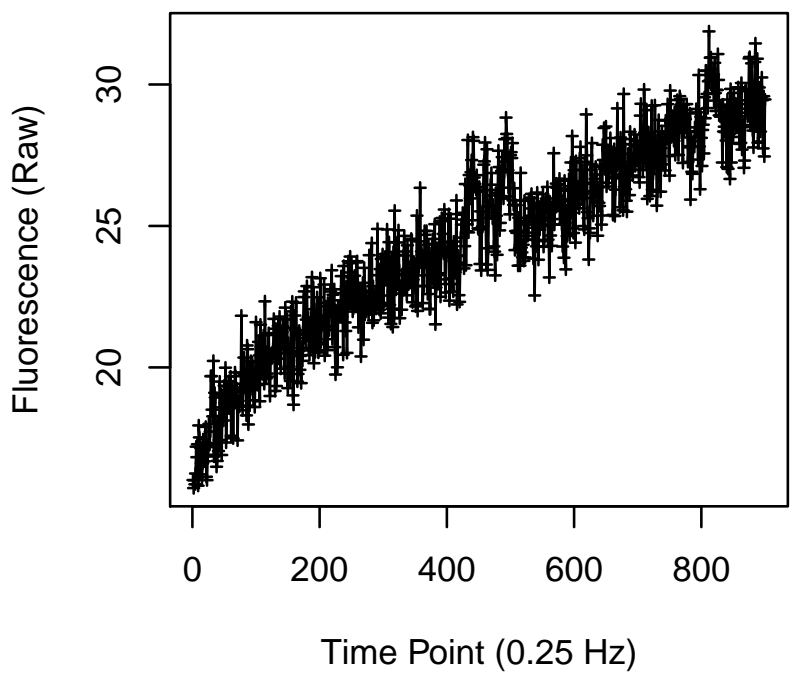

Cell 1966

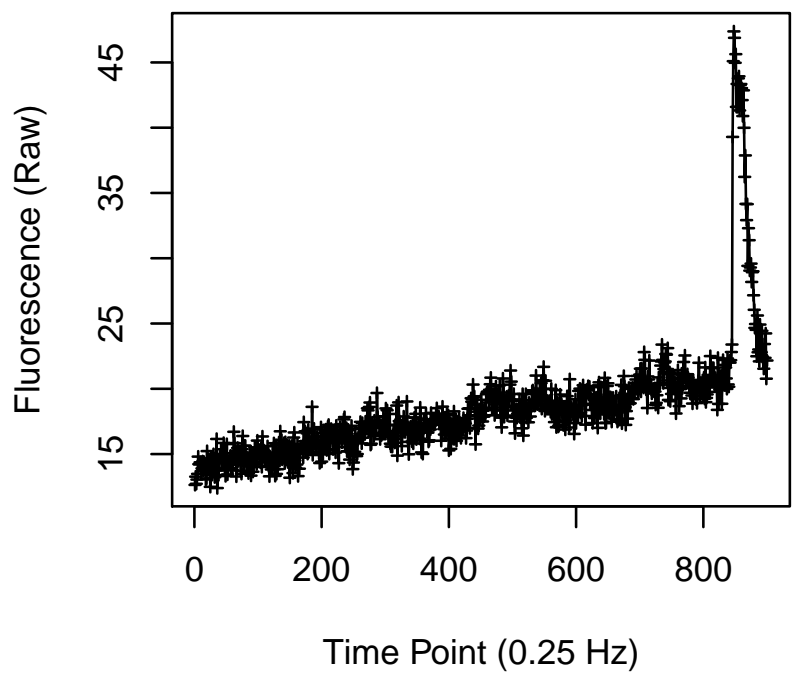

Cell 1968

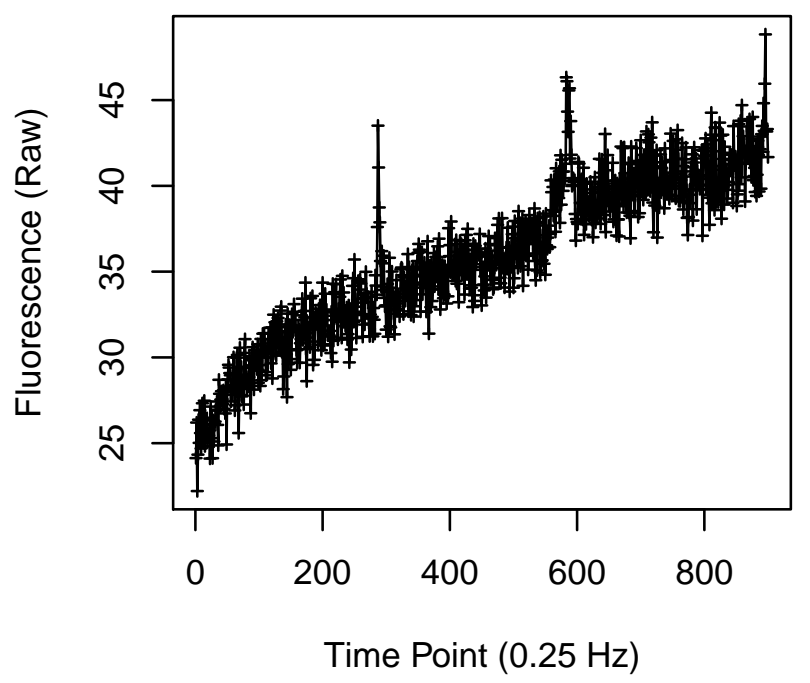


Cell 1969

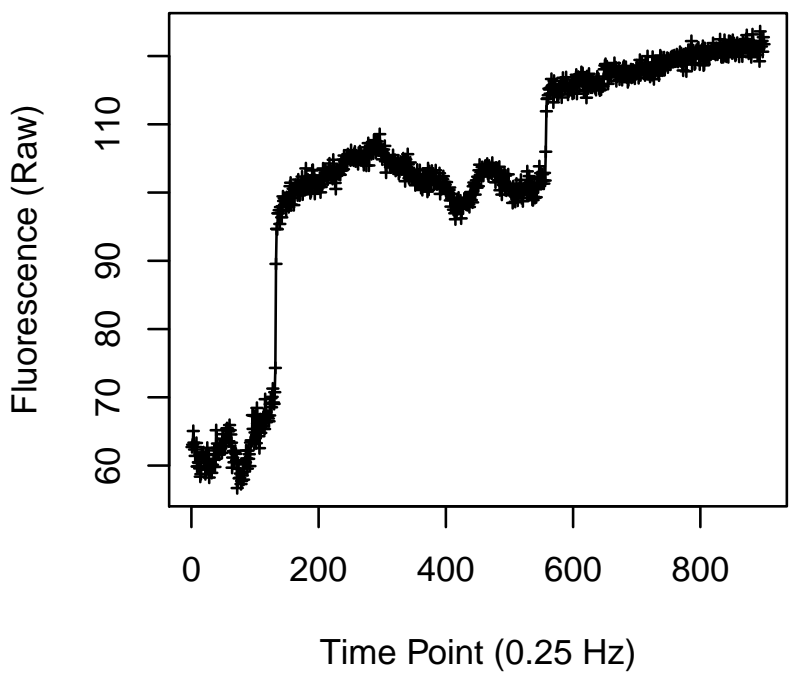

Cell 1971

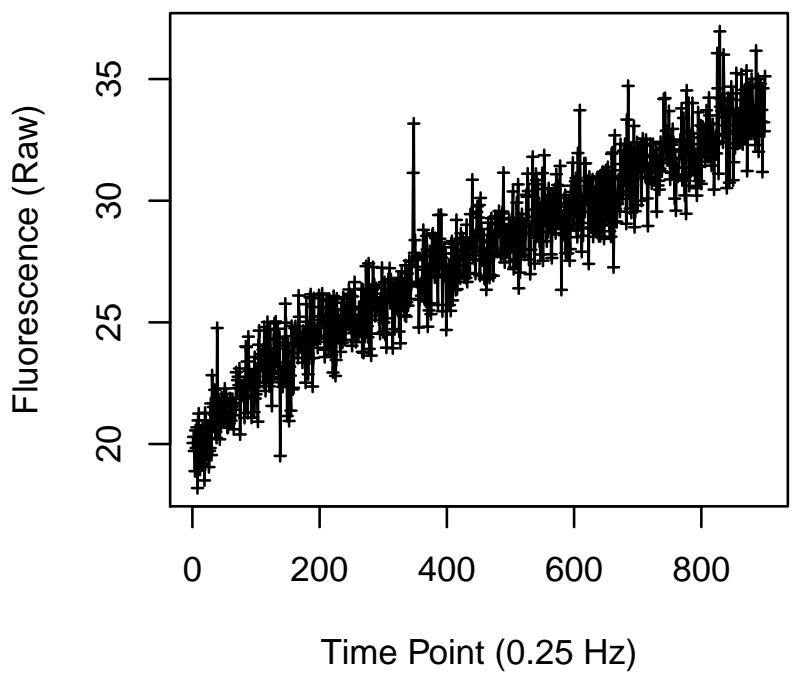

Cell 1970

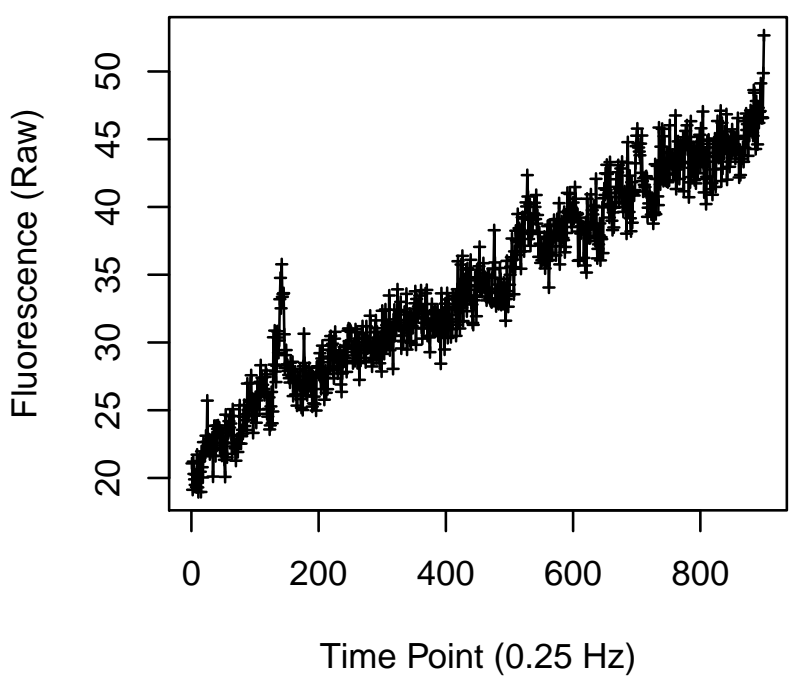

Cell 1972

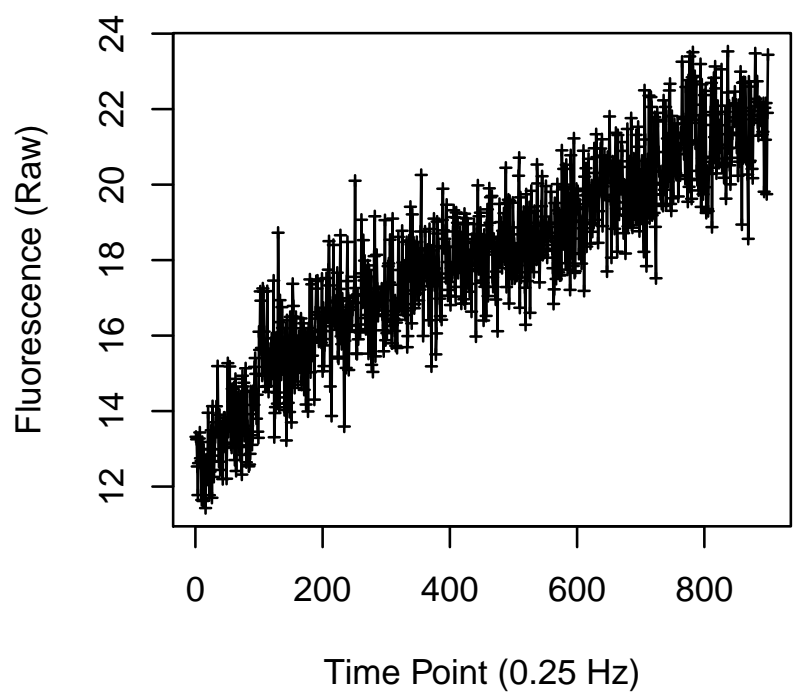


Cell 1973

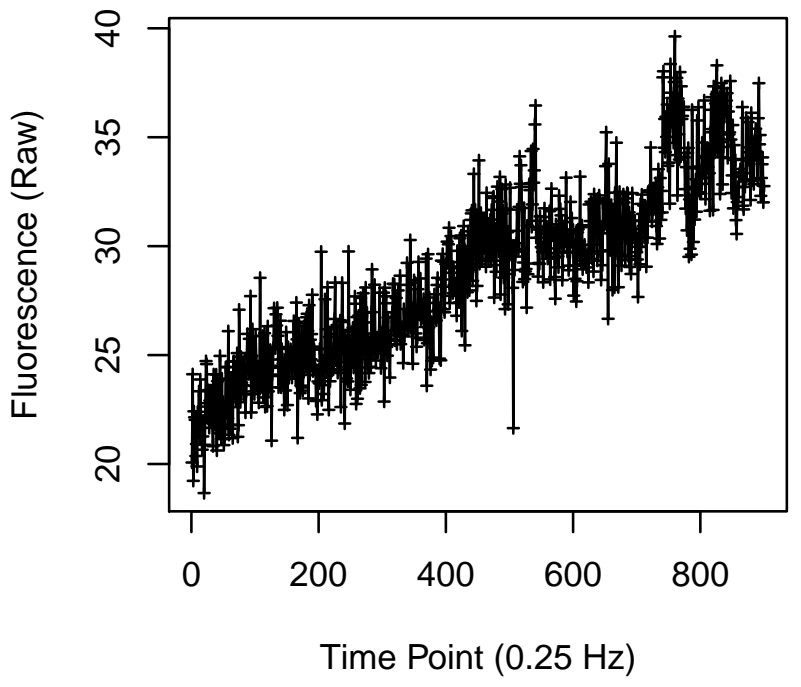

Cell 1975

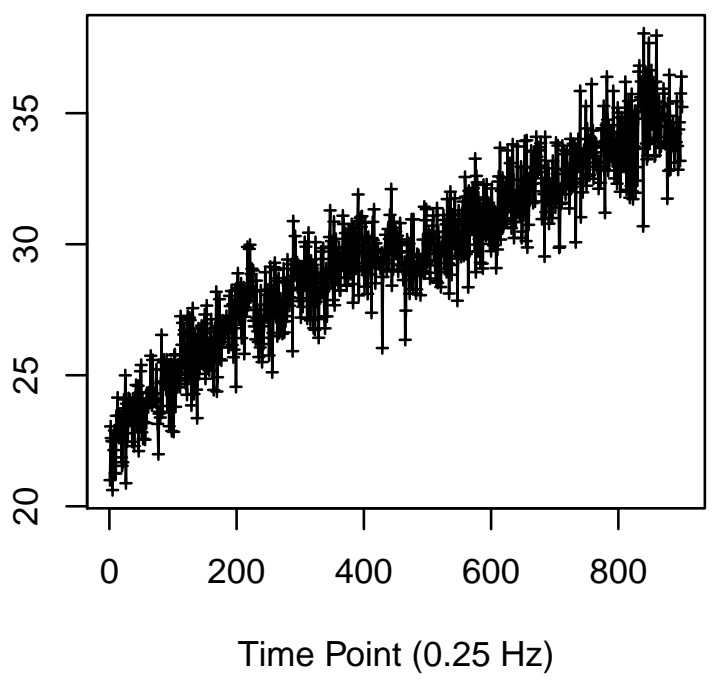

Cell 1974

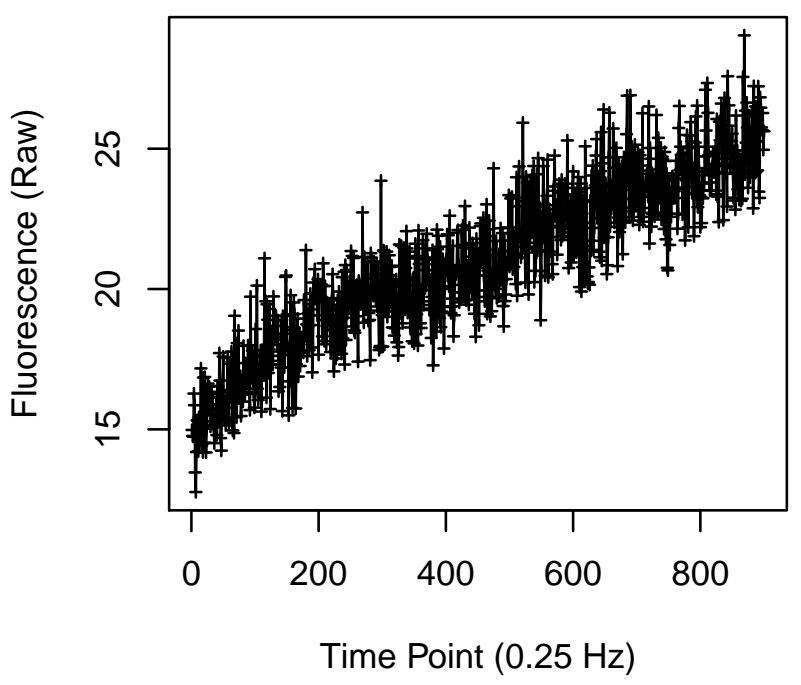

Cell 1976

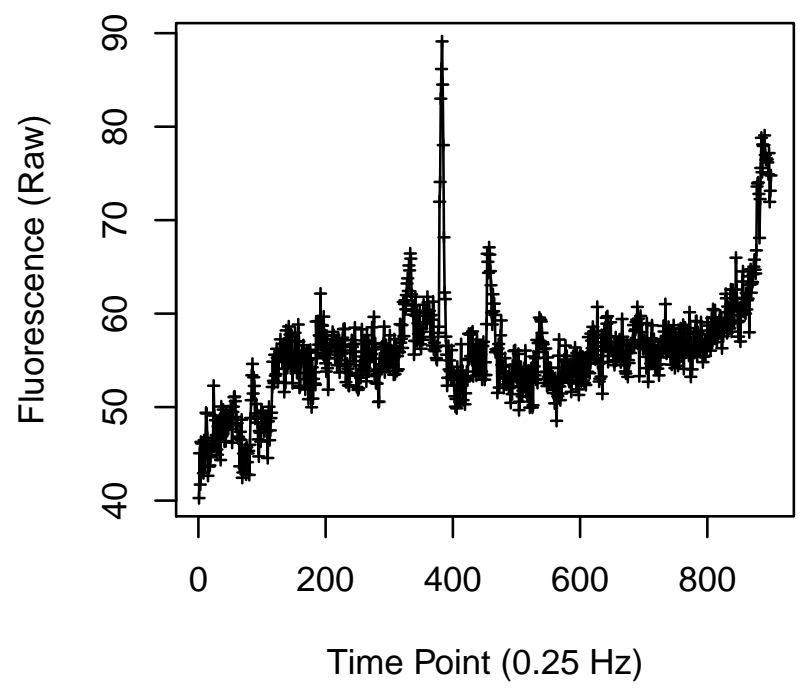


Cell 1977

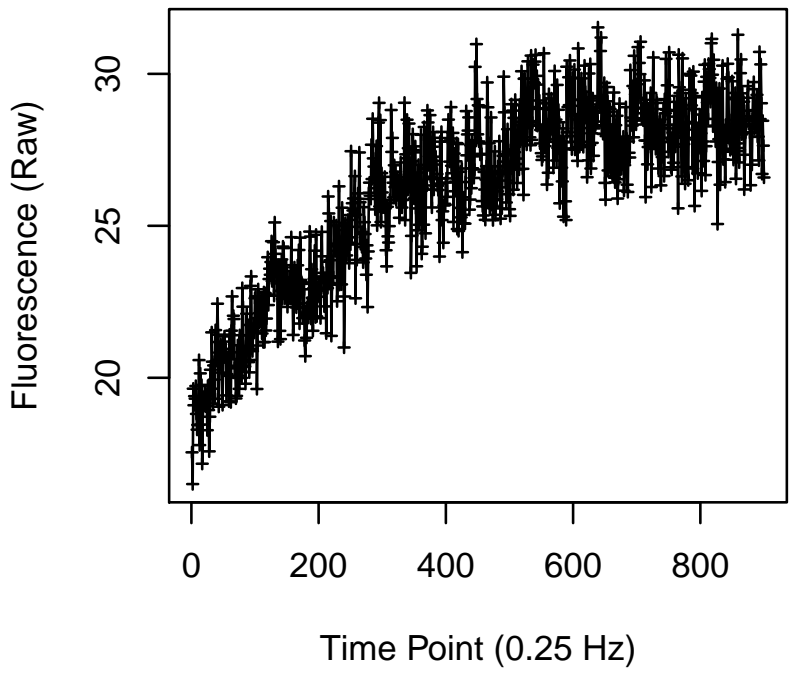

Cell 1979

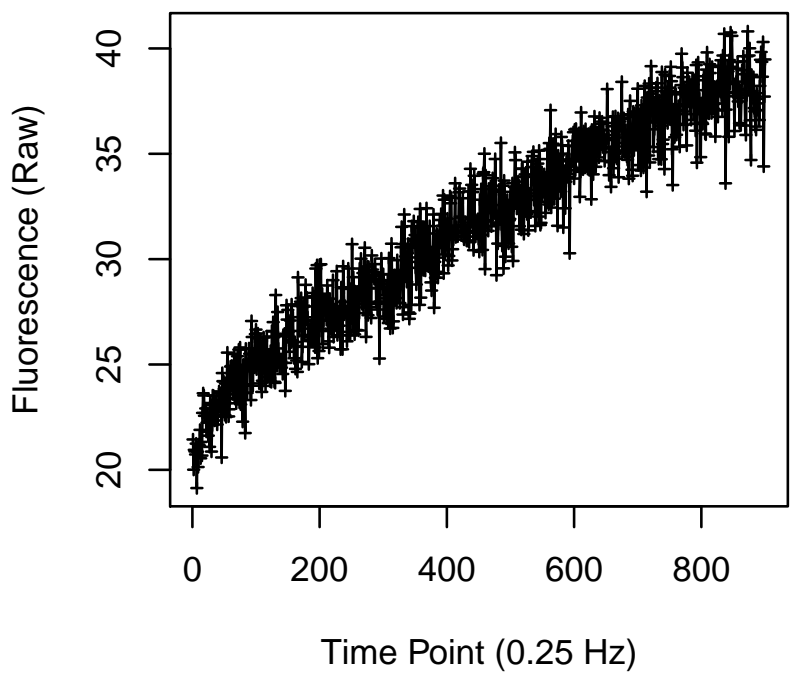

Cell 1978

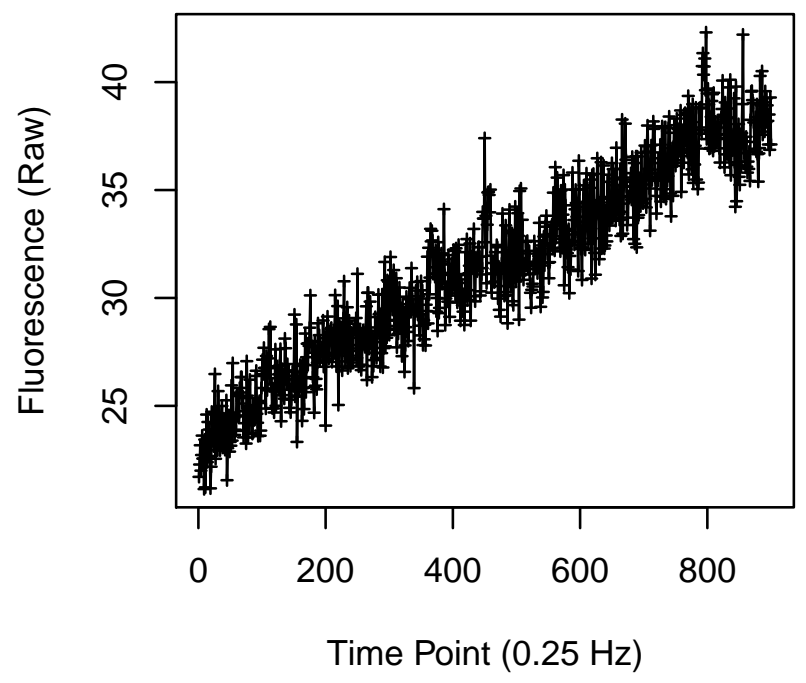

Cell 1980

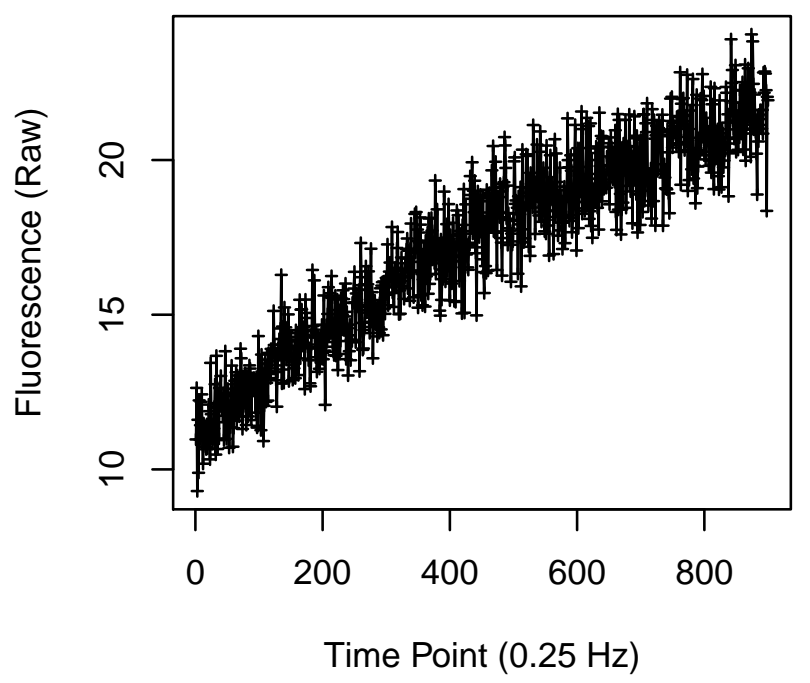


Cell 1981

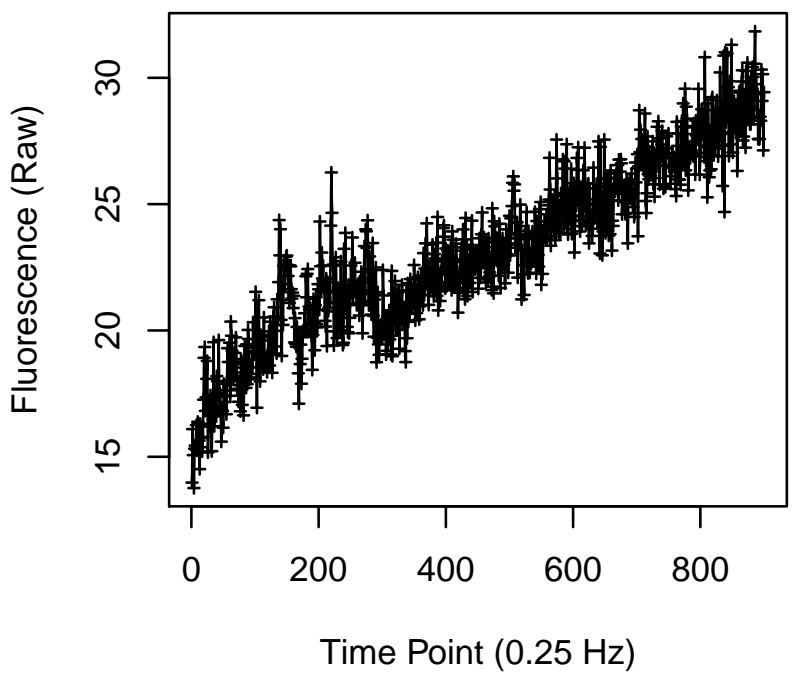

Cell 1983

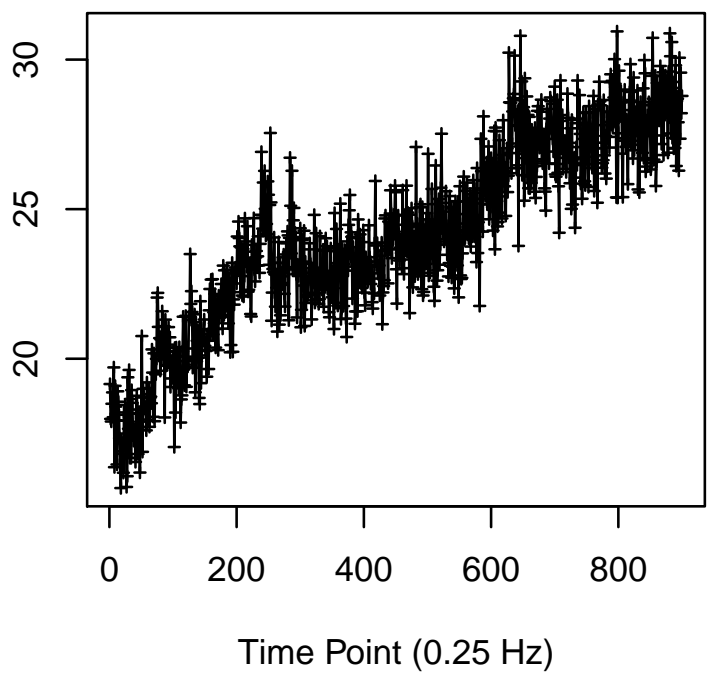

Cell 1982

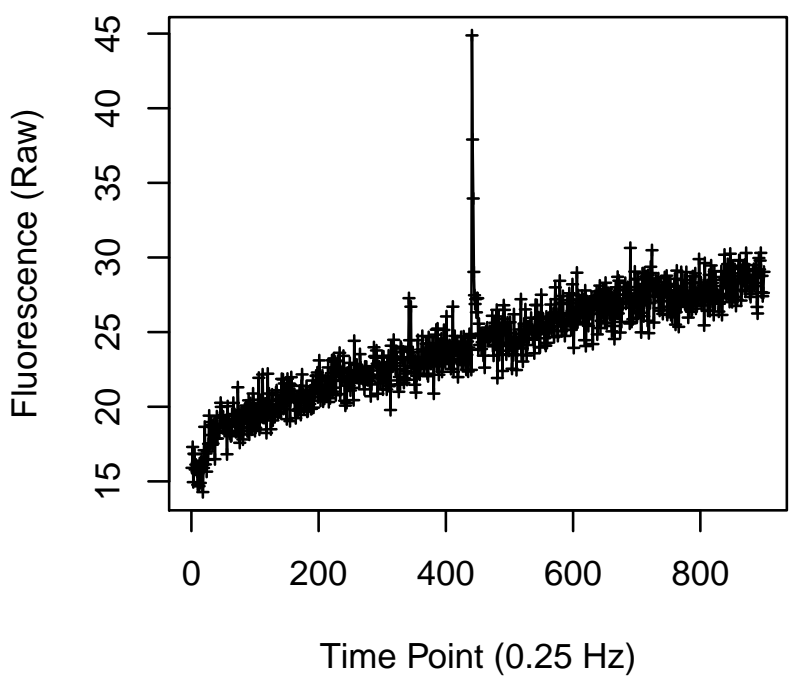

Cell 1984

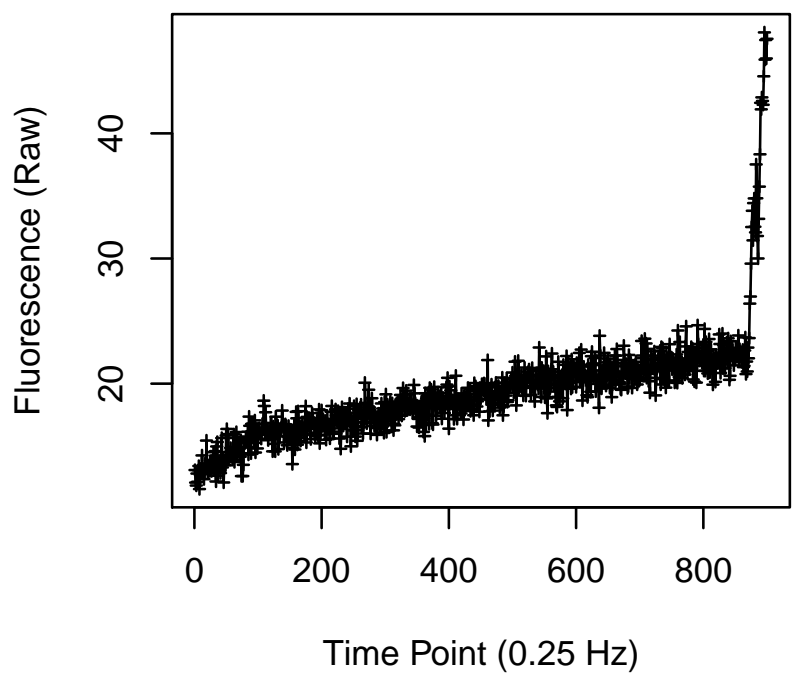


Cell 1985

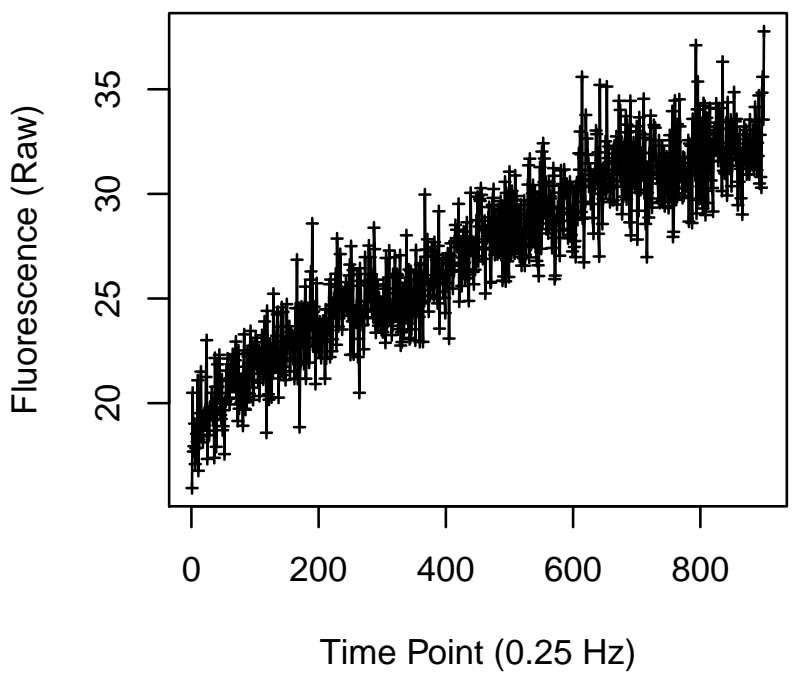

Cell 1987

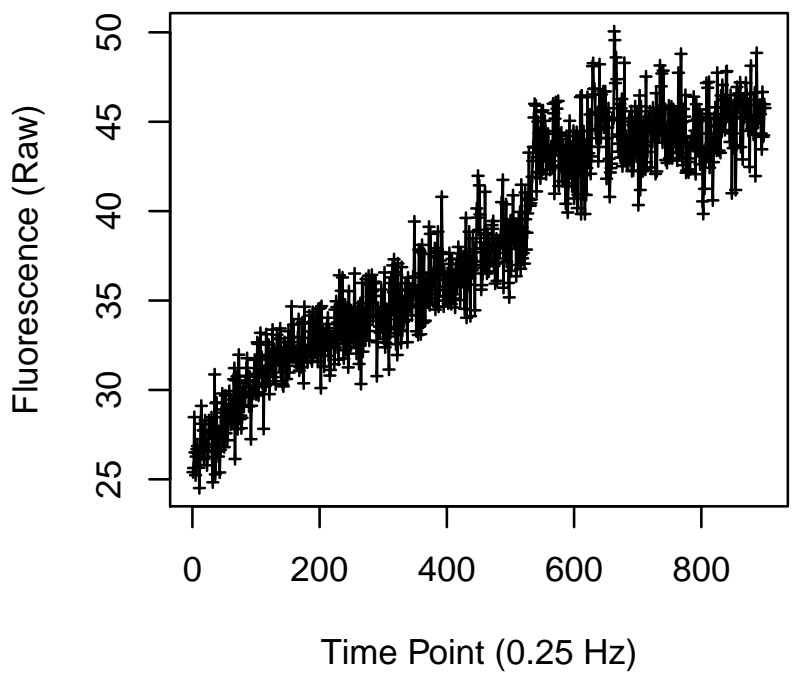

Cell 1986

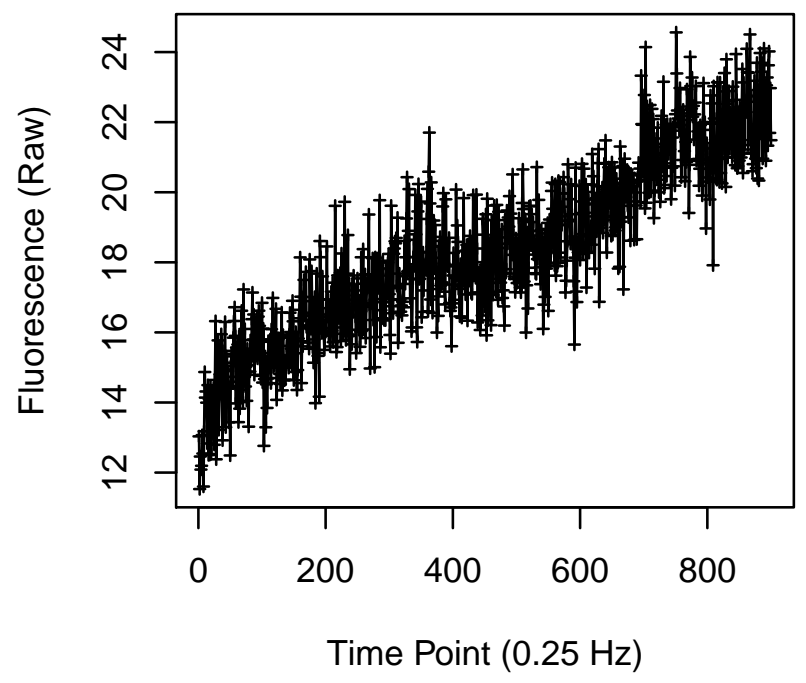

Cell 1988

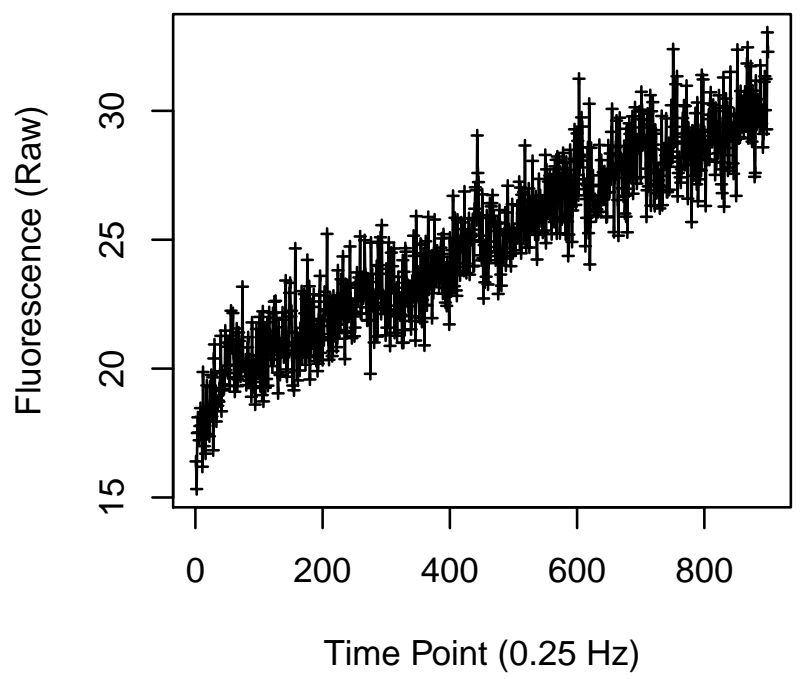


Cell 1989

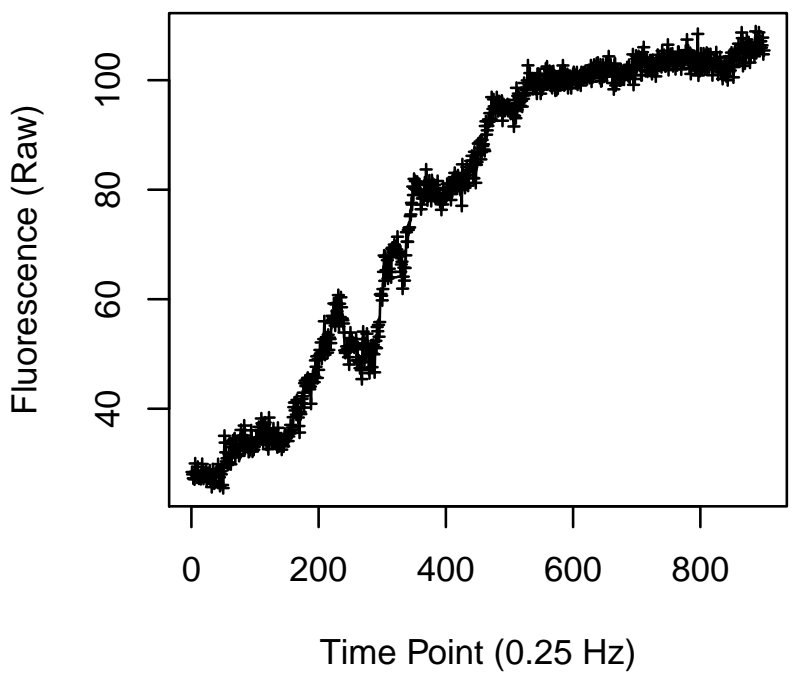

Cell 1991

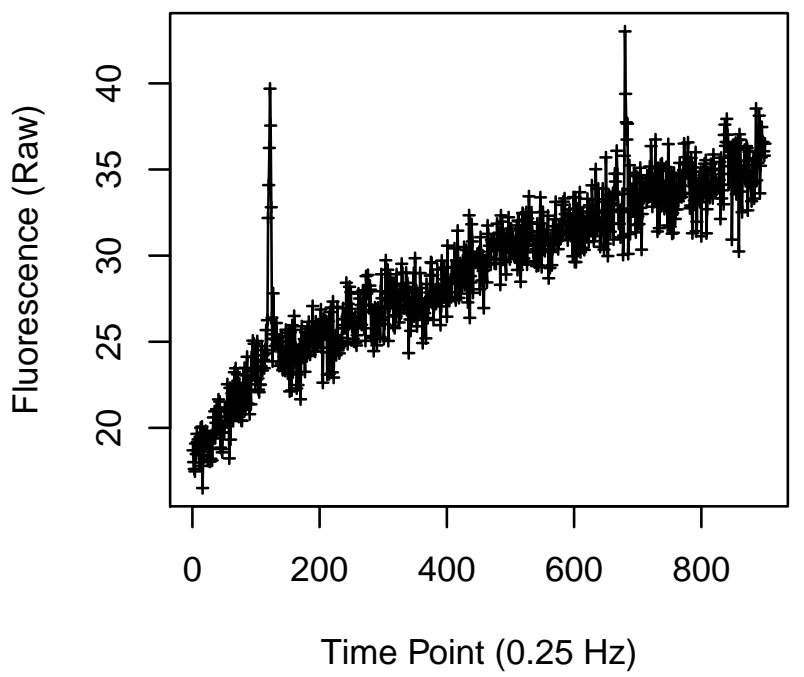

Cell 1990

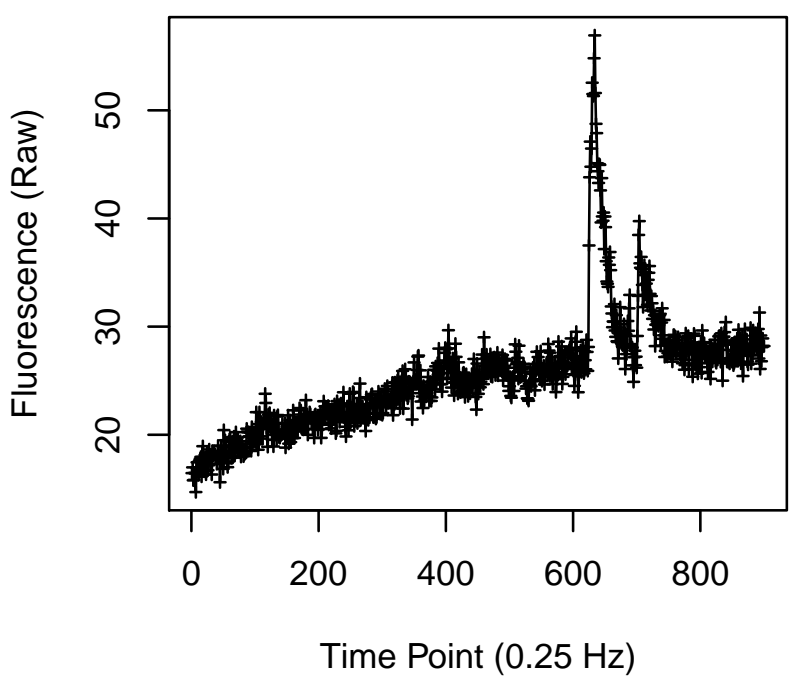

Cell 1992

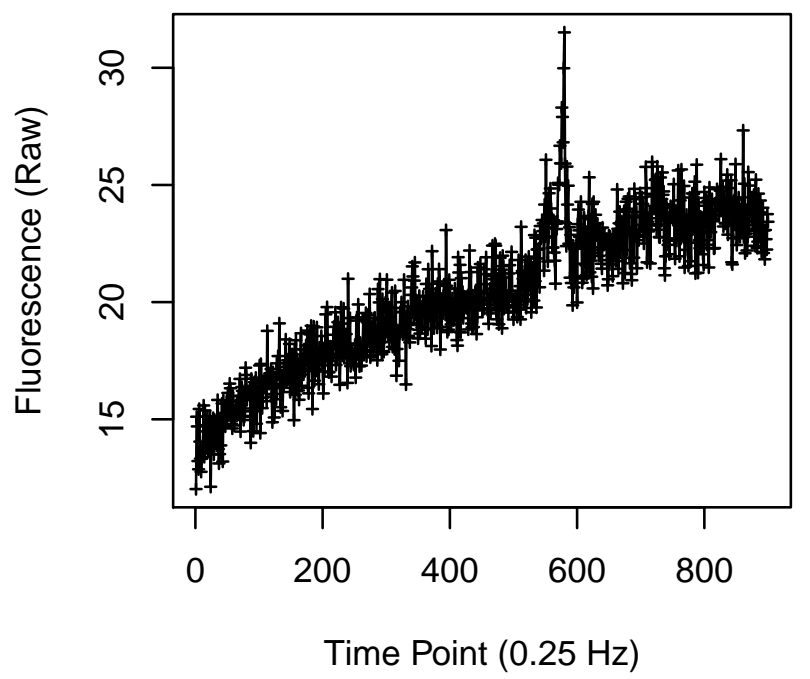


Cell 1993

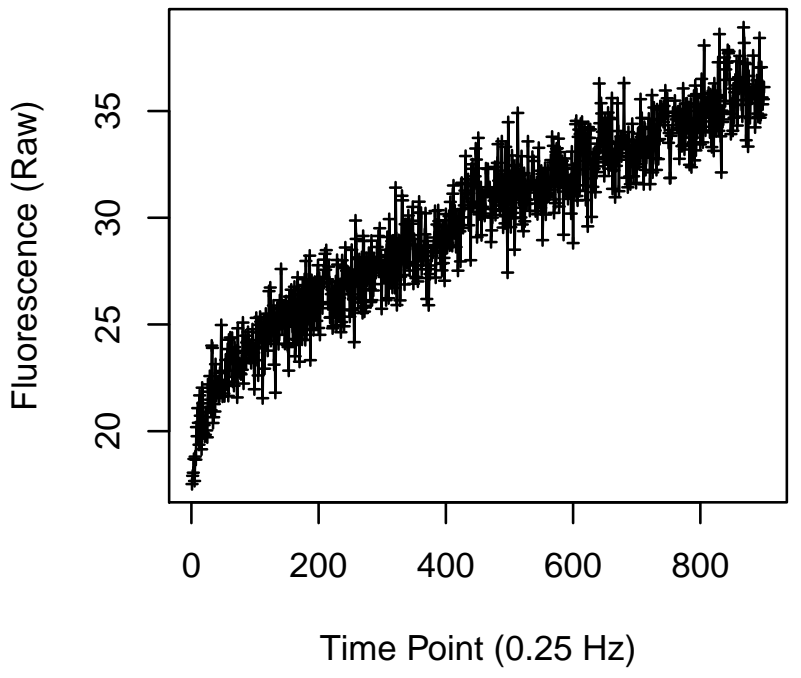

Cell 1995

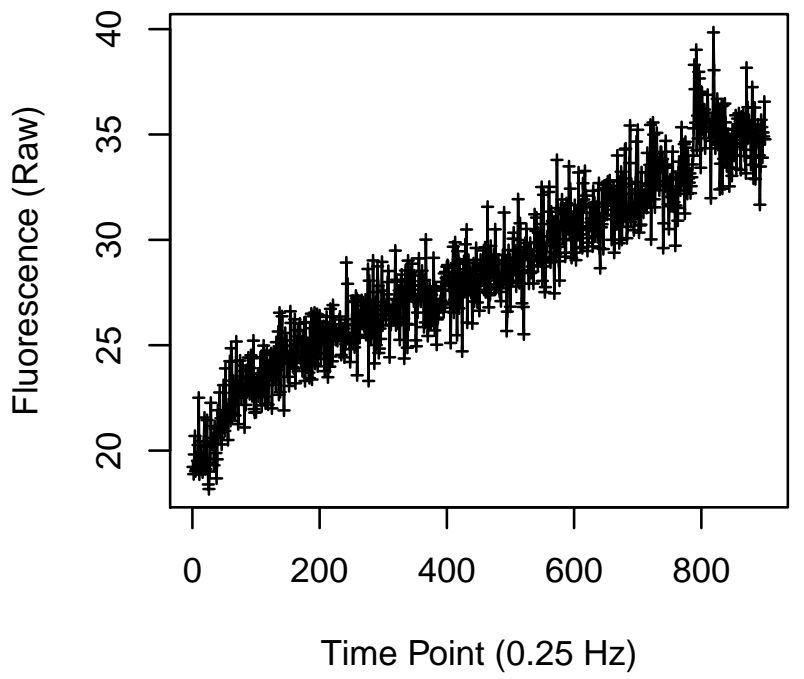

Cell 1994

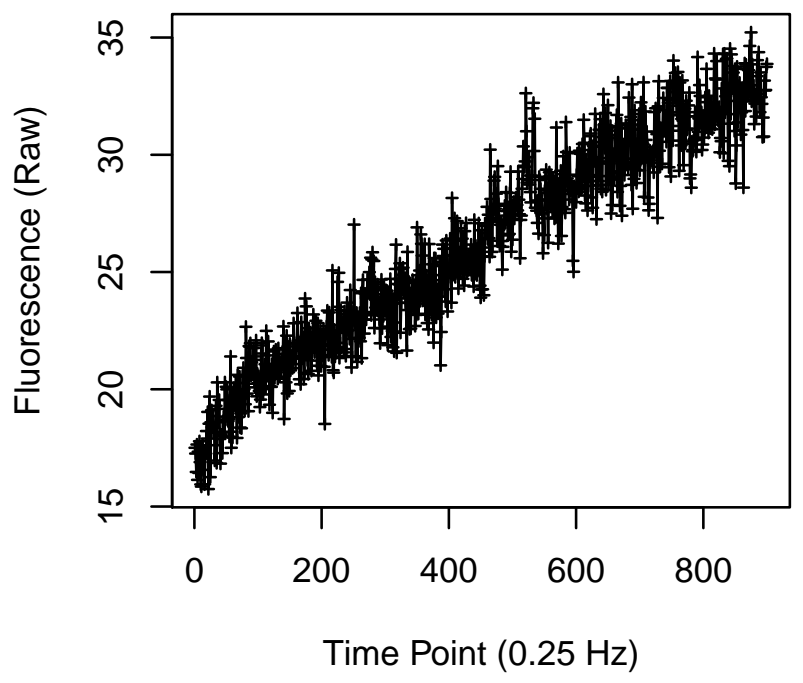

Cell 1996

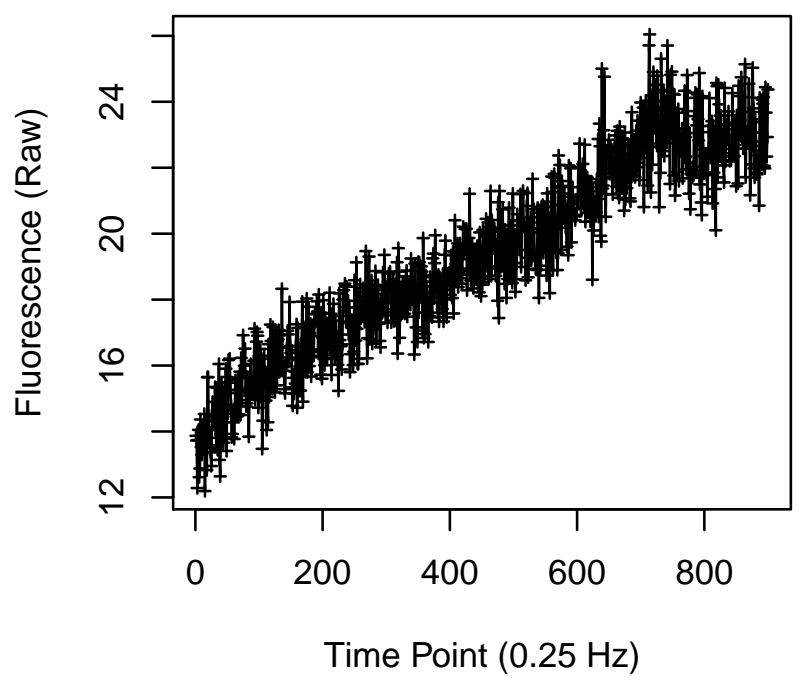


Cell 1997

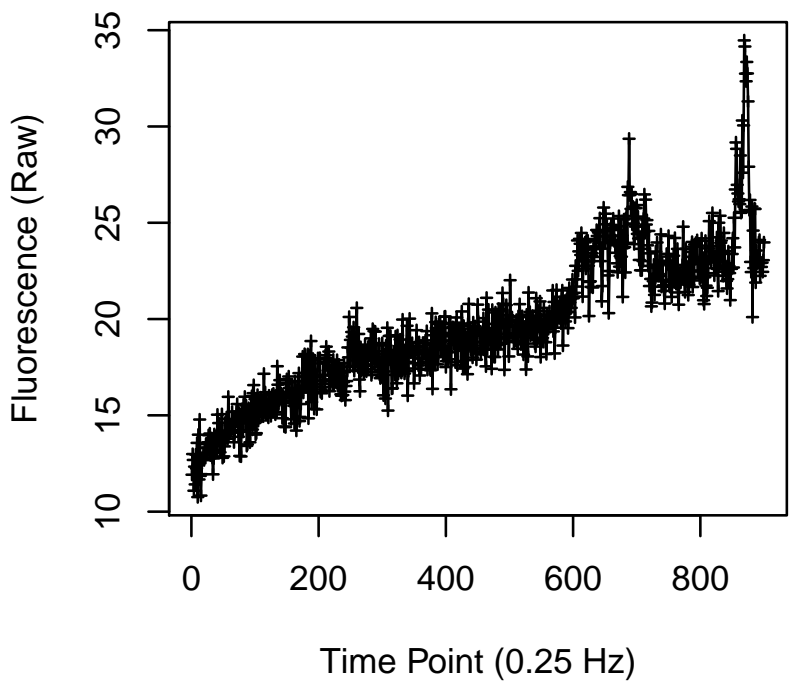

Cell 1999

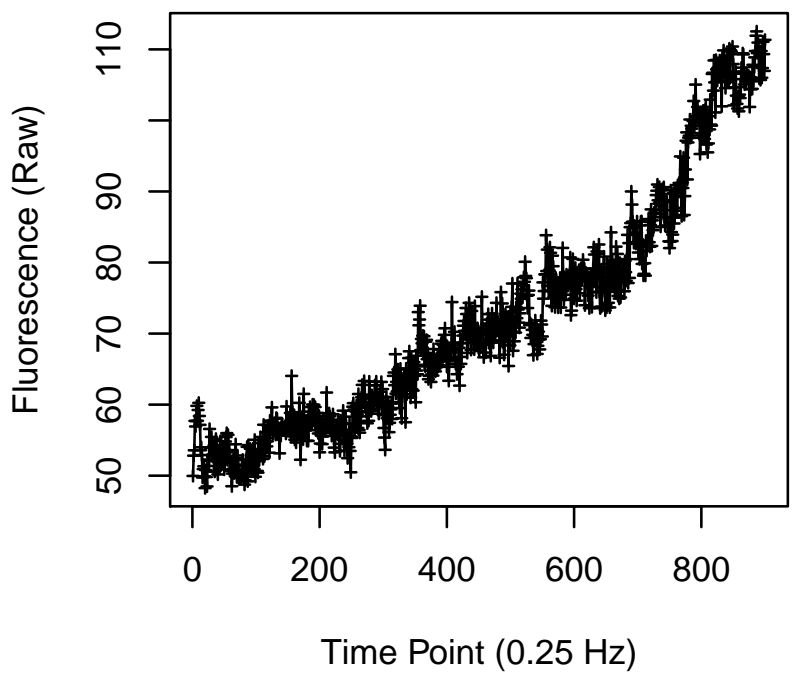

Cell 1998

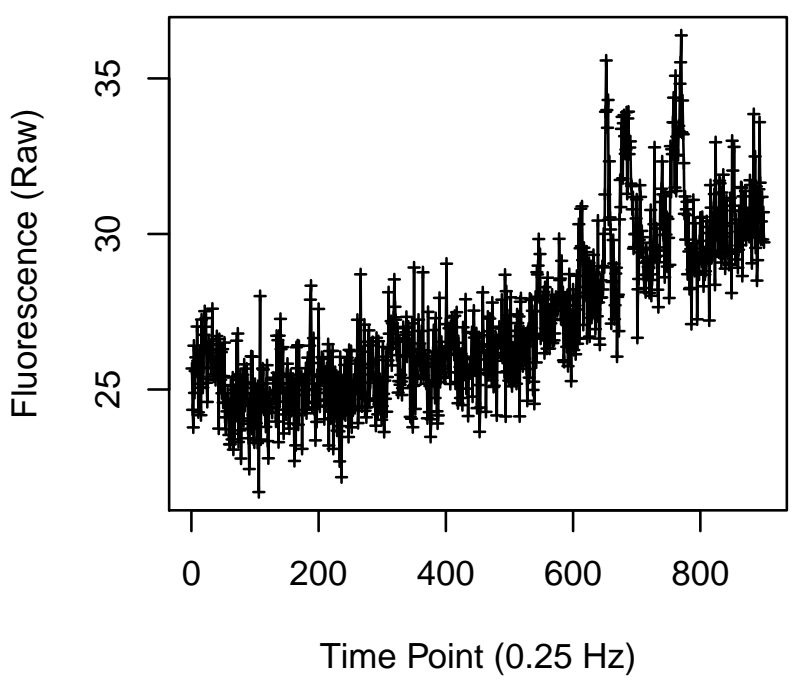

Cell 2000

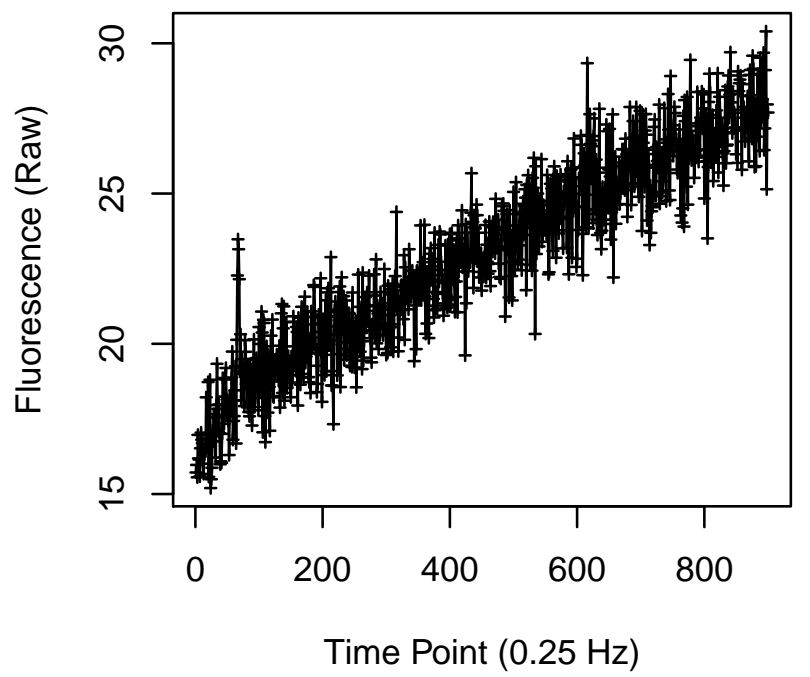


Cell 2001

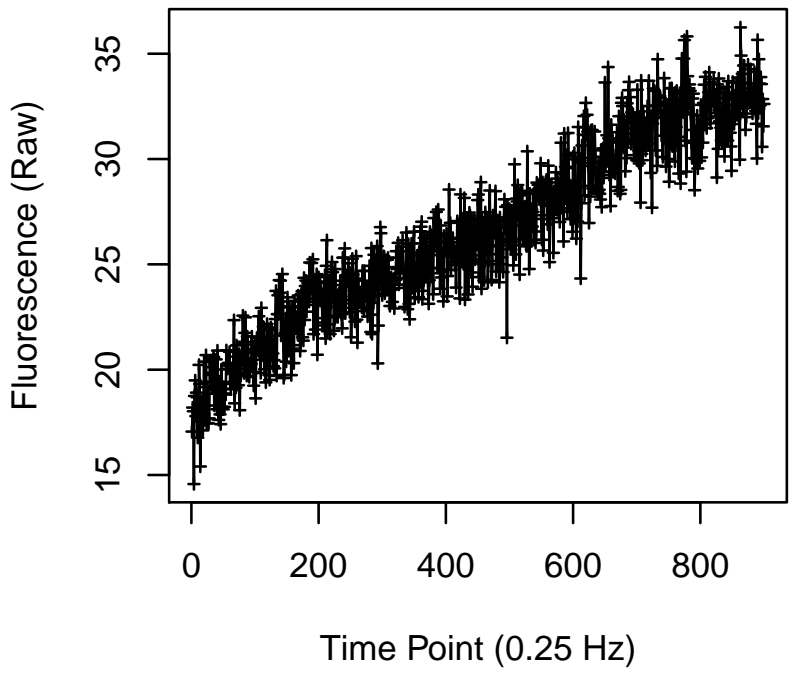

Cell 2003

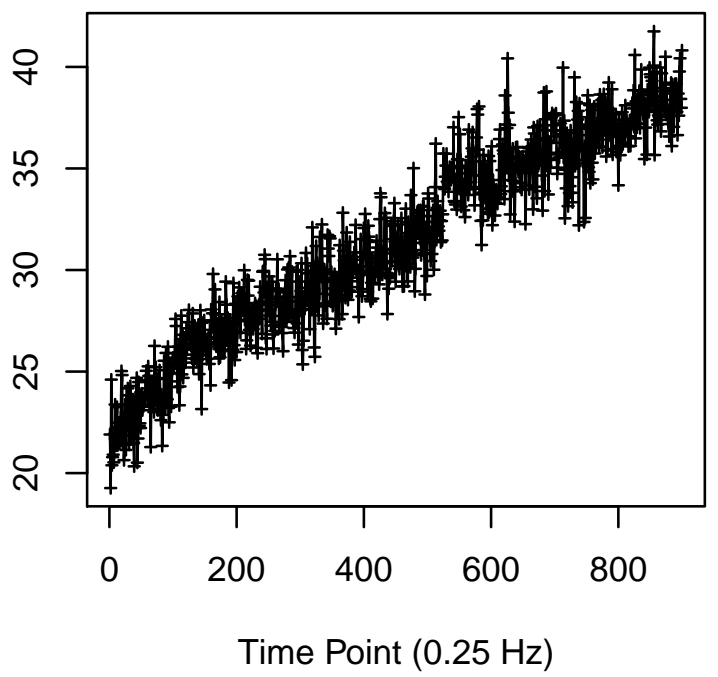

Cell 2002

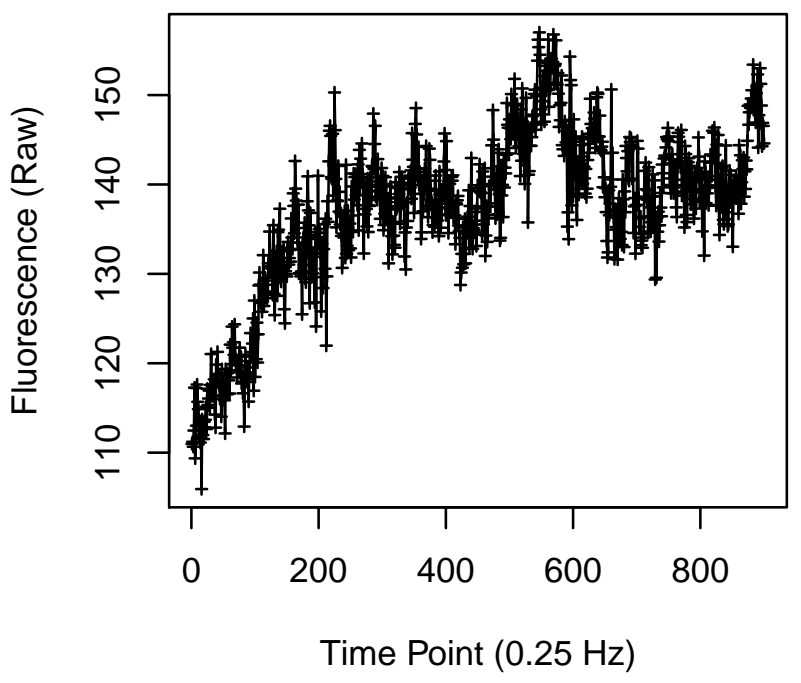

Cell 2004

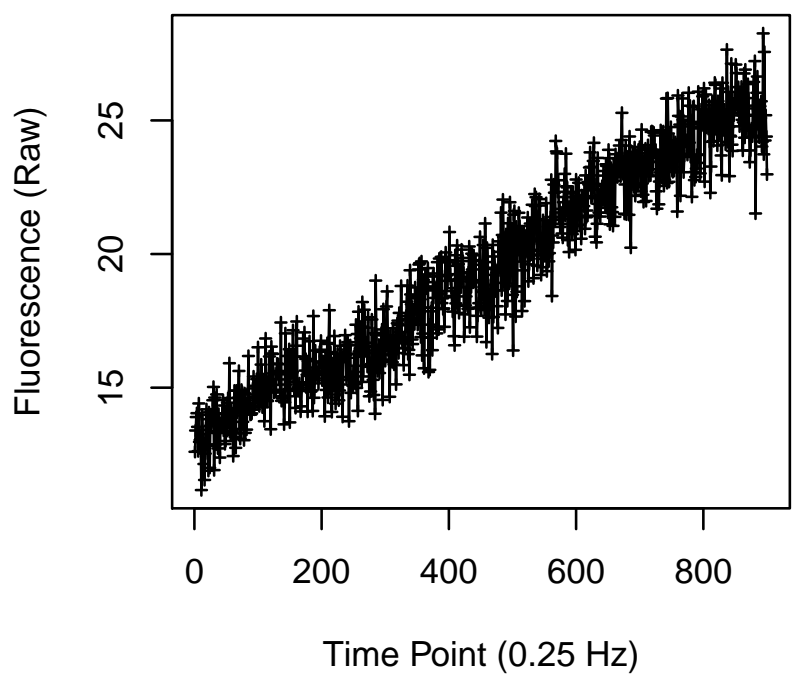


Cell 2005

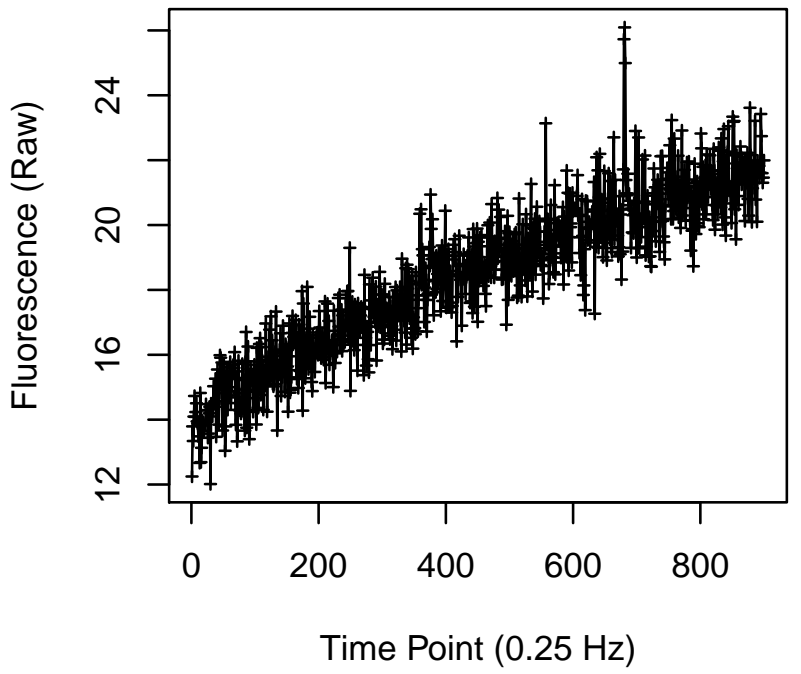

Cell 2007

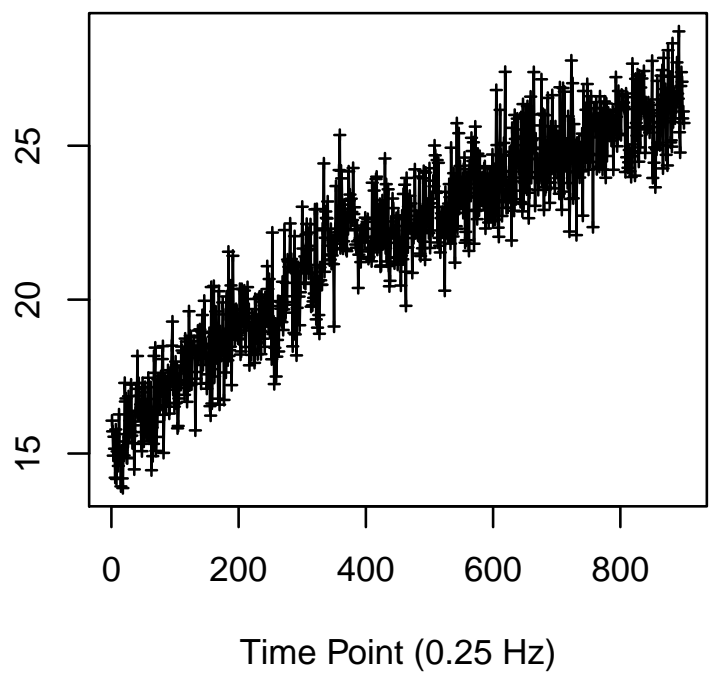

Cell 2006

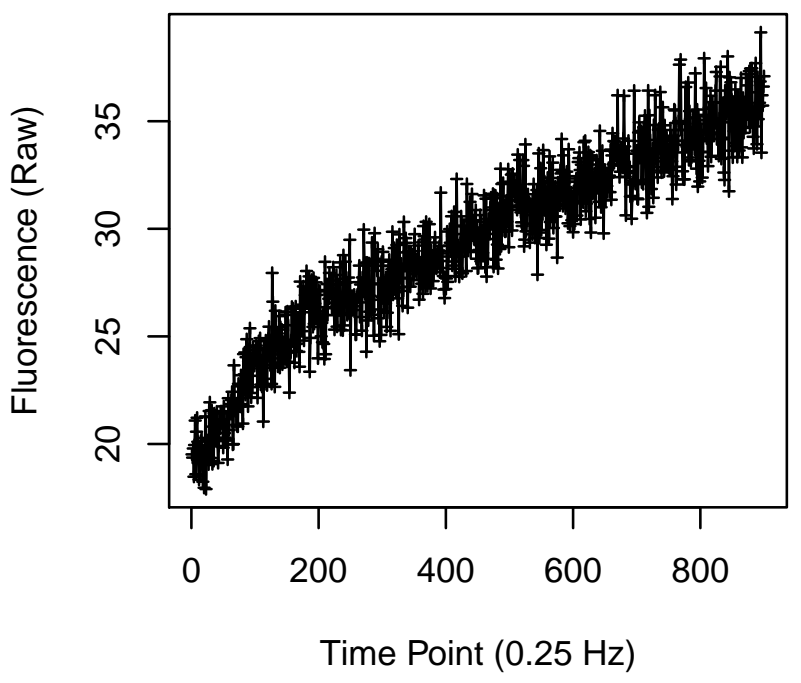

Cell 2008

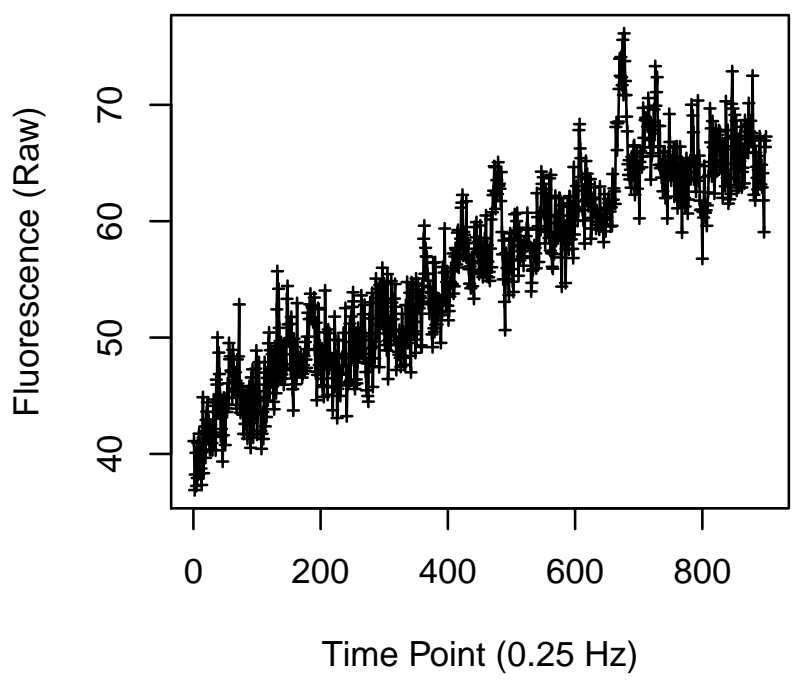


Cell 2013

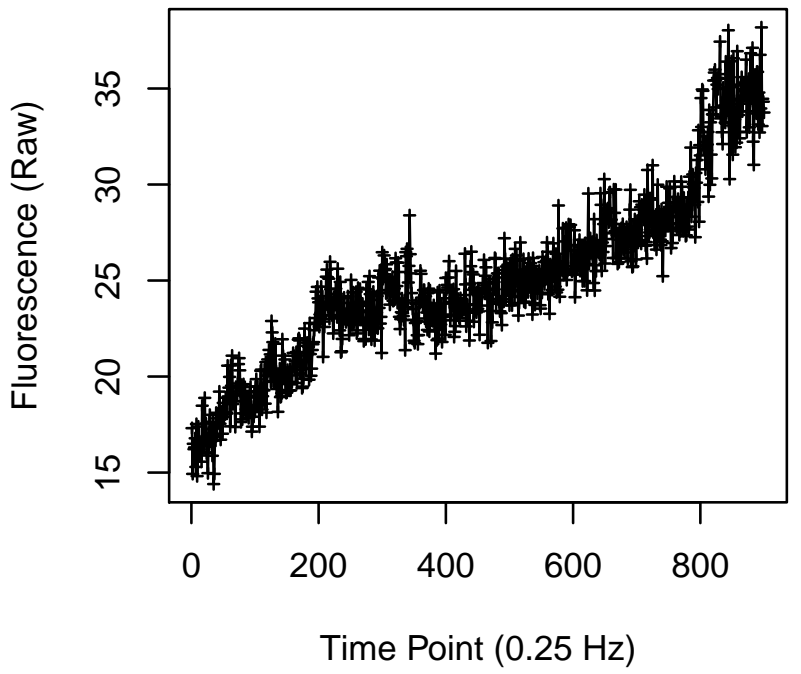

Cell 2015

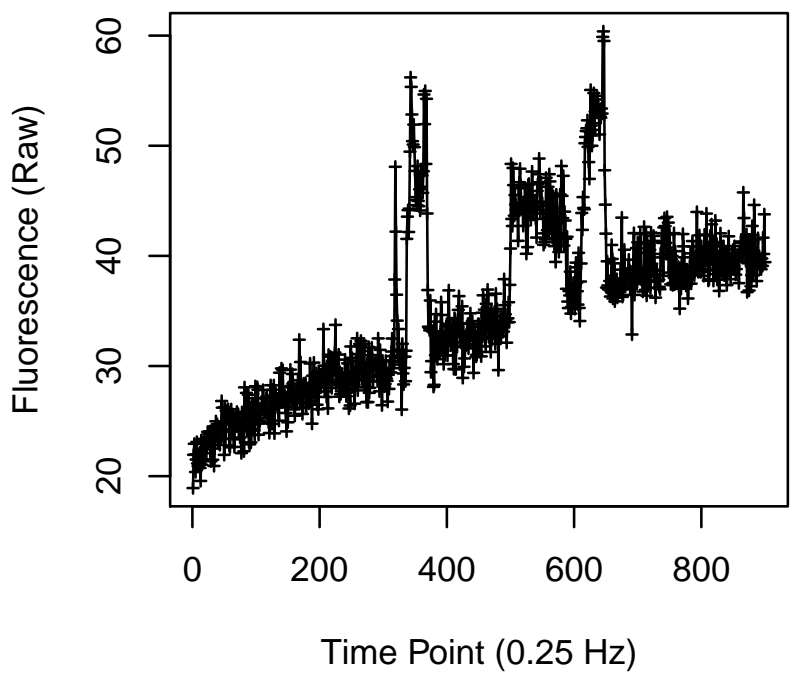

Cell 2014

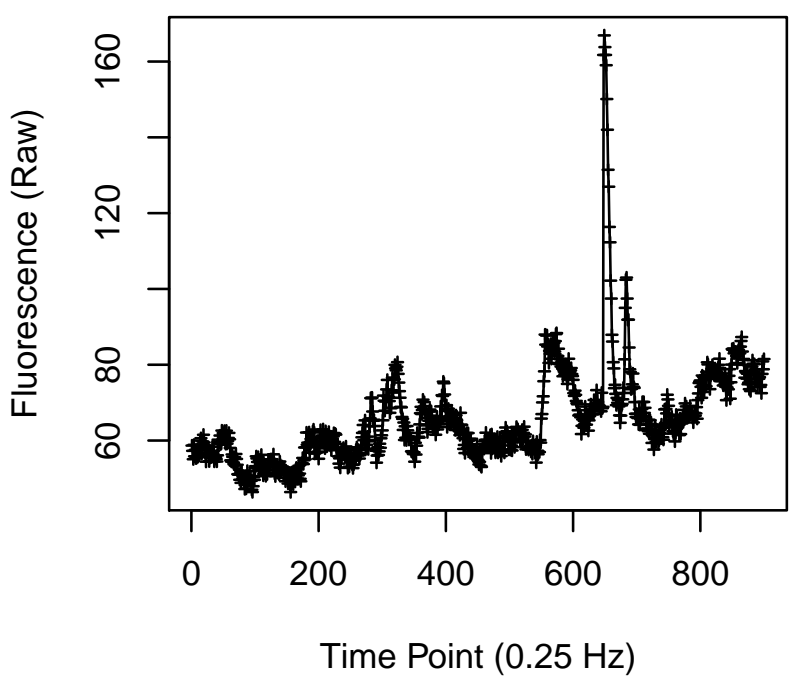

Cell 2016

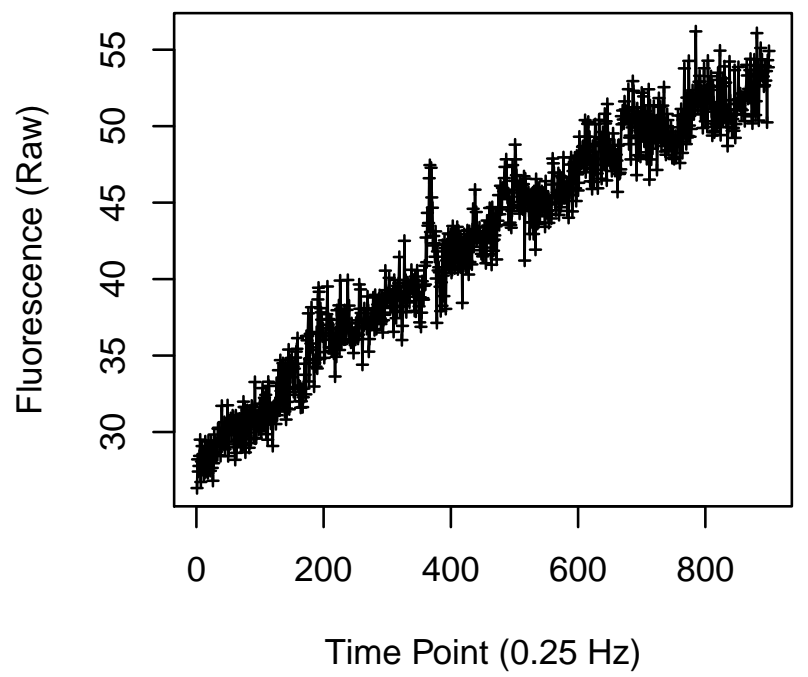


Cell 2017

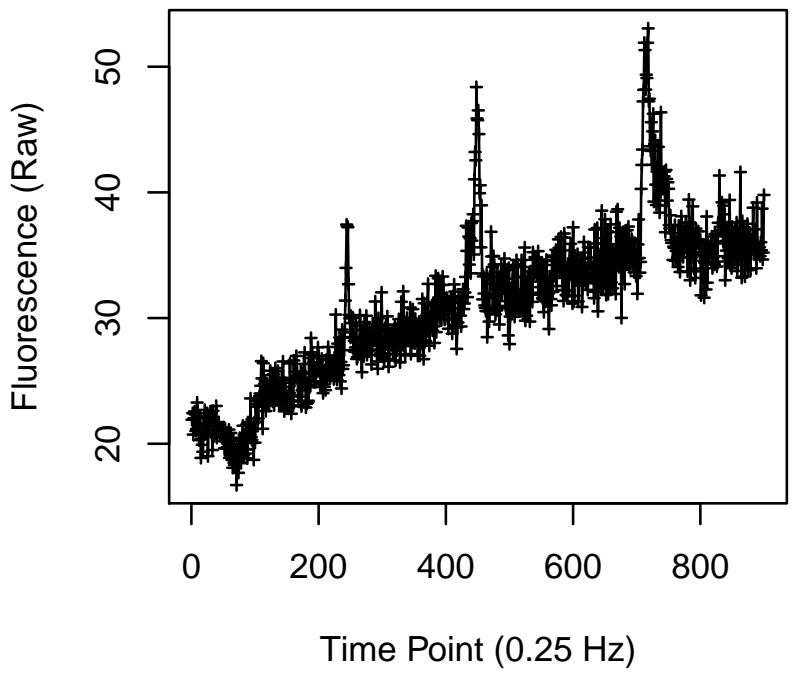

Cell 2019

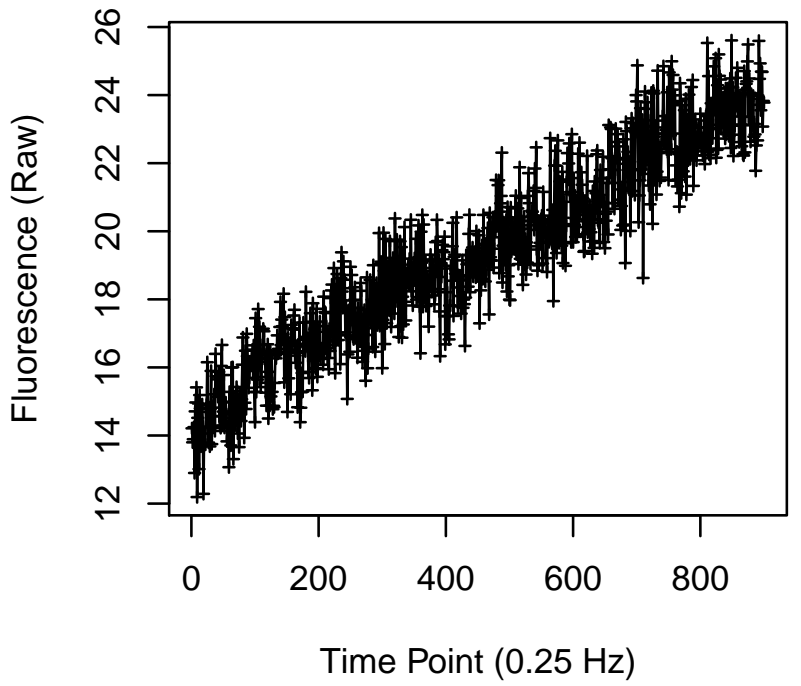

Cell 2018

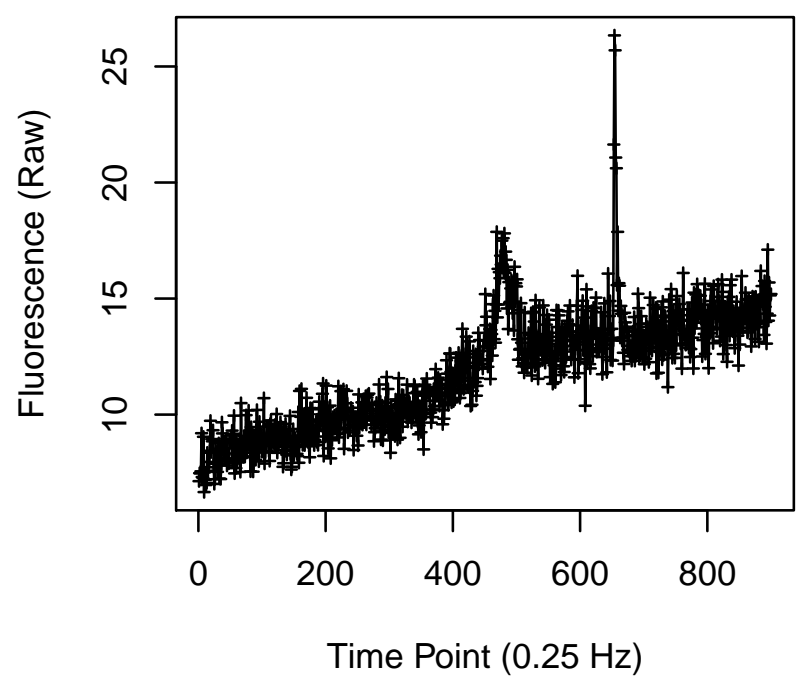

Cell 2020

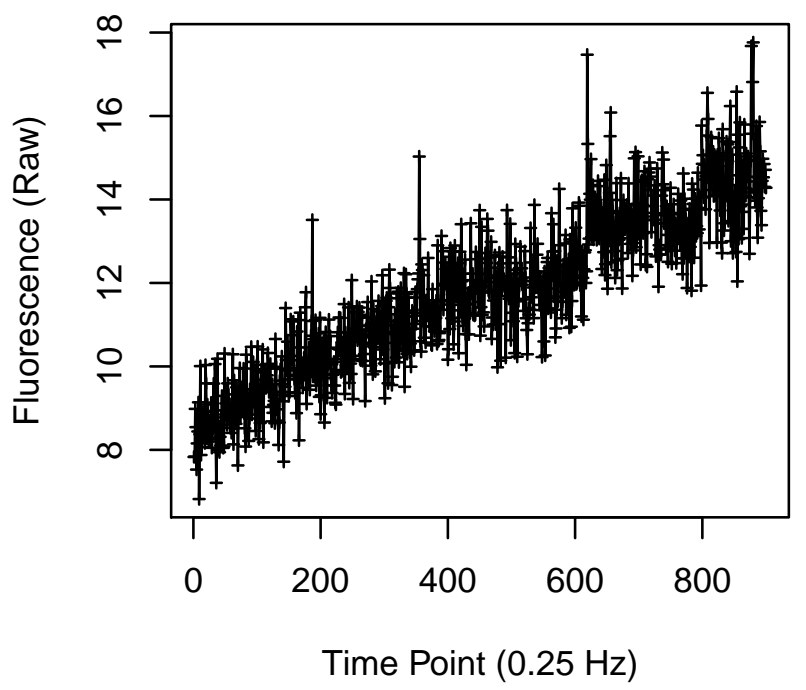


Cell 2021

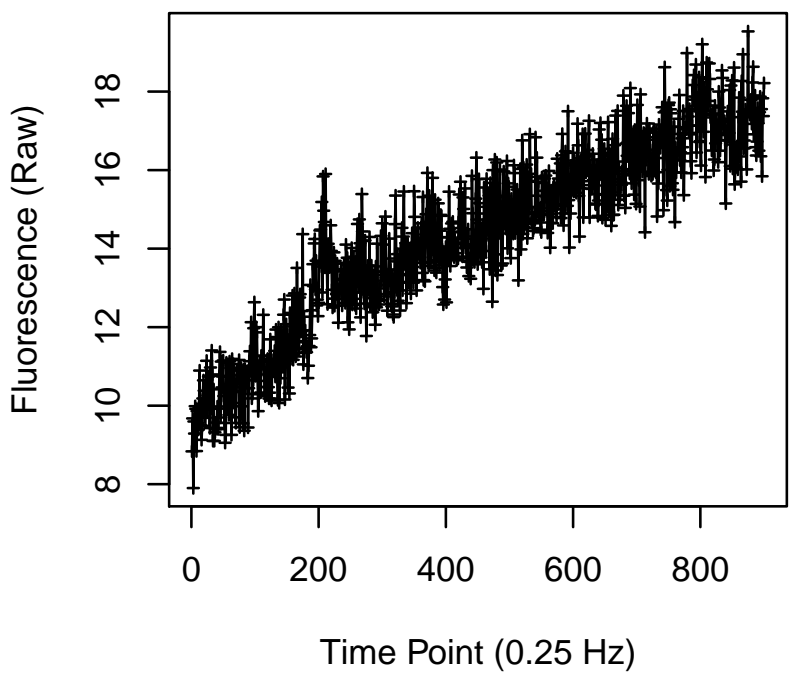

Cell 2023

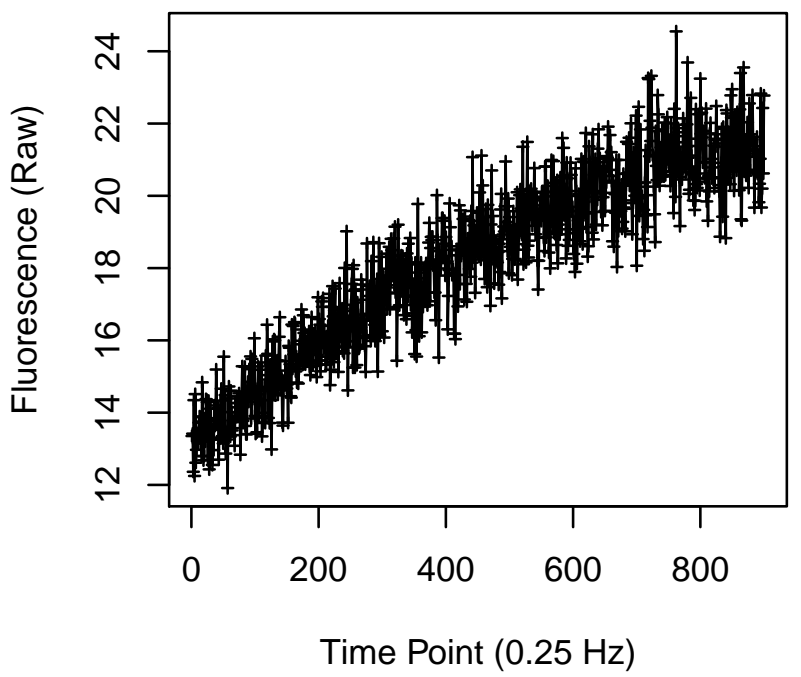

Cell 2022

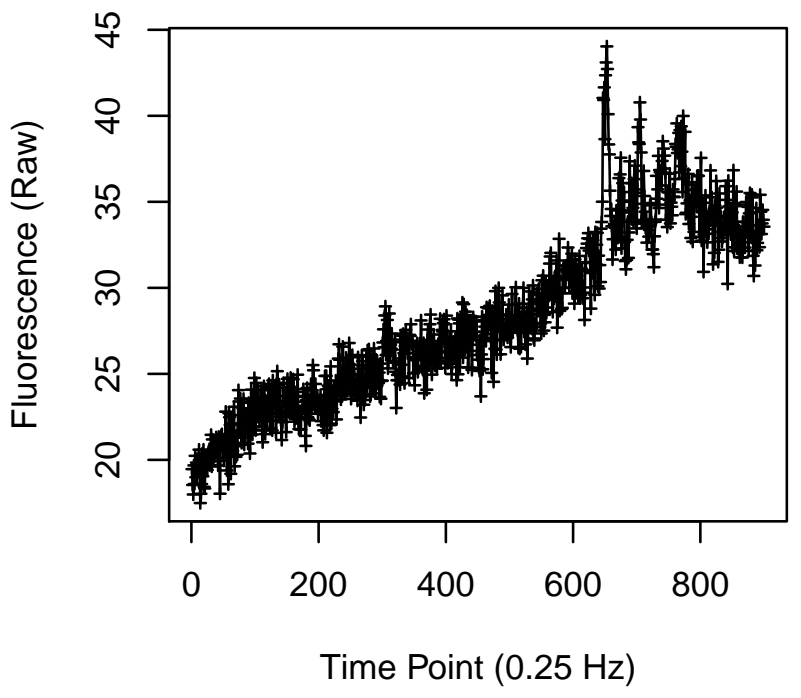

Cell 2024

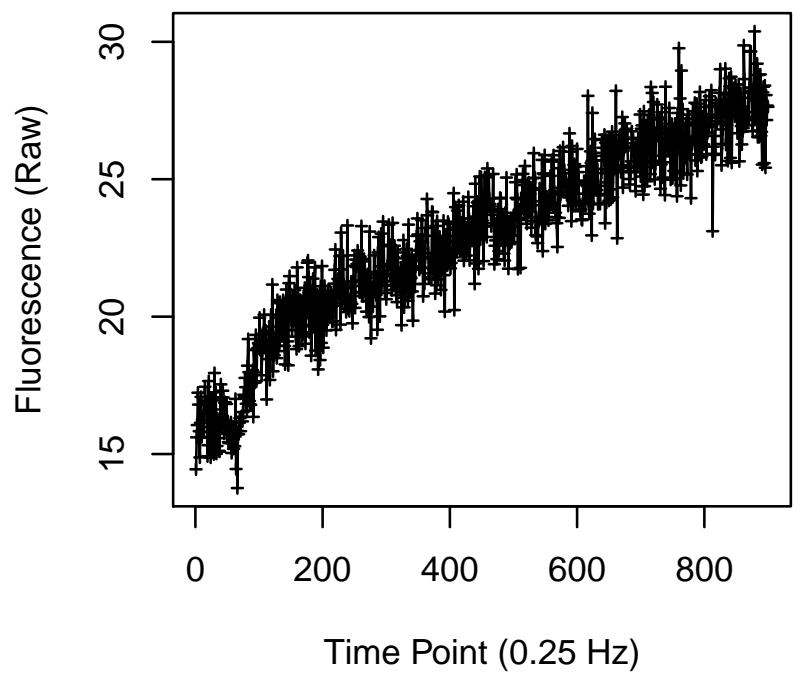


Cell 2025

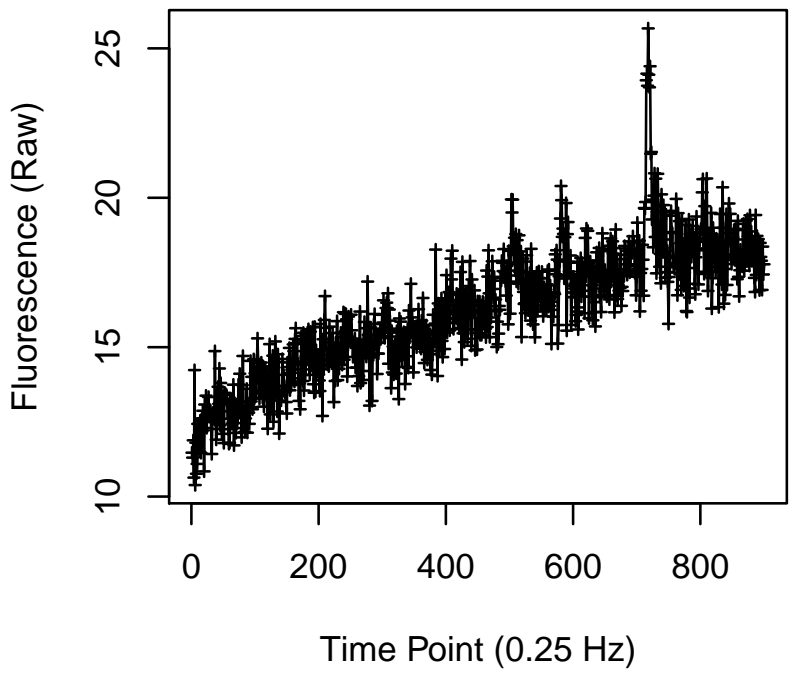

Cell 2027

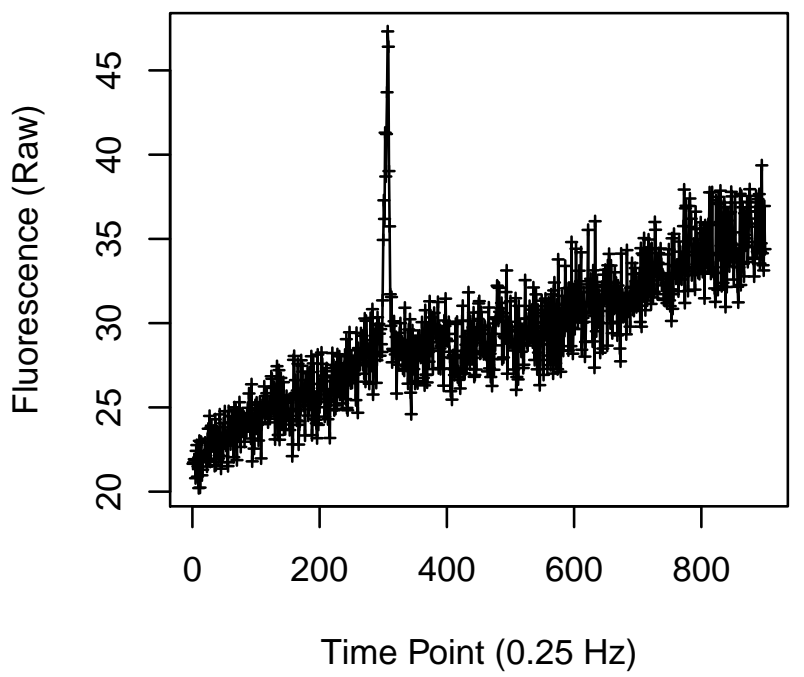

Cell 2026

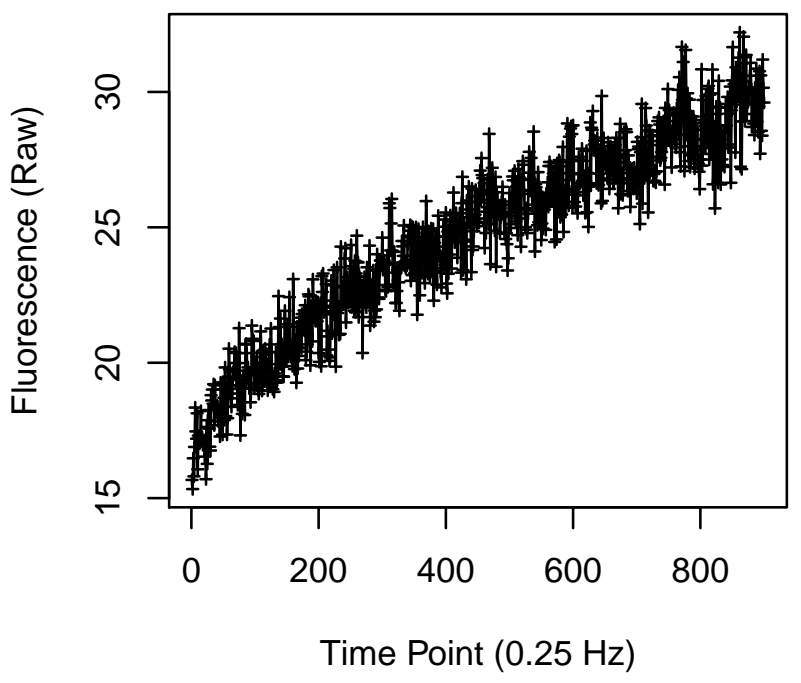

Cell 2028

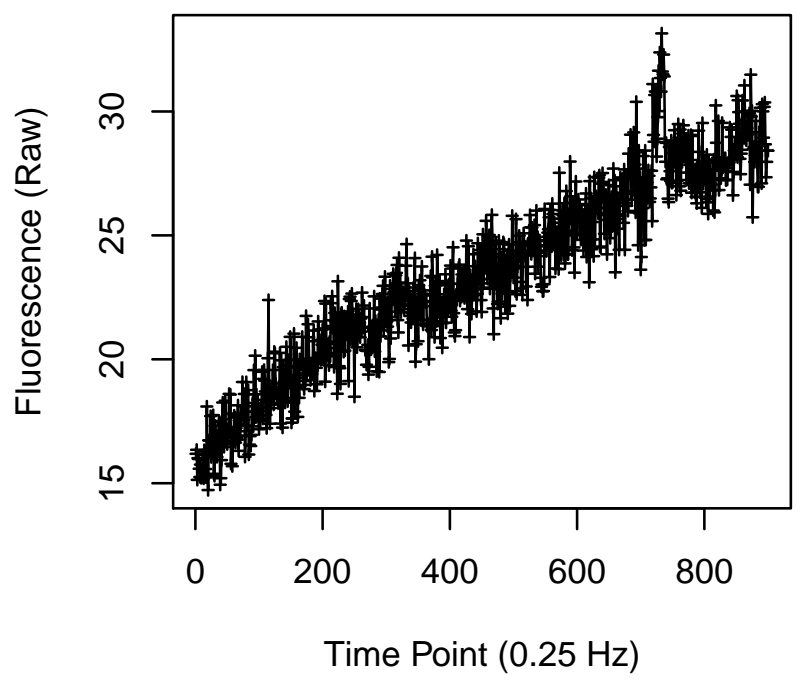


Cell 2029

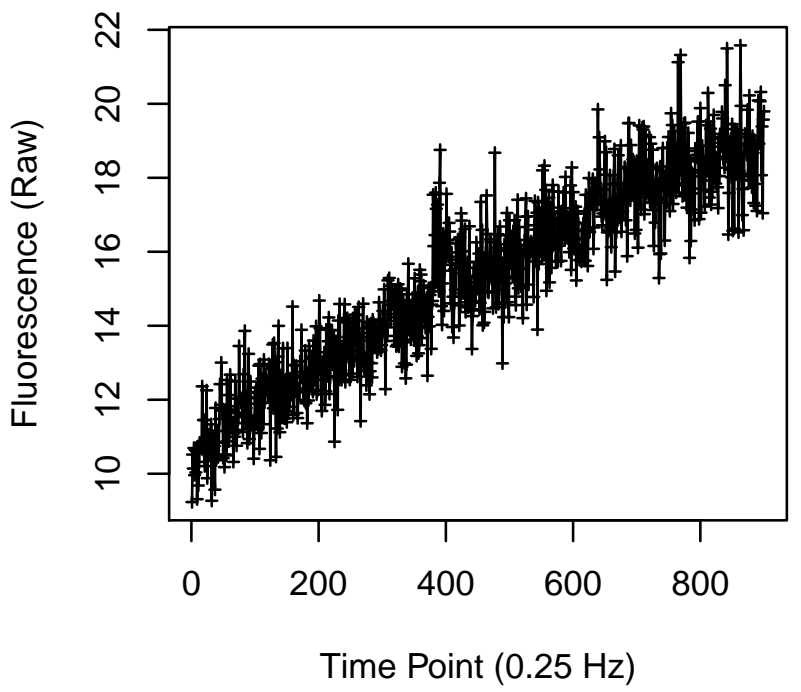

Cell 2031

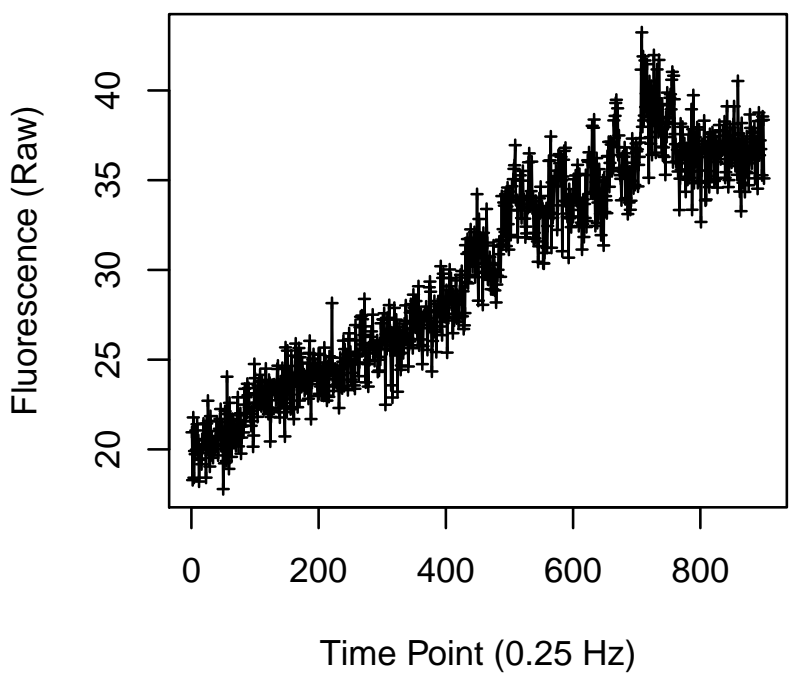

Cell 2030

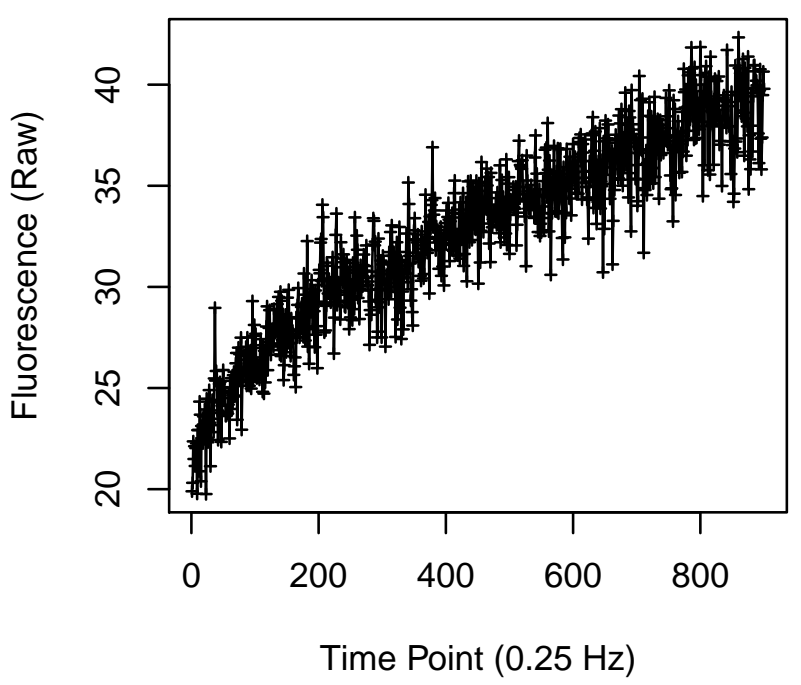

Cell 2032

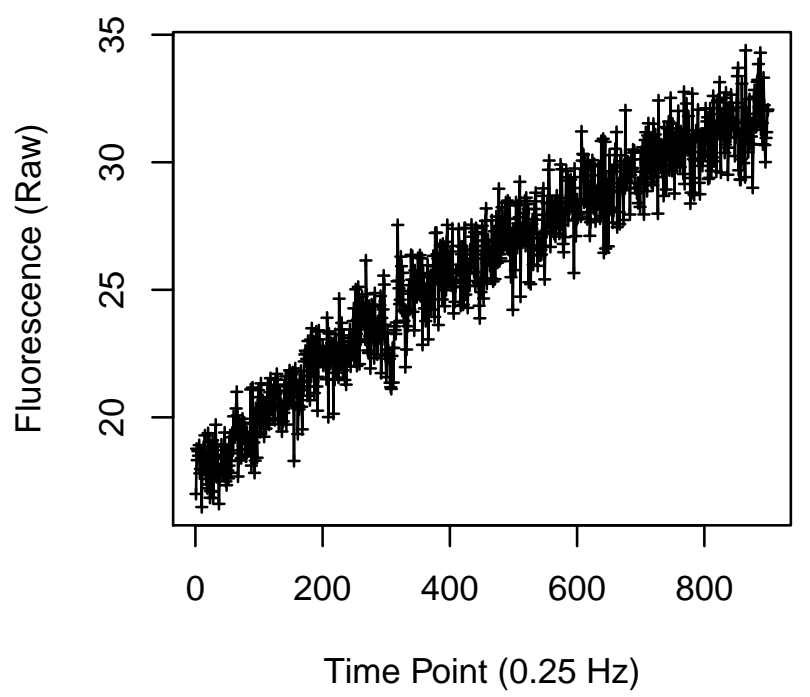


Cell 2033

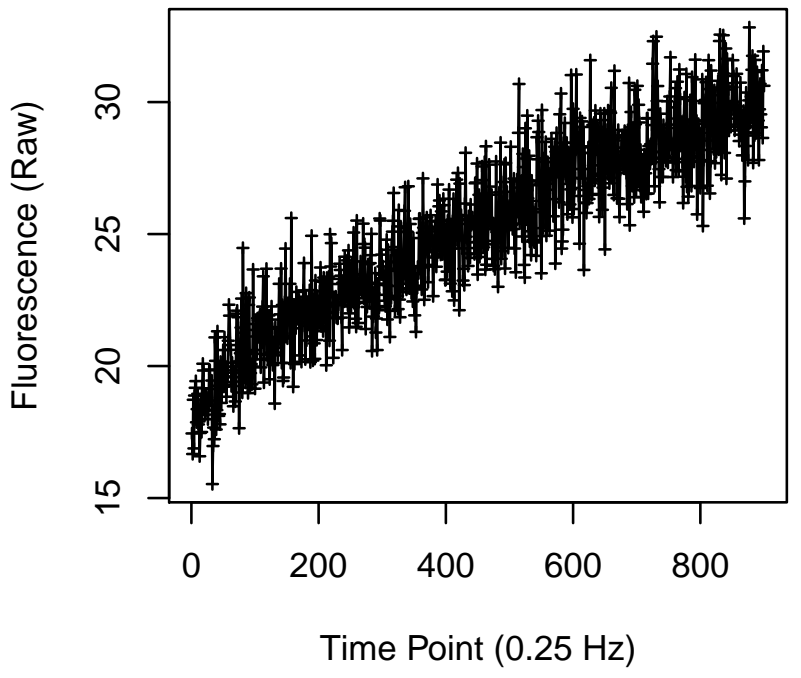

Cell 2035

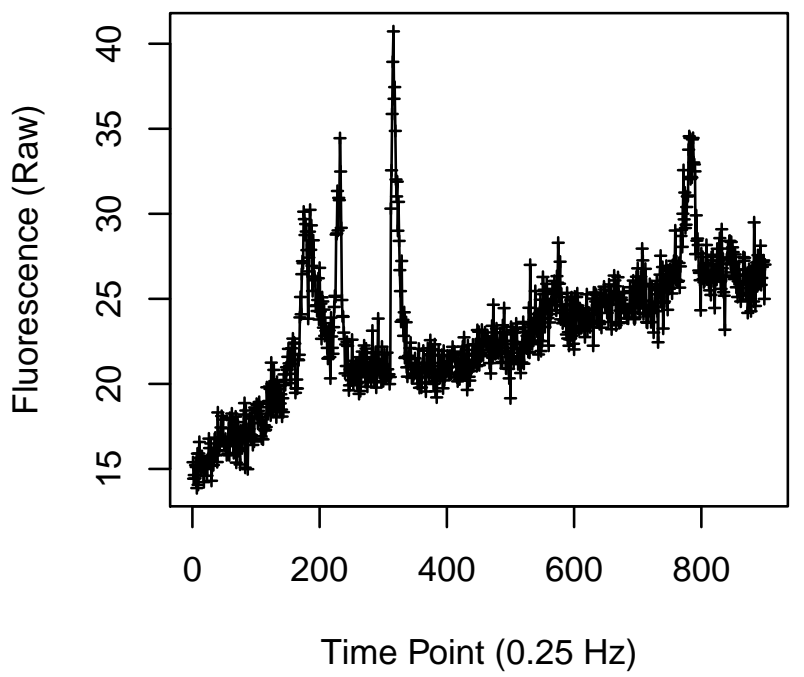

Cell 2034

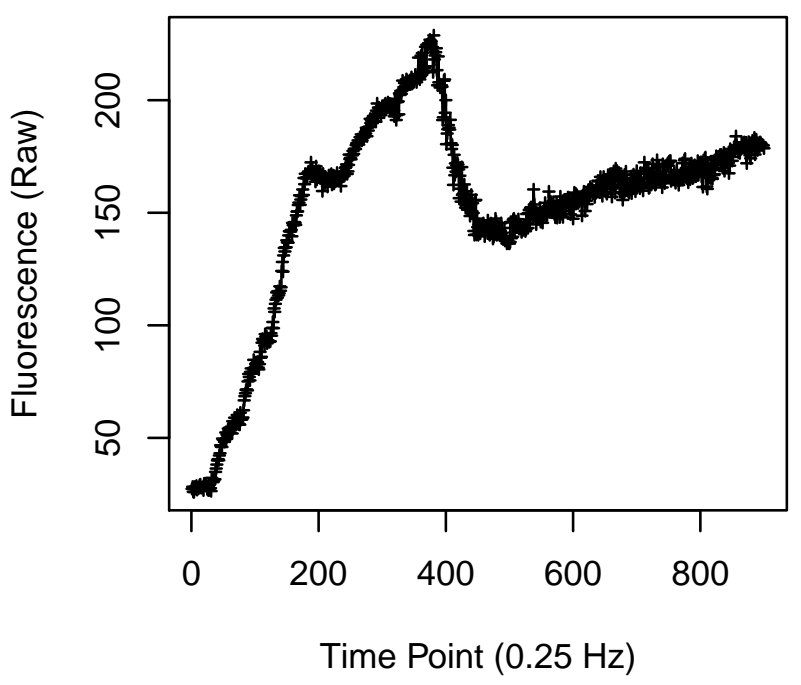

Cell 2036

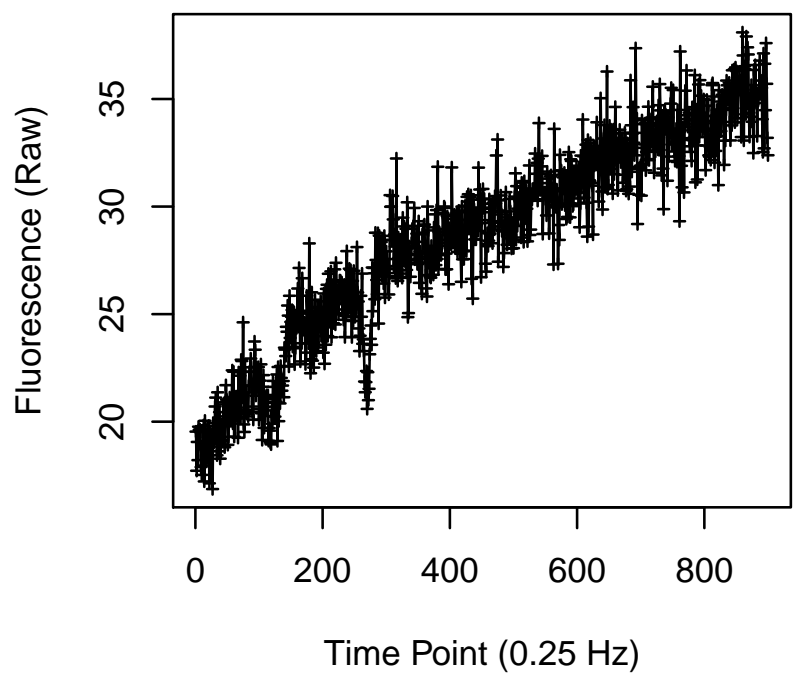


Cell 2037

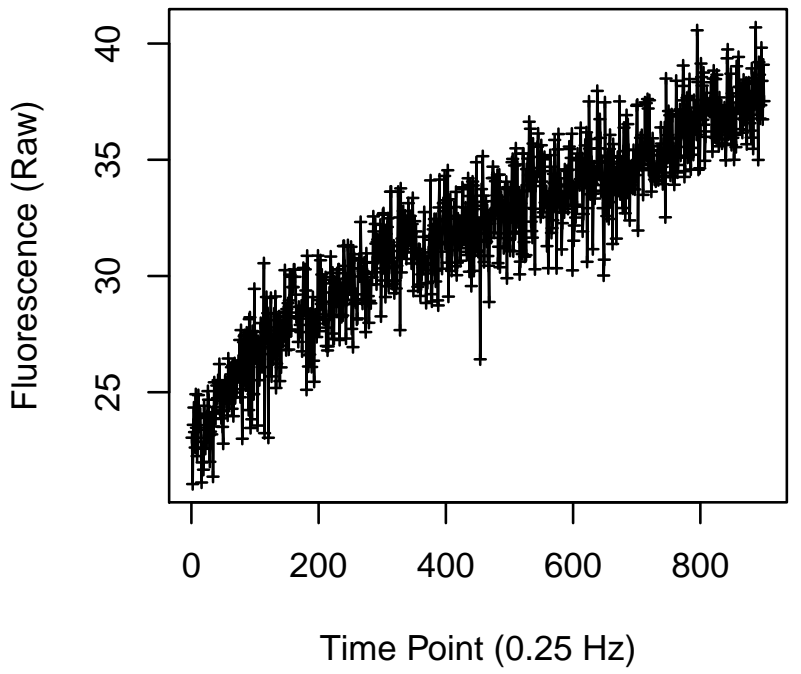

Cell 2039

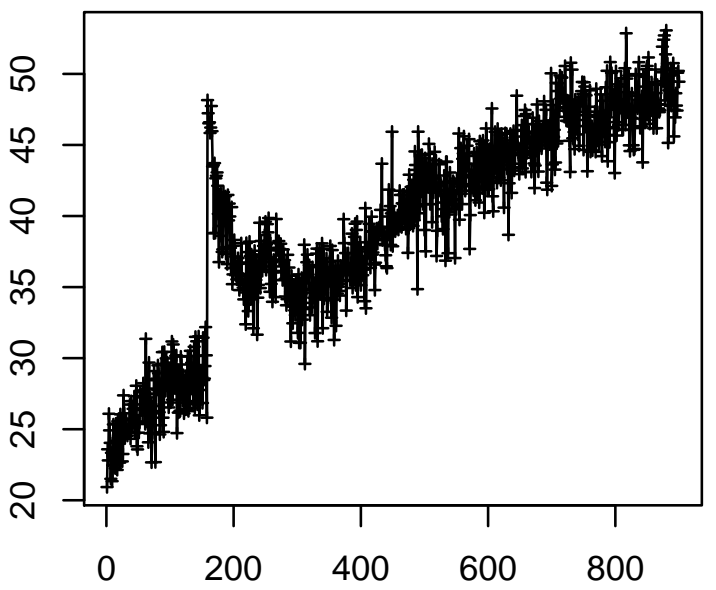

Time Point $(0.25 \mathrm{~Hz})$
Cell 2038

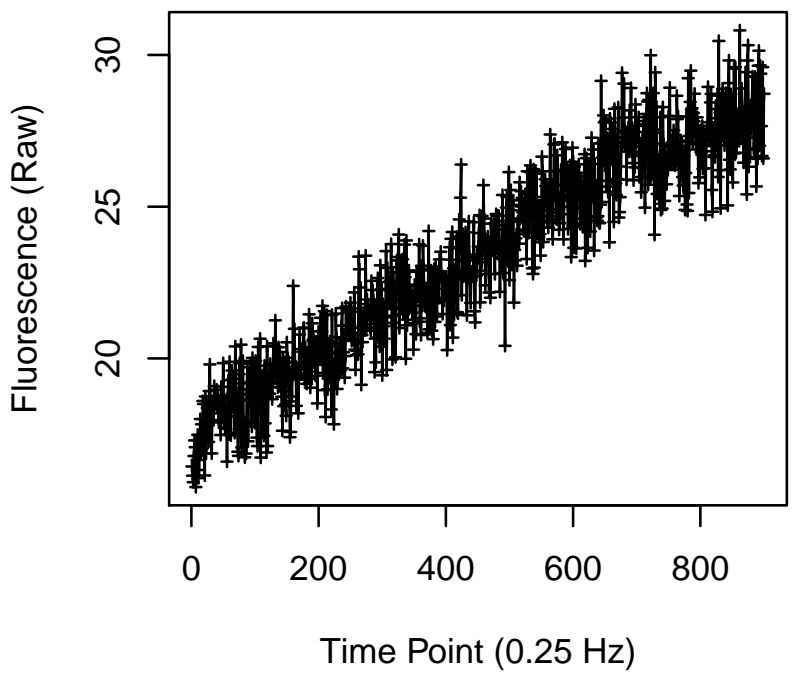

Cell 2040

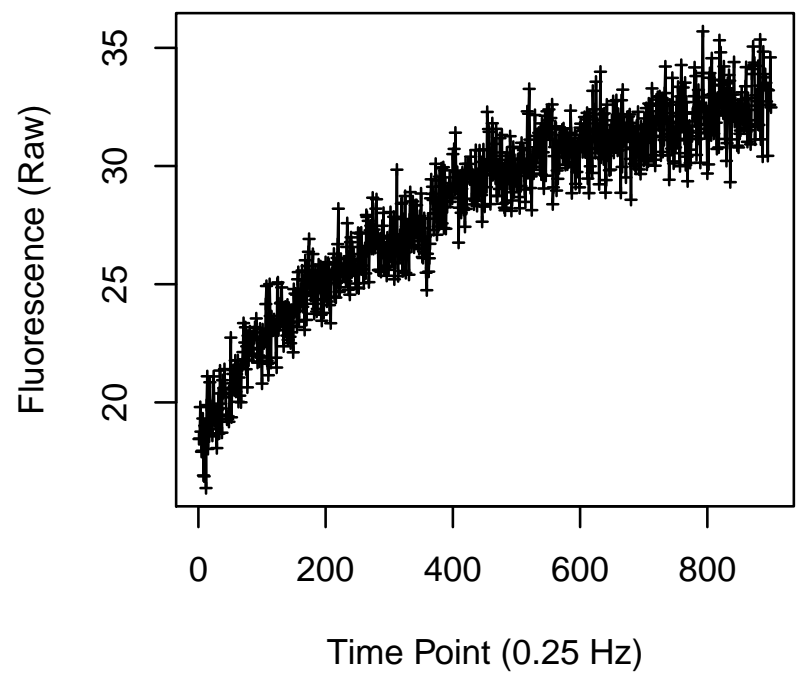


Cell 2041

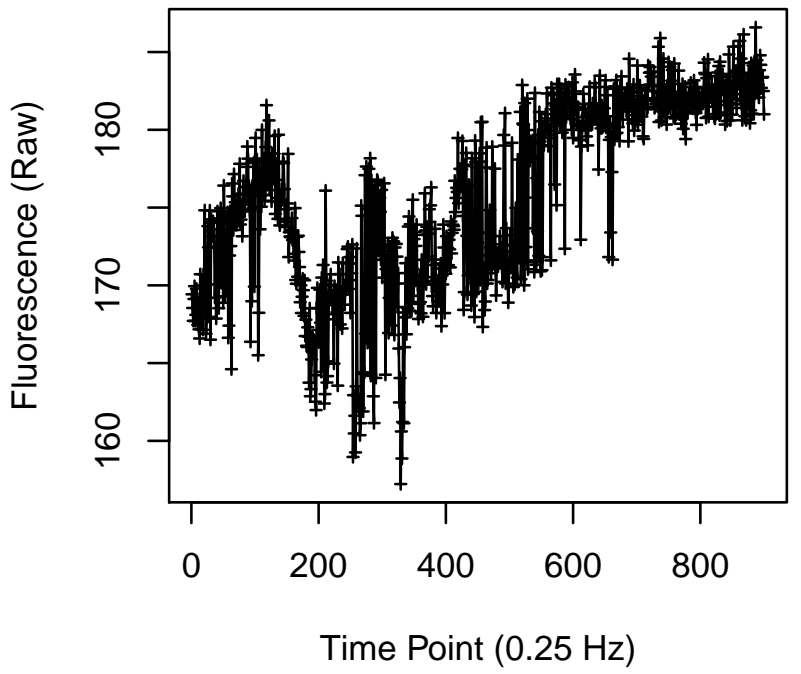

Cell 2043

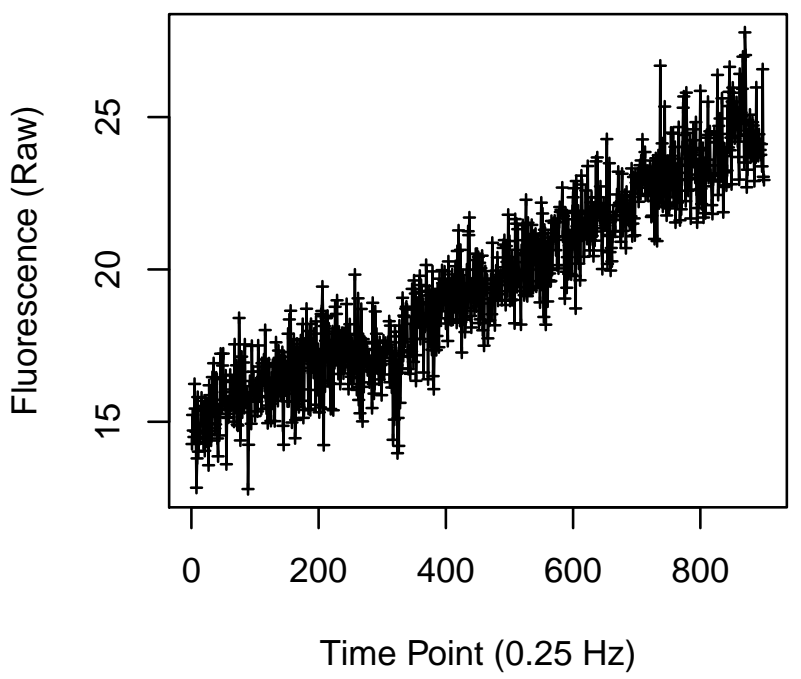

Cell 2042

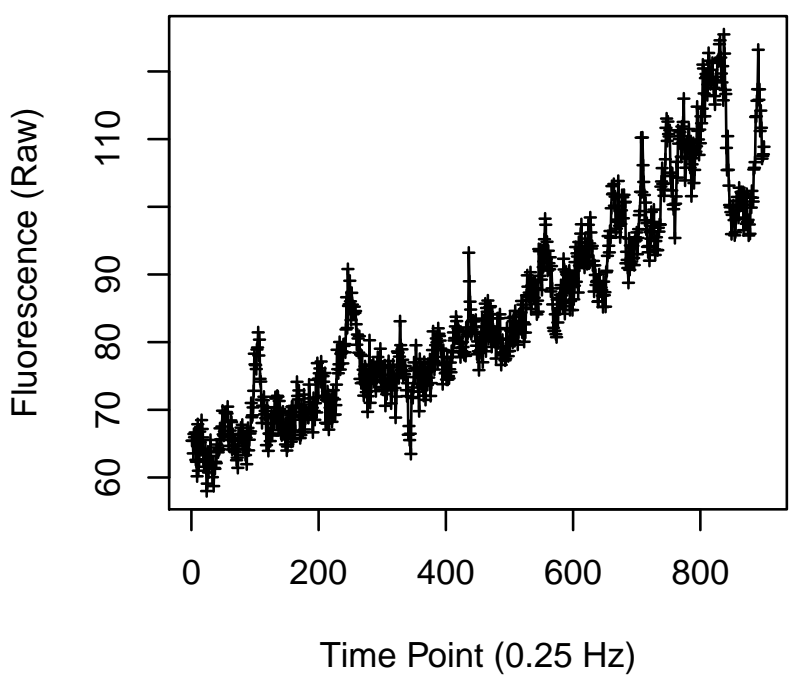

Cell 2044

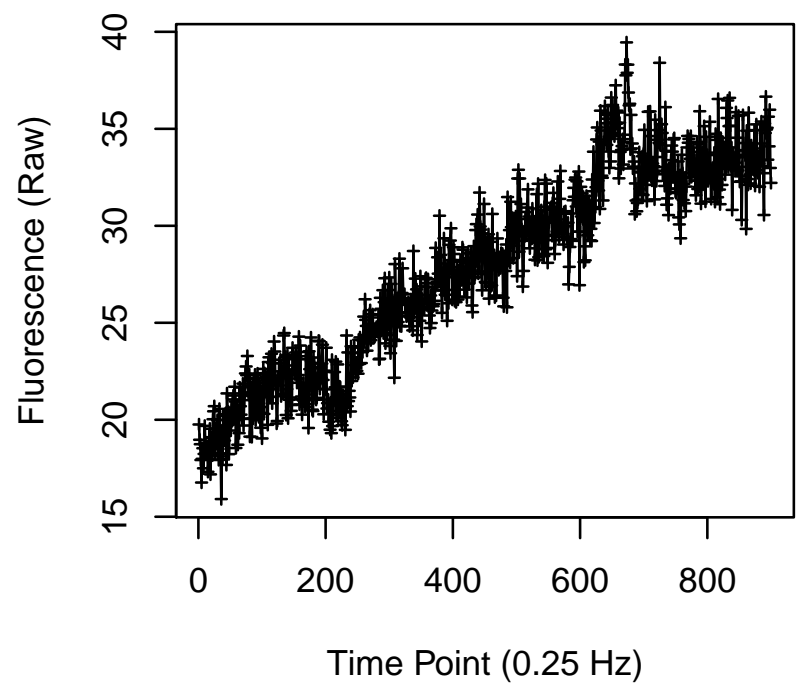


Cell 2045

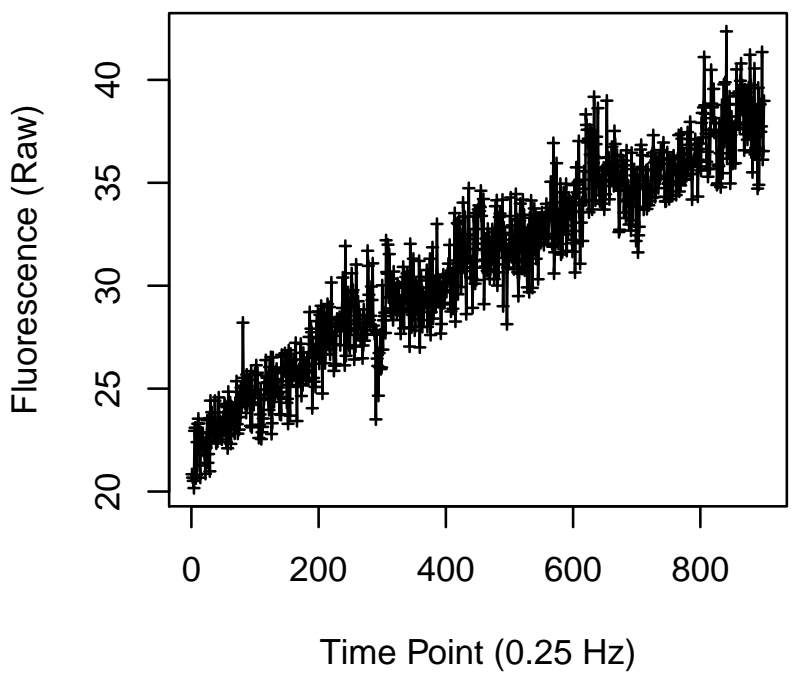

Cell 2047

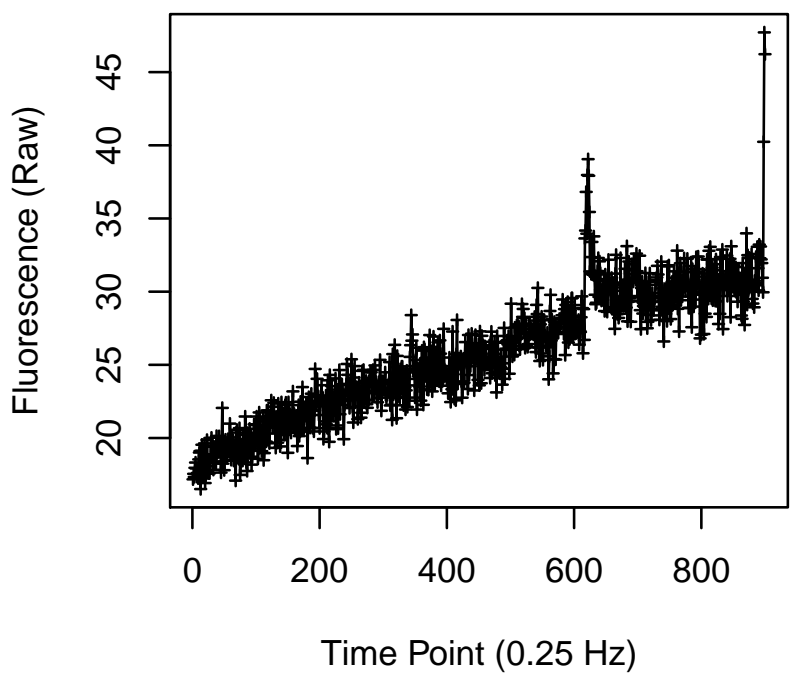

Cell 2046

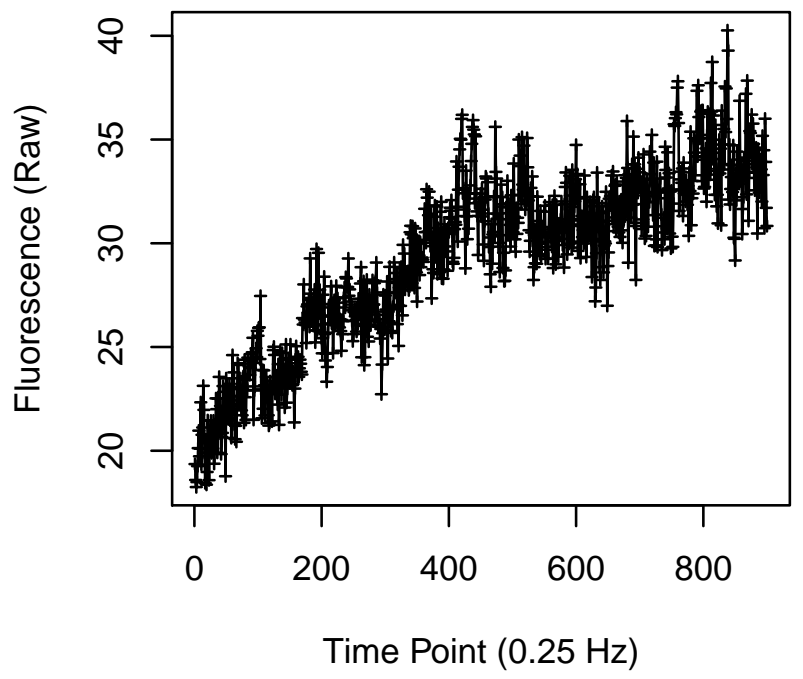

Cell 2048

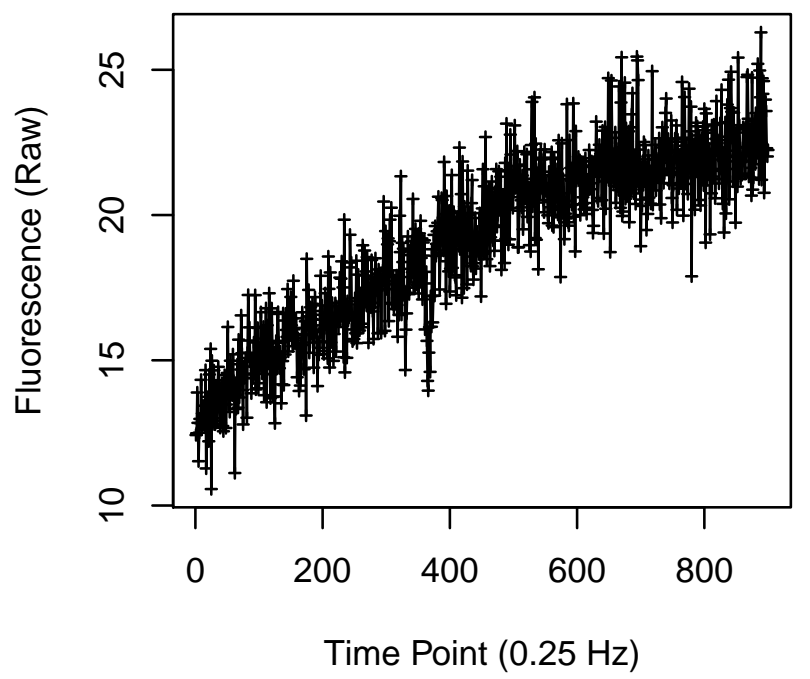


Cell 2049

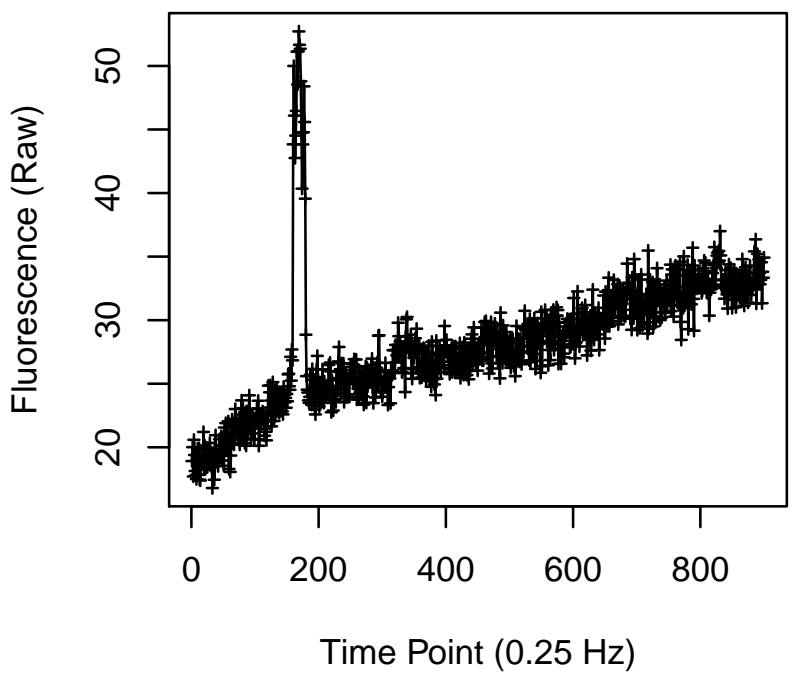

Cell 2051

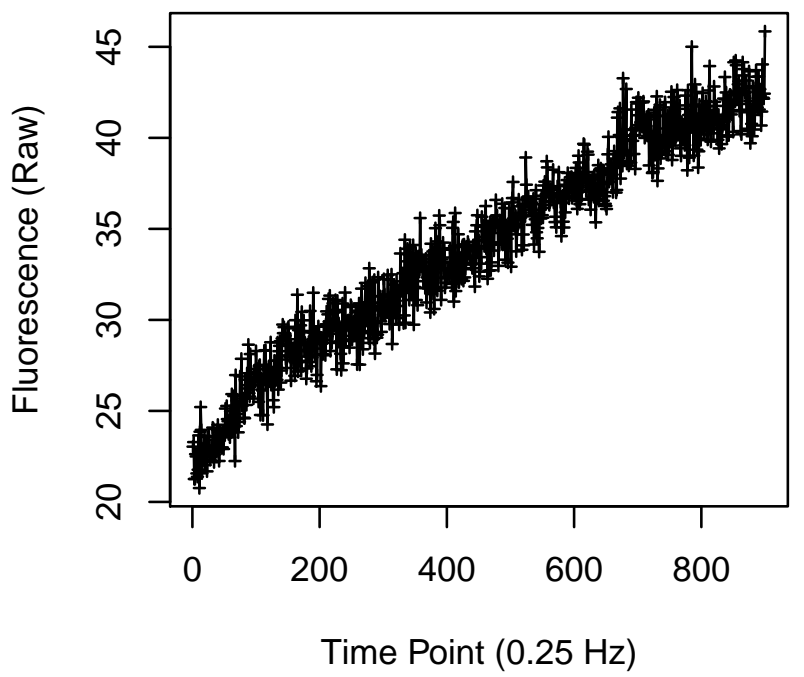

Cell 2050

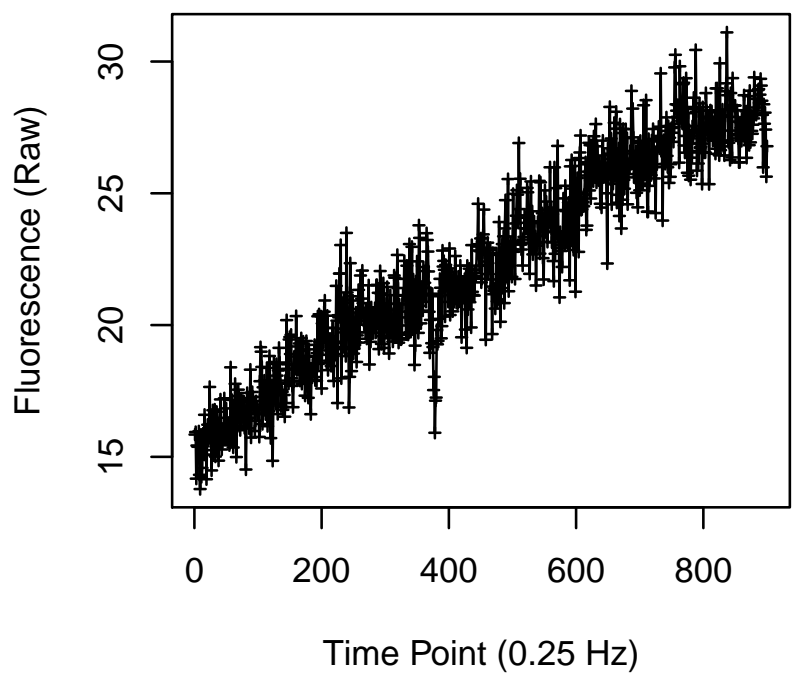

Cell 2052

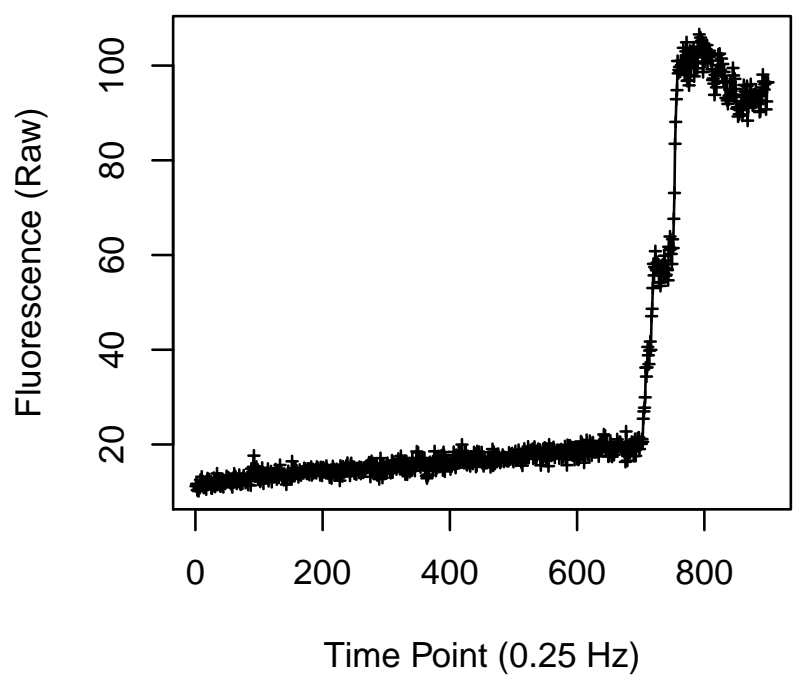


Cell 2053

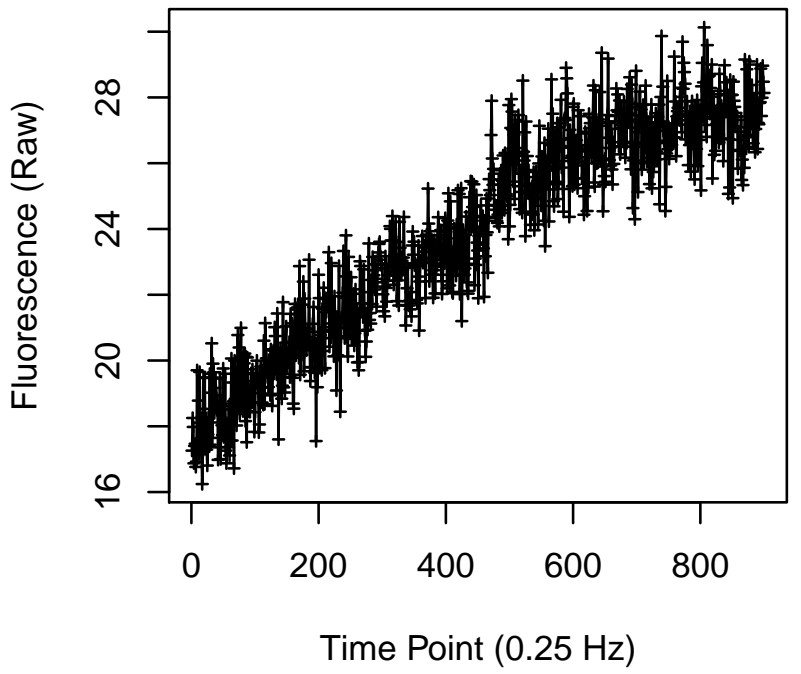

Cell 2055

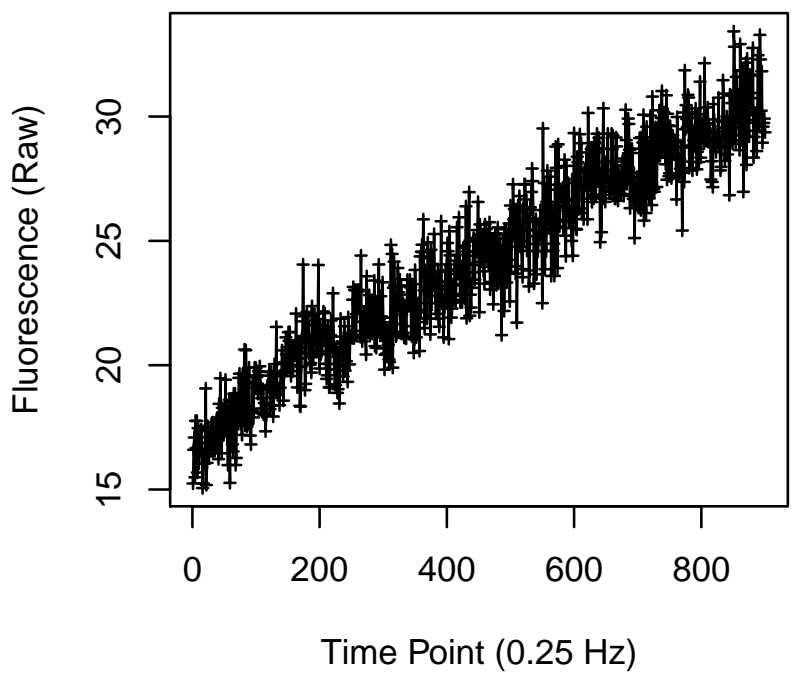

Cell 2054

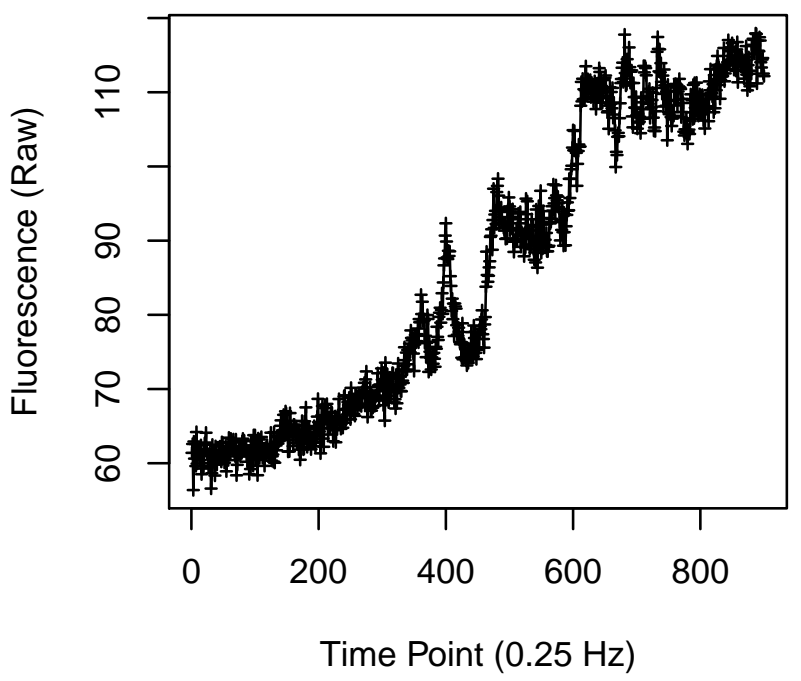

Cell 2056

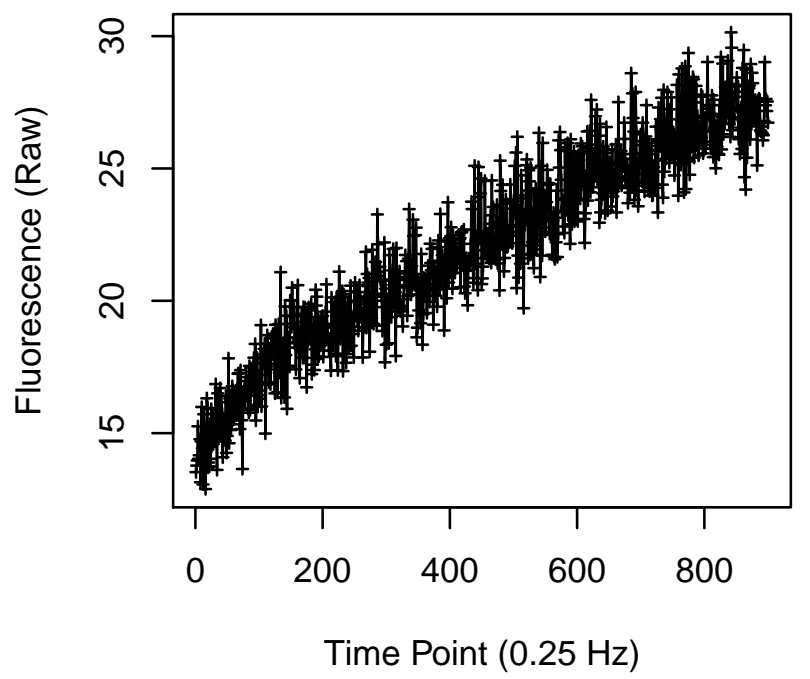


Cell 2057

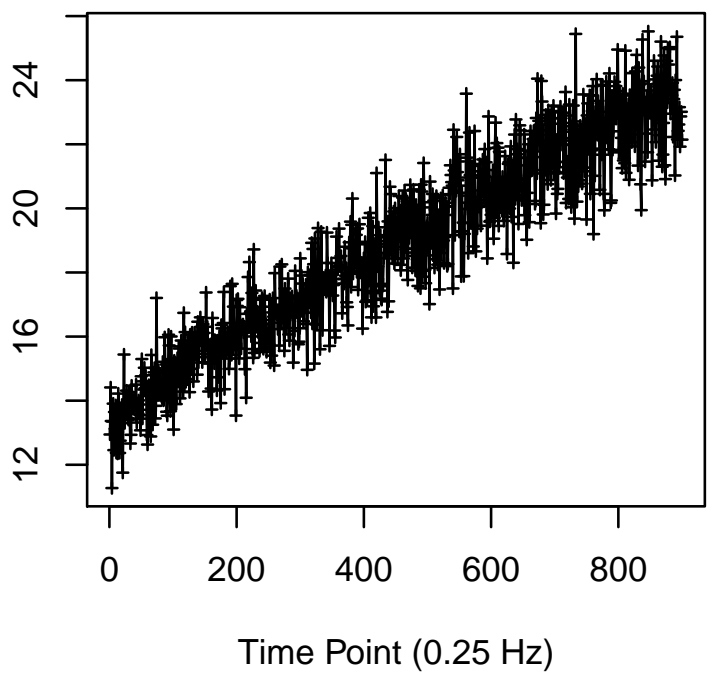

Cell 2059

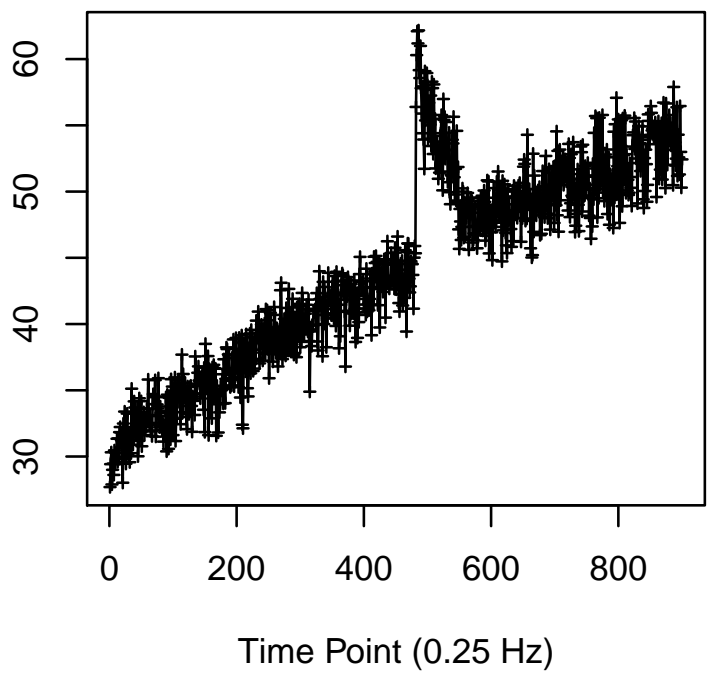

Cell 2058

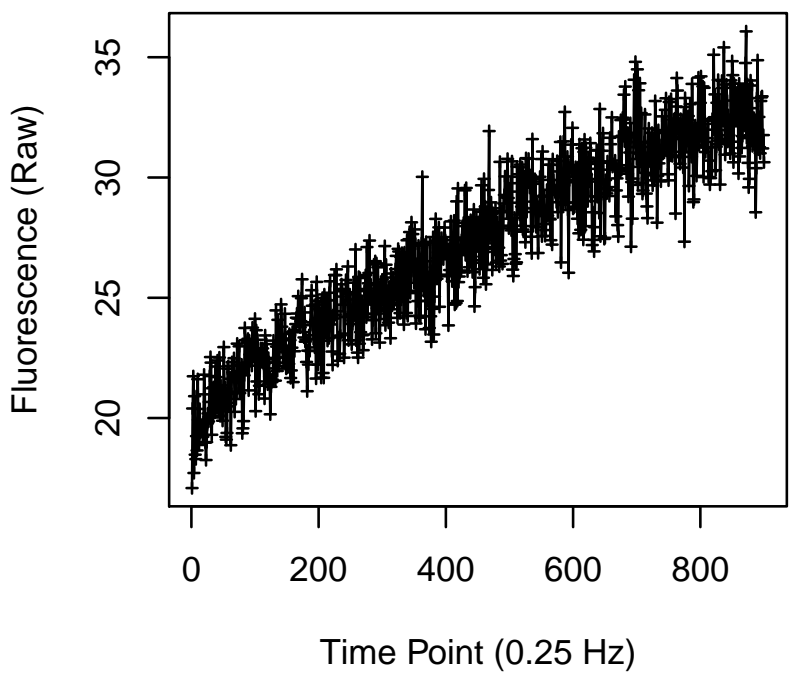

Cell 2060

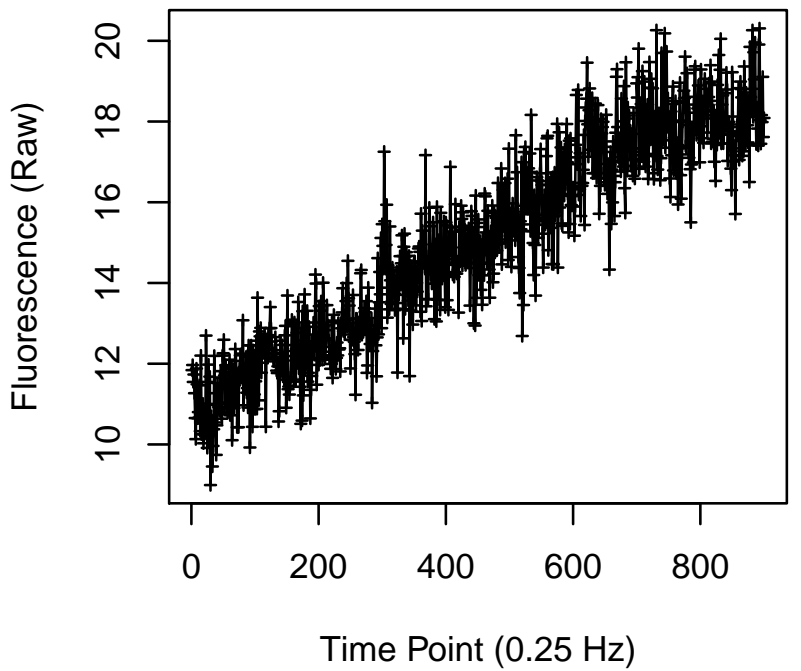


Cell 2061

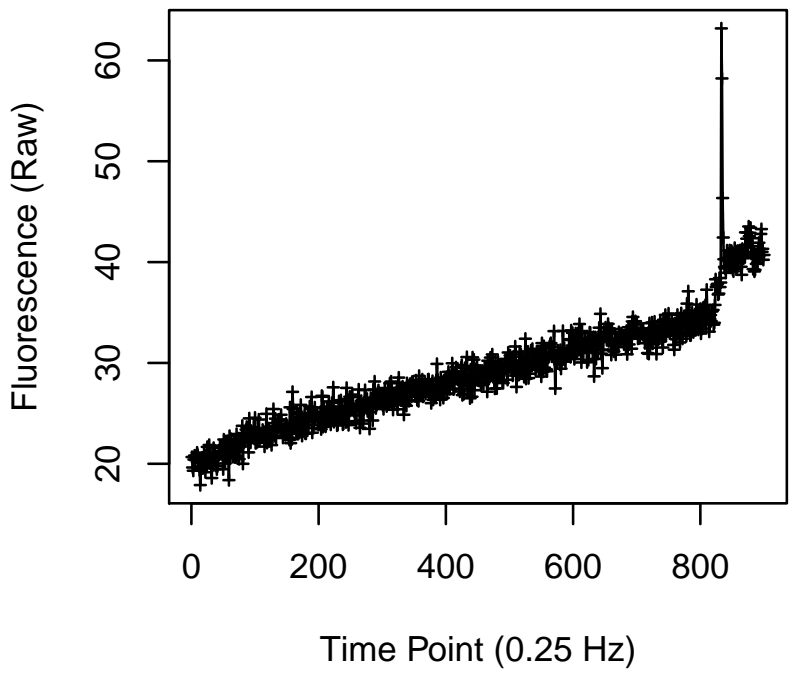

Cell 2063

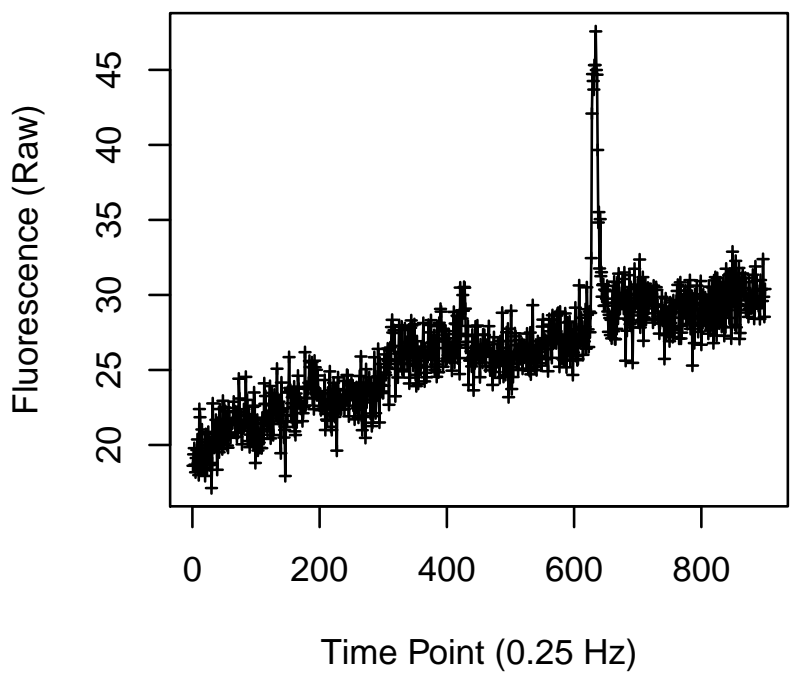

Cell 2062

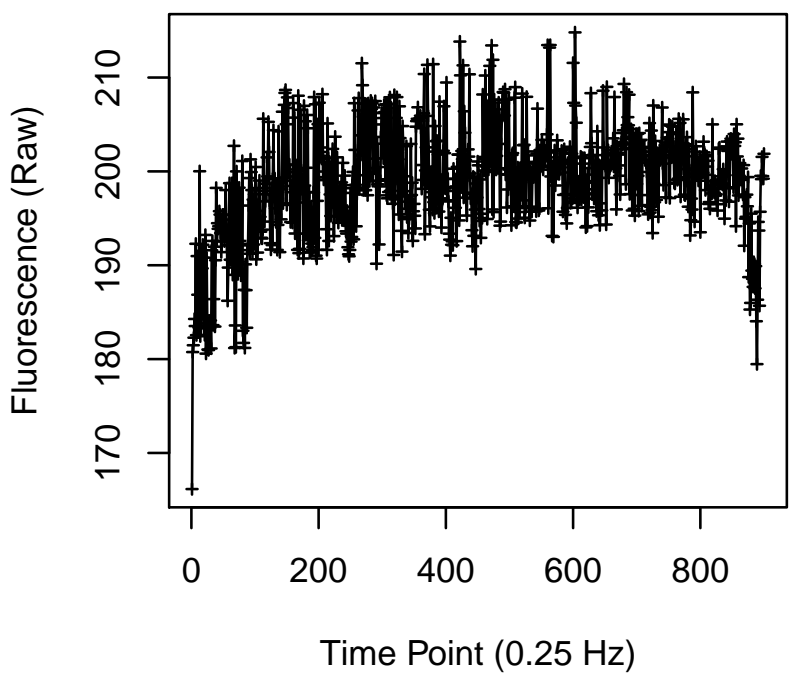

Cell 2064

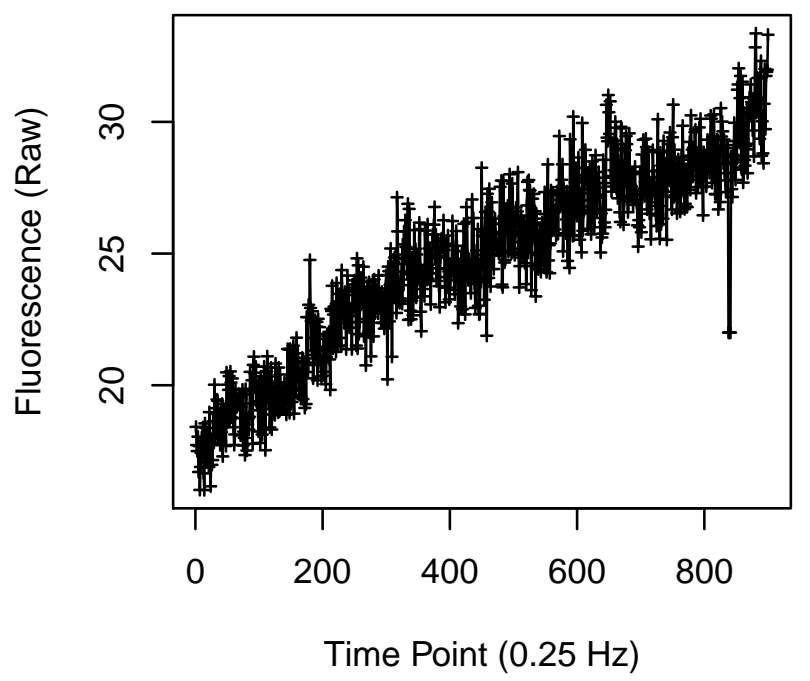


Cell 2065

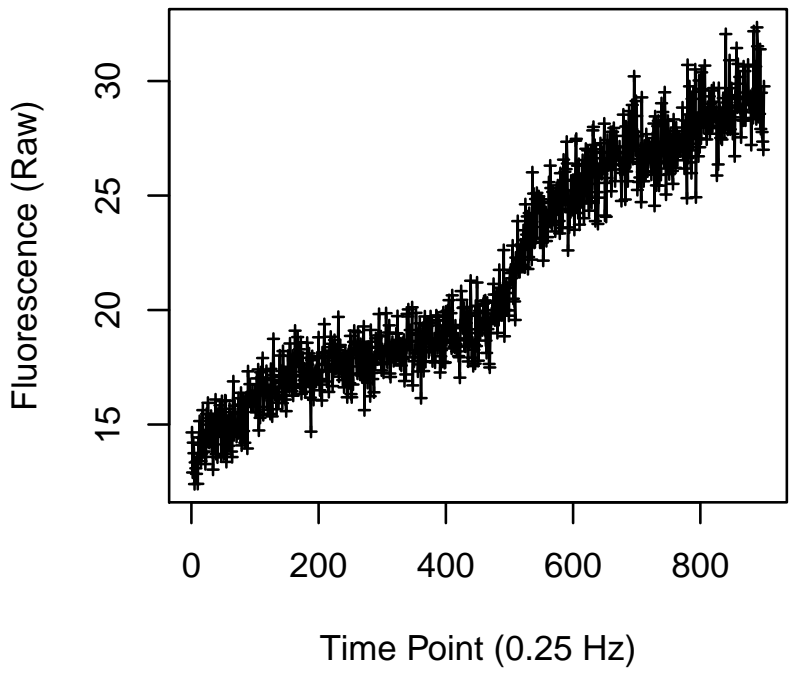

Cell 2067

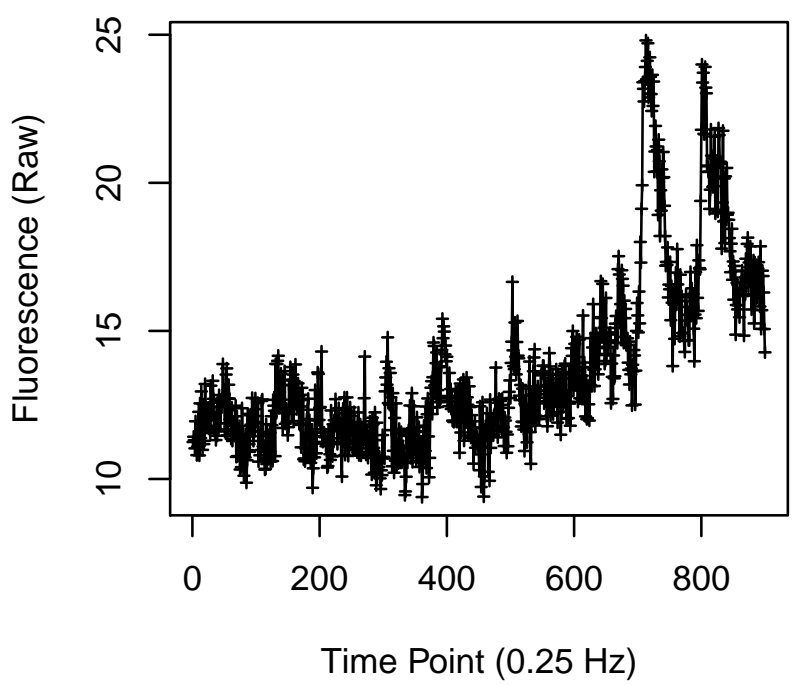

Cell 2066

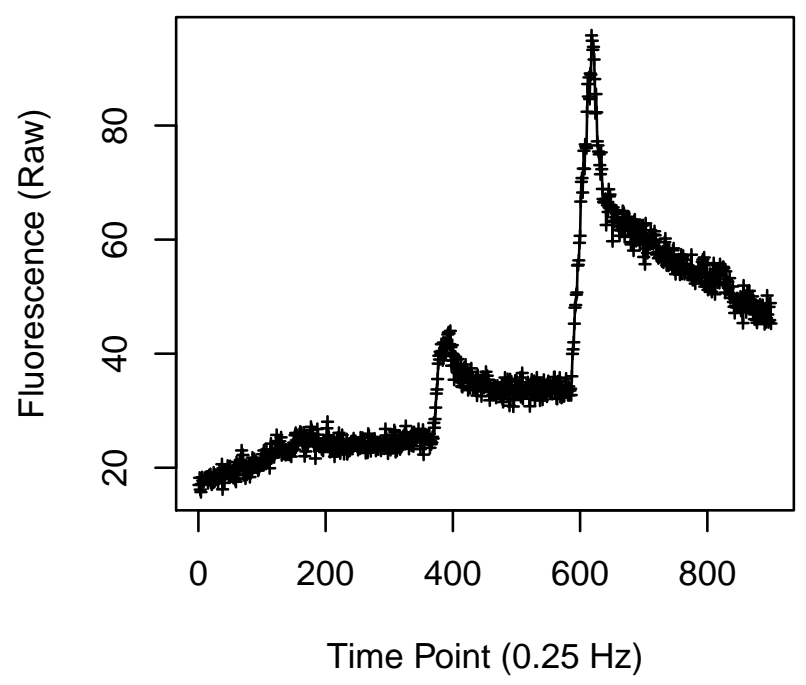

Cell 2068

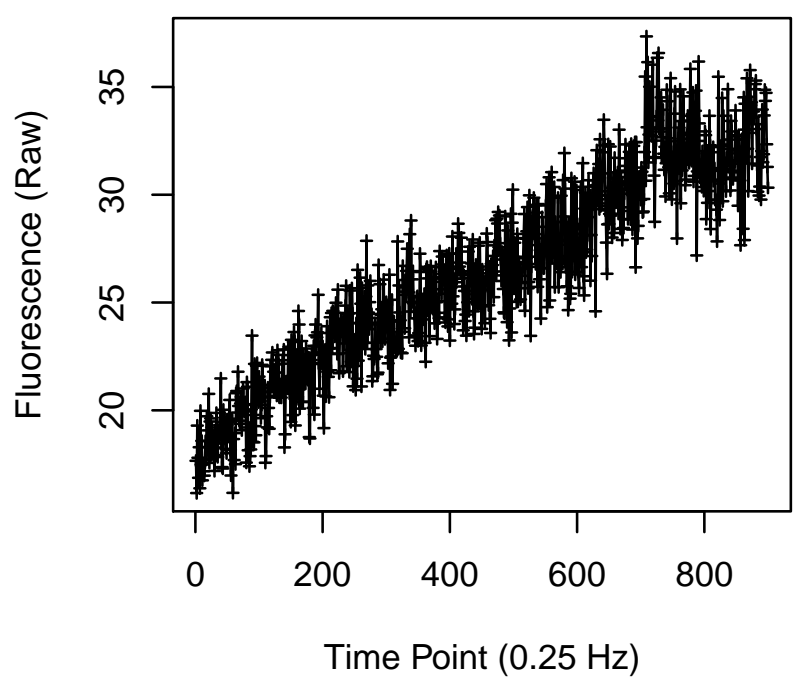


Cell 2069

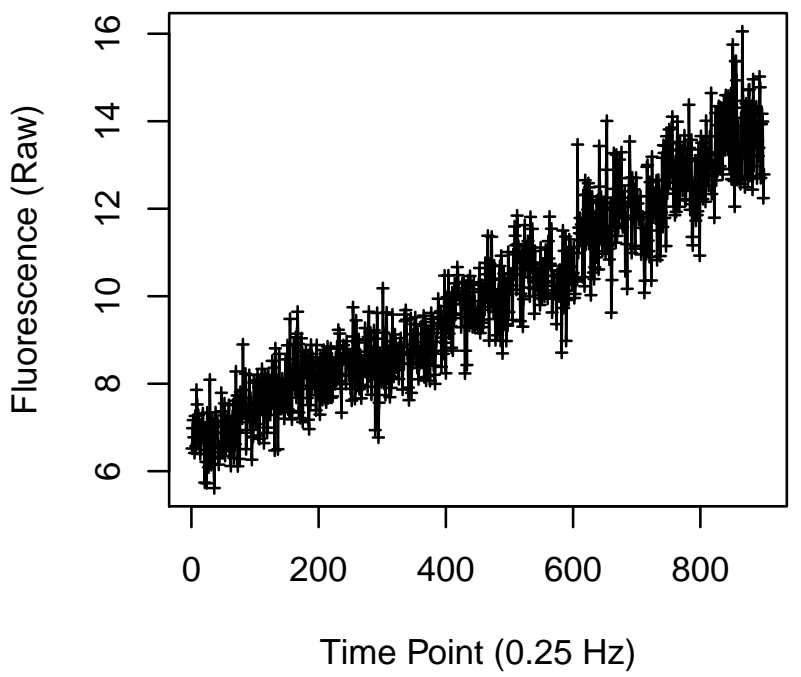

Cell 2071

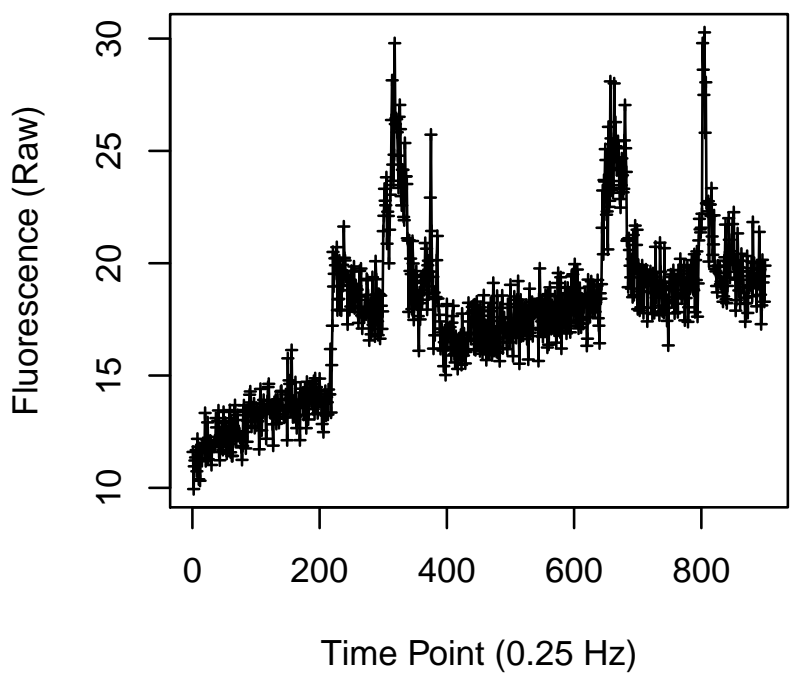

Cell 2070

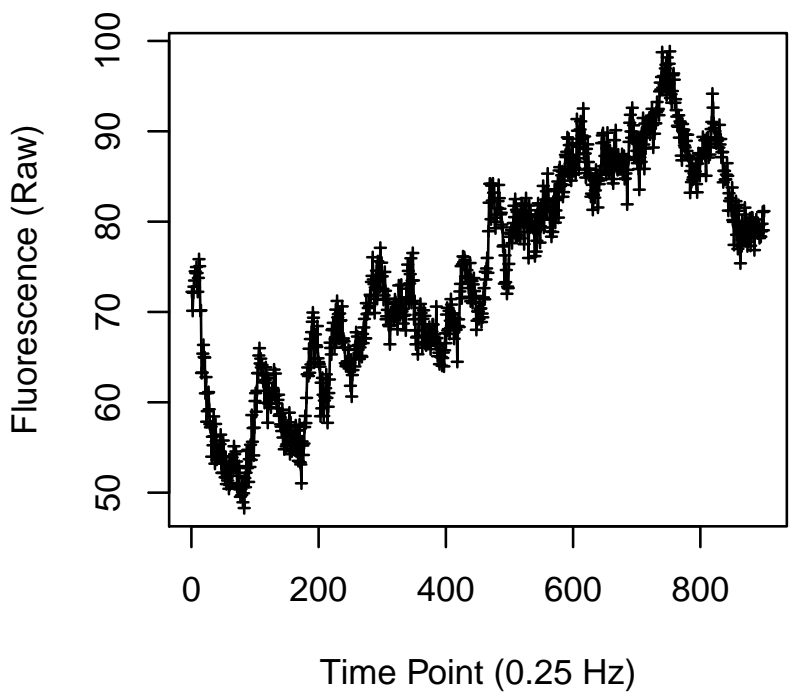

Cell 2072

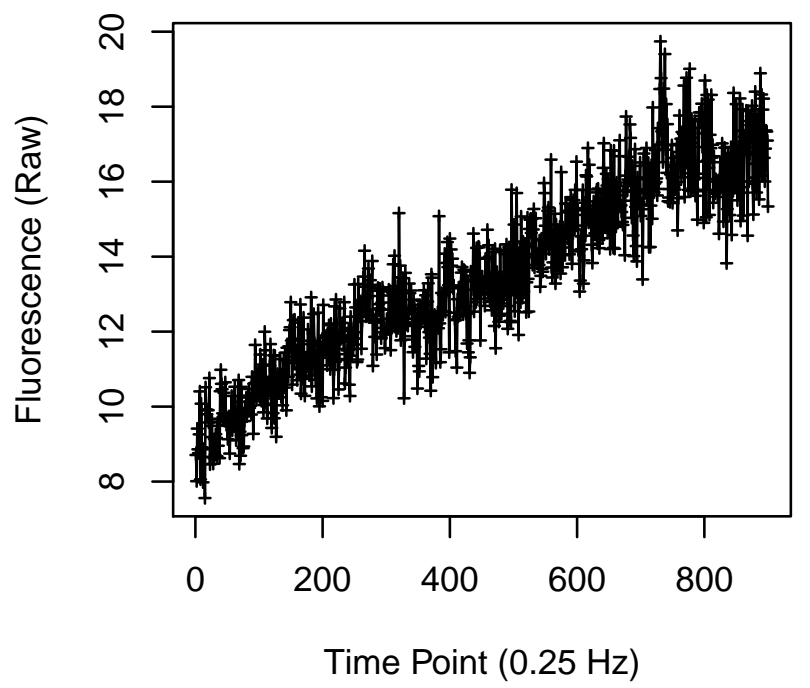


Cell 2073

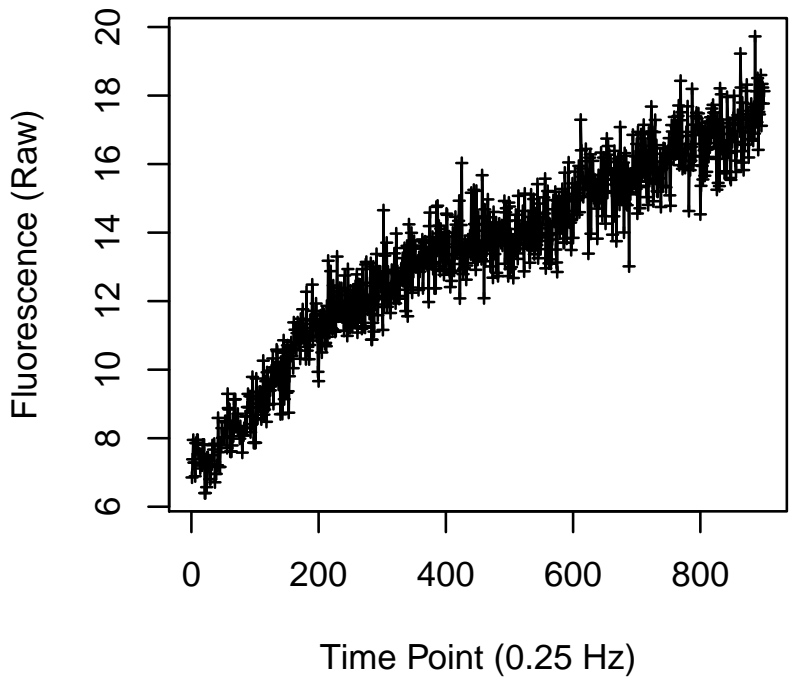

Cell 2075

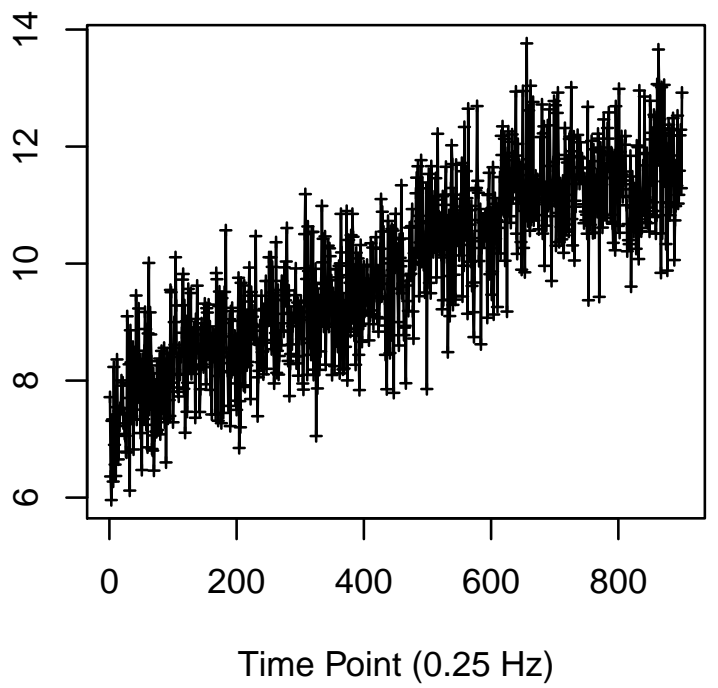

Cell 2074

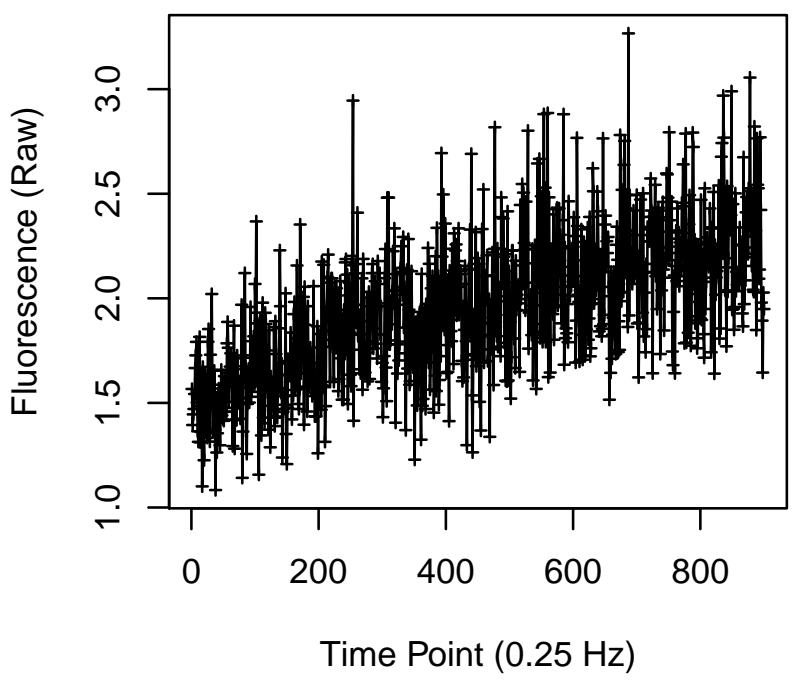

Cell 2076

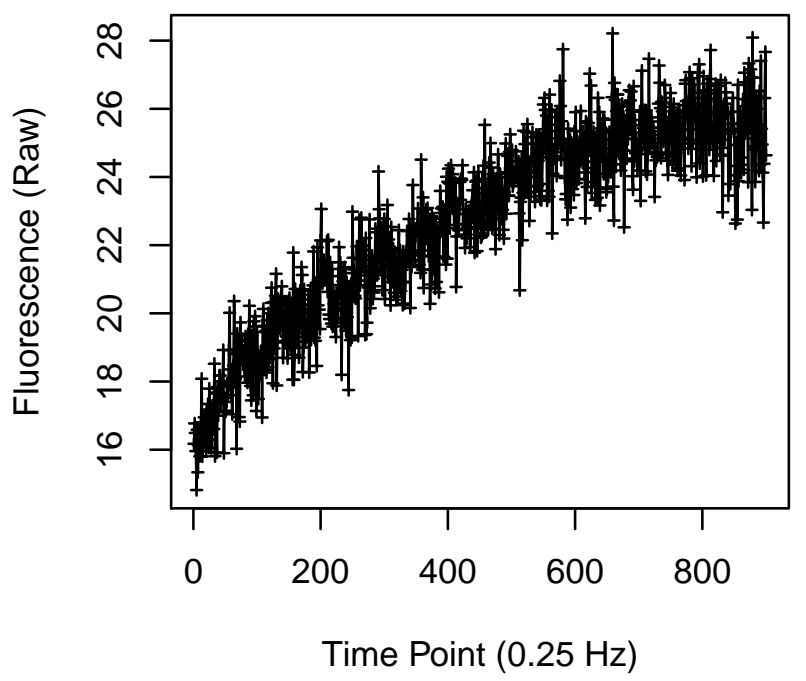


Cell 2077

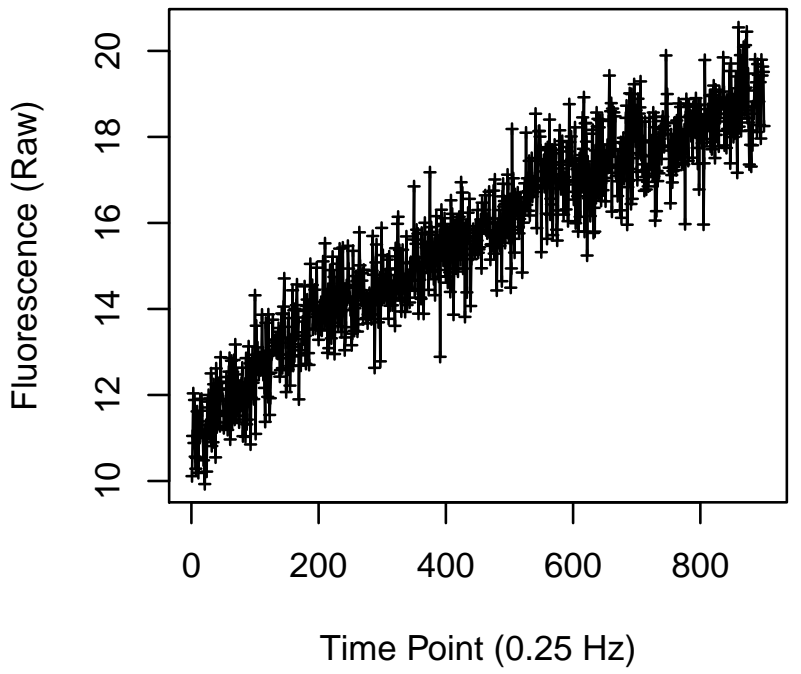

Cell 2079

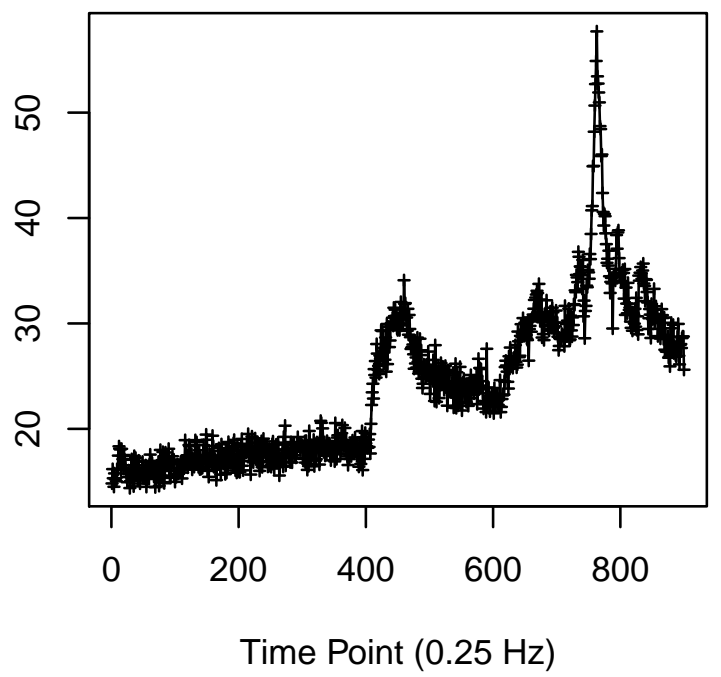

Cell 2078

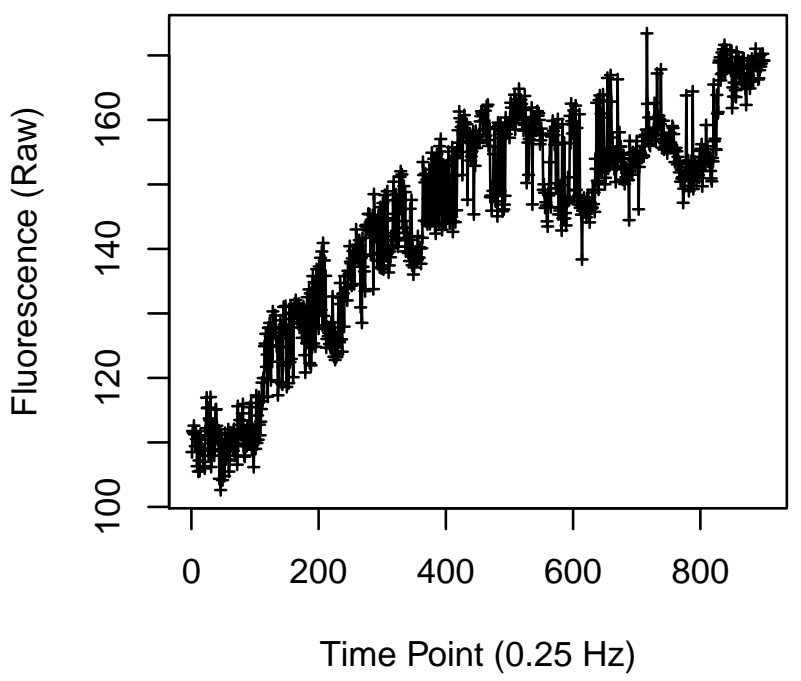

Cell 2080

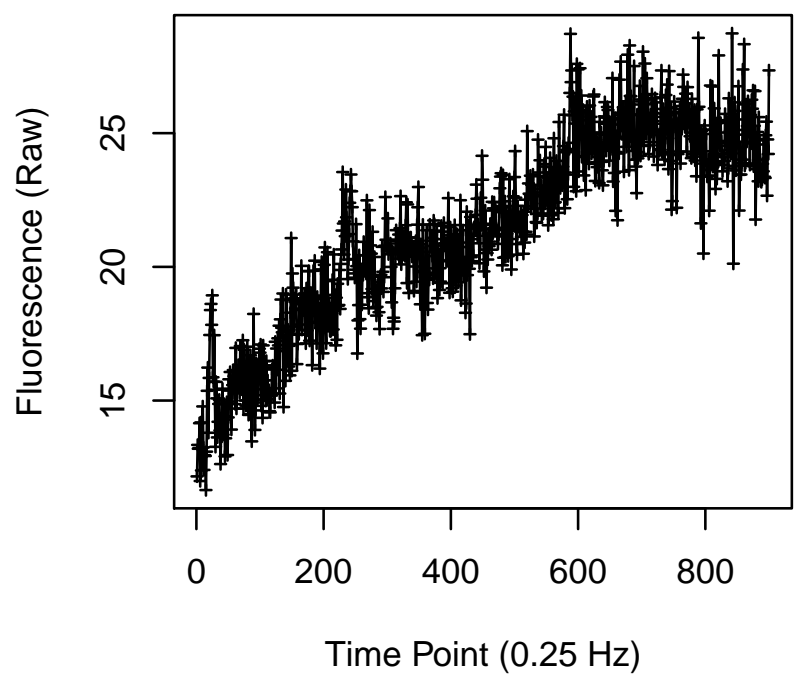




\section{Cell 2081}

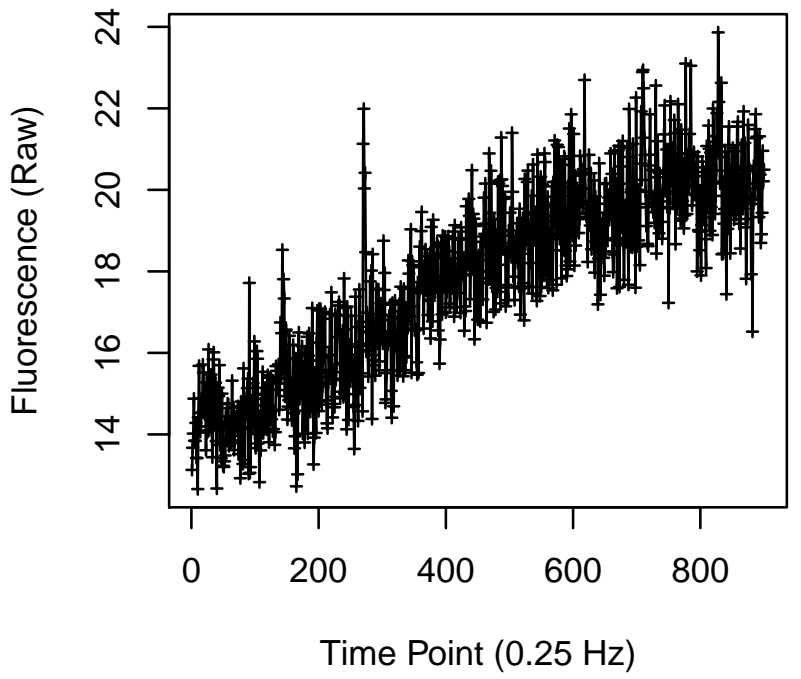

Cell 2083

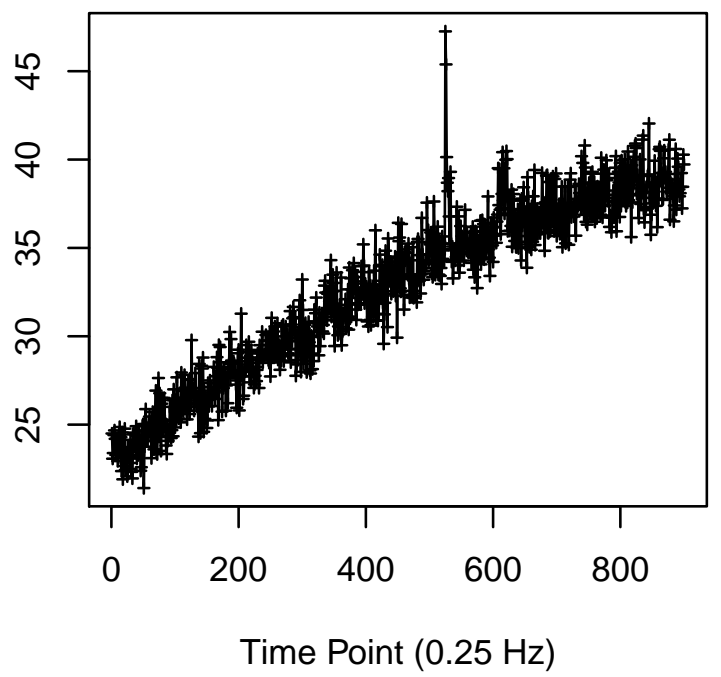

Cell 2082

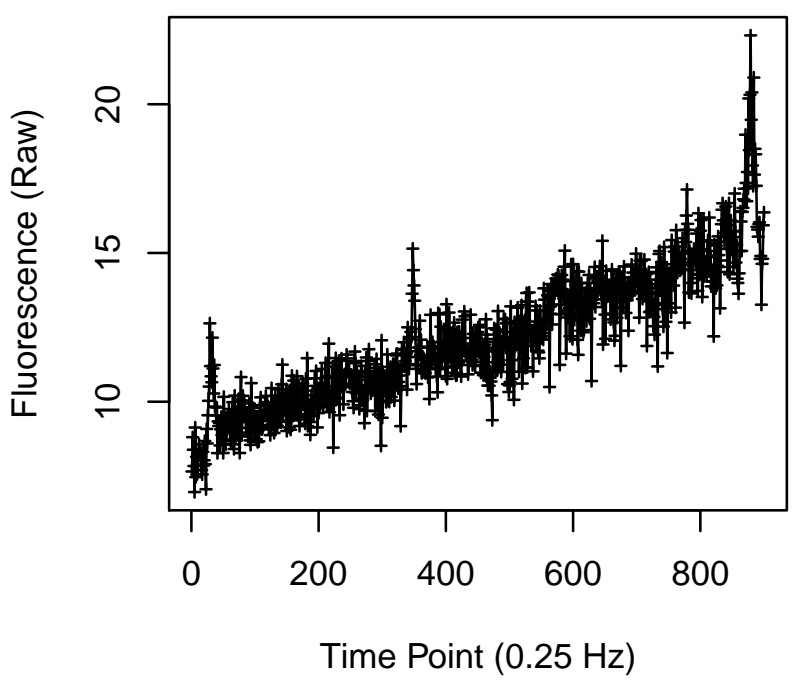

Cell 2084

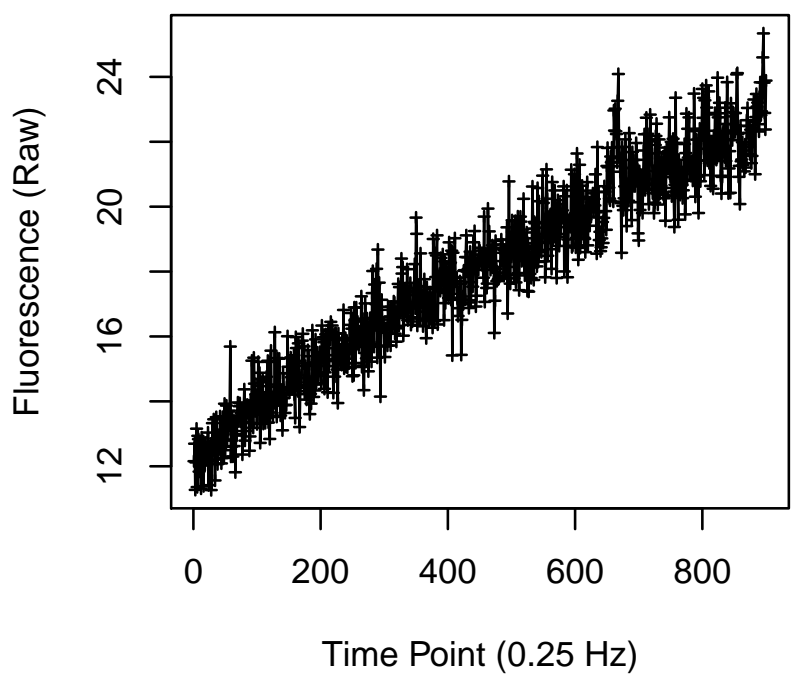


Cell 2085

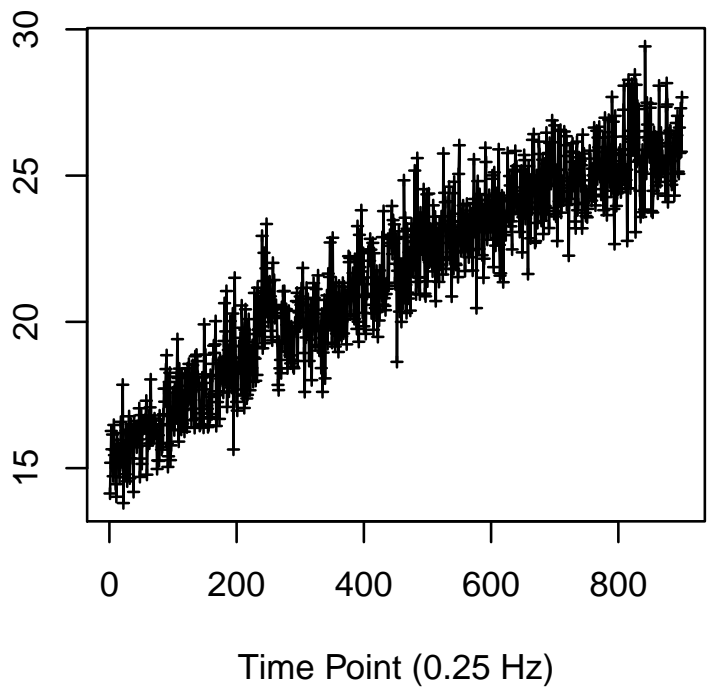

Cell 2087

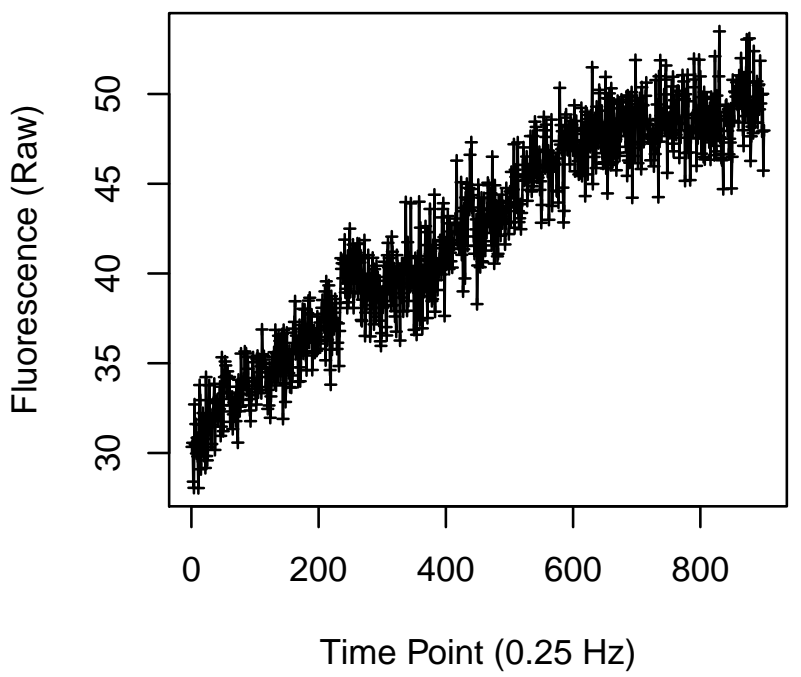

Cell 2086

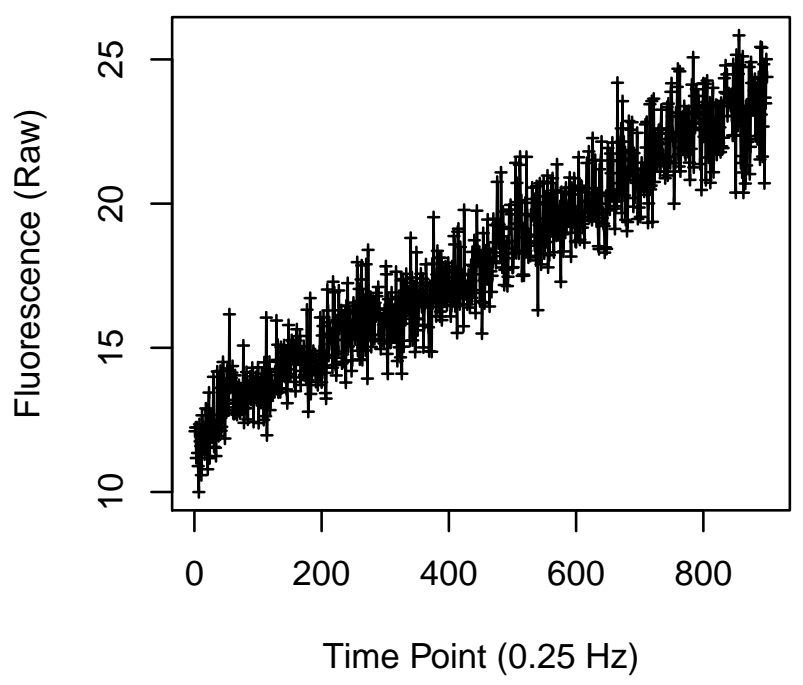

Cell 2088

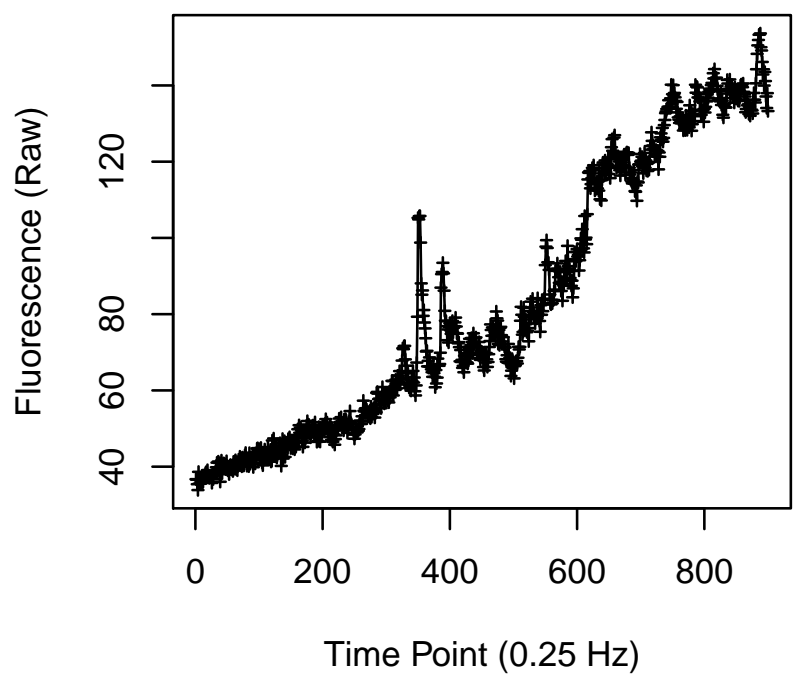


Cell 2089

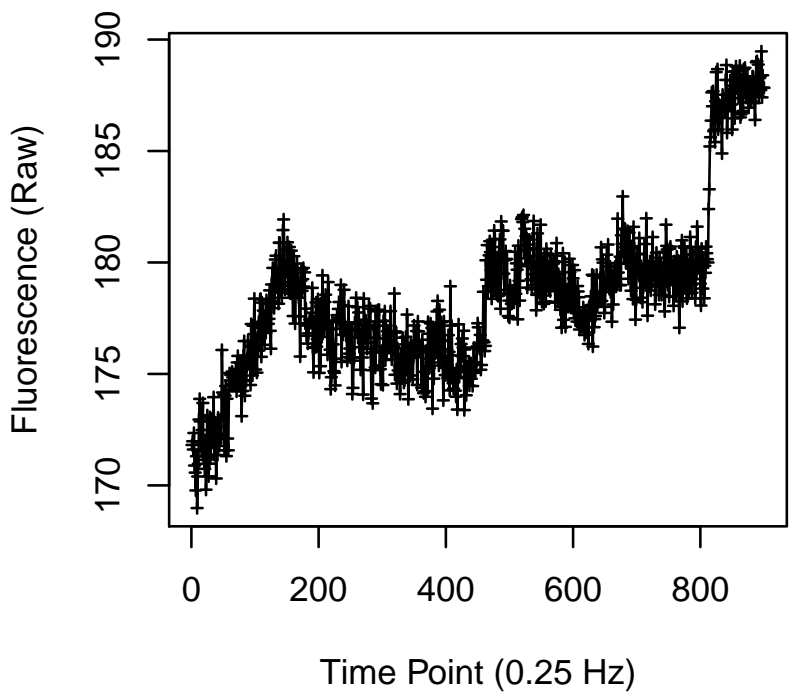

Cell 2091

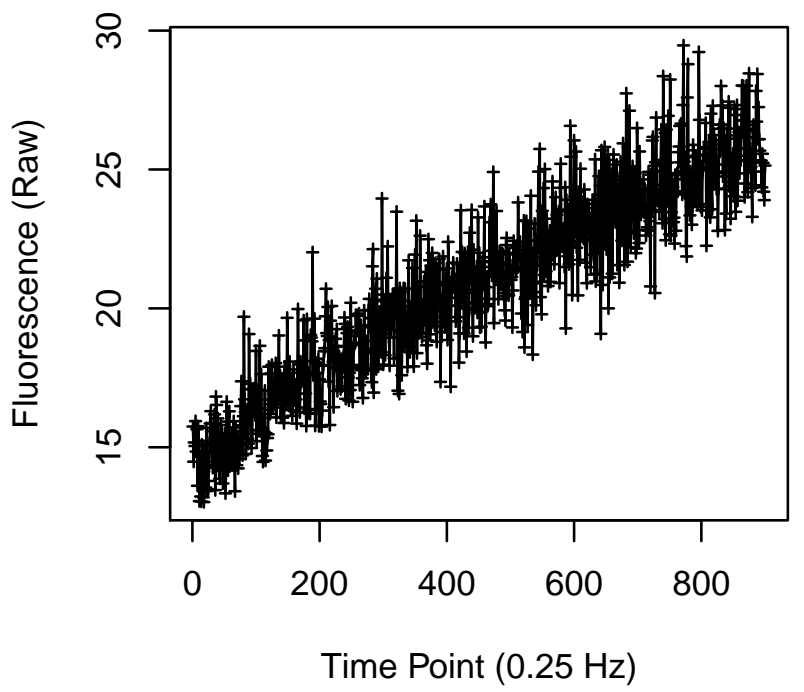

Cell 2090

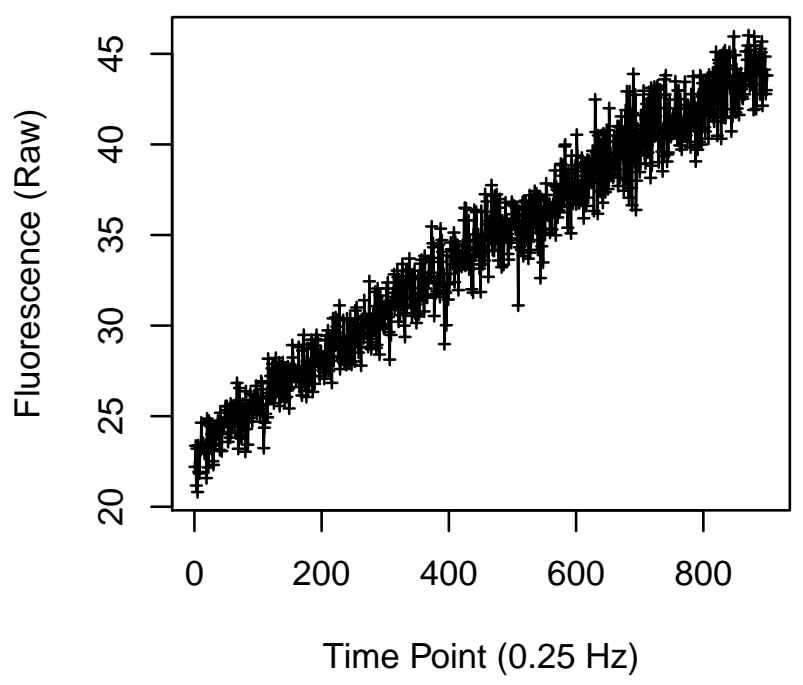

Cell 2092

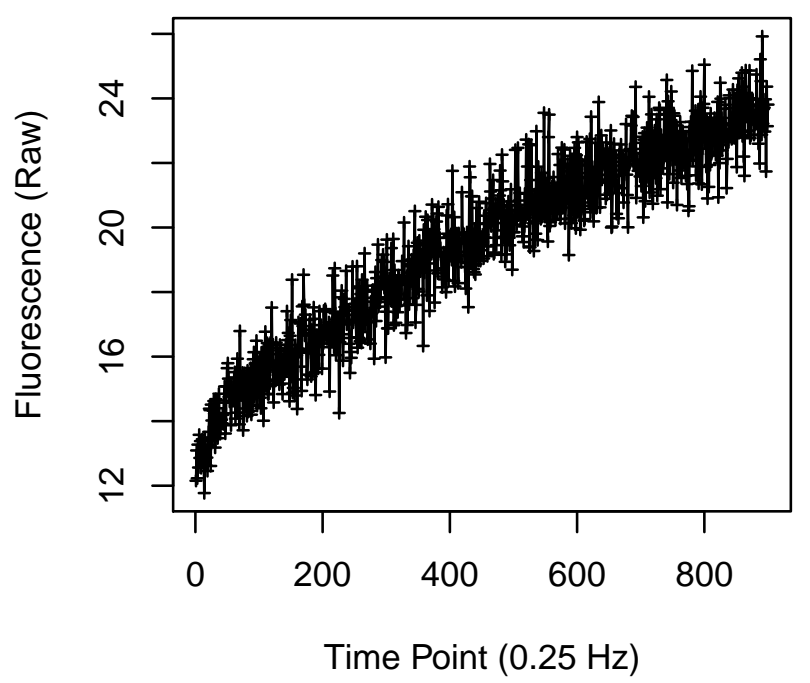


Cell 2093

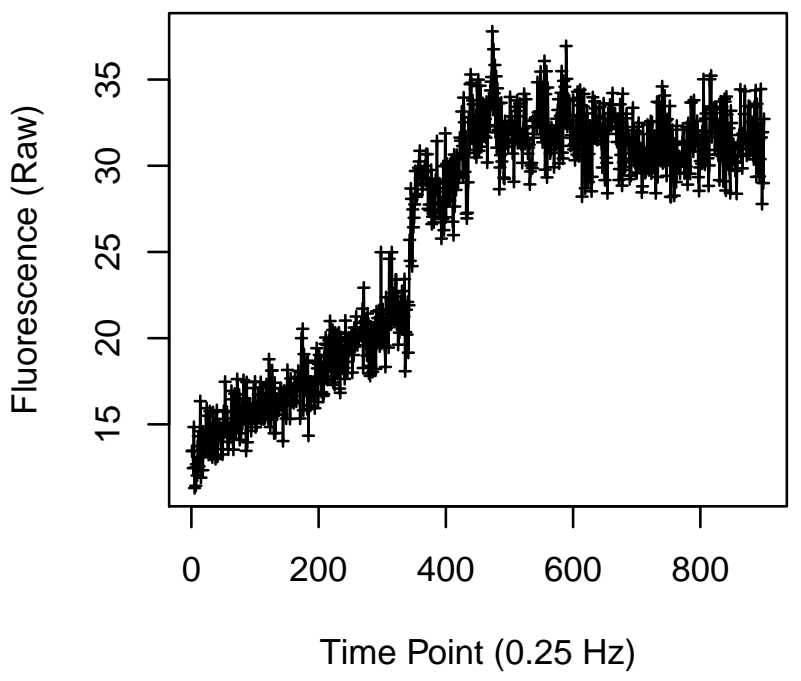

Cell 2095

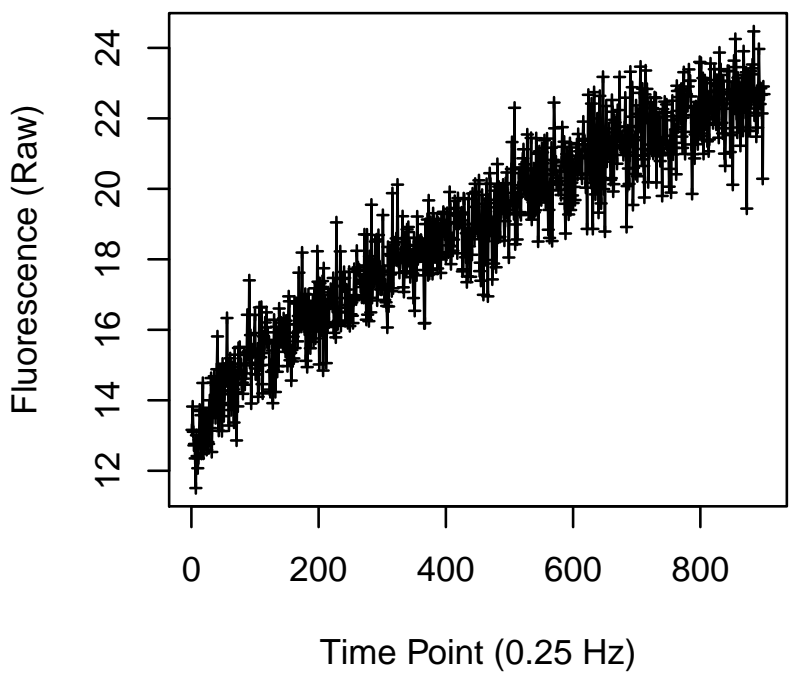

Cell 2094

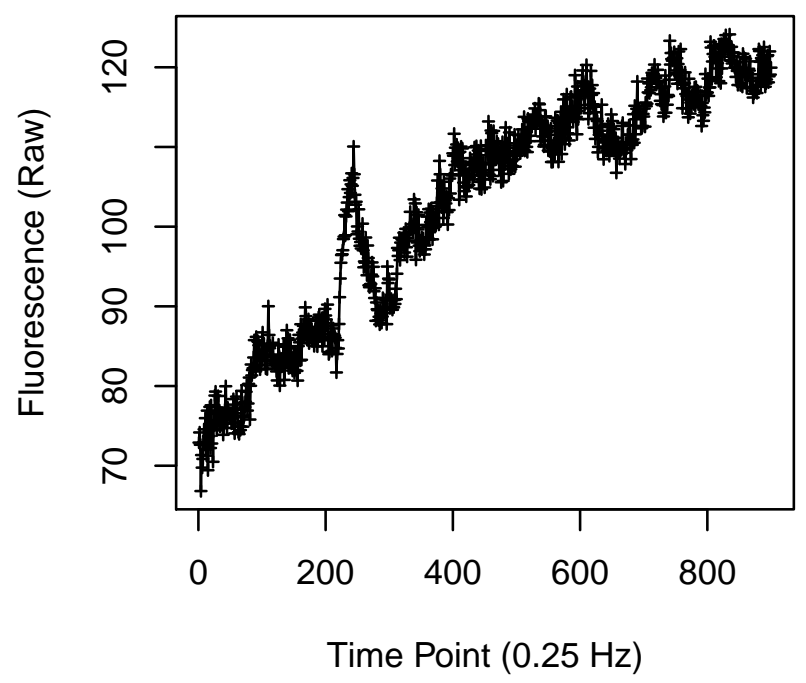

Cell 2096

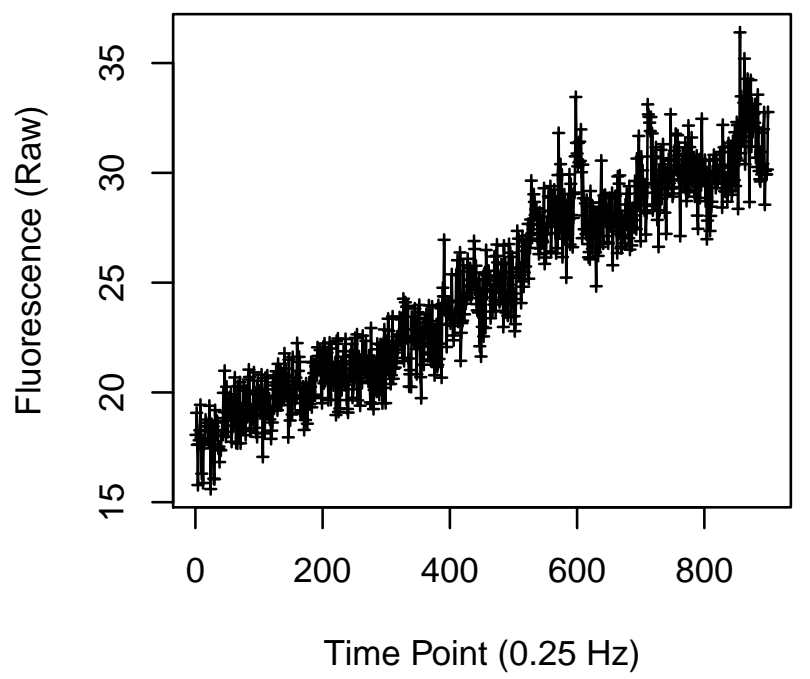


Cell 2097

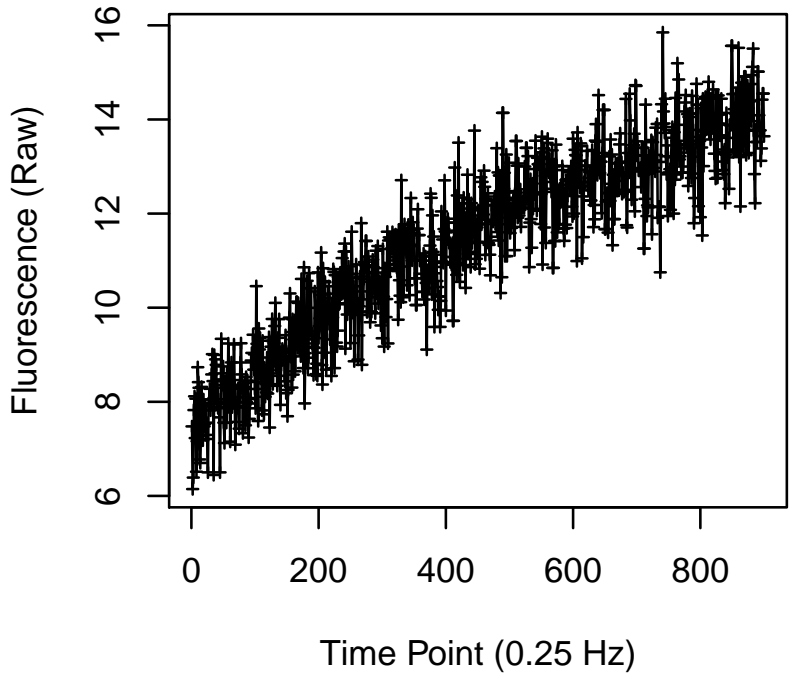

Cell 2099

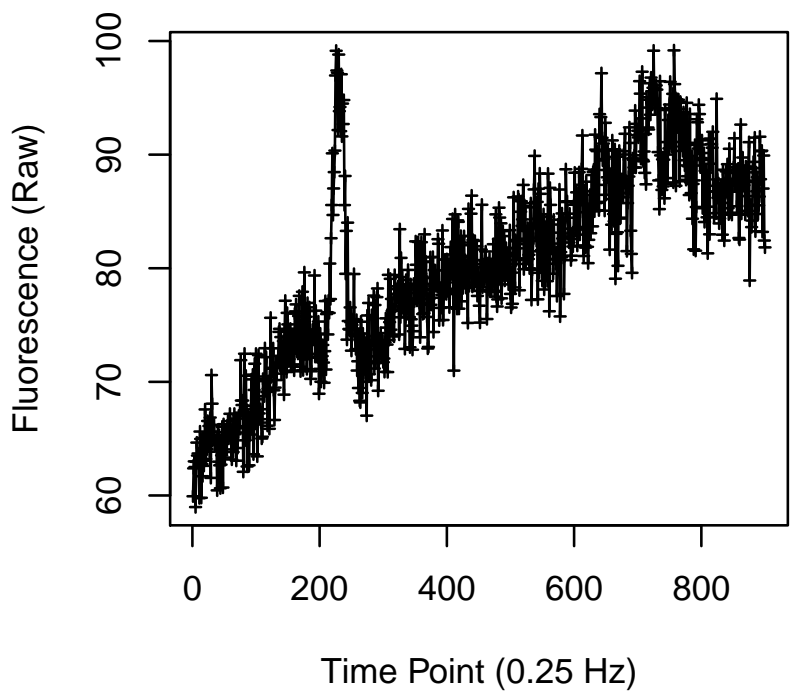

Cell 2098

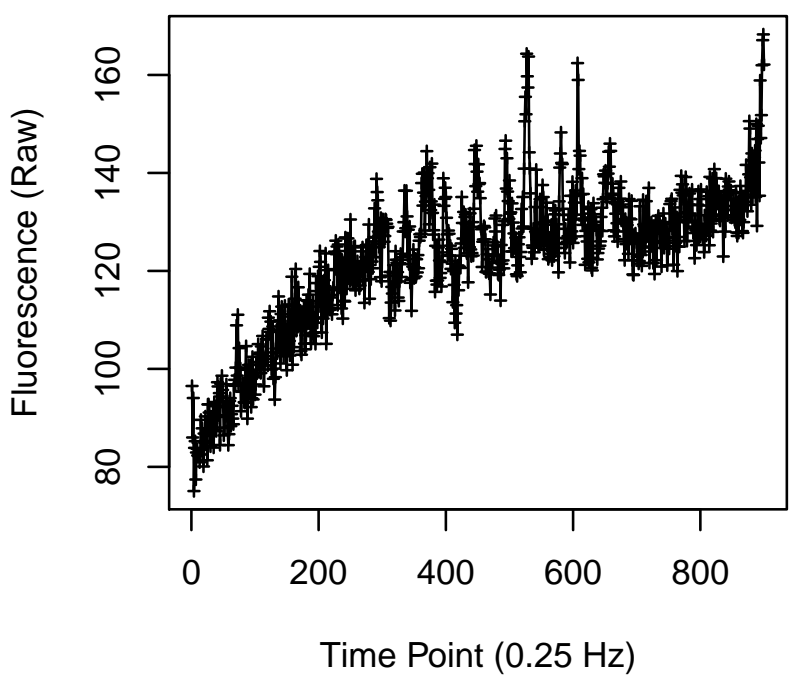

Cell 2100

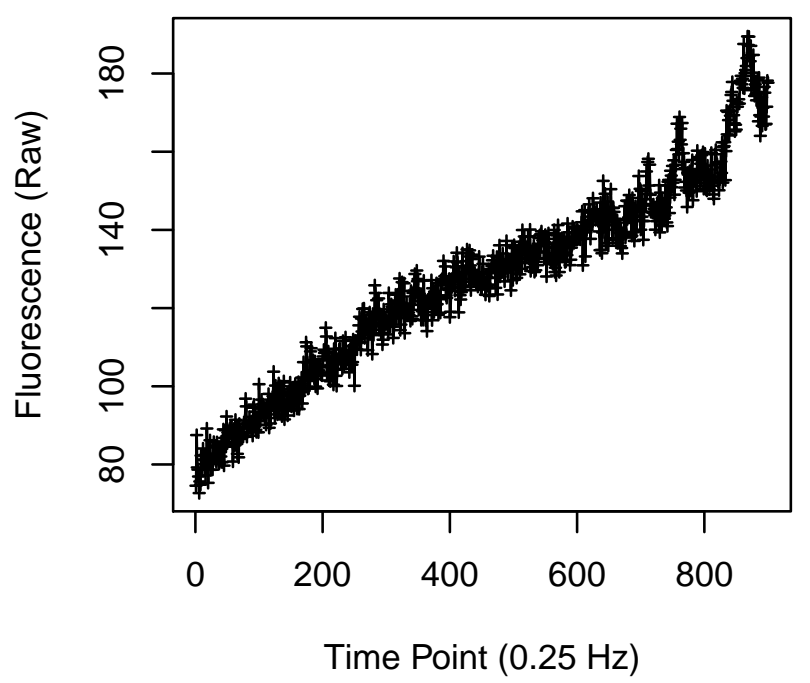


Cell 2101

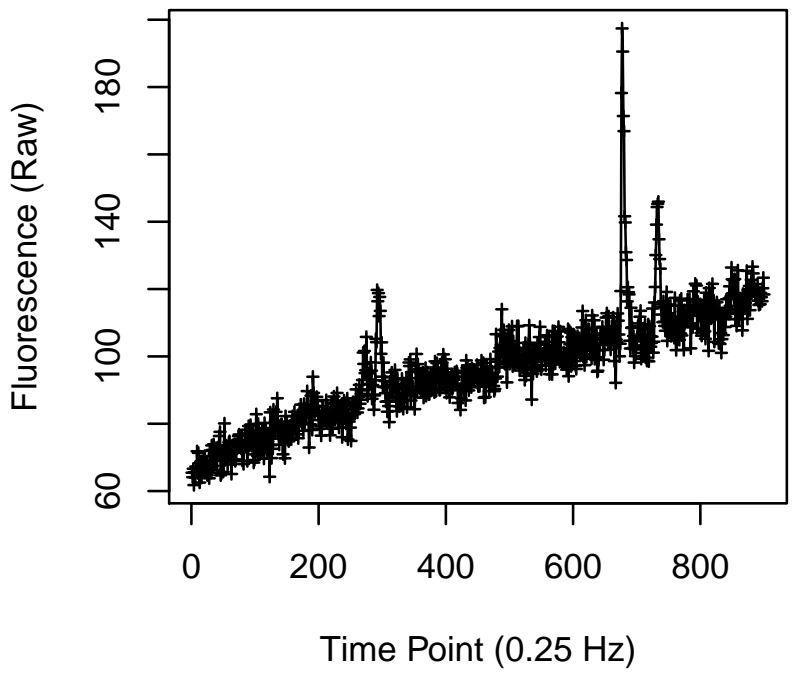

Cell 2103

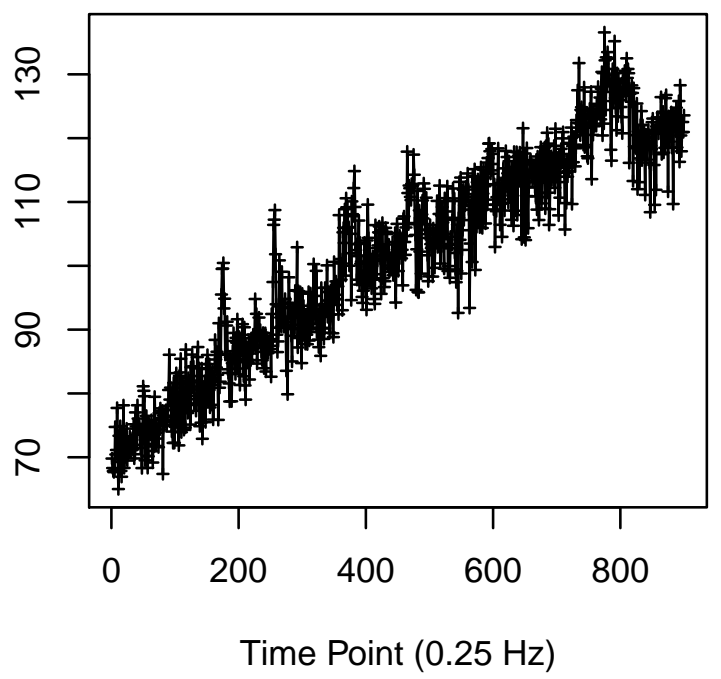

Cell 2102

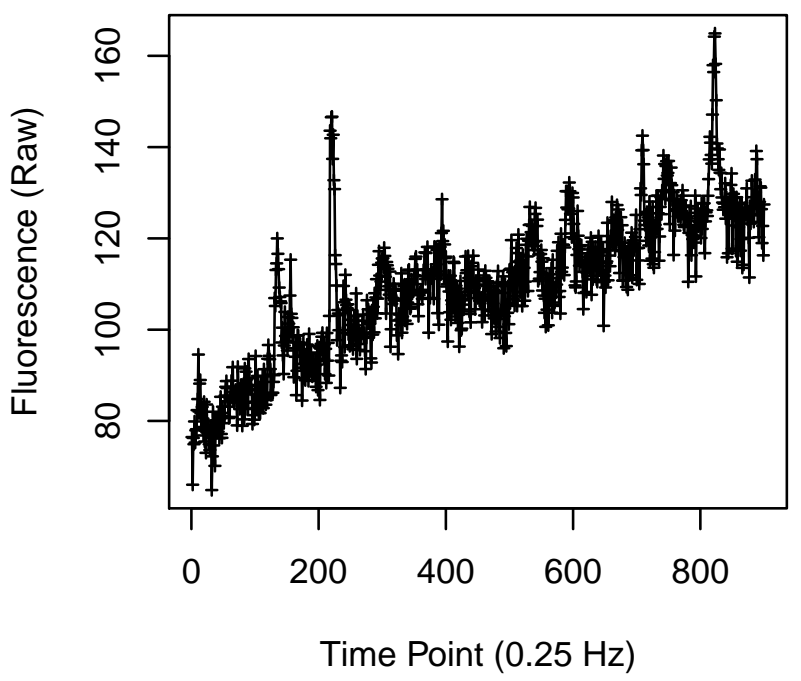

Cell 2104

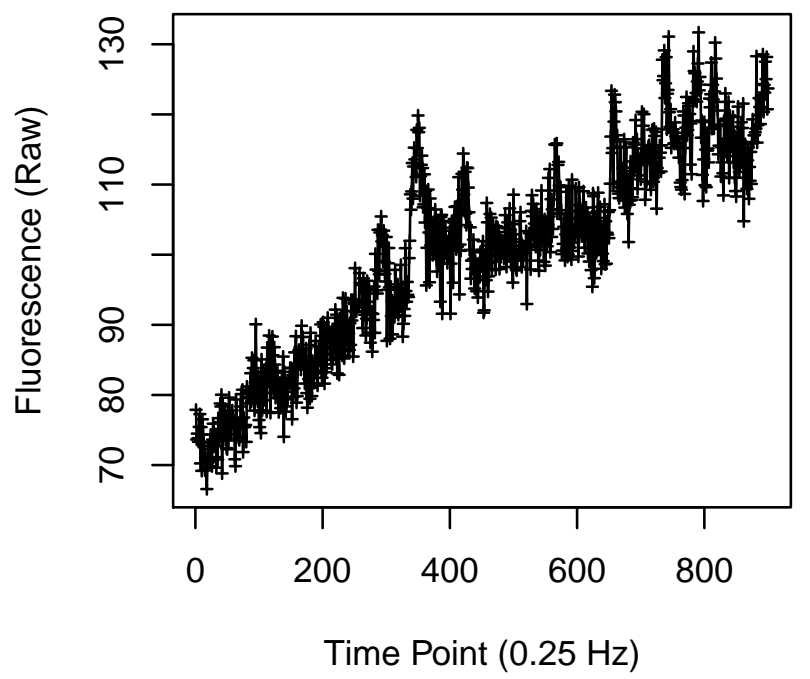


Cell 2105

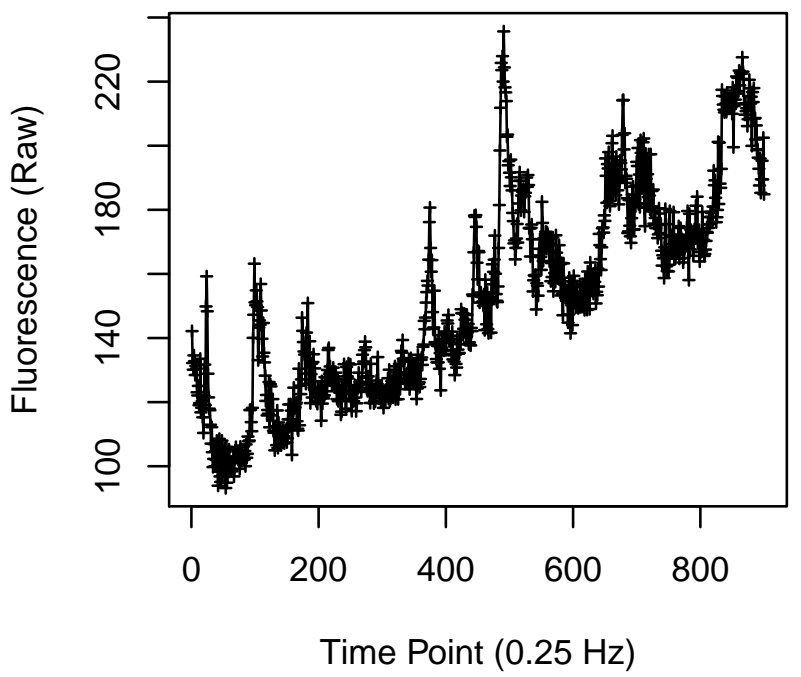

Cell 2107

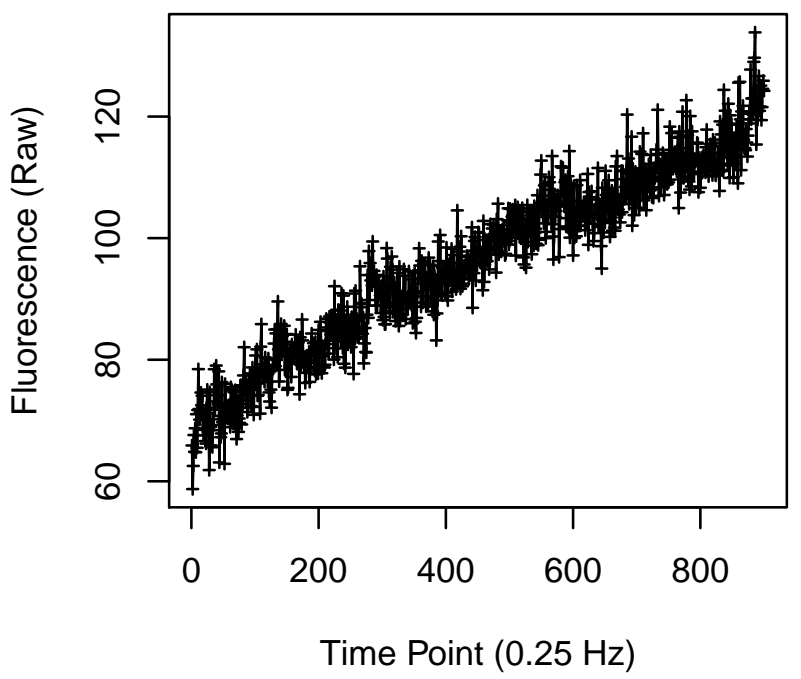

Cell 2106

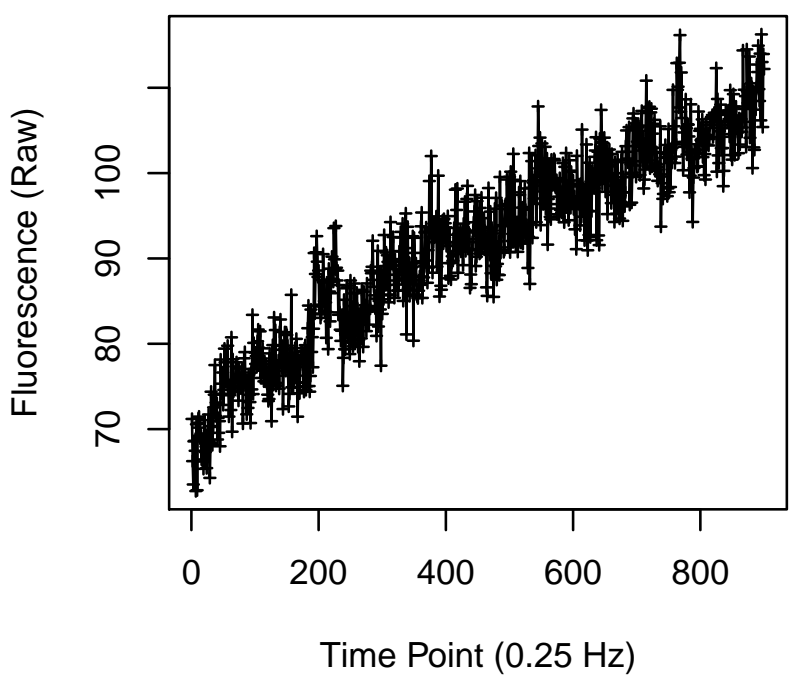

Cell 2108

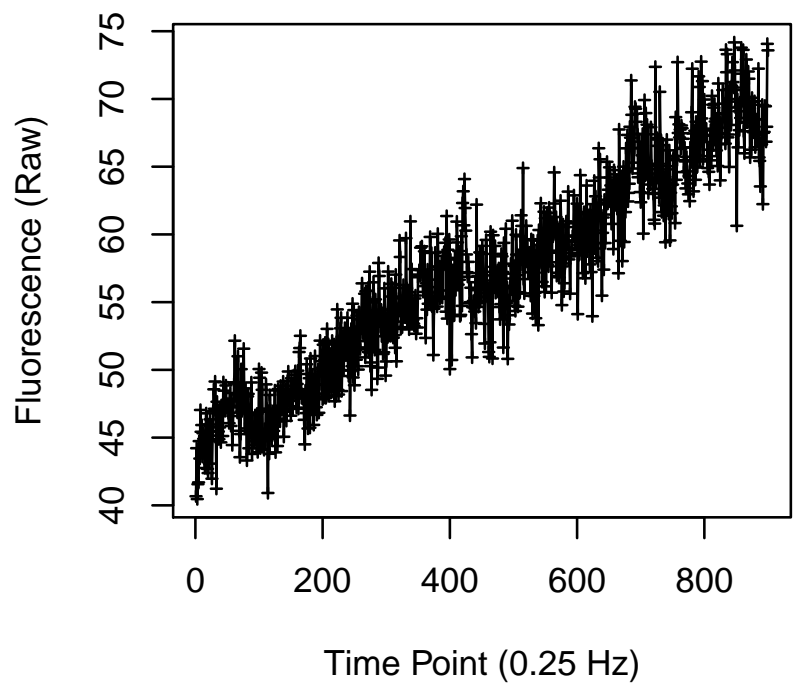


Cell 2109

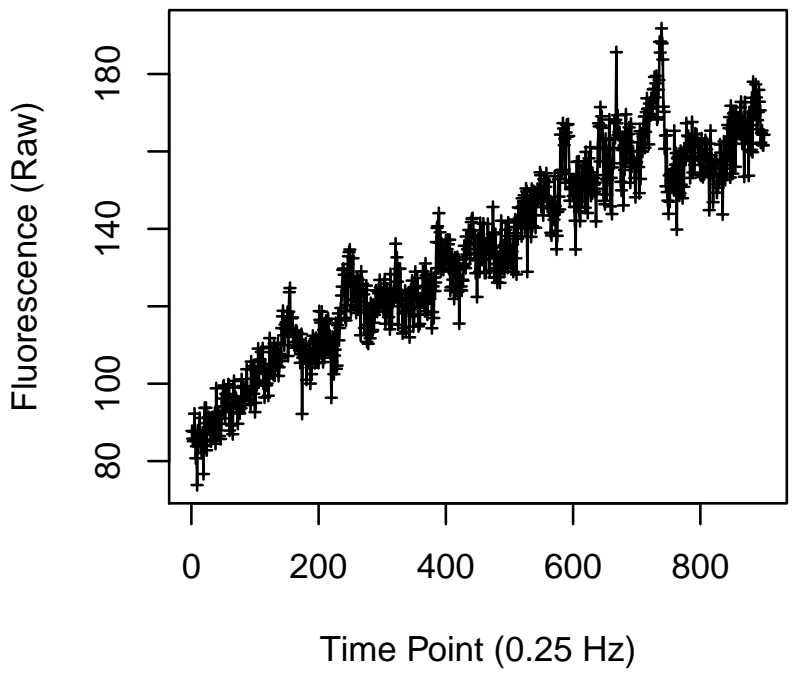

Cell 2111

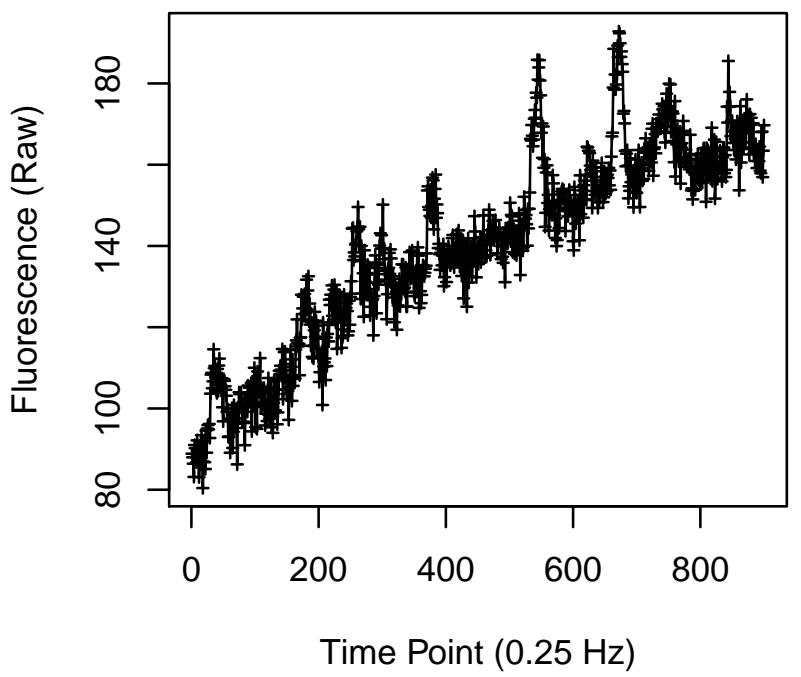

Cell 2110

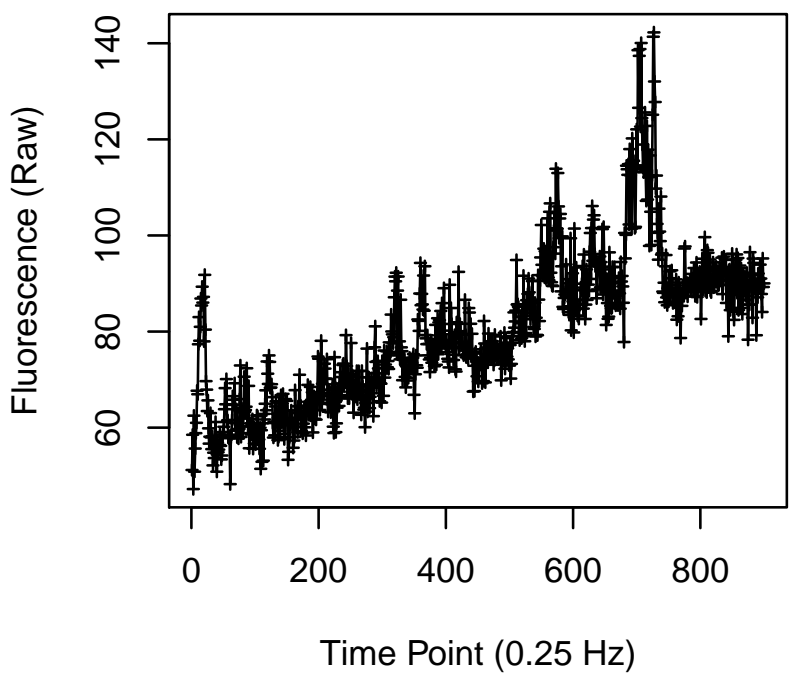

Cell 2112

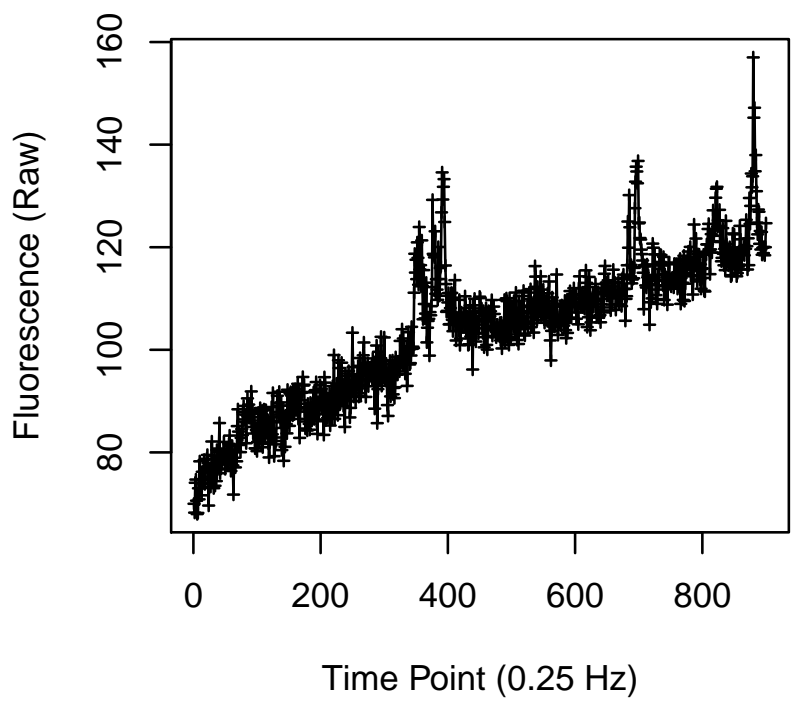


Cell 2113

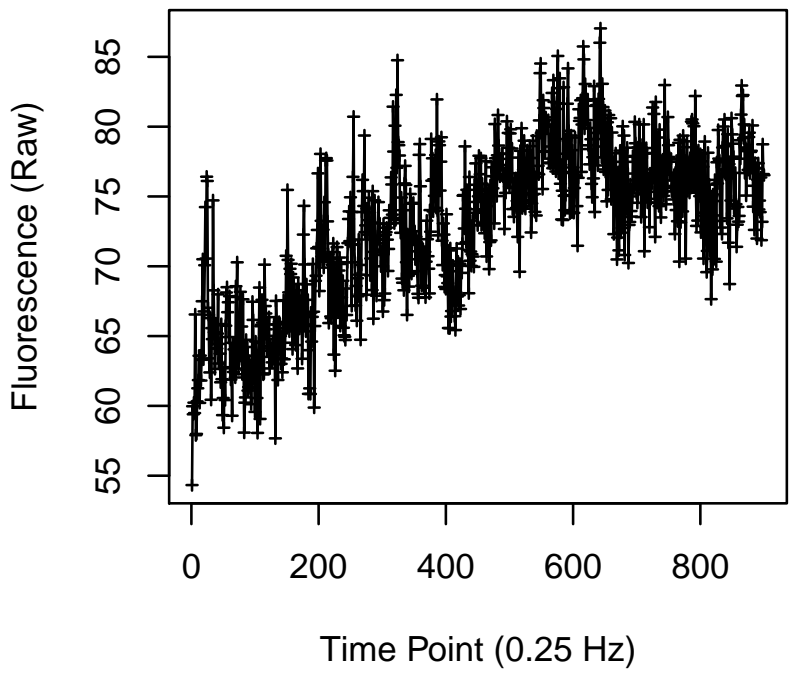

Cell 2115

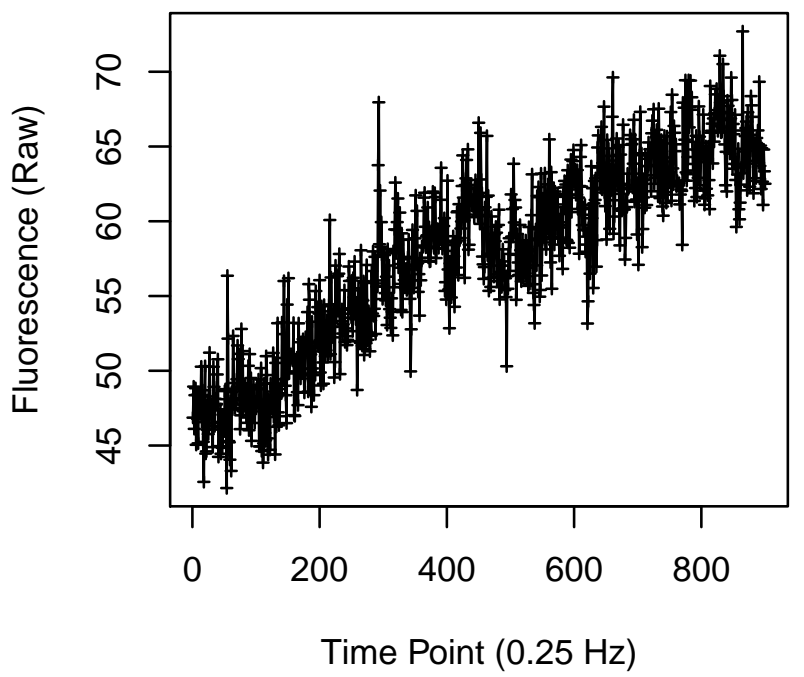

Cell 2114

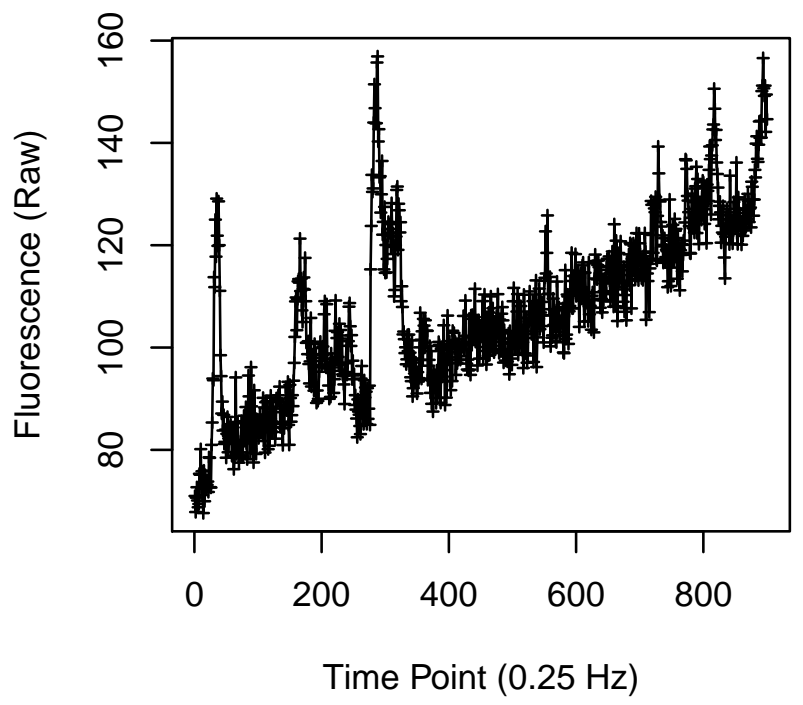

Cell 2116

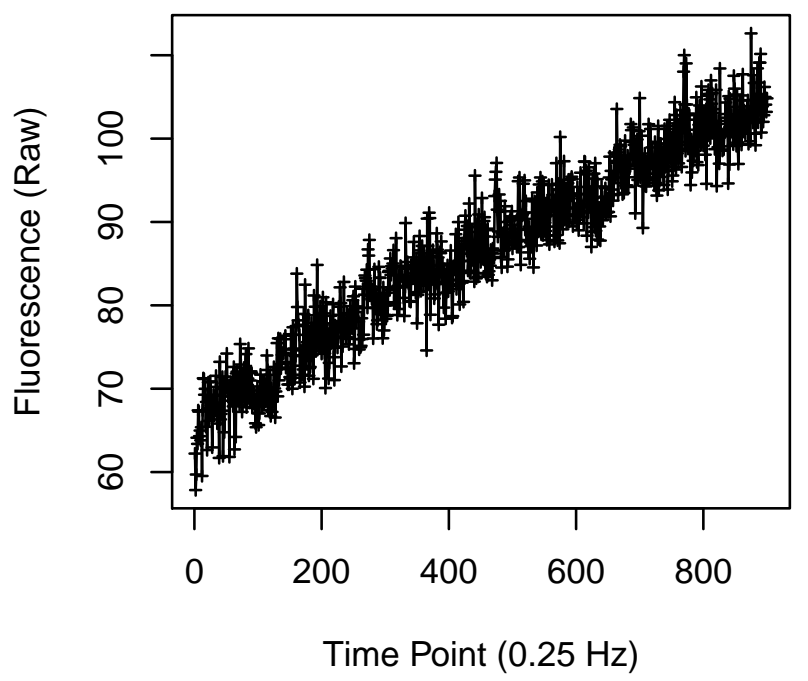


Cell 2117

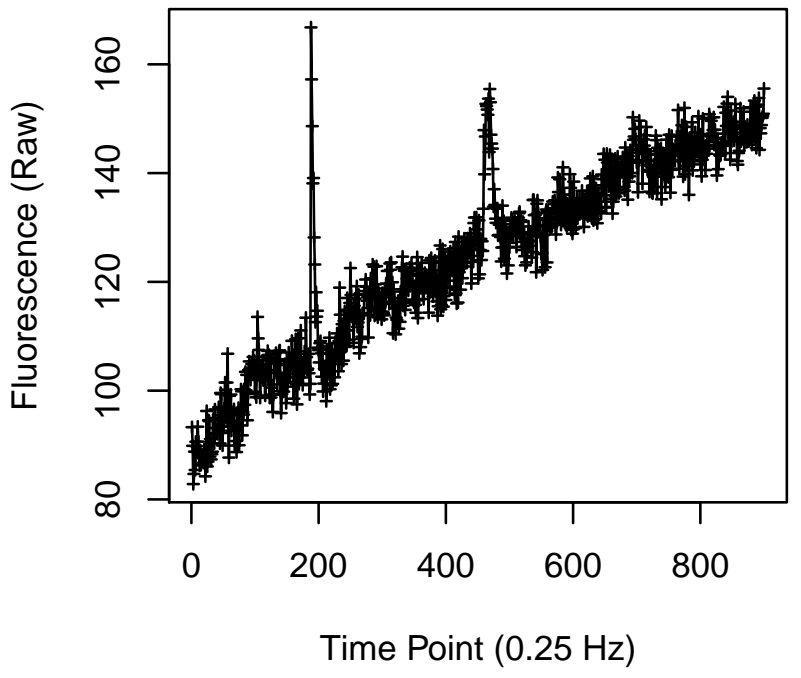

Cell 2119

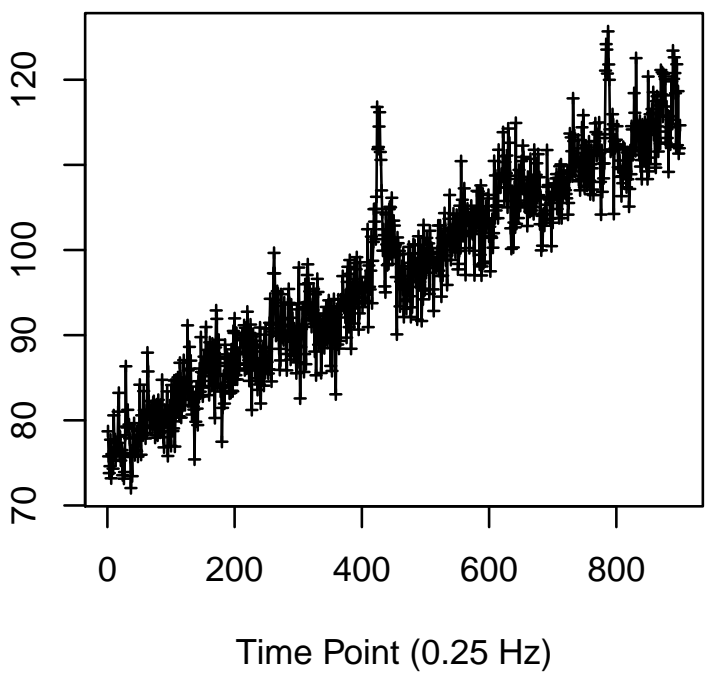

Cell 2118

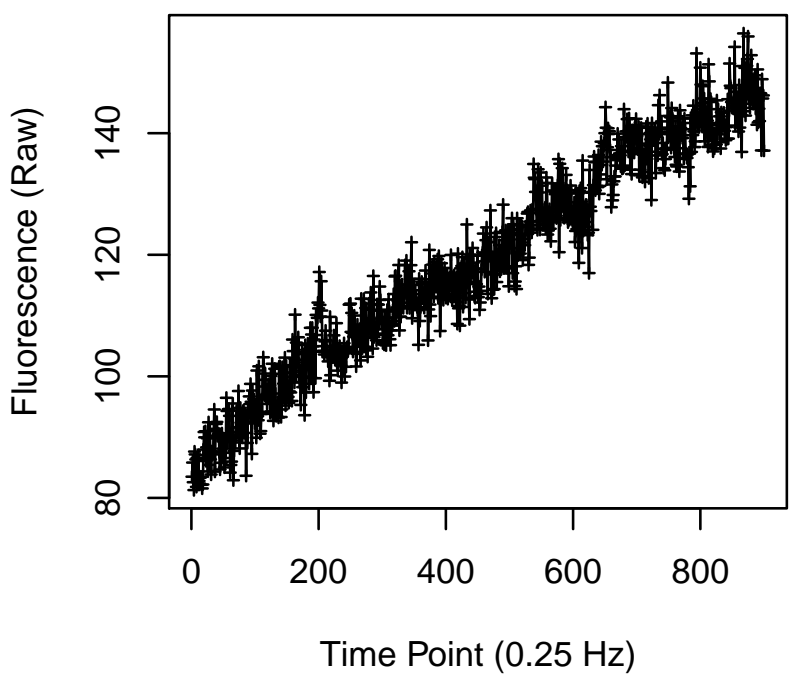

Cell 2120

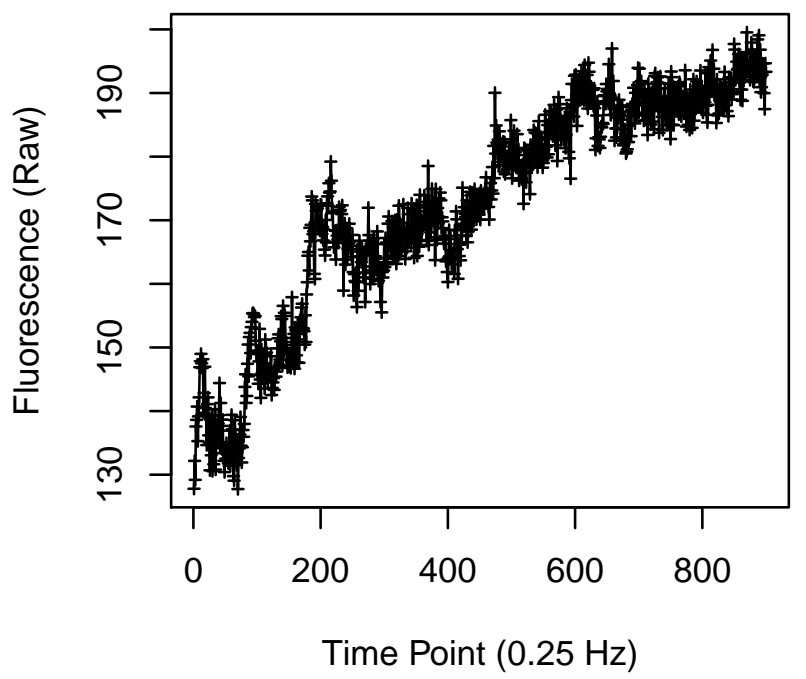


Cell 2121

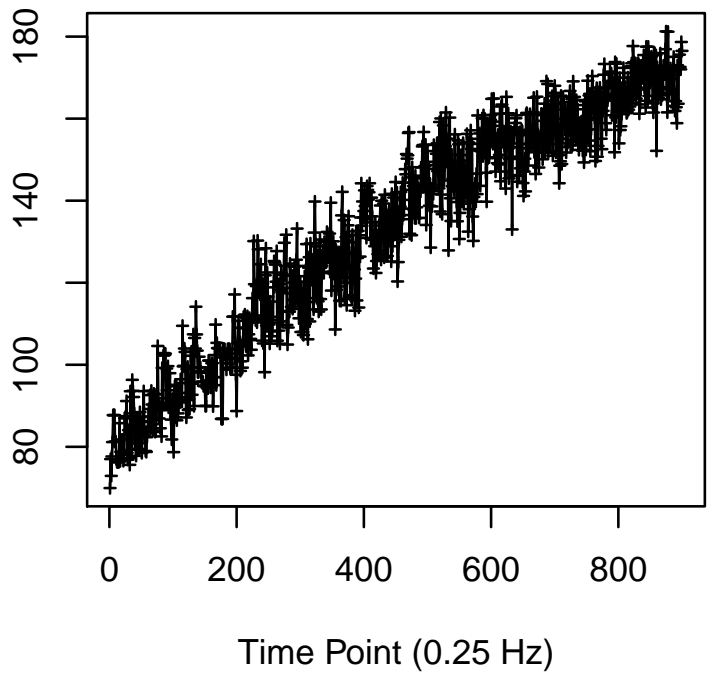

Cell 2123

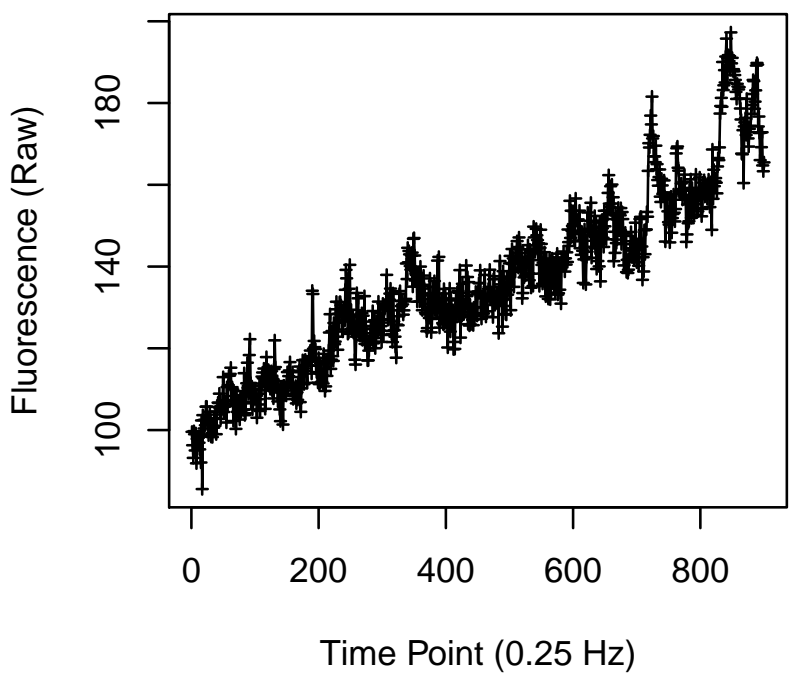

Cell 2122

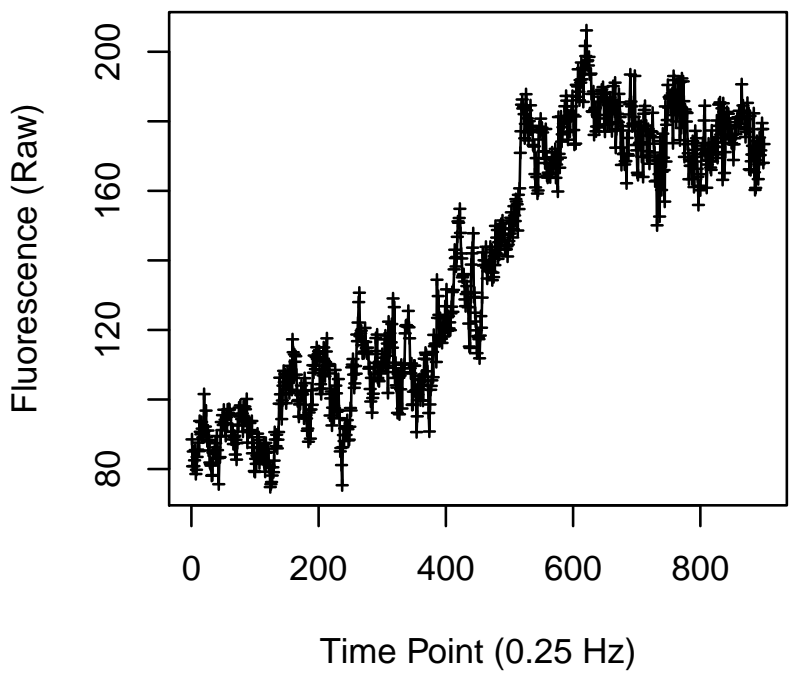

Cell 2124

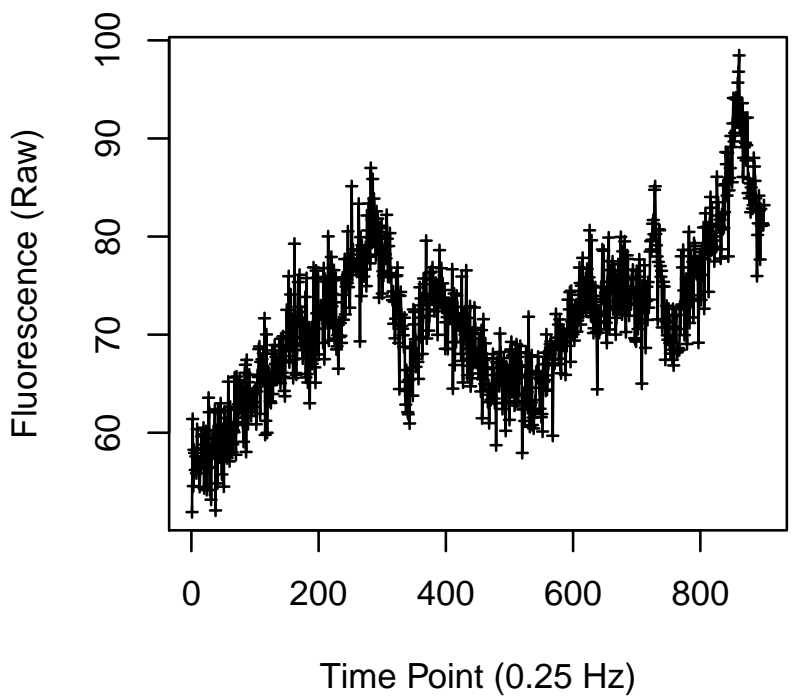


Cell 2125

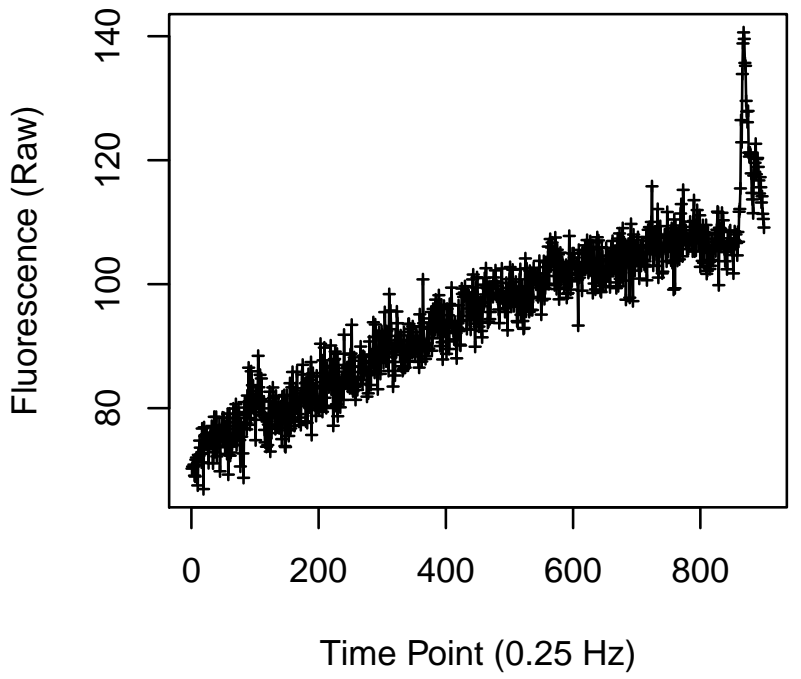

Cell 2127

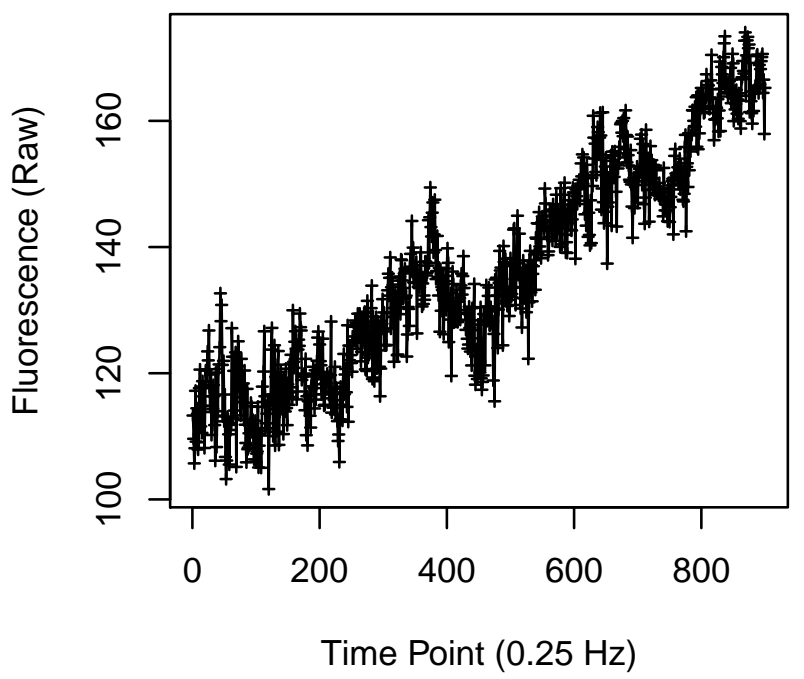

Cell 2126

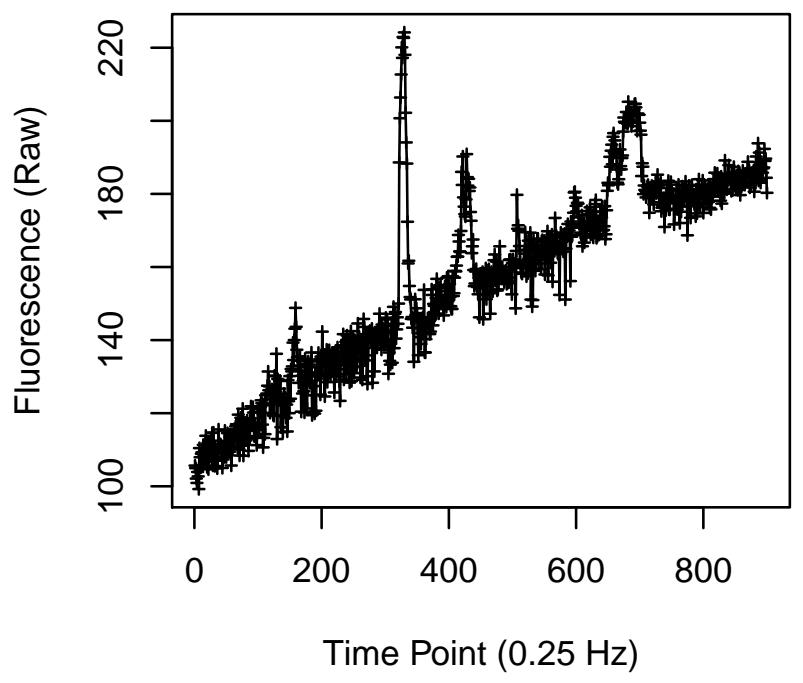

Cell 2128

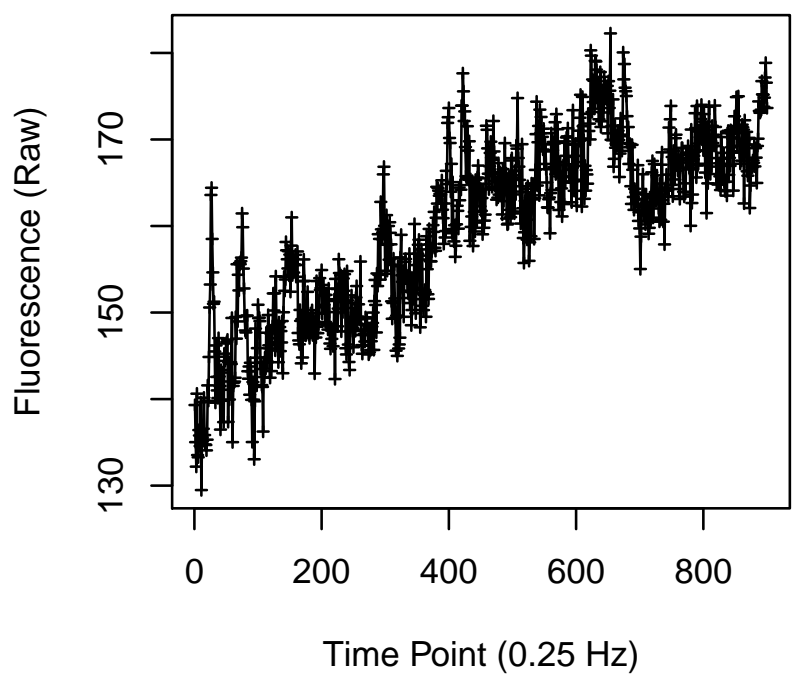


Cell 2129

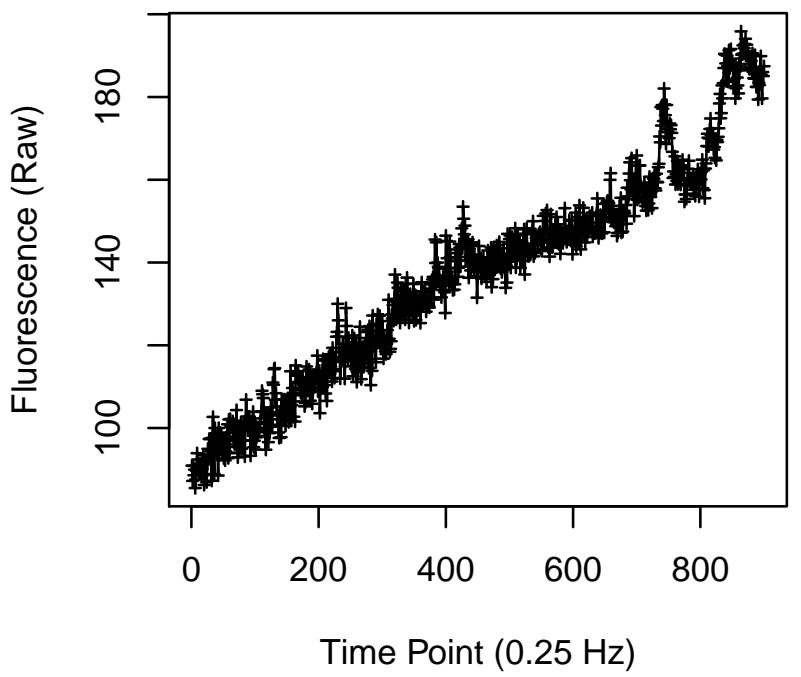

Cell 2131

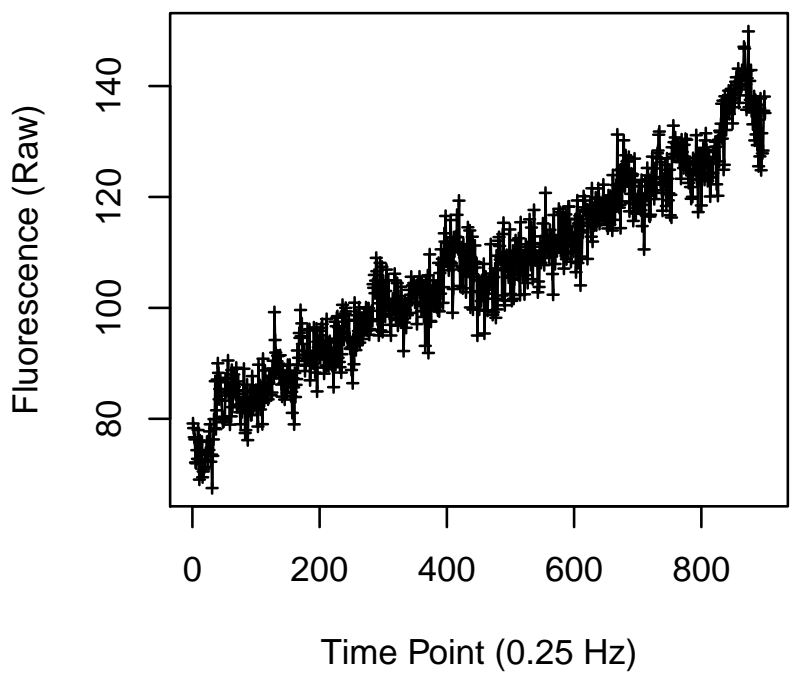

Cell 2130

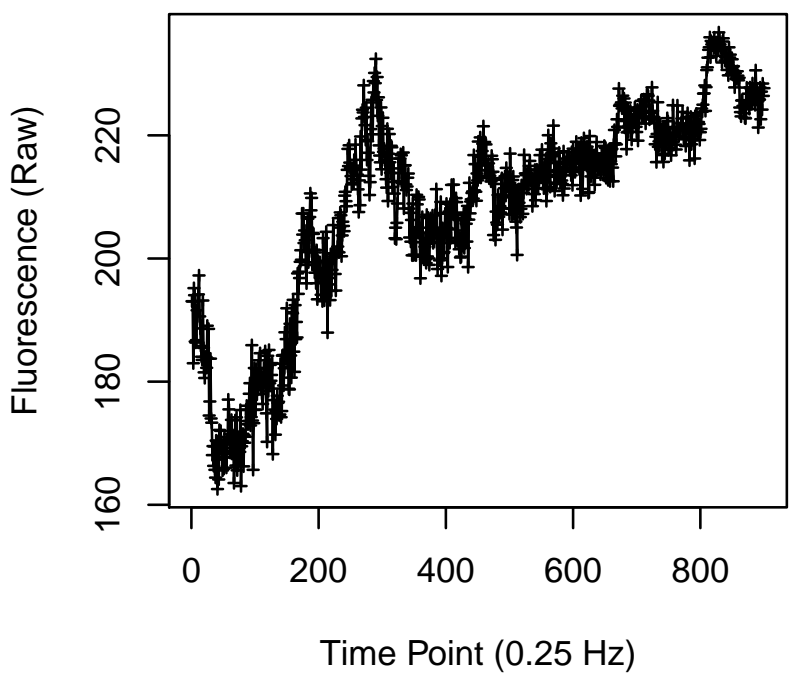

Cell 2132

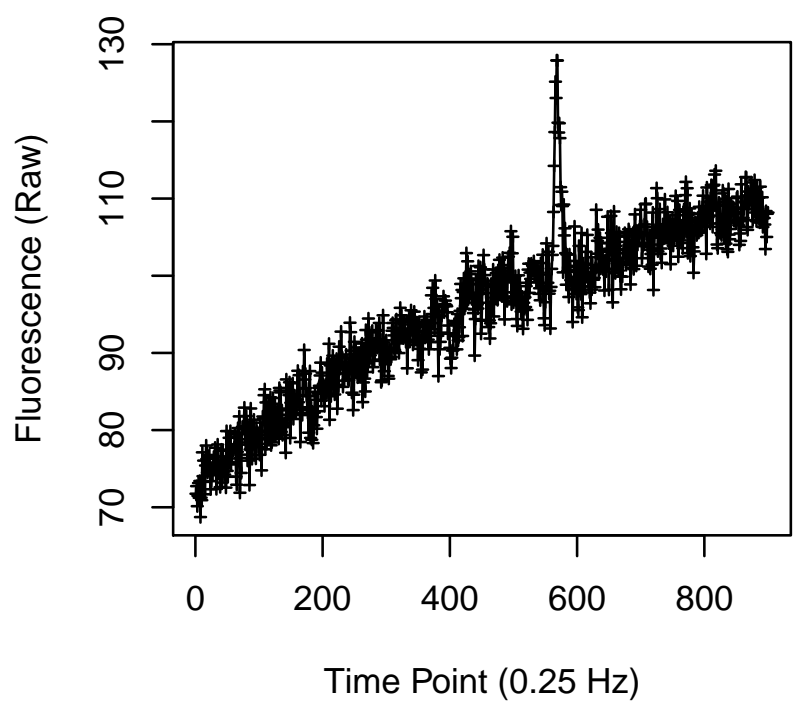


Cell 2133

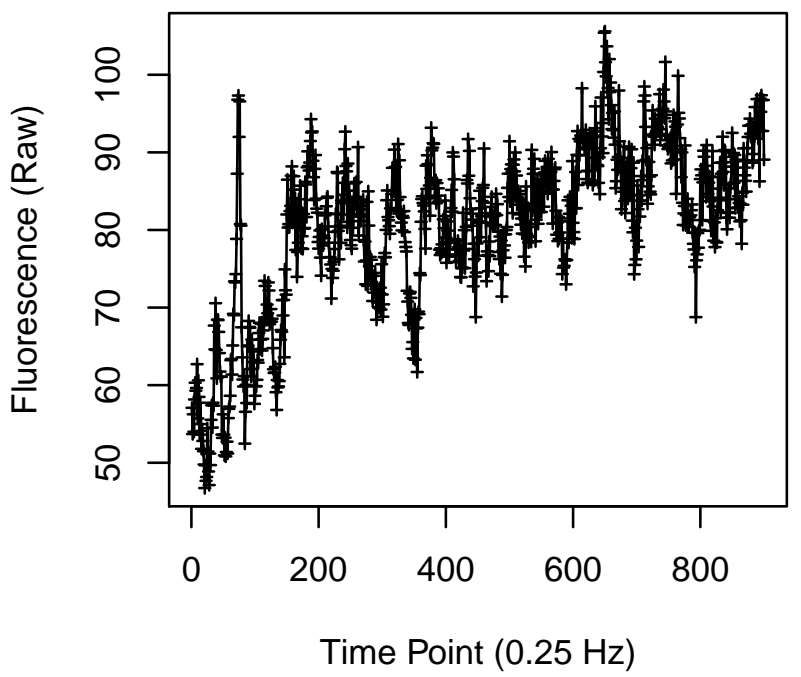

Cell 2135

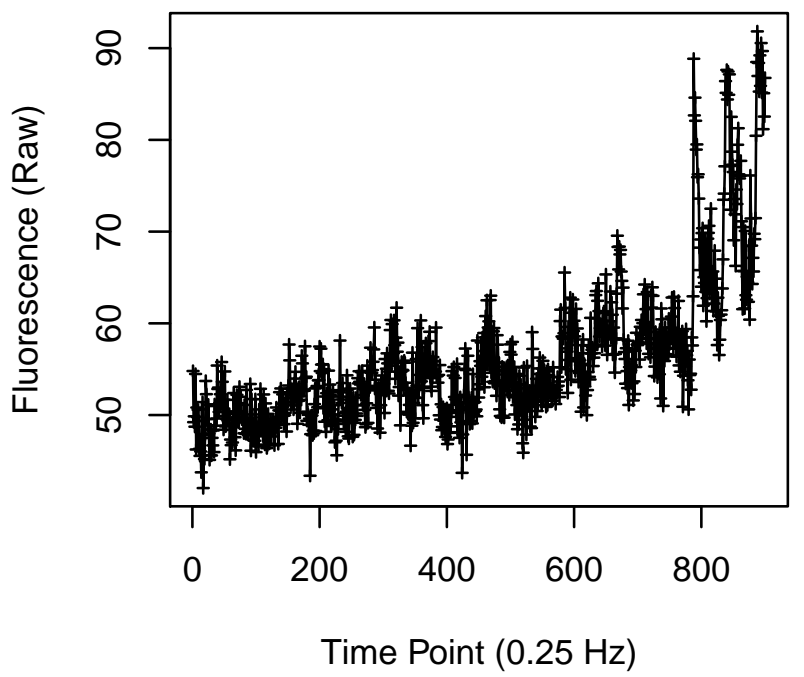

Cell 2134

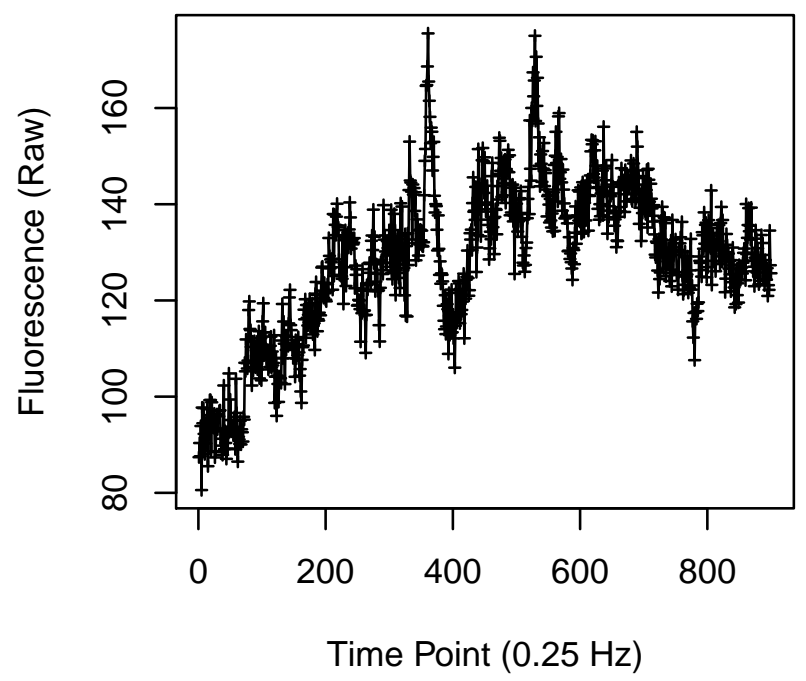

Cell 2136

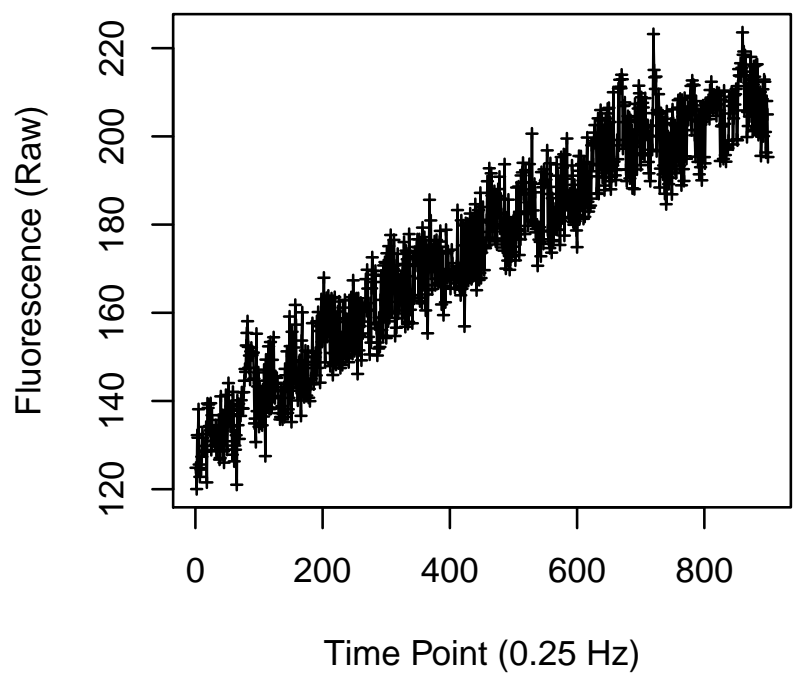


Cell 2137

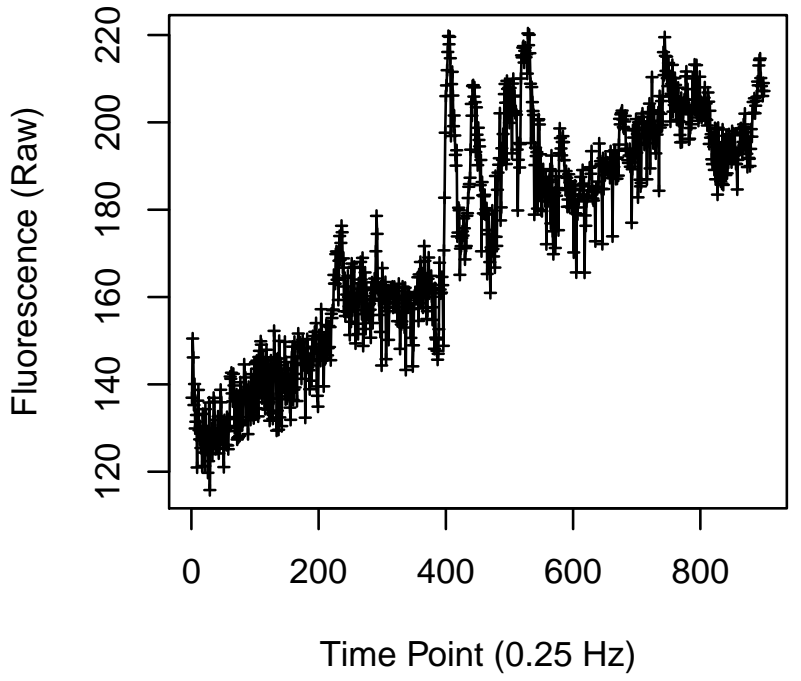

Cell 2139

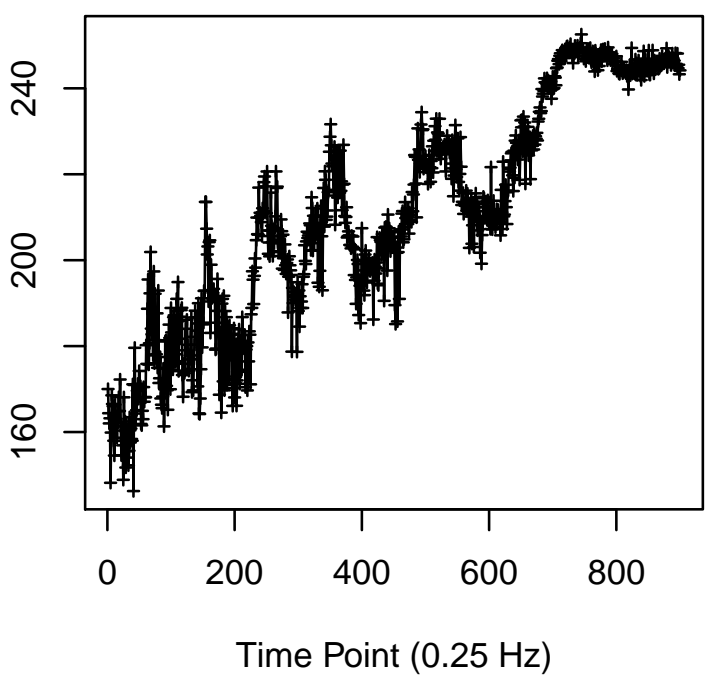

Cell 2138

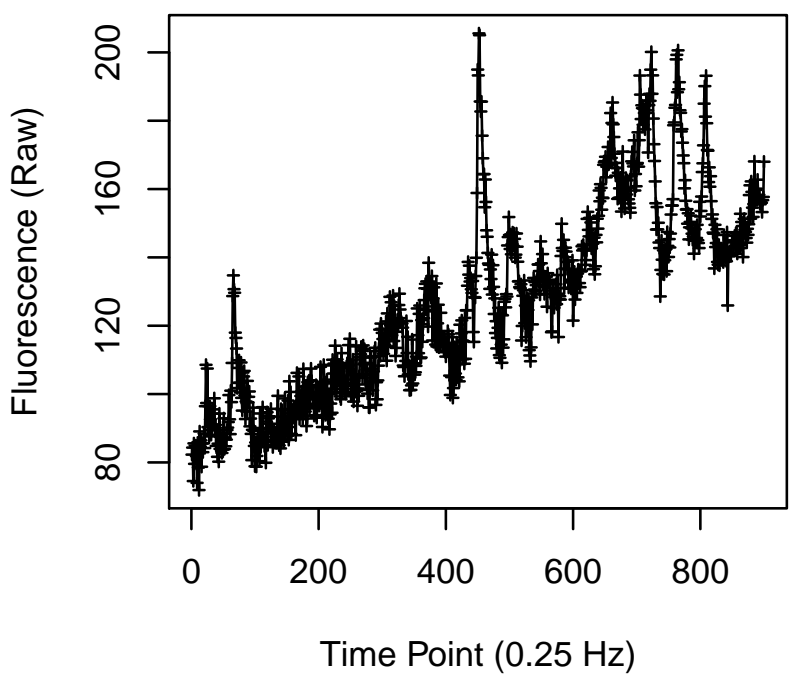

Cell 2140

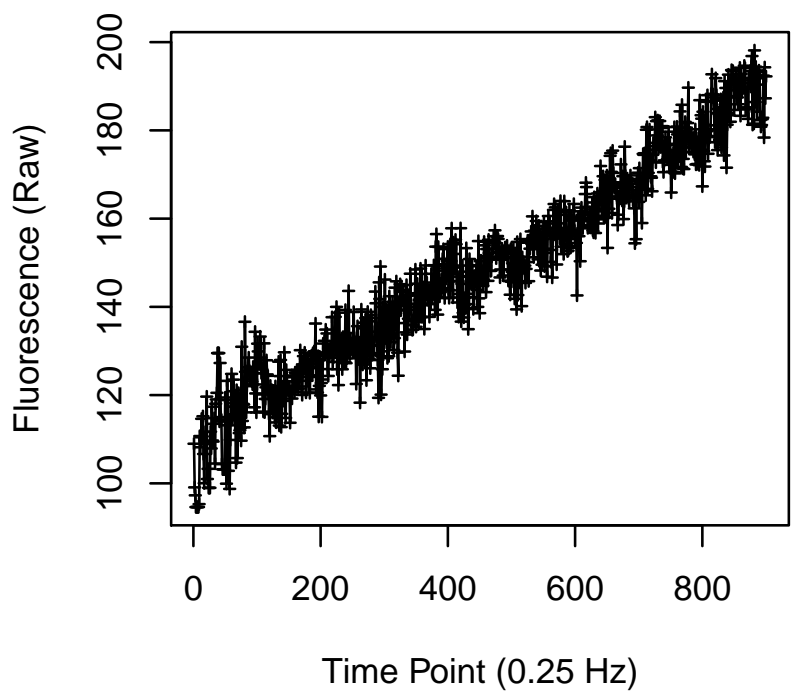


Cell 2141

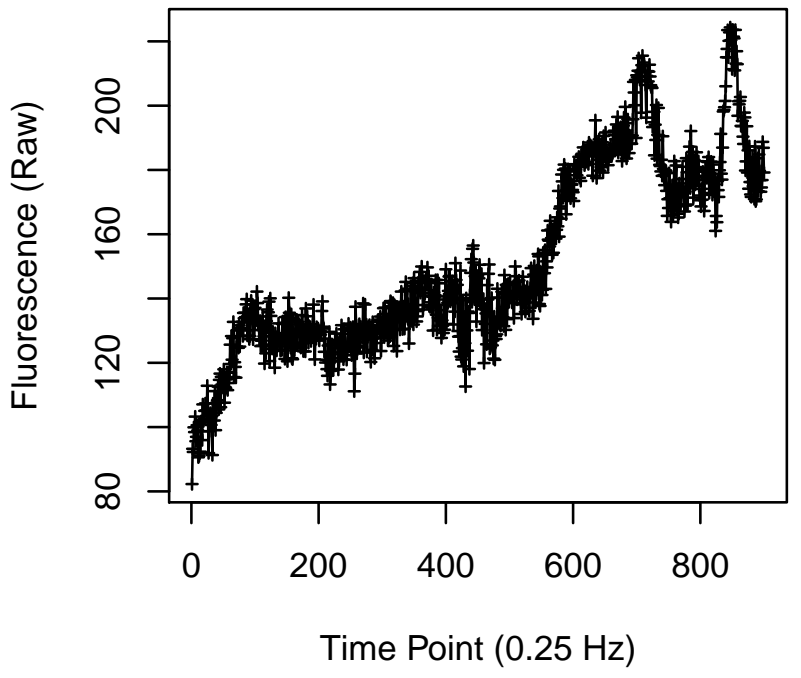

Cell 2143

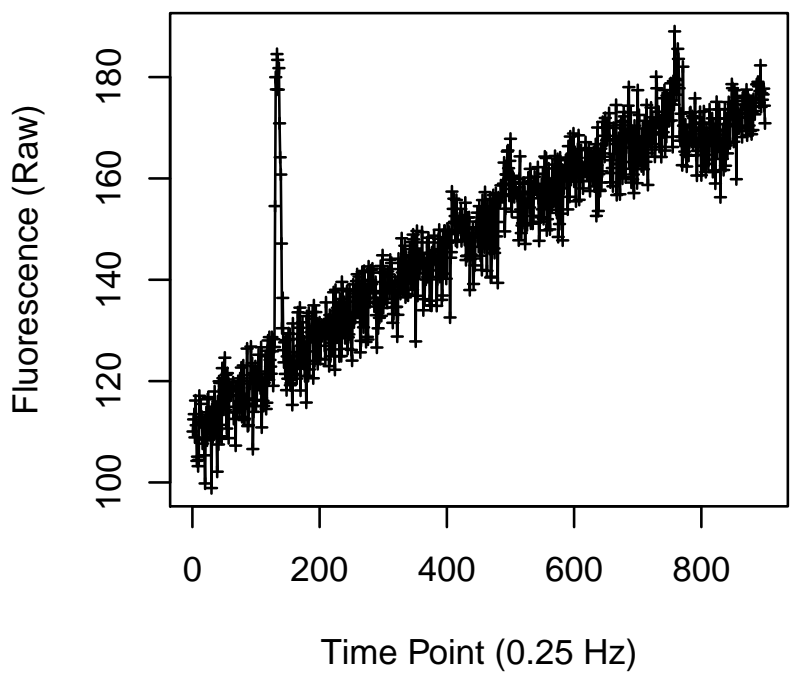

Cell 2142

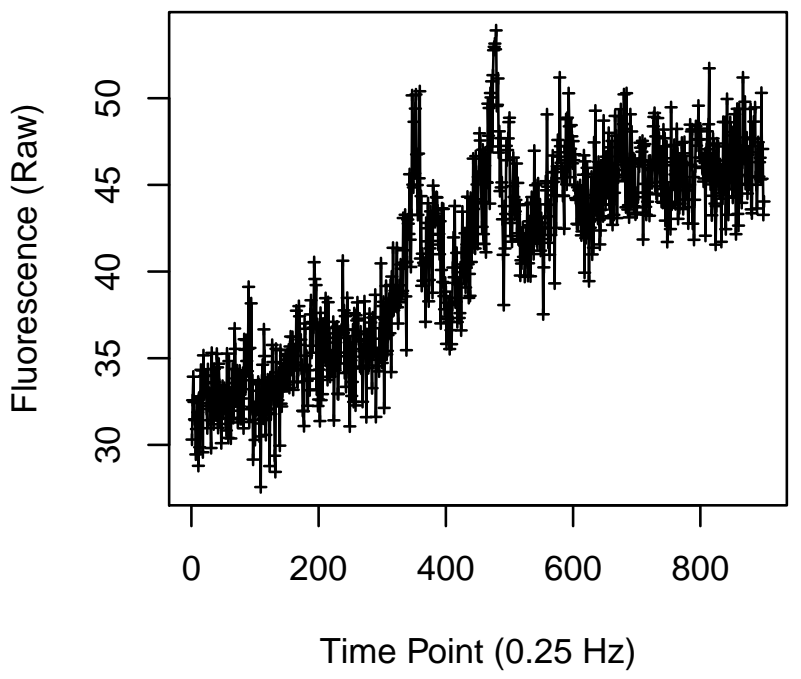

Cell 2144

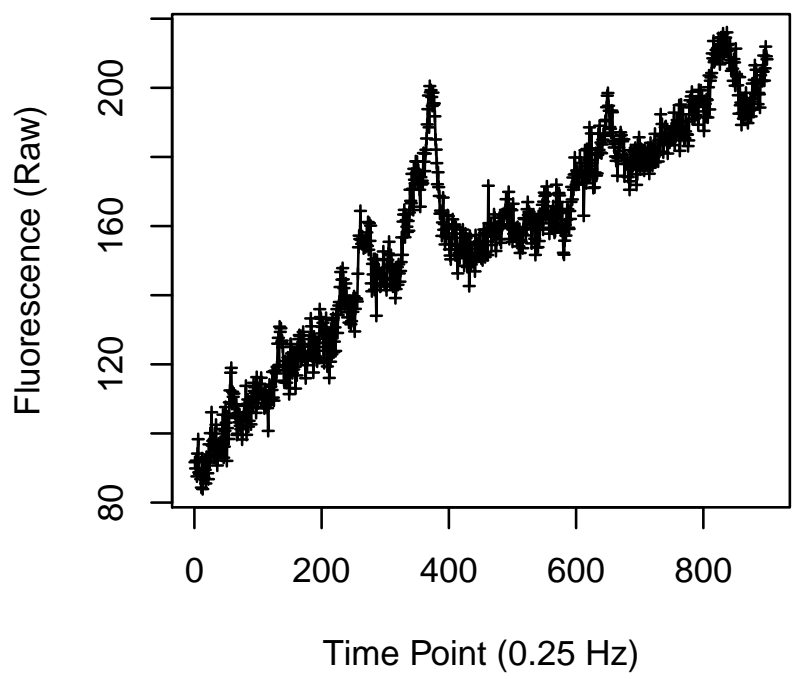


Cell 2145

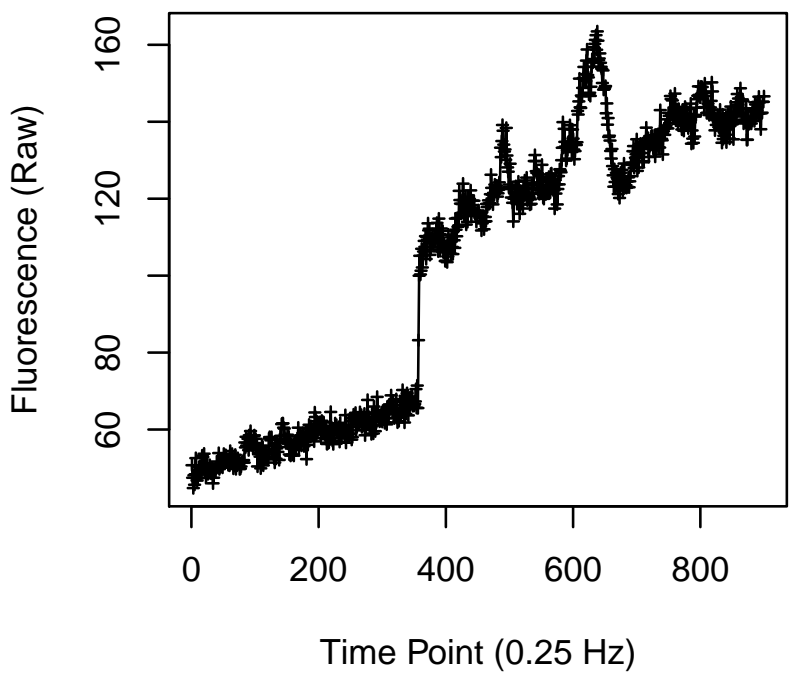

Cell 2147

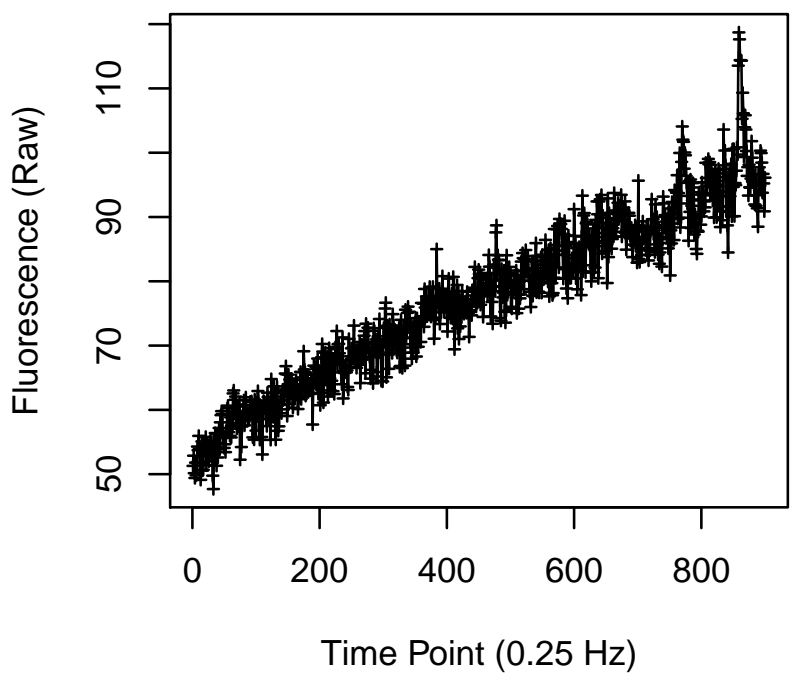

Cell 2146

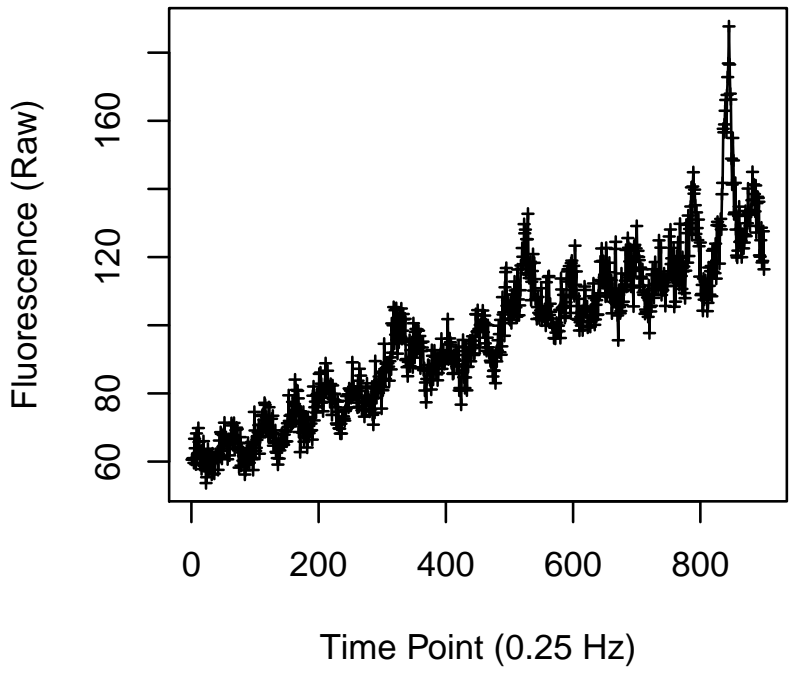

Cell 2148

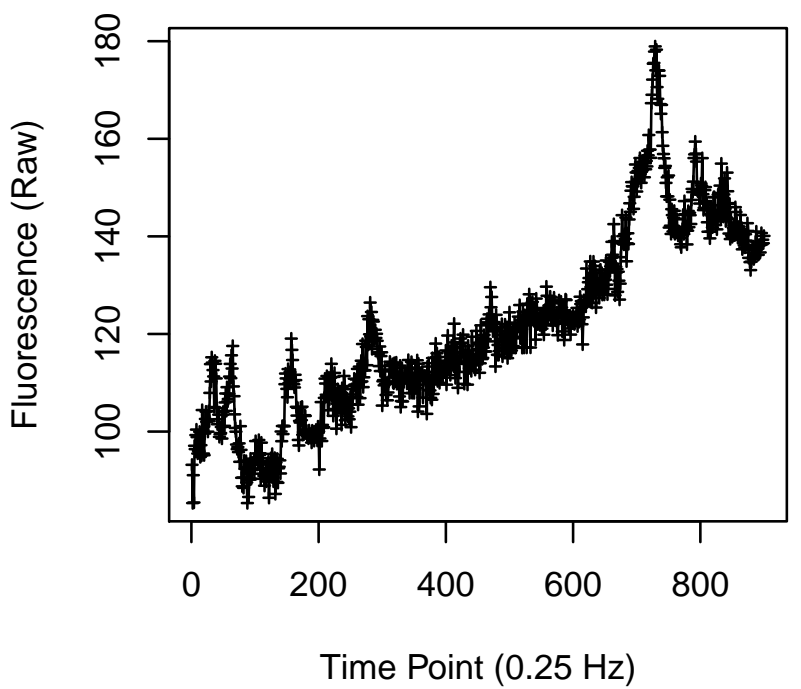


Cell 2149

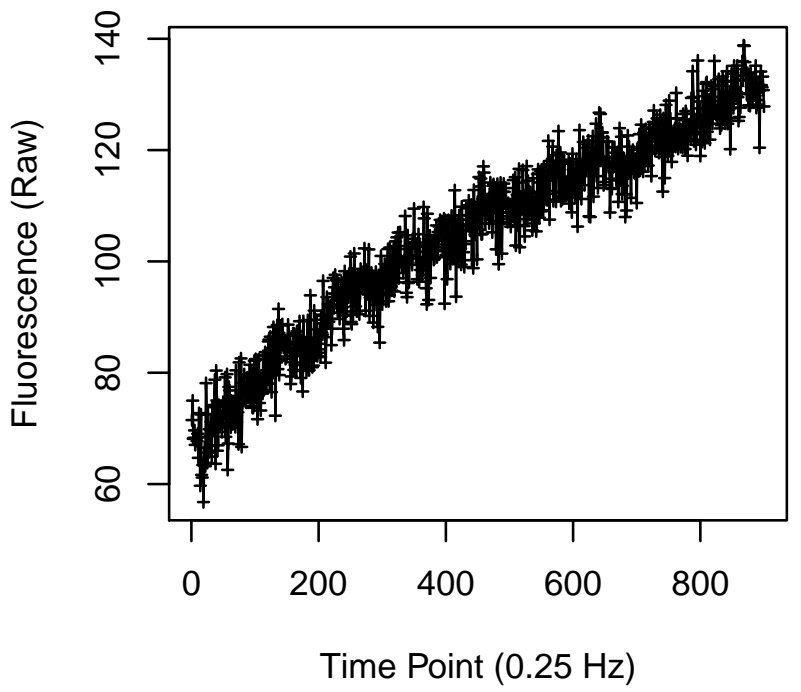

Cell 2151

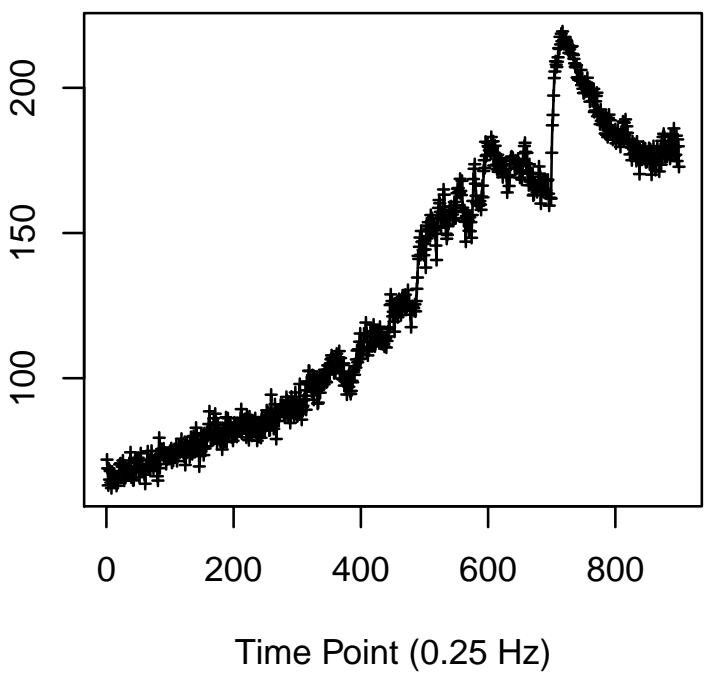

Cell 2150

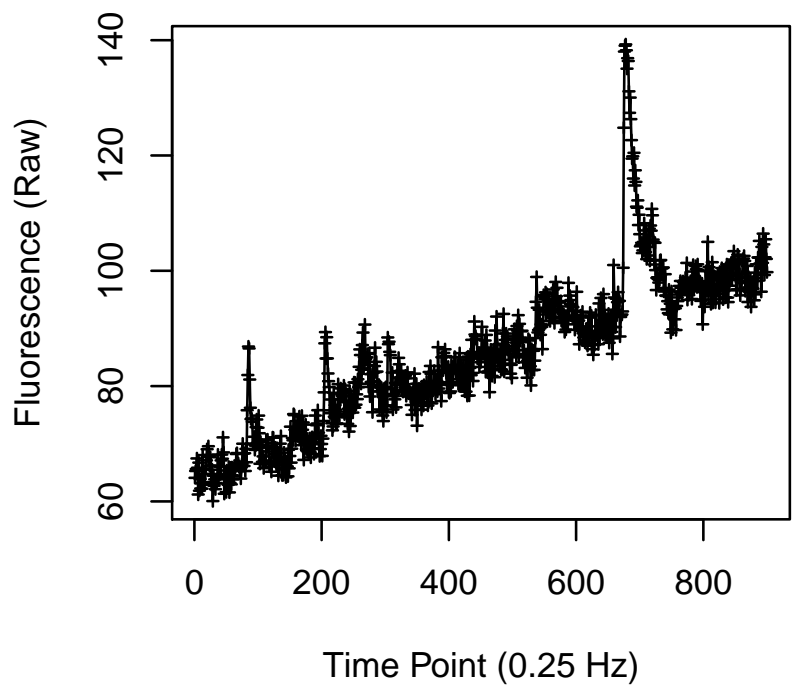

Cell 2152

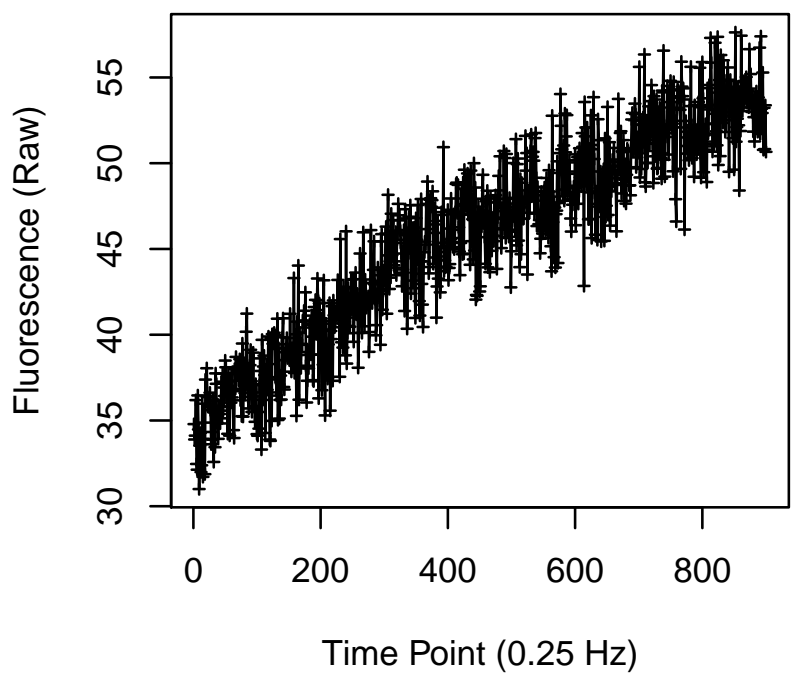


Cell 2153

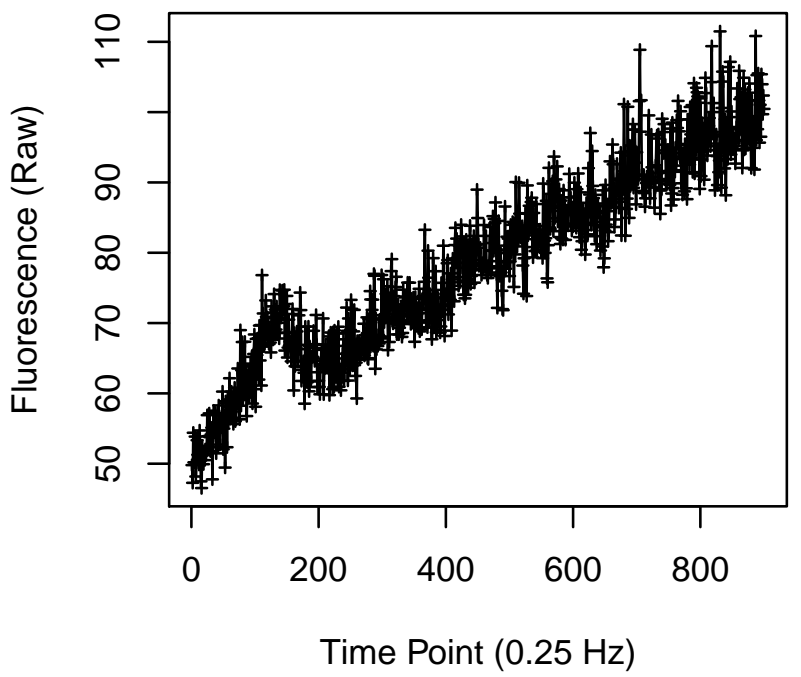

Cell 2155

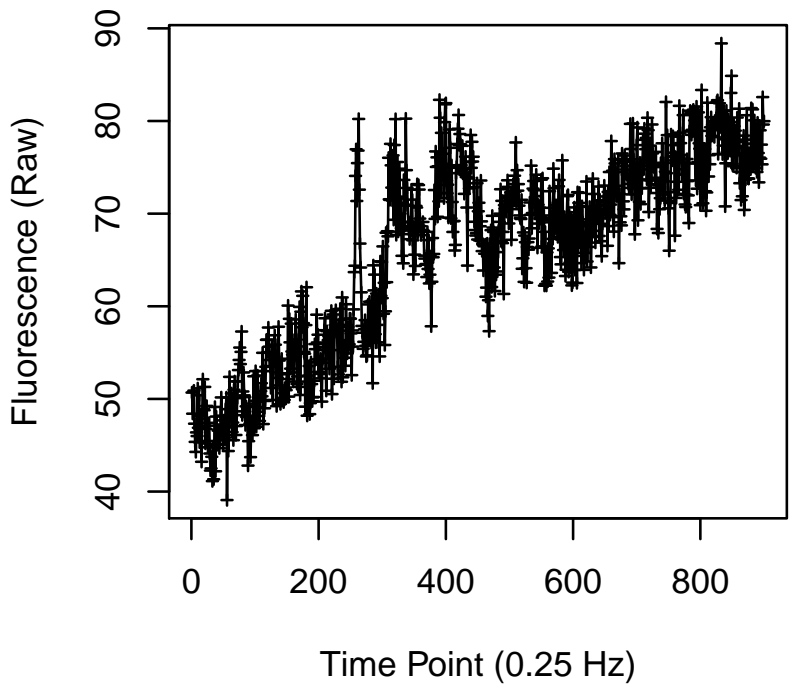

Cell 2154

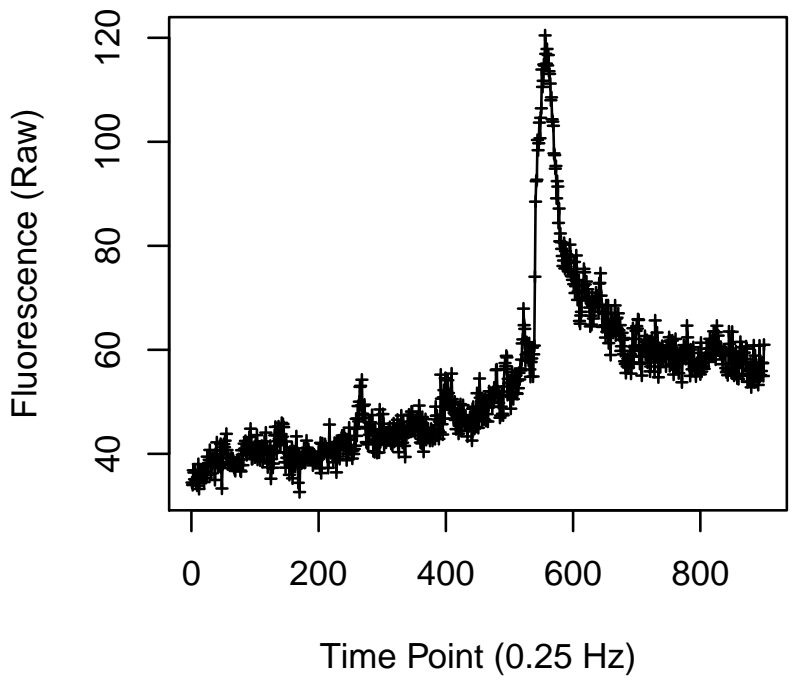

Cell 2156

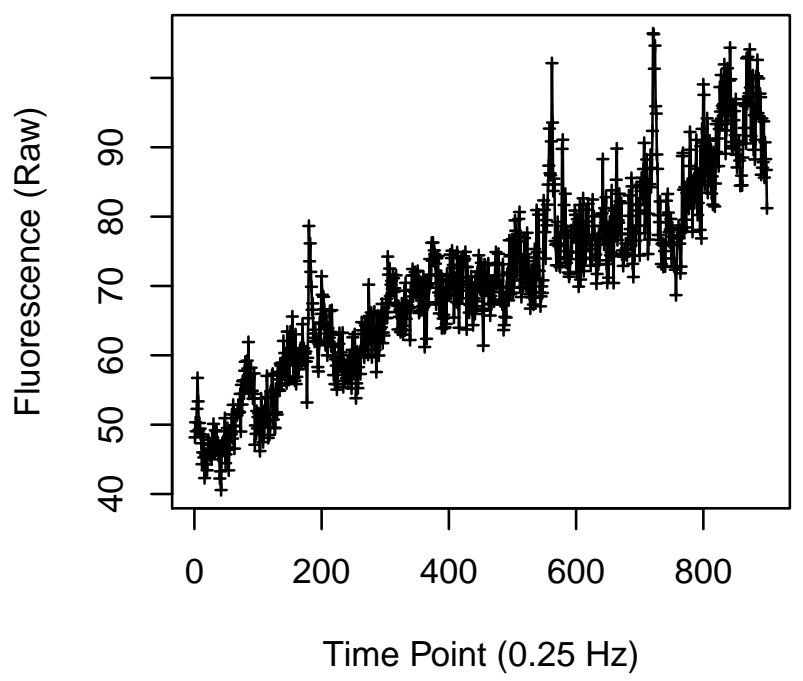


Cell 2157

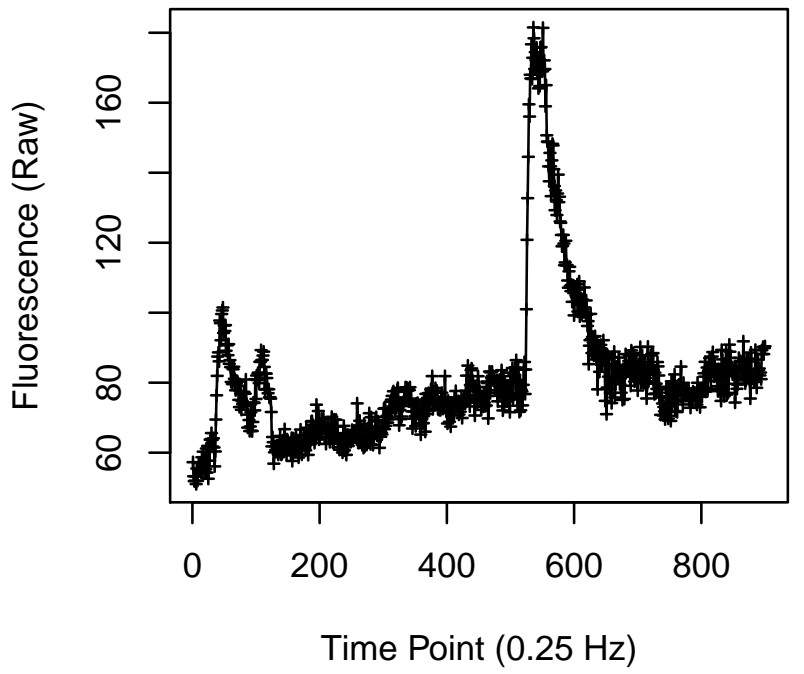

Cell 2159

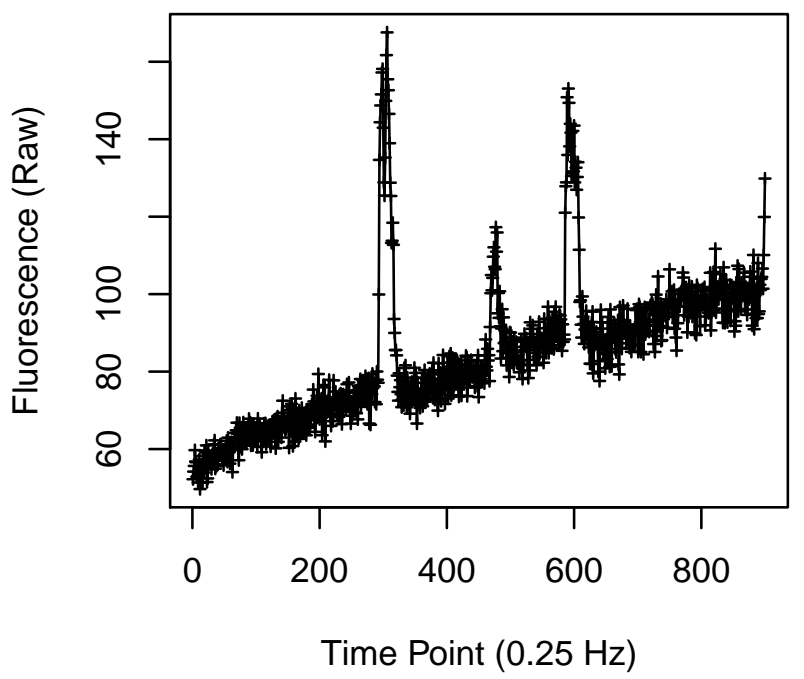

Cell 2158

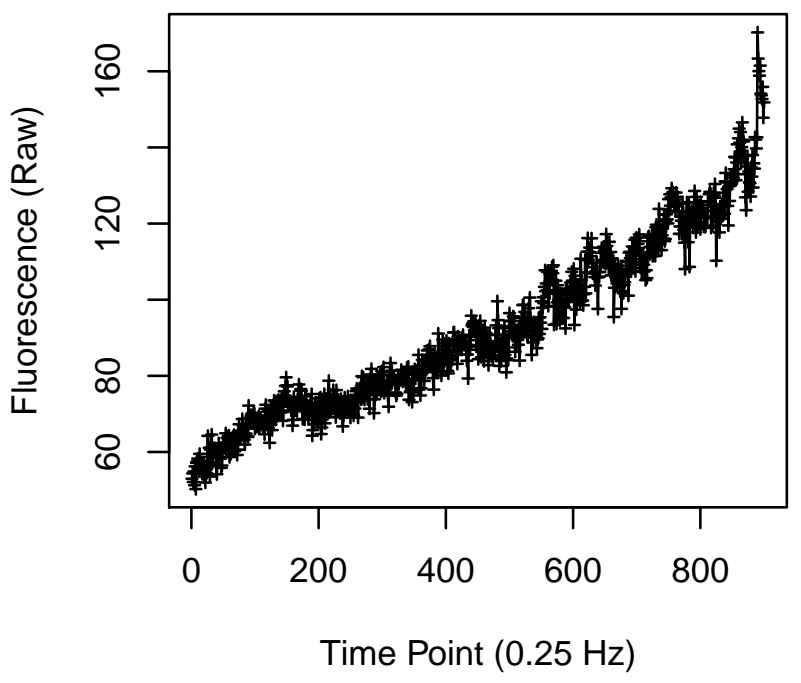

Cell 2160

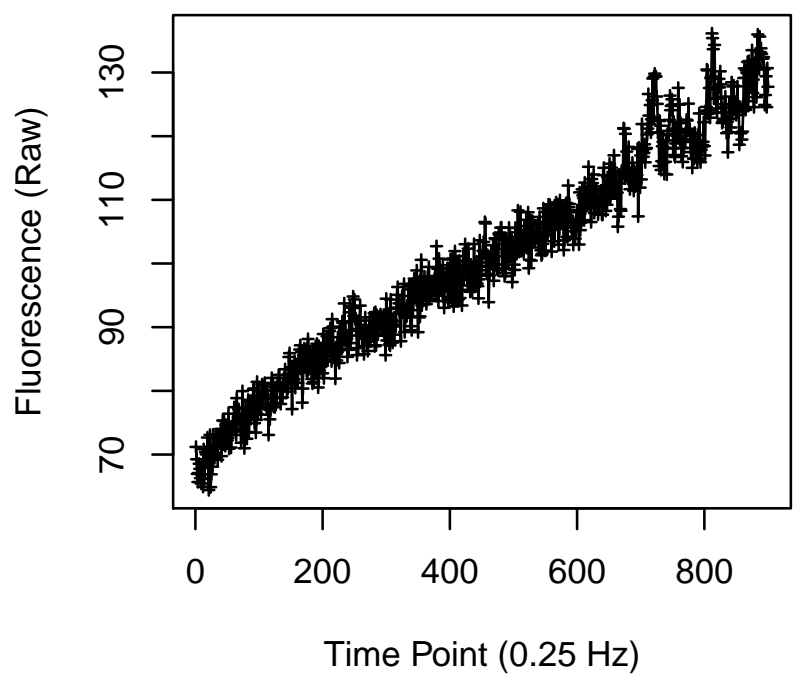


Cell 2165

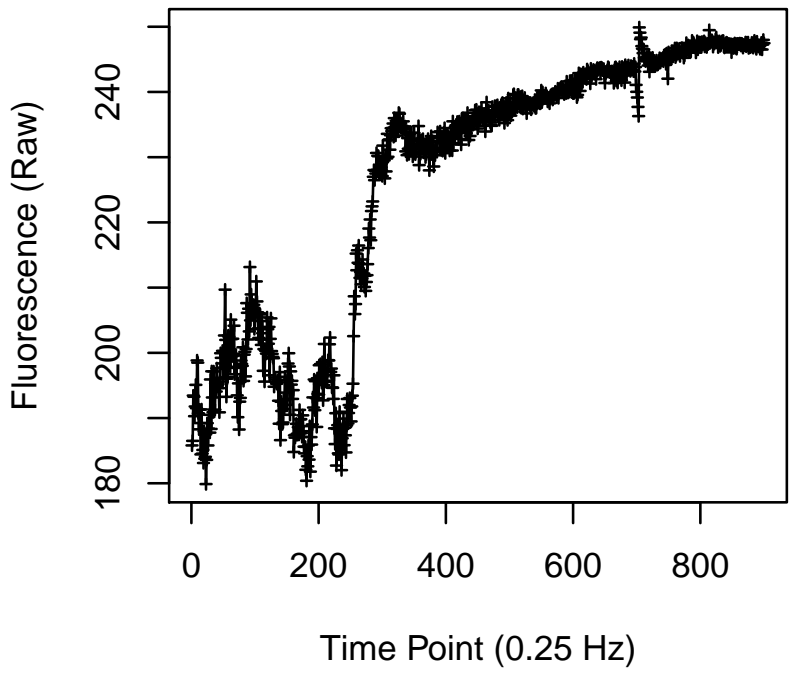

Cell 2167

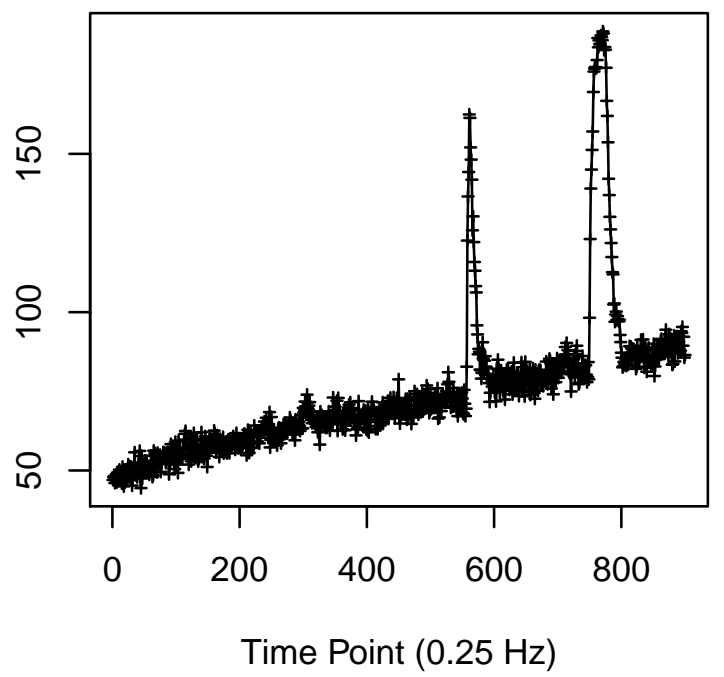

Cell 2166

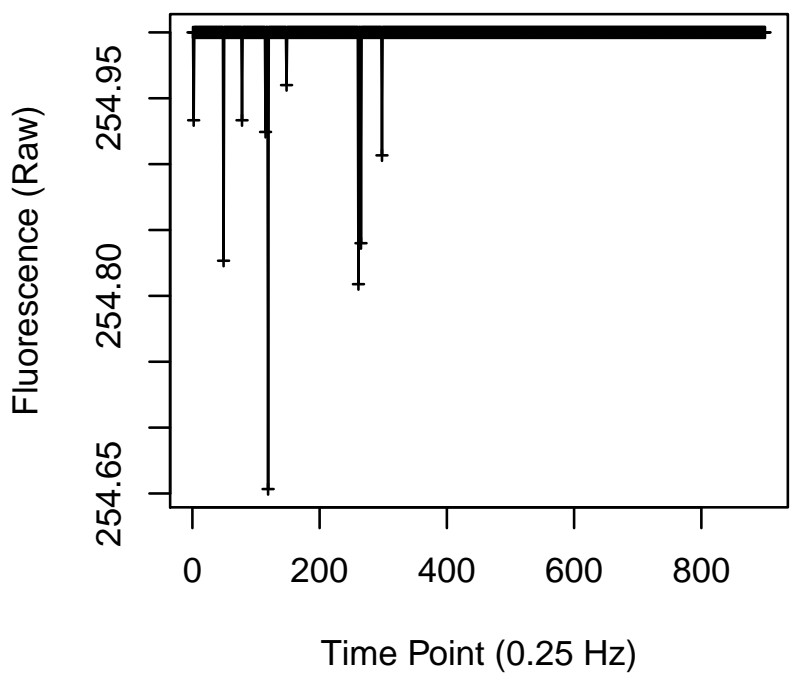

Cell 2168

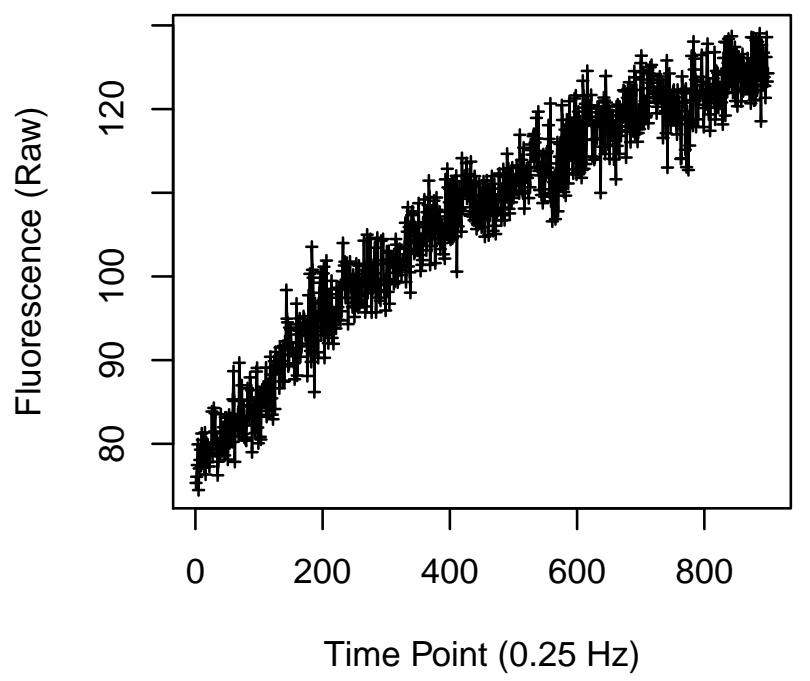


Cell 2169

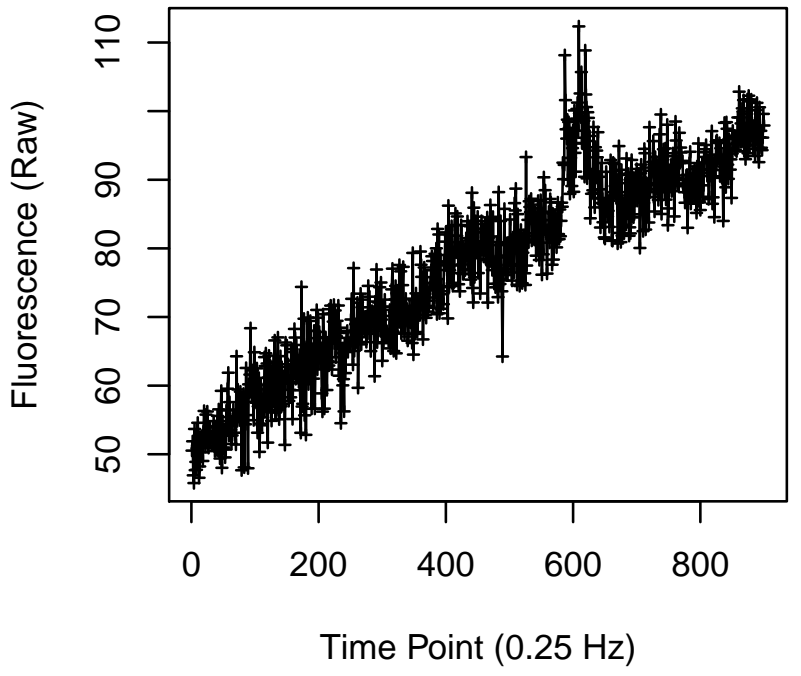

Cell 2171

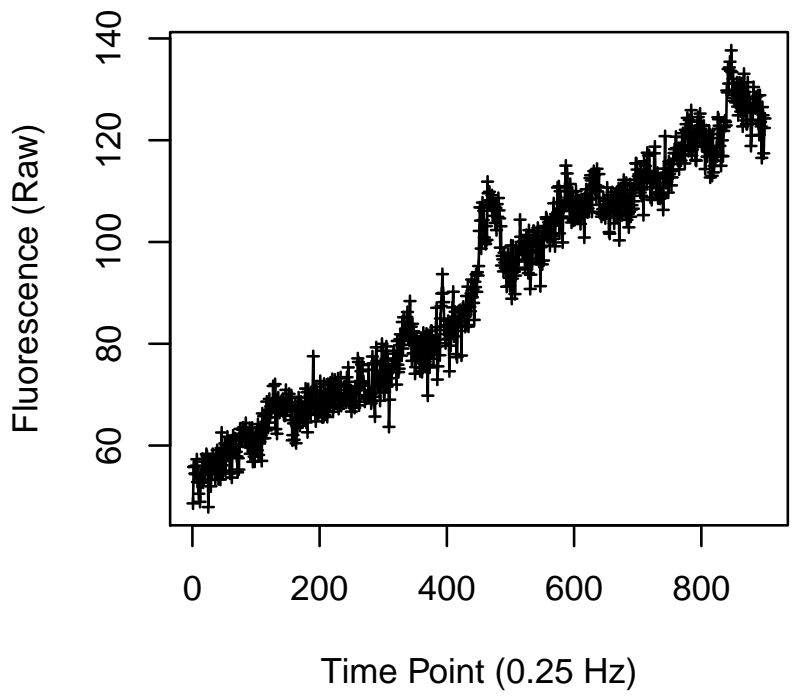

Cell 2170

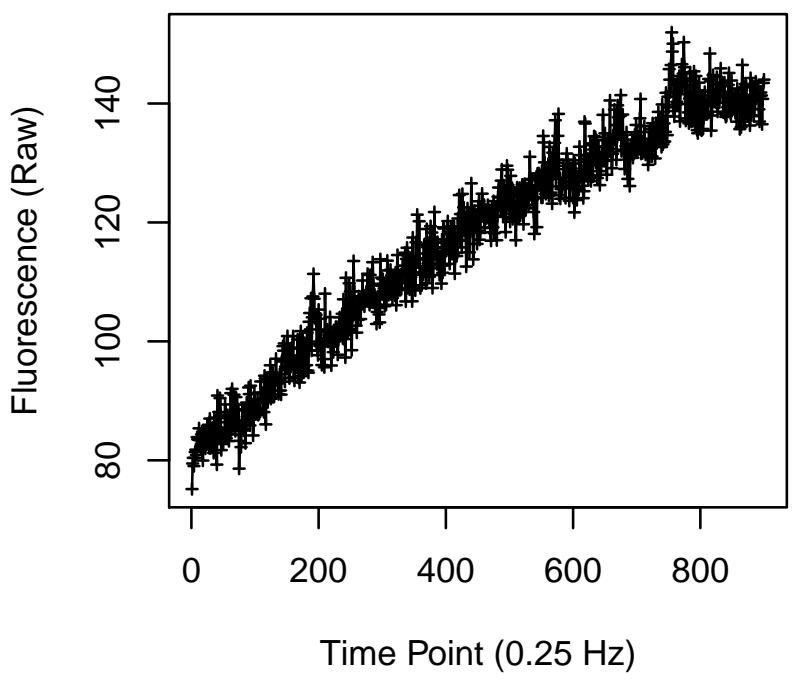

Cell 2172

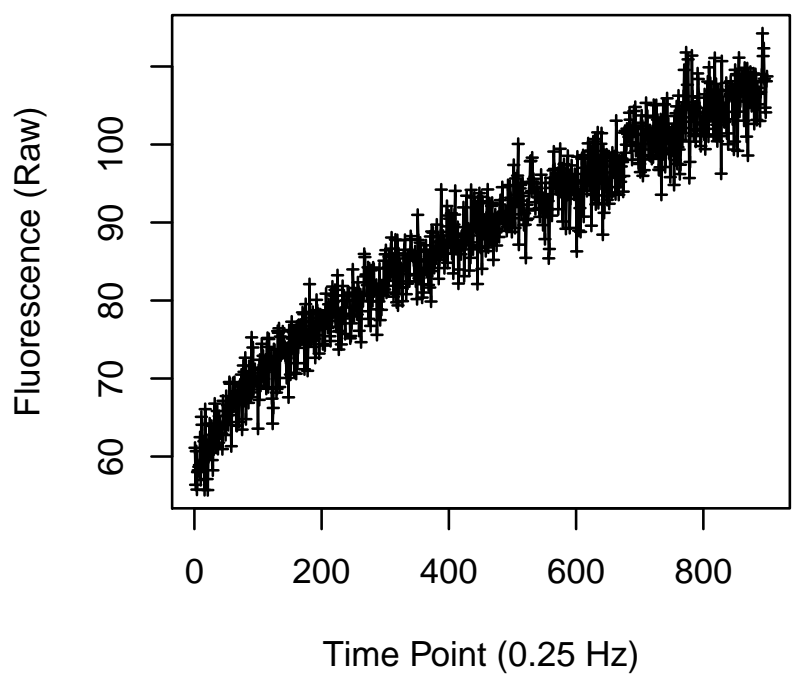


Cell 2173

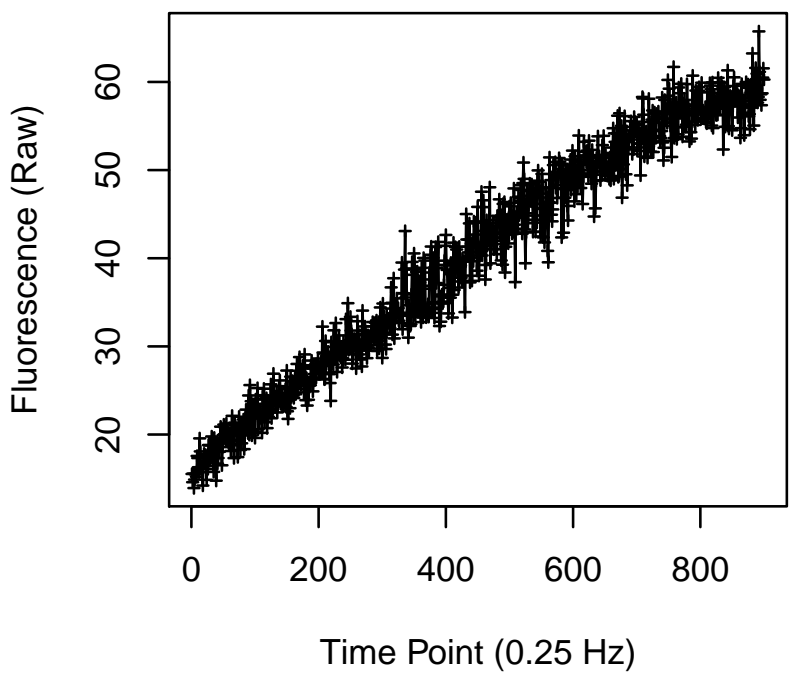

Cell 2175

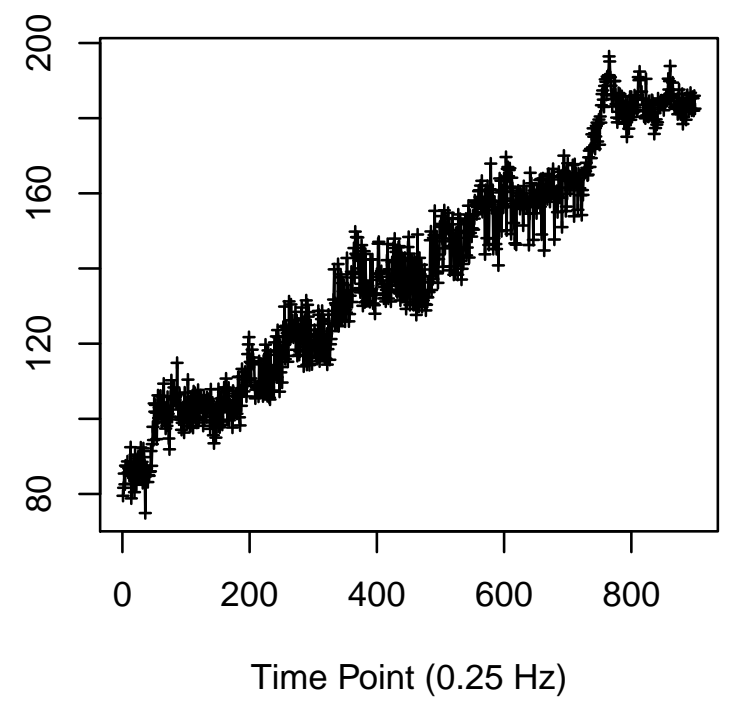

Cell 2174

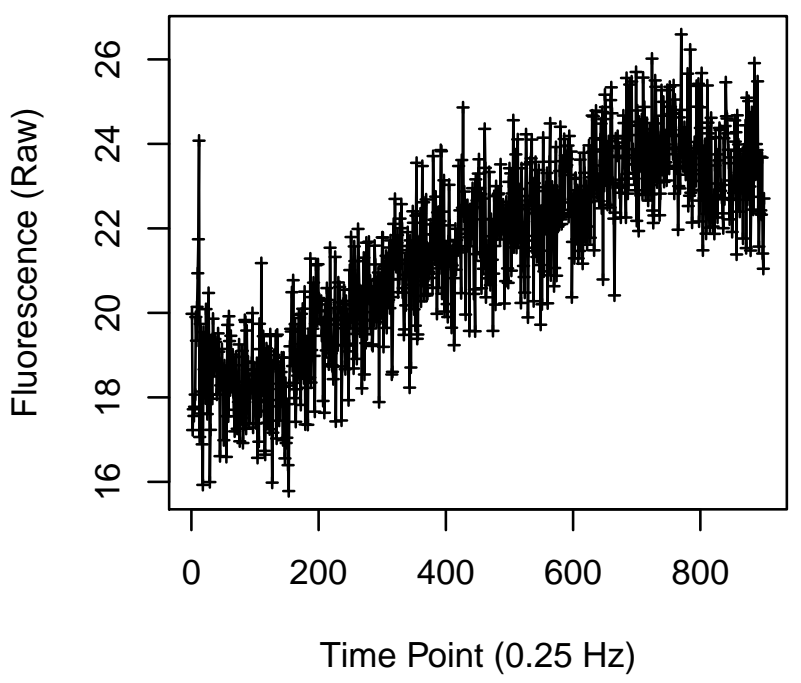

Cell 2176

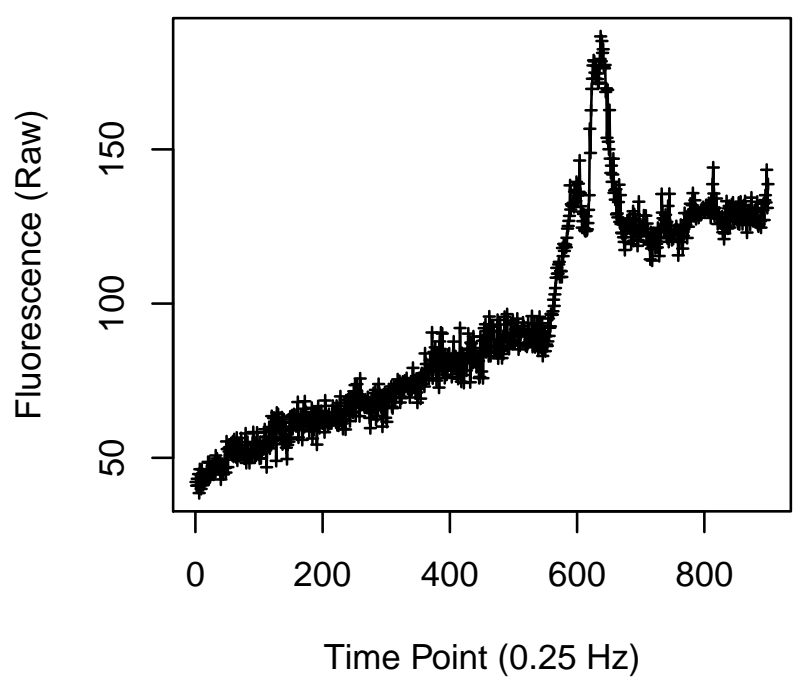

